\title{
(2) OCDE
}

LA AYUDA PARA

EL COMERCIO

EN SINTESIS 2013

CONECTARSE A

LAS CADENAS DE VALOR

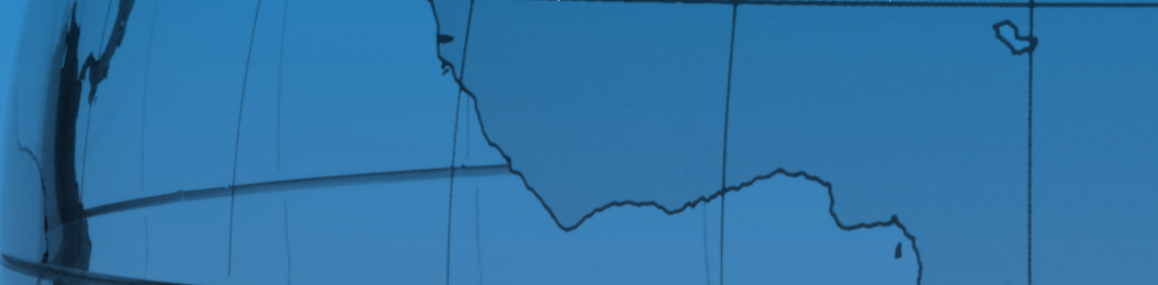




\section{LA AYUDA PARA \\ EL COMERCIO EN SÍNTESIS}

CONECTARSE A

LAS CADENAS DE VALOR

2013
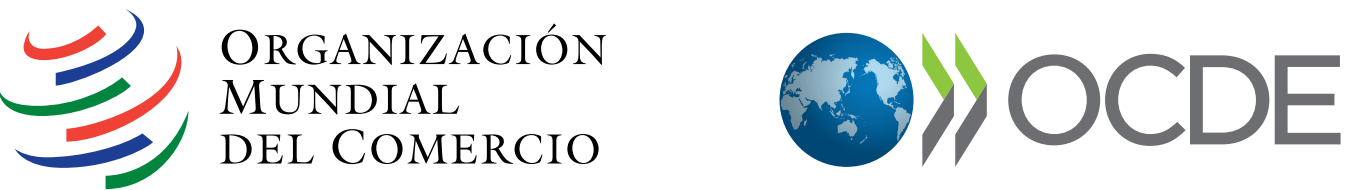
Las opiniones expresadas y los argumentos empleados en esta publicación no reflejan necesariamente las opiniones oficiales de la Organización de Cooperación y de Desarrollo Económicos o de los gobiernos de sus países miembros o los de la Organización Mundial del Comercio o sus Miembros.

Tanto este documento como cualquier mapa que se incluya en él se entenderán sin perjuicio respecto al estatus o la soberanía de cualquier territorio, a la delimitación de fronteras y límites internacionales, ni al nombre de cualquier territorio, ciudad o área.

Sírvanse citar esta publicación como:

OCDE/OMC (2015), La ayuda para el comercio en síntesis 2013: Conectarse a las cadenas de valor, Publicaciones de la OCDE.

DOI: $h$ ttp://dx.doi.org/10.1787/ayuda_sintesis-2013-es

ISBN OMC- 978-92-870-3870-8

ISBN OCDE - 978-92-64-20361-7 (impreso); 978-92-64-20362-4 (PDF)

Series: La ayuda para el comercio en síntesis

OCDE ISSN 24102016 (impreso)

OCDE ISSN 24102024 (PDF)

Los corrigendos de las publicaciones de la OCDE pueden consultarse en línea en: www.oecd.org/publishing/corrigenda.

(C) OCDE, OMC 2015

El material de la OCDE puede descargarse, reproducirse o imprimirse para uso personal, y pueden incluirse fragmentos de las publicaciones, bases de datos y productos multimedia de la OCDE en documentos, ponencias, blogs, sitios Web y material didáctico personales, siempre que se reconozcan el origen y la titularidad de los derechos de autor de la OCDE y la OMC. Todas las peticiones de uso comercial o público y de derechos de traducción deben enviarse a la dirección rights@oecd.org. Las solicitudes del permiso para fotocopiar parte del material para su uso público o comercial deben dirigirse directamente al Copyright Clearance Center (CCC) en la dirección info@copyright.com o al Centre français d'explotation du droit de copie (CFC) en la dirección contact@cfcopies.com. 


\section{PRÓLOGO}

Mucho es lo que se ha logrado mediante la Iniciativa de Ayuda para el Comercio desde que se puso en práctica en 2005. Así, se ha conseguido que se tome conciencia del papel positivo que puede cumplir el comercio en el crecimiento económico y el desarrollo, lo que, a su vez, ha contribuido a una mayor integración de las prioridades relacionadas con el comercio en las estrategias nacionales de desarrollo de los países asociados. En respuesta a ello, los donantes bilaterales y multilaterales, así como los proveedores de cooperación Sur-Sur, están aportando mayor financiación en condiciones concesionarias y en condiciones ordinarias. Por su parte, el sector privado está estudiando la manera de ayudar a que el comercio sirva para promover el desarrollo y reducir la pobreza. Gracias a un examen de la Ayuda para el Comercio centrado no sólo en los progresos realizados sino también en las mejoras que es necesario seguir haciendo está aumentando la confianza en la Iniciativa como medio de lograr resultados tangibles.

El panorama del comercio y el desarrollo ha evolucionado desde que se emprendió la Iniciativa. La labor de investigación del comercio en términos de valor añadido -encabezada por la OMC y la OCDE- ha revelado la complejidad de las redes de producción por las que se encauza el comercio mundial en la actualidad. Como resultado de la profundización y ampliación de las cadenas de valor, ha aumentado la proporción de los bienes intermedios en el comercio, a medida que un número cada vez mayor de empresas y países se incorporan a esas redes difusas. Al centrarse la producción en mayor medida en tareas específicas en desmedro del proceso de producción completo, son mayores las oportunidades que tienen las empresas de los países en desarrollo, incluidas las de los países menos adelantados, de participar en las redes regionales y mundiales de comercio. Además, con la expansión del comercio y de la inversión Sur-Sur, los resultados económicos de los países en desarrollo están más interrelacionados.

En la esfera de la cooperación para el desarrollo el optimismo está cediendo el paso a la nueva realidad fiscal de los países de la OCDE, cuyos presupuestos de ayuda están sometidos a presiones. Pese a la disminución -que cabe esperar sea transitoria- del gasto de los países de la OCDE en ayuda, sigue habiendo un volumen considerable de fondos disponibles, en particular a través de la cooperación Sur-Sur, la cooperación triangular y el sector privado.

La respuesta entusiasta a la encuesta de seguimiento más reciente de la OCDE y la OMC prueba que los donantes, los asociados Sur-Sur, los países en desarrollo y el sector privado siguen resueltos a lograr los objetivos de la Ayuda para el Comercio. Aún queda mucho por hacer, en particular en lo que se refiere a los obstáculos relacionados con el comercio en las fronteras y dentro de ellas, ya que hay indicios de que esos obstáculos pueden limitar la capacidad de las empresas de los países en desarrollo para establecer cadenas de valor, conectarse a ellas y ascender dentro de ellas. Sin embargo, los países en desarrollo están encarando esos problemas mediante la eliminación de muchas de las medidas restrictivas que afectan a su capacidad para conectarse a ellas. 
La presente publicación encierra un mensaje alentador: nuestros esfuerzos por centrar la atención en la Ayuda para el Comercio estaban bien encaminados. Ahora debemos seguir trabajando en la misma dirección, pero debemos redoblar nuestro empeño para lograr resultados en materia de desarrollo. En el presente informe también se señala la necesidad de incrementar la participación de los proveedores de cooperación Sur-Sur y del sector privado, de hacer mayor hincapié en la adquisición de los conocimientos técnicos necesarios, de ampliar el papel que desempeña la financiación para el desarrollo y de establecer condiciones más favorables para los proyectos transfronterizos y la integración regional.

La Alianza Mundial de Cooperación Eficaz para el Desarrollo puede cumplir una función catalizadora a la hora de asegurarse de que los países en desarrollo aprovechen las distintas formas de financiación para el desarrollo a fin de fomentar el comercio y el desarrollo mediante la "inversión para el comercio". En la presente publicación se examinan ésas y otras cuestiones con el objeto de contribuir a que la Ayuda para el Comercio conserve su pertinencia en el cambiante panorama del comercio y el desarrollo. El informe constituirá también una buena base para el debate y la orientación de las deliberaciones durante la Novena Conferencia Ministerial de la OMC, que tendrá lugar en Bali en diciembre de 2013.

Mucho se ha logrado con la Ayuda para el Comercio, que forma parte integral de la labor de nuestras dos Organizaciones. Pero nuestro trabajo dista aún de haber concluido. Compartimos la esperanza de que en los próximos años el conjunto de los participantes en la Iniciativa aborde con energía renovada los retos que quedan por superar.

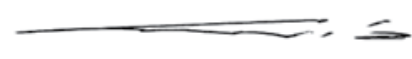

Angel Gurria

Secretario General

OECDE

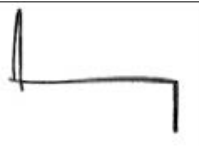

Pascal Lamy

Director General

$\mathrm{OMC}$ 


\section{AGRADECIMIENTOS}

La publicación La Ayuda para el Comercio en síntesis 2013: Conectarse a las cadenas de valor se ha elaborado bajo la dirección del Comité de Asistencia para el Desarrollo y el Comité de Comercio de la OCDE, en estrecha colaboración con el Comité de Comercio y Desarrollo de la OMC.

Las Secretarías de la OCDE y la OMC desean expresar su reconocimiento a todos los gobiernos, organizaciones internacionales y empresas privadas que han participado en esta cuarta labor de vigilancia.

El informe se ha preparado bajo la dirección general de Frans Lammersen (OCDE) y Michael Roberts (OMC).

Los integrantes del equipo de redacción fueron William Hynes, Richard Newfarmer y Michael Plummer, que contaron con la asistencia de Deborah Barker, Olivier Cattaneo, Michael Cornish, María Álvarez de Cózar, Rebecca A. Freeman, Ann Gordon, Marion Jansen, Rainer Lanz, Aime Murigande, Se Eun Park, Ben Shepherd, Alissa Tafti, Conor Trodden y Cristian Ugarte.

El diseño del informe es obra de Peggy Ford-Fyffe King, y John Smith colaboró en la revisión editorial. El equipo contó con la asistencia de Susan Hodgson.

Hacemos extensivo nuestro reconocimiento a los revisores internos, en especial a Evdokia Moïsé, Gregor Slokan y Trudy Witbreuk. 



\section{ÍNDICE}

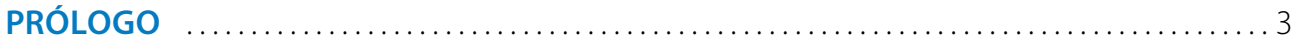

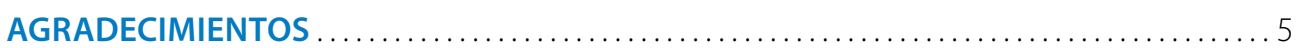

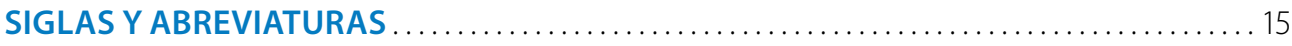

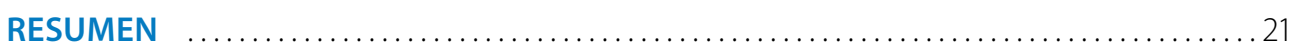

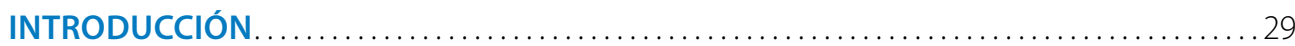

CÓMO SE VIGILA LA AYUDA PARA EL COMERCIO .................................. 31

¿QUIÉN PARTICIPÓ EN LA LABOR DE VIGILANCIA DE 2013? .......................... 32

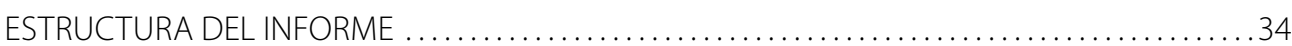

CAPÍTULO 1: ¿SE ESTÁ ADAPTANDO LA AYUDA PARA EL COMERCIO

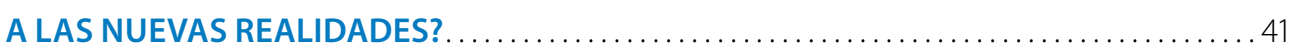

INTRODUCCIÓN ......................................................... 41

¿CÓMO ESTÁN ADAPTANDO SUS ESTRATEGIAS LOS PAÍSES ASOCIADOS? ................42

¿CÓMO ESTÁN REACCIONANDO LOS DONANTES FRENTE A LAS NUEVAS

MODALIDADES DEL COMERCIO? ......................................... 47

¿CÓMO PARTICIPA EL SECTOR PRIVADO? ......................................... 52

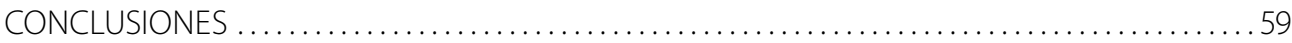

CAPÍTULO 2: CORRIENTES DE AYUDA PARA EL COMERCIO Y FINANCIACIÓN. ........63

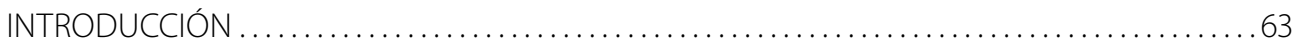

¿QUÉ IMPORTANCIA TIENE LA AYUDA PARA EL COMERCIO EN EL CONTEXTO

DE LA FINANCIACIÓN PARA EL DESARROLLO? ..................................64

¿CUÁL ES LA CUANTÍA DE LA AYUDA PARA EL COMERCIO, Y A QUÉ SE DESTINA? ...........69

¿QUIÉNES SON LOS RECEPTORES DE LA AYUDA PARA EL COMERCIO? ....................80

¿QUIÉNES SON LOS PROVEEDORES DE AYUDA PARA EL COMERCIO? ....................84

¿CÓMO SE SUMINISTRA LA AYUDA PARA EL COMERCIO? .......................... 86

¿CUÁLES SON LAS PERSPECTIVAS DE LAS CORRIENTES DE AYUDA PARA EL COMERCIO? ... 92

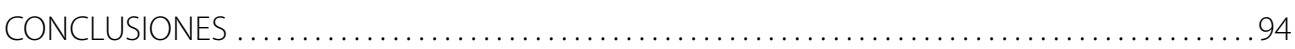

CAPÍTULO 3: LAS CADENAS DE VALOR Y LA SENDA DEL DESARROLLO ............. 99

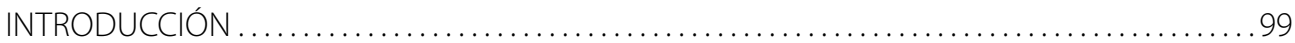

LAS CADENAS DE VALOR COMO SENDA DEL DESARROLLO ........................... 101

¿REPRESENTAN LAS CADENAS DE VALOR UNA PRIORIDAD EN LA AYUDA

PARA EL COMERCIO? .................................................. 106

OPINIÓN DEL SECTOR PÚBLICO SOBRE LOS OBSTÁCULOS QUE SE INTERPONEN AL

ACCESO A LAS CADENAS DE VALOR .............................................. 110 
OPINIÓN DEL SECTOR PRIVADO SOBRE LOS OBSTÁCULOS AL INGRESO

EN LAS CADENAS DE VALOR

LA PARTICIPACIÓN DEL SECTOR PRIVADO ..................................... 128

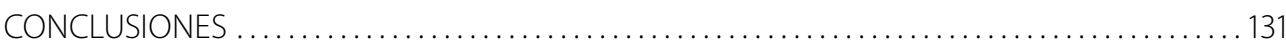

CAPÍTULO 4: IMPULSAR LAS CADENAS DE VALOR POR MEDIO DE LA AYUDA

PARA EL COMERCIO A NIVEL REGIONAL .................................... 137

INTRODUCCIÓN .............................................................. 137

EL REGIONALISMO, LA REGIONALIZACIÓN Y EL PAPEL DE LAS CADENAS DE VALOR........138

REGIONALISMO Y REDES DE PRODUCCIÓN EN LAS ECONOMÍAS EN DESARROLLO.........144

LA AYUDA PARA EL COMERCIO A NIVEL REGIONAL ES UN EFICIENTE CATALIZADOR

DE LAS CADENAS DE VALOR

RELATOS DE EXPERIENCIAS EN QUE LA AYUDA PARA EL COMERCIO A NIVEL

REGIONAL FUE UTILIZADA PARA PROMOVER LAS CADENAS DE VALOR .................. 155

CONCLUSIONES ................................................................ 161

CAPÍTULO 5: EVALUACIÓN DE LA EFICACIA DE LA AYUDA PARA EL COMERCIO ......167

INTRODUCCIÓN ......................................................... 167

¿QUÉ SE ENTIENDE POR ÉXITO EN EL ÁMBITO DE LA AYUDA PARA EL COMERCIO? ..........168

SE NECESITA UN "PRISMA" PARA EVALUAR LOS RESULTADOS DE LA AYUDA .............. 171

ACTUALIZACÓN, SOBRE LA BASE DE NUEVOS DATOS, DE LAS CONCLUSIONES

SOBRE LA RELACIÓN ENTRE LA AYUDA PARA EL COMERCIO Y EL COMERCIO .............. 178

EL SURGIMIENTO DE LAS CADENAS DE VALOR MUNDIALES Y SUS CONSECUENCIAS

PARA LA AYUDA PARA EL COMERCIO ..................................... 182

SISTEMAS DE GESTIÓN: UTILIZACIÓN EFICAZ DE LA AYUDA PARA EL COMERCIO ..........184

CONCLUSIONES ................................................... 189

CAPÍTULO 6: EL CAMINO A SEGUIR ........................................ 199

INTRODUCCIÓN ............................................................ 199

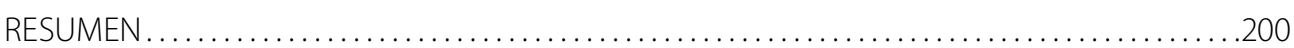

EL CAMINO A SEGUIR..................................................... 204 


\section{HOJAS INFORMATIVAS SOBRE LA AYUDA} PARA EL COMERCIO POR PAÍSES .209

Notas explicativas de las hojas informativas sobre

la ayuda para el comercio por países

Afganistán

Antigua y Barbuda

Bahamas ...

Bangladesh ................................220

Barbados....................................222

Belice .....................................224

Benin...................................226

Bhután.....................................228

Botswana ...................................230

Burkina Faso.................................232

Burundi ....................................234

Cabo Verde .................................236

Camboya ...................................238

Chad ...........................................240

Colombia ...................................242

Comoras ........................................ 244

Costa Rica......................................246

Côte d'Ivoire....................................248

Djibouti ........................................250

Dominica .....................................252

El Salvador .....................................254

Etiopía.......................................256

Fiji......................................258

Gabón .........................................260

Gambia ...................................262

Ghana........................................264

Granada..........................................266

Guatemala ...................................268

Guinea ........................................ 270

Haití.......................................272

Honduras ................................... 274

India ......................................... 276

Indonesia ....................................278

Jamaica ..................................... 280

Jordania........................................ 282

Kenya ......................................284

Lesotho ........................................286

Liberia......................................288
Madagascar...................................290

Malawi ..........................................292

Malí ................................................294

Marruecos.....................................296

Mauricio......................................298

Mauritania......................................300

México ..........................................302

Mozambique.......................................304

Nepal ......................................306

Nicaragua ....................................308

Níger....................................... 310

Nigeria ..................................... 312

Omán................................................ 314

Pakistán ........................................... 316

Panamá ........................................ 318

Papua Nueva Guinea............................... 320

Paraguay.................................... 322

Perú......................................... 324

República Centroafricana...........................326

República del Congo ............................. 328

República Democrática del Congo .................330

República Dominicana ........................... 332

Rwanda........................................ 334

Saint Kitts y Nevis ................................. 336

San Vicente y las Granadinas ....................... 338

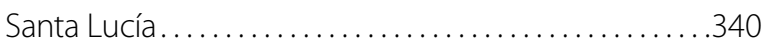

Samoa ......................................... 342

Senegal .........................................344

Sudán...........................................346

Suriname....................................... 348

Tanzanía............................................ 350

Togo ....................................... 352

Trinidad y Tabago ............................. 354

Túnez ................................................ 356

Tuvalu.......................................... 358

Turquía........................................360

Uganda ........................................ 362

Uruguay.......................................364

Vanuatu .......................................366

Yemen .......................................... 368

Zambia...................................... 370

Zimbabwe ..................................372 
NOTAS ESTADÍSTICAS RELATIVAS A LOS DATOS PRINCIPALES SOBRE

LA AYUDA PARA EL COMERCIO.

ANEXO A AYUDA PARA EL COMERCIO: DATOS PRINCIPALES ...................379

Cuadro A.1 Ayuda para el comercio, por categoría ................................ 379

Cuadro A.2A Ayuda para el comercio, por donante y por categoría, por compromisos ......380

Cuadro A.2B Ayuda para el comercio, por donante y por categoría, por desembolsos.......382

Cuadro A.3 Ayuda para el comercio, por donante y por región. ........................384

Cuadro A.4 Ayuda para el comercio, por donante y por grupo de países según nivel de ingresos ................................................. 388

Cuadro A.5A Los 20 principales beneficiarios de ayuda para el comercio en 2011, por compromisos.............................................. 391

Cuadro A.5B Los 20 principales beneficiarios de ayuda para el comercio en 2011, por desembolsos ................................................ 391

Cuadro A.6A Ayuda para el comercio per cápita: los 20 principales beneficiarios de ayuda en 2011, por compromisos per capita ..........................392

Cuadro A.6B Ayuda para el comercio per cápita: los 20 principales beneficiarios de ayuda en 2011, por desembolsos per capita ........................392

Cuadro A.7 Ayuda para el comercio, por beneficiario ................................ 393

Cuadro A.8A Programas multinacionales de ayuda para el comercio, por región . ............396

Cuadro A.8B Programas multinacionales de ayuda para el comercio, por categoría . ........396

Cuadro A.9 Distribución de la ayuda para el comercio, por región . . .....................397

Cuadro A.10 Distribución de la ayuda para el comercio, por grupo de países según nivel

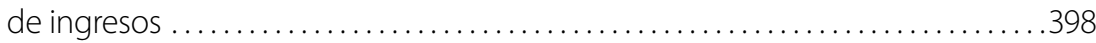

Cuadro A.11 Donaciones y otros tipos de ayuda para el comercio, por categoría. ...........399

Cuadro A.12 Donaciones y otros tipos de ayuda para el comercio, por grupo de ingresos 399

Cuadro A.13A Donaciones en concepto de ayuda para el comercio, por donante . ..........400

Cuadro A.13B Otros tipos de ayuda para el comercio, por donante ......................401

Cuadro A.14 Cauces para el suministro de la ayuda para el comercio....................402

Cuadro A.15 Porcentaje de la ayuda para el comercio en la aod asignada a determinados sectores y en la AOD total. ......................................402

Cuadro A.16 Porcentaje de las otras corrientes oficiales (OCO) relacionadas con el comercio en las OCO asignadas a determinados sectores y en el total de las OCO . .....402

Cuadro A.17 Otras corrientes oficiales relacionadas con el comercio, por categoría.........403

Cuadro A.18 Otras corrientes oficiales relacionadas con el comercio, por donante...........404

Cuadro A.19 Otras corrientes oficiales relacionadas con el comercio, por beneficiario .......405

ANEXO B LISTA DEL CAD DE PAÍSES Y TERRITORIOS BENEFICIARIOS DE AOD, POR GRUPO DE PAÍSES SEGÚN EL NIVEL DE INGRESOS ..............409

ANEXO C LISTA DEL CAD DE PAÍSES Y TERRITORIOS BENEFICIARIOS DE AOD, POR REGIÓN 
ANEXO D CÓDIGOS-OBJETO DEL SNPA RELACIONADOS CON LA AYUDA PARA EL COMERCIO, POR CATEGORÍA. .

ANEXO E ESTIMACIONES MEDIANTE REGRESIÓN.

Cuadro E.1 Efecto de la ayuda para el comercio en las exportaciones de los países en desarrollo (con excepción de las exportaciones de minerales y petróleo) . . . . . 419

Cuadro E.2 Efecto de la ayuda para el comercio en las exportaciones, por grupos de países clasificados según el nivel de ingresos...

Cuadro E.3 Efecto de cada categoría de ayuda para el comercio en las exportaciones, por grupos de países clasificados según el nivel de ingresos

Cuadro E.4 Efecto de la ayuda para el comercio en las exportaciones de piezas y componentes de los países en desarrollo

Cuadro E.5 Efectos de la ayuda para el comercio en las exportaciones de los países en desarrollo en situaciones de buena gestión, por grupos de países clasificados según el nivel de ingresos. .

ANEXO F METODOLOGÍA PARA EL ANÁLISIS ECONOMÉTRICO . .427

Cuadro F.1 Comparación del análisis de la OCDE con otros estudios recientes ............429

Cuadro F.2 Definición de las variables. ....................................430

Cuadro F.3 Resumen estadístico de las principales variables, por grupos de países clasificados según su nivel de ingresos (1995) ........................ 431

Cuadro F.4 Matriz de correlación de las variables de interés.

Cuadro F.5 Efecto diferido de la ayuda para el comercio en las exportaciones de los países en desarrollo (1995).

\section{CUADROS Y GRÁFICOS}

\section{RESUMEN}

\section{Gráficos}

Gráfico 0.1 Participación de las partes interesadas en la Iniciativa de Ayuda para el Comercio. .21

Gráfico 0.2 Ayuda para el comercio por regiones.............................23

Gráfico 0.3 Opiniones del sector público sobre los principales obstáculos que afrontan las empresas para conectarse a las cadenas de valor................... 25

Gráfico 0.4 Opiniones del sector privado sobre los principales obstáculos que afrontan las empresas para conectarse a las cadenas de valor .................... 26

INTRODUCCIÓN

\section{Cuadros}

Cuadro 0.1 Respuestas al cuestionario sobre la ayuda para el comercio. 36 
Cuadro 0.2 Respuestas de los países asociados al cuestionario sobre la ayuda para el comercio ............................................. 36

Cuadro 0.3 Respuestas de los donantes al cuestionario sobre la ayuda para el comercio.... 37

Cuadro 0.4 Respuestas de los proveedores de asistencia en el marco de la cooperación Sur-Sur al cuestionario sobre la ayuda para el comercio ..................... 37

Cuadro 0.5 Respuestas del sector privado al cuestionario sobre la ayuda para el comercio . 37

\section{Gráficos}

Gráfico 0.5

Autoevaluaciones por grupos de encuestados

Gráfico 0.6

Cuestionario dirigido al sector privado. ...

\section{CAPÍTULO 1}

\section{Gráficos}

Gráfico 1.1 Nuevas prioridades en materia de ayuda para el comercio

Gráfico 1.2 Factores que han impulsado la modificación de las estrategias de los países menos adelantados ................................... 45

Gráfico 1.3 Sectores y subsectores identificados como fuentes de crecimiento en las estrategias nacionales de desarrollo de los PMA ....................46

Gráfico 1.4 La función de las importaciones ......................................47 4

Gráfico 1.5 Factores de cambio más importantes y menos importantes para los donantes bilaterales

Gráfico 1.6 Factores de cambio más importantes y menos importantes para los donantes multilaterales......................................... 51

Gráfico 1.7 Consultas con el sector privado para la elaboración de estrategias de ayuda para el comercio.

Gráfico 1.8 Colaboración del sector privado con donantes y proveedores de cooperación Sur-Sur

Gráfico 1.9 Beneficios que los donantes y los proveedores de cooperación Sur-Sur consideran que reportan las asociaciones entre el sector público y el sector privado

Gráfico 1.10 Dificultades con que tropiezan los donantes para establecer asociaciones entre el sector público y el sector privado .58

\section{CAPÍTULO 2}

\section{Cuadros}

Cuadro 2.1 Volumen bruto estimado de las corrientes de financiación en condiciones concesionarias destinadas a la cooperación para el desarrollo suministradas por los BRICS (corrientes "asimilables a la AOD").

\section{Gráficos}

Gráfico 2.1

Corrientes de financiación del desarrollo en los países de ingresos bajos. ...

Gráfico 2.2 Corrientes de financiación del desarrollo en los países de ingresos medianos...66

Gráfico 2.3 Fuentes de financiación más importantes según los países asociados 67

Gráfico 2.4 Fuentes de financiación más importantes para los países menos adelantados, según los donantes bilaterales. 
Gráfico 2.5 Fuentes de financiación más importantes para los países menos adelantados, según los proveedores de asistencia en el marco de la cooperación Sur-Sur . . . .68

Gráfico 2.6 Compromisos de ayuda para el comercio.............................. 70

Gráfico 2.7 Ayuda para la creación de capacidad productiva ........................... 71

Gráfico 2.8 Marcador de fomento del comercio ................................ 73

Gráfico 2.9 Ayuda para la creación de infraestructura económica...................... 74

Gráfico 2.10 Ayuda para la política y la reglamentación comerciales ..................... 76

Gráfico 2.11 Desembolsos por concepto de ayuda para el comercio .................... 79

Gráfico 2.12 Ayuda para el comercio, por región................................. 81

Gráfico 2.13 Ayuda para el comercio, por grupos de países según su nivel de ingresos ..... 82

Gráfico 2.14 Programas multinacionales ..................................... 83

Gráfico 2.15 Los 10 principales donantes de ayuda para el comercio..................... 85

Gráfico 2.16 Ayuda para el comercio prometida por el G-20 ....................... 85

Gráfico 2.17 Desembolsos de préstamos y de donaciones por concepto de ayuda para el comercio .............................................. 87

Gráfico 2.18 Otras corrientes oficiales relacionadas con el comercio ......................88

Gráfico 2.19 Otras corrientes oficiales relacionadas con el comercio, por grupos de países según el nivel de ingresos ............................... 88

Gráfico 2.20 Variación del gasto por concepto de ayuda para el comercio desde el comienzo de la crisis económica .................................... 92

Gráfico 2.21 Variación de la cuantía total de la ayuda para el comercio prevista para los cinco próximos años .................................. 93

\section{CAPÍTULO 3}

\section{Gráficos}

Gráfico 3.1 Experiencia de los donantes bilaterales en materia de creación de cadenas de valor

Gráfico 3.2 Experiencia de los donantes multilaterales en materia de creación de cadenas de valor .......................................... 108

Gráfico 3.3 Experiencia de los proveedores de cooperación Sur-Sur en materia de creación de cadenas de valor

Gráfico 3.4 Principales obstáculos con que tropiezan las empresas para ingresar en las cadenas de valor a juicio de los países asociados ................... 111

Gráfico 3.5 Principales obstáculos con que tropiezan las empresas para ingresar en las cadenas de valor a juicio de los donantes bilaterales 111

Gráfico 3.6 Principales obstáculos con que tropiezan las empresas para ingresar en las cadenas de valor a juicio de los donantes multilaterales

Gráfico 3.7 Principales obstáculos con que tropiezan las empresas para ingresar en las cadenas de valor a juicio de los proveedores de cooperación Sur-Sur relacionada con el comercio .......................................... 113

Gráfico 3.8 Tipos de ayuda que los países asociados consideran "muy eficaces" . . . . . . . . 114 
Gráfico 3.9 Factores que ejercen mayor influencia sobre las decisiones en materia de fuentes de abastecimiento e inversiones en las cadenas de valor del sector agroalimentario .

Gráfico 3.10 Dificultades con que se tropieza para conectar a los países en desarrollo a las cadenas de valor del sector de los textiles y las prendas de vestir ....

Gráfico 3.11 Dificultades con que se tropieza para conectar a los países en desarrollo a las cadenas de valor del sector del turismo............................. 121

Gráfico 3.12 Dificultades con que se tropieza para conectar a los países en desarrollo a las cadenas de valor en el sector del transporte y la logística.

Gráfico 3.13 Dificultades con que se tropieza para conectar a los países en desarrollo a las cadenas de valor en el sector de la tecnología de la información y las comunicaciones

Gráfico 3.14 Iniciativas emprendidas por las empresas líderes para conectar a los proveedores de los países en desarrollo a cadenas de valor ....

Gráfico 3.15 Motivos de las empresas líderes para conectar mejor a los proveedores de los países en desarrollo a sus cadenas de valor.

Gráfico 3.16 Evaluación por las empresas líderes del efecto de las actividades encaminadas a conectar a proveedores de países en desarrollo a las cadenas de valor.

Gráfico 3.17 Conectar a los proveedores de países en desarrollo a cadenas de valor: enseñanzas extraídas

Gráfico 3.18 Gestión público-privada de los programas de ayuda para el comercio 131

\section{CAPÍTULO 4}

\section{Cuadros}

Cuadro 4.1

Reseña de los obstáculos al comercio intrarregional y extrarregional. ... 151

\section{Gráficos}

Gráfico 4.1

Programas regionales y mundiales por categoría (desembolsos) .153

Gráfico 4.2

Distribución geográfica de los programas regionales y mundiales (desembolsos)

\section{CAPÍTULO 5}

\section{Cuadros}

Cuadro 5.1 Estimación del aumento de las exportaciones totales como resultado del aumento de la ayuda para el comercio.

Cuadro 5.2 El sistema de gestión basada en los resultados de Rwanda incluye indicadores de resultados y de aplicación de políticas a diversos niveles del gobierno ..... 187

\section{Gráficos}

Gráfico 5.1 Efecto previsto del incremento de la ayuda para el comercio en las exportaciones

Gráfico 5.2 Efecto de distintos incrementos de la ayuda para el comercio en las exportaciones de partes y componentes....

Gráfico 5.3

Las siete etapas de una gestión basada en los resultados eficaz. ... 


\section{SIGLAS Y ABREVIATURAS}

\begin{tabular}{|c|c|}
\hline \$EE.UU. & Dólar estadounidense \\
\hline AAE & Acuerdo de asociación económica \\
\hline AANZFTA & Zona de libre comercio entre la ASEAN, Australia y Nueva Zelandia \\
\hline $\mathrm{AClCl}$ & Agencia de Cooperación y de Información para el Comercio Internacional \\
\hline ACNUR & Oficina del Alto Comisionado de las Naciones Unidas para los Refugiados \\
\hline ACP & Grupo de Estados de África, el Caribe y el Pacífico \\
\hline ACR & Acuerdo Comercial Regional \\
\hline ADPIC & $\begin{array}{l}\text { Aspectos de los derechos de propiedad intelectual relacionados } \\
\text { con el comercio }\end{array}$ \\
\hline ADVANCE & $\begin{array}{l}\text { Agriculture Development Value Chain Enhancement Programme } \\
\text { (Programa de fomento del desarrollo agrícola mediante cadenas de valor) }\end{array}$ \\
\hline AEC & Comunidad Económica de la ASEAN \\
\hline AECSP & Programa de asistencia en materia de cooperación económica de la AANZFTA \\
\hline AFTA & Zona de Libre Comercio de la ASEAN \\
\hline AFTi & Africa Free Trade Initiative (Iniciativa de Libre Comercio para África) \\
\hline AGOA & Ley de Crecimiento y Oportunidades para África (Estados Unidos) \\
\hline AlF & Asociación Internacional de Fomento \\
\hline ALC & Acuerdo de Libre Comercio \\
\hline ANI & Agencia Nacional de Infraestructura \\
\hline $\mathrm{AOD}$ & Asistencia oficial para el desarrollo \\
\hline APEC & Foro de Cooperación Económica de Asia y el Pacífico \\
\hline ASEAN & Asociación de Naciones del Asia Sudoriental \\
\hline ATRC & Asistencia técnica relacionada con el comercio \\
\hline BADEA & Banco Árabe para el Desarrollo Económico de África \\
\hline BAfD & Banco Africano de Desarrollo \\
\hline BAsD & Banco Asiático de Desarrollo \\
\hline BERD & Banco Europeo de Reconstrucción y Desarrollo \\
\hline $\mathrm{BIC}$ & Banco Interamericano de Desarrollo \\
\hline BIRF & Banco Internacional de Reconstrucción y Fomento \\
\hline BlsD & Banco Islámico de Desarrollo \\
\hline BMD & Banco multilateral de desarrollo \\
\hline GGF & Fundación Bill y Melinda Gates \\
\hline
\end{tabular}


BMZ

CAD

CAFTA

CAO

CAREC

CARICOM

CARTFund

CBI

CE

CEDEAO

CEPA

CEPA

CEPE

CESPAO

CESPAP

CIDA

CPAF

CTPSD

DELP

DFID

DIME

DPAF

DPI

EDIC

EDPRS

EPC

ETLS

EUR

EXPECT
Bundesministerium für wirtschaftliche Zusammenarbeit und Entwicklung

(Ministerio Federal de Alemania para la Cooperación y el Desarrollo

Económicos)

Comité de Asistencia para el Desarrollo

Tratado de Libre Comercio de Centroamérica

Comunidad del África Oriental

Programa de Cooperación Económica Regional de Asia Central

Comunidad del Caribe

Fondo Fiduciario Caribeño de Ayuda para el Comercio y la Integración Regional

Centrum tot Bevordering van de Import uit Ontwikkelingslanden

(Centro de los Países Bajos para la promoción de las importaciones

provenientes de los países en desarrollo)

Comisión Europea

Comunidad Económica de los Estados del África Occidental

Comisión Económica para África

Comisión Económica para África

Comisión Económica para Europa

Comisión Económica y Social para Asia Occidental

Comisión Económica y Social para Asia y el Pacífico

Organismo Canadiense de Desarrollo Internacional

Common Performance Assessment Framework

(Marco común de evaluación de los resultados)

Programa de desarrollo del comercio y el sector privado del Caribe

Documento de estrategia de lucha contra la pobreza

Departamento para el Desarrollo Internacional del Reino Unido

Development Impact Evaluation

(Evaluación del impacto en el desarrollo)

Donor Performance Assessment Framework

(Marco de evaluación de los resultados de los donantes)

Derechos de propiedad intelectual

Estudio de diagnóstico de la integración comercial

Economic Development and Poverty Reduction Strategy

(Estrategia de desarrollo económico y reducción de la pobreza)

Examen de las Políticas Comerciales

Plan de liberalización del comercio de los Estados del África Oriental

Euro

Iniciativa de Promoción de las Exportaciones y Competitividad

de las Empresas para el Comercio 


\begin{tabular}{|c|c|}
\hline FADES & Fondo Árabe de Desarrollo Económico y Social \\
\hline FANFC & Fondo para la Aplicación de Normas y el Fomento del Comercio \\
\hline $\mathrm{FAO}$ & Organización de las Naciones Unidas para la Alimentación y la Agricultura \\
\hline FEM & Foro Económico Mundial \\
\hline FIDA & Fondo Internacional de Desarrollo Agrícola \\
\hline FMAM & Fondo para el Medio Ambiente Mundial \\
\hline $\mathrm{FMl}$ & Fondo Monetario Internacional \\
\hline FTAAP & Zona de Libre Comercio de Asia y el Pacífico \\
\hline $\mathrm{G}-20$ & Grupo de los 20 \\
\hline G-7 & Grupo de los 7 \\
\hline GBM & Grupo del Banco Mundial \\
\hline GFP & Asociación Mundial para la Facilitación del Transporte y el Comercio \\
\hline $\mathrm{GIZ}$ & $\begin{array}{l}\text { Gesellschaft für Internationale Zusammenarbeit } \\
\text { (Sociedad de Cooperación Internacional) }\end{array}$ \\
\hline HLF-4 & Cuarto Foro de Alto Nivel sobre la Eficacia de la Ayuda al Desarrollo \\
\hline ICC & Cámara de Comercio Internacional \\
\hline ICTSD & Centro Internacional de Comercio y Desarrollo Sostenible \\
\hline $\mathrm{IDH}$ & Iniciativa de Comercio Sostenible \\
\hline IED & Inversión extranjera directa \\
\hline IFC & Corporación Financiera Internacional \\
\hline $\mathrm{IFI}$ & Instituciones financieras internacionales \\
\hline INB & Ingreso Nacional Bruto \\
\hline IPRCC & Centro Internacional para la Reducción de la Pobreza - China \\
\hline ITC & Centro de Comercio Internacional \\
\hline IVA & Impuesto sobre el valor añadido \\
\hline$J I C A$ & Organismo de Cooperación Internacional del Japón \\
\hline MdE & Memorándum de Entendimiento \\
\hline $\mathrm{Ml}$ & Marco Integrado \\
\hline MIM & Marco Integrado mejorado \\
\hline MSF & Medidas sanitarias y fitosanitarias \\
\hline NEPAD & Nueva Alianza para el Desarrollo de África \\
\hline NMF & Nación más favorecida \\
\hline $\mathrm{NU}$ & Naciones Unidas \\
\hline OCDE & Organización de Cooperación y Desarrollo Económicos \\
\hline OCO & Otras corrientes oficiales \\
\hline ODM & Objetivos de Desarrollo del Milenio \\
\hline OEA & Organización de los Estados Americanos \\
\hline
\end{tabular}




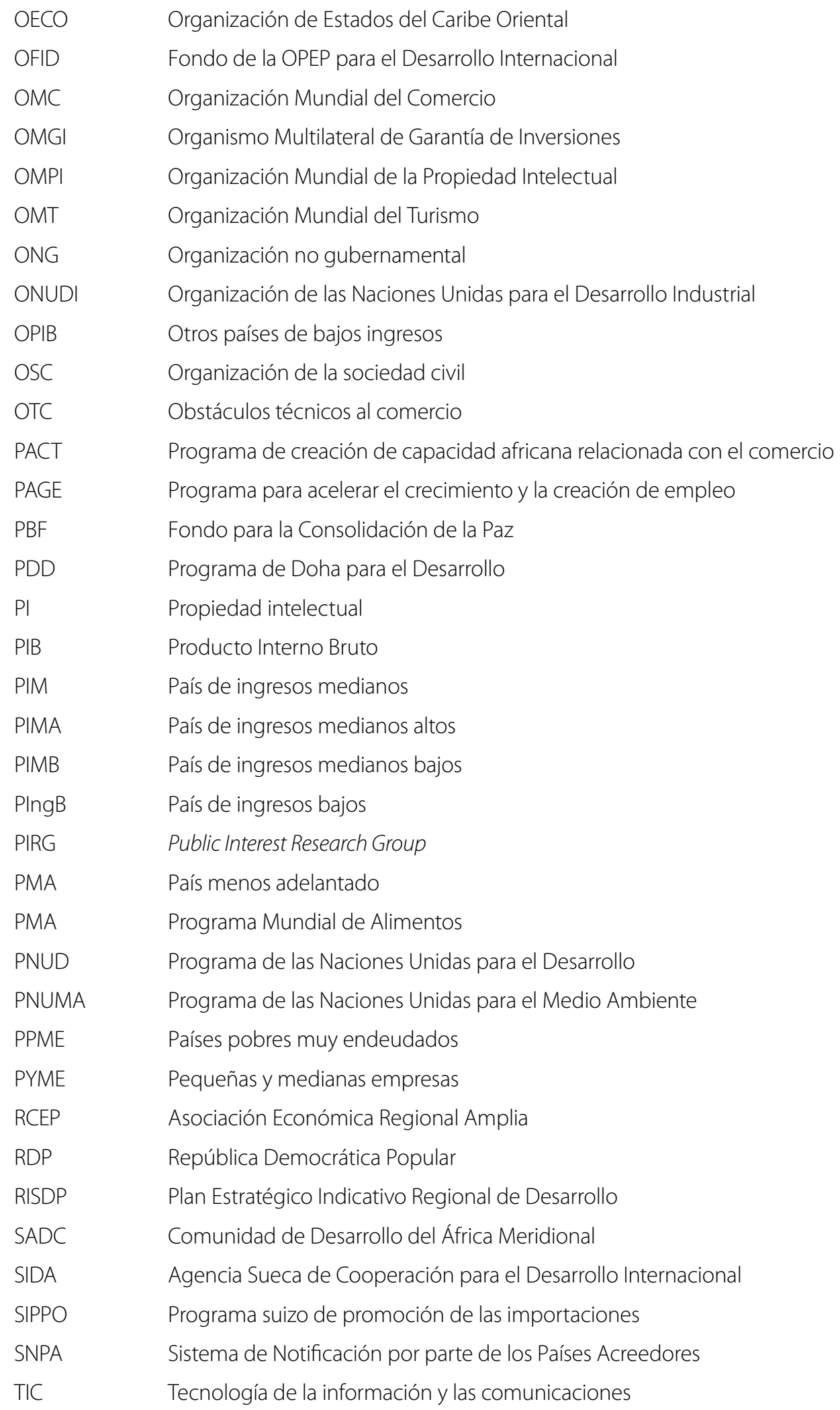


TLCAN Tratado de Libre Comercio de América del Norte

UA Unión Africana

UE Unión Europea

UEMAO Unión Económica y Monetaria del África Occidental

UIT Unión Internacional de Telecomunicaciones

UNCTAD Conferencia de las Naciones Unidas sobre Comercio y Desarrollo

UNICEF Fondo de las Naciones Unidas para la Infancia

USAID Agencia de los Estados Unidos para el Desarrollo Internacional 



\section{RESUMEN}

En el informe La Ayuda para el Comercio en síntesis, 2013: Conectarse a las cadenas de valor se analizan las estrategias, las prioridades y los programas de los sectores público y privado de los países en desarrollo y desarrollados destinados a conectar a los proveedores de los países en desarrollo a las cadenas de valor. Según el informe, la creciente fragmentación de los procesos de producción ofrece a los países en desarrollo nuevas oportunidades de comercio, pero también conlleva riesgos. Las cadenas de valor confirman la importancia de mantener los mercados abiertos, y ponen de relieve el costo de los engorrosos procedimientos que crean "fronteras densas".

La ayuda para el comercio contribuye considerablemente a moderar las políticas y las limitaciones fundamentales relacionadas con el comercio que impiden a las empresas de los países en desarrollo conectarse a las cadenas de valor o ascender en ellas, lo que, según el informe, puede lograrse de forma aún más eficaz dando una mayor participación al sector privado, mejorando el entorno empresarial, mejorando las cualificaciones de la fuerza de trabajo, creando las condiciones necesarias para la ejecución de proyectos regionales, destinando la ayuda al logro de resultados a nivel del comercio y el desarrollo y utilizándola para movilizar la inversión productiva.

\section{Gráfico 0.1 Participación de las partes interesadas en la Iniciativa de Ayuda para el Comercio}

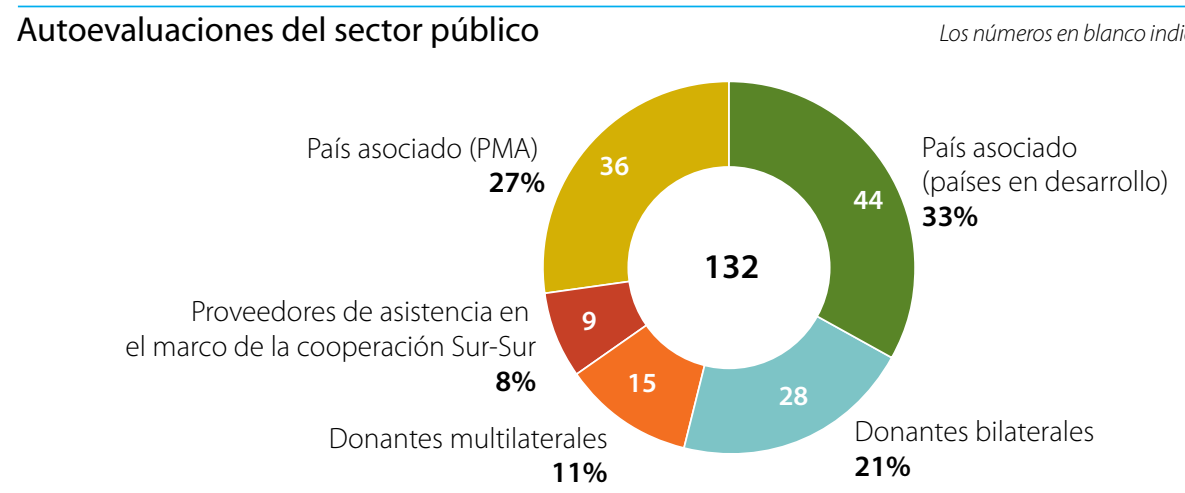

Respuestas del sector privado

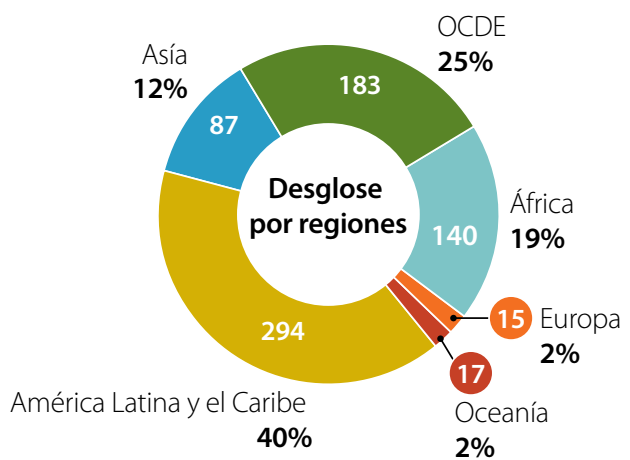

Los números en blanco indican el número de respuestas.

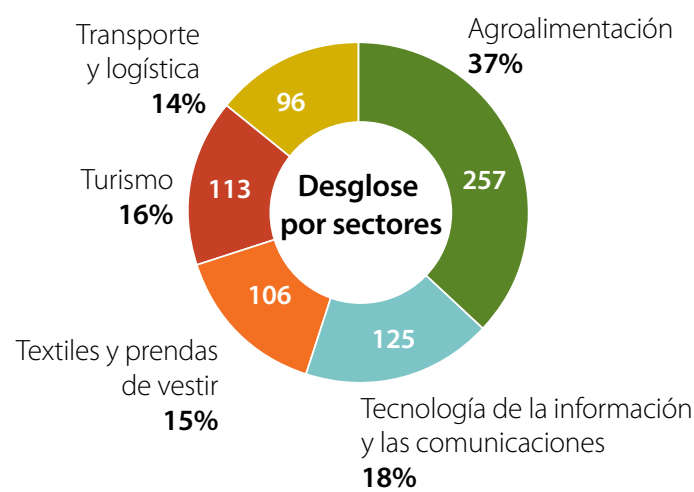

Fuente:: Cuestionario OCDE/OMC (2013), www.aid4trade.org

Nota: Sobre la base de las respuestas de países en desarrollo de África, América Latina y el Caribe, Asia, Europa y Oceanía, así como de países de la OCDE (algunas de estas categorías se superponen). 
Todas las partes interesadas siguen participando activamente en la Iniciativa de Ayuda para el Comercio, como lo demuestran las 132 autoevaluaciones efectuadas por 80 países en desarrollo (incluidos 36 países menos adelantados), 28 donantes bilaterales, 15 donantes multilaterales y 9 proveedores de asistencia en el marco de la cooperación Sur-Sur. Además, 524 empresas proveedoras de países en desarrollo dieron sus opiniones sobre los obstáculos con que tropezaban para conectarse a las cadenas de valor, y 173 empresas líderes (ubicadas, en su mayoría, aunque no exclusivamente, en países de la Organización de Cooperación y Desarrollo Económicos (OCDE)) describieron en sus respuestas las dificultades a que hacían frente para integrar en sus cadenas de valor a empresas de países en desarrollo.

La ayuda para el comercio sigue siendo importante...
La aparición de las cadenas de valor refuerza los argumentos en pro de la prestación de asistencia relacionada con el comercio y está imprimiendo nuevo impulso al debate sobre la ayuda para el comercio. Los países en desarrollo procuran participar en las cadenas de valor para alcanzar sus objetivos de crecimiento económico, creación de empleo y reducción de la pobreza.
... para aumentar la competitividad, reducir el costo de comerciar y conectarse a las cadenas de valor.

\section{El sector privado desempeña un papel cada vez más importante.}

En 2011, los compromisos de ayuda para el comercio alcanzaron la cifra de 41.500 millones de dólares EE.UU., o sea un aumento del $57 \%$ respecto de la cifra correspondiente al período de referencia (2002-2005).

Hay menos ayuda para la infraestructura económica, pero...
Los países en desarrollo, incluidos los menos adelantados, están destinando la inversión pública (incluida la AOD) a reducir la densidad de sus fronteras, a aumentar la competitividad y a crear las condiciones necesarias para que sus empresas puedan conectarse a las cadenas de valor. Los donantes están respondiendo a estas nuevas prioridades centrando su ayuda en el desarrollo del sector privado y en programas regionales encaminados a reducir el costo de comerciar.

Cada vez más se reconoce la importancia del sector privado como parte interesada en el diálogo sobre la ayuda para el comercio, como socio en la prestación de esa clase de ayuda, y, en algunos casos, como proveedor de ayuda para la creación de capacidad. Sin embargo, la función que desempeñan las asociaciones entre los sectores público y privado y las expectativas en torno a ellas siguen planteando dificultades.

Aunque la ayuda destinada a la creación de capacidad a nivel de la oferta sigue siendo una prioridad importante, en 2011 la cuantía de los compromisos disminuyó a 41.500 millones de dólares EE.UU. debido a la crisis financiera, que ejerció una presión a la baja sobre los presupuestos de los miembros del CAD destinados a la ayuda. Ese año, la cuantía de los compromisos en materia de ayuda para el comercio volvió al nivel alcanzado en el período 2008 2009. Sin embargo, pese a haber disminuido en un $14 \%$, ese nivel sigue superando en un $57 \%$ al correspondiente al período de referencia (2002-2005).

Como resultado de la disminución registrada en 2011, por valor de 6.400 millones de dólares EE.UU., disminuyó también la ayuda destinada a grandes proyectos de infraestructura económica: la cuantía de los compromisos destinados a los sectores del transporte y de la energía disminuyó en 3.500 millones de dólares EE.UU. y 3.200 millones de dólares EE.UU., respectivamente. 


\section{Gráfico 0.2 Ayuda para el comercio por regiones (En miles de millones de dólares EE.UU., valores constantes de 2011)}

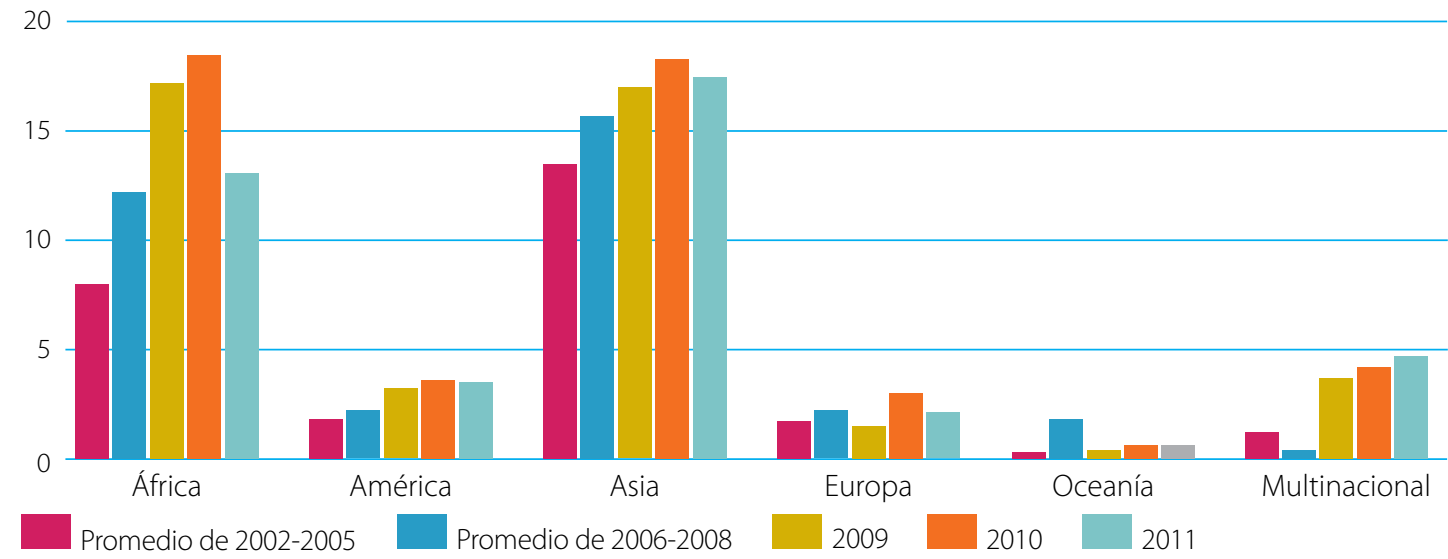

Fuente: Base de datos del SNPA de la OCDE, http://stats.oecd.org/index.aspx?DataSetCode=CRS1\#.

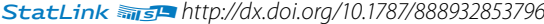

... más para la creación de capacidad productiva, y...

... se han duplicado los fondos destinados al componente de fomento del comercio y al ajuste relacionado con el comercio.

\section{Asia es la región que recibe} más ayuda, y...
Sin embargo, los compromisos para la creación de capacidad productiva aumentaron a 18.000 millones de dólares EE.UU. en 2011, lo que es indicio de la prioridad cada vez mayor que los países asociados y los donantes asignan al desarrollo del sector privado. El apoyo prestado al sector de los servicios a las empresas, al sector agrícola y al sector de la industria aumentó en un 10\%.

Desde 2007 los fondos para programas encaminados claramente a promover el comercio se han duplicado hasta alcanzar 5.400 millones de dólares EE.UU., mientras que la cuantía de los fondos para el ajuste relacionado con el comercio (62.800 millones de dólares EE.UU.) ha aumentado a más del doble de la correspondiente al año anterior. La cuantía de los compromisos destinados a la facilitación del comercio ascendió a 380 millones de dólares EE.UU. en 2011.

Actualmente, Asia es la región que recibe la mayor proporción de la ayuda para el comercio: 17.000 millones de dólares EE.UU. El fuerte crecimiento de la ayuda para el comercio destinada a África registrado en los últimos años se ha detenido: la ayuda disminuyó a 13.100 millones de dólares EE.UU. La ayuda para el comercio destinada a las economías europeas emergentes también ha disminuido, mientras que otras regiones continúan recibiendo niveles de ayuda relativamente estables, aunque más bajos. 

... los países de ingresos bajos
reciben el grueso de la ayuda.

Los países miembros del G-20

y el CAD podrían terminar no cumpliendo su promesa, ...

... pero China y la India han incrementado el nivel de su ayuda.

Se pronostica otra modesta reducción general de la ayuda.

\section{Las cadenas de valor pueden servir para promover el desarrollo económico ...}

... en particular en los sectores de la agroalimentación, el turismo y los textiles, pero ...
La disminución de los presupuestos para la AOD y la consiguiente reducción de los compromisos globales por concepto de ayuda para el comercio han afectado a todos los grupos de países de la clasificación según el nivel de ingresos. Sin embargo, los PMA han sido los menos afectados y los países de ingresos bajos ahora reciben la mayor proporción del total de esa ayuda. Los países en desarrollo, con una situación económica relativamente mejor, recurren cada vez con mayor frecuencia a la inversión interna y a la inversión extranjera directa para hacer frente a las limitaciones fundamentales relacionadas con el comercio.

El nivel de la ayuda para el comercio prestada por los países miembros del G-20 y el CAD está 831 millones de dólares EE.UU. por debajo del nivel medio de la ayuda para el comercio prestada por esos países durante el período 2006-2008, que era el nivel que se comprometieron a mantener después de 2011.

En 2011, China y la India, además de la ayuda prestada en condiciones ordinarias, duplicaron la cuantía de su AOD, que ascendió a 2.400 millones de dólares EE.UU. y 730 millones de dólares EE.UU., respectivamente. La asistencia relacionada con el comercio en el marco de la cooperación Sur-Sur se está convirtiendo en un complemento cada vez más importante de la ayuda para el comercio.

Para 2012 se pronostica otra modesta reducción de los compromisos bilaterales por concepto de ayuda para el comercio, que representan el $60 \%$ de los compromisos totales. A nivel de los donantes multilaterales la situación es más positiva, mientras que los proveedores de asistencia en el marco de la cooperación Sur-Sur han indicado que su financiación seguirá aumentando.

Desde la puesta en marcha de la Iniciativa de Ayuda para el Comercio en 2005, las cadenas de valor han pasado a ser la característica predominante de la economía mundial. Al proporcionar acceso a las redes, a los mercados regionales y mundiales, al capital, a los conocimientos y la tecnología, las cadenas de valor ofrecen un medio más sencillo de lograr el desarrollo económico que la creación de procesos de producción plenamente integrados.

Los proveedores de los países en desarrollo están bien establecidos en las cadenas de valor de los sectores de la agroalimentación, el turismo, los textiles y las prendas de vestir, mientras que las cadenas de valor de los sectores de la tecnología de la información y las comunicaciones y del transporte y la logística ofrecen oportunidades para reducir la densidad de las fronteras. 
... siguen existiendo obstáculos a nivel de la infraestructura, el acceso a la financiación y el cumplimiento de las normas.

Los proveedores hacen hincapié en la falta de acceso a financiación para el comercio y de infraestructura, así como en la incertidumbre a nivel de la reglamentación; ...

... por su parte, las empresas líderes hacen hincapié en los procedimientos aduaneros y las prescripciones en materia de licencias.
Los países asociados consideran que los principales obstáculos para su integración en las cadenas de valor son la falta de infraestructura adecuada, acceso a la financiación del comercio, cumplimiento de las normas y ventajas comparativas, así como el elevado costo del ingreso a los mercados. Los donantes y los proveedores de asistencia en el marco de la cooperación Sur-Sur también mencionan la falta de mano de obra cualificada y de capacidad para atraer IED, así como las restricciones al comercio.

Los proveedores de países en desarrollo señalan la falta de acceso a financiación para el comercio como el principal obstáculo con que tropiezan para incorporarse a las cadenas de valor, crearlas o ascender en ellas. El costo del transporte, el entorno empresarial y las prescripciones en materia de certificación también figuran entre los obstáculos mencionados. Las empresas líderes consideran que el costo del transporte es el principal obstáculo; también mencionan los procedimientos aduaneros, las prescripciones en materia de licencias y el entorno empresarial entre los impedimentos que afrontan para integrar a los proveedores de países en desarrollo en sus cadenas de valor.

\section{Gráfico 0.3 Opiniones del sector público sobre los principales obstáculos que afrontan las empresas para conectarse a las cadenas de valor (porcentaje de respuestas)}

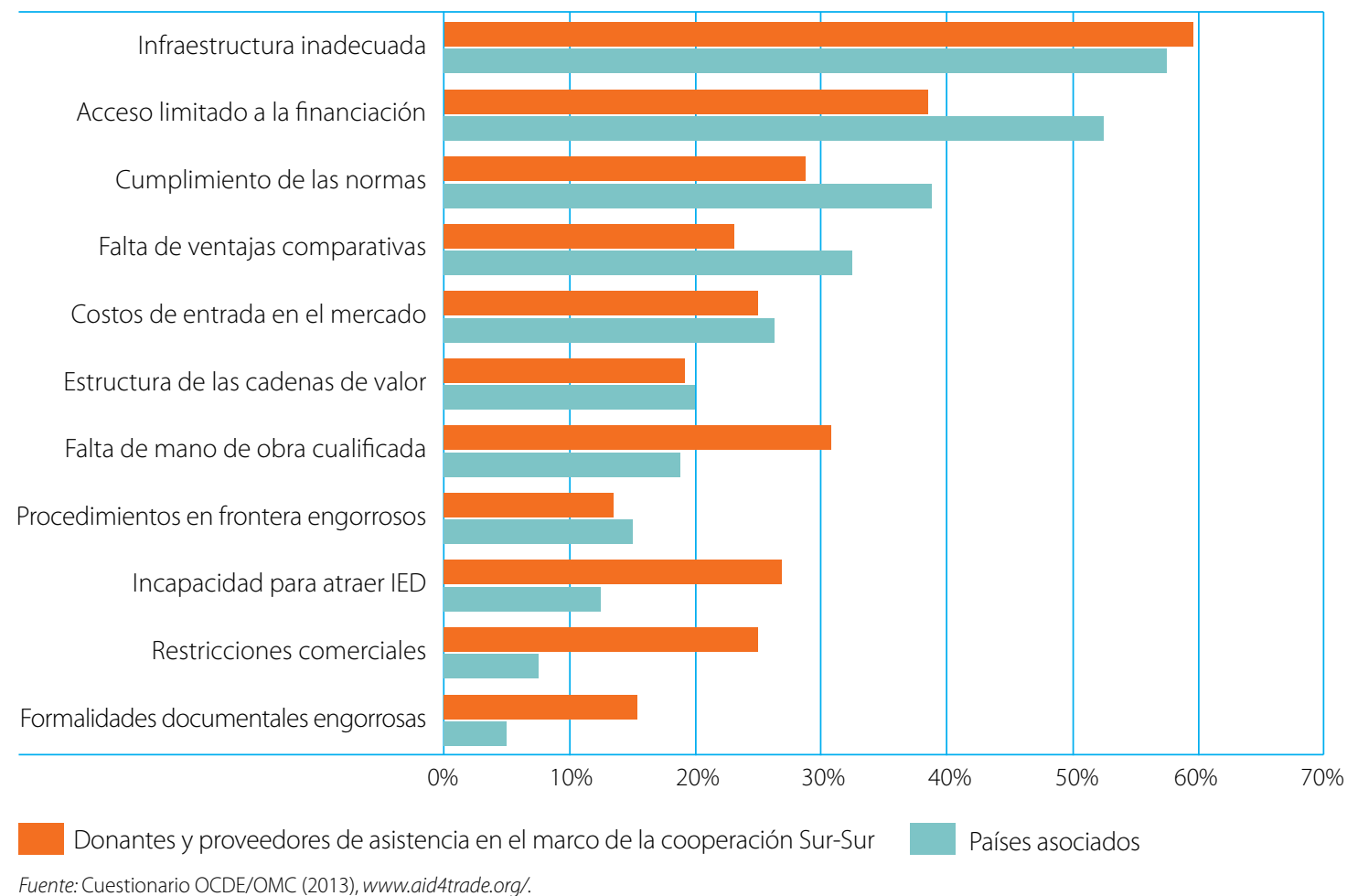




\section{Gráfico 0.4 Opiniones del sector privado sobre los principales obstáculos que afrontan las empresas para conectarse a las cadenas de valor (porcentaje de respuestas)}

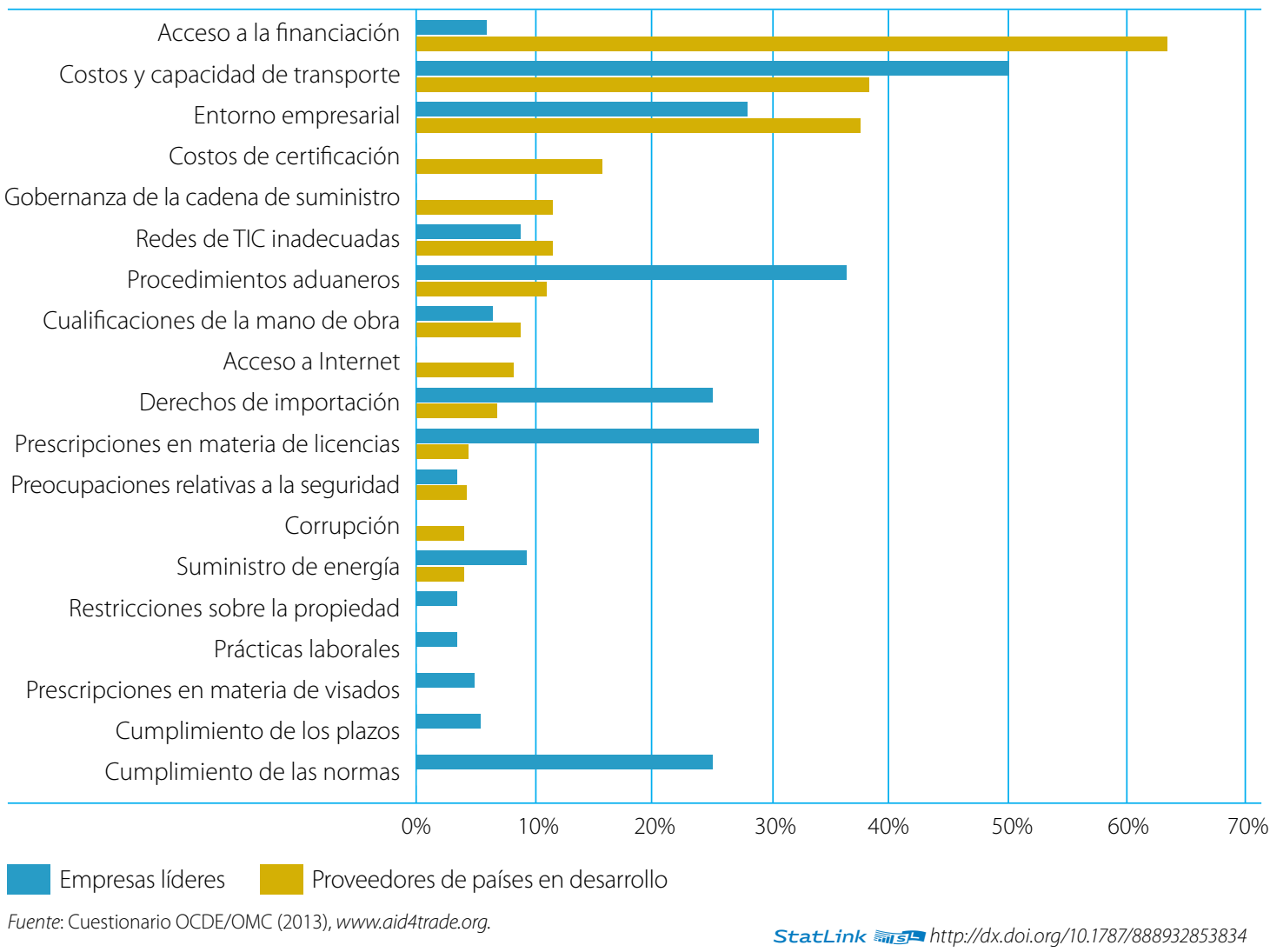

Los programas regionales de ayuda para el comercio pueden reportar mayores beneficios y...

... atraen más fondos para hacer frente a los obstáculos en materia de facilitación del comercio e infraestructura.

La ayuda para el comercio está reduciendo el costo de comerciar, ...
Los programas regionales de ayuda para el comercio son, en general, más eficientes en función del costo para reducir la densidad de las fronteras y suplir las necesidades de infraestructura que los programas destinados a un solo país. Ésos son beneficios que adquieren especial importancia cuando los donantes tienen presupuestos limitados.

El hecho de que en 2011 la ayuda para el comercio a nivel regional se triplicara, para alcanzar 7.700 millones de dólares EE.UU., es prueba de que los países asociados y los donantes son cada vez más conscientes de la repercusión que los programas regionales de ayuda para el comercio pueden tener en el logro de objetivos comerciales y de desarrollo.

Existen abundantes pruebas de que la ayuda para el comercio, en combinación con políticas complementarias, contribuye a reducir el costo de comerciar mediante la creación de infraestructura, la mejora de las instituciones (como las aduanas y las autoridades de normalización), el aumento de políticasy reglamentos másfavorables al comercio, o por medio de procedimientos normativos que aumentan la competencia y reducen los precios. 


\author{
... mejorando los resultados \\ comerciales ...
}

\section{... e incrementando el comercio de piezas y componentes.}

No hay necesidad de dar una nueva orientación a la ayuda para el comercio, pero ...

\section{... hay que prestar más atención a la eficiencia de la importación.}

\section{Podrían aplicarse mejor los principios en materia de eficacia de la ayuda, y ...}

\section{... en los programas de ayuda para el comercio debería tenerse en cuenta el marco normativo más amplio.}

Lo que ahora parece ser más necesario es que todas las partes interesadas renueven su compromiso de seguir ayudando a los países en desarrollo a crear la capacidad a nivel de la oferta y la infraestructura necesarias para hacer del comercio un motor de crecimiento y de reducción de la pobreza. El Cuarto Examen Global de la Ayuda para el Comercio y la Novena Conferencia Ministerial de la Organización Mundial del Comercio (OMC), que tendrán lugar en julio y diciembre de 2013, respectivamente, brindarán a los Miembros una importante oportunidad para examinar la manera de que la Iniciativa de Ayuda para el Comercio siga siendo pertinente en un entorno comercial y de desarrollo en evolución.
El análisis econométrico indica que, en general, la ayuda para el comercio a nivel bilateral guarda relación con la mejora de los resultados comerciales. Según los cálculos que figuran en el presente informe, una inversión de 1 dólar EE.UU. en ayuda para el comercio genera un aumento de casi 8 dólares EE.UU. en las exportaciones procedentes de todos los países en desarrollo; ese aumento es de 9 dólares EE.UU. en el caso de los países de ingresos bajos y medianos bajos y de 20 dólares EE.UU. en el de los países que reciben préstamos de la Asociación Internacional de Fomento (AIF).

Mediante el análisis econométrico también se ha comprobado que la ayuda para el comercio guarda una relación aún más positiva y significativa con el crecimiento del comercio de piezas y componentes.

La progresiva proliferación de las cadenas de valor está modificando la naturaleza de las corrientes comerciales mundiales y dando más oportunidades comerciales a los proveedores de países en desarrollo. La actual orientación de la ayuda para el comercio permite abordar las cuestiones que hace falta abordar para seguir apoyando ese proceso. No parece, pues, necesario dar una nueva orientación a la Iniciativa de Ayuda para el Comercio.

Al mismo tiempo, el aumento de la eficiencia de la importación parece ser un aspecto que requiere mayor atención. Con mucha frecuencia, en los programas de ayuda para el comercio no se presta suficiente atención a esta dimensión de la competitividad, que, no obstante, es indispensable para que los proveedores de los países en desarrollo puedan conectarse a las cadenas de valor.

Todas las partes interesadas insisten en que, para obtener resultados tangibles en materia de comercio y desarrollo, se requiere una mejor gestión de la ayuda. Los gobiernos que colaboran con los donantes en la elaboración de programas de ayuda para el comercio con objetivos e indicadores de resultados claros para cada etapa de la cadena de resultados son los que suelen obtener los mayores beneficios.

También es necesario que en los programas de ayuda para el comercio se tenga en cuenta el marco normativo más amplio, en particular a nivel de la política comercial, pero también de las políticas complementarias. 



\section{INTRODUCCIÓN}

En

general, los economistas coinciden en que existen fuertes vínculos entre el comercio, el — crecimiento económico y la reducción de la pobreza. Los países que han adoptado una estrategia de desarrollo orientada al exterior y centrada en la liberalización del comercio no sólo han obtenido mejores resultados que las economías replegadas sobre sí mismas, como lo demuestran sus tasas de crecimiento global a largo plazo, sino que, además, han logrado reducir los índices de pobreza y tener mejores indicadores sociales. Son muchos los cauces por los que el crecimiento inducido por el comercio reduce la pobreza. Las exportaciones permiten a un país aprovechar su ventaja comparativa e incrementar su eficiencia y productividad globales, y permiten a sus empresas emplear los recursos de manera más eficiente y rentable. Esos factores hacen aumentar la demanda, estimulan el consumo y reducen los riesgos que se corren cuando se depende del mercado interno. También hacen aumentar el empleo en sectores con gran intensidad de mano de obra, así como los salarios y el nivel de vida. Las importaciones dan a los países acceso a una gama más amplia de bienes y servicios; gracias a ellas, las empresas nacionales obtienen acceso a tecnología distinta, más barata y más moderna que les permite aumentar su productividad y competitividad (OCDE, 2011).

Si bien podría seguir incrementándose el acceso de los países en desarrollo a los mercados de los miembros de la OCDE y los países emergentes, por otro lado, las sucesivas rondas de liberalización multilateral del comercio, los acuerdos regionales de libre comercio y diversos arreglos preferenciales han dado a los países en desarrollo más oportunidades de comerciar. Sin embargo, cuando su capacidad es limitada, o cuando carecen de infraestructura para el comercio, los países en desarrollo pueden tener dificultades para transformar las oportunidades en corrientes comerciales. Además, las limitaciones internas relacionadas con el comercio pueden atenuar la repercusión que la expansión comercial tiene en el crecimiento económico y la reducción de la pobreza. La Iniciativa de Ayuda para el Comercio se emprendió para tratar de resolver esa clase de problemas. Mediante la Iniciativa se ha logrado que los países asociados y los países donantes tomen conciencia del papel positivo que puede cumplir el comercio en el fomento del crecimiento económico y el desarrollo. Además, se están dedicando más recursos (en condiciones concesionarias y en condiciones ordinarias) a subsanar las limitaciones fundamentales relacionadas con el comercio y a lograr que el comercio reporte mayores beneficios a los pobres.

Los sucesivos Exámenes Globales de la Ayuda para el Comercio han mostrado que los países asociados, en particular los países menos adelantados (PMA), están logrando formular, integrar y comunicar mejor sus objetivos y estrategias relacionados con el comercio. A su vez, ello ha permitido armonizar mejor la asistencia oficial para el desarrollo (AOD), que ha aumentado de manera sostenida en relación con el promedio correspondiente al período de referencia (2002-2005). El Examen Global de 2011 mostró claramente que la ayuda para el comercio estaba produciendo resultados sobre el terreno. Los estudios de casos específicos presentados en el Examen Global indican que las actividades de ayuda para el comercio son considerables, que han arraigado en una gran variedad de países y que tienen 
una importancia cada vez mayor en las estrategias de desarrollo. En su conjunto, muestran, con un alto grado de detalle, los esfuerzos desplegados por los gobiernos y la comunidad internacional para fomentar el comercio como instrumento de desarrollo. Además, aunque no siempre es fácil establecer una relación de causa a efecto, los estudios de casos muestran claramente la forma en que los programas de ayuda para el comercio están ayudando a los países en desarrollo a crear la capacidad humana e institucional y la infraestructura que necesitan para integrarse en los mercados regionales y mundiales y aprovechar así las oportunidades comerciales.

Desde 2005, año en que se emprendió la Iniciativa, las cadenas de valor han adquirido creciente importancia en el mundo del comercio y la inversión. La integración en una cadena de valor existente, al dar acceso a redes, mercados mundiales, capital, conocimientos y tecnología, puede constituir un medio valioso de promover el desarrollo económico ya que es una forma más sencilla de lograr ese objetivo que el establecimiento de una cadena de valor plenamente integrada. Además, con la expansión de las corrientes comerciales Sur-Sur, las cadenas de valor mundiales están adquiriendo un alcance y un carácter más universales. Las economías en desarrollo pueden integrarse en las cadenas de valor abriendo sus mercados al comercio y la inversión extranjera directa, mejorando el entorno empresarial y de inversión y fortaleciendo la capacidad a nivel de la oferta.

El enfoque del desarrollo también ha evolucionado como resultado de la adopción de la Alianza Mundial de Cooperación Eficaz para el Desarrollo, acordada en 2012 con el objeto de crear un nuevo marco para afianzar los esfuerzos encaminados a ayudar a los países en desarrollo a aprovechar mejor los resultados de las distintas formas de financiación para el desarrollo y asegurarse de que tengan un efecto catalizador en el comercio y el desarrollo. Al mismo tiempo, ha aumentado la importancia de la cooperación Sur-Sur relacionada con el comercio, así como de la cooperación triangular, que están contribuyendo de manera significativa a lograr los objetivos de la Iniciativa de Ayuda para el Comercio. También el sector privado, con la mira puesta en las posibles utilidades, está ayudando cada vez más a reducir el costo de comerciar de los países de bajos ingresos y a integrarlos en las cadenas de valor mundiales. Como resultado de las limitaciones que pesan sobre los presupuestos de ayuda de los países de la OCDE, es probable que esas otras formas de cooperación pública y privada relacionada con el comercio adquieran creciente importancia.

La aparición de cadenas de valor también tiene consecuencias importantes para la manera de enfocar y prestar la ayuda. Cada vez es más necesario considerar de forma integrada la ayuda financiera, el gasto nacional y la inversión privada (tanto nacional como extranjera). Aunque la ayuda para el comercio ha sido definida como una forma de asistencia oficial para el desarrollo (AOD), están surgiendo otras fuentes de financiación que pueden contribuir a crear capacidad comercial en los países de ingresos bajos y medianos. Por ejemplo, por medio de otras corrientes oficiales (OCO) se conceden préstamos en condiciones ordinarias para actividades relacionadas con el comercio, principalmente a países de ingresos medianos. Y tanto la AOD como las OCO contribuyen a consolidar las condiciones básicas que facilitan la inversión extranjera directa (IED) y motivan al sector privado para participar en la creación de capacidad comercial, en particular en las esferas de la adquisición de conocimientos técnicos, las normas y la logística.

En el Cuarto Examen Global de la Ayuda para el Comercio se considerarán los beneficios que reportan las cadenas de valor en la esfera del desarrollo; se examinarán las estrategias y los programas encaminados a vincular a las empresas de los países en desarrollo a las cadenas de valor -en particular por medio de enfoques regionales- y se evaluarán los resultados que esas estrategias y programas han tenido a nivel del comercio y el desarrollo. El análisis está basado en la autoevaluación de los países asociados, los donantes bilaterales y multilaterales y el sector privado. Se ha complementado con datos sobre la ayuda para el comercio extraídos de la base de datos del Sistema de Notificación por parte de los Países Acreedores (SNPA) de la OCDE, conclusiones de evaluaciones, estudios de casos, estudios empíricos y referencias a la bibliografía general sobre comercio y desarrollo. 


\section{CÓMO SE VIGILA LA AYUDA PARA EL COMERCIO}

A fin de evaluar los progresos realizados para la consecución de los objetivos acordados de la Iniciativa de Ayuda para el Comercio, la OCDE y la Organización Mundial del Comercio (OMC) han elaborado conjuntamente un marco de vigilancia que vincula la responsabilidad a nivel nacional (o regional) con la responsabilidad a nivel mundial. Como se señala en la Declaración de París sobre la Eficacia de la Ayuda, la mutua responsabilidad tiene por objeto lograr que se establezcan asociaciones genuinas y que las asociaciones concentren la atención en la obtención de resultados. Para establecer la responsabilidad mutua, se requieren tres elementos fundamentales: un programa común con objetivos claros y compromisos recíprocos; la vigilancia y evaluación de los compromisos y las medidas; y, en estrecha relación con lo anterior, el diálogo y el examen. La Iniciativa de Ayuda para el Comercio es uno de los ejemplos internacionales más claros de la manera en que esos tres elementos crean poderosos incentivos para cumplir los compromisos y, en definitiva, modificar la conducta.

El marco lógico para la evaluación de la Iniciativa de Ayuda para el Comercio se basa en los cuatro elementos principales identificados por el Equipo de Trabajo de la OMC sobre la Ayuda para el Comercio':

- la demanda (es decir, la incorporación del comercio en las estrategias de desarrollo y la asignación de prioridad al comercio en dichas estrategias);

- la respuesta (es decir, los proyectos y programas de ayuda para el comercio);

- los resultados (es decir, el aumento de la capacidad comercial); y

- el impacto (es decir, mejores resultados comerciales y reducción de la pobreza).

La labor de vigilancia se lleva a cabo a nivel cualitativo y cuantitativo. La vigilancia cualitativa está basada en encuestas de autoevaluación en las que participan los donantes, los asociados en el marco de la cooperación Sur-Sur y los beneficiarios de la ayuda para el comercio. En consonancia con el tema de la labor de vigilancia de 2013, se solicitaron no sólo las opiniones de los donantes y los asociados en el marco de la cooperación Sur-Sur, sino también las del sector privado. Se preguntó a todos ellos cuáles eran las limitaciones fundamentales que afrontaba el sector privado para conectarse a las cadenas de valor y, en particular, qué efectos tenía la creación de capacidad productiva relacionada con el comercio (o los programas de desarrollo del sector privado) en los resultados comerciales, el crecimiento económico, el empleo y la reducción de la pobreza en los países en desarrollo. Además, se preguntó a los países asociados y a los donantes por la incorporación de los objetivos comerciales en las estrategias de desarrollo y por las perspectivas de financiación de los programas de desarrollo relacionados con el comercio.

La vigilancia cuantitativa consiste en el seguimiento de las corrientes de ayuda para el comercio a nivel mundial, regional y nacional. Los datos contienen información detallada sobre la "respuesta" (es decir, el volumen de los compromisos y desembolsos de ayuda para el comercio). Esos datos se extraen de la base de datos del SNPA de la OCDE y se usan las variables sustitutivas de la ayuda para el comercio más adecuadas para medir las corrientes de ayuda, según lo acordado por el Equipo de Trabajo de la OMC, a saber:

la asistencia técnica en relación con la política y la reglamentación comerciales;

- la infraestructura relacionada con el comercio;

- la creación de capacidad productiva (incluido el fomento del comercio);

n el ajuste relacionado con el comercio; y

- otras necesidades relacionadas con el comercio, si se consideran prioritarias en las estrategias nacionales de desarrollo de los países asociados. 
El Equipo de Trabajo consideró que la base de datos del SNPA (que abarca un 90\% del total de los datos sobre la AOD y las OCO) era la mejor fuente de datos disponible para el seguimiento de las corrientes mundiales de ayuda para el comercio. La base de datos del SNPA sobre actividades de ayuda, establecida en 1967, es la fuente de datos internacionalmente reconocida sobre esa clase de actividades, permite desgloses geográficos y sectoriales y es utilizada ampliamente por los gobiernos, las organizaciones y los investigadores para examinar las tendencias en materia de AOD y OCO a lo largo del tiempo y en relación con los distintos organismos.

Una novedad de la edición de 2013 de La Ayuda para el Comercio en síntesis es el nuevo formato de las hojas de ayuda para el comercio. En ellas se ha utilizado un enfoque de la gestión basada en los resultados en que se hace hincapié en los insumos (las corrientes de financiación para el desarrollo), los productos (los resultados comerciales), los resultados (la evolución de los principales indicadores comerciales) y los efectos (tanto económicos como sociales), con el fin de estimular el debate sobre los resultados a nivel nacional. Las hojas tienen por objeto comparar los resultados en relación con los cuatro tipos de indicadores durante el período 2005-2010; no pretenden establecer una relación causal entre la ayuda para el comercio y los resultados a nivel macroeconómico ya que hay dificultades metodológicas que impiden establecer esa clase de relación. Más bien, tienen por objeto alentar la investigación a fondo por países, y pueden resultar útiles para revelar esferas en las que pueden observarse los efectos de las contribuciones, esferas que podrán luego ser investigadas a fondo con criterio crítico.

\section{¿QUIÉN PARTICIPÓ EN LA LABOR DE VIGILANCIA DE 2013?}

En 2013, 80 países asociados (36 de ellos, PMA) presentaron sendas autoevaluaciones de la ayuda para el comercio. Ese número es similar al número de países asociados que participó en la labor de vigilancia de 2011. Sin embargo, en comparación con 2011, en 2013 la participación de los PMA aumentó sensiblemente ya que se recibieron cinco respuestas más a un cuestionario que era más complejo. En 2011, se contrajeron compromisos de ayuda para el comercio por un total de 22.800 millones de dólares EE.UU. en relación con 80 países asociados; esa suma representó el 67,4\% del total de la ayuda para el comercio destinada a programas nacionales (es decir, con exclusión de los programas multinacionales). En 2013, 43 donantes bilaterales y multilaterales (el mismo número que en 2011) presentaron sendas autoevaluaciones de la ayuda para el comercio. En su conjunto, esos organismos aportaron prácticamente la totalidad de los compromisos de ayuda para el comercio. En la labor de vigilancia de 2013 participaron nueve proveedores de asistencia en el marco de la cooperación Sur-Sur (incluida China), número que también es similar al correspondiente a 2011. Los asociados en el marco de la cooperación Sur-Sur presentaron más información sobre sus programas que en el pasado, pero los datos sobre las corrientes de ayuda para el comercio siguen siendo anecdóticos y obtenidos de fuentes secundarias.

Otra novedad de la labor de vigilancia de 2013 fue que se solicitó la opinión del sector privado sobre la conexión a las cadenas de valor y la manera en que la ayuda para el comercio puede contribuir a lograr ese objetivo. La novedad consistió no sólo en la participación del sector privado, sino también en las asociaciones que se establecieron para realizar el trabajo. Además de la OCDE y la OMC, participaron también en la labor conjunta de vigilancia Grow Africa, la Cámara Internacional de Comercio (ICC), el Centro de Comercio Internacional (ITC), la Unión Internacional de Telecomunicaciones (UIT) y la Organización Mundial del Turismo (OMT). Como resultado de la colaboración de un mayor número de organizaciones pudo encuestarse a empresas y asociaciones de empresas en cada uno de los cinco sectores incluidos en el estudio. 


\section{Gráfico 0.5 Autoevaluaciones por grupos de encuestados}

Los números en blanco indican el número de respuestas de cada grupo.

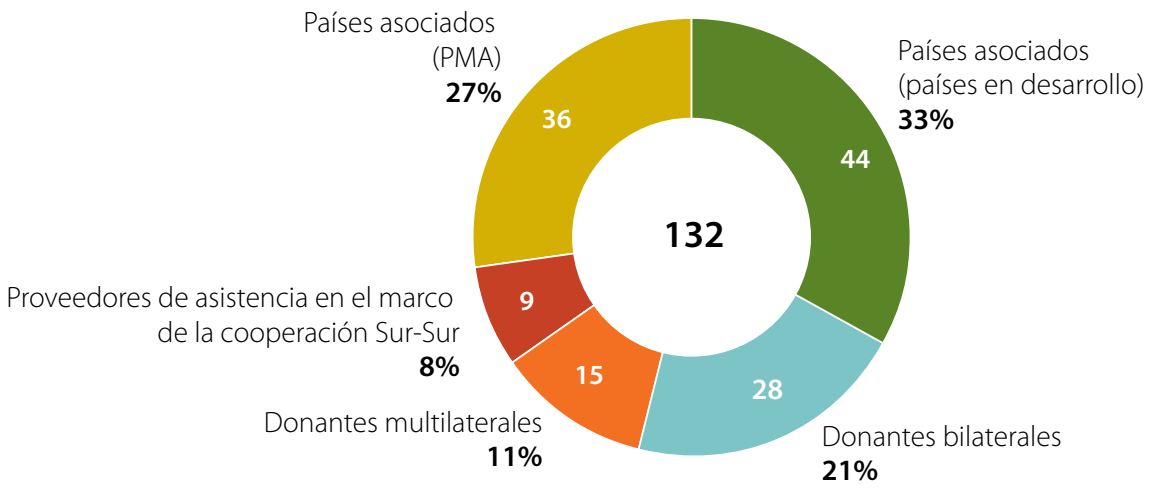

Fuente: Autoevaluaciones y cuestionarios OCDE/OMC, www.aid4trade.org

StatLink 겦내 http://dx.doi.org/10.1787/888932853853

El cuestionario dirigido al sector privado abarcaba las actividades comerciales desarrolladas en cinco sectores fundamentales a través de cadenas de valor: la agroalimentación, la tecnología de la información y las comunicaciones, los textiles y las prendas de vestir, el turismo, y el transporte y la logística. El gran número de respuestas al cuestionario es un indicio claro del interés del sector privado en la Iniciativa de Ayuda para el Comercio. En las 524 respuestas enviadas, las empresas y las asociaciones de empresas de países en desarrollo expresaban opiniones contundentes sobre las limitaciones fundamentales que afrontaban para conectarse a las cadenas de valor y ascender dentro de ellas, así como para establecerlas, mientras que en las 173 respuestas de empresas líderes (ubicadas, en su mayoría, aunque no exclusivamente, en países de la OCDE) se mencionaban los obstáculos con que tropezaban esas empresas para trabajar con empresas de países en desarrollo. En su conjunto, las 697 respuestas del sector privado revelan las esferas en que las asociaciones entre los sectores público y privado tienen más posibilidades de lograr los objetivos de la Iniciativa de Ayuda para el Comercio.

\section{Gráfico 0.6 Cuestionario dirigido al sector privado (697 respuestas)}

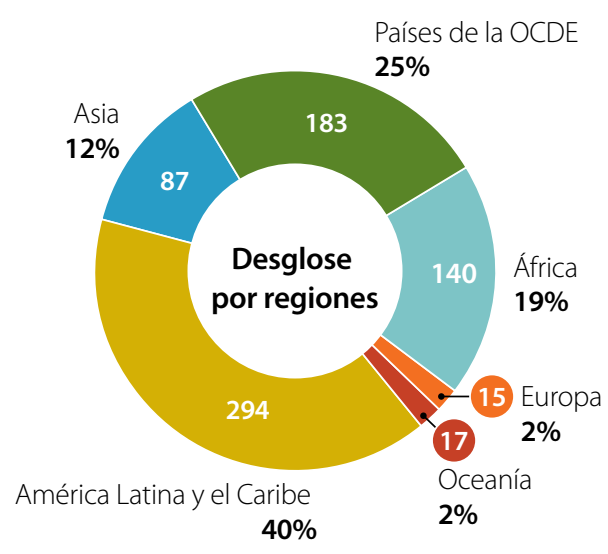

Fuente: Autoevaluaciones y cuestionarios de la OCDE/OMC, 2013,www.aid4trade.org.
Los números en blanco indican el número de respuestas por región y sector.

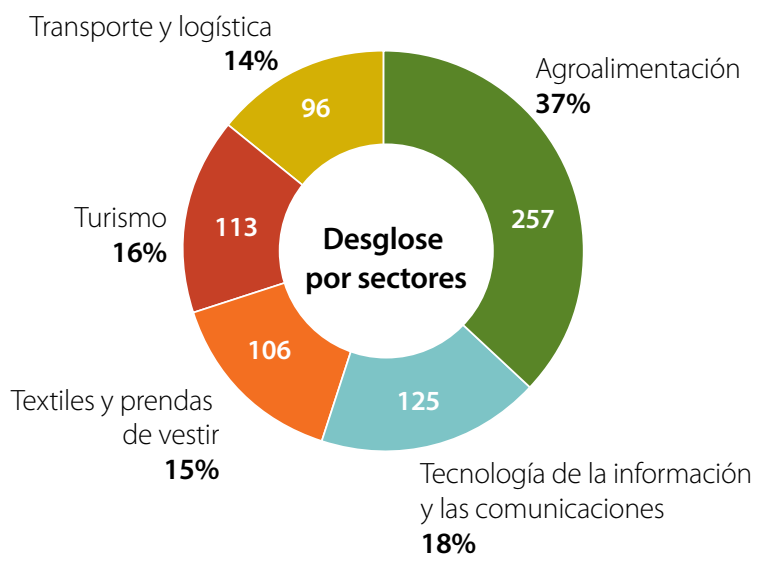

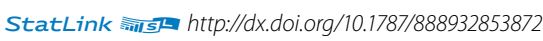

Nota: Datos basados en las respuestas presentadas por países en desarrollo de África, América Latina y el Caribe, Asia, Europa y Oceanía, así como por países de la OCDE (algunas de estas categorías se superponen). 


\section{ESTRUCTURA DEL INFORME}

En el presente informe se examinan estrategias y programas destinados a ayudar a empresas de países en desarrollo, en particular las de los países menos adelantados, a conectarse a las cadenas de valor; la manera en que esas empresas pueden ascender en las cadenas de valor; y los beneficios que ello reporta, en el contexto del debate mundial sobre la agenda para el desarrollo después de 2015.

En el capítulo 1 se describe la situación en materia de comercio y desarrollo, así como la manera en que los cambios recientes afectan a la ayuda para el comercio. En este contexto, y sobre la base de las respuestas al cuestionario de la OCDE y la OMC, se examina cómo están evolucionando las políticas, prioridades y estrategias de ayuda para el comercio. En particular, se analiza en qué medida se tienen en cuenta las cadenas de valor al fijar los objetivos de los países en desarrollo, así como en los programas de los organismos donantes y los proveedores de asistencia en el marco de la cooperación Sur-Sur.

En el capítulo 2 se hace hincapié en la necesidad cada vez más apremiante de examinar en forma integrada la financiación, el gasto nacional y las políticas públicas, así como la inversión privada. Mientras que la ayuda para el comercio ha sido definida como una forma de AOD, están surgiendo otras fuentes de financiación que pueden contribuir a crear capacidad comercial en los países de ingresos bajos y medianos. A través de OCO relacionadas con el comercio se conceden préstamos en condiciones ordinarias principalmente a países de ingresos medianos. Tanto la AOD como las OCO contribuyen a consolidar las condiciones necesarias para facilitar la IED. El sector privado también ha participado en la creación de capacidad comercial.

En el capítulo 3 se examinan las oportunidades de desarrollo que crean las cadenas de valor. Para poder aprovechar las oportunidades que ofrecen las cadenas de valor regionales y mundiales es imprescindible contar con un sector privado vigoroso. Las empresas comercian y organizan las corrientes de capital, la mano de obra, los conocimientos y la tecnología, aunque el grado de reglamentación de esas actividades varía de un país a otro. Sobre la base de las respuestas a los cuestionarios dirigidos a los sectores público y privado, de relatos de casos, así como de estudios de casos, en este capítulo se dan ejemplos de casos en que las inversiones en cadenas de valor están dando fruto y se explican los motivos de que así sea. Asimismo se examina la importancia de las cadenas de valor en cinco sectores principales (la agroalimentación, la tecnología de la información y las comunicaciones (TIC), los textiles y las prendas de vestir, el turismo, y el transporte y la logística). Se resumen las principales constataciones y se extraen conclusiones acerca de esos cinco sectores a partir de las respuestas dadas a los cuestionarios por los donantes, los países asociados y, en particular, el sector privado. Las asociaciones estratégicas establecidas a nivel sectorial o temático con las organizaciones internacionales competentes facilitaron la difusión de los cuestionarios dirigidos al sector privado y la tarea de responder a las preguntas.

En el capítulo 4 se examina la forma en que la ayuda para el comercio a nivel regional contribuye al proceso de desarrollo; se reseñan los desafíos que afrontan las economías en desarrollo en sus esfuerzos por lograr una mayor integración regional; se hace hincapié en las oportunidades que están surgiendo, en particular gracias a las cadenas de valor regionales; y se evalúa la eficacia que ha tenido hasta la fecha la ayuda a nivel regional y multinacional. También se examinan las estrategias de los países asociados más adecuadas para incorporar la ayuda para el comercio a nivel regional en la planificación del desarrollo, y la manera en que los países donantes pueden colaborar con los países asociados a fin de elaborar los mejores proyectos y programas de ayuda para el comercio posibles. Por último, se pasa revista a las cuestiones en materia de aplicación, que son particularmente complejas en el caso de la ayuda para el comercio a nivel regional, y se dan ejemplos de iniciativas recientes en África, Asia y América Latina y el Caribe. 
En el capítulo 5 se pasa revista a los resultados de los proyectos y programas de ayuda para el comercio. Así, se examina la forma en que la ayuda para el comercio, en el contexto de la ampliación de las corrientes de financiación del desarrollo, ha contribuido al logro de los resultados comerciales de los países en desarrollo, y se analiza el modo en que la ayuda para el comercio puede atender de la manera más apropiada y eficiente posible a los diversos problemas a que hacen frente los países en desarrollo con diferentes niveles de desarrollo. En este capítulo se presenta información actualizada sobre los estudios empíricos pertinentes, evaluaciones del impacto, y evaluaciones recientes de los efectos de la ayuda para el comercio (incluidas las evaluaciones sectoriales y las evaluaciones del sector privado), con especial hincapié en la manera en que la ayuda para el comercio ha contribuido a las cadenas de valor. Además se describen los métodos que pueden aplicar los países asociados y los organismos donantes para seguir de cerca los progresos logrados y administrar mejor los recursos con el fin de lograr los objetivos de comercio y desarrollo.

El capítulo 6 está consagrado a la promesa que encierra la ayuda para el comercio. En efecto, la ayuda para el comercio ha logrado que se asigne mayor importancia al comercio en las estrategias de desarrollo y ha ayudado a los países en desarrollo a superar las limitaciones a nivel de la oferta, y a las empresas a conectarse a las cadenas de valor. Los enfoques regionales y las formas de administrar la ayuda para lograr objetivos de comercio y desarrollo están mejorando, y la ayuda para el comercio sigue dando resultado. Con todo, quedan dificultades por superar, los presupuestos para la prestación de ayuda siguen sometidos a presiones y la eficacia de la ayuda se verá comprometida si los donantes y los asociados en el marco de la cooperación Sur-Sur condicionan la ayuda que prestan. La comunidad internacional debe seguir abogando de manera convincente por un aumento de la cantidad y la calidad de la ayuda para el comercio. En este capítulo, con el que concluye el informe, se hacen observaciones sobre el futuro de la ayuda para el comercio y se propone el camino que podría seguirse para asegurarse de que la Iniciativa siga siendo pertinente en un entorno comercial y de desarrollo en evolución.

El resto del informe consiste en las hojas de ayuda para el comercio por países y todos los datos sobre la ayuda para el comercio utilizados en el análisis.

Por último, cabe señalar que toda la información utilizada para la elaboración del informe puede consultarse en el sitio Web conjunto de la OCDE y la OMC sobre la ayuda para el comercio: www.aid4trade.org. 


\begin{tabular}{|l|c|c|c|c|c|}
\hline \multicolumn{2}{|c|}{ Cuadro $\mathbf{0 . 1}$ Respuestas al cuestionario sobre la ayuda para el comercio } & \multicolumn{1}{c|}{$\begin{array}{c}\text { Donantes } \\
\text { Cotal general }\end{array}$} & $\begin{array}{c}\text { Países } \\
\text { asociados }\end{array}$ & PMA & $\begin{array}{c}\text { Cooperación } \\
\text { Sur-Sur }\end{array}$ \\
\hline (incluidas las OIG)
\end{tabular}

Cuadro 0.2 Respuestas de los países asociados al cuestionario sobre la ayuda para el comercio

\section{Región \\ África (38) \\ Países Árabes y Oriente Medio (3)}

\section{Asia y el Pacífico (12) \\ Europa Central y Oriental y Asia Central \\ (2)}

\section{América Latina y el Caribe (25)}

PMA (36)

\section{Respuestas al cuestionario de 2013}

Benin; Botswana; Burkina Faso; Burundi; Cabo Verde; República Centroafricana;

Chad; Comoras; Congo, República Democrática del; Côte d'Ivoire; Djibouti; Etiopía; Gabón; Gambia; Ghana; Guinea; Kenya; Lesotho; Liberia; Madagascar; Malawi; Malí; Mauritania; Mauricio; Marruecos; Mozambique; Níger; Nigeria; República del Congo; Rwanda; Senegal; Sudán; Tanzanía; Togo; Túnez; Uganda; Zambia; Zimbabwe

Jordania; Omán; Yemen

Bangladesh; Bhután; Camboya; Fiji; India; Indonesia; Nepal; Pakistán; Papua Nueva Guinea; Samoa; Tuvalu;2 Vanuatu

Afganistán; Turquía

Antigua y Barbuda; Bahamas; Barbados; Belize; Colombia; Costa Rica; Dominica; República Dominicana; El Salvador; Granada; Guatemala; Haití; Honduras; Jamaica, México; Nicaragua; Panamá; Paraguay; Perú; Saint Kitts y Nevis; San Vicente y las Granadinas; Suriname; Trinidad y Tabago; Uruguay

Afganistán; Bangladesh; Benin; Bhután; Burkina Faso; Burundi; Camboya; República Centroafricana; Chad; Comoras; Congo, República Democrática del; Djibouti; Etiopía; Gambia; Guinea; Haití; Lesotho; Liberia; Madagascar; Malawi; Malí; Mauritania; Mozambique; Nepal; Níger; Rwanda; Samoa; Senegal; Sudán; Tanzanía; Togo; Tuvalu; Uganda; Vanuatu; Yemen; Zambia

\section{Respuestas al cuestionario de 2011}

Angola; Benin; Botswana; Burkina Faso; Burundi; Camerún; Cabo Verde; República Centroafricana; Chad; Comoras; Congo, República Democrática del; Côte d'Ivoire; Etiopía; Gabón; Gambia; Ghana; Guinea; Kenya; Lesotho; Madagascar; Malawi; Mali; Mauricio; Marruecos; Mozambique; Níger; Nigeria; República del Congo; Senegal; Sierra Leona; Swazilandia; Togo; Uganda; Zambia; Zimbabwe

Jordania; Líbano; Yemen

Bangladesh; Fiji; India; Indonesia; Lao, RDP; Maldivas; Mongolia; Nepal; Pakistán; Islas Salomón; Sri Lanka; Tonga; Tuvalu ${ }^{3}$

Afganistán; Azerbaiyán; Croacia; República Kirguisa; Serbia

Antigua y Barbuda; Bahamas; Barbados; Belize; Chile; Colombia; Costa Rica; Dominica; República Dominicana; Ecuador; El Salvador; Granada; Guatemala; Guyana; Haití; Honduras; Jamaica; México; Nicaragua; Panamá; Paraguay; Perú; Saint Kitts y Nevis; San Vicente y las Granadinas; Suriname; Trinidad y Tabago; Uruguay

Afganistán; Angola; Bangladesh; Benin; Burkina Faso; Burundi; República Centroafricana; Chad; Comoras; Congo, República Democrática del; Etiopía; Gambia; Guinea; Haití; Lao, RDP; Lesotho; Madagascar; Malawi; Maldivas; Malí; Mozambique; Nepal; Níger; Senegal; Sierra Leona; Islas Salomón; Togo; Tuvalu; ${ }^{4}$ Uganda; Yemen; Zambia 


\begin{tabular}{|c|c|c|}
\hline & Respuestas al cuestionario de 2013 & Respuestas al cuestionario de 2011 \\
\hline Bilaterales (28) & $\begin{array}{l}\text { Australia; Austria; Bélgica; Bulgaria; Canadá; } \\
\text { República Checa; Dinamarca, Unión } \\
\text { Europea; Finlandia; Francia; Alemania; Grecia; } \\
\text { Irlanda; Italia; Japón; Corea; Lituania; Países } \\
\text { Bajos; Nueva Zelandia; Noruega; Portugal; } \\
\text { Singapur; España; Suecia; Suiza; Taipei } \\
\text { Chino; Reino Unido; Estados Unidos }\end{array}$ & $\begin{array}{l}\text { Australia; Austria; Bélgica; Canadá; República } \\
\text { Checa; Dinamarca; Unión Europea; Finlandia; } \\
\text { Francia; Alemania; Hungría; Irlanda; Israel; } \\
\text { Italia; Japón; Corea; Lituania; Luxemburgo; } \\
\text { Países Bajos; Nueva Zelandia; Noruega; } \\
\text { Portugal; Singapur; España; Suecia; Suiza; } \\
\text { Taipei Chino; Reino Unido; Estados Unidos }\end{array}$ \\
\hline Multilaterales (15) & $\begin{array}{l}\text { BAfD; BERD; MIM; FAO; BID; FMI; BIsD; ITC; } \\
\text { UNCTAD; PNUD; CEPA; CEPE; ONUDI; Banco } \\
\text { Mundial; OMC }\end{array}$ & $\begin{array}{l}\text { BAfD; BERD; FAO; BID; FMI; BIsD; ITC; } \\
\text { UNCTAD; PNUD; CEPA; CEPE; ONUDI; Banco } \\
\text { Mundial; OMC }\end{array}$ \\
\hline
\end{tabular}

Cuadro 0.4 Respuestas de los proveedores de asistencia en el marco de la cooperación Sur-Sur al cuestionario sobre la ayuda para el comercio

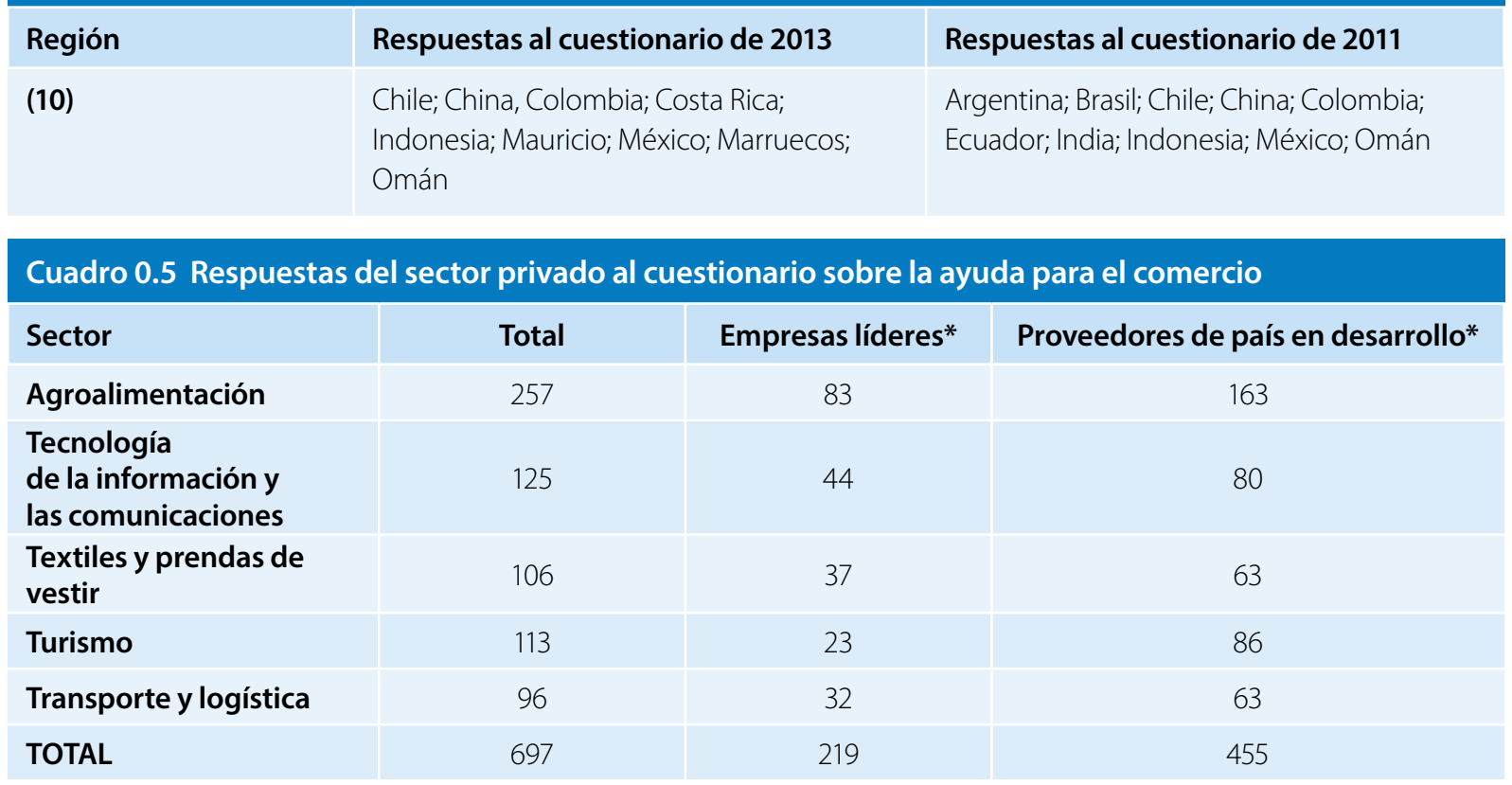

*Algunas de estas categorías se superponen. 


\section{NOTAS}

1. WT/AFT/1 (2006).

2. No es Miembro de la OMC ni tiene la condición de observador.

3. No es Miembro de la OMC ni tiene la condición de observador.

4. No es Miembro de la OMC ni tiene la condición de observador. 


\section{REFERENCIAS}

OCDE (2011), Strengthening Accountability in Aid for Trade, The Development Dimension, OCDE, París, http://dx.doi.org/10.1787/9789264123212-en. 



\section{CAPÍTULO 1:}

\section{¿SE ESTÁ ADAPTANDO LA AYUDA PARA EL COMERCIO A LAS NUEVAS REALIDADES?}

En n el presente capítulo se analiza de qué modo influyen en la ayuda para el comercio los cambios a nivel del comercio y el desarrollo, y se muestra cómo los países asociados, los donantes y los proveedores de cooperación Sur-Sur relacionada con el comercio están utilizando la ayuda para el comercio para ayudar a los países en desarrollo a incorporarse a las cadenas de valor y crear las suyas propias. Sobre la base de conclusiones extraídas de las respuestas al cuestionario de la OCDE y la OMC, se da una idea general de cómo están evolucionando las políticas, las prioridades y las estrategias en materia de ayuda para el comercio. También se analiza hasta qué punto influyen las cadenas de valor a la hora de establecer objetivos los países en desarrollo, y en qué medida se tienen en cuenta esas cadenas en los programas de los organismos donantes y los proveedores de cooperación Sur-Sur relacionada con el comercio. Los países asociados están prestando especial atención a la manera de reducir la densidad de sus fronteras, mejorar el entorno empresarial y crear condiciones que ayuden a las empresas a conectarse a las cadenas de valor regionales y mundiales. Por su parte, los donantes están teniendo en cuenta esas prioridades. Así, están haciendo mayor hincapié en la cooperación entre el sector público y el sector privado y están adaptando sus programas a determinados sectores y cadenas de suministro. Los proveedores de cooperación Sur-Sur relacionada con el comercio siguen incrementando su apoyo a fin de intensificar el comercio Sur-Sur.

\section{INTRODUCCIÓN}

El comercio mundial se caracteriza, cada vez más, por transacciones efectuadas en el marco de complejas cadenas de valor. La expansión mundial de las cadenas de valor ofrece nuevas oportunidades a muchos países en desarrollo. Las cadenas de valor han dejado de consistir, exclusivamente, en una relación Norte-Sur para dar lugar también a interacciones comerciales regionales y Sur-Sur cada vez más complejas que ya no se circunscriben a las mercancías sino que abarcan también los servicios. Sin embargo, algunos países en desarrollo, en particular los menos adelantados (PMA), siguen estando al margen del comercio mundial, atraen pocas inversiones extranjeras o nacionales y no tienen más remedio que seguir suministrando una gama limitada de bienes o servicios. La ayuda para el comercio puede contribuir considerablemente a lograr que las empresas de los países en desarrollo superen las limitaciones fundamentales que les impiden conectarse a las cadenas de valor internacionales. Las cadenas de valor nacionales, regionales y mundiales ofrecen nuevas oportunidades, pero también presentan riesgos para los países en desarrollo. Las cadenas de valor representan un argumento más en favor de la apertura de los mercados y ponen de relieve los costos que acarrea la densidad de las fronteras. Asimismo, exigen un replanteamiento de la cooperación para el desarrollo. 
En el presente capítulo se analiza cómo influyen en la ayuda para el comercio los cambios a nivel del comercio y el desarrollo, y se describe de qué manera están utilizando la ayuda para el comercio los países asociados, los donantes y los proveedores de cooperación Sur-Sur relacionada con el comercio a fin de ayudar a los países en desarrollo a incorporarse a las cadenas de valor y crear las suyas propias. Sobre la base de las respuestas al cuestionario de la OCDE y la OMC de 2013, se da una idea general de la forma en que están evolucionando las políticas, las prioridades y las estrategias de la ayuda para el comercio. También se analiza hasta qué punto influyen las cadenas de valor a la hora de establecer objetivos los países en desarrollo, y en qué medida se tienen en cuenta dichas cadenas en los programas de los organismos donantes y los proveedores de cooperación Sur-Sur relacionada con el comercio..

Muchos países de ingresos bajos tienen un grado de penetración de las cadenas de valor muy limitado, y se encuentran en el "fondo" de las cadenas de valor en las que participan. Por su parte, muchos donantes tienen poca experiencia con las cadenas de valor. En cambio, para otros, como Dinamarca y Alemania, la promoción de las cadenas de valor se ha convertido en una prioridad estratégica. Los principales donantes, como el Reino Unido y los Estados Unidos, cuentan con muchos programas centrados directamente en los beneficios que reporta al desarrollo la conexión con las cadenas de valor.

El capítulo empieza con un análisis de las prioridades de los países asociados; a continuación se examina la forma en que están respondiendo los donantes a esas prioridades, así como el papel del sector privado en la ayuda para el comercio. Al final del capítulo se presentan las conclusiones.

\section{¿CÓMO ESTÁN ADAPTANDO SUS ESTRATEGIAS LOS PAÍSES ASOCIADOS?}

Desde que se puso en marcha la Iniciativa de Ayuda para el Comercio en 2006, los países asociados han estado a la cabeza de la labor de diseño y aplicación de nuevas estrategias comerciales que se están adaptando a los nuevos paradigmas y tendencias del comercio internacional. Además, se ha incorporado el comercio a los planes, las políticas y las actividades generales de desarrollo. Esto se ha logrado mediante un sólido análisis de las oportunidades comerciales y las intervenciones estratégicas, la participación de las partes interesadas y la coordinación de las actuaciones (PNUD, 2011). La labor de vigilancia realizada en 2009 y 2011 reveló que habían mejorado todos los aspectos de la planificación y la prestación de la ayuda para el comercio, y que los programas estaban empezando a arrojar resultados tangibles (OCDE/OMC, 2011). Sin embargo, sigue habiendo problemas para formular estrategias comerciales operacionales orientadas a la obtención de resultados en que se establezcan prioridades y se asignen recursos con criterio realista (PNUD, 2011). La elevada tasa de respuesta al cuestionario de la OCDE y la OMC de 2013 (al que respondieron 80 países asociados) demuestra que los países asociados siguen interesados en la Iniciativa y empeñados en incrementar la eficacia de la ayuda para el comercio. Para ser eficaz, la ayuda para el comercio debe estar orientada a atender a las nuevas prioridades relacionadas con el comercio. De las respuestas de los países asociados se desprende que, para muchos de ellos, esas prioridades siguen evolucionando; el apoyo que se presta por medio de la ayuda para el comercio también debe evolucionar.

\section{La facilitación del comercio, las cadenas de valor y la competitividad están adquiriendo prioridad para los países asociados.}

Desde 2010, las prioridades relacionadas con el comercio de casi el 40\% de los países asociados (31 países) han evolucionado. El gráfico 1.1 muestra que la facilitación del comercio ha adquirido mucha mayor importancia (18 países la clasifican entre sus principales prioridades). Moïsé y Sorescu (2013) han observado que la mejora de la información relacionada con el comercio, la simplificación y armonización de los documentos, la racionalización de los procedimientos y la utilización de procesos automatizados pueden reducir considerablemente el costo de comerciar, 
así como el costo total de comerciar de los países de ingresos bajos (hasta en un 14,5\%). Con creciente frecuencia también se está asignando alta prioridad a las cadenas de valor y la competitividad (13 países en cada caso). De hecho, las cadenas de valor se han convertido en la prioridad más importante de los PMA que han modificado su estrategia desde 2011. Los países asociados consideran que una mayor participación en las cadenas de valor promueve el crecimiento económico y el desarrollo social. Estos datos contrastan marcadamente con los proporcionados en las respuestas al cuestionario de 2011, en las que la facilitación del comercio ocupaba el quinto lugar y las cadenas de valor el séptimo lugar de un total de siete prioridades. Como observa el Níger, las cuestiones tradicionales en materia de ayuda para el comercio (como los problemas a nivel de la oferta, la falta de competitividad y los déficits de infraestructura) siguen siendo importantes, pero esas prioridades se han visto complementadas, o incluso reemplazadas, por otras nuevas. Por su parte, Marruecos ha indicado que, aunque ha definido nuevas prioridades, la infraestructura económica y la política y la reglamentación comerciales siguen siendo importantes.

La competitividad sigue siendo una prioridad fundamental. Las principales prioridades están íntimamente relacionadas entre sí: para conectarse a las cadenas de valor y diversificar las exportaciones, las empresas y los países tienen que ser competitivos, para lo cual, a su vez, es necesario reducir la densidad de las fronteras. Además, hay que seguir invirtiendo en mejorar el entorno empresarial, dar acceso al crédito y a la información sobre los mercados y reducir el costo del transporte y la energía. Estas cuestiones siguen siendo prioritarias para la ayuda para el comercio.

Pese a la importancia adquirida por las cadenas de valor y la facilitación del comercio, las prioridades de muchos países asociados no han cambiado. En los países asociados que han actualizado sus prioridades en la esfera de la ayuda para el comercio, la diversificación de las exportaciones, la infraestructura y la política y la reglamentación comerciales también ocupan un lugar destacado. Se asigna una importancia mucho menor al costo de la adhesión a la OMC y al ajuste relacionado con el comercio.

\section{Gráfico 1.1 Nuevas prioridades en materia de ayuda para el comercio} (porcentaje de respuestas de los países asociados (se han combinado las tres primeras categorías)

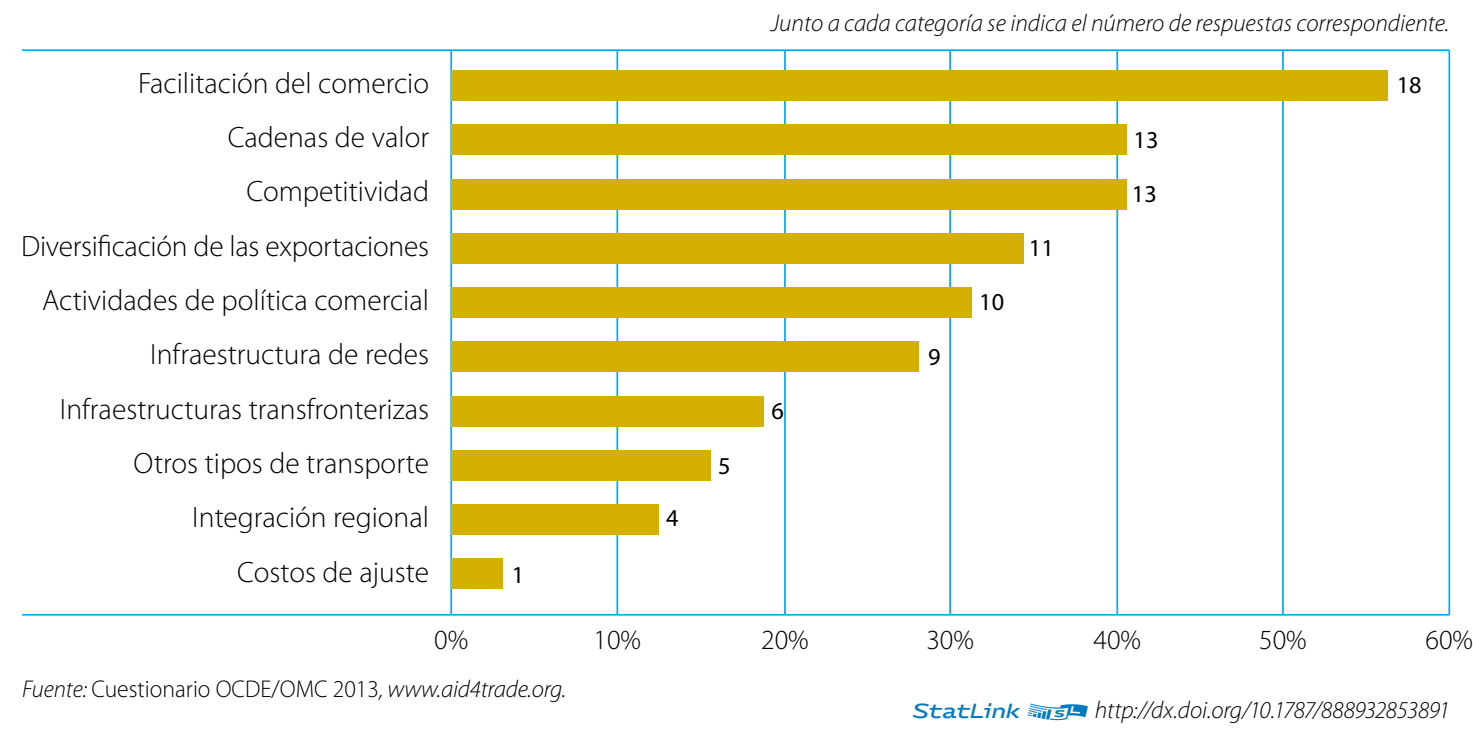


Frecuentemente, los países que han modificado sus prioridades en materia de ayuda para el comercio lo han hecho como resultado de contar con nuevas prioridades y estrategias generales de desarrollo. Así sucede en 24 de los 31 países que han modificado sus prioridades en materia de ayuda para el comercio. Por ejemplo, a principios de 2011 la República Dominicana adoptó una nueva ley por la que se estableció la Estrategia Nacional de Desarrollo 2030. Gambia dio término a la formulación de su Programa de Aceleración del Crecimiento y el Empleo en 2011 y su Estrategia Nacional de Exportación en 2012. Tanto en el Programa como en la Estrategia se reconoce que las cadenas de valor y la facilitación del comercio son esferas importantes para incrementar la competitividad y el crecimiento. En el nuevo estudio de diagnóstico sobre la integración comercial de Gambia se hace hincapié también en la puesta en marcha de procesos destinados a añadir valor para promover el desarrollo de la microempresa y de la pequeña y mediana empresa, así como de las exportaciones, con miras a reducir la pobreza.

Como ya se ha indicado, de las respuestas al cuestionario se desprende claramente que varios países (13) asignan prioridad al aumento de la competitividad. Por ejemplo, el principal motor de cambio en las prioridades de Rwanda en materia de ayuda para el comercio es el aumento de la competitividad a través de la facilitación del comercio y la infraestructura transfronteriza. A tal fin, en 2012 se instaló uno de los sistemas electrónicos de ventanilla única para tramitar las transacciones comerciales más avanzados de África. TradeMark East Africa (TMEA), un programa financiado por múltiples donantes, apoyó el establecimiento de un sistema informatizado denominado Ventanilla Electrónica Única de Rwanda (RESW). Bajo una misma plataforma electrónica, el sistema congrega a todos los organismos que intervienen en el despacho y la aprobación de las importaciones y las mercancías en tránsito, así como el cobro de los derechos correspondientes, todo ello de manera transparente. Este régimen ha permitido reducir en un 40\% (o sea un día completo) el tiempo necesario para despachar las mercancías, lo que representa un ahorro directo de entre 8 y 12 millones de dólares EE.UU. al año (TMEA, 2012).

Como consecuencia de haber mejorado el diálogo sobre cuestiones comerciales entre los beneficiarios y los donantes, según se informó en La Ayuda para el Comercio en síntesis: mostrar resultados (OCDE/OMC, 2011), la mayoría de los países en desarrollo han indicado que ahora incluyen esas nuevas prioridades en los planes nacionales de desarrollo, así como en el diálogo con los donantes. En efecto, de 31 países asociados, 30 tienen prioridades nuevas en sus estrategias nacionales de desarrollo (26 países ya han actualizado sus estrategias y cuatro las están actualizando). Además, 28 países han indicado sus prioridades en el diálogo que mantienen con los donantes.

\section{Los PMA consideran que el comercio es un importante mecanismo de transmisión para reducir la pobreza...}

Aparte de las nuevas prioridades generales de desarrollo, entre las prioridades de los PMA relacionadas con el comercio, el principal motor de cambio es la reducción de la pobreza. Esto indica que se reconoce claramente que la ayuda para el comercio desempeña un papel de primer orden en la tarea de convertir al comercio en un medio para reducir la pobreza (gráfico 1.2). Esto concuerda con el objetivo de la ayuda para el comercio enunciado por el Equipo de Trabajo sobre la Ayuda para el Comercio de la OMC de "permitir a los países en desarrollo, en particular los PMA, utilizar de forma más efectiva el comercio para promover el crecimiento, el desarrollo y la reducción de la pobreza y alcanzar sus objetivos de desarrollo, incluidos los Objetivos de Desarrollo del Milenio (ODM)" (OMC, 2006). En general, los proyectos de ayuda para el comercio no están destinados directamente a los pobres, sino que sirven para reforzar el papel que puede desempeñar el comercio en la reducción de la pobreza. De las respuestas al cuestionario más reciente de la OCDE y la OMC se desprende claramente que los países asociados reconocen la importancia del comercio para la reducción de la pobreza. También los donantes tienen interés en prestar ayuda para el comercio, debido a su potencial para fortalecer las economías y reducir la pobreza. 


\section{Gráfico 1.2 Factores que han impulsado la modificación de las estrategias de los países menos adelantados (porcentaje de respuestas de los PMA asociados (se han combinado las tres primeras categorías)}

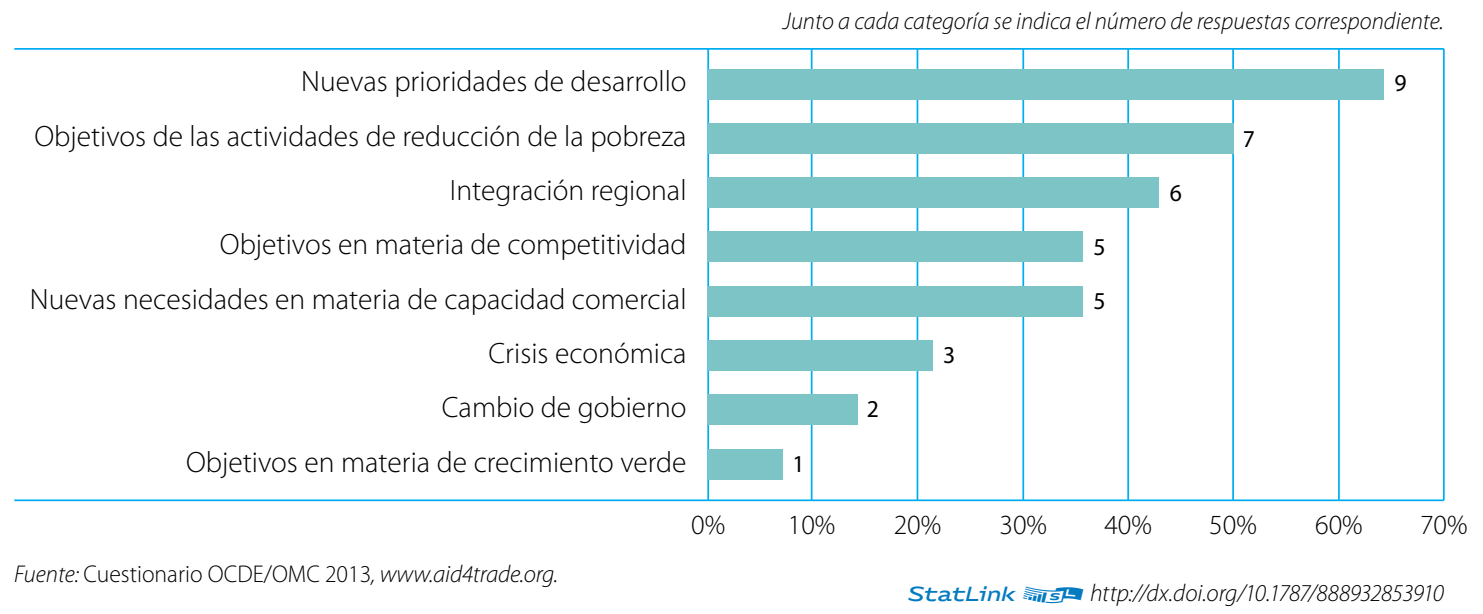

Todos los PMA que respondieron al cuestionario han incluido (o tienen previsto incluir) nuevas prioridades relacionadas con el comercio en sus estrategias nacionales de desarrollo y en las consultas y el diálogo con los donantes, lo que es reflejo de las sólidas estructuras de planificación establecidas en los PMA mediante el Marco Integrado mejorado. En la mayoría de las estrategias nacionales de desarrollo se identifican determinados sectores como fuentes de crecimiento. La agricultura es el sector más frecuentemente identificado como tal. Veintiocho PMA identifican los productos agropecuarios. Con mucha menor frecuencia se hace referencia específicamente a las manufacturas en los planes de desarrollo, pero cuando eso sucede suele tratarse de los textiles (14 PMA) y las prendas de vestir (10 PMA). Los productos básicos distintos de los combustibles también son importantes en este sentido (16 PMA), mientras que los combustibles no lo son tanto (6 PMA) (gráfico 1.3). Un resultado inesperado es la importancia asignada por los PMA a los servicios, que el $80 \%$ de los países identifica como un sector de crecimiento.

\section{... y las cadenas de valor son el factor de cambio más importante en las estrategias comerciales ...}

Las cadenas de valor son uno de los factores mencionados más frecuentemente por los PMA entre los elementos que han generado nuevas necesidades en materia de ayuda para el comercio. Varios PMA mencionan productos y servicios específicos destinados a la exportación, como las artesanías y las alfombras, el cuero y los productos de cuero, el calzado y los productos de plástico, los bienes y servicios culturales y de esparcimiento, los productos farmacéuticos, la goma arábiga, los productos de ingeniería ligera y las embarcaciones. Los ejemplos precedentes ponen de relieve la diversidad de las actividades que llevan a cabo los PMA y cómo está aumentando el valor añadido y la producción de bienes intermedios. La mayoría de esos países producen productos alimenticios acabados (39 PMA), prendas de vestir (39 PMA), textiles (32 PMA) y productos químicos (24 PMA). Parece claro que muchos de ellos están ascendiendo en la cadena de valor. Por ejemplo, en lo que se refiere a los textiles, 24 PMA están produciendo productos intermedios más avanzados. Además, casi todos los PMA cuentan con estrategias específicas para conectarse a las cadenas de valor en los sectores que consideran prioritarios. Por ejemplo, Gambia informa de que en su Programa Nacional de Inversión Agrícola se hace hincapié en la importancia de impulsar la agricultura comercial para aumentar la producción, desarrollar las cadenas de elaboración de alimentos y promover el comercio nacional, intrarregional y extrarregional. Según Gambia, el desarrollo del sector manufacturero está basado en la necesidad de incrementar la competitividad y el valor añadido para lograr un mayor acceso al mercado regional a través del plan de liberalización comercial de la Comunidad Económica de los Estados del África Occidental (CEDEAO). Por el momento no hay estrategias sectoriales para los servicios ni la propiedad intelectual, pero la estrategia comercial que se está ultimando abarcará las mercancías y los servicios. 


\section{Gráfico 1.3 Sectores y subsectores identificados como fuentes de crecimiento en las estrategias nacionales de desarrollo de los PMA (porcentaje de respuestas de los países asociados)}

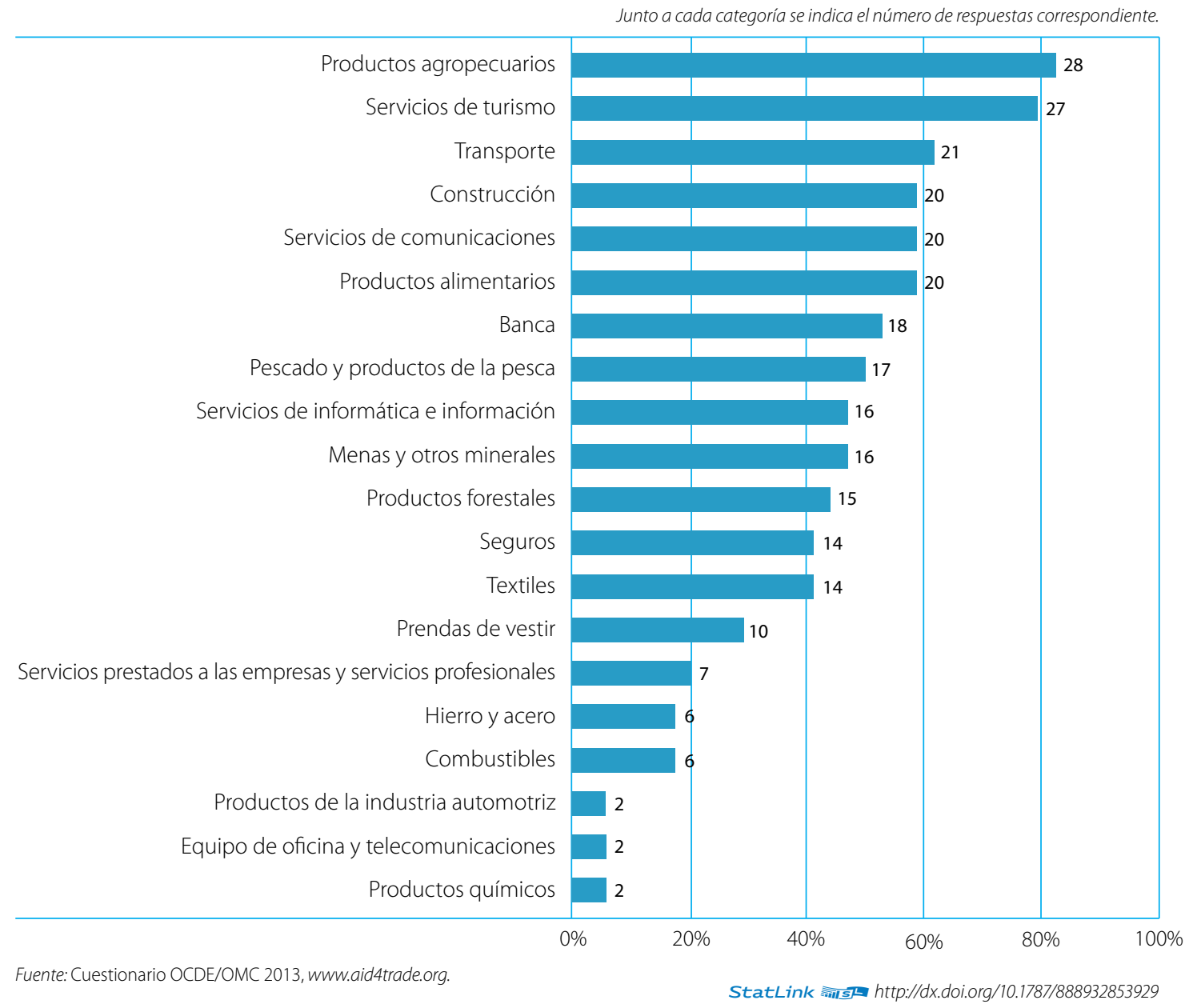

... mientras que las importaciones se están convirtiendo en un factor más importante para el crecimiento futuro.

Hallaert, Cepeda y Kang (2011) consideran que, "aparte de un grupo de economistas especializados en cuestiones comerciales," no hay quien entienda bien la importancia decisiva de las importaciones para el crecimiento económico. Esos autores también señalan que las importaciones ocupan, en el mejor de los casos, un lugar marginal en el debate público, en las decisiones a nivel de la formulación de políticas y en el diseño de los proyectos y programas de ayuda. De las respuestas al cuestionario de la OCDE y la OMC (gráfico 1.4) se desprende que esta situación está cambiando. Así, se considera que las importaciones constituyen un factor importante para el crecimiento futuro, especialmente en las esferas de las manufacturas, los servicios, y los combustibles y los productos de la minería (40 o 41 países en cada caso). Sin embargo, muchos países asociados siguen pensando que las importaciones son un obstáculo para el crecimiento en las esferas de la agricultura y la ganadería, la pesca y la silvicultura (30 países) y, en menor medida, las manufacturas (24 países). Los países asociados asignan importancia a los servicios, pero señalan que en las estrategias sectoriales suele tenerse menos en cuenta esa clase de importaciones que las importaciones de otro tipo. Menos de 


\section{Gráfico 1.4 La función de las importaciones (porcentaje de respuestas de los países asociados)}

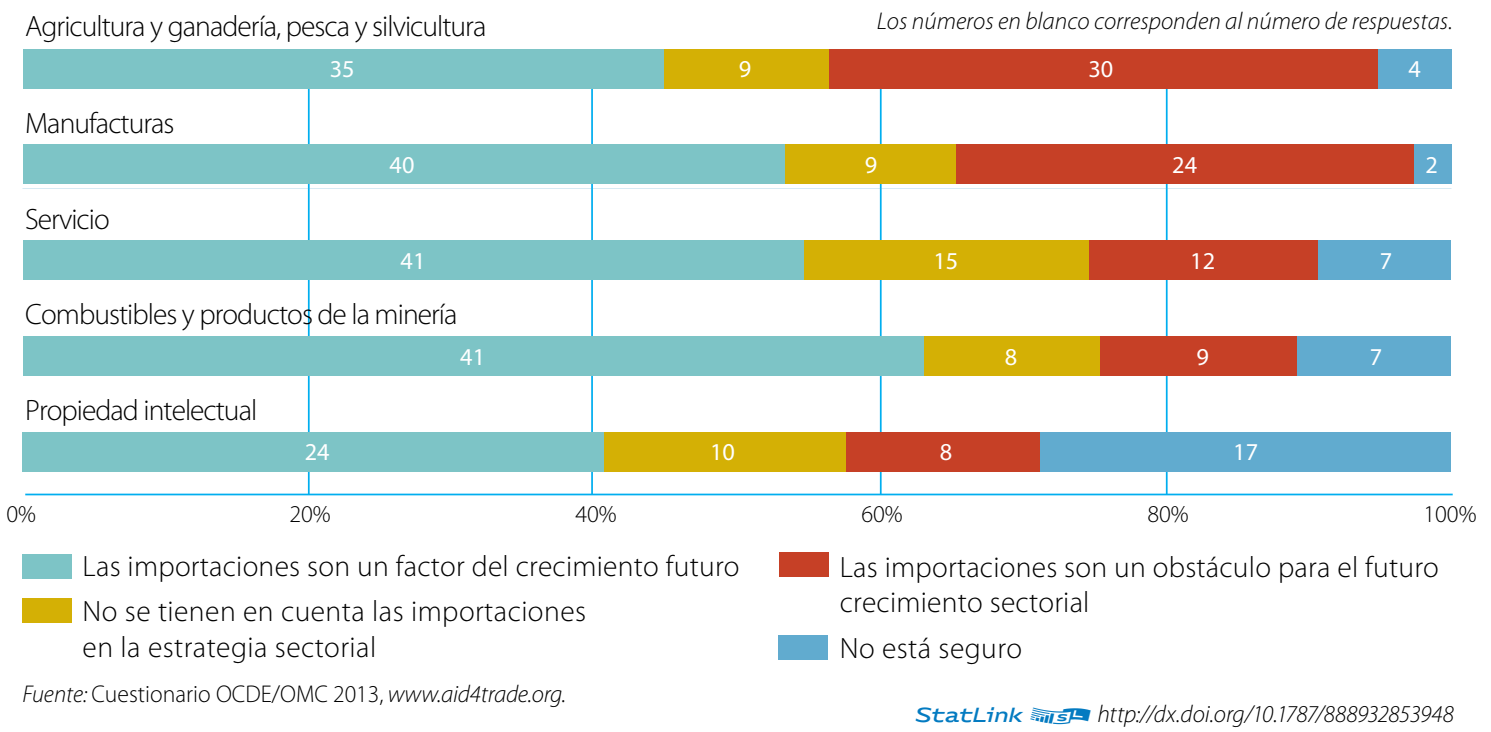

diez países asociados no consideran las importaciones en otras estrategias sectoriales, lo cual es indicio de que, en la mayoría de los casos, las importaciones ya no son un elemento marginal en el debate en torno a la política comercial y el desarrollo. En el contexto de las cadenas de valor, las importaciones son, con creciente frecuencia, un componente de las exportaciones. Como resultado de la creciente importancia que están asignando a las cadenas de valor, los países asociados están prestando cada vez mayor atención a las importaciones en sus estrategias comerciales.

\section{¿CÓMO ESTÁN REACCIONANDO LOS DONANTES FRENTE A LAS NUEVAS MODALIDADES DEL COMERCIO?}

Algunos donantes han puesto en práctica nuevas estrategias de ayuda para el comercio. Casi todos los proveedores de ayuda para el comercio y de ayuda relacionada con el comercio respondieron al cuestionario de autoevaluación. De los cuestionarios cumplimentados por los organismos donantes se desprende que las opiniones de los organismos bilaterales y las de los organismos multilaterales distan de coincidir. Sólo el $40 \%$ de los organismos bilaterales ha modificado sus estrategias, mientras que el $60 \%$ de los multilaterales ha revisado sus enfoques. Los principales donantes bilaterales en función del volumen, (los Estados Unidos y el Japón) no han modificado sus estrategias. El Japón considera que para los países en desarrollo el medio más eficaz de sacar mayor provecho del sistema multilateral de comercio es atraer la inversión extranjera directa; de ahí que la ayuda para el comercio que presta el Japón esté orientada a apoyar la creación de un entorno más favorable a la inversión.' Por su parte, los Estados Unidos están prestando cada vez mayor atención a la facilitación del comercio y a las normas. Con tal fin han establecido el programa Standards Alliance para ayudar a los países en desarrollo a crear la capacidad necesaria para la adopción de normas reconocidas mundialmente para los productos, y ayudarlos así a aclarar y racionalizar sus procesos normativos.

En 2011 el Ministerio Federal de Cooperación Económica y Desarrollo de Alemania (BMZ) publicó una nueva Estrategia de Ayuda al Comercio. ${ }^{2}$ El objetivo prioritario de la política alemana de desarrollo relacionado con el comercio es ayudar a los países asociados a integrarse de manera satisfactoria en el sistema económico mundial y en las comunidades económicas regionales, a diversificar su economía y sus exportaciones, y a utilizar el comercio de 
mercancías y servicios y la inversión extranjera directa para reducir la pobreza de manera más eficaz en el contexto del desarrollo sostenible. Las nuevas esferas prioritarias son la integración económica regional; la facilitación del comercio; las infraestructuras de calidad; y la integración en las cadenas de valor regionales e internacionales (tanto en los sectores agrícolas como en los no agrícolas, incluido el comercio de servicios).

\section{Aun cuando no existen nuevas estrategias, los instrumentos utilizados han evolucionado e influyen en la orientación de los programas}

Aunque la estrategia de ayuda para el comercio de Francia no ha cambiado desde 2009, los instrumentos financieros utilizados han evolucionado. En el Programa de Creación de Capacidad Comercial de Francia se asigna mayor importancia al cambio climático y al crecimiento verde que antes. Además, en 2010 y 2011 se aplicó de manera intensiva una iniciativa adoptada en 2008 en favor del desarrollo del sector privado en África. El programa de Austria de Cooperación para el Desarrollo seguirá apuntando a promover un "entorno propicio para las empresas", así como el acceso a los servicios de infraestructura, sobre todo en lo que se refiere a la energía. La estrategia danesa en la esfera de la cooperación para el desarrollo se basa en el "Derecho a una vida mejor" y hace hincapié en "la lucha contra la pobreza y la promoción de los derechos humanos, el crecimiento económico y los aspectos comerciales del crecimiento verde".

Nueva Zelandia no ha modificado su estrategia de ayuda para el comercio de 2012, pero en su programa de ayuda ha aplicado una nueva política centrada en el desarrollo económico sostenible, especialmente en el Pacífico: "Como consecuencia de apoyar el desarrollo económico sostenible, se presta mayor atención a la agricultura, la pesca y el turismo -sectores productivos de importancia clave para las perspectivas futuras de crecimiento de nuestros interlocutores -, así como a la infraestructura y la energía, por tratarse de factores importantes que impulsan el crecimiento".

La orientación general de la ayuda para el comercio que presta el Reino Unido se ha mantenido constante desde 2010. Las prioridades se volvieron a definir en el Libro Blanco de 2011 titulado Comercio e inversión para el crecimiento, y en el Plan de Reforma Estructural del Departamento de Desarrollo Internacional (DFID), así como en el Examen de la ayuda bilateral y el Examen de la ayuda multilateral. Entre esas prioridades figuran las siguientes: ayudar a los países en desarrollo a integrarse más plenamente en el sistema mundial de comercio; promover la facilitación del comercio; apoyar el comercio ético y sostenible; desarrollar la capacidad para participar en las negociaciones comerciales; y respaldar las iniciativas de integración regional. Nada de eso ha modificado radicalmente la estrategia de ayuda para el comercio del Reino Unido, pero sí ha influido en el enfoque y el diseño de los nuevos programas. El Examen de la ayuda bilateral llevó al Reino Unido a concentrar la ayuda en un número más reducido de países "en los que la ayuda que presta el DFID podía tener mayor efecto y en los que las necesidades eran más acuciantes". El DFID está apoyando el comercio y la integración regional en el África Subsahariana a través de la Iniciativa de Libre Comercio para África (AFTi), a la que el Reino Unido asigna prioridad. En el Asia Meridional, el Reino Unido está trabajando para impulsar el comercio intrarregional mediante la facilitación del comercio y el mejoramiento de la logística, y en el Caribe, el Reino Unido está contribuyendo a establecer una base económica más sólida ayudando a aplicar los acuerdos comerciales, mejorando el entorno empresarial y reduciendo el costo de importar y exportar y el tiempo necesario con tal fin. Asimismo, el Reino Unido está trabajando para mejorar el entorno comercial y de inversión en Estados frágiles y afectados por conflictos en todo el mundo. 
Los donantes bilaterales están prestando mayor atención al desarrollo del sector privado y la integración regional ...

En general, los donantes bilaterales están prestando mayor atención al desarrollo del sector privado y la integración regional (gráfico 1.5). En el caso de los Países Bajos, ha aumentado la importancia relativa de los programas de desarrollo del sector privado y, en menor medida, de los programas de integración regional. En el gráfico 1.5 también puede verse que las presiones presupuestarias no han ejercido mayor influencia en las estrategias, y que ningún donante bilateral ha modificado su enfoque en respuesta a los recortes presupuestarios. De esto se desprende que el apoyo al desarrollo del sector privado no obedece a motivos de índole presupuestaria, sino que se trata, más bien, de una decisión estratégica como resultado de un nuevo enfoque de la asistencia oficial para el desarrollo (AOD) en general y no sólo de la ayuda para el comercio. Sin embargo, la presión a la que se ven sometidos actualmente los presupuestos bien puede estar acelerando esa tendencia. La Alianza de Busán para la Cooperación Eficaz para el Desarrollo de 2011 confirma ese cambio de orientación.

\section{Gráfico 1.5 Factores de cambio más importantes y menos importantes para los donantes bilaterales}

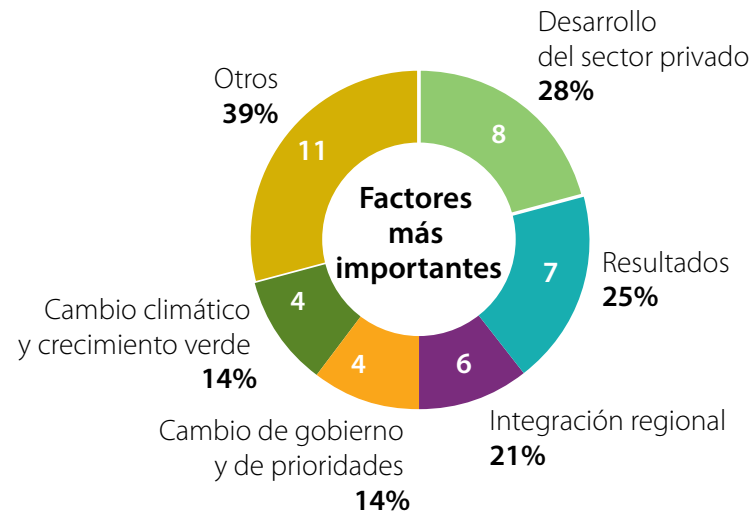

Fuente: Cuestionario OCDE/OMC 2013, www.aid4trade.org.
Los números en blanco corresponden al número de respuestas.

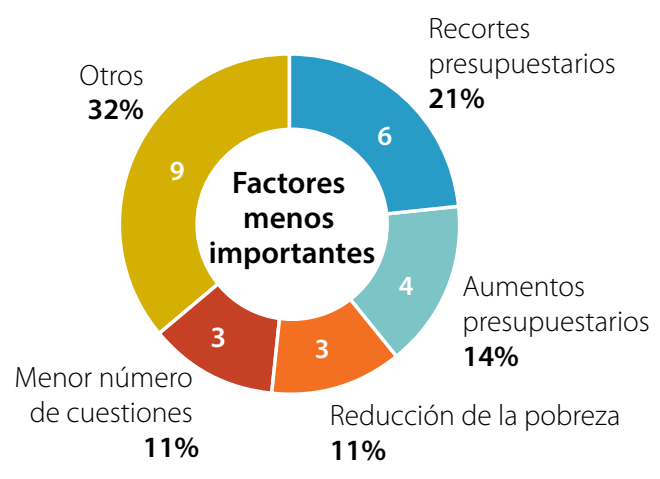

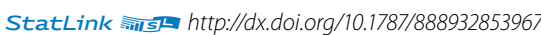

... así como a los resultados, que seguirán teniendo importancia en el futuro ...

Los donantes están asignando mayor importancia a la evaluación, los resultados y los efectos de las intervenciones en la esfera de la ayuda para el comercio. Para siete donantes bilaterales éste es el cambio más importante, y para cuatro se trata de un cambio importante (gráfico 1.5). Al evaluar la ayuda para el comercio, el Japón observó una evidente mejora en los resultados económicos (crecimiento económico y de las exportaciones) de los principales países receptores de ayuda. ${ }^{3}$ Una de las conclusiones fundamentales de la evaluación de la ayuda para el comercio llevada a cabo por Finlandia es que no se ha integrado el comercio en los proyectos y programas sectoriales/temáticos clasificados como ayuda para el comercio. Una proporción considerable de esos proyectos o programas carece de objetivos o resultados relacionados con el comercio. Uno de los principales motivos de que así sea es que no se entienden bien -o no se consideran importantes- los vínculos que pueden existir entre los proyectos o programas que pueden definirse como ayuda para el comercio en sentido lato y los posibles resultados relacionados con el comercio. Esa conclusión confirma los resultados de la metaevaluación llevada a cabo por la OCDE en el estudio Strengthening Accountability in Aid for Trade (OCDE, 2011), según los cuales, normalmente, las evaluaciones de los proyectos y programas de la ayuda 
para el comercio no tienen mucho que decir sobre el comercio y, menos aún, sobre los vínculos de mayor interés para los responsables de formular las políticas. El hecho de que en las evaluaciones no se haga referencia a determinados resultados en la esfera del comercio obedece, al menos parcialmente, a la ausencia de objetivos relacionados con el comercio en el mandato inicial de los proyectos y programas.

\section{... junto con el crecimiento verde.}

Según los donantes, en los próximos cinco años seguirá prestándose considerable atención a los resultados. De hecho, 20 donantes prevén que esta cuestión constituirá el cambio más importante en sus estrategias futuras. Otros factores que también se prevé que tendrán influencia en los próximos cinco años son el cambio climático y el crecimiento verde (14 donantes); el desarrollo del sector privado (12 donantes); la reducción de la pobreza (12 donantes); y la integración regional (10 donantes).

Los donantes consideran que el crecimiento verde será una prioridad en el futuro, pero los países asociados no están tan convencidos. Los donantes bilaterales y multilaterales prevén que en los próximos cinco años se hará mayor hincapié en el crecimiento verde y el cambio climático que en la ayuda para el comercio. Para 14 donantes, se trata del cambio más importante. Esta evaluación concuerda con el llamamiento hecho por el Director General de la OMC, Pascal Lamy, para que se explique de qué manera puede contribuir la ayuda para el comercio al logro de los objetivos de política generales, como la adaptación al cambio climático, la generación de energía y el desarrollo sostenible. La OCDE (2012) ha examinado la cuestión del cambio climático, las políticas adoptadas para mitigarlo y la forma en que todo ello transformará la distribución de la ventaja comparativa. Hay que integrar en los programas de ayuda para el comercio esos posibles cambios en las modalidades del comercio, incluidas las nuevas oportunidades que ofrece la aplicación de las normas encaminadas a reducir los niveles de carbono, algo que, según los donantes, ya están haciendo.

Como se ha indicado precedentemente, los países asociados han declarado que el crecimiento verde y el cambio climático no figuran entre los principales factores en sus estrategias. Resnick et al. (2012) argumentan que el crecimiento verde, como la mayoría de los otros tipos de reformas a nivel de política, significa la aceptación del costo del ajuste a corto plazo a cambio de la obtención de beneficios a largo plazo. Por ejemplo, Maldivas, al responder al cuestionario de la ayuda para el comercio de 2011, dijo que le preocupaba que el cambio climático y el crecimiento verde pudieran convertirse en prioridades para los donantes, ya que se trataba de una preocupación que no era forzosamente compartida por la generalidad de los países asociados.

\section{Los donantes multilaterales también están prestando mayor atención a los resultados, así como a la reducción de la pobreza...}

La mayoría de los donantes multilaterales (9 de 15, o sea un 60\%) han modificado su enfoque de la ayuda para el comercio. Los donantes multilaterales suelen estar más especializados y ya cuentan con amplios programas de promoción tanto del desarrollo del sector privado como de la integración regional. Ningún factor de cambio que afecta a sus estrategias de ayuda para el comercio sobresale especialmente respecto del resto. En algunos casos se trata de cambios institucionales de mayor alcance, como nuevas autoridades o nuevas prioridades generales (4 organismos) (gráfico 1.6). Cabe destacar que los cambios en el presupuesto -ya sean aumentos o disminuciones- no constituyen un factor de cambio, y que 8 organismos los consideran un factor poco importante. Algunos organismos multilaterales (3) están prestando mayor atención a los PMA, y algunos (2) al desarrollo del sector privado, mientras que otros consideran más importantes la integración regional (3) y los resultados (3). 


\section{Gráfico 1.6 Factores de cambio más importantes y menos importantes para los donantes multilaterales}

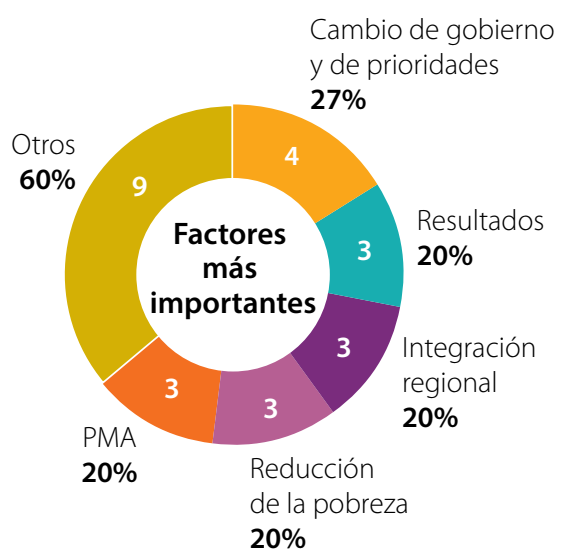

Fuente: Cuestionario OCDE/OMC 2013, www.aid4trade.org.
Los números en blanco corresponden al número de respuestas

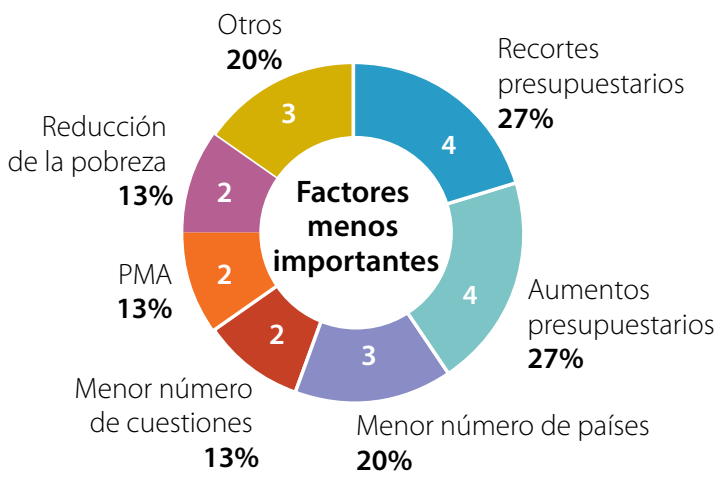

StatLink 青15 http://dx.doi.org/10.1787/888932853986

... y al logro de los objetivos a través de nuevos instrumentos y asociaciones.

El objetivo del mayor donante multilateral, el Grupo del Banco Mundial, es "hacer más inclusivo el comercio y promover sus efectos en la reducción de la pobreza y la desigualdad" (Banco Mundial, 2011). La Estrategia Comercial del Banco Mundial tiene por objeto ayudar al Banco a lograr sus objetivos a través de instrumentos nuevos, como un mejor uso de las asociaciones externas con organismos de desarrollo y el sector privado, así como nuevos mecanismos de coordinación y colaboración destinados a aprovechar de manera más eficaz las sinergias entre los diferentes integrantes del Grupo del Banco Mundial, incluidos el Organismo Multilateral de Garantía de Inversiones (OMGl) y la Corporación Financiera Internacional (CFI).

El Banco Islámico de Desarrollo adoptó recientemente una Nueva Estrategia Empresarial a Mediano Plazo para los próximos tres años, en la que se hace hincapié en la "obtención de resultados, la conectividad y la integración regional". El Banco Africano de Desarrollo (BAfD) terminó recientemente de formular el Programa de desarrollo de infraestructuras en África (PIDA), que ayudará a reducir el déficit de infraestructura que menoscaba gravemente la competitividad de África en el mercado mundial. El PIDA, que comenzó a ejecutarse a principios de 2013, es un programa de planificación estratégica a largo plazo para desarrollar la infraestructura regional de África (2012-2040). La OMC ha "prestado más atención a la gestión basada en los resultados y a una estrategia de formación progresiva en la asistencia técnica relacionada con el comercio" que presta. 


\section{¿CÓMO PARTICIPA EL SECTOR PRIVADO?}

\section{Cada vez más se reconoce el papel que desempeña el sector privado en el desarrollo ...}

En los Objetivos de Desarrollo del Milenio (ODM) se reconoce la necesidad de crear alianzas para el desarrollo, así como el papel que podría desempeñar el sector privado para dar acceso a los beneficios de las nuevas tecnologías, especialmente las de la información y las comunicaciones. En la Alianza de Busán para la Cooperación Eficaz para el Desarrollo también se reconoce el papel clave que cumple el sector privado en "la promoción de la innovación; la creación de riqueza, el ingreso y el empleo; y en la movilización de recursos nacionales contribuyendo así a la reducción de la pobreza". Aunque cada vez más se reconoce la importancia del papel que desempeña el sector privado en el desarrollo, en la práctica está resultando difícil obtener los beneficios correspondientes.

Para el Centro de Comercio Internacional (ITC), el papel del sector privado en la ayuda para el comercio consiste en promover la reforma de las políticas; beneficiarse de la ayuda para el comercio, especialmente en el caso de las pequeñas y medianas empresas de los países en desarrollo y los PMA; y, en calidad de asociado, aportar experiencia, tecnología y mercados para los productos y servicios de las PYME. La Agencia Canadiense de Desarrollo Internacional (CIDA) hace hincapié en la posibilidad de aprovechar los conocimientos, los recursos y la innovación del sector privado para responder a los desafíos y las oportunidades que plantea el desarrollo; esto constituye una prioridad cada vez más importante para muchos donantes y abarca el fomento de la inversión responsable, la facilitación de las conexiones de las empresas locales con cadenas de valor más amplias y la promoción del diálogo entre el sector público y el sector privado.

\section{... y el sector privado participa en el diálogo y la promoción de la ayuda para el comercio.}

El sector privado participa en los programas de desarrollo de muchas maneras diferentes. A nivel de las políticas, se necesita la perspectiva del sector privado en los diálogos de política y las actividades de promoción de las políticas para determinar dónde se encuentran los cuellos de botella relacionados con el comercio, fijar las prioridades nacionales y llevar a cabo reformas encaminadas a mejorar el entorno comercial y empresarial. En los países asociados, según las respuestas al cuestionario de la OCDE y la OMC, el sector privado participa en la elaboración de las estrategias nacionales. Más del $90 \%$ de los países que respondieron al cuestionario señalaron que trabajaban con el sector privado en la elaboración de las estrategias nacionales de desarrollo, las estrategias sectoriales y las estrategias nacionales de desarrollo del comercio.

Las respuestas al cuestionario indican que se está estableciendo un conjunto de estructuras a fin de aumentar la participación del sector privado en la conceptualización, la elaboración y la ejecución de esas diferentes estrategias. Sin embargo, la frecuencia y la calidad del diálogo varían. Algunas de las respuestas indican que ha habido participación del sector privado, pero que éste "carece de capacidad para formular los problemas de manera eficaz". Otras respuestas hacen referencia a las dificultades con que se tropieza a la hora de aplicar las recomendaciones del sector privado.

\section{Todos los proveedores de asistencia suelen consultar al sector privado, pero a veces únicamente en los países donantes...}

Todos los proveedores de asistencia suelen consultar al sector privado al elaborar los programas de ayuda para el comercio y preparar la cooperación relacionada con el comercio: el 78\% de los proveedores de cooperación Sur-Sur relacionada con el comercio, dos tercios de los donantes multilaterales y más de la mitad de los donantes bilaterales (gráfico 1.7). Sin embargo, el sector privado suele estar representado mayormente por empresas o asociaciones de empresas del país donante. Además, la mayoría de los sistemas de incentivos que cubren el costo inicial de la inversión 
y corrigen las asimetrías a nivel de la información suelen beneficiar a empresas de los países donantes. Por ejemplo, con cargo a los fondos del DFID, se ofrecen a las empresas, sobre una base competitiva, subvenciones destinadas a ayudar a cubrir los costos de puesta en marcha. Finlandia ha establecido un sistema denominado Finpartnership que ofrece a empresas finlandesas capital financiero inicial y servicios de asesoramiento para que pongan en marcha y lleven a cabo sus operaciones comerciales en países en desarrollo. Cuando se creó el Fondo para las Asociaciones para el Desarrollo Internacional de Nueva Zelandia, se estableció un fondo al que pueden tener acceso, sobre una base competitiva, las organizaciones neozelandesas del sector público y privado, así como las organizaciones neozelandesas de beneficencia y otras organizaciones sin ánimo de lucro. Nueva Zelandia está constantemente buscando el modo de suplir las carencias, en particular a nivel de la oferta, mediante un enfoque colaborativo que incluye la participación del sector privado.

Los donantes también están recurriendo a los conocimientos prácticos y la experiencia del sector privado. Siete donantes multilaterales, siete donantes bilaterales y siete proveedores de cooperación Sur-Sur relacionada con el comercio celebran consultas con el sector privado a la hora de elaborar sus programas. Los donantes han consultado al sector privado para formular sus estrategias generales de desarrollo. Para la elaboración del Plan Director de la Cooperación Española 2009-2012, España celebró amplias consultas en las que participaron el sector privado, empleadores y empresas privadas, así como cooperativas,. En función de la naturaleza de sus programas, los organismos multilaterales también celebran conversaciones con el sector privado de los países asociados: 10 de esos organismos celebraron ese tipo de consultas, en comparación con sólo tres donantes bilaterales y un proveedor de cooperación Sur-Sur.

\section{Gráfico 1.7 Consultas con el sector privado para la elaboración de estrategias de ayuda para el comercio (porcentaje de respuestas)}

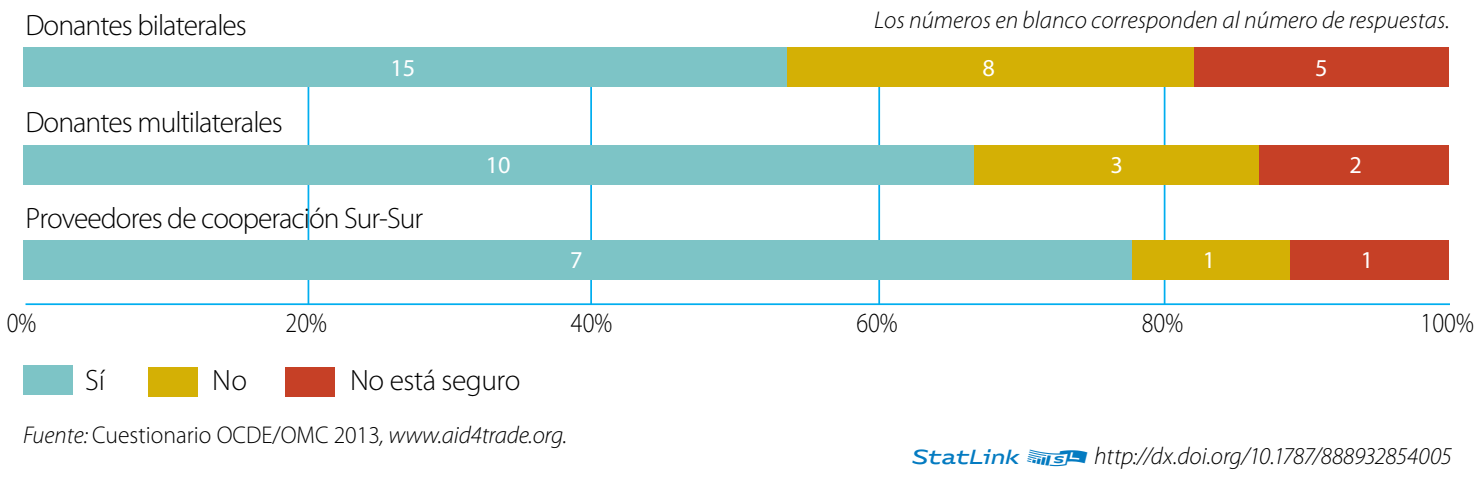

El sector privado participa de muchas maneras. En general, los donantes interactúan en distinta medida con el sector privado: a veces el sector privado participa en los diálogos de política, cumple funciones de asesoramiento, recibe y proporciona financiación, y participa en la ejecución y el intercambio de información. Globalmente, el sector privado participa por igual en cada una de esas funciones (gráfico 1.8). También en este caso, los donantes multilaterales hacen participar al sector privado en medida considerable. El sector privado es beneficiario de la asistencia que prestan muchos organismos (en 7 casos, siempre; en 6 casos, a veces). A veces, el sector privado participa en la ejecución (en 6 casos, siempre; en 5 casos, a veces). Los organismos multilaterales señalan que suelen requerir los servicios de asesoramiento y de expertos del sector privado o su participación en actividades de evaluación o aprendizaje (en 2 casos, siempre; en 8 casos, a veces). La situación relativa a los donantes bilaterales es menos clara: la mayoría de los 
donantes solicita la participación del sector privado en los diálogos de política (4, siempre; 19, a veces), la ejecución (3, siempre; 20, a veces) y recurre a los servicios de asesoramiento y de expertos (3, siempre; 20, a veces). Por ejemplo, las actividades del Canadá orientadas al sector privado incluyen el Programa para crear capacidad comercial en África y el Programa de fomento del espíritu de empresa y la innovación en el Caribe. A través de esa clase de programas, el Canadá está vinculando a empresarios del mundo en desarrollo con compradores canadienses e internacionales e integrándolos en cadenas de valor mundiales.

Los proveedores de cooperación Sur-Sur relacionada con el comercio hacen participar al sector privado a través del diálogo (en 4 casos, siempre; en 2 casos, a veces) y, al igual que otros proveedores de asistencia, consideran que el sector privado es un socio importante a nivel de la ejecución (en 3 casos, siempre; en 4 casos, a veces). Algunos donantes tienen una interacción limitada con el sector privado debido al tipo de servicios que prestan en los países receptores. Algunos no utilizan modalidades de financiación que entrañen la participación del sector privado ni la financiación de contraparte. Además, la experiencia en relación con la participación del sector privado en la evaluación de proyectos y programas parece ser limitada.

\section{Gráfico 1.8 Colaboración del sector privado con donantes y proveedores de cooperación Sur-Sur (porcentaje de respuestas)}

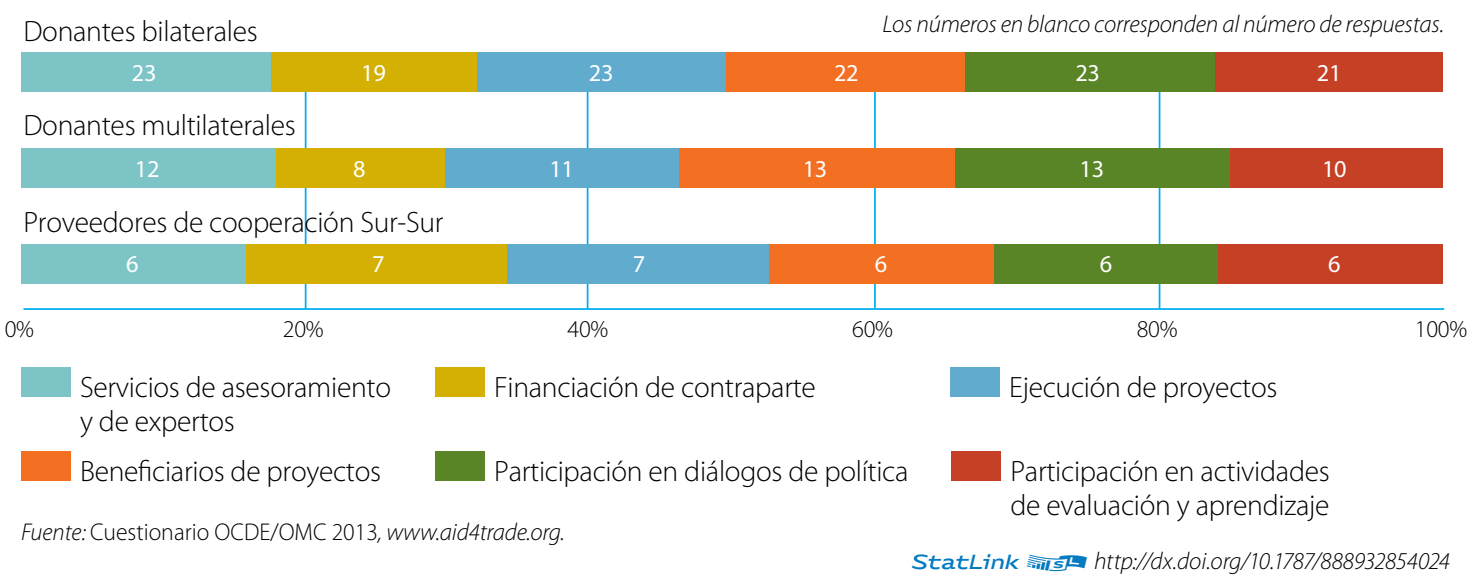

... mientras que los resultados de los programas de desarrollo del sector privado son desparejos.

Según el análisis crítico de las políticas de desarrollo del sector privado realizado por Schulpen y Gibbon (2002), dichas políticas son dictadas sobre todo por la naturaleza y los intereses del sector privado de los países donantes, incorporan una proporción elevada de ayuda condicionada, y no pasan las pruebas más elementales de coherencia. Otros análisis más recientes son más positivos. Por ejemplo, según una evaluación realizada por la UE de los programas de desarrollo del sector privado, aunque hay amplio consenso en cuanto a la importancia del desarrollo del sector privado para la creación de puestos de trabajo, la relación entre la ayuda que presta la UE al desarrollo del sector privado y la generación de empleo (CE, 2013) sigue siendo muy tenue. También según dicha evaluación, la UE ha hecho contribuciones valiosas al desarrollo del sector privado en países de ingresos medios, en particular a través del diálogo de política, la armonización de su política con las prioridades de los países beneficiarios y el claro papel que desempeña la UE en el desarrollo del sector privado. 
Según la metaevaluación del desarrollo del sector privado realizada por el Organismo Danés de Desarrollo Internacional (DANIDA) (Dinamarca, 2009), las intervenciones que apoyan a las empresas abastecedoras y productoras organizadas en cadenas de valor han ido adquiriendo creciente importancia entre los donantes. Además, la manera de encarar las intervenciones mejora conforme se va adquiriendo experiencia y aplicando prácticas óptimas. Sólo hay unas pocas evaluaciones de los efectos a largo plazo y la sostenibilidad, pero los indicios son positivos. Ese tipo de intervención permite obtener efectos sistémicos positivos en las partes interesadas y quienes participan en las cadenas de valor.

\section{Muchos donantes participan en asociaciones entre el sector público y el sector privado ...}

Cuando se trata de crear capacidad comercial, los donantes tienen sobrados incentivos para hacer participar al sector privado, y muchos donantes participan en programas de cooperación entre el sector público y el sector privado. Por ejemplo, mediante el programa de la Deutsche Gesellschaft für Internationale Zusammenarbeit (GIZ/DEG) en la esfera de la asociación entre el sector público y el privado se cofinancian proyectos privados con una importante repercusión en el desarrollo. También se apoya la integración de interlocutores privados en proyectos de cooperación técnica que ejecuta la GIZ con países asociados. La UE está estudiando nuevas maneras de utilizar donaciones para movilizar los recursos del sector privado en pro del desarrollo, para lo cual está ampliando el alcance y la escala de los servicios de recursos mixtos (donaciones y préstamos) y estableciendo mecanismos para compartir riesgos y regímenes de garantía para los inversores privados en asociación con las instituciones europeas de financiación del desarrollo. El Fondo para la Aplicación de Normas y el Fomento del Comercio (STDF) apoya los proyectos encaminados a mejorar la coordinación entre el sector público y el sector privado. Como parte de la labor de investigación realizada por el STDF en 2010, en colaboración con el Banco Interamericano de Desarrollo (BID), se analizó la creación, el funcionamiento y los resultados de determinadas asociaciones encargadas de cuestiones sanitarias y fitosanitarias establecidas entre el sector privado y organismos públicos responsables de la inocuidad alimentaria y la sanidad animal y vegetal y/o el comercio.

La OCDE (2008) ha señalado que para que las asociaciones entre el sector público y el sector privado tengan éxito, los gobiernos deben definir claramente los marcos jurídico y normativo y asegurarse de que cuentan con la capacidad apropiada para poner en marcha y administrar esas asociaciones. El suministro de un entorno propicio de esa índole tiene consecuencias para la gobernanza pública, ya que es indispensable que el sector público sea considerado un socio fiable que cuenta con mecanismos adecuados de reglamentación y supervisión. La competencia que caracteriza al proceso de licitación da al gobierno un mayor poder de negociación, e impide el comportamiento oportunista (monopolista) de los licitantes privados. En un informe del Public Interest Research Group de los Estados Unidos (2011) se enumeraban diez principios para reducir los riesgos y proteger el interés público, entre los que figuraban los siguientes: establecer asociaciones entre el sector público y el sector privado por razones "valederas" y con un "claro valor añadido"; armonizar "los incentivos del sector privado con los objetivos del sector público"; establecer asociaciones entre el sector público y el sector privado únicamente "cuando haya mucha competencia"; asegurarse de que exista un mecanismo "claro de rendición de cuentas"; conservar el control público sobre las decisiones del sistema; limitar la duración de los contratos; y garantizar la transparencia del proceso de contratación.

La aceptabilidad pública y social de esa clase de asociaciones es a menudo un factor clave. El compromiso político de alto nivel es crucial para garantizar que los agentes del sector privado respeten los compromisos a largo plazo y reducir al mínimo el riesgo político. El compromiso político también puede ayudar a convencer a la opinión pública del valor de las asociaciones entre el sector público y el sector privado como modo de suministro de servicios. La Corporación Financiera Internacional (CFI) (2012: 48-51) ha demostrado cómo un análisis de los costos y beneficios 
económicos permite a los gobiernos evaluar los beneficios netos que reportarán los proyectos a la sociedad y proceder luego a seleccionar el que genere más beneficios. El análisis de los costos y los beneficios económicos también minimiza la oposición de la opinión pública, al mostrar que los beneficios para la sociedad son el factor decisivo a la hora de aprobar la ejecución de un proyecto. En esa clase de evaluación deberán abordarse cuestiones como la medida en que a los agricultores les resultará más fácil colocar sus productos en el mercado, y de ese modo pasar de la agricultura de subsistencia a la explotación comercial. O bien, a cuántos nuevos puestos de trabajo tendrán acceso las personas que viven lejos de los centros económicos. Otro elemento guarda relación con los beneficios que el proyecto reportará a la población, por ejemplo, qué tipo de servicios de transporte se pondrán efectivamente a su disposición y en qué condiciones (CFI, 2012:8).

\section{... especialmente en las esferas de la agricultura, y el transporte y la logística ...}

Las respuestas al cuestionario pintan una imagen dinámica de la cooperación entre el sector público y el sector privado y contienen numerosos ejemplos de esa cooperación, en particular en el sector de la agroindustria y la elaboración de alimentos, así como del transporte y la logística. En la esfera de la agricultura, la Organización de las Naciones Unidas para la Alimentación y la Agricultura (FAO) ayuda a las explotaciones agrícolas y a las agroindustrias a adquirir los conocimientos técnicos y de gestión necesarios para apuntalar la producción, las actividades posteriores a la cosecha, las operaciones financieras y de comercialización y creación de infraestructura relacionadas con el desarrollo y el aumento de la eficiencia, la eficacia, la competitividad y la rentabilidad de las empresas agropecuarias y alimentarias. En la esfera del transporte y la logística, la Asociación Mundial para la Facilitación del Transporte y el Comercio (GFP) tiene como objetivo reunir a todas las partes interesadas del ámbito público o privado, a escala nacional e internacional, que desean contribuir a introducir mejoras significativas en la facilitación del transporte y el comercio en países miembros del Banco Mundial. Los asociados han acordado diseñar y ejecutar programas específicos orientados al logro de este objetivo utilizando de forma coordinada la ventaja comparativa respectiva de cada uno en esta esfera.

Nueve donantes multilaterales tienen actividades en la esfera de la agroindustria, y 8 en la del transporte y la logística. Algunos bancos multilaterales tienen asociaciones en todos los sectores, en particular la tecnología de la información y las comunicaciones (6), los textiles y las prendas de vestir (5) y el turismo (5). Los resultados de la labor de investigación del STDF indican que las asociaciones sirven para reforzar las medidas sanitarias y fitosanitarias, obtener mejores resultados en materia sanitaria y fitosanitaria e incrementar el acceso a los mercados. Sólo 3 donantes multilaterales han indicado que no participan en asociaciones entre el sector público y el sector privado.

Asimismo, seis donantes bilaterales han indicado que no participan en asociaciones entre el sector público y el sector privado. De los nueve que sí participan en ellas, siete tienen programas en la esfera del transporte y la logística y seis en el sector de la agroindustria. Por ejemplo, el proyecto de construcción de infraestructura portuaria de Lach Huyen, en Viet Nam, es financiado en parte por el Japón, junto con fondos públicos para las obras públicas necesarias para la construcción del puerto y de la infraestructura básica conexa (como carreteras y puentes de acceso), la contratación de equipo y suministros y los servicios de consultoría. La construcción del puerto de aguas profundas tiene por objeto atender a la demanda generada por el aumento del volumen de la carga, así como del número de embarcaciones de mayor tamaño en el transporte marítimo, e incrementar así la competitividad de Viet Nam. 
En el ámbito de la agricultura, en un estudio de un proyecto llevado a cabo por la Iniciativa Africana del Anacardo con múltiples partes interesadas, se indicaban los progresos que se preveía lograr para 2013: un aumento de la productividad del 50\%; un aumento de por lo menos 100 dólares EE.UU. del ingreso anual de 150.000 productores de anacardos; la triplicación del volumen procesado actual; y la creación de 5.500 puestos de trabajo en la industria procesadora. El organismo principal de ejecución (GIZ), en colaboración con la Fundación Bill \& Melinda Gates (BMGF), que es el principal ente de financiación del programa, reconoce que un factor clave del éxito es el enfoque innovador de la cofinanciación y la ejecución, que congrega a un gran número de grandes contribuyentes privados y de participantes en las cadenas de valor. Además de los incentivos destinados a las empresas, los participantes del sector privado consideran que el apoyo de los organismos donantes y los asociados en la ejecución constituye un factor clave para el rédito de su inversión (Heinrich, 2012).

\section{... mientras los proveedores de cooperación Sur-Sur utilizan ese tipo de asociaciones para aprovechar las oportunidades que ofrece el comercio bilateral}

Según se desprende de sus respuestas, los proveedores de cooperación Sur-Sur relacionada con el comercio tienen un enfoque sectorial similar al de otros donantes. Dos proveedores no indican que haya cooperación entre el sector público y el sector privado; cinco tienen actividades en la esfera del transporte y la logística; y cuatro en la agroindustria y en el sector de la tecnología de la información y las comunicaciones. Para los proveedores de cooperación Sur-Sur, el beneficio más importante de las asociaciones entre el sector público y el sector privado es la posibilidad de crecimiento del comercio bilateral, seguida de la movilización de fuentes de financiación no vinculadas a la ayuda. Para los donantes multilaterales, los beneficios más importantes son la transferencia de tecnología (nueve encuestados la califican de muy importante, y cinco, de importante) y la sostenibilidad después de cesar el apoyo de los donantes. Los donantes bilaterales también conceden gran importancia a la sostenibilidad, así como a la transferencia de los conocimientos especializados del sector privado. Los dos beneficios de las asociaciones del sector privado y el público que los proveedores de cooperación Sur-Sur consideran decisivos son los menos importantes para los donantes bilaterales y multilaterales (gráfico 1.9).

\section{Gráfico 1.9 Beneficios que los donantes y los proveedores de cooperación Sur-Sur consideran que reportan las asociaciones entre el sector público y el sector privado (porcentaje de respuestas que los consideran "más importantes")}

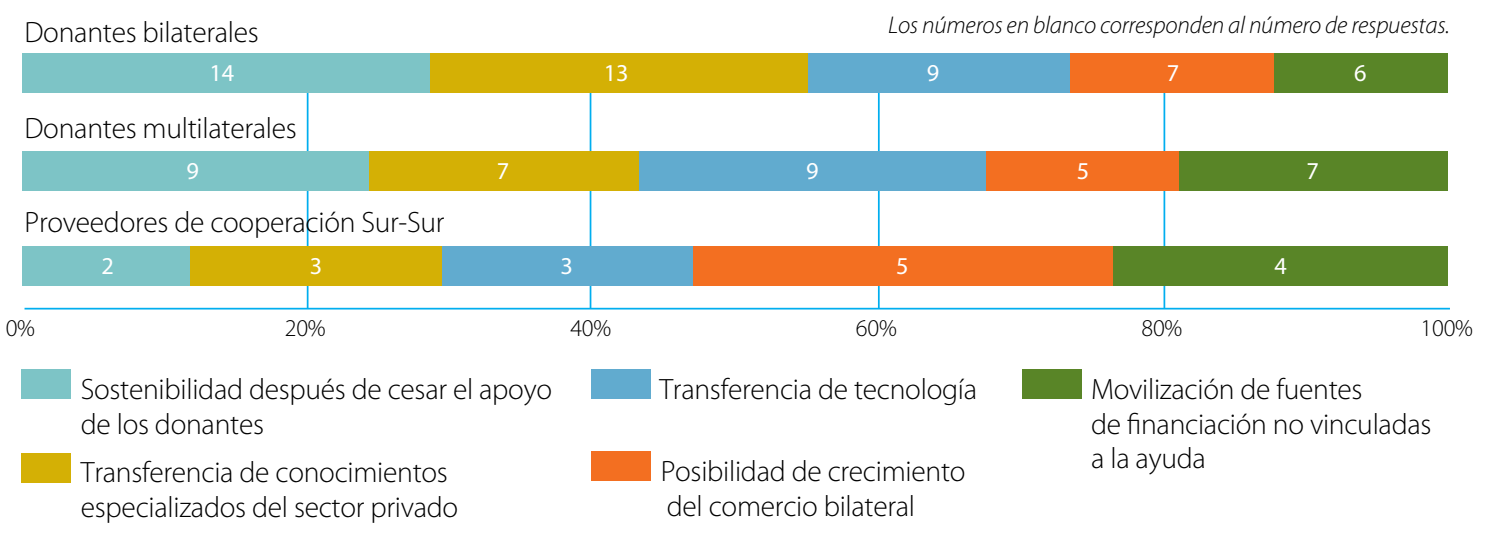




\section{Frecuentemente no se tiene acceso a los conocimientos técnicos y prácticos necesarios para establecer y administrar las asociaciones entre el sector público y el sector privado ...}

Los donantes son conscientes de que las asociaciones entre el sector público y el sector privado permiten obtener mejores resultados (gráfico 1.9), pero también señalan los desafíos fundamentales a que hacen frente para desarrollar, llevar a la práctica y administrar ese tipo de asociaciones (por ejemplo, las diferencias a nivel de la estructura organizativa, la desconfianza, los problemas de comunicación, las diferencias a nivel de las expectativas y la rotación de personal). Frecuentemente no se tiene acceso a los conocimientos técnicos y prácticos necesarios para establecer y administrar las asociaciones entre el sector público y el sector privado. Alemania enumera otras dificultades relacionadas con ese tipo de asociaciones: el escepticismo de los organismos públicos en cuanto a las ventajas de las asociaciones entre el sector público y el sector privado (no se trata únicamente de que sean rentables; sobre todo, deben ser políticamente viables); el desconocimiento del hecho de que esa clase de asociaciones ofrezcan un método de contratación alternativo; y las difíciles condiciones generales en que deben ser administradas.

\section{Gráfico 1.10 Dificultades con que tropiezan los donantes para establecer asociaciones entre el sector público y el sector privado (porcentaje de respuestas)}

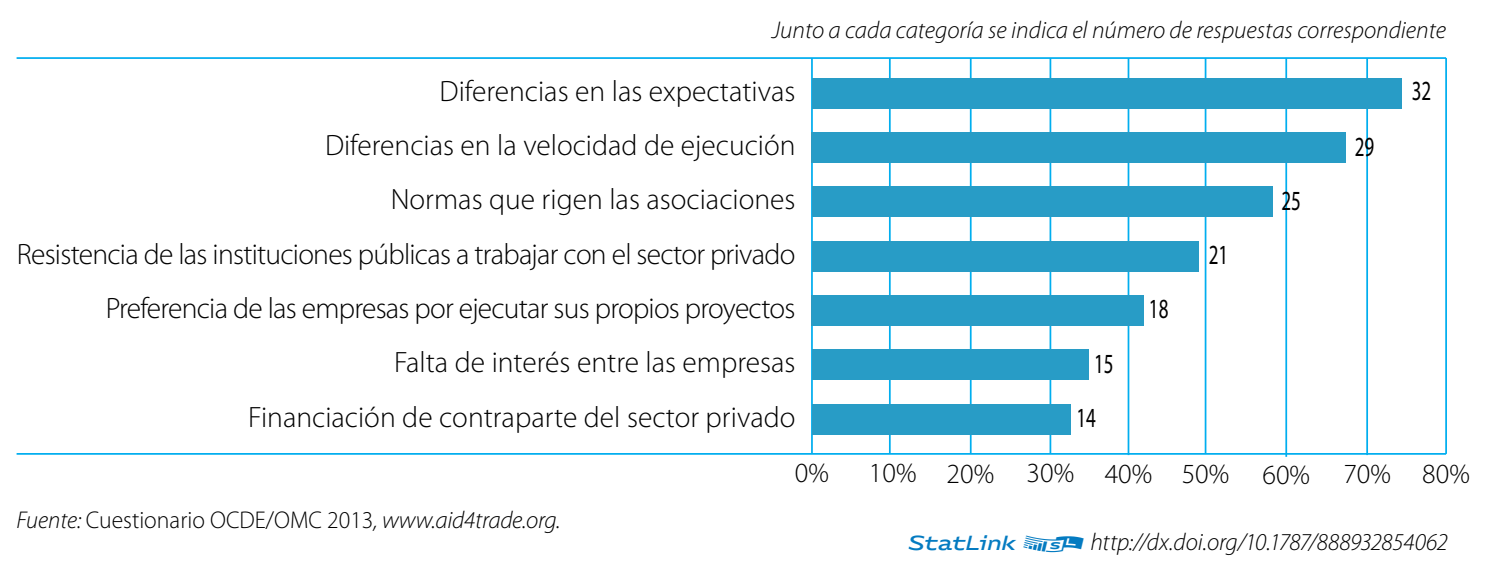

Según los donantes multilaterales y bilaterales, las principales dificultades con que tropiezan para establecer asociaciones entre el sector público y el sector privado son las diferencias entre las expectativas del sector público y las del sector privado, las diferencias entre la velocidad de ejecución del sector privado y la del sector público y la falta de consenso sobre las normas adecuadas (gráfico 1.10). Esto es indicio de que queda mucho por hacer para que las asociaciones entre el sector público y el sector privado beneficien a todas las partes.

Según la CFI (CFI, 2012: 43), la gestión de las asociaciones entre el sector público y el sector privado ha evolucionado y avanzado en Colombia. En 2011 se creó la Agencia Nacional de Infraestructura (ANI) para establecer el marco institucional necesario para acelerar el desarrollo de la infraestructura de transporte del país. Uno de los cambios importantes que se han hecho consiste en incentivar al sector privado para que presente propuestas por iniciativa propia. Colombia ha recibido 13 de esas propuestas no solicitadas en relación con las carreteras y cuatro en relación con los ferrocarriles, que representan una inversión total de 8.000 millones de dólares EE.UU. ${ }^{5}$ Es evidente que un enfoque de esa naturaleza contribuye a subsanar algunas de las dificultades mencionadas supra. 


\section{... sin embargo, la cooperación entre el sector público y el sector privado no debería llevar a condicionar la ayuda.}

La participación del sector privado en los programas de los donantes no debería entrañar la reintroducción de la práctica de condicionar la ayuda. Una y otra vez se ha considerado que el hecho de que el donante condicione el desembolso de la ayuda a su utilización por los asociados para adquirir mercancías y contratar obras y servicios de proveedores con base en el país donante es una prueba irrefutable del nivel de compromiso del donante con una prestación eficiente de la ayuda. Está debidamente documentado que el condicionamiento de la ayuda hace aumentar el costo de muchas mercancías, obras y servicios en un 15\% a un 30\% por término medio. ${ }^{6}$ Éste es un cálculo por lo bajo del costo global, ya que no incluye los costos indirectos. A menudo, el condicionamiento de la ayuda hace aumentar el costo de las transacciones para los países asociados, y obedece, al menos en parte, a consideraciones comerciales en que no se tienen forzosamente en cuenta las necesidades ni las prioridades locales

Para eliminar la distorsión de las corrientes financieras que causa la financiación en condiciones concesionarias, en las Disciplinas sobre la Ayuda Condicionada de la OCDE (1992) se limita la utilización de financiación concesionaria condicionada para la ejecución de proyectos que podrían obtener financiación en condiciones de mercado. En esas normas se prevé también la reorientación de la ayuda condicionada de los países en desarrollo más ricos (es decir, aquéllos con un PIB per cápita que no les da derecho a obtener los préstamos a 17 y 20 años del Banco Mundial), que en principio deberían poder obtener créditos en condiciones de mercado, hacia los países en desarrollo con menos medios. En 2002, la OCDE recomendó suprimir el condicionamiento en todas las clases de ayuda (con excepción de la cooperación técnica y la ayuda alimentaria) que se concediese a los países menos adelantados, y en 2006 decidió que esa recomendación se aplicase también a los países pobres muy endeudados.

Como resultado de esas iniciativas, aumentó considerablemente la proporción de la ayuda no condicionada prestada por países miembros del Comité de Asistencia para el Desarrollo (CAD) de la OCDE: de un 40\% en 2000 al 76\% en 2009, para luego disminuir al 73\% en 2011. Aunque dos años no constituyen una tendencia, deberían preservarse los considerables progresos logrados en la eliminación de la distorsión que introduce en las corrientes comerciales el dinero por concepto de ayuda; de lo contrario, se corre el riesgo de reducir aún más una ayuda cuyo volumen ya está mermando.

\section{CONCLUSIONES}

Como se desprende de las respuestas al cuestionario de 2013 de la OCDE y la OMC, la ayuda para el comercio está evolucionando. Los países asociados, entre los que se cuentan los países menos adelantados (PMA), están prestando especial atención a la manera de reducir la densidad de sus fronteras, mejorar el entorno empresarial y crear condiciones que ayuden a sus empresas a conectarse a las cadenas de valor regionales y mundiales. Por su parte, los donantes están teniendo en cuenta esas prioridades. Así, están haciendo más hincapié en la cooperación entre el sector público y el sector privado y adaptando sus programas para orientarlos hacia sectores específicos y determinadas cadenas de suministro. Los proveedores de cooperación Sur-Sur relacionada con el comercio siguen incrementando su ayuda y afianzando el comercio Sur-Sur. 
Todas las partes interesadas siguen estando firmemente empeñadas en vigilar la aplicación de la Iniciativa de Ayuda para el Comercio; la creciente atención que se está prestando a las cadenas de valor ha revitalizado el debate sobre la ayuda para el comercio. Sin embargo, sigue habiendo problemas. El uso más generalizado de instrumentos como las asociaciones entre el sector público y el sector privado plantea problemas tanto a los países asociados como a los organismos donantes. Además, el aumento de la cooperación con el sector privado no debería servir para que volviese a condicionarse la ayuda. Las cadenas de valor plantean desafíos a la hora de diseñar los programas de ayuda para el comercio. Algunos asociados y donantes siguen teniendo dificultades con el concepto. No obstante, se prevé que los recursos dedicados a la ayuda para el comercio ya no aumentarán. Aunque la prestación de ayuda para el comercio no parece afectar directamente a la formulación de las estrategias y políticas de los países asociados, los donantes o los proveedores de cooperación Sur-Sur relacionada con el comercio, como resultado de las presiones presupuestarias, es cada vez más urgente obtener resultados. Los recursos dedicados a la ayuda para el comercio han aumentado en los últimos cinco años, pero las perspectivas son menos halagüeñas, sobre todo a nivel de los donantes bilaterales. Aunque la inversión extranjera y nacional es indispensable para crear capacidad comercial, la AOD sigue siendo un instrumento esencial, sobre todo para los países menos adelantados. En el capítulo 2 se examina en detalle la evolución de la situación en materia de financiación del desarrollo, y se analizan las perspectivas en materia de recursos destinados a la ayuda para el comercio. 


\section{NOTAS}

1. Declaración del Japón ante el Comité de Comercio y Desarrollo de la OMC (vigésima séptima sesión sobre la Ayuda para el Comercio), marzo de 2013.

2. www.bmz.de/en/publications/type_of_publication/strategies/Strategiepapier308_07_2011.pdf

3. Se determinó que la ayuda para el comercio se había ejecutado eficazmente en Viet Nam y la República Democrática Popular Lao (RDP Lao), los países visitados durante el estudio realizado sobre el terreno en el marco de la evaluación.

4. La primera Estrategia Comercial del Grupo del Banco Mundial, formulada en 2011, consta de cuatro pilares: la competitividad y la diversificación del comercio, a fin de ayudar a los países a establecer entornos normativos propicios para el desarrollo del sector privado, la creación de puestos de trabajo y la reducción sostenible de la pobreza; la facilitación del comercio, la logística del transporte y la financiación del comercio, a fin de reducir el costo, en tiempo y dinero, del transporte internacional de mercancías e incrementar su fiabilidad; el apoyo al acceso a los mercados y la cooperación comercial internacional para crear mercados más grandes e integrados de mercancías y servicios; y la gestión de las perturbaciones externas y la promoción de una mayor inclusión, a fin de que la mundialización reporte mayores beneficios a los hogares pobres y las regiones rezagadas (Banco Mundial, 2011).

5. La Ruta del Sol de Colombia, una autopista con un costo de construcción de 2.600 millones de dólares EE.UU. que conecta Bogotá y el interior del país con los puertos de Santa Marta y Cartagena, en el Caribe, se ha convertido en un modelo de mejor práctica internacional para futuras concesiones viarias. El proyecto recibió el premio del transporte del año 2010 concedido por la Corporación Financiera Internacional (CFI) por su enfoque innovador. Una vez terminada la Ruta del Sol, disminuirán el número de accidentes, el tiempo de viaje y el costo del transporte. Asimismo, la autopista dará un fuerte impulso a las manufacturas, el turismo, la agroindustria y el desarrollo inmobiliario (CFI, 2012: 39).

6. Véase Jepma, C. J. (1991). 


\section{REFERENCIAS}

Banco Mundial (2011), Leveraging Trade for Development and Inclusive Growth: The World Bank Group Trade Strategy, 2011-2021, Banco Mundial, Washington, D.C.

CE (Comisión Europea) (2013), Evaluation of the European Union's Support to Private Sector Development in Third Countries: Final Report, Vol. 1, CE, Bruselas, http:/lec.europa.eu/europeaid/how/evaluation/evaluation_reports/ reports/2013/1317_vol1_en.pdf.

CFI (Corporación Financiera Internacional) (2012), Road \& Rail PPPs, Handshake: IFC's quarterly journal on publicprivatepartnerships, Issue 7, CFI, Washington, D.C., http://viewer.zmags.com/publication/1c3342e7\#/1c3342e7/1.

Dinamarca, Ministerio de Relaciones Exteriores (2009), Synthesis of Evaluations on Support to Business Development, DANIDA, estudio de evaluación 2009/5, www.oecd.org/derec/denmark/44006517.pdf.

Hallaert, J., R. Cavazos Cepeda y G. Kang (2011), Estimating the Constraints to Trade of Developing Countries, OECD Trade Policy Papers, № 116, OCDE, París, www.oecd-ilibrary.org/trade/estimating-the-constraintsto-trade-of-developing-countries_5kg9ma8mx9tc-en.

Heinrich, M. (2012), Case study of the African Cashew Initiative - Focus: Ghana: Lessons from Working with New and Multiple Partners - Emerging Results, Donor Committee on Enterprise Development, Cambridge, Reino Unido, www.value-chains.org/dyn/bds/docs/detail2/824/3.

Jepma, C. J. (1991), The Tying of Aid, OECD Development Centre, París, www.oecd.org/dev/pgd/29412505.pdf.

Moïsé, E. y S. Sorescu (2013), Trade Facilitation Indicators: The Potential Impact of Trade Facilitation on Developing Countries'Trade, OECD Trade Policy Papers, No 144, OCDE, París, http://dx.doi.org/10.1787/5k4bw6kg6ws2-en.

OCDE (2008), Public-Private Partnerships: In Pursuit of Risk Sharing and Value for Money, OCDE, París, http://dx.doi.org/10.1787/9789264046733-en.

OCDE (2011), Strengthening Accountability in Aid for Trade, The Development Dimension, OCDE, París, http://dx.doi.org/10.1787/9789264123212-en.

OCDE (2012), Aid for Trade and Green Growth: State Of Play, COM/DCD/TAD(2012)2/REV1, OCDE, París, www.wto.org/english/tratop_e/devel_e/a4t_e/wkshop_feb12_e/hynes.pdf.

OCDE/OMC (Organización Mundial del Comercio) (2011), La Ayuda para el Comercio en síntesis: mostrar resultados, OCDE y OMC, París y Ginebra, www.wto.org/spanish/res_s/publications_s/aid4trade11_s.pdf.

OMC (Organización Mundial del Comercio) (2006), Recomendaciones del Equipo de Trabajo sobre la Ayuda para el Comercio, WT/AFT/1, http://www.wto.org/spanish/tratop_s/devel_s/a4t_s/implementing_par57_s.htm.

PNUD (Programa de las Naciones Unidas para el Desarrollo) (2011), Trade and Human Development: A Practical Guide to Mainstreaming Trade, COM/DCD/TAD(2013)2/CHAP1, PNUD, Nueva York.

Resnick, D., F. Tarp y J. Thurlow (2012), The Political Economy of Green Growth: Cases from Southern Africa, Public Administration and Development, Vol. 32, 215-228.

Schulpen, L., y P. Gibbon (2002), Private Sector Development: Policies, Practices and Problems, World Development, Vol. 30(1), 1-15.

TMEA (TradeMark East Africa) (2012), Rwanda Opens Wide an Electronic Window for Trade, www.trademarkea.com/rwanda-opens-wide-an-electronic-window-for-trade.

United States Public Interest Research Group (PIRG) Education Fund (2011), High-Speed Rail: Public, Private or Both? Assessing the Prospects, Promise and Pitfalls of Public-Private Partnerships, The Federation of State PIRGs, Boston, www.uspirg.org/sites/pirg/files/reports/HSR-PPP-USPIRG-July-19-2011.pdf. 


\section{CAPÍTULO 2: \\ CORRIENTES DE AYUDA PARA EL COMERCIO Y FINANCIACIÓN}

- n el presente capítulo se proporciona una reseña general de las corrientes de ayuda para Lel comercio, los compromisos y desembolsos por concepto de AOD, las otras corrientes oficiales (OCO) relacionadas con el comercio y la cooperación Sur-Sur relacionada con el comercio. Para el examen de las corrientes de ayuda para el comercio se han utilizado datos del Sistema de notificación por parte de los países acreedores (SNPA) de la OCDE, complementados con resultados de la encuesta de vigilancia de la OCDE y la OMC. El análisis abarca los receptores y los proveedores de ayuda, las condiciones financieras de la asistencia y las perspectivas de la ayuda para el comercio. En un contexto de crisis económica en muchos países miembros de la OCDE, el nivel de la ayuda para el comercio, que aumentó a partir de 2005, en su mayor parte se ha mantenido. En 2011 disminuyó el nivel de las corrientes de ayuda para el comercio y se redujo el apoyo al desarrollo de infraestructura, especialmente en África. Los países menos adelantados (PMA) recibieron menos financiación, pero no han sido los más afectados por la disminución de la ayuda. El análisis de las corrientes indica que se está produciendo un desplazamiento de la financiación hacia el desarrollo del sector privado y el fomento de las cadenas de valor. En consecuencia, las corrientes destinadas al logro de objetivos comerciales en sectores como la agricultura, la industria y los servicios prestados a las empresas siguen aumentando.

\section{INTRODUCCIÓN}

En 2011, por primera vez desde 1997, disminuyó la cuantía global de la AOD (con excepción de la destinada al alivio de la deuda); dicha cuantía volvió a disminuir en 2012. Tras el aumento de las corrientes de ayuda para el comercio durante varios años, la crisis financiera y las ulteriores dificultades económicas a que han debido hacer frente los países miembros de la OCDE se han dejado sentir en los presupuestos destinados a la ayuda para el comercio. En 2011 disminuyó la cuantía de los compromisos de ayuda para el comercio: los donantes que son miembros del CAD', en particular los países del G-72, prestaron menos asistencia, en particular para el desarrollo de infraestructura en África. La asistencia prestada por las instituciones multilaterales se mantuvo al nivel alcanzado en 2010. La asistencia para la creación de capacidad productiva en sectores como la agricultura, la industria y la banca aumentó ligeramente, lo que es indicio de que los donantes están cada vez más convencidos de que el desarrollo del sector privado es un modo importante de multiplicar los efectos de la ayuda y fomentar el comercio. Aunque los países menos adelantados (PMA) han visto reducida la financiación que reciben, no han sido los más afectados por la disminución global de la ayuda. En realidad, han sido el grupo de países en que esa disminución ha sido menor. La asistencia para programas regionales alcanzó el nivel más alto de la historia. 
Si bien se pronostica un estancamiento o una nueva disminución moderada de las corrientes de ayuda, el G-20 se ha comprometido a mantener el nivel de los recursos destinados a la ayuda para el comercio más allá de 2011. Los resultados de la encuesta de vigilancia de la OCDE y la OMC indican que la mayoría de los proveedores de ayuda relacionada con el comercio en el marco de la cooperación Sur-Sur proyecta incrementar su contribución en el futuro. Además, las iniciativas de colaboración con el sector privado y las inversiones en las cadenas de valor son cada vez más numerosas y eficaces y están abriendo un camino innovador para la participación de las empresas en la creación de capacidad relacionada con el comercio.

En el presente capítulo se reseñan en detalle las corrientes de ayuda para el comercio, los compromisos y desembolsos por concepto de AOD, las otras corrientes oficiales (OCO) relacionadas con el comercio y la cooperación Sur-Sur relacionada con el comercio. Para el examen de las corrientes de ayuda para el comercio se han utilizado datos del Sistema de notificación por parte de los países acreedores (SNPA) de la OCDE, complementados con resultados de la encuesta de vigilancia de la OCDE y la OMC. Se examina la ayuda para el comercio en el contexto de otras corrientes de financiación para el desarrollo. También se examinan las tendencias recientes y se detalla, por regiones, países y grupos de ingresos, el destino que se da a la ayuda para el comercio y quienes la reciben. También se pasa revista a los proveedores de asistencia: los donantes bilaterales, los donantes multilaterales y los proveedores de asistencia relacionada con el comercio en el marco de la cooperación Sur-Sur. Además se analizan las condiciones financieras de la asistencia: las donaciones, los préstamos por concepto de AOD y otras corrientes oficiales (OCO) de financiación en condiciones no concesionarias. Por último se consideran las perspectivas de la ayuda para el comercio y se presentan las conclusiones.

\section{¿QUÉ IMPORTANCIA TIENE LA AYUDA PARA EL COMERCIO EN EL CONTEXTO DE LA FINANCIACIÓN PARA EL DESARROLLO?}

Como se destaca en el Consenso de Monterrey sobre la financiación para el desarrollo, el comercio es en muchos casos la fuente externa más importante de financiación para el desarrollo. La expansión del comercio y de la inversión extranjera directa (IED), combinada con políticas complementarias, puede estimular el crecimiento económico y ser una importante fuente de empleo. Sin embargo, a fin de poder aprovechar las oportunidades que ofrecen los mercados regionales y mundiales, los países en desarrollo necesitan asistencia para aumentar la competitividad, reducir el costo del transporte y el costo de comerciar e integrarse plenamente en el sistema de comercio internacional. Muchos países en desarrollo tropiezan con diversos obstáculos a nivel de la oferta y de la infraestructura relacionada con el comercio que limitan su capacidad para participar en el comercio internacional. La ayuda para el comercio ayuda a los países en desarrollo, en particular a los PMA, a utilizar el comercio para impulsar el crecimiento y reducir la pobreza.

Para ayudar a superar las limitaciones que afectan al comercio se utilizan instrumentos financieros de diversa índole, como préstamos, donaciones, fondos comunes y fondos fiduciarios, y fondos encauzados a través de instituciones financieras internacionales. Basnett et al. (2012) han examinado esos instrumentos y han determinado que los mecanismos mixtos de financiación y la apertura de "corredores" para el suministro de la ayuda para el comercio son particularmente eficaces. Además de la ayuda para el comercio, existen también las OcO relacionadas con el comercio, que son suministradas principalmente por donantes multilaterales a países de ingresos medianos. Por su parte, los países de ingresos bajos sólo reciben el 3\% de esa clase de corrientes. Con esos préstamos en condiciones no concesionarias se financian principalmente proyectos de infraestructura, aunque también algunos programas de creación de capacidad productiva. Una buena parte de la asistencia relacionada con el comercio es suministrada y recibida por empresas privadas. Por ejemplo, la Corporación Financiera Internacional (CFI), uno de los miembros del Grupo del Banco Mundial, financia inversiones y proyectos del sector privado en países en desarrollo y les presta asesoramiento. Algunos donantes también prestan asistencia para ayudar a establecer asociaciones entre productores 
locales y empresas mundiales, como WalMart y Danone. El Banco Mundial está trabajando con empresas de logística internacional para facilitar el comercio. El número y la repercusión de ese tipo de iniciativas conjuntas e inversiones en cadenas de valor está aumentando y abriendo nuevos derroteros para la participación de las empresas en la creación de capacidad relacionada con el comercio.

\section{El enfoque de la financiación del desarrollo está cambiando.}

El enfoque del comercio y el desarrollo está cambiando. Cada vez es más necesario examinar de forma integrada la financiación de la ayuda, el gasto nacional y las políticas públicas, así como la inversión privada. Aunque se considera que la ayuda para el comercio forma parte de la AOD, hay otras fuentes de financiación que pueden contribuir a crear capacidad comercial en los países de ingresos bajos y los países de ingresos medianos (PIM). Las OCO relacionadas con el comercio conceden préstamos en condiciones no concesionarias, principalmente a países de ingresos medianos. El sector privado también ha participado en la creación de capacidad.

Los medios de financiar el desarrollo distintos de la ayuda tradicional están recibiendo renovada atención. En los gráficos 2.1 y 2.2 puede verse que la IED y otras corrientes de capital privado han aumentado desde el comienzo del milenio, lo que indica que los inversores saben que en los países en desarrollo las inversiones pueden tener un rendimiento elevado. El gráfico 2.2 muestra que las entradas de IED en los PIM han repuntado desde la crisis financiera mundial, y que la IED es la corriente de financiación del desarrollo más importante en los PIM, mientras que la AOD ha pasado a segundo plano. En los países de ingresos bajos las corrientes más importantes son las remesas, pero, en comparación con los PMI, la AOD sigue representando una parte considerable del conjunto de las entradas de capital. En comparación con los PIM, los países de ingresos bajos actualmente no obtienen una parte considerable de sus ingresos de la IED.

Al interpretar los efectos de estas corrientes hay que andarse con cuidado. Bhinda y Martin (2009) han recomendado no apresurarse a concluir que las corrientes privadas son automáticamente positivas para el desarrollo. En primer lugar, desde el punto de vista de la estabilidad, las corrientes privadas son volátiles y tienen un bajo grado de previsibilidad en comparación con la ayuda oficial. Bhinda y Martin también señalan que, incluso antes de la crisis, en muchos de los "sectores en auge" la IED no estaba contribuyendo de manera sostenible al crecimiento o la reducción de la pobreza mediante la creación de empleo, el aumento de los ingresos presupuestarios y la transferencia de tecnología y conocimientos prácticos.

\section{Gráfico 2.1 Corrientes de financiación del desarrollo en los países de ingresos bajos}

MILES DE MILLONES DE DÓLARES EE.UU., A PRECIOS CORRIENTES

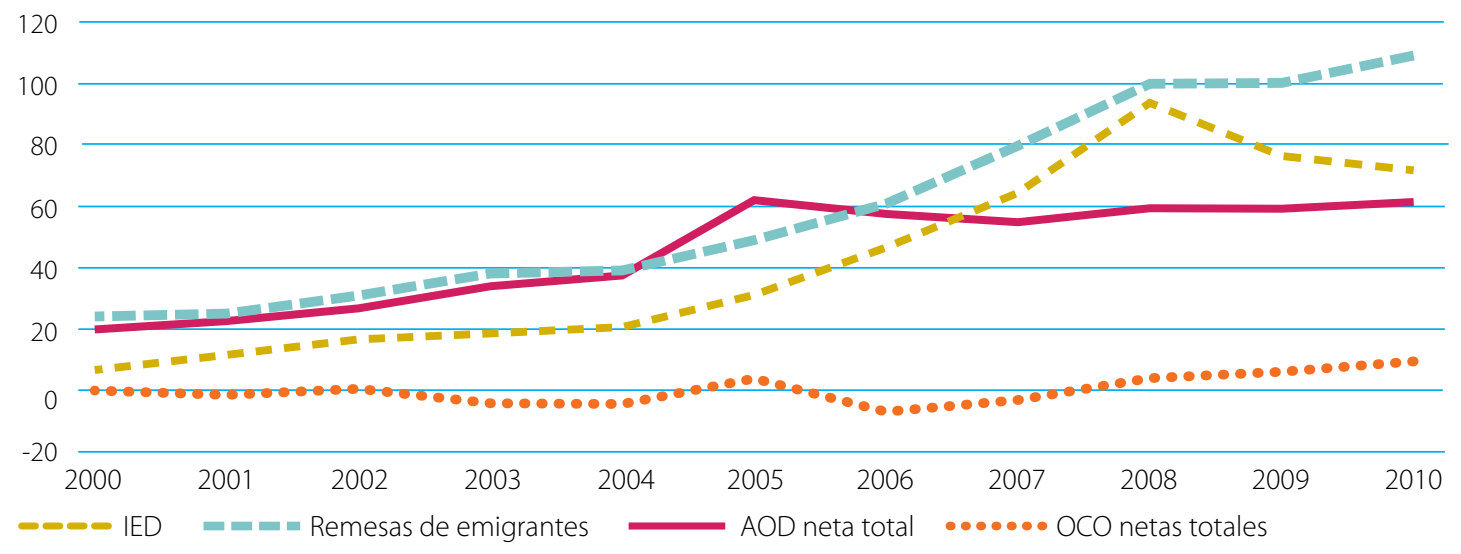




\section{Gráfico 2.2 Corrientes de financiación del desarrollo en los países de ingresos media}

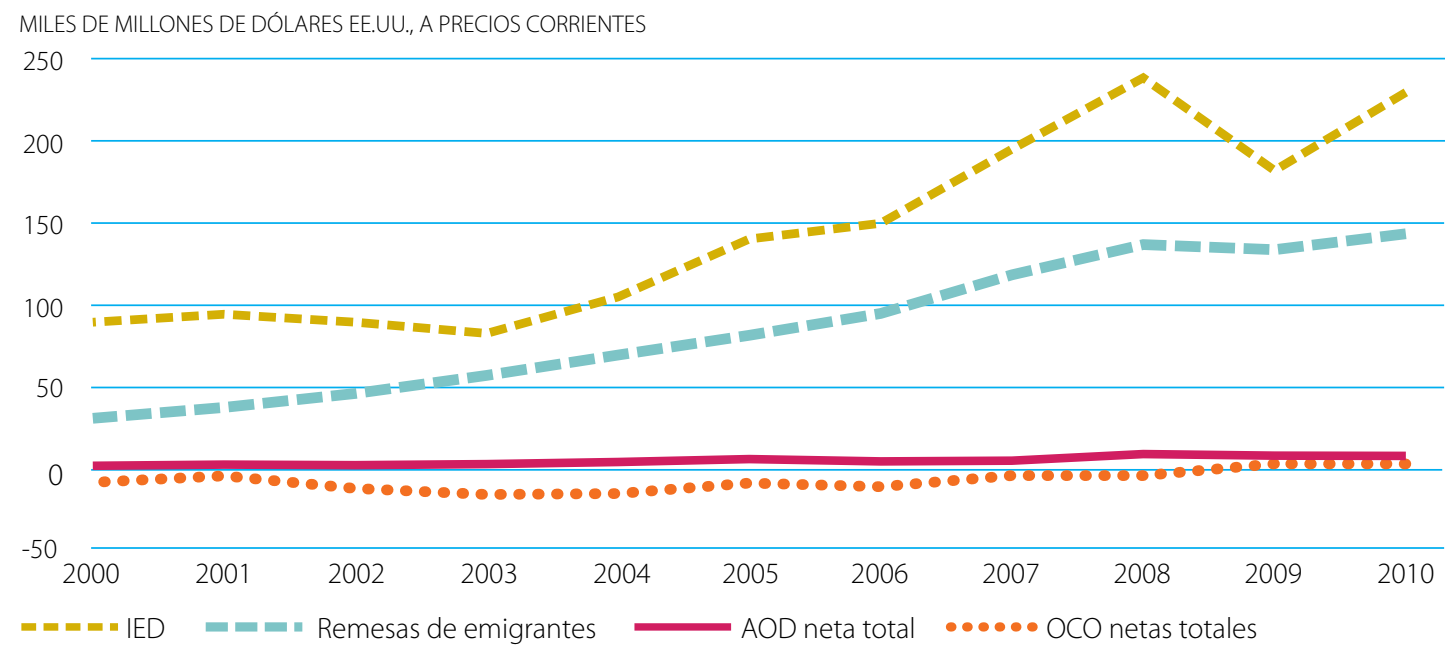

La inversión extranjera directa es la fuente más importante de creación de capacidad comercial ...

Según 53 países asociados, la inversión extranjera directa es la fuente de financiación más importante para conectarse a las cadenas de valor regionales y mundiales (gráfico 2.3). Por orden de importancia, después de la IED vienen la inversión privada interna (46 países) y la inversión pública interna (30 países). Los donantes bilaterales también consideran que la IED es la fuente de financiación más importante (nueve donantes), seguida de la AOD (siete donantes). Los proveedores de asistencia en el marco de la cooperación Sur-Sur coinciden en que la IED tiene importancia primordial: siete de ellos la consideran la fuente de financiación más importante, mientras que seis consideran que la asistencia prestada en el marco de la cooperación Sur-Sur es la fuente más importante. De hecho, la mayoría de los donantes tiende a exaltar las virtudes de sus respectivos instrumentos; así, los donantes multilaterales consideran que la financiación en condiciones no concesionarias es la fuente de financiación más importante para satisfacer las necesidades de creación de capacidad relacionada con el comercio.

\section{... pero la AOD sigue siendo indispensable ...}

En consonancia con los principios de la financiación para el desarrollo, la movilización de los recursos internos debería desempeñar un papel fundamental en la satisfacción de las necesidades de financiación de los países en desarrollo, incluida la creación de capacidad relacionada con el comercio; sin embargo, tanto los asociados como los donantes consideran que la AOD seguirá siendo muy valiosa en los próximos cinco años. Los donantes multilaterales consideran que la AOD ocupa el segundo lugar, por orden de importancia, entre las corrientes de financiación; esta opinión es compartida por los donantes bilaterales. La pregunta dirigida a los países asociados guardaba relación con la financiación destinada a ayudar a las empresas a conectarse a las cadenas de valor, y no con la asistencia destinada a apoyar el entorno empresarial, la infraestructura u otros bienes públicos. La AOD fue considerada la fuente más importante a ese respecto por 27 países asociados, e importante por 28 países, mientras que 16 países dijeron que la consideraban menos importante (gráfico 2.3). Los países asociados también consideran que en los próximos cinco años la AOD tendrá algo menos de importancia que la inversión extranjera y la inversión nacional. 


\section{Gráfico 2.3 Fuentes de financiación más importantes según los países asociados (porcentaje de respuestas)}

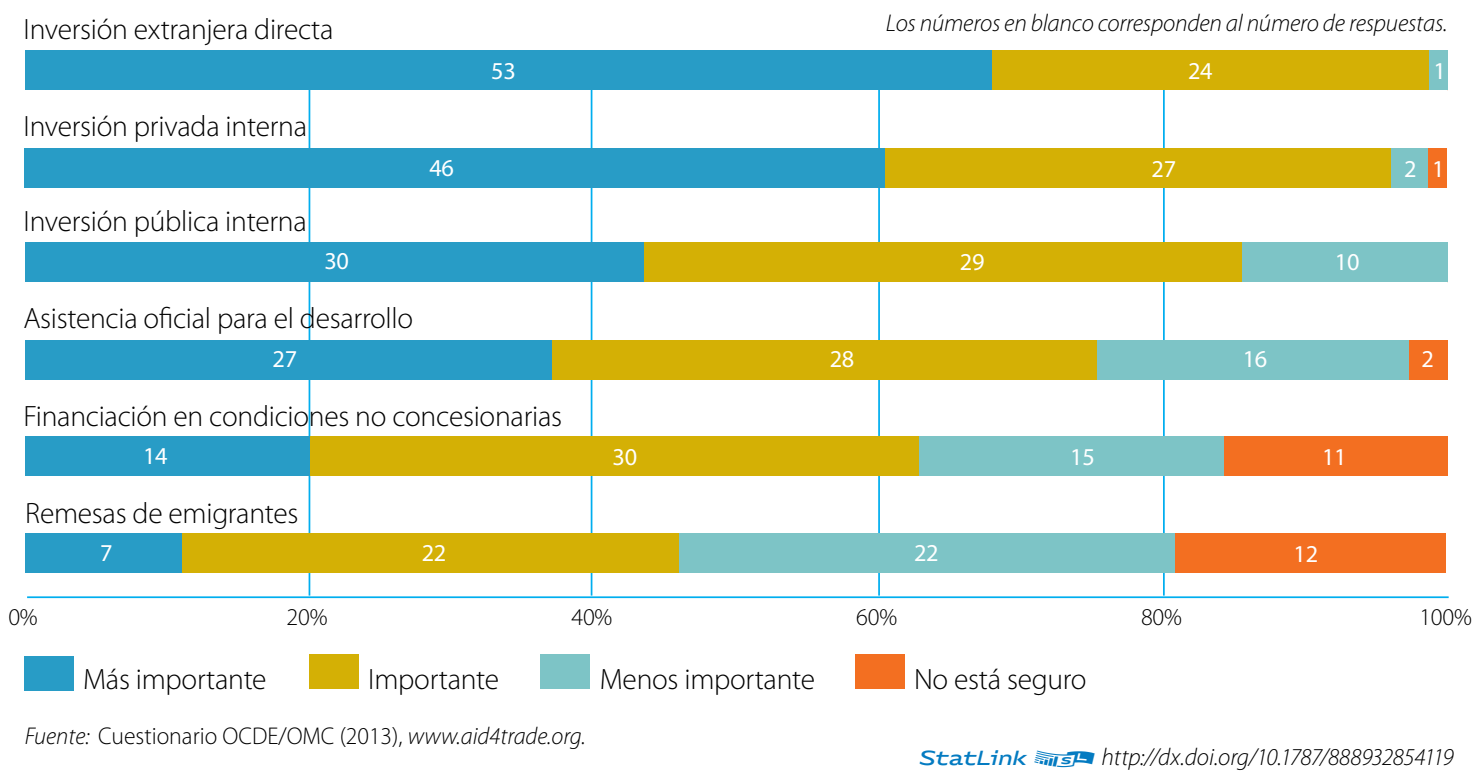

... especialmente para los PMA ...

En los PMA la AOD sigue siendo una fuente de financiación importante para las empresas, ya que el nivel de la formación de capital y la inversión pública en el plano interno no es significativo. Todos los donantes creen que la AOD es una fuente de financiación indispensable para los PMA (gráficos 2.4 y 2.5). Tanto los donantes multilaterales (10) como los bilaterales (18) consideran que la AOD es la corriente de financiación más importante. Siete proveedores de asistencia en el marco de la cooperación Sur-Sur consideraban que la AOD era la corriente de financiación más importante, seguida de la asistencia prestada en el marco de la cooperación Sur-Sur.

\section{... no obstante, debería estar mejor orientada.}

Los datos más recientes indican que las corrientes de AOD pueden ser contingentes y volátiles, por lo que esta clase de fondos debería destinarse a movilizar otras fuentes de financiación (OCDE, 2012). En el Programa para el Cambio adoptado recientemente por la UE, se señala que en el futuro la ayuda de la UE para el desarrollo debe dirigirse a los países que tengan la mayor necesidad de financiación externa y en los que la ayuda para el desarrollo tenga una repercusión decisiva, incluidos los Estados frágiles. La cooperación para el desarrollo debe enfocarse de manera distinta en el caso de los países que ya están creciendo de manera sostenida o cuentan con recursos propios suficientes (CE, 2011). 
Gráfico 2.4 Fuentes de financiación más importantes para los países menos adelantados, según los donantes bilaterales

(porcentaje de respuestas)

Asistencia oficial para el desarrollo

Los números en blanco corresponden al número de respuestas.

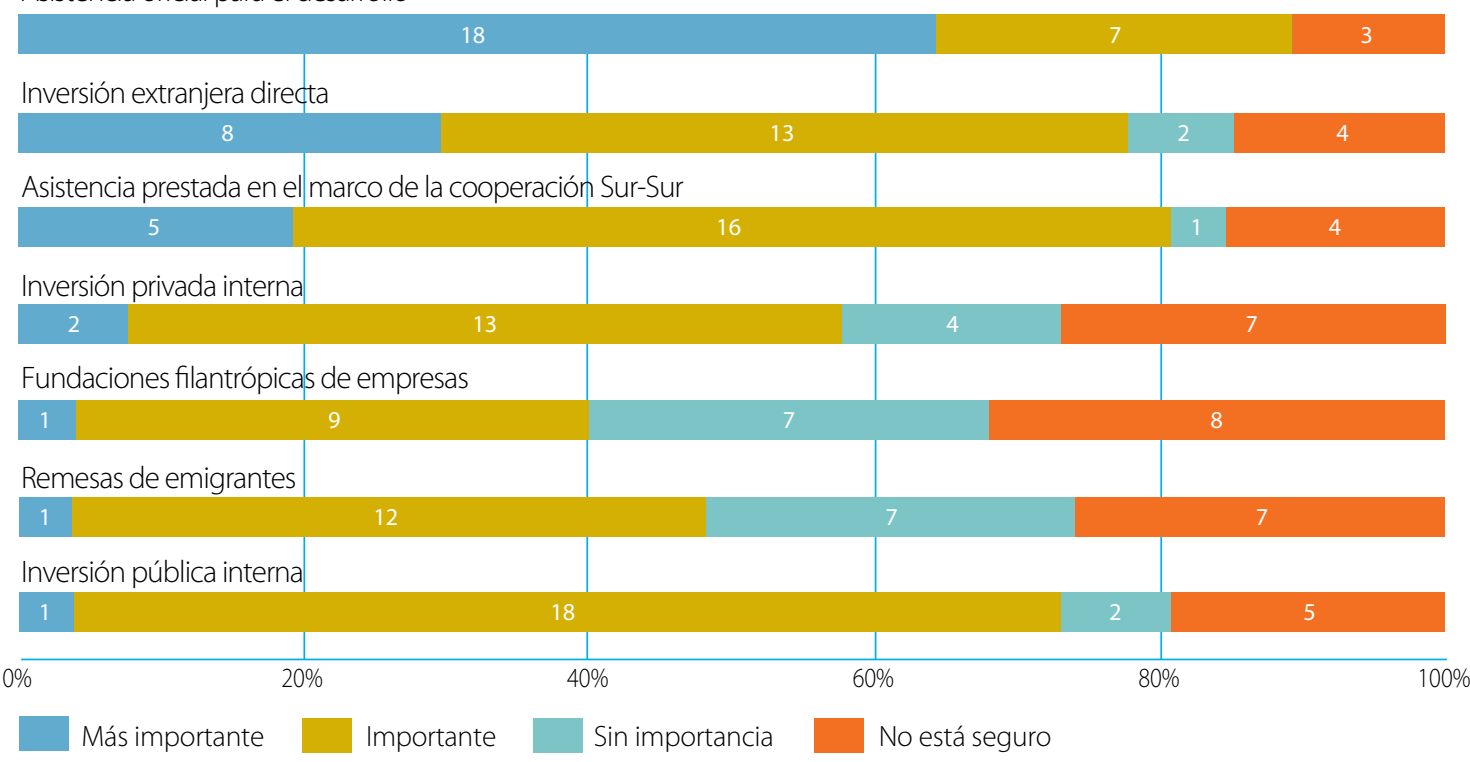

Fuente: Cuestionario OCDE/OMC (2013), www.aid4trade.org.

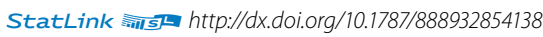

Gráfico 2.5 Fuentes de financiación más importantes para los países menos adelantados, según los proveedores de asistencia en el marco de la cooperación Sur-Sur (porcentaje de respuestas)

Asistencia oficial para el desarrollo

Los números en blanco corresponden al número de respuestas.

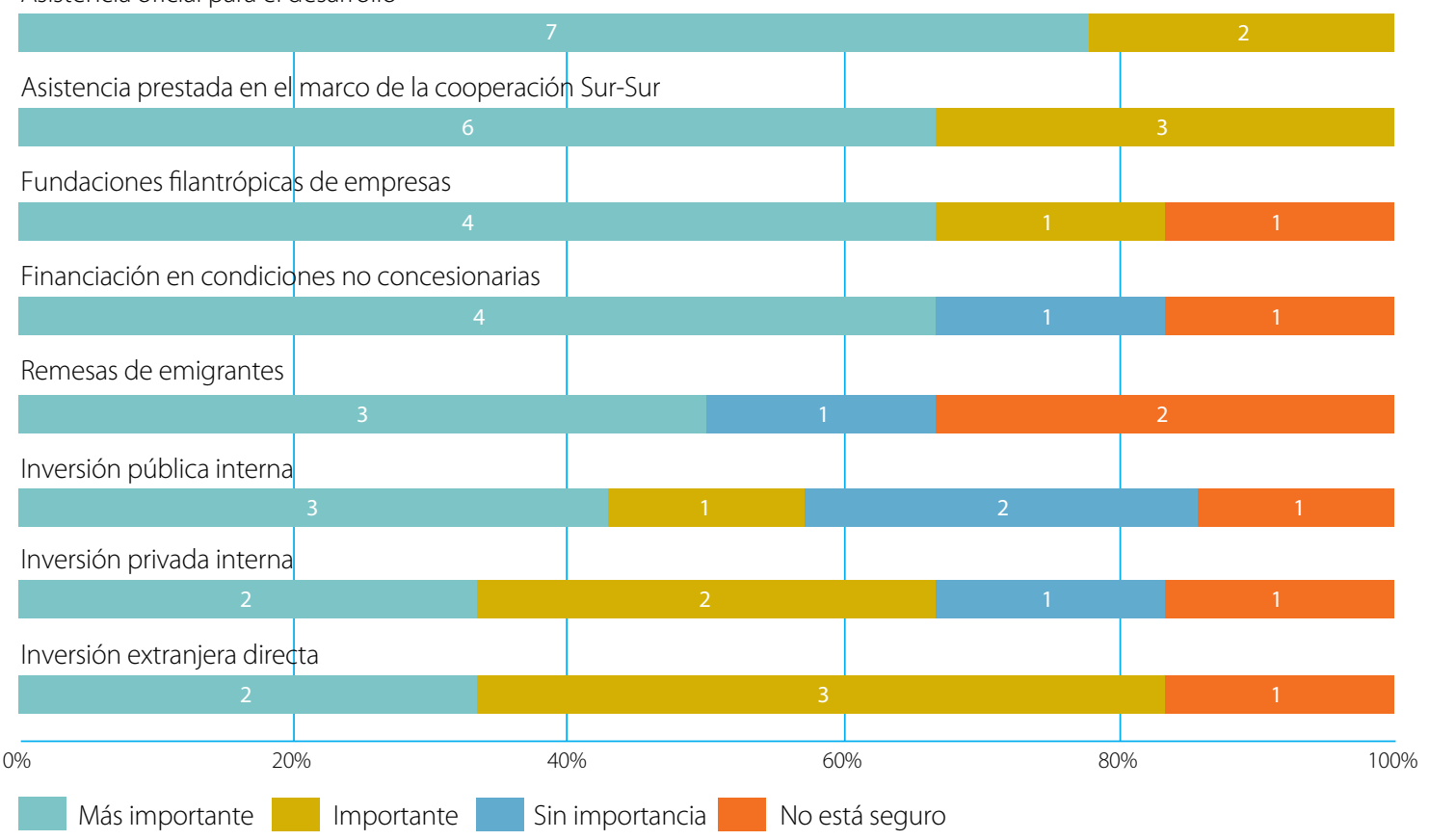




\section{¿CUÁL ES LA CUANTÍA DE LA AYUDA PARA EL COMERCIO, Y A QUÉ SE DESTINA?}

\section{La ayuda para el comercio se vio afectada por la disminución de la AOD en 2011 ...}

El Equipo de Trabajo sobre la Ayuda para el Comercio de la OMC observó que, para cumplir los objetivos de la ayuda para el comercio, era fundamental que hubiera una financiación adicional previsible, sostenible y eficaz (OMC, 2006:1). Los donantes han aportado recursos adicionales, y la ayuda para el comercio ha aumentado en un $57 \%$ respecto del período de referencia acordado para evaluar los progresos (a saber, el promedio de la ayuda para el comercio suministrada entre 2002 y 2005). Además, la proporción correspondiente a la ayuda para el comercio en la AOD asignable a sectores específicos se mantuvo alrededor del 33\%; terminó así un período de disminución de la ayuda destinada a los sectores económicos que había durado decenios. Ese incremento considerable ha beneficiado a todas las categorías de la ayuda para el comercio: la ayuda destinada a la política y la reglamentación comerciales aumentó en un 61\%; la ayuda para la creación de capacidad productiva, en un 58\%; y la ayuda para infraestructura económica en un 55,5\%. La ayuda para el ajuste relacionado con el comercio, una de las fuerzas impulsoras de la Iniciativa de Ayuda para el Comercio, también ha aumentado.

Además ha aumentado la previsibilidad de la ayuda. Esto es importante porque la ayuda es más eficaz cuando se dispone de información periódica, detallada y oportuna sobre su volumen y el destino que se le dará. Muchos donantes han comenzado a facilitar a los países en desarrollo, con tres a cinco años de antelación, planes de ejecución y cifras sobre gastos detallados y fiables. Sin embargo, según una evaluación reciente, varios donantes tropiezan con impedimentos jurídicos y de procedimiento en ese sentido; además, como no conocen a ciencia cierta la cuantía de las futuras asignaciones por concepto de ayuda, les resulta difícil incrementar la previsibilidad de la ayuda (OCDE, 2012). Con todo, según varios estudios (OCDE, 2011; Basnett et al., 2012; Helble et al., 2012), la ayuda para el comercio está debidamente orientada y es eficaz. El interrogante clave que confronta ahora la comunidad de donantes de ayuda para el comercio es si los incrementos anteriores y el nivel actual de la ayuda para el comercio son sostenibles.

En 2011 disminuyó la cuantía total en valores reales de los compromisos contraídos por concepto de AOD. En consecuencia, el volumen de los compromisos asignables a sectores específicos disminuyó en un 11\% en 2011 respecto del nivel alcanzado en 2010 (de 138.000 millones de dólares EE.UU. a 122.000 millones de dólares EE.UU.). La ayuda para el comercio resultó aún más afectada: disminuyó en un 14\%, a 41.500 millones de dólares EE.UU. (gráfico 2.6). Es ésta la primera vez en que la cuantía de los compromisos por concepto de ayuda para el comercio disminuye con respecto a la del período de referencia. Sin embargo, no puede hablarse de una tendencia sobre la base de los datos correspondientes a un solo año; las cifras globales de la disminución de la ayuda enmascaran cambios importantes a nivel sectorial que reflejan una modificación de las prioridades de los donantes en materia de ayuda para el comercio. También cabe señalar que la cuantía de la ayuda para el comercio correspondiente a 2011 es comparable a la de los compromisos contraídos para 2008 y 2009, lo que podría significar que en 2010 el nivel de los compromisos (48.000 millones de dólares EE.UU.) fue excepcionalmente alto. 


\section{Gráfico 2.6 Compromisos de ayuda para el comercio (millones de dólares EE.UU., a precios constantes de 2011)}

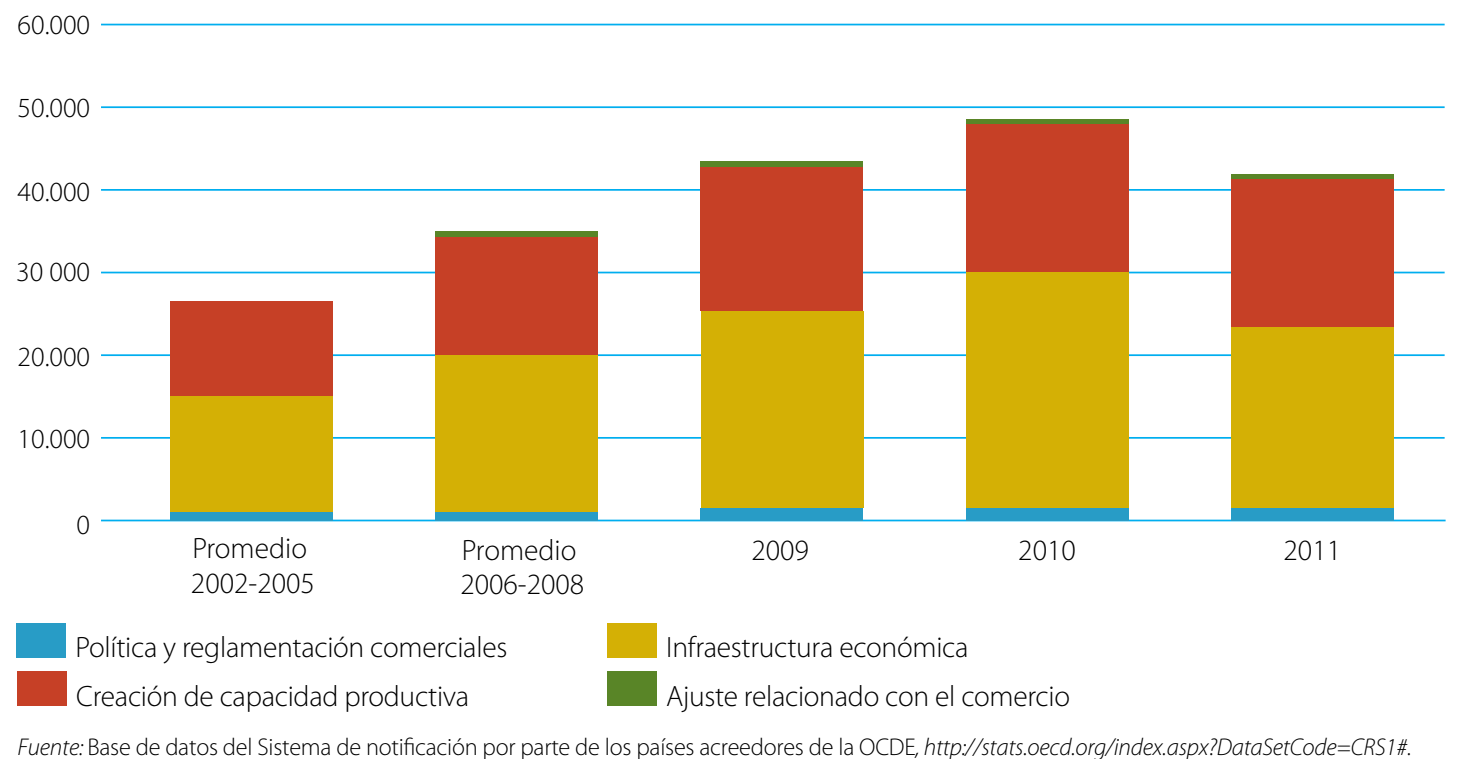

\section{... pero la ayuda para la creación de capacidad productiva sigue aumentando ....}

Los donantes asignan creciente prioridad al desarrollo del sector privado (véase el capítulo 1), como lo confirma el hecho de que, en 2011, la ayuda destinada a la creación de capacidad productiva aumentara en 171 millones de dólares EE.UU. hasta alcanzar 18.200 millones de dólares EE.UU. (gráfico 2.6). En el gráfico 2.7 puede verse que la agricultura, la pesca y la silvicultura recibieron casi el 60\% de la ayuda (10.600 millones de dólares EE.UU.) y que esa cuantía se ha duplicado respecto de la correspondiente al período de referencia (5.300 millones de dólares EE.UU.). La proporción de AOD destinada a la agricultura disminuyó del 17\% aproximadamente a principios de los años ochenta y tocó fondo en 2005 (3\%). Sin embargo, en respuesta a la crisis alimentaria de 2007-2008, los donantes han aumentado el nivel de la ayuda destinada al sector agropecuario (OCDE, 2010a). Una característica recurrente de los proyectos de ayuda para la agricultura es la especial atención que se presta en ellos a la pobreza rural y la seguridad alimentaria. Por ejemplo, en uno de los proyectos más grandes notificados en 2011, el Banco Mundial se comprometió a otorgar a la India préstamos por valor de 1.000 millones de dólares EE.UU. para llevar a cabo un proyecto nacional de desarrollo agrícola encaminado a incrementar los medios de subsistencia de la población de las zonas rurales. El Gobierno de los Estados Unidos prestó ayuda al Afganistán para mejorar la tecnología y las prácticas de gestión destinadas aumentar la eficiencia organizativa y del mercado, con el fin de afianzar la capacidad de recuperación de los sistemas de producción y subsistencia. La UE está prestando ayuda en materia de seguridad alimentaria, para lo cual ha destinado 139 millones de dólares EE.UU. para prestar asistencia a los pobres y vulnerables en situación precaria en países como el Afganistán, Haití, Liberia, Madagascar, la República Democrática del Congo, la República Popular Democrática de Corea, el Pakistán y el Sudán. 


\section{... y beneficia a diversos sectores económicos, desde la agricultura hasta los servicios prestados a las empresas....}

Muchos proyectos tienen un objetivo comercial claramente definido. Por ejemplo, la UE se ha comprometido a proporcionar 21 millones de dólares EE.UU. a Tanzanía para apoyar actividades sostenibles de reducción de la pobreza mediante una mayor participación en el comercio de los propietarios de pequeñas explotaciones agrícolas y los productores agrícolas en pequeña escala. En Mozambique, Suiza está promoviendo el crecimiento del sector privado en beneficio de los pobres destinando la ayuda a nichos específicos en la esfera del fomento de la inversión y el comercio. Entre otros proyectos, cabe mencionar asimismo la asistencia que está prestando Austria a Uzbekistán para la certificación, por el sistema Fair Trade, de frutas y hortalizas. Con el apoyo de Finlandia, Namibia está investigando nuevos mercados para sus productos cárnicos. Por su parte, España está apoyando varios proyectos para obtener la certificación de Fair Trade para productos agrícolas de América Latina.

\section{Gráfico 2.7 Ayuda para la creación de capacidad productiva (millones de dólares EE.UU., a precios constantes de 2011)}

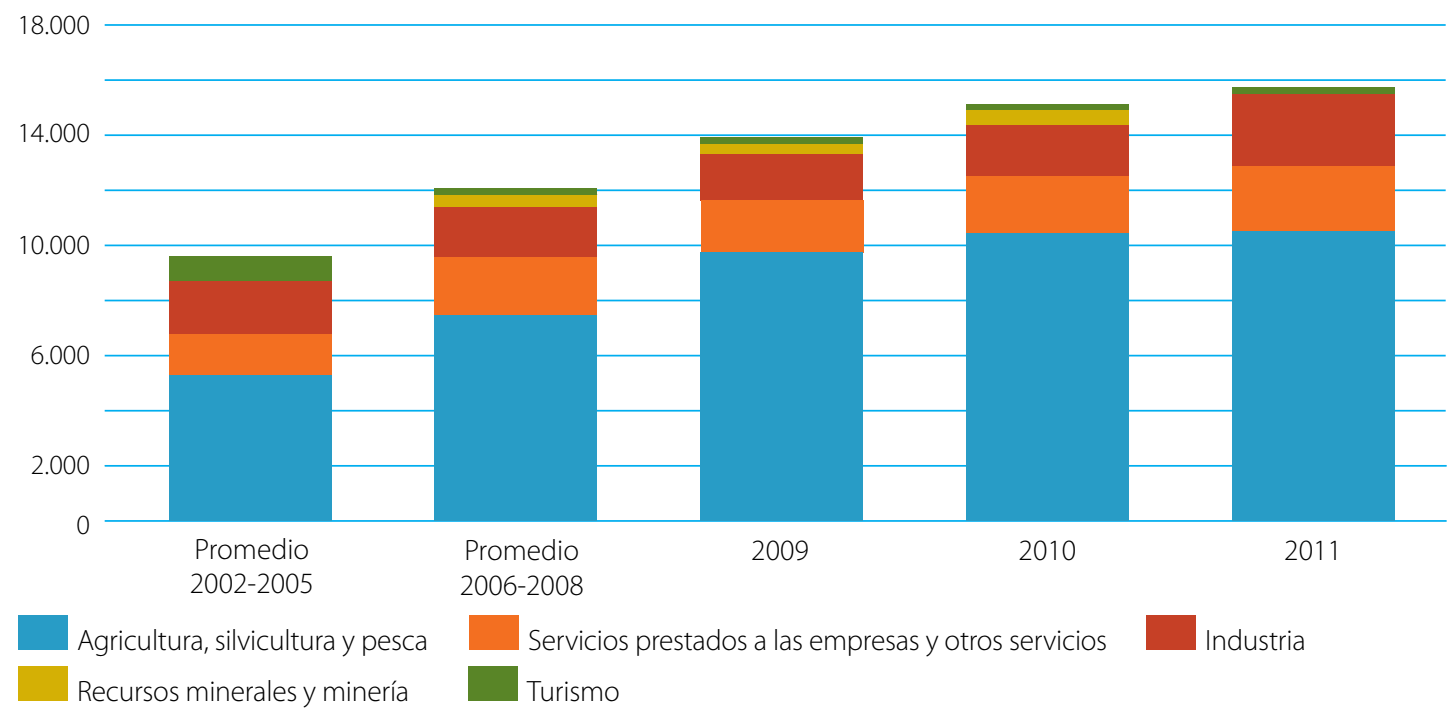

Fuente: Base de datos del Sistema de notificación por parte de los países acreedores de la OCDE, http://stats.oecd.org/index.aspx?DataSetCode=CRS1\#.

Para que el sector privado pueda crecer es indispensable que tenga acceso a financiación. En 2011 los donantes proporcionaron 2.650 millones de dólares EE.UU. para apoyar el establecimiento de instituciones bancarias y servicios financieros en los países en desarrollo. Esa ayuda, que representó el $6 \%$ del total de la ayuda para el comercio, se destinó a apoyar a bancos centrales e intermediarios del sector financiero formal, así como el establecimiento de líneas de crédito y cooperativas de crédito y microcrédito.

Un entorno propicio para la actividad empresarial y la inversión requiere-además de acceso al crédito- asociaciones comerciales y empresariales, la reforma del régimen jurídico y la reglamentación, asesoramiento y creación de capacidad institucional para el sector privado, información comercial, así como ferias comerciales que permitan a los sectores público y privado establecer contacto. En 2011 los servicios prestados a las empresas recibieron financiación por valor de 2.200 millones de dólares EE.UU.; esta cifra, que en los últimos años ha aumentado de manera sostenida, supera en un 55\% a la correspondiente al período de referencia (1.400 millones de dólares EE.UU.). Por ejemplo, los Estados Unidos han otorgado a Jordania un total de 82 millones de dólares EE.UU. por concepto de donaciones destinadas a 
incrementar la capacidad de las empresas para integrarse en los mercados nacionales e internacionales mediante el aumento de la competitividad, la mejora de la gobernanza empresarial y el desarrollo y la aplicación de tecnología y prácticas modernas de comercialización. Los programas de desarrollo de la capacidad comercial incluyen actividades que ayudan a las empresas y asociaciones a aprovechar las oportunidades que ofrecen los mercados internacionales. El Centro de Comercio Internacional (ITC) destinó más de 64 millones de dólares EE.UU. para ayudar a empresas a crear capacidad productiva y participar en el comercio internacional. El ITC también cuenta con una importante iniciativa encaminada a apoyar a las mujeres en relación con la contratación pública de productos y servicios.

\section{... y apoya a las pequeñas y medianas empresas de los países en desarrollo ...}

Como consecuencia de la expansión de las cadenas de valor, la ayuda destinada a apoyar el desarrollo industrial aumentó más que la destinada a apoyar otros sectores productivos. En 2011 el total de la ayuda destinada a la industria ascendió a 2.200 millones de dólares EE.UU. La mayor parte de esa ayuda se destinó al fomento de las pequeñas y medianas empresas (PYME). Aunque el rápido crecimiento de las PYME sirve en buena medida para impulsar la creación de puestos de trabajo en economías de muy diverso tipo, más de dos tercios de las PYME de los países en desarrollo no tienen acceso a la financiación del sector financiero formal. Esa deficiencia del mercado (la gran disparidad entre la demanda y la oferta de financiación para las PYME) constituye un grave impedimento en los esfuerzos por propiciar una recuperación mundial sólida y sostenible. Recientemente, el G-20 decidió abrazar la causa de las PYME por medio del Desafío financiero en apoyo de las pequeñas y medianas empresas, que tiene por objeto hallar los medios de que los gobiernos y las instituciones públicas cumplan más eficazmente su cometido de catalizadores de la financiación privada para las PYME en los países en desarrollo. En 2011 el Canadá, Corea, los Estados Unidos y el Banco Interamericano de Desarrollo contrajeron compromisos destinados a apoyar la iniciativa. ${ }^{3}$

Algunos donantes apoyan la creación de condiciones propicias para el crecimiento de las PYME y el empleo; por ejemplo, Alemania ha donado 24 millones de dólares EE.UU. a Nigeria con tal fin. Por su parte, el Japón ha concedido a Bangladesh un préstamo de 63 millones de dólares EE.UU. para un proyecto del sector financiero de desarrollo de PYME. Otros, en cambio, suministran ayuda para aumentar la competitividad de las PYME. El Japón está ejecutando un proyecto por valor de 376 millones de dólares EE.UU. encaminado a promover el ahorro de energía por PYME de la India. Otros proyectos de ayuda están dirigidos a sectores específicos. Por ejemplo, la UE está ayudando a Jordania a desarrollar el sector de los servicios mediante el establecimiento de empresas sostenibles que añadan valor, a fin de que el sector sea más productivo y esté más conectado en el plano mundial. El Canadá está ayudando a reconstruir el sector privado de Haití promoviendo actividades con fines de exportación. El principal objetivo de la ayuda es desarrollar y fomentar las artesanías para aumentar las exportaciones de Haití en los sectores de la decoración de interiores y los regalos. Evidentemente a través de muchos de estos proyectos se presta apoyo al sector privado para lograr diversos objetivos de desarrollo, como la reducción de la pobreza.

Otras actividades, como la minería y el turismo, atraen mucha menos ayuda. El apoyo al sector minero ha disminuido de manera sostenida: de 852,8 millones de dólares EE.UU. en el período de referencia a 416 millones de dólares EE.UU. en 2011. Es probable que ello se deba a la disponibilidad de otras fuentes de financiación y a la viabilidad comercial de los proyectos mineros. En los últimos años, la ayuda destinada a la política de turismo y la gestión administrativa también ha disminuido de manera sostenida. En 2011 fue de apenas 121 millones de dólares EE.UU., o sea sólo un 6\% más que en el período de referencia. El turismo figura entre las tres exportaciones principales de la mayoría de los países en desarrollo, y es la principal exportación de, por lo menos, 11 PMA. Se trata de un sector con una fuerte intensidad de empleo y vínculos con muchos otros ámbitos de la economía. 


\section{... por lo que la ayuda destinada a fomentar el comercio se ha duplicado en los últimos cuatro años}

Cuando la OCDE y la OMC comenzaron a vigilar la prestación de ayuda para el comercio se modificó el Sistema de notificación por parte de los países acreedores (SNPA) de la OCDE de manera que pudiese indicarse que los componentes de un proyecto de creación de capacidad productiva guardaban relación con el fomento del comercio (mediante el "marcador de políticas de fomento del comercio"). Mediante ese marcador se identifican las actividades de fomento del comercio (es decir, las actividades que contribuyen de manera "principal" o "significativa" al fomento del comercio). Según los datos más recientes (gráfico 2.8), se ha duplicado la cuantía de la ayuda destinada a la creación de capacidad productiva con un componente de fomento del comercio: de 2.600 millones de dólares EE.UU. en 2007 a 5.400 millones en 2011. Aunque ha mermado el volumen de la financiación destinada a programas cuyo objetivo principal es el fomento del comercio (de 2.900 millones de dólares EE.UU. a 2.250 millones de dólares EE.UU. en 2011), esa merma se vio plenamente compensada por el aumento de la financiación destinada a programas con un objetivo significativo de fomento del comercio. Esto significa que, de la ayuda prestada para la creación de capacidad productiva, casi el 30\% tiene como objetivo principal o significativo el fomento del comercio, en comparación con el $23 \%$ en 2007.

\section{Gráfico 2.8 Marcador de fomento del comercio (millones de dólares EE.UU., a precios constantes de 2011)}

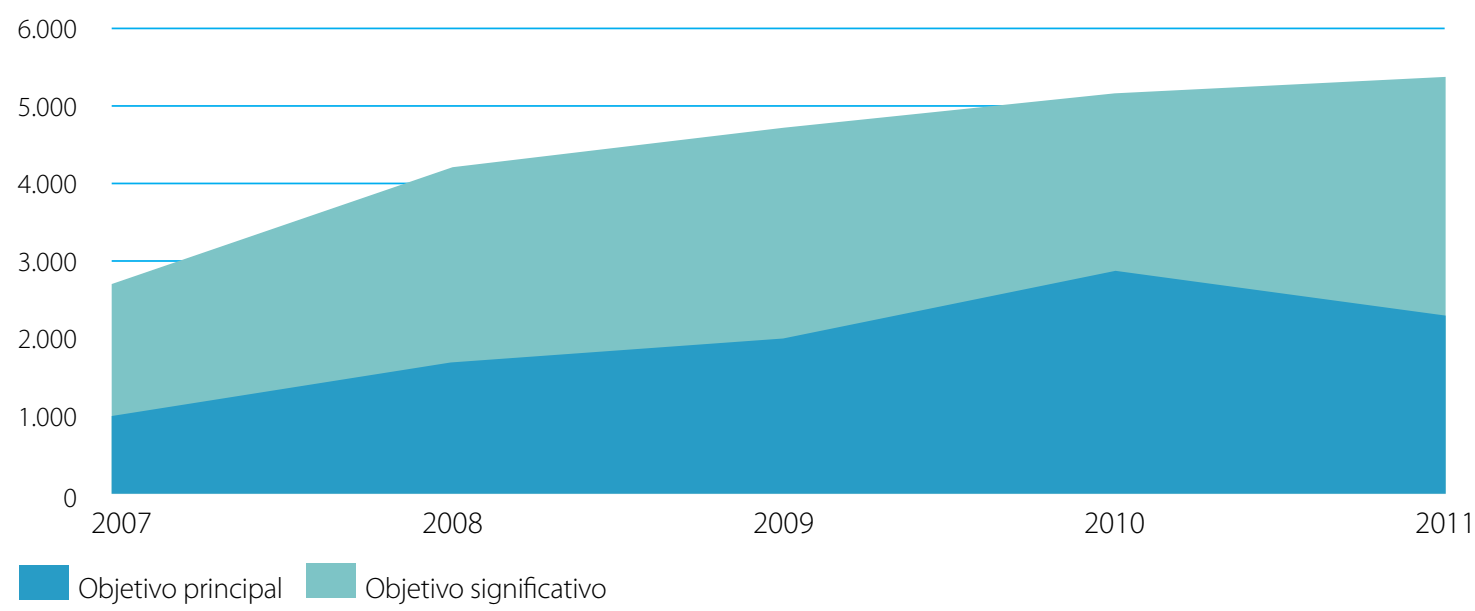

Fuente: Base de datos del Sistema de notificación por parte de los países acreedores de la OCDE, http://stats.oecd.org/index.aspx?DataSetCode=CRS1\#.

Una elevada proporción de los programas de ayuda para servicios prestados a las empresas tiene un objetivo de fomento del comercio. De hecho, la mitad de la cuantía media suministrada para proyectos en 2010 y 2011 tenía como objetivo principal el fomento del comercio; en un 10\% el fomento del comercio era un objetivo significativo. En 20102011, la mitad de la ayuda prestada a la industria tenía entre sus objetivos el fomento del comercio; en casi un tercio de la ayuda destinada al turismo el objetivo principal era el fomento del comercio, mientras que en otro $10 \%$ el fomento del comercio era un objetivo significativo. El fomento del comercio es un objetivo mucho menos frecuente de la ayuda destinada a la agricultura. En 2010-2011, sólo el 6\% de la ayuda para la agricultura tenía como objetivo principal el fomento del comercio, aunque en un 12\% el fomento del comercio era un objetivo significativo. En general, de los datos se desprende que los donantes están asignando creciente importancia al desarrollo del sector privado y la creación de capacidad productiva, y que la cuantía de la ayuda destinada a fomentar el comercio está creciendo. 


\section{La cuantía de la ayuda destinada a la creación de infraestructura económica está disminuyendo...}

En 2011 el grueso de la disminución de la ayuda para el comercio correspondió a la ayuda para la creación de infraestructura económica. En esta categoría la ayuda suele ser más volátil, ya que está destinada a inversiones puntuales en grandes proyectos de infraestructura, que requieren cuantiosos compromisos. Aunque la ayuda para la creación de infraestructura económica siguió absorbiendo el grueso de la ayuda para el comercio (53\%), en 2011 disminuyó en 6.600 millones de dólares EE.UU. (o sea un 23\%) respecto del nivel alcanzado en 2010 (de 28.600 de dólares EE.UU. a 22.000 millones de dólares EE.UU.). Esa disminución refleja la disminución del apoyo prestado a los sectores del transporte (ferrocarriles) y la energía (transmisión de electricidad), que en 2010 habían atraído cuantiosas inversiones. En efecto, en 2010 la ayuda destinada a la creación de infraestructura económica alcanzó un tope de 28.600 millones de dólares EE.UU., nivel sensiblemente superior a los alcanzados antes o después de ese año. No obstante esos dos sectores siguen recibiendo la mayor parte de los fondos: algo más de la mitad (11.500 millones de dólares EE.UU.) en el caso del sector del transporte y el 44\% (9.700 millones de dólares EE.UU.) en el de la energía; un 3\% apenas (617.500 millones de dólares EE.UU.) se destina a las comunicaciones (gráfico 2.9).

\section{Gráfico 2.9 Ayuda para la creación de infraestructura económica (millones de dólares EE.UU., a precios constantes de 2011)}

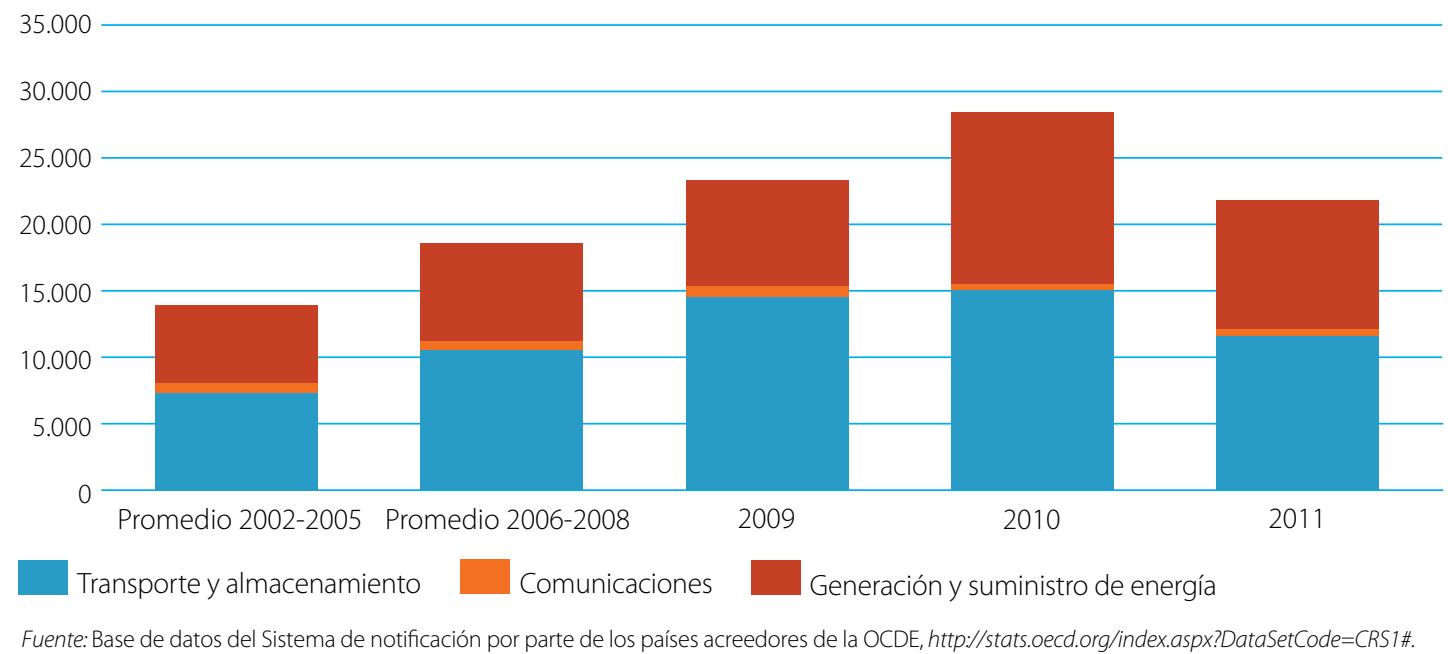

... principalmente en los sectores de la transmisión de electricidad y los ferrocarriles ...

Las corrientes de ayuda para la construcción de infraestructura de distribución a los usuarios finales de la electricidad generada por las centrales de generación de energía (transmisión de electricidad) alcanzaron niveles excepcionalmente altos en 2010: 4.300 millones de dólares EE.UU. Varios grandes proyectos contribuyeron a ese aumento, en particular un préstamo de 454 millones de dólares EE.UU. del Japón a Indonesia para "incrementar la fiabilidad del suministro de electricidad" y un préstamo de 286 millones de dólares EE.UU. del Japón al Pakistán para "mejorar la calidad del suministro de electricidad". Además, el Banco Mundial concedió un préstamo a Kenya (por valor de 211 millones de dólares EE.UU.) para aumentar la capacidad, eficiencia y calidad del suministro de electricidad e incrementar el acceso a ella. Ese préstamo forma parte de un plan a más largo plazo encaminado a financiar la construcción de una central de generación de energía geotérmica de 280 megavatios. También se contrajeron cuantiosos compromisos por concepto de ayuda a Bangladesh, Egipto, Etiopía, Tanzanía y Viet Nam. En 2010 se contrajeron compromisos por valor de más de 100 millones de dólares EE.UU. en relación con 12 proyectos; en 2011, 
en cambio, sólo se contrajeron compromisos por esa cuantía en relación con cuatro proyectos y el volumen total de los recursos destinados a la transmisión de energía se redujo casi a la mitad (2.500 millones de dólares EE.UU.). Entre los proyectos figuró un préstamo de 232 millones de dólares EE.UU. del Japón a la India para un proyecto de modernización del sistema de transmisión de energía de Madhya Pradesh y un préstamo de 232 millones de dólares EE.UU., también del Japón a la India, para mejorar los sistemas de distribución de energía de alta tensión en las zonas rurales. El Banco Mundial concedió préstamos por valor de 148 millones de dólares EE.UU. a Bangladesh para proyectos de electrificación de zonas rurales y energías renovables y 106 millones de dólares EE.UU. a Bolivia para el desarrollo de la infraestructura eléctrica.

En 2010 también se prestó ayuda para la adquisición de infraestructura ferroviaria, equipo ferroviario, locomotoras y sistemas tranviarios y de transporte subterráneo por valor de más de 4.200 millones de dólares EE.UU., incluidos 2.500 millones de dólares EE.UU. en préstamos del Japón a la India para construir un corredor dedicado exclusivamente al transporte de carga, ampliar el sistema de transporte público rápido de Delhi y construir otros sistemas de transporte. ${ }^{4}$ El Japón concedió préstamos a Turquía por valor de 500 millones de dólares EE.UU. para la construcción del ferrocarril subterráneo a través del Bósforo, con lo que por primera vez se vinculará por vía férrea el sector asiático con el sector europeo de Estambul. ${ }^{5}$ En cambio, en 2011 la cuantía de las corrientes destinadas a proyectos ferroviarios se redujo a apenas 833 millones de dólares EE.UU.. El Japón proporcionó 249 millones de dólares EE.UU. para apoyar la construcción del ferrocarril urbano de Bangalore (India). Francia, que también figuró entre los principales donantes de ayuda para proyectos ferroviarios, concedió sendos préstamos para la construcción del Proyecto Urbano Integral Centroriental de Medellín, en Colombia (187 millones de dólares EE.UU.) y de la línea 2 del metro de Santo Domingo, en la República Dominicana (155 millones de dólares EE.UU.).

\section{... pero se está prestando mayor apoyo al transporte por carretera ...}

Por otro lado, en 2011 el nivel de la ayuda destinada al transporte por carretera fue el más alto de la historia: 8.800 millones de dólares EE.UU., o sea el 40\% de la cuantía total de la ayuda para la infraestructura económica. Buys, Deichmann y Wheeler (2006) y Shepherd y Wilson (2008) han determinado que la mejora de las carreteras puede incrementar considerablemente el volumen del comercio. El Japón concedió préstamos por valor de 454 millones de dólares EE.UU. a Filipinas para el mantenimiento de las carreteras nacionales y de 395 millones de dólares EE.UU. a Sri Lanka para la construcción de una autopista en Colombo. El Banco Asiático de Desarrollo (BAsD) concedió un préstamo de 340 millones de dólares EE.UU. al Afganistán para el mejoramiento de la red viaria (incluida la rehabilitación del tramo Qaisar-Bala Murghab (90 km) de la carretera Herat-Andkhoy) con el que se sufragarán gastos por concepto de gestión general del proyecto y contratos, supervisión y seguimiento de la construcción, dispositivos de seguridad y obras conexas de desarrollo a nivel de las comunidades. El proyecto contribuirá a la rehabilitación de la red viaria principal, que sufrió daños durante veinte años de conflicto y abandono.

Sin embargo, es posible que se esté exagerando la cuantía global del apoyo prestado al transporte por carretera como resultado de las dificultades por las que atraviesa el mayor de los proyectos respecto de los cuales se contrajeron compromisos en 2011: la construcción del puente de Padma, un proyecto de 2.900 millones de dólares EE.UU. que tiene por objeto vincular la región sudoccidental con las regiones septentrional y oriental de Bangladesh. En 2011 el Banco Mundial contrajo compromisos por valor de 660 millones de dólares EE.UU. para el proyecto de construcción de un puente multifuncional en Padma, pero en febrero de 2013 el Gobierno de Bangladesh informó al Banco Mundial de que retiraba la solicitud de financiación presentada a la Asociación Internacional de Fomento (AIF). En 2011 el Organismo Japonés de Cooperación Internacional (OJCl) también había contraído compromisos en relación con el proyecto (429 millones de dólares EE.UU.), mientras que el BAsD se había comprometido a aportar 76 millones de dólares EE.UU. 


\section{... y para la construcción de centrales eléctricas alimentadas con carbón ...}

A pesar de la disminución global de la ayuda destinada al sector de la energía, repuntó la asistencia destinada a centrales eléctricas alimentadas con carbón; se invertió así la tendencia anterior entre los donantes a apoyar el aprovechamiento de fuentes de energía renovable. El Japón proporcionó prácticamente la totalidad de los 1.200 millones de dólares EE.UU. destinados a la construcción de centrales eléctricas alimentadas con carbón. De ese total, 880,5 millones de dólares EE.UU. se destinaron a la construcción de la central térmica de Nghi Son ${ }^{6}$, en Viet Nam. Los 354 millones de dólares EE.UU. restantes se destinaron a la construcción de una planta de desulfuración de gases de combustión en la central termoeléctrica Nikola Tesla, en Serbia. La central Nikola Tesla es la más grande de ese tipo en Serbia. Mediante ese proyecto se reducirán las emisiones de contaminantes y aumentará la eficiencia energética?

\section{... la ayuda destinada a la política y la reglamentación comerciales ha disminuido ...}

En 2011 se destinaron 1.300 millones de dólares EE.UU. (o sea un 3\% del total de la ayuda para el comercio) a la ayuda para el comercio en el sentido más estricto de la expresión - el apoyo a la política y la reglamentación comerciales (gráfico 2.10). Después de crecer de manera impresionante durante años, el volumen de esa clase de ayuda disminuyó en un 18,4\% entre 2010 y 2011. La ayuda destinada a la política y la planificación comerciales comprende la prestación de apoyo a los ministerios y departamentos responsables de la política comercial, la legislación relacionada con el comercio y las reformas de la reglamentación, el análisis de las políticas y la aplicación de las disposiciones de los acuerdos comerciales multilaterales, como los relativos a los obstáculos técnicos al comercio (OTC) y las medidas sanitarias y fitosanitarias (MSF). También abarca el costo de incorporar el comercio a las estrategias nacionales de desarrollo (por ejemplo, los documentos con estrategias de reducción de la pobreza). Dentro de la categoría correspondiente a la política y la reglamentación comerciales, la política y la planificación comerciales fue la subcategoría que más apoyo recibió (697 millones de dólares EE.UU.).

\section{Gráfico 2.10 Ayuda para la política y la reglamentación comerciales (millones de dólares EE.UU., a precios constantes de 2011)}

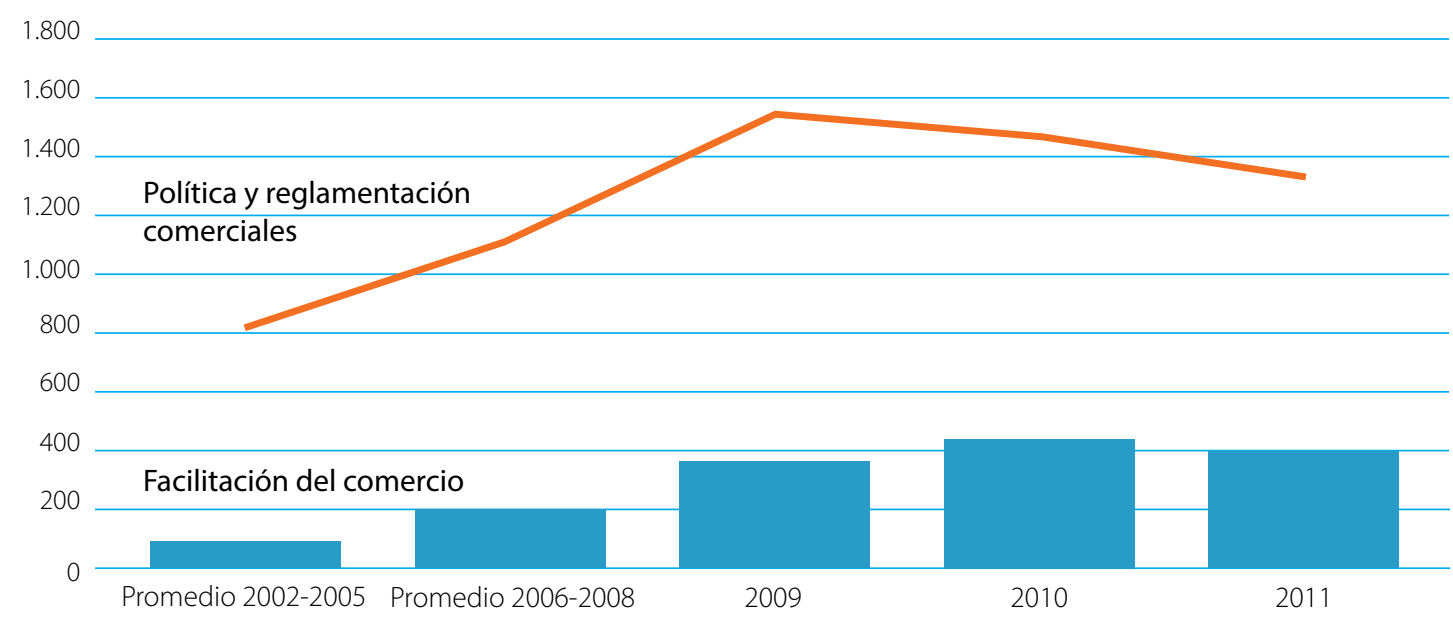

Fuente: Base de datos del Sistema de notificación por parte de los países acreedores de la OCDE, http://stats.oecd.org/index.aspx?DataSetCode=CRS 1 \#. 
Se contrajeron compromisos por valor de 16 millones de dólares EE.UU. para apoyar la participación efectiva de los países en desarrollo en las negociaciones comerciales multilaterales; esa suma tenía por objeto financiar la formación de los responsables de negociaciones comerciales, la evaluación de la repercusión de las negociaciones y los gastos de adhesión a la OMC. Se han destinado 39 millones de dólares EE.UU. a actividades de educación/ formación en la esfera del comercio, esfera que comprende la capacitación de recursos humanos, así como programas universitarios en materia de comercio. El nivel de la ayuda destinada a todas las esferas de la política comercial, salvo las negociaciones multilaterales, ha aumentado respecto del nivel correspondiente al período de referencia. En 2011 el nivel de la ayuda destinada a apoyar las negociaciones disminuyó en un 15\% respecto del correspondiente a 2010, y en un 4\% respecto del correspondiente al período de referencia, tal vez como resultado del estancamiento de la Ronda de Doha.

En 2011 los Países Bajos contrajeron compromisos por valor de 125 millones de dólares EE.UU. para la ejecución del proyecto más grande de apoyo a la política y la reglamentación comerciales: la financiación de la Iniciativa de Comercio Sostenible (IDH). Mediante la IDH se promueve el establecimiento de cadenas de comercio internacional sostenible por conducto de organizaciones no gubernamentales (ONG). Los Países Bajos han proporcionado otros 41 millones de dólares EE.UU. para financiar una iniciativa mundial de apoyo a los productores; se trata de una asociación entre el sector público y el sector privado que tiene por objeto crear y mantener cadenas de suministro de productos agrícolas. La UE suministró a Egipto 28 millones de dólares EE.UU. para ser utilizados por el Ministerio de Industria y Comercio para elaborar y poner en práctica, entre 2011 y 2013, reformas de política esenciales para que el país se integre en mayor medida en la economía regional y mundial. La UE también asignó 21 millones de dólares EE.UU. para ayudar al Grupo de Estados de África, el Caribe y el Pacífico (ACP) a superar obstáculos técnicos al comercio. El Canadá está financiando la labor de investigadores encargados de llevar a cabo una serie de estudios de casos por países con el fin de comprender mejor la naturaleza y el alcance de la piratería en el ámbito de los medios de información y comunicación en el Brasil, la India y Sudáfrica. ${ }^{8}$

\section{.. y la ayuda destinada a la facilitación del comercio ha perdido impulso después de crecer de manera sostenidah}

La ayuda destinada a facilitar el comercio comprende el apoyo que se presta a la simplificación y armonización de los procedimientos internacionales de importación y exportación (por ejemplo, la valoración en aduana, los procedimientos de expedición de licencias, los pagos y los seguros), así como a los departamentos de aduanas y a las reformas arancelarias. El nivel de los compromisos en relación con la ayuda para la facilitación del comercio ha aumentado considerablemente en años recientes -y en un 365\% respecto del nivel correspondiente al período de referencia (2002-2005). En 2011 el nivel de esa ayuda ascendió a 381 millones de dólares EE.UU. Aunque en 2010 el nivel de la ayuda disminuyó en un 10\%, la disminución fue inferior a la merma global del 14\% registrada en relación con los compromisos de ayuda para el comercio (gráfico 2.10). El aumento de los compromisos destinados a facilitar el comercio ha beneficiado mayormente a África. En 2011 la cuantía de los compromisos destinados a África ascendió a 200 millones de dólares EE.UU.; ese nivel fue 17 veces superior al correspondiente al período de referencia. El volumen de las corrientes destinadas a América aumentaron en 2011, año en que alcanzaron los 62 millones de dólares EE.UU. como resultado del apoyo prestado por la UE a países del Caribe. El nivel de las corrientes destinadas a Asia ha variado a lo largo de los años. En 2011 la cuantía de la ayuda disminuyó a 39 millones de dólares EE.UU., mientras que en Europa el volumen de las corrientes aumentó respecto del de años anteriores a 35 millones de dólares EE.UU. Por último, en 2011 la ayuda prestada a Oceanía para facilitar el comercio disminuyó en casi 40 millones de dólares EE.UU., a 6 millones de dólares EE.UU., en relación con el nivel de la ayuda correspondiente a 2010, año en que la UE se comprometió a aportar 40 millones de dólares EE.UU. para financiar un proyecto destinado a "fortalecer la integración económica del Pacífico a través del comercio". 
En 2011 los donantes proporcionaron 168 millones de dólares EE.UU. (el 44\% del total) para financiar programas regionales de facilitación del comercio, y otros 40 millones de dólares EE.UU. para financiar programas multinacionales. ${ }^{9}$ Dinamarca suministró 24 millones de dólares EE.UU. para la ejecución, en la Comunidad del África Oriental (Burundi, Kenya, Rwanda, Tanzanía y Uganda), de un programa encaminado a fomentar la integración económica mediante el establecimiento de un mercado común que promueva el crecimiento económico. Cinco donantes (Dinamarca, el Japón, Suiza, la UE y el Grupo del Banco Mundial) aportaron el $86 \%$ del total de los fondos destinados a facilitar el comercio. La UE proporcionó casi 95 millones de dólares EE.UU. para la ejecución del mayor de los programas, que tiene por objeto "apoyar la construcción de un mercado regional competitivo en el contexto de los Acuerdos de Asociación Económica" en África. ${ }^{10}$ El Banco Mundial suministró el grueso de los 52 millones de dólares EE.UU. que asignó a la ayuda para la facilitación del comercio al Camerún (11,2 millones de dólares EE.UU.), Ghana (20 millones de dólares EE.UU.) y Rwanda (más de 17,5 millones de dólares EE.UU.). Suiza proporcionó 33,2 millones de dólares EE.UU. y Dinamarca 30 millones de dólares EE.UU. para programas mundiales. El Japón suministró 26 millones de dólares EE.UU., de los cuales 20 millones de dólares EE.UU. se destinaron a financiar actividades de cooperación técnica en la región de Asia.

\section{Los donantes están proporcionando información y asistencia en relación con las importaciones que ingresan en sus mercados ...}

Page (2011) ha observado que la falta de información sobre los mercados plantea dificultades a los productores de los países en desarrollo, y que sólo unos pocos donantes bilaterales ofrecen información y asistencia específicas a quienes desean exportar productos a sus mercados. La autora considera que se trata de una deficiencia importante, ya que son los donantes quienes están en mejores condiciones de facilitar información sobre sus propios mercados. Sin embargo, hay indicios de que los donantes están comenzando a reaccionar. En 2011 los Países Bajos y Suiza incrementaron la información sobre sus mercados, ofreciendo información y asistencia específicas en relación con las importaciones que ingresaban en ellos.

Suiza contrajo compromisos por valor de 31 millones de dólares EE.UU. destinados a financiar el Programa suizo de promoción de las importaciones (SIPPO), en el marco de sus actividades de cooperación para el desarrollo económico. Mediante el SIPPO se ayuda a importadores suizos y de la UE a encontrar socios apropiados y productos de alta calidad en determinados países en desarrollo y en transición. En el marco del SIPPO, se prestan servicios de asesoramiento orientados a fomentar la importación de productos de los sectores alimentario, no alimentario y del turismo sostenible, en 14 países en cuatro continentes. Los Países Bajos proporcionaron 208 millones de dólares EE.UU. al Centro de los Países Bajos para la promoción de las importaciones provenientes de los países en desarrollo (CBI) para fomentar el comercio en África. El CBI es un organismo del Ministerio de Relaciones Exteriores de los Países Bajos que ayuda a los productores/exportadores a ingresar en el mercado neerlandés. También presta asistencia a organizaciones de apoyo a las empresas a fin de incrementar su capacidad, y oficia de intermediario entre proveedores y compradores. El Export Helpdesk es un servicio de "ventanilla única" de la UE que, desde 2004, proporciona información en línea a empresas de países en desarrollo que desean exportar a Europa..

\section{... y están prestando más ayuda para el ajuste relacionado con el comercio.}

Mediante la ayuda para el ajuste relacionado con el comercio se ayuda a los países en desarrollo a sufragar los costos vinculados a la liberalización del comercio, como las reducciones de aranceles, la erosión de las preferencias o el deterioro de la relación de intercambio. En 2007 se añadió a la base de datos del SNPA un código-objeto para el seguimiento de los recursos destinados al ajuste. Inicialmente no se disponía de información completa, ya que sólo dos Miembros notificaban sus actividades, pero actualmente la situación ha mejorado y son seis los donantes que informan sobre la ayuda que prestan. En 2011 la cuantía de las corrientes de ayuda para el ajuste relacionado con el comercio ascendieron a casi 63 millones de dólares EE.UU.. 
La UE es el mayor proveedor de ayuda para el ajuste relacionado con el comercio. En la reforma del régimen del azúcar de la UE efectuada en 2006, se prevé la eliminación de contingentes y la reducción gradual del precio garantizado por la UE a los productores. De ese modo los países signatarios del Protocolo relativo al azúcar de la UE se vieron obligados a adoptar medidas para aumentar la competitividad de sus sectores de producción de azúcar de caña y mitigar los efectos negativos de la reforma a nivel económico y social. En 2006 la Unión Europea anunció un plan de ayuda de ocho años para apoyar esos cambios: las medidas complementarias para los países signatarios del Protocolo del Azúcar. Con arreglo a ese plan, en 2011 la UE se comprometió a proporcionar 43 millones de dólares EE.UU. en calidad de apoyo presupuestario sectorial a la industria azucarera de Jamaica, con el fin de "desarrollar y mantener una industria de producción sostenible de caña de azúcar impulsada por el sector privado"1" Esa ayuda representa actualmente casi el 70\% de la ayuda para el ajuste relacionado con el comercio, aunque también Finlandia (10,7 millones de dólares EE.UU.) y Suiza (7,5 millones de dólares EE.UU.) prestan ese tipo de ayuda.

\section{Desde 2006 se han desembolsado 174.000 millones de dólares EE.UU. por concepto de ayuda para el comercio.}

Los desembolsos por concepto de ayuda para el comercio resultaron menos afectados por la disminución de la AOD en 2011. En valores reales, esos desembolsos disminuyeron en un 3,7\%, a 33.500 millones de dólares EE.UU. (gráfico 2.11). Como resultado de haberse contraído compromisos más elevados en años precedentes, el grueso de los desembolsos (17.700 millones de dólares EE.UU.) se destinó a apoyar la creación de infraestructura económica. Sin embargo, como en el caso de los compromisos, los desembolsos destinados a la creación de infraestructura fueron la categoría más afectada por la disminución del gasto: 1.000 millones de dólares EE.UU. menos que en 2010. La cuantía de la ayuda destinada a la creación de capacidad productiva se mantuvo al nivel registrado en 2010, aunque con un ligero aumento: 14.800 millones de dólares EE.UU. Los desembolsos de fondos destinados a la política y la reglamentación comerciales disminuyeron en 300 millones de dólares EE.UU.: de 1.200 millones en 2010 a 982 millones en 2011.

La cuantía de los desembolsos anuales por concepto de ayuda para el comercio aumentó en un 53\% entre 2006 y 2011; en total, se desembolsaron 174.000 millones de dólares EE.UU. por ese concepto entre 2006 y 2011. El 35\% de esos desembolsos se destinó a diez países, principalmente de Asia, que ha sido, invariablemente, la región que más

\section{Gráfico 2.11 Desembolsos por concepto de ayuda para el comercio (millones de dólares EE.UU., a precios constantes de 2011)}

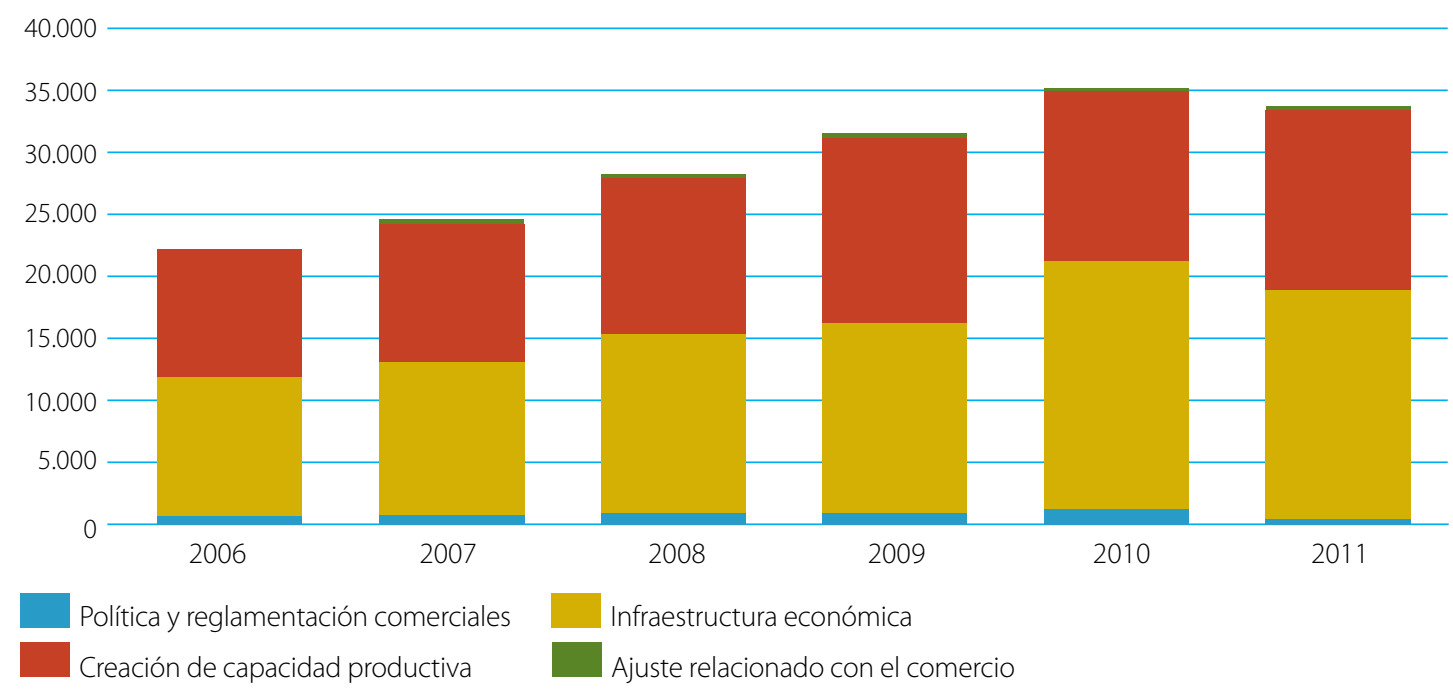

Fuente: Base de datos del Sistema de notificación por parte de los países acreedores de la OCDE, http://stats.oecd.org/index.aspx?DataSetCode=CRS 1\#. 
compromisos ha recibido. La India es el mayor receptor de ayuda, con 11.000 millones de dólares EE.UU., o sea el 6,4\% del total, seguida de Viet Nam, con algo más de 9.000 millones de dólares EE.UU. (5,3\% del total) y el Afganistán, con 8.200 millones de dólares EE.UU. (4,7\% del total). La cuantía de los desembolsos puede reflejar prioridades que han dejado de serlo: por ejemplo, el Iraq recibió 6.900 millones de dólares EE.UU., principalmente para la reconstrucción de posguerra; más recientemente los compromisos contraídos en relación con ese país han disminuido. Aunque los compromisos contraídos en relación con China e Indonesia también han disminuido, esos dos países recibieron desembolsos por valor de 5.800 millones de dólares EE.UU. (3\% del total) y 4.400 millones de dólares EE.UU. (2,5\% del total), respectivamente. El norte de África también ha sido beneficiario de cuantiosos desembolsos. Egipto y Marruecos figuran entre los 10 mayores receptores, con 4.000 millones de dólares EE.UU. (2,3\% del total) y 3.800 millones de dólares EE.UU. (2,2\% del total), respectivamente. Etiopía, con 3.960 millones de dólares EE.UU. (2,2\% del total), es el único país del África Subsahariana que figura entre los 10 beneficiarios principales, seguida de Turquía, el único país europeo, con 3.350 millones de dólares EE.UU. (1,9\% del total). Entre 2006 y 2011, cinco donantes suministraron el 66\% del total de los desembolsos destinados a la ayuda para el comercio. El Japón, cuyos desembolsos ascendieron a 36.000 millones de dólares EE.UU. (21\% del total), fue el principal donante, seguido de los Estados Unidos, con 24.000 millones de dólares EE.UU. (13,8\% del total), el Banco Mundial, con 24.000 millones de dólares EE.UU. (13,7\% del total), la UE, con 16.300 millones de dólares EE.UU. (9,4\% del total) y Alemania, con 14.000 millones de dólares EE.UU. (8\% del total).

\section{¿QUIÉNES SON LOS RECEPTORES DE LA AYUDA PARA EL COMERCIO?}

En 2011 se contrajeron compromisos por concepto de ayuda para el comercio en relación con 146 países. Varios países y territorios (Anguilla, Barbados, Croacia, Mayotte, Omán y Trinidad y Tabago) han dejado de recibir ayuda para el comercio y ya no tienen la condición de receptores de ayuda. Sudán del Sur, que se independizó en 2011, figura en la lista de receptores por primera vez. El volumen de la ayuda para el comercio varía considerablemente de un país a otro. En la presente sección se pasa revista a los receptores de ayuda por región, por grupo de ingresos y a título individual.

\section{La cuantía de las corrientes destinadas a África ha dejado de aumentar...}

En años recientes África recibió buena parte de los incrementos de las corrientes de ayuda para el comercio; así, la cuantía de los compromisos aumentó en un 64\% respecto de la correspondiente al período de referencia (2002-2005); sin embargo, actualmente ese fuerte crecimiento se ha detenido. En 2011 la cuantía de la ayuda para el comercio destinada a África disminuyó en 5.400 millones de dólares EE.UU., a 13.100 millones de dólares EE.UU., o sea una disminución del 29\% en comparación con la cuantía correspondiente a 2010 (gráfico 2.12). La disminución afectó por igual a los países situados al norte del Sáhara (en particular, Egipto y Marruecos), así como al sur del Sáhara (entre otros, Etiopía, Kenya y Tanzanía). Esa disminución fue causada por la reducción de los compromisos contraídos en relación con proyectos de energía y transporte. Otras regiones resultaron mucho menos afectadas que África. Asia, la región que más ayuda recibe (17.500 millones de dólares EE.UU.), recibió un 5\% menos que en 2010.

La región de América Latina y el Caribe, que recibió 3.500 millones de dólares EE.UU., ocupó el tercer lugar entre los receptores de ayuda a nivel regional y resultó mínimamente afectada; las corrientes destinadas a la región se mantuvieron al nivel alcanzado en 2010. Además, los principales beneficiarios de las corrientes de ayuda son mayormente países de América Central y el Caribe, que recibieron casi el doble (un 93\% más) de la ayuda recibida durante el período de referencia (2002-2005). La proporción correspondiente a América Central y el Caribe en la cuantía total de los compromisos contraídos por concepto de ayuda para el comercio en beneficio de países de América es del 57\%, que es el nivel más alto alcanzando desde que se inició el seguimiento. Esa cuantía comprende 779 millones de dólares EE.UU. suministrados a Haití, el único PMA del hemisferio occidental. En 2011 las economías emergentes 


\section{Gráfico 2.12 Ayuda para el comercio, por región (miles de millones de dólares EE.UU., a precios constantes de 2011)}

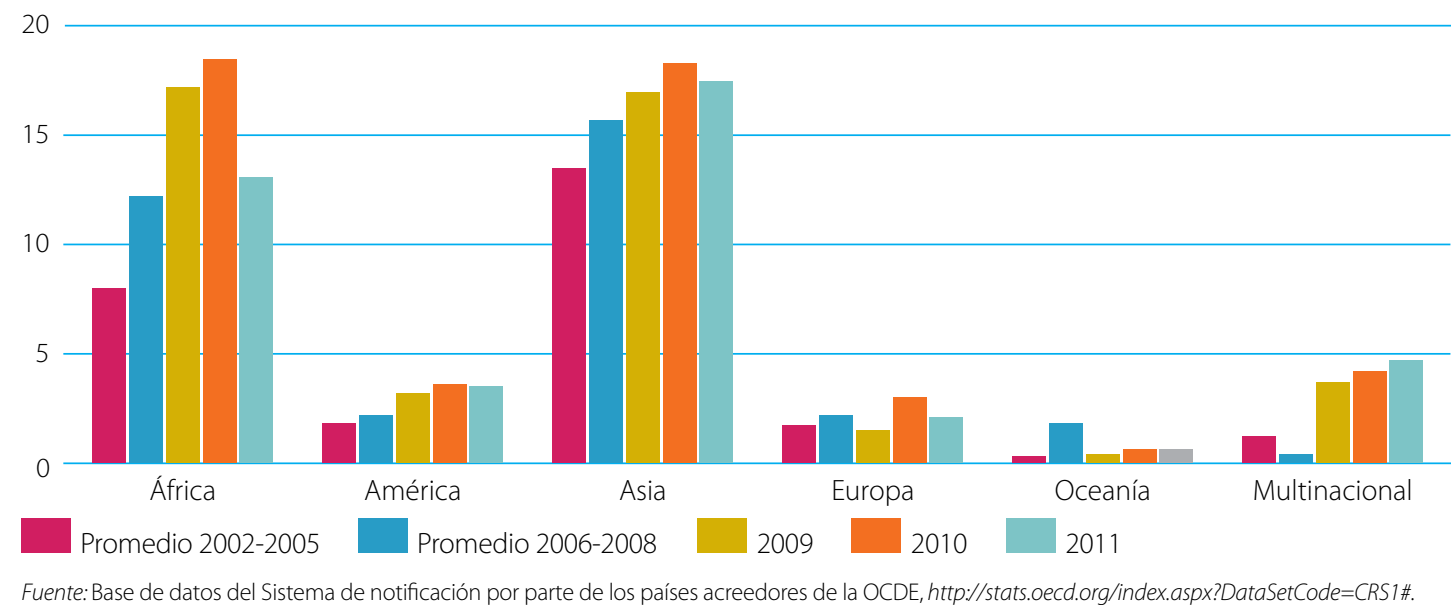

de Europa recibieron 2.100 millones de dólares EE.UU., o sea un aumento del 28\% respecto del nivel correspondiente al período de referencia, pero una disminución del 29\% respecto del nivel alcanzado en 2010. La mitad de los compromisos contraídos en 2011 en relación con países de Europa estuvieron destinados a Serbia (673 millones de dólares EE.UU.) y Turquía (422 millones de dólares EE.UU.). Oceanía es la única región en la que la ayuda para el comercio aumentó de 2010 a 2011. El nivel de los compromisos alcanzó los 644,5 millones de dólares EE.UU., o sea un incremento del 12\% respecto del correspondiente a 2010 y del 121\% en comparación con el correspondiente al período de referencia (2002-2005). Kiribati, Papua Nueva Guinea y Tonga recibieron el 58\% del total de las corrientes destinadas a Oceanía en 2011 (110,4 millones de dólares EE.UU., 183 millones de dólares EE.UU. y 79 millones de dólares EE.UU., respectivamente).

\section{.... pero los PMA no han sido los más afectados ...}

Por primera vez desde que comenzó a seguirse la evolución de la situación, los países de ingresos bajos recibieron el grueso de la ayuda para el comercio dejando muy atrás a los países de ingresos medianos. Sin embargo, la reducción de los presupuestos destinados a la AOD en 2011 ha perjudicado a todos los grupos de ingresos. Aunque los PMA resultaron menos afectados que otros grupos, el nivel de los compromisos contraídos en su beneficio fue inferior en un 7\% al correspondiente a 2010. En 2011 se contrajeron compromisos por valor de más de 13.000 millones de dólares EE.UU. en relación con los PMA, que recibieron el 32\% de la ayuda para el comercio. La proporción correspondiente a los PMA en el total de la ayuda ha aumentado de manera sostenida y la cuantía total de las corrientes de ayuda recibidas se ha duplicado en comparación con la correspondiente al período de referencia, durante el cual los PMA recibieron sólo el 26\% del total de la ayuda para el comercio (gráfico 2.13).

Sólo hay otros seis países de ingresos bajos (OPBI) respecto de los cuales en 2011 se contrajeron compromisos por valor de 1.450 millones de dólares EE.UU. Esos países recibieron un 169\% más de ayuda para el comercio que en el período de referencia. Kenya recibió el 57\% de esas corrientes; la República Kirguisa, el 13\%; Sudán del Sur (país respecto del cual se dispone de datos por primera vez), el 8,6\%; Tayikistán, el 16\% y Zimbabwe, el 5,3\%. La República Popular Democrática de Corea recibió una suma insignificante (0,24 millones de dólares EE.UU.; de esa suma, Francia, Italia y el Programa de las Naciones Unidas para el Desarrollo (PNUD) aportaron 0,23 millones de dólares EE.UU.). 
La disminución de la ayuda para el comercio destinada a OPBI se debe a que los fondos destinados a Kenya se redujeron a la mitad (de 1.750 millones de dólares EE.UU. en 2010 a 850 millones de dólares EE.UU. en 2011). El nivel de los compromisos contraídos por concepto de ayuda para el comercio en relación con los países de ingresos medianos bajos (PIMB) sigue siendo alto (14.900 millones de dólares EE.UU.), pero ha crecido mucho más lentamente que el nivel de la ayuda destinada a los países de ingresos bajos: sólo en un 22\% respecto del nivel correspondiente al período de referencia (2002-2005). El nivel de la ayuda para el comercio prestada a los países de ingresos medianos altos (PIMA) se redujo de 6.300 millones de dólares EE.UU. en 2010 a 4.000 millones de dólares EE.UU. en 2011 y, en realidad, es inferior al correspondiente al período de referencia. Por tener un nivel de ingresos superior, estos países están recibiendo menos AOD y más financiación en forma de OCO e IED. En efecto, en 2011 los PIMA recibieron nada más que 4.000 millones de dólares EE.UU. por concepto de ayuda para el comercio, pero recibieron 18.500 millones de dólares EE.UU. por concepto de OCO relacionadas con el comercio.

\section{Gráfico 2.13 Ayuda para el comercio, por grupos de países según su nivel de ingresos (millones de dólares EE.UU., a precios constantes de 2011)}

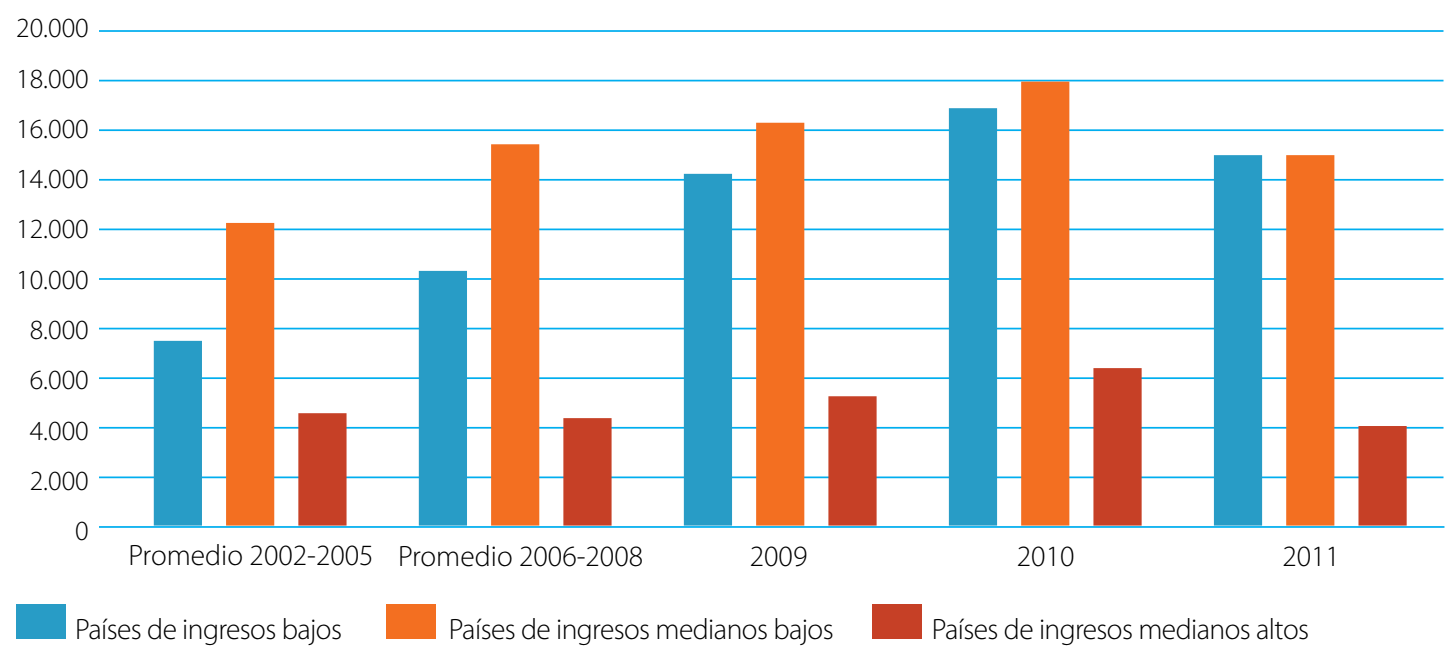

Fuente: Base de datos del Sistema de notificación por parte de los países acreedores de la OCDE, http://stats.oecd.org/index.aspx?DataSetCode=CRS1\#.

\section{... y la cuantía de la ayuda destinada a programas multinacionales alcanzó el nivel más alto de la historia}

En las Recomendaciones del Equipo de Trabajo sobre la Ayuda para el Comercio se señalaba que el "apoyo limitado a los programas y proyectos regionales, subregionales y transfronterizos relacionados con el comercio" constituía una deficiencia fundamental (OMC, 2006:3). Con el tiempo se ha ido subsanando esa deficiencia; de hecho, la cuantía de los compromisos por concepto de ayuda para el comercio contraídos en relación con programas multinacionales ha aumentado a 7.700 millones de dólares EE.UU., el nivel más alto de la historia (gráfico 2.14). En 2011 África recibió la mayor proporción de la ayuda para el comercio a nivel regional: 782 millones de dólares EE.UU., el cuádruple de la recibida durante el período de referencia (2002 2005) y apenas un 1,5\% menos que en 2010. El Fondo Africano de Desarrollo prestó asistencia para la creación de infraestructura en la región, y varios donantes bilaterales suministraron ayuda para el comercio por conducto del Banco Africano de Desarrollo (BAfD). Así, a través del BAfD, el Japón proporcionó a 105 millones de dólares EE.UU. para la industria, y Dinamarca suministró 48 millones de dólares 


\section{Gráfico 2.14 Programas multinacionales (millones de dólares EE.UU., a precios constantes de 2011)}

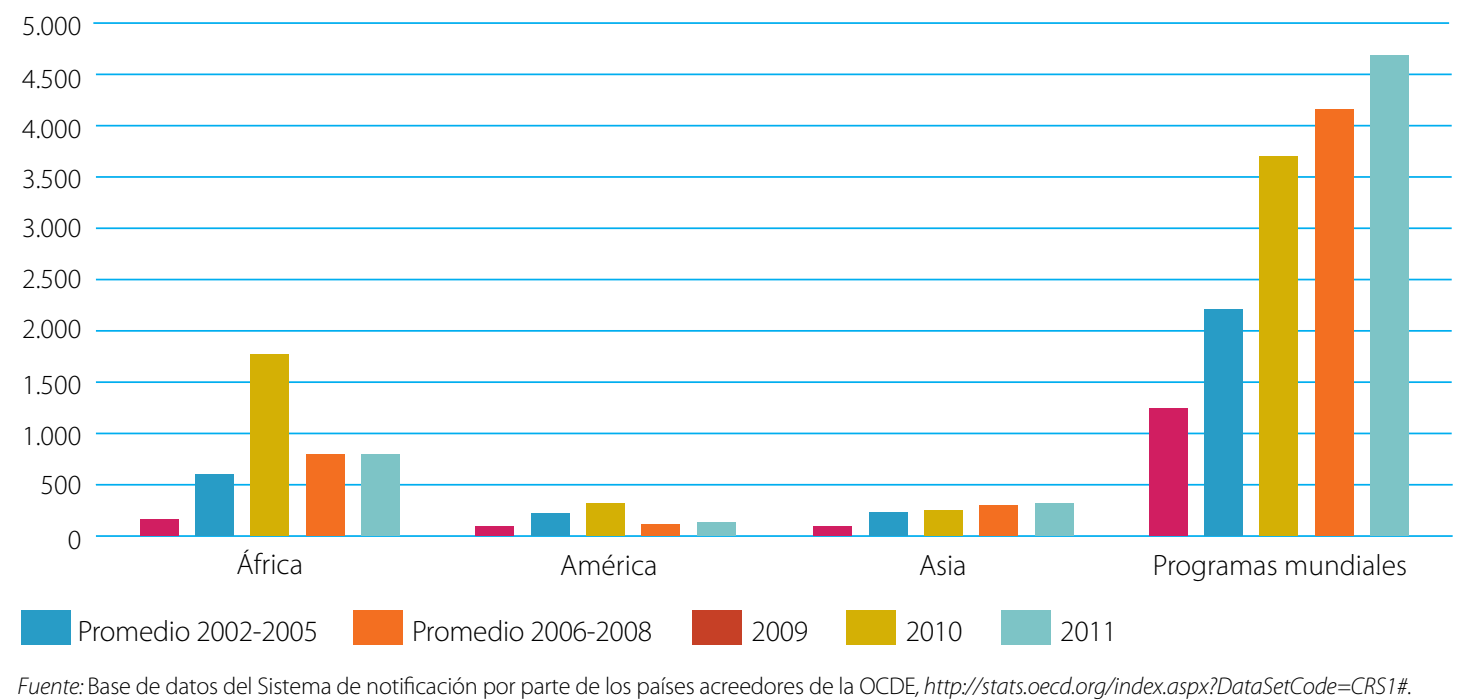

EE.UU. para el sector de la energía. Alemania está prestando asistencia a la Comunidad para el Desarrollo del África Meridional (SADC); con tal fin, ha proporcionado 6,6 millones de dólares EE.UU. para fortalecer la capacidad económica y en materia de política comercial, con el objeto de intensificar la integración económica regional en el contexto de las prioridades del Plan Regional Indicativo de Desarrollo Estratégico (RISDP).12

La ayuda prestada a los programas regionales fue más modesta en Asia (336 millones de dólares EE.UU.) y en América (125,7 millones de dólares EE.UU.), pero aumentó ligeramente respecto de la correspondiente a 2010 y considerablemente respecto de la correspondiente al período de referencia; el apoyo regional a Asia aumentó en un 310\% mientras que el apoyo a América aumentó en un 60,5\%. La UE suministró casi 20 millones de dólares EE.UU. al Asia sudoriental para apoyar la integración económica de la Asociación de Naciones del Asia Sudoriental (ASEAN) con proyectos destinados a fortalecer el marco institucional encargado de administrar la integración. Australia contrajo compromisos por valor de 20 millones de dólares EE.UU. (2013 2014) en relación con el Programa de asistencia en materia de cooperación económica (AECSP) de la Zona de libre comercio entre la ASEAN, Australia y Nueva Zelandia (AANZFTA), que ayuda a los países en desarrollo miembros de la ASEAN a cumplir con los compromisos contraídos en el marco de la AANZFTA y participar así en los beneficios que reporta una mayor liberalización del comercio y la integración económica regional. Alemania financió el 72\% de todos los programas regionales ejecutados en América; con ese objeto proporcionó 47,6 millones de dólares EE.UU. para fortalecer las instituciones financieras regionales y 25 millones de dólares EE.UU. para incrementar el suministro de energía en la región. La ayuda prestada a los programas mundiales ha aumentado marcadamente en relación con la prestada en el período de referencia (20022005). Ese aumento continuó en 2011, año en que alcanzó la cifra de 4.700 millones de dólares EE.UU. Los Países Bajos contrajeron compromisos por valor de 572,5 millones de dólares EE.UU. para financiar, en el marco del mayor programa mundial, inversiones en el sector privado destinadas a apoyar proyectos piloto de inversión en países en desarrollo. Mediante los proyectos piloto se alientan las inversiones (neerlandesas) en mercados emergentes y las relaciones comerciales con empresas radicadas en esos mercados. 


\section{¿QUIÉNES SON LOS PROVEEDORES DE AYUDA PARA EL COMERCIO?}

\section{La ayuda para el comercio prestada por donantes bilaterales ha disminuido, pero sigue siendo la principal fuente de asistencia....}

Los donantes bilaterales siguen aportando el grueso de la ayuda para el comercio: en 2011 suministraron el 60\% del total de esa ayuda. Sin embargo, esa proporción fue inferior a la correspondiente a 2010 (65\%) (gráfico 2.15). En 2011 los 24 miembros del Comité de Asistencia para el Desarrollo (CAD) proporcionaron 28.000 millones de dólares EE.UU., un 19\% menos que en 2010. En 2011 todos los miembros del Grupo de los Siete (G-7) prestaron menos ayuda para el comercio. Esa disminución, por valor de casi 6.400 millones de dólares EE.UU., representó casi la totalidad de la disminución de la ayuda para el comercio (6.600 millones de dólares EE.UU.). En 2011 el Japón siguió siendo el principal donante: 7.900 millones de dólares EE.UU., o sea un 22\% menos que en 2010, pero un 30\% más que en el período de referencia (2002-2005). El Japón es el donante del CAD que más se ha especializado en prestar ayuda para el comercio. El 60\% del total de la AOD del Japón asignable a sectores específicos se destinó a la ayuda para el comercio. Alemania ocupó el segundo lugar entre los donantes bilaterales, con 3.700 millones de dólares EE.UU., cifra que representó un aumento del 176\% respecto de la correspondiente al período de referencia, pero un 20\% menos que la proporcionada en 2010. La ayuda para el comercio de Alemania disminuyó en 2011 respecto de 2010, pero no respecto de 2009, lo cual puede atribuirse al fuerte aumento de la ayuda para el comercio en 2010 como resultado de haberse asumido el compromiso de proporcionar "financiación acelerada" en relación con el clima, en particular la destinada al aprovechamiento de energías renovables, a raíz de la Conferencia de las Naciones sobre el Cambio Climático celebrada en Copenhague.

Los compromisos por concepto de ayuda para el comercio contraídos por los Estados Unidos disminuyeron abruptamente: de 5.900 millones de dólares EE.UU. en 2010 a 3.600 millones de dólares EE.UU. en 2011, o sea un 40\% menos. El nivel de apoyo prestado por los Estados Unidos en 2011 fue inferior en un 8,5\% al correspondiente al período de referencia, lo cual es indicio claro del abandono por los Estados Unidos de la ayuda para el comercio en favor de programas sociales. Además, sólo el 19\% de la AOD asignable a sectores específicos se destinó a la ayuda para el comercio. La UE suministró 3.200 millones de dólares EE.UU., o sea sólo un 2\% menos que en 2010; esa cifra representó un aumento del 8\% respecto de la correspondiente al período de referencia. Francia aportó 1.300 millones de dólares EE.UU., o sea un 29\% menos que en 2010, pero casi un 60\% más que en el período de referencia. La cuantía de los compromisos bilaterales contraídos por el Reino Unido disminuyó en un 22\% respecto de 2010, si bien cabe señalar que el Reino Unido sigue prestando un volumen considerable de asistencia por conducto de instituciones multilaterales (véase la siguiente sección).

Fuera del marco del G-7, la cuantía de los compromisos contraídos por España por concepto de ayuda para el comercio se redujo a casi la mitad (54\%) de la correspondiente a 2010, mientras que Dinamarca, Italia y Portugal contrajeron compromisos por concepto de ayuda para el comercio en 2011 que fueron inferiores a los correspondientes al período de referencia. Sin embargo, algunos donantes aportaron más recursos. Los Países Bajos, que suministraron 1.200 millones de dólares EE.UU., duplicaron la cuantía de la ayuda proporcionada en 2010. Noruega aportó un poco más de 1.000 millones de dólares EE.UU., cifra similar a la suministrada en 2010, y sigue figurando entre los 10 donantes principales. Los 187 millones de dólares EE.UU. aportados por Nueva Zelandia representan un aumento del 165\% respecto de la ayuda prestada en 2010 y del $720 \%$ respecto de la correspondiente al período de referencia (2002-2005). Las corrientes procedentes de Bélgica (478 millones de dólares EE.UU.) aumentaron en un 7\% en 2011 respecto del nivel alcanzado en 2010. Curiosamente, la cuantía de los compromisos contraídos por Grecia e Irlanda por concepto de ayuda para el comercio aumentó en 2011 en un 3\% y un 2,7\%, respectivamente. Otros donantes bilaterales, como la República Checa y los Emiratos Árabes Unidos añadieron otros 204 millones de dólares EE.UU. al total. 


\section{Gráfico 2.15 Los 10 principales donantes de ayuda para el comercio (millones de dólares EE.UU., a precios constantes de 2011)}

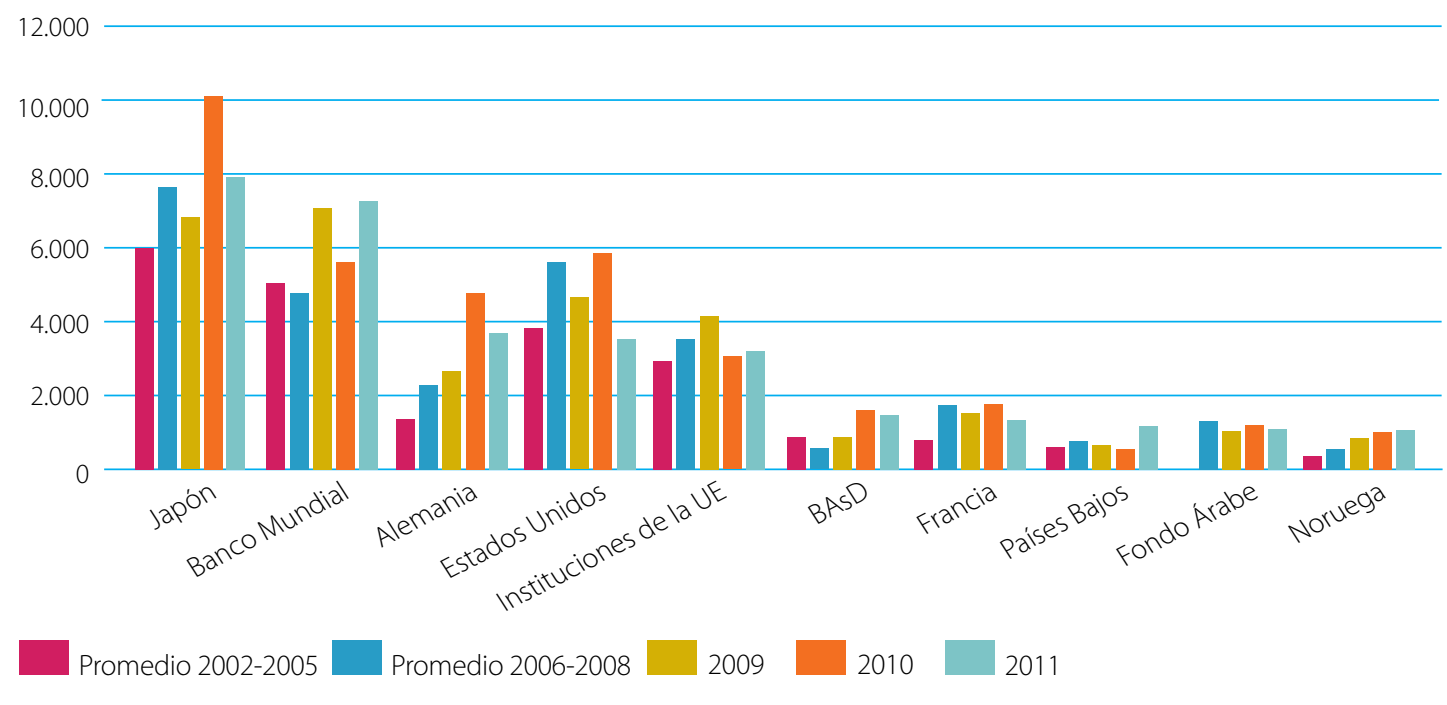

Fuente: Base de datos del Sistema de notificación por parte de los países acreedores de la OCDE, http://stats.oecd.org/index.aspx?DataSetCode=CRS1\#.

... y el nivel de la ayuda para el comercio prestada por el G-20 está ligeramente por debajo del que se habían comprometido a mantener ...

En la Cumbre de Seúl, celebrada los días 11 y 12 de noviembre de 2010, los líderes del Grupo de los 20 prometieron (cuando menos) mantener la cuantía media de la ayuda para el comercio prestada durante el período 2006-2008 después de 2011 y encomendaron a la OCDE y la OMC que vigilaran los progresos logrados. Los datos más recientes correspondientes a 2011 indican que el G-20 no cumplirá el compromiso asumido (gráfico 2.16). En 2011 el G-20 contrajo compromisos por concepto de ayuda para el comercio por valor de 23.300 millones de dólares EE.UU., o sea una disminución del 24\% en valores reales (7.300 millones de dólares EE.UU.) respecto de la cuantía proporcionada en 2010 y del 3,4\% respecto de la correspondiente al período de referencia (2006-2008). El G-20 ha seguido proporcionando recursos a los PMA; esos recursos representaron el 22,5\% del total de la ayuda para el comercio. En 2011 se contrajeron compromisos en relación con los PMA por valor de 5.200 millones de dólares, o sea un 3,4\% más, en valores reales, que la media correspondiente al período 2006-2008. Aun así, los recursos destinados a los PMA disminuyeron en un 24\% respecto de los correspondientes a 2010.

\section{Gráfico 2.16 Ayuda para el comercio prometida por el G-20}

(millones de dólares EE.UU., a precios constantes de 2011)

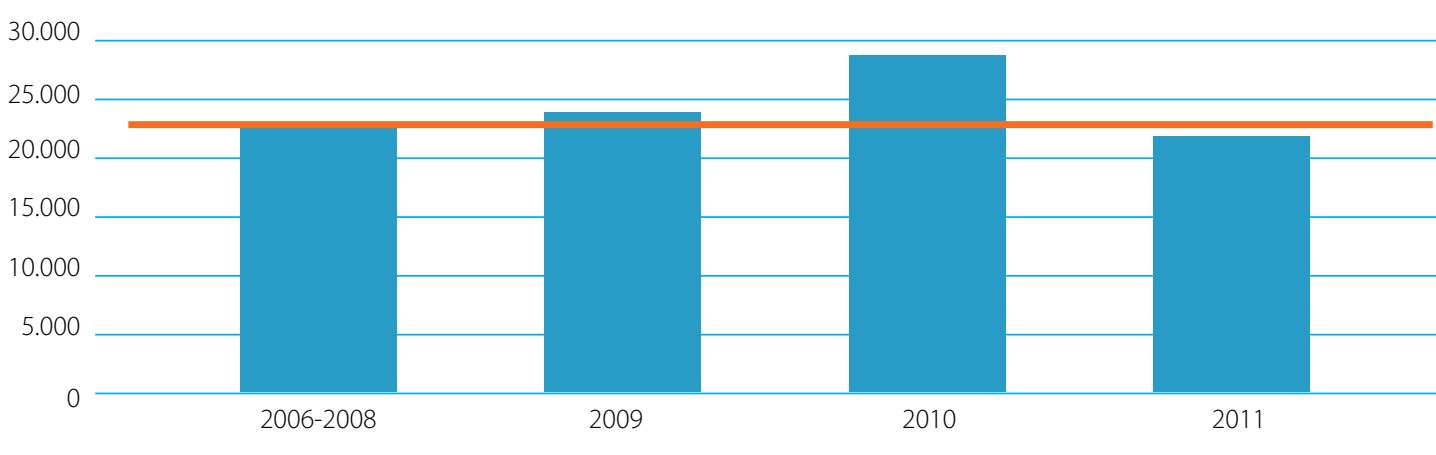

Fuente: Base de datos del Sistema de notificación por parte de los países acreedores de la OCDE, http://stats.oecd.org/index.aspx?DataSetCode=CRSI\#. 


\section{... mientras que se ha mantenido el nivel de los fondos proporcionados por donantes multilaterales}

En 2011 los recursos proporcionados por donantes multilaterales por concepto de ayuda para el comercio se mantuvieron al nivel alcanzado en 2010: 16.600 millones de dólares EE.UU. (o sea el 40\% del total de la ayuda para el comercio). ${ }^{3}$ El Banco Mundial es el principal donante multilateral y ocupa el segundo lugar entre los principales donantes en valores absolutos, con 7.300 millones de dólares EE.UU. El Banco aumentó en un 46\% la cuantía de la ayuda para el comercio en comparación con la correspondiente al período de referencia y en un 29\% (1.600 millones de dólares EE.UU.) en comparación con la correspondiente a 2010. En 2011 el Banco Asiático de Desarrollo contrajo compromisos por valor de 1.450 millones con cargo a sus Fondos Especiales; esa cifra representó una disminución del 10\% en comparación con el apreciable incremento registrado en 2010. El aumento de la ayuda para el comercio suministrada por el Banco Mundial contrarrestó la disminución de la ayuda prestada por otros donantes multilaterales, como el Fondo Africano de Desarrollo (851 millones de dólares EE.UU. menos) y los donantes árabes, específicamente el Fondo de Kuwait para el Desarrollo Económico Árabe (540 millones de dólares EE.UU. menos) y el Fondo de la OPEP para el Desarrollo Internacional (194 millones de dólares EE.UU. menos). El Fondo Árabe de Desarrollo Económico y Social (FADES) viene proporcionado sistemáticamente más de 1.000 millones de dólares EE.UU. por año desde 2008.

\section{¿CÓMO SE SUMINISTRA LA AYUDA PARA EL COMERCIO?}

\section{La ayuda está repartida por partes iguales entre donaciones y préstamos en condiciones concesionarias ...}

La ayuda para el comercio forma parte de la AOD ordinaria, que se proporciona en forma de donaciones y préstamos que satisfacen determinadas condiciones (a saber, transacciones en condiciones concesionarias con un elemento de donación de por lo menos el 25\%). La mitad de la ayuda para el comercio consiste en donaciones y la otra mitad en préstamos en condiciones concesionarias. Esa distribución se ha mantenido más o menos constante en años recientes (gráfico 2.17). La disminución de la ayuda en 2011 afectó en menor medida a las donaciones (por valor de 20.300 millones de dólares EE.UU.), que mermaron en un 10\%, mientras que la cuantía total de los préstamos concedidos disminuyó en un 16\%. En 2011, 22 proveedores de ayuda contrajeron compromisos por valor de 21.300 millones de dólares EE.UU. por concepto de préstamos. Los cinco prestamistas principales (Alemania, Francia, el Japón, el Banco Mundial y el Fondo Árabe de Desarrollo Económico y Social) contrajeron compromisos por valor de 16.600 millones de dólares EE.UU. Los países más pobres tienden a recibir fondos en condiciones más concesionarias. Del apoyo recibido por los PMA, el 60\% consistió en donaciones, mientras que los PIMA recibieron sólo el 23,8\% de la ayuda para el comercio en forma de donaciones. Aun así, la elección del instrumento financiero utilizado tiende a ser, en mayor medida, una función del tipo de proyecto. Casi la totalidad (el 97\%) de los proyectos relacionados con la política y la reglamentación comerciales se financia con donaciones, en comparación con el 36,5\% de los proyectos de infraestructura económica. El 60\% de la ayuda destinada a la creación de capacidad productiva consiste en donaciones y el $40 \%$ en préstamos. El volumen de la ayuda destinada al ajuste relacionado con el comercio sigue siendo pequeño y predominan las donaciones (83\%).

En 2011 los Estados Unidos fueron el principal proveedor de donaciones (3.600 millones de dólares EE.UU.); los Estados Unidos no conceden préstamos. La UE hizo donaciones por valor de 3.200 millones de dólares EE.UU. y no ha notificado ningún préstamo de AOD. Otros donantes principales utilizan ampliamente los préstamos para financiar sus programas. El Japón suministró el grueso de su asistencia en forma de préstamos (6.500 millones de dólares EE.UU.), mientras que el volumen de sus donaciones ascendió a 1.430 millones de dólares EE.UU. El Banco Mundial, 
a través de la Asociación Internacional de Fomento (AIF), suministró 5.700 millones de dólares EE.UU. en préstamos y 1.660 millones de dólares EE.UU. en donaciones. En 2011 la mayor parte de la ayuda prestada por Francia y Alemania consistió también en préstamos. Ambos países han tenido tradicionalmente una mayor proporción de préstamos que de donaciones en sus programas de ayuda para el comercio.

Debido a que los reembolsos se descuentan de la cuantía total de los préstamos de AOD, las donaciones representan una proporción mayor de la cuantía total de los desembolsos por concepto de ayuda para el comercio. Las donaciones representaron, por término medio, el 54\% del total desembolsado entre 2006 y 2011, y el 52,6\% en 2011 y aumentaron sólo en un 36\% respecto de 2006, mientras que los desembolsos por concepto de préstamos aumentaron en un $76 \%$ debido a que en años recientes han aumentado los compromisos de préstamo). Este tipo de préstamos suele tener un período de gracia de 10 años, por lo que la cuantía de los desembolsos en relación con los préstamos es más elevada inicialmente, pero va disminuyendo como resultado de los reembolsos.

\section{Gráfico 2.17 Desembolsos de préstamos y de donaciones por concepto de ayuda para el comercio} (millones de dólares EE.UU., a precios constantes de 2011)

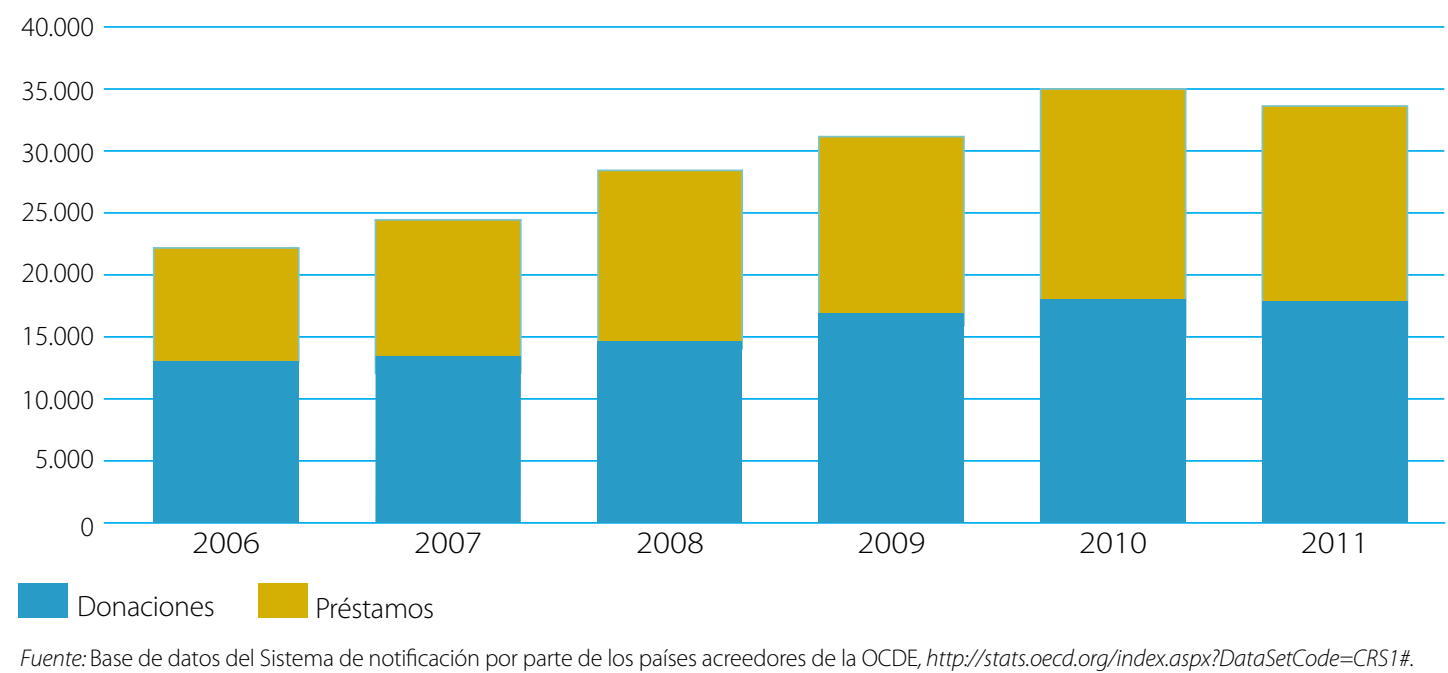

\section{... y han disminuido las otras corrientes oficiales en condiciones no concesionarias}

El sector oficial no concede únicamente préstamos en condiciones concesionarias. Las otras corrientes oficiales $(\mathrm{OCO})$ que suministra el sector oficial son transacciones que no reúnen las condiciones necesarias para ser consideradas AOD, principalmente porque tienen un elemento de donación inferior al 25\% (son, por lo tanto, préstamos en condiciones menos favorables). Como se ha señalado en anteriores informes de la serie La Ayuda para el Comercio en síntesis, esas corrientes pueden cumplir un papel crucial en la financiación de las actividades relacionadas con el comercio, principalmente en la esfera de la infraestructura económica y la creación de capacidad productiva. En 2009 las OCO relacionadas con el comercio aumentaron fuertemente a causa del aumento de los préstamos de donantes multilaterales en el marco de la crisis. Después de ese pico (50.000 millones de dólares EE.UU.), el volumen de las corrientes disminuyó en un 9\% en 2010 y en un 18\% adicional en 2011, en que dicho volumen fue de 37.700 millones de dólares EE.UU. Todos los sectores resultaron afectados por la disminución de la ayuda (gráfico 2.18). En 2011 las OCO para la creación de infraestructura económica representaron el 57\% del total, y alcanzaron la cifra de 21.400 millones de dólares EE.UU. Las OCO destinadas a la creación de capacidad productiva representaron el 42,5\% del total; menos del 1\% se destinó a la política y la reglamentación comerciales. 


\section{Gráfico 2.18 Otras corrientes oficiales relacionadas con el comercio (millones de dólares EE.UU., a precios constantes de 2011)}

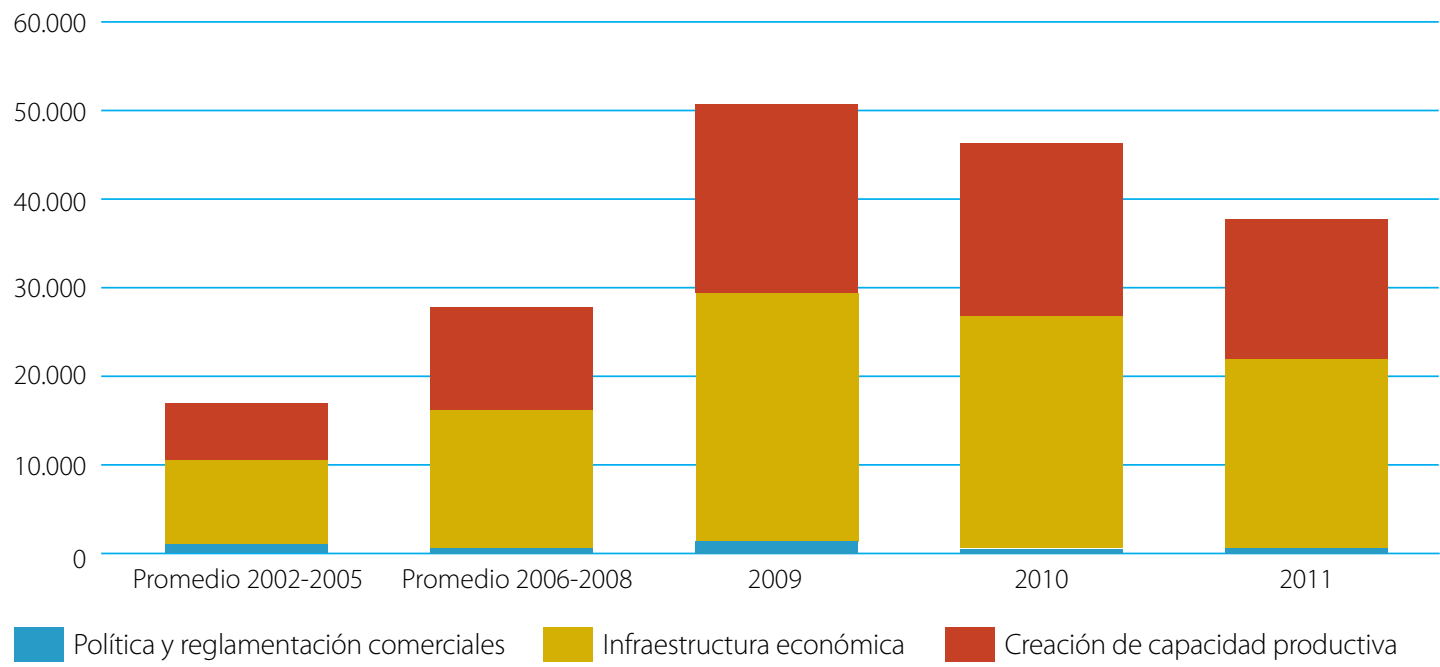

Fuente: Base de datos del Sistema de notificación por parte de los países acreedores de la OCDE, http://stats.oecd.org/index.aspx?DataSetCode=CRS1\#.

Los países de ingresos medianos son los principales beneficiarios de las OCO ...

Desde 2002, por término medio, sólo el 3\% de las OCO se ha destinado a países menos adelantados, y menos del $1 \%$ a otros países de ingresos bajos. En cambio, los países de ingresos medianos altos, recibieron, por término medio, más del 57\% de esas corrientes, y los países de ingresos medianos bajos el 37\% (gráfico 2.19). Cinco países (el Brasil, China, la India, Indonesia y Turquía) recibieron el grueso de las OCO totales (41\%).

\section{Gráfico 2.19 Otras corrientes oficiales relacionadas con el comercio, por grupos de países según el nivel de ingresos}

(millones de dólares EE.UU., a precios constantes de 2011)

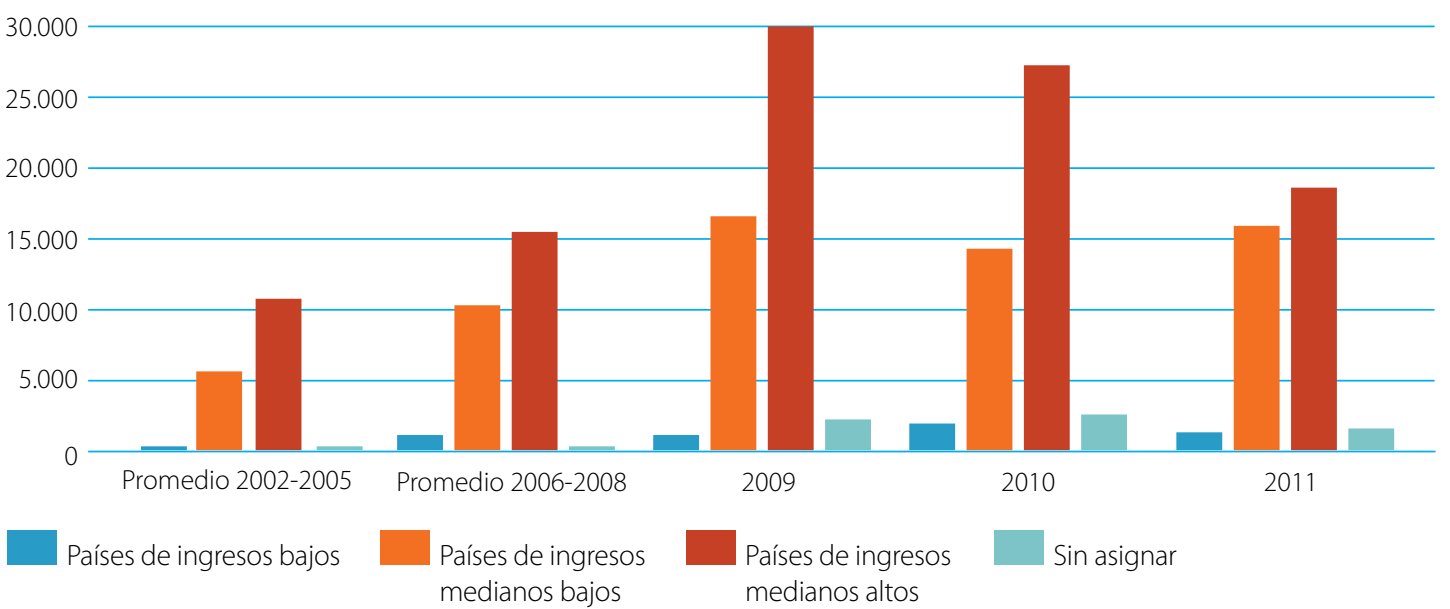

Fuente: Base de datos del Sistema de notificación por parte de los países acreedores de la OCDE, http://stats.oecd.org/index.aspx?DataSetCode=CRS 1\#. 


\section{... que son suministradas principalmente por instituciones multilaterales}

En 2011 las instituciones multilaterales siguieron financiando un volumen de corrientes relacionadas con el comercio en condiciones no concesionarias sensiblemente mayor que el suministrado por los donantes bilaterales. El Banco Mundial fue el principal proveedor de OCO relacionadas con el comercio (25\% del total, o sea, 9.400 millones de dólares EE.UU.). Sin embargo, como resultado de las drásticas medidas de austeridad adoptadas en relación con la financiación que provee el Banco Mundial por conducto del Banco Internacional de Reconstrucción y fomento (BIRF) se registró una disminución por valor de 9.000 millones de dólares EE.UU. en comparación con el nivel correspondiente a 2010. El Banco Mundial no ha sido la única institución multilateral que ha reducido el volumen de las OCO. La cuantía de los recursos suministrados por el Banco Europeo de Reconstrucción y Desarrollo (BERD) disminuyó en 1.200 millones de dólares EE.UU. No obstante, la principal causa de la merma de las OCO relacionadas con el comercio es claramente la disminución de los fondos proporcionados por el Banco Mundial. En 2011 continuó aumentando el uso de este tipo de instrumentos en condiciones no concesionarias. Corea suministró 5.900 millones de dólares EE.UU., o sea 1.800 millones de dólares EE.UU. más que en 2010. Por su parte, el Banco de Exportación e Importación de Corea suministró más de 1.450 millones de dólares EE.UU. para el desarrollo industrial en China, así como 933 millones de dólares EE.UU. para el desarrollo industrial en Indonesia, 675 millones de dólares EE.UU. para el sector de los minerales y la minería en el Brasil y 500 millones de dólares EE.UU. para el desarrollo de los sectores del petróleo y el gas en el Irán. Alemania destinó el 58\% de sus OCO (o sea, 730 millones de dólares EE.UU. de un total de 1.250 millones de dólares EE.UU.) a los sectores de la banca y las finanzas. Los Estados Unidos fueron el otro gran proveedor de OCO relacionadas con el comercio a nivel bilateral; sus préstamos ascendieron a 574 millones, de los que 192 millones de dólares EE.UU. se destinaron al sector de la energía de la India y 90 millones de dólares EE.UU. a los servicios prestados a las empresas y otros servicios en Liberia.

\section{La cooperación Sur-Sur relacionada con el comercio es considerable y está aumentando ...}

El mundo actual es un mundo cada vez más integrado y multipolar. En particular, en los últimos años, como resultado del dinamismo de las economías emergentes y de muchos países en desarrollo, el poder económico se ha desplazado del oeste al este y del norte al sur. El "surgimiento del Sur" ha servido de estímulo para la expansión de los vínculos económicos Sur-Sur, en particular a nivel del comercio, pero también de la IED, la ayuda y las remesas. Según el informe de la OCDE titulado Perspectives on Global Development 2010: Shifting Wealth (Perspectivas para el desarrollo mundial en 2010: El desplazamiento de la riqueza), en 2000 los países en desarrollo tenían el 40\% del PIB mundial; en 2010 tenían el 49\% del PIB mundial y en 2030 tendrán el 57\% del PIB mundial (ajustado en función de la paridad del poder adquisitivo) (OCDE, 2010b). En los cinco últimos años esos países han generado el $65 \%$ del crecimiento de la economía internacional. El desplazamiento resulta más evidente en la estructura del comercio mundial. Según las Naciones Unidas, entre 1990 y 2008, el volumen del comercio mundial se cuadruplicó, mientras que, en ese mismo período, el volumen del comercio Sur-Sur aumentó 20 veces respecto de su nivel inicial. (Naciones Unidas, 2011:3). El comercio Sur-Sur representa el 37\% del comercio mundial (OCDE, 2010b:18) y más del 50\% del total del comercio de los países en desarrollo.

Una característica de la Iniciativa de Ayuda para el Comercio es la importancia que en ella se asigna a la cooperación Sur-Sur entre países en desarrollo como "valioso instrumento para lograr resultados efectivos" en la creación de capacidad comercial, "porque [esos países] hacen frente a los mismos desafíos y comparten el modo de encararlos" (Hayashikawa, 2012). La OCDE utiliza fuentes oficiales para estimar el volumen bruto de las corrientes de financiación en condiciones de favor destinadas a la cooperación para el desarrollo (las corrientes "asimilables a la AOD") (cuadro 2.1). Según esas cifras, los principales proveedores de ayuda son China y la India. Esos países utilizan diversos instrumentos, como la financiación en condiciones no concesionarias, los acuerdos comerciales preferenciales y planes 
de inversión que no están clasificados como AOD, pero que, aun así, se utilizan para ayudar a los países asociados a crear la capacidad necesaria para promover su desarrollo. China y la India son los líderes de la cooperación Sur-Sur, que normalmente combina la ayuda con inversiones y mejores oportunidades de acceso a los mercados y proporciona "conocimientos especializados y apoyo financiero para fomentar el bienestar económico y social de otros países en desarrollo" (Zimmermann y Smith, 2011:726). El aumento de la cooperación Sur-Sur ofrece a los países en desarrollo recursos financieros adicionales y más posibilidades de elección para satisfacer sus necesidades de desarrollo.

CUADRO 2.1 Volumen bruto estimado de las corrientes de financiación en condiciones concesionarias destinadas a la cooperación para el desarrollo suministradas por los BRICS (corrientes "asimilables a la AOD") $^{\prime \prime}$

\begin{tabular}{|c|c|c|c|c|c|c|c|}
\hline & País & 2007 & 2008 & 2009 & 2010 & 2011 & Fuente \\
\hline AOD notificada al CAD & Rusia' & & & & 472,3 & 479 & Notificaciones de Rusia al CAD \\
\hline \multirow{4}{*}{$\begin{array}{l}\text { Estimaciones de } \\
\text { corrientes asimilables } \\
\text { a la AOD tomadas de } \\
\text { publicaciones nacionales }\end{array}$} & Brasil $^{2}$ & 291,9 & 336,8 & 362,2 & n.a. & n.a. & Oficina de la Presidencia, Brasil \\
\hline & China & $1.466,9$ & $1.807,6$ & $1.947,7$ & $2.010,6$ & $2.468,1$ & $\begin{array}{l}\text { Anuario Fiscal, Ministerio de } \\
\text { Hacienda, China }\end{array}$ \\
\hline & India ${ }^{3}$ & 392,6 & 609,5 & 488 & 639,1 & 730,7 & $\begin{array}{l}\text { Informes anuales, Ministerio } \\
\text { de Relaciones Exteriores, India }\end{array}$ \\
\hline & Sudáfrica ${ }^{3}$ & 82,3 & 86 & 82,5 & 87,7 & 95,1 & $\begin{array}{l}\text { Estimaciones del gasto público, } \\
\text { 2010-2012, Tesoro Nacional, } \\
\text { Sudáfrica }\end{array}$ \\
\hline
\end{tabular}

1 La Federación de Rusia comenzó a notificar al CAD las cifras de su AOD en 2011; los datos notificados en 2011 correspondían a las corrientes de 2010.

2 El Brasil no ha publicado datos completos sobre la cooperación para el desarrollo en 2010 y 2011.

3 Las cifras correspondientes a la India y Sudáfrica están basadas en los respectivos ejercicios fiscales. Los datos de 2011 corresponden al ejercicio fiscal 2011-2012.

Fuente: OECD. Stat, http://dotstat.oecd.org/Index.aspx.

\section{... China utiliza la ayuda para apoyar la formación de empresas conjuntas constituidas por empresas chinas y empresas de los países asociados ...}

El Gobierno chino ha sido innovador en la esfera de la cooperación entre los sectores público y privado y ha utilizado el dinero de la ayuda para apoyar a empresas conjuntas constituidas por empresas chinas y empresas de los países receptores. China también ha colaborado con los gobiernos de varios PMA (Camboya, Etiopía y Zambia) en el desarrollo del comercio exterior y el establecimiento de zonas económicas (Hayashikawa, 2012). Además, el grueso de la ayuda de China podría considerarse ayuda para el comercio. Según el Examen de las Políticas Comerciales de China llevado a cabo en 2010, la cuantía de la ayuda desembolsada por China en 2008 fue de unos 3.400 millones de dólares EE.UU.: 1.900 millones en donaciones y préstamos sin intereses y 1.500 millones en préstamos en condiciones de favor (OMC, 2010:23). Una proporción considerable de la ayuda que presta China encuadra en las categorías de la ayuda para el comercio identificadas por la OCDE. El Gobierno chino también ha utilizado el dinero de la ayuda para apoyar la formación de empresas conjuntas constituidas por empresas chinas y empresas de los países receptores. El Consejo de Estado de China (PRC, 2011) analizó la distribución sectorial de los préstamos en condiciones concesionarias durante el mismo período e informó de que China había concedido a 76 países préstamos en condiciones concesionarias para apoyar 325 proyectos. 


\section{... y el grueso del apoyo que presta está destinado al desarrollo de la infraestructura, la industria y la agricultura}

China destina el grueso del volumen de su ayuda a apoyar el desarrollo de la infraestructura y la industria, pero también está intensificando su apoyo al desarrollo agrícola con el objeto de incrementar la capacidad productiva y comercial de los países receptores y ayudarlos a beneficiarse de la apertura de los mercados chinos a sus productos. Entre las esferas a las que se destina la asistencia figuran la planificación agrícola, la transferencia y difusión de tecnología (por ejemplo, el cultivo de arroz híbrido), la acuicultura, la conservación de los recursos hídricos en tierras de cultivo y el desarrollo de maquinaria agrícola. Con el objeto de fomentar la sostenibilidad, China también ha dado a su cooperación una orientación comercial. Las empresas agroindustriales chinas cumplen un importante papel en esa cooperación aportando su capacidad de gestión y sus conocimientos técnicos (OCDE/IPRCC, 2010:11). Del total de los préstamos desembolsados por China en condiciones concesionarias, más del 90\% (unos 9.700 millones de dólares EE.UU.) ha sido destinado al desarrollo de la infraestructura económica, los recursos energéticos y naturales, la industria y la agricultura.

\section{La India suministra asistencia técnica relacionada con el comercio y líneas de crédito.}

No se dispone de fuentes oficiales con un desglose de la cooperación para el desarrollo que presta la India, pero, según Agrawal (2007:7), el 60\% de la asistencia por ese concepto se utiliza para formar a funcionarios públicos, ingenieros y funcionarios públicos de otros países en desarrollo; el 30\% consiste en créditos a la exportación en condiciones concesionarias (líneas de crédito) para que los gobiernos extranjeros puedan adquirir equipo y servicios indios; y el 10\% restante se utiliza para financiar actividades relacionadas con proyectos, como estudios de viabilidad y el desplazamiento de expertos técnicos desde la India. Con frecuencia, la India presta la ayuda en el marco de programas de inversión y acuerdos comerciales más amplios. Por consiguiente, las consideraciones comerciales pueden constituir un componente de su programa de cooperación para el desarrollo. La India también participa en el desarrollo de la infraestructura concediendo préstamos en condiciones concesionarias y prestando asistencia técnica. En 2010 la institución india de financiación de las exportaciones, el Banco de Exportación e Importación, prorrogó una nueva línea de crédito por valor de 3.000 millones de dólares EE.UU., de los cuales 1.000 millones, destinados nada más que a Bangladesh, constituyeron la cuantía individual más elevada que la India haya concedido jamás a un solo país. En 2011 el Banco de Exportación e Importación aprobó 12 nuevas líneas de crédito para diez países, por valor de 473.300 millones de dólares EE.UU., para financiar diversos proyectos en sectores que iban desde la agricultura y la agroindustria (industria azucarera, cultivo de mandioca (yuca), transformación de la leche), la minería (piedra caliza) y la energía (electrificación de zonas rurales, energía solar, biodiésel, generación de electricidad), hasta la construcción de instalaciones de radiodifusión y de un hospital con múltiples especialidades (GOI, 2012).

En el Cónclave sobre el proyecto de asociación entre la India y África organizado por la Confederación de Industrias de la India (CII) en 2013 se examinaron las posibilidades que estaban surgiendo para impulsar la cooperación bilateral en materia de inversiones. Fundamentalmente, el Cónclave tenía como objetivo alentar a los exportadores indios a exportar a países africanos y a establecer una mayor presencia en la región de modo de alcanzar un volumen de inversión de 100.00 millones de dólares EE.UU. para 2015. En 2010 el valor de las adquisiciones de la India representó una tercera parte del valor total de las adquisiciones en el África subsahariana. Tradicionalmente, la India ha invertido en las regiones meridional y oriental de África, pero actualmente las empresas indias están invirtiendo en el África occidental. El aumento de la actividad manufacturera en África significará un aumento de las inversiones en proyectos de infraestructura. El Cónclave de la Cll examinó un total de 475 proyectos, por valor de 64.000 millones de dólares EE.UU., destinados principalmente al desarrollo de la infraestructura y la creación de capacidad. 


\section{¿CUÁLES SON LAS PERSPECTIVAS DE LAS CORRIENTES DE AYUDA PARA EL COMERCIO?}

\section{Los donantes han aumentado apreciablemente la cuantía de la ayuda para el comercio que prestan ...}

Como se ha señalado en el presente capítulo, en los últimos años muchos donantes han aumentado apreciablemente la cuantía de los compromisos contraídos por concepto de ayuda para el comercio. Según los resultados de la encuesta sobre ayuda para el comercio efectuada por la OCDE y la OMC, nueve donantes bilaterales (o sea, una tercera parte del total) indicaron que habían incrementado considerablemente la cuantía de los compromisos contraídos desde 2009 por concepto de ayuda para el comercio, mientras que los recursos suministrados por otros cuatro habían aumentado en menos de un 10\% desde entonces. Siete donantes no habían modificado la cuantía global de los compromisos contraídos. Cinco habían reducido el volumen de su asistencia (gráfico 2.20).

\section{Gráfico 2.20 Variación del gasto por concepto de ayuda para el comercio desde el comienzo de la crisis económica (porcentaje de respuestas)}

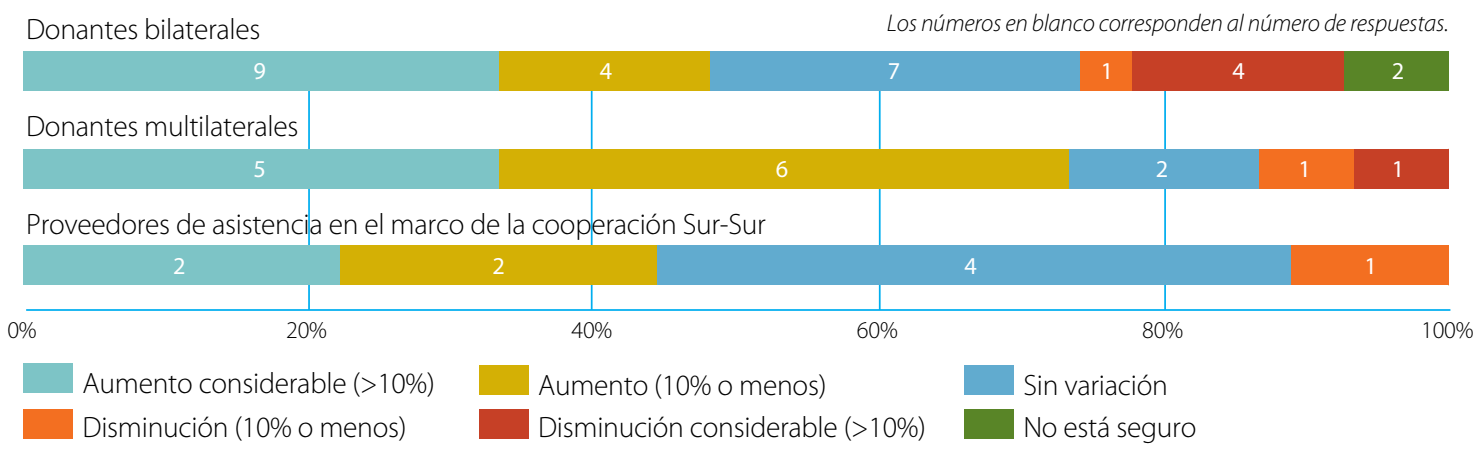

Fuente: Cuestionario OCDE/OMC (2013), www.aid4trade.org.

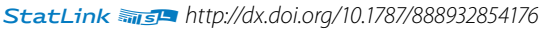

... pero, mientras que los donantes bilaterales estiman que las perspectivas $\mathrm{s}$ on poco halagüeñas,...

Los donantes bilaterales son menos optimistas de cara al futuro que los donantes multilaterales y los proveedores de asistencia en el marco de la cooperación Sur-Sur: ninguno de ellos prevé un aumento importante de la ayuda para el comercio en los próximos cinco años (gráfico 2.21). La mayoría de ellos no pueden estimar con exactitud el volumen de los gastos presupuestarios futuros por concepto de ayuda para el comercio. Diez donantes (el 37\%) no están seguros de cómo evolucionarán los presupuestos de ayuda. Once (el 41\%) no prevén cambio alguno en el nivel actual de financiación, mientras que cinco (el 18,5\%) prevén aumentos moderados. Sólo un donante bilateral prevé una disminución de las corrientes. En general, los donantes bilaterales han indicado que los presupuestos de la ayuda para el comercio resistirán a las restricciones presupuestarias, pero prevén que, como resultado de esas restricciones, así como de la necesidad de demostrar el uso óptimo de los recursos públicos, seguirá asignándose especial importancia a los resultados; 32 donantes indicaron que ésa sería una consideración importante en los próximos cinco años (20 indicaron que los resultados serían el factor más importante en relación con la ayuda futura para el comercio).

Si bien no puede hablarse de una tendencia sobre la base de los datos correspondientes a un solo año, en 2013 las perspectivas de la ayuda para el comercio no parecen halagüeñas. A juzgar por las cifras globales de la AOD correspondientes a 2012, es probable que la ayuda vuelva a disminuir en un 4\% en valores reales, tras una disminución 
del 2\% en 2011. Además, las cifras más recientes muestran que las corrientes de ayuda se están desplazando de los países más pobres del mundo, incluidos los del África Subsahariana, hacia países de ingresos medianos, como China, la India, Indonesia y Viet Nam, que tradicionalmente han sido grandes receptores de ayuda para el comercio. La cuantía de la ayuda bilateral destinada al continente africano disminuyó en casi un 10\% en valores reales respecto de la prestada en 2011 y la destinada al África subsahariana, en un 7,9\%. Ello es indicio de que es probable que, tras la merma registrada en 2011, en 2012 haya continuado la disminución de la ayuda para el comercio prestada a África. Aunque en 2011 los países menos adelantados no fueron los más afectados por la disminución de la ayuda para el comercio, en 2012 la AOD neta bilateral destinada a los PMA mermó en un 12,8\% en valores reales.

La cuantía global de la ayuda prestada por el Japón, el principal donante de ayuda para el comercio, disminuyó en un 2\% en 2012 como resultado de la disminución de las donaciones bilaterales y de las contribuciones a organizaciones internacionales. Alemania aportó un 0,7\% menos, en su mayor parte debido a la reducción de las contribuciones multilaterales. En 2012 los Estados Unidos siguieron siendo el principal donante en función del volumen de la ayuda, pero la cuantía de la ayuda disminuyó en un 2,8\%, principalmente a causa de la reducción de la ayuda destinada al alivio de la deuda bilateral neta, por lo que es posible que la ayuda para el comercio no se vea afectada.

\section{Gráfico 2.21 Variación de la cuantía total de la ayuda para el comercio prevista para los cinco próximos años (porcentaje de respuestas)}

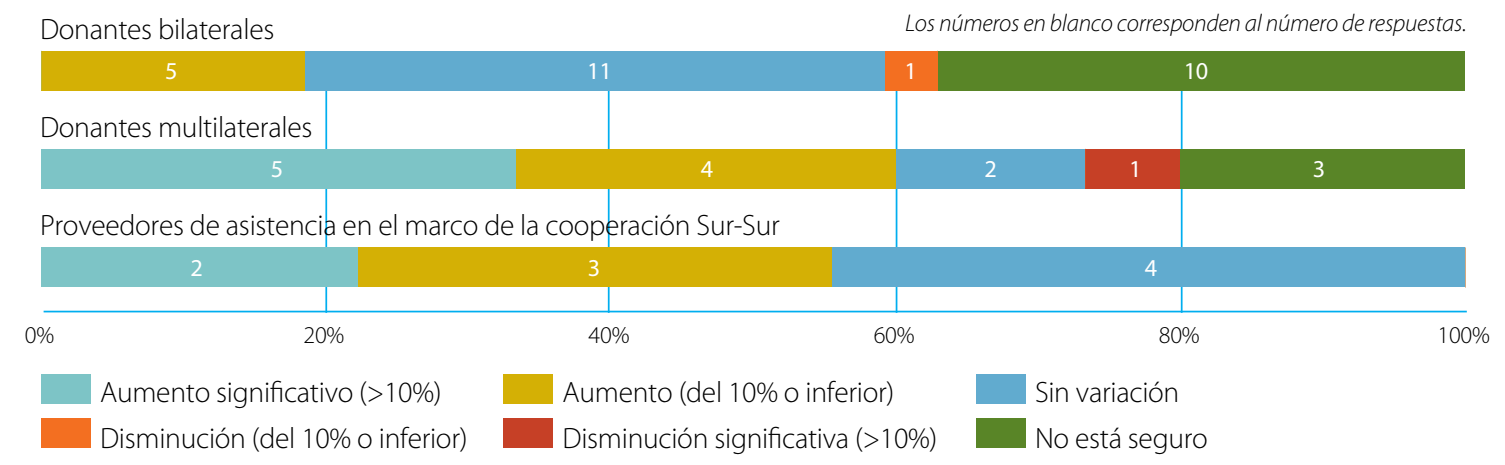

Fuente: Cuestionario OCDE/OMC (2013), www.aid4trade.org.

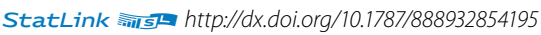

\section{... los donantes multilaterales son más optimistas ...}

Por su parte los donantes multilaterales son más optimistas. Más del 70\% ha aumentado su ayuda para el comercio desde 2009 (cinco organismos, o sea, una tercera parte del total, han proporcionado un volumen apreciablemente mayor de ayuda). En cuanto a los próximos cinco años, los donantes multilaterales tienen más claro que la mayoría de los donantes bilaterales cuál será el nivel de gasto futuro y han indicado que el nivel de sus contribuciones seguirá aumentando: más del 60\% de los encuestados ha informado de que los gastos seguirán aumentando (gráfico 2.21). Sólo un organismo multilateral indicó que reducirá el volumen de su financiación. Además, en los próximos cinco años los donantes multilaterales seguirán asignando especial importancia a los resultados; la integración regional, el desarrollo del sector privado, la reducción de la pobreza, y el crecimiento verde seguirán siendo objetivos importantes. Estas cuestiones intersectoriales requieren un mayor número de iniciativas y proyectos conjuntos interinstitucionales, así como un aumento de la colaboración. 
Según el informe de la OCDE sobre la ayuda multilateral de 2012, en 2011 el volumen de la ayuda multilateral prestada por los miembros del Comité de Asistencia para el Desarrollo (CAD) aumentó a 38.000 millones de dólares EE.UU. Es probable que en 2012, como resultado de ello, aumente en consecuencia el volumen de las corrientes de financiación del sistema multilateral hacia los países asociados (OCDE, 2013). Los donantes bilaterales, en cambio, son más selectivos a la hora de determinar el destino que darán a sus recursos. Por ejemplo, el Departamento de Desarrollo Internacional del Reino Unido (DFID), en consonancia con las prioridades fijadas por el Reino Unido en materia de desarrollo, trabajará principalmente con las organizaciones identificadas como las más eficaces en su examen de la ayuda multilateral.

\section{... y los proveedores de asistencia en el marco de la cooperación Sur-Sur consideran que seguirá aumentando la cuantía de los recursos disponibles}

Los proveedores de asistencia en el marco de la cooperación Sur-Sur son los más optimistas en cuanto al volumen de los recursos que proporcionarán en el futuro; cinco de ellos han indicado que aumentarán el gasto (según dos de ellos, la cuantía de su ayuda aumentará considerablemente), y cuatro han informado de que no modificarán el nivel actual de su financiación (gráfico 2.21). Entre las esferas a las que se prestará especial importancia en el futuro figuran la integración regional (la cuestión a la que se asignó mayor importancia), la reducción de la pobreza y el desarrollo del sector privado. Los proveedores de asistencia en el marco de la cooperación Sur-Sur también otorgan gran importancia al programa para un crecimiento verde.

\section{CONCLUSIONES}

En el presente capítulo se han descrito los diferentes resultados obtenidos en 2011 en materia de ayuda para el comercio. A pesar de la crisis económica que afectaba a muchos miembros de la OCDE, el nivel global de la ayuda para el comercio, que venía aumentando desde 2005, se ha mantenido en la mayoría de los casos. En 2011 disminuyó el volumen de las corrientes de ayuda para el comercio y se contrajo el apoyo prestado al desarrollo de infraestructura, en particular en África. Sin embargo, el análisis de las corrientes indica que el concepto de ayuda para el comercio ha evolucionado y la ayuda se orienta ahora hacia el desarrollo del sector privado y el fomento de las cadenas de valor. En consecuencia, sigue aumentando el volumen de las corrientes destinadas al logro de objetivos comerciales en los sectores de la agricultura, la industria, los servicios prestados a las empresas y el turismo. Aunque cabe lamentar la disminución de la cuantía global de la ayuda, los países pobres han sido los menos afectados. Los donantes están afrontando dificultades, pero deben seguir esforzándose por cumplir sus promesas, en particular los países del G-20.

Más allá de 2012, en los planes de gastos futuros del CAD se indica que para 2013 se prevé una moderada recuperación del nivel de la ayuda. Sin embargo, esa clase de pronósticos no previó las disminuciones que tuvieron lugar en 2011 y 2012. Desde luego, además de los miembros del CAD, hay muchos otros donantes que prestan asistencia relacionada con el comercio que consideran que las perspectivas son más halagüeñas, como las instituciones multilaterales, los donantes árabes y los proveedores de asistencia relacionada con el comercio en el marco de la cooperación Sur-Sur. La cooperación Sur-Sur relacionada con el comercio es considerable y está aumentando. En el Cuarto Examen de la Ayuda para el Comercio se analizarán las formas en que el sector privado puede seguir impulsando las cadenas de valor y los esfuerzos encaminados a la creación de capacidad comercial. Por consiguiente, la ayuda para el comercio ha superado la prueba de adicionalidad y sigue evolucionando; además, a juzgar por los datos disponibles, es probable que el aumento de la asistencia observado en los últimos años se mantenga. 


\section{NOTAS}

1. Alemania, Australia, Austria, Bélgica, Canadá, Corea del Sur, Dinamarca, España, Estados Unidos, Finlandia, Francia, Grecia, Islandia, Irlanda, Italia, Japón, Luxemburgo, Nueva Zelandia, Noruega, Países Bajos, Portugal, República Checa, Reino Unido, Suecia, Suiza, Unión Europea.

2. El G-7 está constituido por Alemania, el Canadá, los Estados Unidos, Francia, Italia, el Japón y el Reino Unido.

3. El Desafío tiene por objeto solicitar al sector privado propuestas innovadoras y ampliables a escala para identificar los medios que pueden usar los gobiernos y las instituciones públicas para incrementar su eficacia como catalizadores de la financiación privada destinada a las PYME de los países en desarrollo. En 2011 el Canadá respaldó esa iniciativa con 20 millones de dólares EE.UU. El Canadá, Corea, los Estados Unidos y el Banco Interamericano de Desarrollo (BID) han acordado establecer un Fondo para la innovación en la financiación de las PYME al que se han comprometido a aportar un total de 528 millones de dólares EE.UU. Véase: www.changemakers.com/g20media/pressrelease11-12-10.

4. Para la vigilancia mundial de las corrientes de ayuda para el comercio se utilizan variables sustitutivas tomadas de las categorías de asistencia sobre las que se presenta información al Sistema de notificación por parte de los países acreedores de la OCDE. La India ha comunicado que, con arreglo a su propia definición de la ayuda para el comercio, la cuantía que recibió en 2010 fue de 1.380 millones de dólares EE.UU., cifra inferior a la obtenida utilizando variables sustitutivas tomadas del SNPA.

5. Se prevé que este proyecto se terminará en una fecha ulterior de 2013.

Véase: www.railjournal.com/index.php/signalling/istanbuls-bosphorus-rail-link-to-open-next-year.html.

6. www.jica.go.jp/english/news/press/2011/pdf/111102_04.pdf.

7. www.jica.go.jp/balkan/english/office/topics/press111123.html.

8. La Fundación Ford está apoyando otros estudios de país en Rusia y los Estados Unidos. Se prevé que el proyecto servirá de base para un debate más racional sobre la cuestión de la piratería en el ámbito de los medios de información y comunicación y reforzará la posición de los negociadores del Sur en las negociaciones Norte-Sur sobre el acceso a los bienes basados en el conocimiento, en particular los programas informáticos.

9. En 2011 casi una tercera parte de la ayuda destinada a la facilitación del comercio (125 millones de dólares EE.UU.) se encauzó a través de instituciones multilaterales. Los principales cauces de esa asistencia fueron el Grupo del Banco Mundial, la OMC, los organismos de las Naciones Unidas y los bancos regionales de desarrollo. Por ejemplo, Australia y otros donantes suministraron financiación a través del Banco Asiático de Desarrollo para prestar asistencia a la "facilitación del comercio y el transporte en la Subregión del Gran Mekong". El proyecto tiene por objeto contribuir a eliminar los principales factores que comprometen la eficiencia del comercio transfronterizo en la Subregión del Gran Mekong. La ayuda destinada a la facilitación del comercio también ha dado lugar a casos interesantes de colaboración entre países asociados y donantes. Aunque la región del Caribe no ha sido tradicionalmente una de las principales beneficiarias de la ayuda para el comercio, la UE otorgó 32 millones de dólares EE.UU. a la República Dominicana y 26 millones de dólares EE.UU. a Haití por medio de un programa encaminado a ampliar el mercado de Dajabon, en la frontera entre ambos países, mediante la construcción de infraestructura adicional para las aduanas dominicana y haitiana.

10. Los acuerdos de asociación económica constituyen un medio de crear una zona de libre comercio entre la UE y el Grupo de Estados de África, el Caribe y el Pacífico (ACP).

11. http://ec.europa.eu/europeaid/documents/aap/2011/af_aap_2011_sugar_jam.pdf. 
12. El Plan Regional Indicativo de Desarrollo Estratégico (RISDP) es un marco general para el desarrollo y la ejecución del programa de integración regional de la Comunidad del África Meridional para el Desarrollo (SADC) durante un período de 15 años (2005-2020). Con arreglo al Plan se proporciona una dirección estratégica clara a los programas, los proyectos y las actividades de la Comunidad en consonancia con el Programa común y las prioridades estratégicas de la SADC, consagradas en el Tratado de la Comunidad de 1992.

13. En 2011 los países miembros del CAD desembolsaron más de 40.000 millones de dólares destinados a organismos multilaterales. El Reino Unido fue el principal donante de fondos a organismos multilaterales (5.400 millones de dólares EE.UU.), seguido de Alemania (5.400 millones de dólares EE.UU.), Francia (4.500 millones de dólares EE.UU.), el Japón (4.200 millones de dólares EE.UU.) y los Estados Unidos (3.700 millones de dólares EE.UU.). En 2011 la UE fue la principal beneficiaria de las contribuciones de los miembros del CAD destinadas a organismos multilaterales (13.100 millones de dólares EE.UU.), seguida del Grupo del Banco Mundial (10.700 millones de dólares EE.UU.). La cuantía de los desembolsos a bancos regionales de desarrollo ascendió a 4.000 millones de dólares EE.UU. El Banco Africano de Desarrollo recibió algo más de 2.000 millones de dólares EE.UU., mientras que el Japón desembolsó la mitad de su contribución total al CAD por valor de 1.600 millones de dólares EE.UU. en beneficio del Banco Asiático de Desarrollo. Los organismos de las Naciones Unidas recibieron desembolsos por valor de 6.500 millones de dólares EE.UU.; a la cabeza de la lista figuró el Programa de las Naciones Unidas para el Desarrollo (PNUD) (1.000 millones de dólares EE.UU.), seguido del Fondo de las Naciones Unidas para la Infancia (UNICEF) (685 millones de dólares EE.UU.) y el Alto Comisionado de las Naciones Unidas para los Refugiados (ACNUR) (450 millones de dólares EE.UU.). El volumen del apoyo prestado por los países del CAD a otras instituciones multilaterales (incluidos el Fondo Mundial y la Alianza GAVI) ascendió a 5.600 millones de dólares EE.UU. 


\section{REFERENCIAS}

Agrawal S. (2007), Emerging Donors in International Development Assistance: The India Case, International Development Research Center, Ottawa, www.idrc.ca/EN/Documents/Case-of-India.pdf.

Basnett, Y., J. Engel, J. Kennan, C. Kingombe, I. Massa y D.W. Te Velde (2012), Increasing the effectiveness of Aid for Trade: The circumstances under which it works best, Overseas Development Institute (ODI), Working Paper 353, Londres, www.odi.org.uk/sites/odi.org.uk/files/odi-assets/publications-opinion-files/7793.pdf.

Bhinda, N. y M. Martin (2009), Private Capital Flows to Low-Income Countries: Dealing with Boom and Bust, Foreign Private Capital Capacity Building Programme (FPC CBP), Debt Relief International Ltd, Londres.

Buys, P., U. Deichmann y D. Wheeler (2006), Road Network Upgrading and Overland Trade Expansion in Sub-Saharan Africa, Banco Mundial, Washington, D.C., http://elibrary.worldbank.org/content/workingpaper/10.1596/1813-9450-4097.

CE (Comisión Europea) (2011), Incremento del impacto de la política de desarrollo de la UE: Programa para el Cambio, CE, Bruselas, http://ec.europa.eu/europeaid/what/development-policies/documents/agenda_for_change_es.pdf.

(Gobierno de la India) (2012), India's Statement, vigesimotercera reunión sobre la Ayuda para el Comercio del Comité de Comercio y Desarrollo, 29 de marzo de 2012, OMC, Ginebra.

Hayashikawa, M. (2012), Trade-Related South-South Co-Operation: China, COM/DCD/TAD(2012)9, OCDE, París, wWw.oecd.org/dac/aft/South-South_China.pdf.

Helble, M., C. Mann y J. Wilson (2012), Aid-for-trade facilitation, Review of World Economics, Vol. 148(2), 357-376.

Naciones Unidas (2011), Estado de la cooperación Sur-Sur: Informe del Secretario General, A/66/229, Nueva York, http://documents.un.org/mother.asp.

OCDE (2010a), Measuring Aid to Agriculture, OCDE, París, www.oecd.org/dac/stats/44116307.pdf.

OCDE (2010b), Perspectives on Global Development 2010: Shifting Wealth, OCDE, París, http://dx.doi.org/10.1787/9789264084728-en.

OCDE (2011), Strengthening Accountability in Aid for Trade, The Development Dimension, OCDE, París, http://dx.doi.org/10.1787/9789264123212-en

OCDE (2012), 2012 DAC Report on Aid Predictability: Survey on Donors' Forward Spending Plans 2012-2015 and efforts since HLF-4, OCDE, París, wWw.oecd.org/dac/aid-architecture/2012_DAC_Report_on_Aid_Predictability.pdf.

OCDE (2013), 2012 DAC Report on Multilateral Aid 2012, DCD/DAC(2012)33, OCDE, París.

OCDE/IPRCC (International Poverty Reduction Center in China) (2010), Agricultural Transformation, Growth and Poverty Reduction, China-DAC Study Group, (2011), China's Foreign Aid, Information Office of the State Council, Beijing.

OMC (Organización Mundial del Comercio) (2006). Recomendaciones del Equipo de Trabajo sobre la Ayuda para el Comercio, WT/AFT/1, OMC, Ginebra, wWW.wto.org/tratop_s/devel_s/implementing_par57_s.htm.

OMC (Organización Mundial del Comercio) (2010). China, Informe de la Secretaría, Examen de las Políticas Comerciales, WT/TPR/S/230/Rev.1, OMC, Ginebra.

Page, S. The Achievements and Risks of Aid for Trade, Trade Negotiations Insights, Vol. 10(7), Centro Internacional para el Comercio y el Desarrollo Sostenible (ICTSD), Ginebra.

República Popular China (2011), China's Foreign Aid, Information Office of the State Council, Beijing. 
Shepherd, B. Y J.S. Wilson (2008), Trade Facilitation in ASEAN Member Countries: Measuring Progress and Assessing Priorities, Policy Research Working Paper 4615, Equipo de Comercio del Grupo de Investigación sobre el Desarrollo del Banco Mundial, Washington, D.C., https://openknowledge.worldbank.org/bitstream/handle/10986/6715/wps4615.pdf?sequence=1.

UNCTAD Stat, http://unctadstat.unctad.org/ReportFolders/reportFolders.aspx.

Zimmermann, F. y K. Smith (2011), More Actors, More Money, More Ideas for International Development Co-operation, Journal of International Development, Vol. 23(5), páginas 722-738. 


\section{CAPÍTULO 3: \\ LAS CADENAS DE VALORY LA SENDA DEL DESARROLLO}

- n el presente capítulo se examinan las oportunidades que ofrecen las cadenas de valor

— para el desarrollo económico. A partir de los resultados de la encuesta de 2013 de la OCDE y la OMC, se evalúa el efecto que tienen las cadenas de valor en las prioridades y las estrategias en materia de ayuda para el comercio de los países asociados, los donantes bilaterales y multilaterales y los proveedores de cooperación Sur-Sur relacionada con el comercio. En el análisis de las cadenas de valor en los sectores agroalimentario, de la tecnología de la información y las comunicaciones, de los textiles y las prendas de vestir, del turismo y del transporte y la logística que figura en el presente capítulo se hace hincapié en que los proveedores de los países en desarrollo forman parte integrante de esas cadenas de valor, y que los países en desarrollo aprovechan su participación en ellas para cumplir sus objetivos en materia de crecimiento, empleo y reducción de la pobreza. De las respuestas al cuestionario de la OCDE y la OMC se desprende claramente que podría mejorarse considerablemente la participación de esos países en las cadenas de valor. Muchos países en desarrollo ven comprometida su competitividad a causa de la ineficiencia de los trámites en frontera, los elevados aranceles y los obstáculos no arancelarios que limitan de manera innecesaria el comercio de mercancías o servicios; las restricciones que pesan sobre la circulación de información; los obstáculos a la inversión extranjera directa (IED); y las restricciones que limitan la libre circulación de las personas. El desafío para los países en desarrollo consiste en diseñar y aplicar estrategias amplias encaminadas a eliminar los obstáculos fundamentales que les impiden integrarse en las cadenas de valor y avanzar en ellas.

\section{INTRODUCCIÓN}

En los últimos 30 años la integración del mercado mundial ha procedido a pasos agigantados. La liberalización del comercio a escala multilateral, regional y unilateral ha incrementado considerablemente el acceso a los mercados y, unida a la fuerte disminución del costo del transporte y las comunicaciones, ha facilitado el surgimiento de cadenas de valor. La producción, que en otras épocas normalmente estaba ubicada cerca de los principales proveedores de insumos (o cerca de los consumidores de los mercados finales), ahora tiene lugar, cada vez más, allí donde se encuentran disponibles las competencias y las materias primas necesarias con la calidad requerida y a un costo competitivo. Esta fragmentación de la producción brinda a los países en desarrollo nuevas oportunidades para ingresar en los mercados mundiales como proveedores de componentes o servicios, sin tener que desarrollar la totalidad de la cadena de valor. Al dar acceso a las redes, los mercados mundiales, el capital, los conocimientos y la tecnología, la integración en una cadena de valor ya establecida puede representar un primer paso en el desarrollo económico, una senda que a menudo es más fácil de tomar que la que consiste en crear una cadena de valor completa (OCDE, 2013a: 10). 
A nivel de las políticas, el surgimiento de las cadenas de valor tiene importantes consecuencias para el crecimiento económico de los países en desarrollo. En muchos sectores, la distribución, entre diversos países, de distintas etapas integradas de la producción ha reducido los costos de producción de los productos finales correspondientes e incrementado la productividad de la fuerza de trabajo y el capital conexos. Como bien señala Baldwin (2011), este hecho tiene dos consecuencias para los países en desarrollo. En primer lugar, la decisión de las empresas productoras de trasladar fragmentos de la cadena de producción y de valor a países en los que la mano de obra es más barata, o a países que, por su ubicación, tienen una ventaja competitiva a nivel de los costos que beneficia a toda la cadena de valor ha dado a los países en desarrollo la oportunidad de industrializarse en una etapa mucho más temprana. La participación en las cadenas de valor reporta beneficios considerables: puede permitir a los proveedores cumplir con las normas y los reglamentos de los países ricos y, así, tener acceso a sus mercados; puede permitir que las importaciones destinadas al comercio intraempresarial gocen de un trato arancelario preferencial; puede permitir a los proveedores utilizar tecnología de redes a la que de otro modo no tendrían acceso; y, por último, puede dar acceso a nuevas fuentes de capital. Sin embargo, la segunda consecuencia de un mundo en el que la producción se puede asignar al lugar con los costos más bajos es que los países que tratan de industrializarse aplicando políticas de sustitución de las importaciones -como las aplicadas antes de 1990- tienen pocas probabilidades de reducir sus costos al punto de que sus productos sean competitivos en los mercados mundiales. Dicho de otro modo, los países que tratan de expandir sus exportaciones aplicando políticas encaminadas a crear redes nacionales de producción competitivas son doblemente penalizados por las cadenas de valor; el establecimiento de obstáculos fronterizos y reglamentarios elevados sólo consigue incrementar el costo de la producción local y perjudicar la conectividad con el mercado mundial.

En suma, por una parte las cadenas de valor crean oportunidades que permiten acelerar el crecimiento económico, pero por otra penalizan doblemente a quienes tienen procedimientos en frontera ineficientes, aranceles altos, obstáculos no arancelarios que limitan innecesariamente el comercio de mercancías y servicios, restricciones que traban la libre circulación de información y de personas, y obstáculos a la IED. Todos los que participan en las cadenas de valor tienen igual interés en reducir las demoras e ineficiencias en las cadenas de valor que son el resultado de la aplicación de determinadas políticas, por lo que pueden ser poderosos aliados a la hora de reducir el costo de comerciar.

En el presente capítulo se examinan las oportunidades que ofrecen las cadenas de valor para el desarrollo económico. A partir de las respuestas a la encuesta de 2013 de la OCDE y la OMC, se evalúa el efecto que tienen las cadenas de valor en las prioridades y las estrategias de la ayuda para el comercio de los países asociados, los donantes bilaterales y multilaterales y los proveedores de cooperación Sur-Sur relacionada con el comercio. Como se destacó en la Introducción, una de las innovaciones de la labor de vigilancia de la OCDE y la OMC correspondiente a 2013 fue solicitar la opinión del sector privado sobre las restricciones que limitan las oportunidades de los proveedores de los países en desarrollo de conectarse a las cadenas de valor. Se ha prestado atención especial a las limitaciones que afectan específicamente a las cadenas de valor que son más importantes para los proveedores de los países en desarrollo, es decir, las de los sectores agroalimentario, de la tecnología de la información y las comunicaciones (TIC), de los textiles y las prendas de vestir, del turismo, y del transporte y la logística. En el presente capítulo se describen los medios de hacer participar más estrechamente al sector privado en el diseño, la ejecución y la evaluación de los programas de ayuda para el comercio. 


\section{LAS CADENAS DE VALOR COMO SENDA DEL DESARROLLO}

Como resultado del éxito logrado por las economías emergentes en las cadenas de valor, un número creciente de países en desarrollo está tratando también de integrarse en mayor medida en las redes de producción internacionales.' Las cadenas de valor, que son una nueva forma de mundialización, permiten a esos países integrarse más rápidamente en la economía mundial. Sin embargo, pese a las grandes ventajas que reportan esas cadenas (como el bajo costo de la mano de obra en valores absolutos), los países en desarrollo resultan perjudicados en otras esferas, como el elevado costo de comerciar como resultado de una amplia gama de factores, entre los que se cuentan los obstáculos arancelarios y no arancelarios, el costo de la logística y el transporte, así como la distancia geográfica y las diferencias culturales. Como muestra claramente una nueva serie de datos mundiales sobre el costo del comercio bilateral, para las economías en desarrollo el costo de comerciar es más elevado y las limitaciones en materia de conectividad son mayores, lo que encarece el costo de trasladar la producción a esos países. ${ }^{2}$

Según un estudio reciente, si se redujesen los obstáculos que entorpecen el funcionamiento de las cadenas de suministro (y que perjudican especialmente a las pequeñas y medianas empresas (PYME)), el PIB mundial podría aumentar seis veces más que lo que aumentaría si se eliminasen todos los aranceles (FEM et al., 2013). Según ese mismo estudio, si se mejorase la administración de las fronteras de todos los países, así como la infraestructura del transporte y las comunicaciones, aunque más no fuera hasta alcanzar un nivel equivalente a la mitad del nivel de las mejores prácticas internacionales, el PIB mundial podría aumentar en un 4,7\% y las exportaciones en un 14,5\%. Siguiendo esa línea de análisis, los autores del estudio argumentan que, dada la importancia de los obstáculos que entorpecen el buen funcionamiento de las cadenas de suministro, la comunidad internacional debería dedicarse urgentemente a eliminarlos. El Banco Interamericano de Desarrollo (BID, 2013) está de acuerdo con esa apreciación y subraya que las redes de transporte y una logística eficiente son indispensables para reducir el costo de comerciar e incrementar la competitividad.

Una característica común de esa clase de limitaciones es la velocidad: cada día que se demora la circulación de mercancías en la cadena de valor, disminuye la competitividad y suben los precios para el consumidor final. Eso significa que importar tiene que ser tan eficiente como exportar, y que los servicios tienen que ser competitivos. Puede haber mala "conectividad" como resultado de obstáculos naturales que frenan un acceso rápido a los mercados mundiales (como sucede, por ejemplo, en el caso de los países sin litoral); del mal estado de la infraestructura, que encarece el costo del transporte; del mal funcionamiento de las instituciones o de la aplicación de políticas que imponen obstáculos, como las restricciones al comercio. La facilitación del comercio y la mejora de la logística constituyeron un factor clave del éxito de las cadenas de valor mundiales en el Asia Oriental, así como del surgimiento de la "Fábrica Asia" (OMC/IDEJETRO, 2011). Debido a la necesidad de coordinar los plazos de entrega y de obtener los múltiples insumos necesarios para la producción en una etapa determinada, es indispensable contar con una gran variedad de servicios públicos y privados para conectar procesos de producción que tienen lugar en diferentes países (OCDE, 2013a).

El costo de comerciar ejerce mayor influencia en el comercio vertical que tiene lugar dentro de las cadenas de valor que en el comercio ordinario, ya que cuando hay especialización vertical las mercancías deben cruzar las fronteras nacionales más veces antes de llegar al consumidor final (Yi, 2003; Ma y Van Assche, 2010). Los aranceles, por ejemplo, pueden haber alcanzado niveles considerables para cuando el producto acabado llega al consumidor, y así frenar la demanda y afectar a la producción y la inversión en todas las etapas de la cadena de valor. Las medidas de protección contra las importaciones de bienes y servicios intermedios hace aumentar el costo de la producción y reduce la capacidad de un país para competir en los mercados de exportación: en la práctica, los aranceles y otros obstáculos a las importaciones son, en realidad, un impuesto sobre las exportaciones. Las políticas que restringen el acceso a bienes y servicios intermedios extranjeros también afectan negativamente a la posición que ocupa un país en las cadenas de suministro regionales y mundiales. 
La integración en cadenas de valor depende, en buena medida, de la facilidad con que circulan a nivel internacional las corrientes de mercancías, servicios, capital, competencias y personas, así como del bajo costo de esas corrientes. Para aumentar la participación en las cadenas de valor hacen falta políticas eficaces en las fronteras y dentro de ellas. La reducción de los obstáculos comerciales ha contribuido enormemente a que las políticas de sustitución de las importaciones hayan cedido el paso a políticas de promoción de las exportaciones y, por ejemplo, ha impulsado considerablemente la integración económica del Asia Oriental (Hummels et al., 2001). El nivel de los aranceles y la existencia de obstáculos no arancelarios constituyen obstáculos al comercio; la eficiencia de los trámites en frontera y las prácticas aduaneras también son un factor decisivo en la determinación de los costos y el tiempo que se necesita para exportar e importar. Además, la reglamentación nacional y la burocracia nacional vinculada al comercio son factores importantes que determinan los costos de empresas que tienen que operar de forma competitiva y con puntualidad dentro de las cadenas de valor (OMC/IDE-JETRO, 2011).

La inversión extranjera directa es un factor importante del crecimiento de la capacidad de exportación. El efecto acumulativo de diversos costos aparentemente reducidos puede desanimar a las empresas a la hora de invertir o de mantener sus inversiones en un país, y puede llevarlas a trasladar sus instalaciones de producción, su tecnología o sus puestos de trabajo a otro lugar. Como en el caso de los obstáculos comerciales, la reducción de los obstáculos a la inversión facilita la integración de los países en las redes internacionales de producción, ya que atrae las inversiones de empresas líderes. Además de determinadas normas o restricciones en materia de inversión, los obstáculos a la inversión abarcan una amplia gama de esferas de política que determinan cuán atractivos son los países para la inversión internacional; dichas esferas abarcan la política de inversión, la política comercial, la política de competencia, la política fiscal, los recursos humanos, la infraestructura, la gobernanza de las empresas, un comportamiento empresarial responsable, la gobernanza pública y la promoción y la facilitación (OCDE, 2013a: 159).

Cada vez está más difundida la opinión de que la calidad de la infraestructura es un factor decisivo para el éxito de los países en las redes de producción internacionales. El acceso a medios de transporte de alta calidad reviste suma importancia para la integración de los países en las cadenas de valor. Los puertos de entrada, los centros de conexión aérea y sus enlaces con los medios de transporte terrestre son de crucial importancia para el traslado internacional de mercancías, servicios y personas. El transporte marítimo se ha beneficiado considerablemente de la contenedorización: la normalización, la automatización y la intermodalidad del transporte de mercancías han acelerado la circulación de mercancías intermedias y finales dentro de las cadenas de valor. El transporte aéreo ha cobrado importancia, sobre todo para el traslado (internacional) de productos de alto valor y poco volumen, así como de productos sensibles al factor tiempo, debido al modelo de producción "justo a tiempo" y otros procesos de producción racionalizada dentro de las cadenas de valor (OCDE, 2013a: 160).

La rapidez y la flexibilidad tienen crucial importancia no sólo para el intercambio de servicios y bienes físicos, sino, en particular, para la difusión de información entre los diferentes países que intervienen en las cadenas de valor. El respeto de las normas internacionales ha cobrado mayor importancia en la producción de mercancías físicas cada vez más modulares y para el intercambio transfronterizo de información. Para las cadenas de valor es indispensable que la información fluya de manera continua e ininterrumpida entre las diferentes empresas y países; las redes de la tecnología de la información y las comunicaciones encauzan la información y los datos de las empresas necesarios para coordinar de manera eficiente las actividades que se desarrollan en distintos lugares. Por consiguiente, se necesita una infraestructura de TIC bien desarrollada para conectar los países a las actividades de las empresas que intervienen en la cadena de valor (OCDE, 2013a: 161). En general, puede considerarse que la reducción del costo efectivo del transporte y las comunicaciones tiene un efecto equivalente al de la liberalización del comercio, ya que, como ésta, reduce el costo de los intercambios e incrementa el comercio entre los países (Globerman, 2011). 
Además de la inversión en infraestructura física de transporte y comunicaciones, el desarrollo de la infraestructura no física (políticas, procedimientos e instituciones que faciliten el comercio) es, cuando menos, igualmente importante para la integración de los países en las cadenas de valor. En un estudio reciente se observa que la calidad del marco institucional es una fuente de ventaja comparativa (Grossman y Helpman, 2005). Como las cadenas de valor exigen que las diferentes empresas en cada cadena de valor (es decir, la empresa líder y los proveedores independientes) celebren contratos respecto de un gran número de actividades la exigibilidad de los contratos es de crucial importancia para el funcionamiento sin tropiezos de las cadenas de valor. De hecho, se ha determinado que los países con mejores sistemas jurídicos exportan más y en sectores más complejos (Levchenko, 2007; Costinot, 2009). Además, las tareas que requieren contratos más complejos (como la investigación y el desarrollo, el diseño o la gestión de las marcas) son más baratas en los países cuyas instituciones contractuales funcionan debidamente (Acemoglu et al., 2007). Los países que se caracterizan por una mala gobernanza y por la inestabilidad política no han logrado atraer a inversores extranjeros a las zonas de elaboración para la exportación, pese a las promesas de que en esas zonas los inversores estarían a resguardo de la reglamentación local (Cadot et al., 2011).

La competitividad de las cadenas de valor depende de manera crítica de la eficiencia de los servicios. Los servicios incorporados constituyen, en buena medida, la "argamasa" que vincula la infraestructura de los países con las actividades de las empresas en la concatenación comercio inversión-servicios de las cadenas de valor. Se ha comprobado que las inversiones en servicios de logística (es decir, los servicios y procesos que tienen por objeto el traslado de mercancías de un país a otro) promueven considerablemente el comercio; valgan como ejemplo la organización y gestión de las operaciones internacionales de transporte marítimo, las operaciones de seguimiento y rastreo, y la calidad del transporte y de las infraestructuras de la tecnología de la información. La alta calidad de las operaciones logísticas ejerce relativamente más influencia en el comercio que factores comerciales menos dependientes de las políticas, como la distancia y el costo del transporte. En un estudio reciente de la OCDE se señala que, por cada día adicional necesario para aprontar una mercancía para su exportación o importación, el comercio se reduce en un 4\% (Korinek y Sourdin, 2011).

Por último, aunque no por ello menos importante, cabe señalar que la capacidad de suministro de las empresas de un país (a menudo, las PYME) es fundamental para conectarlas mejor a las cadenas de valor. A la hora de buscar proveedores independientes en los mercados extranjeros, las empresas líderes tienden a preferir los mercados "profundos": en un gran mercado, las empresas tienen más posibilidades de encontrar lo que buscan y, si el proveedor no cumple, pueden encontrar otras soluciones (OMC, 2008). 


\section{Captación de beneficios}

Conectarse a las cadenas de valor es un primer paso para lograr el desarrollo económico, pero el principal objetivo de los países asociados sigue siendo captar una parte mayor del valor añadido en cada cadena. De hecho, hay quienes siguen cuestionando la relación entre la participación en las cadenas de valor y el desarrollo (Ismail, 2013) y, pese a los beneficios que puede reportar, la participación en las cadenas de valor también entraña riesgos.

\section{Maximizar los beneficios}

No siempre las cadenas de valor sirven para incrementar la transferencia de conocimientos y tecnología de las empresas líderes a los proveedores locales de los países en desarrollo. Staritz et al. (2011) analizaron el papel que cumplen las cadenas de valor en el aumento del nivel socioeconómico de la población y observaron que en la bibliografía sobre el tema a menudo se hacía hincapié en la dimensión económica de esa mejora, más que en la dimensión social (es decir, la mejora de las condiciones de trabajo o el aumento del número de puestos de trabajo mejor remunerados o que requieren mayores cualificaciones). Aunque las dimensiones económica y social de la mejora suelen estar relacionadas entre sí, la una no conduce forzosamente a la otra. Winkler (2013) analizó de manera más sistemática los efectos secundarios de la inversión extranjera en las cadenas de valor, para lo cual utilizó datos de encuestas sobre los vínculos directos entre proveedores y empresas líderes en Chile, Ghana, Kenya, Lesotho, Mozambique, Swazilandia y Viet Nam. Sobre la base de un examen de la bibliografía sobre el tema, el autor concluye que los efectos secundarios dependen de las características del inversor extranjero (por ejemplo, el grado de participación y la estructura de la propiedad extranjera, la duración de la presencia extranjera, la intensidad tecnológica, el país de origen del inversor extranjero, la estrategia en relación con los proveedores y las motivaciones a las que obedece la IED), la capacidad de absorción del país receptor (por ejemplo, la brecha tecnológica, la investigación y el desarrollo, el nivel de formación, el tamaño de la empresa, la exportación y la ubicación) y los cauces de transmisión (por ejemplo, el efecto de la demanda, el efecto de la ayuda, el efecto de la difusión y los efectos de la disponibilidad y la calidad). Por consiguiente, el autor subraya que, para beneficiarse de los efectos secundarios de la IED, no basta con atraer inversiones sino que es necesario incorporar a los inversores extranjeros a la economía local para aumentar la cantidad y la calidad de los vínculos y, por ende, los posibles efectos secundarios de la IED a largo plazo.

Para que los países en desarrollo puedan captar una proporción mayor del valor añadido en la cadena de producción, es necesario reforzar los vínculos con los proveedores de insumos de la economía local. Sin embargo, la aplicación de políticas mal concebidas puede crear nuevos obstáculos a la interconectividad, comprometer la participación de un país en las cadenas de valor y exponerlo a reclamaciones en el marco de la OMC (en particular, reclamaciones relacionadas con el Acuerdo sobre las Medidas en materia de Inversiones relacionadas con el Comercio). Tal es el caso, por ejemplo, de las normas sobre contenido nacional, que tienen por objeto captar una proporción mayor del valor añadido reservando determinadas actividades a las empresas nacionales o dando preferencia a los insumos nacionales frente a los importados. En general, esa clase de normas afectan adversamente a la competitividad de las empresas locales y hacen que el país resulte menos atractivo para los inversores extranjeros. Sin embargo, otros autores argumentan que esa clase de políticas son indispensables para promover los vínculos con los proveedores de insumos y sostienen que las normas del Acuerdo sobre las Medidas en materia de Inversiones relacionadas con el Comercio son, en el mejor de los casos, un error y, en el peor de los casos, un ejemplo de "hipocresía organizada" (Adhikari, 2008). Por consiguiente, es esencial que los gobiernos identifiquen las políticas que son compatibles con la participación en las cadenas de valor, como los regímenes encaminados a recompensar a los abastecedores locales o las políticas que tratan de desarrollar capacidad local para satisfacer las necesidades de las empresas líderes. 
Los programas de ayuda para el comercio -como el apoyo dirigido a aumentar la capacidad de suministro de las PYME locales o a ayudarlas a cumplir con las normas internacionales- ya están ayudando a los países en desarrollo a lograr esos objetivos. ${ }^{3}$ Además, las empresas líderes están prestando apoyo a los proveedores locales a través de efectos secundarios que pueden ser importantes. Por ejemplo, los empleados formados por empresas líderes pueden diversificar sus ventas, suministrando otros productos intermedios o abasteciendo a empresas líderes en otros mercados y a otras empresas líderes en la misma cadena de valor; por otra parte, la adquisición de nueva tecnología puede ayudar a crear centros de producción a nivel local. Esa clase de transferencias públicas y privadas, así como sus efectos secundarios, contribuyen a aumentar la capacidad local a nivel de la oferta y a captar una proporción mayor de los beneficios que ofrece la participación en las cadenas de valor.

\section{Minimizar los riesgos}

Las cadenas de valor mundiales han contribuido a que los países en desarrollo estén más expuestos a las perturbaciones económicas externas como resultado de la mayor elasticidad del comercio (Escaith et al., 2010). Por ejemplo, las dificultades experimentadas por el sector del automóvil en los Estados Unidos se transmitieron inmediatamente a través de la cadena de valor, y afectaron a los ingresos de los recolectores de caucho de Liberia que suministraban la materia prima para la fabricación de neumáticos (Jansen y von Uexkull, 2010). En general, las corrientes comerciales se han vuelto más volátiles: la modificación de las estrategias y prácticas empresariales puede provocar rápidos cambios en la demanda y la restructuración de la cadena de valor. Por ejemplo, la crisis económica de 2008-2009 produjo la fusión o el acortamiento de varias cadenas de valor (es decir, se redujo la segmentación de la cadena de valor e incluso se excluyó a algunos países de ella).

En ocasiones se critica a las cadenas de valor por el comportamiento predatorio de algunas empresas líderes, que utilizan los recursos humanos y naturales de los países en desarrollo de manera irresponsable o insostenible, o no comparten suficientemente las utilidades con los proveedores locales. Es probable que esta clase de problema se plantee con más frecuencia en las actividades no extractivas (manufactureras) que sólo existen gracias a las cadenas de valor mundiales, ya que, en el sector de la minería y el petróleo, la inversión extranjera directa se remonta a una época (varios decenios cuando no siglos atrás) en que no existían las cadenas de valor mundiales. En realidad, la mera existencia de empresas que carecen de fábricas y dependen fundamentalmente de su marca y de su reputación entre los consumidores, está generando nuevos cauces para atender al problema, como los códigos de conducta y la responsabilidad social de las empresas. Por consiguiente, es importante vigilar atentamente el creciente conjunto de códigos y directrices destinados a los proveedores ${ }^{4}$, así como los códigos de empresas y de responsabilidad social, y establecer incentivos para que las empresas líderes cumplan los principios fundamentales en materia de inversión y actuación empresarial responsables, como los Principios de inversión responsable de las Naciones Unidas o el Pacto Mundial de las Naciones Unidas, o las Directrices sobre las Empresas Transnacionales de la OCDE. Más allá de la inversión responsable, las relaciones verticales en las cadenas de valor pueden plantear problemas de competencia. Los gobiernos deben elaborar marcos de competencia adecuados a fin de evitar las relaciones cautivas y la pérdida de libertad económica en las cadenas de valor. 


\section{¿REPRESENTAN LAS CADENAS DE VALOR UNA PRIORIDAD EN LA AYUDA PARA EL COMERCIO?}

El desafío para los países en desarrollo consiste en elaborar y aplicar estrategias amplias encaminadas a eliminar los principales obstáculos a la integración y el ascenso en las cadenas de valor. Para ayudar a los países en desarrollo a superar esa clase de problemas, ingresar en las cadenas de valor y ascender en ellas, el apoyo de la comunidad del desarrollo puede ser útil, en particular si va acompañado de políticas nacionales adecuadas. El apoyo mediante programas de ayuda para el comercio depende de que se integren las cuestiones relacionadas con las cadenas de valor en las estrategias nacionales y sectoriales de desarrollo y de que se planteen esas cuestiones en los diálogos con la comunidad de donantes. En la presente sección se examina la cuestión de si las cadenas de valor constituyen una prioridad en las estrategias de los países asociados, los donantes bilaterales y multilaterales y los proveedores de cooperación Sur-Sur relacionada con el comercio. A continuación, se considera lo que opinan los países asociados sobre determinados obstáculos a los que se enfrentan sus empresas cuando tratan de conectarse a las cadenas de valor.

\section{La experiencia de los donantes en materia de creación de cadenas de valor}

De las respuestas al cuestionario de la OCDE y la OMC se desprende que las cadenas de valor ocupan un lugar cada vez más destacado en los programas de los donantes. Los donantes tienen más experiencia con las cadenas de valor en los sectores agrícola y alimentario. Los donantes bilaterales dicen que participan activamente en las cadenas de valor en esos sectores, así como en las cadenas de valor del pescado y los productos de la pesca, los textiles y las prendas de vestir y el turismo. Los donantes multilaterales dicen tener más experiencia con la creación de cadenas de valor en las esferas del transporte, los servicios financieros y los servicios prestados a las empresas y servicios profesionales. En el caso de los proveedores de cooperación Sur-Sur relacionada con el comercio, destaca la creación de cadenas de valor en el sector de los textiles y las prendas de vestir, así como en el de los productos de la industria automotriz (gráficos 3.1, 3.2 y 3.3).

Hay numerosos ejemplos de donantes que ayudan a los países asociados que promueven las cadenas de suministro vinculadas con las exportaciones, sobre todo en los sectores agrícola y pesquero. Muchos de esos proyectos tienen por objeto apoyar las corrientes comerciales ya establecidas ("margen intensivo"), mejorando la calidad o reduciendo los costos de distribución de suministros a las empresas líderes. Además, los donantes prestan ayuda para reforzar el sector privado de los países en desarrollo mediante la creación de un entorno favorable para las empresas, en particular en lo que se refiere a cuestiones de gobernanza y a los marcos normativo, jurídico y reglamentario. La ayuda destinada al sector privado abarca, además, actividades encaminadas a subsanar las deficiencias del mercado, eliminar las asimetrías en materia de información y prestar servicios de desarrollo empresarial, como investigación y desarrollo, normalización y certificación, y servicios financieros (OCDE/OMC, 2013).

Las actividades de algunos de los donantes consisten en proporcionar asistencia técnica, información, servicios de asesoramiento y financiación a distintas empresas de determinadas cadenas de valor. Cabe mencionar, entre esa clase de actividades, los siguientes proyectos: promoción de las exportaciones de bananos y plátanos en el Camerún; mejora del cultivo de algodón y de arroz en el África Occidental; mejora de la calidad del té en Rwanda; mejora de la calidad del café en Etiopía y Tanzanía; mejora de la calidad de las prendas de vestir de confección en Bangladesh; mejora de los cultivos orgánicos en Guatemala; mejora del cultivo de hortalizas orientales en Honduras; mejora de la pesca en Granada; mejora de la calidad de la leche en el Perú; reactivación de la exportación de anacardos elaborados en Mozambique; y lucha contra la mosca de la fruta en Tonga, así como mejora del ganado lechero en Indonesia. Los donantes financiaron varios proyectos para ayudar a los productores a cumplir con las normas de calidad de sus países y de otros mercados de exportación. Entre ellos cabe mencionar la asistencia prestada por la UE a la producción pesquera en Fiji, Honduras y Mozambique, así como a los productores de aceite de palma en Ghana (OCDE/OMC, 2013). 


\section{Gráfico 3.1 Experiencia de los donantes bilaterales en materia de creación de cadenas de valor (porcentaje de respuestas)}

Junto a cada categoría se indica el número de respuestas correspondiente.

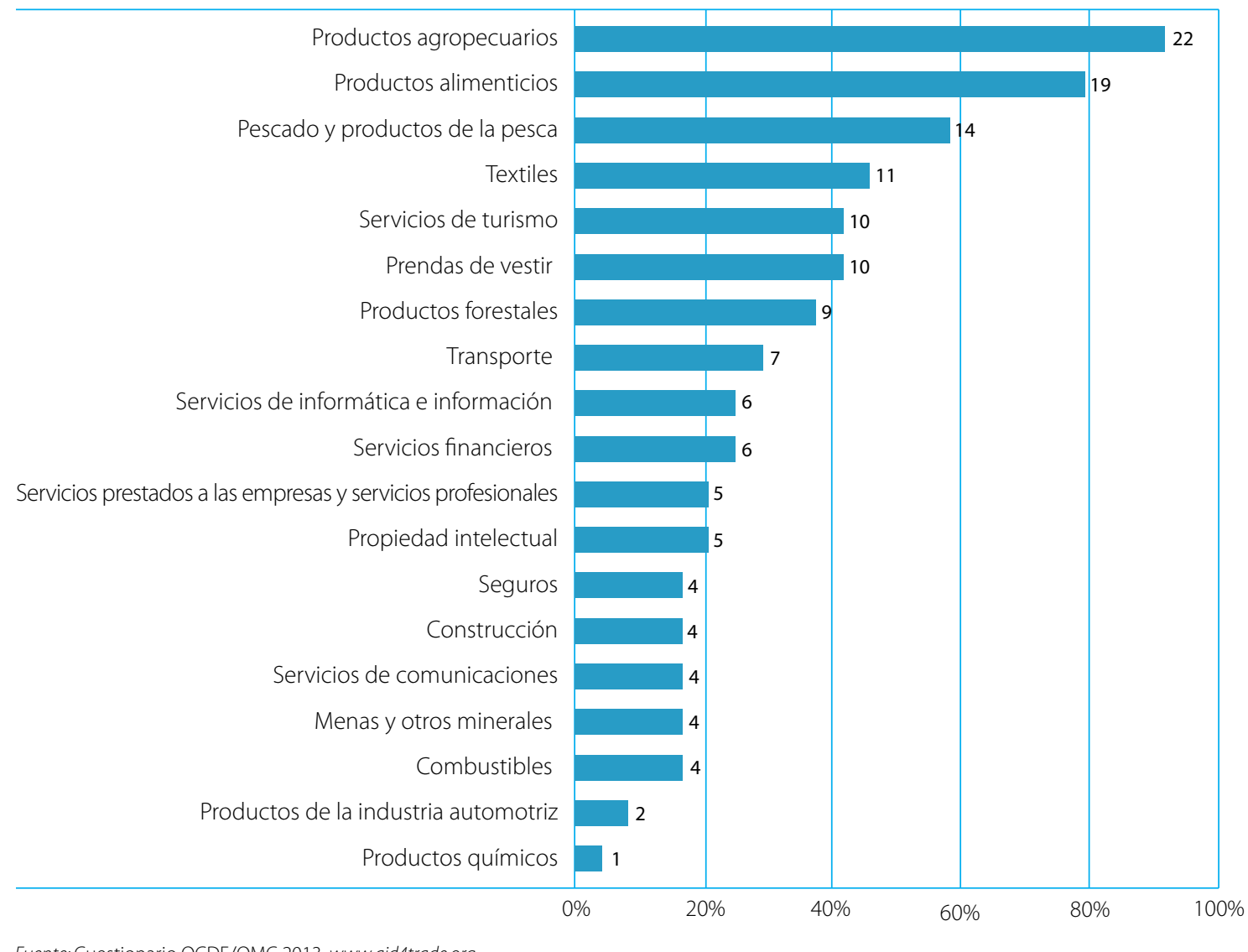

Fuente: Cuestionario OCDE/OMC 2013, www.aid4trade.org.

StatLink 青15 http://dx.doi.org/10.1787/888932854214

Los principales donantes, en particular los Estados Unidos y el Reino Unido, llevan a cabo muchos programas que guardan relación directa con las cadenas de valor. La Iniciativa para el Libre Comercio en África (AFTi), que cuenta con el apoyo del Reino Unido, tiene por objeto lograr que, para 2015, otros 3 millones de personas se beneficien directamente con las cadenas de valor nacionales y transfronterizas, por ejemplo, por medio del Fondo para el fomento empresarial en África, que administra diversos proyectos encaminados a ayudar a las personas a beneficiarse de las cadenas de valor del sector agroalimentario en África. Los Estados Unidos, por medio del Programa de promoción del desarrollo agrícola y de las cadenas de valor (ADVANCE) en Ghana, ha establecido un programa por valor de 32 millones de dólares EE.UU. encaminado a incrementar la competitividad de cadenas de valor de productos agrícolas básicos de importancia clave en los mercados nacional y regional. Mediante la Iniciativa del comercio en las cadenas de valor mundiales se presta apoyo para aumentar y mejorar las oportunidades de empleo, así como incrementar los salarios y mejorar las condiciones de trabajo en las cadenas de valor de los sectores de la horticultura en Kenya y Sudáfrica y de las prendas de vestir en Bangladesh. La Iniciativa encaminada a promover la responsabilidad y la rendición de cuentas en el sector de las prendas de vestir tiene por objeto mejorar las condiciones de trabajo en las cadenas de valor en el sector de las prendas de vestir en países pobres. El Fondo para el fomento del comercio minorista de alimentos concede subvenciones a través de un proceso de selección por concurso en el que pueden participar empresas europeas para desarrollar y ensayar nuevos medios de poner al alcance de los consumidores las exportaciones africanas de alimentos. 


\section{Gráfico 3.2 Experiencia de los donantes multilaterales en materia de creación de cadenas de valor (porcentaje de respuestas)}

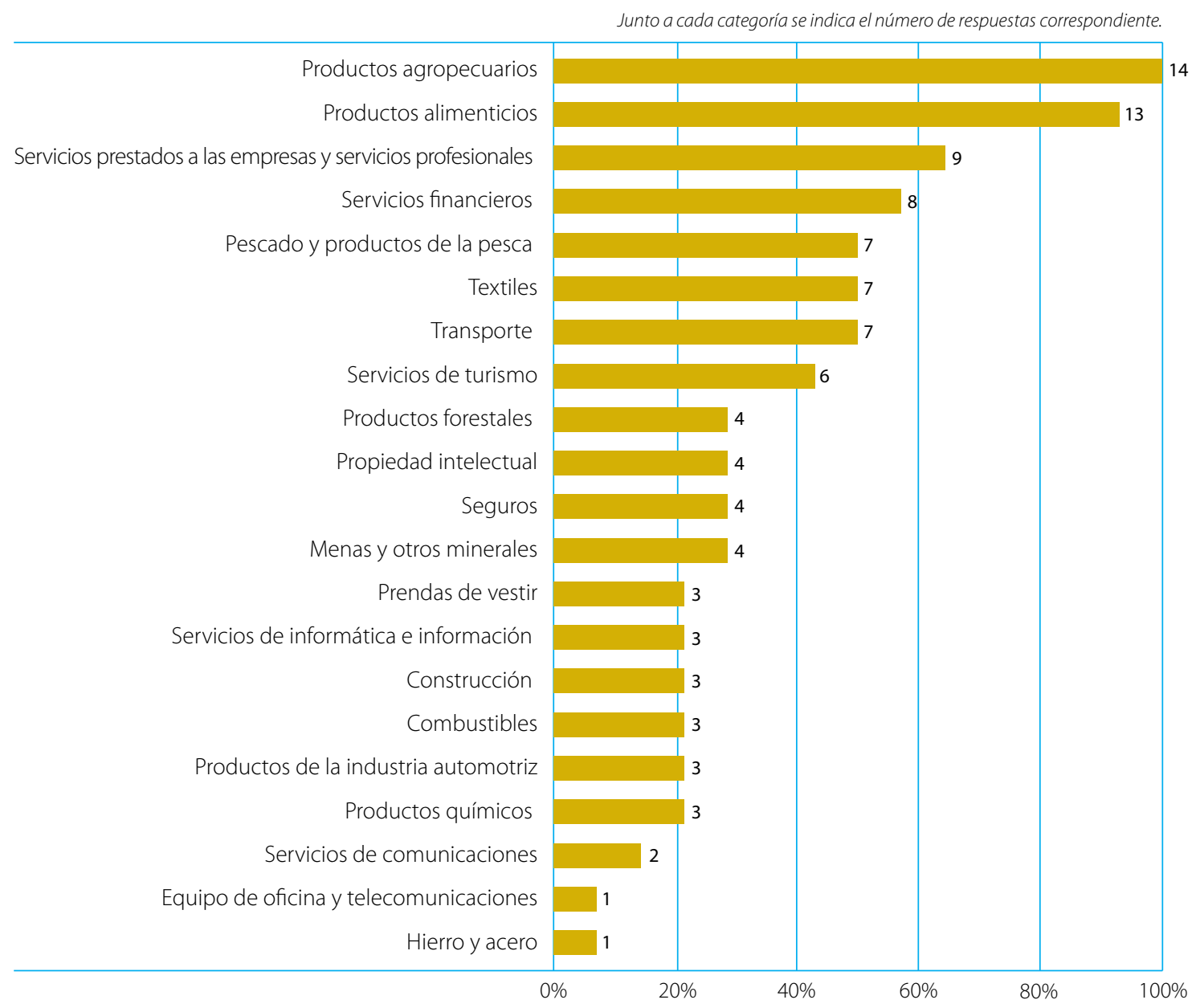

Fuente: Cuestionario OCDE/OMC 2013, www.aid4trade.org.

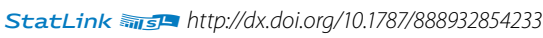

Mediante la Estrategia para el Crecimiento Económico Sostenible, que orienta actividades de ayuda para el comercio, el Canadá apoya activamente varias iniciativas encaminadas a incrementar el acceso a las cadenas de valor mundiales. Esas iniciativas están orientadas, fundamentalmente, a las cadenas de valor del sector de la agroindustria de Bangladesh, Ucrania y Viet Nam, así como las cadenas de valor del sector extractivo, en particular en el Perú. La creación de cadenas de valor ha sido una prioridad estratégica para Dinamarca desde 2010, mientras que la Ayuda para el Comercio de Nueva Zelandia está destinada principalmente a ayudar a las islas del Pacífico a participar en las cadenas de valor y a facilitar su acceso al mercado neozelandés. Alemania asigna prioridad a la tarea de incrementar la integración en las cadenas de valor regionales e internacionales y promover el respeto de las normas sociales y ambientales (BMZ, 2011: 6). Alemania también ayuda a las PYME y a las pequeñas explotaciones agropecuarias a aumentar su capacidad de exportación y de comercialización, a fin de que puedan utilizar, a nivel individual, las cadenas de valor para obtener mayor valor añadido. 


\section{Gráfico 3.3 Experiencia de los proveedores de cooperación Sur-Sur en materia de creación de cadenas de valor (porcentaje de respuestas)}

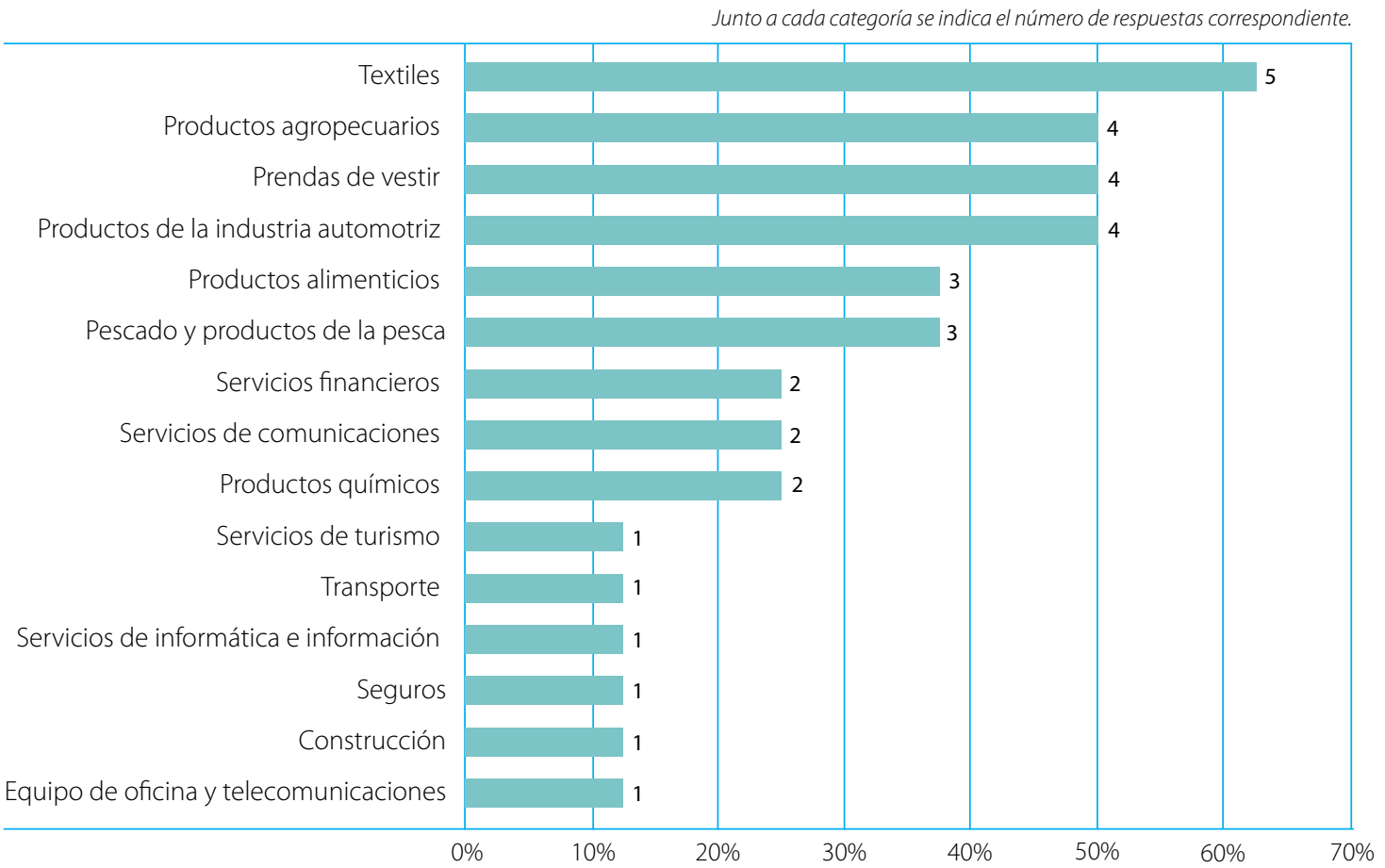

Fuente: Cuestionario OCDE/OMC 2013, www.aid4trade.org.

Para que las PYME de los países en desarrollo estén en condiciones de exportar - uno de los principales objetivos del Centro de Comercio Internacional (ITC) - a menudo es necesario desarrollar los segmentos nacional e internacional de la cadena de valor. Eso significa, por ejemplo, elaborar y poner en práctica estrategias de cadenas de valor regionales en el sector de los productos básicos en África (como la Iniciativa sobre el algodón). En muchos proyectos se hace especial hincapié en mejorar la calidad y las normas a fin de cumplir con los requisitos de las empresas líderes (como el proyecto destinado a mejorar la calidad del café etíope), o en crear productos que puedan ser de interés para las empresas líderes (como la iniciativa Moda Ética). El ITC también imparte capacitación específicamente en gestión de las cadenas de suministro y participación en las cadenas de valor internacionales, y analiza otras esferas de cooperación con las empresas líderes con el objeto de mejorar la gestión de las cadenas de suministro en los países en desarrollo y conectar mejor a las cadenas de valor las PYME dirigidas por mujeres. ${ }^{5}$ Del mismo modo en que el diálogo entre el sector público y el sector privado es un elemento clave para el desarrollo de cadenas de valor nacionales en los países en desarrollo, la cooperación entre el sector público y el sector privado en el diseño y la prestación de asistencia a las comunidades y otros beneficiarios también es un aspecto clave para lograr el éxito.

Hasta la fecha se han evaluado pocos programas bilaterales en esta esfera, pero los que se han evaluado muestran que se han obtenido resultados tangibles. Por ejemplo, mediante la labor de vigilancia provisional de las actividades relacionadas con las cadenas de valor y los proyectos de ayuda para el comercio, el Reino Unido ha determinado que los ingresos de los trabajadores de los países asociados han aumentado, que las condiciones de trabajo han mejorado y que el empleo ha aumentado. Recientemente, los Países Bajos también evaluaron los programas que llevan a cabo en relación con el té, el algodón y el cacao y comprobaron que los ingresos de los hogares y la sostenibilidad habían aumentado. 
Desde hace años, varias organizaciones internacionales especializadas vienen trabajando en los países menos adelantados (PMA) para promover la expansión de las cadenas de valor locales e internacionales que benefician a los pequeños productores y empresarios agrícolas, quienes, a su vez, crean puestos de trabajo y generan ingresos. Así, en la Declaración de Abuja de $2010^{6}$ se encomendó a la Organización de las Naciones Unidas para la Alimentación y la Agricultura (FAO), al Fondo Internacional de Desarrollo Agrícola (FIDA), el Banco Africano de Desarrollo (BAfD) y a la Organización de las Naciones Unidas para el Desarrollo Industrial (ONUDI) que emprendiesen actividades conjuntas en la esfera de las cadenas de valor del sector de la agroindustria de África. En respuesta a ello, las tres organizaciones pusieron en marcha la Iniciativa Acelerada de Desarrollo de los Agronegocios y las Agroindustrias de África (3ADI). Según esas organizaciones, la Iniciativa tomó como punto de partida el compromiso político existente de promover el desarrollo del sector agropecuario a fin de que la proporción de productos alimentarios diferenciados de alto valor aumentase al 50\% del total de los productos alimentarios del continente. Las actividades encaminadas a la consecución de ese objetivo de la $3 \mathrm{ADI}$ se financian con cargo a corrientes de inversión adicionales del sector privado y con recursos proporcionados por donantes. Además, la ONUDI ha diseñado y ejecutado programas de asistencia técnica y prestado apoyo a las políticas como parte de esos programas. En los programas de la ONUDI se centra la atención en los pilares fundamentales del desarrollo de la agroindustria: la modernización de toda la cadena de valor, el fortalecimiento de la tecnología, la promoción de fuentes innovadoras de financiación y el fomento de la participación del sector privado.? El Gobierno de Haití también solicitó oficialmente asistencia técnica a la ONUDI para acelerar el desarrollo de las cadenas de valor más prometedoras de la agroindustria (banano y tubérculos). ${ }^{8}$

Mientras que en las estrategias de ayuda para el comercio de algunos donantes no se abordan expresamente las cuestiones relacionadas con las cadenas de valor (por ejemplo, Suecia no prevé expresamente el análisis ni la identificación de cadenas de valor en sus programas), en otros casos se hace referencia a ellas de manera indirecta. Por ejemplo, en la estrategia de ayuda para el comercio de Francia no se utiliza la expresión "cadena de valor", pero las actividades previstas en ella están orientadas hacia las actividades emprendidas por las empresas para crear valor.

\section{OPINIÓN DEL SECTOR PÚBLICO SOBRE LOS OBSTÁCULOS QUE SE INTERPONEN AL ACCESO A LAS CADENAS DE VALOR}

Las explotaciones agrícolas y las fábricas de muchos productores de países en desarrollo son competitivas, pero tropiezan con diversas limitaciones en los mercados regionales y mundiales que menoscaban su competitividad y limitan sus posibilidades de crecimiento. En la presente sección se describen los obstáculos a los que se enfrentan los proveedores de los países en desarrollo a la hora de ingresar en las cadenas de valor, sobre la base de las respuestas dadas al cuestionario de la OCDE y la OMC por los países asociados, los donantes y los proveedores de cooperación Sur-Sur. Por último, sobre la base de las respuestas de los países asociados, se evalúa en qué medida es eficaz la ayuda de los donantes para reducir los obstáculos que se interponen al acceso a las cadenas de valor.

Tanto los países asociados como los proveedores de asistencia relacionada con el comercio consideran que la limitación más importante es la falta de infraestructura adecuada (gráficos 3.4, 3.5, 3.6 y 3.7). El 68\% de los países asociados indicaron que las deficiencias a nivel del suministro eléctrico eran una limitación importante, lo que confirma la opinión de la OCDE (2013b) de que el acceso a la electricidad y la fiabilidad del suministro eléctrico constituyen una limitación fundamental que compromete los resultados comerciales de las empresas de los países en desarrollo. En las encuestas de empresas que realiza el Banco Mundial también se subraya reiteradamente la magnitud de ese obstáculo.

Los países asociados, los donantes multilaterales y los proveedores de cooperación Sur-Sur relacionada con el comercio están de acuerdo en que las dificultades para obtener financiación ocupan el segundo lugar entre las limitaciones más importantes (para los donantes bilaterales la falta de acceso a la financiación ocupa el tercer lugar). 
La financiación del comercio es la tabla de salvación del comercio internacional: más del $90 \%$ de las transacciones requieren algún tipo de crédito, seguro o garantía. En particular, los pequeños exportadores carecen de acceso adecuado a la financiación para el comercio (ITC, 2009:2). ${ }^{9}$

\section{Gráfico 3.4 Principales obstáculos con que tropiezan las empresas para ingresar en las cadenas de valor a juicio de los países asociados (porcentaje de respuestas)}

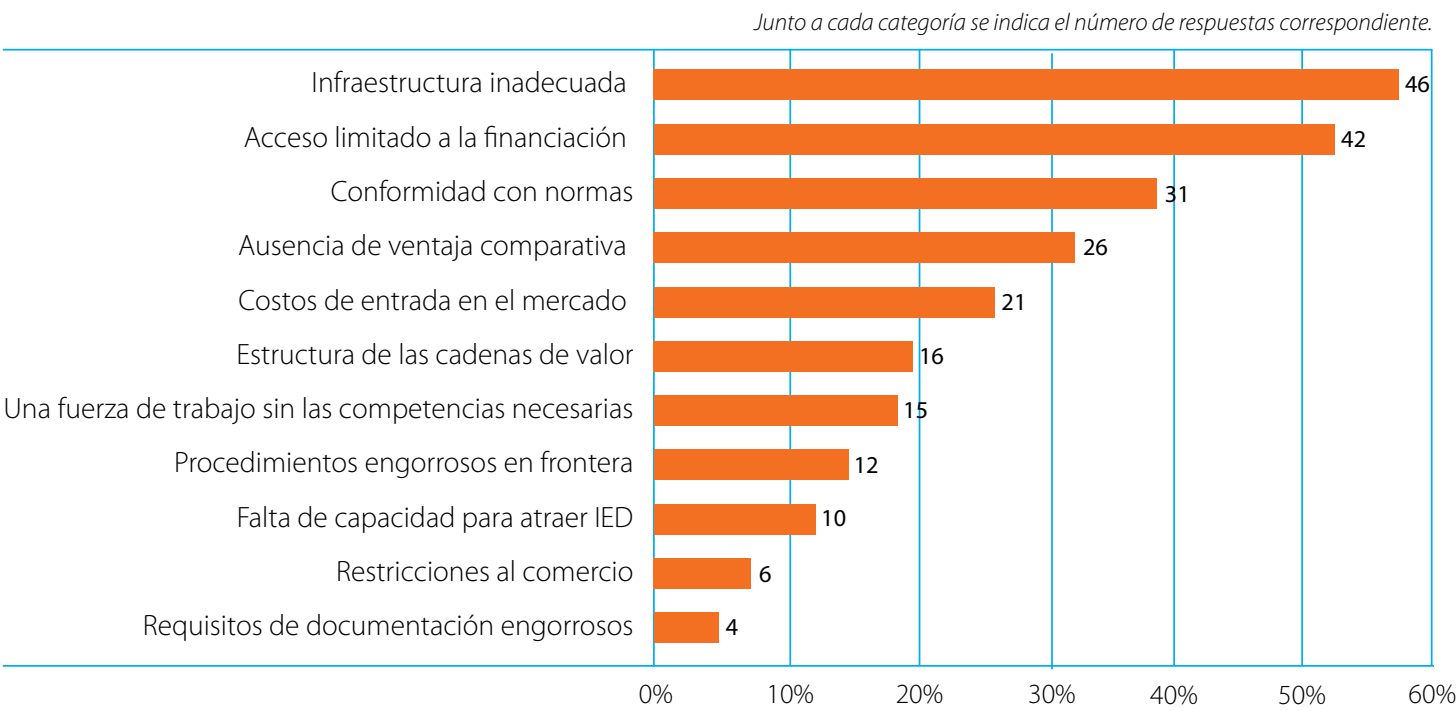

Fuente: Cuestionario OCDE/OMC 2013, www.aid4trade.org.

\section{Gráfico 3.5 Principales obstáculos con que tropiezan las empresas para ingresar en las cadenas de valor a juicio de los donantes bilaterales (porcentaje de respuestas)}

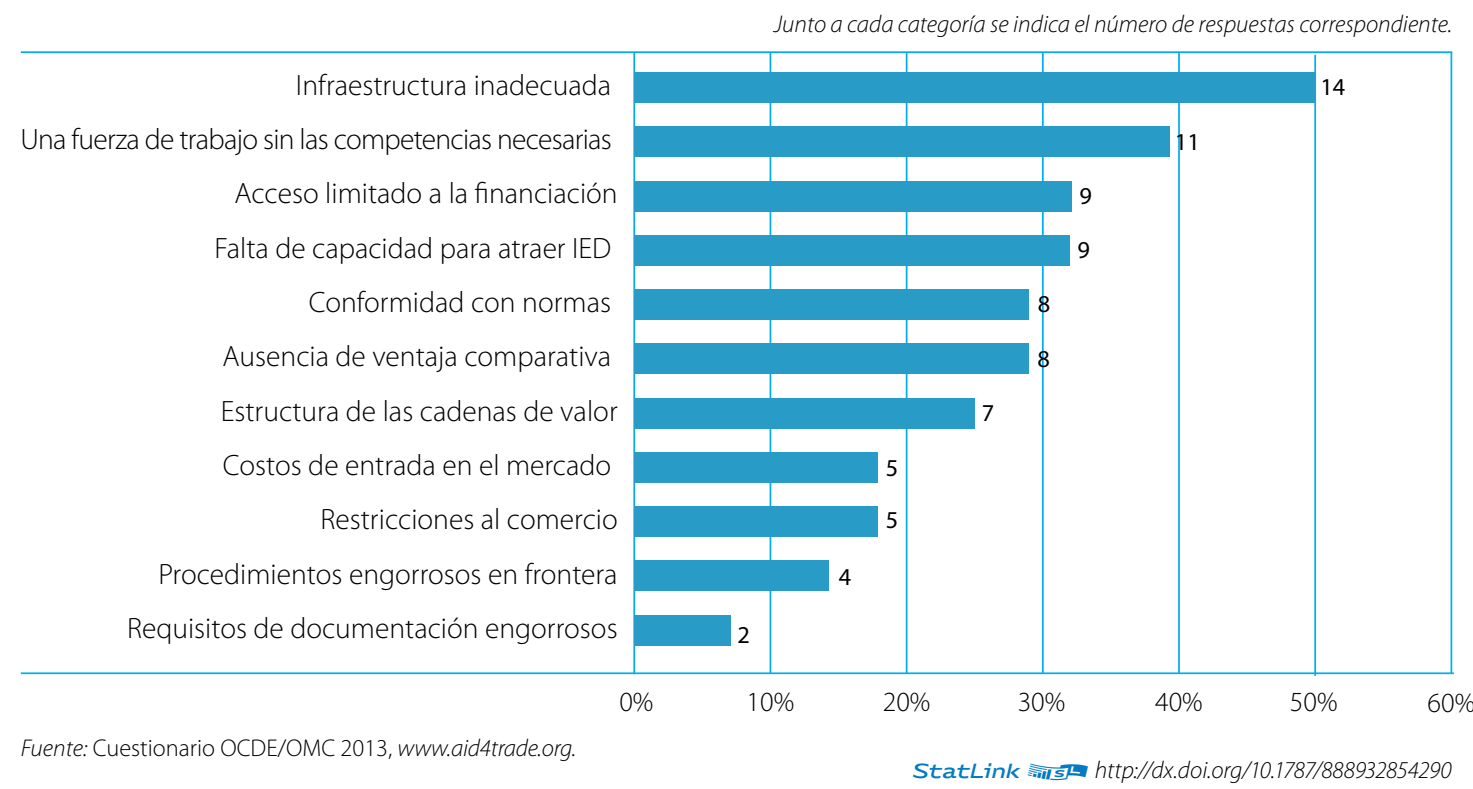




\section{Gráfico 3.6 Principales obstáculos con que tropiezan las empresas para ingresar en las cadenas de valor a juicio de los donantes multilaterales (porcentaje de respuestas)}

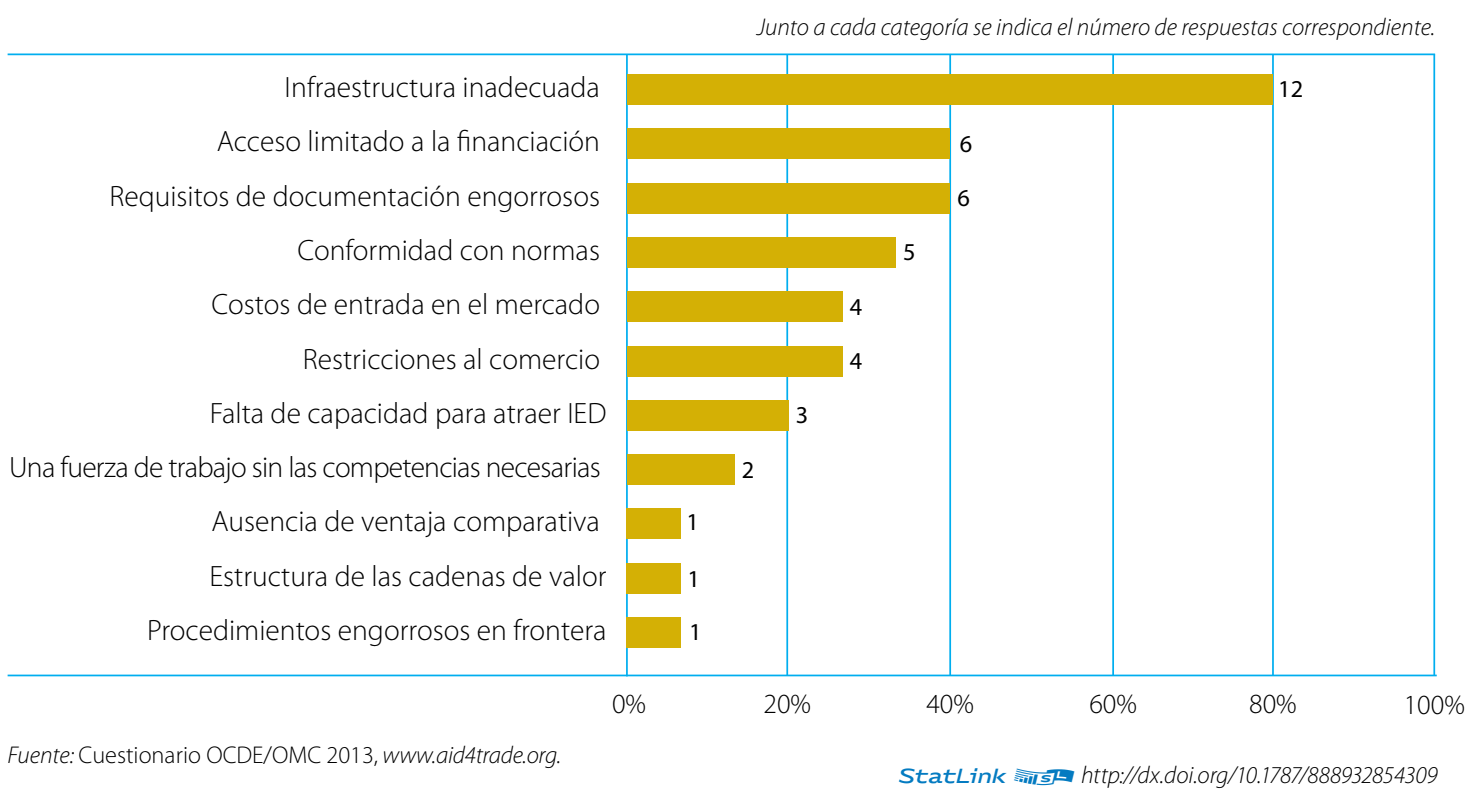

Otra limitación importante a juicio de los países asociados y los donantes bilaterales y multilaterales, así como, en menor medida, de los proveedores de cooperación Sur-Sur relacionada con el comercio, es la necesidad de cumplir con las normas técnicas, sanitarias y de inocuidad para obtener acceso a mercados maduros y participar en las cadenas de valor. Mientras que la existencia de normas estrictas fomenta el comercio en la medida en que inspira mayor confianza en compradores y consumidores, en ocasiones esa clase de normas puede también constituir un obstáculo arbitrario e injustificado, difícil de impugnar y eliminar.

Los donantes bilaterales mencionan, en particular, la falta de competencias y de capital humano, así como la falta de capacidad de los países asociados para atraer IED. Los donantes multilaterales prestan mayor atención a las cuestiones relacionadas con el entorno empresarial y mencionan los engorrosos trámites burocráticos, reglamentos y documentación conexa que, a su juicio, constituyen un obstáculo importante para el ingreso de las empresas en las cadenas de valor. Ni los países asociados, ni los donantes bilaterales ni los proveedores de cooperación Sur-Sur relacionada con el comercio asignaron tanta importancia a ese tipo de obstáculos. Los costos de entrada en el mercado y las restricciones al comercio también se mencionaron entre los impedimentos, en particular a nivel de los donantes multilaterales y los proveedores de cooperación Sur-Sur relacionada con el comercio, pero considerablemente menos en el caso de los países asociados y los donantes bilaterales. Todos los participantes en la encuesta estuvieron de acuerdo en cuanto a la importancia relativa de obstáculos como la ausencia de ventaja comparativa y la estructura de las cadenas de valor. 


\section{Gráfico 3.7 Principales obstáculos con que tropiezan las empresas para ingresar en las cadenas de valor a juicio de los proveedores de cooperación Sur-Sur relacionada con el comercio (porcentaje de respuestas)}

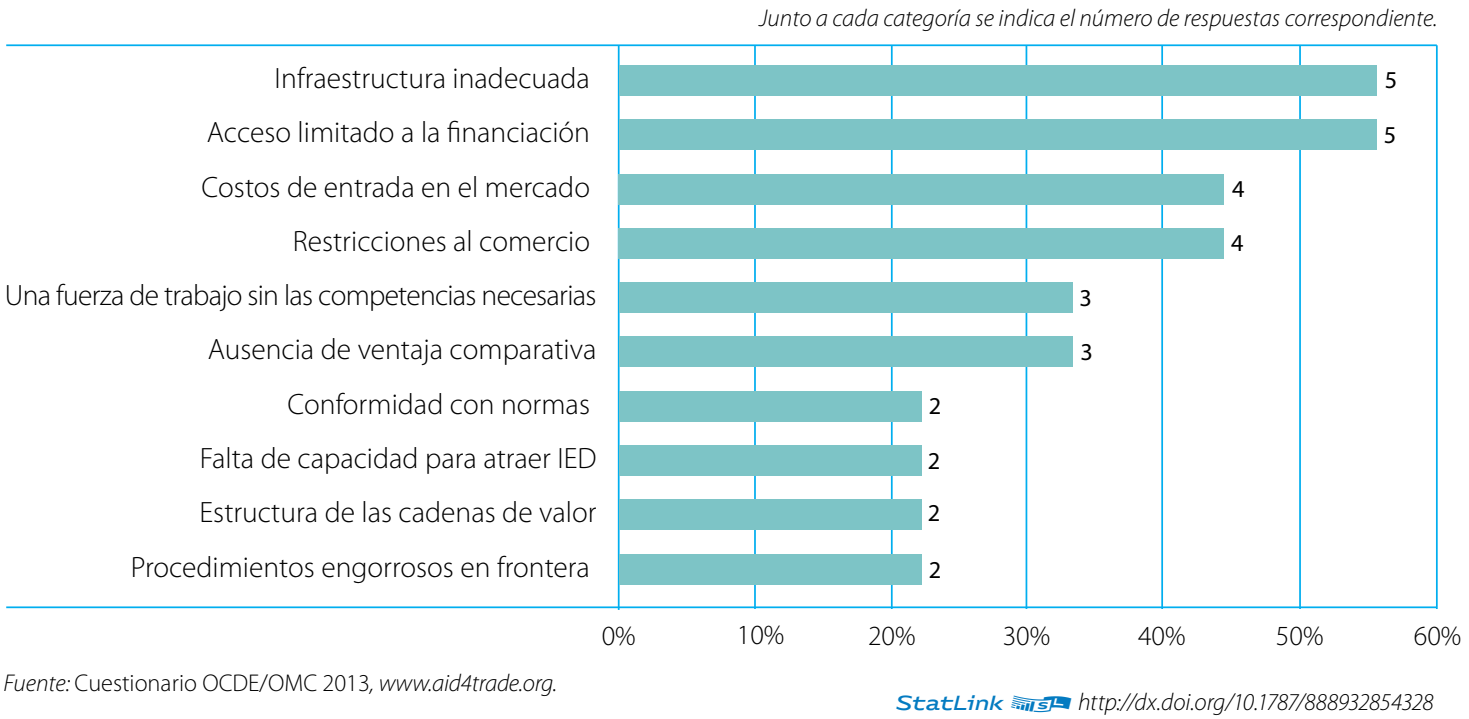

\section{¿Cuán eficaz es la ayuda que prestan los donantes?}

Los países asociados consideran que la ayuda para el comercio es eficaz para subsanar las limitaciones relacionadas con el comercio. En su opinión, el apoyo al desarrollo de infraestructura es muy eficaz (68 países) o eficaz (10 países) para ayudar a las empresas a ingresar o avanzar en las cadenas de valor (gráfico 3.8). Pese a que, como se ha indicado supra, los países donantes no estiman que una fuerza de trabajo sin las competencias necesarias constituya uno de los principales obstáculos para ingresar o avanzar en las cadenas de valor, consideran, no obstante, que los programas encaminados a mejorar las competencias de la fuerza de trabajo son eficaces para eliminar las limitaciones relacionadas con el comercio. El apoyo de los donantes para mejorar el entorno empresarial figura entre los tres programas de ayuda considerados más eficaces para ayudar a las empresas a conectarse a las cadenas de valor. Las conclusiones a las que llegaron Chang et al. (2009) confirman ampliamente que los efectos positivos del comercio en el crecimiento son mayores si van acompañados de una mejora de la infraestructura económica, un aumento de la educación y las competencias y una profundización de los mercados financieros, pero también de reformas institucionales y reglamentarias. Los países asociados consideran ese tipo de programas especialmente eficaces.

El apoyo sectorial directo no se considera tan eficaz como un apoyo más orientado hacia la promoción del comercio, el análisis de mercados, el desarrollo empresarial y la promoción de las inversiones. Se considera que el apoyo a las zonas francas industriales es mucho menos eficaz. De hecho, no todas las zonas francas industriales han sido un éxito, y las inversiones en infraestructura y los generosos incentivos fiscales no siempre han generado un aumento de la IED. Incluso cuando se han hecho IED, con frecuencia el valor añadido ha sido bajo, y el establecimiento de vínculos con los proveedores de insumos y la transferencia de tecnología, bastante limitados (Engman et al., 2007). En general, los efectos de la mayoría de las zonas francas industriales en África, en particular en el desarrollo económico local, han sido, en el mejor de los casos, ambiguos. 


\section{Gráfico 3.8 Tipos de ayuda que los países asociados consideran "muy eficaces" (porcentaje de respuestas)}

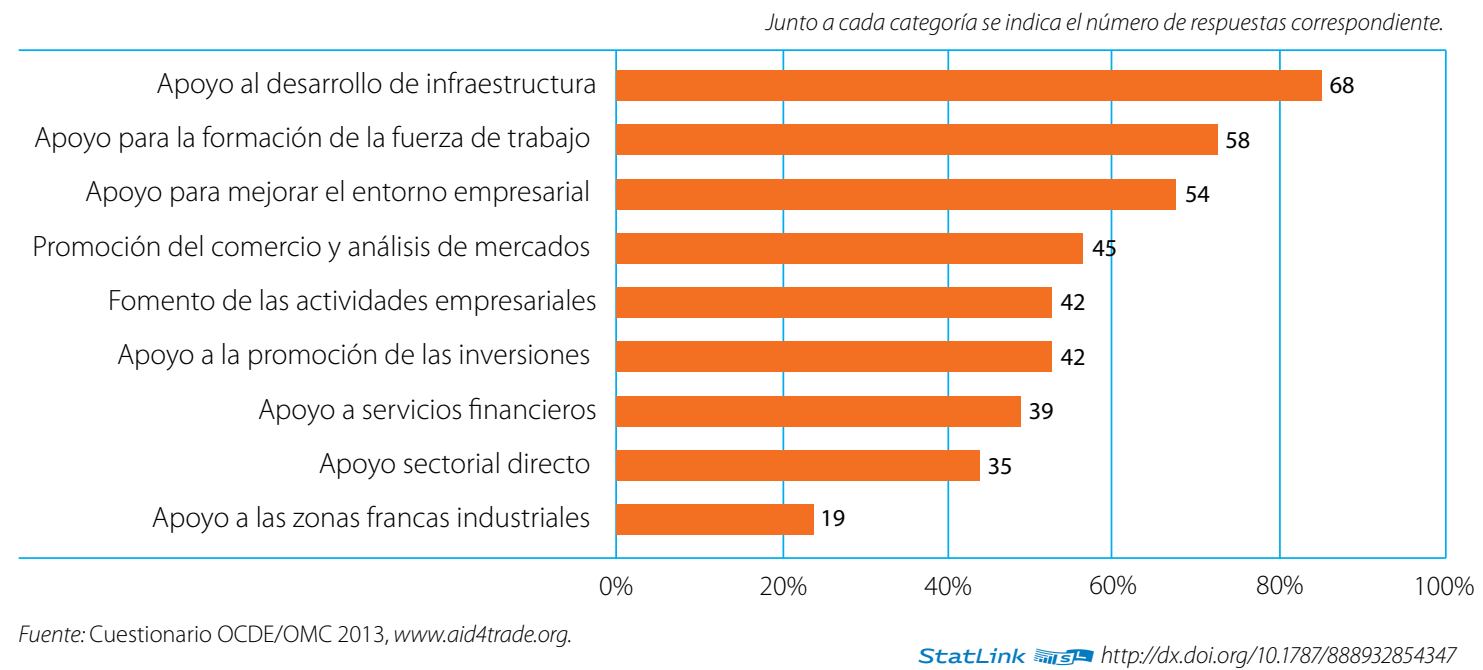

\section{OPINIÓN DEL SECTOR PRIVADO SOBRE LOS OBSTÁCULOS AL INGRESO EN LAS CADENAS DE VALOR}

La encuesta de la OCDE y la OMC a nivel del sector privado se dirigió a empresas en cinco sectores de especial importancia para los proveedores de los países en desarrollo: el agroalimentario, el de los textiles y las prendas de vestir, el del turismo, el de la tecnología de la información y las comunicaciones, y el del transporte y la logística. Esa labor se realizó en colaboración con la Iniciativa "Grow Africa", la Cámara de Comercio Internacional (ICC), el Centro de Comercio Internacional (ITC), la Unión Internacional de Telecomunicaciones (UIT) y la Organización Mundial del Turismo (OMT).

Puede ser que la encuesta, que obtuvo cerca de 700 respuestas de más de 120 países, no sea estadísticamente significativa debido a las limitaciones metodológicas de ese tipo de trabajo; sin embargo, la amplitud y el alcance de las respuestas dan una buena idea de las limitaciones a las que hace frente el sector privado cuando trata de incorporar en las cadenas de valor a proveedores de países en desarrollo, sobre todo cuando se analizan las respuestas en el contexto de otro estudio sobre el mismo tema (OCDE, 2013a).

Se dejó a cada empresa la decisión de participar como proveedor de un país en desarrollo o como empresa líder. Se les pidió que clasificasen, por orden de importancia, los principales obstáculos con que tropezaban las empresas de los países en desarrollo como proveedores en las cadenas de valor, así como los principales factores que tenían en cuenta las empresas líderes cuando decidían recurrir a un proveedor de un país en desarrollo e invertir en él para integrarlos en sus cadenas de valor. La presente sección se basa, en buena medida, en estudios sectoriales más a fondo sobre las cadenas de valor en el sector agroalimentario, el sector de los textiles y las prendas de vestir, el sector del turismo, el sector de la TIC y el sector del transporte y la logística, que fueron publicados por separado como estudios de antecedentes y están destinados al Cuarto Examen Global de la Ayuda para el Comercio. 


\section{Principales conclusiones}

Para los proveedores de países en desarrollo en los sectores agroalimentario, de los textiles y las prendas de vestir, del turismo, de la TIC y del transporte y la logística, la falta de acceso a la financiación (en particular, a la financiación del comercio) constituye el principal obstáculo para ingresar en cadenas de valor, establecerlas o avanzar en ellas. Entre otros obstáculos importantes mencionados figuraban el costo del transporte y la expedición, la falta de infraestructura adecuada y la incertidumbre en torno a la reglamentación aplicable (a menudo como resultado de un entorno empresarial complejo). Los proveedores de países en desarrollo en los cinco sectores incluidos en la encuesta mencionaron la falta de competencias de la mano de obra entre las limitaciones a nivel de la oferta.

Las empresas líderes en los cinco sectores escogidos mencionaron los trámites aduaneros entre los principales obstáculos con que tropezaban para incluir a proveedores de países en desarrollo en sus cadenas de valor. Otras preocupaciones importantes eran la incertidumbre en torno a la reglamentación aplicable (que refleja los problemas que se plantean a los proveedores de los países en desarrollo como resultado de la complejidad del entorno empresarial) y los problemas relacionados con el cumplimiento de normas. Las prácticas informales y las solicitudes de pago también fueron mencionadas entre los motivos de especial preocupación en las relaciones con los proveedores.

Entre los factores que, según las empresas, influían en las decisiones en materia de abastecimiento e inversión figuraban el costo de la producción y la mano de obra, la conformidad con las normas, el volumen de producción y el tiempo total de fabricación (cuestión ésta de especial importancia en el caso de los textiles), así como los incentivos a la inversión y los incentivos fiscales. Las competencias de la mano de obra también se consideraban un factor importante (en particular en los sectores de la TIC, los textiles y las prendas de vestir, y el turismo) en la adopción de decisiones a la hora de invertir. Las deficiencias del entorno empresarial, las demoras en las aduanas, la incertidumbre en torno a la reglamentación aplicable y la corrupción y la venalidad también figuraron entre los factores que influían negativamente en las decisiones sobre abastecimiento e inversión.

Tanto los proveedores de países en desarrollo como las empresas líderes opinaban que, en el futuro, la ayuda se debería concentrar principalmente en mejorar el entorno empresarial. Ambos grupos de encuestados también señalaron que la facilitación del acceso a los mercados los ayudaría a ingresar en cadenas de valor, establecer cadenas de valor o avanzar en ellas. Los proveedores de países en desarrollo hicieron mayor hincapié en la financiación como medio eficaz de ayuda (el acceso a la financiación y los incentivos encaminados a promover la inversión nacional y extranjera). Las empresas líderes asignaban especial importancia a la facilitación del comercio y a la mejora del diálogo entre el sector público y el sector privado. La capacitación de la mano de obra también se consideraba un medio eficaz de aumentar la capacidad a nivel de la oferta.

\section{Resultados de los estudios sectoriales}

\section{Sector agroalimentario}

El sector agroalimentario se encuentra en una fase de cambio dinámico. La rápida urbanización y el aumento del nivel de los ingresos en los países en desarrollo, la evolución de los hábitos alimentarios, la tecnología de la información y las comunicaciones, la transformación de la estructura de los mercados minoristas y las oportunidades que ofrecen los mercados de exportación son los catalizadores de ese rápido cambio. En su conjunto, esos factores están contribuyendo a revolucionar la manera en que se producen, elaboran y venden los alimentos, si bien la velocidad con que tiene lugar esa evolución varía de un mercado a otro y dentro de cada mercado en los países desarrollados, en desarrollo y menos adelantados. Los nuevos mercados de exportación, en particular los mercados asiáticos, populosos y en rápido crecimiento, constituyen otro de los rasgos distintivos de esa tendencia, como lo es la adopción del enfoque moderno del comercio minorista en los países en desarrollo, incluidos los países de bajos ingresos. 
Como resultado del surgimiento de cadenas de valor a nivel local, regional y mundial el sector privado está participando en mayor medida en la agricultura y se está prestando especial atención al desarrollo y la mejora de la calidad, la productividad, la eficiencia y el alcance de las cadenas de valor agrícolas. A medida que aumenta la demanda de alimentos inocuos y de calidad, así como de comidas preparadas, entre los consumidores (urbanos), se acelera también el ritmo del cambio en los mercados de alimentos. En muchos mercados agropecuarios, esta tendencia está llevando al sector privado a desempeñar un papel más activo y asertivo frente al Estado.

Al cuestionario de la OCDE y la OMC respondieron 250 empresas del sector agroalimentario de 79 países (160 proveedores de países en desarrollo y 89 empresas líderes). ${ }^{10}$ Los encuestados subrayaron que los costos (por ejemplo, de transporte y mano de obra) desempeñaban un papel importante a la hora de decidir si había de vincularse a un proveedor a una cadena de valor. La capacidad para cumplir con las normas y las especificaciones de los productos también ocupaban un lugar destacado, junto con otros factores, como el entorno reglamentario y las competencias de la fuerza de trabajo. El acceso a la financiación y la falta de infraestructura constituían un motivo de preocupación principalmente para los proveedores de países en desarrollo que deseaban conectarse a cadenas de valor. Otros factores, como el tamaño y la proximidad del mercado nacional, eran importantes para las empresas líderes y los inversores.

Los proveedores de los países en desarrollo consideraban que los factores que ejercían mayor influencia sobre las decisiones en materia de fuentes de abastecimiento e inversiones en las cadenas de valor del sector agroalimentario eran los costos de producción (64\% de las respuestas), la capacidad para cumplir con las normas de calidad e inocuidad (60\%), el entorno empresarial (44\%), la calidad de la infraestructura (42\%) y las competencias/ productividad de la mano de obra (38\%). A la hora de crear cadenas de valor, las empresas líderes consideraban que un país en desarrollo era atractivo como fuente de suministros o para invertir en él cuando era capaz de cumplir sistemáticamente con las especificaciones de los productos (58\%), tenía costos de producción y mano de obra bajos (41\% y 33\%, respectivamente), tenía un mercado interno grande (38\%) y ofrecía incentivos a la inversión o incentivos fiscales atractivos (31\%).

Otros factores mencionados fueron la confianza en el entorno reglamentario (27\% de las respuestas), las competencias de la mano de obra (26\%), la profundidad del mercado de mercancías y servicios locales (26\%), la apertura del mercado y la participación en acuerdos comerciales (25\% en cada caso), el idioma (25\%), la proximidad de los mercados (21\%) y el tiempo que se tardaba en atender a pedidos hechos con poco tiempo de antelación (16\%). Un país no era atractivo cuando había corrupción y venalidad (53\%), el costo del transporte y la logística era elevado (51\%), el entorno empresarial y normativo era deficiente (48\%), se producían demoras en la aduana (38\%), el mercado era pequeño y tenía bajo poder adquisitivo (33\%) y el nivel de competencia de la fuerza de trabajo era bajo (27\%).

Cuando se les preguntó sobre el apoyo que necesitaban para ingresar y avanzar en las cadenas de valor, los proveedores de los países en desarrollo indicaron que para ellos tenían prioridad los siguientes factores: un mejor acceso a la financiación (59\% de las respuestas), incentivos a la inversión (57\%), un mejor acceso a los mercados (56\%), inversiones en infraestructura (46\%), normas reconocidas internacionalmente (38\%) y planes de capacitación de la fuerza de trabajo (36\%). Esas prioridades se correspondían en buena medida con las de las empresas líderes, que mencionaron un mejor acceso a los mercados (52\%), las inversiones en infraestructura (46\%), un mejor diálogo entre el sector privado y las autoridades nacionales (44\%), las medidas de facilitación del comercio (42\%), una mejor infraestructura en materia de normas y una mayor capacidad de certificación (37\%), y apoyo para mejorar el entorno empresarial (36\%). 


\section{Gráfico 3.9 Factores que ejercen mayor influencia sobre las decisiones en materia de fuentes de abastecimiento e inversiones en las cadenas de valor del sector agroalimentario (porcentaje de las respuestas)}

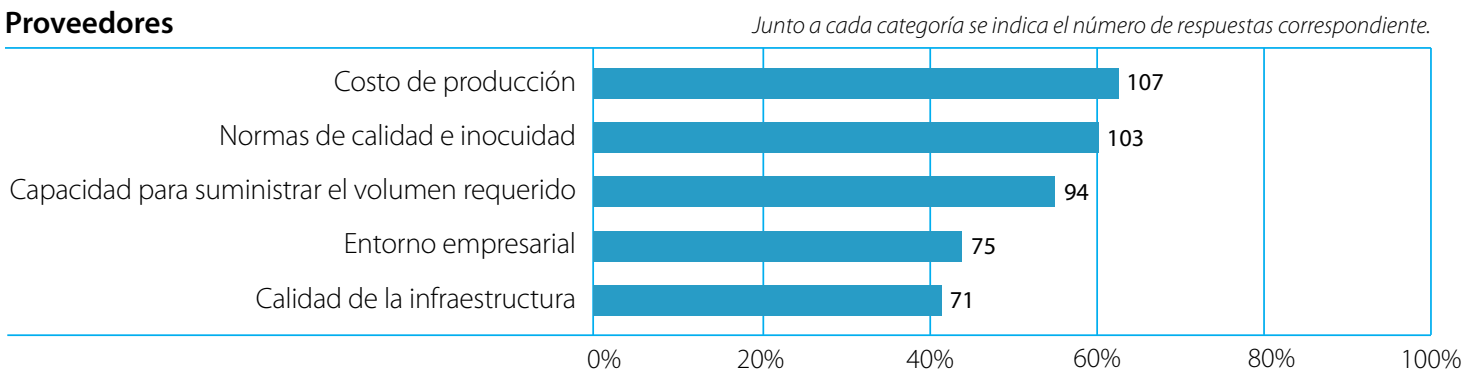

\section{Empresas líderes (factores positivos)}

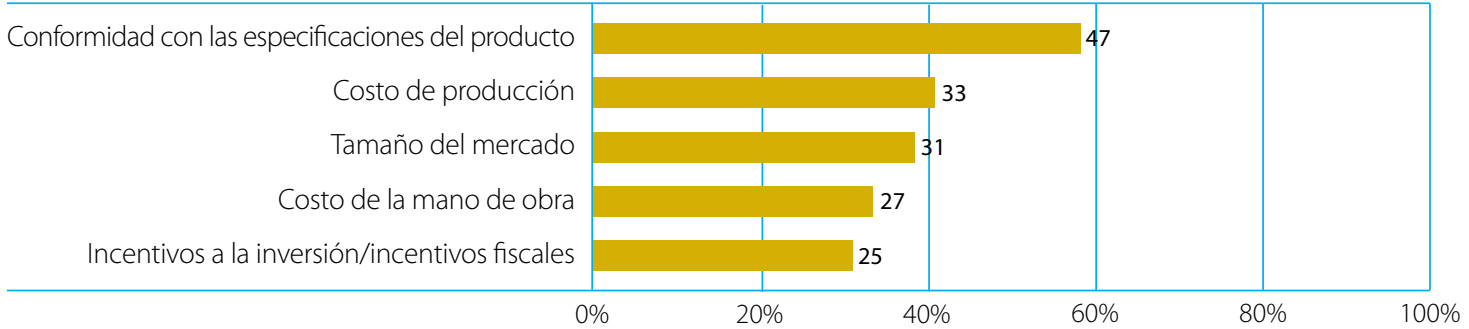

Empresas líderes (factores negativos)

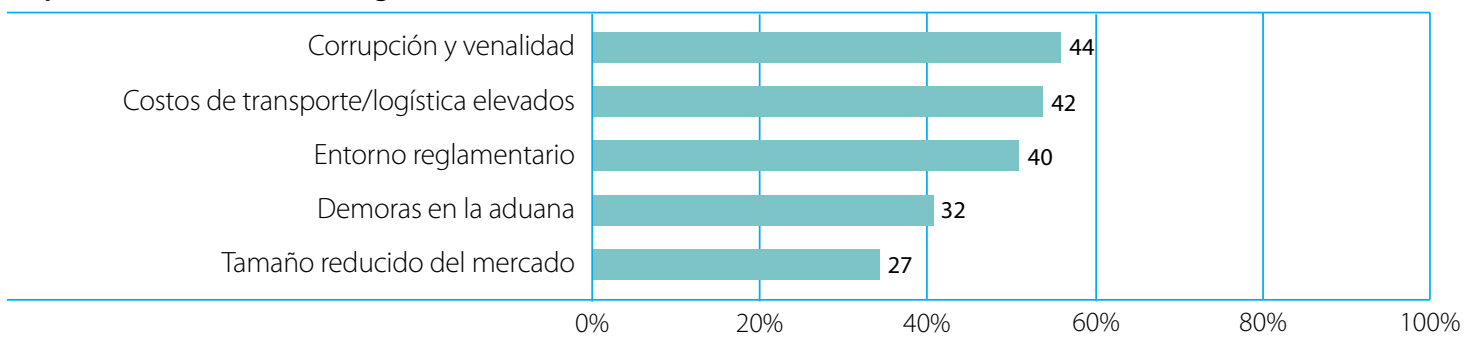

Fuente: Cuestionario OCDE/OMC 2013,www.aid4trade.org.

De los 160 proveedores de países en desarrollo que respondieron al cuestionario, el 70\% era beneficiario de una iniciativa gubernamental; el 50\% era beneficiario de una iniciativa de un organismo de desarrollo y el $20 \%$ era beneficiario de una iniciativa de una empresa extranjera. Para las empresas que recibían apoyo, los efectos más importantes de la ayuda habían sido la obtención de mejor información sobre los mercados de exportación (46\% de las respuestas), la diversificación geográfica de los mercados y la diversificación de los productos de exportación (46\% en relación con mercados nuevos y 25\% en relación con la exportación de nuevos productos), una mayor conformidad con las normas (33\%) y una mayor competitividad (28\%). Menos del 5\% de las empresas encuestadas consideraban que la ayuda para el comercio no tenía efecto alguno o era contraproducente. 


\section{Textiles y prendas de vestir}

La rama de producción de los textiles y las prendas de vestir desempeña un papel fundamental en el desarrollo industrial de muchos países de ingresos bajos y países menos adelantados. Como se trata de una actividad con baja intensidad de capital, gran intensidad de mano de obra y que utiliza una tecnología de producción relativamente sencilla, se ha convertido en un sector característico de las etapas tempranas del proceso de industrialización (Gereffi y Memedovic, 2003). Las exportaciones de esa rama de producción, en particular de prendas de vestir, constituyen una proporción importante de las exportaciones totales de manufacturas de algunos PMA, como Lesotho (70\%), Bangladesh (71\%), Camboya (85\%) y Haití (86\%) (Frederick y Staritz, 2012). Además, el sector genera importantes posibilidades de empleo para los trabajadores no cualificados, en su mayoría mujeres. Para los países en desarrollo, un beneficio evidente del ingreso en las cadenas de valor del sector de los textiles y las prendas de vestir es que dichas cadenas dan empleo a muchas mujeres, sobre todo jóvenes y con un bajo nivel de formación (por ejemplo, la proporción de trabajadoras en este sector es del 80\% en Bangladesh, el 82\% en Sri Lanka y el 89\% en Camboya) (OIT, 2005).

Al expirar el Acuerdo sobre los Textiles y el Vestido de la OMC el $1^{\circ}$ de enero de 2005, el comercio mundial de prendas de vestir, que hasta entonces había sido un comercio dirigido, pasó a una situación de competencia mundial más abierta. Sin embargo, el mercado sigue estando sujeto a distorsiones, como la progresividad arancelaria, las crestas arancelarias y la utilización continuada de subvenciones a la exportación. Como resultado del estancamiento de las negociaciones de la Ronda de Doha para el Desarrollo, ha quedado sin resolver la cuestión del acceso libre de derechos y de contingentes para las exportaciones de los PMA, aunque ha habido algunos progresos: se han mejorado los regímenes vigentes, mientras que diversas economías desarrolladas y economías emergentes han introducido nuevos regímenes. Los regímenes de acceso preferencial -en particular el régimen "Todo menos armas" de la UE, la Ley sobre Crecimiento y Oportunidades para África de los Estados Unidos y los Sistemas Generalizados de Preferencias de esos dos Miembros de la OMC- desempeñan un papel importante en la definición de las condiciones de acceso a los mercados mundiales de los países de bajos ingresos. En 2011 el valor conjunto de las importaciones de prendas de vestir de la UE (44\%) y los Estados Unidos (23\%) representó dos terceras partes del valor total de las importaciones mundiales de prendas de vestir (431.000 millones de dólares EE.UU.). Los mercados de varios países emergentes también están cobrando importancia como mercados de destino. Entre 2009 y 2011 las importaciones del Brasil, Chile, China, la India, la Federación de Rusia y Tailandia aumentaron entre el 65\% y el 132\%. El valor total de las importaciones de prendas de vestir de esos seis mercados fue de 17.100 millones de dólares EE.UU. en 2011, en comparación con 3.900 millones de dólares EE.UU. en 2005.

La evolución de la política comercial y las condiciones de acceso a los mercados ha ido acompañada de una nueva dinámica en el mercado de las prendas de vestir. Las cadenas de suministro han experimentado una profunda reestructuración para atender a las nuevas demandas del mercado de "moda rápida", caracterizado por la brevedad de los plazos para la expedición de mercancías, mayores exigencias de calidad y bajo volumen de existencias a nivel del comercio minorista. Esa reestructuración hacia nuevos estilos y modelos asigna prioridad a los ciclos de entrega más cortos, una mano de obra más cualificada y una mejor gestión de la cadena de suministro, en particular en relación con la producción de tejidos, el abastecimiento de materias primas y el proceso de acabado. A escala global, los compradores e intermediarios de todo el mundo acuden con creciente frecuencia a proveedores que pueden suministrar materias primas, coordinar las operaciones de logística, promover la creatividad y operar en lugares dispersos geográficamente a fin de acortar los ciclos de entrega. La necesidad de contar con redes de transporte rápido y fiable y de reducir al mínimo el tiempo necesario para el despacho de aduanas ha adquirido tanta importancia como el costo de la mano de obra y las materias primas. 


\section{Gráfico 3.10 Dificultades con que se tropieza para conectar a los países en desarrollo a las cadenas de valor del sector de los textiles y las prendas de vestir (porcentaje de respuestas)}

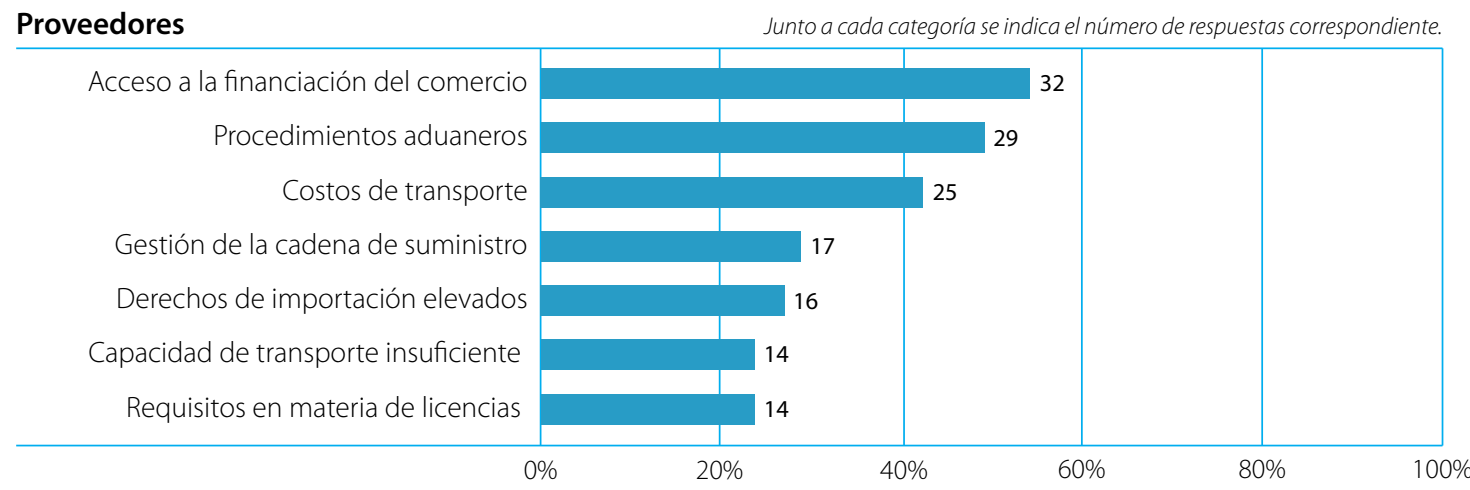

\section{Empresas líderes}

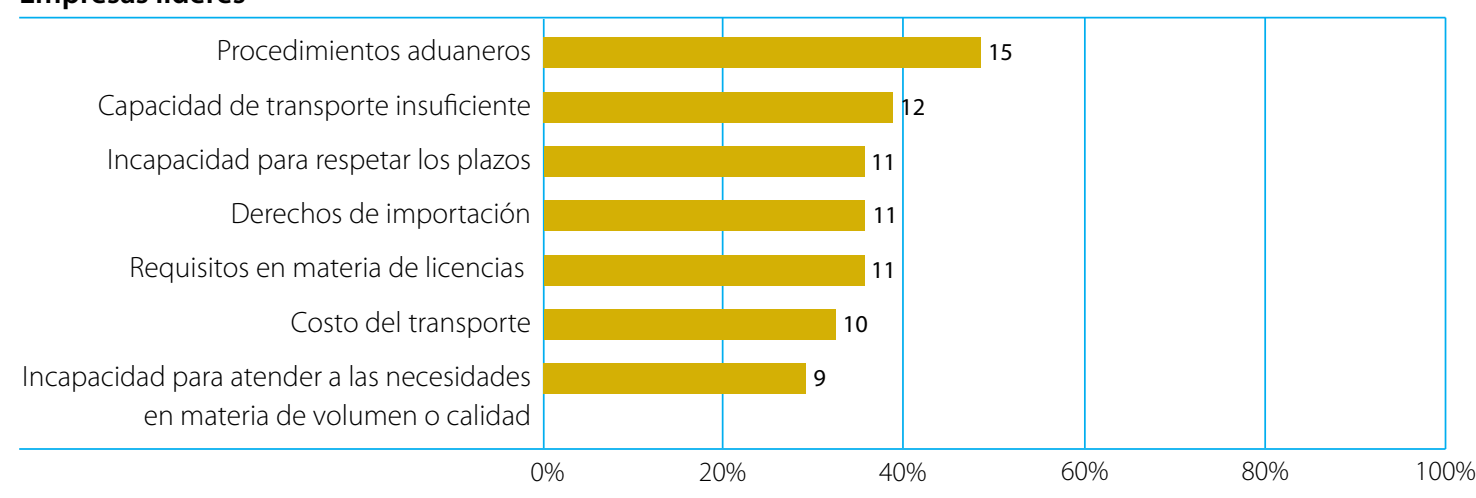

Fuente: Cuestionario OCDE/OMC 2013,www.aid4trade.org.

El resultado de esa evolución ha sido la fusión, en medida considerable, de las cadenas de suministro, con la consiguiente reducción del número de países y aumento del tamaño de los proveedores, y el surgimiento de relaciones estratégicas de abastecimiento. Los principales compradores ya no recurren a múltiples empresas pequeñas que prestan servicios de corte, confección y acabado a la vieja usanza, sino que establecen relaciones comerciales con un número menor de proveedores estratégicos, que gestionan la producción en muchas fábricas y en muchos lugares del mundo, comparten la responsabilidad financiera, proporcionan servicios con mayor valor añadido y, en definitiva, obtienen una proporción mayor de las utilidades del comercio de textiles y prendas de vestir. A partir de 2005, la fabricación de prendas de vestir disminuyó abruptamente en la República Dominicana (-194\%), Costa Rica (-174\%), Filipinas (-63\%), México (-57\%), el Taipei Chino (-57\%), Swazilandia (-51\%) y Sudáfrica (-45\%), pero su valor ha aumentado fuertemente en Bangladesh (+192\%), Viet Nam (+181\%), China (+106\%), Malasia (+84\%), Camboya (+82\%), el Pakistán (+79\%) y la India (+64\%).

Las respuestas al cuestionario de la OCDE y la OMC recibidas reflejan esos cambios en la dinámica del mercado. En total se recibieron 106 respuestas de 47 países, incluidas las respuestas de 39 empresas líderes de 27 países (19 de ellas de países o territorios en desarrollo) y de 63 proveedores de 35 países en desarrollo. Cinco de las empresas líderes y uno de los proveedores de países en desarrollo tenían ingresos superiores a los 1.000 millones de dólares EE.UU. 
Tanto los proveedores de países en desarrollo como las empresas líderes (gráfico 3.10) asignaban alta prioridad a los procedimientos aduaneros (32 respuestas y 15 respuestas, respectivamente). La eficiencia de los procedimientos aduaneros es sumamente importante en una cadena de valor caracterizada por el bajo volumen de las existencias a nivel del comercio minorista, el gran volumen de pedidos y los procesos de fabricación "justo a tiempo", que permiten responder a los rápidos cambios en las tendencias de la moda. La importancia de la rapidez también se observa en la alta prioridad asignada a la necesidad de eliminar las limitaciones resultantes del costo y las demoras en relación con la expedición de mercancías (25 respuestas de proveedores y 10 de empresas líderes) y de la falta de capacidad suficiente de los medios o las conexiones de transporte aéreo, marítimo o terrestre (12 respuestas de empresas líderes). Las políticas comerciales siguen constituyendo un obstáculo más importante en la rama de producción de los textiles y las prendas de vestir que en la mayoría de las demás cadenas de valor: 16 proveedores y 11 empresas líderes mencionaron los elevados derechos de importación y los acuerdos de exportación y de concesión de licencias.

Por su parte, los proveedores mencionaron el acceso a la financiación como el obstáculo más importante con que tropezaban para incorporarse a las cadenas de valor en el sector de los textiles y las prendas de vestir (52\%). Como resultado de la crisis económica de 2008-2009, todos los compradores tomaron conciencia de la importancia que revestía la estabilidad financiera de los proveedores. La crisis ha incrementado considerablemente las dificultades para obtener crédito y, en el futuro, las empresas tendrán que demostrar su solidez financiera para poder convertirse en proveedores. Para colmo, algunos clientes se están demorando en pagar y los bancos están restringiendo el acceso al crédito. La disminución general del acceso al crédito afecta a todos los proveedores, pero las más perjudicadas como resultado de la renuencia de quienes conceden los créditos a asumir riesgos en sus decisiones sobre préstamos son las pequeñas y medianas empresas y las empresas de propiedad local (cuyo capital de explotación es menor) (Barrie y Ayling, 2009; Driscoll y Wang, 2009).

Al preguntárseles sobre los factores que influían en sus decisiones en materia de fuentes de abastecimiento e inversiones en las cadenas de valor, tanto los proveedores como las empresas líderes mencionaron los costos de producción (70\% y 48\%, respectivamente) y la capacidad de cumplir con las normas (50\% y 48\%, respectivamente). Hubo mucho menos acuerdo en cuanto a la importancia de las competencias de la fuerza de trabajo: para los proveedores la falta de competencias era un obstáculo importante (55\%), mientras que para las empresas líderes ese factor tenía menor importancia (19\%). Esa divergencia de opiniones refleja probablemente las diferentes perspectivas de los encuestados. Mientras que los contingentes contribuyen inicialmente al establecimiento de la industria textil y de prendas de vestir en los países en desarrollo, para que un país pueda mantener o mejorar su posición en la cadena de valor mundial de prendas de vestir se requiere un proceso continuo de capacitación de la fuerza de trabajo. A largo plazo, la capacidad de innovación depende de que se disponga del capital humano adecuado (Gereffi y Frederick, 2010).

\section{Turismo}

En 2012 el número de arribos de turistas superó los 1.000 millones por vez primera. A pesar de perturbaciones esporádicas, el número de arribos de turistas internacionales ha aumentado prácticamente de manera ininterrumpida: de 277 millones en 1980, a 528 millones en 1995 y a 1.035 millones en 2012." Los países en desarrollo desempeñan un papel cada vez más destacado en este sector en expansión. El turismo es uno de los tres principales productos de exportación de la mayoría de los países en desarrollo. Asimismo, es el primer producto de exportación de, por lo menos, 11 PMA y representa un importante sector de la actividad económica de todos los PMA que han logrado salir de la categoría de países menos adelantados o que están a punto de hacerlo. 


\section{Gráfico 3.11 Dificultades con que se tropieza para conectar a los países en desarrollo a las cadenas de valor del sector del turismo (porcentaje de respuestas)}

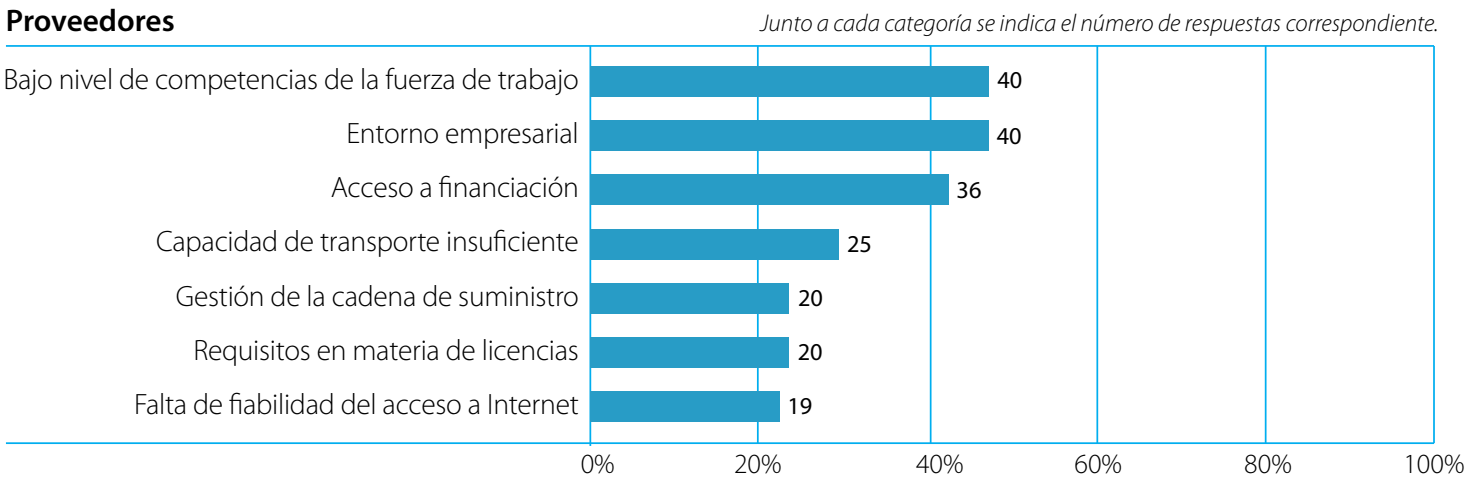

\section{Empresas líderes}

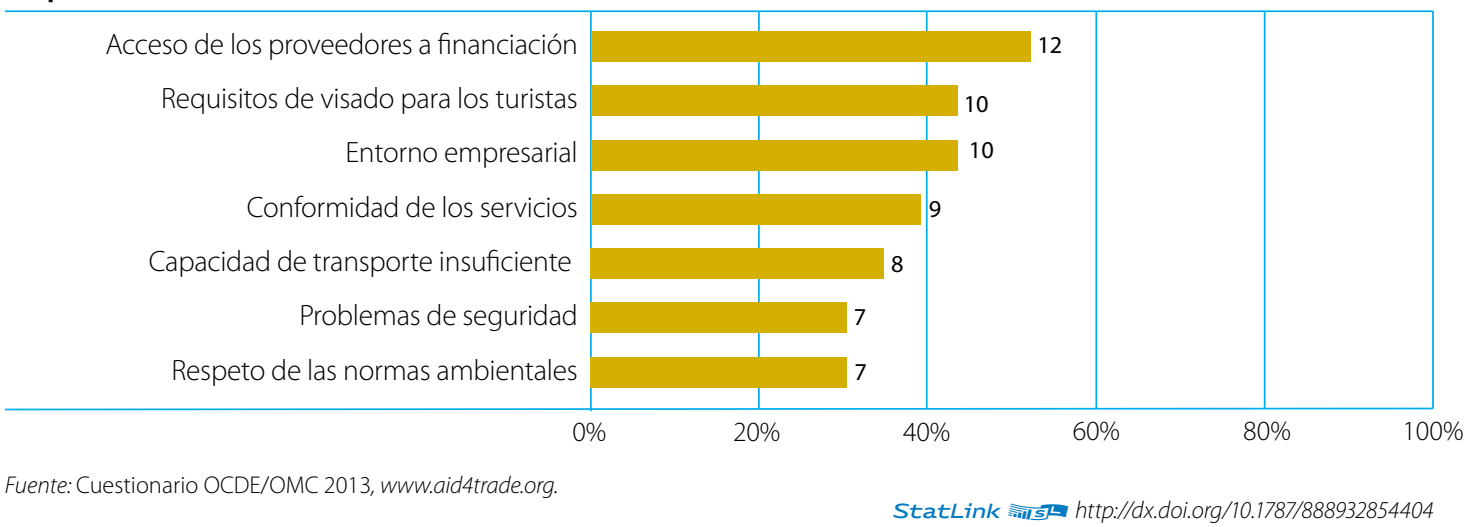

El sector del turismo contribuye al crecimiento económico de los países en desarrollo y puede ser una fuente importante de crecimiento adicional. El turismo genera mucho empleo y está vinculado a otros muchos sectores de la economía. Además, contribuye directamente a reducir la pobreza, especialmente entre las mujeres. Esas ventajas han sido reconocidas por los encargados de formular políticas a nivel nacional e internacional. En las estrategias de desarrollo de los PMA y de otros países de bajos ingresos con frecuencia se asigna especial importancia al sector del turismo y se reconoce su gran potencial para estimular el crecimiento y reducir la pobreza. En la mayoría de los estudios de diagnóstico sobre la integración comercial de los PMA se indica que el turismo es un sector prioritario para el crecimiento y las exportaciones.

En la presente sección se examinan las cadenas de valor en el sector del turismo y la función que cumplen las empresas de países en desarrollo en ese sector global. Se hace especial hincapié en la identificación de los obstáculos con que tropiezan las empresas de los países en desarrollo para conectarse a las cadenas de valor en el sector del turismo, o que hacen que a los países en desarrollo les resulte difícil beneficiarse con el turismo. El análisis está basado en las 113 respuestas de empresas líderes y operadores turísticos de países en desarrollo en 46 países a una encuesta de seguimiento realizada conjuntamente por la OCDE, la OMCy la Organización Mundial del Turismo (OMT) en colaboración con la Cámara de Comercio Internacional (CCI), el Centro de Comercio Internacional (ITC) y la iniciativa "Grow Africa". En total respondieron a la encuesta 23 empresas líderes de 17 países (entre ellos, seis países en desarrollo) y 83 operadores turísticos de 34 países en desarrollo. Tres de las empresas líderes tenían una cifra de negocios superior a los 1.000 millones de dólares anuales. De las respuestas a la encuesta (gráfico 3.11) se desprende en particular lo siguiente: 
- La calidad del entorno empresarial general y el acceso a la financiación son elementos fundamentales para que los proveedores de los países de ingresos bajos y medianos puedan funcionar de forma eficaz y conectarse a las cadenas de valor mundiales. Esta observación concuerda con las conclusiones de estudios empíricos sobre el tema y observaciones empíricas.

- Las competencias del personal son otro factor decisivo para el éxito de los proveedores de servicios en el sector del turismo. Aunque en los estudios efectuados en el pasado se ha prestado menos atención a este factor, no es sorprendente que las competencias sean un factor importante en vista de la frecuencia y la importancia de los contactos personales entre los proveedores de servicios y los clientes en el sector del turismo.

- La apertura a las importaciones, la seguridad y un régimen de visados que funcione sin tropiezos son otros elementos indispensables para el crecimiento sostenido y sostenible del sector del turismo.

- La disponibilidad y la calidad de la infraestructura desempeñan un papel fundamental en el desarrollo del sector del turismo porque permiten a los turistas ingresar en el país y viajar en él.

A fin de aprovechar al máximo los efectos benéficos del sector del turismo en otros sectores de la economía, es importante tener en cuenta los vínculos con esos otros sectores, como la posibilidad de obtener alimentos producidos por la economía local, ofrecer otros servicios de esparcimiento o vender productos locales a los turistas. Se está tratando cada vez más de planificar el crecimiento del sector sobre la base de una utilización eficiente de los recursos, especialmente el agua y la energía, a fin de controlar el impacto del sector en el medio ambiente.

Se requiere una gestión cuidadosa de los vínculos con otras partes de la economía para que el sector del turismo pueda desarrollar plenamente su potencial. En el ámbito de la formulación de la política nacional, es necesario coordinar las actividades de distintos ministerios -en particular los de turismo y comercio- con las de otros organismos, comunidades de empresarios y autoridades locales. En el contexto de la ayuda para el comercio, se necesitará la coordinación entre los organismos de ejecución de los donantes y los países asociados, y entre distintas esferas destinatarias de la ayuda -en particular la infraestructura y el turismo- y posiblemente un incremento del volumen habitual de los proyectos de ayuda destinados al sector del turismo.

Hay pruebas de que los donantes y los organismos de ejecución reconocen la necesidad de coordinar los proyectos de asistencia técnica en la esfera del turismo. Varios proyectos recientes tratan de fortalecer simultáneamente el sector del turismo propiamente dicho y los sectores de suministro, como las artesanías o la agricultura. La ejecución de esa clase de proyectos se ve facilitada por la creciente coordinación entre los organismos internacionales, especialmente en el marco del Comité Directivo de las Naciones Unidas sobre turismo para el desarrollo.12

\section{Transporte y logística}

El transporte y la logística es un sector en que las cadenas de valor mundiales desempeñan una función fundamental ya que sirven para conectar a los países, difundir tecnología y promover las mejores prácticas en todo el mundo. En este sector, las cadenas de valor se caracterizan por la diversidad de las empresas líderes que participan en ellas - entre las que se cuentan importantes empresas de transporte marítimo, de envíos urgentes y de expedición de carga - y la diversidad de las empresas locales con las que se asocian. Cada vez más las cadenas de valor en el sector del transporte y la logística están ampliando el alcance de sus operaciones a los países en desarrollo, en particular algunos países de ingresos bajos y países menos adelantados. 
Además de la función que desempeña como cadena de valor, el sector del transporte y la logística también tiene importancia decisiva para el funcionamiento de otros sectores de la economía. Los sectores manufacturero y agrícola dependen del transporte para que sus productos lleguen a los consumidores de forma rápida, económica y fiable. El modelo empresarial basado en cadenas de valor, que tanta importancia ha adquirido en sectores como la electrónica o la agroalimentación, no puede ponerse en práctica sin un sector de transporte y logística sólido en cada uno de los países que participan en la cadena de valor. Los datos parecen indicar que los países con mejor desempeño a nivel de la logística tienden a especializarse en mayor medida en las cadenas de valor del sector manufacturero.

En efecto, el transporte y la logística tienen vínculos directos o indirectos con importantes objetivos de desarrollo económico y social. Por un lado, el sector puede incrementar los resultados comerciales, lo que, en circunstancias apropiadas, genera un aumento de los ingresos, más empleo y la reducción de los índices de pobreza. Además, el desempeño del sector es uno de los principales factores que determinan la capacidad de los gobiernos para distribuir entre la población, al costo más bajo posible, importantes productos necesarios para el desarrollo humano, como alimentos básicos y vacunas, en especial en zonas alejadas.

Según los datos disponibles, en el mundo en desarrollo se observa una alentadora tendencia a mejorar muchos aspectos del funcionamiento del sector del transporte y la logística. Desde luego, los resultados varían considerablemente de una región a otra, lo que es indicio de que existen importantes posibilidades de intercambio de conocimientos Sur-Sur en la materia. En cuanto a los principales factores que influyen en el funcionamiento de la cadena de valor en el sector del transporte y la logística, según un estudio realizado por la OCDE y la OMC ${ }^{13}$ sobre la base de información proporcionada por el sector privado (gráfico 3.12) pueden observarse las siguientes tendencias:

- Infraestructura: la falta de una infraestructura comercial y de transporte adecuada sigue constituyendo una grave limitación en muchos países en desarrollo. Sin embargo, hay indicios de que en los últimos años la situación ha mejorado en el África Subsahariana, el Oriente Medio y el África septentrional. No obstante, la tendencia más sorprendente es la rápida difusión de la tecnología de la información y las comunicaciones en la mayoría de las regiones en desarrollo. La telefonía móvil, en particular, podría contribuir en gran medida a subsanar los problemas en materia de comunicaciones, especialmente en las zonas rurales. La disponibilidad de dispositivos de telecomunicaciones baratos y de fácil uso reviste especial interés a la hora de establecer agrupaciones en el sector agropecuario o el turismo ecológico en países en desarrollo. Ésta es una esfera en que los donantes (multilaterales y bilaterales), los gobiernos de los países asociados y el sector privado han hecho importantes contribuciones para lograr un resultado significativo en términos de desarrollo.

- Procedimientos aduaneros y otros procedimientos en frontera: en la mayoría de las regiones se observan mejoras evidentes en este ámbito, pero las mejoras a nivel de los procedimientos aduaneros son más marcadas. En parte, esta dinámica refleja la difusión mundial de las mejores prácticas mediante instrumentos internacionales, así como la participación activa de los donantes y los países asociados en la modernización de los procedimientos aduaneros. No obstante, para mejorar el funcionamiento de las cadenas de suministro, también hay que prestar atención a otros organismos que intervienen en la frontera, como los organismos de salud/cuarentena y los responsables de aplicar medidas sanitarias y fitosanitarias. Esos organismos son especialmente importantes en el caso de los países en desarrollo que participan en cadenas de valor emergentes en el sector agroalimentario. 


\section{Gráfico 3.12 Dificultades con que se tropieza para conectar a los países en desarrollo a las cadenas de valor en el sector del transporte y la logística (porcentaje de respuestas)}

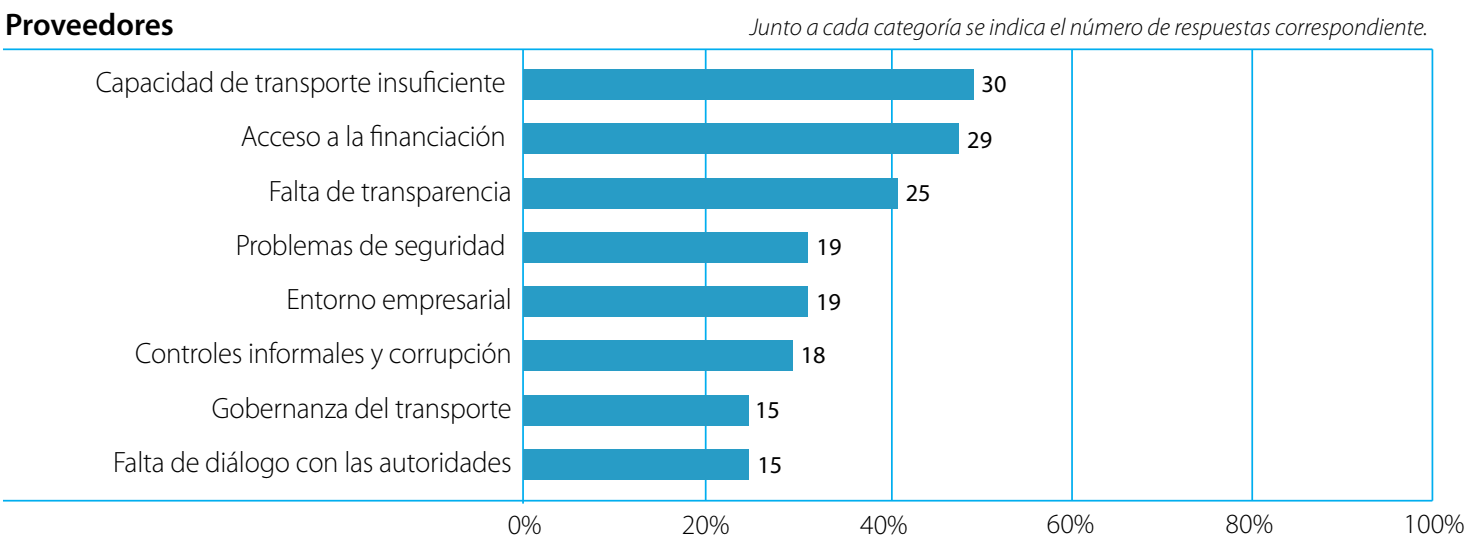

\section{Empresas líderes}

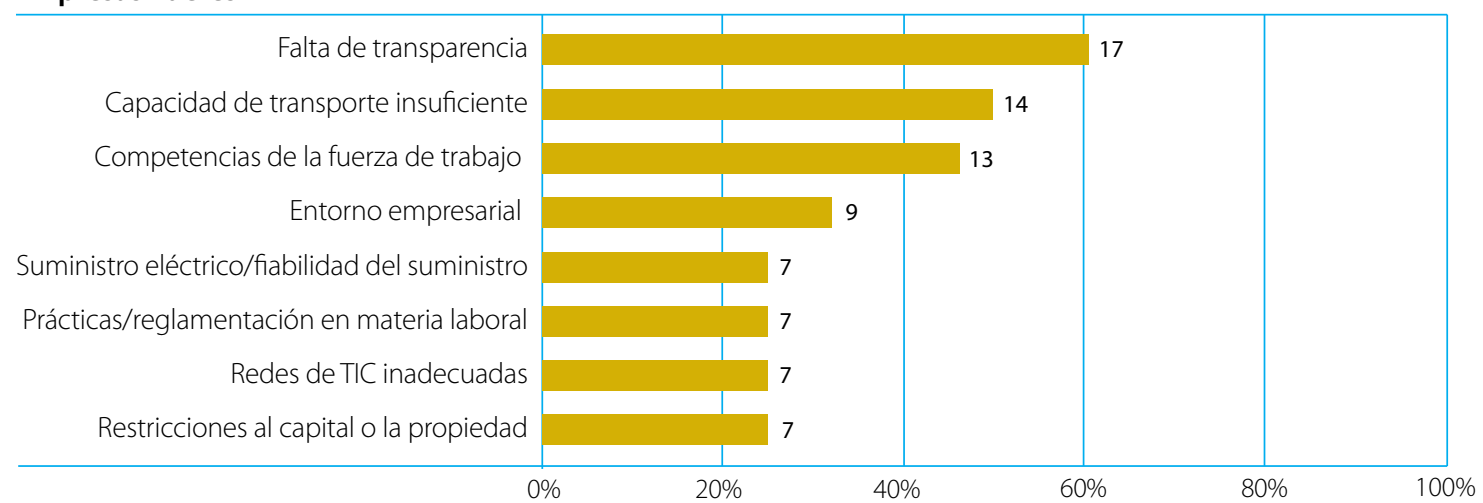

Fuente: Cuestionario OCDE/OMC 2013,www.aid4trade.org.

Servicios del sector privado y reglamentación: los datos indican que, en líneas generales, la calidad de los proveedores privados de servicios de transporte y logística está mejorando a nivel mundial, por lo que parecería que los esfuerzos orientados al desarrollo del sector privado en este ámbito están dando fruto. En cambio, en lo que respecta a la reglamentación que apoya y determina el desempeño del sector privado, las mejoras avanzan con más lentitud. Es importante que quienes se encargan de formular las políticas, así como quienes tienen la responsabilidad de regular el sector, velen por que la mayor participación del sector privado no se vea inhibida por un entorno reglamentario indebidamente restrictivo.

- Trámites burocráticos: según datos del proyecto del Banco Mundial "Doing Business", si bien es evidente que en muchos aspectos el funcionamiento de las cadenas de valor en el sector del transporte y la logística ha mejorado, los trámites burocráticos siguen siendo un problema grave para los importadores y exportadores en muchos países en desarrollo. En años recientes, las formalidades en materia de documentación apenas han disminuido mientras que los costos han aumentado en muchos países. Muchos países deberían seguir reduciendo las demoras y mejorar el funcionamiento de las cadenas de suministro mediante la racionalización de los requisitos burocráticos. 
- Gobernanza: frente a un exceso de formalidades burocráticas, los operadores frecuentemente se muestran más dispuestos a efectuar pagos oficiosos para acelerar los trámites, lo que atenta contra la optimización de la gobernanza. Los datos indican que los problemas a nivel de la gobernanza siguen siendo una importante limitación en muchos países en desarrollo. La incertidumbre vinculada a una gobernanza deficiente de la cadena de suministro puede significar un aumento de los costos indirectos de los operadores. Por lo general, los proveedores de servicios de transporte y logística prefieren aceptar una demora conocida de antemano, aunque no sea todo lo breve que debería ser, que hacer frente a una demora altamente incierta. Por consiguiente, el mejoramiento de la gobernanza debería ser un aspecto importante de la optimización de las cadenas de valor en todo el mundo.

Los países asociados en general están de acuerdo en que la inversión privada nacional y extranjera y la asistencia oficial para el desarrollo son fuentes importantes de financiación para el desarrollo de las cadenas de valor en el sector del transporte y la logística. Según los países asociados, las siguientes esferas seguirán siendo de fundamental importancia para el sector: Infraestructura física: muchos países en desarrollo siguen necesitando inversiones considerables en infraestructura básica, como puertos, aeropuertos, carreteras y enlaces ferroviarios. Sin embargo, no basta con movilizar fondos para la inversión inicial; también se necesita disponer de fondos para el mantenimiento continuo de las instalaciones, de modo que sigan siendo productivas durante años. Infraestructura "no física": el desarrollo de la infraestructura física sólo reporta máximos beneficios cuando va acompañado de la reglamentación necesaria del sector del transporte, ya que en ella se establecen las condiciones para el acceso de los operadores a importantes puntos de entrada internacionales. Los procedimientos aduaneros y en frontera también son importantes, ya que pueden ser causa de las demoras y la incertidumbre que afrontan los comerciantes. Por último, el desarrollo del sector privado también es decisivo, pues este sector es el motor de la modernización tecnológica del sector del transporte y la logística, función cuya importancia aumenta a medida que se desarrollan las cadenas de valor en el sector del transporte y la logística.

\section{Tecnología de la información y las comunicaciones}

Las cadenas de valor del sector de la tecnología de la información y las comunicaciones (TIC) están integradas por empresas que realizan una amplia gama de actividades manufactureras y de prestación de servicios. Debido a las normas técnicas y a la normalización de diseños e interfaces, las cadenas de valor dedicadas a la fabricación de productos de la TIC tienen carácter modular; en ellas los proveedores producen componentes siguiendo el diseño que proveen las empresas líderes. Como resultado de ese carácter modular, la fabricación de productos de la TIC es una de las actividades en que el proceso de producción está más fragmentado a nivel internacional y en que la proporción de insumos importados es muy elevada.

Las cadenas de valor dedicadas a la fabricación de productos de la TIC están concentradas en la "Fábrica Asia". China, el Japón y Corea son los productores más grandes; las exportaciones chinas de productos de la TIC representan el 37\% de las exportaciones mundiales de productos de la TIC. Con excepción de la India, Indonesia y Filipinas, los países menos adelantados y los países de ingresos medianos y bajos participan marginalmente en la producción y el comercio que tienen lugar en el marco de cadenas de fabricación de productos de la TIC. La posibilidad de que un país en desarrollo se integre satisfactoriamente en las cadenas de valor dedicadas a la fabricación de productos de la TIC depende, entre otras cosas, de su proximidad a un gran mercado o a una red regional de producción como la "Fábrica Asia". 
Los servicios de TIC pueden ofrecer a los países en desarrollo más posibilidades de integración en las cadenas de valor de la TIC, ya que la distancia y las economías de escala son menos importantes que en el caso de las manufacturas. Además, los servicios de TIC, como las telecomunicaciones y los servicios de informática, son insumos vitales para otros sectores y, por ende, de crucial importancia para la productividad de las empresas nacionales y el desarrollo económico general de un país. Las respuestas al cuestionario de la OCDE y la OMC destinado a los países asociados confirman que los países en desarrollo asignan mayor prioridad a los servicios de TIC que a la fabricación de productos de la TIC. Más del 55\% de los receptores de asistencia oficial para el desarrollo ha incluido los servicios de comunicaciones y los servicios de informática e información en sus estrategias de desarrollo, pero sólo el 12\% ha incluido la fabricación de equipo de oficina y telecomunicaciones.

La reglamentación de las telecomunicaciones desempeña una importante función en la productividad de las empresas y el desarrollo económico al promover el acceso universal y garantizar la competencia. Desde mediados del decenio de 1990, los países en desarrollo vienen privatizando a los operadores de propiedad estatal, estableciendo organismos de reglamentación independientes e introduciendo la competencia en el mercado. La mayoría de los países de América Latina ha abierto plenamente sus mercados de telecomunicaciones a la competencia, en tanto que en África y los Estados Árabes siguen existiendo algunos monopolios o la competencia sigue siendo limitada. Al igual que en el caso de los países desarrollados, los países en desarrollo se enfrentan con problemas de reglamentación, como los que se plantean a nivel de la gestión del espectro o la interconexión mediante el Protocolo de Internet. Los países en desarrollo han avanzado considerablemente en la liberalización de sus mercados de telecomunicaciones, pero algunos de ellos siguen aplicando restricciones a la propiedad extranjera o conservan facultades discrecionales en relación con la concesión de licencias y la entrada de empresas extranjeras.

El acceso a la infraestructura de la TIC y su utilización son condiciones necesarias para el desarrollo económico y pueden servir de importante catalizador para el logro de los Objetivos de Desarrollo del Milenio. Desde 2005, los países en desarrollo han realizado considerables progresos en el desarrollo de la infraestructura de la TIC. En los PMA, la penetración de la telefonía móvil aumentó del 7\% en 2005 al 46\% en 2011. A pesar de esos progresos, la brecha digital entre los países desarrollados y los países en desarrollo, en particular los PMA, sigue siendo considerable. Sólo el $7 \%$ de los habitantes de los PMA utilizan Internet y la penetración de la banda ancha fija es inferior al 1\%. Sin embargo, está aumentando rápidamente el acceso a la banda ancha móvil, y se prevé que el porcentaje de abonados en África aumentará del 4\% en 2011 al 11\% para finales de 2013.

Tras la difusión de la telefonía móvil, los países en desarrollo deben hacer frente ahora al desafío de garantizar a particulares y empresas el acceso a la banda ancha necesario para fomentar el crecimiento y el desarrollo económicos. Aunque las inversiones de infraestructura en cables submarinos están impulsadas en buena medida por el sector privado, la financiación del desarrollo y la asociación entre los sectores público y privado pueden incentivarlas y multiplicar sus efectos. Además de facilitar las inversiones en infraestructura, los organismos encargados de la formulación de políticas y de la reglamentación se enfrentan con el desafío de aumentar la competencia en el acceso a cables submarinos de manera que la disminución de los precios de acceso acelere la difusión de la banda ancha.

La TIC facilita el desarrollo económico y social de las empresas y los hogares que la utilizan. Gracias a Internet y la telefonía móvil el comercio electrónico se ha hecho realidad. El comercio electrónico proporciona a los empresarios mayor acceso a los mercados nacionales y extranjeros y permite suministrar nuevos tipos de servicios, como las transferencias de dinero mediante teléfonos móviles. No obstante, los países en desarrollo siguen enfrentándose con importantes problemas a nivel del comercio electrónico, como la falta de acceso a Internet, la inseguridad de los sistemas de pago, la falta de "alfabetización digital" o de redes de distribución adecuadas y procedimientos aduaneros inadecuados para la expedición de los productos vendidos en línea. 


\section{Gráfico 3.13 Dificultades con que se tropieza para conectar a los países en desarrollo a las cadenas de valor en el sector de la tecnología de la información y las comunicaciones (porcentaje de respuestas)}

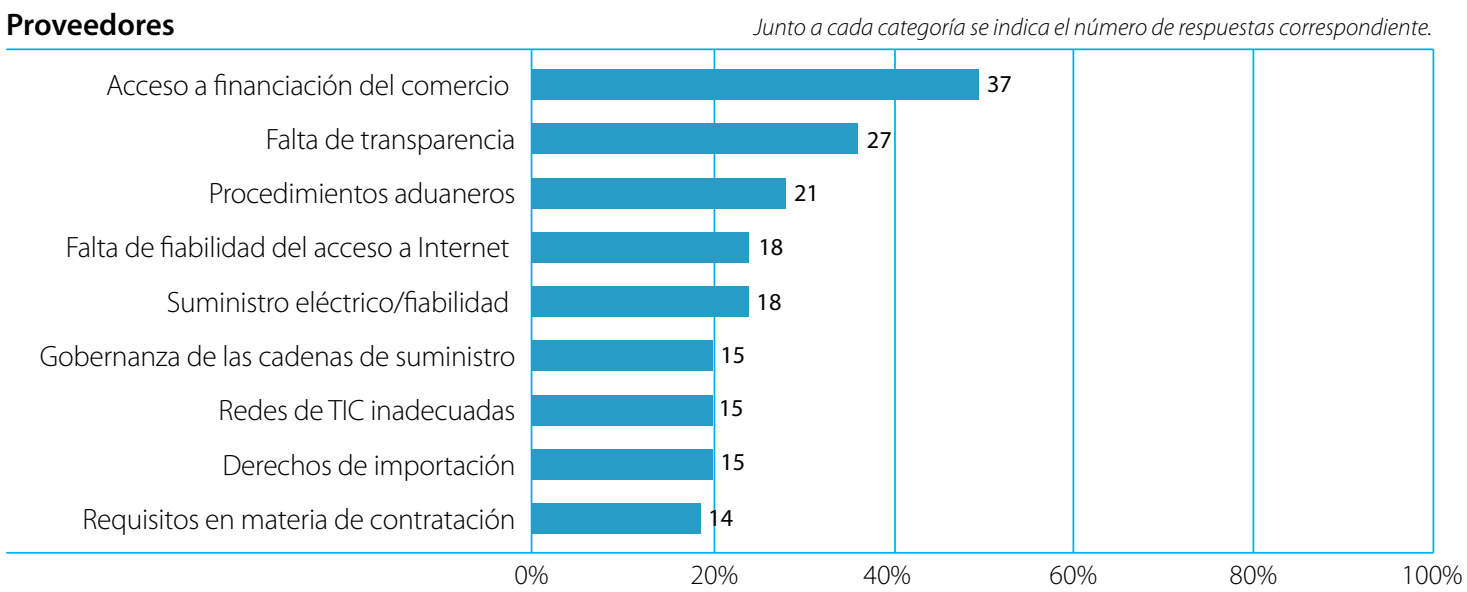

\section{Empresas líderes}

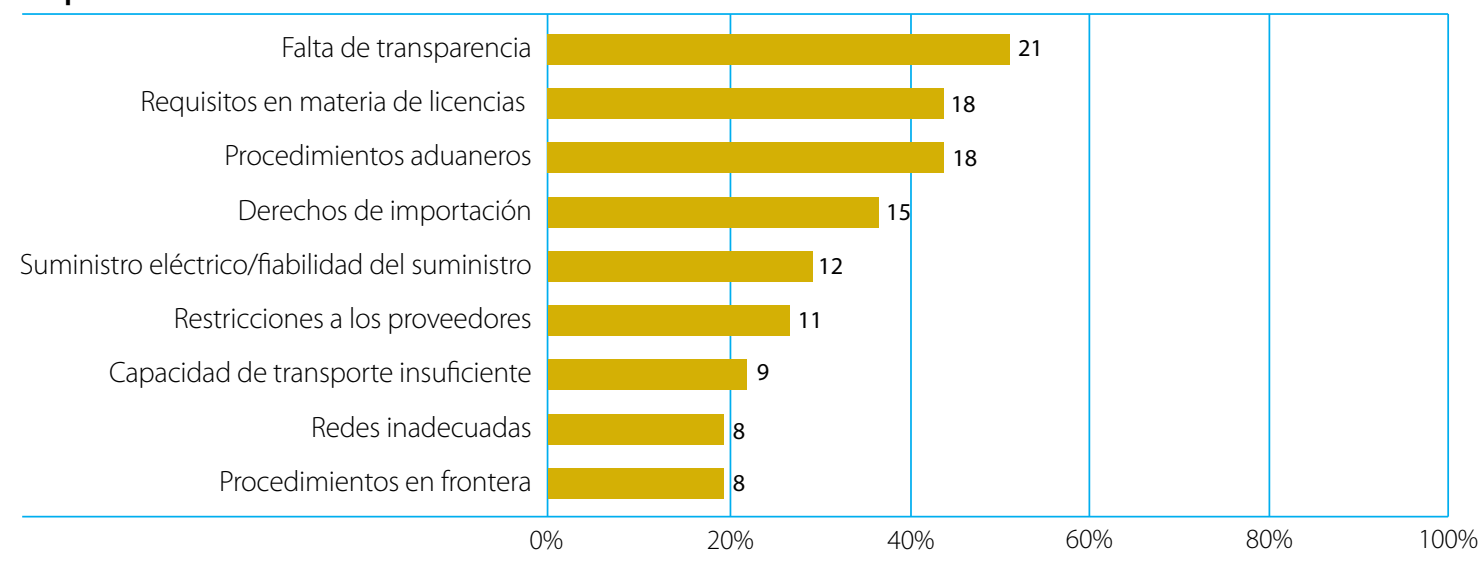

Fuente: Cuestionario OCDE/OMC 2013, www.aid4trade.org.

StatLink 完II

El análisis de las respuestas de 80 proveedores de 41 países y 44 empresas líderes de 30 países (nueve de ellas con una cifra de negocios anual superior a los 1.000 millones de dólares EE.UU.) al cuestionario de la OCDE y la OMC dirigido al sector privado da una idea de las principales dificultades con que tropiezan las empresas de los países en desarrollo cuando tratan de entrar en cadenas de valor de la TIC, establecerlas o avanzar en ellas.

Las dificultades relacionadas con el comercio que mencionan los proveedores -así como las empresas líderescon mayor frecuencia son la falta de acceso a la financiación del comercio y los procedimientos aduaneros (gráfico 3.13). Además, las empresas líderes consideran que las peticiones oficiosas de pago constituyen un problema habitual en sus relaciones comerciales con proveedores de países en desarrollo. Para los proveedores de países en desarrollo, las principales limitaciones a nivel de la oferta son la falta de acceso a la financiación, así como de mano de obra con cualificaciones en materia de TIC. Las empresas líderes consideran que el principal obstáculo a que hacen frente para establecer una presencia comercial en un país en desarrollo es la falta de un entorno empresarial favorable, así como de transparencia en el entorno reglamentario. 
Por consiguiente, en muchos casos, las empresas de TIC se enfrentan con problemas similares a los de los proveedores en otras cadenas de valor y se beneficiarían si recibiesen ayuda para el comercio destinada a subsanar limitaciones horizontales importantes, como las relacionadas con la financiación (incluida la financiación del comercio), el entorno empresarial y reglamentario, los procedimientos aduaneros y las demoras a nivel de las aduanas. Además, las intervenciones de la ayuda para el comercio son importantes para ayudar a superar tres obstáculos específicos del sector: la falta de mano de obra con conocimientos en materia de TIC, la falta de infraestructura de TIC adecuada y la reglamentación de los mercados de telecomunicaciones.

Además, las respuestas al cuestionario de la OCDE y la OMC revelan que, aunque para muchos proveedores de países en desarrollo la infraestructura de la TIC tiene la misma importancia que el suministro de electricidad, el suministro de electricidad es la principal limitación a nivel de la oferta a la que hacen frente los proveedores de los PMA. El volumen de la ayuda destinada a proyectos de TIC es muy inferior al de la ayuda destinada a la infraestructura de transporte y la energía, lo que obedece al hecho de que las inversiones en infraestructura de la TIC suelan correr a cargo del sector privado y requieran menos capital. Por otra parte, la brecha digital entre los países en desarrollo y los países desarrollados no se ha cerrado y, en el caso de los PMA, va en aumento.

\section{LA PARTICIPACIÓN DEL SECTOR PRIVADO}

La Iniciativa de la Ayuda para el Comercio siempre ha reconocido el papel fundamental que desempeña el sector privado. Los estudios de casos reunidos como parte de la preparación del tercer Examen Global de la Ayuda para el Comercio arrojaron algo de luz sobre la convergencia de los programas del sector público y el sector privado (Banco Mundial, 2011; OCDE/OMC, 2013). Además, los donantes y los países asociados han indicado que han intensificado el diálogo que mantienen con el sector privado (véase el capítulo 2).

En la presente sección se describen los principales factores que impulsan la participación del sector privado en las actividades de creación de capacidad en los países en desarrollo, y se proporciona la evaluación, por el sector privado, de la eficacia de los programas de los donantes para conectar a las empresas proveedoras de los países en desarrollo a las cadenas de valor. Por último, se presentan las enseñanzas que se han extraído de las iniciativas encaminadas a conectar a los proveedores de los países en desarrollo con las cadenas de valor.

La encuesta de la OCDE y la OMC proporciona información adicional sobre esta convergencia y sobre las asociaciones entre el sector público y el sector privado en la esfera de la ayuda para el comercio. De las 219 empresas líderes encuestadas, más del 65\% declaró que participaban en iniciativas destinadas a conectar mejor a los países en desarrollo a las cadenas de valor de las empresas. Esas iniciativas fundamentalmente partían de las propias empresas, pero también era importante el porcentaje de las que se emprendían en asociación con gobiernos y organismos donantes; más del $40 \%$ de las empresas líderes participaban en proyectos liderados por organismos de desarrollo (gráfico 3.14).

Gradualmente ha ido surgiendo una nueva generación de programas destinados a conectar mejor a los países en desarrollo a cadenas de valor; en ellos participan donantes, países asociados, empresas privadas y organizaciones de la sociedad civil. Por ejemplo, el programa "Grow Africa" es una plataforma de asociación creada por la Comisión de la Unión Africana, la Nueva Alianza para el Desarrollo de África (NEPAD) y el Foro Económico Mundial que tiene por objeto acelerar las inversiones del sector privado, facilitar la constitución de asociaciones entre diversas partes interesadas y difundir y dar a conocer las mejores prácticas y las iniciativas que ya están en marcha, con miras a promover la transformación de la agricultura africana sobre la base de las prioridades nacionales en ese sector. 


\section{Gráfico 3.14 Iniciativas emprendidas por las empresas líderes para conectar a los proveedores de los países en desarrollo a cadenas de valor (porcentaje de respuestas)}

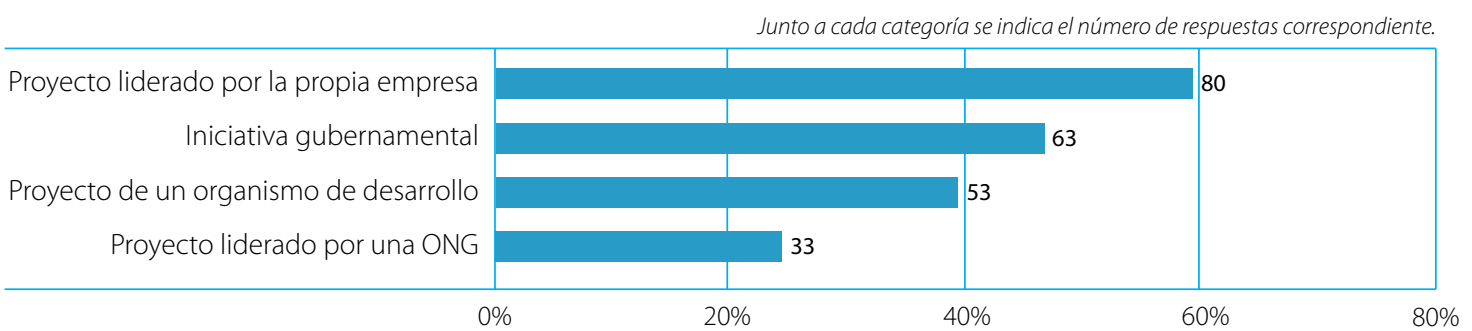

Fuente: Cuestionario OCDE/OMC 2013, www.aid4trade.org.

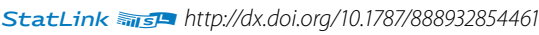

Las empresas líderes emprenden iniciativas destinadas a conectar mejor a los proveedores de los países en desarrollo a sus cadenas de valor fundamentalmente por interés propio. La estrategia que guía el quehacer fundamental de cada empresa es el principal motivo (gráfico 3.15). Además, más del $40 \%$ de las iniciativas de las empresas líderes en esta esfera guarda relación con sus programas de responsabilidad social. La participación en programas entre empresas (por ejemplo, los códigos de conducta de los proveedores) y la filantropía también figuran entre esos motivos. Una de cada cuatro empresas líderes participa en programas específicos en esta esfera en asociación con organismos de desarrollo.

\section{Gráfico 3.15 Motivos de las empresas líderes para conectar mejor a los proveedores de los países en desarrollo a sus cadenas de valor (porcentaje de respuestas)}

Junto a cada categoría se indica el número de respuestas correspondiente.

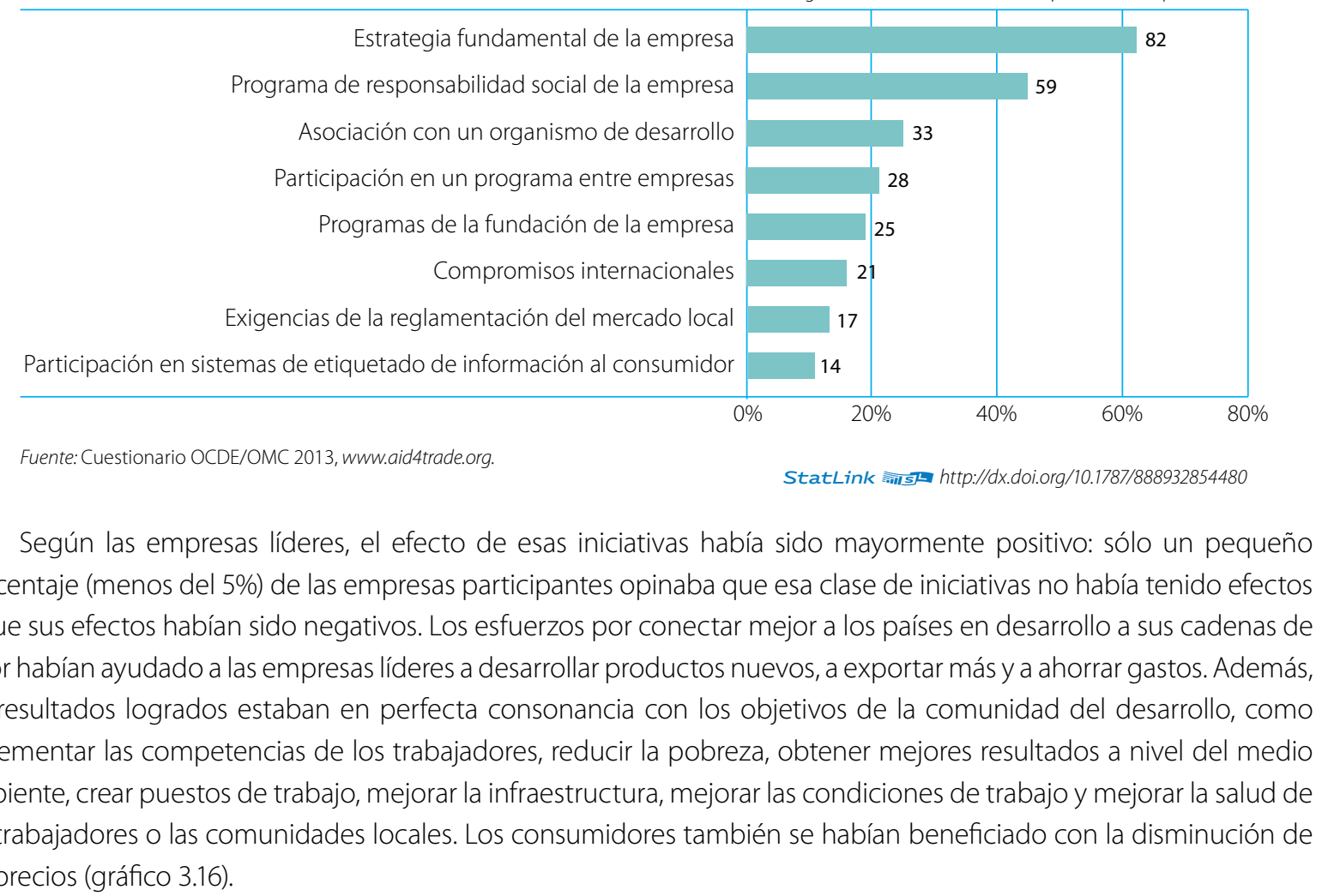




\section{Gráfico 3.16 Evaluación por las empresas líderes del efecto de las actividades encaminadas a conectar a proveedores de países en desarrollo a las cadenas de valor (porcentaje de respuestas)}

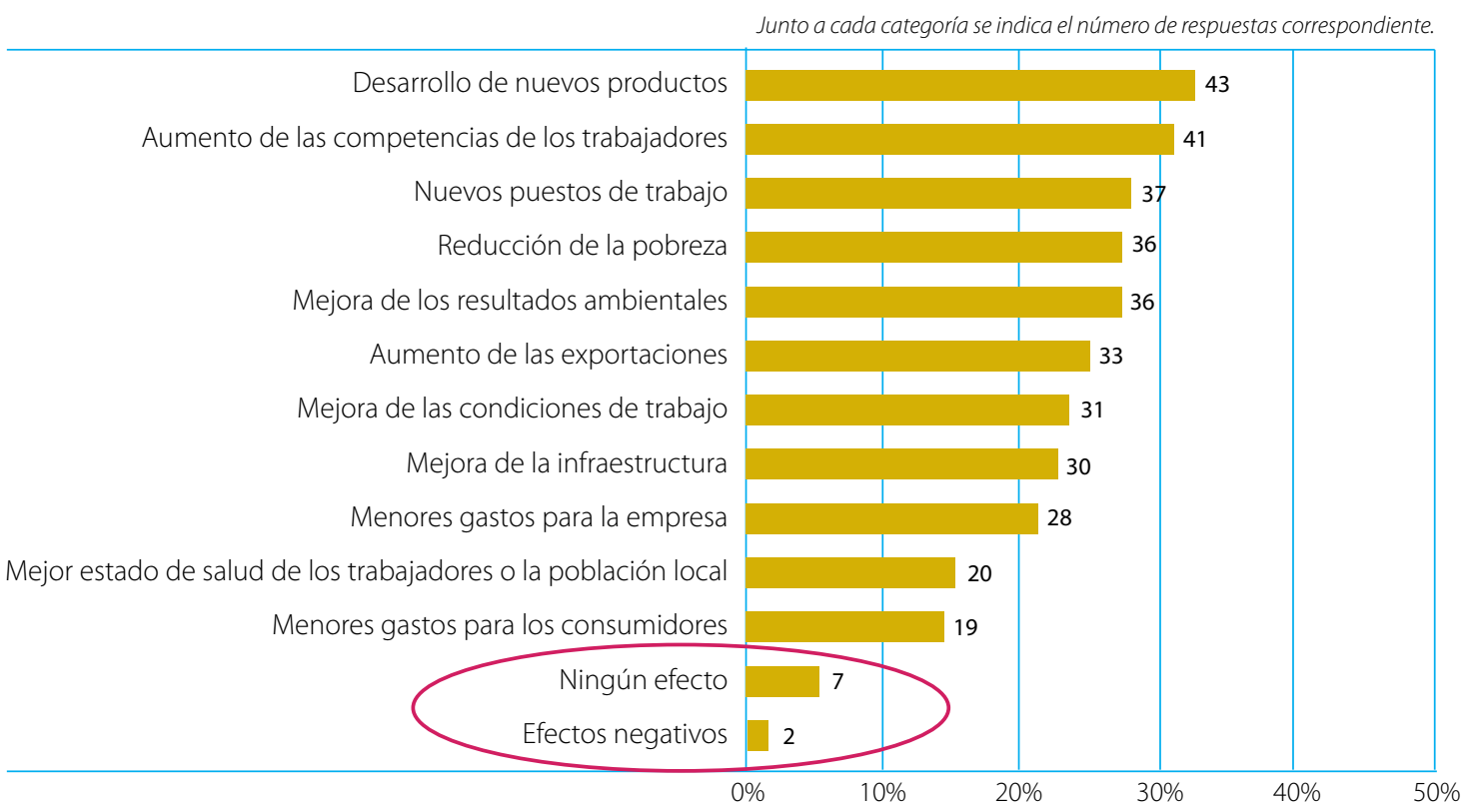

Fuente: Cuestionario OCDE/OMC 2013, www.aid4trade.org.

Las enseñanzas extraídas de esas experiencias también eran positivas. Ninguna de las empresas encuestadas excluyó participar en el futuro en actividades de esa naturaleza (gráfico 3.17). Las empresas líderes consideraban que las actividades de creación de cadenas de valor en los países en desarrollo habían sido útiles para la empresa: en particular, habían contribuido a establecer nuevas relaciones con proveedores y consumidores, así como a mejorar la imagen de la empresa. Sin embargo, cerca del $40 \%$ de las empresas que participaron en la encuesta seguían experimentando dificultades para trabajar con el sector público y opinaban que podían seguir mejorándose las asociaciones entre el sector público y el sector privado (gráfico 3.17).

\section{Gráfico 3.17 Conectar a los proveedores de países en desarrollo a cadenas de valor: enseñanzas extraídas (porcentaje de respuestas)}

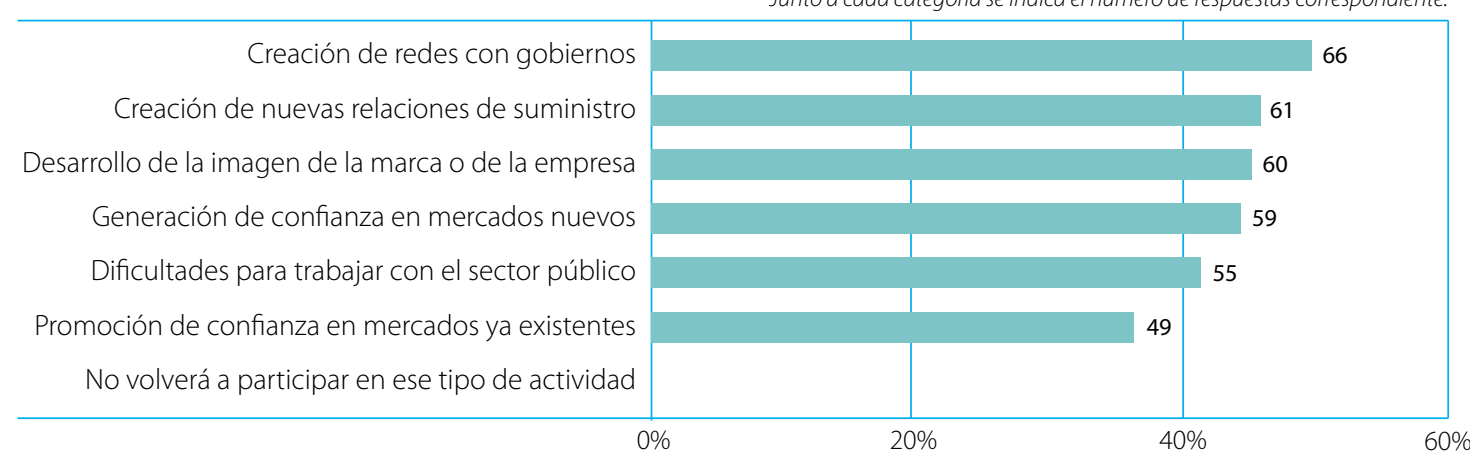

Fuente: Cuestionario OCDE/OMC 2013, www.aid4trade.org 
En el ciclo de vida de los proyectos de ayuda para el comercio hay cuatro etapas diferentes en que el sector privado puede participar en mayor medida en esa clase de proyectos: en la etapa de identificación de los proyectos con objeto de reducir las limitaciones fundamentales relacionadas con el comercio; en esta etapa se puede pedir al sector privado que facilite información sobre los obstáculos que hay que eliminar o los incentivos que es preciso incrementar (OCDE, 2013c); en la etapa de concepción de los proyectos, en la que el sector privado puede compartir las mejores prácticas que haya observado en otros programas de ayuda para el comercio o en programas que hayan ejecutado las propias empresas; en la etapa de ejecución de los proyectos, en la que el gobierno, los donantes y las empresas privadas pueden aunar fuerzas para incrementar el número de medidas y maximizar su repercusión; y en la etapa de gestión y evaluación de los proyectos, en la que el sector privado puede aportar pruebas de su éxito o fracaso (gráfico 3.18).

\section{Gráfico 3.18 Gestión público-privada de los programas de ayuda para el comercio}

\begin{abstract}
Identificación
Diálogo entre el sector público y el sector privado sobre las limitaciones funamentales relacionadas con el comercio
\end{abstract}

Fuente: OCDE (2013c).

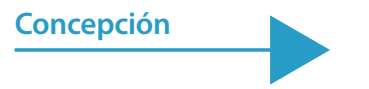

Descripción de las mejores prácticas

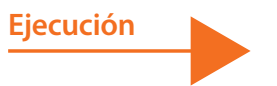

Financiación público-privada
Evaluación

Gestión público-privada orientada a los resultados en materia de desarrollo

\section{CONCLUSIONES}

Las cadenas de valor crean oportunidades de crecimiento económico en los países en desarrollo. El análisis de las cadenas de valor de los sectores agroalimentario, de la TIC, de los textiles y las prendas de vestir, del turismo, y del transporte y la logística revela que los países en desarrollo forman parte integrante de esas cadenas de valor, y que pueden aprovechar su participación en ellas para lograr objetivos en materia de crecimiento, empleo y reducción de la pobreza. De las respuestas al cuestionario de la OCDE y la OMC también se desprende que es mucho lo que se puede hacer para mejorar esa participación; muchos países en desarrollo ven menoscabada su competitividad como resultado de procedimientos aduaneros ineficientes, aranceles elevados, obstáculos no arancelarios que limitan innecesariamente el comercio de mercancías o servicios, restricciones a la libre circulación de información y de personas y obstáculos a la IED. El desafío para las economías en desarrollo consiste en diseñar y aplicar estrategias amplias que les permitan eliminar esos obstáculos fundamentales a su integración y ascenso en las cadenas de valor.

De las respuestas al cuestionario de la OCDE y la OMC también se desprende que las cadenas de valor ejercen creciente influencia en los programas de los donantes. La experiencia de los donantes con las cadenas de valor suele estar concentrada en los sectores agrícola y alimentario, del pescado y los productos de la pesca, de los textiles y las prendas de vestir y del turismo. Por su parte, los donantes multilaterales suelen tener más experiencia en los sectores del transporte, los servicios financieros y los servicios prestados a las empresas y servicios profesionales, mientras que la experiencia de los proveedores de cooperación Sur-Sur relacionada con el comercio suele concertarse en los sectores de los textiles y las prendas de vestir, así como de los productos de la industria automotriz.

Las principales prioridades de política de los gobiernos de los países en desarrollo en relación con la expansión de sus exportaciones de mercancías y servicios consisten en añadir valor a sus exportaciones y resolver los problemas que menoscaban la competitividad de sus exportaciones. Los principales obstáculos mencionados en este contexto son la falta de infraestructura nacional adecuada, el acceso a la financiación del comercio y cuestiones relacionadas con la conformidad con las normas. Los donantes y los asociados Sur-Sur también mencionaron la falta de capacidad 
para atraer la inversión extranjera directa y la falta de ventajas comparativas. Por su parte, los países en desarrollo consideraban que el aumento de las exportaciones y el crecimiento económico, junto con el empleo y la reducción de la pobreza, eran los efectos más importantes de conectarse a las cadenas de valor.

Todos los proveedores de países en desarrollo clasificaron el acceso a la financiación (en particular, la financiación del comercio) como el principal obstáculo que se interponía a su ingreso o ascenso en las cadenas de valor, o al establecimiento de dichas cadenas. El costo del transporte y la expedición, la falta de infraestructura adecuada y la incertidumbre a nivel de la reglamentación (a menudo como resultado de un entorno empresarial complejo) también figuraban entre los obstáculos importantes, junto con la falta de competencias de la fuerza de trabajo. Las empresas líderes consideraban que los procedimientos aduaneros en los cinco sectores constituían un obstáculo importante a la hora de incorporar a los proveedores de países en desarrollo a sus cadenas de valor. Otras preocupaciones importantes eran la incertidumbre en materia de reglamentación (como resultado de los problemas a que hacían frente los proveedores de los países en desarrollo en un entorno empresarial complejo) y cuestiones relativas a la conformidad con las normas. Las prácticas informales y las peticiones de pagos también se mencionaron como aspectos que suscitaban especial preocupación en las relaciones con los proveedores.

Los factores que según los proveedores y las empresas líderes influían en sus decisiones en materia de abastecimiento e inversión eran el costo de la producción y la mano de obra, la conformidad con las normas, los volúmenes de producción y el tiempo total de fabricación (una cuestión de especial importancia en el caso de los textiles), así como los incentivos a la inversión y los incentivos fiscales. También consideraban que las competencias de la fuerza de trabajo, en particular en los sectores de la TIC, los textiles y las prendas de vestir y el turismo, constituían un factor importante en las decisiones en materia de inversión. Entre los factores que afectaban negativamente a las decisiones en materia de abastecimiento e inversión figuraban un entorno empresarial desfavorable, las demoras en las aduanas, la falta de certidumbre en materia de reglamentación, la corrupción y la venalidad.

Esos resultados también dan una idea clara de las esferas en que la ayuda para el comercio puede contribuir a conectar a los países en desarrollo a las cadenas de valor. Los gobiernos, los donantes y el sector privado coincidían en su apreciación de los problemas que había que resolver. Las prioridades que ha revelado la encuesta pueden ayudar a establecer una cooperación y una sinergia más estrechas entre el sector público y el privado a la hora de identificar proyectos de ayuda para el comercio, financiar su ejecución, mejorar su vigilancia y evaluar sus efectos y, en definitiva, aumentar la eficacia de la ayuda. Este enfoque coincide con el de la Declaración de París (2005), el Programa de Acción de Accra (2008) y la Alianza de Busán para la Cooperación Eficaz para el Desarrollo (2011). 


\section{NOTAS}

1. No todas las cadenas de valor son iguales. Entre otras cosas, hay diferencias en cuanto al grado de competencia de mercado dentro de cada cadena, los obstáculos para acceder al mercado final y el control que ejerce la empresa líder (en materia de tecnología, especificaciones de los productos y gestión de la marca). Gereffi et al. (2005) distinguen cinco tipos generales de cadenas de valor, cada uno de ellos con una "gobernanza" diferente y con su propia distribución de funciones entre las empresas: i) las cadenas con orientación de mercado, en las que compradores y proveedores comercian con diferentes fuentes, el precio es fijado íntegramente por el mercado y el costo de cambiar de asociado es bajo, como sucede, por ejemplo, en los mercados de productos básicos; ii) las cadenas modulares, en las que los proveedores producen según las especificaciones de los compradores utilizando tecnología genérica, como en la rama de producción de la electrónica; iii) las cadenas de valor con base en una relación, en las que las interacciones entre compradores y vendedores están basadas en la dependencia mutua, suelen ser de larga data y tienen su origen en vínculos familiares o étnicos que suelen reforzar las relaciones comerciales, como en muchas cadenas del sector de las prendas de vestir; iv) las cadenas cautivas, en las que la empresa líder controla un producto altamente diferenciado, la tecnología clave y/o las normas del producto, y los proveedores tienen pocos incentivos para salirse de la cadena de producción a fin de trabajar con la competencia; como ejemplo cabe mencionar las grandes empresas del sector de la electrónica, como Apple, que tienen ese tipo de relación con sus proveedores; y v) las cadenas jerárquicas, en las que la relación comprador-proveedor tiene lugar dentro de la empresa; éste es el caso de las empresas del sector del automóvil cuyos numerosos proveedores forman parte de la propia empresa; todas las relaciones intraempresariales encuadran en esta categoría.

2. Elaborado por el Banco Mundial y la Comisión Económica y Social para Asia y el Pacífico (CESPAP) de las Naciones Unidas.

3. Véase, por ejemplo, el programa Capturing the Gains (Obtener los beneficios), que tiene por objeto compartir conocimientos; el programa puede consultarse en la dirección www.capturingthegains.org/.

4. El Centro de Comercio Internacional (ITC) ha iniciado un examen de las normas voluntarias. Véase: www.standardsmap.org.

5. Véase www.intracen.org.

6. Declaración de Abuja (2010); puede consultarse en la dirección: www.hlcd-3a.org/.

7. www.unido.org/businesspartnerships.html.

8. www.3adi.org/haiti.

9. El ITC ha elaborado una guía en la que se reseñan cuestiones en materia de financiación desde la perspectiva de las pequeñas empresas exportadoras y se indica cuáles son los instrumentos financieros más idóneos, qué entidades proveedoras de estos servicios son las más adecuadas y cómo tomar contacto con ellas.

10. De las 89 empresas líderes que respondieron, 54 eran empresas de 36 países en desarrollo; en el caso de la Argentina, Barbados, Costa Rica, Guatemala, México, Nigeria y el Pakistán, hubo empresas que presentaron tres o más respuestas. De las 89 empresas líderes, diez indicaron que tenían una cifra de negocios que superaba los 1.000 millones de dólares EE.UU. anuales.

11. Panorama OMT del turismo internacional 2012, http://mkt.unwto.org/es/publication/unwto-tourism-highlights-2012-edition.

12. http://icr.unwto.org/en/content/un-steering-committee-tourism-development-sctd. 
13. El estudio realizado por la OCDE y la OMC abarcó 96 participantes de diversos países desarrollados y en desarrollo. Como se trata de una muestra reducida, los resultados deben tomarse con cautela; no obstante, el estudio resulta útil para darse una idea de cómo ven las cosas las empresas del sector privado que participan en las cadenas de valor en el sector del transporte y la logística. 


\section{REFERENCIAS}

Acemoglu, D., P. Antràs, y E. Helpman (2007), "Contracts and technology adoption", The American Economic Review, Vol. 97, 916-943.

Adhikari, R. (2008), "The Local Content Paradox at the WTO: A Minor Lapse or Lapse or Organised Hypocrisy?", Bridges Weekly, Vol. 12(3), International Centre for Trade and Sustainable Development (ICTSD), Ginebra.

Baldwin, R. (2011), Trade and Industrialisation after globalisation 2nd unbundling: How building and joining a supply chain are different and why it matters, NBER Working Paper Series, № 17716, Cambridge, MA, www.nber.org/papers/w17716.

Banco Mundial (2011), The Role of International Business in Aid for Trade: Building Capacity for Trade in Developing Countries, Banco Mundial, Washington, D.C.

Barrie, L., y J. Ayling (2009), Apparel industry outlook for 2009, Management Briefing, Aroq Limited, Bromsgrove, Reino Unido.

BID (Banco Interamericano de Desarrollo) (2013), Diagnóstico sobre el desempeño de los puertos y estudio de conectividad portuaria en Belice, Centroamérica y la República Dominicana, P. Guerrero y J. Abad (eds.), Departamento de Infraestructura y Medio Ambiente del BID, IDB-TN-512, Washington, D.C.

BMZ (Ministerio Federal de Cooperación Económica y Desarrollo de Alemania) (2011), Aid for Trade in German Development Policy, Documento de estrategia No 7 del BMZ, http://www.bmz.de/en/publications/type_of_publication/strategies/Strategiepapier308_07_2011.pdf.

Cadot, O., et al. (2011), Where to Spend the Next Million? Applying Impact Evaluation to Trade Assistance, Centre for Economic Policy Research (CEPR), Londres, www.cepr.org/pubs/books/cepr/next_million_WB.pdf.

Chang, R., L. Kaltani y N. Loayza (2009), "Openness Can be Good for Growth: The Role of Policy Complementarities", Journal of Development Economics, Vol. 90(1), 33-49.

Costinot, A. (2009), "On the origins of comparative advantage", Journal of International Economics, Vol. 77, 255-264.

Driscoll, M. y P. Wang (2009), Apparel \& footwear: retailers \& brands, Standard \& Poor's (S\&P), Nueva York.

Engman, M., O. Onodera y E. Pinali (2007), Export Processing Zones: Past and Future Role in Trade and Development, OCDE, París, http://dx.doi.org/10.1787/035168776831.

Escaith, H., N. Lindinberg y S. Miroudot (2010), "Global Value Chains and the Crisis: Reshaping Trade Elasticity?" en O. Cattaneo, G. Gereffi y C. Staritz (eds.), Global Value Chains in a Postcrisis World. A Development Perspective, Banco Mundial, Washington, D.C.

FEM (Foro Económico Mundial), Bain \& Company y el Banco Mundial (2013), Enabling Trade Valuing Growth Opportunities, FEM, Ginebra, www.weforum.org/reports/enabling-trade-valuing-growth-opportunities.

Frederick, S. y C. Staritz (2012), "Developments in The Global Apparel Industry after the MFA Phaseout" en G. López Acevedo y R. Robertson (eds.), Sewing Success? Employment, Wages, and Poverty following the End of the Multi-fibre Arrangement, Banco Mundial, Washington, D.C.

Gereffi, G. y O. Memedovic (2003), The Global Apparel Value Chain: What Prospects for Upgrading by Developing Countries?, Organización de las Naciones Unidas para el Desarrollo Industrial, Ginebra.

Gereffi, G. y S. Frederick (2010), "The Global Apparel Value Chain, Trade and the Crisis: Challenges and Opportunities for Developing Countries" en O. Cattaneo, G. Gereffi y C. Staritz (eds.), Global Value Chains in a Postcrisis World. A Development Perspective, Banco Mundial, Washington, D.C. 
Gereff, G., J. Humphrey y T. Sturgeon (2005), "The governance of global value chains", Review of International Political Economy, Vol. 12(1), 78-104.

Globerman S. (2011), "Global Value Chains: Economic and Policy Issues", Western Washington UniversityCenter for International Business, Bellingham, Washington.

Grossman, G. y E. Helpman (2005), "Outsourcing in a Global Economy”, Review of Economic Studies, Vol. 72(1), 135-159.

Hummels, D., J. Ishiib y K.-M. Yic (2001), "The nature and growth of vertical specialization in world trade", Journal of International Economics, Vol. 54(1), 75-96.

Ismail, F. (2013), "Towards an alternative narrative for the multilateral trading system", Bridges Africa Review, 2(2).

ITC (Centro de Comercio Internacional) (2009), Cómo Conseguir Financiación para el Comercio: Guía para PYME Exportadoras, ITC, Ginebra.

Jansen, M. y E. Von Uexkull (2010), El comercio y el empleo en la crisis mundial, Organización Internacional del Trabajo, Ginebra, www.ilo.org/global/publications/books/WCMS_141911/lang--en/index.htm.

Korinek, J. y P. Sourdin (2011), To What Extent Are High-Quality Logistics Services Trade Facilitating? OECD Trade Policy Papers, № 108, OCDE, París, www.oecd-ilibrary.org/trade/to-what-extent-are-high-quality-logisticsservices-trade-facilitating_5kggdthrizn-en.

Levchenko, A. A. (2007), "Institutional quality and international trade", Review of Economic Studies, Vol. 73(3), 791-819.

Ma, A. C. y A. Van Assche (2010), The Role of Trade Costs in Global Production Networks: Evidence from China's Processing Trade Regime, World Bank Policy Research Working Paper No 5490, Banco Mundial, Washington D.C.

OCDE (2013a), Interconnected Economies: Benefiting from Global Value Chains (versión preliminar), OCDE, París, http://dx.doi.org/10.1787/9789264189560-en.

OCDE (2013b), Succeeding with Trade Reforms: The Role of Aid for Trade, OECD Development Series, OCDE, París, http://dx.doi.org/10.1787/9789264201200-en.

OCDE (2013c), Aid for Trade and Development Results: A Management Framework, OCDE, París, http://dx.doi.org/10.1787/9789264112537-en.

OCDE/OMC (2013), Aid for Trade in Action, OCDE, París, http://dx.doi.org/10.1787/9789264201453-en.

OIT (Organización Internacional del Trabajo) (2005), Promoción de una globalización justa en el sector de los textiles y el vestido tras la expiración del Acuerdo Multifibras, OIT, Ginebra.

OMC (Organización Mundial del Comercio) (2008), Informe sobre el Comercio Mundial, OMC, Ginebra.

OMC/IDE-JETRO (Instituto de Economías en Desarrollo - Organización de Comercio Exterior del Japón) (2011), Pautas del comercio y cadenas de valor mundiales en el caso de Asia Oriental: Del comercio de mercancías al comercio de tareas, OMC e IDE-JETRO, Ginebra y Tokio.

Staritz, C., G. Gereffi y O. Cattaneo (2011), "Shifting End Markets and Upgrading Prospects in Global Value Chains", International Journal of Technological Learning, Innovation and Development, Vol. 4(1/2/3), 1-12.

Winkler, D. (2013), Potential and Actual Spillovers in Global Value Chains: The Role of Foreign Investor Characteristics, Absorptive Capacity and Transmission Channels, Policy Research Working Paper, № 6424, Banco Mundial, Washington, D.C.

Yi, K. M. (2003), "Can Vertical Specialisation Explain the Growth of World Trade?", Journal of Political Economy, Vol. 111(1), 52-102. 


\section{CAPÍTULO 4: IMPULSAR LAS CADENAS DE VALOR POR MEDIO DE LA AYUDA PARA EL COMERCIO A NIVEL REGIONAL}

En el presente capítulo se muestra que la ayuda para el comercio a nivel regional los países de ingresos bajos y los países menos adelantados, en las redes regionales de producción, y les permite conectarse a las cadenas de valor y ascender en ellas. Asimismo se hace hincapié en que una de las principales causas de la tendencia a la integración regional es la necesidad de reducir los obstáculos en las redes regionales de producción. Los obstáculos al comercio y el exceso de trámites burocráticos, así como las deficiencias de la infraestructura, hacen que esos países resulten menos atractivos para funcionar como los radios en torno al eje de las redes de producción. Los programas regionales de ayuda para el comercio (que han aumentado considerablemente desde el período de referencia (2002-2005)) son un medio eficaz para reducir esas limitaciones. Aunque los programas regionales de ayuda para el comercio son, por definición, complejos debido a la necesidad de obtener y coordinar la participación de múltiples gobiernos, sus diversos organismos y numerosas partes interesadas del sector privado, constituyen un medio eficaz en función del costo de ayudar a los países a alcanzar sus objetivos comerciales y de desarrollo.

\section{INTRODUCCIÓN}

Como se señaló en el tercer Examen Global de la Ayuda para el Comercio (2011), el programa comercial de los países en desarrollo se está llevando a cabo, cada vez más, mediante la integración y la cooperación económicas a nivel regional. En este contexto, la ayuda para el comercio a nivel regional puede contribuir a impulsar el comercio y facilitar el desplazamiento a lo largo de las cadenas de valor. En Asia, la cooperación regional está impulsada por los beneficios que reporta la participación en las redes regionales de producción: actualmente, dos tercios de las exportaciones de la Asociación de Naciones del Sudeste Asiático (ASEAN) pueden atribuirse a la participación en esa clase de redes (BAsD e IBAsD, 2013). En África, donde el comercio y la competitividad se ven obstaculizados por el pequeño tamaño y la fragmentación de los mercados, la cooperación regional constituye un medio de desarrollar los mercados nacionales, fomentar la especialización y compartir riesgos. América Latina, que tiene una larga tradición de cooperación económica, está utilizando activamente los foros regionales para reducir los costos de las transacciones comerciales en toda la región y con los asociados externos. 
En el presente capítulo se muestra que la ayuda para el comercio a nivel regional contribuye de manera fundamental a incrementar la participación, en particular de los países de ingresos bajos y los países menos adelantados (PMA), en las redes regionales de producción, y les permite conectarse a las cadenas de valor y ascender en ellas. Una de las principales causas de la tendencia que impulsa la integración regional es la necesidad de reducir los obstáculos en las redes regionales de producción. Los obstáculos al comercio y el exceso de trámites burocráticos, así como las deficiencias de la infraestructura, hacen que esos países resulten menos atractivos para funcionar como los radios de la rueda en torno al eje de las redes de producción.

En el presente capítulo se examinan, en primer lugar, los vínculos entre el regionalismo y la integración regional en el contexto de las redes de producción, y a continuación el papel que desempeña la actual tendencia hacia el regionalismo en las estrategias de desarrollo, así como sus repercusiones en el desarrollo de las cadenas de valor. Asimismo se resumen los resultados pertinentes de las encuestas llevadas a cabo en 2013 por la Organización Mundial del Comercio (OMC), la Unión Africana (UA) y la Comisión Económica para África de las Naciones Unidas (CEPA) sobre cuestiones relacionadas con la ayuda para el comercio a nivel regional y sus repercusiones. En la siguiente sección se considera la forma en que la ayuda para el comercio a nivel regional puede constituir un medio eficaz y económico de reducir las limitaciones fundamentales que impiden la integración regional y la formación de redes regionales de producción. Mediante relatos de experiencias se ilustra la forma en que la ayuda para el comercio a nivel regional ha facilitado, directa o indirectamente, la formación de cadenas productivas y la integración en el ámbito regional. El capítulo concluye con una evaluación general.

\section{EL REGIONALISMO, LA REGIONALIZACIÓN Y EL PAPEL DE LAS CADENAS DE VALOR}

Como se desprende claramente del presente estudio, de números anteriores de La Ayuda para el Comercio en síntesis y de numerosos estudios sobre el tema, el comercio ha desempeñado un papel cada vez más importante en las estrategias de desarrollo que han tenido éxito, y la ayuda para el comercio ha sido un instrumento indispensable y eficaz en función del costo para eliminar las limitaciones fundamentales que atentan contra la integración internacional. En la presente sección se analiza la forma en que los programas multinacionales y regionales de ayuda para el comercio pueden apuntalar la integración regional (o "regionalización") y las cadenas de valor, y se resumen las consecuencias en la esfera de las políticas que tiene la cooperación económica bilateral y regional (o "regionalismo") para las economías emergentes y en desarrollo. La sección comienza con un análisis sobre la cooperación y el desarrollo regionales en el contexto del sistema multilateral de comercio, tras lo cual se pasa revista a los efectos económicos de la cooperación regional en las redes de producción. A continuación, se analiza la forma en que la cooperación regional puede incrementar las perspectivas de integración y formación de redes de producción regionales. Por último, se exponen los factores complementarios necesarios para el éxito de los programas de integración económica a nivel regional.

\section{El regionalismo en el contexto mundial}

La OMC ha recibido unas 546 notificaciones de acuerdos comerciales regionales (ACR), que la Organización define como los acuerdos comerciales recíprocos entre dos o más países. Actualmente hay 354 ACR en vigor', en comparación con 300 a finales de 2005 y 130 a comienzos de 1995. Los ACR han sido uno de los cambios decisivos de la política internacional ocurridos durante el período transcurrido desde la puesta en marcha de la Iniciativa de Ayuda para el Comercio. Los países en desarrollo, especialmente de África y Asia, pero también de América Latina y otras regiones, han participado muy activamente en el movimiento regionalista. ${ }^{2}$ Lo que ha impulsado, en buena medida, ese proceso ha sido el deseo de promover las redes regionales de producción (como es evidente, por ejemplo, en el caso de Asia). Cabe prever que ese proceso continuará, pese a la preocupación que suscita la relación 
entre los enfoques multilateral y bilateral de las normas comerciales; sin embargo, esa tendencia puede constituir un componente básico del comercio, en lugar de un obstáculo, siempre y cuando las redes de producción prosperen sobre la base de la apertura y la eficiencia, y no de la formación de bloques discriminatorios (Plummer, 2007).

\section{La economía de las redes regionales de producción}

Para las economías en desarrollo y las economías emergentes, la cooperación regional puede reportar considerables beneficios, a condición de que los gobiernos adopten un marco normativo flexible y preparen debidamente a sus economías. Las zonas de libre comercio (ZLC) eliminan la discriminación entre los países asociados y las empresas nacionales, lo que incrementa la eficiencia de la producción ("creación de comercio") y posiblemente genera un aumento de las corrientes de inversión para aprovechar la disminución de los obstáculos al comercio entre los asociados, así como las sinergias en potencia ("creación de inversión"). Sin embargo, como las ZLC otorgan a los países asociados preferencias que no se conceden a los que no pertenecen al grupo, se genera una distorsión comercial que beneficia a las empresas de los países asociados a la par que perjudica a las empresas de otros países ("desviación del comercio").

En definitiva, la desviación del comercio repercute negativamente en la relación de intercambio ya que puede obligar a un país a adquirir sus importaciones de una fuente más cara, con la consiguiente pérdida de eficiencia. De ahí que la desviación del comercio resulte especialmente problemática para las redes de producción, que necesitan abastecerse al más bajo costo. Ésta es una de las principales razones por las que el movimiento regionalista respaldado por las redes de producción debe ser abierto y estar orientado hacia el exterior: la desviación del comercio es anatema para quienes preconizan una organización eficaz de las cadenas de valor. También proporciona un fuerte incentivo para que las normas de origen (que son esenciales en los ALC para evitar el "desplazamiento" de las corrientes comerciales ${ }^{3}$ ) sean liberales, simples y simétricas.

Además, cuanto mayor sea el grado de discriminación en una ZLC, mayores serán las posibilidades de "desviación de la inversión": en estos casos la inversión extranjera directa (IED) se orienta hacia un país determinado pura y simplemente para beneficiarse de un acceso regional protegido. En una época, tanto las economías desarrolladas como las economías en desarrollo, a fin de atraer mayores corrientes de inversión, promovían ampliamente la IED que tenía por objeto eludir obstáculos arancelarios. Sin embargo, en la actualidad ese enfoque plantea crecientes problemas para las redes de producción, que prosperan cuando los mercados son abiertos, no cerrados. En efecto, la creciente importancia de las redes de producción podría explicar no sólo el motivo por el que las ZLC y otras formas de cooperación regional son cada vez más abiertas, sino también por qué se han ido derrumbando los obstáculos al comercio y a la inversión en todo el mundo. El costo de mantener una economía al margen del mercado internacional siempre ha sido alto, pero lo es aún más en una economía verdaderamente mundializada (OCDE, 2012). ${ }^{4}$

Además, las cadenas de valor amplifican el costo de los obstáculos arancelarios. Incluso cuando los obstáculos arancelarios en una región son bajos, el desarrollo de las cadenas de valor puede verse inhibido, ya que los efectos son acumulativos. Las empresas que llevan a cabo las fases posteriores del proceso de producción tienen que pagar los aranceles que gravan sus insumos y el valor de sus exportaciones, lo que hace aumentar geométricamente los costos de la red de producción (OCDE, 2013). Esta amplificación de los efectos de la protección a lo largo de la cadena de valor también tiene lugar en relación con los obstáculos no arancelarios y los impedimentos que existen dentro de las fronteras (véase asimismo el capítulo 3). Por lo tanto, la eficiencia de las ZLC tiende a ser mayor en el contexto de las redes de producción. En el estudio de la OCDE (2013) se describe la forma en que las diversas disposiciones "profundas" de los ALC pueden generar un aumento considerable del comercio a través de las cadenas de suministro. En este proceso, el papel que desempeña la ayuda para el comercio regional en lo que atañe a facilitar el funcionamiento de las redes de producción y lograr los objetivos de la cooperación regional es evidente. 
Aparte del aumento de la eficiencia en la asignación de recursos y de las corrientes de IED, la cooperación regional reporta los siguientes beneficios: la posibilidad de obtener mayores economías de escala como resultado del acceso a un mercado más grande; la transferencia de tecnología a través de la IED y otros aspectos de la integración; y la posibilidad de desarrollar un marco normativo más eficiente como resultado de las medidas dentro de la frontera y las medidas de facilitación del comercio incluidas en los ALC modernos (por ejemplo, en materia de normas de calidad, medidas complejas en relación específicamente con el sector de los servicios, legislación en materia de gobernanza de las empresas o gobernanza pública, procedimientos aduaneros y política de competencia). Todas esas esferas guardan relación con la creación y la mejora de las redes regionales de producción a lo largo de la cadena de valor, como se examina en detalle en el presente capítulo.

\section{Impulsar las redes regionales de producción}

Así, el comercio y la inversión generados por la cooperación regional son muy importantes para las redes de producción. Al reducir los obstáculos al comercio y a la inversión dentro de la región, las empresas líderes pueden organizar la producción en función de las ventajas comparativas de los distintos países miembros. Para crear esas redes utilizan diversos cauces, desde la IED a la concesión de licencias y la contratación. Las empresas líderes proceden luego a comerciar de manera fragmentada dentro de las cadenas de valor, lo que intensifica la regionalización. Las entradas de IED procedentes de dentro y de fuera de la región aumentan, y ese aumento puede reportar un sinfín de beneficios a las economías receptoras, como el aumento del empleo, capital de riesgo compartido, divisas, obtención indirecta de tecnología y otros efectos que aumentan la productividad. Una presencia regional permite a las empresas líderes minimizar los costos de transporte y beneficiarse de costos comerciales más bajos como resultado de la cooperación regional. A su vez, este marco de cooperación regional allana el camino para una mayor liberalización multilateral.

Las redes regionales de producción permiten a un país obtener mejores resultados comerciales y generan la demanda de medidas de fomento del comercio encaminadas a promover la eficiencia mediante, por ejemplo, la facilitación del comercio y la mejora de las infraestructuras física y no física. La participación en las redes regionales da a la producción local acceso a mercados externos ya organizados y, a medida que la economía se abre a los mercados regionales y mundiales, las empresas locales "aprenden haciendo". Las entradas de IED y otras formas de interacción con las empresas líderes tienen importantes repercusiones en la economía que tienden a acelerar el avance en la cadena de valor. Dicho de otro modo, las redes de producción aprovechan las ventajas comparativas de cada economía para incrementar la productividad y reducir los costos, a la par que promueven la inversión y la transferencia de tecnología y conectan a las economías en desarrollo con la economía mundial de una manera que habría sido imposible hace veinte años. Mediante la fragmentación de la producción, las empresas líderes asignan los segmentos con gran intensidad de mano de obra a las economías en que los salarios son bajos, lo que genera un rápido crecimiento del comercio intraindustrial de partes y componentes en la cadena de valor.

La cooperación regional ofrece oportunidades especialmente importantes a los pequeños países de ingresos bajos, que, como se señaló más arriba, en el pasado en general no solían beneficiarse del vínculo entre la IED y el comercio. Por lo tanto, la cooperación regional es un medio de lograr una integración más profunda en mercados regionales y mundiales más vastos y facilita el ascenso en las cadenas de valor. Viet Nam, por ejemplo, se benefició con su adhesión a la ASEAN en 1995 al adoptar, a través de los programas de la Zona de Libre Comercio de la ASEAN (AFTA) y de la Zona de Inversiones de la ASEAN, un régimen de comercio e inversión cada vez más liberal que le ha permitido participar, junto con sus interlocutores más desarrollados, en varias redes de producción (proceso que recibió un nuevo impulso tras su adhesión a la OMC en 2007). Esto ha significado la creciente internacionalización de su economía; el aumento de las entradas de IED, la obtención indirecta de tecnología, el aumento del nivel de empleo de su fuerza de trabajo; y la disminución de la pobreza. Con el transcurso del tiempo, Viet Nam comenzó a ascender 
en la cadena de valor, y en 2012 pasó a ser un país de ingresos medianos. Viet Nam espera seguir cosechando éxitos mediante la participación en acuerdos megarregionales de cooperación económica en la región de Asia y el Pacífico, como se detalla más adelante. El éxito logrado por Viet Nam en este ámbito ha servido de ejemplo a otras economías en transición de la región: Camboya ha seguido los pasos de Viet Nam en años recientes y Myanmar, cuya apertura política en 2012 fue seguida de la adopción entusiasta de reformas económicas orientadas hacia el exterior, cuenta con la integración en redes de producción como importante fuente futura de IED, empleo y reducción de la pobreza en el sector de los recursos naturales y las manufacturas.

El Asia Sudoriental ha logrado atraer redes regionales de producción gracias a las diferencias en el nivel de los salarios y de la productividad de la mano de obra en todos los Estados de la región, que facilitan la obtención de beneficios en las cadenas de valor; la liberalización regional del comercio y las inversiones, a través de iniciativas como la Zona de Libre Comercio de la ASEAN (AFTA) y la Comunidad Económica de la ASEAN (AEC); la creciente competitividad de las infraestructuras comercial, física y no física, como puertos marítimos eficientes, sistemas nacionales de "ventanilla única" para los trámites aduaneros en el marco del programa de Ventanilla Única de la ASEAN, y varios "triángulos de crecimiento" industriales (similares en muchos aspectos a las zonas de procesamiento de las exportaciones); y vínculos intrarregionales e internacionales cada vez más sólidos que abaratan los costos logísticos y de producción (Plummer y Chia, 2009; Athukorala, 2010).

Por ejemplo, a principios del decenio de 1980 la ASEAN comenzó a crear un sector comercial dinámico mediante la liberalización del comercio y la IED, así como la inversión en infraestructura relacionada con el comercio. El programa de reformas transformó radicalmente la estructura del comercio, que dejó de depender predominantemente de los recursos naturales y los productos agrícolas para orientarse hacia las manufacturas. En el sector manufacturero, los cambios más importantes ocurrieron en el subsector de la maquinaria y el equipo de transporte (sección 7 de la Clasificación Uniforme para el Comercio Internacional). El cambio más espectacular en este sector ha sido el registrado en las exportaciones de válvulas termoiónicas (subgrupo 776 de la Clasificación), cuyo valor aumentó de 12.000 millones de dólares EE.UU. en 1990 a 120.000 millones de dólares EE.UU. en 2006, y que representan el 16\% del valor de las exportaciones totales de la ASEAN (759.000 millones de dólares EE.UU.) (Plummer y Chia, 2009). El valor de las exportaciones de válvulas termoiónicas de la ASEAN representa casi la tercera parte del valor del comercio mundial de válvulas termoiónicas (379.000 millones de dólares EE.UU.); dichas exportaciones incluyen tubos para receptores de televisión; otras válvulas y tubos eléctricos; diodos, transistores y semiconductores similares; microcircuitos electrónicos; y cristales piezoeléctricos. Estas exportaciones forman parte de una cadena de valor en el sector de la electrónica de la que la ASEAN es el eslabón clave. Uno de los principales objetivos de la AEC es lograr el mismo éxito en relación con cadenas de valor en otras esferas.

\section{Factores complementarios que fomentan la integración económica nacional}

Para que la cooperación regional (o cualquier innovación en materia de política comercial) logre promover la integración regional deben darse ciertas condiciones necesarias. En primer lugar, los efectos dependerán de la solidez de las políticas económicas nacionales de los países miembros. Pocas son las empresas que logran beneficiarse del comercio regional en situaciones de inestabilidad macroeconómica, cuando los derechos de propiedad son débiles, cuando reina la corrupción o cuando las leyes fiscales y la reglamentación comercial no son transparentes. Normalmente los ALC promueven la reforma de la política económica nacional; el hecho de que los ALC por lo general sean más profundos que los acuerdos multilaterales pone de relieve una importante ventaja del regionalismo como estrategia complementaria de la política comercial. Por ejemplo, México ha logrado incorporar los compromisos contraídos en el marco del Tratado de Libre Comercio de América del Norte (TLCAN) en un programa nacional amplio de reforma económica, y la consiguiente liberalización dentro de las fronteras ha sido óptima. 
En segundo lugar, la capacidad para atraer redes de producción por medio de los ALC dependerá también de la eficiencia del transporte y otros tipos de infraestructura, de la facilitación del comercio y de otras medidas relacionadas con las políticas. Por ejemplo, para cosechar los beneficios que pueden derivarse de un ALC es necesario que las redes de transporte y logística entre los países miembros tengan capacidad suficiente para atender al mayor volumen del comercio. Los países sin litoral, en particular, dependen en medida crítica de la calidad de la infraestructura de los países vecinos.

Por lo tanto, para que la liberalización del comercio dé fruto a menudo es necesario que las economías en desarrollo introduzcan mejoras en diversas esferas que tradicionalmente constituyen los aspectos centrales de la Iniciativa de Ayuda para el Comercio: la infraestructura relacionada con el comercio, la facilitación del comercio y la creación de un entorno favorable al comercio son indispensables para que los países en desarrollo puedan beneficiarse de la liberalización comercial, independientemente del contexto. Los acuerdos comerciales regionales facilitan el progreso en esas esferas, ya que es más fácil encarar esas cuestiones (a menudo políticamente delicadas) en el marco de un pequeño grupo de economías afines de una región que, por ejemplo, en el contexto multilateral. A continuación se examinan las políticas complementarias que contribuyen a determinar el éxito de la liberalización y la facilitación del comercio, y más adelante se analiza la forma en que el surgimiento del regionalismo en la economía mundial está incentivando el desarrollo de redes de producción y la fragmentación del comercio a lo largo de la cadena de valor.

\section{Corredores de tránsito/de transporte}

Los corredores de tránsito/transporte son excelentes ejemplos de las ventajas que los ALC y otras formas de cooperación económica regional reportan a las economías de los miembros en desarrollo, ya que, por su propia naturaleza, tienen alcance regional. Los corredores suelen definirse como rutas físicas que conectan dos o más zonas y permiten la circulación de personas y mercancías entre esas zonas o a lo largo de la ruta. Los corredores pueden servir para conectar diferentes zonas dentro un mismo país o para conectar subregiones y regiones. Están compuestos por carreteras, vías férreas, puentes y accesos portuarios. Pueden establecerse para incrementar el comercio dentro de una región, facilitar el acceso a países sin litoral o crear una puerta de acceso internacional para el comercio de mercancías mediante la conexión de una región a puertos. Los corredores de tránsito/transporte son especialmente importantes para las perspectivas comerciales y de crecimiento de los países sin litoral.

El alto costo del transporte reduce los beneficios que puede reportar la liberalización del comercio y puede anular los efectos sobre los precios de la reducción de los obstáculos arancelarios y no arancelarios a través de un ALC. En consecuencia, limita la capacidad de las economías para participar en las redes de producción. En muchos estudios sobre el comercio se hace hincapié en la importancia de este factor como obstáculo para el comercio. Por ejemplo, Limao y Venables (2001) estimaron que en los países en desarrollo entre el 40\% y el 60\% de la variación del costo del transporte se debía a la calidad de la infraestructura, y que una disminución del 10\% en dicho costo generaba un incremento del comercio de cerca del 25\%. Por lo tanto, la atención que se presta, en particular en los programas de ayuda para el comercio, a los corredores de tránsito está plenamente justificada.

Al principio, en las cuestiones relacionadas con el transporte se prestaba atención fundamentalmente a la construcción y la mejora de la infraestructura física, como carreteras, vías férreas y puentes. Más recientemente, el alcance de los proyectos y programas destinados a mejorar los corredores de transporte se ha ampliado para incluir medidas encaminadas a eliminar los embotellamientos en los cruces fronterizos y reducir directa e indirectamente el tiempo y el costo del transporte mediante, por ejemplo, la armonización de los controles fronterizos, la mejora de la tecnología y las comunicaciones, la reducción de la documentación requerida y el aumento de la eficiencia de los organismos estatales y los agentes fronterizos. 
La adopción de un enfoque regional es un medio eficiente, pero a menudo difícil a nivel político, de desarrollar los corredores de tránsito (OCDE, 2009). Como la proporción del costo de los proyectos sufragada por cada país no es la misma, existen incentivos asimétricos para gastar los limitados fondos y recursos destinados al corredor en otros proyectos nacionales, sobre todo cuando no hay acuerdo sobre qué país resultará particularmente beneficiado. En este sentido, la intervención de un "intermediario desinteresado", como un banco multilateral o regional de desarrollo, puede ayudar a superar esa clase de problema. A modo de ejemplo cabe mencionar la intervención del Banco Asiático de Desarrollo (BAsD) en la Subregión del Gran Mekong y en el Programa de Cooperación Económica Regional de Asia Central (CAREC), que se examina en detalle más abajo; se trata de proyectos en los que el BAsD ha invertido sumas considerables y en los cuales desempeña la función de intermediario desinteresado.

Los beneficios tangibles de aplicar un enfoque regional en lugar de una serie de enfoques nacionales pueden ir desde la estandarización de la construcción de las líneas férreas (a fin de que los vagones de los distintos países de una región puedan circular a lo largo de todo el corredor) hasta el desarrollo de normas regionales de pesas y medidas. La OCDE (2009, capítulo 2) describe la forma en que las organizaciones de cooperación regional han trabajado con los gobiernos donantes y los asociados para mejorar los enlaces de transporte transfronterizo en el marco de un plan estratégico destinado a impulsar la integración económica regional. Además, como han señalado Kuroda et al. (2007), "la buena calidad de las carreteras no sirve de nada cuando el tráfico queda atascado en la frontera". ${ }^{5}$ Con el fin de maximizar el efecto que tiene la infraestructura en el comercio es necesario también armonizar la reglamentación y los sistemas, y que los Gobiernos cooperen para garantizar el cruce rápido de las fronteras.

\section{Facilitación del comercio}

En general, es más fácil abordar la cuestión de la facilitación del comercio a nivel regional que en negociaciones multilaterales, ya que guarda relación con medidas internas complejas y en ocasiones políticamente delicadas. La facilitación del comercio se diferencia de otras cuestiones relacionadas con el comercio internacional porque en ella la atención está centrada en la eficiencia de los procesos (PNUD, 2007). Las medidas destinadas a promover la facilitación del comercio son de vital importancia para las estrategias comerciales y de desarrollo de los países, ya que permiten una expansión del comercio que de otro modo se vería entorpecida por obstáculos no arancelarios y dentro de las fronteras. Esa clase de obstáculos al comercio reducen las posibilidades de incrementar la eficiencia y aumentar la productividad, así como las consiguientes posibilidades de crecimiento gracias al incremento de las exportaciones y las importaciones. Además, esa clase de obstáculos dificultan la formación de redes de producción y a menudo son la causa de que se excluya a algunos países de las cadenas de valor.

La facilitación del comercio, desde una perspectiva regional, abarca muchos elementos que no se prestan a la discriminación entre asociados comerciales y, por lo tanto, incrementa no sólo la eficiencia del comercio regional sino también la del comercio mundial. El Foro de Cooperación Económica de Asia y el Pacífico (APEC) ha realizado importantes progresos en materia de facilitación del comercio sobre una base completamente voluntaria y no discriminatoria, que incluye un conjunto de principios en materia de facilitación del comercio elaborados en estrecha colaboración con el sector privado (que se examina infra).

Tal vez el argumento más evidente en pro de las iniciativas regionales de facilitación del comercio sea el geográfico, en la medida en que la proximidad geográica permite a los comerciantes intercambiar más información, compartir prácticas culturales y, con el tiempo, desarrollar sistemas comunes (Maur, 2008). Como muchos de los obstáculos no arancelarios y obstáculos dentro de la frontera que se interponen al comercio tienen una base geográfica, es lógico aplicar soluciones regionales. Las iniciativas regionales de facilitación del comercio específicamente relacionadas con 
la geografía pueden consistir en la utilización de instalaciones fronterizas comunes o en la armonización y cooperación regionales para evitar la duplicación (como consecuencia de la existencia de normas diferentes en cada país) y los costos de fricción (como el uso ineficiente del tiempo debido a la reiterada carga y descarga de las mercancías).

En segundo lugar, la facilitación del comercio regional puede incrementar la eficiencia mediante la eliminación de trámites y servicios costosos. En este sentido, las soluciones regionales son a veces más fáciles de aplicar que los enfoques multilaterales debido a la complejidad de los acuerdos sobre facilitación del comercio y al hecho de que la aplicación de medidas para reducir los costos requiere a menudo la cooperación regional sobre el terreno. La eliminación de trámites costosos incrementa la eficiencia de las empresas y da a los pequeños productores mayor acceso a los mercados de exportación, una cuestión de importancia clave en los países en desarrollo. Las soluciones regionales incluyen la armonización, la asistencia mutua entre las autoridades en materia de valoración en aduana y el reconocimiento mutuo de resoluciones, sistemas de certificación y pruebas (OCDE, 2009).

En tercer lugar, la facilitación del comercio a nivel regional también puede dar lugar a la competencia en las actividades relacionadas con el comercio. Los acuerdos regionales que generan una mayor transparencia en la reglamentación pueden, a su vez, promover una gestión más eficiente de las fronteras. Los servicios relacionados con el comercio que dependen de la cooperación en materia de reglamentación también resultan beneficiados.

En resumen, la experiencia indica que los corredores de tránsito y la facilitación del comercio son importantes para el éxito de toda estrategia de política comercial, y que suele ser más sencillo y eficiente abordar las cuestiones conexas a través de la cooperación económica regional que mediante otros enfoques.

\section{REGIONALISMO Y REDES DE PRODUCCIÓN EN LAS ECONOMÍAS EN DESARROLLO}

Del análisis precedente se desprende claramente la importancia de la cooperación regional para facilitar la participación de las economías en desarrollo en las cadenas de valor, así como de las políticas complementarias necesarias para apoyar ese proceso. La reducción de los obstáculos al comercio y a la inversión a través de acuerdos comerciales regionales reduce el costo de las transacciones como resultado de la fragmentación del comercio y, por lo tanto, permite la formación de cadenas de valor regionales (OCDE, 2013). Orefice y Rocha (2011), por ejemplo, utilizan un modelo gravitacional para demostrar los efectos de los acuerdos de cooperación económica más profundos en el comercio relacionado con redes de producción. Esos autores estiman que, como resultado de esa clase de acuerdos, el comercio entre los países asociados aumenta en casi 35 puntos porcentuales. Además, es más fácil promover reformas profundas en el contexto de los acuerdos regionales, ya que en ellos suele participar un número más limitado de países con puntos de vista compartidos y que, por lo general, se excluye a los que pretenden beneficiarse a expensas de los demás. Incluso el trato "especial y diferenciado" previsto en los ALC adopta cada vez en mayor medida la forma de períodos de transición más largos en lugar de una exención de las obligaciones de reforma de las políticas.

En la presente sección se analizan brevemente las experiencia de la región que mayor éxito ha tenido en el establecimiento de cadenas de valor (Asia) y de la región que menos éxito ha tenido (África). Además, se describen las actividades llevadas a cabo en el Caribe, una subregión que ha intentado promover las cadenas de valor con especial empeño. También se pasa revista a análisis de los puntos fuertes y débiles de la ayuda para el comercio a nivel regional como elemento catalizador de la integración regional utilizando para ello los resultados de la encuesta realizada en 2013 por la OMC, la UA y la CEPA entre donantes y países asociados de África y la labor de vigilancia y evaluación de la ayuda para el comercio llevada a cabo en 2011 por la OCDE y la OMC. ${ }^{6}$ En la siguiente sección se considera en qué medida la ayuda para el comercio a nivel regional constituye un instrumento eficaz para promover las cadenas de valor y contribuir al éxito de los acuerdos regionales. 


\section{La cooperación regional en Asia: un medio eficaz de promover las cadenas de valor}

La región del Asia Oriental ha sido, con mucho, la que se ha dedicado con mayor empeño y éxito a movilizar la cooperación regional para promover la fragmentación del comercio y las redes de producción. La mayoría de los ALC de Asia son de naturaleza bilateral, lo que significa que suelen ser más fáciles de negociar que, por ejemplo, los acuerdos en que participan muchos miembros o los acuerdos que son más profundos, como los de unión aduanera. Además, la mayoría de estos ALC se han celebrado con economías no asiáticas. Por ejemplo, la ASEAN, en su carácter de organización regional, ha celebrado siete ALC (con Australia, China, Corea, Corea del Sur, la India, el Japón y Nueva Zelandia), mientras que sus países miembros han celebrado diez acuerdos separados con economías del Asia Oriental que no son miembros de la ASEAN y nueve con países totalmente ajenos a la región, varios de los cuales son más amplios que incluso los acuerdos de cooperación entre los países de la ASEAN (Petri et al., 2012). Las redes de producción y la fragmentación del comercio en la región y con interlocutores ajenos a ella han sido objeto de numerosos estudios empíricos?

La fuerza impulsora de la cooperación regional en el Asia Oriental es el mercado: los ALC tienen por objeto, en buena medida, aumentar las corrientes de IED a fin de consolidar las cadenas de producción existentes y promover la creación de otras nuevas. Como se señaló más arriba, el éxito logrado por la región en este sentido ha sido considerable: las corrientes intrarregionales de comercio e inversión han aumentado marcadamente con el correr del tiempo, hasta el punto de que el comercio regional representa en la actualidad más de la mitad del comercio total. Sin embargo, cuando se calcula el comercio en función del valor añadido, el comercio intrarregional representa mucho menos de la mitad del comercio total (BAsD, 2008). En otras palabras, debido a la importancia creciente de las redes de producción regionales se plantea un problema de "doble cómputo" de las corrientes comerciales intrarregionales (en valores nominales). También se llega a esta conclusión si se utilizan los datos de la base de datos sobre el comercio en función del valor añadido (TiVA) elaborada por la OCDE y la OMC para determinados países. Por ejemplo, en 2007 China pasó a ser el asociado comercial más importante del Japón en valores nominales, pero en parte eso se debió a la creciente importancia de China en las redes de producción encabezadas por empresas japonesas. Según la base de datos TiVA, en función del valor añadido, los Estados Unidos siguen siendo el principal asociado comercial del Japón.

Aunque la gran mayoría de los estudios empíricos sobre los ALC bilaterales de Asia indican que los ALC han tenido (o tendrán) un efecto positivo en el bienestar de los Estados miembros, los ALC también tienen importantes deficiencias: como la promoción de las redes regionales de producción es la fuerza impulsora del regionalismo en Asia, los ALC bilaterales inevitablemente tenderán a dar resultados muy inferiores a los que se podrían lograr. En cambio, si los ALC fueran regionales, se podrían optimizar las cadenas de valor y reducir los costos en relación, por ejemplo, con las normas de origen (mediante la "acumulación"), elaborar normas regionales en materia de propiedad intelectual y adoptar medidas regionales de facilitación del comercio, entre otras cosas. Cabe señalar que esta clase de políticas constituyen la mejor opción, ya que no sólo benefician a los países asociados, sino a todos los países.

Los Gobiernos asiáticos son conscientes de esas limitaciones y por ello han entablado negociaciones encaminadas a concertar acuerdos "megarregionales" -el Acuerdo Transpacífico de Asociación (TPP) y la Asociación Económica Amplia Regional (RCEP)- tendencia que se conoce con el nombre de "nuevo regionalismo" de Asia (Petri et al., 2012). Como cada uno de ellos abarcará aproximadamente el $40 \%$ del comercio mundial, los acuerdos constituirán instituciones nuevas muy importantes para la economía mundial que permitirán eliminar muchas de las ineficiencias achacadas a la "maraña de ALC asiáticos". 
Las negociaciones en relación con el TPP comenzaron en 2008; en mayo de 2013 se celebró la 17a ronda de negociaciones. El TPP se basa en un ALC de alta calidad entre cuatro economías pequeñas y abiertas (Brunei Darussalam, Chile, Nueva Zelandia y Singapur), conocidas como el "P4". Además del P4, en las negociaciones sobre el TPP participan Australia, los Estados Unidos, Malasia, el Perú, Viet Nam y, más recientemente, el Canadá y México. El Japón confirmó en marzo de 2013 su intención de sumarse a los participantes y probablemente comenzará a hacerlo como miembro de pleno derecho en julio.

El TPP es un acuerdo singular no sólo porque existen grandes diferencias en el nivel de desarrollo de los países en cuestión, sino también porque el objetivo es que se convierta en un acuerdo moderno "del siglo XXI" que abarque esferas muy diversas, como los obstáculos fronterizos y no fronterizos al comercio, la IED, la protección de la propiedad intelectual, la facilitación del comercio y la política de competencia. El acuerdo incluso contiene artículos consagrados a la ciencia y la tecnología y a las pequeñas y medianas empresas. Todas esas esferas guardan relación con las redes de producción.

La RCEP es una iniciativa mucho más reciente, que se puso en marcha en noviembre de 2012. Se trata de la primera iniciativa de gran envergadura de la ASEAN en el marco de su estrategia sobre el papel "central de la ASEAN". Inicialmente, sólo la ASEAN y los países con los que ha concertado ACL (Australia, China, Corea, la India, el Japón y Nueva Zelandia) participarán en las negociaciones sobre la RCEP. No obstante, con arreglo a los principios rectores para la negociación de la RCEP aprobados por la ASEAN y los dirigentes de los países con los que ha concertado ALC, los asociados económicos de la región, a la larga, podrán adherirse al acuerdo. Se prevé que la RCEP será un acuerdo de "alta calidad", aunque el hecho de que apunte a ser más "flexible" que el TPP, así como su composición, parecerían indicar que será menos amplio. En mayo de 2013 los dirigentes de los países de la RCEP concluyeron la primera ronda de negociaciones, que versaron sobre el alcance y la metodología; se prevé celebrar una segunda reunión en septiembre. Los dirigentes de la RCEP prevén concertar el acuerdo para finales de 2015. ${ }^{8}$

Según estudios empíricos, esos acuerdos regionales tendrán importantes efectos en el crecimiento económico regional, en buena medida debido a las repercusiones del TPP y la RCEP sobre las entradas y salidas de IED, es decir, a sus efectos positivos en las redes de producción. Petri et al. (2012) utilizan un modelo avanzado de equilibrio general computable para calcular los efectos económicos de la RCEP y el TPP como cauces para el establecimiento de la Zona de Libre Comercio de Asia y el Pacífico (FTAAP) en 2025. Según esos autores, ambos acuerdos generarán importantes beneficios: aunque consideran que inicialmente los efectos en la economía mundial serán pequeños, para 2025 los beneficios anuales a nivel del bienestar ascenderían a 223.000 millones de dólares EE.UU. en el caso del TPP, a 499.000 millones de dólares EE.UU. en el caso de los dos acuerdos y a 1,9 billones de dólares EE.UU. cuando se haya establecido la FTAAP, cuantía que representa casi el 2\% del PIB mundial, una repercusión muy importante resultante, fundamentalmente, de la participación de China y los Estados Unidos en el mismo ALC.

\section{La cooperación regional en África: iniciativas para desarrollar nuevas redes de integración}

África ha estado tan ocupada como Asia formulando ALC e instrumentos de integración aún más profundos, como uniones aduaneras (por ejemplo, la Unión Aduanera del África Meridional, la SADC y la Comunidad Económica de los Estados de África Occidental (CEDEAO), e incluso uniones monetarias (como la Unión Económica y Monetaria del África Occidental, conocida por su acrónimo francés, UEMOA (Union Économique et Monétaire Ouest Africaine). Los documentos del Banco Africano de Desarrollo (BafD) sobre estrategias de integración regional para diversas 
regiones recogen amplios estudios sobre esas iniciativas y planes para el futuro. ${ }^{10}$ Al igual que Asia, África ha considerado la posibilidad de integrar sus numerosos ALC en un ALC "continental" o "panafricano". Esa posibilidad comenzó a examinarse activamente en el sexto período ordinario de sesiones de la Conferencia de Ministros de Comercio de la Unión Africana, celebrada en 2010. Sin embargo, existe una diferencia importante entre las experiencias asiática y africana, ya que los esfuerzos de Asia por estimular el comercio intrarregional han sido mucho más eficaces que los de África, en la que el comercio intrarregional sólo representa el 10\% del comercio total.

El mayor éxito logrado por Asia en materia de expansión del comercio intrarregional guarda relación, en parte, con la estructura de la producción: las economías africanas tienden a intercambiar productos (por ejemplo, exportaciones de recursos naturales a cambio de importaciones de manufacturas), mientras que la estructura de las exportaciones asiáticas está mucho más diversificada y se caracteriza, cada vez más, por el comercio intraindustrial, incluido el comercio fragmentado por medio de redes de producción. Sin embargo, en las primeras fases de desarrollo la mayoría de las economías asiáticas también empezaron con el comercio interindustrial; la diversificación tiene lugar a medida que los países se desarrollan y avanzan en las cadenas de valor. Además, como en África, en el pasado el comercio intrarregional en Asia también se vio afectado por problemas de conectividad. Los países del Asia Sudoriental han asignado prioridad y una cantidad considerable de recursos a mejorar los enlaces transfronterizos por carretera y por vía férrea, así como los puertos y la infraestructura no física, y han establecido corredores de tránsito, entre otras iniciativas, a fin de reducir el costo de los intercambios intrarregionales, con un éxito considerable.

Por ejemplo, en 2012 se creó el Fondo de Infraestructura de la ASEAN, y mediante el programa para la Subregión del Gran Mekong, que fue establecido en 1992 y cuya secretaría tiene su sede en el BAsD, se ha conseguido eliminar los principales obstáculos al comercio en la región del Mekong. Es importante señalar que esta clase de iniciativas a menudo tienen por objeto atender a la necesidad de reducir el costo de los intercambios intrarregionales y no de aumentar la participación en el comercio intrarregional como fin en sí; no obstante, como atraen redes de producción, frecuentemente eso suele redundar en un incremento del comercio intrarregional (desde que se estableció la Zona de Libre Comercio de la ASEAN hasta la fecha, el comercio intrarregional en la ASEAN sólo ha aumentado del 20\% al 25\%). Pero el éxito en este ámbito debería medirse según la repercusión de las iniciativas en materia de reducción de los costos, aumento de la competitividad e incremento de la IED, que caracterizan al éxito logrado por la ASEAN en los últimos 20 años.

Además, el proceso de integración impulsado por las redes de producción que ha tenido lugar en la totalidad del Asia Oriental se ha apoyado en una cooperación regional "profunda" (que incluye la eliminación de los obstáculos fronterizos y no fronterizos al comercio). La importancia asignada a la liberalización de los servicios en el contexto de la Comunidad Económica de la ASEAN y la RCEP es indicio de la prioridad que se otorga a las cadenas de valor; como se desprende claramente de la base de datos TiVA, el comercio internacional de servicios es mucho mayor en términos de valor añadido (50\%) de lo que parece ser en términos nominales (cerca del 30\%). La diferencia obedece, en buena medida, al importante papel que desempeña el sector de los servicios en el apoyo a las redes internacionales de producción. Los responsables de la formulación de políticas en el Asia Oriental actualmente están asignando prioridad a los servicios.

Así pues, cabe atribuir el hecho de que África no haya logrado crear cadenas regionales de producción en buena medida a los deslucidos resultados en materia de integración regional. En los documentos relativos a las estrategias de integración regional del Banco Africano de Desarrollo se destaca que la falta de comercio intraindustrial y el insuficiente desarrollo de las redes de producción constituyen obstáculos para una mayor integración regional. 
Evidentemente, los líderes africanos tienen consciencia de estos problemas y han buscado la forma de corregirlos. Por ejemplo, en el Plan de fomento del comercio intrarregional de la Unión Africana (Unión Africana, 2012) se señalan los obstáculos que se interponen al comercio intrarregional y se proponen proyectos específicos para eliminarlos. Entre otras cosas, se observa que "Ios países africanos comerciarán más entre ellos si incrementan su capacidad productiva en sectores dinámicos de la economía y apoyan el establecimiento de empresas y cadenas de valor regionales" (página 8). También se asigna prioridad a los programas encaminados a aumentar la IED y a establecer empresas y cadenas de valor regionales.

Los donantes también han dirigido la atención a esas limitaciones fundamentales al comercio intrarregional en África. Las encuestas realizadas por la OMC, la UA y la CEPA en 2013 tuvieron lugar en el marco de la labor de vigilancia y evaluación en relación con el cuarto Examen Global de la Ayuda para el Comercio. La OMC, en colaboración con la Unión Africana (UA) y la Comisión Económica de las Naciones Unidas para África (CEPA), diseñó un cuestionario en línea destinado a evaluar la mejor forma en que la ayuda para el comercio podía contribuir a la consecución del objetivo de la UA de aumentar el comercio intraafricano. La UA y la CEPA distribuyeron el cuestionario entre países africanos y organizaciones regionales de cooperación económica, así como entre donantes e interlocutores del Sur. Se recibieron en total 51 respuestas al cuestionario, de las que 30 procedían de países africanos, cinco de organizaciones regionales de cooperación económica y 16 de donantes (ocho donantes bilaterales y ocho donantes multilaterales).

Por lo que se refiere a la cooperación e integración regionales, la encuesta a nivel de los donantes reveló lo siguiente:

- Tres cuartas partes de los donantes encuestados estaban invirtiendo en corredores de tránsito en África y, de ellos, tres cuartas partes indicaron que sus actividades se basaban en estrategias regionales y en estrategias de desarrollo de corredores.

- Más de las tres cuartas partes de los donantes dijeron que la asistencia solicitada por los asociados en relación con programas comerciales regionales había aumentado considerablemente desde 2005, lo que indica que ha aumentado el interés en desarrollar programas de cooperación regional con los donantes ("cooperación triangular"). Casi todos los donantes indicaron que el apoyo prestado se había ajustado a las diversas iniciativas comerciales de la Unión Africana y, especialmente, a la Iniciativa para aumentar la capacidad productiva de África (aproximadamente el 90\%) y al Programa de desarrollo de infraestructuras en África (dos tercios).

- Más del $80 \%$ de los donantes dijeron que habían participado en proyectos panafricanos encaminados a promover la cooperación y la integración regionales en el ámbito del comercio, y más de la mitad de ellos dijeron que también participaban en diversas iniciativas subregionales, como la Comunidad del África Oriental (CAO) (63\%), la CEDEAO (56\%) y la SADC (50\%).

- De las evaluaciones de los programas de los donantes en materia de cooperación comercial regional se desprende que esos programas han tenido mucho éxito: unos dos tercios de los donantes consideraban que mediante esos programas habían aumentado las exportaciones y el comercio; más de dos quintas partes consideraban que había aumentado el crecimiento económico y disminuido la pobreza, y algo más de un tercio señaló que los programas habían ayudado a diversificar las exportaciones. 
Así, según los resultados de la encuesta entre los donantes, la ayuda para el comercio a nivel regional se ha centrado en eliminar las limitaciones fundamentales que se interponen a la integración regional y en aumentar la cooperación económica regional mediante la mejora de la infraestructura física y no física; se ha orientado hacia iniciativas regionales y subregionales, y se ha desarrollado en estrecha cooperación con los asociados para el desarrollo; además ha logrado impulsar el crecimiento, reducir la pobreza y diversificar la economía (los objetivos esenciales de la cooperación regional).

La encuesta realizada en 2013 por la OMC, la UEy la CEPA entre los asociados corroboró muchos de esos aspectos." Según los resultados de esa encuesta, la infraestructura relacionada con el comercio y el transporte, al igual que la agricultura, el comercio de servicios y los servicios de apoyo a las exportaciones, son sectores clave en las estrategias comerciales regionales. Los encuestados declararon también que sus estrategias regionales de cooperación se habían elaborado en consulta con los donantes asociados y los asociados regionales, así como sobre la base de una evaluación de las necesidades, si bien añadieron que las consultas con el sector privado (tanto nacional como extranjero) eran una parte importante del proceso. También mencionaron a la UE como la principal fuente de asistencia en materia de integración comercial regional.12 Sin embargo, menos del 10\% de los encuestados estuvieron de acuerdo con la afirmación de que el apoyo a los programas comerciales regionales había aumentado significativamente desde 2005, y menos de la mitad indicaron que había aumentado ligeramente. Esto puede llevar a pensar que existe una demanda de asistencia regional no satisfecha.

Aunque los sectores prioritarios de la cooperación regional mencionados por los países receptores fueron similares a los mencionados por los donantes, al parecer los países receptores consideraban que el apoyo prestado por los donantes no se ajustaba a sus estrategias; sólo un 10\% afirmó que el apoyo estaba en consonancia con sus estrategias y dos terceras partes declararon que la coincidencia era moderada. Asimismo, dos terceras partes de los países indicaron que no habían solicitado ayuda en relación con las iniciativas de la UA. Entre la dificultades más importantes para llevar a cabo las estrategias comerciales regionales y/o sectoriales se señaló la falta de aplicación de las estrategias por parte de los países asociados de la región (lo que pone de relieve los problemas vinculados a los bienes públicos regionales) y la limitada capacidad de los ministerios encargados de la aplicación.

Las evaluaciones de los programas arrojaron resultados similares a los de la encuesta efectuada entre los donantes: entre los principales logros mencionados figuraban el aumento del crecimiento económico y el comercio y la reducción de la pobreza. Sin embargo, en las evaluaciones también se mencionó entre los logros importantes el incremento de los fondos regionales de ayuda para el comercio. La mitad de los encuestados dijo que, gracias a ello, la ayuda para el comercio a nivel regional había aumentado, mientras que entre los donantes menos del 20\% consideraba que era así.

En suma, aunque la cooperación regional puede constituir un importante estímulo para el comercio regional en África, como se ha señalado en el presente capítulo, para obtener resultados, es necesario contar con políticas encaminadas a apoyar el desarrollo de la infraestructura física y no física y otras políticas complementarias. Es por ello que muchos de los intentos de cooperación económica formal aún no han tenido repercusiones importantes en la integración regional. Por consiguiente, la ayuda para el comercio a nivel regional es particularmente eficaz para crear un entorno más propicio para las cadenas de valor. Las encuestas llevadas a cabo por la OMC, la UA y la CEPA en 2013 indican que la ayuda para el comercio a nivel regional ha sido eficaz, pero que aún queda mucho por hacer. 


\section{El Caribe: utilización de la ayuda para el comercio a nivel regional para promover la integración}

La Comunidad del Caribe (CARICOM) es una organización integrada por 15 Estados miembros y territorios dependientes. El Caribe tiene una larga tradición de cooperación económica. La Comunidad y Mercado Común del Caribe (1973) pasó a ser el Mercado y Economía Únicos de la CARICOM, que fue establecido en 2006. Aunque se trata de una subregión pequeña que cuenta con apenas 17 millones de habitantes, sus objetivos en materia de integración han sido ambiciosos: el Mercado y Economía Únicos de la CARICOM es, fundamentalmente, un mercado unificado con un arancel exterior común en que las mercancías, los servicios, los trabajadores y el capital circulan libremente. ${ }^{13}$ La CARICOM, junto a la República Dominicana, está vinculada a la UE a través de un acuerdo de asociación económica que entró en vigor en 2013, y a los Estados Unidos a través de un ALC especial (la Iniciativa de la Cuenca del Caribe).

La CARICOM ha utilizado activamente la ayuda para el comercio para fomentar la integración regional y fortalecer la cooperación. En diciembre de 2012 emprendió la Estrategia Regional de Ayuda para el Comercio de la Comunidad del Caribe 2013-2015 (CARICOM, 2012), en que se establecen las prioridades y los objetivos en materia de ayuda para el comercio a nivel regional para ese período. En el documento se indica que, a pesar de las mejores intenciones de la Comunidad en materia de cooperación económica, el nivel de interacción económica dentro de la región es menos de un $50 \%$ de lo que podría (y debería) ser. En el documento se observa asimismo que "los esfuerzos de la Región por promover el crecimiento económico a través del comercio se han visto entorpecidos por una infraestructura económica deficiente, un nivel de competitividad bajo y decreciente, instituciones débiles, sistemas de producción fragmentados y capacidad de producción limitada", es decir, muchos de los obstáculos mencionados precedentemente que pueden ser superados mediante una ayuda para el comercio debidamente orientada. De hecho, la utilización de la ayuda para el comercio a nivel regional a fin de aumentar el valor añadido de la producción es una de las prioridades principales de la Estrategia.

\section{¿Cuáles son los principales desafíos mencionados por los asociados?}

En sus respuestas a la encuesta de seguimiento llevada a cabo por la OCDE y la OMC en 2011 las organizaciones regionales indicaron cuáles eran, a su juicio, los obstáculos más importantes al comercio, tanto a nivel intrarregional como extrarregional. En el cuadro 4.1 se resumen los resultados de la encuesta. En general, los encuestados consideraban que los obstáculos más importantes para el comercio intrarregional y extrarregional eran la falta de competitividad, la diversificación limitada de las exportaciones y la falta de enlaces de transporte adecuados, que se aplicaban en buena medida a las dos categorías de comercio. Todas las regiones tropezaban con problemas en relación con la infraestructura física y no física; la financiación del comercio y la diversificación limitada de las exportaciones también constituían importantes limitaciones en varias regiones. Los encuestados también mencionaban frecuentemente las cuestiones relativas a las normas y la conformidad con las normas, especialmente en relación con el comercio exterior de la mayoría de las organizaciones subregionales africanas y de la CARICOM.

Además, de las respuestas se desprende que hay diferencias de apreciación incluso entre las organizaciones de una misma región. Por ejemplo, las respuestas de las tres comunidades económicas regionales cuyos miembros son Estados del África occidental a las preguntas relativas a los principales obstáculos al comercio intrarregional son bastante diferentes. El entorno reglamentario fue mencionado entre los principales obstáculos al comercio intrarregional por la CEDEAO y entre los principales obstáculos al comercio exterior por el Organismo de coordinación de transporte de tránsito del corredor norte (TTCA-NC), pero no por la Comunidad del África Meridional para el Desarrollo (SADC) (ni por la Organización de los Estados del Caribe Oriental (OECO)). El acceso limitado a la financiación del comercio constituía un obstáculo importante al comercio intrarregional para la SADC y para la OECO, que también la consideraba un obstáculo importante para el comercio exterior. Todos los encuestados, excepto la CEDEAO, 


\section{Cuadro 4.1 Reseña de los obstáculos al comercio intrarregional y extrarregional}

\section{Organización regional}

Comunidad de Estados Sahelosaharianos (CEN-SAD)

CEDEAO

OECO

SADC

\section{Organismo de coordinación de transporte de tránsito del corredor norte (TTCA-NC)}

\section{Restricciones más importantes al comercio intrarregional}

Competitividad

- Diversificación limitada de las exportaciones

Escasa demanda regional

- Competitividad

- Diversificación limitada de las exportaciones

- Entorno reglamentario para la actividad comercial

- Enlaces de transporte inadecuados

- Costo de los servicios de transporte

- Acceso limitado a la financiación del comercio

Competitividad

Enlaces de transporte inadecuados

Acceso limitado a la financiación del comercio

Conformidad con normas

Escasa demanda regional

- Competitividad

Diversificación limitada de las exportaciones

- Enlaces de transporte inadecuados

- Trámites aduaneros y fronterizos

Restricciones informales

Competitividad

- Entorno reglamentario para la actividad comercial

- Enlaces de transporte inadecuados

Conformidad con normas

- Trámites aduaneros y fronterizos

Restricciones informales

\section{Restricciones más importantes} al comercio extrarregional

Competitividad

- Diversificación limitada de las exportaciones

- Enlaces de transporte inadecuados

Conformidad con las normas

Escasa demanda regional

- Competitividad

Costo de exportar

Competitividad

- Diversificación limitada de las exportaciones

- Conformidad con las normas

Competitividad

Conexiones de transporte insuficientes

- Acceso limitado a la financiación del comercio

- Conformidad con normas

- Competitividad

Diversificación limitada de las exportaciones

- Costo de exportar

- Trámites aduaneros y fronterizos

Restricciones informales

- Competitividad

- Diversificación limitada de las exportaciones

Enlaces de transporte inadecuados

- Costo de exportar

- Acceso limitado a la financiación del comercio

Conformidad con normas

- Trámites aduaneros y fronterizos

Restricciones informales 
asignaron gran importancia a la competitividad. El costo de los servicios de transporte era considerado un obstáculo importante por la CEDEAO, pero no por otras organizaciones regionales. Resulta difícil explicar esas diferencias de opinión, aunque tal vez se trate de un problema de interpretación (por ejemplo, el costo de los servicios de transporte hace aumentar los costos y reduce la competitividad).

En cualquier caso, según las respuestas al cuestionario, los obstáculos más importantes al comercio intrarregional y extrarregional guardan relación con las políticas relacionadas con el comercio, la facilitación del comercio, la financiación del comercio, los enlaces de transporte, la diversificación limitada de las exportaciones y una demanda regional baja. Como se desprende claramente de las encuestas llevadas a cabo por la OMC, la UA y la CEPA en 2013, así como de los relatos de experiencias regionales (que se examinan más adelante en el presente capítulo), la ayuda para el comercio a nivel regional ha demostrado ser un instrumento eficaz para superar todos estos problemas, excepto la financiación del comercio.

\section{LA AYUDA PARA EL COMERCIO A NIVEL REGIONAL ES UN EFICIENTE CATALIZADOR DE LAS CADENAS DE VALOR}

Para que las economías en desarrollo puedan obtener los beneficios que reportan la integración y la cooperación regionales, deben corregir diversas deficiencias y limitaciones del mercado. En ese ámbito la ayuda para el comercio a nivel multinacional y regional puede desempeñar un papel importante. Como se desprende claramente de los relatos de experiencias sobre la ayuda para el comercio a nivel regional (OCDE/OMC, 2011) y de las encuestas realizadas por la OMC, la UA y la CEPA en 2013, la ayuda para el comercio regional está abordando de forma eficiente y eficaz los obstáculos que impiden una mayor integración bilateral y regional en muchas esferas, en el contexto de acuerdos regionales formales o por otros medios.

La ayuda para el comercio a nivel regional puede ser una forma eficaz en función del costo de apoyar la integración y la cooperación regionales. Se trata de una esfera clave en la que los países donantes y los países receptores pueden optimizar el uso de sus recursos. Cabe, pues, preguntarse en qué medida los países receptores y los países donantes han respondido hasta ahora a la necesidad evidente de ayuda para el comercio regional. ¿Cómo ha evolucionado la ayuda para el comercio a nivel regional en lo que se refiere al crecimiento de las corrientes agregadas? ¿Cómo se comparan estas corrientes con el total de las corrientes de ayuda para el comercio? ¿Qué sectores están recibiendo la mayor proporción de la ayuda para el comercio a nivel regional? Y, por último, ¿existen diferencias importantes entre una región y otra en la distribución de las corrientes de ayuda para el comercio a nivel regional?

En el capítulo 2 se señaló que el nivel de los compromisos en materia de ayuda para el comercio seguía siendo considerable en comparación con el correspondiente al período de referencia (2002 2005), si bien había disminuido más recientemente, al igual que el nivel de la asistencia para el desarrollo en general. Durante este difícil período, la ayuda para el comercio ha evolucionado de manera bastante positiva, si bien, como era tal vez inevitable, ha experimentado una reducción. Este hecho pone de relieve la importancia de velar por que la ayuda para el comercio sea lo más eficiente y eficaz posible. En el resto de la presente sección se examina la evolución de la ayuda para el comercio a nivel multinacional y regional por sectores. En la siguiente sección se relatan experiencias con la ayuda para el comercio a nivel regional. Esas experiencias ilustran la manera en que la ayuda para el comercio a nivel regional puede servir para apoyar el proceso de cooperación económica. 


\section{Evolución de las corrientes regionales de ayuda para el comercio}

En el capítulo 2 se reseñó en detalle la evolución de las corrientes totales de ayuda para el comercio en el contexto de las corrientes agregadas de asistencia oficial para el desarrollo. La ayuda para el comercio a nivel regional y subregional -como se define en el Sistema de Notificación por parte de los Países Acreedores de la OCDE (SNPA)representa una proporción relativamente pequeña del total de las corrientes de ayuda para el comercio, pero ha estado aumentando. En 2006, la cuantía de los desembolsos totales por concepto de ayuda para el comercio a nivel regional y subregional ascendía a 2.600 millones de dólares EE.UU.; en 2011 esa cuantía había aumentado a 6.200 millones de dólares EE.UU. Por lo tanto, la proporción de la ayuda para el comercio a nivel regional y subregional en el total de la ayuda para el comercio aumentó de aproximadamente el 12\% en 2006 al 19\% en 2011. Durante el período 2006-2011, el total de las corrientes de ayuda para el comercio aumentó en un 50\%, mientras que la ayuda para el comercio a nivel regional y subregional aumentó 2,5 veces.

En el ámbito sectorial hay importantes diferencias entre las corrientes de ayuda para el comercio a nivel regional y subregional y la ayuda para el comercio total. Desde 2006, la creación de capacidad productiva ha sido sistemáticamente el componente más importante de la ayuda para el comercio a nivel regional y subregional (gráfico 4.1). La proporción de los desembolsos destinados a este sector se mantuvo relativamente estable durante el período 2006-2009 (entre el 69\% y el 74\%). No obstante, entre 2009 y 2011 la ayuda para la creación de capacidad productiva disminuyó en un 7\%, principalmente en favor de la infraestructura económica y, en menor medida, de la política y reglamentación comerciales (gráfico 4.1).

\section{Gráfico 4.1 Programas regionales y mundiales por categoría (desembolsos) (Proporción y valor total)}

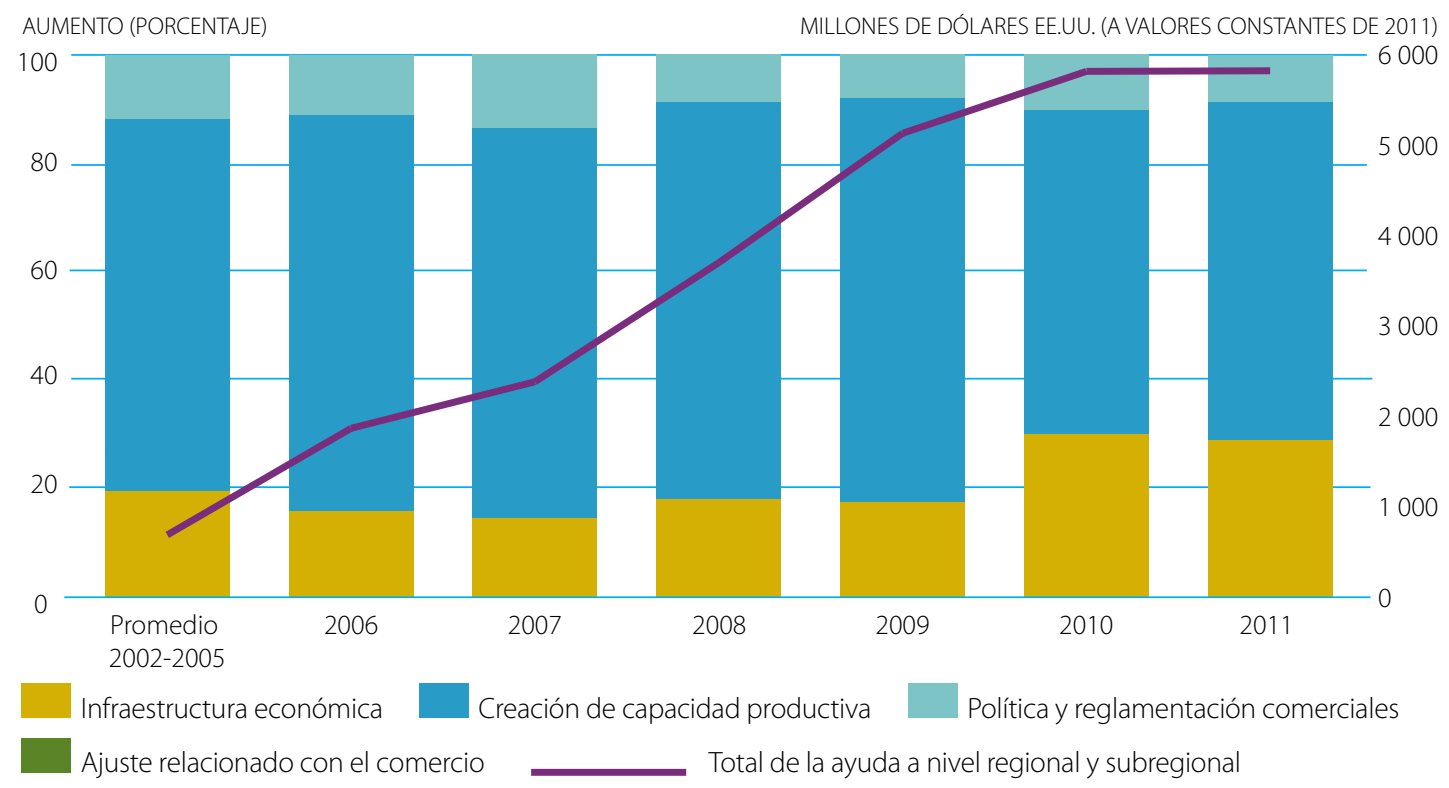

Fuente: Base de datos del Sistema de Notificación por parte de los Países Acreedores de la OCDE, http://stats.oecd.ora/index.aspx?DataSetCode=CRSI 


\section{Gráfico 4.2 Distribución geográfica de los programas regionales y mundiales (desembolsos) (Proporción y valor total)}

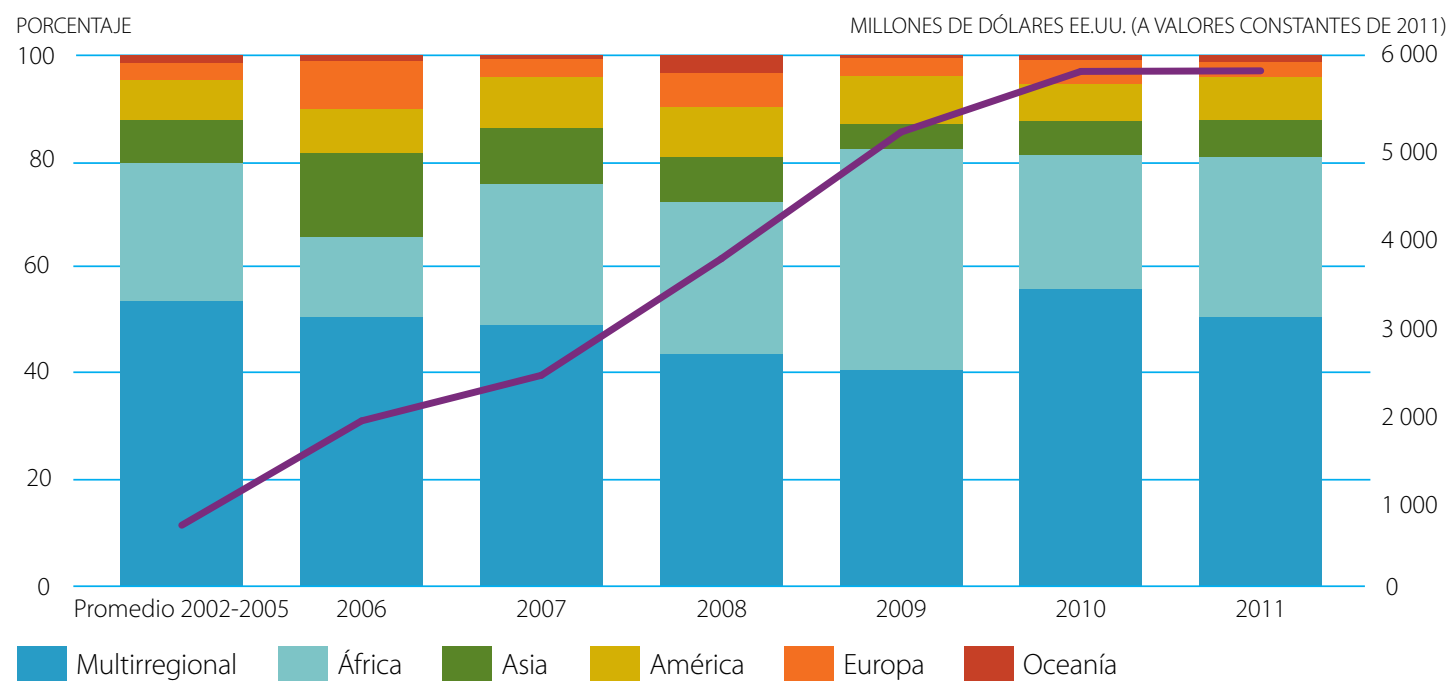

Fuente: Base de datos del Sistema de Notificación por parte de los Países Acreedores de la OCDE, http://stats.oecd.org/index.aspx?DataSetCode=CRS1

En el gráfico 4.2 figuran los datos agregados de la ayuda para el comercio total y por región y subregión (África, Asia, América, Europa, Oceanía) y una categoría "mundial (multirregional)". La distribución de los desembolsos por concepto de ayuda para el comercio entre las categorías mundial y por región y subregión varía considerablemente, como cabía esperar dada la naturaleza de las corrientes regionales y subregionales. La categoría mundial es la más voluminosa y abarca proyectos relacionados con la cooperación Sur-Sur, que ha adquirido creciente importancia en años recientes, así como las corrientes multinacionales de ayuda para el comercio asignadas a países con necesidades similares, independientemente de su ubicación geográfica.

A nivel regional y subregional, la proporción de los desembolsos por concepto de ayuda para el comercio destinados a África es aproximadamente cuatro veces superior a la correspondiente a Asia; si se excluyen los desembolsos mundiales, la proporción correspondiente a África prácticamente se ha duplicado (del 31\% en 2006 al 61\% en 2011), mientras que en el mismo período la proporción correspondiente a Asia ha disminuido en más de la mitad (del 32\% al 14\%). Estos datos reflejan, sin duda, la gran prioridad que los dirigentes africanos asignan a la integración regional.

En suma, la proporción de las corrientes regionales y subregionales de ayuda para el comercio ha aumentado desde 2006, a pesar de una ligerísima disminución de la cuantía en dólares de las corrientes totales y regionales (de 6.300 millones de dólares EE.UU. en 2010 a 6.200 millones de dólares EE.UU. en 2011). No obstante, el volumen de la ayuda para el comercio a nivel regional sigue siendo relativamente pequeño, especialmente si se tiene en cuenta su potencial, del que ya se ha hablado, y su probada eficacia, de que trata la siguiente sección.

Aunque la composición de estas corrientes ha variado en cierta medida a lo largo del tiempo, la "creación de capacidad productiva" y la "infraestructura económica" han sido sistemáticamente las categorías preponderantes de las corrientes a nivel regional. Los estudios sobre los obstáculos fundamentales al comercio indican que ese predominio está justificado, y los relatos de experiencias que se examinan a continuación son ejemplos de varios proyectos que tuvieron éxito. No obstante, la facilitación del comercio, la aplicación de políticas de ajuste más eficientes y prácticas y la facilitación del cambio estructural tienen cada vez más importancia para el éxito de las estrategias de desarrollo en general y para la cooperación e integración regionales en particular. Por consiguiente, estas esferas podrían ocupar un lugar preponderante en los futuros programas de ayuda para el comercio a nivel regional. 


\section{RELATOS DE EXPERIENCIAS EN QUE LA AYUDA PARA EL COMERCIO A NIVEL REGIONAL FUE UTILIZADA PARA PROMOVER LAS CADENAS DE VALORS}

De las secciones precedentes se desprende claramente que la ayuda para el comercio a nivel regional constituye un instrumento eficaz para reducir los obstáculos a la creación y expansión de las redes de producción y facilitar la participación en las cadenas de valor. Sin embargo, para cosechar los beneficios que puede reportar la ayuda para el comercio a nivel regional se requiere una planificación eficaz del desarrollo que incorpore de manera efectiva los proyectos regionales en los programas nacionales de desarrollo. Y he ahí el meollo del problema, ya que a los gobiernos nacionales a menudo les resulta difícil asignar sus escasos recursos financieros a proyectos con importantes externalidades y que no reportan beneficios exclusivamente en el plano nacional. Es por ello que en la Iniciativa de Ayuda para el Comercio se ha centrado la atención en buena medida en el ámbito nacional y que los instrumentos en apoyo de los programas multinacionales y regionales están menos desarrollados. Dada la disminución de los recursos por concepto de AOD a nivel mundial, el incremento de la ayuda para el comercio a nivel regional plantea numerosos desafíos. Sin embargo, el análisis precedente confirma claramente la tesis de que el aumento de la ayuda para el comercio a nivel regional reportará abundantes beneficios; debidamente orientada, la ayuda para el comercio puede ayudar considerablemente a las empresas de los países en desarrollo sirviendo de plataforma para su integración en las redes de producción internacionales, la integración regional y la competitividad en el ámbito mundial.

Existen abundantes pruebas de que es así. En julio de 2010, la OCDE y la OMC, como parte de los preparativos el Examen Global de la Ayuda para el Comercio de 2011 (OCDE/OMC, 2011), pidieron a las partes interesadas que proporcionaran relatos de sus experiencias. Un 10\% de los relatos presentados podrían clasificarse como proyectos de ayuda para el comercio a nivel multinacional o regional -porcentaje ligeramente inferior al que representa la ayuda para el comercio a nivel regional en el total de las corrientes de ayuda para el comercio-. A continuación se resumen algunos de los principales relatos y otros proyectos pertinentes para ilustrar la forma en que la ayuda para el comercio a nivel regional puede contribuir a desarrollar redes de producción, así como a aumentar la participación en las cadenas de valor. ${ }^{14}$

\section{Clasificación de los relatos de experiencias a nivel regional}

A fin de organizar de manera sistemática los relatos de experiencias, se han clasificado los proyectos en las siguientes categorías: infraestructura económica, facilitación del comercio, políticas relacionadas con el comercio, creación de capacidad productiva y promoción de las cadenas de valor. Cabe observar, no obstante, que ello se ha hecho por una cuestión de conveniencia, y no sobre la base de una prioridad u objetivo de orden económico. De hecho, muchos proyectos encuadrarían fácilmente en más de una categoría, y todos los proyectos que se describen a continuación han ayudado de manera importante a superar algunos de los obstáculos fundamentales a la integración y la creación de redes de producción a nivel regional.

\section{Infraestructura económica}

Como se señaló precedentemente, una infraestructura económica insuficiente es uno de los obstáculos fundamentales con que tropiezan las economías emergentes y en desarrollo, en particular las de los países de ingresos bajos, para la integración económica y la creación de cadenas de valor a nivel regional. De los relatos de experiencias se desprende claramente que la ayuda para el comercio a nivel regional destinada a proyectos y programas encaminados a crear infraestructura económica depende inevitablemente de que exista una estrecha coordinación plurinacional. La coordinación plurinacional da lugar a una verdadera red de organismos públicos y partes interesadas externas cuyas relaciones deben ser gestionadas con cuidado, teniendo en cuenta la necesidad de lograr un equilibrio adecuado entre los intereses políticos y económicos individuales. Con un número tan grande de partes interesadas resulta difícil cobrar impulso y mantenerlo, y es tanto mayor la importancia de lograr un compromiso y un apoyo políticos de alto nivel. 
Para asegurar la gestión eficaz y la sostenibilidad futura de los proyectos de infraestructura económica, así como para aprovechar plenamente los beneficios que puede reportar la eliminación de los obstáculos, el establecimiento de corredores de transporte esenciales y el fortalecimiento de las redes de tecnología de la información y las comunicaciones (medidas indispensables para promover la creación de redes de producción y avanzar en las cadenas de valor), es necesario disponer de algún tipo de financiación continuada que vaya acompañada de medidas encaminadas a crear capacidad.

El Programa estratégico de desarrollo económico del corredor de Nacala, que es financiado por el Organismo Japonés de Cooperación Internacional (JICA) en estrecha colaboración con el Gobierno de Mozambique, tiene por principal objetivo formular estrategias de desarrollo que sirvan para orientar un desarrollo e inversión apropiados. También podría tener efectos positivos en las cadenas de valor y en la creación de valor añadido en la región a través de los servicios prestados a las empresas..$^{15}$ El corredor de Nacala ha sido históricamente un importante corredor de tránsito del África Sudoriental, pero su uso se vio interrumpido por la guerra civil de Mozambique, que terminó en 1992. El corredor, cuya infraestructura se encontraba en ruinas, se convirtió en una prioridad importante de los donantes internacionales. El programa tiene por objeto formular una estrategia de desarrollo integrada para el corredor de Nacala y un marco de planificación eficaz. Para ello se ha seguido un enfoque regional (que abarca regiones de Mozambique y conexiones con países vecinos (Malawi, Tanzanía y Zambia)), así como sectorial (el programa abarca los sectores de la logística, el turismo, la minería, la industria, la silvicultura, la agricultura, los recursos hídricos, la electricidad, las comunicaciones, la infraestructura social y la infraestructura de transporte), lo que permite asignar prioridades y formular los proyectos de manera integrada. Mediante el programa se han mejorado las bases de datos disponibles en esferas que guardan relación con el desarrollo social y la actividad comercial, se han examinado planes de desarrollo, se han establecido prioridades respecto de los proyectos de desarrollo y las inversiones públicas y privadas, y se han analizado las limitaciones en materia de capacidad e identificado los obstáculos al desarrollo del corredor de Nacala con el objeto de orientar la selección y planificación de los proyectos.

El Programa de Cooperación Económica Regional de Asia Central (CAREC), que se puso en marcha en 2001 y que cuenta con la participación de diez países del Asia Central (incluida China) y el apoyo de seis instituciones multilaterales, tiene por objeto promover el desarrollo económico mediante la cooperación regional. ${ }^{16}$ En el marco del programa se están ejecutando proyectos regionales en materia de transporte, desarrollo de corredores económicos, facilitación del comercio, energía y política comercial; hasta la fecha se ha ejecutado un total de 140 proyectos, por valor de 21.000 millones de dólares EE.UU. Puede decirse que, hasta el momento, los mayores beneficios se han obtenido en las esferas de la mejora de la conectividad, lo que ha permitido reducir el costo de las transacciones comerciales a nivel nacional y en toda la región del CAREC, y el fomento del comercio. ${ }^{7}$

\section{Facilitación del comercio}

Como se señala en otra parte del presente capítulo, la facilitación del comercio tiene importantes consecuencias para la creación de redes de producción. Los representantes del sector privado suelen alegar que la reducción del costo de la integración económica mediante la facilitación del comercio es indispensable para crear redes de producción e impulsar el comercio internacional, así como para asegurar que el aumento de la eficiencia de la infraestructura física redunde en menores costos. La ayuda para el comercio a nivel regional puede desempeñar una función catalizadora cuando se trata de reducir esa clase de obstáculos a los intercambios comerciales.

Diversas iniciativas de facilitación del comercio emprendidas en el marco del APEC ofrecen excelentes ejemplos de la forma en que la cooperación regional puede reducir el costo de la interacción económica y promover las cadenas de valor. ${ }^{18}$ Durante el período 2002-2010, las economías del APEC consiguieron reducir en un 10\% el costo de las transacciones de empresas de toda la región mediante dos planes de acción para la facilitación del comercio. 
Además, se ha puesto en ejecución un plan de acción para el establecimiento de un sistema de ventanilla aduanera única (en 2007), y se ha creado una página Web del APEC con información sobre aranceles y normas de origen ("WebTR"). También se ha emitido una Tarjeta para Viajes de Negocios del APEC que permite viajar sin necesidad de obtener un visado y da acceso a vías de despacho rápido en los aeropuertos, lo que permite reducir el costo de los viajes de negocios.

En América, el Acuerdo de Libre Comercio entre los Estados Unidos, América Central y la República Dominicana ha puesto de relieve la importancia de la facilitación del comercio; en 2011 los Ministros de países de la región pusieron en marcha la Iniciativa de facilitación del comercio a fin de identificar los principales obstáculos que se interponían a los intercambios económicos en la región. ${ }^{19}$ Las tres esferas principales seleccionadas fueron los procedimientos aduaneros y de facilitación del comercio; la logística y la cadena de suministro; y las normas técnicas (incluidas las medidas sanitarias y fitosanitarias). Las encuestas realizadas entre las partes interesadas revelaron que las cuestiones que requerían una mayor atención eran la administración aduanera, incluida la gestión del riesgo; la logística y la infraestructura conexa; la necesidad de una gestión integrada de las fronteras; y el exceso de trámites burocráticos en las fronteras. Esa clase de cooperación regional resulta eficaz para ayudar a una región a determinar cuáles son los principales retos en materia de integración regional y establecer un orden de prioridad para atender a ellos.

Además, en el marco del Sistema de Tránsito Internacional de Mercancías, que puso en marcha el Banco Interamericano de Desarrollo (BID) en 2008, se creó un documento electrónico único con el objeto de simplificar y armonizar los trámites aduaneros en El Amatillo, localidad situada en la frontera entre El Salvador y Honduras, por la que pasa el mayor volumen de comercio de América Central.

Otro de los proyectos relacionados con la facilitación del comercio y la reducción de los costos ha sido llevado a cabo por Trademark Southern Africa (TMSA). En Chirundu, el primer puesto fronterizo de ventanilla única de África en el Corredor Norte-Sur, las mejoras resultantes de la facilitación del comercio han consistido en una reducción del costo del tránsito para el sector privado y un aumento de la recaudación pública de impuestos. Entre junio de 2010 y junio de 2012, el tiempo necesario para cruzar la frontera disminuyó en un 36\% -a 25 horas por término medio-; durante ese mismo período, el volumen del tráfico en el puesto fronterizo se intensificó considerablemente, con un incremento del $65 \%$ en el número de vehículos. Como resultado de la disminución del tiempo necesario para cruzar la frontera, hacia mediados de 2012, el sector privado economizaba unos 20 millones de dólares EE.UU. por mes por término medio. Además, entre 2009 y 2012 los ingresos del Gobierno de Zambia generados por el impuesto sobre el comercio se duplicaron, sin que se hubiesen modificado las tasas impositivas, gracias a la mayor eficiencia de las operaciones aduaneras.

\section{Políticas relacionadas con el comercio}

Como se indicó más arriba, la política y la reglamentación comerciales constituyen una categoría relativamente pequeña en comparación con la infraestructura económica y la creación de capacidad productiva. Esta categoría incluye proyectos relacionados con la política comercial y la gestión administrativa; la facilitación del comercio; los acuerdos comerciales regionales; las negociaciones comerciales multilaterales; la educación y la capacitación en materia de comercio; y la política de turismo y la gestión administrativa. ${ }^{20}$ Así pues, este sector abarca parte de la infraestructura no física destinada a la cooperación e integración regionales. No obstante, en las encuestas realizadas por la OCDE y la OMC y por la OMC, la UA y la CEPA examinadas más arriba se insiste en la importancia de mejorar las políticas relacionadas con el comercio a fin de impulsar la integración regional y la competitividad. 
Por lo tanto, la ayuda para el comercio regional en la esfera de la política y la reglamentación comerciales puede ser importante para facilitar la integración intrarregional y crear capacidad no física en los organismos públicos. Aunque actualmente la cuantía de la ayuda para el comercio a nivel regional que se asigna a la política y la reglamentación comerciales no es elevada, muy bien podría serlo en el futuro, especialmente si surgen nuevos tipos de acuerdos comerciales regionales (como el ALC panafricano y la RCEP mencionados precedentemente). Además, los beneficios que puede reportar una mayor facilitación del comercio a nivel multinacional y regional harán que esta esfera resulte cada vez más interesante para las corrientes de ayuda para el comercio.

El Fondo Fiduciario Caribeño de Ayuda para el Comercio y la Integración Regional (CARTFund): Mecanismo de prestación de ayuda a CARICOM y CARIFORUM en el marco de la iniciativa de Ayuda para el Comercio, es un programa que comenzó a ejecutarse en 2009, cuenta con el apoyo del Reino Unido y es administrado por la CARICOM y el CARIFORUM. Se trata de un mecanismo basado en la demanda cuyo objetivo es apoyar la aplicación en el Caribe de los acuerdos de asociación económica concertados por Europa y el Mercado y Economía Únicos de la CARICOM. Hasta 2011 se habían aprobado 18 proyectos en ocho Estados del CARIFORUM (cinco proyectos regionales y 13 proyectos nacionales) que representaban aproximadamente el $70 \%$ de los fondos disponibles, y la demanda superaba los recursos disponibles. La creación de este Fondo es digna de mención, ya que se trata de un verdadero esfuerzo conjunto de los donantes y las organizaciones regionales beneficiarias.

Según los estudios económicos en la materia (por ejemplo, Park y Lippoldt, 2008), es evidente que existe un vínculo entre la IED, la protección de los derechos de propiedad intelectual y el avance en las cadenas de valor. Sin embargo, a menudo se pone en tela de juicio la conveniencia de proteger los derechos de propiedad intelectual, lo que a veces ha llevado a adoptar políticas que han reducido las posibilidades de atraer redes regionales de producción. El objetivo de la Estrategia de exportación del Caribe para la recuperación de plusvalías relacionadas con la propiedad intelectual, patrocinada por la Organización de Estados Americanos (OEA), es lograr que los agentes nacionales y regionales tomen conciencia de que la aplicación de estrategias en materia de propiedad intelectual puede incrementar los ingresos de exportación. La clave del éxito del programa reside en que los interesados a nivel nacional y regional participen en la selección de los productos; que se incluya al sector privado en el proceso y en el módulo de capacitación; que se organicen secuencialmente las etapas del programa; y que se formule de manera definitiva la metodología que se podrá utilizar en el Caribe y en otras regiones para prestar apoyo a otros productos.

La falta de armonización de las políticas en materia de normas y conformidad también puede entorpecer el funcionamiento de las redes regionales de producción. El proyecto de "Establecimiento de una infraestructura regional de la calidad en la Comunidad del África Oriental", que es financiado por Alemania, tiene por objeto mejorar la infraestructura regional de la calidad en el África Oriental mediante la normalización, la garantía de la calidad, la acreditación y los ensayos. La ejecución del proyecto, que tiene una duración de nueve años (2004-2013), comenzó con el establecimiento de una infraestructura regional de la calidad compatible con las prescripciones de la OMC. En 2007 la Comunidad del África Oriental (CAO) aprobó la Ley de normalización, calidad, metrología y ensayos, por la que se estableció un marco para la armonización de las normas y la coordinación de las actividades. Partiendo prácticamente de la nada, se creó un sistema regional de infraestructura de la calidad que abarcó la armonización de 1.100 normas, que aún no han sido plenamente adoptadas en el ámbito nacional; se formó un grupo de asesores capacitados para la acreditación de laboratorios médicos, de pruebas y de calibración, y en 2009 se estableció la Junta de Acreditación del África Oriental; se desarrolló capacidad para la armonización regional de los procedimientos de inspección y la certificación de productos; y se introdujeron mejoras en los laboratorios de metrología de todos los países de la CAO. 
El sistema de notificación y solución de diferencias en materia de obstáculos no arancelarios del Foro Tripartito COMESA-CAO-SADC es un programa con base en la Web al que pueden acceder todos los comerciantes usando teléfonos móviles. Además, el sistema ha sido incorporado plenamente en las estructuras y los enfoques institucionales de la comunidad económica regional, los gobiernos nacionales y el sector privado. A finales de marzo de 2013 se había resuelto el 73\% de las reclamaciones relacionadas con obstáculos no arancelarios, a menudo en el plazo de días o semanas en comparación con los meses o incluso años que ese proceso demoraba en el pasado. Las reclamaciones frecuentemente guardan relación con los prolongados y costosos trámites aduaneros en toda la región del Foro Tripartito; la aplicación de las normas de origen; el elevado costo de los peajes que deben pagar los usuarios de las carreteras; y problemas en relación con la aplicación de las medidas sanitarias y fitosanitarias. Al eliminarse la disposición por la que se prohibía a autobuses y vehículos pesados pasar por el puesto fronterizo de Kariba, se ha intensificado el comercio en pequeña escala, ha aumentado el volumen del comercio transfronterizo, ha disminuido el tiempo de viaje y el tiempo de tránsito y han aumentado el empleo y la capacidad de despacho de mercancías.

\section{La creación de capacidad productiva}

De los relatos de experiencias se desprende claramente que la participación del sector privado en la creación de capacidad productiva a nivel regional y la movilización de ese sector con tal fin plantean un reto fundamental que requiere constante atención. ${ }^{21}$ Sin embargo, el sector privado cumple una función central en la integración y las redes de producción internacionales y regionales. Los proyectos regionales de ayuda para el comercio permiten abordar de forma bastante eficaz algunas de las mayores dificultades a las que se enfrenta el sector privado en las regiones en desarrollo.

Por ejemplo, en el marco de la Fase II (Componente de Exportaciones del Caribe) del Programa de desarrollo del comercio y del sector privado del Caribe, que es patrocinado por la UE, se aportaron fondos al Organismo de Desarrollo de las Exportaciones del Caribe (CARIBEXPORT), -organismo regional de promoción de las exportaciones y el comercio- a fin de prestar apoyo al sector privado en relación con la firma del Acuerdo de Asociación Económica CARIFORUM-UE. El programa tiene por objeto ayudar a reforzar la capacidad de exportación de la región mediante una utilización más eficaz de las organizaciones regionales. Con tal fin, se consideró que la participación del Organismo de Desarrollo de las Exportaciones del Caribe en calidad de asociado era indispensable para el éxito del programa, ya que se trataba de una organización regional establecida antes de que existiera el programa que mantenía importantes vínculos de asociación con participantes de los sectores público y privado en el ámbito regional.

Un ejemplo interesante de una economía en desarrollo más avanzada que ha compartido sus experiencias a fin de promover las mejores prácticas en el ámbito regional es el programa de fortalecimiento del sistema sanitario oficial para productos agrícolas de exportación en los Estados Miembros de la CARICOM, patrocinado por la OEA. El Gobierno de Chile, por conducto de la Secretaría de la OEA, compartió con los países de la CARICOM información sobre normas y mejores prácticas sanitarias y fitosanitarias. El éxito de este programa demuestra la eficacia de la cooperación Sur-Sur.

El Programa para la creación de capacidad en materia de comercio en África (PACT), patrocinado por el Canadá, es un proyecto ejecutado conjuntamente por el ITC, la Oficina de Facilitación del Comercio del Canadá y diversas organizaciones africanas que tiene por objeto incrementar y diversificar las exportaciones en los países receptores africanos y desarrollar la capacidad de exportación de las PYME. Mediante el programa se proporcionó formación en materia de capacidad de exportación y difusión de información sobre el mercado utilizando tecnología de la información y las comunicaciones, así como asesoramiento de expertos en capacidad del mercado y misiones de acceso a los mercados. Gracias al programa, aumentaron las exportaciones a Europa y se dio acceso a los mercados de 
Europa y el Canadá a pequeños agricultores africanos. Además, el programa facilitó la introducción en la UE, el Canadá y los Estados Unidos de la marca Design Africa de decoración de interiores y la exportación de productos de esa marca a esos mercados. Mediante el proyecto Access!, para empresarias africanas que participan en el comercio internacional se impartió capacitación en materia de exportación y se proporcionó asesoramiento a empresarias africanas. Según la información recibida, cuando menos 100 empresarias habían participado durante dos años en seminarios de preparación para exportar celebrados en los cuatro países iniciales y habían sido seleccionadas para participar en misiones comerciales y/o asistir a ferias comerciales. De ellas, entre el 50\% y el 60\% había establecido vínculos comerciales con un distribuidor en el país importador y un 20\% había recibido pedidos o estaban recibiéndolos.

\section{Promoción de las cadenas de valor}

Todos los relatos de experiencias considerados supra guardaban relación directa o indirecta con la mejora de las perspectivas de integración en las cadenas de valor. Sin embargo, en varios de ellos también se indicaba que la promoción de las cadenas de valor era el principal objetivo.

Así, por ejemplo, en 2012 se emprendió, bajo la dirección de la CEDEAO, la Iniciativa de Promoción de las Exportaciones y la Competitividad de las Empresas para el Comercio (EXPECT) a fin de desarrollar y promover cadenas de valor con gran potencial de exportación. La Iniciativa se emprendió con el objeto de lograr la aceptación y la sostenibilidad del PACT II (Programa para la creación de capacidad en materia de comercio en África, Fase II) en la región. En efecto, la Iniciativa apunta a establecer y fortalecer las estructuras y la capacidad necesarias a nivel técnico, administrativo e institucional para facilitar la ejecución del programa de desarrollo comercial de la región en la esfera de las cadenas de valor. Hasta la fecha, mediante el proyecto se han obtenido los siguientes resultados: la Comisión de la CEDEAO y el ICT/PACT II contrajeron un importante compromiso financiero en relación con el período 2011-2013 destinado a apoyar la aplicación; la CEDEAO-10 elaboró un plan de trabajo basado en los resultados para 2011; y se llevó a cabo un análisis de la cadena de valor del mango en el que participaron los sectores públicos y privados de la región con el objeto de desarrollar una estrategia regional en el sector del mango, entre otras cosas. En 2011, se amplió el alcance del programa para incluir la creación de agrupaciones encargadas de aumentar la competitividad de las PYME en las cadenas de valor del mango, el anacardo y el aceite de palma incluidas en el programa EXPECT; se validó la estrategia regional para el mango a nivel nacional; se dio término al proceso en relación con otro producto; y se organizó el primer Foro de exportadores de la CEDEAO para examinar las prioridades en materia de desarrollo y competitividad de las cadenas de valor de las exportaciones. 


\section{CONCLUSIONES}

Del análisis precedente cabe sacar las siguientes conclusiones generales: las redes regionales de producción se están convirtiendo en un factor cada vez más importante del éxito de los programas comerciales de las economías en desarrollo; además de permitir la obtención de mejores resultados comerciales y generar muchos de los mismos beneficios que reporta un entorno más abierto para el comercio y la inversión, la participación en redes regionales de producción puede servir para reducir la pobreza, aumentar el empleo, y, a la larga, ayudar a los países a avanzar en la cadena de valor; la cooperación económica regional orientada hacia el exterior puede constituir una estrategia eficaz para promover la integración en las cadenas de valor y mejorar la integración regional; y la ayuda para el comercio a nivel regional puede facilitar la integración y la creación de cadenas de valor regionales. La creciente proporción que corresponde a la ayuda para el comercio a nivel regional en el total de las corrientes de ayuda para el comercio y las respuestas a los cuestionarios de la OMC, la UA y la CEPA de 2013 indican que los asociados y los donantes son cada vez más conscientes de la eficacia de la ayuda para el comercio a nivel regional para el logro de los objetivos de comercio y desarrollo.

En la publicación de la OCDE y la OMC titulada La Ayuda para el Comercio en síntesis - 2009 se señalaban las importantes consecuencias que podían tener los proyectos de ayuda para el comercio a nivel regional, así como también los problemas que planteaban esos proyectos. En particular, en ese documento se describían dos importantes retos que habría que afrontar en el futuro: la necesidad de mejorar la coordinación en el ámbito regional y la necesidad de reforzar la capacidad humana e institucional. En cuanto al primero de esos retos, en el presente capítulo se han identificado tres problemas principales en esa esfera: las deficiencias en la formulación de solicitudes de Ayuda para el Comercio a nivel regional; la falta de coherencia entre las prioridades nacionales y regionales; y la falta de una coordinación eficaz a nivel regional. En cuanto a la necesidad de reforzar la capacidad humana e institucional, en el presente capítulo se ha indicado que la capacidad institucional y humana varía considerablemente de una organización de cooperación económica regional a otra, lo que puede afectar considerablemente a la capacidad de absorción de ayuda para el comercio a nivel regional. Además, la existencia de múltiples mecanismos y organizaciones de integración regional con esferas de acción superpuestas puede dificultar el establecimiento de una relación estable entre donantes y receptores.

De las encuestas entre donantes y países asociados llevadas a cabo en África por la OMC, la UA y la CEPA en 2013 y los relatos de experiencias examinados supra se desprende que desde 2009 se ha avanzado considerablemente en lo que respecta a la formulación de solicitudes de ayuda para el comercio a nivel regional y al fomento de una cooperación más estrecha entre donantes y países asociados, aunque todavía queda bastante por hacer. Una mayor coherencia entre las prioridades nacionales y regionales sigue siendo uno de los desafíos a mediano y largo plazo. Otro de los desafíos a mediano y largo plazo en relación con el proceso de desarrollo es el fortalecimiento de la capacidad humana e institucional. Por su parte, los donantes y las organizaciones regionales han desplegado, con éxito considerable, importantes esfuerzos a fin de mitigar ese problema, y la tendencia hacia los acuerdos megarregionales, especialmente en Asia y África, debería reducir los problemas que se plantean como consecuencia de la superposición de las disposiciones. 
En cuanto a la experiencia adquirida en relación con los proyectos y programas regionales, resulta difícil generalizar ya que sus objetivos, el contexto y las características y el tamaño de los países son muy diversos. No obstante, las investigaciones y encuestas realizadas por la OCDE, la OMC y otras organizaciones internacionales permiten formular las siguientes "recetas para lograr el éxito":

- Para que un proyecto tenga éxito, es necesario asignar alta prioridad a lograr la aceptación del proyecto por las partes interesadas.

- En relación con ese punto, es necesario que los interesados sean parte del proyecto a fin de asegurarse de que el proyecto reciba apoyo durante toda su ejecución. Esto es particularmente importante en el caso de los proyectos de alcance regional y multinacional.

- Es necesario incorporar al diseño de los proyectos sistemas de vigilancia y evaluación periódicas con fines correctivos que permitan también efectuar comparaciones a nivel regional/nacional. El CAREC constituye un ejemplo de la aplicación de las mejores prácticas en esta esfera.

- Los proyectos deben tener objetivos claros y realistas. El calendario de ejecución debe ser práctico y realista, aunque no excesivamente conservador. No obstante, también es necesario dotar al proyecto de suficiente de flexibilidad para poder atender a imprevistos.

- Aunque cada proyecto persigue objetivos diferentes, la sostenibilidad debe ser una consideración importante en la mayoría de los proyectos, sobre todo en la categoría de la infraestructura económica.

- En los proyectos regionales de ayuda para el comercio, y particularmente en los sectores relacionados con la infraestructura económica y la creación de capacidad productiva, es importante involucrar al sector privado y otros asociados no gubernamentales, como se desprende claramente de la encuesta llevada a cabo por la OMC, la UA y la CEPA entre los asociados.

Aunque los proyectos regionales de ayuda para el comercio son, por naturaleza, complejos debido a la necesidad de involucrar y coordinar a múltiples gobiernos, sus diversos organismos y numerosas partes interesadas del sector privado, constituyen un medio eficaz en función del costo de ayudar a los países a alcanzar sus objetivos comerciales y de desarrollo. En un período en que los presupuestos fiscales de los países donantes son limitados, la ayuda para el comercio a nivel regional constituye un excelente ejemplo de la forma de generar importantes beneficios con un nivel de recursos determinado. 


\section{NOTES}

1. www.wto.org/spanish/tratop_s/region_s/region_s.htm.

2. Puede consultarse una lista de estos acuerdos, actualizada al 13 de enero de 2013, en www.wto.org/spanish/ tratop_s/region_s/region_s.htm.

3. Por "desplazamiento del comercio" se entiende la posibilidad de que las economías no asociadas desplacen sus exportaciones hacia el país miembro de un ALC con los aranceles más bajos.

4. En los estudios sobre "aranceles endógenos" se ha elaborado un enfoque formal en relación con esta realidad cambiante.

5. Véase H. Kuroda, M. Kawai y R. Nangia (2007).

6. Los detalles relativos a las encuestas llevadas a cabo por la OMC, la UA y la CEPA en 2013 se examinan más adelante en la presente sección.

7. Kimura y Obashi (2011) han examinado en detalle los estudios publicados sobre el tema.

8. Véase "Joint Declaration on the Launch of Negotiations for the Regional Comprehensive Economic Partnership" (Declaración conjunta sobre la puesta en marcha de negociaciones para establecer una asociación económica amplia a nivel regional), www.meti.go.jp/press/2012/11/20121120003/20121120003-2.pdf.

9. En el estudio de Petri et al. (2012), los cálculos relativos a la RCEP sólo incluyen a las economías de la "ASEAN+3", es decir, a la ASEAN, China, Corea y el Japón, mientras que las simulaciones relativas al TPP no incluyen a los tres miembros que se adhirieron el año pasado (el Canadá, el Japón y México). No obstante, en el sitio Web que sirve de complemento del libro (http://Www.asiapacifictrade.org/) figuran las cifras correspondientes a la RCEP ("ASEAN+6") y a los doce países que son partes en el TPP.

10. www.afdb.org/en/.

11. Aunque el índice de respuesta a la encuesta efectuada entre los asociados fue bastante bueno (30 países respondieron al cuestionario), sólo un pequeño número de esos países respondió a muchas de las preguntas, y sólo unos cinco encuestados respondieron a la mayoría de ellas.

12. En el capítulo 2 del documento de la OCDE (2009) se proporciona una reseña de la asistencia prestada por la UE a los países africanos en relación con la aplicación de los acuerdos de asociación económica.

13. Para más información sobre el Mercado y Economía Únicos de la CARICOM, véase www.caricom.org/jsp/single _ market/single_market_index.jsp?menu=csme.

14. Antes que nada, cabe observar que se trata de relatos de experiencias y no de estudios de casos; los relatos suelen ser descriptivos e informativos más que analíticos. Así, por ejemplo, los relatos no incluyen un análisis de la relación costo-beneficio.

15. www.jica.go.jp/project/english/mozambique/002/outline/index.html.

16. www.carecprogram.org/index.php?page=carec-development-effectiveness-review.

17. Para un "inventario" de los progresos realizados a lo largo de 10 años, véase www.carecprogram.org/uploads/ events/2010/9th-MC/Draft-10Year-Commemorative-Study-Main-Text.pdf.

18. www.apec.org/About-Us/About-APEC/Achievements-and-Benefits.aspx.

19. www.iadb.org/intal/intalcdi/PE/2013/11612.pdf. 
20. En la base de datos del SNAP, la categoría relativa a la creación de capacidad productiva incluye asimismo el ajuste relacionado con el comercio, pero se trata de un componente de mínima importancia en las corrientes regionales de ayuda para el comercio.

21. En la base de datos del SNAP, la categoría relativa a la creación de capacidad productiva incluye los proyectos relacionados con los servicios bancarios y financieros; los servicios prestados a las empresas y de otro tipo; y la agricultura, la silvicultura y la pesca. 


\section{REFERENCIAS}

Athukorala, P. (2010), Production Networks and Trade Patterns in East Asia: Regionalization or Globalization? Banco Asiático de Desarrollo (BAsD), Working Paper Series on Regional Economic Integration No 56, ADB, Manila, www.adb.org/publications/production-networks-and-trade-patterns-east-asia-regionalization-or-globalization.

BAsD (Banco Asiático de Desarrollo) (2008), Emerging Asian Regionalism: Partnership for Shared Prosperity, ADB, Manila,

BAsD y ADBI, 2013, Connecting South and Southeast Asia: Interim Report, puede consultarse en www.adbi.org/ book/2013/05/05/5632.connecting.south.asia.southeast.asial.

CARICOM (Comunidad del Caribe) (2012), Estrategia Regional de Ayuda para el Comercio de la Comunidad del Caribe 2013-2015, www.caricom.org/.

http://aric.adb.org/emergingasianregionalism/pdfs/Final_ear_chapters/final\%20report.pdf.

Kimura F.y A. Obashi (2011), Production Networks in East Asia: What We Know So Far, Asian Development Bank Institute (ADBI) Working Paper № 320, ADBI, Tokio.

Kuroda, H. M. Kawai y R. Nangia (2007), "Infrastructure and Regional Cooperation", en F. Bourguignon y B. Pleskovic (eds.), Rethinking Infrastructure for Development, Banco Mundial, Washington, D.C., página 246.

Limao, N. y A. Venables (2001), "Infrastructure, Geographical Disadvantage, Transport Costs and Trade", World Bank Economic Review, volumen 15(3), páginas 451-479.

Maur, J.-C. (2008), Regionalism and Trade Facilitation: A Primer, World Bank Policy Research Working Paper No 4464, http://www-wds.worldbank.org/servlet/WDSContentServer/WDSP/IB/2008/01/03/000158349_20080103113436/ Rendered/PDF/wps4464.pdf.

OCDE (2009), Overcoming Border Bottlenecks: The Costs and Benefits of Trade Facilitation, OECD Trade Policy Studies, OCDE, París, http://dx.doi.org/10.1787/9789264056954-en.

OCDE (2012), Reducing the Thickness of Borders to Promote Trade and Participation in Global Value Chains, COM/DCD/TAD/RD(2012)2/RD4, OCDE, París, www.oecd.org/dac/aft/ReducingtheThicknessofBorders.pdf.

OCDE (2013), Trade Policy Implications of Global Value Chains. Contribution to the Report on Global Value Chains, TAD/TC/WP(2012)31/FINAL, OCDE, París.

OCDE/OMC (Organización Mundial del Comercio) (2011), La ayuda para el comercio en síntesis 2011: Mostrar resultados, OCDE y OMC, París y Ginebra, http://dx.doi.org/10.1787/9789264117471-es.

Orefice, G. y N. Rocha, (2011), Deep Integration and Production Networks, Staff Working Paper ERSD-2011-11, Organización Mundial del Comercio, División de Estudios Económicos y Estadística, Ginebra.

Park, W.G. y D.C. Lippoldt (2008), Technology Transfer and the Economic Implications of the Strengthening of Intellectual Property Rights in Developing Countries, OECD Trade Policy Working Papers, № 62, OCDE, París.

Petri, P.A., M.G. Plummer y F. Zhai (2012), "The Economic Impact of the ASEAN Economic Community: An Applied General Equilibrium Approach", Asian Economic Journal, volumen 26(2), páginas 93-118.

Plan\%20for\%20boosting\%20intra-African\%20trade\%20F-English.pdf.

Plummer, Michael G. (2007), "Best Practices in Regional Trading Agreements: An Application to Asia," The World Economy, volumen 30, № 12, diciembre, páginas 1771-1796. 
Plummer, Michael G. y Chia Siow Yue (eds.) (2009), Realizing the ASEAN Economic Community: A Comprehensive Assessment, Singapur, ISEAS, noviembre.

PNUD (Programa de las Naciones Unidas para el Desarrollo) (2007), Trade Facilitation Beyond the Multilateral Trade Negotiations: Regional Practices, Customs Valuation and Other Emerging Issues, PNUD, Ginebra, www.unescap.org/tid/artnet/pub/tipub2466.pdf.

Unión Africana (2012), Action Plan for Boosting Intra-Regional Trade, http://www.au.int/en/sites/default/files/Action\%20 


\section{CAPÍTULO 5: \\ EVALUACIÓN DE LA EFICACIA DE LA AYUDA PARA EL COMERCIO}

- n el presente capítulo se examina en qué medida la ayuda para el comercio resulta eficaz

— para promover el comercio -tanto de las exportaciones como de las importaciones- $y$ las condiciones que suelen ser necesarias para que resulte más eficaz. El examen realizado indica claramente que, en términos generales, existe una correlación entre la ayuda para el comercio y el aumento del comercio. La ayuda para el comercio es más eficaz cuando se orienta a reducir el costo de comerciar mediante la mejora de las infraestructuras, la facilitación del comercio, las instituciones públicas relacionadas con el comercio (por ejemplo, las aduanas, la gestión de las normas y la promoción de las exportaciones) y las políticas (incluidas las destinadas a eliminar los obstáculos normativos a la competencia). La ayuda para el comercio (en sus distintas formas) que se destina a los países de ingresos bajos resulta particularmente útil para promover el comercio. El análisis que figura en el presente capítulo indica que es probable que la ayuda para el comercio destinada a los países de ingresos bajos y medianos bajos tenga importantes efectos positivos. Normalmente, por cada dólar invertido en la ayuda para el comercio, se obtiene un aumento de casi 8 dólares EE.UU. en las exportaciones de todos los países en desarrollo, mientras que por cada dólar por concepto de ayuda para el comercio recibido por los países más pobres que reúnen las condiciones necesarias para recibir asistencia de la Asociación Internacional de Fomento (AIF), se obtienen 20 dólares EE.UU. en nuevas exportaciones; en el caso de todos los países de ingresos bajos y medianos bajos el aumento es de 9 dólares EE.UU. por cada dólar recibido por concepto de ayuda para el comercio.

\section{INTRODUCCIÓN}

La ayuda para el comercio, que siempre ha sido un componente importante de la asistencia para el desarrollo, ha aumentado considerablemente desde que se celebró la Conferencia Ministerial de la OMC en Hong Kong en diciembre de 2005. La cuantía de los compromisos por concepto de ayuda para el comercio aumentó de 19.000 millones de dólares EE.UU. en 1995 a 23.000 millones de dólares EE.UU. en 2005, y a 41.700 millones de dólares EE.UU. en 2011. La evidente aceleración registrada durante el período 2006-2010 parece haber disminuido en cierta medida en relación con el nivel máximo alcanzado en 2010 (44.900 millones de dólares EE.UU.) a causa de la presión ejercida por la crisis económica mundial. A pesar de ello, no hay duda de que los gobiernos donantes han invertido sumas considerables en la creación de capacidad comercial (véase el capítulo 2). Al mismo tiempo, el comercio de los países en desarrollo aumentó notablemente, a una tasa de aumento similar a la registrada por la ayuda para el comercio durante el mismo período (1995-2011). Las exportaciones de los países en desarrollo aumentaron de aproximadamente 4 billones de dólares EE.UU. a más de 15 billones de dólares EE.UU. 
Desde el comienzo de la crisis económica en 2008, los presupuestos de los donantes se han visto sometidos a una creciente presión, como resultado de lo cual todos los gastos, incluidos los destinados a financiar la asistencia para el desarrollo, son objeto de un cuidadoso examen para verificar la obtención de resultados. La OCDE y la OMC han trabajado arduamente analizando la información disponible a fin de determinar la forma en que la ayuda para el comercio ha afectado a los resultados comerciales mediante el estímulo del crecimiento económico y la reducción de la pobreza (OCDE, 2011c). En el presente capítulo se analiza información sobre los vínculos entre la ayuda para el comercio y el crecimiento del comercio en los países en desarrollo receptores, y se examinan estudios en que se abordan los tres interrogantes siguientes:

- Es eficaz la ayuda para el comercio para incrementar los intercambios comerciales y, de ese modo, promover un crecimiento económico más rápido y reducir en mayor medida la pobreza? En caso afirmativo, ¿en qué circunstancias resulta más eficaz la ayuda para el comercio?

- ¿Qué consecuencias tiene para la ayuda para el comercio el hecho de que las cadenas de valor mundiales y regionales se estén convirtiendo en un componente fundamental del panorama comercial? Y ¿ha contribuido la ayuda para el comercio prestada en el pasado a promover la participación efectiva en las cadenas mundiales y regionales de producción?

- ¿Permiten los sistemas de gestión pública, en asociación con los donantes, incrementar la eficacia de la ayuda para el comercio?

En el presente capítulo se postula que sólo es posible responder adecuadamente a esas preguntas si se tiene una visión completa de los efectos de la ayuda sobre el comercio, para lo cual hay que examinar esa relación a través de diferentes prismas metodológicos (entre los que figuran los estudios comparativos de varios países, los exámenes de programas y las evaluaciones de proyectos). En la primera sección se pasa revista a las conclusiones generales sobre la relación entre la ayuda para el comercio y el fomento del comercio. En la segunda sección se actualizan algunos de los resultados empíricos obtenidos en el pasado y se amplía el alcance del análisis transnacional para abarcar nuevas esferas, mediante el examen de las repercusiones de distintas clases de ayuda para el comercio en determinadas categorías de países en desarrollo. La tercera sección trata de la nueva función que cumplen las cadenas de valor y de sus consecuencias para la ayuda para el comercio. En la penúltima sección se analiza el papel de los sistemas públicos de gestión y se describe la forma en que interactúan con los donantes de ayuda para el comercio a fin de determinar cuáles modelos parecen funcionar mejor. A partir de ese análisis, en la última sección se presentan conclusiones y enseñanzas en materia de política.

\section{¿QUÉ SE ENTIENDE POR ÉXITO EN EL ÁMBITO DE LA AYUDA PARA EL COMERCIO?}

Como puede decirse de buena parte de la asistencia para el desarrollo, el objetivo último de la ayuda para el comercio es mejorar el nivel de vida y reducir la pobreza mediante el crecimiento económico. Como se observa en un documento de la OCDE sobre esta cuestión (2011b), existen tres postulados generales sobre los efectos de la ayuda para el comercio en el crecimiento y la reducción de la pobreza: la ayuda para el comercio genera un aumento más rápido de las exportaciones y las importaciones; el aumento más rápido del comercio hace aumentar la productividad y crecer los ingresos; y al aumentar los ingresos como resultado del crecimiento disminuye la pobreza entre la población. Esta relación de causalidad, que sin duda es una generalización válida cuando se trata de múltiples países y de períodos prolongados', no se cumple forzosamente en cada país en un momento determinado. Por ejemplo, hay muchos factores que afectan al vínculo entre el crecimiento del comercio y el aumento de los ingresos, como los conflictos, el endeudamiento, la gobernanza o la ausencia de políticas complementarias a nivel de la financiación, la educación y/o la inversión. Asimismo, en el último eslabón de la cadena (el que vincula el crecimiento a la reducción 
de la pobreza), la estructura básica de la economía (la distribución inicial de los ingresos, la propiedad de la tierra o de los recursos naturales, las cualificaciones de la fuerza de trabajo o la intensidad de mano de obra de los procesos de producción) repercutirá marcadamente en la tasa de reducción de la pobreza y la distribución de los beneficios que reporta el aumento de los ingresos.

En la presente sección se pasa revista a estudios sobre la eficacia de la ayuda para el comercio, con especial hincapié en los datos que indican que la ayuda para el comercio promueve un crecimiento más rápido de las exportaciones y las importaciones. El objetivo consiste en identificar los tipos de proyectos relacionados con el comercio y los contextos nacionales en que la ayuda para el comercio tiene mayores posibilidades de éxito.

\section{La mejora de los resultados comerciales}

Los representantes de los países en desarrollo encargados de las negociaciones comerciales en la Conferencia Ministerial de la OMC celebrada en Hong Kong en 2005, medían el éxito de la ayuda para el comercio en función del aumento de las exportaciones y la creación de la capacidad productiva nacional necesaria para aprovechar las nuevas oportunidades de acceso a los mercados que daría la Ronda de Doha. El Equipo de Trabajo de la OMC sobre la Ayuda para el Comercio de 2006 que se estableció a raíz de la Conferencia Ministerial de Hong Kong resumió esos objetivos de la siguiente manera:

La Ayuda para el Comercio tiene por objeto prestar asistencia a los países en desarrollo para que aumenten las exportaciones de bienes y servicios, se integren en el sistema multilateral de comercio y se beneficien de la liberalización del comercio y el incremento del acceso a los mercados. Una ayuda para el comercio eficaz mejorará las perspectivas de crecimiento y reducirá la pobreza en los países en desarrollo, a la vez que complementará las reformas del comercio multilateral y distribuirá los beneficios mundiales de forma más equitativa entre los países en desarrollo y dentro de éstos. ${ }^{2}$

Además del aumento de las exportaciones para impulsar el crecimiento, otros objetivos que el informe del Equipo de Trabajo mayormente pasa por alto hacían hincapié en la necesidad de modificar paulatinamente la composición del comercio. Para ello hay que diversificar las exportaciones de modo que dependan en menor medida de unas pocas materias primas cuyos precios son volátiles; aumentar el valor añadido a las exportaciones a nivel nacional y expandir el comercio intrarregional y el comercio Sur-Sur.

\section{Otros indicadores del éxito: la reducción del costo de comerciar}

En este contexto, los encargados de las negociaciones advirtieron que para incrementar y diversificar las exportaciones se necesitaba que la ayuda para el comercio estuviera destinada expresamente a crear una mayor capacidad comercial, lo que tiene dos dimensiones que se superponen conceptualmente. La primera de ellas consiste en aumentar la inversión en nueva capacidad productiva y en la nueva infraestructura necesaria para apoyarla a fin de ampliar la oferta de exportaciones. La segunda consiste en reducir el costo de comerciar mediante un uso más eficiente de la infraestructura moderna y adoptar nueva tecnología para aumentar la productividad y mejorar las instituciones, la reglamentación y las políticas relacionadas con el comercio. ${ }^{3}$

Del análisis de la OCDE (véanse, por ejemplo, OCDE, 2012; Moïsé y Le Bris, 2013) se desprende que el mal estado de la infraestructura es uno de los principales factores de los elevados costos que frenan el comercio y, en particular, las exportaciones agrícolas de los países en desarrollo (Moisé et al., 2013), por lo que la mejora de la infraestructura 
constituye un objetivo apropiado de la ayuda para el comercio. Limão y Venables (2001) fueron de los primeros en estudiar la relación entre las carreteras, las telecomunicaciones y el costo del transporte y, posteriormente, la relación entre el costo del transporte y el volumen del comercio. Para los países sin litoral el costo del transporte es mayor, ya que la capacidad de esos países para comerciar depende del estado de la infraestructura de los países de tránsito vecinos. Por ejemplo, en el África Oriental el tiempo necesario para despachar mercancías destinadas a países sin litoral es, por lo menos, tres veces mayor que el necesario en los países costeros. Los autores concluyen que "cabe atribuir al mal estado de la infraestructura el $40 \%$ del costo del transporte estimado para los países ribereños y hasta el $60 \%$ en el caso de los países sin litoral" (Limao y Venables, 2011). Varios estudios posteriores han confirmado que la infraestructura es uno de los factores determinantes del alto costo de comerciar.

Asimismo, las instituciones y la política y la reglamentación relacionadas con el comercio (como las operaciones portuarias, las aduanas, la política cambiaria, los impuestos a la exportación o los obstáculos normativos que traban el acceso a sectores de servicios fundamentales) también inciden considerablemente en el costo de comerciar y menoscaban la eficacia de la ayuda para el comercio. Hummels y Schaur (2012), por ejemplo, han demostrado (utilizando datos de los Estados Unidos sobre importaciones fletadas por avión) que cada día de retraso en el tránsito equivale a un incremento del 0,6\%-2,3\% en los aranceles. La pérdidas en materia de bienestar social como resultado de esos retrasos puede ser elevada. La OCDE estima que en algunos países africanos la cuantía de las pérdidas como resultado de la ineficiencia de los procedimientos fronterizos es superior al 5\% del PIB (Moïsé y Sorescu, 2013).

Todos esos elementos indican que los programas y proyectos de ayuda para el comercio centrados en la infraestructura, las instituciones y las políticas como medios de aumentar la inversión en capacidad comercial y reducir el costo de comerciar, cuando son diseñados y ejecutados debidamente, probablemente generen importantes beneficios en forma de un crecimiento más rápido del comercio. La reglamentación que restringe la competencia en la cadena logística del comercio puede ser la causa de márgenes comerciales elevados y de la ineficiencia de los servicios; el proceso puede convertirse en un círculo vicioso cuando los beneficiarios del statu quo presionan para que se impongan nuevas restricciones a la entrada o reglamentos técnicos que terminan siendo otros tantos obstáculos a la entrada (Portugal y Wilson, 2009). Raballand et al. (2010) han determinado que los precios de los servicios de transporte por camión han aumentado excesivamente como resultado de una reglamentación del mercado que limita la competencia. Esta clase problemas de política son especialmente agudos en el caso de los países sin litoral. Arvi et al. (2010) señalan que en los países sin litoral la reglamentación ha desempeñado un papel importante no sólo en los países exportadores, sino también en los países de tránsito. Teravaninthorn y Raballand (2008) muestran que como resultado de las restricciones del mercado, en el África Occidental y Central los precios se han mantenido altos, mientras que en el África Oriental, gracias a la competencia, los costos de los usuarios son más bajos. Los corredores meridionales son los más eficientes del continente africano en buena medida porque son los más desregulados y competitivos.

Además, los economistas especializados en cuestiones comerciales y los organismos de desarrollo vienen insistiendo desde hace tiempo en la necesidad de aplicar políticas complementarias para contrarrestar las posibles consecuencias negativas de los ajustes comerciales o del crecimiento impulsado por el comercio. Entre las políticas de especial importancia, cabe mencionar las destinadas a mejorar el entorno para la inversión a fin de atraer nuevas inversiones mediante una mayor protección de los derechos de propiedad y la estabilidad macroeconómica, así como las encaminadas a incrementar la inversión pública en la educación y otros bienes públicos a fin de aumentar la competitividad (OCDE, 2011b). Las políticas que incluyen reformas comerciales a fin de crear un clima propicio para la inversión, proteger a los trabajadores, mantener buenas condiciones de trabajo y facilitar las transiciones en el mercado de trabajo pueden desempeñar un papel importante para el logro de los beneficios que puede reportar el comercio en materia de salarios, empleo e ingresos (Newfarmer y Sztajerowska, 2012). 
De lo precedente, cabe concluir que un corolario importante de la evaluación de la ayuda para el comercio es que, como las políticas complementarias pueden consolidar o reducir la eficacia de los distintos programas de ayuda para el comercio, el análisis de esas políticas debería constituir un elemento fundamental de toda evaluación definitiva de la ayuda para el comercio.

\section{SE NECESITA UN "PRISMA" PARA EVALUAR LOS RESULTADOS DE LA AYUDA}

El problema más difícil que se plantea en relación con la evaluación de los efectos de la ayuda para el comercio es establecer la relación de causalidad entre, por un lado, las corrientes de ayuda para el comercio, y, por el otro, el aumento de los ingresos y la reducción de la pobreza. Debido a la diversidad de objetivos comerciales, objetivos intermedios, instrumentos, sectores y actividades (para no hablar de las condiciones iniciales de cada país), no es posible sacar conclusiones firmes sobre los resultados y los efectos de la ayuda para el comercio a partir de un único método. ${ }^{4}$ Para efectuar una evaluación completa de la eficacia de la ayuda para el comercio hay que utilizar distintos métodos de evaluación (las diferentes lentes del prisma) para examinar los efectos de la ayuda en el comercio (Cadot y Newfarmer, 2011). En la presente sección se analizan brevemente los resultados de evaluaciones de los efectos de la ayuda para el comercio llevadas a cabo recientemente, con arreglo a tres categorías: evaluaciones transnacionales agregadas, evaluaciones sectoriales y evaluaciones de proyectos. El análisis se centra fundamentalmente en el objetivo enunciado por el Equipo de Trabajo de la OMC de incrementar las exportaciones de los países en desarrollo.

\section{Evaluaciones transnacionales agregadas}

Una de las formas de enfocar el análisis de los efectos de la ayuda para el comercio en el crecimiento del comercio consiste en aplicar técnicas econométricas a datos longitudinales de múltiples países. ${ }^{5}$ Normalmente, en los estudios de este tipo el problema de la causalidad se resuelve aislando la ayuda para el comercio de otros factores que pueden determinar los resultados comerciales (o el costo de comerciar).

Cali y te Velde (2010) utilizan un modelo gravitacional para examinar los efectos sinérgicos de la ayuda para el comercio en los países exportadores y en los países importadores que son sus asociados comerciales bilaterales. Así, demuestran que la ayuda para el comercio tiene un efecto global positivo e importante en las exportaciones (que depende casi exclusivamente de la infraestructura económica). También demuestran que la ayuda para el comercio asignada a la infraestructura genera un aumento de las exportaciones, principalmente en los sectores de la minería y las manufacturas, y que los mayores efectos se observan en África. La ayuda para el comercio asignada a la creación de capacidad productiva (en contraposición con la asignada a la infraestructura o a la facilitación del comercio) no tiene un efecto estadísticamente significativo en las exportaciones.

Tres de los relatos de experiencias recibidos por la OCDE y la OMC en 2011 incluían también los resultados de análisis econométricos. Según los informes de la Secretaría del Commonwealth, una duplicación del volumen de la ayuda para el comercio destinada a la infraestructura económica permitiría incrementar las exportaciones de mercancías en un 3,5\%, mientras que una duplicación del volumen de la ayuda destinada a la facilitación del comercio reduciría los costos de importación en un 5\%. Los estudios econométricos llevados a cabo por la Comisión Económica de las Naciones Unidas para África (CEPA) muestran que cuando se aumenta la ayuda para el comercio en un 10\% el índice de diversificación económica aumenta un 0,4\% (OCDE, 2011a, páginas 144-145). En la evaluación realizada por los Estados Unidos de su programa de ayuda para el comercio, en que se examinaron 265 proyectos ejecutados entre 2002-2006, se concluía que "por cada dólar EE.UU. invertido se obtenía, dos años después, un rendimiento de 42 dólares en las exportaciones de los países en desarrollo" (USAID, 2010). 
En otros estudios agregados se centra la atención en la ayuda destinada a reducir el costo de comerciar. La asistencia para el desarrollo destinada a la facilitación del comercio ha sido objeto de numerosos estudios, aunque las definiciones del concepto varían considerablemente. La conclusión general es que la mejora de las medidas de facilitación del comercio comporta un aumento de las corrientes comerciales (Basnett et al., 2012). Las reformas aduaneras que tienen por objeto aumentar la eficiencia, reducir el costo de las transacciones en la frontera, eliminar las intervenciones burocráticas que pueden dar pie a la corrupción y adoptar procedimientos para agilizar el tránsito de mercancías a través de las fronteras pueden reducir el costo de comerciar para importadores y exportadores por igual. Helble et al. (2012) analizan estos posibles beneficios utilizando estimaciones del modelo gravitacional obtenidas a partir de regresiones transnacionales, con hincapié en la ayuda para el comercio. En particular, comparan los efectos en las corrientes comerciales bilaterales de la asistencia para el desarrollo relacionada con el comercio (es decir, la creación de capacidad productiva), la asistencia en materia de política comercial y la ayuda destinada a la infraestructura y llegan a la conclusión de que la ayuda para el comercio destinada expresamente a apoyar proyectos de reforma de la política y reglamentación comerciales tiene una elevada tasa de rendimiento. Según sus estimaciones, por cada dólar EE.UU. por concepto de ayuda para el comercio destinado a reformar la políticas y la reglamentación comerciales se obtendrían unos 1,3 dólares EE.UU. en transacciones comerciales adicionales. ${ }^{6}$ También Cali y te Velde (2010) consideran que existe una fuerte correlación positiva entre las corrientes de ayuda y la reducción del costo de comerciar: un aumento de 1 millón de dólares EE.UU. en la ayuda para la facilitación del comercio redundaría en una disminución del 6\% en el costo de embalar las mercancías, cargarlas en contenedores, transportarlas hasta el puerto de partida y cargarlas en una embarcación o un camión.

Los enfoques econométricos transnacionales agregados tienen la ventaja de que establecen claramente una relación general estadísticamente significativa entre, por una parte, la ayuda para el comercio y, por otra, las corrientes comerciales o la disminución del costo de comerciar, a la par que controlan los efectos de otros factores que podrían explicar el comportamiento del comercio. Además, los resultados de esos enfoques pueden, en principio, aplicarse a diferentes contextos, ya que muestran relaciones medias y controlan los efectos de otros factores económicos. Sin embargo, esos enfoques tienen tres limitaciones. En primer lugar, en relación con la identificación de vínculos causales, no debe perderse de vista que incluso los enfoques econométricos más ingeniosos no siempre consiguen eliminar todos los factores de confusión, tener en cuenta todas las variables omitidas o eliminar debidamente la posibilidad de una causalidad inversa. En segundo lugar, en esos estudios econométricos, por simples razones de economía, resulta difícil incorporar los efectos en eslabones posteriores de la cadena de resultados o los efectos simultáneos en cuestiones transversales como el género, la distribución de los ingresos y el medio ambiente. Para ello, el analista se ve obligado a recurrir a los estudios pertinentes. Por último, los promedios de varios países rara vez ayudan a orientar la política de un país determinado. Para obtener una imagen más completa de la ayuda para el comercio, tenemos que examinarla a través de la siguiente lente del prisma de la evaluación.

\section{Evaluaciones por sectores y programas}

Varios donantes han llevado a cabo evaluaciones de sus programas de ayuda para el comercio. Las evaluaciones normalmente consisten en un examen a fondo de un conjunto de proyectos a lo largo del tiempo a fin de evaluar su repercusión global en el comercio, el crecimiento y la pobreza y, frecuentemente, sus efectos en cuestiones transversales. En 2006 la OCDE realizó un examen de la primera generación de evaluaciones relacionadas con el comercio.? En el examen se señalaba que "a menudo resulta difícil determinar la eficacia y los efectos a más largo plazo de la ayuda relacionada con el comercio que prestan los donantes" y que las evaluaciones de varios programas de desarrollo del comercio indicaban que esos programas habían "servido para mejorar el entorno para el comercio" 
(OCDE, 2006, página 10). En la mitad de las evaluaciones examinadas se llegaba a la conclusión de que la ayuda relacionada con el comercio había contribuido a que los países asociados comprendieran mejor la importancia que tenía el comercio para el crecimiento y la reducción de la pobreza. En el informe no se llega, a partir de las evaluaciones de los donantes, a conclusiones categóricas acerca de la repercusión de la ayuda para el comercio en el incremento, el costo o la composición del comercio, sino que sólo se señalan varios de los problemas que en ocasiones atentan contra la eficacia de la ayuda para el comercio.

Indudablemente, desde que la OCDE llevó a cabo ese examen en 2006, algunos de esos problemas han sido resueltos en cierta medida. Por ejemplo, la afirmación de que "las evaluaciones de las necesidades no son sistemáticas o son incompletas" ha dejado, al menos en parte, de ser válida como resultado de las docenas de estudios de diagnóstico sobre la integración comercial (EDIC) que se han llevado a cabo desde 2003, así como de los numerosos estudios sectoriales de países en desarrollo más avanzados (que constituyen por sí solos una forma valiosísima de ayuda para el comercio). Además, el debate sobre la ayuda para el comercio iniciado en Hong Kong a finales de 2005 y articulado desde entonces a través de la labor de la OCDE y la OMC ha logrado que se tome mayor conciencia de la importancia del comercio y la asistencia relacionada con el comercio - lo que, a su vez, ha influido no sólo en el volumen de los recursos destinados a la ayuda para el comercio, sino también en la "incorporación" del comercio a las políticas. Como simple ejemplo de ello, cabe mencionar el caso de Uganda: un análisis de los discursos anuales sobre el presupuesto pronunciados desde el 2000 por el Ministro de Hacienda de Uganda, así como de los documentos de planificación nacional, mostró que la atención prestada al comercio, medida por el número total de términos relacionados con el comercio, había aumentado considerable y sostenidamente (Banco Mundial, 2013). Asimismo, un análisis realizado por Cossack (2008) para el Programa de las Naciones Unidas para el Desarrollo (PNUD) de documentos con las estrategias de lucha contra la pobreza de distintos países reveló que en los programas financiados por los gobiernos se incluía el comercio con creciente frecuencia. Los estudios de casos elaborados para el Diálogo de Política de la OCDE sobre la ayuda para el comercio celebrado en enero de 2013 confirman que, en la mayoría de los países, el comercio ocupa actualmente un lugar más destacado que en el pasado entre las preocupaciones en materia de política. Además, es probable que la aplicación generalizada de sistemas de gestión basada en los resultados, una de las principales recomendaciones del estudio realizado por la OCDE en 2006, haya servido para mejorar la gestión de los proyectos (si bien en varios países de ingresos bajos probablemente siga habiendo problemas). También la coordinación entre donantes ha mejorado (aunque sigue distando de ser óptima en algunos países) como resultado del establecimiento de grupos de trabajo en el país (en algunos casos en países menos adelantados (PMA)), según lo previsto en el Marco Integrado mejorado (MIM).

Desde 2006, tras la celebración de la Conferencia de Hong Kong, nuevas evaluaciones han sido llevadas a cabo por Suecia (Goppers y Lindahl, 2009), el Banco Mundial (2009), Finlandia (Bird et al., 2011), la Unión Europea y USAID (2011), el Japón (Mizuhu, 2012) y el Reino Unido (Basnett et al., 2012), entre otros. La OCDE realizó una metaevaluación de 162 programas de ayuda relacionada con el comercio en Ghana, en Viet Nam y en el sector del transporte y el almacenamiento (OCDE, 2011a). Las evaluaciones de la eficacia de la ayuda para el comercio son, en general, más optimistas, aunque con reservas. Por ejemplo, en la evaluación del Reino Unido se llega a la conclusión de que:

En general, los estudios empíricos existentes tienden a confirmar que la ayuda para el comercio puede ser eficaz tanto a nivel macroeconómico como microeconómico. Sin embargo, sus efectos pueden variar considerablemente en función del tipo de la intervención de ayuda para el comercio, el nivel de ingresos y la región geográfica del país receptor, así como del sector beneficiario de las corrientes de ayuda (Basnett et al., 2012, página 25). 
Más específicamente, las conclusiones mencionadas son las siguientes:

- Aunque no hay acuerdo sobre los efectos de los distintos tipos de corrientes de ayuda, parecería que las destinadas a actividades específicas relacionadas con el comercio (como la facilitación del comercio y la infraestructura) son más eficaces para promover las exportaciones.

- Hay indicios de que la ayuda destinada a la infraestructura, en particular la infraestructura de transporte, es más eficaz en los países de ingresos bajos, mientras que las corrientes de ayuda destinadas a los sectores empresariales son más eficaces en los países en desarrollo con ingresos más elevados.

- Las evaluaciones realizadas indican que una de las regiones que más probabilidades tiene de beneficiarse de la ayuda para el comercio es el África Subsahariana (Basnett et al., 2012, página 24).

Los autores del examen llevado a cabo por el Japón están de acuerdo con la opinión general de que la ayuda para el comercio fomenta el comercio: "Teniendo en cuenta la evidente mejora de los resultados económicos (en materia de crecimiento económico y de las exportaciones) de los principales países receptores de la ayuda para el comercio que presta el Japón, cabría concluir que esa clase de ayuda es eficaz ..." (Mizuho, 2012).

En general, los autores del estudio sueco están de acuerdo con esa evaluación, pero lamentan que no sea posible analizar sistemáticamente los resultados hasta llegar a los efectos finales de la ayuda:

En general, la ejecución de los proyectos parece ser satisfactoria en lo relativo a los insumos y los resultados previstos. Así, se ha impartido formación de buena calidad en materia de comercio, se han establecido normas y sistemas de certificación, se han creado instituciones de acreditación y se han desarrollado sistemas de mercado, entre otras cosas. Aparte de ello, los resultados disponibles no permiten extraer conclusiones claras con respecto al logro de los objetivos de los proyectos de asistencia técnica relacionados con el comercio (como la influencia en la política comercial, la prestación de servicios al sector del comercio, el aumento de la competitividad o el crecimiento del comercio) (Goppers y Lindahl, 2009, página 9).

En los primeros estudios de casos por países del Centro Internacional para el Comercio y el Desarrollo Sostenible (ICTSD) también se hace hincapié en la eficacia de la ayuda para el comercio a nivel de los resultados comerciales, aunque las conclusiones a que se llega respecto de cada uno de los cuatro países estudiados (Camboya, Malawi, Mauricio y Nepal) difieren ligeramente (ICTSD, 2012, página 4).

En esas evaluaciones recientes se señala la persistencia de algunos problemas y la aparición de otros nuevos, entre los que figuran los siguientes:

- Aunque en prácticamente todas las evaluaciones se llega a la conclusión de que la ayuda para el comercio ha sido mayormente eficaz para ayudar a los países en desarrollo a aprovechar las oportunidades que ofrece el comercio internacional, sigue resultando difícil seguir la compleja concatenación que vincula los fondos aportados por los donantes (los insumos de la cadena de resultados) con el aumento del comercio o el crecimiento impulsado por el comercio y, mucho menos aún, con la reducción de la pobreza.

- En algunas evaluaciones se hace hincapié en que los donantes no prestan suficiente atención a las políticas complementarias necesarias para evitar que las reformas comerciales y la liberalización del comercio tengan efectos negativos y creen perdedores (véase, por ejemplo, Banco Mundial, 2006). 
- Es necesario establecer objetivos medibles y niveles de referencia cuantitativos, así como grupos de comparación apropiados para poder evaluar el éxito logrado; éste es un aspecto que sigue dejando mucho que desear. ${ }^{8}$

- Con suma frecuencia, los donantes prestan atención a un problema en la evaluación de un país o sector determinados, pero pasan por alto ese mismo problema al evaluar a otro país o sector; en el estudio de la OCDE (2011c) de los proyectos ejecutados en Ghana, en Viet Nam y en el sector del transporte y el almacenamiento se señala esta deficiencia.

- Además, en las evaluaciones de los donantes se presta muy poca atención al contexto general en materia de política y a su posible influencia en un programa o proyecto. Por ejemplo, la tasa de rentabilidad social de muchos proyectos puede verse afectada (positiva o negativamente) por el elevado nivel de los aranceles y/u otras restricciones al comercio, pero en las evaluaciones rara vez se examinan (o se mencionan) esos factores (OCDE, 2011c, página 49).

- La falta de competencia suficiente en materia comercial entre los donantes, en particular en el caso de las misiones sobre el terreno, sigue constituyendo un obstáculo para un diálogo provechoso sobre las cuestiones relacionadas con el comercio.

- La falta de coordinación suficiente entre el personal de la sede y el personal sobre el terreno de los organismos donantes sigue planteando problemas de desconexión, como se señala en las evaluaciones llevadas a cabo recientemente por el Japón y Finlandia (Bird et al., 2011; Mizuho, 2012).

- Los debates sobre la ayuda para el comercio que se celebran en París o Ginebra no guardan forzosamente relación con los esfuerzos que se están desplegando en los países, muchos de los cuales tienen por objeto el desarrollo del sector privado, de la infraestructura o de la agricultura. Algunos estudios de casos por países ${ }^{9}$ muestran que los grupos de trabajo que se ocupan del desarrollo del sector privado y generalmente están integrados por representantes de los donantes y funcionarios públicos a menudo han utilizado los indicadores de Doing Business del Banco Mundial para medir el éxito de los programas, a pesar de que sólo algunos de ellos guardan relación con el comercio.

Dada la amplitud de la definición de la ayuda para el comercio, otra esfera que convendría incluir en el "prisma" es la de las evaluaciones sectoriales de los programas de los donantes en los que podrían denominarse los "sectores de la ayuda para el comercio" - el transporte, la agricultura, la infraestructura de la energía y el desarrollo del sector privado. Normalmente, en esa clase de evaluaciones el comercio no ocupa un lugar destacado (si acaso se lo menciona) ni tiene por qué hacerlo, ya que los factores que no guardan relación con el comercio pueden incidir en mayor medida en los resultados. Un ejemplo en que se menciona el comercio, aunque más no sea de pasada, es la evaluación (muy crítica) del Banco Mundial de los esfuerzos desplegados por el Banco en el sector de la agricultura en África:

Por tratarse de una de las principales esferas de análisis en la actualidad en este ámbito, se ha producido un trabajo que tiene por objeto respaldar los esfuerzos del Banco encaminados a ejercer presión para que la Ronda de Doha promueva auténticamente el desarrollo, así como para eliminar las subvenciones que conceden a la agricultura los países de la OCDE. Incluso la labor analítica llevada a cabo más recientemente por el Banco en relación con el comercio no ha tenido mayor influencia en los préstamos ni en el diálogo entre los países. ${ }^{10}$ 
El estudio de las actividades de transporte realizado por el Banco Mundial, en que no se hace referencia alguna al comercio salvo indirectamente, es más representativo del enfoque del Banco Mundial:

... las intervenciones anteriores han sido ... eficaces, especialmente en lo que se refiere a la construcción y rehabilitación de carreteras interurbanas, y el enfoque del Banco en el ámbito del transporte ha contribuido al desarrollo del sector privado. ... Sin embargo, las actividades en materia de transporte deben ahora orientarse a resolver cuestiones transversales, como la congestión del tráfico, los daños medioambientales, la seguridad y la eficiencia."

En suma, esta clase de evaluaciones tienen ventajas y desventajas que son la exacta contrapartida de las de los estudios trasnacionales: son sumamente útiles para dar una idea acabada del contexto del país y las enseñanzas conexas, pero tienden a pasar por alto los aspectos cuantitativos, y las generalizaciones se basan a menudo en evaluaciones cualitativas. Mientras que el alcance de los estudios transnacionales suele ser limitado (por ejemplo, la expansión de las exportaciones), las evaluaciones de los donantes tienen a menudo un alcance tan amplio (diversos países, sectores, instrumentos y variables dependientes) que a veces no hay conclusiones claras que puedan servir de enseñanza.

\section{Evaluaciones a nivel de los proyectos - y el potencial de las evaluaciones del impacto}

Las evaluaciones a nivel de los proyectos son comunes en las intervenciones relacionadas con el comercio. La mayoría de los organismos de desarrollo lleva a cabo evaluaciones básicas al final de cada proyecto, pero hay muchos tipos de evaluaciones de proyectos (OCDE, 2011a). El Banco Mundial, por ejemplo, realiza evaluaciones de diversa índole: evaluaciones de control de calidad en diferentes etapas del ciclo de ejecución de los proyectos que abarcan un subconjunto de proyectos; informes de terminación de la ejecución en colaboración con los gobiernos beneficiarios para evaluar los resultados de los proyectos en materia de desarrollo y su eficacia financiera; evaluaciones formales independientes de proyectos y programas seleccionados (por ejemplo, en la esfera del comercio); y evaluaciones del impacto realizadas en el marco de la Iniciativa de Evaluación del Impacto en el Desarrollo (Iniciativa DIME), emprendida en fecha relativamente reciente) en relación con proyectos seleccionados (aunque hasta la fecha se han evaluado relativamente pocos proyectos comerciales). A pesar de esos esfuerzos, la comunidad del comercio aún no ha asimilado plenamente la necesidad de incorporar en su enfoque la información necesaria para evaluar cuantitativamente los proyectos, como lo demuestra el hecho de que, de los 269 relatos de casos presentados a la OCDE y la OMC en 2011, sólo el 44\% incluía algún tipo de medida cuantitativa de los productos obtenidos, y sólo el 22\% incluía una medida cuantitativa, aunque fuera parcial, de los resultados, y la gran mayoría de esas medidas eran, en el mejor de los casos, rudimentarias y de alcance limitado..$^{2}$

La limitada información disponible indica que los resultados de los proyectos de ayuda para el comercio son positivos. El Banco Mundial, en su examen de los proyectos relacionados con el comercio terminados en el período 2002-2008, señaló que un 83\% de ellos habían sido calificados de satisfactorios. La tasa media de rendimiento económico de los proyectos relacionados con el comercio había sido del 32,4\%, mientras que la de los proyectos no comerciales era del 23,7\% (Banco Mundial, 2009). Sin embargo, un examen más a fondo de esos proyectos indica que no hay razón para ser tan optimista. Cadot et al. (2011) examinaron 85 proyectos de inversión relacionados con el comercio ejecutados por el Banco Mundial durante el período 1995-2005 y llegaron a la conclusión de que muy frecuentemente las evaluaciones eran parciales o simplemente inexistentes. La mayoría de los proyectos utilizaba cálculos sencillos de la tasa de rentabilidad económica (31\%), a veces en combinación con talleres y/o encuestas en que participaban las partes interesadas para evaluar los aspectos cualitativos (otro 26\%). Un 10\% de los proyectos examinados no había sido objeto de evaluación alguna. Muchas de las evaluaciones posteriores a la ejecución, incluidas 
las cuantitativas, no controlaban los efectos de factores externos y atribuían a los proyectos beneficios vinculados a condiciones favorables; a la inversa, otras veces se atribuía a condiciones externas el hecho de que no se hubiesen logrado los resultados previstos.

La evaluación a nivel de los proyectos podría ser mucho más informativa y resultaría más fácil establecer relaciones de causalidad si se adoptasen las técnicas utilizadas en los métodos formales de evaluación del impacto. Generalmente, mediante esa clase de métodos se compara el desempeño de un grupo afectado por una política determinada (el "grupo experimental") antes y después de la aplicación de la política con el de un grupo que no se ha beneficiado de la intervención (el "grupo de control"); ambos grupos son seleccionados aleatoriamente de entre las más numerosas subpoblaciones respectivas. Estas técnicas se emplean con frecuencia para analizar las intervenciones en las esferas de la salud, la educación y otras esferas relacionadas con las actividades de desarrollo. ${ }^{3}$ Por su naturaleza, esta clase de métodos sólo pueden aplicarse a intervenciones de política que afectan a determinados grupos o empresas de manera diferente, como los programas de promoción de las exportaciones o de asistencia técnica y las intervenciones limitadas a determinadas zonas geográficas.

Por diversas razones, estas técnicas son más difíciles de aplicar a los proyectos relacionados con el comercio, por lo que la OCDE (2011a) ha desaconsejado su uso. Uno de los problemas que se plantean es que las políticas comerciales (y muchos de los programas relacionados con la infraestructura) afectan a la totalidad del país, por lo que es prácticamente imposible distinguir a quienes se benefician de quienes no se benefician con la intervención, una condición necesaria para llevar a cabo un análisis aleatorio con un grupo de control y un grupo experimental. Además, resultaría lento, difícil -y enormemente costoso- llevar a cabo proyectos piloto en experimentos controlados, esperar el tiempo necesario (uno o dos años) hasta obtener los resultados definitivos y luego tomar medidas. El costo no es un factor de poca monta. Para muchos proyectos de asistencia técnica en pequeña escala, las evaluaciones del impacto podrían fácilmente resultar tan costosas como la actividad misma. Por último, en los casos en que las evaluaciones del impacto permiten identificar con precisión las relaciones de causalidad, cuantificar los resultados y sacar conclusiones muy importantes sobre el terreno, a menudo no resulta claro cómo podrían aplicarse esas conclusiones en contextos diferentes.

Con todo, podría hacerse mucho más en esta esfera. Cadot et al. (2011) sugieren la forma de realizar "estudios cuasi-experimentales" (a fin de soslayar las limitaciones de los métodos aleatorios más tradicionales) aplicando métodos de "emparejamiento" y de "diferencias en diferencias". Un ejemplo de diseño cuasi-experimental es el utilizado por Estevadeordal y Taylor (2009), quienes, tomando como punto de partida la ola de liberalizaciones comerciales que tuvo lugar después de 1990, formularon un experimento natural en el que dividieron a los países en un "grupo experimental" (integrado por los países "liberalizadores") y un grupo de control (integrado por los países "no liberalizadores"). Los resultados del análisis indicaron claramente que, como resultado de la liberalización de los aranceles que gravaban las importaciones de bienes de capital y bienes intermedios, la tasa de crecimiento de los países liberalizadores había aumentado en un punto porcentual por año. En cambio, en el caso de la modificación de los aranceles que gravaban los bienes de consumo, la correlación con los resultados a nivel del crecimiento era débil.

Los ejemplos de evaluaciones a nivel de los proyectos en que se cuantifican los beneficios que reporta la ayuda para el comercio son muy pocos como para que puedan hacerse generalizaciones sobre los efectos de la ayuda. Brenton y Von Uexkull (2009) utilizaron el método de "diferencias en diferencias" para examinar los efectos de 88 programas de promoción de las exportaciones en 48 países diferentes y determinaron que, por término medio, los programas coincidían con un fuerte aumento de las exportaciones, o eran anteriores al aumento. Volpe y Carballo (2008), en su evaluación de programas de promoción de las exportaciones en seis países latinoamericanos, también llegaron a la conclusión de que los programas habían tenido un efecto positivo sobre las exportaciones. 


\section{ACTUALIZACIÓN, SOBRE LA BASE DE NUEVOS DATOS, DE LAS CONCLUSIONES SOBRE LA RELACIÓN ENTRE LA AYUDA PARA EL COMERCIO Y EL COMERCIO}

Desde que se llevaron a cabo los primeros estudios agregados de la relación entre la ayuda para el comercio y el crecimiento del comercio, el comercio de los países en desarrollo ha seguido creciendo más rápidamente que las exportaciones mundiales y el PIB de esos países. Además, la composición del comercio se está orientando hacia las cadenas mundiales de valor. Por lo tanto, es un buen momento para rever algunos de los primeros resultados obtenidos y analizar más detenidamente la relación entre las corrientes de ayuda para el comercio y el crecimiento del comercio.

A partir de un marco empírico similar al empleado por Helble et al. (2012), Cali y te Velde (2010) y Vijil (2012)14, en la preparación del presente capítulo se ha utilizado un modelo gravitacional del comercio para estimar los efectos de los compromisos bilaterales por concepto de ayuda para el comercio en un grupo de países en desarrollo durante 16 años (1995-2011), período en relación con el cual se dispone de datos desagregados de la OCDE sobre los compromisos contraídos, así como de cifras sobre el comercio de muchos países pequeños de ingresos bajos. Se incluyeron en la muestra todos los países en desarrollo que no exportan petróleo y que fueron clasificados en 1995 como países en desarrollo (ya que el análisis tenía por objeto dar cuenta de todos los efectos históricos). Así, el análisis abarcó 110 países exportadores en desarrollo y más de 200 países importadores que eran sus asociados bilaterales (incluidos países ricos) y 140.000 observaciones positivas de corrientes comerciales bilaterales durante ese período. ${ }^{15}$

A fin de determinar si, gracias a la ayuda para el comercio, aumentaban las exportaciones de productos distintos de los minerales y el petróleo, se utilizó un modelo gravitacional para estimar los efectos de los compromisos bilaterales por concepto de ayuda para el comercio notificados al CAD en un año determinado sobre las exportaciones de productos distintos de los minerales tres años después. Ese desfase entre la notificación de los compromisos y los resultados previstos en relación con las exportaciones es necesario ya que los compromisos pueden demorar un tiempo en convertirse en inversiones y exportaciones efectivas. También sirve, en cierta medida, para verificar la hipótesis de que la dirección de la relación de causalidad va de la ayuda al comercio, y no viceversa. Para determinar el papel que desempeña la ayuda para el comercio en contraposición con el que pueden tener otros factores determinantes, en las estimaciones se controlaron los efectos de 11 factores determinantes del nivel del comercio utilizados tradicionalmente en los modelos gravitacionales, como las características del país exportador y el país importador (el tamaño, entre otras cosas), la distancia que separa a los asociados comerciales y la participación en acuerdos comerciales, así como factores que pueden reducir los intercambios comerciales, como los conflictos sociales y la condición de país sin litoral. Para controlar los efectos de ciertas peculiaridades que afectan al comercio se utilizaron efectos fijos por país y por año (en el anexo E figuran las estimaciones obtenidas mediante regresión, y en el anexo F se proporciona una explicación detallada de la metodología aplicada para efectuar las regresiones).

\section{Existe una correlación positiva entre la ayuda para el comercio y el aumento de las exportaciones ...}

La ayuda para el comercio está vinculada de manera considerabley positiva con un aumento de las exportaciones. Los resultados indican que un incremento del 10\% en la cuantía de la ayuda para el comercio a nivel bilateral destinada a países en desarrollo redundaría en un aumento del 0,3\% aproximadamente de sus exportaciones. Aunque estos porcentajes pueden parecer pequeños, si el volumen de la ayuda para el comercio hubiese aumentado en 10\% (es decir, unos 1.000 millones de dólares EE.UU.), las exportaciones de los países en desarrollo habrían aumentado unos 9.000 millones de dólares EE.UU. en años recientes (cuadro 5.1). 
La ayuda para el comercio no sólo repercute en las corrientes de exportación del país receptor. La ayuda para el comercio que se presta a un asociado comercial bilateral también hace aumentar las importaciones procedentes del país exportador. Por ejemplo, si en un período determinado Rwanda exporta a Kenya, la ayuda para el comercio no sólo ayudará a Rwanda a exportar más que los países que no reciben ayuda sino que, si además se presta ayuda para el comercio a Kenya, las exportaciones de Rwanda serán aún mayores, ya que la ayuda destinada a la infraestructura de transporte o los puestos fronterizos de Kenya también beneficiará a los exportadores rwandeses. De hecho, en el caso de las corrientes bilaterales entre dos países que reciben ayuda, si aumenta la ayuda para el comercio que se presta a los dos asociados aumenta también el nivel de los dos coeficientes a cerca del 0,4\%.16

\section{... especialmente en el caso de los países de ingresos bajos ...}

La ayuda para el comercio beneficia especialmente a los países más pobres que reúnen las condiciones necesarias para recibir préstamos de la Asociación Internacional de Fomento (AIF). A los efectos del análisis que permitió llegar a esta conclusión, se dividió la muestra en tres grupos de países, en función del nivel de ingresos que tenían en 1995 y según las categorías de la clasificación del Banco Mundial."7 En general, se trata de PMA sobre los que se disponía de datos y otros países de ingresos bajos. Por lo tanto, quedaron excluidos los países en desarrollo que en 1995 pertenecían a la categoría de países de ingresos medianos altos. La ayuda para el comercio generó beneficios especialmente elevados para los 53 países que reunían las condiciones necesarias para recibir préstamos de la AlF en 1995 (y cuyos datos comerciales se habían publicado): por cada dólar invertido en ayuda para el comercio se obtuvieron casi 20 dólares (cuadro 5.1). Así, si se toman como punto de partida los ingresos medios de exportación de estos países durante el período 2009-2011, un aumento del 10\% en la ayuda haría aumentar sus exportaciones colectivas en casi 8.000 millones de dólares EE.UU., mientras que si el aumento fuese del 25\%, el comercio aumentaría en unos 20.000 millones de dólares EE.UU. En los países de ingresos muy bajos, los efectos son mucho menores (sin duda porque tropiezan con muchos más obstáculos para incrementar el volumen de exportaciones). Así, con un aumento del 10\%, las exportaciones aumentan 1.400 millones de dólares EE.UU., en parte debido al volumen mucho menor de la base de exportación.

\section{Cuadro 5.1 Estimación del aumento de las exportaciones totales como resultado del aumento de la ayuda para el comercio}

(Millones de dólares EE.UU.)

Aumento de la ayuda para el comercio:

\begin{tabular}{|l|c|c|c|c|c|c|}
\hline & Tasa de rendimiento & $\mathbf{5 \%}$ & $\mathbf{1 0} \%$ & $\mathbf{1 5 \%}$ & $\mathbf{2 0} \%$ & $\mathbf{2 5 \%}$ \\
\hline Países de ingresos bajos & 2,7 & 720,5 & $1.441,0$ & $2.161,4$ & $2.881,9$ & $3.602,3$ \\
\hline $\begin{array}{l}\text { Países de ingresos } \\
\text { medianos bajos }\end{array}$ & 9,1 & $2.109,4$ & $4.218,8$ & $6.328,1$ & $8.437,5$ & $10.546,8$ \\
\hline $\begin{array}{l}\text { Países que reciben } \\
\text { préstamos de la AIF }\end{array}$ & 19,5 & $3.986,2$ & $7.972,4$ & $11.958,6$ & $15.944,8$ & $19.931,0$ \\
\hline Países en desarrollo & 8,1 & $4.554,1$ & $9.108,1$ & $13.662,2$ & $18.216,2$ & $22.770,2$ \\
\hline
\end{tabular}

Fuente: Estimaciones obtenidas sobre la base de las regresiones que figuran en el Anexo E (cuadro E.2). La clasificación de los países por nivel de ingresos se basa en los cálculos del Banco Mundial de 1995. Los países que reciben préstamos de la AlF incluyen algunos países de ingresos bajos y unos pocos países de ingresos medianos bajos también incluidos en los dos primeros renglones. El aumento del volumen del comercio se calcula a partir del volumen medio del comercio anual durante el período 2009-2011, agregado para cada una de las categorías por nivel de ingresos de la muestra. 
Los resultados obtenidos confirman también las enormes desventajas a que hacen frente los países en conflicto cuando tratan de exportar más. En muchos casos los coeficientes de los países en conflicto son altamente negativos (anexo E, cuadro E.1), lo que demuestra la importancia que tienen la paz y la seguridad para el comercio (así como la importancia de un entorno propicio para que la ayuda para el comercio sea productiva).

Además, cabe señalar que la participación en acuerdos comerciales preferenciales tiene efectos importantes y uniformemente positivos en las exportaciones, incluso cuando se controlan los efectos de otros factores que podrían explicar esa relación (como una frontera o un idioma común). Los resultados son los mismos para la casi totalidad de las estimaciones de los cuadros del anexo y coinciden con la conclusión de Vijil (2012) de que la ayuda para el comercio ( $y$, en particular, la destinada a mejorar las instituciones) tiende a ser especialmente eficaz en presencia de acuerdos comerciales preferenciales a nivel regional (véase también el capítulo 4).

\section{... pero es difícil generalizar acerca de lo que constituye una asignación óptima de la ayuda según la categoría a la que pertenecen los países}

En algunos estudios se ha intentado generalizar acerca del destino que debe darse a la ayuda para el comercio (infraestructura, creación de capacidad productiva, política y reglamentación comerciales, entre otros) según la categoría en que encuadran los países en desarrollo. Así, Cali y te Velde (2010), en su estudio sobre los efectos de los desembolsos de la ayuda para el comercio por subcategorías de la ayuda durante el período 2002-2007, llegan a la conclusión de que la asignación de la ayuda a la infraestructura fue más importante para los países de ingresos bajos, mientras que, para los países en desarrollo de ingresos medianos, la asignación de la ayuda a los sectores productivos fue más importante.

Sobre la base de un detallado estudio de las limitaciones fundamentales a las que se enfrentaban los países en desarrollo en materia de comercio, la OCDE (2012b) presentó a los principales grupos de miembros de la OMC algunas conclusiones generales sobre las limitaciones fundamentales que la ayuda para el comercio podría contribuir a reducir en parte:

- En el caso de los países sin litoral, se había determinado que las limitaciones geográficas no constituían la única explicación de los resultados comerciales relativamente pobres obtenidos por esos países. Como se ha demostrado en países en rápido crecimiento tan diversos como Botswana, Burkina Faso, Rwanda y Uganda, la existencia de políticas internas apropiadas puede promover el crecimiento del comercio. Las políticas comerciales restrictivas (en particular en el sector de los servicios) tienen una mayor repercusión en los resultados comerciales de los países sin litoral que en los de otros países. Asimismo se había determinado que las políticas de fomento de la inversión tenían un efecto considerable en el comercio, aunque ligeramente menor que el que tenían en el total de la muestra de países. Las políticas macroeconómicas también contribuían al logro de mejores resultados económicos, en particular en materia de gestión de los tipos de cambio y (en menor medida) de política fiscal. Según el estudio, una infraestructura deficiente (en particular, la falta de acceso a la electricidad) constituía uno de los principales obstáculos para el desarrollo del comercio.

- En las economías pequeñas y vulnerables, el comercio era la piedra angular del crecimiento económico. El pequeño tamaño del mercado redundaba, entre otras cosas, en una importante concentración de las exportaciones en unos pocos grupos de productos. La infraestructura (en particular la relacionada con la energía y, a diferencia de lo que ocurría en otras categorías de países, con las telecomunicaciones) desempeñaba un papel fundamental en los resultados de las economías pequeñas y vulnerables. 
- En los países exportadores de productos básicos, la gobernanza y la política macroeconómica constituían una prioridad. Según el estudio, una mejor gestión del gasto público con el consiguiente aumento de la productividad de la inversión pública y una mejor política monetaria para reducir la sobrevaloración del tipo de cambio efectivo real también tenían importancia fundamental.

Como se indicó supra, en el análisis efectuado a los fines del presente capítulo se utilizó un período más largo y una formulación ligeramente diferente para estudiar los efectos sobre el comercio de tres categorías de ayuda bilateral: la destinada a la infraestructura económica, la destinada a la creación de capacidad productiva y la destinada a otros aspectos (fundamentalmente, la política y la reglamentación relacionadas con el comercio). La ayuda destinada a la política y la reglamentación relacionadas con el comercio parece ser el componente más importante de la ayuda para el comercio en todos los países. Puede que esto guarde relación con los efectos desproporcionadamente grandes que tienen cuantías relativamente pequeñas asignadas a la asistencia técnica, incluso una vez que se han controlado los efectos de otros programas de ayuda para el comercio que promueven un aumento de las exportaciones. Además, en el caso de los países de ingresos bajos, la ayuda que se destina a la creación de capacidad productiva parece surtir mayor efecto que la que se asigna a la infraestructura, mientras que en los países de ingresos medianos bajos se da la situación inversa (el coeficiente correspondiente a la capacidad productiva es positivo, pero pequeño y no significativo, por lo que no se ha incluido en el gráfico 5.1).18

\section{Gráfico 5.1 Efecto previsto del incremento de la ayuda para el comercio en las exportaciones (Variación porcentual de las exportaciones)}

Aumento de la ayuda para el comercio: $10 \%$

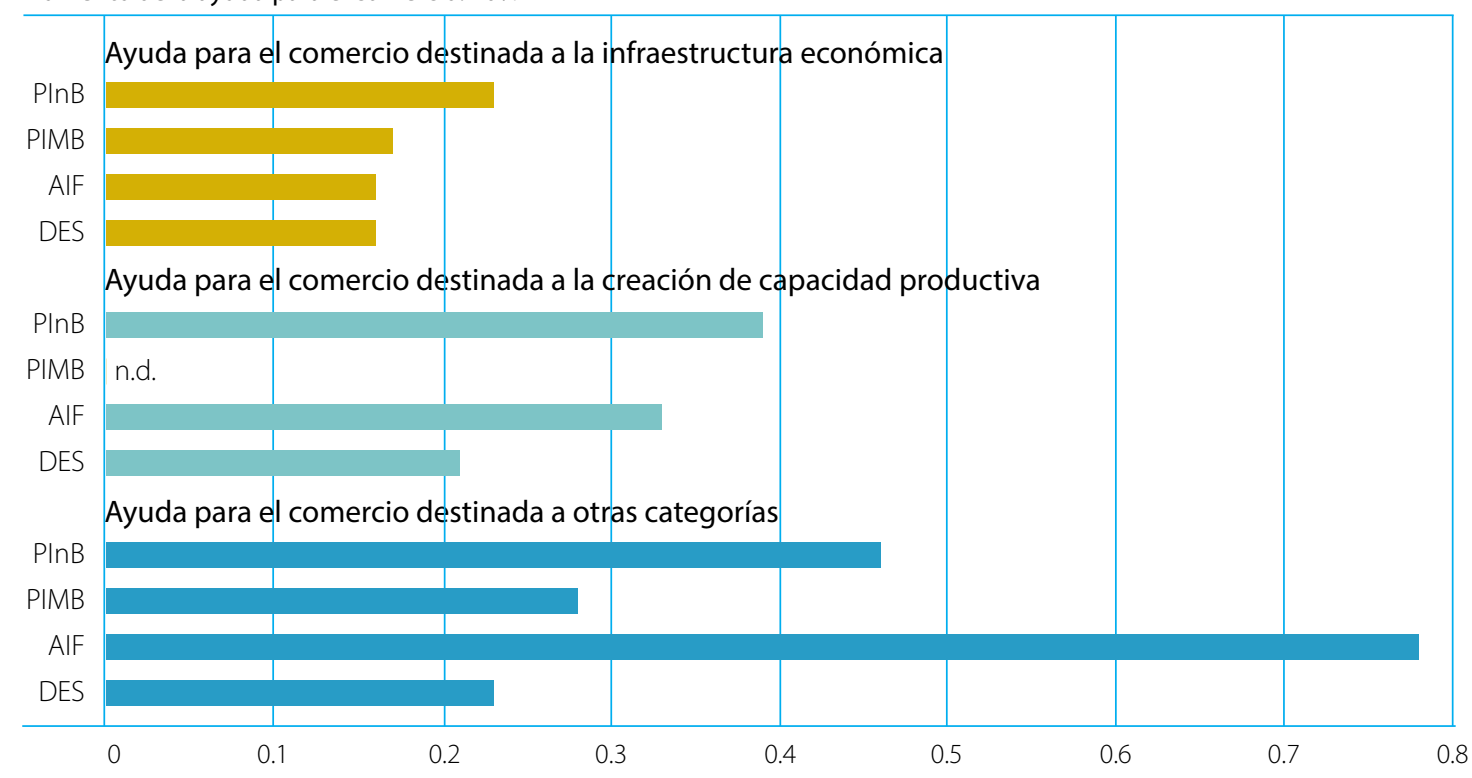

Siglas: PInB - Países de ingresos bajos; PIMB - Países de ingresos medianos bajos; AIF - Países que reciben préstamos de la AIF; DES - Países en desarrollo Fuente: Resultados del anexo E, cuadro E.4.

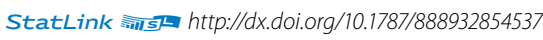

Estos resultados se contraponen con los obtenidos por Cali y te Velde en su estudio (2010), lo que puede obedecer a las diferencias entre la metodología utilizada por esos autores y la utilizada en el presente capítulo (por ejemplo, desembolsos en lugar de compromisos retardados, distintos períodos seleccionados (2002-2007 en contraposición con 1995-2011) y la diferente clasificación de los países en categorías según el nivel de ingresos). Por lo tanto, para poder formular generalizaciones de carácter más definitivo habrá que aguardar los resultados de nuevas 
investigaciones. En todo caso, puede decirse que las generalizaciones de este tipo son prácticamente irrelevantes cuando se aplican a contextos nacionales específicos; las limitaciones fundamentales varían considerablemente dentro de cada categoría de países, de modo que no se puede recurrir a esta clase de generalizaciones para encontrar soluciones a los problemas comerciales de un país determinado, sino únicamente para hacerse una idea de dónde empezar a buscar.

\section{La ayuda para el comercio y otras formas de AOD}

En el análisis estadístico efectuado a los fines del presente capítulo, la distinción entre los efectos sobre las exportaciones de la ayuda para el comercio y de otras formas de asistencia oficial para el desarrollo no es clara. Por un lado, el aumento de la AOD bilateral (distinta de la ayuda para el comercio) tiende a deprimir los resultados a nivel de las exportaciones. ${ }^{19}$ Esto puede obedecer a los efectos que tienen las entradas de asistencia para el desarrollo en el tipo de cambio real; no es raro que la entrada de voluminosas corrientes de AOD haga aumentar el valor de la moneda nacional y, de ese modo, reduzca la competitividad de las exportaciones del país. Por otro lado, este efecto es pequeño y se ve contrarrestado por los efectos positivos que tienen otras corrientes de AOD destinadas a los asociados comerciales importadores, por lo que cualquier efecto parece quedar efectivamente neutralizado.

\section{EL SURGIMIENTO DE LAS CADENAS DE VALOR MUNDIALES Y SUS CONSECUENCIAS PARA LA AYUDA PARA EL COMERCIO}

La creciente importancia de las cadenas de valor mundiales, descrita en el capítulo 3, pone de relieve la relevancia de la ayuda para el comercio. En un informe reciente de la OCDE sobre los factores a nivel de las políticas que tienen importancia decisiva para la participación en las cadenas de valor mundiales se enumeran siete elementos: acuerdos comerciales regionales; menores obstáculos a la inversión de las empresas multinacionales; infraestructura de calidad; velocidad y flexibilidad de la circulación de los bienes físicos y la información; sistemas jurídicos y reglamentarios eficaces; servicios eficientes; y empresas nacionales (a menudo PYME) con la capacidad necesaria para contribuir a la cadena de suministro (OCDE, 2013b). En cada una de esas esferas se ha demostrado que la ayuda para el comercio puede ser un instrumento útil para promover las inversiones y las mejores políticas que son tan necesarias. Aunque las modalidades actuales de la ayuda para el comercio atienden a las limitaciones en relación con todos esos aspectos, hay determinadas esferas que, por su creciente importancia, requieren la adopción de medidas (véase el capítulo 3). Según el Foro Económico Mundial (FEM, 2013) esas esferas son:

- La administración de las fronteras y la facilitación del comercio, ya que el tiempo que se demora la carga en fronteras y puertos afecta en mayor medida a las cadenas de valor mundiales.

- Los obstáculos al acceso a los mercados, incluida la reglamentación sanitaria o de seguridad no normalizada y restrictiva.

- El desarrollo de los servicios, debido a la creciente importancia del transporte y las comunicaciones, la normalización, las normas de contabilidad, las funciones relacionadas con la garantía de la calidad y la logística del transporte.

- El entorno empresarial, ya que la reglamentación puede resultar perjudicial para las cadenas de suministro, y la inseguridad física provocada por los conflictos sociales o la no observancia de las leyes compromete su crecimiento. 


\section{¿Contribuye la ayuda para el comercio a promover la participación en las cadenas de valor mundiales?}

Para determinar si la ayuda para el comercio ha promovido la participación de los países en desarrollo en las cadenas de valor, en la presente sección se lleva a cabo una investigación similar a la de la sección anterior, pero en relación con las exportaciones de partes y componentes como la variable de interés en materia de exportaciones. El comercio de partes y componentes, ya sea dentro de las empresas, en las redes de las empresas líderes o mediante transacciones basadas en el mercado, suele indicar la existencia de comercio en cadenas de valor regionales y mundiales. (El presente análisis se basa en el análisis llevado a cabo por Kimura et al. (2007) en relación con esa clase de mercancías.)

El análisis econométrico efectuado a los fines del presente capítulo confirma que existe una correlación positiva y fuerte entre la ayuda para el comercio y el aumento de las exportaciones de partes y componentes de los países en desarrollo. De hecho, los resultados son más marcados que en el caso de las exportaciones totales: en efecto, un incremento del $10 \%$ en la ayuda para el comercio destinada a todos los países en desarrollo resulta en un aumento del $0,4 \%$ en las exportaciones de partes y componentes, en comparación con un aumento del 0,3\% en las exportaciones totales..$^{20}$ Además, como sucede con la relación entre la ayuda para el comercio y todas las exportaciones de productos distintos de los minerales, la ayuda para el comercio prestada a un país en desarrollo importador acarrea un aumento del comercio. También en este caso, el efecto combinado de un incremento del 10\% en la ayuda para el comercio prestada a los países exportadores y a los países importadores es un aumento del 0,5\% en el comercio de partes y componentes, en comparación con un aumento del 0,4\% en las exportaciones totales de productos distintos de los minerales. El aumento de la ayuda para el comercio podría hacer aumentar considerablemente el comercio en las cadenas de valor. En el gráfico 5.2 puede verse el efecto directo sobre las exportaciones de distintos incrementos porcentuales, sin tomar en cuenta la influencia de la ayuda para el comercio en los países importadores.

\section{Gráfico 5.2 Efecto de distintos incrementos de la ayuda para el comercio en las exportaciones de partes y componentes (porcentaje de la ayuda para el comercio adicional)}

VARIACIÓN DE LAS EXPORTACIONES (PORCENTAJE) 1,0

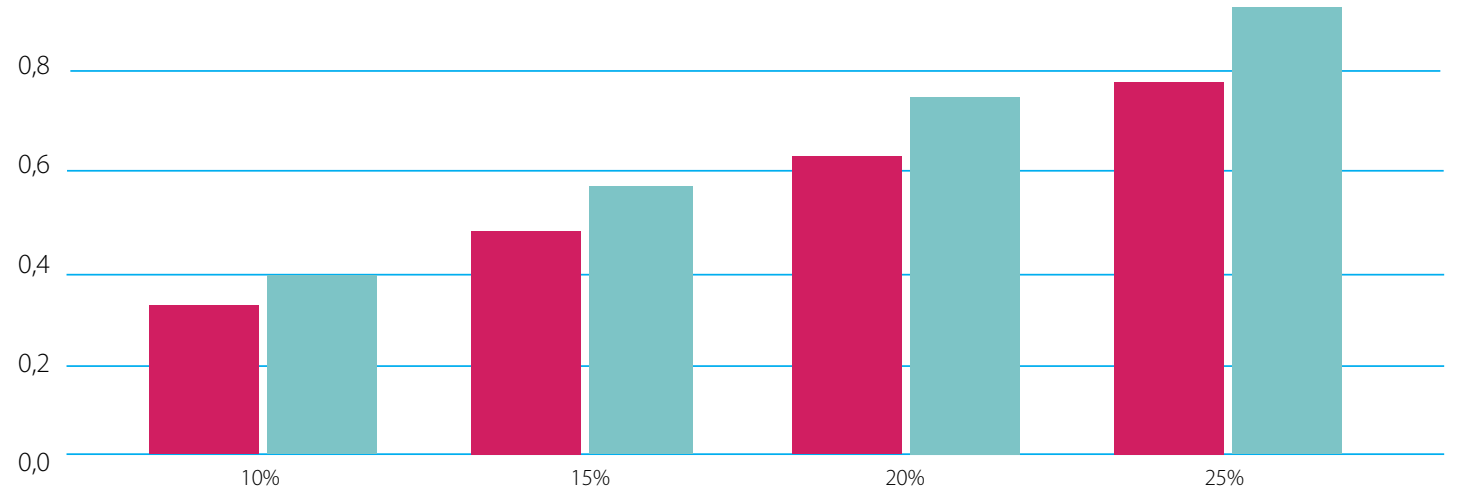

Exportaciones totales Exportaciones de partes y componentes 
En suma, muchos programas de ayuda para el comercio ya incluyen cuestiones que guardan relación con las cadenas de valor mundiales (administración de las fronteras, acceso a los mercados, facilitación del comercio y entorno empresarial); el comercio de bienes intermedios es indicio del desarrollo de cadenas de valor. Esto significa que probablemente sólo haya que hacer pequeños ajustes adicionales en las estrategias de ayuda para el comercio para poder aprovechar las nuevas oportunidades comerciales generadas por las cadenas de valor mundiales. De hecho, el análisis de la encuesta de la OCDE y la OMC realizado en los capítulos 2 y 3 muestra que esa evolución positiva ya está teniendo lugar.

\section{SISTEMAS DE GESTIÓN: UTILIZACIÓN EFICAZ DE LA AYUDA PARA EL COMERCIO}

Como resultado de la presión a la que se han visto sometidos los presupuestos de ayuda, también ha aumentado la presión ejercida sobre los donantes y los gobiernos para que utilicen más eficazmente los limitados recursos disponibles. Los gobiernos receptores son los principales responsables de velar por que todos los fondos de asistencia para el desarrollo, incluidos los de la ayuda para el comercio, tengan un rendimiento económico positivo. Desde la adopción de los Principios de París en 2006, los donantes y los gobiernos han intentado establecer marcos de responsabilidad mutua a fin de asegurar el mejor uso posible de la asistencia para el desarrollo. Por un lado, se ha encomendado a los donantes que ajusten sus programas de asistencia a las prioridades fundamentales de los gobiernos receptores, que coordinen unos con otros sus actividades para apoyar mejor los programas aprobados y que, siempre que sea factible, utilicen los sistemas de los países receptores. Por otra, los países en desarrollo se han comprometido a proporcionar orientación estratégica para el establecimiento de las prioridades de desarrollo y a trabajar con todas las partes interesadas a nivel nacional y de los donantes para establecer sistemas de gestión eficaces que permitan obtener resultados. ${ }^{21}$

Los países, en colaboración con los donantes y las instituciones financieras multilaterales, han establecido diversos tipos de sistemas de gestión para supervisar la ejecución de los distintos proyectos y programas y comparar sus resultados con los objetivos originales. Esos sistemas de gestión tienen por objeto no sólo controlar los insumos y los productos (por ejemplo, las sumas gastadas en la construcción de carreteras o el número de kilómetros de carretera construidos), sino también controlar los resultados (por ejemplo, la disminución del costo del transporte o el incremento de las exportaciones de mercancías) y los efectos finales (por ejemplo, el aumento del volumen de las exportaciones y el incremento de los ingresos). Para ello, es necesario definir los eslabones de la cadena de resultados: insumos, actividades, productos, resultados y efectos a largo plazo.

La cadena de resultados proporciona un marco para la supervisión y medición de los cambios que se desea introducir mediante las actividades de los proyectos. Los principales cambios descritos en la cadena de resultados constituyen los objetivos del proyecto; asimismo se identifican los indicadores para medir los resultados en cada etapa de la ejecución del proyecto. Por lo tanto, los indicadores constituyen un componente indispensable de los sistemas de gestión basada en los resultados (OCDE, 2011c, página 75).

\section{Gestión de la ayuda para el comercio basada en los resultados}

A fin de ayudar a los países en desarrollo y los organismos donantes a identificar objetivos cuantificables para los programas de ayuda para el comercio, la OCDE ha recopilado indicadores para medir los progresos realizados en la consecución de esos objetivos (OCDE, 2013a). Esta herramienta se diseñó sobre la base de seis estudios de casos sobre sistemas de gestión basada en los resultados en países en diferentes fases de desarrollo. Los países eran Bangladesh, Colombia, Ghana, las Islas Salomón, Rwanda y Viet Nam. Los estudios de casos muestran que en los seis países se había procedido a incorporar el comercio en las estrategias nacionales de desarrollo, o sea a integrarlo en los planes nacionales de desarrollo asignándole una función central. Esas conclusiones quedaron confirmadas 
por tres estudios de casos por países llevados a cabo por el ICTSD en Camboya, Malawi y Nepal. El ICTSD también señaló que "el reconocimiento público de la vital importancia del comercio en tanto que componente del crecimiento económico era la primera condición fundamental para el desarrollo sostenido relacionado con el comercio" y que "la ulterior incorporación del comercio en las estrategias oficiales de desarrollo permitía, en principio, lograr una mejor coordinación y armonización ..." (ICTSD, 2012, página 11). El Banco Mundial llegó a las mismas conclusiones en su estudio de diagnóstico sobre la integración del comercio en Uganda (Banco Mundial, 2013).

Desde luego, la incorporación revistió diferentes formas en cada uno de los seis países estudiados. En Bangladesh, el instrumento principal fue el Plan a Largo Plazo, un programa de actividades para el período 2011-2021. A mediados del decenio de 1990, Ghana elaboró el documento "Visión 2020" que luego sirvió de marco para la elaboración de programas trienales, el más reciente de los cuales fue el Programa de Crecimiento Compartido y Desarrollo para el período 2010-2013. Las Islas Salomón elaboraron la Estrategia Nacional de Desarrollo 2011-2020. En los seis países se establecieron objetivos generales para un período de diez o veinte años, que generalmente iban acompañados de planes nacionales de segundo orden más específicos, con un horizonte de dos a tres años. En todos ellos los resultados comerciales ocupaban un lugar destacado entre los objetivos y, lo mismo sucedía, con mayor frecuencia aún, en el caso de los objetivos en relación con los factores determinantes de la capacidad comercial, en particular, la infraestructura y la capacitación de los recursos humanos. Por ejemplo, uno de los cinco pilares del Plan Nacional de Desarrollo de Colombia era "el crecimiento sostenible y la competitividad basados en la innovación, el crecimiento de la competitividad y la productividad, las locomotoras de crecimiento y la generación de empleo" (OCDE, 2013a).

\section{Gráfico 5.3 Las siete etapas de una gestión basada en los resultados eficaz}

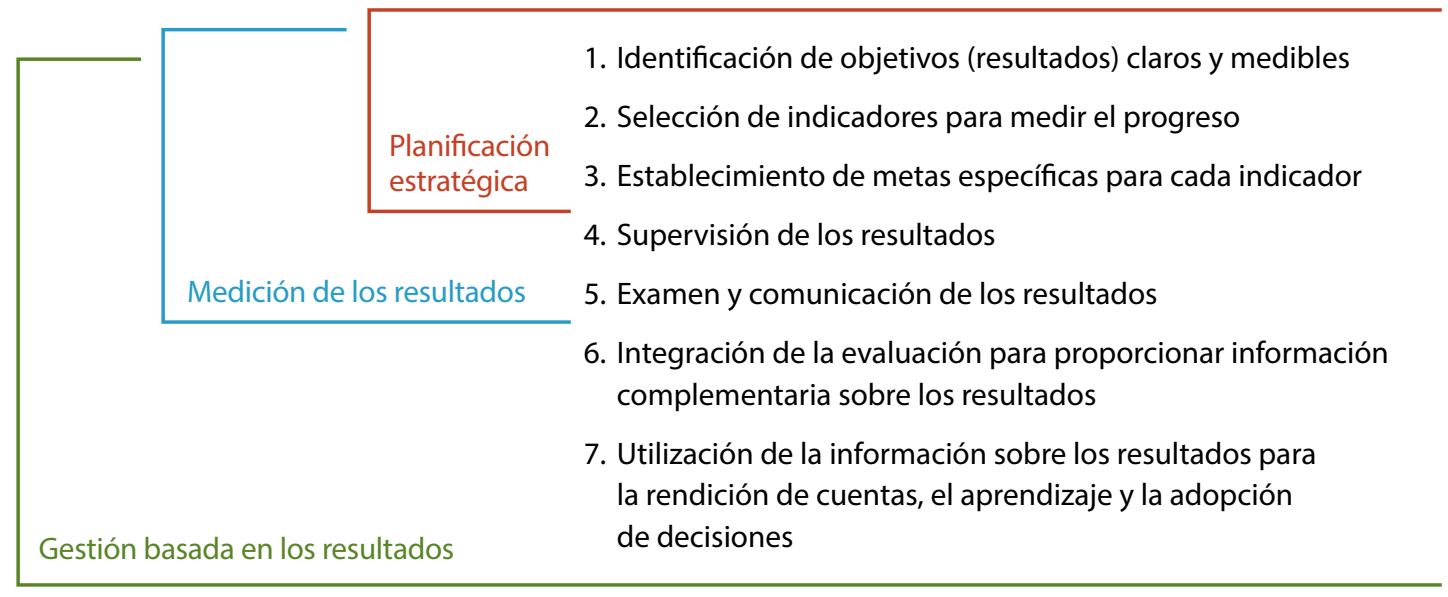

Fuente: OCDE (2011c)

Los planes nacionales de desarrollo, tanto a largo como a más corto plazo, proporcionaban un marco para estrategias sectoriales claras en muchos de los países cuyos casos se estudiaron. En Ghana, por ejemplo, la Política de desarrollo del sector alimentario y agrícola y el correspondiente plan de inversión incluido en el Plan de mediano plazo de inversión en el sector agrícola tenían por objeto acelerar la modernización del sector agrícola mediante la ejecución de un programa sectorial específico. En Rwanda, los ministerios y organismos competentes habían formulado más de dos docenas de estrategias sectoriales y subsectoriales para su aplicación en conjunción con los respectivos planes ministeriales. Aunque en todos los países estudiados los objetivos comerciales habían sido incorporados en los programas nacionales, sólo Colombia, Ghana, Rwanda y, en menor medida, Viet Nam, habían formulado claramente objetivos expresos con fines de vigilancia y evaluación (las cuestiones que figuran en la parte inferior del gráfico 5.3). 
A diferencia de Bangladesh y las Islas Salomón, estos países tenían objetivos comerciales bastante específicos e indicadores medibles. Un número aún menor de países indicaron que tenían sistemas detallados de vigilancia y evaluación que proporcionaban periódicamente a los responsables de la formulación de políticas información que pudiera ser utilizada para corregir el rumbo de la ejecución.

El ICTSD indicó, en relación con sus tres estudios de casos, que "... la integración del comercio a nivel formal ... no significa forzosamente su integración en la práctica ..." (ICTSD, 2012, página 11). Según el estudio de diagnóstico del Banco Mundial sobre la integración del comercio (2013), Uganda sí dispone de un sistema viable de gestión basada en los resultados y de vigilancia y evaluación. El sistema es sólo parcialmente eficaz, pero permite vigilar la ejecución de los programas de ayuda para el comercio y transmitir a las instancias superiores información obtenida mediante las actividades de vigilancia y evaluación a fin de mejorar la ejecución futura.

\section{Evaluación de la actuación de los donantes}

Como la responsabilidad mutua significa no sólo que los gobiernos han contraído obligaciones con los donantes, sino también que los donantes tienen obligaciones respecto de los gobiernos, algunos gobiernos han comenzado a trabajar con los donantes a fin de acordar un sistema para evaluar la actuación de los donantes. Por ejemplo, según el estudio de diagnóstico sobre la integración del comercio de 2013 (Banco Mundial, 2013), en Uganda la Oficina del Primer Ministro prepara una evaluación anual de la actuación de los donantes con arreglo a los Principios de París. En 20102011 el Gobierno llevó a cabo su tercera encuesta sobre la base de la Declaración de París a fin de medir los progresos realizados con arreglo a 15 indicadores predefinidos. La encuesta reveló que, en relación con 8 de los 15 indicadores, se habían obtenido, hasta cierto punto, mejores resultados, particularmente en las esferas de "la armonización con las prioridades nacionales, una mejor coordinación de la ayuda y la eliminación de sistemas paralelos en la ejecución de los proyectos", mientras que otros 6 indicadores no mostraban variación alguna o revelaban un empeoramiento de la situación, por ejemplo, en la utilización de sistemas nacionales, el aumento de la previsibilidad de los fondos y un mejor uso de los marcos orientados a la obtención de resultados.

\section{Un ejemplo digno de mención: Rwanda}

Rwanda ha desarrollado un sistema de gestión basada en los resultados que se encuentra entre los más completos y sofisticados de entre los países de ingresos bajos. El sistema es un ejemplo de aplicación eficaz de todas las etapas de la gestión basada en los resultados descritas en el gráfico 5.3, así como de una colaboración en materia de ayuda para el comercio que, junto con otras iniciativas, ha promovido un rápido crecimiento y reducido la pobreza. Versailles (2012) señalaba que "... actualmente Rwanda puede preciarse de contar con un marco de responsabilidad mutua que está muy cerca de figurar entre las 'mejores prácticas'".

\section{La gestión basada en resultados}

El programa de ayuda para el comercio se estableció en el contexto general de los objetivos fijados en la Visión 2020 del Gobierno, y se puso en marcha mediante la Estrategia quinquenal de desarrollo económico y reducción de la pobreza. El Gobierno ha establecido también varios objetivos e indicadores susceptibles de ser vigilados que constan en el Marco común para la evaluación de los resultados. A fin de que los asociados para el desarrollo participen en el proceso, el Gobierno ha establecido 16 grupos de trabajo y/o dependencias sectoriales hasta el nivel de organismo de ejecución integrados por representantes de ministerios, organismos, donantes encargados de supervisar sistemáticamente la aplicación de las políticas y los progresos realizados en relación con los indicadores establecidos. Los resultados son evaluados anualmente y comunicados a los distintos niveles jerárquicos de la cadena de ejecución hasta llegar al gabinete económico. 
El sistema se basa en un conjunto de indicadores de productos y resultados que deben obtenerse mediante la aplicación de las políticas y medidas indicadas (y a menudo cuantificadas), comenzando por el nivel más alto del gobierno en sentido descendente hasta llegar a los distintos ministerios y organismos. Se ha asignado a cada instancia gubernamental sus propios productos/resultados y el plan de ejecución correspondiente. Nada más que a nivel del Ministerio de Industria y Comercio (MINICOM) y el Ministerio de la Comunidad del África Oriental (MINECOFIN), el Gobierno sigue de cerca unos 90 indicadores relacionados con la ayuda para el comercio y más de 540 medidas conexas (sin contar los planes de acción anuales y los contratos de ejecución de los demás ministerios) (cuadro 5.2). Por último, los resultados anuales se incorporan a la planificación y los planes de acción futuros, por lo que la comunicación de información en función de los resultados desempeña un papel importante para garantizar la utilización eficaz de la asistencia para el desarrollo.

\section{Cuadro 5.2 El sistema de gestión basada en los resultados de Rwanda incluye indicadores} de resultados y de aplicación de políticas a diversos niveles del gobierno

\begin{tabular}{|c|c|c|c|c|c|}
\hline & & \multicolumn{2}{|c|}{ Total } & \multicolumn{2}{|c|}{ Relacionados con el comercio } \\
\hline & & Indicadores & Políticas & Indicadores & Políticas/medidas \\
\hline \multirow[t]{10}{*}{ Planes } & $\begin{array}{l}\text { Estrategia de desarrollo económico y } \\
\text { reducción de la pobreza 2008-2012 }\end{array}$ & 73 & .. & 25 & 29 \\
\hline & $\begin{array}{l}\text { Marco común de evaluación de } \\
\text { los resultados oct. } 2011\end{array}$ & 45 & 80 & 12 & 22 \\
\hline & $\begin{array}{l}\text { Grupo de trabajo sectorial sobre } \\
\text { el desarrollo del sector privad }\end{array}$ & & & 2 & 4 \\
\hline & $\begin{array}{l}\text { Otros grupos de trabajo } \\
\text { sectoriales (relacionados con } \\
\text { la ayuda para el comercio) }\end{array}$ & & & 10 & 18 \\
\hline & Resultados anuales & & & & \\
\hline & $\begin{array}{l}\text { Examen anual de los resultados } \\
\text { del MINICOM 2011/2012 }\end{array}$ & & & 4 & 123 \\
\hline & $\begin{array}{l}\text { Contrato (imihigo) del MINICOM } \\
\text { 2012/2013 }\end{array}$ & & & 3 & 59 \\
\hline & $\begin{array}{l}\text { Examen anual de los resultados } \\
\text { del MINEAC 2011/2012 }\end{array}$ & & & 9 & 52 \\
\hline & $\begin{array}{l}\text { Contrato (imihigo) del MINEAC } \\
2012 / 2013\end{array}$ & & & 5 & 62 \\
\hline & $\begin{array}{l}\text { Seminario para dirigentes } \\
\text { (-Umwiherero) }\end{array}$ & 6 & 70 & 4 & 52 \\
\hline \multirow[t]{2}{*}{ Estrategias } & $\begin{array}{l}\text { Estrategia Nacional de } \\
\text { Exportaciones }\end{array}$ & & & 10 & 56 \\
\hline & Estrategia comercial 2009-2012 & & & 30 & 113 \\
\hline $\begin{array}{l}\text { Total } \\
(1+2+3+4)\end{array}$ & & & & 90 & 546 \\
\hline
\end{tabular}

Nota: No incluye los indicadores ni las políticas de las estrategias sectoriales relativas a la infraestructura y los sectores productivos ni los exámenes de los ministerios competentes. En algunos casos, las "políticas" comprenden la ejecución de programas específicos u otras actuaciones. Fuente: Newfarmer, et al. (2013) 


\section{Responsabilidad de los donantes: los Principios de París}

Como la responsabilidad mutua también comprende las obligaciones de los donantes para con los asociados, el Gobierno ha establecido, en colaboración con los donantes, un Marco amplio para evaluar la actuación de los donantes como parte de la administración de la AOD. Esta iniciativa ha demostrado ser eficaz para incentivar a los donantes a considerar la forma de contribuir en mayor medida a la aplicación en Rwanda de los cinco principios fundamentales de la Declaración de París sobre la Eficacia de la Ayuda. El Marco de evaluación de la actuación de los donantes se divide en cinco grupos de indicadores: las estrategias financieras a nivel nacional para la consecución de los Objetivos de Desarrollo del Milenio y la "Visión 2020" de Rwanda; la utilización de sistemas nacionales para fortalecer la apropiación del programa y la rendición de cuentas; la facilitación de la planificación a largo plazo mediante una financiación del desarrollo previsible; la reducción de los costos de transacción mediante la adopción de enfoques armonizados; y el apoyo presupuestario para incrementar la previsibilidad en materia de apropiación y reducir los costos de transacción. A cada una de esas esferas corresponden entre tres y siete indicadores que resumen el objetivo. En general, entre los 14 donantes sobre los que se dispone de series de datos cronológicas se observa cierta mejora de los resultados. No obstante, globalmente los resultados siguen estando muy lejos de los objetivos que se desea alcanzar. De los 22 indicadores en las cinco esferas, los donantes sólo habían alcanzado plenamente el objetivo fijado en relación con dos de ellos ("porcentaje de cooperación técnica prestada mediante programas coordinados" y "porcentaje de misiones llevadas a cabo con el Gobierno"). Aunque alguno que otro país ha empezado también a establecer marcos de responsabilidad de los donantes, el marco rwandés es sin duda uno de los más avanzados.

\section{¿Permiten los sistemas eficaces de gestión basada en los resultados incrementar la eficacia de la ayuda para el comercio?}

Los estudios de casos indican que un sistema sólido de gestión basada en los resultados puede incrementar la eficacia de la ayuda para el comercio. En los estudios que tratan de la eficacia de la ayuda se proporcionan numerosos ejemplos convincentes de la relación general entre la "eficacia gubernamental" y una mejor utilización de la asistencia oficial para el desarrollo, pero en ellos prácticamente no se menciona la ayuda para el comercio.

Para tratar de llenar esa laguna, en la investigación llevada a cabo a los fines del presente capítulo se utilizaron técnicas econométricas para estimar la interacción entre la ayuda para el comercio y una gestión adecuada. Como ya se ha indicado, las estimaciones revelaron que existía una correlación importante y positiva entre la ayuda para el comercio y las exportaciones de los países receptores, tras controlar los efectos que podían tener las características de los países que eran asociados comerciales, el contexto en que se desenvolvía el comercio (distancia, acuerdos comerciales regionales, conflictos, etc.) y el año. A fin de comprender los efectos que podía tener una gestión adecuada, en el análisis se utilizaron los mismos modelos, pero en este caso se combinó la medida de la ayuda para el comercio con indicadores de la eficacia gubernamental. Se consideró que el mejor indicador indirecto de una gestión adecuada era el coeficiente de la "eficacia gubernamental" utilizado por el Banco Mundial (ya que se disponía de datos para la totalidad del período 1995-2011). ${ }^{22}$ Los resultados revelaron que, cuando se hacía interactuar la medida de la "eficacia gubernamental" con la ayuda para el comercio, el incremento medio de las exportaciones era considerablemente mayor. ${ }^{23}$ Lo que es aún más revelador, cuando el análisis incluía la medida de la interacción con la gestión, los efectos positivos que se observaban en las pruebas de base cuando la ayuda para el comercio se tomaba por separado se volvían marcadamente negativos, lo que es claro indicio de que la gestión es un factor de crucial importancia para la eficacia de la ayuda para el comercio. 
Además, una gestión adecuada también permitía que otras formas de asistencia para el desarrollo afectaran positivamente a las exportaciones, lo que sugiere una interpretación adicional del coeficiente negativo de las regresiones a que se hizo referencia en el párrafo precedente. Bien puede ser que, gracias a una mejor gestión de todos los tipos de asistencia para el desarrollo, se obtengan mejores resultados comerciales, mientras que sólo los países que reciben un volumen considerable de ayuda en un contexto en que la gestión es menos adecuada sufren los efectos de una reducción del comercio a través de los tipos de cambio. Esta hipótesis requiere un análisis más detenido.

\section{CONCLUSIONES}

\section{La ayuda para el comercio es eficaz ... pero requiere un entorno propicio}

En el presente capítulo se ha examinado la eficacia de la ayuda para el comercio en la promoción del comercio -tanto a nivel de las exportaciones como de las importaciones - y las condiciones que suelen requerirse para que sea más eficaz. Se han proporcionado abundantes elementos de prueba de que, en general, la ayuda para el comercio a nivel bilateral guarda relación con el aumento del comercio. El análisis presentado indica que la ayuda para el comercio prestada a los países de ingresos bajos y medianos bajos suele ser altamente rentable. Normalmente, por cada dólar invertido en ayuda para el comercio se obtiene, por término medio, un aumento de casi 8 dólares EE.UU. en las exportaciones de todos los países en desarrollo, mientras que, por cada dólar de ayuda para el comercio prestada a los países más pobres que reúnen las condiciones para recibir préstamos de la AlF se obtiene un aumento de 20 dólares EE.UU. en sus exportaciones; en el caso de todos los países de ingresos bajos y medianos bajos el aumento es de 9 dólares EE.UU.

Además, se ha demostrado abundantemente que la asignación de la ayuda para el comercio a la reducción del costo de comerciar mediante la creación de infraestructura adicional; la mejora de las instituciones (como las aduanas y las autoridades de normalización); y la aplicación de políticas y reglamentos más propicios para el comercio (a nivel de los aranceles, los obstáculos no arancelarios o medidas reglamentarias que expongan a las empresas de logística a nueva competencia) constituye un uso apropiado de dicha ayuda. Sin embargo, como la situación varía de un país a otro, en cada caso la selección de los instrumentos apropiados deberá basarse en los obstáculos y las oportunidades comerciales de cada país, y no en generalizaciones trasnacionales.

No obstante estas conclusiones generales, es evidente que la ayuda para el comercio no es un medio eficaz en todos los contextos nacionales de lograr los objetivos intermedios relacionados con el aumento del comercio y, menos aún, de promover un crecimiento rápido y reducir la pobreza. La ayuda para el comercio tiene máxima eficacia como medio de aumentar el comercio y promover un crecimiento impulsado por el comercio cuando los países receptores cuentan con un entorno propicio para las empresas, políticas macroeconómicas particularmente estables y un clima de inversión favorable para la inversión privada.

La ausencia de paz y seguridad reduce considerablemente los resultados de las exportaciones, y los conflictos pueden anular los beneficios de la inversión en ayuda para el comercio. Asimismo, es bien sabido que una inflación elevada e inestable, la corrupción, la inestabilidad de los derechos de propiedad y la imprevisibilidad de las políticas microeconómicas menoscaban la eficacia de todos los tipos de ayuda, incluida la ayuda para el comercio (OCDE, 2012b). 


\section{La ayuda para el comercio puede promover el desarrollo de las cadenas de valor regionales y mundiales}

Sólo ahora está comenzado a prestarse atención, a nivel de los profesores universitarios y los encargados de formular políticas, a la función que cumple la ayuda para el comercio en la promoción del comercio en cadenas regionales y mundiales de valor. Sin embargo, como se ha observado en el presente capítulo, hay tres hechos que indican que la ayuda para el comercio contribuye sensiblemente al desarrollo de las cadenas de valor. En primer lugar, la ayuda para el comercio prestada a las dos partes en una relación comercial bilateral tiene un efecto sinérgico, lo que es lógico, ya que si, gracias a la ayuda para el comercio, aumenta la eficiencia de los cruces fronterizos a ambos lados de una frontera, aumentarán también los intercambios comerciales entre los asociados bilaterales y con terceros países. Del mismo modo, la ayuda para el comercio destinada al desarrollo de la infraestructura (como carreteras e infraestructura de comunicaciones) incentiva el comercio bilateral. El segundo hecho que demuestra que la ayuda para el comercio promueve el desarrollo de las cadenas de valor regionales y mundiales es que el aumento de las exportaciones es aún mayor cuando el país que recibe esa clase de ayuda es parte en un acuerdo comercial regional o comparte una frontera o el idioma con sus asociados comerciales.

Por último, aún más convincentes son las observaciones directas de que la ayuda para el comercio fomenta el comercio de partes y componentes intermedios, que constituyen indicadores clave de la existencia de cadenas de valor. Mediante el análisis econométrico realizado a los fines del presente capítulo se determinó la existencia de una correlación positiva e importante entre la ayuda para el comercio y el crecimiento del comercio de partes y componentes, lo que indicaría que, aunque la proliferación gradual de cadenas de valor mundiales y regionales está modificando las modalidades del comercio mundial e incrementando las oportunidades comerciales de los países en desarrollo, los esfuerzos que se están desplegando actualmente a fin de mejorar la infraestructura, aumentar la capacidad productiva y reducir el costo de comerciar sirven para promover tanto el desarrollo de cadenas de valor como las transacciones comerciales entre partes independientes. El surgimiento de cadenas de valor mundiales no parece requerir un reajuste importante de las estrategias de ayuda para el comercio.

\section{La mejora de los sistemas de gestión dentro del país puede contribuir a aumentar la eficacia de la ayuda para el comercio}

Si las políticas son importantes, también lo son los sistemas públicos de gestión. Los gobiernos que trabajan con los donantes en el marco de programas bien formulados y con metas específicas para superar las limitaciones en la esfera de la oferta suelen ser los más beneficiados. La información proporcionada en el presente capítulo ha mostrado que cuando los sistemas públicos de gestión son eficaces la ayuda para el comercio, medida en función del aumento de las exportaciones, puede utilizarse de manera mucho más productiva. Esto demuestra la importancia que revisten la apropiación estatal, la responsabilidad mutua, y la alineación y armonización generales de la ayuda para el comercio (los consabidos Principios de París). Como ya se ha dicho en este capítulo, la capacidad para definir las necesidades, planificar, presupuestar, vigilar y evaluar la ayuda para el comercio varía de un país a otro. La asistencia que se presta a los gobiernos para ayudarlos a crear la capacidad de gestión basada en los resultados necesaria tiene importantes repercusiones positivas tanto para todas las formas de asistencia para el desarrollo como para el comercio. 


\section{Las evaluaciones de la ayuda para el comercio podrían ser más amplias}

El examen realizado indica también que hay que seguir mejorando las evaluaciones. Un primer paso en esa dirección consiste en establecer, en relación con cada proyecto, objetivos claros y medidas cuantificadas para cada etapa de la cadena de resultados. La OCDE (2013) ofrece un amplio conjunto de indicadores entre los que elegir. En segundo lugar, en las evaluaciones debe tenerse en cuenta el entorno político en sentido amplio, incluidas, en particular, las políticas comerciales, así como las políticas que en los estudios sobre el comercio se denominan "políticas complementarias". En tercer lugar, importar eficientemente es tan importante como exportar; con mucha frecuencia, las evaluaciones descuidan esta dimensión de la competitividad, como se desprende claramente de los estudios de casos presentados a la OCDE y la OMC y de la metaevaluación de los proyectos ejecutados en Ghana, en Viet Nam y en los sectores del transporte y el almacenamiento llevada a cabo por la OCDE (OCDE, 2011c). Por último, las evaluaciones del impacto, pese a circunscribirse a un conjunto más limitado de políticas y proyectos de ayuda para el comercio, podrían aportar enseñanzas importantes y deberían ser efectuadas de manera más frecuente y creativa.

\section{Ajustar las expectativas en materia de ayuda para el comercio: no siempre es posible incluir la reducción de la pobreza entre los objetivos de la ayuda}

Un corolario importante es que no es necesario (en realidad, no es posible) incluir en todos los proyectos de ayuda para el comercio las políticas complementarias indispensables para el éxito de la ayuda para el comercio. Con frecuencia, las cuestiones relacionadas con la creación de puestos de trabajo, la educación, el medio ambiente y la protección social (importantes complementos del comercio) requieren políticas independientes de las de ayuda para el comercio. Eso significa, por ejemplo, que para que un proyecto en el sector de la energía o un proyecto cuyo objeto es establecer un puesto fronterizo de ventanilla única sean considerados eficaces no es necesario que estén directamente vinculados con la reducción de la pobreza o con otros objetivos transversales de interés para la comunidad de desarrollo, como el medio ambiente, la paridad de género o la creación de capital social. Muchos proyectos de ayuda para el comercio pueden servir para reducir la pobreza, aunque no sea a través del comercio. Un proyecto agrícola puede incrementar la seguridad alimentaria y tener mínima influencia sobre las exportaciones. En otras palabras, para evaluar la ayuda para el comercio hay que examinar atentamente las políticas y los resultados de un país. 


\section{NOTAS}

1. En varios estudios se proporcionan pruebas claras de los principales vínculos. Para la relación entre un crecimiento más rápido del comercio y el aumento de la productividad y los ingresos, véase Newfarmer y Sztajerowska (2012), en que se resumen los 14 estudios econométricos más recientes. La OCDE también llega a la conclusión de que "... El aumento de las importaciones y las exportaciones impulsa el crecimiento económico, aunque las restricciones a las exportaciones son muy distintas de las que restricciones a las importaciones. Esto (significa) ... que para promover el crecimiento, reducir la pobreza e impulsar el desarrollo, la reforma del comercio (y de la ayuda para el comercio) debe apuntar no sólo a promover las exportaciones, sino también las importaciones" (OCDE, 2012b, página 2). Para el vínculo entre el aumento de los ingresos y la reducción de la pobreza, véanse Roemer y Gugerty (1997), Rodrik (2000), Dollar y Kraay (2005) y Ravallion (2007). La existencia de este vínculo ha sido corroborada también en más de una docena de estudios de países realizados en los últimos diez años.

2. OMC (2006), "Recomendaciones del Equipo de Trabajo sobre la Ayuda para el Comercio", WT/AFT/1, OMC. Ginebra, 27 de julio, página 1. La mayoría de las evaluaciones se apoyan en esta definición. Por ejemplo, la evaluación de Finlandia dice que "El objetivo de la ayuda para el comercio es contribuir a aumentar el volumen y el valor de los productos que exportan los países en desarrollo, promover su integración en el sistema multilateral de comercio y permitirles beneficiarse de un mayor acceso a los mercados (2011, página 25)."

3. Aunque conceptualmente diferente, en los estudios económicos formales se ha subsumido este elemento en el concepto de reducción del costo de comerciar (Cadot et al. 2013).

4. En el anexo a un documento de la OCDE (2011c) figura una útil reseña de los distintos métodos de evaluación.

5. Basnett et al. (2012), en una de las reseñas más completas de los estudios recientes sobre la evaluación de la ayuda para el comercio, realizan un útil examen de los métodos y las variables utilizados en los análisis agregados.

6. En este documento de trabajo, frecuentemente citado, Helble et al. (2009), utilizando una metodología diferente, estimaron que el incremento conexo era de unos 700 dólares EE.UU. En la versión publicada se redujo esa estimación.

7. Para un resumen detallado de esas evaluaciones véase Trade-Related Assistance: What do Recent Evaluations Tell Us?, OCDE, París, 2006. Entre ellas figuran las evaluaciones llevadas a cabo por la Comisión Europea (2004), la USAID (2004), el Reino Unido (2005), los Países Bajos (2005), el Banco Mundial (2004 y 2006), la Conferencia de las Naciones Unidas sobre Comercio y Desarrollo (UNCTAD) (2002), la Comisión Económica y Social de las Naciones Unidas para Asia y el Pacífico (CESPAP) (2003) y el Marco Integrado (2003).

8. Véanse, por ejemplo, los estudios de casos recogidos en OCDE (2011a). Cadot y Mattoo (2011) también han desarrollado esta cuestión.

9. Véase el caso de Rwanda descrito por Newfarmer, Savini y Vijil (2013) en la serie de estudios de la OCDE. En el estudio de diagnóstico sobre la integración comercial de Uganda llevado a cabo por el Banco Mundial se describe un problema similar (2013).

10. Banco Mundial (2007).

11. Banco Mundial (2006).

12. Según determinaron Cadot y Newfarmer (2011) sobre la base de datos de la OCDE (2011c, cuadro, página 147). 
13. Para más detalles sobre este enfoque de la economía del desarrollo, véanse Banerjee y Duflo (2011) y Karlan y Appel (2011). Para aplicaciones limitadas al comercio, véanse Cadot et al. (2011) y Cadot y Newfarmer (2011).

14. Véase también Portugal-Perez y Wilson (2009) para otro ejemplo del uso de modelos gravitacionales en este tipo de estudios.

15. Los países exportadores de petróleo no fueron incluidos entre los exportadores de la muestra. Esos países figuraban entre los 15 principales exportadores de petróleo (según el Servicio de Información sobre Energía de los Estados Unidos) o eran países cuyas exportaciones de petróleo habían superado el 75\% de sus exportaciones totales durante el período considerado. Véase el anexo F, cuadro F.3.

16. Otras variables de control incluidas en el análisis de regresión tienen un efecto constante y previsible en las corrientes de exportación bilaterales. Por ejemplo, los acuerdos comerciales regionales tienden a hacer aumentar el volumen total del comercio de mercancías entre dos países, mientras que los conflictos repercuten negativamente en las exportaciones.

17. Para el análisis se utilizó, en lugar de la clasificación actual, la clasificación de los países según su nivel de ingresos correspondiente a 1995 a fin de poder examinar los efectos de la ayuda para el comercio en las exportaciones a lo largo del tiempo (véase el anexo F).

18. Véase el anexo E, cuadro E.3.

19. Véanse, en particular, los coeficientes que figuran en los cuadros E.1 y E.2 del anexo E.

20. Esto puede verse si se comparan los coeficientes correspondientes a la ayuda para el comercio que figuran en el cuadro E.4 del anexo E con los del cuadro E.1 del mismo anexo.

21. Las responsabilidades mutuas de conformidad con los Principios de París y la Declaración de Accra se describen en el documento Declaración de París sobre la Eficacia de la Ayuda y Programa de Acción de Accra, OCDE, París, http://www.oecd.org/dac/effectiveness/34580968.pdf. Los cinco Principios de París son la apropiación, la alineación, la armonización, la gestión de los recursos basada en los resultados y la responsabilidad mutua.

22. También se ensayaron otras medidas, como una combinación de subíndices sobre el sector público y el comercio tomados de la Evaluación de las políticas e instituciones nacionales (CPIA) (2007-2009) del Banco Mundial y el Índice de eficiencia de la inversión pública del FMI (2010). Esas medidas tenían el inconveniente de abarcar sólo determinados países (en el caso del índice del FMI) o determinados años (en el caso de los datos disponibles de la CPIA).

23. Véanse los coeficientes que figuran en el cuadro E.5 del anexo E. 


\section{REFERENCIAS}

Argent, J., B. Augsburg y I. Rasul (2013), Livestock Asset Transfers With and Without Training: Evidence from Rwanda, mimeografiado, International Growth Center, Reino Unido.

Arvis, J.-F., G. Raballand y J.-F. Marteau (2010), The Cost of Being Landlocked: Logistics Costs and Supply Chain Reliability, World Bank, Washington, D.C., http://elibrary.worldbank.org/content/workingpaper/10.1596/1813-9450-4258.

Banerjee, A. y E. Duflo (2011), Poor Economics: A Radical Rethinking of Ways to Fight Global Poverty, Public Affairs, Londres.

Basnett, Y. et al. (2012), Increasing the effectiveness of Aid for Trade: the Circumstances under which it works best, ODI Working Paper No 353, agosto, Overseas Development Institute, Londres, www.odi.org.uk/publications/6771-increasing-effectiveness-aid-trade.

Bird, K. et al. (2011), Finnish Aid for Trade, Evaluation Report 2011:4, Ministerio de Relaciones Exteriores de Finlandia, www.oecd.org/derec/finland/49442624.pdf.

Bolaky, B. y C. Freund (2004), Trade, Regulations, and Growth, World Bank Policy Research Paper 3255, revisado en noviembre de 2005 para su presentación a la Conferencia sobre Comercio y Crecimiento, Departamento de Estudios, Fondo Monetario Internacional, Washington, D.C., 9 de enero de 2006.

Borchert, I. et al. (2012), Landlocked or Policy Locked? How Services Trade Protection Deepens Economic Isolation, elaborado para el taller "Aid for Trade: What have we Learnt? Which Way Ahead?", 6 de diciembre de 2012, Ginebra. Versiones de enero. Fundación para los Estudios e Investigaciones sobre Desarrollo Internacional (FERDI) y Centro de Comercio Internacional (ITC), Ginebra.

Brenton, P. y E. von Uexkull (2009), "Product specific technical assistance for exports - has it been effective?", The Journal of International Trade \& Economic Development: An International and Comparative Review, Vol. 18(2), páginas 235-254.

Cadot, O., A. M. Fernandes, J. Gourdon y A. Mattoo (2011), "Impact Evaluation of Trade Assistance: Paving the Way", en O. Cadot et al. (eds.), Where to Spend the Next Million? Applying Impact Evaluation to Trade Assistance, Centre for Economic Policy Research (CEPR), Banco Mundial, Washington, D.C.

Cadot, O., A. M. Fernandes, J. Gourdon y A. Mattoo (2012), "Are the Benefits of Export Support Durable? Evidence from Tunisia", documento preparado para el taller titulado "Aid for Trade: What have we Learnt? Which Way Ahead?", 6 de diciembre de 2012, Ginebra. Septiembre. Fundación para los Estudios e Investigaciones sobre Desarrollo Internacional (FERDI) y Centro de Comercio Internacional (CCI), Ginebra.

Cadot, O., A. M. Fernandes, J. Gourdon, A. Mattoo y J. de Melo (2013), "Evaluation in Aid for Trade: From Case-study Counting to Measuring", documento preparado para el taller titulado "Aid for Trade: What have we Learnt? Which Way Ahead?", 6 de diciembre de 2012, Ginebra. Revisado en enero de 2013. Fundación para los Estudios e Investigaciones sobre Desarrollo Internacional (FERDI) y Centro de Comercio Internacional (ITC), Ginebra.

Cadot y Mattoo (eds.) (2011), Where to Spend the Next Million?, Banco Mundial, Washington, D.C.

Cadot, O. y R. Newfarmer (2011), "Does it Work? Aid for Trade through the Evaluation Prism", Trade Negotiation Insights, Vol. 7, № 10, Centro Internacional para el Comercio y el Desarrollo Sostenible (ICTSD), Ginebra.

Cali, M. y D.W. te Velde (2010), "Does Aid for Trade Really Improve Trade Performance?", World Development, Vol. 39(5), páginas 725-740.

Carrère, C. (2006), "Revisiting the effects of regional trade agreements on trade flows with proper specification of the gravity model", European Economic Review, Vol. 50(2), páginas 223-247. 
Cattaneo, O. (2013), Managing Aid to Achieve Development Results: An Analysis of Trade-related Targets, OECD COM/DCD/ TAD(2012)12, OCDE, París, www.oecd.org/dac/aft/Managing_Aid_To_Achieve_Trade_Dev_Results.pdf.

Cattaneo O. y S. Miroudot (2013, se publicará próximamente), "From Global Value Chains to Global Development Chains", en B. Hoekman y E. Zedillo (eds.), 21st Century Trade Policy: Back to the Past, Yale University Press, New Haven.

Djankov, S. et al. (2010), "Trading on Time", The Review of Economics and Statistics, 92(1), páginas 166-173.

Dollar, D. y A. Kraay (2005), "Trade, Growth and Poverty", The Economic Journal, Vol. 114(493), F22-F49.

Estevadeordal, A. y A. M. Taylor (2009), "Is the Washington Consensus Dead?: Growth, Openness, and the Great Liberalization, 1970s-2000s", IDB Publications, № 9298, Banco Interamericano de Desarrollo.

Ferro, E., A. Portugal-Perez y J. Wilson (2012), "Aid to the Services Sector: Does it Affect Manufacturing Exports", documento preparado para el taller "Aid for Trade: What Have we Learnt? Which way Ahead?", 6 de diciembre de 2012, Ginebra. Fundación para los Estudios e Investigaciones sobre Desarrollo Internacional (FERDI) y Centro de Comercio Internacional (ITC), Ginebra.

Folleti, L. y R. Newfarmer (2011), Aid for Trade 2011: Results Emerging from the Case Stories. OCDE y OMC, París y Ginebra, www.wto.org/english/tratop_e/devel_ela4t_e/results_emerging_case_sories_e.pdf.

Gereffi, G., J. Humphrey y T. Sturgeon (2005), "The Governance of Global Value Chains", Review of International Political Economy, Vol. 12(1), páginas 78-104.

Goppers, K. y C. Lindahl (2009), SIDA's Trade-Related Assistance: Results and Management, Sida Evaluation 2009:01, Agencia Sueca de Cooperación Internacional para el Desarrollo (Sida), Departamento de Evaluación, http://www.sida.se/Global/About\%20Sida/S por cientoC3 por cientoA5\%20arbetar\%20vi/SE-2009-01_SIDA52035en_ web.pdf.

Hallaert, J.-J., R. Cavazos Cepeda y G. Kang (2011), Estimating the Constraints to Trade of Developing Countries, OECD Trade Policy Papers No 116, OCDE, París, http://dx.doi.org/10.1787/5kg9mq8mx9tc-en.

Helble, M., C. Mann y J. Wilson (2009), Aid for Trade Facilitation, Policy Research Working Paper 5064, Banco Mundial, Washington, D.C.

Helble, M., C. Mann y J. Wilson (2012), "Aid for Trade Facilitation", Review of World Economics, Vol. 148, número 2, páginas 357-376.

Hoekman, B. (2012), Global Supply Chains, Logistics Services and International Cooperation, mimeografiado, 4 de mayo, http://www.wto.org/english/forums_e/public_forum12_e/art_pf12_e/art5.htm.

Hoekman, B. y J.S. Wilson (2010), "Aid for Trade: Building on Progress Today for Tomorrow's Future", en S. Fardoust, Y. Kim y C. Sepulveda (eds.), Post-Crisis Growth and Development: A Development Agenda for the G-20, Banco Mundial, Washington, D.C.

Hoekman, B. y M. Olarreaga (eds.) (2005), Global Trade and Poor Nations: The Poverty Impacts and Policy Implications of Liberalisation, Brookings Institution, Washington, D.C.

Hummels, D. (2001), Time as a Trade Barrier, Time as a Trade Barrier GTAP Working Paper No 18, mimeografiado, Purdue University.

Hummels, D. y G. Schaur (2012), Time as a Barrier to Trade, Working Paper 17758, National Bureau of Economic Research, Cambridge, www.nber.org/papers/w17758.pdf?new_window=1.

ICTSD (Centro Internacional para el Comercio y el Desarrollo Sostenible) (2011), Aid for Trade on the Ground: Early Findings from the Country Case Studies, Nota informativa No 20, julio, ICTSD, Ginebra. 
ICTSD (2012), Aid for Trade and the Least Developed Countries: Recent Trends and Impacts on the Ground: Early Findings from the Country Case Studies, Nota informativa, octubre, ICTSD, Ginebra.

Jaud, M. y O. Cadot (2011), A Second Look at the Pesticides Initiative Program: Evidence from Senegal, World Bank Policy Research Working Paper 5635, Banco Mundial, Washington, D.C.

International Rivers (2012), Infrastructure for Whom? A Critique of the Infrastructure Strategies of the Group of 20 and the World Bank.

Karlan, D. y J. Appel (2011), More than Good Intentions: How a New Economics is Helping to Solve Global Poverty, Dutton Adult Publishing.

Kimura, F., Y. Takahashi y K. Hayakawa (2007), "Fragmentation and parts and components trade: Comparison between East Asia and Europe", The North American Journal of Economics and Finance, Vol. 18(1), páginas 23-40.

Kosack, S. (2008), Trade for Poverty Reduction: The Role of Trade Policy in Poverty Reduction Strategy Papers, mimeografiado, Documento de trabajo, Programa de las Naciones Unidas para el Desarrollo, Nueva York.

Limão, N. y A.J. Venables (2001), "Infrastructure, Geographical Disadvantage, Transport Costs, and Trade", World Bank Economic Review, Vol. 15(3), páginas 45-79.

Miroudot, S., R. Lanz y A. Ragoussis (2009), Trade in Intermediate Goods and Services, OECD Trade Policy Working Papers No 93, París, OCDE, www.oecd.org/std/its/44056524.pdf.

Mizuho Information and Research Institute, Inc. (2012), Evaluation of Aid for Trade - Summary, Third Party Evaluation Report, 2011, febrero, Ministerio de Relaciones Exteriores del Japón.

Moïsé, E. y F. Le Bris (2013), Trade Costs: What Have We Learned? A Synthesis Report, OECD Trade Policy Papers No 150, OCDE, París, http://dx.doi.org/10.1787/5k47x2hifn48-en.

Moïsé, E. y S. Sorescu (2013), Trade Facilitation Indicators: The Potential Impact of Trade Facilitation on Developing Countries' Trade, OECD Trade Policy Papers No 144, OCDE, París, http://dx.doi.org/10.1787/5k4bw6kg6ws2-en.

Moïsé, E. et al. (2013), Estimating the Constraints to Agricultural Trade of Developing Countries, OECD Trade Policy Papers No 142, OCDE, París, http://dx.doi.org/10.1787/5k4c9kwfdx8r-en.

Newfarmer, R. y M. Sztajerowska (2012), "Trade and Employment in a Fast Changing World" en D. Lippolt (ed.), Policy Priorities in International Trade and Jobs, OCDE, París.

Newfarmer, R., M. Savini y M. Vigil (2013), Managing Aid for Trade and Development Results: Rwanda Case Study, OCDE, París, www.oecd.org/dac/aft/RwandaCaseStudyFinal.pdf.

OCDE (2011a)/OMC (2011), La ayuda para el comercio en síntesis: Mostrar resultados, OCDE, París, http://dx.doi.org/10.1787/9789264117471-es.

OCDE (2011b), Trade for Growth and Poverty Reduction: How Aid for Trade Can Help, OCDE, París, http://dx.doi.org/10.1787/9789264098978-en.

OCDE (2011c), Strengthening Accountability in Aid for Trade, OCDE, París, http://dx.doi.org/10.1787/9789264123212-en.

OCDE (2012a), Succeeding with Trade Reforms: the Role of Aid for Trade - Synthesis, COM/DCD/TAD/RD(2012)2/RD2, septiembre, OCDE, París.

OCDE (2012b), Succeeding with Trade Reforms: the Role of Aid for Trade, OCDE, París, http://dx.doi.org/10.1787/9789264201200-en. 
OCDE (2013a), Aid for trade and development results: A management framework, OCDE, París, http://dx.doi.org/10.1787/9789264112537-en.

OCDE (2013b), Interconnected Economies: Benefiting from Global Value, OCDE, París, http://dx.doi.org/10.1787/9789264189560-en.

Portugal-Perez, A. y J. S. Wilson (2009), "Why trade facilitation matters to Africa”, World Trade Review, Vol. 8(3), páginas 379-416.

Raballand, G., P. Machchi y C. Petracco (2010), Rural Road Investment Efficiency: Lessons from Burkina Faso, Cameroon and Uganda, Banco Mundial, Washington, D.C., https://openknowledge.worldbank.org/handle/10986/2425.

Ravallion, M. (2007), Economic Growth and Poverty Reduction: Do Poor Countries Need to Worry about Inequality? IFPRI Conference Focus Brief, octubre, Instituto Internacional de Investigación sobre Políticas Alimentarias (IFPRI), Washington, D.C., www.ifpri.org/sites/default/files/publications/oc63ch11.pdf.

Rodrik, D. (2000), "Growth Versus Poverty Reduction: A Hollow Debate", Finance and Development, Vol. $37,4$.

Roemer, M. y M.K. Gugerty (1997), Does Economic Growth Reduce Poverty?, Technical Paper, marzo, Harvard Institute for International Development, Harvard University, Cambridge, http://pdf.usaid.gov/pdf_docs/PNACA656.pdf.

Turner, L. y L. Rovamaa (2012), Aid for Trade; Reviewing EC and DFID Monitoring and Evaluation Practices, Saana Consulting, Traidcraft and Catholic Agency for Overseas Development (CAFOD), Londres, www.traidcraft.co.uk/Resources/Traidcraft/Documents/PDF/tx/Aid\%20for\%20Trade\%20Report\%202012.pdf.pdf.

Teravaninthorn, S. y G. Raballand (2008), Transport Prices and Costs in Africa, Banco Mundial, Washington, D.C., https://openknowledge.worldbank.org/handle/10986/6610.

USAID (Agencia de los Estados Unidos para el Desarrollo Internacional) (2010), From Aid to Trade: Delivering Results: A Cross Country Evaluation of USAID Trade Capacity Building, USAID, Washington, D.C., http://pdf.usaid.gov/pdf_docs/PDACR202.pdf.

Versailles, B. (2012), Rwanda: budgeting and planning processes, Overseas Development Institute (ODI) Budget Strengthening Initiative, Country Learning Notes, abril, Overseas Development Institute.

Vijil, M. (2012), "Aid for Trade Effectiveness: Complementarities with Economic Integration", documento preparado para el taller "Aid for Trade: What have we Learnt? Which Way Ahead?", 6 de diciembre de 2012, Ginebra. Revisado en enero de 2013. Fundación para los Estudios e Investigaciones sobre Desarrollo Internacional (FERDI) y Centro de Comercio Internacional (ITC), Ginebra.

Vijil, M. y L. Wagner (2012), "Does Aid for Trade Enhance Export Performance Investigating the Infrastructure Channel", The World Economy, Vol. 35(7), páginas 838-868.

Volpe Martincus, C. y J. Carballo (2008), "Is export promotion effective in developing countries? Firm-level evidence on the intensive and the extensive margins of exports", Journal of International Economics, Vol. 76(1), páginas 89-106.

Winters, A.L. (2004), "Trade Liberalization and Economic Performance", The Economic Journal, Vol. 114, F4-F21.

Winters, A.L., N. McCulloch y A. McKay (2004), "Trade Liberalization and Poverty: The Evidence so Far", Journal of Economic Literature, Vol. 42(1), páginas 72-115.

Banco Mundial (2006), Transport, Grupo de Evaluación Independiente, Banco Mundial, Washington, D.C.

Banco Mundial (2007), Agriculture in Africa, Grupo de Evaluación Independiente, Banco Mundial, Washington, D.C.

Banco Mundial (2001), Leveraging Trade for Development: The World Bank Group's Agenda, informe preparado por funcionarios del Banco Mundial para los Directores Ejecutivos, septiembre, Banco Mundial, Washington, D.C. 
Banco Mundial (2006), Assessing World Bank Support for Trade, 1987-2004, Grupo de Evaluación Independiente, Banco Mundial, Washington, D.C.

Banco Mundial (2009), Unlocking Global Opportunities: The Aid for Trade Program of the World Bank Group, Banco Mundial, Washington, D.C., http://siteresources.worldbank.org/INTPREMNET/Resources/UnlockingGlobalOpp.pdf.

Banco Mundial (2013), Uganda: Diagnostic Trade Integration Study Up-date, borrador (diciembre), Banco Mundial, Washington, D.C.

WEF (Foro Económico Mundial) (2013), Enabling Trade Valuing Growth Opportunities (en colaboración con Bain \& Company y el Banco Mundial), WEF, Ginebra, www.weforum.org/reports/enabling-trade-valuing-growth-opportunities.

OMC (Organización Mundial del Comercio) (2006), Recomendaciones del Equipo de Trabajo sobre la Ayuda para el Comercio, WT/AfT/1, 27 de julio, OMC, Ginebra, http://aric.adb.org/aid-for-trade-asia/pdf/WT\%20AFT\%201.pdf. 


\section{CAPÍTULO 6: EL CAMINO A SEGUIR}

\section{INTRODUCCIÓN}

Mucho se ha logrado desde que se puso en marcha la Iniciativa de Ayuda para el Comercio en 2005. Los anteriores exámenes globales de la ayuda para el comercio y ediciones de La Ayuda para el Comercio en síntesis han demostrado claramente que, merced a la ayuda para el comercio, ha mejorado la vida de muchos hombres y mujeres de países en desarrollo. La amplia labor de vigilancia de la Iniciativa ha mostrado claramente que la Iniciativa ha servido para dar prioridad al comercio en las estrategias de desarrollo y ha movilizado el apoyo de los donantes para superar los obstáculos que menoscaban la capacidad de los productores de los países en desarrollo para aprovechar las oportunidades de acceso a los mercados regionales y mundiales. La ayuda para el comercio está ayudando a los países en desarrollo a aprovechar el poder del mercado y a establecer vínculos con nuevos polos de crecimiento de la economía mundial. Los relatos de experiencias relacionadas con la ayuda para el comercio (OCDE/OMC, 2013) también trazan un cuadro alentador de los numerosos proyectos y programas en la esfera del comercio que reciben apoyo de los donantes y que están generando una amplia gama de resultados tangibles a nivel de los resultados comerciales, la inversión privada y la creación de empleo en muchos países en desarrollo. La labor conjunta de vigilancia llevada a cabo por la OCDE y la OMC (2013) y descrita en la presente publicación muestra que esas tendencias positivas continúan.

Sin embargo, desde que en 2005 la Conferencia Ministerial de la OMC celebrada en Hong Kong acordó el mandato relativo a la ayuda para el comercio (que fue luego definido por el Equipo de Trabajo de la OMC en 2006), el entorno del comercio y el desarrollo ha evolucionado considerablemente. Los estudios del comercio en términos de valor añadido realizados por la OCDE y la OMC han echado luz sobre las complejas redes de producción que caracterizan al comercio mundial de hoy. La mayor profundidad y extensión de las cadenas de valor ha hecho aumentar la proporción correspondiente a los bienes y servicios intermedios en el comercio, a medida que un creciente número de empresas y países se suman a esas redes difusas. La fragmentación de la producción ha creado nuevas oportunidades para la integración en el comercio regional y mundial.

En el ámbito de la cooperación para el desarrollo, la Alianza Global para la Cooperación Eficaz al Desarrollo de 2012 proporciona un marco nuevo y amplio para coordinar los esfuerzos de diversos donantes con el objeto de ayudar a los países en desarrollo a aprovechar las diferentes formas de financiación para el desarrollo y velar por que todos esos esfuerzos tengan un efecto catalizador en el comercio y el desarrollo.

En el presente capítulo se resumen los principales cambios ocurridos en la esfera de la ayuda para el comercio desde el Examen Global de 2011. Sobre la base de los resultados de la labor de vigilancia realizada por la OCDE y la OMC, el análisis de las corrientes de ayuda para el comercio y las conclusiones de estudios sobre comercio y desarrollo de carácter más general, cabe concluir 
que, frente a la proliferación y profundización de las cadenas de valor y el aumento concomitante de las oportunidades comerciales de los países en desarrollo, no se requiere una reorientación importante de la ayuda para el comercio. Sin embargo, sí es posible mejorar la prestación de la ayuda, por ejemplo, dando mayor participación a los proveedores de cooperación Sur-Sur relacionada con el comercio y al sector privado; ampliando el alcance de la definición para abarcar, además de la AOD, la financiación del desarrollo; mejorando las condiciones para la ejecución de los proyectos regionales; y mejorando la gestión de la ayuda para el comercio mediante la aplicación de la gestión basada en los resultados. Para que la Iniciativa siga siendo pertinente en el cambiante contexto del comercio y el desarrollo, es necesario que la Novena Conferencia Ministerial de la OMC, que se celebrará en Bali (Indonesia) en diciembre de 2013, examine esas cuestiones.

\section{RESUMEN}

En 2013, 80 países asociados (entre los que figuraban 36 PMA) llevaron a cabo sendas autoevaluaciones de la ayuda para el comercio. En 2011 el valor de los compromisos por concepto de ayuda para el comercio para esos países fue de 22.800 millones de dólares EE.UU., o sea el 67\% del total de la ayuda para el comercio programable por países (excluidos los programas multinacionales). En 2013, 43 donantes bilaterales y multilaterales presentaron sus autoevaluaciones de la ayuda para el comercio. En conjunto, a esos organismos correspondió prácticamente la totalidad de los compromisos de ayuda para el comercio. Además, en la labor de vigilancia llevada a cabo en 2013 por la OCDE y la OMC participaron nueve proveedores de cooperación Sur-Sur relacionada con el comercio (incluidas China y la India).

Una nueva característica de la labor de vigilancia de 2013 consistió en pedir al sector privado que diera su parecer sobre la forma en que la ayuda para el comercio podía ayudar a conectarse a las cadenas de valor. Lo novedoso no fue únicamente que se pidiera al sector privado que diera sus opiniones, sino que, además, se establecieran asociaciones con Grow Africa, la Cámara Internacional de Comercio (ICC), el Centro de Comercio Internacional (ITC), la Unión Internacional de Telecomunicaciones (UIT) y la Organización Mundial del Turismo (OMT) para la puesta en práctica. En las 524 respuestas presentadas por empresas y asociaciones de empresas de países en desarrollo se expresan opiniones categóricas sobre las limitaciones fundamentales a las que se hace frente para conectarse a las cadenas de valor, ascender en ellas y establecerlas, mientras que en las 173 respuestas de empresas líderes se señalan los obstáculos con que tropiezan para establecer relaciones con empresas de países en desarrollo. En las 697 respuestas del sector privado se indican las esferas en que las asociaciones entre el sector público y el sector privado tienen mayores posibilidades de alcanzar los objetivos de la Iniciativa de Ayuda para el Comercio.

\section{Prioridades}

La ayuda para el comercio está evolucionando en respuesta a los cambios en el contexto del comercio y el desarrollo. Los países asociados, incluidos los menos desarrollados, están haciendo creciente hincapié en políticas encaminadas a reducir la densidad de sus fronteras, mejorar el entorno necesario para un crecimiento económico impulsado por el sector privado y crear condiciones que ayuden a sus empresas a conectarse a las cadenas de valor regionales y mundiales. Por su parte, los donantes bilaterales están teniendo en cuenta esta evolución de las prioridades. También están asignando mayor importancia a programas destinados a promover el desarrollo del sector privado, en particular mediante la corrección de las deficiencias del mercado (como las asimetrías de información y la financiación del comercio) y la prestación de ayuda a las PYME para que puedan exportar más, sobre todo a nivel del margen intensivo. A su vez, los donantes multilaterales están concentrando la atención en la mejora de la infraestructura 
relacionada con el comercio, mientras que los proveedores de cooperación Sur-Sur siguen incrementando la ayuda destinada a fomentar el comercio Sur -Sur. Muchos donantes han indicado que en sus estrategias y en el diseño de los programas otorgan prioridad al desarrollo de las cadenas de valor, pero otros siguen teniendo dificultades para integrar ese concepto en sus programas.

Entre los desafíos por superar cabe mencionar las dificultades con que se tropieza para promover el desarrollo del sector privado y modernizar la infraestructura física y no física mediante instrumentos como las asociaciones entre el sector público y el sector privado. Pese a haberse logrado notables mejoras, muchos proyectos tropiezan con dificultades debido a las diferentes expectativas acerca de la función de cada uno y la distribución de los gastos y los beneficios. En relación con la participación del sector privado, los donantes deberían adoptar una actitud abierta y estar dispuestos a aplicar nuevas soluciones. En particular, el sector público debería estar preparado para prestar apoyo a las iniciativas del sector privado. Todas las partes interesadas siguen participando plenamente en la Iniciativa de la Ayuda para el Comercio, y, al parecer, las oportunidades que ofrece el surgimiento de las cadenas de valor han reactivado el debate. La prestación de ayuda para el comercio no parece ser una consideración decisiva en la formulación de las estrategias y las políticas de los países asociados, los donantes ni los proveedores de cooperación Sur-Sur relacionada con el comercio, pero, como resultado de la presión a que están sometidos los presupuestos, urge más que nunca mostrar que se obtienen resultados. Esto se ha convertido en una prioridad.

\section{La inversión en capacidad comercial}

En el Consenso de Monterrey se hace hincapié en que el comercio es en muchos casos la fuente externa más importante de financiación para el desarrollo. La expansión del comercio y la inversión extranjera directa, combinada con políticas complementarias, podría estimular el crecimiento económico y ser una importante fuente de empleo. Aunque en muchos países en desarrollo la inversión extranjera y nacional es la principal fuente de financiación de la creación de capacidad comercial y la conexión a las cadenas de valor, la AOD desempeña un papel esencial como complemento de otras fuentes de financiación para el desarrollo, sobre todo para los países menos adelantados.

Después de varios años de aumento del volumen de las corrientes de ayuda para el comercio, los donantes que son miembros de la OCDE han recortado sus presupuestos de ayuda como resultado de la crisis financiera y los ulteriores problemas económicos y presupuestarios a los que han tenido que hacer frente. El volumen de la ayuda para el comercio también se ha visto afectado por esta situación. En 2011, la cuantía de los compromisos ascendió a 41.500 millones de dólares EE.UU. (o sea un incremento del 57\% en comparación con la media correspondiente al período de referencia (2002-2005), pero una disminución del 14\% respecto del nivel alcanzado en 2010). Sin embargo, en 2011 la ayuda destinada al sector privado aumentó en 171 millones de dólares de EE.UU. y alcanzó la suma de 18.230 millones de dólares EE.UU. (o sea, un incremento del 58\% respecto del nivel correspondiente al período de referencia), lo que refleja la creciente importancia que los países asociados y los donantes asignan al desarrollo de ese sector. Además, la cuantía destinada al objetivo de desarrollo del comercio de esos programas se duplicó con creces: de 2.600 millones de dólares EE.UU. en 2007 a 5.400 millones de dólares EE.UU. en 2011. El apoyo prestado a los programas multinacionales, que suelen tener una mayor repercusión que los programas nacionales, alcanzó un máximo histórico de 7.700 millones de dólares EE.UU.

Aunque los recursos destinados a la ayuda para el comercio han aumentado considerablemente en los últimos cinco años, las perspectivas para los próximos años son menos halagüeñas, sobre todo a nivel de los donantes bilaterales. Según los datos provisionales sobre la AOD correspondientes a 2012, se prevé una disminución global del $4 \%$ en valores reales en el nivel de la AOD, por lo que es probable que el volumen de la ayuda para el comercio vuelva a disminuir. Según la encuesta llevada a cabo por el Comité de Asistencia para el Desarrollo de la OCDE en 
relación con los planes de gastos futuros de los donantes y la labor de vigilancia que realizan la OCDE y la OMC, cabe prever una recuperación moderada del nivel de la ayuda en 2013. Los donantes multilaterales han informado de que van a mantener el nivel de sus gastos. Un motivo de optimismo es que los proveedores de cooperación Sur-Sur relacionada con el comercio han indicado que seguirán aumentando los recursos en los próximos cinco años. Como las perspectivas de una recuperación del crecimiento económico en los países miembros de la OCDE son, en el mejor de los casos, bajas, la asistencia que puedan prestar los asociados Sur-Sur para facilitar la conexión con los polos de crecimiento de la economía mundial puede ser particularmente valiosa.

\section{Las cadenas de valor como senda del desarrollo}

La fragmentación internacional de la producción en cadenas de valor (impulsada por el progreso tecnológico, la reducción de los costos, el acceso a los recursos y mercados, y la reforma de la política comercial) tiene importantes consecuencias de política para el crecimiento económico de los países en desarrollo. Las cadenas de valor pueden crear las condiciones necesarias para que los países logren industrializarse en una etapa mucho más temprana del proceso de desarrollo. La participación en cadenas de valor puede también encerrar importantes oportunidades al alentar a los proveedores a respetar normas y reglamentos a fin de acceder a los mercados de exportación; permitir la utilización de tecnología de redes que de otra manera sería inaccesible; y proporcionar acceso a nuevas fuentes de capital. Sin embargo, las cadenas de valor también hacen aumentar el costo de los procedimientos fronterizos ineficientes, los aranceles elevados y los obstáculos no arancelarios que limitan innecesariamente el comercio de mercancías o servicios, las restricciones a la libre circulación de información, los obstáculos a la inversión extranjera directa y las restricciones a la libre circulación de las personas.

Las respuestas al cuestionario de la OCDEy la OMC indican que las cadenas de valor efectivamente están ejerciendo creciente influencia en las estrategias de desarrollo de los países asociados y en los programas de los donantes. Los objetivos principales que persiguen los gobiernos de los países en desarrollo al conectarse a las cadenas de valor son añadir valor a sus exportaciones, aumentar el empleo y reducir la pobreza. Los principales obstáculos a los que se enfrentan para alcanzar esos objetivos son la falta de acceso a la financiación necesaria (en particular, a la financiación del comercio), el costo del transporte y de la expedición, una infraestructura deficiente, la incertidumbre en materia de reglamentación (a menudo relacionada con un entorno empresarial complejo) y la falta de cualificaciones de la fuerza de trabajo. Los donantes y los asociados Sur-Sur también señalan entre los obstáculos la falta de capacidad para atraer IED, así como la falta de ventaja comparativa. Para las empresas líderes, los procedimientos aduaneros figuran entre los principales obstáculos, así como la incertidumbre en materia de reglamentación (que se refleja en los problemas a que deben hacer frente los proveedores de los países en desarrollo en el complejo entorno en que operan las empresas) y la conformidad con las normas. También han mencionado las prácticas y las solicitudes de pago informales entre los factores que eran objeto de especial preocupación por su repercusión negativa en las decisiones de inversión.

De las opiniones de los gobiernos, los donantes y el sector privado se desprende claramente que hay acuerdo sobre los problemas que hay que resolver para que, mediante la ayuda para el comercio, los países en desarrollo puedan conectarse a las cadenas de valor. Las prioridades que puso de manifiesto la encuesta realizada por la OCDE y la OMC también podrían servir de base para establecer una cooperación más estrecha y sinergias entre los sectores público y privado en relación con la identificación de proyectos de ayuda para el comercio, la financiación de su ejecución, la mejora de la labor de vigilancia y evaluación del impacto y, en definitiva, el aumento de su eficacia. Esta clase de enfoque cooperativo concordaría con los principios consagrados en la Alianza de Busán de Cooperación Eficaz para el Desarrollo. 


\section{El potencial de los enfoques regionales}

Las redes regionales de producción promueven el comercio y generan la demanda de medidas de fomento del comercio encaminadas a incrementar la eficiencia mediante, por ejemplo, la facilitación del comercio y una mejor infraestructura física y no física. La participación en redes regionales puede dar a los productos locales acceso a mercados externos establecidos. Además, a medida que la economía se va abriendo a los mercados regionales y mundiales, dicha participación ayuda a las empresas locales a "aprender haciendo". La cooperación regional ofrece oportunidades especialmente importantes a los países pequeños de ingresos bajos, que en otra época en general no tenían acceso a los beneficios que reporta la relación entre la IED y el comercio. Por lo tanto, la cooperación regional puede servir para facilitar los vínculos con las cadenas de valor y una mayor integración en mercados regionales y mundiales más grandes.

Para tener acceso a los beneficios de la integración y la cooperación regionales, las economías en desarrollo deben eliminar diversas restricciones y deficiencias del mercado. La ayuda para el comercio a nivel multinacional y regional puede desempeñar un papel importante en este ámbito. Los donantes han apoyado la cooperación regional mediante programas de ayuda para el comercio encaminados a eliminar las limitaciones fundamentales a la integración regional. Los programas, desarrollados en estrecha cooperación con los asociados, han sido fundamentalmente de alcance subregional. Las evaluaciones de esos programas han puesto de manifiesto su eficacia para impulsar el crecimiento, reducir la pobreza y diversificar la economía. La ayuda para el comercio a nivel regional puede ser una estrategia eficaz en función del costo para apoyar la integración y la cooperación regionales. Se trata de una esfera clave en que los países donantes y los países receptores de la ayuda obtienen máximo beneficio de la inversión.

\section{Resultados tangibles}

Cada vez se advierte con mayor claridad que existe una correlación positiva entre la ayuda para el comercio y la expansión del comercio. En el caso del comercio entre dos países, los estudios econométricos y los análisis estadísticos de la presente publicación indican que existe un vínculo entre la ayuda para el comercio y el aumento de las exportaciones y las importaciones. La ayuda para el comercio destinada a la infraestructura ha contribuido a crear nuevas conexiones con los mercados regionales y mundiales mediante la financiación de inversiones en carreteras, puertos y telecomunicaciones. Del mismo modo, la ayuda para el comercio destinada a la creación de capacidad productiva (por ejemplo, para desarrollar el turismo, la agricultura o zonas económicas especiales) está ayudando a incrementar los intercambios comerciales.

La ayuda para el comercio reporta mayores beneficios cuando se orienta a reducir el costo del comercio mediante la mejora de la infraestructura, la facilitación del comercio, las instituciones públicas relacionadas con el comercio (como las aduanas, los organismos de normalización y la promoción de las exportaciones) y las políticas (incluidas las encaminadas a eliminar los obstáculos a la competencia a través de las políticas). Además, para que la ayuda para el comercio permita obtener mejores resultados comerciales y promover un crecimiento impulsado por el comercio, los países receptores deben ofrecer un entorno propicio para las empresas, políticas macroeconómicas estables y condiciones favorables para la inversión privada. La ausencia de paz y seguridad frena considerablemente las exportaciones y puede anular todos los beneficios de la inversión en ayuda para el comercio. Del mismo modo, los efectos negativos de una inflación elevada e inestable, la corrupción, la falta de derechos de propiedad bien definidos o políticas microeconómicas imprevisibles menoscaban la eficacia de todos los tipos de ayuda, incluida la ayuda para el comercio. 
Si las políticas son importantes, no lo son menos los sistemas públicos de gestión. Los gobiernos que colaboran con los donantes en el marco de programas bien diseñados, con objetivos específicos para atender a las limitaciones en la esfera de la oferta tienen más probabilidades de obtener mayores beneficios. Ello requiere la apropiación a nivel del gobierno, la responsabilidad mutua, la alineación y la armonización generales, así como la gestión basada en los resultados (es decir, la adhesión a los Principios de París sobre la Eficacia de la Ayuda). Un primer paso hacia esa clase de cooperación consiste en incorporar a cada proyecto objetivos cuantitativos claros para cada una de las etapas de la cadena de resultados, así como indicadores para medir el progreso. La asistencia prestada a los gobiernos para ayudarlos a crear ese tipo de capacidad de gestión basada en los resultados reporta grandes beneficios para todas las formas de asistencia para el desarrollo, incluida la ayuda para el comercio.

\section{EL CAMINO A SEGUIR}

La Iniciativa de la Ayuda para el Comercio ha servido para que se tome conciencia de las posibilidades que ofrece el comercio para el desarrollo, así como para incorporar el comercio en las políticas y la planificación de los países asociados y los organismos donantes, movilizar recursos y obtener resultados. Asimismo ha resultado ser suficientemente flexible como para tener en cuenta las nuevas dimensiones del comercio y el desarrollo.

Inicialmente, esa labor de vigilancia bienal tenía por objeto focalizar la atención en la ayuda para el comercio (es decir, dar a conocer mejor la función del comercio como motor del crecimiento y del desarrollo económico, medir las corrientes de ayuda para el comercio a fin de evaluar su adicionalidad y sostenibilidad, y crear incentivos para incrementar y mejorar la ayuda para el comercio). Posteriormente el proceso de vigilancia pasó a abarcar también el examen de la aplicación, la eficacia y los resultados y ha llevado al establecimiento de una comunidad que intercambia conocimientos sobre las mejores prácticas de ayuda para el comercio. Como resultado de la evolución del marco de vigilancia, ha aumentado el número de asociados que intervienen en la Iniciativa, que cuenta con una importante participación de la comunidad de donantes, los países asociados y proveedores de cooperación Sur-Sur relacionada con el comercio, y (como se ha indicado en la presente publicación), el sector privado.

A nivel mundial, un programa amplio de ayuda para el comercio encuentra su justificación en la necesidad de superar las diversas limitaciones fundamentales a que se enfrentan los países en desarrollo para incrementar la capacidad comercial. A nivel de los países, el diálogo sobre la ayuda para el comercio debe centrarse en un menor número de prioridades que reflejen las condiciones locales y las limitaciones de cada país. Además, como se ha indicado en la presente publicación, los sectores público y privado de los países en desarrollo están a favor de una concepción amplia de la ayuda para el comercio, que incluya la inversión (nacional y extranjera) y dé prioridad a la competitividad, la infraestructura relacionada con el comercio, el acceso a la financiación y la capacitación.

\section{¿Hay que modificar el marco de vigilancia?}

La labor de vigilancia de la ayuda para el comercio se basa en autoevaluaciones, que se llevan a cabo a través de cuestionarios. Este enfoque pone a disposición de todas las partes interesadas un cauce para comunicar sus opiniones sobre el proceso. Además, las autoevaluaciones han generado un cúmulo de información de inestimable valor, que permite sacar conclusiones sobre las "mejores prácticas" en materia de políticas, programas y procedimientos de ayuda para el comercio. Eso no significa que esas conclusiones deban ser aceptadas ciegamente ni que deba prescindirse de un análisis sistemático más riguroso. Por el contrario, uno de los puntos fuertes de la Iniciativa ha sido su flexibilidad, que ha permitido incorporar nuevas ideas y los resultados de las evaluaciones, los estudios del 
impacto y las conclusiones de investigaciones llevadas a cabo por organismos internacionales, grupos de estudio y universidades. La labor de vigilancia mundial que se lleva a cabo a través de la Iniciativa contribuye a orientar esos otros enfoques. A medida que el programa ha ido evolucionando, la Iniciativa ha fomentado una amplia gama de iniciativas y actividades a nivel regional y nacional. De no haberse contado con la dimensión mundial de la Iniciativa, es probable que esas otras iniciativas sólo hubieran despertado un interés limitado.

Se ha expresado preocupación acerca de la desconexión entre el diálogo mundial sobre la ayuda para el comercio, que tiene lugar en Ginebra y en las capitales de los países donantes, por una parte, y, por otra, la colaboración entre donantes y gobiernos a los efectos de la gestión de la ayuda para el comercio que tiene lugar en cada país. Como el Equipo de Trabajo sobre la Ayuda para el Comercio de la OMC recomendó en 2006 que se aplicara una definición amplia para medir la ayuda para el comercio a nivel mundial, se han incluido ciertas actividades a pesar de que varios ministerios y departamentos competentes de los donantes han indicado que no se consideran proveedores de ayuda para el comercio. Una posible forma de atender a ese problema consiste en distinguir más claramente entre el concepto amplio aplicado para cuantificar la Ayuda para el Comercio -que es útil para la vigilancia a escala mundial-y un conjunto más reducido de actividades directamente relacionadas con la expansión del comercio, como los proyectos de reforma de puestos fronterizos, aduanas, organismos de normalización, aranceles y obstáculos no arancelarios, entre otros. Una definición más limitada se ajustaría en mayor medida a la definición de la ayuda para el comercio como los "proyectos y programas ... [identificados] como prioridades para el desarrollo relacionado con el comercio en las estrategias nacionales de desarrollo del país receptor" ${ }^{\prime \prime}$, formulada por el Equipo de Trabajo. Una óptica local como ésa, de alcance más restringido, permitiría orientar el debate hacia un conjunto limitado de objetivos de política y facilitaría el diálogo a nivel mundial y local - no sólo entre donantes y países asociados, sino también entre la sede en los países donantes y el personal sobre el terreno, así como entre la comunidad del comercio y la comunidad del desarrollo.

Como se insinúa en la Declaración de París sobre la Eficacia de la Ayuda, la promoción de la responsabilidad mutua, como la que tiene lugar en el marco de la Iniciativa, tiene por objeto establecer auténticas asociaciones entre las diferentes comunidades a fin de concentrar la atención en la obtención de resultados. Son tres los elementos indispensables para establecer ese tipo de asociaciones: un programa común con objetivos claros y compromisos recíprocos; la vigilancia y evaluación del cumplimiento de eso compromisos; y, en estrecha relación con ello, un proceso de examen y diálogo destinado a incentivar el cumplimiento de los compromisos y, en definitiva, modificar el comportamiento. Se ha caracterizado a la Iniciativa de Ayuda para el Comercio como "uno de los mejores ejemplos de alianzas mundiales para el desarrollo que existen actualmente".2

\section{Orientación de la agenda para el desarrollo después de 2015}

La Declaración del Milenio y los Objetivos de Desarrollo del Milenio (ODM) lograron que la comunidad mundial cerrara filas en torno a una visión común del desarrollo. Los ODM han servido eficazmente para movilizar a la opinión pública mundial, movilizar recursos, guiar los esfuerzos mundiales, seguir de cerca los progresos y promover la responsabilidad mutua. La prestación de asistencia para la creación de capacidad comercial es uno de los indicadores que miden el progreso hacia una alianza mundial para el desarrollo (ODM 8). La ayuda para el comercio desempeña, pues, una función de apoyo en el marco de la consecución de los ODM, especialmente el ODM 1 (erradicar la pobreza extrema y el hambre). 
Ya se ha empezado a trabajar en un nuevo marco y agenda para después de 2015. La OMC y otras partes interesadas han sostenido que "el crecimiento económico y el comercio -como motor de crecimiento- merecen un lugar destacado en la agenda para el desarrollo después de 2015", y han abogado por una "agenda que integre el crecimiento económico con la inclusión social y la protección del medio ambiente" (Lamy, 2013). En cuanto al marco de desarrollo para después de 2015, la OCDE propone un pequeño número de grandes objetivos y metas a nivel mundial, así como objetivos, metas e indicadores a nivel nacional, que se definan y ajusten en función del punto de partida, el contexto específico, las prioridades y la capacidad de cada país (OCDE, 2013). Además, la OCDE ha propuesto un conjunto de objetivos y metas vinculados a los ODM destinados a orientar las estrategias y los indicadores nacionales relacionados con el comercio, que podrían utilizarse para medir los progresos realizados.

\section{Renovar el compromiso}

Lo que más se necesita actualmente es que todas las partes interesadas se comprometan nuevamente a ayudar a los países en desarrollo a crear la capacidad necesaria en la esfera de la oferta y la infraestructura para convertir el comercio en un motor de crecimiento y reducir la pobreza. El Cuarto Examen Global, que tendrá lugar en julio de 2013, y la Novena Conferencia Ministerial de la OMC, que se celebrará en diciembre de 2013, constituyen sendas oportunidades importantes para considerar la forma de que la Iniciativa de Ayuda para el Comercio siga siendo pertinente en el entorno cambiante en que se desenvuelven el comercio y el desarrollo. 


\section{NOTAS}

1. WT/AFT/1 (2006).

2. Equipo de Tareas del Sistema de las Naciones Unidas sobre la agenda de desarrollo de las Naciones Unidas después de 2015 (2013: 6). 


\section{REFERENCIAS}

Lamy, P., (2013), El crecimiento debe ocupar un lugar destacado en la agenda para el desarrollo después de 2015, Conferencia sobre la Cooperación Internacional en 2020, La Haya, (7 de marzo de 2013), OMC, Ginebra. http://www.wto.org/spanish/news_s/sppl_s/sppl268_s.htm.

OCDE (2013), Aid for Trade and Development Results: A Management Framework, OCDE, París, http://dx.doi.org/10.1787/9789264112537-en.

OCDE/OMC (2013), Aid for Trade in Action, OCDE y Organización Mundial del Comercio, París y Ginebra. http://dx.doi.org/10.1787/9789264201453-en 


\section{HOJAS INFORMATIVAS SOBRE LA AYUDA PARA EL COMERCIO POR PAÍSES}





\section{NOTAS EXPLICATIVAS DE LAS HOJAS INFORMATIVAS SOBRE LA AYUDA PARA EL COMERCIO POR PAÍSES}

En las hojas informativas sobre la Ayuda para el Comercio por países se proporciona información fáctica destinada a incentivar el debate sobre los resultados obtenidos por cada país. Las hojas permiten comparar, con arreglo a cuatro categorías de indicadores, los resultados obtenidos durante el período comprendido entre 2005 y 2010. Las hojas informativas no tienen por objeto determinar a que obedecen los resultados de la Ayuda para el Comercio a escala macroeconómica, dado que, por diversos problemas metodológicos, no es posible establecer ese tipo de relación causal. Se trata, más bien, de incentivar un análisis por países más a fondo.

La estructura de las hojas informativas de los países sigue la estructura del marco de la cadena de resultados que se utiliza habitualmente en las intervenciones de desarrollo a base de proyectos. En las hojas informativas se muestran cuatro elementos, a saber:

a) aportes; b) productos; c) resultados; y d) efectos, que ilustran la secuencia causal de una intervención encaminada a lograr objetivos de comercio y desarrollo. Los aportes y las actividades conexas generan productos, que, a su vez, dan lugar a determinados resultados que contribuyen a generar los efectos a largo plazo de la intervención en el desarrollo.

Las hojas informativas sitúan el marco de la cadena de resultados en un contexto macroeconómico para ilustrar la importancia de los desembolsos por concepto de la Ayuda para el Comercio. Esos desembolsos se comparan con otras corrientes de financiación para el desarrollo. Aunque las hojas informativas no permiten establecer una relación causal, ayudan a comprender mejor la importancia que tienen las corrientes de Ayuda para el Comercio para el logro de los objetivos comerciales y de desarrollo de los países cuya consecución se persigue mediante esas corrientes.

En la elección de los indicadores ha influido la disponibilidad de series cronológicas de datos. Están apareciendo nuevos indicadores que, en algunos casos, podrían ser más adecuados para los fines de este análisis. Sin embargo, debido a la falta de datos históricos y la insuficiente cobertura geográfica sería prematuro tenerlos en cuenta en la etapa actual. En ediciones futuras se actualizarán y aplicarán los indicadores de las hojas informativas.

De conformidad con la estructura del marco de la cadena de resultados, las hojas informativas constan de cuatro secciones:

\section{INVERSIÓN Y FINANCIACIÓN (APORTES)}

La sección dedicada a los aportes abarca las corrientes financieras y de inversión de la economía que constituyen la base del desarrollo y el crecimiento económico. Los indicadores en relación con esta sección son: la formación bruta de capital fijo (total, público y privado), que mide las inversiones en capital fijo; y la entrada de financiación externa, que refleja la medida en que se depende de la financiación externa para las inversiones de capital. La financiación externa se puede utilizar para financiar las inversiones de capital, pero también puede servir para otros fines, como el consumo público y privado. Las corrientes de financiación externa se miden por medio de los siguientes indicadores: las entradas de inversión extranjera directa (IED); la deuda externa a largo plazo y los fondos desembolsados por el FMl; las corrientes comerciales en condiciones no concesionarias; los compromisos de Ayuda para el Comercio desembolsados (en total, por sector y por donante); y las remesas de trabajadores y la remuneración de empleados en relación con los trabajadores migrantes y no residentes.

La comparación de las corrientes correspondientes a los compromisos de la Ayuda para el Comercio desembolsados con otros aportes financieros externos muestra la importancia relativa que tiene la Ayuda para el Comercio para la inversión en la economía local. 


\section{Fuentes y variables:}

- OCDE, base de datos del SNPA del CAD sobre las actividades de ayuda: desembolsos de la Ayuda para el Comercio (total, por sector y por donante), corrientes comerciales en condiciones no concesionarias, es decir, «otras corrientes oficiales» que no se consideran ayuda oficial por no tener como objeto primordial el desarrollo o porque el elemento de donación es inferior al 25\%.

Banco Mundial (BM), Indicadores del Desarrollo Mundial: formación bruta de capital fijo (total, público y privado), entradas de inversión extranjera directa, remesas de trabajadores y remuneración de empleados.

BM, estadísticas de la deuda internacional: deuda externa a largo plazo y fondos desembolsados por el FMI.

\section{INDICADORES COMERCIALES (PRODUCTOS)}

En la cadena de resultados, con los aportes y las actividades conexas se obtienen productos. Los indicadores comerciales (productos) reflejan los aportes, las políticas y la evolución económica. La relación comercio/PIB es una medida sencilla de la apertura del comercio y de su importancia para la economía. La importancia del comercio de servicios para el país se aprecia en el porcentaje que corresponde a las exportaciones (importaciones) de servicios comerciales en el total de las exportaciones (importaciones). El porcentaje de las exportaciones (importaciones) de productos intermedios distintos de los combustibles en el total de las exportaciones (importaciones) de mercancías da la parte del posicionamiento de un país en las etapas intermedias de las cadenas de valor. Además, el cuadro muestra el valor de las exportaciones y las importaciones totales de servicios comerciales (desglosadas por categorías) en 2005 y 2011, junto con la correspondiente variación. Por último, para dar una imagen dinámica de la estructura de las exportaciones de los diferentes países, se presentan los cinco principales mercados y productos de exportación e importación de mercancías en 2005 y 2011 (u otros años, en función de los datos disponibles).

\section{Fuentes y variables:}

Secretaría de la OMC: relación comercio/PIB; exportaciones (importaciones) de servicios comerciales como porcentaje de las exportaciones (importaciones) totales; productos intermedios distintos de los combustibles (porcentaje de las exportaciones (importaciones) de mercancías); exportaciones e importaciones de mercancías y servicios comerciales; cinco principales mercados de exportación (importación); cinco principales productos de exportación (importación).

\section{INDICADORES COMERCIALES (RESULTADOS)}

En la sección dedicada a los resultados se evalúan las políticas comerciales y los resultados comerciales de cada país. Los indicadores utilizados son la tasa de crecimiento del PIB y el número de empresas exportadoras; tanto el crecimiento del PIB como número de empresas exportadoras son importantes indicadores de los avances logrados en materia de desarrollo a largo plazo. El índice Hirschman-Herfindahl de concentración de las exportaciones mide el grado de concentración o diversificación de las exportaciones de productos de un país (un índice cercano a 0 indica una cartera de exportación más diversificada, mientras que un índice más próximo a 1 indica una alta concentración de las exportaciones en un número reducido de productos). Asimismo, el cuadro con datos sobre la participación en las exportaciones por región contiene información sobre la concentración de las exportaciones por mercados de destino. El número de acuerdos comerciales regionales sobre mercancías y de acuerdos de integración económica de servicios refleja los esfuerzos de liberalización del comercio a escala regional realizados por cada país. Los promedios aritméticos y ponderados de los aranceles de importación aplicados indican el grado de acceso a los mercados de mercancías que permite cada país. En cambio, las condiciones de acceso a los mercados a las que se enfrenta un país al exportar se reflejan en los aranceles impuestos por los importadores en los cinco principales mercados de exportación y el porcentaje de las exportaciones que llegan a esos mercados libres de derechos. Los indicadores relativos al costo de exportar e importar y el tiempo para exportar y para importar, así como el Índice de Desempeño Logístico (LPI) (va de 1 a 5 y en el que una puntuación más elevada significa un mejor desempeño logístico), reflejan los costos comerciales relacionados con la administración y la infraestructura. En el caso de estos últimos, se evalúa a cada país en relación con el grupo de países al que pertenecen por su nivel de ingresos según la clasificación del Banco Mundial. 


\section{Fuentes y variables:}

- Naciones Unidas, base de datos Comtrade: índice Hirschman-Herfindahl de concentración de las exportaciones a nivel de producto, que va de 0 (cartera de exportación perfectamente diversificada) a 1 (cuando un país exporta un único producto).

- BM, base de datos sobre dinámica de las empresas de exportación: número de exportadores.

- BM, Indicadores del Desarrollo Mundial: crecimiento del PIB, costo de exportar (importar) y tiempo para exportar (importar), Índice de Desempeño Logístico (LPl; va de 1=bajo a 5=alto).

- OMC, perfiles comerciales y arancelarios: acuerdos comerciales regionales sobre mercancías y acuerdos de integración económica de servicios notificados a la OMC; sectores de servicios con compromisos en el marco del AGCS; participación en las exportaciones de mercancías por región; aranceles NMF aplicados a las importaciones (promedio aritmético y promedio ponderado); aranceles de exportación impuestos por los importadores (promedio ponderado) y exportaciones libres de derechos (valor porcentual). Los aranceles de exportación impuestos por los importadores y las exportaciones libres de derechos corresponden a los cinco principales mercados de exportación en 2005 en términos absolutos y a los cinco principales mercados de exportación para los productos agrícolas y para los productos no agrícolas en 2011.

\section{INDICADORES DE DESARROLLO (EFECTOS)}

La sección dedicada a los efectos abarca indicadores que describen los objetivos de desarrollo económico que se pretende alcanzar a largo plazo mediante la Ayuda para el Comercio. El PIB per cápita (en dólares EE.UU. constantes de 2000 y en dólares internacionales corrientes) refleja la evolución económica general del país a lo largo del tiempo y en comparación con la del grupo de países al que pertenecen según la clasificación de países por nivel de ingresos del Banco Mundial. La tasa de desempleo y el porcentaje de la población activa femenina muestran en qué medida el desarrollo es inclusivo. La proporción correspondiente a la asistencia oficial para el desarrollo en el conjunto del ingreso nacional bruto, la participación de los derechos de importación en los ingresos fiscales y el porcentaje que representa el total del servicio de la deuda en las exportaciones totales indican la medida en que el país depende de la ayuda exterior, la aplicación de una política comercial para generar ingresos públicos y la carga de la deuda externa, respectivamente. El índice de desarrollo humano va de 0 (nivel mínimo de desarrollo) a 1 (nivel máximo de desarrollo), y engloba las tres dimensiones básicas del desarrollo: la salud, la educación y el nivel de vida. Por último, la proporción de la población que vive con menos de 1,25 dólares EE.UU. por día y 2 dólares EE.UU. por día y la proporción de los ingresos correspondientes al 20\% de la población con ingresos más elevados ilustran los aspectos del desarrollo a nivel de la distribución.

\section{Fuentes y variables:}

- Programa de las Naciones Unidas para el Desarrollo (PNUD), indicadores internacionales sobre desarrollo humano: índice de desarrollo humano (de 0=nivel mínimo de desarrollo a 1=nivel máximo de desarrollo).

- BM, Indicadores del Desarrollo Mundial: PIB per cápita (en dólares EE.UU. constantes de 2000 y sobre la base de la paridad de poder adquisitivo (PPA, en dólares internacionales corrientes); el desempleo (porcentaje de la fuerza de trabajo total); la población activa femenina (porcentaje de la fuerza de trabajo total); la asistencia oficial para el desarrollo (AOD) neta recibida (porcentaje del ingreso nacional bruto); la población que vive con menos de 1,25 dólares EE.UU. por día y de 2 dólares EE.UU. por día (PPA) (porcentaje); la proporción de los ingresos correspondientes al 20\% de la población con ingresos más elevados.

- OMC, perfiles comerciales y arancelarios: derechos de importación percibidos (porcentaje de los ingresos fiscales).

\section{Leyenda:}

«d.p.c.» división por cero

«n.d.» información no disponible 
Indicadores de la ayuda, el comercio y el desarrollo relativos al Afganistán

\begin{tabular}{|c|c|c|c|c|}
\hline Indicador (millones de \$̦EE.UU. corrientes) & 2005 & 2008 & 2010 & $\Delta: 05-10(\%)$ \\
\hline Formación bruta de capital fijo & $2.130,9$ & $1.949,6$ & $2.807,6$ & $32 \%$ \\
\hline del cual: público & $1.540,1$ & 994,4 & s.o. & s.o. \\
\hline del cual: privado & 590,8 & 955,2 & s.o. & s.o. \\
\hline \multicolumn{5}{|l|}{ Entrada de financiación externa } \\
\hline Entradas de IED & 271,0 & 300,0 & 75,7 & $-72 \%$ \\
\hline $\begin{array}{l}\text { Deuda externa a largo plazo y fondos } \\
\text { desembolsados por el FMl }\end{array}$ & 0,0 & 132,1 & 87,4 & d.p.c. \\
\hline $\begin{array}{l}\text { Corrientes comerciales en condiciones no } \\
\text { concesionarias }\end{array}$ & 0,0 & 21,4 & 26,5 & d.p.c. \\
\hline Corrientes de Ayuda para el Comercio & 872,7 & $1.180,1$ & $1.750,7$ & $101 \%$ \\
\hline $\begin{array}{l}\text { Remesas de trabajadores y remuneración } \\
\text { de empleados }\end{array}$ & s.o. & s.o. & S.o. & S.o. \\
\hline
\end{tabular}

Fuentes: OCDE, base de datos del SNPA del CAD sobre las actividades de ayuda; Banco Mundial, Indicadores del Desarrollo Mundial; Banco Mundial, estadísticas de la deuda internacional.

Desembolsos de la ayuda para el comercio, por sector (millones de \$̦EE.UU. corrientes)

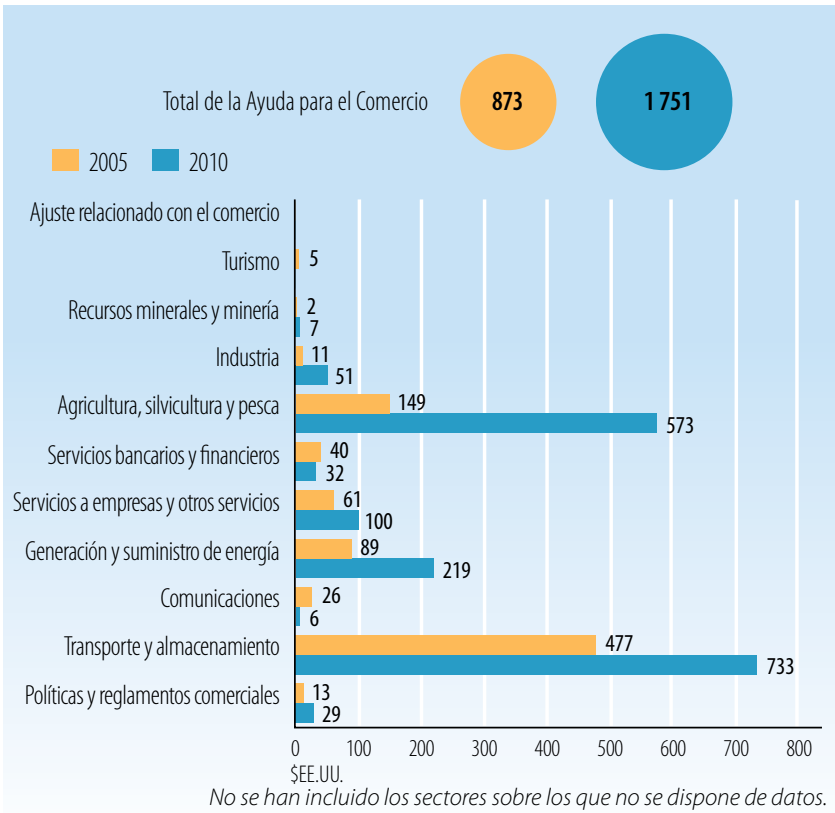

Fuentes: OCDE, base de datos del SNPA del CAD sobre las actividades de ayuda

Desembolsos de la ayuda para el comercio: principales donantes (millones de \$EE.UU. corrientes)

\begin{tabular}{|l|c|c|}
\hline $\mathbf{2 0 0 5}$ & Valor & $\%$ \\
\hline Estados Unidos & 631,5 & 72 \\
\hline Banco Mundial & 142,7 & 16 \\
\hline Instituciones de la UE & 20,0 & 2 \\
\hline Reino Unido & 19,3 & 2 \\
\hline Alemania & 19,3 & 2 \\
\hline $\mathbf{2 0 1 0}$ & Valor & $\%$ \\
\hline Estados Unidos & 1115,6 & 64 \\
\hline Banco Asiático de Desarrollo & 230,4 & 13 \\
\hline Banco Mundial & 78,7 & 4 \\
\hline Canadá & 73,0 & 4 \\
\hline Japón & 67,8 & 4 \\
\hline
\end{tabular}
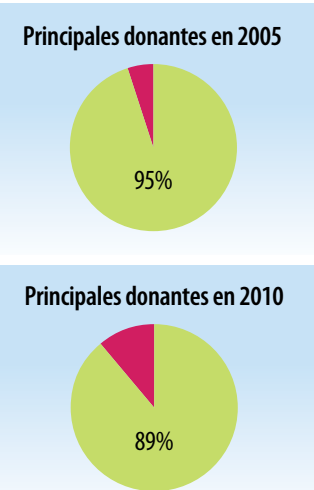

Fuentes: OCDE, base de datos del SNPA del CAD sobre las actividades de ayuda.

\section{INDICADORES COMERCIALES (PRODUCTOS)}

\section{Indicador}

$2005 \quad 2008 \quad 2011 \quad \Delta: 05-11(\%)$

Relación comercio/PIB (\%)

n.d. $\quad$ n.d. $\quad$ n.d. n.d.

Exportaciones de servicios comerciales como

$\%$ de las exportaciones totales

Importaciones de servicios comerciales como

$\%$ de las importaciones totales

Productos intermedios distintos de los combustibles

(\% de las exportaciones de mercancías)

Productos intermedios distintos de los combustibles

(\% de las importaciones de mercancías)

n.d. n.d. n.d. n.d.

n.d. n.d. n.d. n.d.

n.d. $\quad 7 \quad$ n.d. $\quad$ n.d.

n.d. $27 \quad$ n.d. $\quad$ n.d.

Fuentes: Secretaría de la OMC

Corrientes comerciales (millones de \$EE.UU. corrientes)

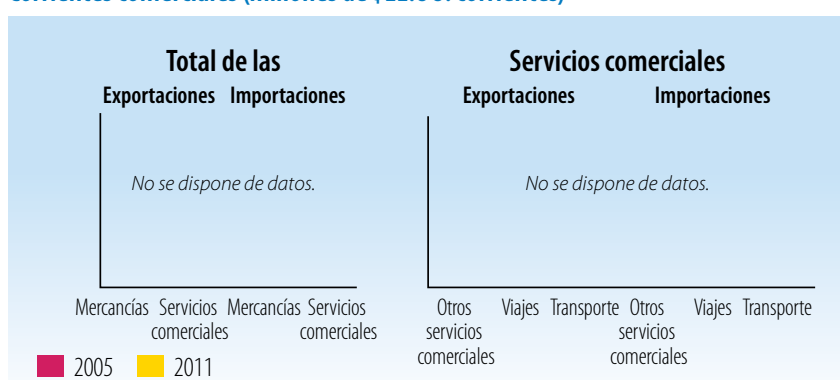

Fuentes: Secretaría de la OMC.

Cinco principales mercados de exportación de mercancías (\%)

\begin{tabular}{|l|r|l|r|}
\hline 2008 & $\%$ & 2010 & $\%$ \\
\hline Pakistán & 49 & Pakistán & 39 \\
\hline India & 24 & India & 17 \\
\hline Federación de Rusia & 7 & Turquía & 9 \\
\hline Emiratos Árabes Unidos & 3 & Irán & 8 \\
\hline Irán & 3 & Federación de Rusia & 8
\end{tabular}

Fuentes: Secretaría de la OMC.

Cinco principales productos de exportación (\% de las exportaciones de mercancías)

\begin{tabular}{|c|c|c|c|}
\hline 2008 & $\%$ & 2010 & $\%$ \\
\hline $\begin{array}{l}\text { Frutas y nueces, excepto nueces } \\
\text { oleaginosas }\end{array}$ & 51 & Operaciones especiales no clasificadas & 29 \\
\hline Recubrimientos para pisos, etc. & 28 & $\begin{array}{l}\text { Frutas y nueces, excepto nueces } \\
\text { oleaginosas }\end{array}$ & 28 \\
\hline Operaciones especiales no clasificadas & 8 & Recubrimientos para pisos, etc. & 18 \\
\hline Obras de arte, antigüedades, etc. & 6 & Productos vegetales en bruto, n.e.p. & 10 \\
\hline Productos vegetales en bruto, n.e.p. & 4 & $\begin{array}{l}\text { Semillas oleaginosas (aceites vegetales } \\
\text { fijos blandos) }\end{array}$ & 6 \\
\hline
\end{tabular}

Fuentes: Secretaría de la OMC

Cinco principales mercados de importación de mercancías (\%)

\begin{tabular}{|l|l|l|l|}
\hline 2008 & $\%$ & 2010 & $\%$ \\
\hline Pakistán & 16 & Uzbekistán & 21 \\
\hline China & 14 & China & 14 \\
\hline Japón & 12 & Pakistán & 12 \\
\hline Irán & 6 & UE (27) & 10 \\
\hline Uzbekistán & 6 & Japón & 10 \\
\hline
\end{tabular}

Fuentes: Secretaría de la OMC.

Cinco principales productos de importación (\% de las importaciones de mercancías)

\begin{tabular}{|c|c|c|c|}
\hline 2008 & $\%$ & 2010 & $\%$ \\
\hline Operaciones especiales no clasificadas & 49 & Operaciones especiales no clasificadas & 46 \\
\hline Obras de arte, antigüedades, etc. & 14 & Briquetas, lignito y turba & 19 \\
\hline $\begin{array}{l}\text { Grasas } 0 \text { aceites de origen animal o vegetal, } \\
\text { n.e.p. }\end{array}$ & 5 & $\begin{array}{l}\text { Sémola y harina de trigo y harina de } \\
\text { morcajo o tranquillón }\end{array}$ & 4 \\
\hline $\begin{array}{l}\text { Sémola y harina de trigo y harina de } \\
\text { morcajo o tranquillón }\end{array}$ & 5 & Cal, cemento y materiales de construcción & 3 \\
\hline $\begin{array}{l}\text { Neumáticos, cámaras de aire, etc., de } \\
\text { caucho }\end{array}$ & 4 & $\begin{array}{l}\text { Partes y piezas de tractores y vehículos } \\
\text { automotores }\end{array}$ & 3 \\
\hline
\end{tabular}




\section{LA AYUDA PARA EL COMERCIO EN SIINTESIS 2013}

\begin{tabular}{l|r|r|}
\hline \multicolumn{2}{|l|}{ INDICADORES COMERCIALES (RESULTADOS) } \\
\hline Indicador & 2005 & 2011 \\
\hline Crecimiento del PIB (\%) & 14,5 & 8,2 \\
\hline Número de exportadores & n.d. & n.d. \\
\hline Indice de concentración de las exportaciones (productos) (0 a 1) & n.d. & 0.07 \\
\hline ACR sobre mercancías notificados a la OMC & n.d. & 2 \\
\hline AlE (servicios) notificados a la OMC & n.d. & 0 \\
\hline Sectores de servicios con compromisos en el marco del AGCS & 0 & 0 \\
\hline Aranceles (\%) & & \\
\hline Importaciones: promedio aritmético de los aranceles NMF aplicados & 5,7 & n.d. \\
\hline Importaciones: promedio ponderado de los aranceles NMF aplicados & n.d. & n.d. \\
\hline Exportaciones: promedio ponderado de los aranceles impuestos & 13,5 & n.d. \\
por los importadores & 36,6 & n.d. \\
\hline Exportaciones: libres de derechos (en \%) &
\end{tabular}

Fuentes: Naciones Unidas, base de datos Comtrade; Banco Mundial, base de datos sobre dinámica de las empresas de exportación; Banco Mundial, Indicadores del Desarrollo Mundial; OMC, perfiles comerciales y arancelarios.

Participación en las exportaciones por región (\%)

\begin{tabular}{|l|r|r|}
\hline & 2005 & 2010 \\
\hline África & n.d. & 1,0 \\
\hline Asia & n.d. & 59,3 \\
\hline Comunidad de Estados Independientes & n.d. & 12,1 \\
\hline Europa & n.d. & 13,9 \\
\hline Oriente Medio & n.d. & 12,7 \\
\hline América del Norte & n.d. & 1,1 \\
\hline América del Sury América Central & n.d. & 0,0 \\
\hline
\end{tabular}

Fuentes: OMC, perfiles comerciales y arancelarios

Indicadores de facilitación del comercio
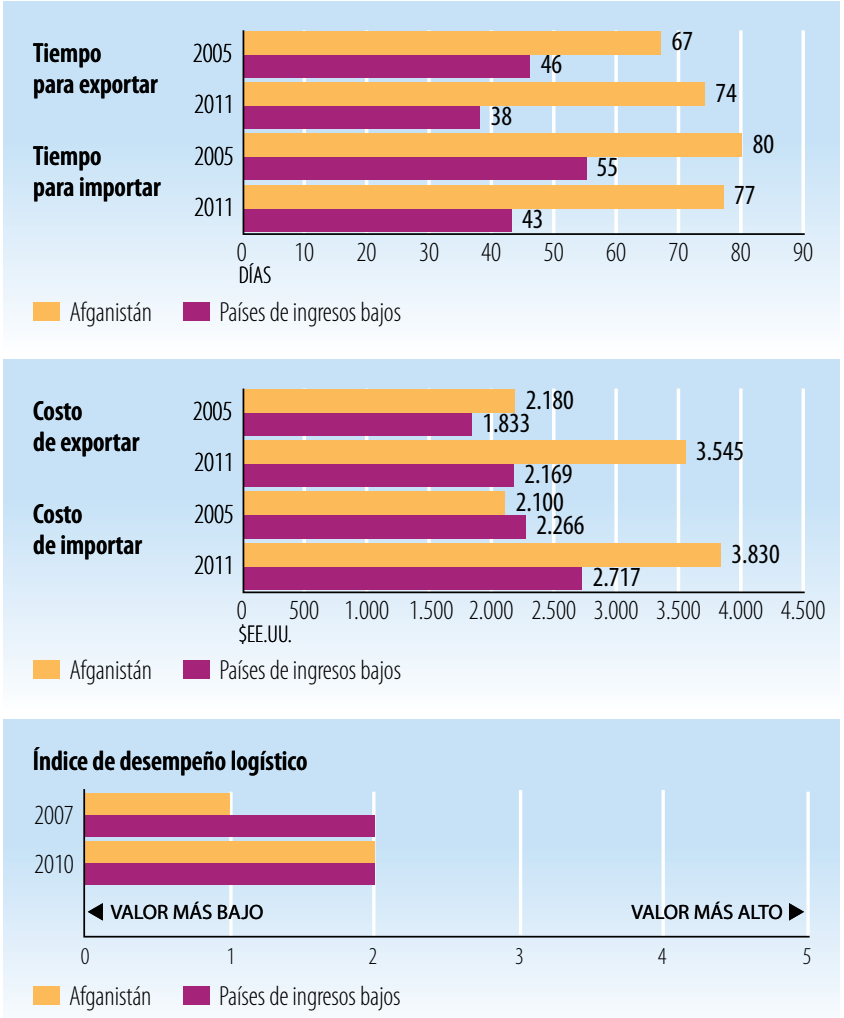

Fuentes: Banco Mundial, Indicadores del Desarrollo Mundial.

\begin{tabular}{l|c|c|}
\hline INDICADORES DE DESARROLLO (EFECTOS) \\
\hline Indicador & 2005 & 2010 \\
\hline Desempleo (\% de la fuerza de trabajo total) & 8,5 & n.d. \\
\hline Población activa, mujeres (\% de la fuerza de trabajo total) & 13,7 & 15,2 \\
\hline AOD neta recibida (\% del INB) & 41,6 & 42,4 \\
\hline Derechos de importación percibidos (\% de los ingresos fiscales) & n.d. & 41,3 \\
\hline Total del servicio de la deuda (\% de las exportaciones totales) & n.d. & n.d. \\
\hline Índice de desarrollo humano (0 a 1) & 0,34 & 0,39 \\
\hline
\end{tabular}

Fuentes: PNUD, indicadores internacionales sobre desarrollo humano; Banco Mundial, Indicadores del Desarrollo Mundial.

Producto interno bruto

PIB per cápita (PPA, dólares internacionales corrientes)

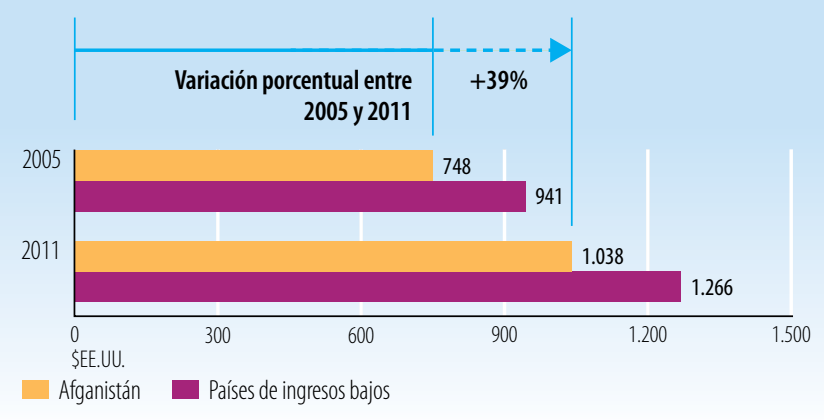

PIB per cápita (\$\$EE.UU. constantes de 2000)

Variación porcentual entre 2005 y 2011 No se dispone de datos

$$
\begin{aligned}
& 2005 \text { No se dispone de datos } \\
& \text { No se dispone de datos } \\
& 2011 \text { No se dispone de datos } \\
& \text { No se dispone de datos } \\
& \text { \$EE.UU. } \\
& \text { Afganistán Países de ingresos bajos }
\end{aligned}
$$

Fuentes: Banco Mundial, Indicadores del Desarrollo Mundial.

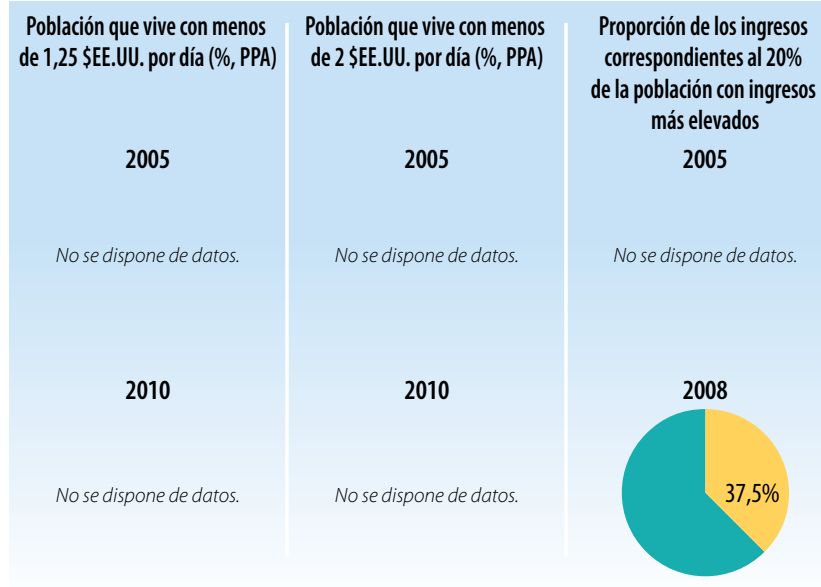

Fuentes: Banco Mundial, Indicadores del Desarrollo Mundial.

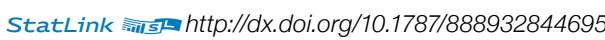




\begin{tabular}{|c|c|c|c|c|}
\hline Indicador (millones de \$EE.UU. corrientes) & 2005 & 2008 & 2010 & $\Delta: 05-10(\%)$ \\
\hline Formación bruta de capital fijo & 367,2 & 342,8 & n.d. & n.d. \\
\hline del cual: público & n.d. & n.d. & n.d. & n.d. \\
\hline del cual: privado & n.d. & n.d. & n.d. & n.d. \\
\hline \multicolumn{5}{|l|}{ Entrada de financiación externa } \\
\hline Entradas de IED & 221,0 & 174,2 & 96,7 & $-56 \%$ \\
\hline $\begin{array}{l}\text { Deuda externa a largo plazo y fondos } \\
\text { desembolsados por el FMl }\end{array}$ & n.d. & n.d. & n.d. & n.d. \\
\hline $\begin{array}{l}\text { Corrientes comerciales en condiciones no } \\
\text { concesionarias }\end{array}$ & 0,0 & 0,0 & 0,0 & $0 \%$ \\
\hline Corrientes de Ayuda para el Comercio & 5,5 & 0,5 & 6,7 & $22 \%$ \\
\hline $\begin{array}{l}\text { Remesas de trabajadores y remuneración } \\
\text { de empleados }\end{array}$ & 22,0 & 25,5 & 24,8 & $13 \%$ \\
\hline
\end{tabular}

Fuentes: OCDE, base de datos del SNPA del CAD sobre las actividades de ayuda; Banco Mundial, Indicadores del Desarrollo Mundial; Banco Mundial, estadísticas de la deuda internacional.

Desembolsos de la ayuda para el comercio, por sector (millones de \$EE.UU. corrientes)

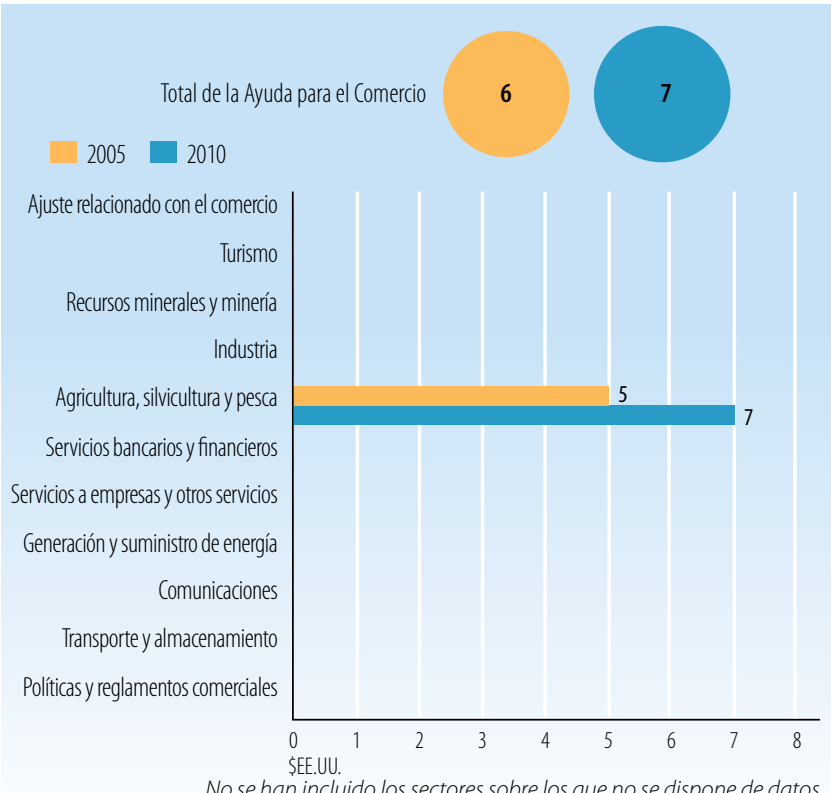

Fuentes: OCDE, base de datos del SNPA del CAD sobre las actividades de ayuda

Desembolsos de la ayuda para el comercio: principales donantes (millones de \$̦E.UU. corrientes)

\begin{tabular}{|l|r|r|}
\hline $\mathbf{2 0 0 5}$ & Valor & $\%$ \\
\hline Japón & 5,4 & 97 \\
\hline Instituciones de la UE & 0,1 & 2 \\
\hline Estados Unidos & 0,0 & 0 \\
\hline
\end{tabular}

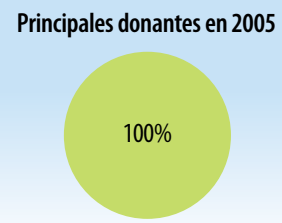

\begin{tabular}{|l|r|r|}
\hline 2010 & Valor & $\%$ \\
\hline Japón & 6,5 & 97 \\
\hline OMC & 0,1 & 2 \\
\hline Instituciones de la UE & 0,1 & 1 \\
\hline Alemania & 0,0 & 0 \\
\hline Corea, Rep. de & 0,0 & 0 \\
\hline
\end{tabular}

Principales donantes en 2010

Fuentes: OCDE, base de datos del SNPA del CAD sobre las actividades de ayuda.

\section{INDICADORES COMERCIALES (PRODUCTOS)}

\section{Indicador}

Relación comercio/PIB (\%)

Exportaciones de servicios comerciales como

$\%$ de las exportaciones totales

Importaciones de servicios comerciales como

$\%$ de las importaciones totales

Productos intermedios distintos de los combustibles

(\% de las exportaciones de mercancías)

Productos intermedios distintos de los combustibles

(\% de las importaciones de mercancías)
$2005 \quad 2008 \quad 2011 \quad \Delta: 05-11(\%)$

\begin{tabular}{l|l|l|l|l|l|l|}
118 & 114 & 103 & -16
\end{tabular}

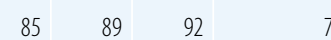

$32 \quad 28 \quad 33 \quad 0$

$7 \quad$ n.d. $\quad 21 \quad 14$

$20 \quad$ n.d. $18 \quad-2$

Corrientes comerciales (millones de \$EE.UU. corrientes)

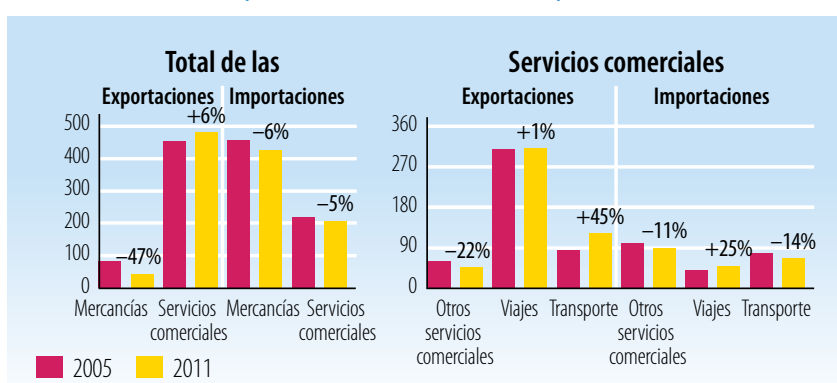

Fuentes: Secretaría de la OMC.

Cinco principales mercados de exportación de mercancías (\%)

\begin{tabular}{|l|c|l|c|}
\hline 2005 & $\%$ & 2011 & $\%$ \\
\hline Antillas Neerlandesas & 23 & Estados Unidos & 38 \\
\hline UE (27) & 23 & UE (27) & 16 \\
\hline Saint Kitts y Nevis & 10 & Barbados & 7 \\
\hline Estados Unidos & 8 & Trinidady Tabago & 7 \\
\hline Anguila & 7 & Jamaica & 4
\end{tabular}

Fuentes: Secretaría de la OMC.

Cinco principales productos de exportación (\% de las exportaciones de mercancías)

\begin{tabular}{|c|c|c|c|}
\hline 2005 & $\%$ & 2011 & $\%$ \\
\hline Productos derivados del petróleo & 70 & Artículos textiles, n.e.p. & 22 \\
\hline $\begin{array}{l}\text { Buques, embarcaciones y estructuras } \\
\text { flotantes }\end{array}$ & 11 & Bebidas alcohólicas & 8 \\
\hline $\begin{array}{l}\text { Equipos de telecomunicaciones y sus } \\
\text { partes, n.e.p. }\end{array}$ & 5 & Grabadores de sonido y fonógrafos & 8 \\
\hline Artículos textiles, n.e.p. & 2 & $\begin{array}{l}\text { Buques, embarcaciones y estructuras } \\
\text { flotantes }\end{array}$ & 6 \\
\hline Impresos & 2 & Equipos mecánicos de manipulación & 4 \\
\hline
\end{tabular}

Fuentes: Secretaría de la OMC.

Cinco principales mercados de importación de mercancías (\%)

\begin{tabular}{|l|r|l|r|}
\hline 2005 & $\%$ & 2011 & $\%$ \\
\hline Estados Unidos & 49 & Estados Unidos & 33 \\
\hline UE (27) & 12 & UE (27) & 8 \\
\hline Trinidad y Tabago & 11 & Trinidad y Tabago & 4 \\
\hline Antillas Neerlandesas & 10 & China & 3 \\
\hline Japón & 3 & Japón & 2 \\
\hline Fuentes: Secretaría de la OMC. & & &
\end{tabular}

Cinco principales productos de importación (\% de las importaciones de mercancías)

\begin{tabular}{|c|c|c|c|}
\hline 2005 & $\%$ & 2011 & $\%$ \\
\hline Productos derivados del petróleo & 34 & Operaciones especiales no clasificadas & 35 \\
\hline $\begin{array}{l}\text { Buques, embarcaciones y estructuras } \\
\text { flotantes }\end{array}$ & 4 & Otras carnes y despojos de carnes & 3 \\
\hline $\begin{array}{l}\text { Vehículos automotores para pasajeros, } \\
\text { excepto autobuses }\end{array}$ & 4 & Bebidas alcohólicas & 2 \\
\hline Muebles, cojines, etc. & 2 & Bebidas no alcohólicas, n.e.p. & 2 \\
\hline $\begin{array}{l}\text { Equipos de telecomunicaciones y sus } \\
\text { partes, n.e.p. }\end{array}$ & 2 & $\begin{array}{l}\text { Productos y preparados comestibles, } \\
\text { n.e.p. }\end{array}$ & 2 \\
\hline
\end{tabular}




\begin{tabular}{|c|c|c|}
\hline Indicador & 2005 & 2011 \\
\hline Crecimiento del PIB (\%) & 4,2 & $-4,2$ \\
\hline Número de exportadores & n.d. & n.d. \\
\hline Índice de concentración de las exportaciones (productos) (0 a 1) & n.d. & n.d. \\
\hline ACR sobre mercancías notificados a la OMC & n.d. & 2 \\
\hline AIE (servicios) notificados a la OMC & n.d. & 2 \\
\hline Sectores de servicios con compromisos en el marco del AGCS & 32 & 32 \\
\hline \multicolumn{3}{|l|}{ Aranceles $(\%, 2006$ et 2011$)$} \\
\hline Importaciones: promedio aritmético de los aranceles NMF aplicados & 9,7 & 10,4 \\
\hline Importaciones: promedio ponderado de los aranceles NMF aplicados & n.d. & n.d. \\
\hline $\begin{array}{l}\text { Exportaciones: promedio ponderado de los aranceles impuestos } \\
\text { por los importadores }\end{array}$ & 0,8 & 6,5 \\
\hline Exportaciones: libres de derechos (en \%) & 96,7 & 40,3 \\
\hline
\end{tabular}

Fuentes: Naciones Unidas, base de datos Comtrade; Banco Mundial, base de datos sobre dinámica de las empresas de exportación; Banco Mundial, Indicadores del Desarrollo Mundial; OMC, perfiles comerciales y arancelarios.

Participación en las exportaciones por región (\%)

\begin{tabular}{|l|r|r|}
\hline & 2005 & 2010 \\
\hline África & 8,4 & 0,0 \\
\hline Asia & 0,1 & 2,1 \\
\hline Comunidad de Estados Independientes & 0,0 & 0,0 \\
\hline Europa & 23,2 & 16,6 \\
\hline Oriente Medio & 0,0 & 0,1 \\
\hline América del Norte & 8,1 & 39,9 \\
\hline América del Sury América Central & 60,2 & 38,4 \\
\hline
\end{tabular}

Fuentes: OMC, perfiles comerciales y arancelarios

Indicadores de facilitación del comercio
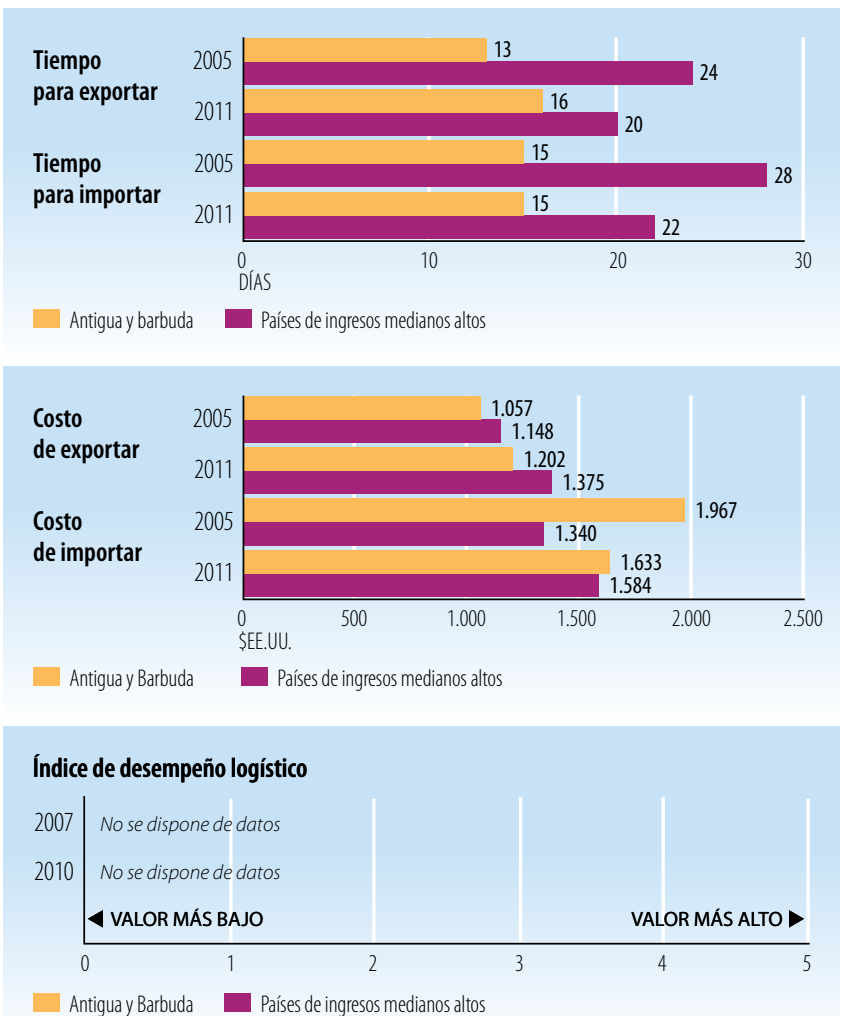

Fuentes: Banco Mundial, Indicadores del Desarrollo Mundial.

\begin{tabular}{l|c|c|}
\hline \begin{tabular}{l} 
INDICADORES DE DESARROLLO (EFECTOS) \\
\hline Indicador
\end{tabular} & 2005 & 2010 \\
\hline Desempleo (\% de la fuerza de trabajo total) & n.d. & n.d. \\
\hline Población activa, mujeres (\% de la fuerza de trabajo total) & n.d. & n.d. \\
\hline AOD neta recibida (\% del INB) & 0,8 & 1,7 \\
\hline Derechos de importación percibidos (\% de los ingresos fiscales) & n.d. & n.d. \\
\hline Total del servicio de la deuda (\% de las exportaciones totales) & n.d. & n.d. \\
\hline Índice de desarrollo humano (0 a 1) & n.d. & 0.76 \\
\hline
\end{tabular}

Fuentes: PNUD, indicadores internacionales sobre desarrollo humano; Banco Mundial, Indicadores del Desarrollo Mundial.

Producto interno bruto

PIB per cápita (PPA, dólares internacionales corrientes)
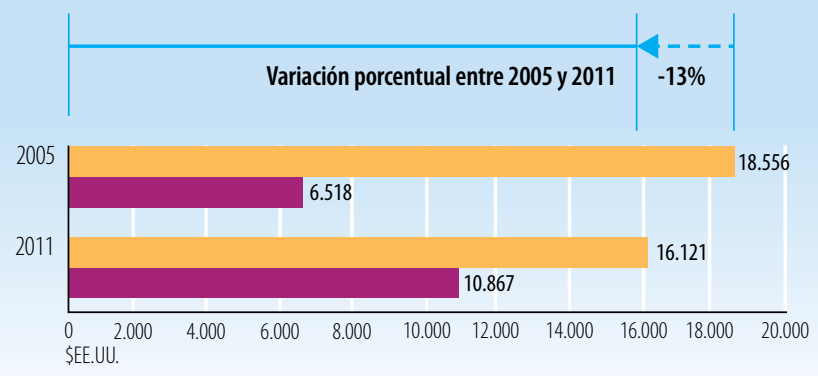

Antigua y Barbuda Países de ingresos medianos altos

\section{PIB per cápita (\$\$EE.UU. constantes de 2000)}
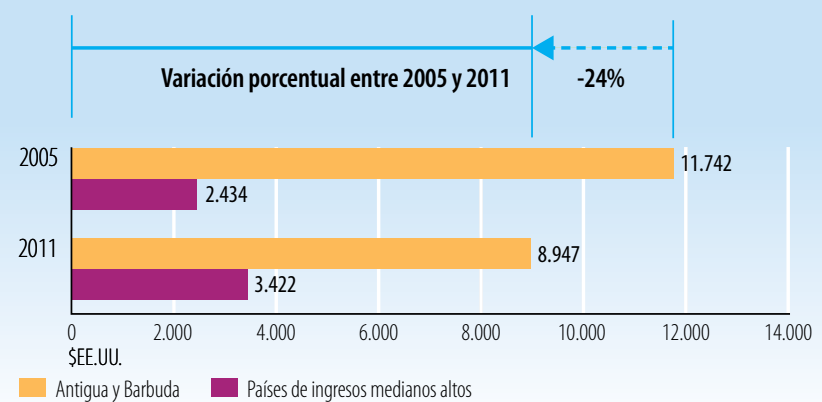

Fuentes: Banco Mundial, Indicadores del Desarrollo Mundial.

\begin{tabular}{c|c|c|}
\hline $\begin{array}{c}\text { Población que vive con menos } \\
\text { de 1,25 \$EE.UU. por día (\%, PPA) }\end{array}$ & $\begin{array}{c}\text { Población que vive con menos } \\
\text { de 2 \$EE.UU. por día (\%, PPA) }\end{array}$ & $\begin{array}{c}\text { Proporción de los ingresos } \\
\text { correspondientes al 20\% } \\
\text { de la población con ingresos } \\
\text { más elevados }\end{array}$ \\
\hline 2005 & 2005 & 2005 \\
\hline No se dispone de datos. & No se dispone de datos. & \\
\hline & & \\
\hline 2010 & 2010 & 2010 \\
\hline No se dispone de datos. & No se dispone de datos. & \\
\hline
\end{tabular}

Fuentes: Banco Mundial, Indicadores del Desarrollo Mundial.

StatLink 完Is] http://dx.doi.org/10.1787/888932844714 


\section{Indicadores de la ayuda, el comercio y el desarrollo relativos a las Bahamas}

\begin{tabular}{|c|c|c|c|c|}
\hline \multicolumn{5}{|c|}{ INVERSIÓN Y FINANCIACIÓN (APORTES) } \\
\hline Indicador (millones de \$̦EE.UU. corrientes) & 2005 & 2008 & 2010 & $\Delta: 05-10(\%)$ \\
\hline Formación bruta de capital fijo & $1.863,9$ & $2.112,8$ & $1.821,2$ & $-2 \%$ \\
\hline del cual: público & n.d. & n.d. & n.d. & n.d. \\
\hline del cual: privado & n.d. & n.d. & n.d. & n.d. \\
\hline \multicolumn{5}{|l|}{ Entrada de financiación externa } \\
\hline Entradas de IED & 563,4 & 860,2 & 872,0 & $55 \%$ \\
\hline $\begin{array}{l}\text { Deuda externa a largo plazo y fondos } \\
\text { desembolsados por el FMl }\end{array}$ & n.d. & n.d. & n.d. & n.d. \\
\hline $\begin{array}{l}\text { Corrientes comerciales en condiciones no } \\
\text { concesionarias }\end{array}$ & 0,0 & 0,0 & 0,0 & $0 \%$ \\
\hline Corrientes de Ayuda para el Comercio & 0,0 & 0,0 & 0,0 & $0 \%$ \\
\hline $\begin{array}{l}\text { Remesas de trabajadores y remuneración } \\
\text { de empleados }\end{array}$ & n.d. & n.d. & n.d. & n.d. \\
\hline
\end{tabular}

Fuentes: OCDE, base de datos del SNPA del CAD sobre las actividades de ayuda; Banco Mundial, Indicadores del Desarrollo Mundial; Banco Mundial, estadísticas de la deuda internacional.

Desembolsos de la ayuda para el comercio, por sector (millones de \$EE.UU. corrientes)

\begin{tabular}{r|r} 
Total de la Ayuda para el Comercio & No se dispone de datos. \\
Tujuste relacionado con el comercio & \\
Recursos minerales y minería & \\
Industria & \\
Agricultura, silviculturar y pesca & \\
Servicios bancarios y financieros & No se dispone de datos. \\
Servicios a empresas y otros servicios & \\
Generación y suministro de energía & \\
Comunicaciones & \\
Transporte y almacenamiento & \\
Políticas y reglamentos comerciales &
\end{tabular}

Fuentes: OCDE, base de datos del SNPA del CAD sobre las actividades de ayuda

Desembolsos de la ayuda para el comercio: principales donantes (millones de \$EE.UU. corrientes)

\begin{tabular}{|c|c|c|c|}
\hline 2005 & Valor & $\%$ & Principales donantes en 2005 \\
\hline \multicolumn{4}{|l|}{ No se dispone de datos. } \\
\hline 2010 & Valor & $\%$ & Principales donantes en 2010 \\
\hline No se dispone de datos. & & & \\
\hline & & & \\
\hline & & & \\
\hline
\end{tabular}

Fuentes: OCDE, base de datos del SNPA del CAD sobre las actividades de ayuda.

\section{INDICADORES COMERCIALES (PRODUCTOS)}

Indicador

Relación comercio/PIB (\%)

Exportaciones de servicios comerciales como

$\%$ de las exportaciones totales

Importaciones de servicios comerciales como

\% de las importaciones totales

Productos intermedios distintos de los combustibles

(\% de las exportaciones de mercancías)

Productos intermedios distintos de los combustibles

(\% de las importaciones de mercancías)

Fuentes: Secretaría de la OMC.

Corrientes comerciales (millones de \$EE.UU. corrientes)

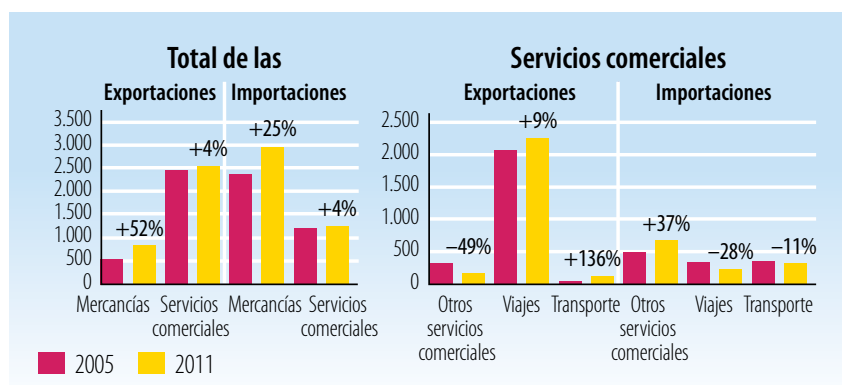

Fuentes: Secretaría de la OMC.

Cinco principales mercados de exportación de mercancías (\%)

\begin{tabular}{|l|r|l|r|}
\hline 2005 & $\%$ & 2010 & $\%$ \\
\hline Estados Unidos & 61 & Estados Unidos & 76 \\
\hline UE (27) & 30 & UE (27) & 10 \\
\hline Canadá & 6 & Nigeria & 4 \\
\hline Sudáfrica & 1 & Canadá & 3 \\
\hline Australia & 1 & Jamaica & 1 \\
\hline
\end{tabular}

Fuentes: Secretaría de la OMC.

Cinco principales productos de exportación (\% de las exportaciones de mercancías)

\begin{tabular}{|l|c|l|l|}
\hline 2005 & $\%$ & 2011 & $\%$ \\
\hline Polímeros de estireno & 43 & Productos derivados del petróleo & 30 \\
\hline Crustáceos, moluscos, etc. & 29 & Polímeros de estireno & 19 \\
\hline Compuestos orgánico-inorgánicos & 15 & Crustáceos, moluscos, etc. & 10 \\
\hline Bebidas alcohólicas & 6 & Compuestos orgánico-inorgánicos & 10 \\
\hline Otros minerales en bruto & 5 & Productos de perfumería, cosméticos, etc. & 5
\end{tabular}

Fuentes: Secretaría de la OMC.

Cinco principales mercados de importación de mercancías (\%)

\begin{tabular}{|l|r|l|r|}
\hline 2005 & $\%$ & 2010 & $\%$ \\
\hline Estados Unidos & 86 & Estados Unidos & 91 \\
\hline Antillas Neerlandesas & 7 & Trinidady Tabago & 2 \\
\hline UE (27) & 2 & UE (27) & 2 \\
\hline Japón & 1 & Suiza & 1 \\
\hline Brasil & 1 & Canadá & 1 \\
\hline Fuentes: Secretaría de la OMC. & & & \\
\hline
\end{tabular}

Cinco principales productos de importación (\% de las importaciones de mercancías)

\section{5}

Productos derivados del petróleo

Operaciones especiales no clasificadas

Vehículos automotores para pasajeros, excepto autobuses

Muebles, cojines, etc.

Productos y preparados comestibles, n.e.p.

Fuentes: Secretaría de la OMC. 


\section{LA AYUDA PARA EL COMERCIO EN SÍNTESIS 2013}

\begin{tabular}{|l|c|c|}
\hline \multicolumn{3}{|l|}{ INDICADORES COMERCIALES (RESULTADOS) } \\
\hline Indicador & 2005 & 2011 \\
\hline Crecimiento del PIB (\%) & 3,4 & 1,6 \\
\hline Número de exportadores & n.d. & n.d. \\
\hline Índice de concentración de las exportaciones (productos) (0 a 1) & n.d. & n.d. \\
\hline ACR sobre mercancías notificados a la OMC & n.d. & 2 \\
\hline AIE (servicios) notificados a la OMC & n.d. & 2 \\
\hline Sectores de servicios con compromisos en el marco del AGCS & 0 & 0 \\
\hline Aranceles (\%, 2006 et 2011) & & \\
\hline Importaciones: promedio aritmético de los aranceles NMF aplicados & 30,2 & 35,9 \\
\hline Importaciones: promedio ponderado de los aranceles NMF aplicados & n.d. & 20.2 \\
\hline Exportaciones: promedio ponderado de los aranceles impuestos & 0,3 & 0,1 \\
\hline por los importadores & $0.17,7$ & 77,3 \\
\hline Exportaciones: libres de derechos (en \%)
\end{tabular}

Fuentes: Naciones Unidas, base de datos Comtrade; Banco Mundial, base de datos sobre dinámica de las empresas de exportación; Banco Mundial, Indicadores del Desarrollo Mundial; OMC, perfiles comerciales y arancelarios.

Participación en las exportaciones por región (\%)

\begin{tabular}{|l|r|r|}
\hline & 2005 & 2010 \\
\hline África & 1,1 & 0,0 \\
\hline Asia & 0,9 & 2,2 \\
\hline Comunidad de Estados Independientes & 0,0 & 0,0 \\
\hline Europa & 29,7 & 12,2 \\
\hline Oriente Medio & 0,0 & 0,1 \\
\hline América del Norte & 67,2 & 81,4 \\
\hline América del Sury América Central & 1,0 & 3,7 \\
\hline
\end{tabular}

Fuentes: OMC, perfiles comerciales y arancelarios

Indicadores de facilitación del comercio
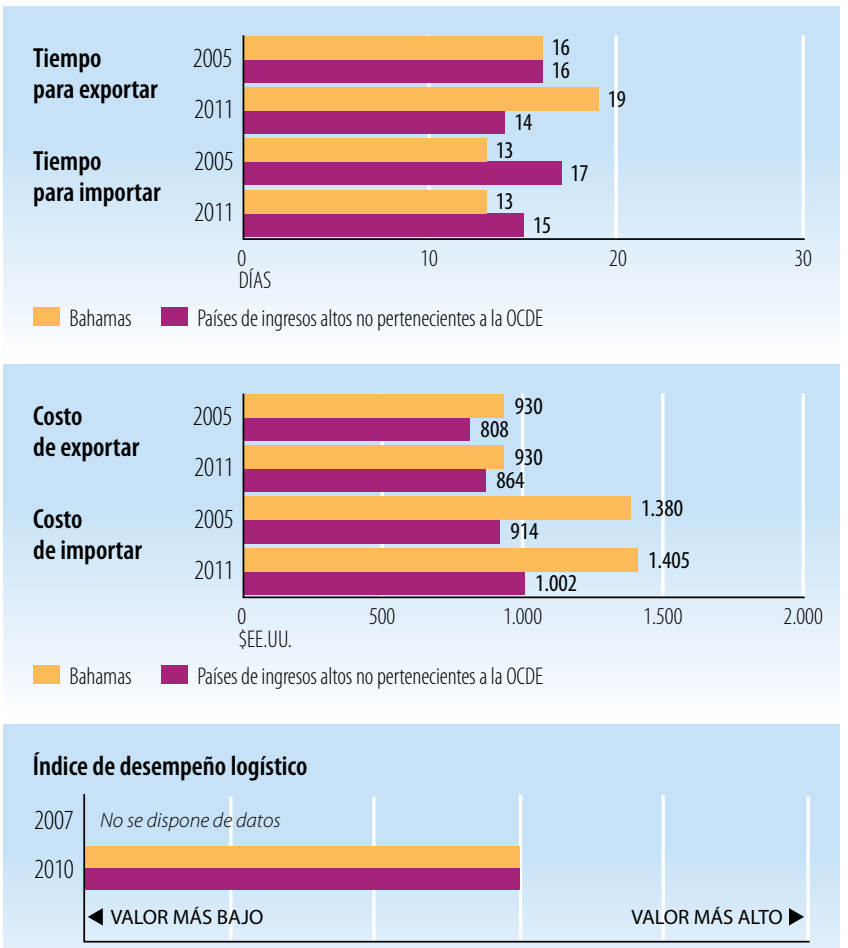

Bahamas

Países de ingresos altos no pertenecientes a la OCDE

Fuentes: Banco Mundial, Indicadores del Desarrollo Mundial.

\begin{tabular}{l|c|c|}
\hline \begin{tabular}{l} 
INDICADORES DE DESARROLLO (EFECTOS) \\
\hline Indicador
\end{tabular} & $\mathbf{2 0 0 5}$ & $\mathbf{2 0 1 0}$ \\
\hline Desempleo (\% de la fuerza de trabajo total) & 10,2 & 14,2 \\
\hline Población activa, mujeres (\% de la fuerza de trabajo total) & 48,4 & 48,3 \\
\hline AOD neta recibida (\% del INB) & n.d. & n.d. \\
\hline Derechos de importación percibidos (\% de los ingresos fiscales) & 47,2 & 32,8 \\
\hline Total del servicio de la deuda (\% de las exportaciones totales) & n.d. & n.d. \\
\hline Índice de desarrollo humano (0 a 1) & 0,77 & 0,77 \\
\hline
\end{tabular}

Fuentes: PNUD, indicadores internacionales sobre desarrollo humano; Banco Mundial, Indicadores del Desarrollo Mundial.

Producto interno bruto

PIB per cápita (PPA, dólares internacionales corrientes)
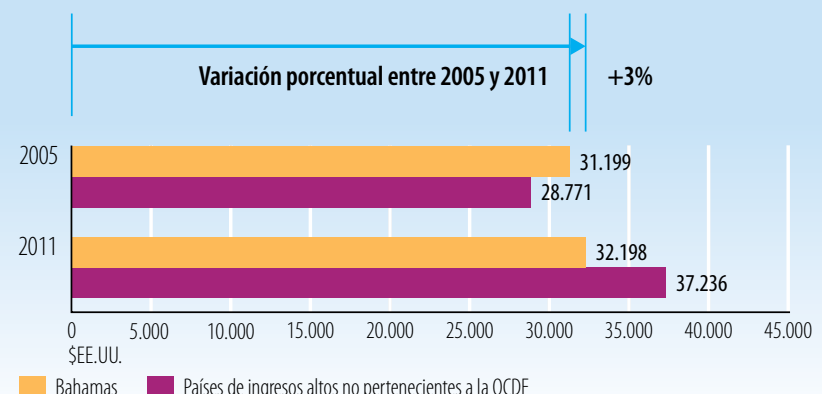

Bahamas Países de ingresos altos no pertenecientes a la OCDE

\section{PIB per cápita (\$巨E.UU. constantes de 2000)}
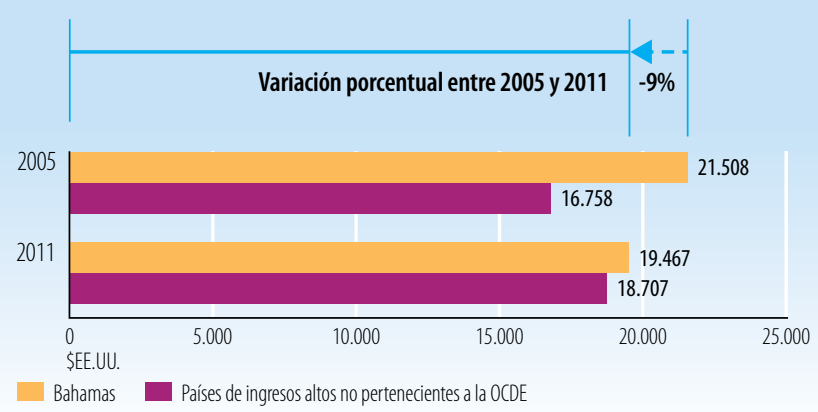

Fuentes: Banco Mundial, Indicadores del Desarrollo Mundial.

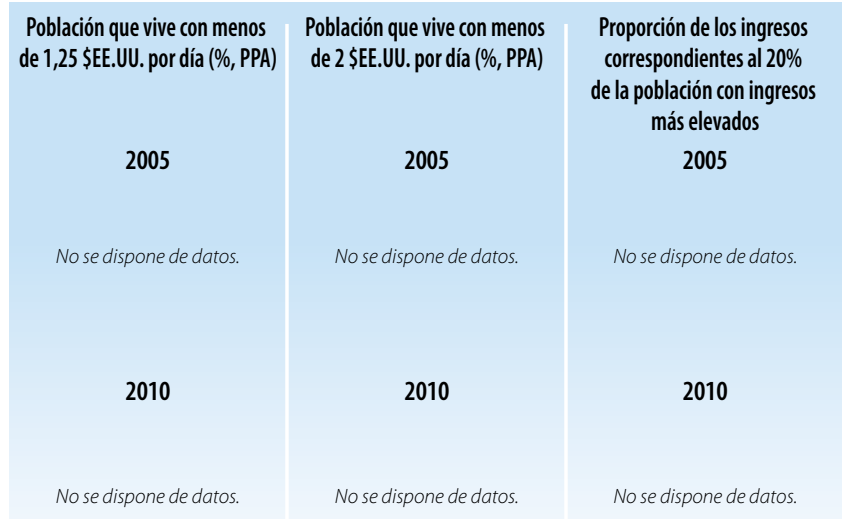

Fuentes: Banco Mundial, Indicadores del Desarrollo Mundial.

StatLink 엔 $h$ ttp://dx.doi.org/10.1787/888932844733 


\section{BANGLADESH}

\section{LA AYUDA PARA EL COMERCIO EN SINTTESIS 2013}

\section{Indicadores de la ayuda, el comercio y el desarrollo relativos a Bangladesh}

\begin{tabular}{|c|c|c|c|c|}
\hline \multicolumn{5}{|c|}{ INVERSIÓN Y FINANCIACIÓN (APORTES) } \\
\hline Indicador (millones de \$EE.UU. corrientes) & 2005 & 2008 & 2010 & $\Delta: 05-10(\%)$ \\
\hline Formación bruta de capital fijo & $14.784,4$ & $19.258,4$ & $24.500,9$ & $66 \%$ \\
\hline del cual: público & $3.740,8$ & $3.941,4$ & $5.032,9$ & $35 \%$ \\
\hline del cual: privado & $11.043,6$ & $15.317,0$ & $19.468,0$ & $76 \%$ \\
\hline \multicolumn{5}{|l|}{ Entrada de financiación externa } \\
\hline Entradas de IED & 813,3 & $1.009,6$ & 916,9 & $13 \%$ \\
\hline $\begin{array}{l}\text { Deuda externa a largo plazo y fondos } \\
\text { desembolsados por el FMI }\end{array}$ & 975,9 & $1.938,5$ & 962,7 & $-1 \%$ \\
\hline $\begin{array}{l}\text { Corrientes comerciales en condiciones no } \\
\text { concesionarias }\end{array}$ & 12,4 & 0,0 & 145,3 & $1073 \%$ \\
\hline Corrientes de Ayuda para el Comercio & 449,5 & 549,9 & 466,7 & $4 \%$ \\
\hline $\begin{array}{l}\text { Remesas de trabajadores y remuneración } \\
\text { de empleados }\end{array}$ & $4.314,5$ & $8.940,6$ & $10.851,9$ & $152 \%$ \\
\hline
\end{tabular}

Fuentes: OCDE, base de datos del SNPA del CAD sobre las actividades de ayuda; Banco Mundial, Indicadores del Desarrollo Mundial; Banco Mundial, estadísticas de la deuda internacional.

Desembolsos de la ayuda para el comercio, por sector (millones de \$EE.UU. corrientes)

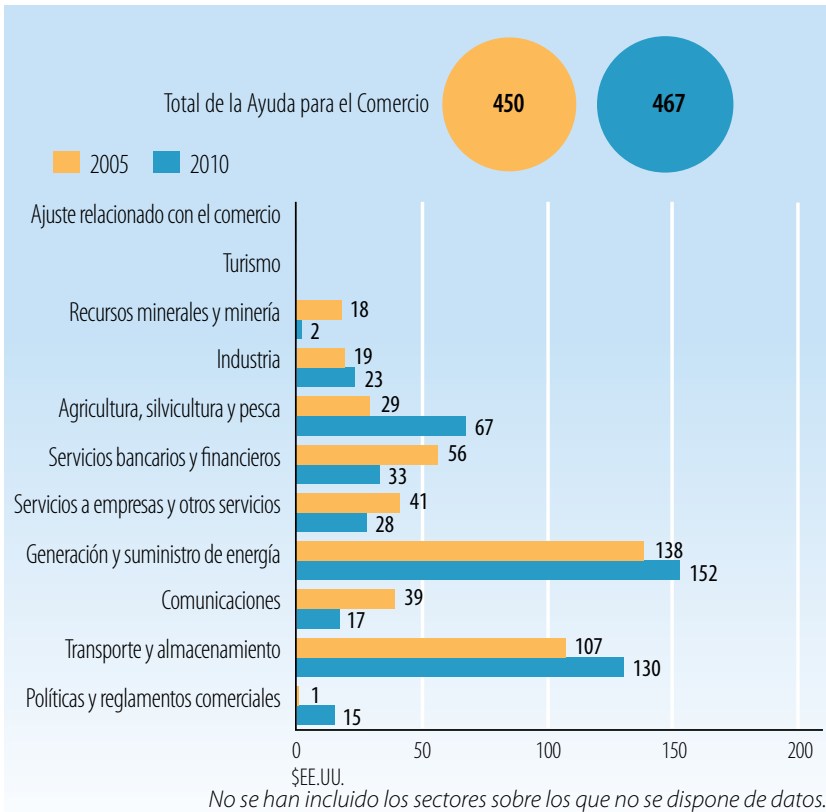

Fuentes: OCDE, base de datos del SNPA del CAD sobre las actividades de ayuda

Desembolsos de la ayuda para el comercio: principales donantes (millones de \$̦E.UU. corrientes)

\begin{tabular}{|l|c|c|c|}
\hline $\mathbf{2 0 0 5}$ & Valor & $\%$ & Principales donantes en 2005 \\
\hline Banco Mundial & 267,7 & 60 & \\
\hline Reino Unido & 43,1 & 10 & \\
\hline Alemania & 31,1 & 7 & $88 \%$ \\
\hline Dinamarca & 30,0 & 7 & \\
\hline Japón & 22,0 & 5 & \\
\hline $\mathbf{2 0 1 0}$ & Valor & $\%$ & Principales donantes en 2010 \\
\hline Banco Mundial & 143,3 & 31 & \\
\hline Japón & 58,3 & 12 & \\
\hline Corea, Rep. de & 50,1 & 11 & \\
\hline Banco Asiático de Desarrollo & 49,6 & 11 & $72 \%$ \\
\hline Canadá & 33,7 & 7 & \\
\hline
\end{tabular}

\section{INDICADORES COMERCIALES (PRODUCTOS)}

\section{Indicador}

$2005 \quad 2008 \quad 2011 \quad \Delta: 05-11(\%)$

Relación comercio/PIB (\%)

Exportaciones de servicios comerciales como

$\%$ de las exportaciones totales

Importaciones de servicios comerciales como

$\%$ de las importaciones totales

Productos intermedios distintos de los combustibles

(\% de las exportaciones de mercancías)

Productos intermedios distintos de los combustibles

(\% de las importaciones de mercancías)

\begin{tabular}{|l|l|l|l|}
\hline 40 & 52 & 57 & 17
\end{tabular}

Fuentes: Secretaría de la OMC.

Corrientes comerciales (millones de \$̦E.UU. corrientes)

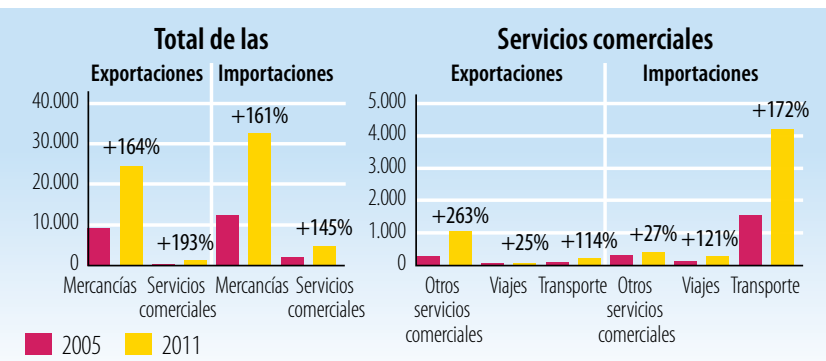

Fuentes: Secretaría de la OMC.

Cinco principales mercados de exportación de mercancías (\%)

\begin{tabular}{|l|r|r|r|}
\hline 2005 & $\%$ & 2011 & $\%$ \\
\hline UE (27) & 51 & & \\
\hline Estados Unidos & 29 & & \\
\hline Canadá & 4 & & No se dispone de datos. \\
\hline India & 2 & & \\
\hline Hong Kong, China & 1 & &
\end{tabular}

Fuentes: Secretaría de la OMC.

Cinco principales productos de exportación (\% de las exportaciones de mercancías)

\begin{tabular}{|c|c|c|}
\hline 2005 & $\%$ & 2011 \\
\hline $\begin{array}{l}\text { Otros artículos textiles y prendas de vestir, } \\
\text { n.e.p. }\end{array}$ & 28 & \\
\hline $\begin{array}{l}\text { Prendas de vestir para hombres y niños, } \\
\text { excepto las de punto }\end{array}$ & 25 & \\
\hline $\begin{array}{l}\text { Prendas de vestir para mujeres y niñas, } \\
\text { excepto las de punto }\end{array}$ & 11 & No se dispone de datos. \\
\hline $\begin{array}{l}\text { Prendas de vestir para hombres y niños, } \\
\text { de punto }\end{array}$ & 6 & \\
\hline Crustáceos, moluscos, etc. & 4 & \\
\hline
\end{tabular}

Cinco principales mercados de importación de mercancías (\%)

\begin{tabular}{|l|c|c|c|}
\hline 2005 & $\%$ & 2011 & \\
\hline China & 16 & & \\
\hline UE (27) & 11 & & \\
\hline India & 11 & & No se disponededatos. \\
\hline Kuwait & 7 & & \\
\hline Japón & 6 & \\
\hline Fuentes: Secretaría de la OMC. & &
\end{tabular}

Cinco principales productos de importación (\% de las importaciones de mercancías)

\begin{tabular}{l|r|r|r|}
\hline 2005 & $\%$ & 2011 & \\
\hline Productos derivados del petróleo & 9 & & \\
\hline Algodón & 5 & & \\
\hline Maquinaria textil y para trabajar cueros & 5 & & No se dispone de datos. \\
\hline $\begin{array}{l}\text { Equipos de telecomunicaciones y sus } \\
\text { partes, n.e.p. }\end{array}$ & 5 & \\
\hline Tejidos de algodón & 4 & \\
\hline Fuentes: Secretaría de la OMC. & &
\end{tabular}




\section{LA AYUDA PARA EL COMERCIO EN SÍNTESIS 2013}

\begin{tabular}{|c|c|c|}
\hline Indicador & 2005 & 2011 \\
\hline Crecimiento del PIB (\%) & 6,0 & 6,7 \\
\hline Número de exportadores & 5.610 & 7.694 \\
\hline Índice de concentración de las exportaciones (productos) (0 a 1) & 0,05 & n.d. \\
\hline ACR sobre mercancías notificados a la OMC & n.d. & 5 \\
\hline AIE (servicios) notificados a la OMC & n.d. & 0 \\
\hline Sectores de servicios con compromisos en el marco del AGCS & 9 & 9 \\
\hline \multicolumn{3}{|l|}{ Aranceles $(\%, 2006$ et 2011$)$} \\
\hline Importaciones: promedio aritmético de los aranceles NMF aplicados & 15,2 & 14,4 \\
\hline Importaciones: promedio ponderado de los aranceles NMF aplicados & n.d. & n.d. \\
\hline $\begin{array}{l}\text { Exportaciones: promedio ponderado de los aranceles impuestos } \\
\text { por los importadores }\end{array}$ & 4,9 & 4,4 \\
\hline Exportaciones: libres de derechos (en \%) & 69,3 & 72,5 \\
\hline
\end{tabular}

Fuentes: Naciones Unidas, base de datos Comtrade; Banco Mundial, base de datos sobre dinámica de las empresas de exportación; Banco Mundial, Indicadores del Desarrollo Mundial; OMC, perfiles comerciales y arancelarios.

Participación en las exportaciones por región (\%)

\begin{tabular}{|l|r|r|}
\hline África & 2005 & $\mathbf{2 0 1 0}$ \\
\hline Asia & 1,1 & n.d. \\
\hline Comunidad de Estados Independientes & 9,7 & n.d. \\
\hline Europa & 0,2 & n.d. \\
\hline Oriente Medio & 52,6 & n.d. \\
\hline América del Norte & 2,0 & n.d. \\
\hline América del Sury América Central & 32,6 & n.d. \\
\hline
\end{tabular}

Fuentes: OMC, perfiles comerciales y arancelarios

Indicadores de facilitación del comercio
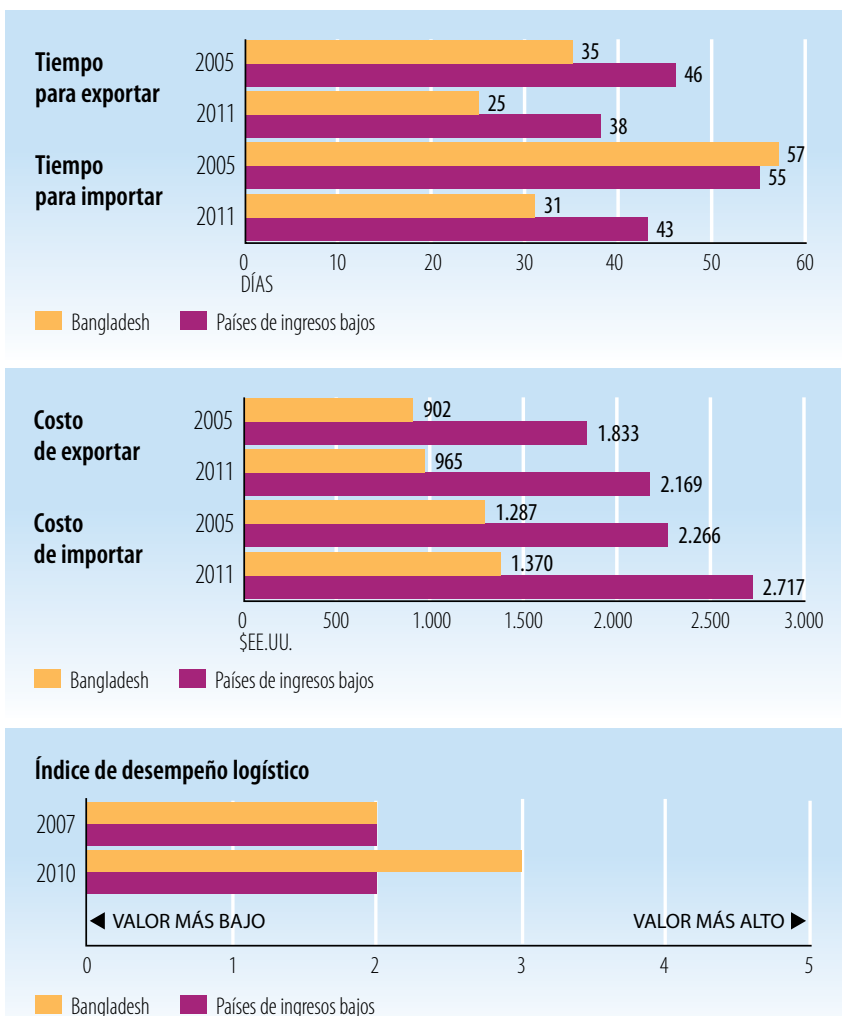

Fuentes: Banco Mundial, Indicadores del Desarrollo Mundial.

\begin{tabular}{|l|r|r|}
\hline INDICADORES DE DESARROLLO (EFECTOS) \\
\hline Indicador & 2005 & $\mathbf{2 0 1 0}$ \\
\hline Desempleo (\% de la fuerza de trabajo total) & 4,3 & 5,0 \\
\hline Población activa, mujeres (\% de la fuerza de trabajo total) & 38,4 & 39,9 \\
\hline AOD neta recibida (\% del INB) & 2,1 & 1,3 \\
\hline Derechos de importación percibidos (\% de los ingresos fiscales) & 42,5 & n.d. \\
\hline Total del servicio de la deuda (\% de las exportaciones totales) & 7,5 & 4,7 \\
\hline Índice de desarrollo humano (0 a 1) & 0,46 & 0,50 \\
\hline
\end{tabular}

Fuentes: PNUD, indicadores internacionales sobre desarrollo humano; Banco Mundial, Indicadores del Desarrollo Mundial.

Producto interno bruto

PIB per cápita (PPA, dólares internacionales corrientes)

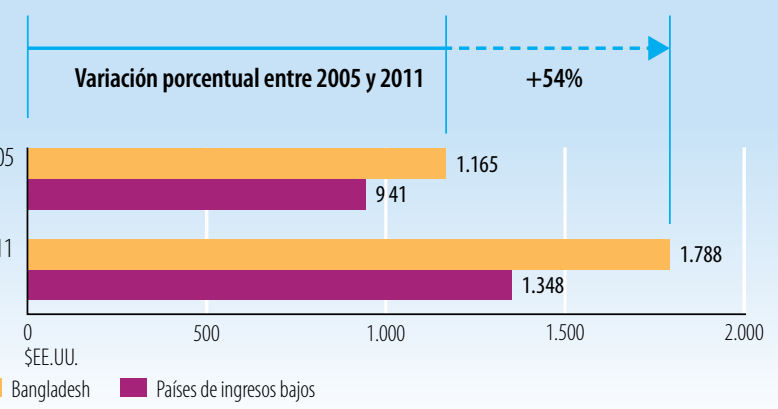

PIB per cápita (\$\$EE.UU. constantes de 2000)
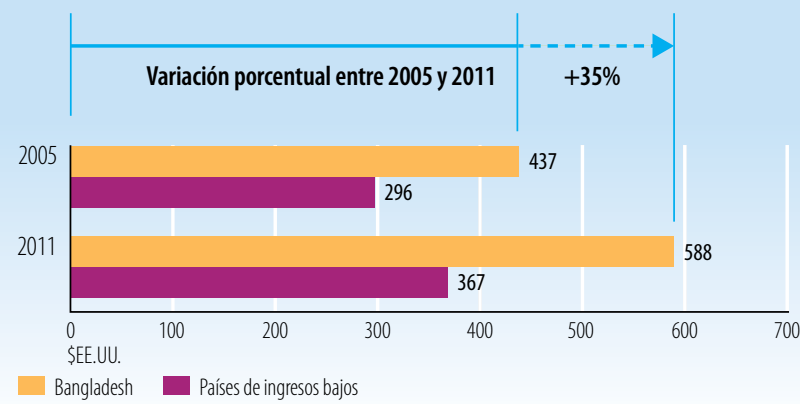

Fuentes: Banco Mundial, Indicadores del Desarrollo Mundial.

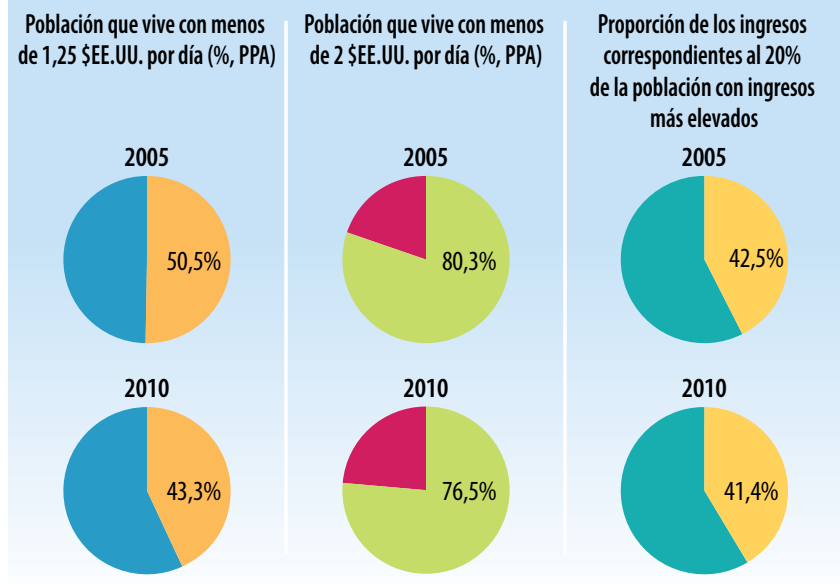

Fuentes: Banco Mundial, Indicadores del Desarrollo Mundial.

StatLink inils $h$ ttp://dx.doi.org/10.1787/888932844752 
Indicadores de la ayuda, el comercio y el desarrollo relativos a Barbados

\begin{tabular}{|c|c|c|c|c|}
\hline Indicador (millones de \$̦EE.UU. corrientes) & 2005 & 2008 & 2010 & $\Delta: 05-10(\%)$ \\
\hline Formación bruta de capital fijo & 720,9 & 826,8 & 601,2 & $-17 \%$ \\
\hline del cual: público & 0,9 & n.d. & n.d. & n.d. \\
\hline del cual: privado & 720,0 & n.d. & n.d. & n.d. \\
\hline \multicolumn{5}{|l|}{ Entrada de financiación externa } \\
\hline Entradas de IED & 238,3 & 462,0 & 668,8 & $181 \%$ \\
\hline $\begin{array}{l}\text { Deuda externa a largo plazo y fondos } \\
\text { desembolsados por el FMl }\end{array}$ & n.d. & n.d. & n.d. & n.d. \\
\hline $\begin{array}{l}\text { Corrientes comerciales en condiciones no } \\
\text { concesionarias }\end{array}$ & 0,0 & 0,0 & 46,7 & d.p.c. \\
\hline Corrientes de Ayuda para el Comercio & 0,6 & 0,6 & 10,3 & $1613 \%$ \\
\hline $\begin{array}{l}\text { Remesas de trabajadores y remuneración } \\
\text { de empleados }\end{array}$ & 134,8 & 101,2 & 123,0 & $-9 \%$ \\
\hline
\end{tabular}

Fuentes: OCDE, base de datos del SNPA del CAD sobre las actividades de ayuda; Banco Mundial, Indicadores del Desarrollo Mundial; Banco Mundial, estadísticas de la deuda internacional.

Desembolsos de la ayuda para el comercio, por sector (millones de \$̦EE.UU. corrientes)

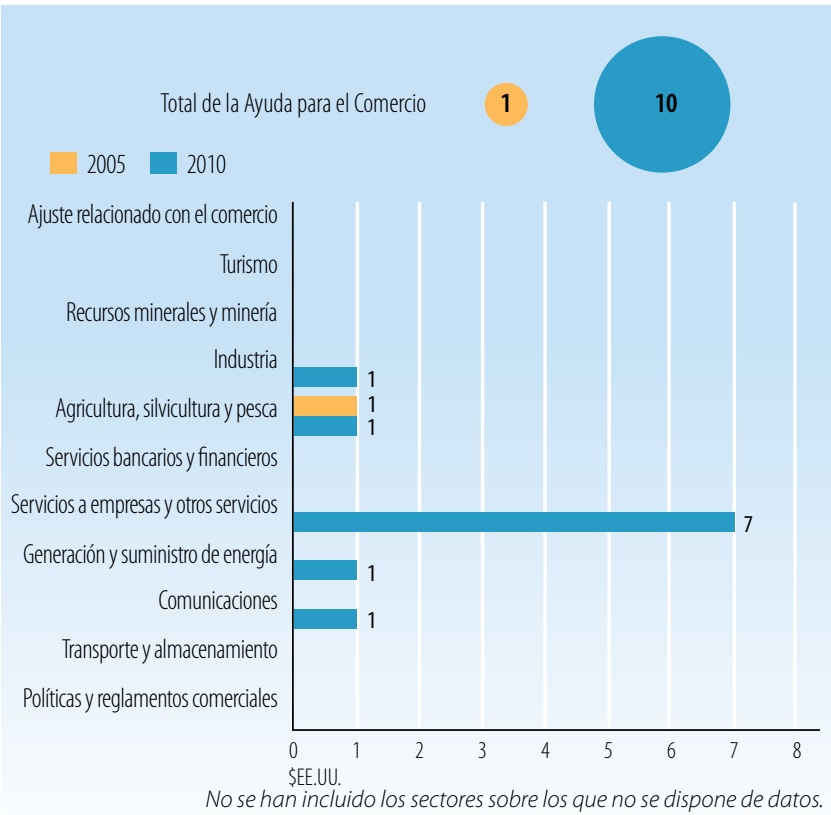

Fuentes: OCDE, base de datos del SNPA del CAD sobre las actividades de ayuda

Desembolsos de la ayuda para el comercio: principales donantes (millones de \$EE.UU. corrientes)

\begin{tabular}{|l|r|r|}
\hline $\mathbf{2 0 0 5}$ & Valor & $\%$ \\
\hline Japón & 0,5 & 85 \\
\hline Canadá & 0,1 & 14 \\
\hline Estados Unidos & 0,0 & 1 \\
\hline
\end{tabular}

Principales donantes en 2005

\begin{tabular}{|l|r|r|}
\hline $\mathbf{2 0 1 0}$ & Valor & $\%$ \\
\hline Instituciones de la UE & 8,5 & 82 \\
\hline BID & 1,4 & 13 \\
\hline Canadá & 0,2 & 2 \\
\hline Australia & 0,1 & 1 \\
\hline Alemania & 0,1 & 1 \\
\hline
\end{tabular}

Principales donantes en 2010

Fuentes: OCDE, base de datos del SNPA del CAD sobre las actividades de ayuda.

\section{INDICADORES COMERCIALES (PRODUCTOS)}

\section{Indicador}

$2005 \quad 2008 \quad 2011 \quad \Delta: 05-11(\%)$

Relación comercio/PIB (\%)

Exportaciones de servicios comerciales como

$\%$ de las exportaciones totales

Importaciones de servicios comerciales como

$\%$ de las importaciones totales

Productos intermedios distintos de los combustibles

(\% de las exportaciones de mercancías)

Productos intermedios distintos de los combustibles

(\% de las importaciones de mercancías)

\begin{tabular}{|l|l|l|l|}
130 & 131 & 116 & -14 \\
\hline
\end{tabular}

\begin{tabular}{|l|l|l|l|}
80 & 79 & 77 & -3
\end{tabular}

\begin{tabular}{|l|l|r|r|}
29 & 27 & 29 & 1
\end{tabular}

\begin{tabular}{|l|l|l|l|}
27 & 25 & 17 & -10 \\
\hline
\end{tabular}

\begin{tabular}{|l|l|r|r|}
29 & 33 & 28 & -1
\end{tabular}

Fuentes: Secretaría de la OMC.

Corrientes comerciales (millones de \$EE.UU. corrientes)

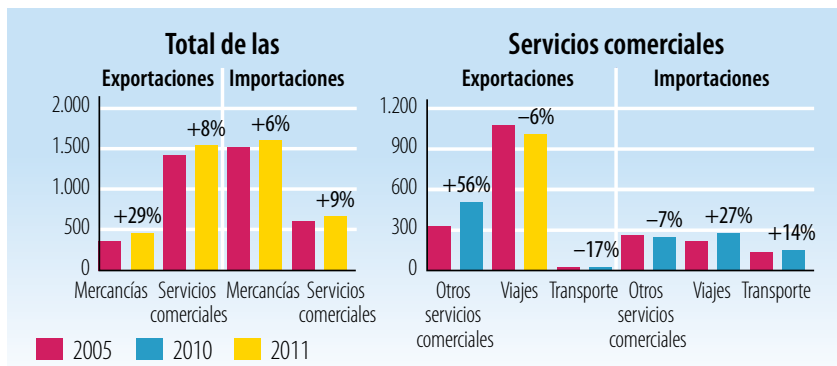

Fuentes: Secretaría de la OMC.

Cinco principales mercados de exportación de mercancías (\%)

\begin{tabular}{|l|r|l|r|}
\hline 2005 & $\%$ & 2010 & $\%$ \\
\hline Estados Unidos & 13 & Estados Unidos & 25 \\
\hline UE (27) & 12 & UE (27) & 20 \\
\hline Trinidady Tabago & 11 & Trinidad y Tabago & 8 \\
\hline Santa Lucía & 6 & Santa Lucía & 6 \\
\hline Jamaica & 6 & Jamaica & 6
\end{tabular}

Fuentes: Secretaría de la OMC.

Cinco principales productos de exportación (\% de las exportaciones de mercancías)

\begin{tabular}{|l|r|l|c|}
\hline 2005 & $\%$ & 2011 & $\%$ \\
\hline Productos derivados del petróleo & 27 & Productos derivados del petróleo & 36 \\
\hline Bebidas alcohólicas & 9 & Medicamentos & 14 \\
\hline Azúcares, melaza y miel & 6 & Bebidas alcohólicas & 9 \\
\hline Medicamentos & 5 & Aceites de petróleo, crudos & 4 \\
\hline Cal, cemento y materiales de construcción & 5 & Impresos & 2 \\
\hline
\end{tabular}

Fuentes: Secretaría de la OMC.

Cinco principales mercados de importación de mercancías (\%)

\begin{tabular}{|l|r|l|r|}
\hline 2005 & $\%$ & 2010 & $\%$ \\
\hline Estados Unidos & 36 & Estados Unidos & 44 \\
\hline Trinidad y Tabago & 21 & UE (27) & 15 \\
\hline UE (27) & 13 & Trinidad y Tabago & 7 \\
\hline Japón & 8 & China & 5 \\
\hline Canadá & 3 & Canadá & 4
\end{tabular}

Fuentes: Secretaría de la OMC.

Cinco principales productos de importación (\% de las importaciones de mercancías)

\begin{tabular}{|c|c|c|c|}
\hline 2005 & $\%$ & 2011 & $\%$ \\
\hline Productos derivados del petróleo & 17 & Productos derivados del petróleo & 26 \\
\hline $\begin{array}{l}\text { Vehículos automotores para pasajeros, } \\
\text { excepto autobuses }\end{array}$ & 7 & Medicamentos & 3 \\
\hline $\begin{array}{l}\text { Equipos de telecomunicaciones y sus } \\
\text { partes, n.e.p. }\end{array}$ & 4 & $\begin{array}{l}\text { Vehículos automotores para pasajeros, } \\
\text { excepto autobuses }\end{array}$ & 2 \\
\hline Medicamentos & 3 & $\begin{array}{l}\text { Equipos de telecomunicaciones y sus } \\
\text { partes, n.e.p. }\end{array}$ & 2 \\
\hline Joyas y objetos de oro o plata, n.e.p. & 2 & Artículos, n.e.p., de materiales plásticos & 2 \\
\hline
\end{tabular}

Fuentes: Secretaría de la OMC. 


\section{LA AYUDA PARA EL COMERCIO EN SINNTESIS 2013}

\section{INDICADORES COMERCIALES (RESULTADOS)}

Indicador

Crecimiento del PIB (\%)

Número de exportadores

Índice de concentración de las exportaciones (productos) ( 0 a 1$)$

ACR sobre mercancías notificados a la OMC

AIE (servicios) notificados a la OMC

Sectores de servicios con compromisos en el marco del AGCS

\section{Aranceles (\%, 2006 et 2011)}

\begin{tabular}{l|l|l|l|} 
Importaciones: promedio aritmético de los aranceles NMF aplicados & 13,5 & 10,7
\end{tabular}

\begin{tabular}{ll|l}
\hline Importaciones: promedio ponderado de los aranceles NMF aplicados & n.d. & 14,7
\end{tabular}

Exportaciones: promedio ponderado de los aranceles impuestos

por los importadores

Exportaciones: libres de derechos (en \%)

$0,3 \quad 0,0$

$97,8 \quad 99,9$

Fuentes: Naciones Unidas, base de datos Comtrade; Banco Mundial, base de datos sobre dinámica de las empresas de exportación; Banco Mundial, Indicadores del Desarrollo Mundial; OMC, perfiles comerciales y arancelarios.

Participación en las exportaciones por región (\%)

\begin{tabular}{|l|r|r|}
\hline & 2005 & 2010 \\
\hline África & 0,1 & 0,1 \\
\hline Asia & 0,9 & 1,7 \\
\hline Comunidad de Estados Independientes & 0,0 & 0,0 \\
\hline Europa & 12,7 & 13,3 \\
\hline Oriente Medio & 0,1 & 0,1 \\
\hline América del Norte & 15,5 & 15,6 \\
\hline América del Sury América Central & 44,4 & 43,5 \\
\hline
\end{tabular}

Fuentes: OMC, perfiles comerciales y arancelarios

Indicadores de facilitación del comercio

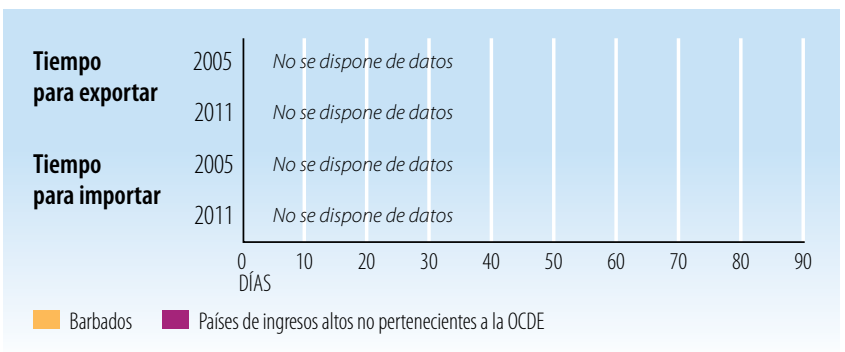

\begin{tabular}{|c|c|c|}
\hline \multirow{2}{*}{$\begin{array}{l}\text { Costo } \\
\text { de exportar }\end{array}$} & 2005 & No se dispone de datos \\
\hline & 2011 & No se dispone de datos \\
\hline \multirow{3}{*}{$\begin{array}{l}\text { Costo } \\
\text { de importar }\end{array}$} & 2005 & No se dispone de datos \\
\hline & 2011 & No se dispone de datos \\
\hline & \multicolumn{2}{|c|}{ \$EE.UU. } \\
\hline Barbados & País & gresos altos no pertenecientes a la OCDE \\
\hline
\end{tabular}

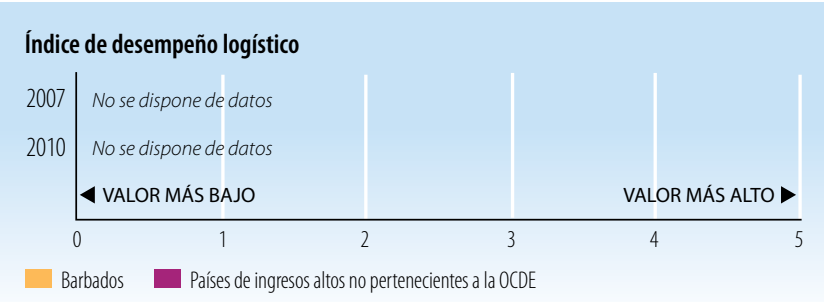

Fuentes: Banco Mundial, Indicadores del Desarrollo Mundial.

\begin{tabular}{|l|c|c|}
\hline INDICADORES DE DESARROLLO (EFECTOS) & \\
\hline Indicador & $\mathbf{2 0 0 5}$ & $\mathbf{2 0 1 0}$ \\
\hline Desempleo (\% de la fuerza de trabajo total) & 9,1 & 8,1 \\
\hline Población activa, mujeres (\% de la fuerza de trabajo total) & 46,8 & 46,7 \\
\hline AOD neta recibida (\% del INB) & $-0,1$ & 0,3 \\
\hline Derechos de importación percibidos (\% de los ingresos fiscales) & n.d. & n.d. \\
\hline Total del servicio de la deuda (\% de las exportaciones totales) & n.d. & n.d. \\
\hline Índice de desarrollo humano (0 a 1) & 0,79 & 0,79 \\
\hline
\end{tabular}

Fuentes: PNUD, indicadores internacionales sobre desarrollo humano; Banco Mundial, Indicadores del Desarrollo Mundial.

Producto interno bruto

PIB per cápita (PPA, dólares internacionales corrientes)

Variación porcentual entre 2005 y 2011 No se dispone de datos

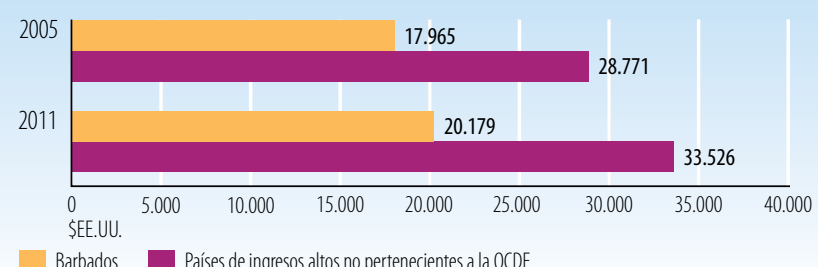

Barbados Países de ingresos altos no pertenecientes a la OCDE

PIB per cápita (\$\$EE.UU. constantes de 2000)

Variación porcentual entre 2005 y 2011 No se dispone de datos

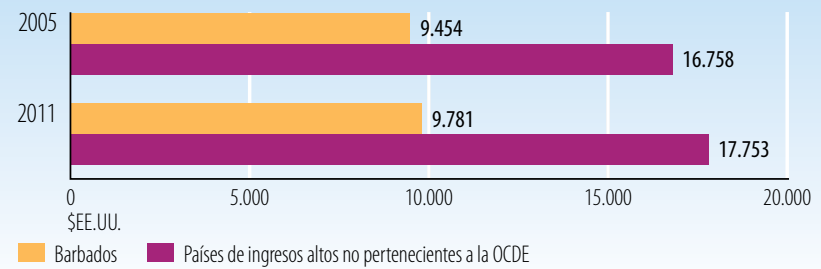

Fuentes: Banco Mundial, Indicadores del Desarrollo Mundial.

\begin{tabular}{|c|c|c|}
\hline $\begin{array}{l}\text { Población que vive con menos } \\
\text { de } 1,25 \$ \text { EE.UU. por día }(\%, P P A)\end{array}$ & $\begin{array}{l}\text { Población que vive con menos } \\
\text { de } 2 \text { \$EE.UU. por día }(\%, P P A)\end{array}$ & $\begin{array}{c}\text { Proporción de los ingresos } \\
\text { correspondientes al } 20 \% \\
\text { de la población con ingresos } \\
\text { más elevados }\end{array}$ \\
\hline 2005 & 2005 & 2005 \\
\hline No se dispone de datos. & No se dispone de datos. & No se dispone de datos. \\
\hline 2010 & 2010 & 2010 \\
\hline No se dispone de datos. & No se dispone de datos. & No se dispone de datos. \\
\hline
\end{tabular}

Fuentes: Banco Mundial, Indicadores del Desarrollo Mundial.

StatLink 青15 $h$ ttp://dx.doi.org/10.1787/888932844771 
Indicadores de la ayuda, el comercio y el desarrollo relativos a Belice

\begin{tabular}{|c|c|c|c|c|}
\hline Indicador (millones de \$̦EE.UU. corrientes) & 2005 & 2008 & 2010 & $\Delta: 05-10(\%)$ \\
\hline Formación bruta de capital fijo & 206,3 & 345,9 & n.d. & n.d. \\
\hline del cual: público & n.d. & n.d. & n.d. & n.d. \\
\hline del cual: privado & n.d. & n.d. & n.d. & n.d. \\
\hline \multicolumn{5}{|l|}{ Entrada de financiación externa } \\
\hline Entradas de IED & 126,9 & 169,7 & 96,4 & $-24 \%$ \\
\hline $\begin{array}{l}\text { Deuda externa a largo plazo y fondos } \\
\text { desembolsados por el FMl }\end{array}$ & 212,6 & 41,3 & 31,0 & $-85 \%$ \\
\hline $\begin{array}{l}\text { Corrientes comerciales en condiciones no } \\
\text { concesionarias }\end{array}$ & 0,5 & 0,0 & 4,3 & $701 \%$ \\
\hline Corrientes de Ayuda para el Comercio & 1,5 & 10,8 & 12,8 & $758 \%$ \\
\hline $\begin{array}{l}\text { Remesas de trabajadores y remuneración } \\
\text { de empleados }\end{array}$ & 46,1 & 78,1 & 79,5 & $73 \%$ \\
\hline
\end{tabular}

Fuentes: OCDE, base de datos del SNPA del CAD sobre las actividades de ayuda; Banco Mundial, Indicadores del Desarrollo Mundial; Banco Mundial, estadísticas de la deuda internacional.

Desembolsos de la ayuda para el comercio, por sector (millones de \$EE.UU. corrientes)

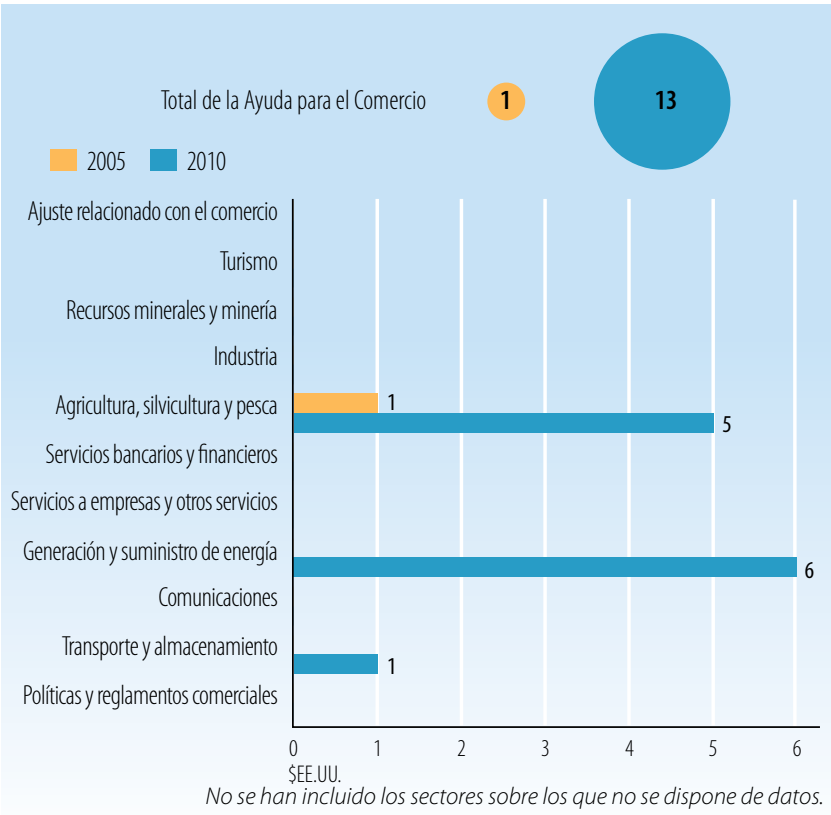

Fuentes: OCDE, base de datos del SNPA del CAD sobre las actividades de ayuda

Desembolsos de la ayuda para el comercio: principales donantes (millones de \$EE.UU. corrientes)

\begin{tabular}{|l|c|c|c|}
\hline $\mathbf{2 0 0 5}$ & Valor & $\%$ & Principales donantes en 2005 \\
\hline Instituciones de la UE & 0,7 & 50 & \\
\hline Japón & 0,7 & 44 & $100 \%$ \\
\hline Estados Unidos & 0,1 & 4 & \\
\hline Austria & 0,0 & 2 & \\
\hline & & & Principales donantes en 2010 \\
\hline $\mathbf{2 0 1 0}$ & Valor & $\%$ & \\
\hline Japón & 6,1 & 48 & \\
\hline Instituciones de la UE & 5,3 & 42 & $98 \%$ \\
\hline OFID & 0,5 & 4 & \\
\hline Kuwait & 0,4 & 3 & \\
\hline Estados Unidos & 0,2 & 1 & \\
\hline
\end{tabular}

Fuentes: OCDE, base de datos del SNPA del CAD sobre las actividades de ayuda.

\section{INDICADORES COMERCIALES (PRODUCTOS)}

\section{Indicador}

$2005 \quad 2008 \quad 2011 \quad \Delta: 05-11(\%)$

Relación comercio/PIB (\%)

Exportaciones de servicios comerciales como

$\%$ de las exportaciones totales

Importaciones de servicios comerciales como

$\%$ de las importaciones totales

Productos intermedios distintos de los combustibles

(\% de las exportaciones de mercancías)

Productos intermedios distintos de los combustibles

(\% de las importaciones de mercancías)

\begin{tabular}{|l|l|l|l|}
118 & 131 & 126 & 8 \\
\hline
\end{tabular}

\begin{tabular}{l|l|l|l|}
47 & 43 & 34 & -12 \\
\hline
\end{tabular}

\begin{tabular}{|l|l|l|l|}
\hline 21 & 17 & 17 & -4 \\
\hline
\end{tabular}

\begin{tabular}{l|l|l|l}
21 & 14 & n.d.
\end{tabular}

\begin{tabular}{l|l|l|}
32 & 28 & n.d.
\end{tabular}

Fuentes: Secretaría de la OMC.

Corrientes comerciales (millones de \$EE.UU. corrientes)

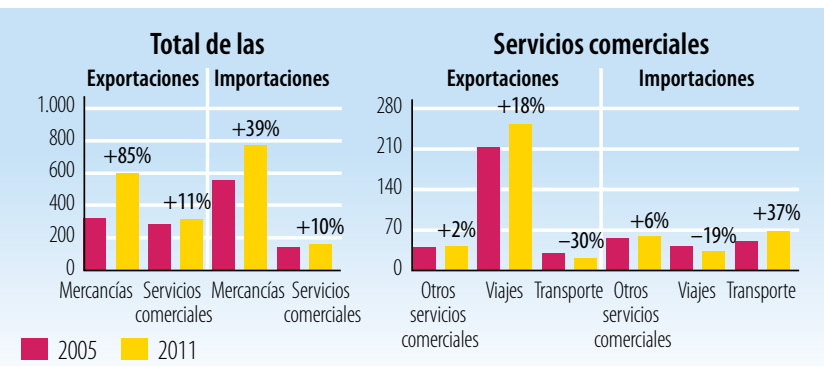

Fuentes: Secretaría de la OMC

Cinco principales mercados de exportación de mercancías (\%)

\begin{tabular}{|l|r|l|r|}
\hline 2005 & $\%$ & 2010 & $\%$ \\
\hline Estados Unidos & 54 & Estados Unidos & 49 \\
\hline UE (27) & 27 & UE (27) & 31 \\
\hline Trinidady Tabago & 5 & Costa Rica & 4 \\
\hline Jamaica & 5 & Japón & 3 \\
\hline México & 4 & México & 3
\end{tabular}

Fuentes: Secretaría de la OMC.

Cinco principales productos de exportación (\% de las exportaciones de mercancías)

\begin{tabular}{|c|c|c|c|}
\hline 2005 & $\%$ & 2010 & $\%$ \\
\hline Jugos de frutas o legumbres & 26 & Aceites de petróleo, crudos & 36 \\
\hline Crustáceos, moluscos, etc. & 20 & $\begin{array}{l}\text { Frutas y nueces, excepto nueces } \\
\text { oleaginosas }\end{array}$ & 19 \\
\hline $\begin{array}{l}\text { Frutas y nueces, excepto nueces } \\
\text { oleaginosas }\end{array}$ & 18 & Jugos de frutas o legumbres & 15 \\
\hline Azúcares, melaza y miel & 17 & Azúcares, melaza y miel & 12 \\
\hline $\begin{array}{l}\text { Prendas de vestir para hombres y niños, } \\
\text { de punto }\end{array}$ & 8 & Crustáceos, moluscos, etc. & 10 \\
\hline
\end{tabular}

Cinco principales mercados de importación de mercancías (\%)

\begin{tabular}{|l|r|l|c|}
\hline 2005 & $\%$ & 2010 & $\%$ \\
\hline Estados Unidos & 40 & Estados Unidos & 48 \\
\hline Cuba & 15 & México & 10 \\
\hline México & 12 & China & 10 \\
\hline UE (27) & 7 & Guatemala & 8 \\
\hline Guatemala & 7 & Panamá & 5 \\
\hline
\end{tabular}

Fuentes: Secretaría de la OMC.

Cinco principales productos de importación (\% de las importaciones de mercancías)

2005

\begin{tabular}{|l|l|l|l|}
\hline Productos derivados del petróleo & 20 & Productos derivados del petróleo & 15
\end{tabular}

\begin{tabular}{ll|l|l|l} 
Equipos de telecomunicaciones y sus & 4 & Operaciones especiales no clasificadas
\end{tabular}

partes, n.e.p.

Artículos, n.e.p., de materiales plásticos 3 Calzado

\begin{tabular}{|l|l|l|} 
Productos y preparados comestibles, n.e.p. & 3 & Papeles y cartones recortados, etc.
\end{tabular}

Pienso para animales $\quad 2$ Prendas de vestir para hombres y niños,

Fuentes: Secretaría de la OMC. 


\section{LA AYUDA PARA EL COMERCIO EN SIINTESIS 2013}

\begin{tabular}{|l|c|c|}
\hline \begin{tabular}{l} 
INDICADORES COMERCIALES (RESULTADOS) \\
\hline Indicador
\end{tabular} & 2005 & 2011 \\
\hline Crecimiento del PIB (\%) & 3,0 & 2,0 \\
\hline Número de exportadores & n.d. & n.d. \\
\hline Índice de concentración de las exportaciones (productos) (0 a 1) & 0,12 & 0,17 \\
\hline ACR sobre mercancías notificados a la OMC & n.d. & 2 \\
\hline AlE (servicios) notificados a la OMC & n.d. & 2 \\
\hline Sectores de servicios con compromisos en el marco del AGCS & 17 & 17 \\
\hline Aranceles (\%, 2006 et 2011) & & \\
\hline Importaciones: promedio aritmético de los aranceles NMF aplicados & 10,8 & 11,0 \\
\hline Importaciones: promedio ponderado de los aranceles NMF aplicados & n.d. & 15,5 \\
\hline Exportaciones: promedio ponderado de los aranceles impuestos & 16,2 & 1,2 \\
\hline por los importadores & 63,5 & 91,1 \\
\hline Exportaciones: libres de derechos (en \%) & & \\
\hline
\end{tabular}

Fuentes: Naciones Unidas, base de datos Comtrade; Banco Mundial, base de datos sobre dinámica de las empresas de exportación; Banco Mundial, Indicadores del Desarrollo Mundial; OMC, perfiles comerciales y arancelarios.

Participación en las exportaciones por región (\%)

\begin{tabular}{|l|r|r|}
\hline & 2005 & 2010 \\
\hline África & 0,0 & 0,0 \\
\hline Asia & 1,9 & 3,4 \\
\hline Comunidad de Estados Independientes & 0,0 & 0,0 \\
\hline Europa & 27,0 & 31,3 \\
\hline Oriente Medio & 0,4 & 0,3 \\
\hline América del Norte & 58,3 & 52,2 \\
\hline América del Sury América Central & 12,4 & 12,7 \\
\hline
\end{tabular}

Fuentes: OMC, perfiles comerciales y arancelarios

Indicadores de facilitación del comercio
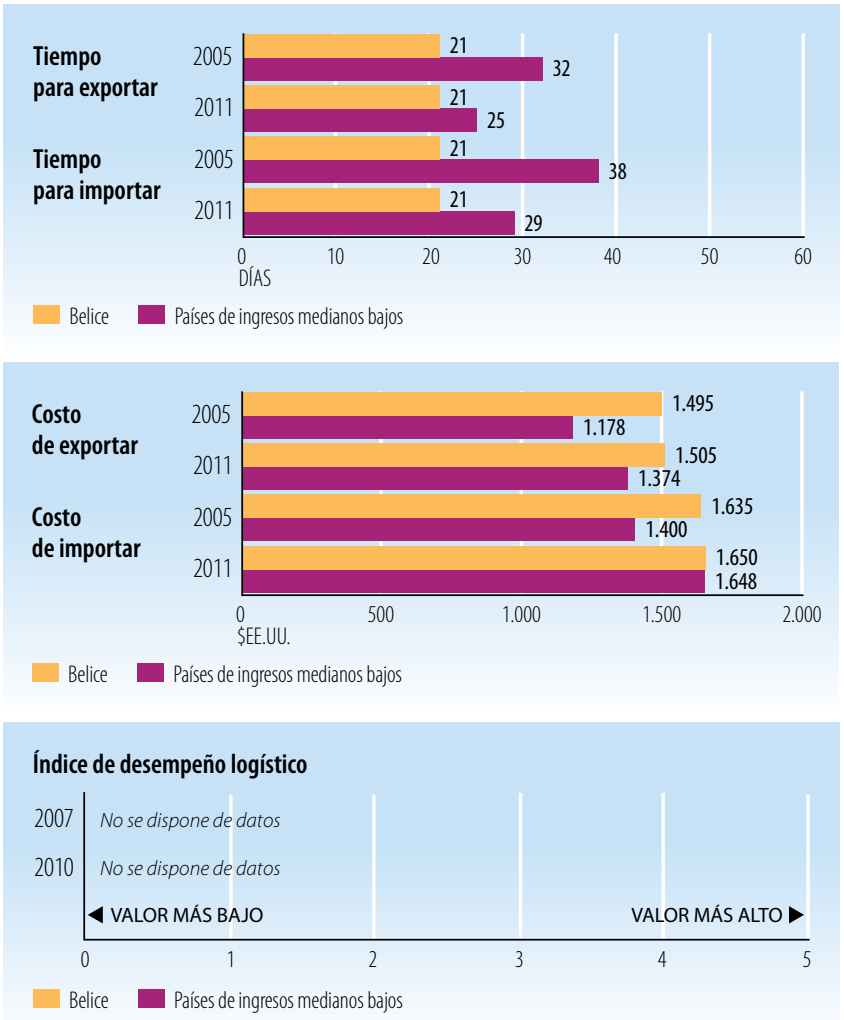

Fuentes: Banco Mundial, Indicadores del Desarrollo Mundial.

\begin{tabular}{l|c|c|}
\hline INDICADORES DE DESARROLLO (EFECTOS) \\
\hline Indicador & $\mathbf{2 0 0 5}$ & $\mathbf{2 0 1 0}$ \\
\hline Desempleo (\% de la fuerza de trabajo total) & 11,0 & 8,2 \\
\hline Población activa, mujeres (\% de la fuerza de trabajo total) & 35,9 & 37,5 \\
\hline AOD neta recibida (\% del INB) & 1,2 & 2,0 \\
\hline Derechos de importación percibidos (\% de los ingresos fiscales) & n.d. & n.d. \\
\hline Total del servicio de la deuda (\% de las exportaciones totales) & 36,5 & 12,1 \\
\hline Índice de desarrollo humano (0 a 1) & 0,69 & 0,70 \\
\hline
\end{tabular}

Fuentes: PNUD, indicadores internacionales sobre desarrollo humano; Banco Mundial, Indicadores del Desarrollo Mundial.

Producto interno bruto

PIB per cápita (PPA, dólares internacionales corrientes)

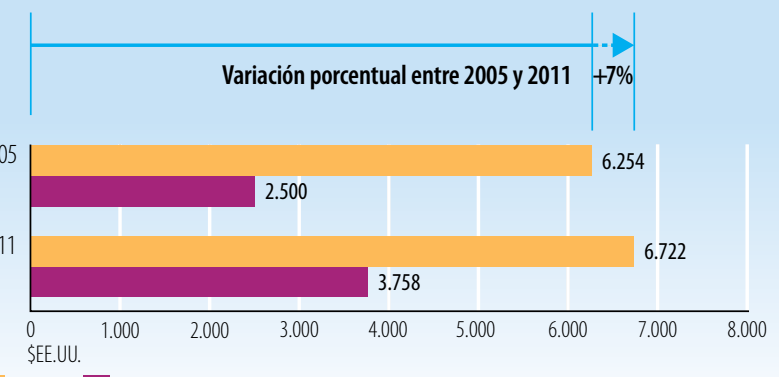

Belice Países de ingresos medianos bajos

PIB per cápita (\$EE.UU. constantes de 2000)
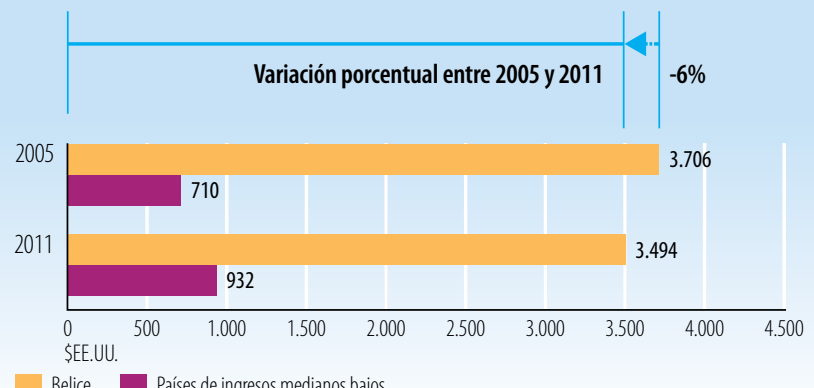

Belice Países de ingresos medianos bajos

Fuentes: Banco Mundial, Indicadores del Desarrollo Mundial.

\begin{tabular}{c|c|c}
$\begin{array}{c}\text { Población que vive con menos } \\
\text { de 1,25 \$EE.UU. por día (\%, PPA) }\end{array}$ & $\begin{array}{c}\text { Población que vive con menos } \\
\text { de 2 \$EE.UU. por día (\%, PPA) }\end{array}$ & $\begin{array}{c}\text { Proporción de los ingresos } \\
\text { correspondientes al 20\% } \\
\text { de la población con ingresos } \\
\text { más elevados }\end{array}$ \\
\hline 2005 & 2005 & 2005 \\
\hline No se dispone de datos. & No se dispone de datos. & \\
\hline & & \\
\hline 2010 & 2010 & 2010 \\
\hline No se dispone de datos. & No se dispone de datos. & \\
\hline
\end{tabular}

Fuentes: Banco Mundial, Indicadores del Desarrollo Mundial.

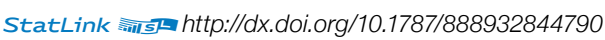




\begin{tabular}{|c|c|c|c|c|}
\hline \multicolumn{5}{|c|}{ INVERSIÓN Y FINANCIACIÓN (APORTES) } \\
\hline Indicador (millones de \$̦EE.UU. corrientes) & 2005 & 2008 & 2010 & $\Delta: 05-10(\%)$ \\
\hline Formación bruta de capital fijo & 811,2 & $1.382,8$ & $1.710,3$ & $111 \%$ \\
\hline del cual: público & 286,8 & 387,5 & 652,5 & $127 \%$ \\
\hline del cual: privado & 524,4 & 995,4 & $1.057,7$ & $102 \%$ \\
\hline \multicolumn{5}{|l|}{ Entrada de financiación externa } \\
\hline Entradas de IED & 53,0 & 169,8 & 110,9 & $109 \%$ \\
\hline $\begin{array}{l}\text { Deuda externa a largo plazo y fondos } \\
\text { desembolsados por el FMl }\end{array}$ & 98,0 & 162,2 & 209,1 & $113 \%$ \\
\hline $\begin{array}{l}\text { Corrientes comerciales en condiciones no } \\
\text { concesionarias }\end{array}$ & 0,0 & 0,0 & 0,0 & $0 \%$ \\
\hline Corrientes de Ayuda para el Comercio & 66,8 & 182,8 & 184,9 & $177 \%$ \\
\hline $\begin{array}{l}\text { Remesas de trabajadores y remuneración } \\
\text { de empleados }\end{array}$ & 172,7 & 251,3 & 248,1 & $44 \%$ \\
\hline
\end{tabular}

Fuentes: OCDE, base de datos del SNPA del CAD sobre las actividades de ayuda; Banco Mundial, Indicadores del Desarrollo Mundial; Banco Mundial, estadísticas de la deuda internacional.

Desembolsos de la ayuda para el comercio, por sector (millones de \$EE.UU. corrientes)

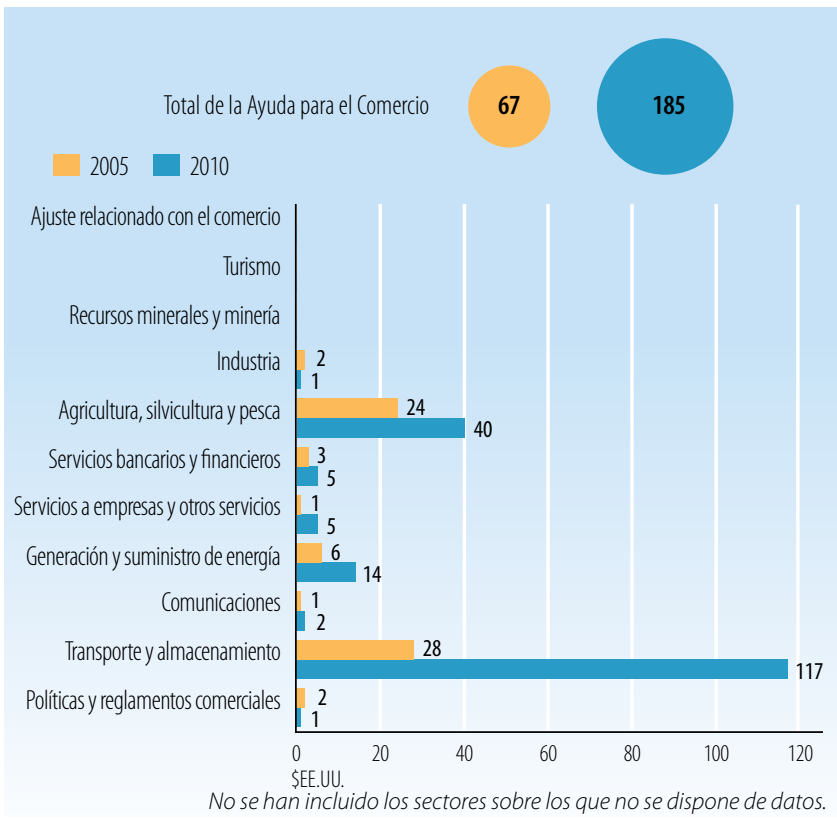

Fuentes: OCDE, base de datos del SNPA del CAD sobre las actividades de ayuda

Desembolsos de la ayuda para el comercio: principales donantes (millones de \$̦E.UU. corrientes)

\begin{tabular}{|l|c|c|c|}
\hline $\mathbf{2 0 0 5}$ & Valor & $\%$ & Principales donantes en 2005 \\
\hline Instituciones de la UE & 16,7 & 25 & \\
\hline Banco Mundial & 13,1 & 20 & $83 \%$ \\
\hline Dinamarca & 10,7 & 16 & \\
\hline Banco Africano de Desarrollo & 9,0 & 13 & \\
\hline Japón & 6,0 & 9 & Principales donantes en 2010 \\
\hline $\mathbf{2 0 1 0}$ & Valor & $\%$ & \\
\hline Estados Unidos & 57,6 & 31 & \\
\hline Instituciones de la UE & 46,4 & 25 & \\
\hline Banco Mundial & 29,8 & 16 & $\mathbf{8 8 \%}$ \\
\hline Banco Africano de Desarrollo & 16,5 & 9 & \\
\hline Dinamarca & 13,2 & 7 & \\
\hline
\end{tabular}

Fuentes: OCDE, base de datos del SNPA del CAD sobre las actividades de ayuda.

\section{INDICADORES COMERCIALES (PRODUCTOS)}

\section{Indicador}

$20052008 \quad 2011 \quad \Delta: 05-11(\%)$

Relación comercio/PIB (\%)

Exportaciones de servicios comerciales como

$\%$ de las exportaciones totales

\begin{tabular}{|l|l|l|l|}
44 & 60 & 53 & 9
\end{tabular}

Importaciones de servicios comerciales como

$\%$ de las importaciones totales

$\begin{array}{lll}24 & 20 & \text { n.d. }\end{array}$

Productos intermedios distintos de los combustibles

(\% de las exportaciones de mercancías)

Productos intermedios distintos de los combustibles

(\% de las importaciones de mercancías)

\begin{tabular}{l|l|l|l|}
24 & 21 & n.d. & n.d.
\end{tabular}

$81 \quad 72 \quad$ n.d. $\quad$ n.d.

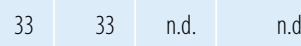

Fuentes: Secretaría de la OMC.

Corrientes comerciales (millones de \$EE.UU. corrientes)

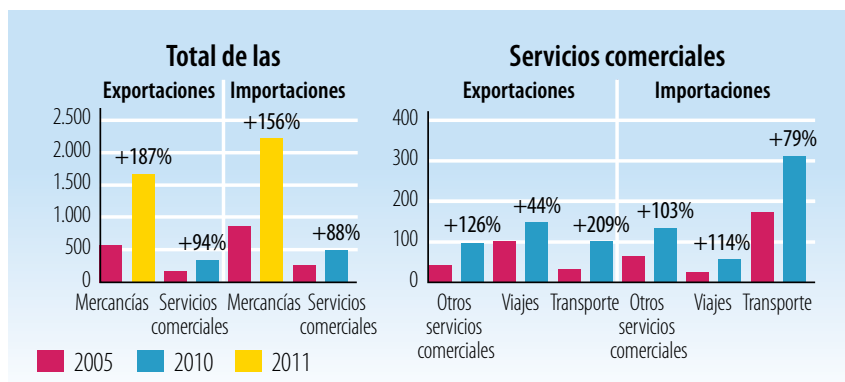

Fuentes: Secretaría de la OMC.

Cinco principales mercados de exportación de mercancías (\%)

\begin{tabular}{|l|r|l|r|}
\hline $\mathbf{2 0 0 5}$ & $\%$ & $\mathbf{2 0 1 0}$ & $\%$ \\
\hline China & 36 & Nigeria & 49 \\
\hline UE (27) & 10 & China & 12 \\
\hline India & 7 & UE (27) & 7 \\
\hline Nigeria & 6 & India & 5 \\
\hline Níger & 5 & Chad & 4 \\
\hline Fuentes: Secretaría de la OMC. & & &
\end{tabular}

Cinco principales productos de exportación (\% de las exportaciones de mercancías)

\begin{tabular}{|c|c|c|c|}
\hline 2005 & $\%$ & 2010 & $\%$ \\
\hline Algodón & 58 & Algodón & 23 \\
\hline $\begin{array}{l}\text { Frutas y nueces, excepto nueces } \\
\text { oleaginosas }\end{array}$ & 7 & Otras carnes y despojos de carnes & 21 \\
\hline Tabaco manufacturado & 7 & Arroz & 21 \\
\hline Cal, cemento y materiales de construcción & 4 & $\begin{array}{l}\text { Frutas y nueces, excepto nueces } \\
\text { oleaginosas }\end{array}$ & 7 \\
\hline $\begin{array}{l}\text { Aceites y grasas fijos de origen vegetal, } \\
\text { blandos }\end{array}$ & 3 & Barras, perfiles, etc., de hierro y acero & 5 \\
\hline
\end{tabular}

Cinco principales mercados de importación de mercancías (\%)

\begin{tabular}{|l|r|l|r|}
\hline 2005 & $\%$ & 2010 & $\%$ \\
\hline UE $(27)$ & 38 & UE $(27)$ & 41 \\
\hline China & 9 & China & 13 \\
\hline Ghana & 7 & Togo & 11 \\
\hline Côte d'Ivoire & 7 & Malasia & 5 \\
\hline Tailandia & 7 & Nigeria & 4 \\
\hline
\end{tabular}

Fuentes: Secretaría de la OMC.

Cinco principales productos de importación (\% de las importaciones de mercancías)

\begin{tabular}{|l|c|l|c|}
\hline 2005 & $\%$ & 2010 & $\%$ \\
\hline Productos derivados del petróleo & 14 & Productos derivados del petróleo & 12 \\
\hline Arroz & 11 & Otras carnes y despojos de carnes & 9 \\
\hline Corriente eléctrica & 6 & Corriente eléctrica & 8 \\
\hline Otras carnes y despojos de carnes & 5 & Arroz & 5 \\
\hline Cal, cemento y materiales de construcción & 5 & $\begin{array}{l}\text { Aceites y grasas fijos de origen vegetal, } \\
\text { blandos }\end{array}$ & 5 \\
\hline Fuentes: Secretaría de la OMC. & & &
\end{tabular}




\section{LA AYUDA PARA EL COMERCIO EN SIINTESIS 2013}

\begin{tabular}{|l|c|c|}
\hline \begin{tabular}{l} 
INDICADORES COMERCIALES (RESULTADOS) \\
\hline Indicador
\end{tabular} & 2005 & 2011 \\
\hline Crecimiento del PIB (\%) & 2,9 & 3,1 \\
\hline Número de exportadores & n.d. & n.d. \\
\hline Índice de concentración de las exportaciones (productos) (0 a 1) & 0,20 & 0,13 \\
\hline ACR sobre mercancías notificados a la OMC & n.d. & 3 \\
\hline AlE (servicios) notificados a la OMC & n.d. & 0 \\
\hline Sectores de servicios con compromisos en el marco del AGCS & 12 & 12 \\
\hline Aranceles (\%, 2006 et 2011) & & \\
\hline Importaciones: promedio aritmético de los aranceles NMF aplicados & 12,0 & 11,9 \\
\hline Importaciones: promedio ponderado de los aranceles NMF aplicados & 12,3 & n.d. \\
\hline Exportaciones: promedio ponderado de los aranceles impuestos & 24,3 & 4,0 \\
\hline por los importadores & 24,7 & 44,7 \\
\hline Exportaciones: libres de derechos (en \%) & & \\
\hline
\end{tabular}

Fuentes: Naciones Unidas, base de datos Comtrade; Banco Mundial, base de datos sobre dinámica de las empresas de exportación; Banco Mundial, Indicadores del Desarrollo Mundial; OMC, perfiles comerciales y arancelarios.

Participación en las exportaciones por región (\%)

\begin{tabular}{|l|r|r|}
\hline & 2005 & 2010 \\
\hline África & 28,0 & 63,2 \\
\hline Asia & 58,9 & 28,0 \\
\hline Comunidad de Estados Independientes & 0,0 & 0,0 \\
\hline Europa & 12,3 & 7,7 \\
\hline Oriente Medio & 0,4 & 0,9 \\
\hline América del Norte & 0,0 & 0,0 \\
\hline América del Sury América Central & 0,4 & 0,1 \\
\hline
\end{tabular}

Fuentes: OMC, perfiles comerciales y arancelarios

Indicadores de facilitación del comercio
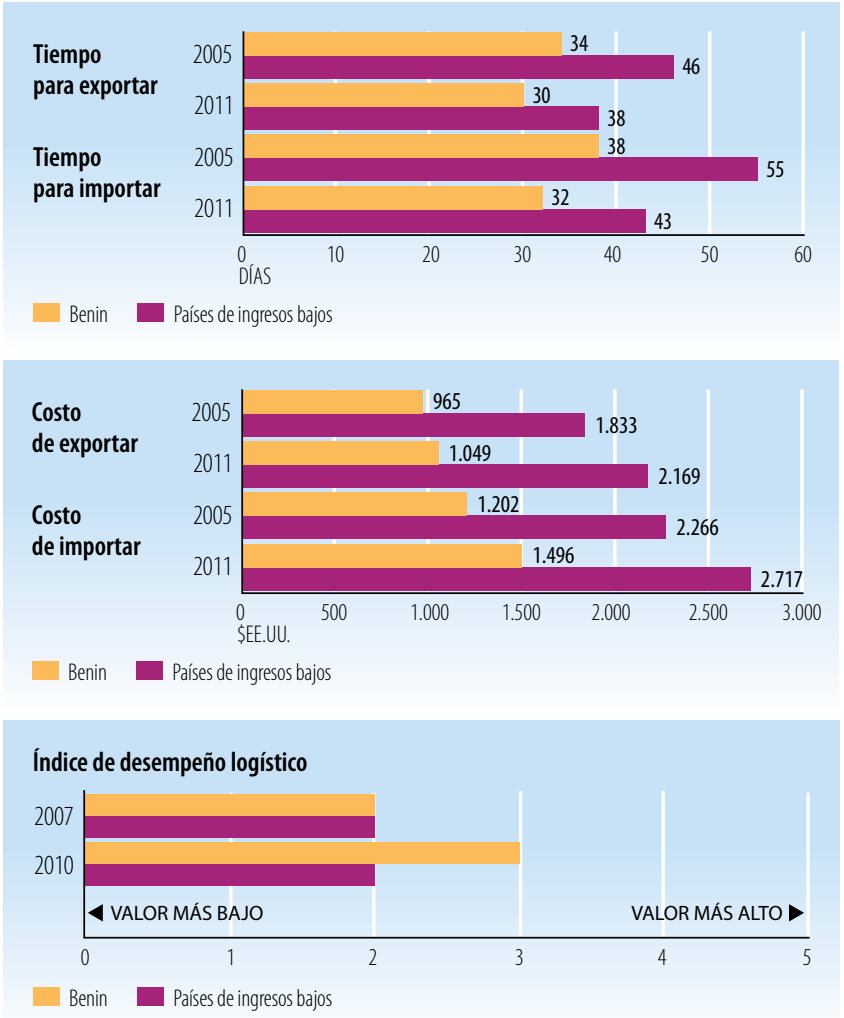

Fuentes: Banco Mundial, Indicadores del Desarrollo Mundial.

\begin{tabular}{l|c|c|}
\hline \multicolumn{2}{|l|}{ INDICADORES DE DESARROLLO (EFECTOS) } \\
\hline Indicador & $\mathbf{2 0 0 5}$ & $\mathbf{2 0 1 0}$ \\
\hline Desempleo (\% de la fuerza de trabajo total) & n.d. & n.d. \\
\hline Población activa, mujeres (\% de la fuerza de trabajo total) & 47,5 & 47,5 \\
\hline AOD neta recibida (\% del INB) & 8,1 & 10,5 \\
\hline Derechos de importación percibidos (\% de los ingresos fiscales) & 25,5 & 26,4 \\
\hline Total del servicio de la deuda (\% de las exportaciones totales) & 5,9 & 2,5 \\
\hline Índice de desarrollo humano (0 a 1) & 0,41 & 0,43 \\
\hline
\end{tabular}

Fuentes: PNUD, indicadores internacionales sobre desarrollo humano; Banco Mundial, Indicadores del Desarrollo Mundial.

Producto interno bruto

PIB per cápita (PPA, dólares internacionales corrientes)

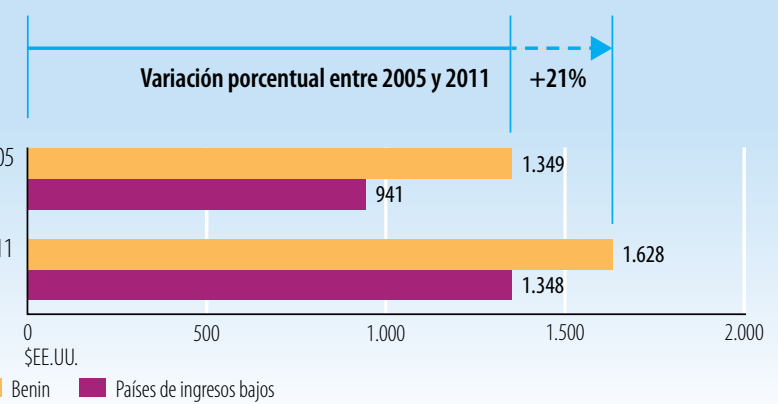

PIB per cápita (\$EE.UU. constantes de 2000)
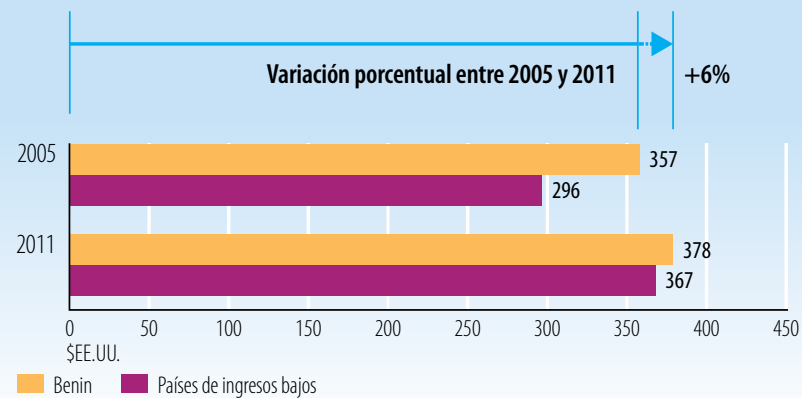

Fuentes: Banco Mundial, Indicadores del Desarrollo Mundial.

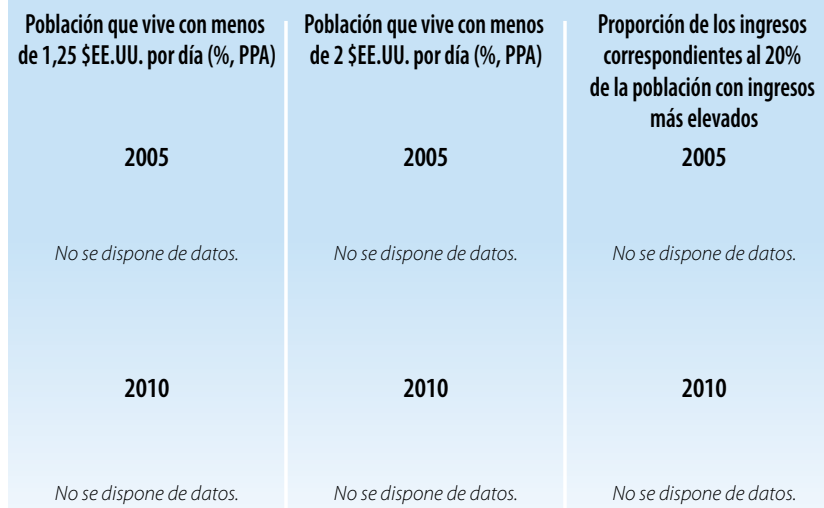

Fuentes: Banco Mundial, Indicadores del Desarrollo Mundial.

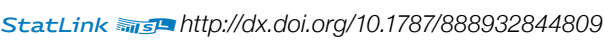




\section{Indicadores de la ayuda, el comercio y el desarrollo relativos a Bhután}

\begin{tabular}{|c|c|c|c|c|}
\hline \multicolumn{5}{|c|}{ INVERSIÓN Y FINANCIACIÓN (APORTES) } \\
\hline Indicador (millones de \$̦EE.UU. corrientes) & 2005 & 2008 & 2010 & $\Delta: 05-10(\%)$ \\
\hline Formación bruta de capital fijo & 408,8 & 486,4 & n.d. & n.d. \\
\hline del cual: público & 83,2 & 154,7 & n.d. & n.d. \\
\hline del cual: privado & 325,6 & 331,8 & n.d. & n.d. \\
\hline \multicolumn{5}{|l|}{ Entrada de financiación externa } \\
\hline Entradas de IED & 9,1 & 3,1 & 19,0 & $109 \%$ \\
\hline $\begin{array}{l}\text { Deuda externa a largo plazo y fondos } \\
\text { desembolsados por el FMl }\end{array}$ & 81,9 & 31,7 & 177,8 & $117 \%$ \\
\hline $\begin{array}{l}\text { Corrientes comerciales en condiciones no } \\
\text { concesionarias }\end{array}$ & 0,0 & 0,0 & 21,0 & d.p.c. \\
\hline Corrientes de Ayuda para el Comercio & 32,1 & 20,0 & 87,0 & $171 \%$ \\
\hline $\begin{array}{l}\text { Remesas de trabajadores y remuneración } \\
\text { de empleados }\end{array}$ & n.d. & 3,6 & 4,8 & n.d. \\
\hline
\end{tabular}

Fuentes: OCDE, base de datos del SNPA del CAD sobre las actividades de ayuda; Banco Mundial, Indicadores del Desarrollo Mundial; Banco Mundial, estadísticas de la deuda internacional.

Desembolsos de la ayuda para el comercio, por sector (millones de \$̦EE.UU. corrientes)

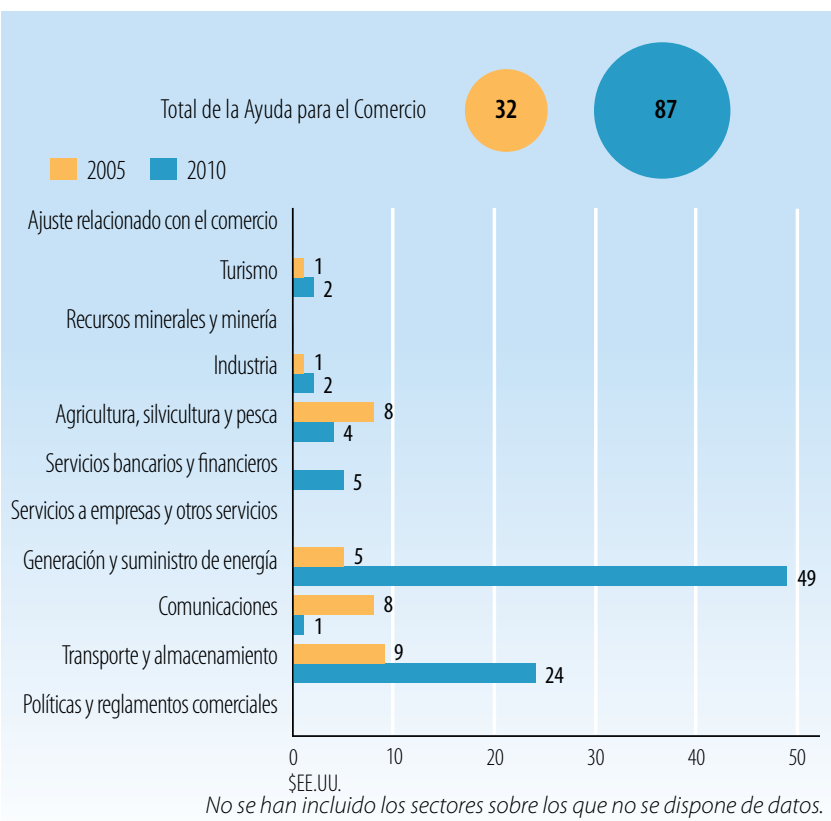

Fuentes: OCDE, base de datos del SNPA del CAD sobre las actividades de ayuda

Desembolsos de la ayuda para el comercio: principales donantes (millones de \$EE.UU. corrientes)

\begin{tabular}{|l|c|c|c|}
\hline $\mathbf{2 0 0 5}$ & Valor & $\%$ & Principales donantes en $\mathbf{2 0 0 5}$ \\
\hline Japón & 12,7 & 40 & \\
\hline Dinamarca & 6,6 & 20 & \\
\hline Banco Mundial & 3,4 & 11 & $86 \%$ \\
\hline Países Bajos & 2,7 & 8 & \\
\hline Austria & 2,4 & 7 & \\
\hline $\mathbf{2 0 1 0}$ & Valor & $\%$ & Principales donantes en $\mathbf{2 0 1 0}$ \\
\hline Japón & 37,8 & 43 & \\
\hline Banco Asiático de Desarrollo & 36,5 & 42 & \\
\hline Banco Mundial & 4,4 & 5 & $97 \%$ \\
\hline Austria & 3,8 & 4 & \\
\hline Noruega & 1,5 & 2 & \\
\hline Fuentes: OCDE, base de datos del SNPA del CAD sobre las actividades de ayuda.
\end{tabular}

\section{INDICADORES COMERCIALES (PRODUCTOS)}

Indicador $2005 \quad 2008 \quad 2011 \quad \Delta: 05-11(\%)$

Relación comercio/PIB (\%)

Exportaciones de servicios comerciales como $\%$ de las exportaciones totales

Importaciones de servicios comerciales como $\%$ de las importaciones totales

Productos intermedios distintos de los combustibles (\% de las exportaciones de mercancías)

Productos intermedios distintos de los combustibles

(\% de las importaciones de mercancías)

\begin{tabular}{|l|l|l|l|}
\hline 97 & 112 & 121 & 23 \\
\hline
\end{tabular}

Fuentes: Secretaría de la OMC.

Corrientes comerciales (millones de \$EE.UU. corrientes)

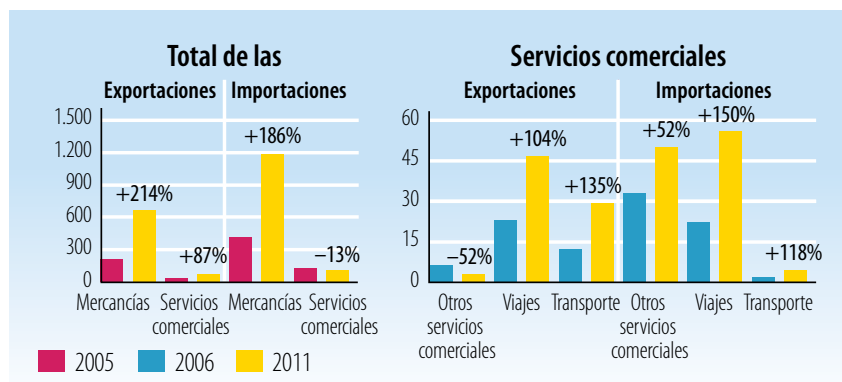

Fuentes: Secretaría de la OMC.

Cinco principales mercados de exportación de mercancías (\%)

\begin{tabular}{|l|r|l|r|}
\hline 2005 & $\%$ & 2011 & $\%$ \\
\hline India & 88 & India & 82 \\
\hline Hong Kong, China & 6 & Hong Kong, China & 12 \\
\hline Bangladesh & 5 & Bangladesh & 5 \\
\hline Singapur & 1 & Japón & 1 \\
\hline Nepal & 0 & Nepal & 0 \\
\hline
\end{tabular}

Cinco principales productos de exportación (\% de las exportaciones de mercancías)

\begin{tabular}{|c|c|c|c|}
\hline 2005 & $\%$ & 2011 & $\%$ \\
\hline Corriente eléctrica & 30 & Arrabio, fundición especular, etc. & 30 \\
\hline Hilados de fibra textil & 7 & Instrumentos musicales, etc. & 11 \\
\hline $\begin{array}{l}\text { Artículos de alambre, excepto cables para } \\
\text { electricidad }\end{array}$ & 7 & Cobre & 9 \\
\hline Otros compuestos químicos & 6 & Cal, cemento y materiales de construcción & 8 \\
\hline Arrabio, fundición especular, etc. & 6 & Otros compuestos químicos & 7 \\
\hline
\end{tabular}

Fuentes: Secretaría de la OMC.

Cinco principales mercados de importación de mercancías (\%)

\begin{tabular}{|l|r|l|r|}
\hline 2005 & $\%$ & 2010 & $\%$ \\
\hline India & 75 & India & 75 \\
\hline UE (27) & 5 & Corea, Rep. de & 5 \\
\hline Japón & 4 & UE (27) & 4 \\
\hline Singapur & 3 & Tailandia & 3 \\
\hline Tailandia & 2 & Singapur & 2 \\
\hline
\end{tabular}

Fuentes: Secretaría de la OMC.

Cinco principales productos de importación (\% de las importaciones de mercancías)

\begin{tabular}{|c|c|c|c|}
\hline 2005 & $\%$ & 2010 & $\%$ \\
\hline Productos derivados del petróleo & 12 & Productos derivados del petróleo & 11 \\
\hline Barras, perfiles, etc., de hierro y acero & 5 & Equipo de ingeniería civil & 7 \\
\hline $\begin{array}{l}\text { Vehículos automotores para pasajeros, } \\
\text { excepto autobuses }\end{array}$ & 4 & Cobre & 5 \\
\hline $\begin{array}{l}\text { Aparatos de electricidad y sus partes y } \\
\text { piezas }\end{array}$ & 3 & $\begin{array}{l}\text { Vehículos automotores para el transporte } \\
\text { de mercancías y vehículos automotores } \\
\text { para usos especiales }\end{array}$ & 4 \\
\hline Hilados de fibra textil & 3 & $\begin{array}{l}\text { Vehículos automotores para pasajeros, } \\
\text { excepto autobuses }\end{array}$ & 4 \\
\hline
\end{tabular}

Fuentes: Secretaría de la OMC. 


\section{LA AYUDA PARA EL COMERCIO EN SÍNTESIS 2013}

\section{INDICADORES COMERCIALES (RESULTADOS)}

\section{Indicador}

Crecimiento del PIB (\%)

Número de exportadores

Índice de concentración de las exportaciones (productos) ( 0 a 1)

ACR sobre mercancías notificados a la OMC

AIE (servicios) notificados a la OMC

Sectores de servicios con compromisos en el marco del AGCS

\section{Aranceles (\%)}

Importaciones: promedio aritmético de los aranceles NMF aplicados

Importaciones: promedio ponderado de los aranceles NMF aplicados

Exportaciones: promedio ponderado de los aranceles impuestos

por los importadores

Exportaciones: libres de derechos (en \%)

\begin{tabular}{|c|c|}
\hline 2005 & 2011 \\
\hline 8,8 & 8,4 \\
\hline n.d. & n.d. \\
\hline 0,12 & 0,13 \\
\hline n.d. & 3 \\
\hline n.d. & 0 \\
\hline 0 & 0 \\
\hline
\end{tabular}

Fuentes: Naciones Unidas, base de datos Comtrade; Banco Mundial, base de dato sobre dinámica de las empresas de exportación; Banco Mundial, Indicadores del

Desarrollo Mundial; OMC, perfiles comerciales y arancelarios.

Participación en las exportaciones por región (\%)

\begin{tabular}{|l|r|r|}
\hline & 2005 & 2010 \\
\hline África & 0,0 & 0,0 \\
\hline Asia & 99,9 & 99,9 \\
\hline Comunidad de Estados Independientes & 0,0 & 0,0 \\
\hline Europa & 0,1 & 0,1 \\
\hline Oriente Medio & 0,0 & 0,0 \\
\hline América del Norte & 0,0 & 0,0 \\
\hline América del Sury América Central & 0,0 & 0,0 \\
\hline
\end{tabular}

Fuentes: OMC, perfiles comerciales y arancelarios

Indicadores de facilitación del comercio
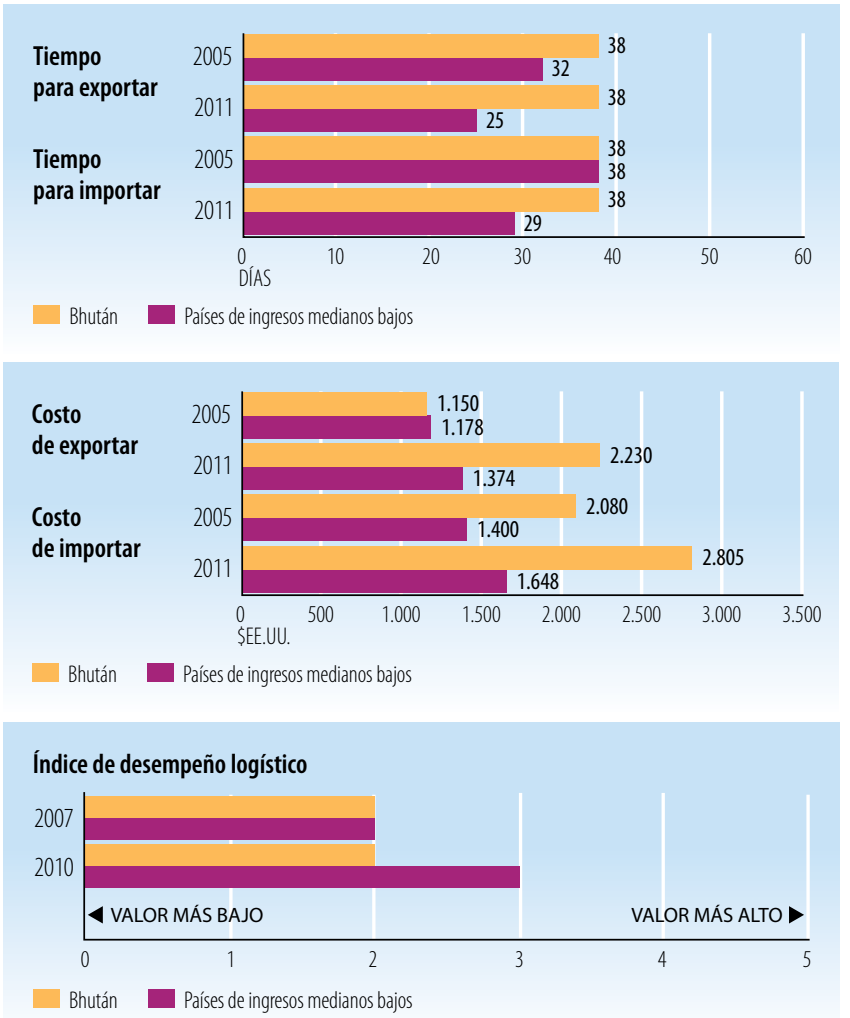

Fuentes: Banco Mundial, Indicadores del Desarrollo Mundial

\begin{tabular}{|l|c|c|}
\hline INDICADORES DE DESARROLLO (EFECTOS) & \\
\hline Indicador & $\mathbf{2 0 0 5}$ & $\mathbf{2 0 1 0}$ \\
\hline Desempleo (\% de la fuerza de trabajo total) & 3,1 & 4,0 \\
\hline Población activa, mujeres (\% de la fuerza de trabajo total) & 41,5 & 42,5 \\
\hline A0D neta recibida (\% del INB) & 12,6 & 9,2 \\
\hline Derechos de importación percibidos (\% de los ingresos fiscales) & 7,7 & n.d. \\
\hline Total del servicio de la deuda (\% de las exportaciones totales) & 2,7 & 14,1 \\
\hline Índice de desarrollo humano (0 a 1) & n.d. & 0,52 \\
\hline
\end{tabular}

Fuentes: PNUD, indicadores internacionales sobre desarrollo humano; Banco Mundial, Indicadores del Desarrollo Mundial.

Producto interno bruto

PIB per cápita (PPA, dólares internacionales corrientes)

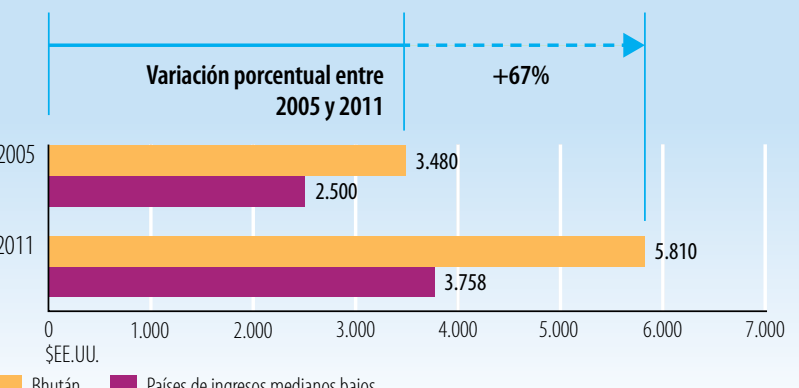

Bhután Países de ingresos medianos bajos

PIB per cápita (\$EE.UU. constantes de 2000)

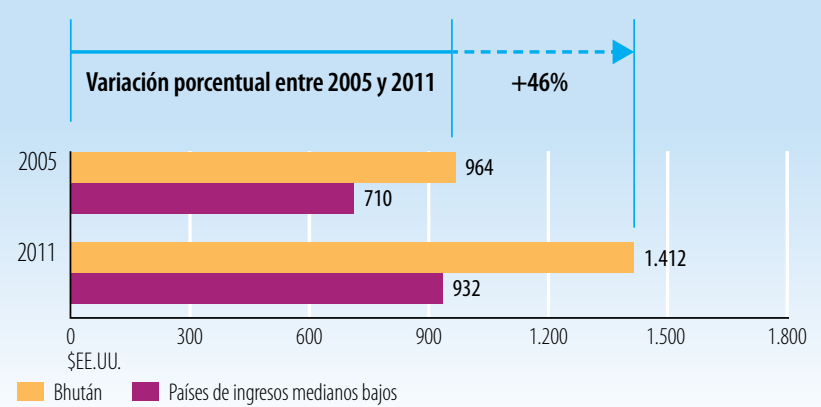

Fuentes: Banco Mundial, Indicadores del Desarrollo Mundial.

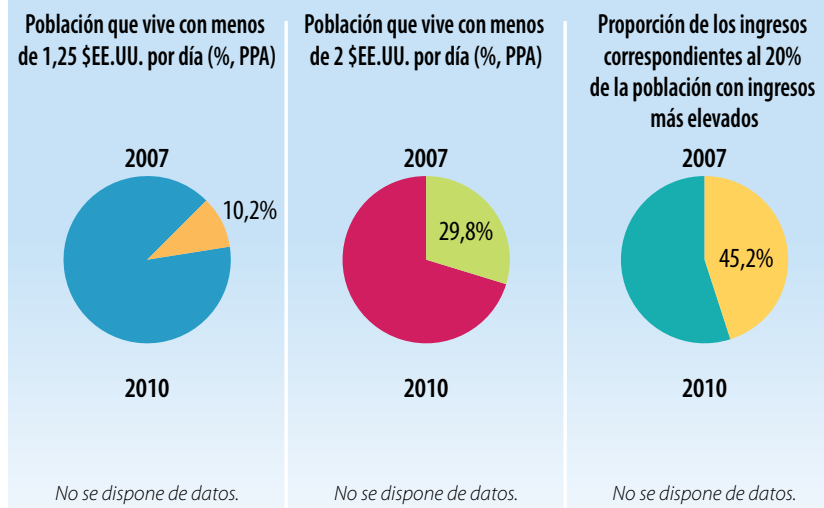

Fuentes: Banco Mundial, Indicadores del Desarrollo Mundial.

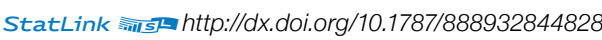




\section{BOTSWANA}

\section{LA AYUDA PARA EL COMERCIO EN SÍNTESIS 2013}

\section{Indicadores de la ayuda, el comercio y el desarrollo relativos a Botswana}

\begin{tabular}{|c|c|c|c|c|}
\hline Indicador (millones de \$ॄE.UU. corrientes) & 2005 & 2008 & 2010 & $\Delta: 05-10(\%)$ \\
\hline Formación bruta de capital fijo & $2.516,5$ & $3.064,2$ & $4.041,4$ & $61 \%$ \\
\hline del cual: público & 740,4 & $1.678,4$ & $1.959,5$ & $165 \%$ \\
\hline del cual: privado & $1.776,2$ & $1.385,7$ & $2.081,9$ & $17 \%$ \\
\hline \multicolumn{5}{|l|}{ Entrada de financiación externa } \\
\hline Entradas de IED & 492,4 & 902,4 & 265,0 & $-46 \%$ \\
\hline $\begin{array}{l}\text { Deuda externa a largo plazo y fondos } \\
\text { desembolsados por el FMl }\end{array}$ & 10,7 & 54,5 & 16,7 & $56 \%$ \\
\hline $\begin{array}{l}\text { Corrientes comerciales en condiciones no } \\
\text { concesionarias }\end{array}$ & 0,0 & 0,0 & 2,7 & d.p.c. \\
\hline Corrientes de Ayuda para el Comercio & 16,3 & 10,7 & 24,8 & $52 \%$ \\
\hline $\begin{array}{l}\text { Remesas de trabajadores y remuneración } \\
\text { de empleados }\end{array}$ & 131,0 & 114,3 & 99,5 & $-24 \%$ \\
\hline
\end{tabular}

Fuentes: OCDE, base de datos del SNPA del CAD sobre las actividades de ayuda; Banco Mundial, Indicadores del Desarrollo Mundial; Banco Mundial, estadísticas de la deuda internacional.

Desembolsos de la ayuda para el comercio, por sector (millones de \$EE.UU. corrientes)

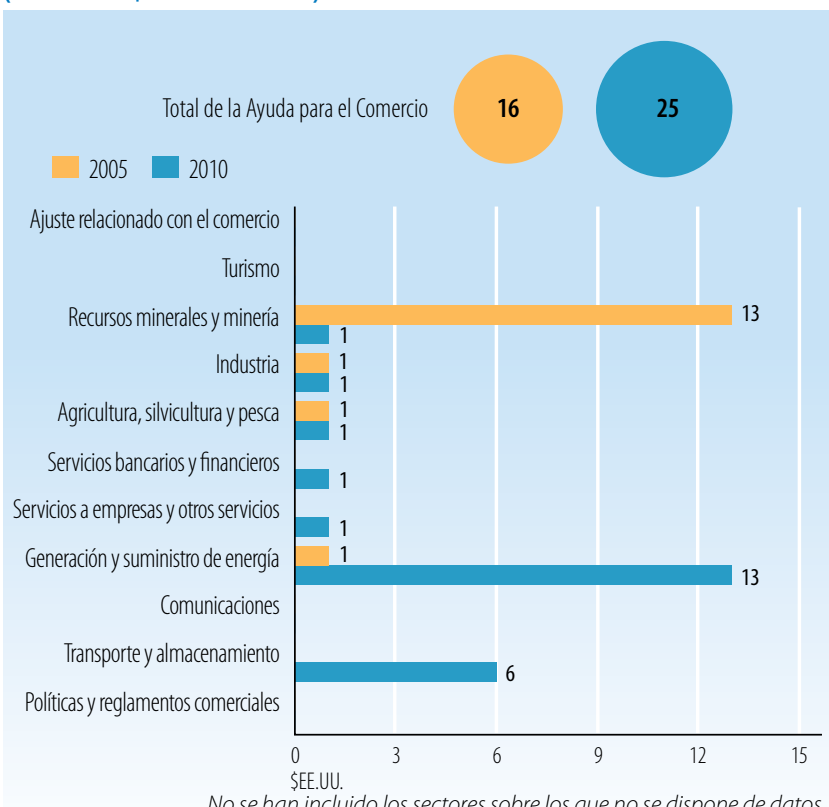

Fuentes: OCDE, base de datos del SNPA del CAD sobre las actividades de ayuda

Desembolsos de la ayuda para el comercio: principales donantes (millones de \$EE.UU. corrientes)

\begin{tabular}{|l|c|c|c|}
\hline $\mathbf{2 0 0 5}$ & Valor & $\%$ & Principales donantes en $\mathbf{2 0 0 5}$ \\
\hline Instituciones de la UE & 13,0 & 80 & \\
\hline Japón & 1,1 & 7 & \\
\hline Estados Unidos & 1,0 & 6 & $98 \%$ \\
\hline Alemania & 0,5 & 3 & \\
\hline Dinamarca & 0,4 & 2 & \\
\hline $\mathbf{2 0 1 0}$ & Valor & $\%$ & Principales donantes en $\mathbf{2 0 1 0}$ \\
\hline Japón & 13,6 & 55 & \\
\hline OFID & 5,8 & 24 & \\
\hline Suecia & 1,3 & 5 & \\
\hline Estados Unidos & 0,9 & 3 & \\
\hline Instituciones de la UE & 0,8 & 3 & \\
\hline Fuentes: OCDE, base de datos del SNPA del CAD sobre las actividades de ayuda.
\end{tabular}

\section{INDICADORES COMERCIALES (PRODUCTOS)}

\section{Indicador}

$20052008 \quad 2011 \quad \Delta: 05-11(\%)$

Relación comercio/PIB (\%)

\begin{tabular}{|l|l|l|l|}
86 & 80 & 79 & -7
\end{tabular}

Exportaciones de servicios comerciales como

$\%$ de las exportaciones totales

$16 \quad 15 \quad$ n.d. $\quad$ n.d.

mportaciones de servicios comerciales como

$\%$ de las importaciones totales

Productos intermedios distintos de los combustibles

(\% de las exportaciones de mercancías)

Productos intermedios distintos de los combustibles

(\% de las importaciones de mercancías)

\begin{tabular}{l|l|l|l|}
24 & 15 & 15 & -9
\end{tabular}

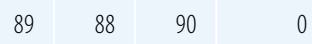

\begin{tabular}{l|l|l|l|}
39 & 42 & 44 & 5
\end{tabular}

Fuentes: Secretaría de la OMC

Corrientes comerciales (millones de \$EE.UU. corrientes)

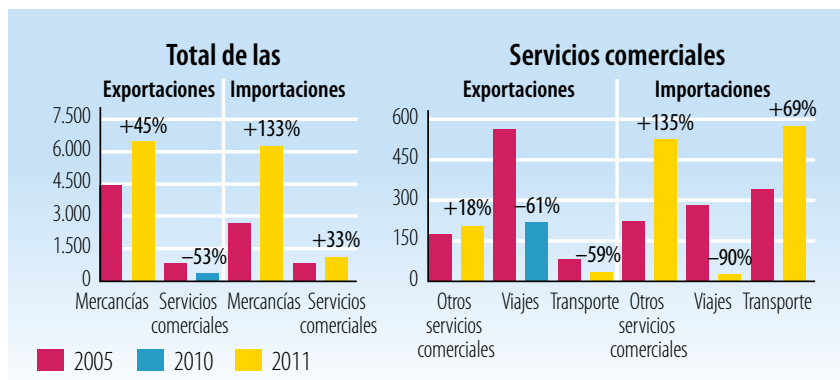

Fuentes: Secretaría de la OMC.

Cinco principales mercados de exportación de mercancías (\%)

\begin{tabular}{|l|r|l|c|}
\hline 2005 & $\%$ & 2010 & $\%$ \\
\hline UE (27) & 77 & UE (27) & 61 \\
\hline Sudáfrica & 9 & Sudáfrica & 13 \\
\hline Noruega & 6 & Noruega & 9 \\
\hline Zimbabwe & 4 & Israel & 5 \\
\hline Estados Unidos & 2 & Zimbabwe & 4 \\
\hline
\end{tabular}

Fuentes: Secretaría de la OMC.

Cinco principales productos de exportación (\% de las exportaciones de mercancías)

\begin{tabular}{|c|c|c|c|}
\hline 2005 & $\%$ & 2011 & $\%$ \\
\hline Perlas y piedras preciosas & 74 & Perlas y piedras preciosas & 75 \\
\hline Minerales de cobre y sus concentrados & 10 & $\begin{array}{l}\text { Minerales de níquel y sus concentrados, y } \\
\text { matas de níquel }\end{array}$ & 6 \\
\hline $\begin{array}{l}\text { Otros artículos textiles y prendas de } \\
\text { vestir, n.e.p. }\end{array}$ & 2 & $\begin{array}{l}\text { Prendas de vestir para mujeres y niñas, } \\
\text { excepto las de punto }\end{array}$ & 1 \\
\hline Vehículos automotores de carretera, n.e.p. & 2 & Oro no monetario, excepto minerales & 1 \\
\hline Carne de ganado bovino & 2 & Minerales de cobre y sus concentrados & 1 \\
\hline
\end{tabular}

Cinco principales mercados de importación de mercancías (\%)

\begin{tabular}{|l|r|l|r|}
\hline 2005 & $\%$ & 2010 & $\%$ \\
\hline Sudáfrica & 84 & Sudáfrica & 73 \\
\hline UE (27) & 7 & UE (27) & 13 \\
\hline Zimbabwe & 2 & China & 5 \\
\hline Estados Unidos & 1 & Israel & 2 \\
\hline China & 1 & Estados Unidos & 1 \\
\hline
\end{tabular}

Fuentes: Secretaría de la OMC

Cinco principales productos de importación (\% de las importaciones de mercancías)

\begin{tabular}{|c|c|c|c|}
\hline 2005 & $\%$ & 2011 & $\%$ \\
\hline Productos derivados del petróleo & 12 & Productos derivados del petróleo & 13 \\
\hline $\begin{array}{l}\text { Vehículos automotores para el transporte } \\
\text { de mercancías y vehículos automotores } \\
\text { para usos especiales }\end{array}$ & 4 & Perlas y piedras preciosas & 12 \\
\hline $\begin{array}{l}\text { Vehículos automotores para pasajeros, } \\
\text { excepto autobuses }\end{array}$ & 4 & $\begin{array}{l}\text { Vehículos automotores para el transporte } \\
\text { de mercancías y vehículos automotores } \\
\text { para usos especiales }\end{array}$ & \\
\hline Operaciones especiales no clasificadas & 3 & Aparatos eléctricos rotativos & \\
\hline Medicamentos & 2 & Corriente eléctrica & \\
\hline
\end{tabular}

Fuentes: Secretaría de la OMC. 


\section{LA AYUDA PARA EL COMERCIO EN SINNTESIS 2013}

\begin{tabular}{|c|c|c|}
\hline Indicador & 2005 & 2011 \\
\hline Crecimiento del PIB (\%) & 1,6 & 5,1 \\
\hline Número de exportadores & 1.572 & 1.855 \\
\hline Índice de concentración de las exportaciones (productos) (0 a 1) & n.d. & 0,42 \\
\hline ACR sobre mercancías notificados a la OMC & n.d. & 3 \\
\hline AIE (servicios) notificados a la OMC & n.d. & 0 \\
\hline Sectores de servicios con compromisos en el marco del AGCS & 19 & 19 \\
\hline \multicolumn{3}{|l|}{ Aranceles $(\%, 2006$ et 2011$)$} \\
\hline Importaciones: promedio aritmético de los aranceles NMF aplicados & 8,0 & 7,7 \\
\hline Importaciones: promedio ponderado de los aranceles NMF aplicados & n.d. & 7,6 \\
\hline $\begin{array}{l}\text { Exportaciones: promedio ponderado de los aranceles impuestos } \\
\text { por los importadores }\end{array}$ & 0,8 & 2,8 \\
\hline Exportaciones: libres de derechos (en \%) & 98,9 & 90,2 \\
\hline
\end{tabular}

Fuentes: Naciones Unidas, base de datos Comtrade; Banco Mundial, base de datos sobre dinámica de las empresas de exportación; Banco Mundial, Indicadores del Desarrollo Mundial; OMC, perfiles comerciales y arancelarios.

Participación en las exportaciones por región (\%)

\begin{tabular}{|l|r|r|}
\hline & 2005 & $\mathbf{2 0 1 0}$ \\
\hline África & 13,7 & 18,9 \\
\hline Asia & 0,2 & 3,1 \\
\hline Comunidad de Estados Independientes & 0,0 & 0,0 \\
\hline Europa & 83,5 & 71,5 \\
\hline Oriente Medio & 0,3 & 5,4 \\
\hline América del Norte & 2,2 & 1,1 \\
\hline América del Sury América Central & 0,0 & 0,0 \\
\hline
\end{tabular}

Fuentes: OMC, perfiles comerciales y arancelarios

Indicadores de facilitación del comercio
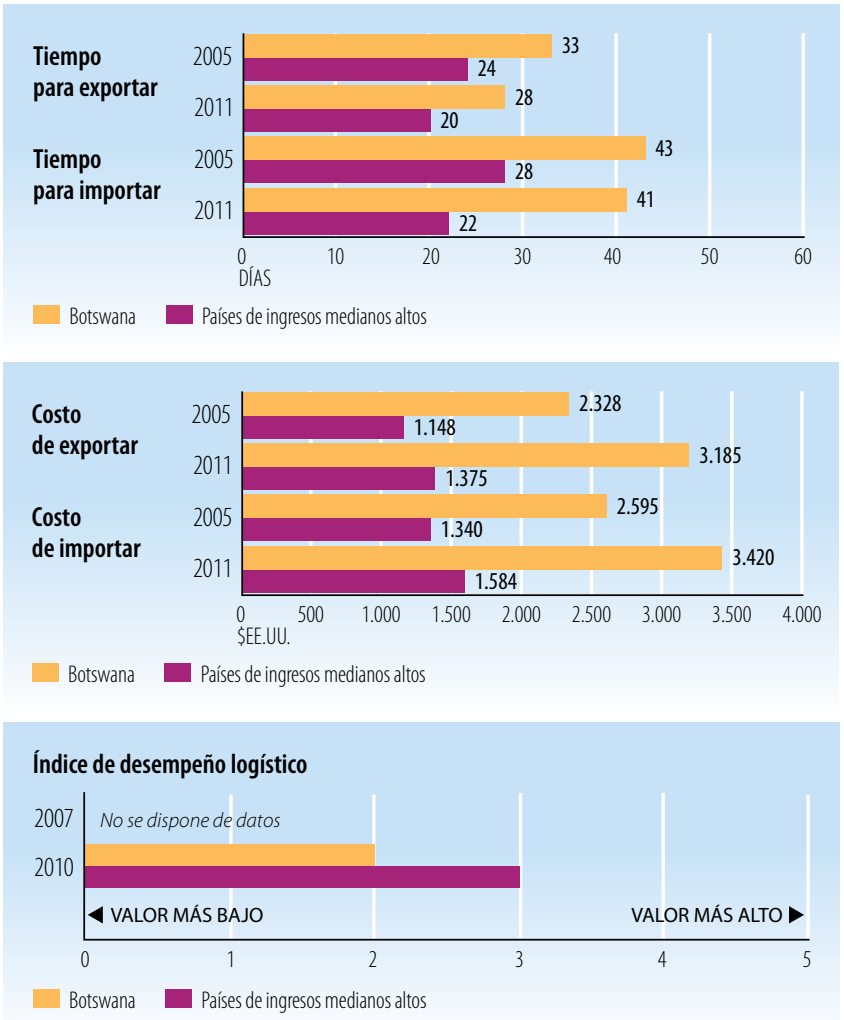

Fuentes: Banco Mundial, Indicadores del Desarrollo Mundial.

\begin{tabular}{l|c|c|}
\hline \multicolumn{2}{|l|}{ INDICADORES DE DESARROLLO (EFECTOS) } \\
\hline Indicador & 2005 & $\mathbf{2 0 1 0}$ \\
\hline Desempleo (\% de la fuerza de trabajo total) & 17,6 & n.d. \\
\hline Población activa, mujeres (\% de la fuerza de trabajo total) & 46,7 & 46,3 \\
\hline AOD neta recibida (\% del INB) & 0,5 & 1,1 \\
\hline Derechos de importación percibidos (\% de los ingresos fiscales) & n.d. & n.d. \\
\hline Total del servicio de la deuda (\% de las exportaciones totales) & 0,9 & 1,5 \\
\hline Índice de desarrollo humano (0 a 1) & 0,60 & 0,63 \\
\hline
\end{tabular}

Fuentes: PNUD, indicadores internacionales sobre desarrollo humano; Banco Mundial, Indicadores del Desarrollo Mundial.

Producto interno bruto

PIB per cápita (PPA, dólares internacionales corrientes)
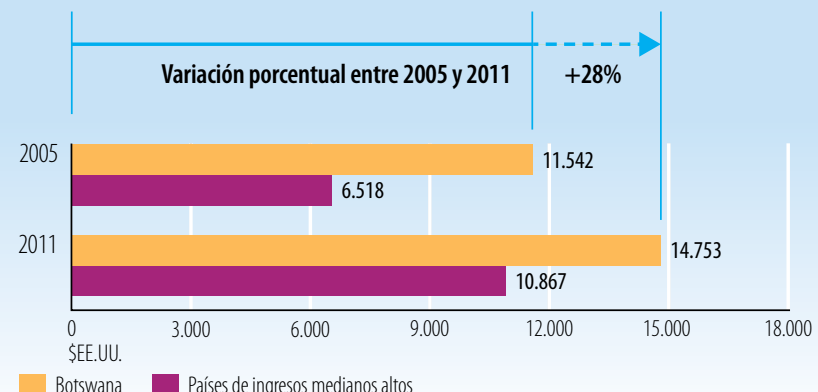

Botswana Países de ingresos medianos altos

PIB per cápita (\$EE.UU. constantes de 2000)
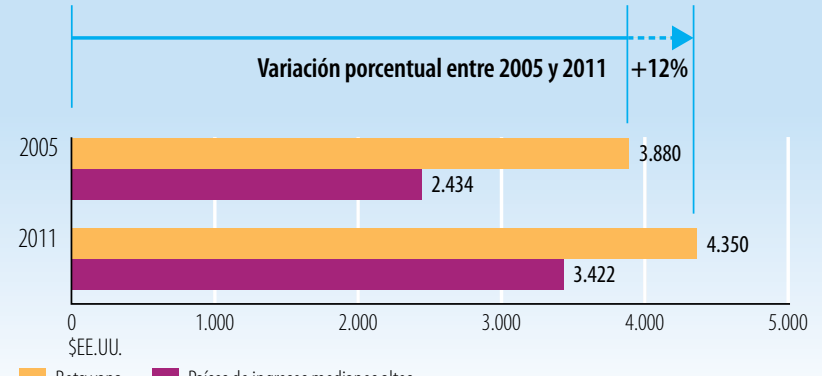

Botswana $\square$ Países de ingresos medianos altos

Fuentes: Banco Mundial, Indicadores del Desarrollo Mundial.

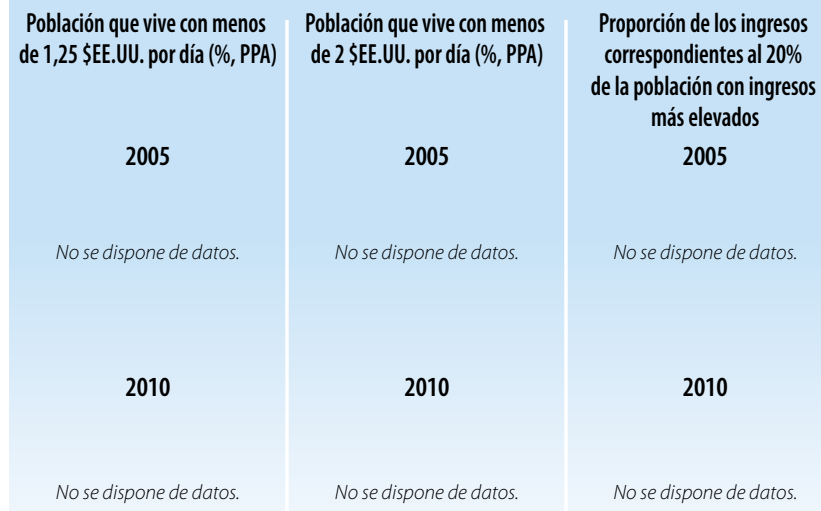

Fuentes: Banco Mundial, Indicadores del Desarrollo Mundial.

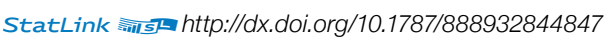




\section{Indicadores de la ayuda, el comercio y el desarrollo relativos a Burkina Faso}

\section{INVERSIÓN Y FINANCIACIÓN (APORTES)}

Indicador (millones de \$EE.UU. corrientes) $2005 \quad 2008 \quad 2010 \quad \Delta: 05-10(\%)$

\begin{tabular}{|l|l|l|l|l|}
\hline Formación bruta de capital fijo & $1.055,2$ & n.d. & n.d. & n.d.
\end{tabular}

del cual: público n.d. n.d. n.d. n.d.

del cual: privado

n.d. n.d. n.d. n.d.

\section{Entrada de financiación externa}

Entradas de IED

Deuda externa a largo plazo y fondos

desembolsados por el FMI

\begin{tabular}{|r|r|r|r|}
\hline 32,0 & 152,5 & 37,1 & $16 \%$ \\
\hline 218,4 & 312,0 & 295,6 & $35 \%$ \\
\hline 0,0 & 0,0 & 0,0 & $0 \%$ \\
\hline 128,6 & 175,2 & 231,2 & $80 \%$ \\
\hline 56,6 & 99,3 & 95,0 & $68 \%$ \\
\hline
\end{tabular}

Corrientes comerciales en condiciones no concesionarias

Corrientes de Ayuda para el Comercio

Remesas de trabajadores y remuneración de empleados

$56,6 \quad 99,3 \quad 95,0 \quad 68 \%$

Fuentes: OCDE, base de datos del SNPA del CAD sobre las actividades de ayuda; Banco Mundial, Indicadores del Desarrollo Mundial; Banco Mundial, estadísticas de la deuda internacional.

Desembolsos de la ayuda para el comercio, por sector (millones de \$̦EE.UU. corrientes)

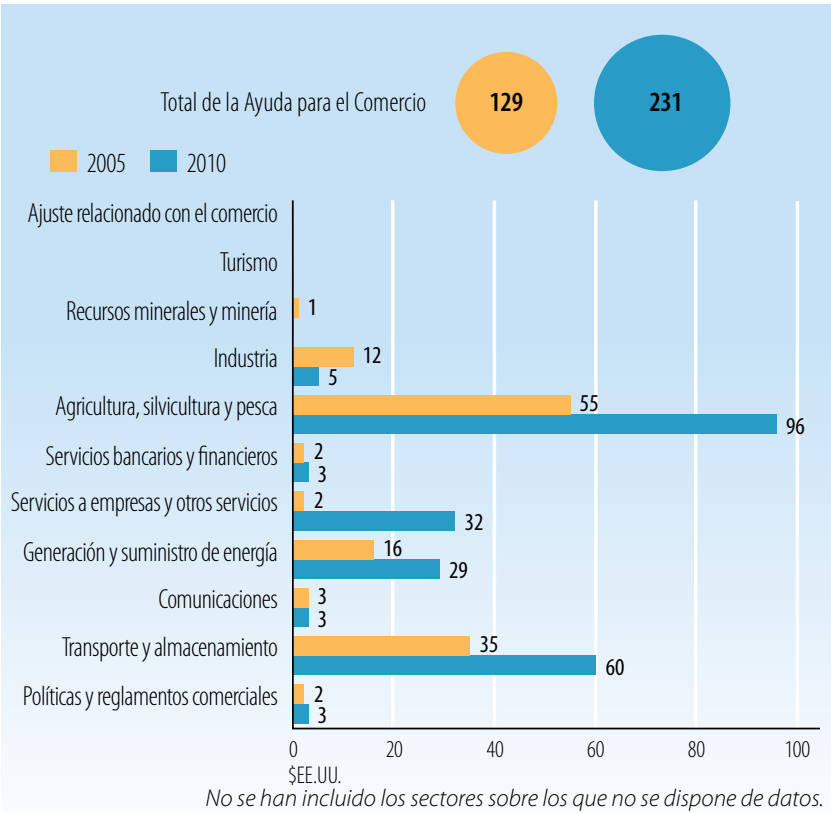

Fuentes: OCDE, base de datos del SNPA del CAD sobre las actividades de ayuda

Desembolsos de la ayuda para el comercio: principales donantes (millones de \$EE.UU. corrientes)

\begin{tabular}{|l|c|c|}
\hline $\mathbf{2 0 0 5}$ & Valor & $\%$ \\
\hline Banco Mundial & 35,0 & 27 \\
\hline Dinamarca & 24,4 & 19 \\
\hline Instituciones de la UE & 24,0 & 19 \\
\hline Banco Africano de Desarrollo & 10,6 & 8 \\
\hline Japón & 8,3 & 6 \\
\hline $\mathbf{2 0 1 0}$ & Valor & $\%$ \\
\hline Banco Mundial & 106,3 & 46 \\
\hline Banco Africano de Desarrollo & 34,5 & 15 \\
\hline Instituciones de la UE & 18,5 & 8 \\
\hline Alemania & 11,6 & 5 \\
\hline Estados Unidos & 11,0 & 5 \\
\hline
\end{tabular}

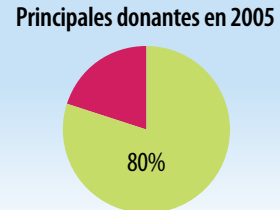

Principales donantes en 2010

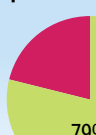

$79 \%$
Fuentes: OCDE, base de datos del SNPA del CAD sobre las actividades de ayuda.

\section{INDICADORES COMERCIALES (PRODUCTOS)}

\section{Indicador}

$2005 \quad 2008 \quad 2011 \quad \Delta: 05-11(\%)$

Relación comercio/PIB (\%)

Exportaciones de servicios comerciales como

$\%$ de las exportaciones totales

Importaciones de servicios comerciales como

$\%$ de las importaciones totales

Productos intermedios distintos de los combustibles

(\% de las exportaciones de mercancías)

Productos intermedios distintos de los combustibles

(\% de las importaciones de mercancías)

\begin{tabular}{l|r|r|r}
35 & 40 & 45 & 10
\end{tabular}

$12 \quad 12 \quad$ n.d. $\quad$ n.d.

$25 \quad 25 \quad$ n.d. $\quad$ n.d.

$89 \quad 91 \quad$ n.d. $\quad$ n.d.

$40 \quad 40 \quad$ n.d. $\quad$ n.d.

Fuentes: Secretaría de la OMC

Corrientes comerciales (millones de \$EE.UU. corrientes)

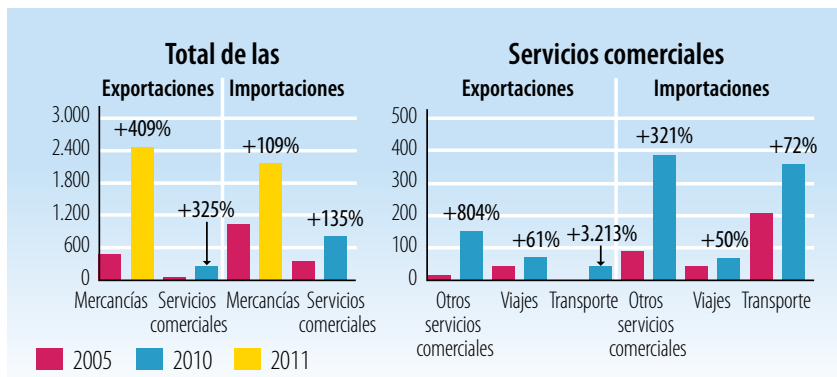

Fuentes: Secretaría de la OMC

Cinco principales mercados de exportación de mercancías (\%)

\begin{tabular}{|l|r|l|r|}
\hline 2005 & $\%$ & 2010 & $\%$ \\
\hline Togo & 41 & Suiza & 63 \\
\hline Ghana & 17 & Sudáfrica & 11 \\
\hline UE (27) & 14 & UE (27) & 9 \\
\hline Côte d'Ivoire & 10 & Singapur & 5 \\
\hline Suiza & 9 & Ghana & 3 \\
\hline
\end{tabular}

Fuentes: Secretaría de la OMC.

Cinco principales productos de exportación (\% de las exportaciones de mercancías)

\begin{tabular}{|c|c|c|c|}
\hline 2005 & $\%$ & 2010 & $\%$ \\
\hline Algodón & 75 & Oro no monetario, excepto minerales & 69 \\
\hline $\begin{array}{l}\text { Semillas oleaginosas (aceites vegetales } \\
\text { fijos blandos) }\end{array}$ & 4 & Algodón & 17 \\
\hline Tabaco manufacturado & 2 & $\begin{array}{l}\text { Semillas oleaginosas (aceites vegetales } \\
\text { fijos blandos) }\end{array}$ & 4 \\
\hline Animales vivos & 2 & $\begin{array}{l}\text { Semillas oleaginosas (otros aceites } \\
\text { vegetales fijos) }\end{array}$ & 1 \\
\hline $\begin{array}{l}\text { Frutas y nueces, excepto nueces } \\
\text { oleaginosas }\end{array}$ & 2 & $\begin{array}{l}\text { Frutas y nueces, excepto nueces } \\
\text { oleaginosas }\end{array}$ & 1 \\
\hline
\end{tabular}

Fuentes: Secretaría de la OMC

Cinco principales mercados de importación de mercancías (\%)

\begin{tabular}{|l|c|l|c|}
\hline 2005 & $\%$ & 2010 & $\%$ \\
\hline UE (27) & 33 & UE (27) & 30 \\
\hline Côte d'Ivoire & 18 & Côte d'Ivoire & 16 \\
\hline Togo & 11 & China & 10 \\
\hline Benin & 7 & Togo & 4 \\
\hline Ghana & 6 & Estados Unidos & 4 \\
\hline
\end{tabular}

Cinco principales productos de importación (\% de las importaciones de mercancías)

\begin{tabular}{|l|r|l|r|}
\hline 2005 & $\%$ & 2010 & $\%$ \\
\hline Productos derivados del petróleo & 19 & Productos derivados del petróleo & 21 \\
\hline Arroz & 6 & Cal, cemento y materiales de construcción & 4 \\
\hline Abonos, excepto los del grupo 272 & 5 & Abonos, excepto los del grupo 272 & 4 \\
\hline Cal, cemento y materiales de construcción & 4 & Medicamentos & 4 \\
\hline Medicamentos & 4 & Arroz & 3 \\
\hline
\end{tabular}

Fuentes: Secretaría de la OMC. 


\section{LA AYUDA PARA EL COMERCIO EN SIINTESIS 2013}

\section{INDICADORES COMERCIALES (RESULTADOS)}

\section{Indicador}

Crecimiento del PIB (\%)

Número de exportadores

Índice de concentración de las exportaciones (productos) ( 0 a 1)

ACR sobre mercancías notificados a la OMC

AIE (servicios) notificados a la OMC

Sectores de servicios con compromisos en el marco del AGCS

\section{Aranceles $(\%, 2006$ et 2011)}

Importaciones: promedio aritmético de los aranceles NMF aplicados $\quad 12,0 \quad 11,9$

\begin{tabular}{ll|l|l|} 
Importaciones: promedio ponderado de los aranceles NMF aplicados & 11,7 & 10,5
\end{tabular}

Exportaciones: promedio ponderado de los aranceles impuestos $\quad 26,8 \quad 1,2$

por los importadores

$25,2 \quad 63,9$

Exportaciones: libres de derechos (en \%)

Fuentes: Naciones Unidas, base de datos Comtrade; Banco Mundial, base de datos sobre dinámica de las empresas de exportación; Banco Mundial, Indicadores del

Desarrollo Mundial; OMC, perfiles comerciales y arancelarios.

Participación en las exportaciones por región (\%)

\begin{tabular}{|l|r|r|}
\hline & 2005 & 2010 \\
\hline África & 73,4 & 20,3 \\
\hline Asia & 2,5 & 5,6 \\
\hline Comunidad de Estados Independientes & 0,0 & 0,0 \\
\hline Europa & 23,1 & 72,6 \\
\hline Oriente Medio & 0,0 & 0,8 \\
\hline América del Norte & 0,1 & 0,6 \\
\hline América del Sury América Central & 0,0 & 0,0 \\
\hline
\end{tabular}

Fuentes: OMC, perfiles comerciales y arancelarios

Indicadores de facilitación del comercio
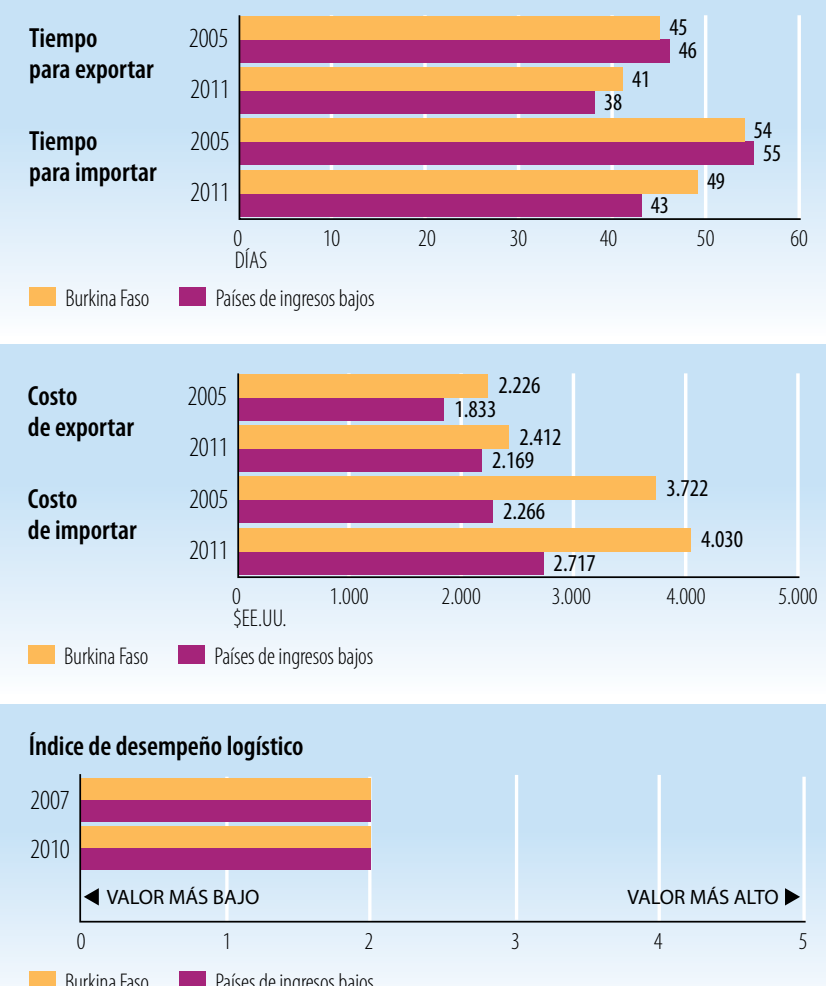

Burkina Faso Países de ingresos bajos

Fuentes: Banco Mundial, Indicadores del Desarrollo Mundial.

\begin{tabular}{|l|c|c|}
\hline INDICADORES DE DESARROLLO (EFECTOS) & \\
\hline Indicador & $\mathbf{2 0 0 5}$ & $\mathbf{2 0 1 0}$ \\
\hline Desempleo (\% de la fuerza de trabajo total) & 2,7 & n.d. \\
\hline Población activa, mujeres (\% de la fuerza de trabajo total) & 47,8 & 47,6 \\
\hline A0D neta recibida (\% del INB) & 12,8 & 12,0 \\
\hline Derechos de importación percibidos (\% de los ingresos fiscales) & 17,3 & 17,0 \\
\hline Total del servicio de la deuda (\% de las exportaciones totales) & 7,7 & 3,7 \\
\hline Índice de desarrollo humano (0 a 1) & 0,30 & 0,33 \\
\hline
\end{tabular}

Fuentes: PNUD, indicadores internacionales sobre desarrollo humano; Banco Mundial, Indicadores del Desarrollo Mundial.

Producto interno bruto

PIB per cápita (PPA, dólares internacionales corrientes)
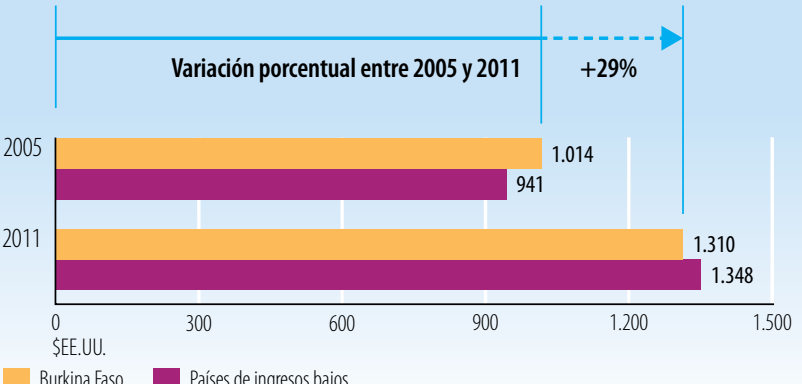

Burkina Faso Países de ingresos bajos

PIB per cápita (\$EE.UU. constantes de 2000)
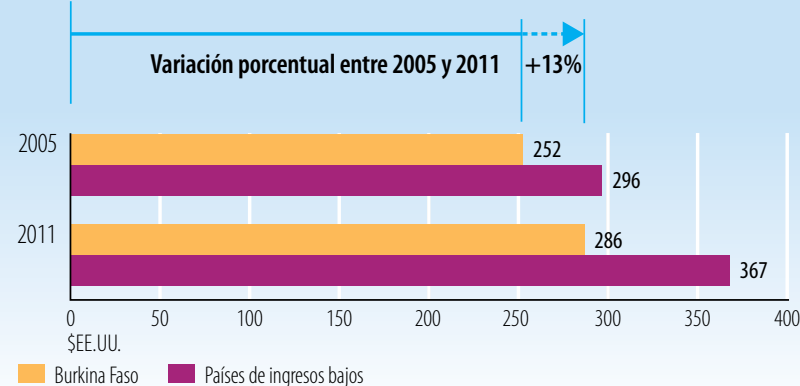

Fuentes: Banco Mundial, Indicadores del Desarrollo Mundial.

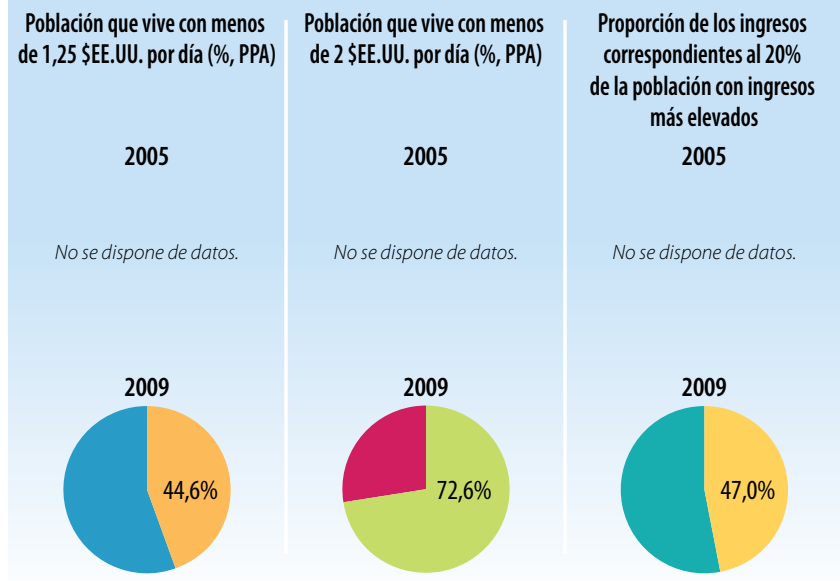

Fuentes: Banco Mundial, Indicadores del Desarrollo Mundial.

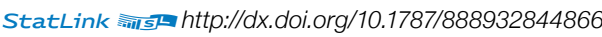


Indicadores de la ayuda, el comercio y el desarrollo relativos a Burundi

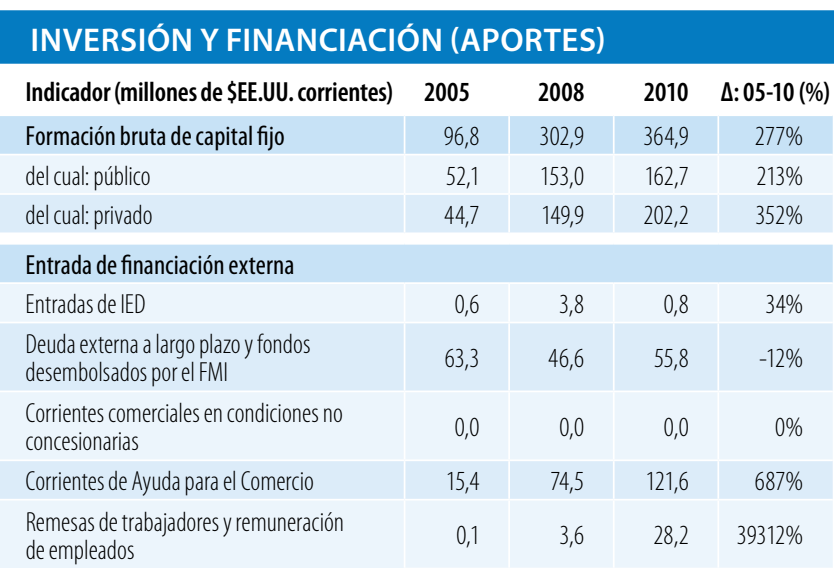

Fuentes: OCDE, base de datos del SNPA del CAD sobre las actividades de ayuda; Banco Mundial, Indicadores del Desarrollo Mundial; Banco Mundial, estadísticas de la deuda internacional.

Desembolsos de la ayuda para el comercio, por sector (millones de \$EE.UU. corrientes)

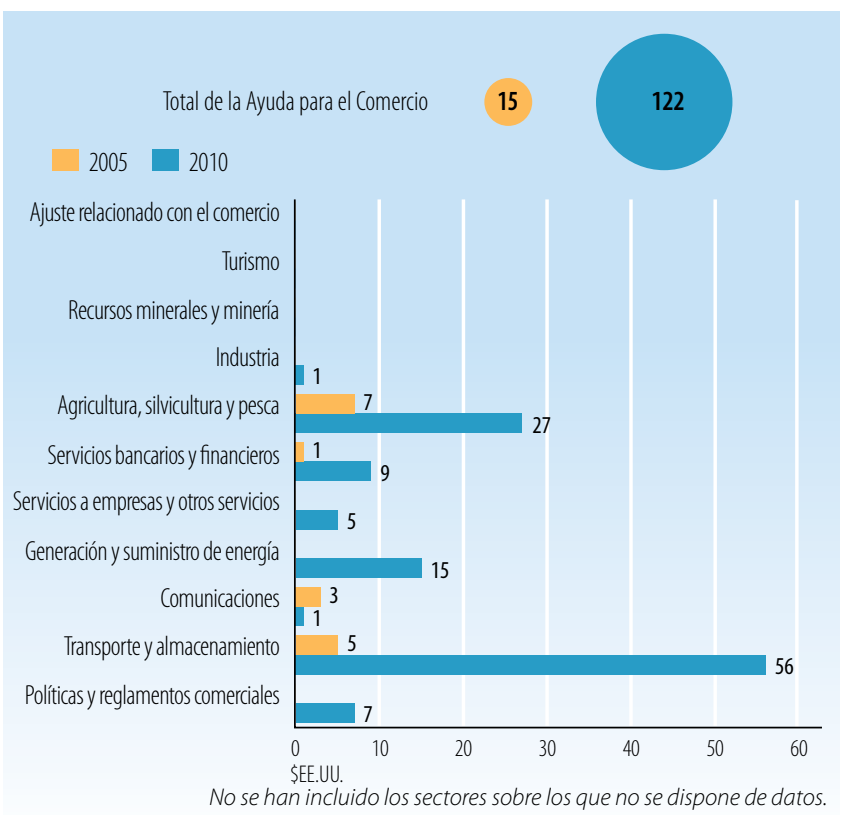

Fuentes: OCDE, base de datos del SNPA del CAD sobre las actividades de ayuda

Desembolsos de la ayuda para el comercio: principales donantes (millones de \$EE.UU. corrientes)

\begin{tabular}{|l|c|c|c|}
\hline $\mathbf{2 0 0 5}$ & Valor & $\%$ & Principales donantes en $\mathbf{2 0 0 5}$ \\
\hline Banco Mundial & 7,8 & 51 & \\
\hline Bélgica & 3,7 & 24 & \\
\hline Banco Africano de Desarrollo & 2,4 & 16 & $97 \%$ \\
\hline Italia & 0,6 & 4 & \\
\hline PNUD & 0,4 & 3 & \\
\hline $\mathbf{2 0 1 0}$ & Valor & $\%$ & Principales donantes en $\mathbf{2 0 1 0}$ \\
\hline Instituciones de la UE & 36,9 & 30 & \\
\hline Banco Mundial & 32,5 & 27 & \\
\hline Japón & 17,2 & 14 & $89 \%$ \\
\hline Bélgica & 12,0 & 10 & \\
\hline Banco Africano de Desarrollo & 9,8 & 8 & \\
\hline Fuentes: OCDE, base de datos del SNPA del CAD sobre las actividades de ayuda.
\end{tabular}

\section{INDICADORES COMERCIALES (PRODUCTOS)}

Indicador $20052008 \quad 2011 \quad \Delta: 05-11(\%)$

Relación comercio/PIB (\%)

Exportaciones de servicios comerciales como

$\%$ de las exportaciones totales

Importaciones de servicios comerciales como

$\%$ de las importaciones totales

Productos intermedios distintos de los combustibles

(\% de las exportaciones de mercancías)

Productos intermedios distintos de los combustibles

(\% de las importaciones de mercancías)

\begin{tabular}{|l|l|l|l|}
\hline 34 & 40 & 33 & -1 \\
\hline
\end{tabular}

\begin{tabular}{l|l|l|l|}
\hline 10 & 4 & n.d. & n.d.
\end{tabular}

\begin{tabular}{l|l|l|l|}
40 & 42 & n.d. & n.d.
\end{tabular}

\begin{tabular}{l|l|l|l|}
95 & n.d. & n.d.
\end{tabular}

\begin{tabular}{l|l|r|r|}
51 & 55 & n.d. & n.d.
\end{tabular}

Fuentes: Secretaría de la OMC.

Corrientes comerciales (millones de \$EE.UU. corrientes)

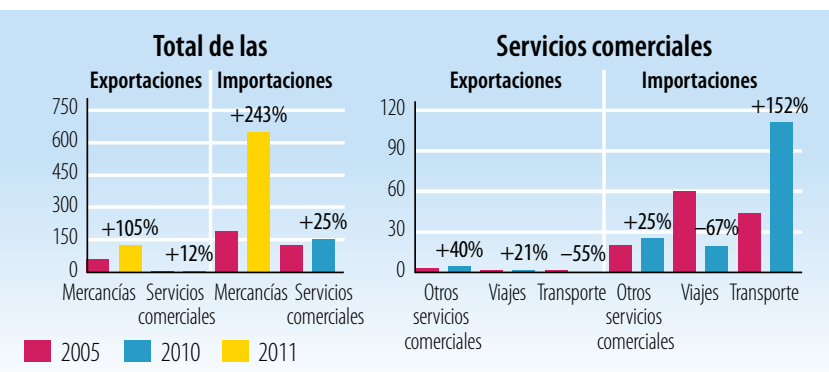

Fuentes: Secretaría de la OMC

Cinco principales mercados de exportación de mercancías (\%)

\begin{tabular}{|l|r|l|r|}
\hline 2005 & $\%$ & 2010 & $\%$ \\
\hline Suiza & 36 & UE (27) & 31 \\
\hline Emiratos Árabes Unidos & 25 & Suiza & 27 \\
\hline UE (27) & 20 & Emiratos Árabes Unidos & 9 \\
\hline Kenya & 7 & Kenya & 9 \\
\hline Rwanda & 4 & Congo, Rep. Democrática del & 6 \\
\hline Fuentes: Secretaría de la OMC & & & \\
\hline
\end{tabular}

Cinco principales productos de exportación (\% de las exportaciones de mercancías)

\begin{tabular}{|c|c|c|c|}
\hline 2005 & $\%$ & 2010 & $\%$ \\
\hline Oro no monetario, excepto minerales & 48 & Café y sucedáneos del café & 60 \\
\hline Café y sucedáneos del café & 41 & Oro no monetario, excepto minerales & 11 \\
\hline Algodón & 2 & Téy mate & 9 \\
\hline $\begin{array}{l}\text { Vehículos automotores para el transporte } \\
\text { de mercancías y vehículos automotores } \\
\text { para usos especiales }\end{array}$ & 1 & $\begin{array}{l}\text { Minerales de metales comunes y sus } \\
\text { concentrados }\end{array}$ & 3 \\
\hline Bebidas alcohólicas & 1 & $\begin{array}{l}\text { Cueros y pieles (excepto pieles finas), } \\
\text { sin curtir }\end{array}$ & 3 \\
\hline
\end{tabular}

Fuentes: Secretaría de la OMC

Cinco principales mercados de importación de mercancías (\%)

\begin{tabular}{|l|r|l|c|}
\hline 2005 & $\%$ & 2010 & $\%$ \\
\hline UE (27) & 34 & UE (27) & 27 \\
\hline Kenya & 12 & China & 12 \\
\hline Japón & 9 & Japón & 9 \\
\hline Turquía & 8 & Zambia & 8 \\
\hline Tanzanía & 5 & Kenya & 7 \\
\hline
\end{tabular}

Fuentes: Secretaría de la OMC

Cinco principales productos de importación (\% de las importaciones de mercancías)

\begin{tabular}{|c|c|c|c|}
\hline 2005 & $\%$ & 2010 & $\%$ \\
\hline Barras, perfiles, etc., de hierro y acero & 9 & Medicamentos & 9 \\
\hline Productos derivados del petróleo & 8 & Cal, cemento y materiales de construcción & 9 \\
\hline Medicamentos & 6 & $\begin{array}{l}\text { Vehículos automotores para pasajeros, } \\
\text { excepto autobuses }\end{array}$ & 5 \\
\hline $\begin{array}{l}\text { Vehículos automotores para el transporte } \\
\text { de mercancías y vehículos automotores } \\
\text { para usos especiales }\end{array}$ & 5 & $\begin{array}{l}\text { Equipos de telecomunicaciones y sus } \\
\text { partes, n.e.p. }\end{array}$ & 4 \\
\hline $\begin{array}{l}\text { Vehículos automotores para pasajeros, } \\
\text { excepto autobuses }\end{array}$ & 5 & Azúcares, melaza y miel & 3 \\
\hline
\end{tabular}




\section{LA AYUDA PARA EL COMERCIO EN SÍNTESIS 2013}

\section{INDICADORES COMERCIALES (RESULTADOS)}

\section{Indicador}

Crecimiento del PIB (\%)

Número de exportadores

Índice de concentración de las exportaciones (productos) ( 0 a 1)

ACR sobre mercancías notificados a la OMC

AlE (servicios) notificados a la OMC

Sectores de servicios con compromisos en el marco del AGCS

\section{Aranceles $(\%, 2006$ et 2011)}

\begin{tabular}{l|l|l|l|} 
Importaciones: promedio aritmético de los aranceles NMF aplicados & 12,7 & 12,5
\end{tabular}

Importaciones: promedio ponderado de los aranceles NMF aplicados n.d. 13,9

Exportaciones: promedio ponderado de los aranceles impuestos $\quad 0,5 \quad 1,2$

por los importadores

Exportaciones: libres de derechos (en \%)

$94,0 \quad 87,7$

Fuentes: Naciones Unidas, base de datos Comtrade; Banco Mundial, base de datos sobre dinámica de las empresas de exportación; Banco Mundial, Indicadores del

Desarrollo Mundial; OMC, perfiles comerciales y arancelarios.

Participación en las exportaciones por región (\%)

\begin{tabular}{|l|r|r|}
\hline & $\mathbf{2 0 0 5}$ & $\mathbf{2 0 1 0}$ \\
\hline África & 15,4 & 22,8 \\
\hline Asia & 1,6 & 8,4 \\
\hline Comunidad de Estados Independientes & 0,6 & 0,1 \\
\hline Europa & 56,4 & 57,9 \\
\hline Oriente Medio & 25,4 & 10,6 \\
\hline América del Norte & 0,2 & 0,1 \\
\hline América del Sury América Central & 0,0 & 0,0 \\
\hline
\end{tabular}

Fuentes: OMC, perfiles comerciales y arancelarios

Indicadores de facilitación del comercio
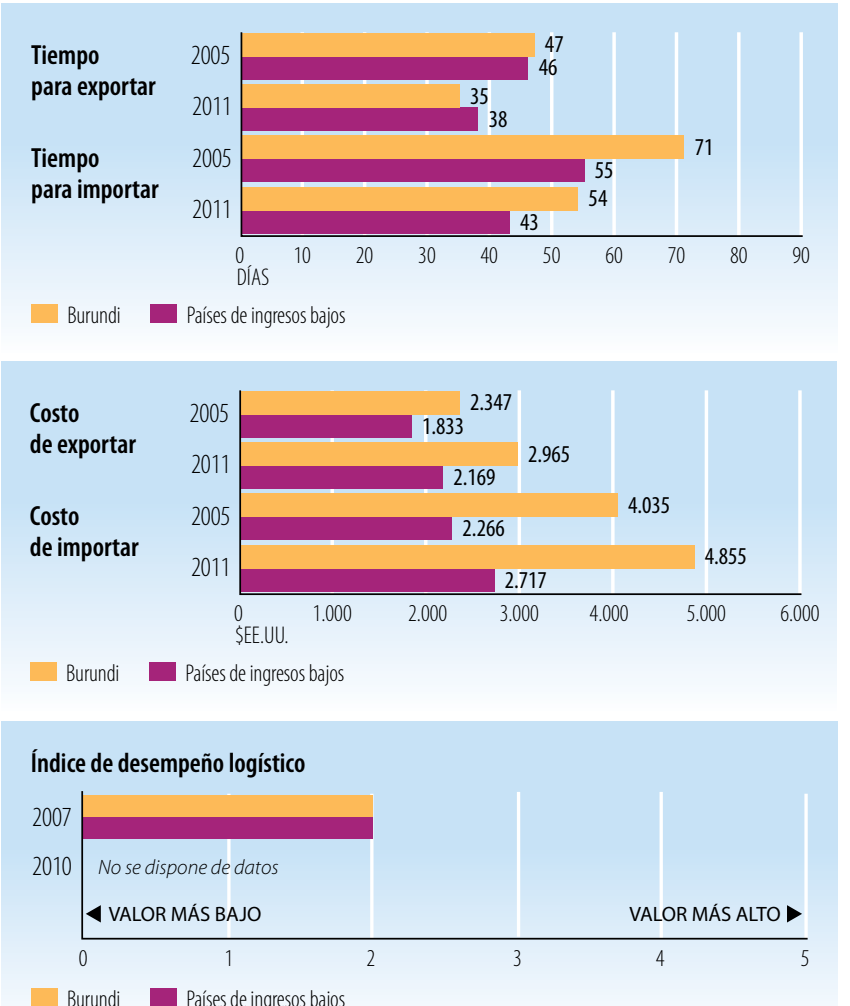

Burundi Países de ingresos bajos

Fuentes: Banco Mundial, Indicadores del Desarrollo Mundial.

\begin{tabular}{l|c|c|}
\hline INDICADORES DE DESARROLLO (EFECTOS) & \\
\hline Indicador & $\mathbf{2 0 0 5}$ & $\mathbf{2 0 1 0}$ \\
\hline Desempleo (\% de la fuerza de trabajo total) & n.d. & n.d. \\
\hline Población activa, mujeres (\% de la fuerza de trabajo total) & 52,6 & 52,1 \\
\hline AOD neta recibida (\% del INB) & 32,1 & 31,0 \\
\hline Derechos de importación percibidos (\% de los ingresos fiscales) & n.d. & n.d. \\
\hline Total del servicio de la deuda (\% de las exportaciones totales) & 39,8 & 16,6 \\
\hline Índice de desarrollo humano (0 a 1) & 0,27 & 0,31 \\
\hline
\end{tabular}

Fuentes: PNUD, indicadores internacionales sobre desarrollo humano; Banco Mundial, Indicadores del Desarrollo Mundial.

Producto interno bruto

PIB per cápita (PPA, dólares internacionales corrientes)
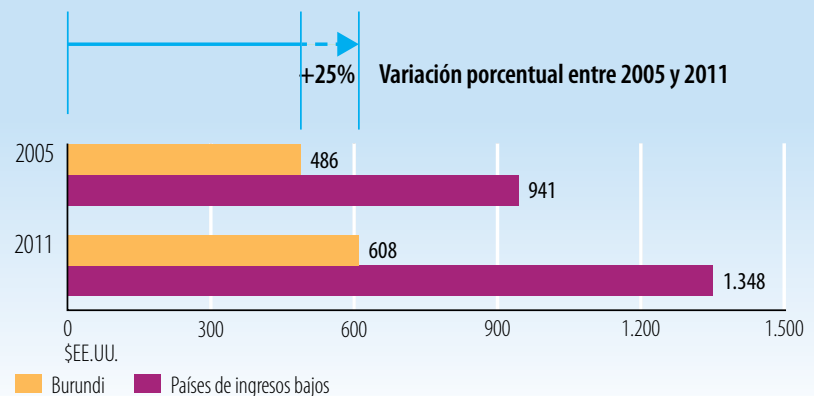

PIB per cápita (\$EE.UU. constantes de 2000)
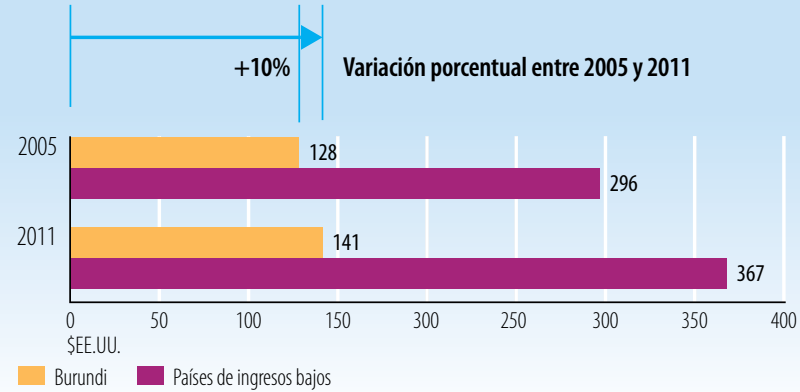

Fuentes: Banco Mundial, Indicadores del Desarrollo Mundial.

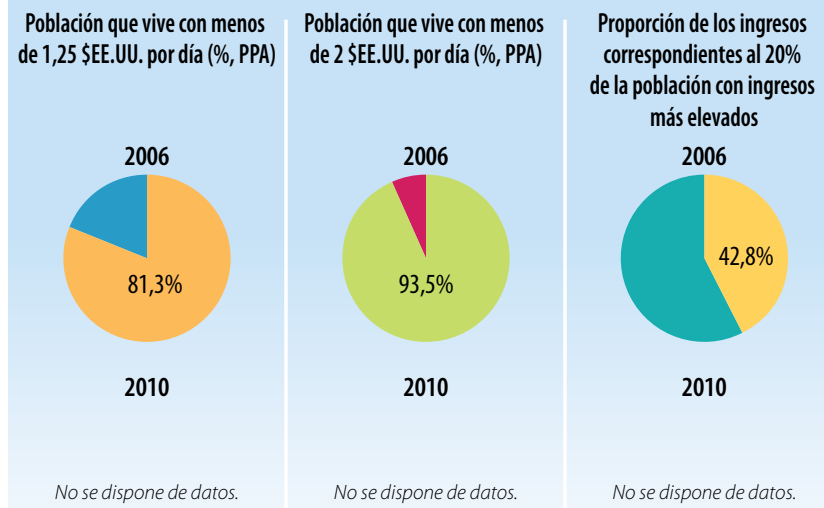

Fuentes: Banco Mundial, Indicadores del Desarrollo Mundial.

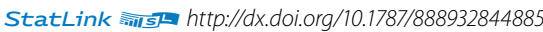


Indicadores de la ayuda, el comercio y el desarrollo relativos a Cabo Verde

\begin{tabular}{|c|c|c|c|c|}
\hline Indicador (millones de \$EE.UU. corrientes) & 2005 & 2008 & 2010 & $\Delta: 05-10(\%)$ \\
\hline Formación bruta de capital fijo & 348,0 & 722,1 & 776,7 & $123 \%$ \\
\hline del cual: público & 124,9 & 216,0 & 311,4 & $149 \%$ \\
\hline del cual: privado & 223,1 & 506,0 & 465,3 & $109 \%$ \\
\hline \multicolumn{5}{|l|}{ Entrada de financiación externa } \\
\hline Entradas de IED & 80,4 & 211,3 & 111,7 & $39 \%$ \\
\hline $\begin{array}{l}\text { Deuda externa a largo plazo y fondos } \\
\text { desembolsados por el FMI }\end{array}$ & 77,9 & 74,8 & 192,1 & $147 \%$ \\
\hline $\begin{array}{l}\text { Corrientes comerciales en condiciones no } \\
\text { concesionarias }\end{array}$ & 0,0 & 0,0 & 2,7 & d.p.c. \\
\hline Corrientes de Ayuda para el Comercio & 38,6 & 99,4 & 158,1 & $309 \%$ \\
\hline $\begin{array}{l}\text { Remesas de trabajadores y remuneración } \\
\text { de empleados }\end{array}$ & 136,6 & 155,1 & 138,6 & $1 \%$ \\
\hline
\end{tabular}

Fuentes: OCDE, base de datos del SNPA del CAD sobre las actividades de ayuda; Banco Mundial, Indicadores del Desarrollo Mundial; Banco Mundial, estadísticas de la deuda internacional.

Desembolsos de la ayuda para el comercio, por sector (millones de \$EE.UU. corrientes)

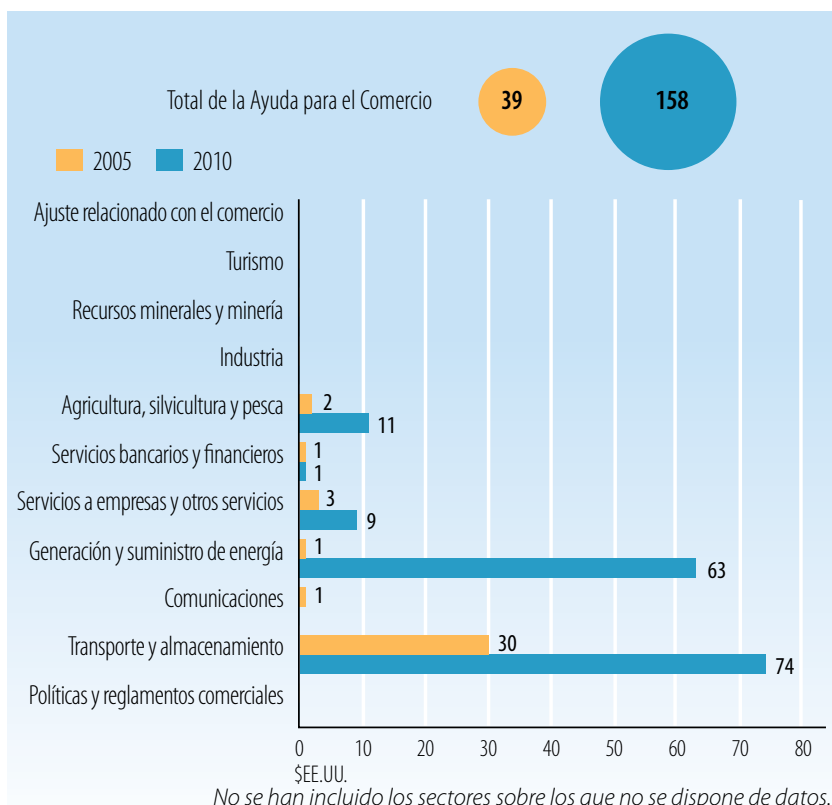

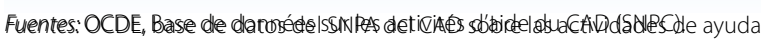

Desembolsos de la ayuda para el comercio: principales donantes (millones de \$EE.UU. corrientes)

\begin{tabular}{|l|c|c|c|}
\hline $\mathbf{2 0 0 5}$ & Valor & $\%$ & Principales donantes en 2005 \\
\hline Portugal & 16,4 & 43 & \\
\hline Banco Mundial & 6,4 & 16 & \\
\hline Estados Unidos & 6,3 & 16 & $88 \%$ \\
\hline Instituciones de la UE & 2,6 & 7 & \\
\hline Luxemburgo & 2,3 & 6 & \\
\hline $\mathbf{2 0 1 0}$ & Valor & $\%$ & Principales donantes en $\mathbf{2 0 1 0}$ \\
\hline Portugal & 82,5 & 52 & \\
\hline Estados Unidos & 34,1 & 22 & \\
\hline Banco Mundial & 12,7 & 8 & \\
\hline Japón & 8,9 & 6 & $92 \%$ \\
\hline España & 7,1 & 4 & \\
\hline
\end{tabular}

Fuentes: OCDE, base de datos del SNPA del CAD sobre las actividades de ayuda.

\section{INDICADORES COMERCIALES (PRODUCTOS)}

Indicador

$2005 \quad 2008 \quad 2011 \quad \Delta: 05-11(\%)$

Relación comercio/PIB (\%)

\begin{tabular}{|l|l|l|l|}
101 & 120 & 113 & 12 \\
\hline
\end{tabular}

Exportaciones de servicios comerciales como

$\%$ de las exportaciones totales

Importaciones de servicios comerciales como

$\%$ de las importaciones totales

Productos intermedios distintos de los combustibles

(\% de las exportaciones de mercancías)

Productos intermedios distintos de los combustibles

(\% de las importaciones de mercancías)

\begin{tabular}{|l|l|l|l|}
74 & 83 & 73 & -1
\end{tabular}

Fuentes: Secretaría de la OMC.

Corrientes comerciales (millones de \$EE.UU. corrientes)

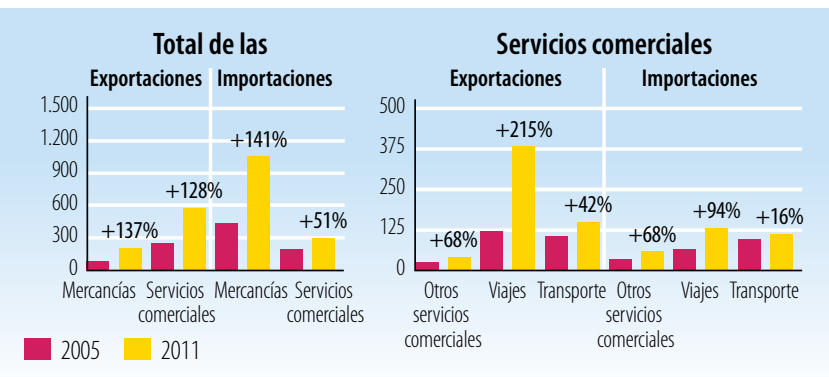

Fuentes: Secretaría de la OMC

Cinco principales mercados de exportación de mercancías (\%)

\begin{tabular}{|l|r|l|r|}
\hline 2005 & $\%$ & 2011 & $\%$ \\
\hline UE (27) & 57 & UE (27) & 94 \\
\hline Côte d'Ivoire & 13 & El Salvador & 4 \\
\hline Senegal & 10 & Santo Tomé y Príncipe & 1 \\
\hline Estados Unidos & 6 & Estados Unidos & 1 \\
\hline Arabia Saudita, Reino de la & 5 & India & 0 \\
\hline Fuentes: Secretaría de la OMC & & & \\
\hline
\end{tabular}

Cinco principales productos de exportación (\% de las exportaciones de mercancías)

\begin{tabular}{|c|c|c|c|}
\hline 2005 & $\%$ & 2011 & $\%$ \\
\hline Productos derivados del petróleo & 47 & $\begin{array}{l}\text { Pescados, etc., preparados o en } \\
\text { conserva, n.e.p. }\end{array}$ & 44 \\
\hline Remolques, semirremolques, etc. & 14 & Pescado, fresco, refrigerado o congelado & 36 \\
\hline Pescado, fresco, refrigerado o congelado & 12 & Calzado & 7 \\
\hline Instrumentos de medición y control & 3 & $\begin{array}{l}\text { Prendas de vestir para hombres y niños, } \\
\text { excepto las de punto }\end{array}$ & 3 \\
\hline Calzado & 3 & $\begin{array}{l}\text { Otros artículos textiles y prendas de } \\
\text { vestir, n.e.p. }\end{array}$ & 3 \\
\hline
\end{tabular}

Cinco principales mercados de importación de mercancías (\%)

\begin{tabular}{|l|r|l|r|}
\hline 2005 & $\%$ & 2011 & $\%$ \\
\hline UE (27) & 72 & UE (27) & 80 \\
\hline Brasil & 8 & Brasil & 4 \\
\hline Estados Unidos & 4 & Japón & 3 \\
\hline Japón & 3 & China & 3 \\
\hline China & 1 & Tailandia & 2 \\
\hline Fuentes:Secretaría de la OMC & & &
\end{tabular}

Cinco principales productos de importación (\% de las importaciones de mercancías)

\begin{tabular}{|c|c|c|c|}
\hline 2005 & $\%$ & 2011 & $\%$ \\
\hline Productos derivados del petróleo & 8 & Productos derivados del petróleo & 18 \\
\hline Cal, cemento y materiales de construcción & 5 & Aparatos eléctricos rotativos & 4 \\
\hline Leche y crema & 4 & Leche y crema & 3 \\
\hline $\begin{array}{l}\text { Vehículos automotores para pasajeros, } \\
\text { excepto autobuses }\end{array}$ & 3 & Cal, cemento y materiales de construcción & 3 \\
\hline $\begin{array}{l}\text { Buques, embarcaciones y estructuras } \\
\text { flotantes }\end{array}$ & 3 & Arroz & 3 \\
\hline
\end{tabular}




\section{LA AYUDA PARA EL COMERCIO EN SIINTESIS 2013}

\section{INDICADORES COMERCIALES (RESULTADOS)}

\section{Indicador}

Crecimiento del PIB (\%)

Número de exportadores

Índice de concentración de las exportaciones (productos) ( 0 a 1)

ACR sobre mercancías notificados a la OMC

AlE (servicios) notificados a la OMC

Sectores de servicios con compromisos en el marco del AGCS

\section{Aranceles (\%)}

\begin{tabular}{l|l|l|l|} 
Importaciones: promedio aritmético de los aranceles NMF aplicados & 10,4 & 10,2
\end{tabular}

\begin{tabular}{l|l|l|} 
Importaciones: promedio ponderado de los aranceles NMF aplicados & 12,3 & 11,2
\end{tabular}

Exportaciones: promedio ponderado de los aranceles impuestos

por los importadores

$0,2 \quad 1,1$

Exportaciones: libres de derechos (en \%)

$96,9 \quad 92,2$

Fuentes: Naciones Unidas, base de datos Comtrade; Banco Mundial, base de datos sobre dinámica de las empresas de exportación; Banco Mundial, Indicadores del

Desarrollo Mundial; OMC, perfiles comerciales y arancelarios.

Participación en las exportaciones por región (\%)

\begin{tabular}{|l|r|r|}
\hline & 2005 & 2010 \\
\hline África & 30,7 & 1,0 \\
\hline Asia & 0,4 & 0,6 \\
\hline Comunidad de Estados Independientes & 0,0 & 0,0 \\
\hline Europa & 57,1 & 94,2 \\
\hline Oriente Medio & 5,2 & 0,1 \\
\hline América del Norte & 6,0 & 0,5 \\
\hline América del Sury América Central & 0,6 & 3,5 \\
\hline
\end{tabular}

Fuentes: OMC, perfiles comerciales y arancelarios

Indicadores de facilitación del comercio
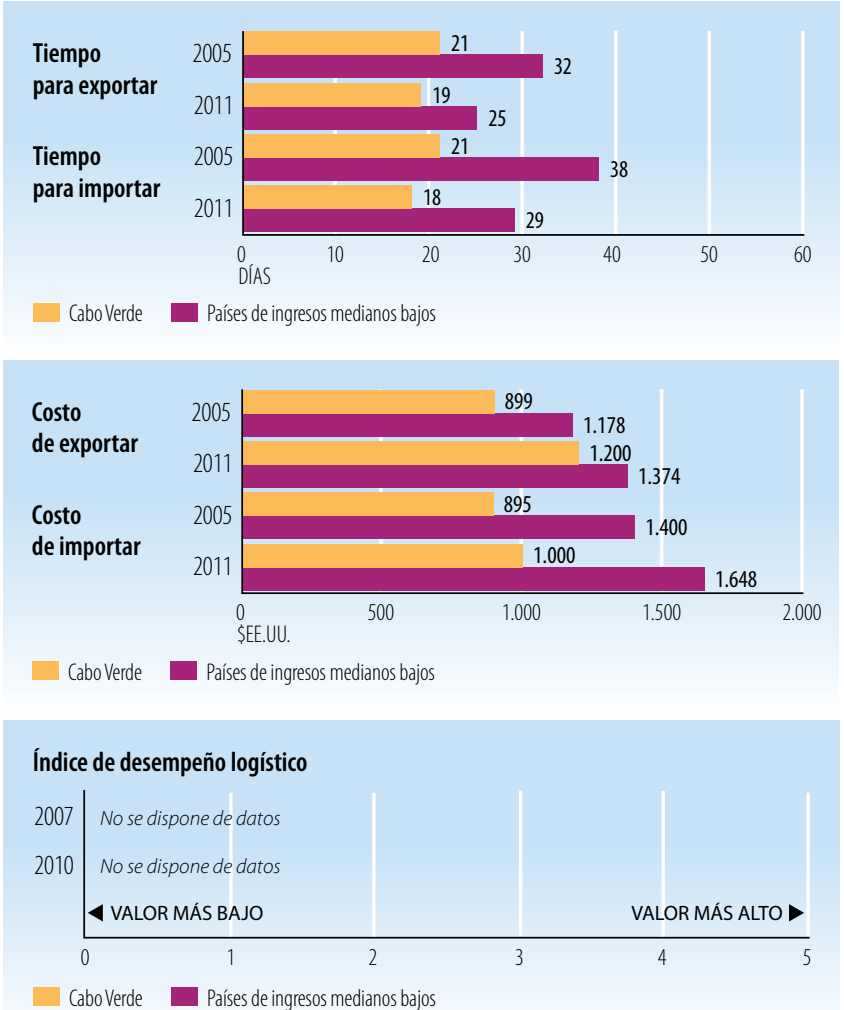

Fuentes: Banco Mundial, Indicadores del Desarrollo Mundial.

\begin{tabular}{l|c|c|}
\hline INDICADORES DE DESARROLLO (EFECTOS) & \\
\hline Indicador & $\mathbf{2 0 0 5}$ & $\mathbf{2 0 1 0}$ \\
\hline Desempleo (\% de la fuerza de trabajo total) & n.d. & n.d. \\
\hline Población activa, mujeres (\% de la fuerza de trabajo total) & 38,3 & 38,4 \\
\hline AOD neta recibida (\% del INB) & 17,3 & 20,7 \\
\hline Derechos de importación percibidos (\% de los ingresos fiscales) & n.d. & n.d. \\
\hline Total del servicio de la deuda (\% de las exportaciones totales) & 9,5 & 5,3 \\
\hline Índice de desarrollo humano ( 0 a 1) & 0,54 & 0,57 \\
\hline
\end{tabular}

Fuentes: PNUD, indicadores internacionales sobre desarrollo humano; Banco Mundial, Indicadores del Desarrollo Mundial.

Producto interno bruto

PIB per cápita (PPA, dólares internacionales corrientes)

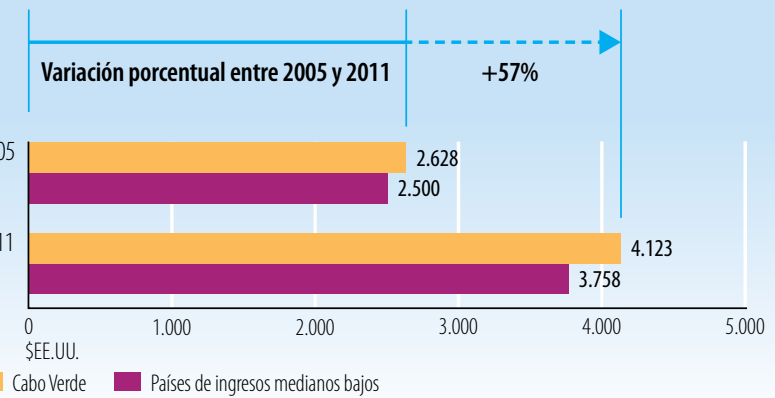

PIB per cápita (\$EE.UU. constantes de 2000)

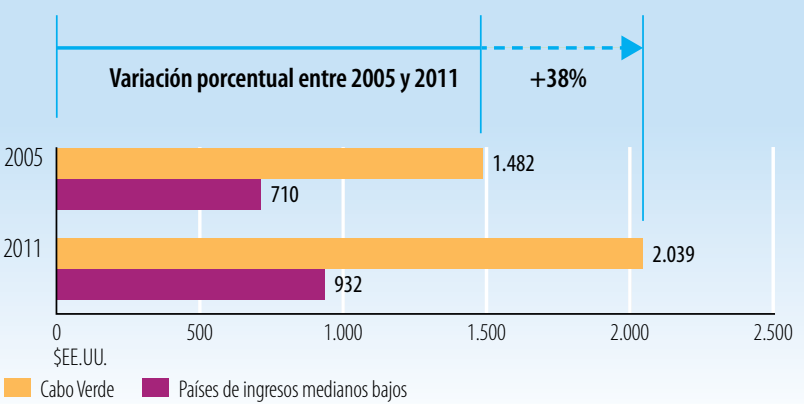

Fuentes: Banco Mundial, Indicadores del Desarrollo Mundial.

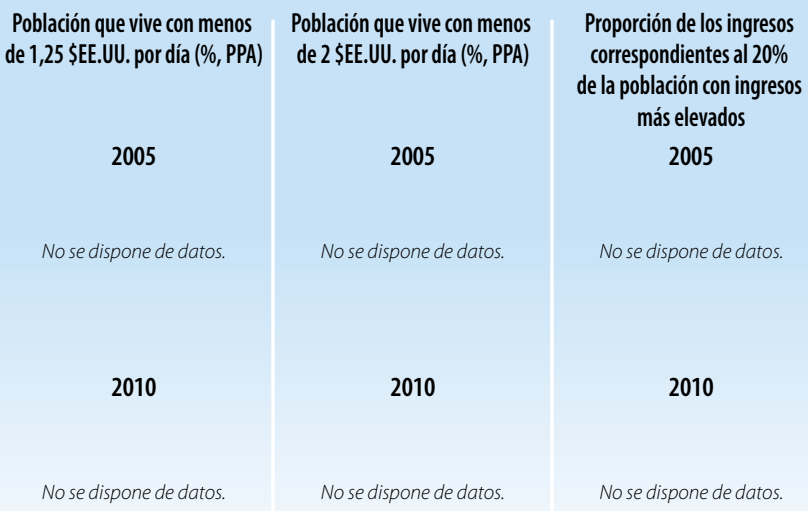

Fuentes: Banco Mundial, Indicadores del Desarrollo Mundial.

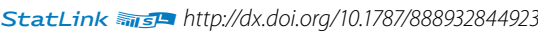


Indicadores de la ayuda, el comercio y el desarrollo relativos a Camboya

\begin{tabular}{|c|c|c|c|c|}
\hline Indicador (millones de \$EE.UU. corrientes) & 2005 & 2008 & 2010 & $\Delta: 05-10(\%)$ \\
\hline Formación bruta de capital fijo & $1.188,6$ & $1.787,5$ & $1.820,6$ & $53 \%$ \\
\hline del cual: público & 339,0 & 652,1 & 728,2 & $115 \%$ \\
\hline del cual: privado & 849,6 & $1.135,3$ & $1.092,3$ & $29 \%$ \\
\hline \multicolumn{5}{|l|}{ Entrada de financiación externa } \\
\hline Entradas de IED & 381,2 & 815,2 & 782,6 & $105 \%$ \\
\hline $\begin{array}{l}\text { Deuda externa a largo plazo y fondos } \\
\text { desembolsados por el FMl }\end{array}$ & 168,1 & 383,3 & 346,7 & $106 \%$ \\
\hline $\begin{array}{l}\text { Corrientes comerciales en condiciones no } \\
\text { concesionarias }\end{array}$ & 10,0 & 11,5 & 5,7 & $-44 \%$ \\
\hline Corrientes de Ayuda para el Comercio & 75,4 & 140,4 & 211,0 & $180 \%$ \\
\hline $\begin{array}{l}\text { Remesas de trabajadores y remuneración } \\
\text { de empleados }\end{array}$ & 199,7 & 325,2 & 369,5 & $85 \%$ \\
\hline
\end{tabular}

Fuentes: OCDE, base de datos del SNPA del CAD sobre las actividades de ayuda; Banco Mundial, Indicadores del Desarrollo Mundial; Banco Mundial, estadísticas de la deuda internacional.

Desembolsos de la ayuda para el comercio, por sector (millones de \$EE.UU. corrientes)

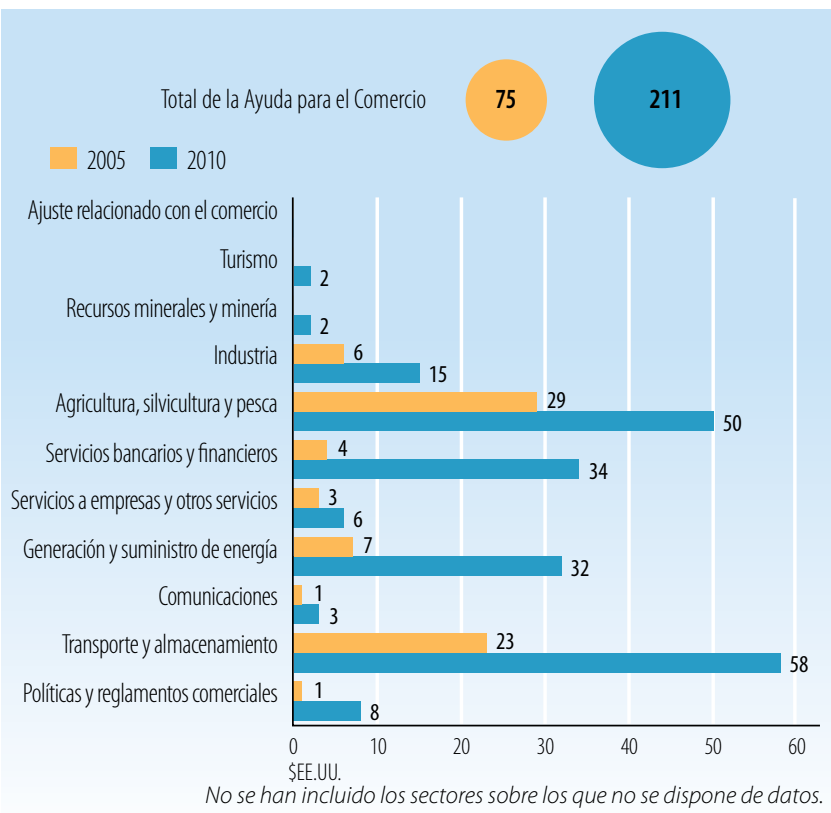

Fuentes: OCDE, base de datos del SNPA del CAD sobre las actividades de ayuda

Desembolsos de la ayuda para el comercio: principales donantes (millones de \$EE.UU. corrientes)

\begin{tabular}{|l|c|c|c|}
\hline $\mathbf{2 0 0 5}$ & Valor & $\%$ & Principales donantes en 2005 \\
\hline Japón & 24,8 & 33 & \\
\hline Banco Mundial & 21,1 & 28 & \\
\hline Australia & 7,5 & 10 & $86 \%$ \\
\hline Francia & 5,7 & 7 & \\
\hline Alemania & 5,4 & 7 & \\
\hline $\mathbf{2 0 1 0}$ & Valor & $\%$ & Principales donantes en $\mathbf{2 0 1 0}$ \\
\hline Japón & 55,7 & 26 & \\
\hline Banco Asiático de Desarrollo & 46,3 & 22 & \\
\hline Corea, Rep. de & 20,6 & 10 & \\
\hline España & 16,3 & 8 & $73 \%$ \\
\hline Alemania & 15,1 & 7 & \\
\hline
\end{tabular}

Fuentes: OCDE, base de datos del SNPA del CAD sobre las actividades de ayuda.

\section{INDICADORES COMERCIALES (PRODUCTOS)}

Indicador

$2005 \quad 2008 \quad 2011 \quad \Delta: 05-11(\%)$

Relación comercio/PIB (\%)

\begin{tabular}{|l|l|l|l|}
135 & 133 & 150 & 15 \\
\hline
\end{tabular}

Exportaciones de servicios comerciales como

$\%$ de las exportaciones totales

Importaciones de servicios comerciales como

$\%$ de las importaciones totales

Productos intermedios distintos de los combustibles

(\% de las exportaciones de mercancías)

Productos intermedios distintos de los combustibles

(\% de las importaciones de mercancías)

\begin{tabular}{l|l|l|l|}
27 & 26 & 23 & -4
\end{tabular}

\begin{tabular}{l|l|r|r}
14 & 13 & 15 & 1
\end{tabular}

\begin{tabular}{l|l|r|r|}
23 & 25 & n.d.
\end{tabular}

$60 \quad 61 \quad$ n.d. $\quad$ n.d.

Fuentes: Secretaría de la OMC

Corrientes comerciales (millones de \$EE.UU. corrientes)

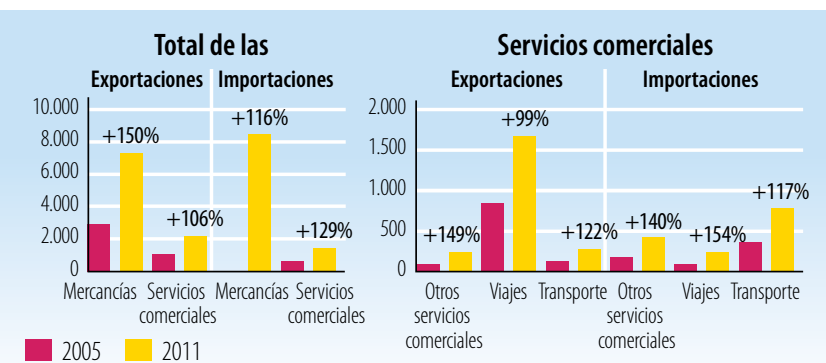

Fuentes: Secretaría de la OMC

Cinco principales mercados de exportación de mercancías (\%)

\begin{tabular}{|l|r|l|r|}
\hline 2005 & $\%$ & 2010 & $\%$ \\
\hline Estados Unidos & 53 & Estados Unidos & 34 \\
\hline Hong Kong, China & 18 & Hong Kong, China & 25 \\
\hline UE (27) & 17 & UE (27) & 17 \\
\hline Canadá & 4 & Singapur & 8 \\
\hline Singapur & 2 & Canadá & 5 \\
\hline Fuentes: Secretaría de la OMC & & &
\end{tabular}

Cinco principales productos de exportación (\% de las exportaciones de mercancías)

\begin{tabular}{|c|c|c|c|}
\hline 2005 & $\%$ & 2010 & $\%$ \\
\hline $\begin{array}{l}\text { Prendas de vestir para mujeres y niñas, } \\
\text { de punto }\end{array}$ & 29 & Impresos & 32 \\
\hline $\begin{array}{l}\text { Otros artículos textiles y prendas de } \\
\text { vestir, n.e.p. }\end{array}$ & 24 & $\begin{array}{l}\text { Prendas de vestir para mujeres y niñas, } \\
\text { de punto }\end{array}$ & 21 \\
\hline Impresos & 19 & $\begin{array}{l}\text { Otros artículos textiles y prendas de } \\
\text { vestir, n.e.p. }\end{array}$ & 20 \\
\hline $\begin{array}{l}\text { Prendas de vestir para hombres y niños, } \\
\text { de punto }\end{array}$ & 16 & $\begin{array}{l}\text { Prendas de vestir para hombres y niños, } \\
\text { de punto }\end{array}$ & 12 \\
\hline $\begin{array}{l}\text { Prendas de vestir para mujeres y niñas, } \\
\text { excepto las de punto }\end{array}$ & 2 & Calzado & 3 \\
\hline
\end{tabular}

Cinco principales mercados de importación de mercancías (\%)

\begin{tabular}{|l|c|l|l|}
\hline $\mathbf{2 0 0 5}$ & $\%$ & $\mathbf{2 0 1 0}$ & $\%$ \\
\hline Hong Kong, China & 18 & China & 24 \\
\hline China & 17 & Tailandia & 14 \\
\hline Taipei Chino & 11 & Hong Kong, China & 11 \\
\hline Tailandia & 11 & Viet Nam & 10 \\
\hline UE (27) & 9 & Taipei Chino & 10 \\
\hline
\end{tabular}

Cinco principales productos de importación (\% de las importaciones de mercancías)

\begin{tabular}{|l|r|l|r|}
\hline $\mathbf{2 0 0 5}$ & $\%$ & $\mathbf{2 0 1 0}$ & $\%$ \\
\hline Tejidos de punto o ganchillo, n.e.p. & 17 & Tejidos de punto o ganchillo, n.e.p. & 20 \\
\hline Tejidos de fibras manufacturadas & 15 & Tejidos de fibras manufacturadas & 8 \\
\hline Productos derivados del petróleo & 7 & Productos derivados del petróleo & 6 \\
\hline Aparatos fotográficos, etc., n.e.p. & 5 & Equipo de ingeniería civil & 4 \\
\hline Tabaco manufacturado & 3 & Oro no monetario, excepto minerales & 3
\end{tabular}

Fuentes: Secretaría de la OMC 


\section{LA AYUDA PARA EL COMERCIO EN SÍNTESIS 2013}

\section{INDICADORES COMERCIALES (RESULTADOS)}

Indicador

Crecimiento del PIB (\%)

Número de exportadores

Índice de concentración de las exportaciones (productos) ( 0 a 1)

ACR sobre mercancías notificados a la OMC

AIE (servicios) notificados a la OMC

Sectores de servicios con compromisos en el marco del AGCS

\section{Aranceles $(\%, 2006$ et 2011)}

\begin{tabular}{l|l|l|l|} 
Importaciones: promedio aritmético de los aranceles NMF aplicados & 14,3 & 10,9
\end{tabular}

\begin{tabular}{l|l|l|l|} 
Importaciones: promedio ponderado de los aranceles NMF aplicados & 10,9 & 9,5
\end{tabular}

\begin{tabular}{c|c|c|c|} 
Exportaciones: promedio ponderado de los aranceles impuestos & 10,6 & 8,9
\end{tabular}

por los importadores

$35,0 \quad 46,5$

Exportaciones: libres de derechos (en \%) sobre dinámica de las empresas de exportación; Banco Mundial, Indicadores del

Desarrollo Mundial; OMC, perfiles comerciales y arancelarios.

Participación en las exportaciones por región (\%)

\begin{tabular}{|l|r|r|}
\hline & 2005 & 2010 \\
\hline África & 0,0 & 0,2 \\
\hline Asia & 25,7 & 41,7 \\
\hline Comunidad de Estados Independientes & 0,1 & 0,4 \\
\hline Europa & 17,3 & 17,2 \\
\hline Oriente Medio & 0,1 & 0,3 \\
\hline América del Norte & 56,6 & 39,5 \\
\hline América del Sury América Central & 0,1 & 0,6 \\
\hline
\end{tabular}

Fuentes: OMC, perfiles comerciales y arancelarios

Indicadores de facilitación del comercio
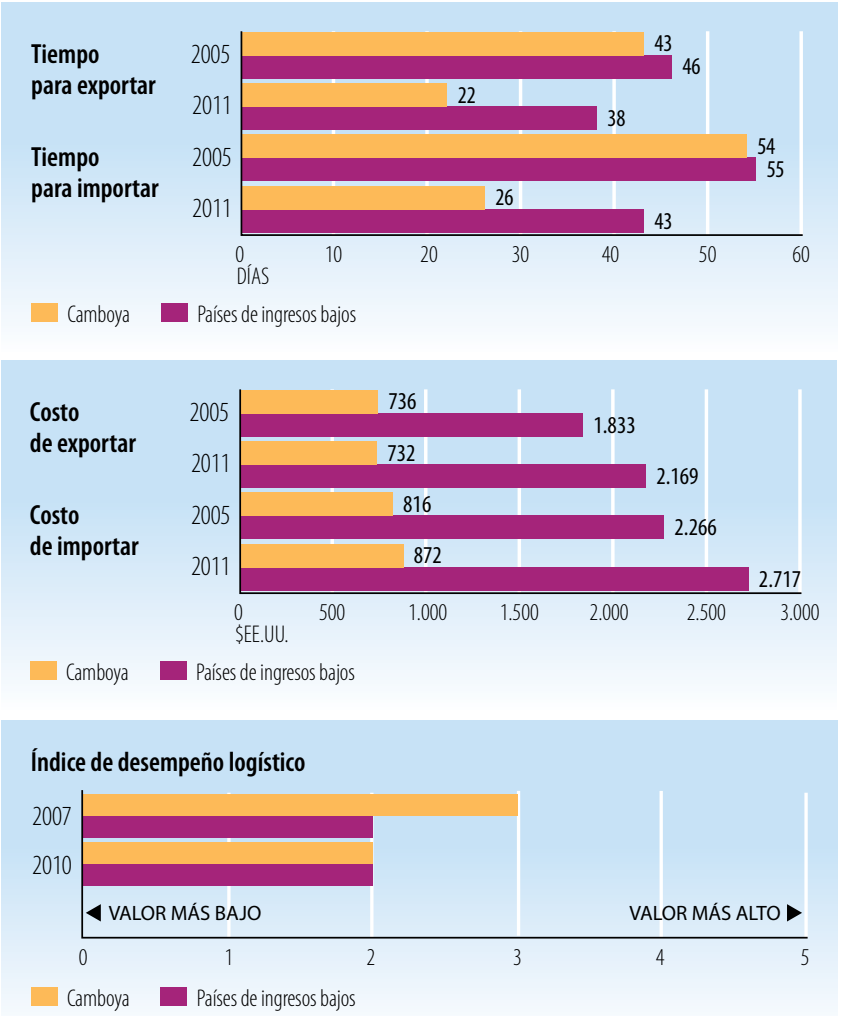

Fuentes: Banco Mundial, Indicadores del Desarrollo Mundial.

\begin{tabular}{l|c|c|}
\hline INDICADORES DE DESARROLLO (EFECTOS) & \\
\hline Indicador & 2005 & 2010 \\
\hline Desempleo (\% de la fuerza de trabajo total) & n.d. & 1,7 \\
\hline Población activa, mujeres (\% de la fuerza de trabajo total) & 49,3 & 49,9 \\
\hline AOD neta recibida (\% del INB) & 8,9 & 6,9 \\
\hline Derechos de importación percibidos (\% de los ingresos fiscales) & 27,1 & 21,8 \\
\hline Total del servicio de la deuda (\% de las exportaciones totales) & 0,8 & 0,8 \\
\hline Índice de desarrollo humano ( 0 a 1) & 0,49 & 0,52 \\
\hline
\end{tabular}

Fuentes: PNUD, indicadores internacionales sobre desarrollo humano; Banco Mundial, Indicadores del Desarrollo Mundial.

Producto interno bruto

PIB per cápita (PPA, dólares internacionales corrientes)

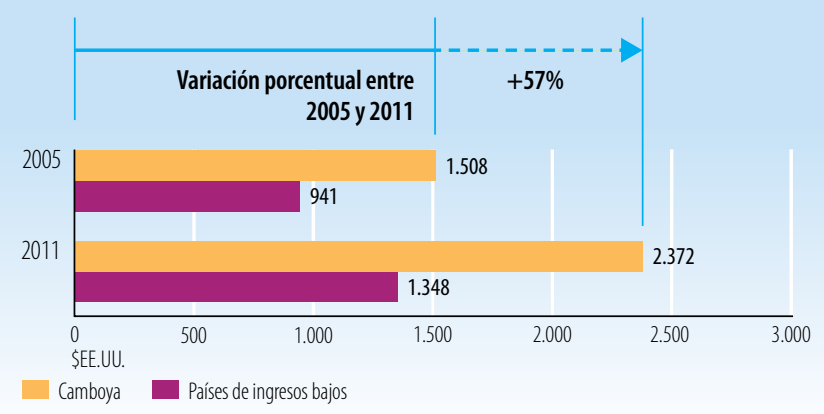

PIB per cápita (\$\$EE.UU. constantes de 2000)

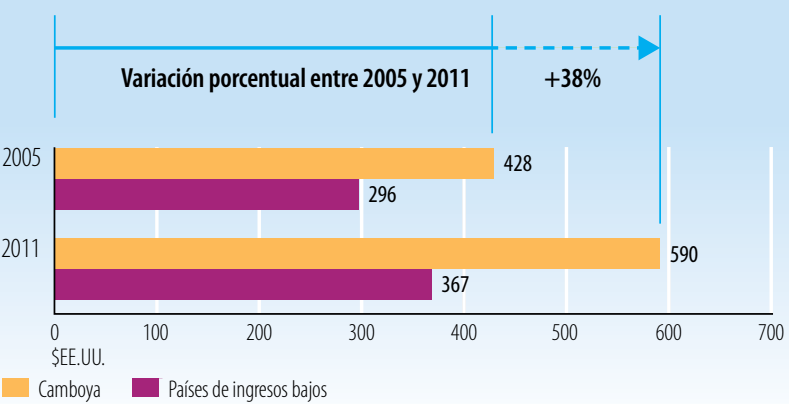

Fuentes: Banco Mundial, Indicadores del Desarrollo Mundial.

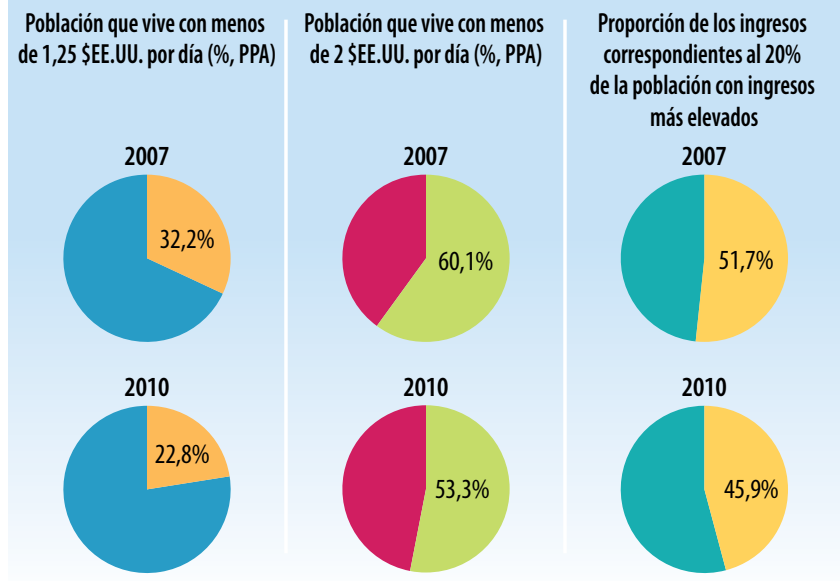

Fuentes: Banco Mundial, Indicadores del Desarrollo Mundial.

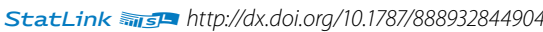


Indicadores de la ayuda, el comercio y el desarrollo relativos al Chad

\begin{tabular}{|c|c|c|c|c|}
\hline Indicador (millones de \$EE.UU. corrientes) & 2005 & 2008 & 2010 & $\Delta: 05-10(\%$ \\
\hline Formación bruta de capital fijo & 883,4 & $1.997,4$ & $2.716,4$ & $207 \%$ \\
\hline del cual: público & 411,3 & 660,2 & 773,9 & $88 \%$ \\
\hline del cual: privado & 472,1 & $1.337,1$ & $1.942,4$ & $311 \%$ \\
\hline \multicolumn{5}{|l|}{ Entrada de financiación externa } \\
\hline Entradas de IED & $-99,3$ & 233,6 & 781,4 & $887 \%$ \\
\hline $\begin{array}{l}\text { Deuda externa a largo plazo y fondos } \\
\text { desembolsados por el FMI }\end{array}$ & 115,7 & 97,2 & 57,4 & $-50 \%$ \\
\hline $\begin{array}{l}\text { Corrientes comerciales en condiciones no } \\
\text { concesionarias }\end{array}$ & 0,5 & 4,3 & 0,0 & $-100 \%$ \\
\hline Corrientes de Ayuda para el Comercio & 76,3 & 69,8 & 26,4 & $-65 \%$ \\
\hline $\begin{array}{l}\text { Remesas de trabajadores y remuneración } \\
\text { de empleados }\end{array}$ & n.d. & n.d. & n.d. & n.d. \\
\hline
\end{tabular}

Fuentes: OCDE, base de datos del SNPA del CAD sobre las actividades de ayuda; Banco Mundial, Indicadores del Desarrollo Mundial; Banco Mundial, estadísticas de la deuda internacional.

Desembolsos de la ayuda para el comercio, por sector (millones de \$EE.UU. corrientes)

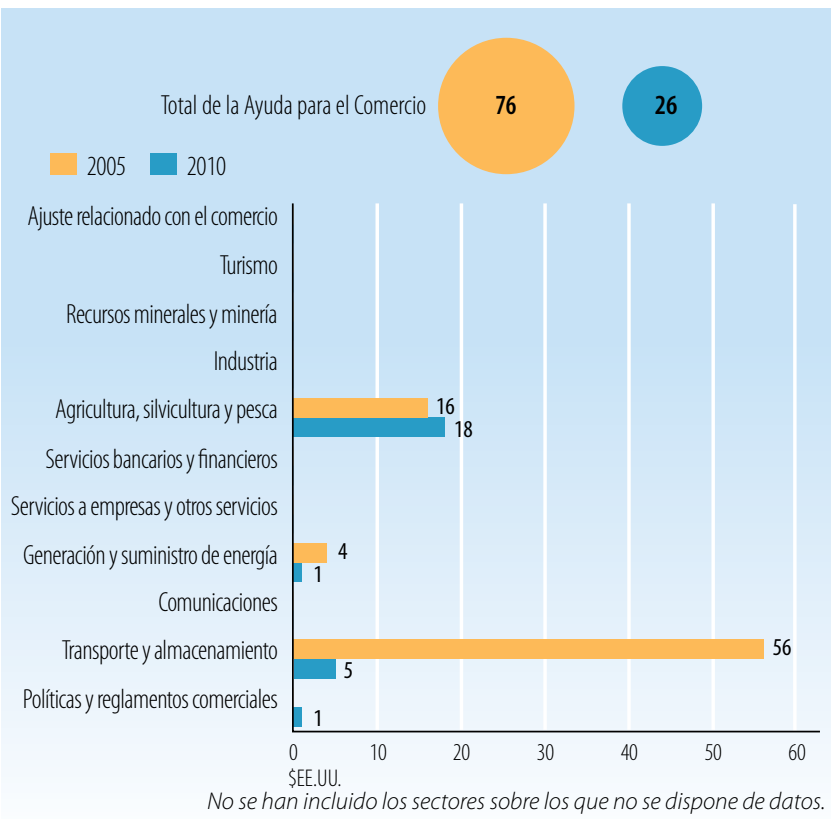

Fuentes: OCDE, base de datos del SNPA del CAD sobre las actividades de ayuda

Desembolsos de la ayuda para el comercio: principales donantes (millones de \$̦E.UU. corrientes)

\begin{tabular}{|l|r|r|r|}
\hline $\mathbf{2 0 0 5}$ & Valor & $\%$ & Principales donantes en 2005 \\
\hline Banco Mundial & 40,3 & 53 & \\
\hline Instituciones de la UE & 22,6 & 30 & \\
\hline Francia & 5,3 & 7 & $97 \%$ \\
\hline Banco Africano de Desarrollo & 4,0 & 5 & \\
\hline Suiza & 2,2 & 3 & \\
\hline $\mathbf{2 0 1 0}$ & Valor & $\%$ & Principales donantes en 2010 \\
\hline Banco Africano de Desarrollo & 11,5 & 44 & \\
\hline Instituciones de la UE & 6,2 & 24 & \\
\hline Banco Mundial & 2,7 & 10 & \\
\hline Suiza & 2,6 & 10 & $94 \%$ \\
\hline OFID & 1,7 & 6 & \\
\hline
\end{tabular}

Fuentes: OCDE, base de datos del SNPA del CAD sobre las actividades de ayuda.

\section{INDICADORES COMERCIALES (PRODUCTOS)}

\section{Indicador}

$2005 \quad 2008 \quad 2011 \quad \Delta: 05-11(\%)$

Relación comercio/PIB (\%)

Exportaciones de servicios comerciales como

$\%$ de las exportaciones totales

\begin{tabular}{l|l|l|r|}
106 & 98 & 72 & -35 \\
\hline
\end{tabular}

Importaciones de servicios comerciales como $\%$ de las importaciones totales

\begin{tabular}{|r|r|r|r|}
\hline 2 & 3 & n.d. & n.d. \\
\hline 62 & 48 & n.d. & n.d. \\
\hline n.d. & n.d. & n.d. & n.d. \\
\hline n.d. & n.d. & n.d. & n.d. \\
\hline
\end{tabular}

Productos intermedios distintos de los combustibles

(\% de las exportaciones de mercancías)

Productos intermedios distintos de los combustibles

(\% de las importaciones de mercancías)

Fuentes: Secretaría de la OMC.

Corrientes comerciales (millones de \$EE.UU. corrientes)

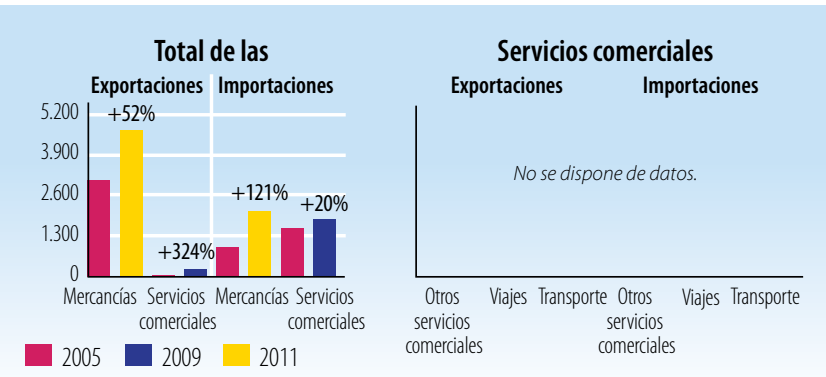

Fuentes: Secretaría de la OMC

Cinco principales mercados de exportación de mercancías (\%)

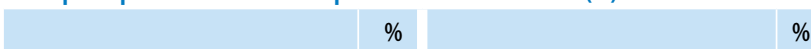

No se dispone de datos.

No se dispone de datos.

Fuentes: Secretaría de la OMC

Cinco principales productos de exportación (\% de las exportaciones de mercancías)

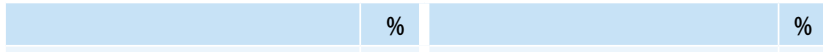

No se dispone de datos.

No se dispone de datos.

Fuentes: Secretaría de la OMC

Cinco principales mercados de importación de mercancías (\%)

$\%$

No se dispone de datos.

Fuentes: Secretaría de la OMC

Cinco principales productos de importación (\% de las importaciones de mercancías) $\%$ 


\section{LA AYUDA PARA EL COMERCIO EN SINNTESIS 2013}

\section{INDICADORES COMERCIALES (RESULTADOS)}

\section{Indicador}

Crecimiento del PIB (\%)

Número de exportadores

Índice de concentración de las exportaciones (productos) ( 0 a 1)

ACR sobre mercancías notificados a la OMC

AlE (servicios) notificados a la OMC

Sectores de servicios con compromisos en el marco del AGCS

\section{Aranceles (\%)}

\begin{tabular}{l|l|l|l|} 
Importaciones: promedio aritmético de los aranceles NMF aplicados & 18,0 & 17,8
\end{tabular}

Importaciones: promedio ponderado de los aranceles NMF aplicados n.d. n.d.

\begin{tabular}{|l|l|l|} 
Exportaciones: promedio ponderado de los aranceles impuestos & 0,5 & 1,1
\end{tabular}

por los importadores

$94,7 \quad 90,7$

Exportaciones: libres de derechos (en \%)
Fuentes: Naciones Unidas, base de datos Comtrade; Banco Mundial, base de datos sobre dinámica de las empresas de exportación; Banco Mundial, Indicadores del Desarrollo Mundial; OMC, perfiles comerciales y arancelarios.

Participación en las exportaciones por región (\%)

\begin{tabular}{|l|r|r|}
\hline África & 2005 & 2011 \\
\hline Asia & n.d. & n.d. \\
\hline Comunidad de Estados Independientes & n.d. & n.d. \\
\hline Europa & n.d. & n.d. \\
\hline Oriente Medio & n.d. & n.d. \\
\hline América del Norte & n.d. & n.d. \\
\hline América del Sury América Central & n.d. & n.d. \\
\hline
\end{tabular}

Fuentes: OMC, perfiles comerciales y arancelarios

Indicadores de facilitación del comercio
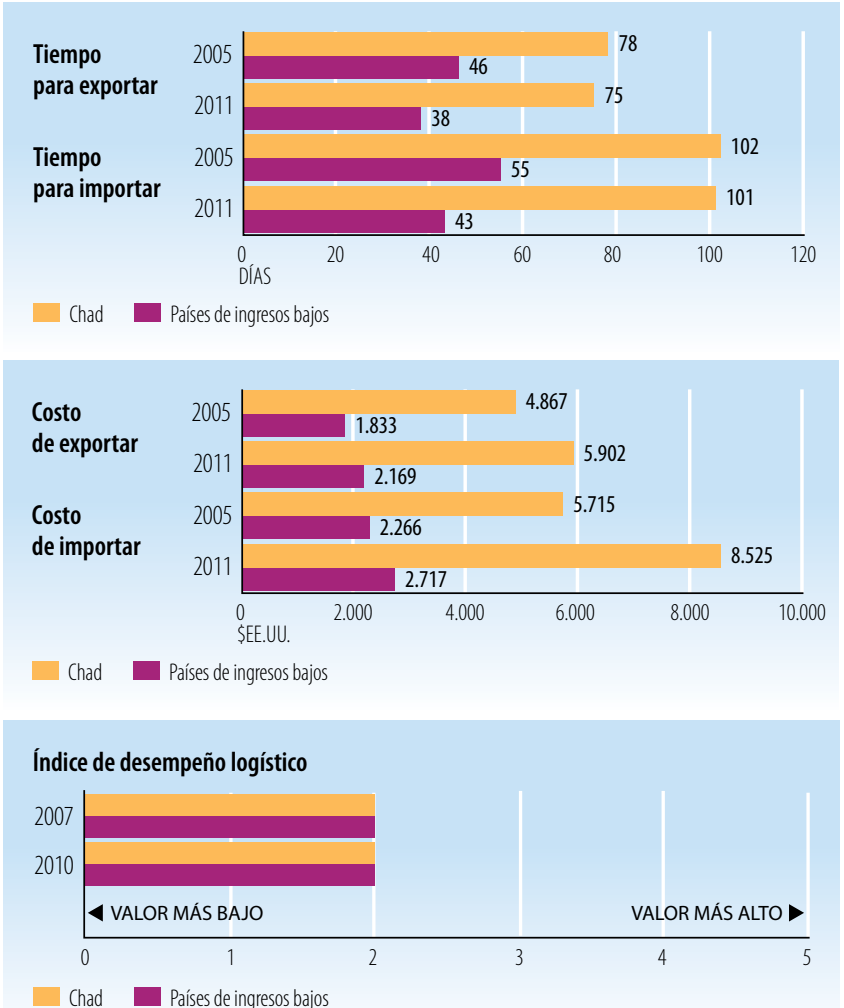

Fuentes: Banco Mundial, Indicadores del Desarrollo Mundial.

\begin{tabular}{l|c|c|}
\hline INDICADORES DE DESARROLLO (EFECTOS) & \\
\hline Indicador & 2005 & $\mathbf{2 0 1 0}$ \\
\hline Desempleo (\% de la fuerza de trabajo total) & n.d. & n.d. \\
\hline Población activa, mujeres (\% de la fuerza de trabajo total) & 45,4 & 45,3 \\
\hline AOD neta recibida (\% del INB) & 9,0 & 6,2 \\
\hline Derechos de importación percibidos (\% de los ingresos fiscales) & n.d. & n.d. \\
\hline Total del servicio de la deuda (\% de las exportaciones totales) & n.d. & n.d. \\
\hline Índice de desarrollo humano (0 a 1) & 0,31 & 0,33 \\
\hline
\end{tabular}

Fuentes: PNUD, indicadores internacionales sobre desarrollo humano; Banco Mundial, Indicadores del Desarrollo Mundial.

Producto interno bruto

\section{PIB per cápita (PPA, dólares internacionales corrientes)}
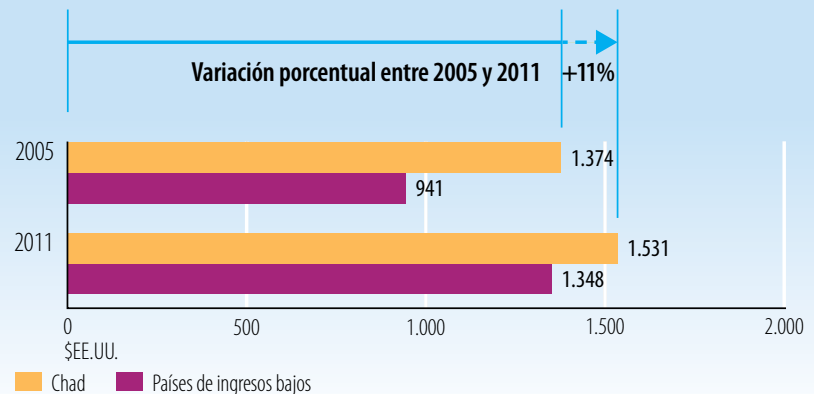

PIB per cápita (\$EE.UU. constantes de 2000)
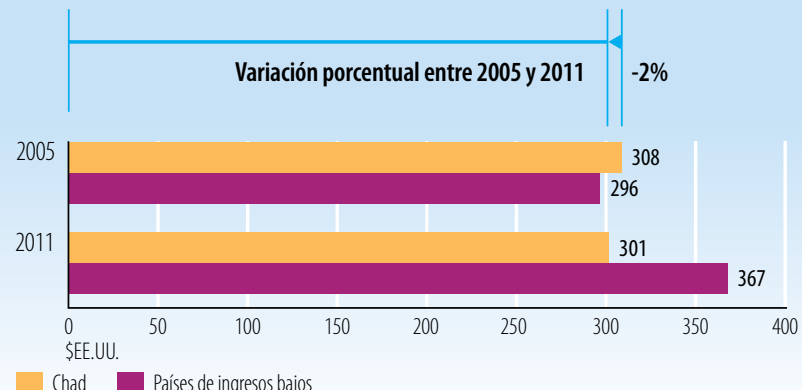

Fuentes: Banco Mundial, Indicadores del Desarrollo Mundial.

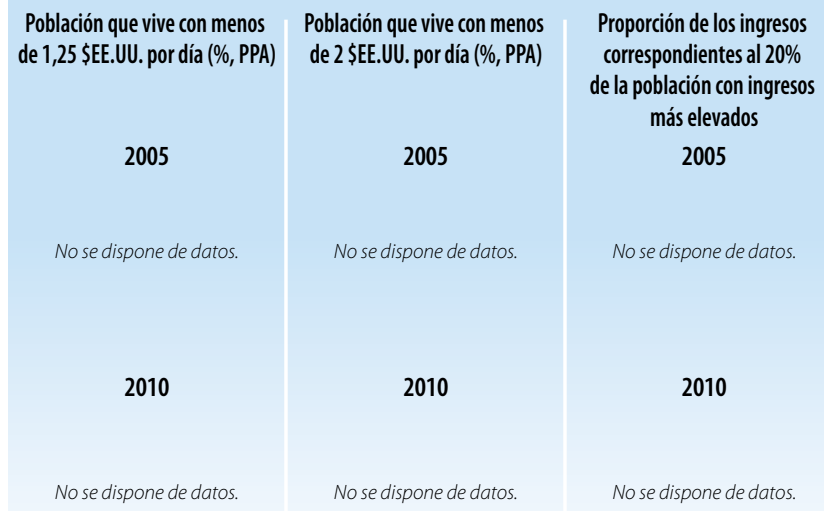

Fuentes: Banco Mundial, Indicadores del Desarrollo Mundial.

StatLink 첵ㄴ $h$ ttp://dx.doi.org/10.1787/888932844961 


\section{Indicadores de la ayuda, el comercio y el desarrollo relativos a Colombia}

\begin{tabular}{|c|c|c|c|c|}
\hline \multicolumn{5}{|c|}{ INVERSIÓN Y FINANCIACIÓN (APORTES) } \\
\hline Indicador (millones de \$̦EE.UU. corrientes) & 2005 & 2008 & 2010 & $\Delta: 05-10(\%)$ \\
\hline Formación bruta de capital fijo & $28.813,4$ & $50.583,4$ & $66.576,1$ & $131 \%$ \\
\hline del cual: público & n.d. & n.d. & n.d. & n.d. \\
\hline del cual: privado & n.d. & n.d. & n.d. & n.d. \\
\hline \multicolumn{5}{|l|}{ Entrada de financiación externa } \\
\hline Entradas de IED & $10.252,0$ & $10.619,6$ & $6.899,3$ & $-33 \%$ \\
\hline $\begin{array}{l}\text { Deuda externa a largo plazo y fondos } \\
\text { desembolsados por el FMl }\end{array}$ & $6.520,6$ & $7.094,4$ & $12.839,8$ & $97 \%$ \\
\hline $\begin{array}{l}\text { Corrientes comerciales en condiciones no } \\
\text { concesionarias }\end{array}$ & 334,2 & 451,1 & 247,2 & $-26 \%$ \\
\hline Corrientes de Ayuda para el Comercio & 38,7 & 164,4 & 145,4 & $275 \%$ \\
\hline $\begin{array}{l}\text { Remesas de trabajadores y remuneración } \\
\text { de empleados }\end{array}$ & $3.345,6$ & $4.884,1$ & $4.058,0$ & $21 \%$ \\
\hline
\end{tabular}

Fuentes: OCDE, base de datos del SNPA del CAD sobre las actividades de ayuda; Banco Mundial, Indicadores del Desarrollo Mundial; Banco Mundial, estadísticas de la deuda internacional.

Desembolsos de la ayuda para el comercio, por sector

(millones de \$EE.UU. corrientes)

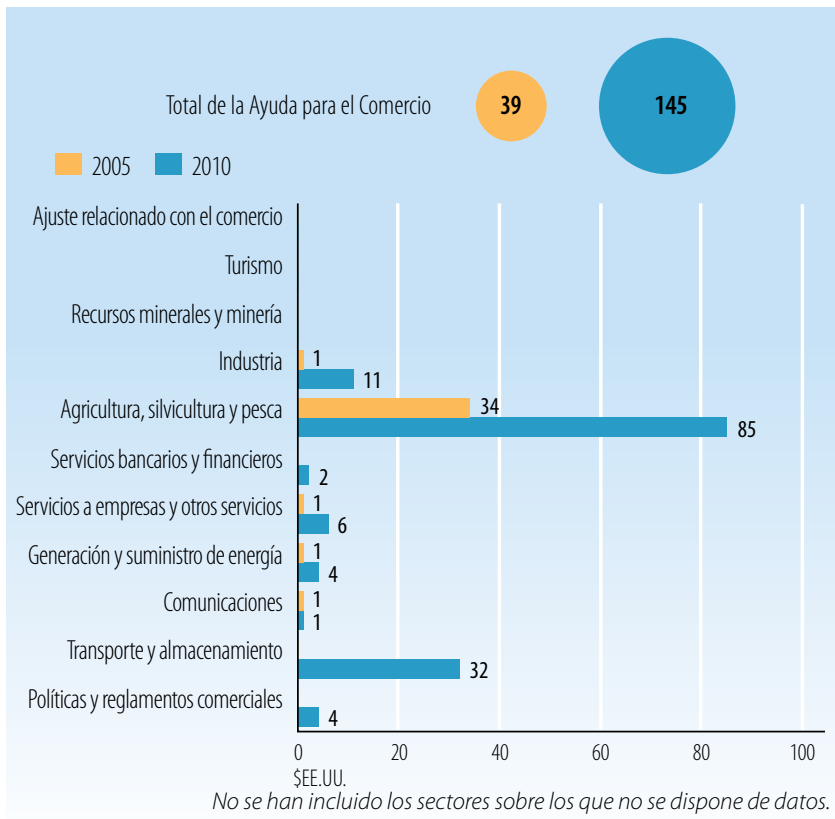

Fuentes: OCDE, base de datos del SNPA del CAD sobre las actividades de ayuda

Desembolsos de la ayuda para el comercio: principales donantes (millones de \$EE.UU. corrientes)

\begin{tabular}{|l|r|r|r|}
\hline $\mathbf{2 0 0 5}$ & Valor & $\%$ & Principales donantes en 2005 \\
\hline Estados Unidos & 20,8 & 54 & \\
\hline Países Bajos & 5,9 & 15 & \\
\hline Instituciones de la UE & 3,6 & 9 & \\
\hline Alemania & 2,7 & 7 & \\
\hline España & 2,3 & 6 & \\
\hline $\mathbf{2 0 1 0}$ & Valor & $\%$ & Principales donantes en $\mathbf{2 0 1 0}$ \\
\hline Estados Unidos & 71,3 & 49 & \\
\hline OFID & 30,0 & 21 & \\
\hline BID & 8,8 & 6 & \\
\hline España & 6,9 & 5 & \\
\hline Alemania & 5,7 & 4 & \\
\hline
\end{tabular}

Fuentes: OCDE, base de datos del SNPA del CAD sobre las actividades de ayuda.

\begin{tabular}{|c|c|c|c|c|}
\hline Indicador & 2005 & 2008 & 2011 & $\Delta: 05-11(\%)$ \\
\hline Relación comercio/PIB (\%) & 34 & 36 & 37 & 4 \\
\hline $\begin{array}{l}\text { Exportaciones de servicios comerciales como } \\
\text { \% de las exportaciones totales }\end{array}$ & 11 & 10 & 8 & -3 \\
\hline $\begin{array}{l}\text { Importaciones de servicios comerciales como } \\
\text { \% de las importaciones totales }\end{array}$ & 19 & 16 & 15 & -4 \\
\hline $\begin{array}{l}\text { Productos intermedios distintos de los combustibles } \\
\text { (\% de las exportaciones de mercancías) }\end{array}$ & 33 & 31 & 22 & -11 \\
\hline $\begin{array}{l}\text { Productos intermedios distintos de los combustibles } \\
\text { (\% de las importaciones de mercancias) }\end{array}$ & 53 & 51 & 46 & -8 \\
\hline
\end{tabular}
Fuentes: Secretaría de la OMC.

Corrientes comerciales (millones de \$EE.UU. corrientes)

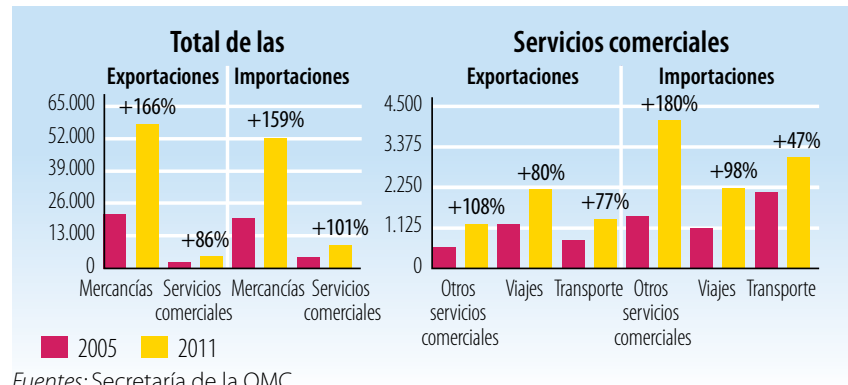

Cinco principales mercados de exportación de mercancías (\%)

\begin{tabular}{|l|r|l|r|}
\hline 2005 & $\%$ & 2011 & $\%$ \\
\hline Estados Unidos & 42 & Estados Unidos & 39 \\
\hline UE (27) & 13 & UE (27) & 16 \\
\hline Venezuela, Rep. Bolivariana de & 10 & Chile & 4 \\
\hline Ecuador & 6 & China & 3 \\
\hline Perú & 3 & Panamá & 3 \\
\hline Fuentes: Secretaría de la OMC & & & \\
\hline
\end{tabular}

Cinco principales productos de exportación (\% de las exportaciones de mercancías)

\begin{tabular}{|c|c|c|c|}
\hline 2005 & $\%$ & 2011 & $\%$ \\
\hline Aceites de petróleo, crudos & 19 & Aceites de petróleo, crudos & 40 \\
\hline Hulla sin aglomerar & 12 & Hulla sin aglomerar & 14 \\
\hline Café y sucedáneos del café & 8 & Productos derivados del petróleo & 8 \\
\hline Productos derivados del petróleo & 7 & Caféy sucedáneos del café & 5 \\
\hline Productos vegetales en bruto, n.e.p. & 4 & Oro no monetario, excepto minerales & 5 \\
\hline
\end{tabular}

Cinco principales mercados de importación de mercancías (\%)

\begin{tabular}{|l|r|l|r|}
\hline 2005 & $\%$ & 2011 & $\%$ \\
\hline Estados Unidos & 28 & Estados Unidos & 25 \\
\hline UE (27) & 14 & China & 15 \\
\hline México & 8 & UE (27) & 14 \\
\hline China & 8 & México & 11 \\
\hline Brasil & 7 & Brasil & 5 \\
\hline Fuentes: Secretaría de la OMC & & & \\
\hline
\end{tabular}

Cinco principales productos de importación (\% de las importaciones de mercancías)

\begin{tabular}{|c|c|c|c|}
\hline 2005 & $\%$ & 2011 & $\%$ \\
\hline $\begin{array}{l}\text { Equipos de telecomunicaciones y sus } \\
\text { partes, n.e.p. }\end{array}$ & 8 & Productos derivados del petróleo & 7 \\
\hline $\begin{array}{l}\text { Vehículos automotores para pasajeros, } \\
\text { excepto autobuses }\end{array}$ & 4 & Aeronaves y equipo conexo & 5 \\
\hline Aeronaves y equipo conexo & 3 & $\begin{array}{l}\text { Vehículos automotores para pasajeros, } \\
\text { excepto autobuses }\end{array}$ & 5 \\
\hline Hidrocarburos, n.e.p., y sus derivados & 3 & $\begin{array}{l}\text { Equipos de telecomunicaciones y sus } \\
\text { partes, n.e.p. }\end{array}$ & 4 \\
\hline $\begin{array}{l}\text { Productos laminados planos de hierro, } \\
\text { etc. }\end{array}$ & 3 & $\begin{array}{l}\text { Vehículos automotores para el } \\
\text { transporte de mercancías y vehículos } \\
\text { automotores para usos especiales }\end{array}$ & 3 \\
\hline
\end{tabular}

Fuentes: Secretaría de la OMC 


\section{LA AYUDA PARA EL COMERCIO EN SÍNTESIS 2013}

\section{INDICADORES COMERCIALES (RESULTADOS)}

\section{Indicador}

Crecimiento del PIB (\%)

Número de exportadores

Índice de concentración de las exportaciones (productos) (0 a 1)

ACR sobre mercancías notificados a la OMC

AIE (servicios) notificados a la OMC

Sectores de servicios con compromisos en el marco del AGCS

\section{Aranceles (\%, 2006 et 2011)}

\begin{tabular}{l|l|l|l|} 
Importaciones: promedio aritmético de los aranceles NMF aplicados & 12,5 & 8,4
\end{tabular}

\begin{tabular}{ll|l|l|l|} 
Importaciones: promedio ponderado de los aranceles NMF aplicados & 11,4 & 7,9
\end{tabular}

\begin{tabular}{|l|l|l|l|} 
Exportaciones: promedio ponderado de los aranceles impuestos & 0,2
\end{tabular}

por los importadores

Exportaciones: libres de derechos (en \%)

$91,0 \quad 95,8$

Fuentes: Naciones Unidas, base de datos Comtrade; Banco Mundial, base de datos sobre dinámica de las empresas de exportación; Banco Mundial, Indicadores del

Desarrollo Mundial; OMC, perfiles comerciales y arancelarios.

Participación en las exportaciones por región (\%)

\begin{tabular}{|l|r|r|}
\hline & 2005 & 2011 \\
\hline África & 0,2 & 0,6 \\
\hline Asia & 4,3 & 7,2 \\
\hline Comunidad de Estados Independientes & 0,4 & 0,2 \\
\hline Europa & 14,7 & 18,6 \\
\hline Oriente Medio & 1,1 & 1,3 \\
\hline América del Norte & 46,1 & 40,9 \\
\hline América del Sury América Central & 31,4 & 30,7 \\
\hline
\end{tabular}

Fuentes: OMC, perfiles comerciales y arancelarios

Indicadores de facilitación del comercio
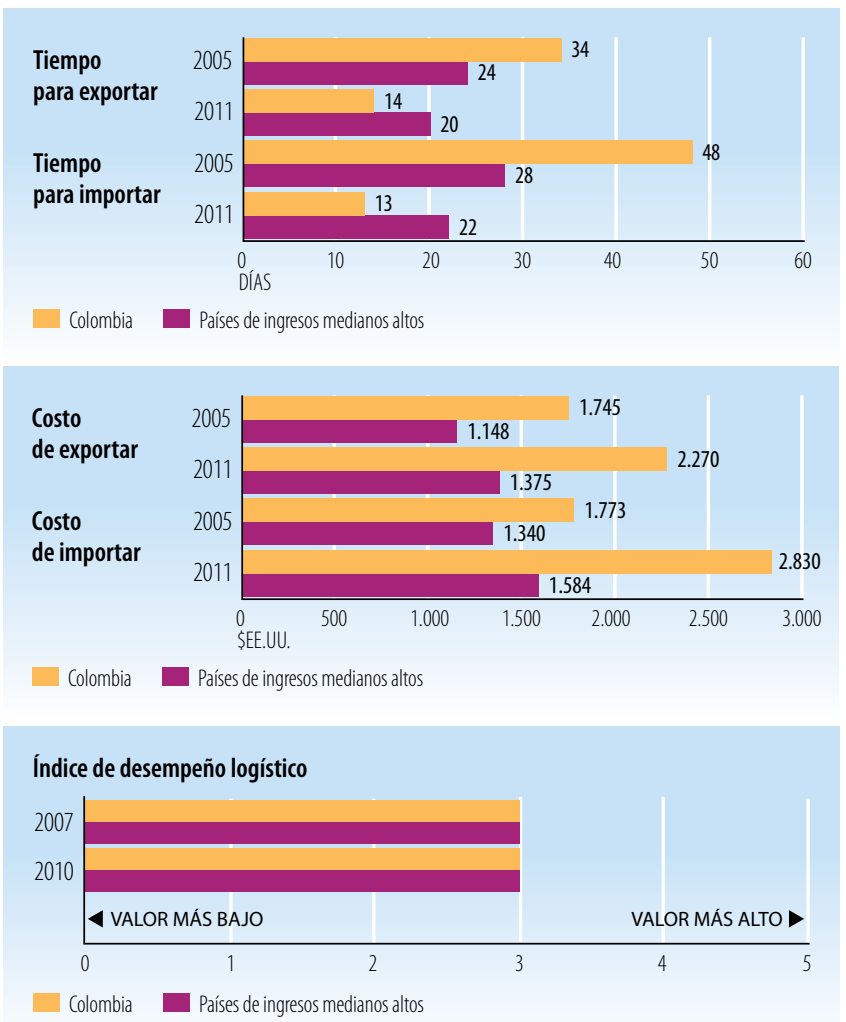

Fuentes: Banco Mundial, Indicadores del Desarrollo Mundial.

\begin{tabular}{l|c|c|}
\hline \multicolumn{2}{|l}{ INDICADORES DE DESARROLLO (EFECTOS) } \\
\hline Indicador & 2005 & $\mathbf{2 0 1 0}$ \\
\hline Desempleo (\% de la fuerza de trabajo total) & 11,3 & 11,6 \\
\hline Población activa, mujeres (\% de la fuerza de trabajo total) & 40,9 & 42,5 \\
\hline AOD neta recibida (\% del INB) & 0,4 & 0,3 \\
\hline Derechos de importación percibidos (\% de los ingresos fiscales) & $n . d$. & 6,5 \\
\hline Total del servicio de la deuda (\% de las exportaciones totales) & 40,2 & 21,0 \\
\hline Índice de desarrollo humano (0 a 1) & 0,68 & 0,71 \\
\hline
\end{tabular}

Fuentes: PNUD, indicadores internacionales sobre desarrollo humano; Banco Mundial, Indicadores del Desarrollo Mundial.

Producto interno bruto

PIB per cápita (PPA, dólares internacionales corrientes)
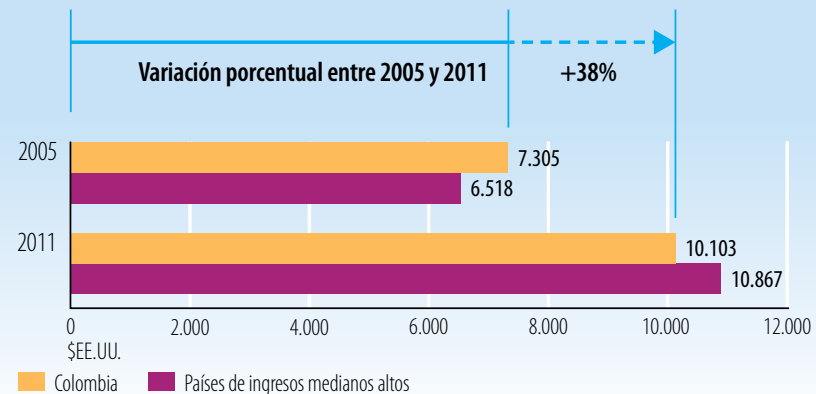

Colombia $\square$ Países de ingresos medianos altos

PIB per cápita (\$EE.UU. constantes de 2000)
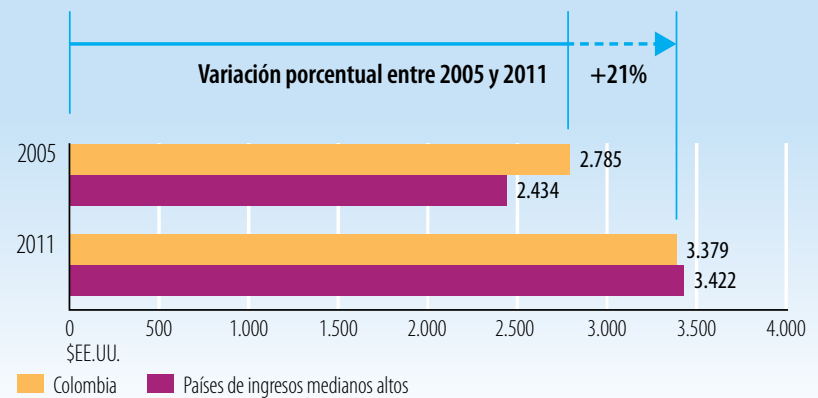

Colombia Países de ingresos medianos altos

Fuentes: Banco Mundial, Indicadores del Desarrollo Mundial.

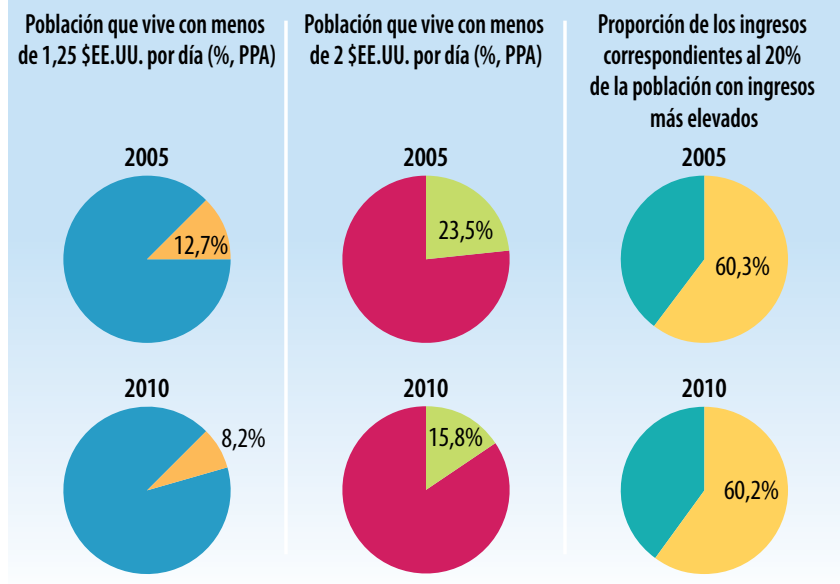

Fuentes: Banco Mundial, Indicadores del Desarrollo Mundial.

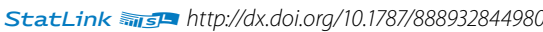




\section{LA AYUDA PARA EL COMERCIO EN SÍNTESIS 2013}

Indicadores de la ayuda, el comercio y el desarollo relativos a Comoras

\begin{tabular}{|c|c|c|c|c|}
\hline Indicador (millones de \$̦EE.UU. corrientes) & 2005 & 2008 & 2010 & $\Delta: 05-10(\%)$ \\
\hline Formación bruta de capital fijo & 36,0 & 75,7 & n.d. & n.d. \\
\hline del cual: público & 17,4 & 49,1 & n.d. & n.d. \\
\hline del cual: privado & 18,6 & 26,6 & n.d. & n.d. \\
\hline \multicolumn{5}{|l|}{ Entrada de financiación externa } \\
\hline Entradas de IED & 0,6 & 7,5 & 9,4 & $1581 \%$ \\
\hline $\begin{array}{l}\text { Deuda externa a largo plazo y fondos } \\
\text { desembolsados por el FMI }\end{array}$ & 3,3 & 6,7 & 217,4 & $6568 \%$ \\
\hline $\begin{array}{l}\text { Corrientes comerciales en condiciones no } \\
\text { concesionarias }\end{array}$ & 0,1 & 0,0 & 2,6 & $4250 \%$ \\
\hline Corrientes de Ayuda para el Comercio & 5,0 & 3,4 & 7,9 & $57 \%$ \\
\hline $\begin{array}{l}\text { Remesas de trabajadores y remuneración } \\
\text { de empleados }\end{array}$ & n.d. & n.d. & n.d. & n.d. \\
\hline
\end{tabular}

Fuentes: OCDE, base de datos del SNPA del CAD sobre las actividades de ayuda; Banco Mundial, Indicadores del Desarrollo Mundial; Banco Mundial, estadísticas de la deuda internacional.

Desembolsos de la ayuda para el comercio, por sector (millones de \$EE.UU. corrientes)

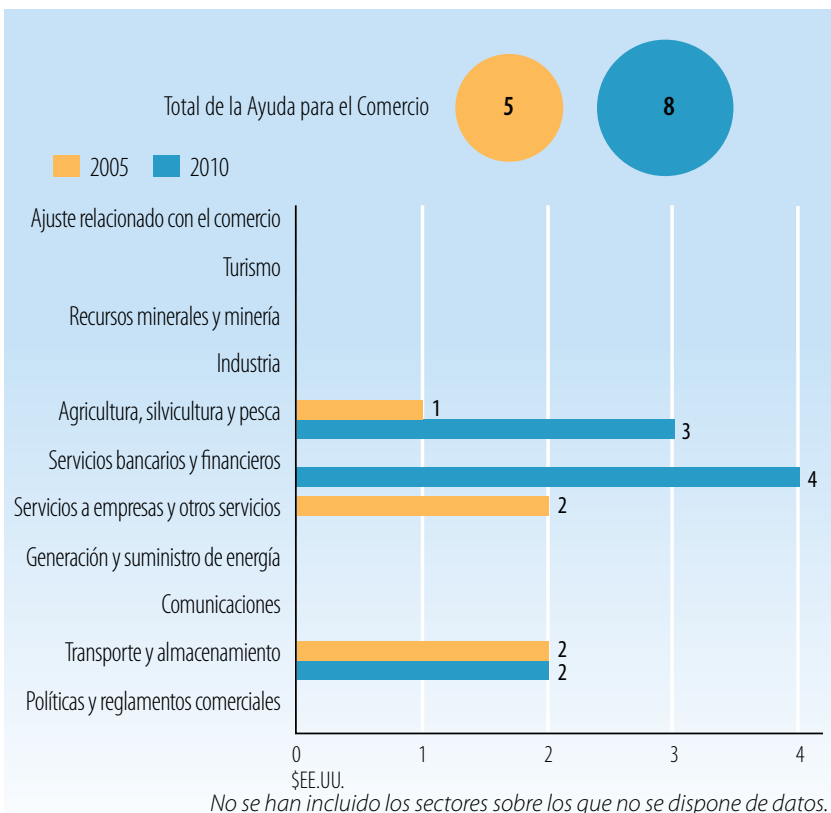

Fuentes: OCDE, base de datos del SNPA del CAD sobre las actividades de ayuda

Desembolsos de la ayuda para el comercio: principales donantes (millones de \$EE.UU. corrientes)

\begin{tabular}{|l|r|r|r|}
\hline $\mathbf{2 0 0 5}$ & Valor & $\%$ & Principales donantes en $\mathbf{2 0 0 5}$ \\
\hline Francia & 4,4 & 88 & \\
\hline Banco Mundial & 0,4 & 8 & $100 \%$ \\
\hline Bélgica & 0,1 & 3 & \\
\hline Instituciones de la UE & 0,0 & 1 & \\
\hline Japón & 0,0 & 1 & \\
\hline $\mathbf{2 0 1 0}$ & Valor & $\%$ & Principales donantes en 2010 \\
\hline Francia & 5,9 & 74 & \\
\hline Instituciones de la UE & 1,7 & 22 & \\
\hline Banco Mundial & 0,2 & 2 & $\mathbf{1 0 0 \%}$ \\
\hline Japón & 0,1 & 1 & \\
\hline Turquía & 0,0 & 0 & \\
\hline
\end{tabular}

Fuentes: OCDE, base de datos del SNPA del CAD sobre las actividades de ayuda.

\section{INDICADORES COMERCIALES (PRODUCTOS)}

\section{Indicador}

$2005 \quad 2008 \quad 2011 \quad \Delta: 05-11(\%)$

Relación comercio/PIB (\%)

Exportaciones de servicios comerciales como

$\%$ de las exportaciones totales

\begin{tabular}{|l|l|l|l|}
\hline 49 & 60 & 33 & -17 \\
\hline
\end{tabular}

Importaciones de servicios comerciales como

$\%$ de las importaciones totales

\begin{tabular}{l|l|l|l|}
\hline 73 & 86 & n.d. & n.d.
\end{tabular}

Productos intermedios distintos de los combustibles

(\% de las exportaciones de mercancías)

Productos intermedios distintos de los combustibles

(\% de las importaciones de mercancías)

\begin{tabular}{l|l|l|l|}
\hline 33 & 30 & n.d. & n.d.
\end{tabular}

n.d. n.d. n.d. n.d.

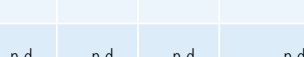

Fuentes: Secretaría de la OMC.

Corrientes comerciales (millones de \$EE.UU. corrientes)

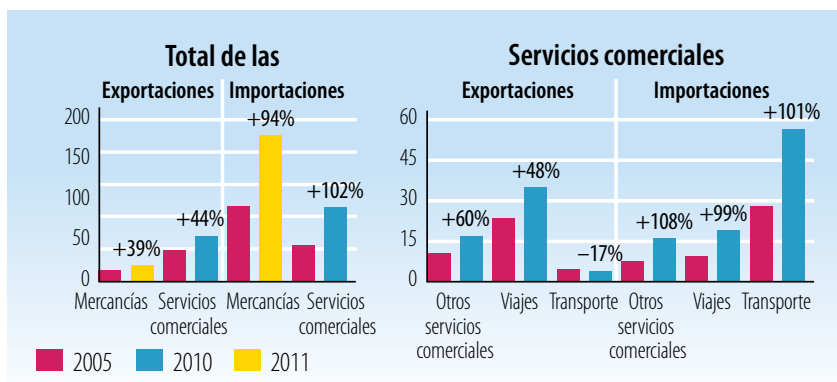

Fuentes: Secretaría de la OMC

Cinco principales mercados de exportación de mercancías (\%)

\begin{tabular}{|l|r|r|}
\hline 2005 & $\%$ & \\
\hline UE $(27)$ & 84 & \\
\hline India & 6 & \\
\hline Mauricio & 2 & No se dispone de datos. \\
\hline Emiratos Árabes Unidos & 2 & \\
\hline Singapur & 2 & \\
Fuentes: Secretaría de la OMC & &
\end{tabular}

Cinco principales productos de exportación (\% de las exportaciones de mercancías)

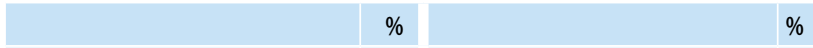

No se dispone de datos.

No se dispone de datos.

Fuentes: Secretaría de la OMC

Cinco principales mercados de importación de mercancías (\%)

\begin{tabular}{|l|r|l|}
\hline 2005 & $\%$ & \\
\hline Emiratos Árabes Unidos & 30 & \\
\hline UE (27) & 26 & \\
\hline Sudáfrica & 17 & No se dispone de datos. \\
\hline India & 4 & \\
\hline Pakistán & 3 & \\
Fuentes: Secretaría de la OMC & &
\end{tabular}

Cinco principales productos de importación (\% de las importaciones de mercancías) $\%$ $\%$
No se dispone de datos. 


\section{LA AYUDA PARA EL COMERCIO EN SÍNTESIS 2013}

\section{INDICADORES COMERCIALES (RESULTADOS)}

\section{Indicador}

Crecimiento del PIB (\%)

Número de exportadores

Índice de concentración de las exportaciones (productos) (0 a 1)

ACR sobre mercancías notificados a la OMC

AIE (servicios) notificados a la OMC

Sectores de servicios con compromisos en el marco del AGCS

\section{Aranceles (\%, 2006 et 2011)}

\begin{tabular}{l|l|l|l|} 
Importaciones: promedio aritmético de los aranceles NMF aplicados & 28,9 & 11,3
\end{tabular}

Importaciones: promedio ponderado de los aranceles NMF aplicados n.d. n.d.

\begin{tabular}{|l|l|l|}
\hline Exportaciones: promedio ponderado de los aranceles impuestos & 0,6 & 3,7 \\
\hline
\end{tabular}

por los importadores

Exportaciones: libres de derechos (en \%)

$82,5 \quad 71,2$

Fuentes: Naciones Unidas, base de datos Comtrade; Banco Mundial, base de datos sobre dinámica de las empresas de exportación; Banco Mundial, Indicadores del Desarrollo Mundial; OMC, perfiles comerciales y arancelarios.

Participación en las exportaciones por región (\%)

\begin{tabular}{|l|r|r|}
\hline África & 2005 & 2010 \\
\hline Asia & 4,2 & n.d. \\
\hline Comunidad de Estados Independientes & 9,6 & n.d. \\
\hline Europa & 0,0 & n.d. \\
\hline Oriente Medio & 84,2 & n.d. \\
\hline América del Norte & 1,8 & n.d. \\
\hline América del Sury ymérica Central & 0,0 & n.d. \\
\hline
\end{tabular}

Fuentes: OMC, perfiles comerciales y arancelarios

Indicadores de facilitación del comercio
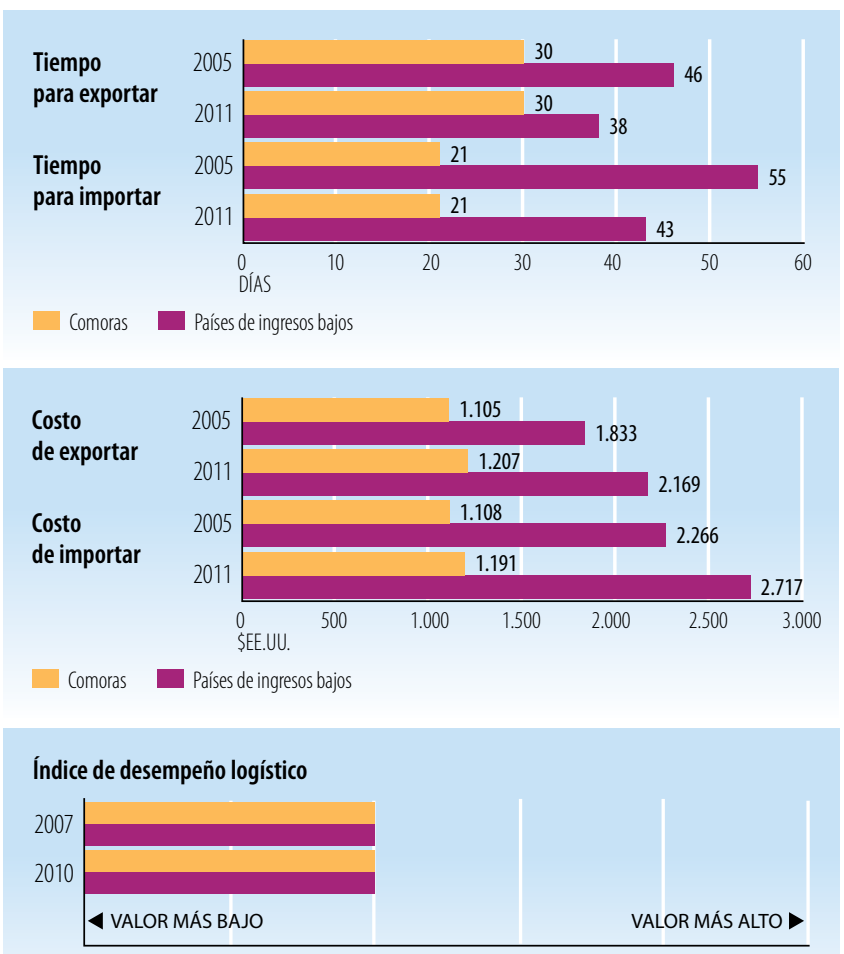

Comoras Países de ingresos bajos

Fuentes: Banco Mundial, Indicadores del Desarrollo Mundial.

\begin{tabular}{|l|c|c|}
\hline INDICADORES DE DESARROLLO (EFECTOS) & \\
\hline Indicador & $\mathbf{2 0 0 5}$ & $\mathbf{2 0 1 0}$ \\
\hline Desempleo (\% de la fuerza de trabajo total) & n.d. & n.d. \\
\hline Población activa, mujeres (\% de la fuerza de trabajo total) & 29,1 & 30,2 \\
\hline AOD neta recibida (\% del INB) & 5,9 & 12,5 \\
\hline Derechos de importación percibidos (\% de los ingresos fiscales) & n.d. & n.d. \\
\hline Total del servicio de la deuda (\% de las exportaciones totales) & 6,7 & 14,8 \\
\hline Índice de desarrollo humano (0 a 1) & 0,43 & 0,43 \\
\hline
\end{tabular}

Fuentes: PNUD, indicadores internacionales sobre desarrollo humano; Banco Mundial, Indicadores del Desarrollo Mundial.

Producto interno bruto

PIB per cápita (PPA, dólares internacionales corrientes)
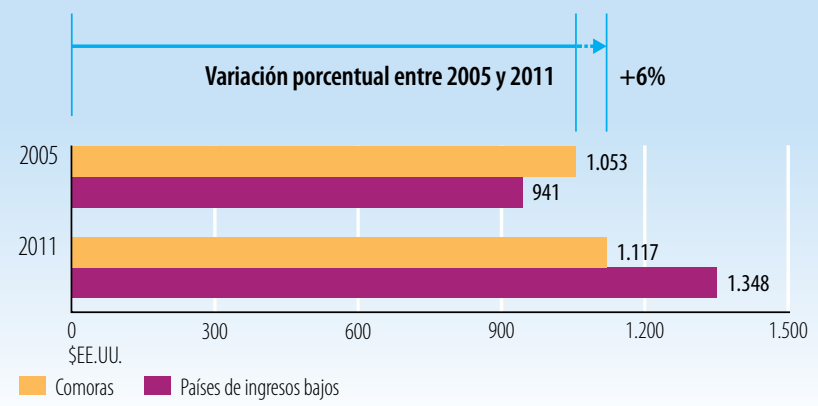

PIB per cápita (\$EE.UU. constantes de 2000)
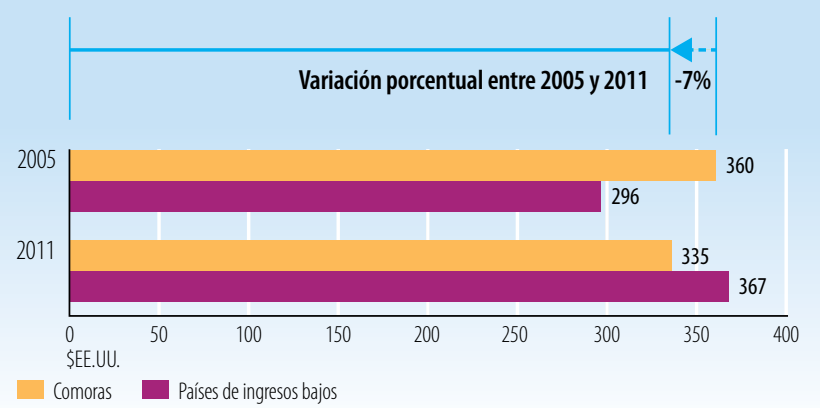

Fuentes: Banco Mundial, Indicadores del Desarrollo Mundial.

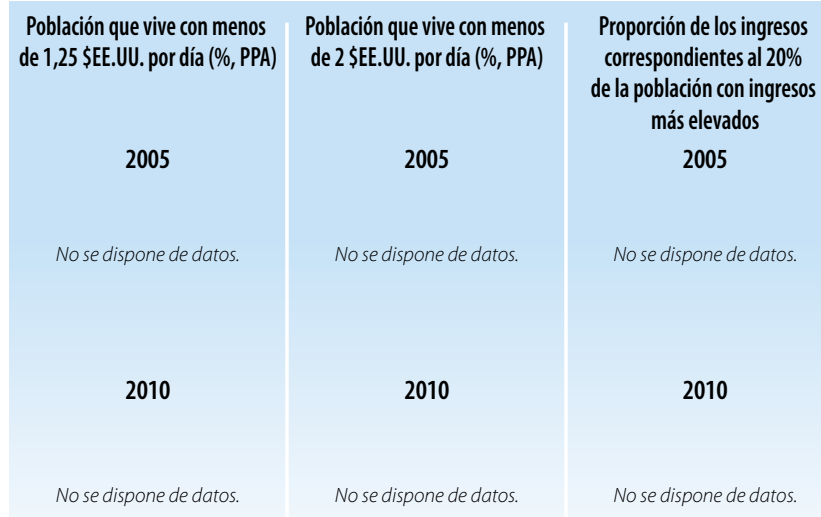

Fuentes: Banco Mundial, Indicadores del Desarrollo Mundial.

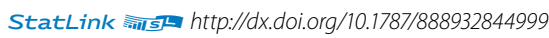


Indicadores de la ayuda, el comercio y el desarrollo relativos a Costa Rica

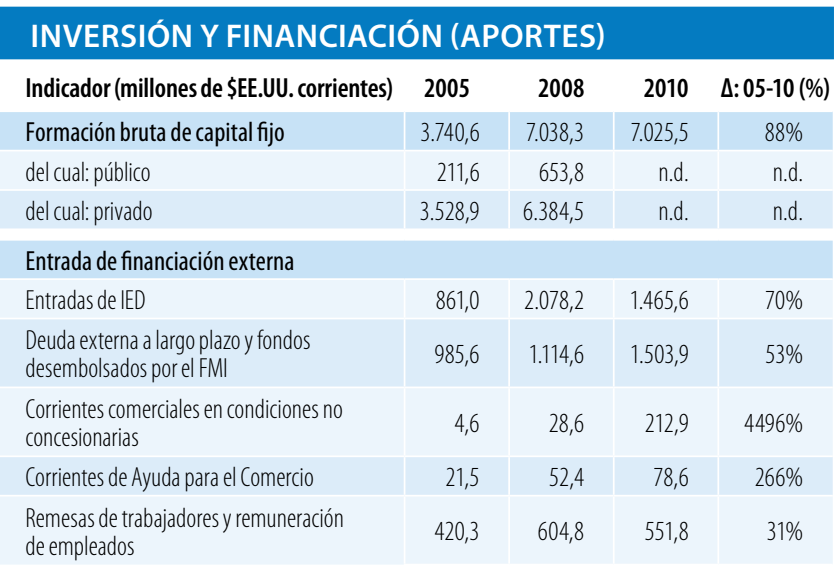

Fuentes: OCDE, base de datos del SNPA del CAD sobre las actividades de ayuda; Banco Mundial, Indicadores del Desarrollo Mundial; Banco Mundial, estadísticas de la deuda internacional.

Desembolsos de la ayuda para el comercio, por sector (millones de \$EE.UU. corrientes)

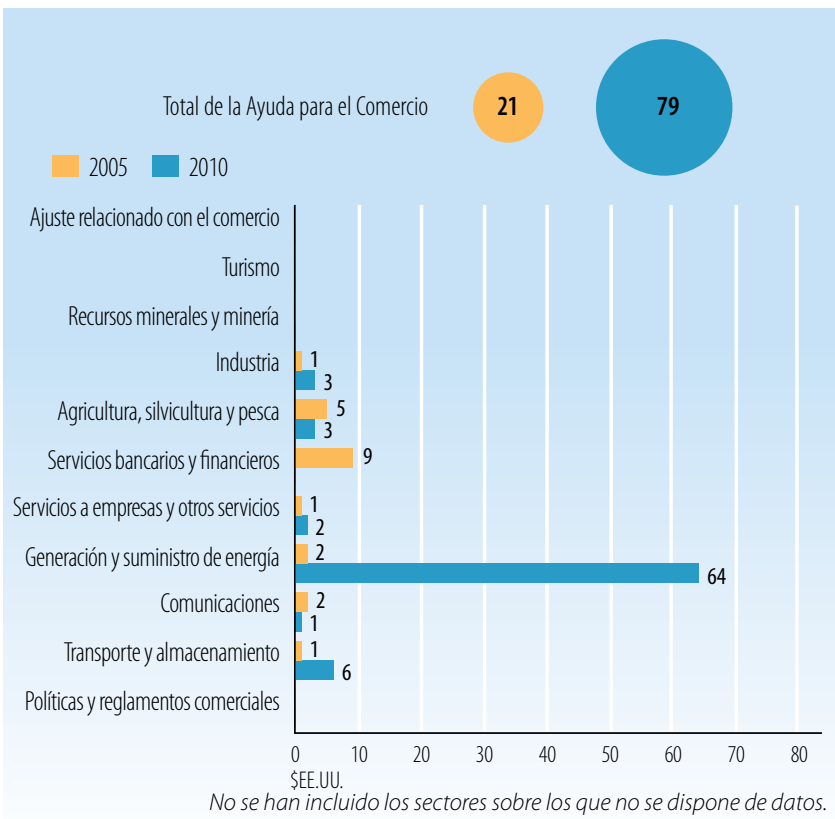

Fuentes: OCDE, base de datos del SNPA del CAD sobre las actividades de ayuda

Desembolsos de la ayuda para el comercio: principales donantes (millones de \$EE.UU. corrientes)

\begin{tabular}{|l|r|r|r|}
\hline $\mathbf{2 0 0 5}$ & Valor & $\%$ & Principales donantes en 2005 \\
\hline Japón & 5,3 & 25 & \\
\hline Noruega & 5,2 & 24 & \\
\hline Bélgica & 3,5 & 16 & $92 \%$ \\
\hline Alemania & 3,1 & 14 & \\
\hline Suiza & 2,5 & 12 & \\
\hline $\mathbf{2 0 1 0}$ & Valor & $\%$ & Principales donantes en $\mathbf{2 0 1 0}$ \\
\hline Japón & 65,3 & 83 & \\
\hline Alemania & 6,7 & 8 & \\
\hline BID & 1,0 & 1 & \\
\hline Bélgica & 1,0 & 1 & $95 \%$ \\
\hline España & 1,0 & 1 & \\
\hline
\end{tabular}

Fuentes: OCDE, base de datos del SNPA del CAD sobre las actividades de ayuda.

\section{INDICADORES COMERCIALES (PRODUCTOS)}

\section{Indicador}

$2005 \quad 2008 \quad 2011 \quad \Delta: 05-11(\%)$

Relación comercio/PIB (\%)

\begin{tabular}{l|l|l|l|}
102 & 101 & 80 & -23 \\
\hline
\end{tabular}

Exportaciones de servicios comerciales como

$\%$ de las exportaciones totales

Importaciones de servicios comerciales como

$\%$ de las importaciones totales

Productos intermedios distintos de los combustibles

(\% de las exportaciones de mercancías)

Productos intermedios distintos de los combustibles

(\% de las importaciones de mercancías)

\begin{tabular}{l|l|l|l|}
27 & 30 & 32 & 6
\end{tabular}

Fuentes: Secretaría de la OMC

Corrientes comerciales (millones de \$EE.UU. corrientes)
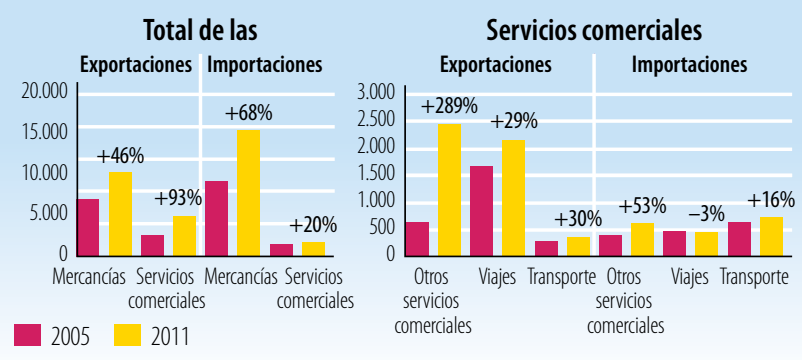

Fuentes: Secretaría de la OMC

Cinco principales mercados de exportación de mercancías (\%)

\begin{tabular}{|l|r|l|r|}
\hline 2005 & $\%$ & 2010 & $\%$ \\
\hline Estados Unidos & 43 & Estados Unidos & 37 \\
\hline UE (27) & 17 & UE (27) & 18 \\
\hline Hong Kong, China & 7 & Hong Kong, China & 5 \\
\hline Guatemala & 4 & Panamá & 5 \\
\hline Nicaragua & 4 & Nicaragua & 4
\end{tabular}

Fuentes: Secretaría de la OMC

Cinco principales productos de exportación (\% de las exportaciones de mercancías)

\begin{tabular}{|c|c|c|c|}
\hline 2005 & $\%$ & 2011 & $\%$ \\
\hline $\begin{array}{l}\text { Frutas y nueces, excepto nueces } \\
\text { oleaginosas }\end{array}$ & & Transistores, válvulas, etc. & 19 \\
\hline Transistores, válvulas, etc. & & $\begin{array}{l}\text { Frutas y nueces, excepto nueces } \\
\text { oleaginosas }\end{array}$ & 15 \\
\hline Partes y piezas para máquinas de oficina & & Instrumentos, n.e.p., de medicina & 8 \\
\hline Instrumentos, n.e.p., de medicina & & $\begin{array}{l}\text { Productos y preparados comestibles, } \\
\text { n.e.p. }\end{array}$ & 4 \\
\hline Café y sucedáneos del café & & Café y sucedáneos del café & 4 \\
\hline
\end{tabular}

Fuentes: Secretaría de la OMC

Cinco principales mercados de importación de mercancías (\%)

\begin{tabular}{|l|r|l|r|}
\hline 2005 & $\%$ & 2010 & $\%$ \\
\hline Estados Unidos & 41 & Estados Unidos & 47 \\
\hline UE (27) & 13 & UE (27) & 8 \\
\hline Japón & 6 & China & 7 \\
\hline Venezuela, Rep. Bolivariana de & 5 & México & 4 \\
\hline México & 5 & Japón &
\end{tabular}

Fuentes: Secretaría de la OMC

Cinco principales productos de importación (\% de las importaciones de mercancías)

\begin{tabular}{|l|r|l|c|}
\hline 2005 & $\%$ & 2011 & $\%$ \\
\hline Transistores, válvulas, etc. & 17 & Productos derivados del petróleo & 11 \\
\hline Productos derivados del petróleo & 8 & $\begin{array}{l}\text { Transistores, válvulas, etc. } \\
\text { Circuitos eléctricos de conmutación } \\
\text { Medicamentos }\end{array}$ & 8 \\
\hline Papel y cartón & 3 & $\begin{array}{l}\text { Vehículos automotores para pasajeros, } \\
\text { excepto autobuses }\end{array}$ & 4 \\
\hline $\begin{array}{l}\text { Vehículos automotores para pasajeros, } \\
\text { excepto autobuses }\end{array}$ & 2 & $\begin{array}{l}\text { Equipos de telecomunicaciones y sus } \\
\text { partes, n.e.p. }\end{array}$ & 3 \\
\hline $\begin{array}{l}\text { Fuentes:Secretaría de la OMC } \\
\text { Mente }\end{array}$ & & &
\end{tabular}




\section{LA AYUDA PARA EL COMERCIO EN SÍNTESIS 2013}

\section{INDICADORES COMERCIALES (RESULTADOS)}

\section{Indicador}

Crecimiento del PIB (\%)

Número de exportadores

Índice de concentración de las exportaciones (productos) ( 0 a 1)

ACR sobre mercancías notificados a la OMC

AIE (servicios) notificados a la OMC

Sectores de servicios con compromisos en el marco del AGCS

\section{Aranceles (\%)}

Importaciones: promedio aritmético de los aranceles NMF aplicados

Importaciones: promedio ponderado de los aranceles NMF aplicados

Exportaciones: promedio ponderado de los aranceles impuestos

por los importadores

Exportaciones: libres de derechos (en \%)

\begin{tabular}{|r|r|}
\hline 2005 & 201 \\
\hline 5,9 & 4,2 \\
\hline 2.500 & 2.802 \\
\hline 0,03 & 0,05 \\
\hline n.d. & 8 \\
\hline n.d. & 6 \\
\hline 20 & 20 \\
\hline
\end{tabular}

Fuentes: Naciones Unidas, base de datos Comtrade; Banco Mundial, base de dato sobre dinámica de las empresas de exportación; Banco Mundial, Indicadores del

Desarrollo Mundial; OMC, perfiles comerciales y arancelarios.

Participación en las exportaciones por región (\%)

\begin{tabular}{|l|r|r|}
\hline & $\mathbf{2 0 0 5}$ & $\mathbf{2 0 1 1}$ \\
\hline África & 0,1 & 0,1 \\
\hline Asia & 14,5 & 12,5 \\
\hline Comunidad de Estados Independientes & 0,3 & 0,3 \\
\hline Europa & 17,5 & 17,7 \\
\hline Oriente Medio & 0,1 & 0,2 \\
\hline América del Norte & 46,3 & 42,0 \\
\hline América del Sury América Central & 21,2 & 27,3 \\
\hline
\end{tabular}

Fuentes: OMC, perfiles comerciales y arancelarios

Indicadores de facilitación del comercio
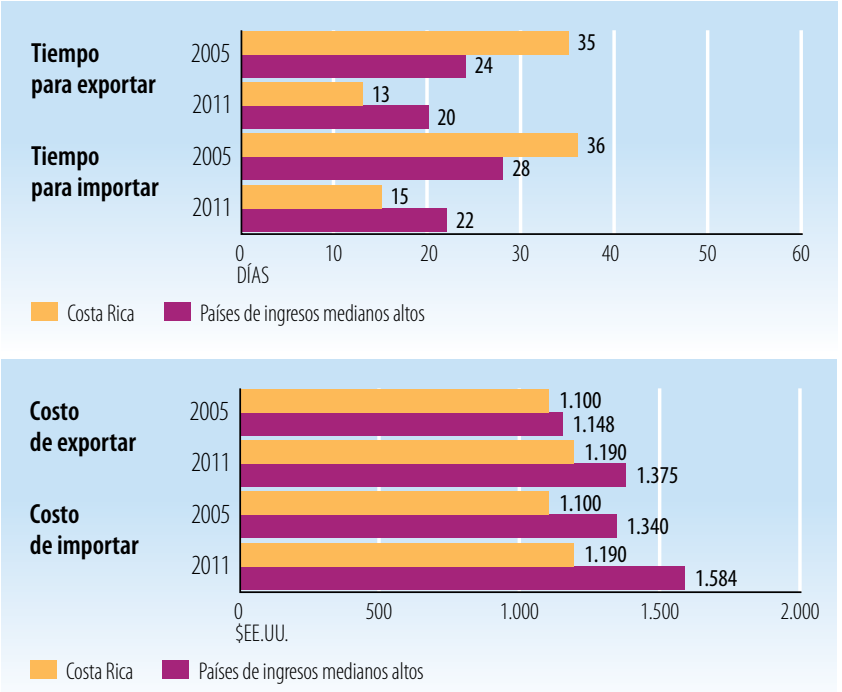

Índice de desempeño logístico

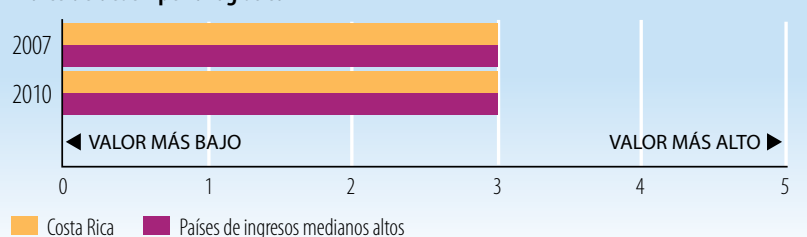

Costa Rica Países de ingresos medianos altos

Fuentes: Banco Mundial, Indicadores del Desarrollo Mundial.

\begin{tabular}{l|r|r|}
\hline INDICADORES DE DESARROLLO (EFECTOS) & \\
\hline Indicador & 2005 & 2010 \\
\hline Desempleo (\% de la fuerza de trabajo total) & 6,6 & 7,8 \\
\hline Población activa, mujeres (\% de la fuerza de trabajo total) & 34,8 & 36,2 \\
\hline AOD neta recibida (\% del INB) & 0,1 & 0,3 \\
\hline Derechos de importación percibidos (\% de los ingresos fiscales) & n.d. & 4,9 \\
\hline Total del servicio de la deuda (\% de las exportaciones totales) & 8,0 & 7,7 \\
\hline Índice de desarrollo humano (0 a 1) & 0,72 & 0,74 \\
\hline
\end{tabular}

Fuentes: PNUD, indicadores internacionales sobre desarrollo humano; Banco Mundial, Indicadores del Desarrollo Mundial.

Producto interno bruto

PIB per cápita (PPA, dólares internacionales corrientes)

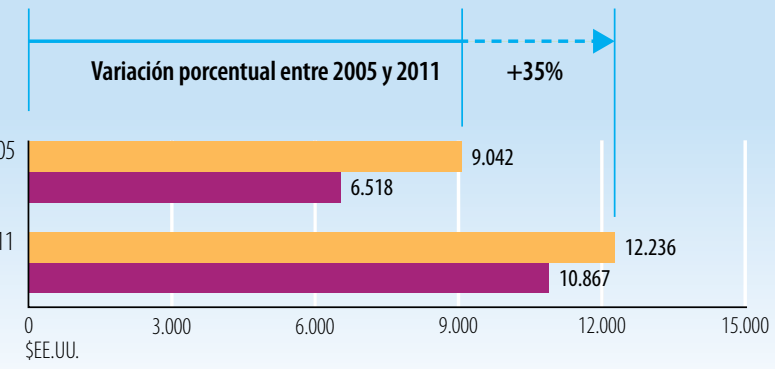

Costa Rica Países de ingresos medianos altos

PIB per cápita (\$EE.UU. constantes de 2000)

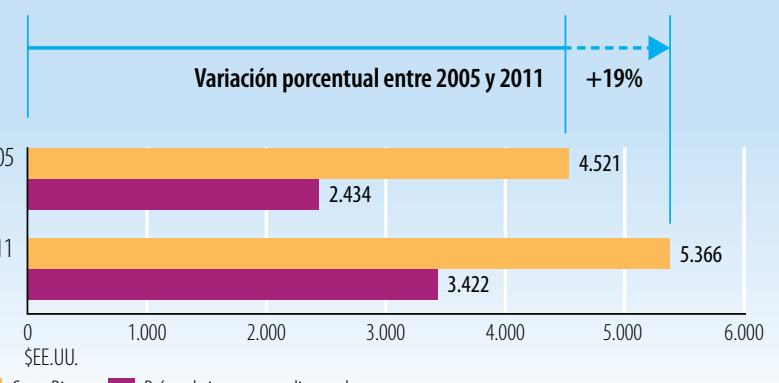

Costa Rica Países de ingresos medianos altos

Fuentes: Banco Mundial, Indicadores del Desarrollo Mundial.

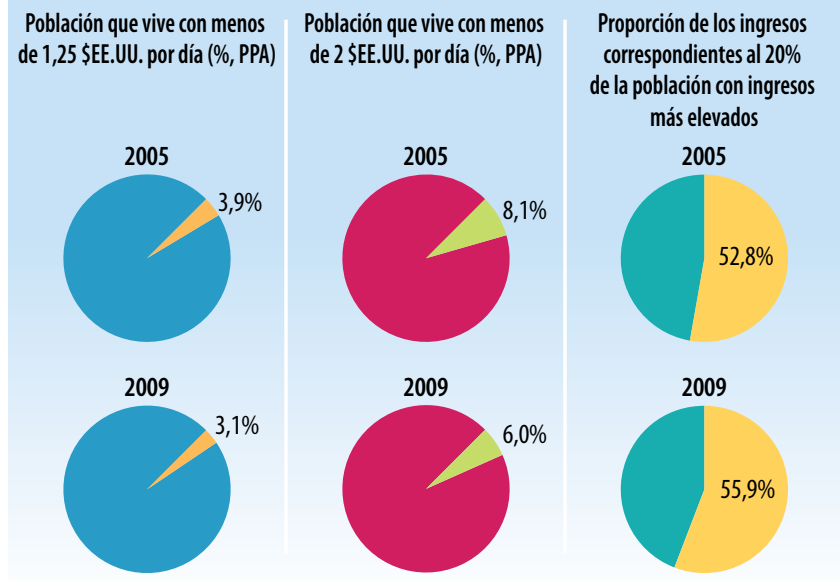

Fuentes: Banco Mundial, Indicadores del Desarrollo Mundial.

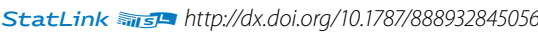




\section{LA AYUDA PARA EL COMERCIO EN SIINTESIS 2013}

\section{Indicadores de la ayuda, el comercio y el desarrollo relativos a Côte d'Ivoire}

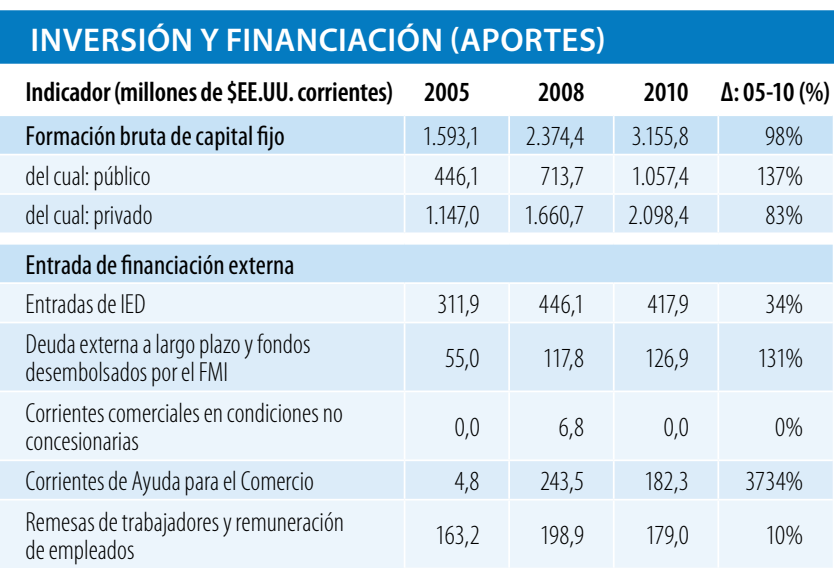

Fuentes: OCDE, base de datos del SNPA del CAD sobre las actividades de ayuda; Banco Mundial, Indicadores del Desarrollo Mundial; Banco Mundial, estadísticas de la deuda internacional.

Desembolsos de la ayuda para el comercio, por sector (millones de \$EE.UU. corrientes)

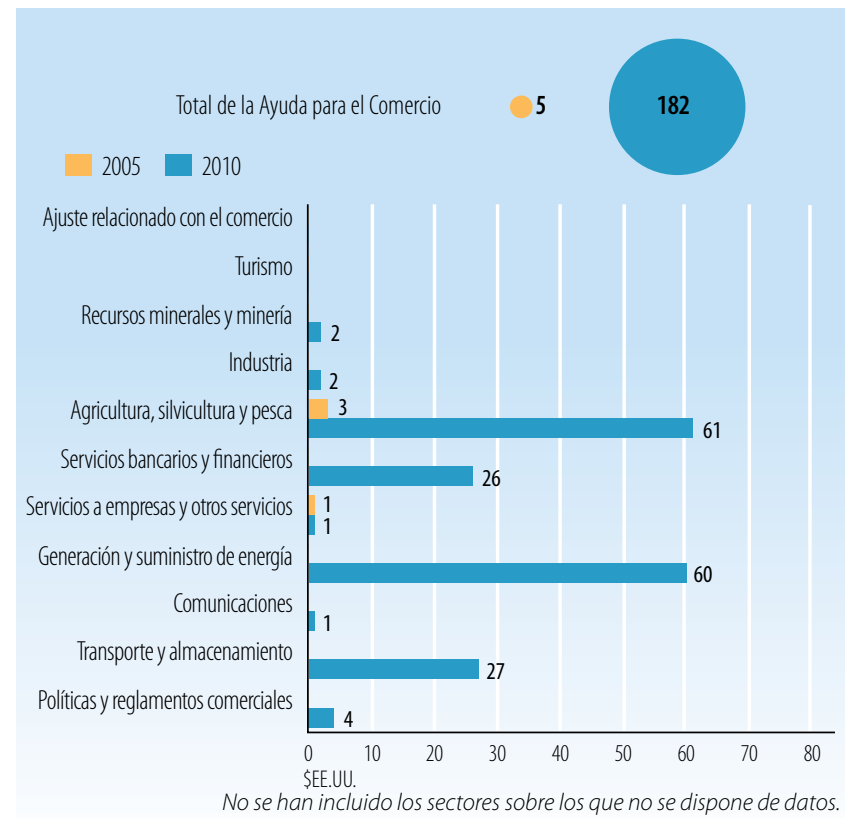

Fuentes: OCDE, base de datos del SNPA del CAD sobre las actividades de ayuda

Desembolsos de la ayuda para el comercio: principales donantes (millones de \$̦EE.UU. corrientes)

\begin{tabular}{|l|c|c|c|}
\hline $\mathbf{2 0 0 5}$ & Valor & $\%$ & Principales donantes en 2005 \\
\hline Francia & 1,3 & 28 & \\
\hline Alemania & 1,3 & 27 & \\
\hline Banco Africano de Desarrollo & 0,7 & 15 & $90 \%$ \\
\hline Bélgica & 0,5 & 11 & \\
\hline Instituciones de la UE & 0,4 & 9 & \\
\hline $\mathbf{2 0 1 0}$ & Valor & $\%$ & Principales donantes en $\mathbf{2 0 1 0}$ \\
\hline Banco Mundial & 95,9 & 53 & \\
\hline Instituciones de la UE & 29,8 & 16 & \\
\hline Reino Unido & 25,7 & 14 & \\
\hline Japón & 17,8 & 10 & \\
\hline Bélgica & 6,9 & 4 & \\
\hline
\end{tabular}

Fuentes: OCDE, base de datos del SNPA del CAD sobre las actividades de ayuda.

\section{INDICADORES COMERCIALES (PRODUCTOS)}

Indicador $2005 \quad 2008 \quad 2011 \quad \Delta: 05-11(\%)$

Relación comercio/PIB (\%)

\begin{tabular}{l|l|l|r|}
96 & 89 & 72 & -24 \\
\hline
\end{tabular}

Exportaciones de servicios comerciales como

$\%$ de las exportaciones totales

Importaciones de servicios comerciales como

$\%$ de las importaciones totales

Productos intermedios distintos de los combustibles

(\% de las exportaciones de mercancías)

Productos intermedios distintos de los combustibles

(\% de las importaciones de mercancías)

\begin{tabular}{|r|r|r|r|}
\hline 8 & 8 & n.d. & n.d. \\
\hline 27 & 26 & n.d. & n.d. \\
\hline 46 & 48 & 64 & 18 \\
\hline 27 & 30 & 32 & 6 \\
\hline
\end{tabular}

Fuentes: Secretaría de la OMC.

Corrientes comerciales (millones de \$EE.UU. corrientes)

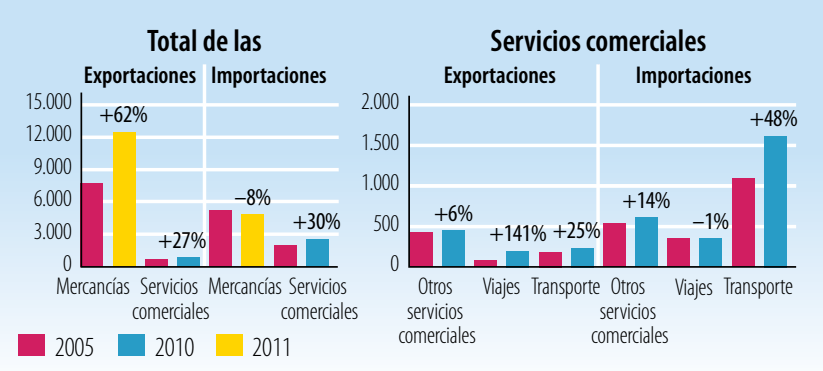

Fuentes: Secretaría de la OMC

Cinco principales mercados de exportación de mercancías (\%)

\begin{tabular}{|l|r|l|r|}
\hline 2005 & $\%$ & 2010 & $\%$ \\
\hline UE $(27)$ & 42 & UE $(27)$ & 39 \\
\hline Estados Unidos & 14 & Estados Unidos & 10 \\
\hline Nigeria & 8 & Ghana & 8 \\
\hline Panamá & 4 & Nigeria & 7 \\
\hline Burkina Faso & 3 & Burkina Faso & 4 \\
\hline
\end{tabular}

Fuentes: Secretaría de la OMC

Cinco principales productos de exportación (\% de las exportaciones de mercancías)

\begin{tabular}{|c|c|c|c|}
\hline 2005 & $\%$ & 2011 & $\%$ \\
\hline Cacao & 27 & Cacao & 37 \\
\hline Productos derivados del petróleo & 20 & Aceites de petróleo, crudos & 12 \\
\hline Aceites de petróleo, crudos & 7 & Productos derivados del petróleo & 12 \\
\hline Armas y municiones & 6 & Caucho natural, etc. & 10 \\
\hline $\begin{array}{l}\text { Buques, embarcaciones y estructuras } \\
\text { flotantes }\end{array}$ & 5 & Oro no monetario, excepto minerales & 5 \\
\hline
\end{tabular}

Fuentes: Secretaría de la OMC

Cinco principales mercados de importación de mercancías (\%)

\begin{tabular}{|l|r|l|r|}
\hline 2005 & $\%$ & 2010 & $\%$ \\
\hline UE (27) & 41 & Nigeria & 26 \\
\hline Nigeria & 25 & UE $(27)$ & 25 \\
\hline Singapur & 7 & China & 7 \\
\hline China & 3 & Tailandia & 4 \\
\hline Estados Unidos & 2 & Colombia & 3 \\
\hline
\end{tabular}

Fuentes: Secretaría de la OMC

Cinco principales productos de importación (\% de las importaciones de mercancías)

\begin{tabular}{|c|c|c|c|}
\hline 2005 & $\%$ & 2011 & $\%$ \\
\hline Aceites de petróleo, crudos & 27 & Aceites de petróleo, crudos & 26 \\
\hline Armas y municiones & 8 & Arroz & 8 \\
\hline $\begin{array}{l}\text { Buques, embarcaciones y estructuras } \\
\text { flotantes }\end{array}$ & 6 & Pescado, fresco, refrigerado o congelado & 5 \\
\hline Arroz & 4 & Medicamentos & 4 \\
\hline Pescado, fresco, refrigerado o congelado & 3 & Trigo y morcajo o tranquillón, sin moler & 3 \\
\hline
\end{tabular}




\section{LA AYUDA PARA EL COMERCIO EN SIINTESIS 2013}

\section{INDICADORES COMERCIALES (RESULTADOS)}

\section{Indicador}

Crecimiento del PIB (\%)

Número de exportadores

Índice de concentración de las exportaciones (productos) ( 0 a 1 )

ACR sobre mercancías notificados a la OMC

AIE (servicios) notificados a la OMC

Sectores de servicios con compromisos en el marco del AGCS

\section{Aranceles (\%, 2006 et 2011)}

\begin{tabular}{ll|l|l|} 
Importaciones: promedio aritmético de los aranceles NMF aplicados & 12,0 & 11,9
\end{tabular}

Importaciones: promedio ponderado de los aranceles NMF aplicados n.d. $\quad 7,5$

\begin{tabular}{ll|l|l|} 
Exportaciones: promedio ponderado de los aranceles impuestos & 3,5 & 0,5
\end{tabular}

por los importadores

Exportaciones: libres de derechos (en \%)

$87,0 \quad 90,0$

Fuentes: Naciones Unidas, base de datos Comtrade; Banco Mundial, base de datos sobre dinámica de las empresas de exportación; Banco Mundial, Indicadores del

Desarrollo Mundial; OMC, perfiles comerciales y arancelarios.

Participación en las exportaciones por región (\%)

\begin{tabular}{|l|r|r|}
\hline África & 2005 & 2011 \\
\hline Asia & 29,8 & 30,0 \\
\hline Comunidad de Estados Independientes & 5,1 & 9,0 \\
\hline Europa & 1,6 & 0,2 \\
\hline Oriente Medio & 43,2 & 40,2 \\
\hline América del Norte & 0,5 & 0,2 \\
\hline América del Sury América Central & 14,4 & 18,3 \\
\hline
\end{tabular}

Fuentes: OMC, perfiles comerciales y arancelarios

Indicadores de facilitación del comercio
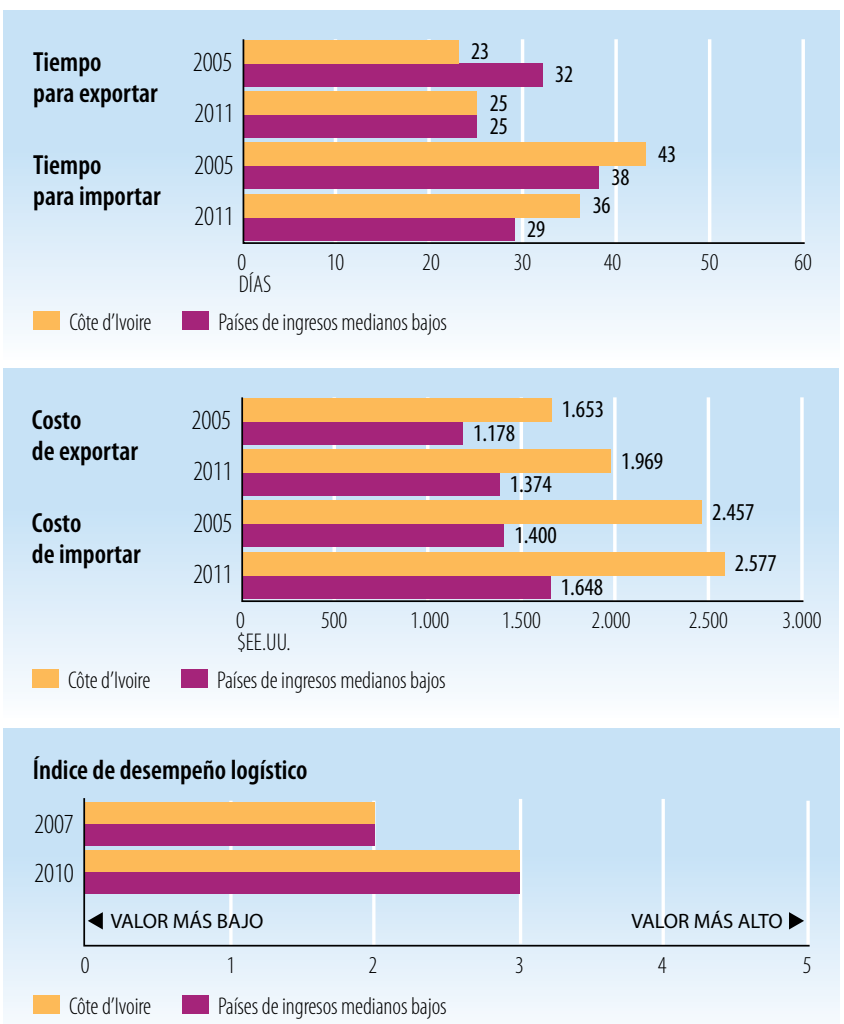

Fuentes: Banco Mundial, Indicadores del Desarrollo Mundial.

\begin{tabular}{|l|c|c|}
\hline INDICADORES DE DESARROLLO (EFECTOS) & \\
\hline Indicador & $\mathbf{2 0 0 5}$ & $\mathbf{2 0 1 0}$ \\
\hline Desempleo (\% de la fuerza de trabajo total) & n.d. & n.d. \\
\hline Población activa, mujeres (\% de la fuerza de trabajo total) & 36,2 & 37,4 \\
\hline AOD neta recibida (\% del INB) & 0,6 & 3,9 \\
\hline Derechos de importación percibidos (\% de los ingresos fiscales) & 41,2 & 35,9 \\
\hline Total del servicio de la deuda (\% de las exportaciones totales) & 3,5 & 9,5 \\
\hline Índice de desarrollo humano (0 a 1) & 0,38 & 0,40 \\
\hline
\end{tabular}

Fuentes: PNUD, indicadores internacionales sobre desarrollo humano; Banco Mundial, Indicadores del Desarrollo Mundial.

Producto interno bruto

PIB per cápita (PPA, dólares internacionales corrientes)
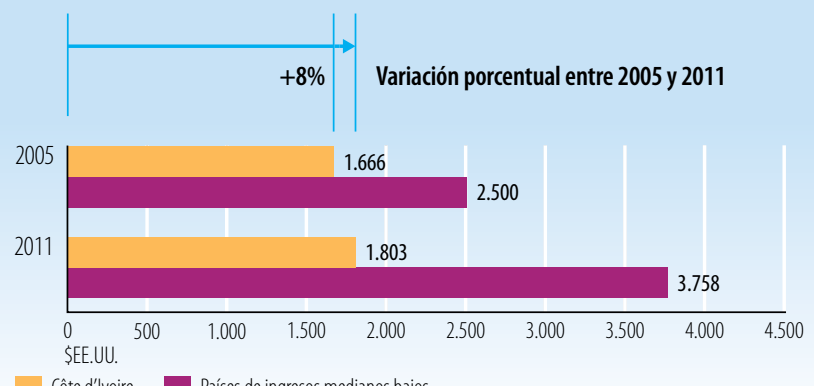

Côte d'lvoire Países de ingresos medianos bajos

PIB per cápita (\$EE.UU. constantes de 2000)

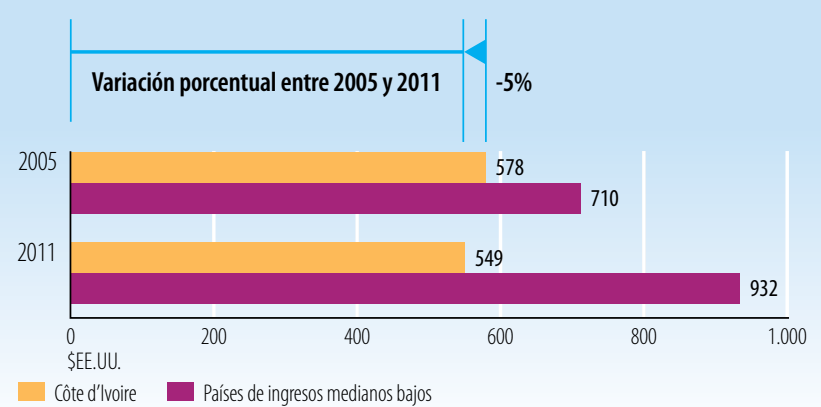

Fuentes: Banco Mundial, Indicadores del Desarrollo Mundial.

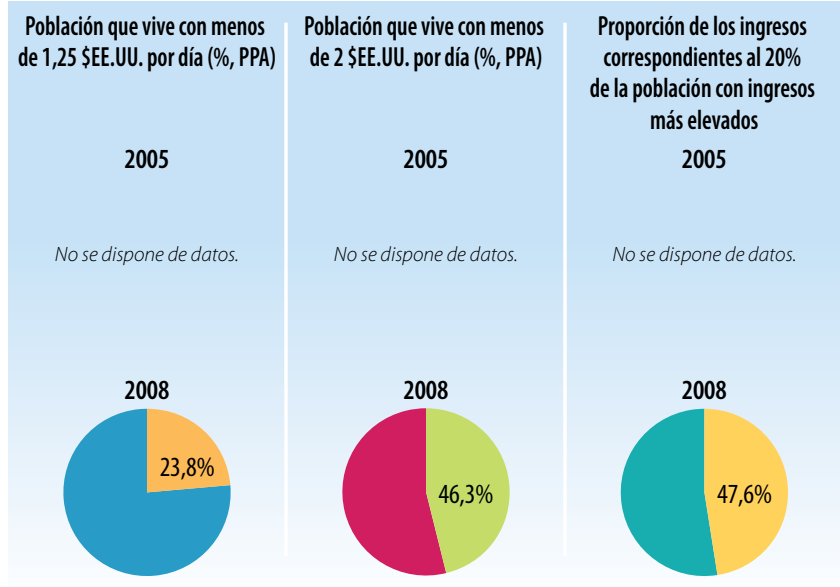

Fuentes: Banco Mundial, Indicadores del Desarrollo Mundial. StatLink ㅊiाs] http://dx.doi.org/10.1787/888932845075 
Indicadores de la ayuda, el comercio y el desarrollo relativos a Djibouti

\begin{tabular}{|c|c|c|c|c|}
\hline Indicador (millones de \$EE.UU. corrientes) & 2005 & 2008 & 2010 & $\Delta: 05-10(\%)$ \\
\hline Formación bruta de capital fijo & 134,5 & n.d. & n.d. & n.d. \\
\hline del cual: público & 65,9 & n.d. & n.d. & n.d. \\
\hline del cual: privado & 68,6 & n.d. & n.d. & n.d. \\
\hline \multicolumn{5}{|l|}{ Entrada de financiación externa } \\
\hline Entradas de IED & 22,2 & 227,7 & 36,5 & $64 \%$ \\
\hline $\begin{array}{l}\text { Deuda externa a largo plazo y fondos } \\
\text { desembolsados por el FMl }\end{array}$ & 26,5 & 52,0 & 37,3 & $40 \%$ \\
\hline $\begin{array}{l}\text { Corrientes comerciales en condiciones no } \\
\text { concesionarias }\end{array}$ & 0,0 & 0,0 & 21,3 & d.p.c. \\
\hline Corrientes de Ayuda para el Comercio & 3,5 & 16,3 & 37,2 & $957 \%$ \\
\hline $\begin{array}{l}\text { Remesas de trabajadores y remuneración } \\
\text { de empleados }\end{array}$ & 25,8 & 30,3 & 32,7 & $26 \%$ \\
\hline
\end{tabular}

\section{INDICADORES COMERCIALES (PRODUCTOS)}

\section{Indicador}

$2005 \quad 2008 \quad 2011 \quad \Delta: 05-11(\%)$

Relación comercio/PIB (\%)

Exportaciones de servicios comerciales como

$\%$ de las exportaciones totales

Importaciones de servicios comerciales como

\% de las importaciones totales

Productos intermedios distintos de los combustibles

(\% de las exportaciones de mercancías)

Productos intermedios distintos de los combustibles

(\% de las importaciones de mercancías)

\begin{tabular}{l|l|l|l|}
69 & 91 & n.d. & n.d.
\end{tabular}

$7166 \quad$ n.d. $\quad$ n.d.

$22 \quad 17 \quad$ n.d. n.d.

n.d. n.d. n.d. n.d.

n.d. n.d. n.d. n.d.

Fuentes: Secretaría de la OMC

Corrientes comerciales (millones de \$EE.UU. corrientes)

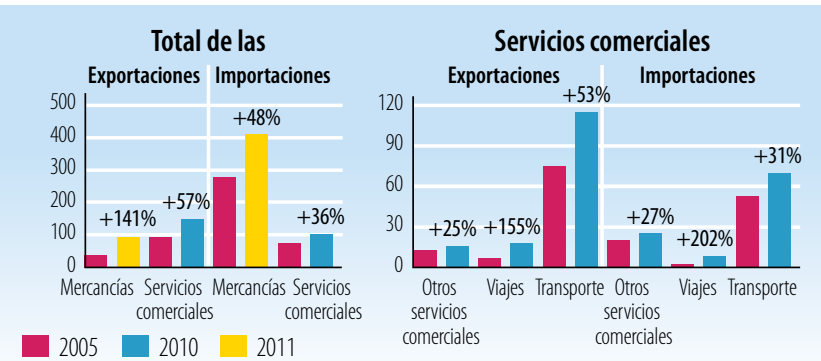

Fuentes: Secretaría de la OMC

Cinco principales mercados de exportación de mercancías (\%)

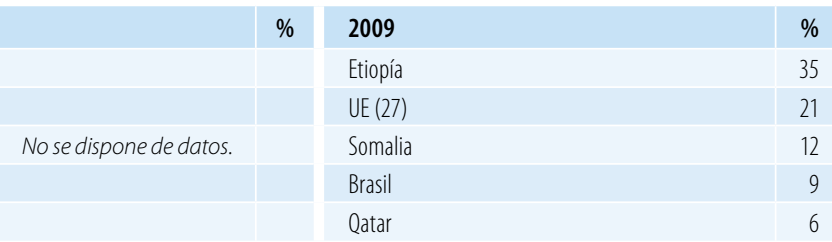

Fuentes: Secretaría de la OMC

Cinco principales productos de exportación (\% de las exportaciones de mercancías)

\begin{tabular}{|l|l|l|r|}
\hline & $\%$ & 2009 & $\%$ \\
\hline & $\begin{array}{l}\text { Vehículos automotores para el transporte de mer- } \\
\text { cancías y vehículos automotores para usos especiales }\end{array}$ & 15 \\
\hline No se dispone de datos. & & Artículos de caucho, n.e.p. & 12 \\
\hline & Maquinaria agrícola, excepto tractores & 9 \\
\hline & Lechey crema & 8 \\
\hline & Partes y piezas de tractores y vehículos automotores & 7 \\
\hline
\end{tabular}

Fuentes: Secretaría de la OMC

Cinco principales mercados de importación de mercancías (\%)

\begin{tabular}{|l|l|l|c|}
\hline & $\%$ & 2009 & $\%$ \\
\hline & & UE (27) & 37 \\
\hline \multirow{2}{*}{ No se dispone de datos. } & & Emiratos Árabes Unidos & 18 \\
\hline & Arabia Saudita, Reino de la & 6 \\
\hline & Japón & 5 \\
\hline & Etiopía & 5 \\
\hline
\end{tabular}

Fuentes: Secretaría de la OMC

Cinco principales productos de importación (\% de las importaciones de mercancías)

\begin{tabular}{|c|c|c|c|}
\hline & $\%$ & 2009 & $\%$ \\
\hline & & Equipos de telecomunicaciones y sus partes, n.e.p. & 8 \\
\hline & & Productos derivados del petróleo & 6 \\
\hline \multirow[t]{3}{*}{ No se dispone de datos. } & & Productos y preparados comestibles, n.e.p. & 6 \\
\hline & & $\begin{array}{l}\text { Vehículos automotores para pasajeros, excepto } \\
\text { autobuses }\end{array}$ & 6 \\
\hline & & Frutas y nueces, excepto nueces oleaginosas & 3 \\
\hline
\end{tabular}

Fuentes: Secretaría de la OMC

\section{(millones de \$EE.UU. corrientes)}

\begin{tabular}{|l|r|r|}
\hline $\mathbf{2 0 0 5}$ & Valor & $\%$ \\
\hline Instituciones de la UE & 2,3 & 66 \\
\hline Japón & 0,4 & 12 \\
\hline Banco Africano de Desarrollo & 0,4 & 12 \\
\hline Francia & 0,3 & 7 \\
\hline Banco Mundial & 0,1 & 2 \\
\hline $\mathbf{2 0 1 0}$ & Valor & $\%$ \\
\hline Japón & 17,1 & 46 \\
\hline Kuwait & 6,6 & 18 \\
\hline Estados Unidos & 4,8 & 13 \\
\hline Banco Africano de Desarrollo & 3,9 & 11 \\
\hline Instituciones de la UE & 3,1 & 8 \\
\hline
\end{tabular}

Fuentes: OCDE, base de datos del SNPA del CAD sobre las actividades de ayuda.

\section{Principales donantes en 2005}

Principales donantes en 2010

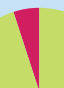

$95 \%$ 


\section{LA AYUDA PARA EL COMERCIO EN SIINTESIS 2013}

\section{INDICADORES COMERCIALES (RESULTADOS)}

Indicador

Crecimiento del PIB (\%)

Número de exportadores

Índice de concentración de las exportaciones (productos) (0 a 1)

ACR sobre mercancías notificados a la OMC

AIE (servicios) notificados a la OMC

Sectores de servicios con compromisos en el marco del AGCS

\section{Aranceles (\%)}

\begin{tabular}{l|l|l|l|} 
Importaciones: promedio aritmético de los aranceles NMF aplicados & 28,1 & 21,0
\end{tabular}

\begin{tabular}{ll|l} 
Importaciones: promedio ponderado de los aranceles NMF aplicados & n.d.
\end{tabular}

\begin{tabular}{|l|l|l|l|}
\hline Exportaciones: promedio ponderado de los aranceles impuestos & 6,4 & 0,7 \\
\hline
\end{tabular}

por los importadores

Exportaciones: libres de derechos (en \%)

$59,9 \quad 91,7$

Fuentes: Naciones Unidas, base de datos Comtrade; Banco Mundial, base de datos sobre dinámica de las empresas de exportación; Banco Mundial, Indicadores del Desarrollo Mundial; OMC, perfiles comerciales y arancelarios.

Participación en las exportaciones por región (\%)

\begin{tabular}{|l|r|r|}
\hline África & 2005 & 2009 \\
\hline Asia & n.d. & 49,4 \\
\hline Comunidad de Estados Independientes & n.d. & 4,6 \\
\hline Europa & n.d. & 0,0 \\
\hline Oriente Medio & n.d. & 20,7 \\
\hline América del Norte & n.d. & 11,5 \\
\hline América del Sury América Central & n.d. & 0,5 \\
\hline
\end{tabular}

Fuentes: OMC, perfiles comerciales y arancelarios

Indicadores de facilitación del comercio
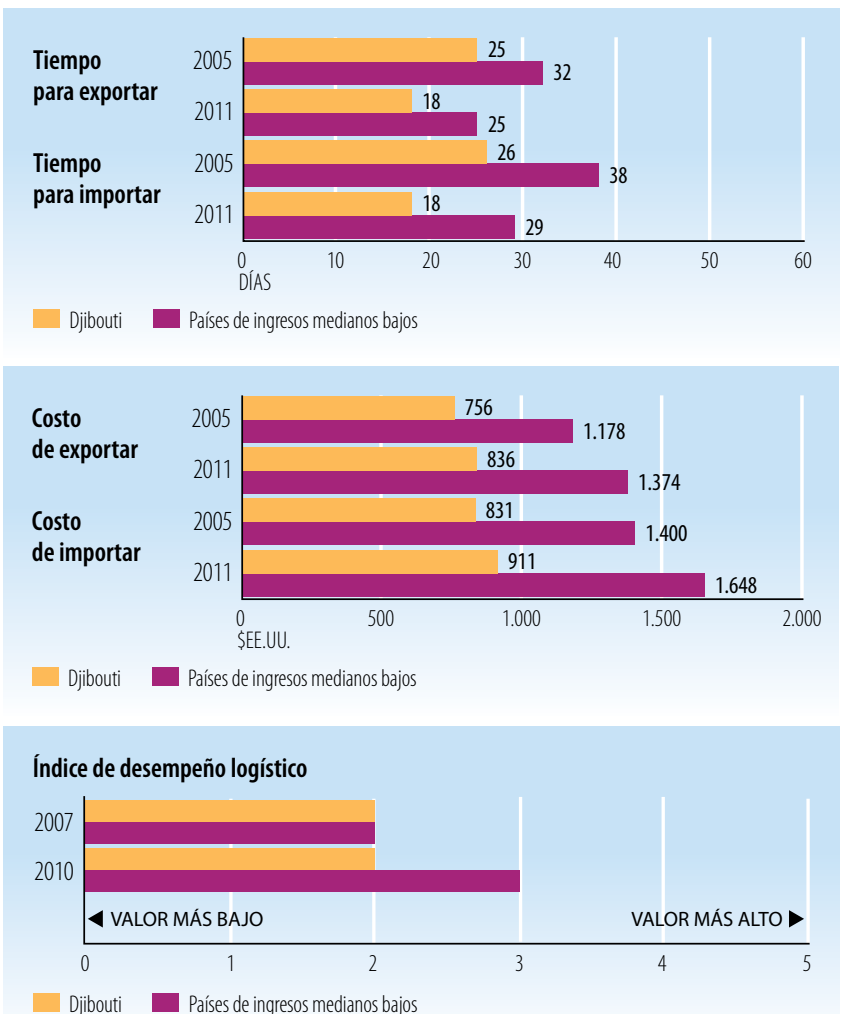

Fuentes: Banco Mundial, Indicadores del Desarrollo Mundial.

\begin{tabular}{|l|c|c|}
\hline INDICADORES DE DESARROLLO (EFECTOS) & \\
\hline Indicador & $\mathbf{2 0 0 5}$ & $\mathbf{2 0 1 0}$ \\
\hline Desempleo (\% de la fuerza de trabajo total) & n.d. & n.d. \\
\hline Población activa, mujeres (\% de la fuerza de trabajo total) & 33,7 & 34,8 \\
\hline A0D neta recibida (\% del InB) & 9,6 & 14,9 \\
\hline Derechos de importación percibidos (\% de los ingresos fiscales) & n.d. & n.d. \\
\hline Total del servicio de la deuda (\% de las exportaciones totales) & 4,9 & 7,5 \\
\hline Índice de desarrollo humano (0 a 1) & 0,40 & 0,43 \\
\hline
\end{tabular}

Fuentes: PNUD, indicadores internacionales sobre desarrollo humano; Banco Mundial, Indicadores del Desarrollo Mundial.

Producto interno bruto

PIB per cápita (PPA, dólares internacionales corrientes)

Variación porcentual entre 2005 y 2011 No se dispone de datos

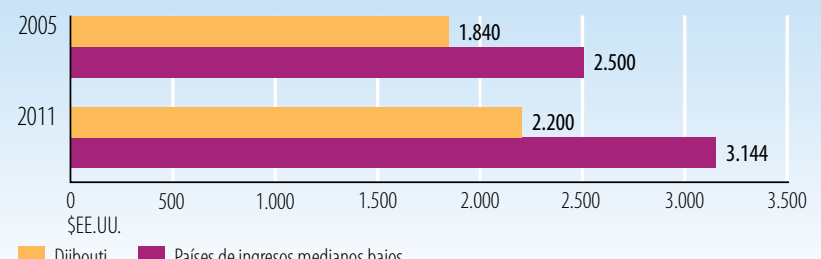

Dijbouti Países de ingresos medianos bajos

PIB per cápita (\$EE.UU. constantes de 2000)

Variación porcentual entre 2005 y $2011 \quad$ No se dispone de datos

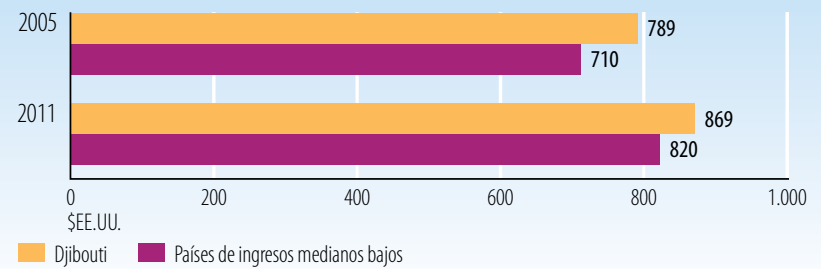

Fuentes: Banco Mundial, Indicadores del Desarrollo Mundial.

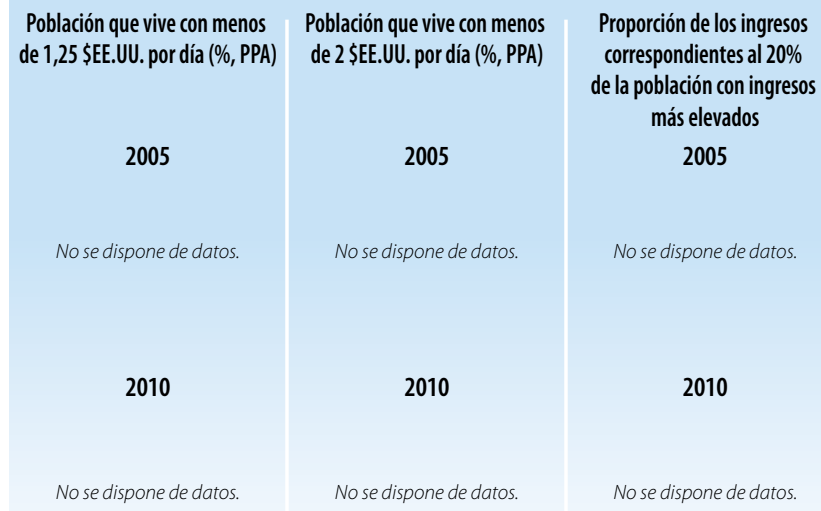

Fuentes: Banco Mundial, Indicadores del Desarrollo Mundial.

StatLink 첵ㄴ $h$ ttp://dx.doi.org/10.1787/888932845094 


\section{Indicadores de la ayuda, el comercio y el desarrollo relativos a Dominica}

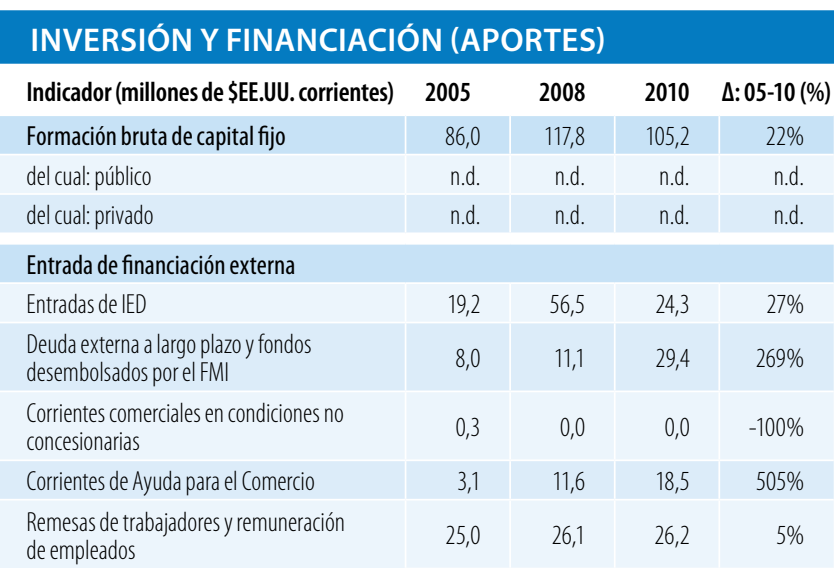

Fuentes: OCDE, base de datos del SNPA del CAD sobre las actividades de ayuda; Banco Mundial, Indicadores del Desarrollo Mundial; Banco Mundial, estadísticas de la deuda internacional.

Desembolsos de la ayuda para el comercio, por sector (millones de \$EE.UU. corrientes)

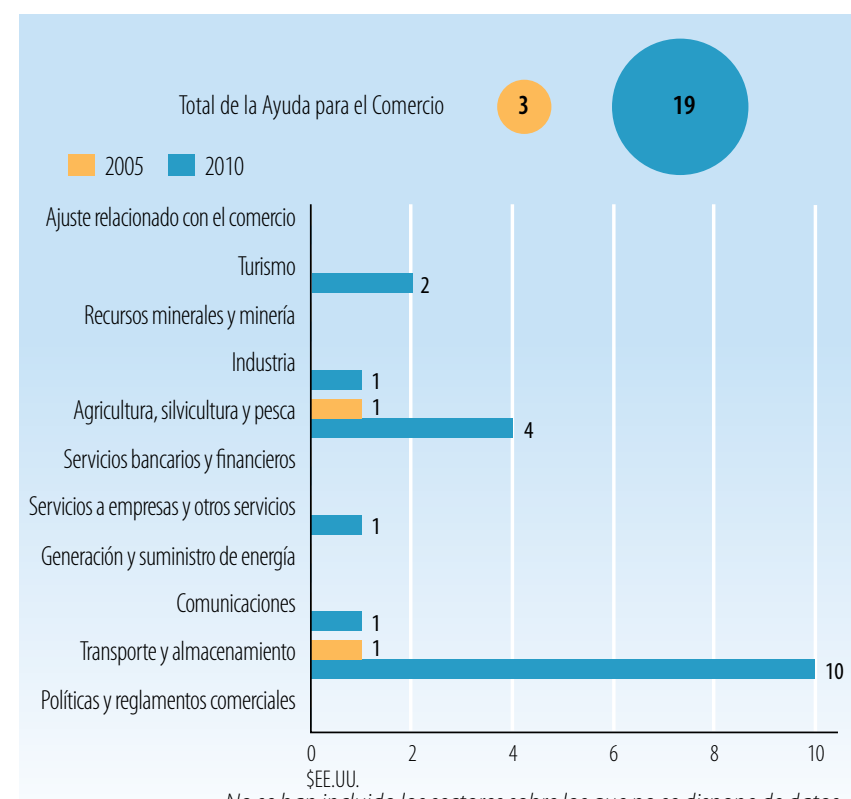

Fuentes: OCDE, base de datos del SNPA del CAD sobre las actividades de ayuda

Desembolsos de la ayuda para el comercio: principales donantes (millones de \$EE.UU. corrientes)

\begin{tabular}{|l|r|r|r|}
\hline $\mathbf{2 0 0 5}$ & Valor & $\%$ & Principales donantes en 2005 \\
\hline Instituciones de la UE & 2,0 & 64 & \\
\hline Japón & 0,5 & 16 & $100 \%$ \\
\hline Banco Mundial & 0,4 & 14 & \\
\hline Bélgica & 0,2 & 5 & \\
\hline & & & \\
\hline $\mathbf{2 0 1 0}$ & Valor & $\%$ & Principales donantes en 2010 \\
\hline Instituciones de la UE & 11,0 & 59 & \\
\hline Francia & 3,1 & 16 & \\
\hline Kuwait & 2,2 & 12 & \\
\hline Japón & 2,0 & 11 & \\
\hline Banco Mundial & 0,2 & 1 & \\
\hline
\end{tabular}

Fuentes: OCDE, base de datos del SNPA del CAD sobre las actividades de ayuda.

\begin{tabular}{|c|c|c|c|c|}
\hline Indicador & 2005 & 2008 & 2011 & $\Delta: 05-11(\%)$ \\
\hline Relación comercio/PIB (\%) & 88 & 97 & 87 & -1 \\
\hline $\begin{array}{l}\text { Exportaciones de servicios comerciales como } \\
\% \text { de las exportaciones totales }\end{array}$ & 67 & 73 & 79 & 13 \\
\hline $\begin{array}{l}\text { Importaciones de servicios comerciales como } \\
\% \text { de las importaciones totales }\end{array}$ & 25 & 24 & 25 & 1 \\
\hline $\begin{array}{l}\text { Productos intermedios distintos de los combustibles } \\
\text { (\% de las exportaciones de mercancías) }\end{array}$ & 17 & 25 & n.d. & n.d. \\
\hline $\begin{array}{l}\text { Productos intermedios distintos de los combustibles } \\
\text { (\% de las importaciones de mercancías) }\end{array}$ & 37 & 39 & n.d. & n.d. \\
\hline
\end{tabular}

Fuentes: Secretaría de la OMC.

Corrientes comerciales (millones de \$EE.UU. corrientes)

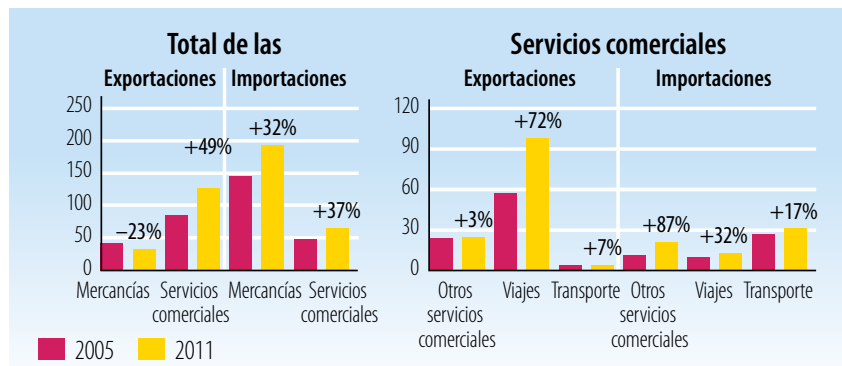

Fuentes: Secretaría de la OMC

Cinco principales mercados de exportación de mercancías (\%)

\begin{tabular}{|l|r|l|r|}
\hline 2005 & $\%$ & 2010 & $\%$ \\
\hline UE (27) & 28 & Saint Kitts y Nevis & 18 \\
\hline Jamaica & 13 & Jamaica & 17 \\
\hline Antigua y Barbuda & 11 & UE (27) & 17 \\
\hline Trinidady Tabago & 9 & Trinidady Tabago & 14 \\
\hline Santa Lucía & 7 & Antigua y Barbuda & 9 \\
\hline
\end{tabular}

Fuentes: Secretaría de la OMC

Cinco principales productos de exportación (\% de las exportaciones de mercancías)

\begin{tabular}{|l|r|l|c|}
\hline 2005 & $\%$ & 2010 & $\%$ \\
\hline $\begin{array}{l}\text { Jabón, preparados para limpiar y pulir, } \\
\text { etc. }\end{array}$ & 28 & $\begin{array}{l}\text { Jabón, preparados para limpiary } \\
\text { pulir, etc. }\end{array}$ & 40 \\
\hline $\begin{array}{l}\text { Frutas y nueces, excepto nueces } \\
\text { oleaginosas }\end{array}$ & 25 & $\begin{array}{l}\text { Frutas y nueces, excepto nueces } \\
\text { oleaginosas }\end{array}$ & 14 \\
\hline \begin{tabular}{l|l|l|} 
Productos de perfumería, cosméticos, etc. \\
Pigmentos, pinturas, etc.
\end{tabular} & 14 & Impresos & 13 \\
\hline $\begin{array}{l}\text { Piedra, arena y grava } \\
\text { Fuentes: Secretaría de la OMC }\end{array}$ & 6 & Pigmentos, pinturas, etc. & 6 \\
\hline
\end{tabular}

Cinco principales mercados de importación de mercancías (\%)

\begin{tabular}{|l|r|l|r|}
\hline 2005 & $\%$ & 2010 & $\%$ \\
\hline Estados Unidos & 37 & Estados Unidos & 42 \\
\hline Trinidady Tabago & 21 & Trinidad y Tabago & 15 \\
\hline UE (27) & 13 & UE (27) & 8 \\
\hline Japón & 5 & Venezuela, Rep. Bolivariana de & 7 \\
\hline Barbados & 3 & Japón & 4 \\
\hline
\end{tabular}

Fuentes: Secretaría de la OMC

Cinco principales productos de importación (\% de las importaciones de mercancías)

\begin{tabular}{|c|c|c|c|}
\hline 2005 & $\%$ & 2010 & $\%$ \\
\hline Productos derivados del petróleo & 12 & Productos derivados del petróleo & 16 \\
\hline $\begin{array}{l}\text { Equipos de telecomunicaciones y sus } \\
\text { partes, n.e.p. }\end{array}$ & 5 & Otras carnes y despojos de carnes & 3 \\
\hline Papeles y cartones recortados, etc. & 3 & $\begin{array}{l}\text { Vehículos automotores para pasajeros, } \\
\text { excepto autobuses }\end{array}$ & 2 \\
\hline Otras carnes y despojos de carnes & 3 & Aceites y grasas de origen animal & 2 \\
\hline $\begin{array}{l}\text { Vehículos automotores para el transporte } \\
\text { de mercancías y vehículos automotores } \\
\text { para usos especiales }\end{array}$ & 3 & Papeles y cartones recortados, etc. & 2 \\
\hline
\end{tabular}




\section{LA AYUDA PARA EL COMERCIO EN SÍNTESIS 2013}

\section{INDICADORES COMERCIALES (RESULTADOS)}

Indicador

Crecimiento del PIB (\%)

Número de exportadores

Índice de concentración de las exportaciones (productos) ( 0 a 1$)$

ACR sobre mercancías notificados a la OMC

AIE (servicios) notificados a la OMC

Sectores de servicios con compromisos en el marco del AGCS

\section{Aranceles (\%, 2006 et 2011)}

\begin{tabular}{l|l|l|} 
Importaciones: promedio aritmético de los aranceles NMF aplicados & 9,9 & 10,2
\end{tabular}

Importaciones: promedio ponderado de los aranceles NMF aplicados n.d. $\quad 12,4$

\begin{tabular}{|l|l|l|}
\hline Exportaciones: promedio ponderado de los aranceles impuestos & 16,8 & 4,8
\end{tabular}

por los importadores

Exportaciones: libres de derechos (en \%)

$50,0 \quad 75,4$

Fuentes: Naciones Unidas, base de datos Comtrade; Banco Mundial, base de datos sobre dinámica de las empresas de exportación; Banco Mundial, Indicadores del Desarrollo Mundial; OMC, perfiles comerciales y arancelarios.

Participación en las exportaciones por región (\%)

\begin{tabular}{|l|r|r|}
\hline África & 2005 & 2010 \\
\hline Asia & 0,0 & 0,0 \\
\hline Comunidad de Estados Independientes & 0,0 & 0,0 \\
\hline Europa & 0,0 & 0,0 \\
\hline Oriente Medio & 27,8 & 16,8 \\
\hline América del Norte & 0,0 & 0,0 \\
\hline América del Sury América Central & 4,8 & 3,9 \\
\hline
\end{tabular}

Fuentes: OMC, perfiles comerciales y arancelarios

Indicadores de facilitación del comercio
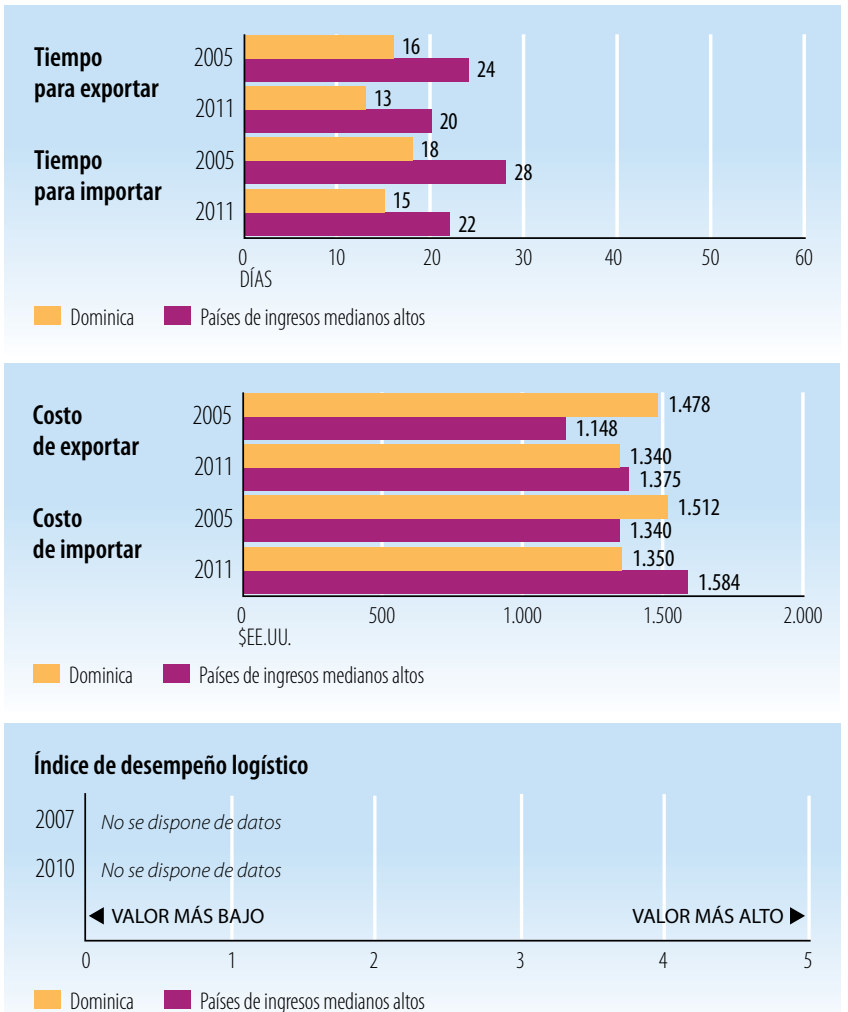

Fuentes: Banco Mundial, Indicadores del Desarrollo Mundial.

\begin{tabular}{|l|c|c|}
\hline INDICADORES DE DESARROLLO (EFECTOS) & \\
\hline Indicador & 2005 & 2010 \\
\hline Desempleo (\% de la fuerza de trabajo total) & n.d. & n.d. \\
\hline Población activa, mujeres (\% de la fuerza de trabajo total) & n.d. & n.d. \\
\hline AOD neta recibida (\% del INB) & 6,2 & 7,0 \\
\hline Derechos de importación percibidos (\% de los ingresos fiscales) & n.d. & n.d. \\
\hline Total del servicio de la deuda (\% de las exportaciones totales) & 12,0 & 9,8 \\
\hline Índice de desarrollo humano (0 a 1) & 0,71 & 0,72 \\
\hline
\end{tabular}

Fuentes: PNUD, indicadores internacionales sobre desarrollo humano; Banco Mundial, Indicadores del Desarrollo Mundial.

Producto interno bruto

PIB per cápita (PPA, dólares internacionales corrientes)
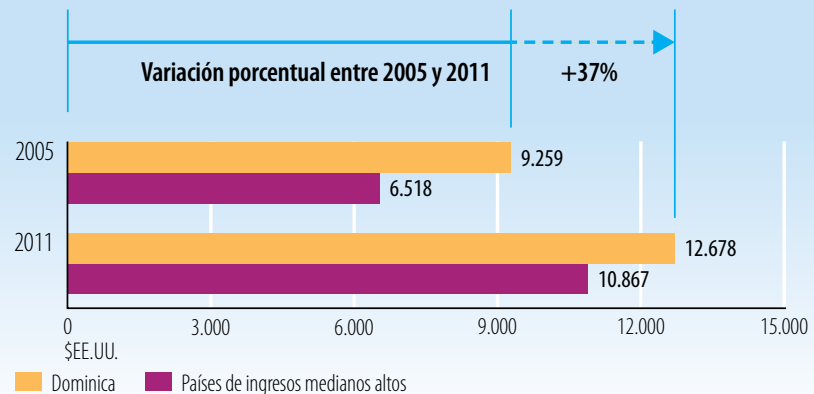

Dominica Países de ingresos medianos altos

PIB per cápita (\$EE.UU. constantes de 2000)
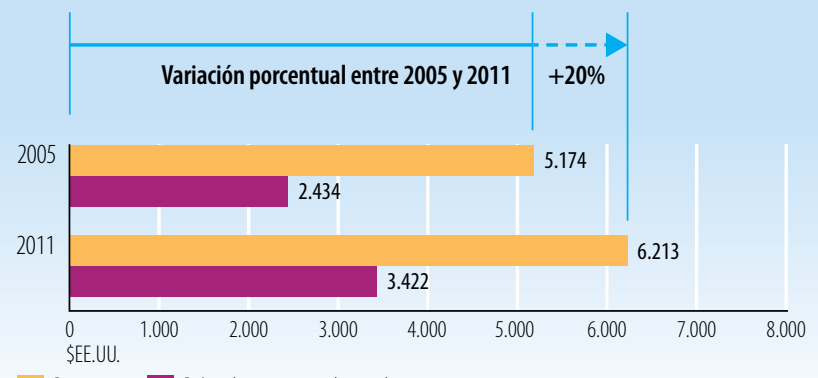

Dominica Países de ingresos medianos altos

Fuentes: Banco Mundial, Indicadores del Desarrollo Mundial.

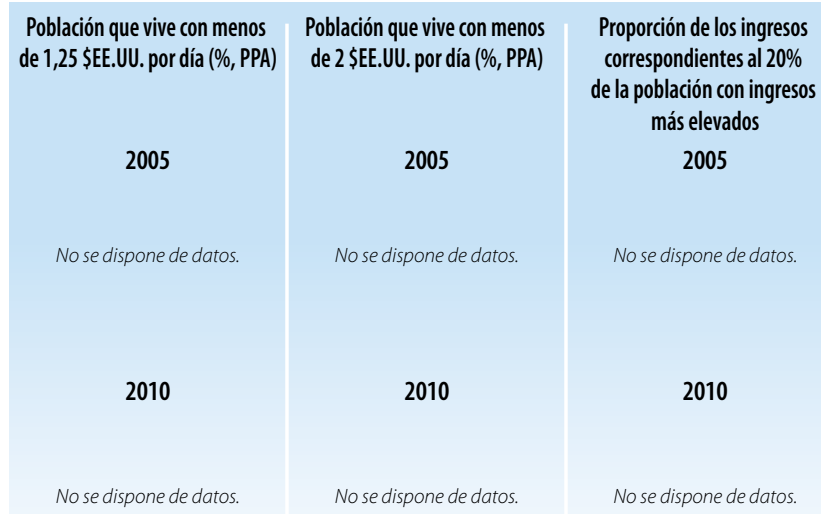

Fuentes: Banco Mundial, Indicadores del Desarrollo Mundial.

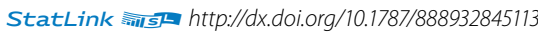


Indicadores de la ayuda, el comercio y el desarrollo relativos a El Salvador

\begin{tabular}{|c|c|c|c|c|}
\hline Indicador (millones de \$EE.UU. corrientes) & 2005 & 2008 & 2010 & $\Delta: 05-10(\%$ \\
\hline Formación bruta de capital fijo & $2.611,0$ & $3.257,7$ & $2.852,5$ & $9 \%$ \\
\hline del cual: público & 402,0 & 520,0 & 483,9 & $20 \%$ \\
\hline del cual: privado & $2.209,0$ & $2.737,7$ & $2.368,6$ & $7 \%$ \\
\hline \multicolumn{5}{|l|}{ Entrada de financiación externa } \\
\hline Entradas de IED & 55,1 & 371,2 & $-5,3$ & $-110 \%$ \\
\hline $\begin{array}{l}\text { Deuda externa a largo plazo y fondos } \\
\text { desembolsados por el FMl }\end{array}$ & $1.221,9$ & $1.042,2$ & $1.054,8$ & $-14 \%$ \\
\hline $\begin{array}{l}\text { Corrientes comerciales en condiciones no } \\
\text { concesionarias }\end{array}$ & 25,0 & 1,0 & 29,7 & $19 \%$ \\
\hline Corrientes de Ayuda para el Comercio & 53,6 & 76,7 & 138,9 & $159 \%$ \\
\hline $\begin{array}{l}\text { Remesas de trabajadores y remuneración } \\
\text { de empleados }\end{array}$ & $3.029,7$ & $3.758,1$ & $3.449,4$ & $14 \%$ \\
\hline
\end{tabular}

Fuentes: OCDE, base de datos del SNPA del CAD sobre las actividades de ayuda; Banco Mundial, Indicadores del Desarrollo Mundial; Banco Mundial, estadísticas de la deuda internacional.

Desembolsos de la ayuda para el comercio, por sector (millones de \$EE.UU. corrientes)

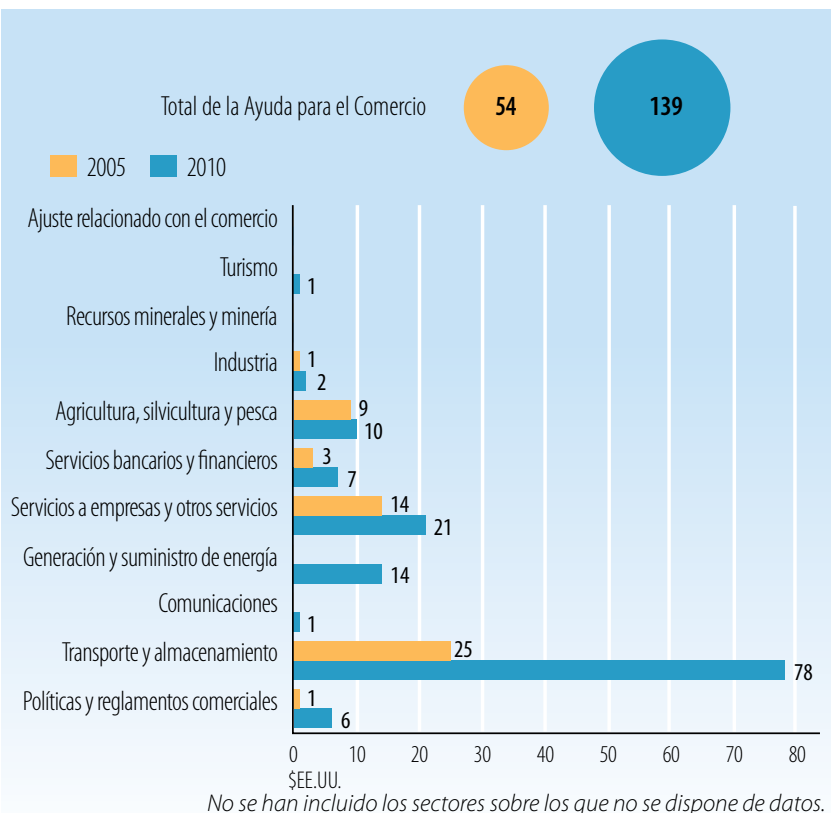

Fuentes: OCDE, base de datos del SNPA del CAD sobre las actividades de ayuda

Desembolsos de la ayuda para el comercio: principales donantes (millones de \$EE.UU. corrientes)

\begin{tabular}{|l|r|r|r|}
\hline $\mathbf{2 0 0 5}$ & Valor & $\%$ & Principales donantes en 2005 \\
\hline Japón & 26,4 & 49 & \\
\hline Estados Unidos & 11,0 & 20 & \\
\hline España & 5,0 & 9 & $91 \%$ \\
\hline Instituciones de la UE & 4,0 & 7 & \\
\hline Alemania & 2,1 & 4 & \\
\hline $\mathbf{2 0 1 0}$ & Valor & $\%$ & Principales donantes en $\mathbf{2 0 1 0}$ \\
\hline Estados Unidos & 109,4 & 79 & \\
\hline España & 9,2 & 7 & \\
\hline Alemania & 6,3 & 5 & \\
\hline Instituciones de la UE & 5,3 & 4 & $96 \%$ \\
\hline Japón & 3,4 & 2 & \\
\hline
\end{tabular}

Fuentes: OCDE, base de datos del SNPA del CAD sobre las actividades de ayuda.

\section{INDICADORES COMERCIALES (PRODUCTOS)}

Indicador

$2005 \quad 2008 \quad 2011 \quad \Delta: 05-11(\%)$

Relación comercio/PIB (\%)

Exportaciones de servicios comerciales como

$\%$ de las exportaciones totales

Importaciones de servicios comerciales como

$\%$ de las importaciones totales

Productos intermedios distintos de los combustibles

(\% de las exportaciones de mercancías)

Productos intermedios distintos de los combustibles

(\% de las importaciones de mercancías)

\begin{tabular}{l|l|l|r|}
70 & 76 & 75 & 5 \\
\hline
\end{tabular}

Fuentes: Secretaría de la OMC.

Corrientes comerciales (millones de \$EE.UU. corrientes)

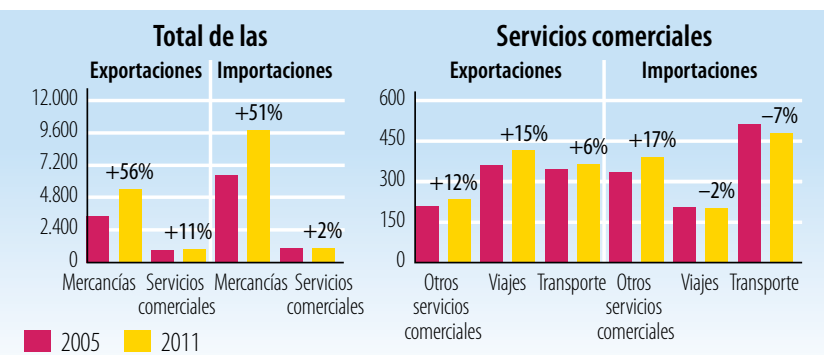

Fuentes: Secretaría de la OMC

Cinco principales mercados de exportación de mercancías (\%)

\begin{tabular}{|l|r|l|c|}
\hline $\mathbf{2 0 0 5}$ & $\%$ & $\mathbf{2 0 1 0}$ & $\%$ \\
\hline Estados Unidos & 53 & Estados Unidos & 48 \\
\hline Honduras & 14 & Guatemala & 14 \\
\hline Guatemala & 12 & Honduras & 13 \\
\hline UE (27) & 5 & Nicaragua & 5 \\
\hline Nicaragua & 5 & UE (27) & 4 \\
\hline
\end{tabular}

Fuentes: Secretaría de la OMC

Cinco principales productos de exportación (\% de las exportaciones de mercancías)

\begin{tabular}{|c|c|c|c|}
\hline 2005 & $\%$ & 2010 & $\%$ \\
\hline $\begin{array}{l}\text { Otros artículos textiles y prendas de } \\
\text { vestir, n.e.p. }\end{array}$ & 27 & $\begin{array}{l}\text { Otros artículos textiles y prendas de } \\
\text { vestir, n.e.p. }\end{array}$ & 23 \\
\hline $\begin{array}{l}\text { Prendas de vestir para mujeres y niñas, } \\
\text { de punto }\end{array}$ & 6 & Café y sucedáneos del café & \\
\hline $\begin{array}{l}\text { Prendas de vestir para hombres y niños, } \\
\text { de punto }\end{array}$ & 6 & $\begin{array}{l}\text { Prendas de vestir para hombres y niños, } \\
\text { de punto }\end{array}$ & \\
\hline Caféy sucedáneos del café & 5 & Maquinaria y aparatos eléctricos, n.e.p & \\
\hline Maquinaria y aparatos eléctricos, n.e.p & 4 & Azúcares, melaza y miel & \\
\hline
\end{tabular}

Fuentes: Secretaría de la OMC

Cinco principales mercados de importación de mercancías (\%)

\begin{tabular}{|l|r|l|c|}
\hline 2005 & $\%$ & 2010 & $\%$ \\
\hline Estados Unidos & 37 & Estados Unidos & 37 \\
\hline Guatemala & 9 & Guatemala & 9 \\
\hline México & 8 & México & 9 \\
\hline UE (27) & 7 & UE (27) & 7 \\
\hline Brasil & 4 & China & 6 \\
\hline Fuentes: Secretaría de la OMC & & & \\
\hline
\end{tabular}

Cinco principales productos de importación (\% de las importaciones de mercancías)

\begin{tabular}{|l|c|l|c|}
\hline 2005 & $\%$ & 2010 & $\%$ \\
\hline Productos derivados del petróleo & 7 & Productos derivados del petróleo & 8 \\
\hline Tejidos de punto o ganchillo, n.e.p. & 7 & Aceites de petróleo, crudos & 6 \\
\hline Aceites de petróleo, crudos & 5 & Tejidos de punto o ganchillo, n.e.p. & 5 \\
\hline Medicamentos & 3 & Medicamentos & 3 \\
\hline Operaciones especiales no clasificadas & 3 & Hilados de fibra textil & 3 \\
\hline
\end{tabular}




\section{LA AYUDA PARA EL COMERCIO EN SÍNTESIS 2013}

\section{INDICADORES COMERCIALES (RESULTADOS)}

\section{Indicador}

Crecimiento del PIB (\%)

Número de exportadores

Índice de concentración de las exportaciones (productos) (0 a 1)

ACR sobre mercancías notificados a la OMC

AIE (servicios) notificados a la OMC

Sectores de servicios con compromisos en el marco del AGCS

\section{Aranceles (\%)}

Importaciones: promedio aritmético de los aranceles NMF aplicado

Importaciones: promedio ponderado de los aranceles NMF aplicados

Exportaciones: promedio ponderado de los aranceles impuestos

por los importadores

Exportaciones: libres de derechos (en \%)

\begin{tabular}{|r|r|}
\hline 2005 & 2011 \\
\hline 3,6 & 1,5 \\
\hline 2.471 & 2.569 \\
\hline 0,04 & 0,04 \\
\hline n.d. & 8 \\
\hline n.d. & 7 \\
\hline 29 & 29 \\
\hline
\end{tabular}

Fuentes: Naciones Unidas, base de datos Comtrade; Banco Mundial, base de datos sobre dinámica de las empresas de exportación; Banco Mundial, Indicadores del

Desarrollo Mundial; OMC, perfiles comerciales y arancelarios.

Participación en las exportaciones por región (\%)

\begin{tabular}{|l|r|r|}
\hline & 2005 & 2010 \\
\hline África & 0,0 & 0,1 \\
\hline Asia & 1,1 & 1,8 \\
\hline Comunidad de Estados Independientes & 0,7 & 0,4 \\
\hline Europa & 5,2 & 4,3 \\
\hline Oriente Medio & 0,0 & 0,0 \\
\hline América del Norte & 54,8 & 51,6 \\
\hline América del Sury América Central & 38,2 & 41,8 \\
\hline
\end{tabular}

Fuentes: OMC, perfiles comerciales y arancelarios

Indicadores de facilitación del comercio
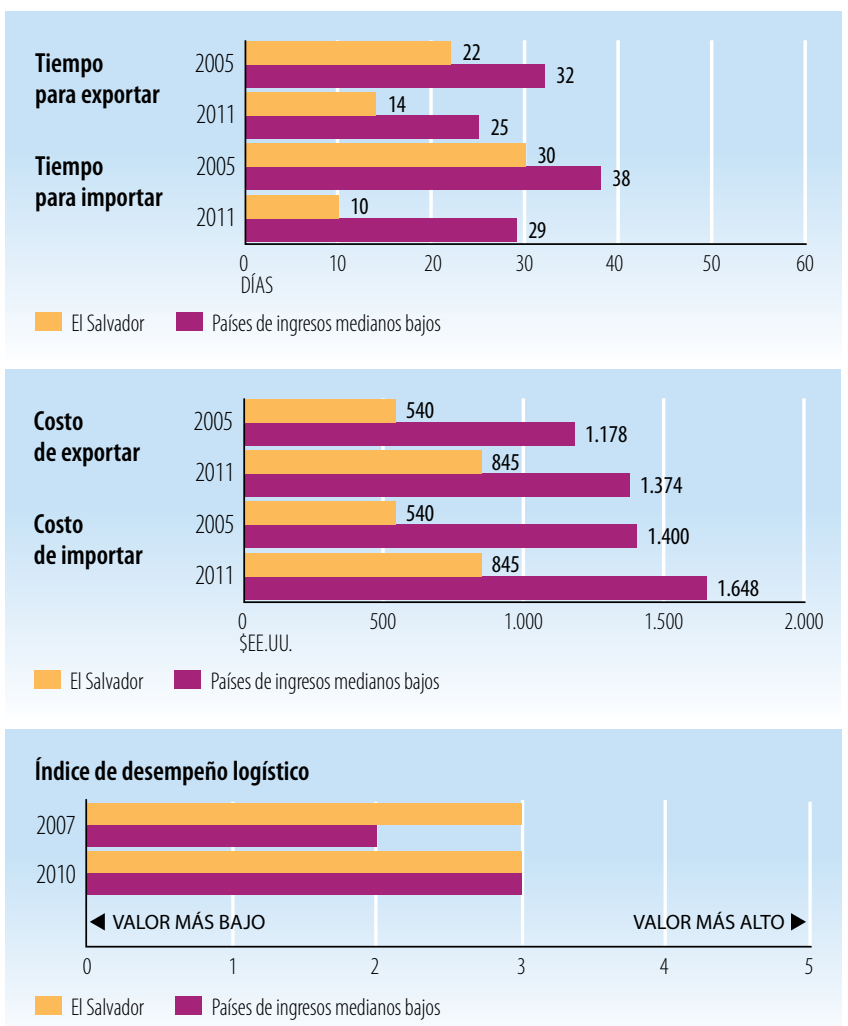

Fuentes: Banco Mundial, Indicadores del Desarrollo Mundial.

\begin{tabular}{|l|r|r|}
\hline INDICADORES DE DESARROLLO (EFECTOS) \\
\hline Indicador & 2005 & $\mathbf{2 0 1 0}$ \\
\hline Desempleo (\% de la fuerza de trabajo total) & 7,2 & 7,3 \\
\hline Población activa, mujeres (\% de la fuerza de trabajo total) & 40,4 & 41,4 \\
\hline AOD neta recibida (\% del INB) & 1,2 & 1,4 \\
\hline Derechos de importación percibidos (\% de los ingresos fiscales) & 8,3 & 4,8 \\
\hline Total del servicio de la deuda (\% de las exportaciones totales) & 18,5 & 19,0 \\
\hline Índice de desarrollo humano (0 a 1) & 0,65 & 0,67 \\
\hline
\end{tabular}

Fuentes: PNUD, indicadores internacionales sobre desarrollo humano; Banco Mundial, Indicadores del Desarrollo Mundial.

Producto interno bruto

PIB per cápita (PPA, dólares internacionales corrientes)
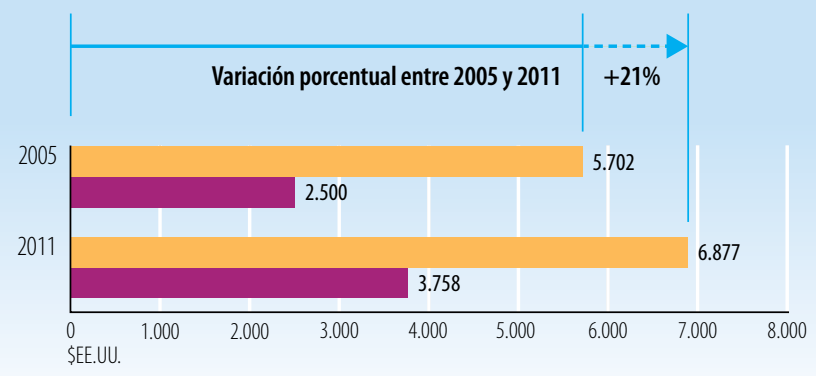

El Salvador Países de ingresos medianos bajos

PIB per cápita (\$EE.UU. constantes de 2000)
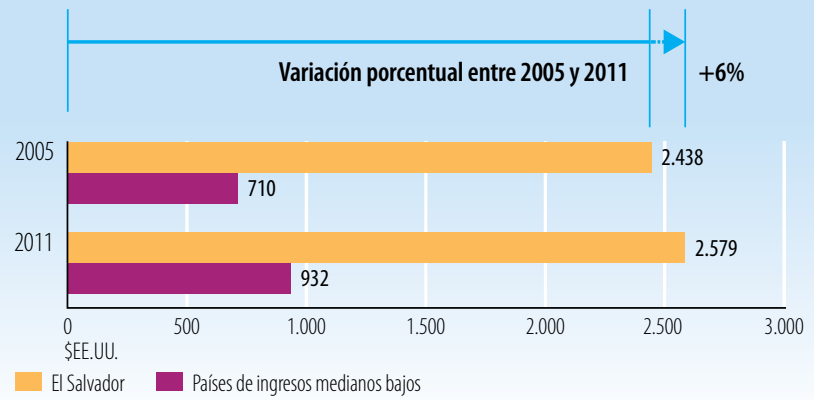

Fuentes: Banco Mundial, Indicadores del Desarrollo Mundial.

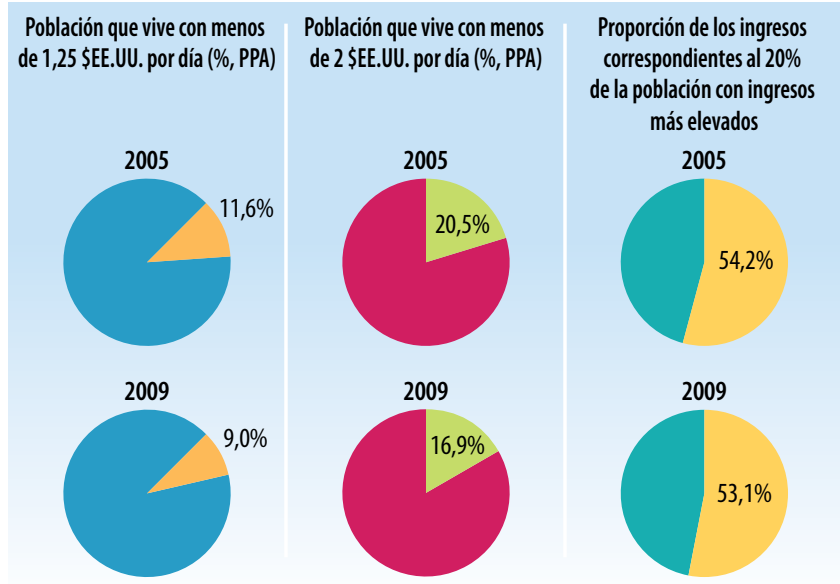

Fuentes: Banco Mundial, Indicadores del Desarrollo Mundial.

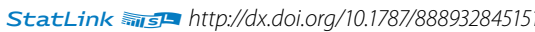


Indicadores de la ayuda, el comercio y el desarrollo relativos a Etiopía

\begin{tabular}{|c|c|c|c|c|}
\hline Indicador (millones de \$EE.UU. corrientes) & 2005 & 2008 & 2010 & $\Delta: 05-10(\%$ \\
\hline Formación bruta de capital fijo & $2.829,8$ & $5.293,7$ & $6.382,2$ & $126 \%$ \\
\hline del cual: público & $1.811,1$ & $3.726,8$ & $4.892,2$ & $170 \%$ \\
\hline del cual: privado & $1.018,7$ & $1.566,9$ & $1.490,0$ & $46 \%$ \\
\hline \multicolumn{5}{|l|}{ Entrada de financiación externa } \\
\hline Entradas de IED & 265,1 & 108,5 & 288,3 & $9 \%$ \\
\hline $\begin{array}{l}\text { Deuda externa a largo plazo y fondos } \\
\text { desembolsados por el FMl }\end{array}$ & 527,3 & 379,2 & $1.882,4$ & $257 \%$ \\
\hline $\begin{array}{l}\text { Corrientes comerciales en condiciones no } \\
\text { concesionarias }\end{array}$ & 0,0 & 0,0 & 0,0 & $0 \%$ \\
\hline Corrientes de Ayuda para el Comercio & 332,9 & 560,4 & 557,3 & $67 \%$ \\
\hline $\begin{array}{l}\text { Remesas de trabajadores y remuneración } \\
\text { de empleados }\end{array}$ & 173,5 & 386,7 & 224,5 & $29 \%$ \\
\hline
\end{tabular}

Fuentes: OCDE, base de datos del SNPA del CAD sobre las actividades de ayuda; Banco Mundial, Indicadores del Desarrollo Mundial; Banco Mundial, estadísticas de la deuda internacional.

Desembolsos de la ayuda para el comercio, por sector (millones de \$EE.UU. corrientes)

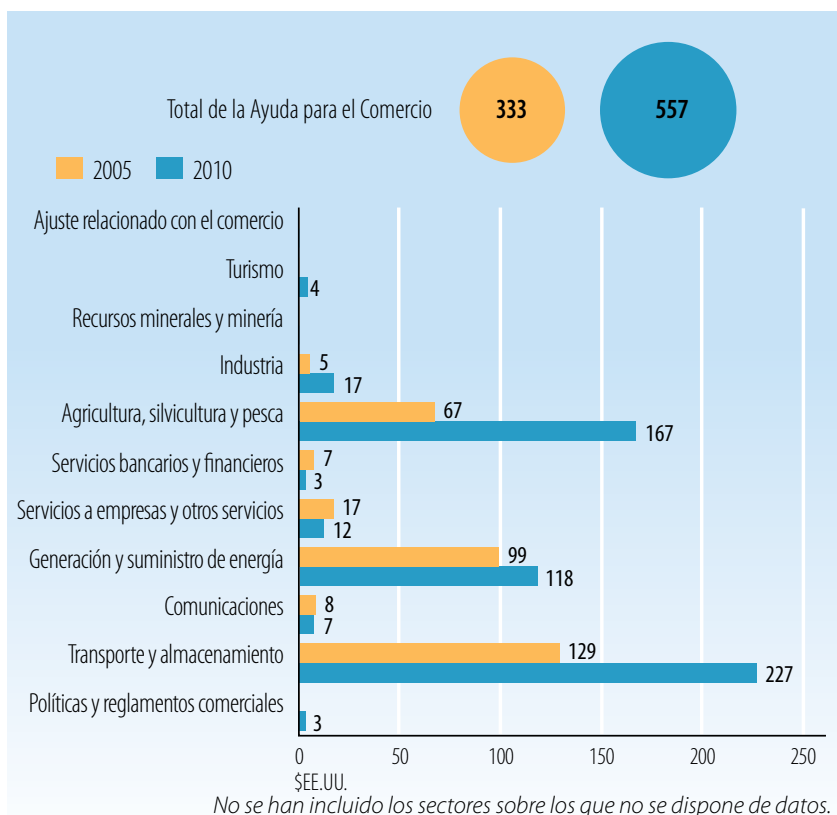

Fuentes: OCDE, base de datos del SNPA del CAD sobre las actividades de ayuda

Desembolsos de la ayuda para el comercio: principales donantes (millones de \$EE.UU. corrientes)

\begin{tabular}{|l|c|c|c|}
\hline $\mathbf{2 0 0 5}$ & Valor & $\%$ & Principales donantes en 2005 \\
\hline Banco Mundial & 92,2 & 28 & \\
\hline Italia & 75,6 & 23 & \\
\hline Instituciones de la UE & 52,9 & 16 & $83 \%$ \\
\hline Banco Africano de Desarrollo & 40,6 & 12 & \\
\hline Japón & 15,8 & 5 & \\
\hline $\mathbf{2 0 1 0}$ & Valor & $\%$ & Principales donantes en 2010 \\
\hline Banco Mundial & 171,9 & 31 & \\
\hline Instituciones de la UE & 96,1 & 17 & \\
\hline Banco Africano de Desarrollo & 84,7 & 15 & $81 \%$ \\
\hline Canadá & 68,6 & 12 & \\
\hline Japón & 32,5 & 6 & \\
\hline
\end{tabular}

Fuentes: OCDE, base de datos del SNPA del CAD sobre las actividades de ayuda.

\section{INDICADORES COMERCIALES (PRODUCTOS)}

\section{Indicador}

$2005 \quad 2008 \quad 2011 \quad \Delta: 05-11(\%)$

Relación comercio/PIB (\%)

Exportaciones de servicios comerciales como

$\%$ de las exportaciones totales

Importaciones de servicios comerciales como

$\%$ de las importaciones totales

Productos intermedios distintos de los combustibles

(\% de las exportaciones de mercancías)

Productos intermedios distintos de los combustibles

(\% de las importaciones de mercancías)

\begin{tabular}{|l|l|l|l|}
54 & 48 & 54 & 1
\end{tabular}

Fuentes: Secretaría de la OMC.

Corrientes comerciales (millones de \$EE.UU. corrientes)

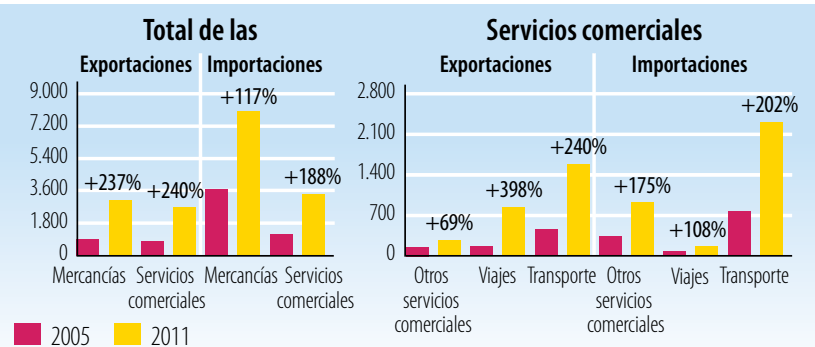

Fuentes: Secretaría de la OMC

Cinco principales mercados de exportación de mercancías (\%)

\begin{tabular}{|l|r|l|r|}
\hline 2005 & $\%$ & 2011 & $\%$ \\
\hline UE (27) & 32 & UE (27) & 34 \\
\hline China & 10 & China & 11 \\
\hline Japón & 7 & Somalia & 9 \\
\hline Somalia & 6 & Sudán & 7 \\
\hline Arabia Saudita, Reino de la & 6 & Arabia Saudita, Reino de la & 6
\end{tabular}

Fuentes: Secretaría de la OMC

Cinco principales productos de exportación (\% de las exportaciones de mercancías)

\section{5}

Caféy sucedáneos del café

Semillas oleaginosas (aceites vegetales

fijos blandos)

Productos vegetales en bruto, n.e.p.

Oro no monetario, excepto minerales

Legumbres

Fuentes: Secretaría de la OMC

\begin{tabular}{|c|c|c|}
\hline 46 & 53 & 46 \\
\hline 24 & 25 & 30 \\
\hline 55 & 73 & 69 \\
\hline 45 & 45 & 47 \\
\hline
\end{tabular}




\section{LA AYUDA PARA EL COMERCIO EN SIINTESIS 2013}

\section{INDICADORES COMERCIALES (RESULTADOS)}

Indicador

Crecimiento del PIB (\%)

Número de exportadores

Índice de concentración de las exportaciones (productos) ( 0 a 1)

ACR sobre mercancías notificados a la OMC

AlE (servicios) notificados a la OMC

Sectores de servicios con compromisos en el marco del AGCS

\section{Aranceles (\%, 2006 et 2011)}

\begin{tabular}{l|l|l|l|} 
Importaciones: promedio aritmético de los aranceles NMF aplicados & 16,8
\end{tabular}

Importaciones: promedio ponderado de los aranceles NMF aplicados $\quad$ n.d.
10,4

\begin{tabular}{|l|l|l|l|} 
Exportaciones: promedio ponderado de los aranceles impuestos & 2,1 & 0,3
\end{tabular}

por los importadores

$89,8 \quad 94,4$

Exportaciones: libres de derechos (en \%)
Fuentes: Naciones Unidas, base de datos Comtrade; Banco Mundial, base de dato sobre dinámica de las empresas de exportación; Banco Mundial, Indicadores del

Desarrollo Mundial; OMC, perfiles comerciales y arancelarios.

Participación en las exportaciones por región (\%)

\begin{tabular}{|l|r|r|}
\hline & $\mathbf{2 0 0 5}$ & $\mathbf{2 0 1 1}$ \\
\hline África & 17,3 & 22,3 \\
\hline Asia & 21,0 & 17,6 \\
\hline Comunidad de Estados Independientes & 0,3 & 0,4 \\
\hline Europa & 39,2 & 40,7 \\
\hline Oriente Medio & 15,9 & 14,4 \\
\hline América del Norte & 5,6 & 4,3 \\
\hline América del Sury América Central & 0,2 & 0,3 \\
\hline
\end{tabular}

Fuentes: OMC, perfiles comerciales y arancelarios

Indicadores de facilitación del comercio
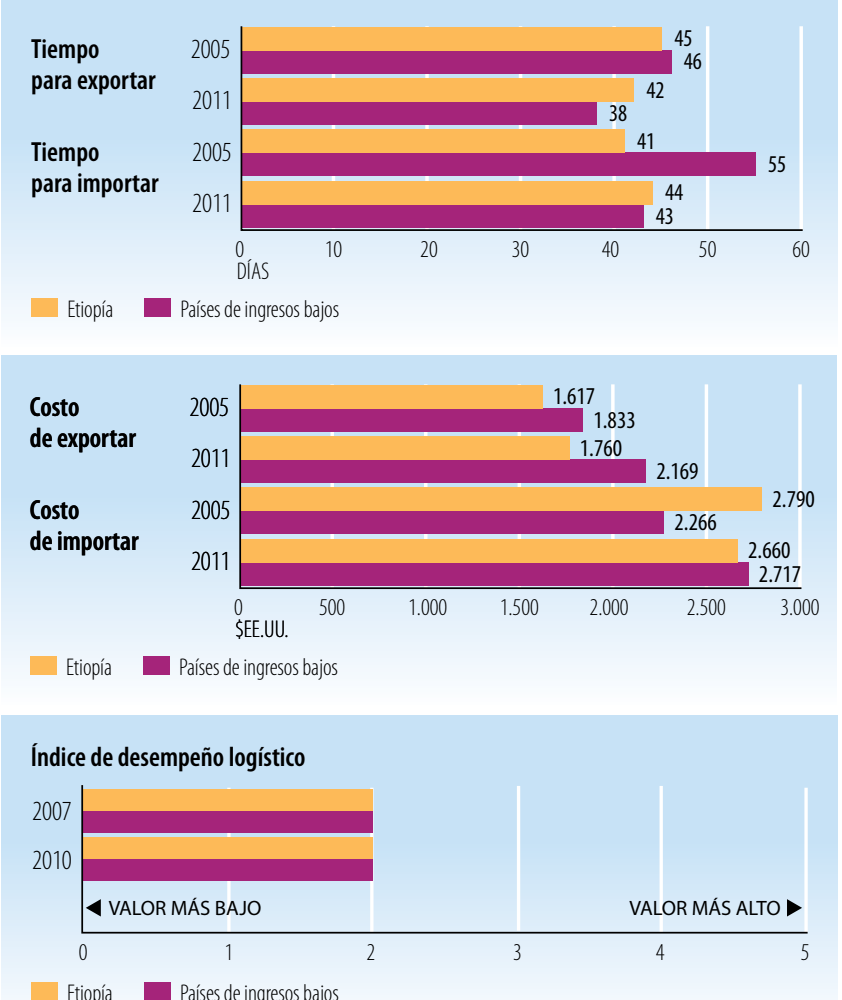

Etiopía Países de ingresos bajos

Fuentes: Banco Mundial, Indicadores del Desarrollo Mundial.

\begin{tabular}{|l|r|c|}
\hline INDICADORES DE DESARROLLO (EFECTOS) \\
\hline Indicador & $\mathbf{2 0 0 5}$ & $\mathbf{2 0 1 0}$ \\
\hline Desempleo (\% de la fuerza de trabajo total) & 5,4 & 20,5 \\
\hline Población activa, mujeres (\% de la fuerza de trabajo total) & 46,9 & 47,2 \\
\hline AOD neta recibida (\% del INB) & 15,7 & 11,9 \\
\hline Derechos de importación percibidos (\% de los ingresos fiscales) & 61,8 & 32,6 \\
\hline Total del servicio de la deuda (\% de las exportaciones totales) & 4,7 & 3,0 \\
\hline Índice de desarrollo humano ( 0 a 1) & 0,31 & 0,36 \\
\hline
\end{tabular}

Fuentes: PNUD, indicadores internacionales sobre desarrollo humano; Banco Mundial, Indicadores del Desarrollo Mundial.

Producto interno bruto

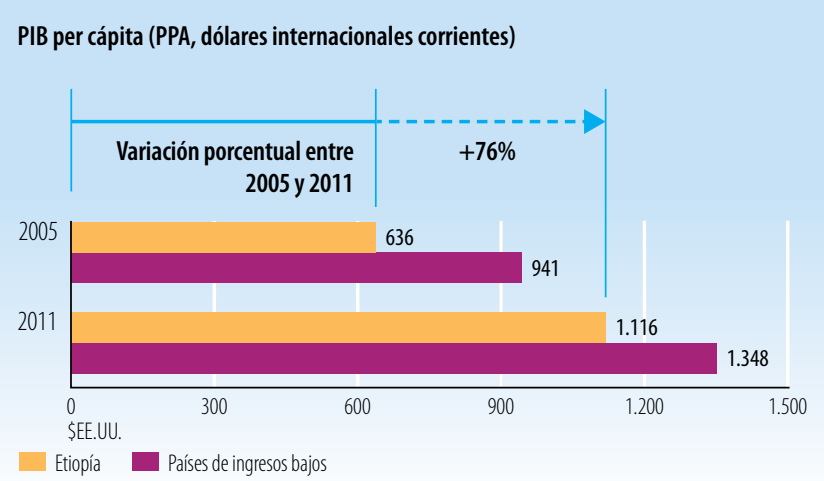

PIB per cápita (\$EE.UU. constantes de 2000)
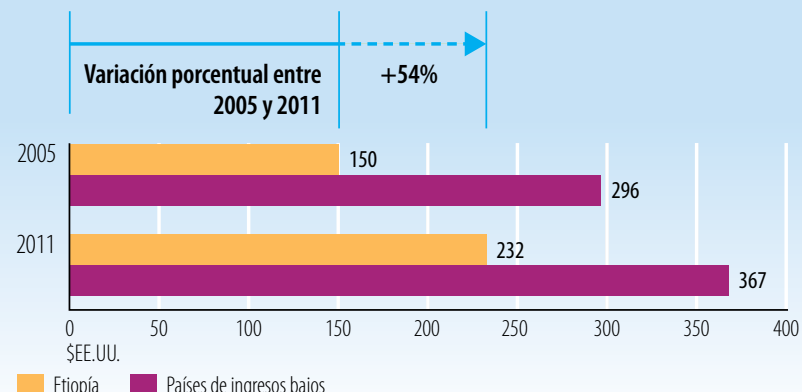

Etiopía Países de ingresos bajos

Fuentes: Banco Mundial, Indicadores del Desarrollo Mundial.

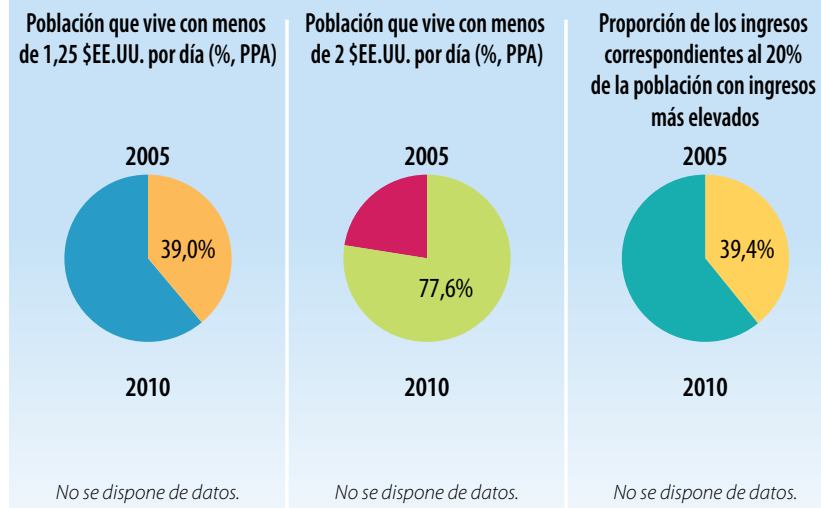

Fuentes: Banco Mundial, Indicadores del Desarrollo Mundial.

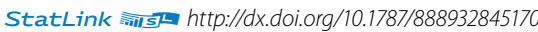




\section{Indicadores de la ayuda, el comercio y el desarrollo relativos a Fiji}

\begin{tabular}{|c|c|c|c|c|}
\hline \multicolumn{5}{|c|}{ INVERSIÓN Y FINANCIACIÓN (APORTES) } \\
\hline Indicador (millones de \$EE.UU. corrientes) & 2005 & 2008 & 2010 & $\Delta: 05-10(\%)$ \\
\hline Formación bruta de capital fijo & 630,3 & 743,8 & n.d. & n.d. \\
\hline del cual: público & 93,4 & 94,1 & n.d. & n.d. \\
\hline del cual: privado & 536,9 & 649,7 & n.d. & n.d. \\
\hline \multicolumn{5}{|l|}{ Entrada de financiación externa } \\
\hline Entradas de IED & 155,7 & 309,4 & 196,2 & $26 \%$ \\
\hline $\begin{array}{l}\text { Deuda externa a largo plazo y fondos } \\
\text { desembolsados por el FMl }\end{array}$ & 14,1 & 13,4 & 32,6 & $131 \%$ \\
\hline $\begin{array}{l}\text { Corrientes comerciales en condiciones no } \\
\text { concesionarias }\end{array}$ & 0,0 & 0,0 & 7,4 & d.p.c. \\
\hline Corrientes de Ayuda para el Comercio & 11,3 & 7,3 & 9,6 & $-15 \%$ \\
\hline $\begin{array}{l}\text { Remesas de trabajadores y remuneración } \\
\text { de empleados }\end{array}$ & 185,1 & 123,4 & 183,3 & $-1 \%$ \\
\hline
\end{tabular}

Fuentes: OCDE, base de datos del SNPA del CAD sobre las actividades de ayuda; Banco Mundial, Indicadores del Desarrollo Mundial; Banco Mundial, estadísticas de la deuda internacional.

Desembolsos de la ayuda para el comercio, por sector (millones de \$EE.UU. corrientes)

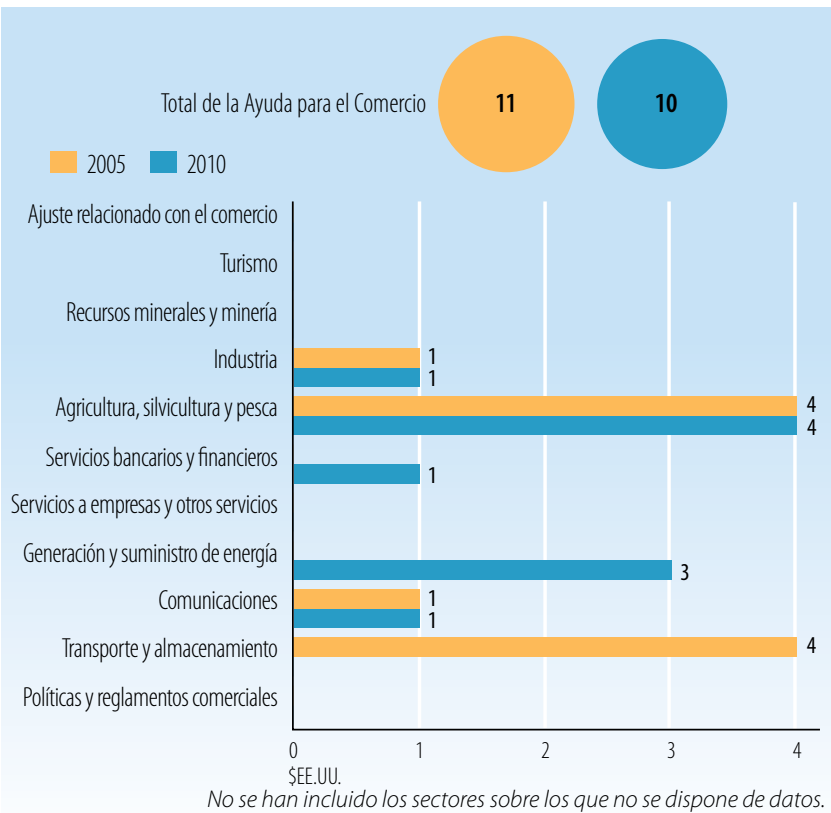

Fuentes: OCDE, base de datos del SNPA del CAD sobre las actividades de ayuda

Desembolsos de la ayuda para el comercio: principales donantes (millones de \$̦E.UU. corrientes)

\begin{tabular}{|c|c|c|c|}
\hline 2005 & Valor & $\%$ & \multirow[t]{6}{*}{ Principales donantes en 2005} \\
\hline Japón & 6,6 & 58 & \\
\hline Instituciones de la UE & 3,8 & 34 & \\
\hline Australia & 0,7 & 6 & \\
\hline Nueva Zelandia & 0,2 & 1 & \\
\hline PNUD & 0,1 & 0 & \\
\hline 2010 & Valor & $\%$ & \multirow{6}{*}{ Principales donantes en 2010} \\
\hline Japón & 3,2 & 33 & \\
\hline Australia & 3,1 & 32 & \\
\hline Corea, Rep. de & 1,7 & 18 & \\
\hline Turquía & 0,5 & 5 & \\
\hline Instituciones de la UE & 0,5 & 5 & \\
\hline
\end{tabular}

Fuentes: OCDE, base de datos del SNPA del CAD sobre las actividades de ayuda.

\begin{tabular}{|c|c|c|c|c|}
\hline Indicador & 2005 & 2008 & 2011 & $\Delta: 05-11(\%)$ \\
\hline Relación comercio/PIB (\%) & 115 & 125 & 75 & -41 \\
\hline $\begin{array}{l}\text { Exportaciones de servicios comerciales como } \\
\text { \% de las exportaciones totales }\end{array}$ & 55 & 52 & n.d. & n.d. \\
\hline $\begin{array}{l}\text { Importaciones de servicios comerciales como } \\
\text { \% de las importaciones totales }\end{array}$ & 26 & 22 & n.d. & n.d. \\
\hline $\begin{array}{l}\text { Productos intermedios distintos de los combustibles } \\
\text { (\% de las exportaciones de mercancías) }\end{array}$ & 38 & 35 & n.d. & n.d. \\
\hline $\begin{array}{l}\text { Productos intermedios distintos de los combustibles } \\
\text { (\% de las importaciones de mercancías) }\end{array}$ & 34 & 33 & n.d. & n.d. \\
\hline
\end{tabular}
Fuentes: Secretaría de la OMC.

Corrientes comerciales (millones de \$EE.UU. corrientes)

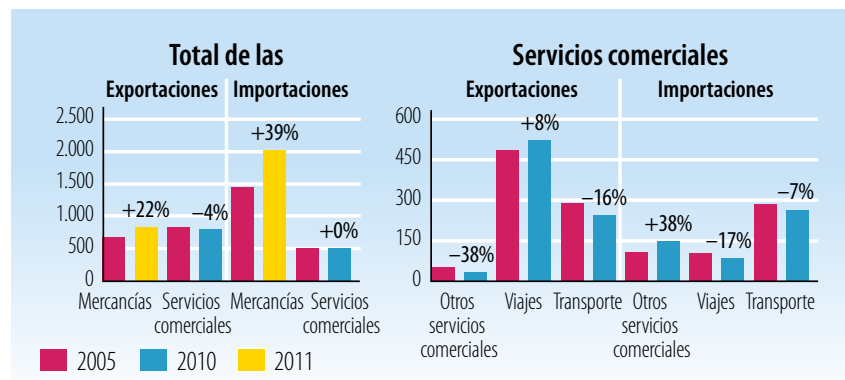

Fuentes: Secretaría de la OMC

Cinco principales mercados de exportación de mercancías (\%)

\begin{tabular}{|l|c|l|c|}
\hline 2005 & $\%$ & 2010 & $\%$ \\
\hline Australia & 20 & Australia & 21 \\
\hline Singapur & 20 & Estados Unidos & 11 \\
\hline UE (27) & 16 & Japón & 8 \\
\hline Estados Unidos & 15 & Nueva Zelandia & 6 \\
\hline Japón & 6 & UE (27) & 5 \\
\hline
\end{tabular}

Fuentes: Secretaría de la OMC

Cinco principales productos de exportación (\% de las exportaciones de mercancías)

\begin{tabular}{|l|c|l|l|}
\hline $\mathbf{2 0 0 5}$ & $\%$ & $\mathbf{2 0 1 0}$ & $\%$ \\
\hline Productos derivados del petróleo & 23 & Productos derivados del petróleo & 25 \\
\hline Azúcares, melaza y miel & 19 & Pescado, fresco, refrigerado o congelado & 13 \\
\hline Bebidas no alcohólicas, n.e.p. & 8 & Oro no monetario, excepto minerales & 9 \\
\hline Pescado, fresco, refrigerado o congelado & 6 & Bebidas no alcohólicas, n.e.p. & 8 \\
\hline Oro no monetario, excepto minerales & 5 & Azúcares, melaza y miel & 6 \\
\hline
\end{tabular}
Fuentes: Secretaría de la OMC

Cinco principales mercados de importación de mercancías (\%)

\begin{tabular}{|l|r|l|l|}
\hline 2005 & $\%$ & 2010 & $\%$ \\
\hline Singapur & 30 & Singapur & 33 \\
\hline Australia & 25 & Australia & 20 \\
\hline Nueva Zelandia & 18 & Nueva Zelandia & 16 \\
\hline Japón & 4 & China & 6 \\
\hline Estados Unidos & 4 & Estados Unidos & 4 \\
\hline
\end{tabular}

Cinco principales productos de importación (\% de las importaciones de mercancías)

\begin{tabular}{|c|c|c|c|}
\hline 2005 & $\%$ & 2010 & $\%$ \\
\hline Productos derivados del petróleo & 28 & Productos derivados del petróleo & 30 \\
\hline $\begin{array}{l}\text { Vehículos automotores para el transporte } \\
\text { de mercancías y vehícul os automotores } \\
\text { para usos especiales }\end{array}$ & 2 & Trigo y morcajo o tranquillón, sin moler & 3 \\
\hline Artículos, n.e.p., de materiales plásticos & 2 & Pescado, fresco, refrigerado o congelado & 2 \\
\hline $\begin{array}{l}\text { Equipos de telecomunicaciones y sus } \\
\text { partes, n.e.p. }\end{array}$ & 2 & $\begin{array}{l}\text { Equipos de telecomunicaciones y sus } \\
\text { partes, n.e.p. }\end{array}$ & 2 \\
\hline Trigo y morcajo o tranquillón, sin moler & 2 & Aeronaves y equipo conexo & 2 \\
\hline
\end{tabular}




\section{LA AYUDA PARA EL COMERCIO EN SIINTESIS 2013}

\section{INDICADORES COMERCIALES (RESULTADOS)}

Indicador

Crecimiento del PIB (\%)

Número de exportadores

Índice de concentración de las exportaciones (productos) (0 a 1)

ACR sobre mercancías notificados a la OMC

AIE (servicios) notificados a la OMC

Sectores de servicios con compromisos en el marco del AGCS

\section{Aranceles (\%, 2006 et 2011)}

Importaciones: promedio aritmético de los aranceles NMF aplicados $\quad 10,2 \quad 12,0$

Importaciones: promedio ponderado de los aranceles NMF aplicados n.d. 13,9

\begin{tabular}{|l|l|l|l|l|}
\hline Exportaciones: promedio ponderado de los aranceles impuestos & 1,7 & 0,6
\end{tabular}

por los importadores

Exportaciones: libres de derechos (en \%)

77,9

Fuentes: Naciones Unidas, base de datos Comtrade; Banco Mundial, base de datos sobre dinámica de las empresas de exportación; Banco Mundial, Indicadores del Desarrollo Mundial; OMC, perfiles comerciales y arancelarios.

Participación en las exportaciones por región (\%)

\begin{tabular}{|l|r|r|}
\hline & 2005 & 2010 \\
\hline África & 0,1 & 0,7 \\
\hline Asia & 66,8 & 61,7 \\
\hline Comunidad de Estados Independientes & 0,0 & 0,0 \\
\hline Europa & 15,9 & 5,7 \\
\hline Oriente Medio & 0,0 & 0,2 \\
\hline América del Norte & 15,5 & 11,6 \\
\hline América del Sury América Central & 0,2 & 2,9 \\
\hline
\end{tabular}

Fuentes: OMC, perfiles comerciales y arancelarios

Indicadores de facilitación del comercio
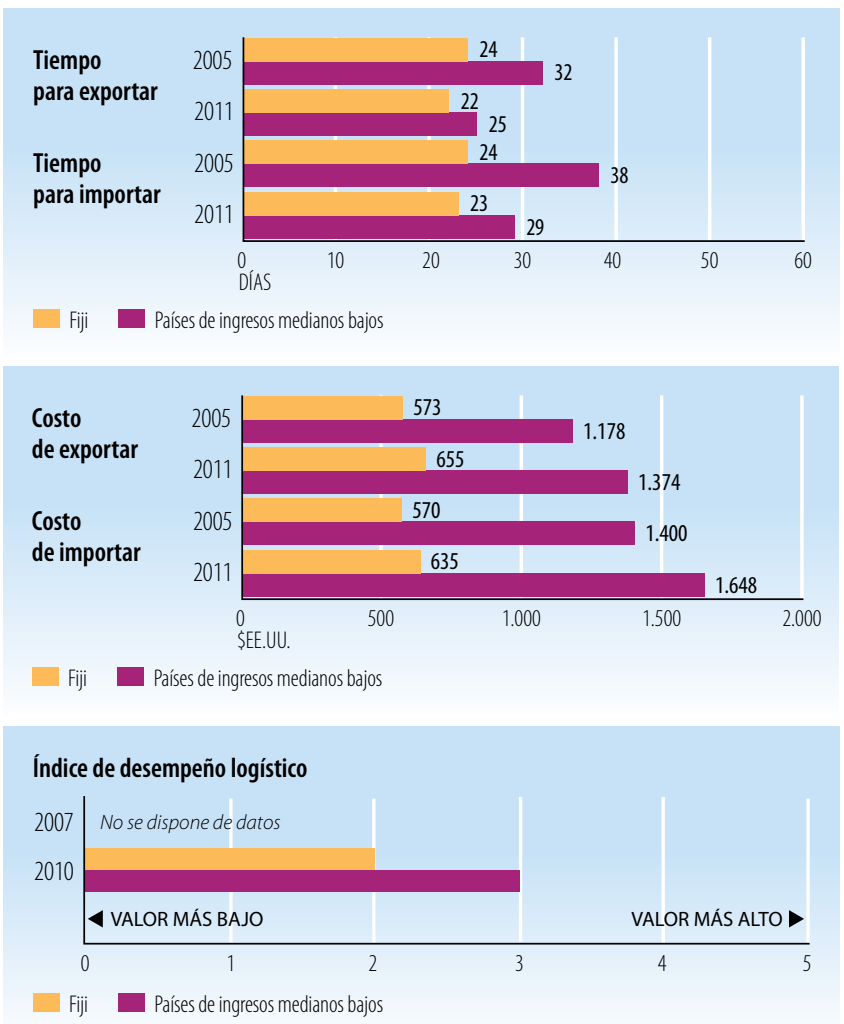

Fuentes: Banco Mundial, Indicadores del Desarrollo Mundial.

\begin{tabular}{|l|c|c|}
\hline INDICADORES DE DESARROLLO (EFECTOS) & \\
\hline Indicador & $\mathbf{2 0 0 5}$ & $\mathbf{2 0 1 0}$ \\
\hline Desempleo (\% de la fuerza de trabajo total) & 4,6 & n.d. \\
\hline Población activa, mujeres (\% de la fuerza de trabajo total) & 32,6 & 32,4 \\
\hline A0D neta recibida (\% del InB) & 2,2 & 2,5 \\
\hline Derechos de importación percibidos (\% de los ingresos fiscales) & 19,2 & n.d. \\
\hline Total del servicio de la deuda (\% de las exportaciones totales) & 0,9 & 1,8 \\
\hline Índice de desarrollo humano (0 a 1) & 0,68 & 0,69 \\
\hline
\end{tabular}

Fuentes: PNUD, indicadores internacionales sobre desarrollo humano; Banco Mundial, Indicadores del Desarrollo Mundial.

Producto interno bruto

PIB per cápita (PPA, dólares internacionales corrientes)

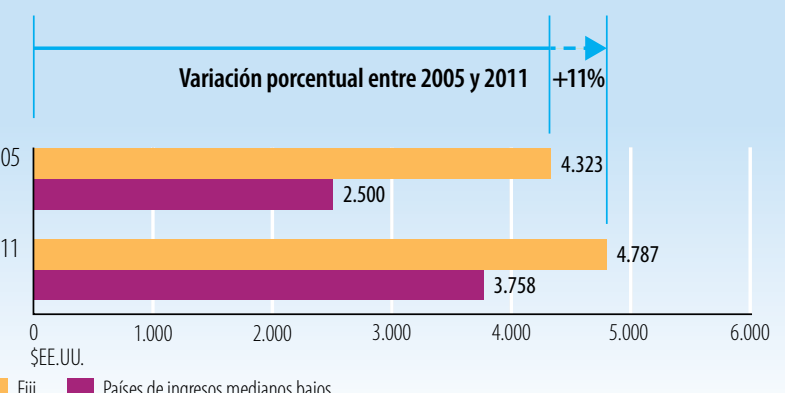

Fiji Países de ingresos medianos bajos

PIB per cápita (\$EE.UU. constantes de 2000)
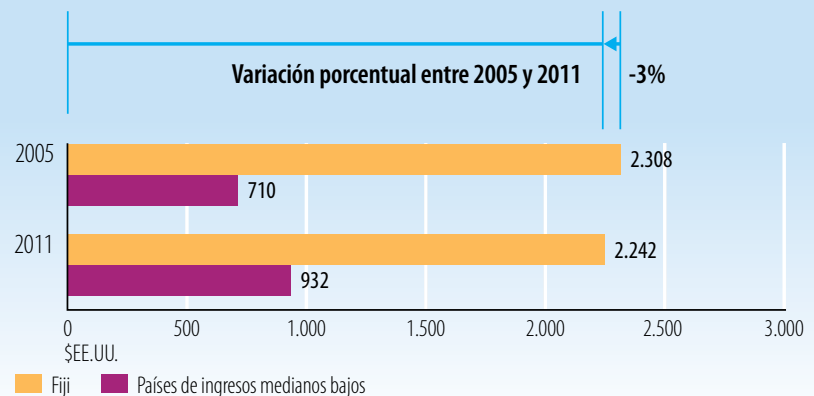

Fuentes: Banco Mundial, Indicadores del Desarrollo Mundial.

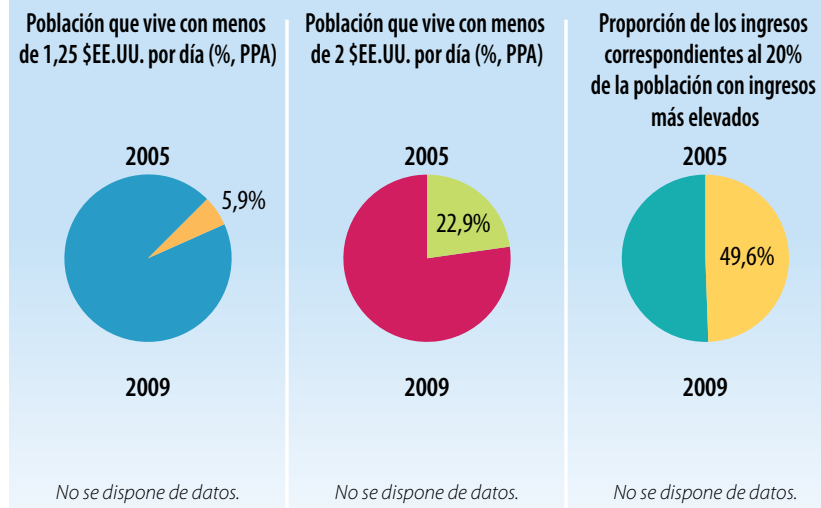

Fuentes: Banco Mundial, Indicadores del Desarrollo Mundial.

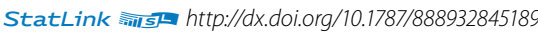




\section{Indicadores de la ayuda, el comercio y el desarrollo relativos al Gabón}

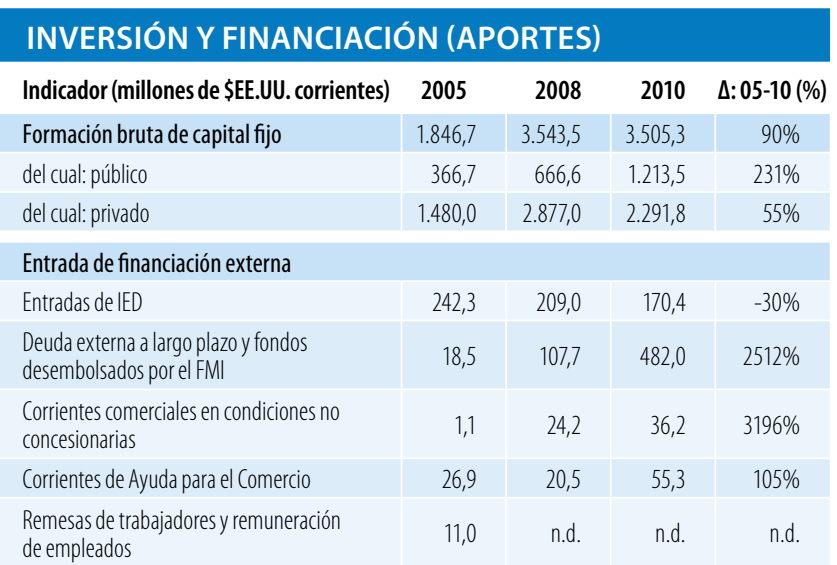

Fuentes: OCDE, base de datos del SNPA del CAD sobre las actividades de ayuda; Banco Mundial, Indicadores del Desarrollo Mundial; Banco Mundial, estadísticas de la deuda internacional.

Desembolsos de la ayuda para el comercio, por sector (millones de \$EE.UU. corrientes)

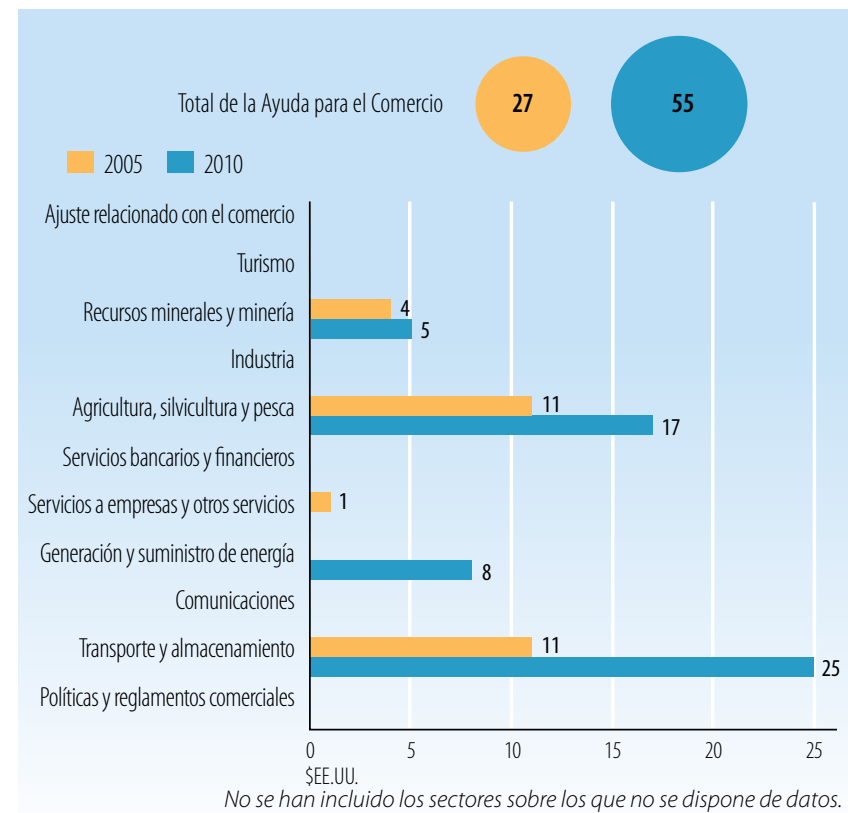

Fuentes: OCDE, base de datos del SNPA del CAD sobre las actividades de ayuda

Desembolsos de la ayuda para el comercio: principales donantes (millones de \$̦E.UU. corrientes)

\begin{tabular}{|l|r|r|r|}
\hline $\mathbf{2 0 0 5}$ & Valor & $\%$ & Principales donantes en 2005 \\
\hline Instituciones de la UE & 12,8 & 48 & \\
\hline Francia & 7,8 & 29 & \multirow{2}{*}{$\mathbf{1 0 0 \%}$} \\
\hline Japón & 6,2 & 23 & \\
\hline PNUD & 0,1 & 0 & \\
\hline Alemania & 0,0 & 0 & \\
\hline $\mathbf{2 0 1 0}$ & Valor & $\%$ & Principales donantes en 2010 \\
\hline Japón & 23,9 & 43 & \\
\hline Francia & 22,6 & 41 & \\
\hline Instituciones de la UE & 7,9 & 14 & $100 \%$ \\
\hline Kuwait & 0,5 & 1 & \\
\hline Estados Unidos & 0,2 & 0 & \\
\hline
\end{tabular}

Fuentes: OCDE, base de datos del SNPA del CAD sobre las actividades de ayuda.

\section{INDICADORES COMERCIALES (PRODUCTOS)}

Indicador $2005 \quad 20082011 \quad \Delta: 05-11(\%)$

Relación comercio/PIB (\%)

\begin{tabular}{l|l|l|l|}
92 & 92 & 95 & 3
\end{tabular}

Exportaciones de servicios comerciales como

$\%$ de las exportaciones totales

Importaciones de servicios comerciales como

$\%$ de las importaciones totales

Productos intermedios distintos de los combustibles

(\% de las exportaciones de mercancías)

Productos intermedios distintos de los combustibles

(\% de las importaciones de mercancías)

$2 \quad 2 \quad$ n.d. n.d.

\begin{tabular}{l|l|l|l|}
\hline 43 & 43 & n.d. & n.d.
\end{tabular}

\begin{tabular}{l|l|l|l|}
14 & 10 & n.d.
\end{tabular}

46
$43 \quad$ n.d.

Fuentes: Secretaría de la OMC.

Corrientes comerciales (millones de \$EE.UU. corrientes)

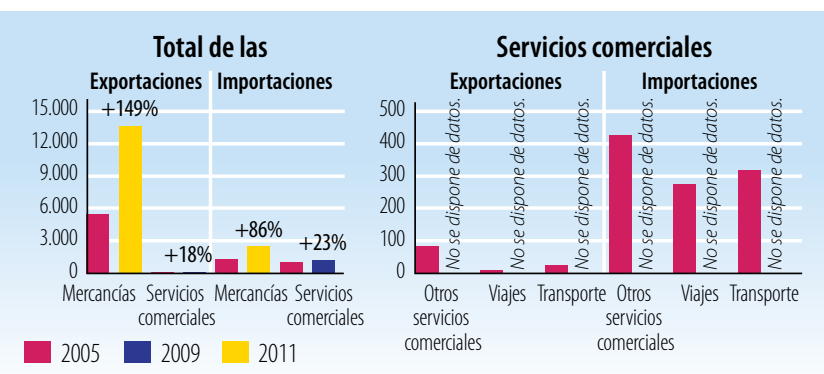

Fuentes: Secretaría de la OMC

Cinco principales mercados de exportación de mercancías (\%)

\begin{tabular}{|l|r|l|c|}
\hline 2005 & $\%$ & 2009 & $\%$ \\
\hline Estados Unidos & 66 & Estados Unidos & 59 \\
\hline UE (27) & 10 & UE (27) & 18 \\
\hline Suiza & 5 & China & 8 \\
\hline China & 4 & Malasia & 4 \\
\hline India & 2 & Corea, Rep. de & 2 \\
\hline
\end{tabular}

Fuentes: Secretaría de la OMC

Cinco principales productos de exportación (\% de las exportaciones de mercancías)

\begin{tabular}{|c|c|c|c|}
\hline 2005 & $\%$ & 2009 & $\%$ \\
\hline Aceites de petróleo, crudos & 83 & Aceites de petróleo, crudos & 81 \\
\hline $\begin{array}{l}\text { Madera en bruto o simplemente } \\
\text { escuadrada }\end{array}$ & 6 & $\begin{array}{l}\text { Madera en bruto o simplemente } \\
\text { escuadrada }\end{array}$ & 7 \\
\hline $\begin{array}{l}\text { Minerales de metales comunes y sus } \\
\text { concentrados }\end{array}$ & 4 & $\begin{array}{l}\text { Minerales de metales comunes y sus } \\
\text { concentrados }\end{array}$ & 3 \\
\hline $\begin{array}{l}\text { Hojas de madera para enchapado, } \\
\text { madera terciada, etc. }\end{array}$ & 2 & $\begin{array}{l}\text { Hojas de madera para enchapado, } \\
\text { madera terciada, etc. }\end{array}$ & 2 \\
\hline Productos derivados del petróleo & 1 & Productos derivados del petróleo & 2 \\
\hline
\end{tabular}

Cinco principales mercados de importación de mercancías (\%)

\begin{tabular}{|l|r|l|r|}
\hline 2005 & $\%$ & 2009 & $\%$ \\
\hline UE (27) & 65 & UE (27) & 65 \\
\hline Estados Unidos & 6 & Estados Unidos & 7 \\
\hline Camerún & 4 & China & 5 \\
\hline Japón & 3 & Japón & 2 \\
\hline Brasil & 2 & Camerún & 2 \\
\hline Fuentes:Secretaría de la OMC & & & \\
\hline
\end{tabular}

Cinco principales productos de importación (\% de las importaciones de mercancías)

\begin{tabular}{|c|c|c|c|}
\hline 2005 & $\%$ & 2009 & $\%$ \\
\hline Tubos, caños, etc., de hierro o acero & 5 & Tubos, caños, etc., de hierro 0 acero & 7 \\
\hline $\begin{array}{l}\text { Vehículos automotores para pasajeros, } \\
\text { excepto autobuses }\end{array}$ & 4 & Productos derivados del petróleo & 6 \\
\hline Equipo de ingeniería civil & 3 & Estructuras metálicas, n.e.p. & 4 \\
\hline Otras carnes y despojos de carnes & 3 & Equipo de ingeniería civil & 4 \\
\hline Medicamentos & 3 & $\begin{array}{l}\text { Vehículos automotores para pasajeros, } \\
\text { excepto autobuses }\end{array}$ & \\
\hline
\end{tabular}

Fuentes: Secretaría de la OMC 


\section{LA AYUDA PARA EL COMERCIO EN SÍNTESIS 2013}

\section{INDICADORES COMERCIALES (RESULTADOS)}

\section{Indicador}

Crecimiento del PIB (\%)

Número de exportadores

Índice de concentración de las exportaciones (productos) (0 a 1)

ACR sobre mercancías notificados a la OMC

AIE (servicios) notificados a la OMC

Sectores de servicios con compromisos en el marco del AGCS

\section{Aranceles (\%)}

\begin{tabular}{l|l|l|l|} 
Importaciones: promedio aritmético de los aranceles NMF aplicados & 18,0 & 17,8
\end{tabular}

Importaciones: promedio ponderado de los aranceles NMF aplicados $\quad 16,9 \quad$ n.d.

Exportaciones: promedio ponderado de los aranceles impuestos

por los importadores

Exportaciones: libres de derechos (en \%)

$0,0 \quad 0,5$

$99,9 \quad 91,0$

Fuentes: Naciones Unidas, base de datos Comtrade; Banco Mundial, base de datos sobre dinámica de las empresas de exportación; Banco Mundial, Indicadores del Desarrollo Mundial; OMC, perfiles comerciales y arancelarios.

Participación en las exportaciones por región (\%)

\begin{tabular}{|l|r|r|}
\hline África & $\mathbf{2 0 0 5}$ & $\mathbf{2 0 0 9}$ \\
\hline Asia & 4,7 & 5,4 \\
\hline Comunidad de Estados Independientes & 10,8 & 15,7 \\
\hline Europa & 0,7 & 0,1 \\
\hline Oriente Medio & 16,2 & 19,6 \\
\hline América del Norte & 0,0 & 0,2 \\
\hline América del Sury América Central & 66,5 & 59,0 \\
\hline
\end{tabular}

Fuentes: OMC, perfiles comerciales y arancelarios

Indicadores de facilitación del comercio
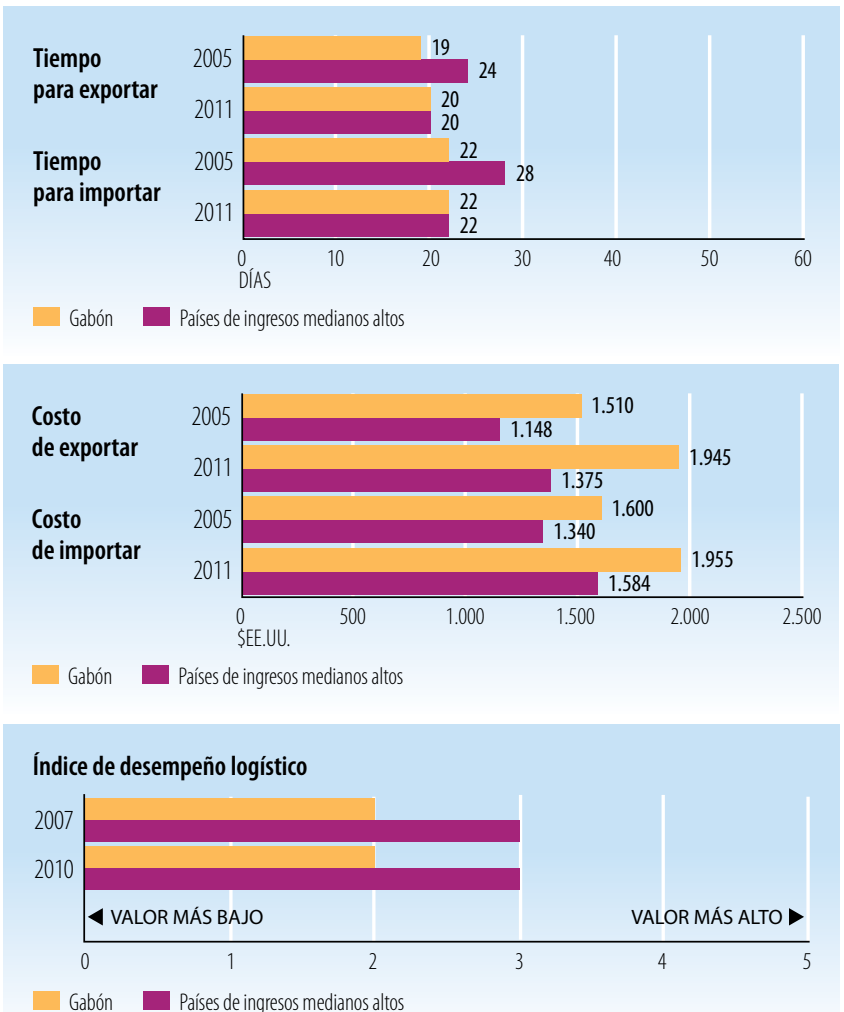

Fuentes: Banco Mundial, Indicadores del Desarrollo Mundial.

\begin{tabular}{l|c|c|}
\hline INDICADORES DE DESARROLLO (EFECTOS) \\
\hline Indicador & 2005 & $\mathbf{2 0 1 0}$ \\
\hline Desempleo (\% de la fuerza de trabajo total) & n.d. & n.d. \\
\hline Población activa, mujeres (\% de la fuerza de trabajo total) & 46,2 & 46,3 \\
\hline AOD neta recibida (\% del INB) & 0,8 & 0,9 \\
\hline Derechos de importación percibidos (\% de los ingresos fiscales) & n.d. & n.d. \\
\hline Total del servicio de la deuda (\% de las exportaciones totales) & 3,4 & n.d. \\
\hline Índice de desarrollo humano (0 a 1) & 0,65 & 0,67 \\
\hline
\end{tabular}

Fuentes: PNUD, indicadores internacionales sobre desarrollo humano; Banco Mundial, Indicadores del Desarrollo Mundial.

Producto interno bruto

PIB per cápita (PPA, dólares internacionales corrientes)

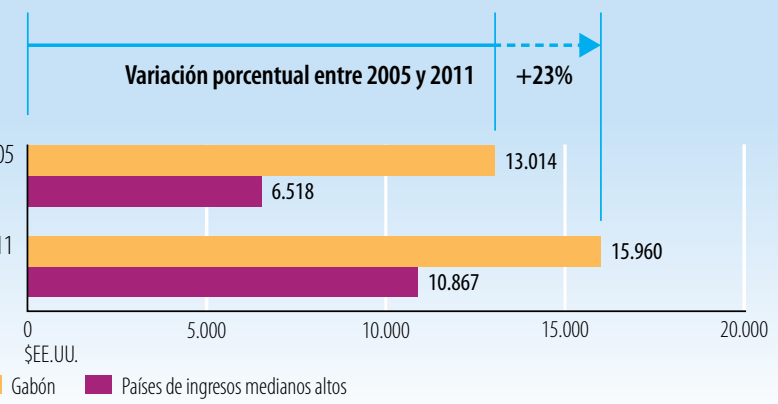

PIB per cápita (\$EE.UU. constantes de 2000)
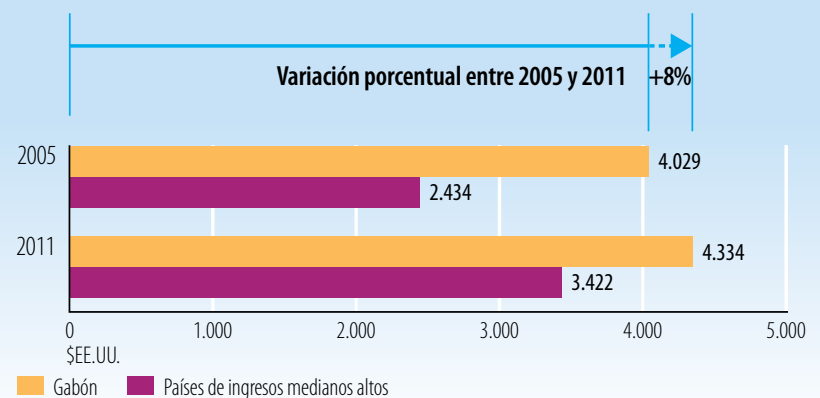

Fuentes: Banco Mundial, Indicadores del Desarrollo Mundial.

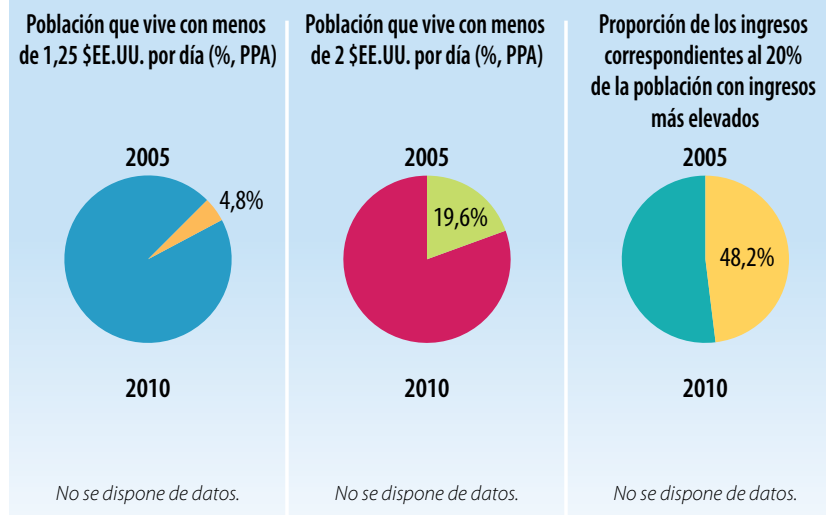

Fuentes: Banco Mundial, Indicadores del Desarrollo Mundial.

StatLink ㅊiा st $h$ ttp://dx.doi.org/10.1787/888932845208 


\section{Indicadores de la ayuda, el comercio y el desarrollo relativos a Gambia}

\begin{tabular}{|c|c|c|c|c|}
\hline Indicador (millones de \$̦EE.UU. corrientes) & 2005 & 2008 & 2010 & $\Delta: 05-10(\%)$ \\
\hline Formación bruta de capital fijo & 137,2 & 145,0 & 203,9 & $49 \%$ \\
\hline del cual: público & 50,7 & 38,6 & 85,9 & $69 \%$ \\
\hline del cual: privado & 86,5 & 106,4 & 118,0 & $36 \%$ \\
\hline \multicolumn{5}{|l|}{ Entrada de financiación externa } \\
\hline Entradas de IED & 53,7 & 78,6 & 37,4 & $-30 \%$ \\
\hline $\begin{array}{l}\text { Deuda externa a largo plazo y fondos } \\
\text { desembolsados por el FMI }\end{array}$ & 54,3 & 43,6 & 46,9 & $-14 \%$ \\
\hline $\begin{array}{l}\text { Corrientes comerciales en condiciones no } \\
\text { concesionarias }\end{array}$ & 0,0 & 0,0 & 0,0 & $0 \%$ \\
\hline Corrientes de Ayuda para el Comercio & 16,1 & 16,7 & 33,6 & $109 \%$ \\
\hline $\begin{array}{l}\text { Remesas de trabajadores y remuneración } \\
\text { de empleados }\end{array}$ & 59,3 & 64,8 & 115,7 & $95 \%$ \\
\hline
\end{tabular}

Fuentes: OCDE, base de datos del SNPA del CAD sobre las actividades de ayuda; Banco Mundial, Indicadores del Desarrollo Mundial; Banco Mundial, estadísticas de la deuda internacional.

Desembolsos de la ayuda para el comercio, por sector (millones de \$EE.UU. corrientes)

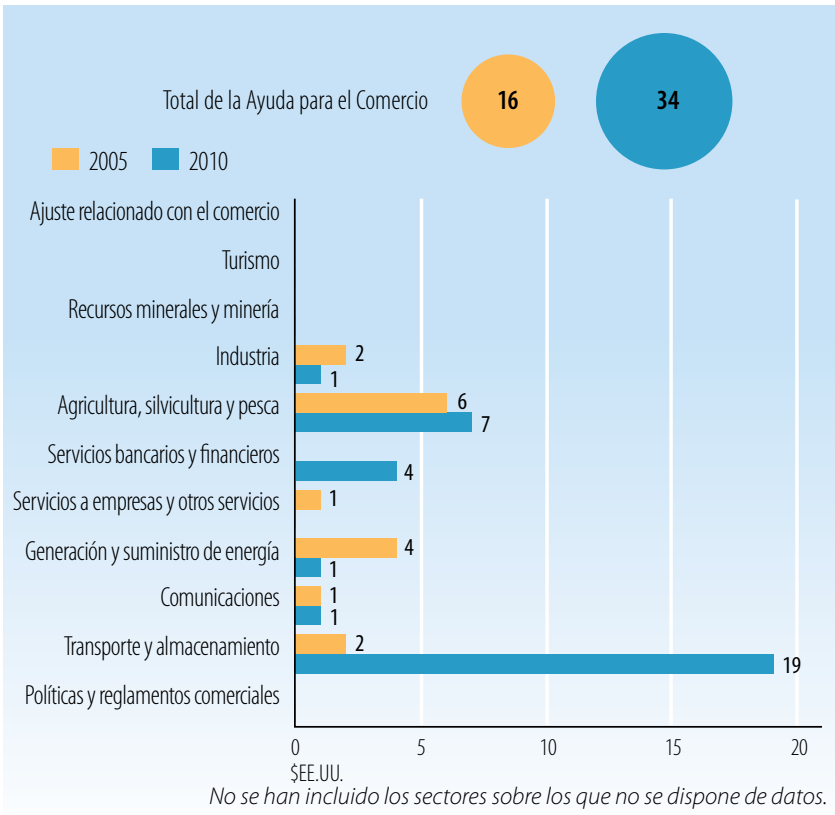

Fuentes: OCDE, base de datos del SNPA del CAD sobre las actividades de ayuda

Desembolsos de la ayuda para el comercio: principales donantes (millones de \$EE.UU. corrientes)

\begin{tabular}{|l|r|r|r|}
\hline $\mathbf{2 0 0 5}$ & Valor & $\%$ & Principales donantes en 2005 \\
\hline Banco Africano de Desarrollo & 7,2 & 44 & \\
\hline Banco Mundial & 4,3 & 27 & \\
\hline Japón & 1,6 & 10 & $93 \%$ \\
\hline Alemania & 1,2 & 7 & \\
\hline Estados Unidos & 0,7 & 4 & \\
\hline $\mathbf{2 0 1 0}$ & Valor & $\%$ & Principales donantes en 2010 \\
\hline Instituciones de la UE & 17,3 & 52 & \\
\hline Banco Mundial & 6,4 & 19 & \\
\hline Banco Africano de Desarrollo & 4,4 & 13 & \\
\hline Kuwait & 2,8 & 8 & $95 \%$ \\
\hline Japón & 1,0 & 3 & \\
\hline
\end{tabular}

Fuentes: OCDE, base de datos del SNPA del CAD sobre las actividades de ayuda.

\section{INDICADORES COMERCIALES (PRODUCTOS)}

\section{Indicador}

$20052008 \quad 2011 \quad \Delta: 05-11(\%)$

Relación comercio/PIB (\%)

Exportaciones de servicios comerciales como

$\%$ de las exportaciones totales

Importaciones de servicios comerciales como

$\%$ de las importaciones totales

Productos intermedios distintos de los combustibles

(\% de las exportaciones de mercancías)

Productos intermedios distintos de los combustibles

(\% de las importaciones de mercancías)

\begin{tabular}{l|l|l|r|}
72 & 66 & 61 & -11 \\
\hline
\end{tabular}

Fuentes: Secretaría de la OMC.

Corrientes comerciales (millones de \$EE.UU. corrientes)

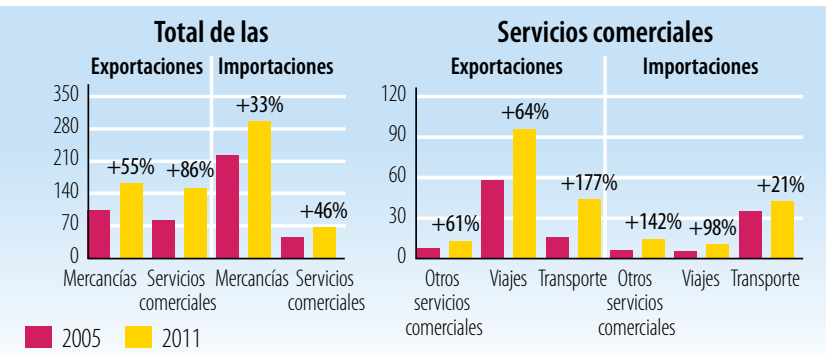

Fuentes: Secretaría de la OMC

\section{Cinco principales mercados de exportación de mercancías (\%)}

\begin{tabular}{|l|r|l|c|}
\hline 2005 & $\%$ & 2010 & $\%$ \\
\hline Guinea & 45 & UE (27) & 50 \\
\hline UE (27) & 35 & Senegal & 16 \\
\hline Senegal & 9 & India & 8 \\
\hline Mauritania & 3 & Hong Kong, China & 8 \\
\hline Estados Unidos & 1 & Guinea & 6 \\
\hline
\end{tabular}

Fuentes: Secretaría de la OMC

Cinco principales productos de exportación (\% de las exportaciones de mercancías)

\begin{tabular}{|l|r|l|r|}
\hline 2005 & $\%$ & 2011 & $\%$ \\
\hline Bebidas no alcohólicas, n.e.p. & 44 & Tejidos de fibras manufacturadas & 44 \\
\hline Legumbres & 10 & Ropa vieja y otros artículos textiles viejos & 5 \\
\hline Crustáceos, moluscos, etc. & 9 & Artículos, n.e.p., de materiales plásticos & 4 \\
\hline Pescado, fresco, refrigerado o congelado & 6 & Leche y crema & 4 \\
\hline $\begin{array}{l}\text { Maquinaria textil y para trabajar cueros } \\
\text { Fentes: Secretaría de la OMC }\end{array}$ & 5 & Azúcares, melaza y miel & 3 \\
\hline
\end{tabular}

Cinco principales mercados de importación de mercancías (\%)

\begin{tabular}{|l|c|l|c|}
\hline 2005 & $\%$ & 2010 & $\%$ \\
\hline UE $(27)$ & 45 & UE $(27)$ & 30 \\
\hline Côte d'Ivoire & 13 & Côte d'Ivoire & 20 \\
\hline China & 9 & Brasil & 13 \\
\hline Estados Unidos & 6 & China & 7 \\
\hline India & 5 & India & 3 \\
\hline
\end{tabular}

Fuentes: Secretaría de la OMC

Cinco principales productos de importación (\% de las importaciones de mercancías)

\begin{tabular}{|c|c|c|c|}
\hline 2005 & $\%$ & 2011 & $\%$ \\
\hline Productos derivados del petróleo & 16 & Productos derivados del petróleo & 22 \\
\hline $\begin{array}{l}\text { Vehículos automotores para pasajeros, } \\
\text { excepto autobuses }\end{array}$ & 9 & Arroz & 9 \\
\hline Arroz & 9 & $\begin{array}{l}\text { Otros aceites y grasas fijos de origen } \\
\text { vegetal }\end{array}$ & 5 \\
\hline Azúcares, melaza y miel & 6 & $\begin{array}{l}\text { Vehículos automotores para pasajeros, } \\
\text { excepto autobuses }\end{array}$ & 5 \\
\hline $\begin{array}{l}\text { Otros aceites y grasas fijos de origen } \\
\text { vegetal }\end{array}$ & 6 & Azúcares, melaza y miel & 4 \\
\hline
\end{tabular}




\section{LA AYUDA PARA EL COMERCIO EN SINNTESIS 2013}

\section{INDICADORES COMERCIALES (RESULTADOS)}

Indicador

Crecimiento del PIB (\%)

Número de exportadores

Índice de concentración de las exportaciones (productos) (0a 1)

ACR sobre mercancías notificados a la OMC

AIE (servicios) notificados a la OMC

Sectores de servicios con compromisos en el marco del AGCS

\section{Aranceles (\%)}

\begin{tabular}{l|l|l|l|} 
Importaciones: promedio aritmético de los aranceles NMF aplicados & n.d. & 14,1
\end{tabular}

Importaciones: promedio ponderado de los aranceles NMF aplicados n.d. $\quad 12,9$

$\begin{array}{ll}\text { Exportaciones: promedio ponderado de los aranceles impuestos } & \text { n.d. }\end{array}$

por los importadores

Exportaciones: libres de derechos (en \%)

n.d. $\quad 94,7$

Fuentes: Naciones Unidas, base de datos Comtrade; Banco Mundial, base de datos sobre dinámica de las empresas de exportación; Banco Mundial, Indicadores del

Desarrollo Mundial; OMC, perfiles comerciales y arancelarios.

Participación en las exportaciones por región (\%)

\begin{tabular}{|l|r|r|}
\hline & $\mathbf{2 0 0 5}$ & $\mathbf{2 0 1 1}$ \\
\hline África & 59,0 & 87,2 \\
\hline Asia & 4,4 & 6,5 \\
\hline Comunidad de Estados Independientes & 0,0 & 0,0 \\
\hline Europa & 34,9 & 5,6 \\
\hline Oriente Medio & 0,4 & 0,2 \\
\hline América del Norte & 1,4 & 0,1 \\
\hline América del Sury América Central & 0,0 & 0,4 \\
\hline
\end{tabular}

Fuentes: OMC, perfiles comerciales y arancelarios

Indicadores de facilitación del comercio
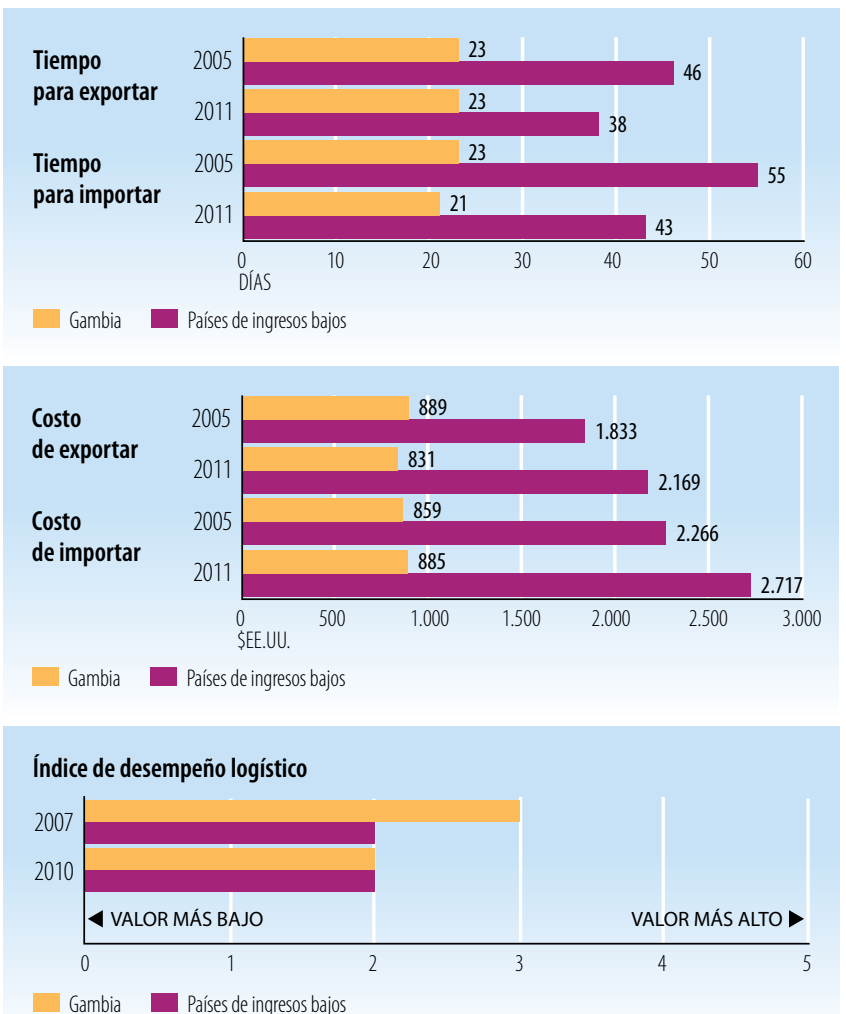

Fuentes: Banco Mundial, Indicadores del Desarrollo Mundial.

\begin{tabular}{|l|c|c|}
\hline INDICADORES DE DESARROLLO (EFECTOS) & \\
\hline Indicador & $\mathbf{2 0 0 5}$ & $\mathbf{2 0 1 0}$ \\
\hline Desempleo (\% de la fuerza de trabajo total) & n.d. & n.d. \\
\hline Población activa, mujeres (\% de la fuerza de trabajo total) & 47,6 & 47,9 \\
\hline A0D neta recibida (\% del InB) & 10,2 & 11,9 \\
\hline Derechos de importación percibidos (\% de los ingresos fiscales) & n.d. & n.d. \\
\hline Total del servicio de la deuda (\% de las exportaciones totales) & 15,0 & 7,2 \\
\hline Índice de desarrollo humano (0 a 1) & 0,38 & 0,42 \\
\hline
\end{tabular}

Fuentes: PNUD, indicadores internacionales sobre desarrollo humano; Banco Mundial, Indicadores del Desarrollo Mundial.

Producto interno bruto

PIB per cápita (PPA, dólares internacionales corrientes)
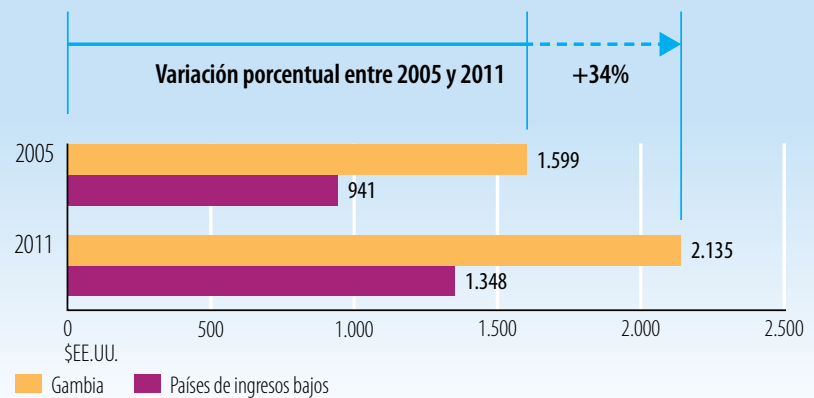

PIB per cápita (\$EE.UU. constantes de 2000)
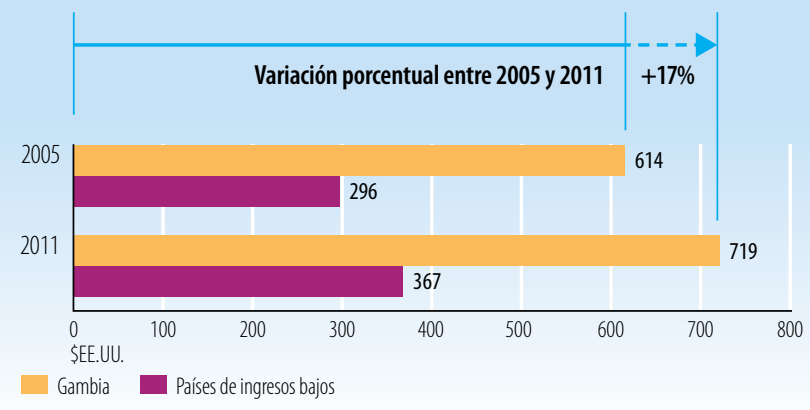

Fuentes: Banco Mundial, Indicadores del Desarrollo Mundial.

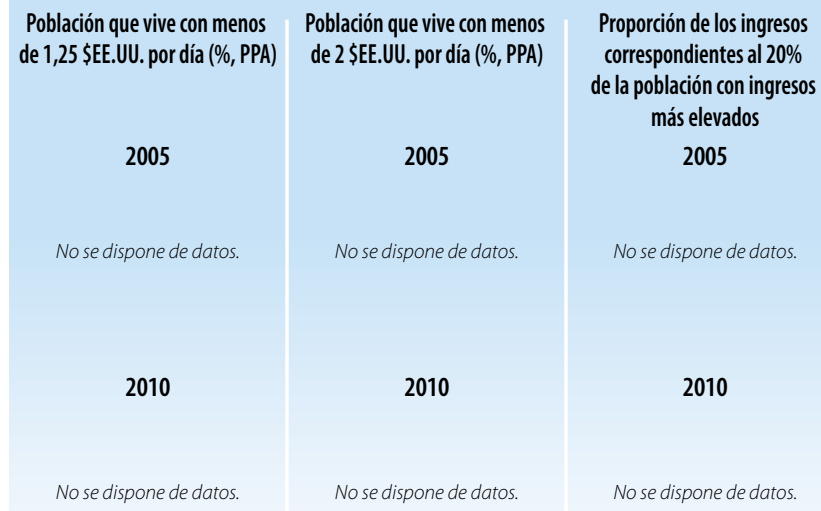

Fuentes: Banco Mundial, Indicadores del Desarrollo Mundial.

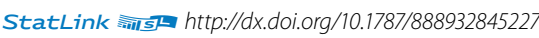


Indicadores de la ayuda, el comercio y el desarrollo relativos a Ghana

\begin{tabular}{|c|c|c|c|c|}
\hline Indicador (millones de \$̦EE.UU. corrientes) & 2005 & 2008 & 2010 & $\Delta: 05-10(\%)$ \\
\hline Formación bruta de capital fijo & $3.109,1$ & $6.119,7$ & $7.013,9$ & $126 \%$ \\
\hline del cual: público & $1.286,7$ & $2.667,5$ & $1.265,6$ & $-2 \%$ \\
\hline del cual: privado & $1.822,5$ & $3.452,2$ & $5.748,3$ & $215 \%$ \\
\hline \multicolumn{5}{|l|}{ Entrada de financiación externa } \\
\hline Entradas de IED & 145,0 & $2.714,9$ & $2.527,4$ & $1643 \%$ \\
\hline $\begin{array}{l}\text { Deuda externa a largo plazo y fondos } \\
\text { desembolsados por el FMl }\end{array}$ & 515,8 & 598,4 & 1279,5 & $148 \%$ \\
\hline $\begin{array}{l}\text { Corrientes comerciales en condiciones no } \\
\text { concesionarias }\end{array}$ & 0,0 & 41,2 & 49,3 & d.p.c. \\
\hline Corrientes de Ayuda para el Comercio & 307,9 & 381,0 & 552,8 & $80 \%$ \\
\hline $\begin{array}{l}\text { Remesas de trabajadores y remuneración } \\
\text { de empleados }\end{array}$ & 99,2 & 126,1 & 135,9 & $37 \%$ \\
\hline
\end{tabular}

Fuentes: OCDE, base de datos del SNPA del CAD sobre las actividades de ayuda; Banco Mundial, Indicadores del Desarrollo Mundial; Banco Mundial, estadísticas de la deuda internacional.

Desembolsos de la ayuda para el comercio, por sector (millones de \$EE.UU. corrientes)

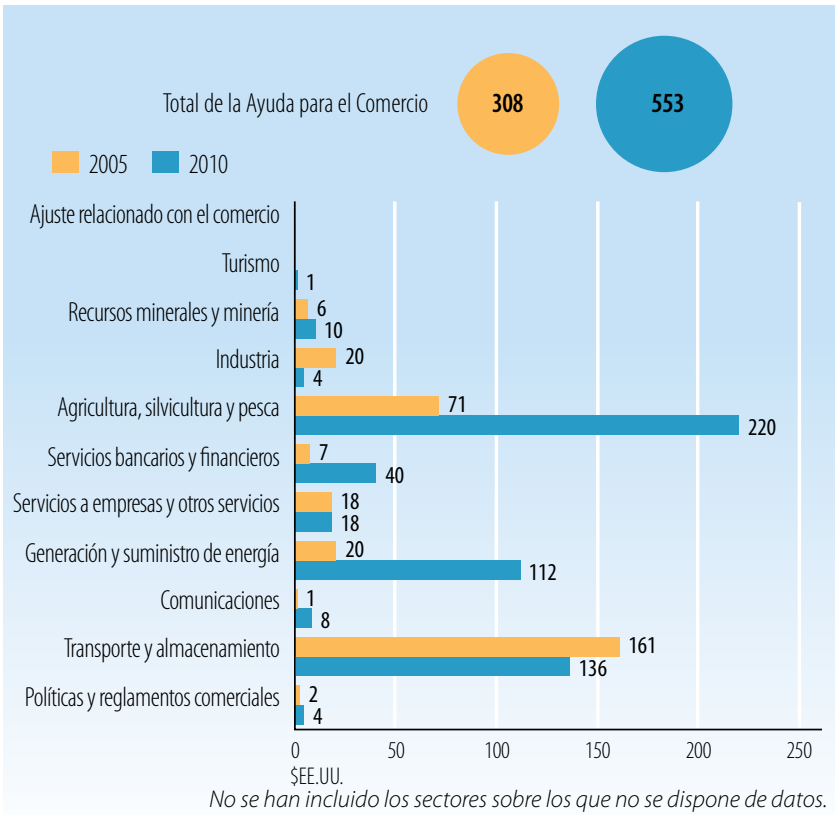

Fuentes: OCDE, base de datos del SNPA del CAD sobre las actividades de ayuda

Desembolsos de la ayuda para el comercio: principales donantes (millones de \$EE.UU. corrientes)

\begin{tabular}{|l|c|c|c|}
\hline $\mathbf{2 0 0 5}$ & Valor & $\%$ & Principales donantes en 2005 \\
\hline Banco Mundial & 96,8 & 31 & \\
\hline Instituciones de la UE & 39,2 & 13 & \\
\hline Banco Africano de Desarrollo & 29,1 & 9 & \\
\hline Alemania & 28,6 & 9 & $71 \%$ \\
\hline Japón & 23,3 & 8 & \\
\hline $\mathbf{2 0 1 0}$ & Valor & $\%$ & Principales donantes en 2010 \\
\hline Banco Mundial & 161,5 & 29 & \\
\hline Estados Unidos & 122,9 & 22 & \\
\hline Banco Africano de Desarrollo & 69,4 & 13 & \\
\hline Canadá & 63,3 & 11 & $82 \%$ \\
\hline Japón & 36,6 & 7 & \\
\hline
\end{tabular}

Fuentes: OCDE, base de datos del SNPA del CAD sobre las actividades de ayuda.

\section{INDICADORES COMERCIALES (PRODUCTOS)}

\section{Indicador}

$2005 \quad 2008 \quad 2011 \quad \Delta: 05-11(\%)$

Relación comercio/PIB (\%)

\begin{tabular}{|l|l|l|l|}
97 & 67 & 85 & -12 \\
\hline
\end{tabular}

Exportaciones de servicios comerciales como

$\%$ de las exportaciones totales

\begin{tabular}{|l|l|l|l|}
28 & 23 & 11 & -17
\end{tabular}

mportaciones de servicios comerciales como

$\%$ de las importaciones totales

Productos intermedios distintos de los combustibles

(\% de las exportaciones de mercancías)

Productos intermedios distintos de los combustibles

(\% de las importaciones de mercancías)

\begin{tabular}{|l|l|l|l|}
\hline 18 & 17 & 16 & -2 \\
\hline
\end{tabular}

\begin{tabular}{|l|l|l|l|}
\hline 88 & 91 & 49 & -38
\end{tabular}

Fuentes: Secretaría de la OMC.

Corrientes comerciales (millones de \$EE.UU. corrientes)

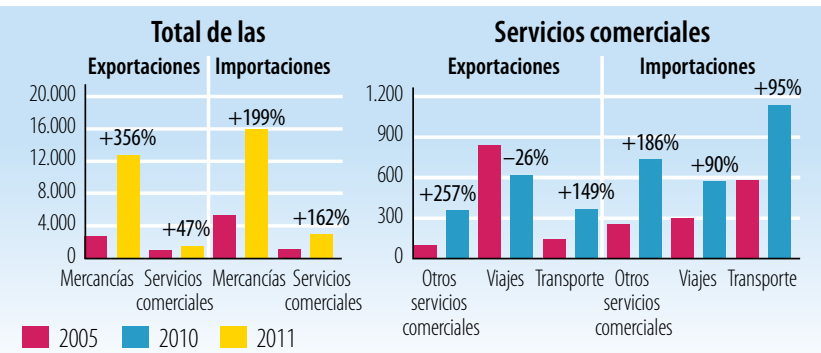

Fuentes:Secretaría de la OMC

Cinco principales mercados de exportación de mercancías (\%)

\begin{tabular}{|l|c|l|c|}
\hline 2005 & $\%$ & 2010 & $\%$ \\
\hline UE (27) & 40 & Sudáfrica & 53 \\
\hline Sudáfrica & 25 & UE (27) & 18 \\
\hline Nigeria & 13 & Emiratos Árabes Unidos & 7 \\
\hline Suiza & 5 & Suiza & 4 \\
\hline Estados Unidos & 3 & Malí & 2 \\
\hline
\end{tabular}

Fuentes: Secretaría de la OMC

Cinco principales productos de exportación (\% de las exportaciones de mercancías)

\begin{tabular}{|l|c|l|c|}
\hline 2005 & $\%$ & 2011 & $\%$ \\
\hline Cacao & 29 & Oro no monetario, excepto minerales & 26 \\
\hline $\begin{array}{l}\text { Oro no monetario, excepto minerales } \\
\text { Hojas de madera para enchapado, }\end{array}$ & 28 & Propano y butano licuados & 24 \\
\hline $\begin{array}{l}\text { madera terciada, etc. } \\
\text { Madera trabajada simplemente }\end{array}$ & 4 & Aceites de petróleo, crudos & 16 \\
\hline Productos derivados del petróleo & 2 & $\begin{array}{l}\text { Frutas y nueces, excepto nueces } \\
\text { oleaginosas }\end{array}$ & 12 \\
\hline
\end{tabular}

Fuentes: Secretaría de la OMC

Cinco principales mercados de importación de mercancías (\%)

\begin{tabular}{|l|c|l|c|}
\hline $\mathbf{2 0 0 5}$ & $\%$ & $\mathbf{2 0 1 0}$ & $\%$ \\
\hline UE (27) & 36 & UE (27) & 31 \\
\hline Nigeria & 12 & Estados Unidos & 14 \\
\hline China & 8 & China & 13 \\
\hline Estados Unidos & 7 & Corea, Rep. de & 4 \\
\hline Sudáfrica & 4 & Sudáfrica & 4
\end{tabular}

Fuentes: Secretaría de la OMC

Cinco principales productos de importación (\% de las importaciones de mercancías)

\begin{tabular}{|c|c|c|c|}
\hline 2005 & $\%$ & 2011 & $\%$ \\
\hline Aceites de petróleo, crudos & 13 & Impresos & 13 \\
\hline $\begin{array}{l}\text { Vehículos automotores para pasajeros, } \\
\text { excepto autobuses }\end{array}$ & 8 & $\begin{array}{l}\text { Vehículos automotores para pasajeros, } \\
\text { excepto autobuses }\end{array}$ & 6 \\
\hline $\begin{array}{l}\text { Vehículos automotores para el transporte } \\
\text { de mercancías y vehículos automotores } \\
\text { para usos especiales }\end{array}$ & 4 & $\begin{array}{l}\text { Vehículos automotores para el } \\
\text { transporte de mercancías y vehículos } \\
\text { automotores para usos especiales }\end{array}$ & 5 \\
\hline Impresos & 4 & $\begin{array}{l}\text { Equipos de telecomunicaciones y sus } \\
\text { partes, n.e.p. }\end{array}$ & \\
\hline Cal, cemento y materiales de construcción & 3 & Equipo de ingeniería civil & \\
\hline
\end{tabular}

Fuentes: Secretaría de la OMC 


\section{LA AYUDA PARA EL COMERCIO EN SÍNTESIS 2013}

\section{INDICADORES COMERCIALES (RESULTADOS)}

\section{Indicador}

Crecimiento del PIB (\%)

Número de exportadores

Índice de concentración de las exportaciones (productos) ( 0 a 1$)$

ACR sobre mercancías notificados a la OMC

AIE (servicios) notificados a la OMC

Sectores de servicios con compromisos en el marco del AGCS

\section{Aranceles (\%, 2004-2010)}

Importaciones: promedio aritmético de los aranceles NMF aplicados $\quad 13,0 \quad 13,0$

Importaciones: promedio ponderado de los aranceles NMF aplicados n.d. 10,1

\begin{tabular}{|l|l|l|l|} 
Exportaciones: promedio ponderado de los aranceles impuestos & 0,4 & 0,5
\end{tabular}

por los importadores

Exportaciones: libres de derechos (en \%)

$97,1 \quad 89,1$

Fuentes: Naciones Unidas, base de datos Comtrade; Banco Mundial, base de datos sobre dinámica de las empresas de exportación; Banco Mundial, Indicadores del

Desarrollo Mundial; OMC, perfiles comerciales y arancelarios.

Participación en las exportaciones por región (\%)

\begin{tabular}{|l|r|r|}
\hline África & $\mathbf{2 0 0 5}$ & $\mathbf{2 0 1 1}$ \\
\hline Asia & 40,3 & 51,8 \\
\hline Comunidad de Estados Independientes & 7,0 & 7,1 \\
\hline Europa & 0,7 & 0,3 \\
\hline Oriente Medio & 46,8 & 31,5 \\
\hline América del Norte & 1,0 & 5,6 \\
\hline América del Sury América Central & 3,5 & 3,2 \\
\hline
\end{tabular}

Fuentes: OMC, perfiles comerciales y arancelarios

Indicadores de facilitación del comercio
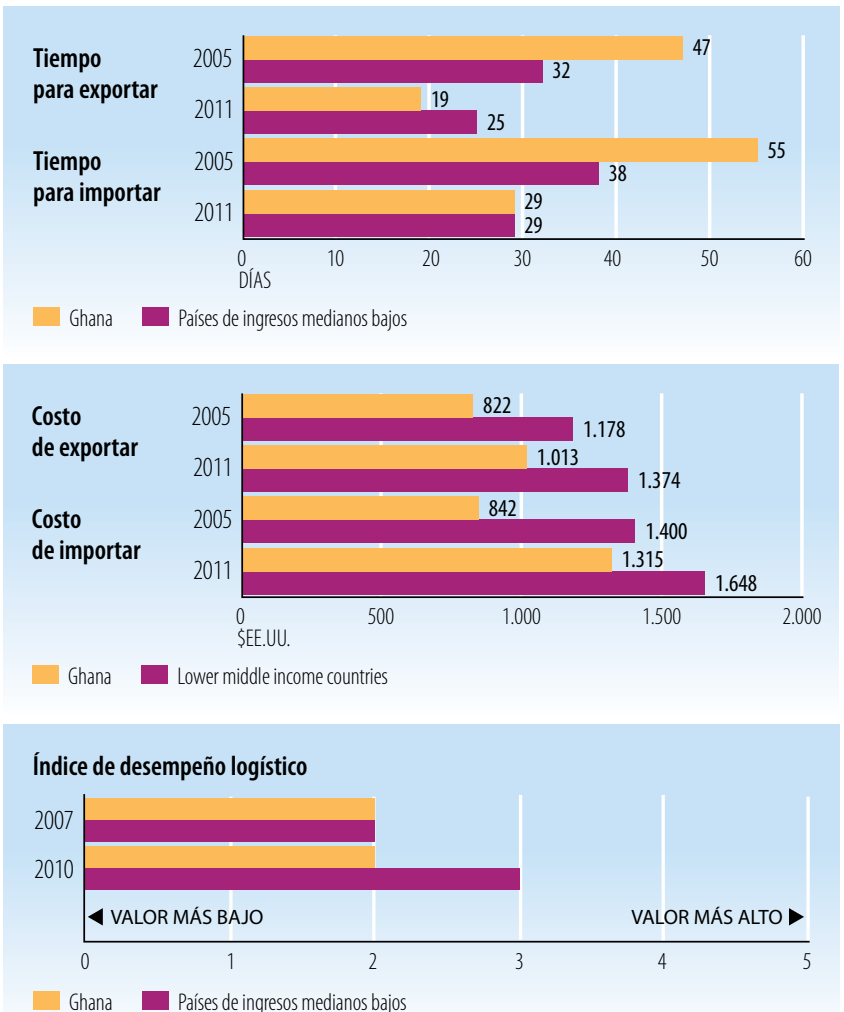

Ghana Páses de ingresos medianos bajos

Fuentes: Banco Mundial, Indicadores del Desarrollo Mundial.

\begin{tabular}{l|c|c|}
\hline INDICADORES DE DESARROLLO (EFECTOS) \\
\hline Indicador & 2005 & $\mathbf{2 0 1 0}$ \\
\hline Desempleo (\% de la fuerza de trabajo total) & 3,6 & n.d. \\
\hline Población activa, mujeres (\% de la fuerza de trabajo total) & 47,9 & 47,6 \\
\hline AOD neta recibida (\% del INB) & 10,9 & 5,3 \\
\hline Derechos de importación percibidos (\% de los ingresos fiscales) & 16,8 & 23,3 \\
\hline Total del servicio de la deuda (\% de las exportaciones totales) & 7,1 & 3,4 \\
\hline Índice de desarrollo humano (0 a 1) & 0,48 & 0,53 \\
\hline
\end{tabular}

Fuentes: PNUD, indicadores internacionales sobre desarrollo humano; Banco Mundial, Indicadores del Desarrollo Mundial.

Producto interno bruto

PIB per cápita (PPA, dólares internacionales corrientes)

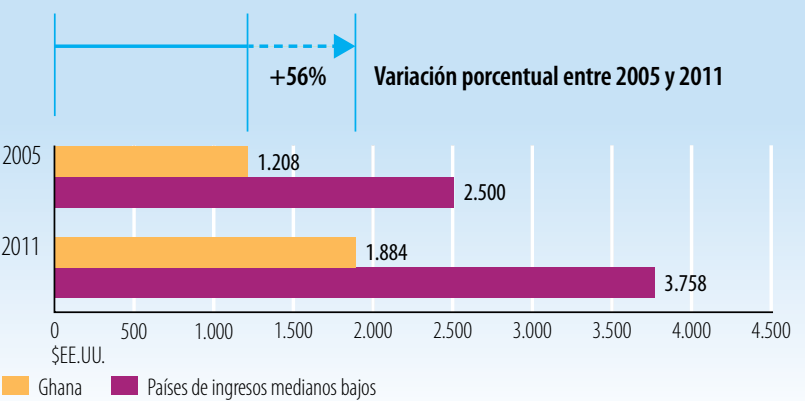

PIB per cápita (\$EE.UU. constantes de 2000)

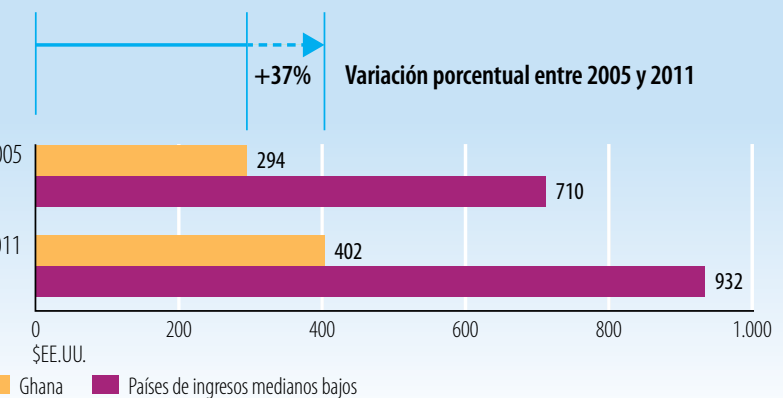

Fuentes: Banco Mundial, Indicadores del Desarrollo Mundial.

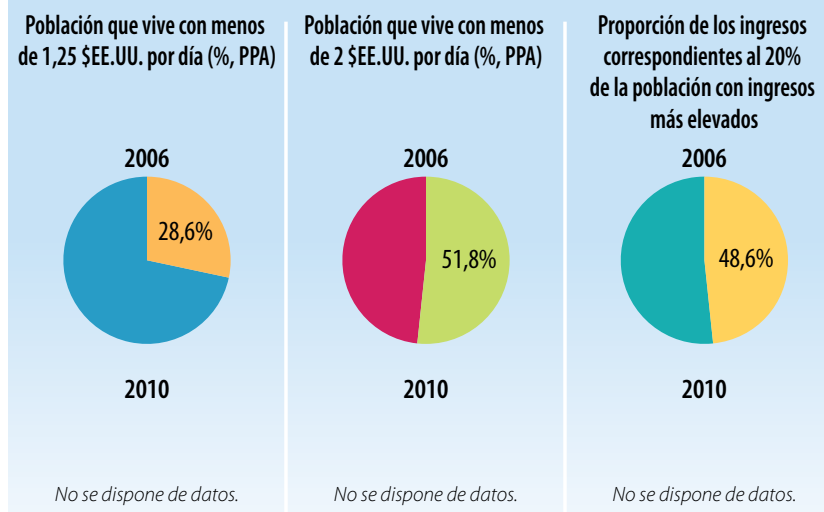

Fuentes: Banco Mundial, Indicadores del Desarrollo Mundial.

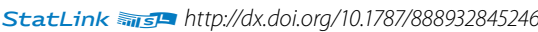




\section{Indicadores de la ayuda, el comercio y el desarrollo relativos a Granada}

\section{INVERSIÓN Y FINANCIACIÓN (APORTES)}

\begin{tabular}{|c|c|c|c|c|}
\hline Indicador (millones de \$EE.UU. corrientes) & 2005 & 2008 & 2010 & $\Delta: 05-10(\%)$ \\
\hline Formación bruta de capital fijo & 279,1 & 223,3 & n.d. & n.d. \\
\hline del cual: público & n.d. & n.d. & n.d. & n.d. \\
\hline del cual: privado & n.d. & n.d. & n.d. & n.d. \\
\hline \multicolumn{5}{|l|}{ Entrada de financiación externa } \\
\hline Entradas de IED & 70,2 & 142,2 & 60,2 & $-14 \%$ \\
\hline $\begin{array}{l}\text { Deuda externa a largo plazo y fondos } \\
\text { desembolsados por el FMI }\end{array}$ & 38,5 & 39,1 & 27,5 & $-29 \%$ \\
\hline $\begin{array}{l}\text { Corrientes comerciales en condiciones no } \\
\text { concesionarias }\end{array}$ & 0,3 & 0,1 & 2,0 & $523 \%$ \\
\hline Corrientes de Ayuda para el Comercio & 0,6 & 1,9 & 9,8 & $1462 \%$ \\
\hline $\begin{array}{l}\text { Remesas de trabajadores y remuneración } \\
\text { de empleados }\end{array}$ & 51,6 & 55,4 & 54,5 & $6 \%$ \\
\hline
\end{tabular}

Fuentes: OCDE, base de datos del SNPA del CAD sobre las actividades de ayuda; Banco Mundial, Indicadores del Desarrollo Mundial; Banco Mundial, estadísticas de la deuda internacional.

Desembolsos de la ayuda para el comercio, por sector (millones de \$EE.UU. corrientes)

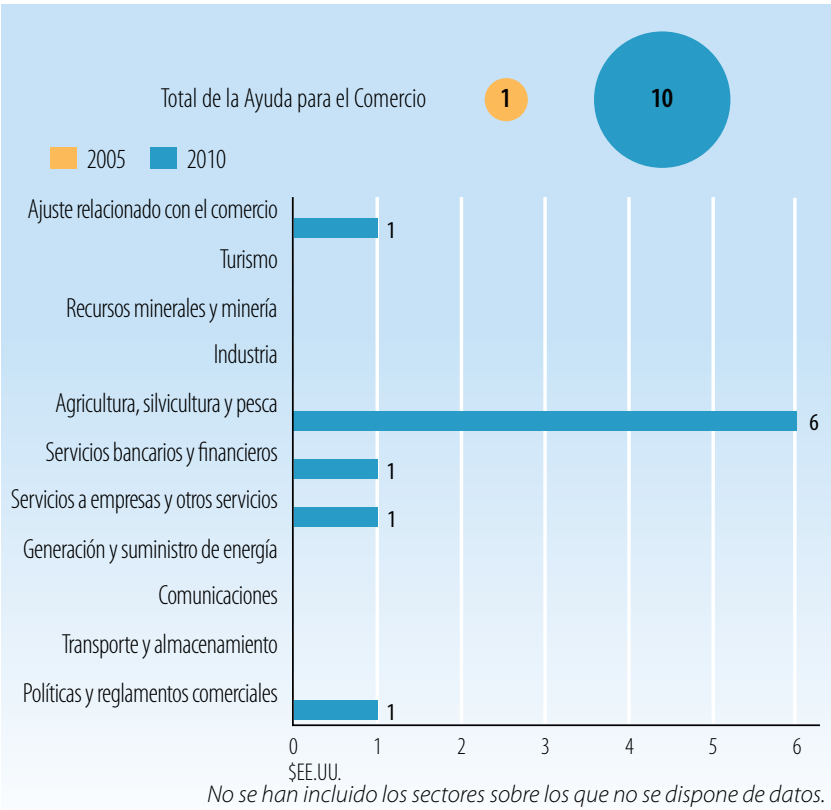

Fuentes: OCDE, base de datos del SNPA del CAD sobre las actividades de ayuda

Desembolsos de la ayuda para el comercio: principales donantes (millones de \$EE.UU. corrientes)

\begin{tabular}{|l|r|r|}
\hline $\mathbf{2 0 0 5}$ & Valor & $\%$ \\
\hline Instituciones de la UE & 0,3 & 46 \\
\hline Banco Mundial & 0,2 & 27 \\
\hline Reino Unido & 0,1 & 18 \\
\hline Japón & 0,1 & 9 \\
\hline
\end{tabular}

\begin{tabular}{|l|r|r|}
\hline $\mathbf{2 0 1 0}$ & Valor & $\%$ \\
\hline Japón & 5,7 & 59 \\
\hline Banco Mundial & 2,0 & 21 \\
\hline Instituciones de la UE & 1,5 & 15 \\
\hline Kuwait & 0,3 & 4 \\
\hline Australia & 0,1 & 1 \\
\hline
\end{tabular}

Principales donantes en 2005 $100 \%$ Principales donantes en 2010

$99 \%$

Fuentes: OCDE, base de datos del SNPA del CAD sobre las actividades de ayuda.

\section{INDICADORES COMERCIALES (PRODUCTOS)}

\section{Indicador}

$2005 \quad 2008 \quad 2011 \quad \Delta: 05-11(\%)$

Relación comercio/PIB (\%)

Exportaciones de servicios comerciales como

$\%$ de las exportaciones totales

Importaciones de servicios comerciales como

$\%$ de las importaciones totales

Productos intermedios distintos de los combustibles

(\% de las exportaciones de mercancías)

Productos intermedios distintos de los combustibles

(\% de las importaciones de mercancías)

\begin{tabular}{|r|r|r|r|}
\hline 77 & 76 & 70 & -7 \\
\hline 23 & 79 & 80 & 2 \\
\hline 26 & 24 & 23 & 1 \\
\hline 47 & 33 & n.d. & n.d. \\
\hline
\end{tabular}

Fuentes: Secretaría de la OMC.

Corrientes comerciales (millones de \$EE.UU. corrientes)
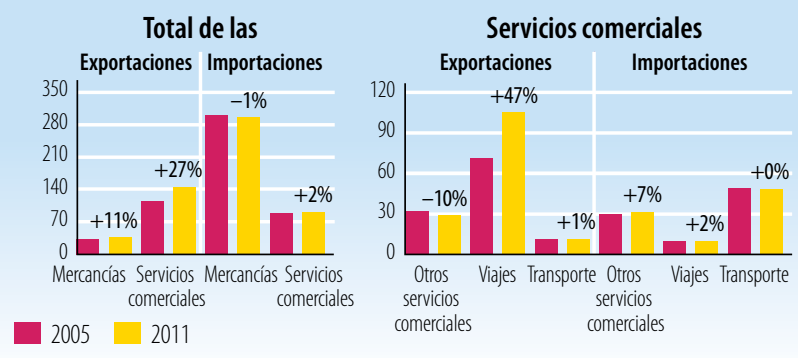

Fuentes: Secretaría de la OMC

Cinco principales mercados de exportación de mercancías (\%)

\begin{tabular}{|l|r|l|c|}
\hline 2005 & $\%$ & 2008 & $\%$ \\
\hline UE $(27)$ & 24 & Dominica & 16 \\
\hline Estados Unidos & 21 & Estados Unidos & 16 \\
\hline Trinidady Tabago & 10 & UE (27) & 16 \\
\hline Santa Lucía & 9 & Santa Lucía & 11 \\
\hline Barbados & 6 & Barbados & 9 \\
\hline
\end{tabular}

Fuentes: Secretaría de la OMC

Cinco principales productos de exportación (\% de las exportaciones de mercancías)

\begin{tabular}{|c|c|c|c|}
\hline 2005 & $\%$ & 2008 & $\%$ \\
\hline Especias & 30 & $\begin{array}{l}\text { Sémola y harina de trigo y harina de } \\
\text { morcajo o tranquillón }\end{array}$ & 25 \\
\hline $\begin{array}{l}\text { Sémola y harina de trigo y harina de } \\
\text { morcajo } 0 \text { tranquillón }\end{array}$ & 14 & Papeles y cartones recortados, etc. & 10 \\
\hline Pescado, fresco, refrigerado o congelado & 12 & Pescado, fresco, refrigerado o congelado & 10 \\
\hline Papeles y cartones recortados, etc. & 9 & Especias & 9 \\
\hline $\begin{array}{l}\text { Vehículos automotores para el transporte } \\
\text { de mercancías y vehícul os automotores } \\
\text { para usos especiales }\end{array}$ & 5 & Cacao & 8 \\
\hline
\end{tabular}

Cinco principales mercados de importación de mercancías (\%)

\begin{tabular}{|l|r|l|r|}
\hline $\mathbf{2 0 0 5}$ & $\%$ & $\mathbf{2 0 0 9}$ & $\%$ \\
\hline Estados Unidos & 37 & Estados Unidos & 32 \\
\hline Trinidad y Tabago & 21 & Trinidad y Tabago & 25 \\
\hline UE (27) & 14 & UE (27) & 12 \\
\hline Japón & 4 & Japón & 4 \\
\hline China & 3 & China & 3
\end{tabular}

Fuentes: Secretaría de la OMC

Cinco principales productos de importación (\% de las importaciones de mercancías)

\section{5}

Productos derivados del petróleo

Madera trabajada simplemente

Hojas de madera para enchapado, madera terciada, etc.

Aparatos eléctricos rotativos

Vehículos automotores para pasajeros,

excepto autobuses

Fuentes: Secretaría de la OMC 


\section{LA AYUDA PARA EL COMERCIO EN SÍNTESIS 2013}

\section{INDICADORES COMERCIALES (RESULTADOS)}

\section{Indicador}

Crecimiento del PIB (\%)

Número de exportadores

Índice de concentración de las exportaciones (productos) ( 0 a 1)

ACR sobre mercancías notificados a la OMC

AIE (servicios) notificados a la OMC

Sectores de servicios con compromisos en el marco del AGCS

\section{Aranceles $(\%, 2006$ et 2011)}

\begin{tabular}{l|l|l|l|} 
Importaciones: promedio aritmético de los aranceles NMF aplicados $\quad 10,2$ & 10,3
\end{tabular}

Importaciones: promedio ponderado de los aranceles NMF aplicados n.d. n.d.

\begin{tabular}{|l|l|l|}
\hline Exportaciones: promedio ponderado de los aranceles impuestos & 0,5 & 3,7
\end{tabular}

por los importadores

Exportaciones: libres de derechos (en \%)

$92,9 \quad 58,1$

Fuentes: Naciones Unidas, base de datos Comtrade; Banco Mundial, base de datos sobre dinámica de las empresas de exportación; Banco Mundial, Indicadores del

Desarrollo Mundial; OMC, perfiles comerciales y arancelarios.

Participación en las exportaciones por región (\%)

\begin{tabular}{|l|r|r|}
\hline & 2005 & 2008 \\
\hline África & 0,0 & 0,1 \\
\hline Asia & 1,0 & 4,6 \\
\hline Comunidad de Estados Independientes & 0,0 & 0,0 \\
\hline Europa & 24,3 & 17,2 \\
\hline Oriente Medio & 0,0 & 0,0 \\
\hline América del Norte & 23,9 & 19,2 \\
\hline América del Sury América Central & 50,8 & 59,0 \\
\hline
\end{tabular}

Fuentes: OMC, perfiles comerciales y arancelarios

Indicadores de facilitación del comercio
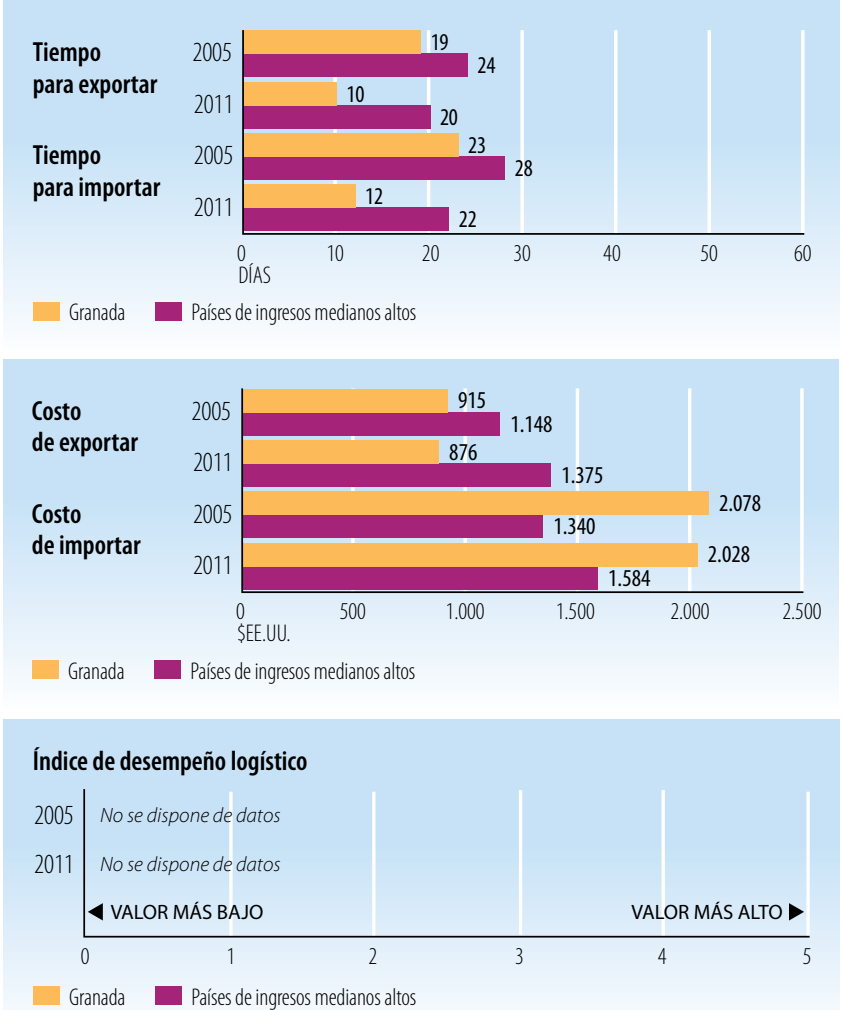

Fuentes: Banco Mundial, Indicadores del Desarrollo Mundial.

\section{INDICADORES DE DESARROLLO (EFECTOS)}

Indicador

2005

2010

Desempleo (\% de la fuerza de trabajo total)

n.d. n.d.

Población activa, mujeres (\% de la fuerza de trabajo total)

n.d. n.d.

AOD neta recibida (\% del INB)

$7,8 \quad 4,6$

Derechos de importación percibidos (\% de los ingresos fiscales) n.d. n.d.

Total del servicio de la deuda (\% de las exportaciones totales) $\quad 6,6 \quad 14,3$

Índice de desarrollo humano (0 a 1)

n.d.

0,75

Fuentes: PNUD, indicadores internacionales sobre desarrollo humano; Banco Mundial, Indicadores del Desarrollo Mundial.

Producto interno bruto

PIB per cápita (PPA, dólares internacionales corrientes)
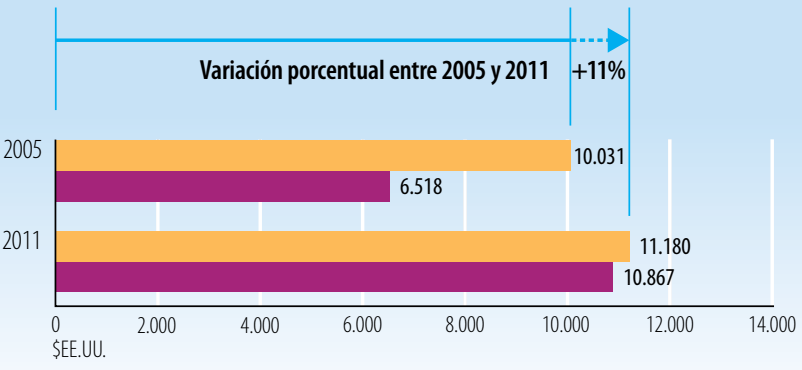

Granada Países de ingresos medianos altos

PIB per cápita (\$EE.UU. constantes de 2000)
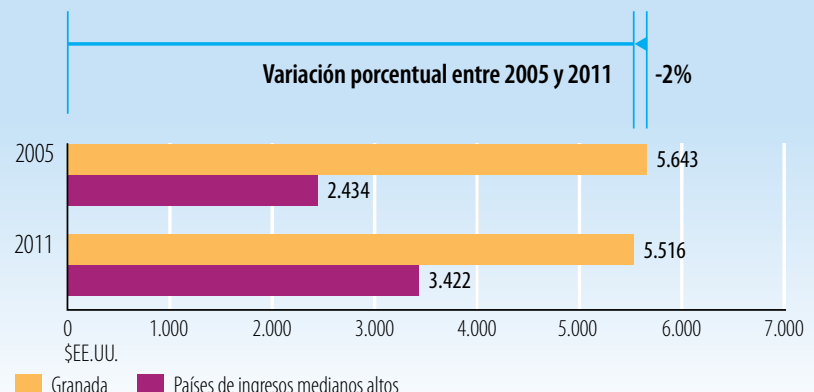

Fuentes: Banco Mundial, Indicadores del Desarrollo Mundial.

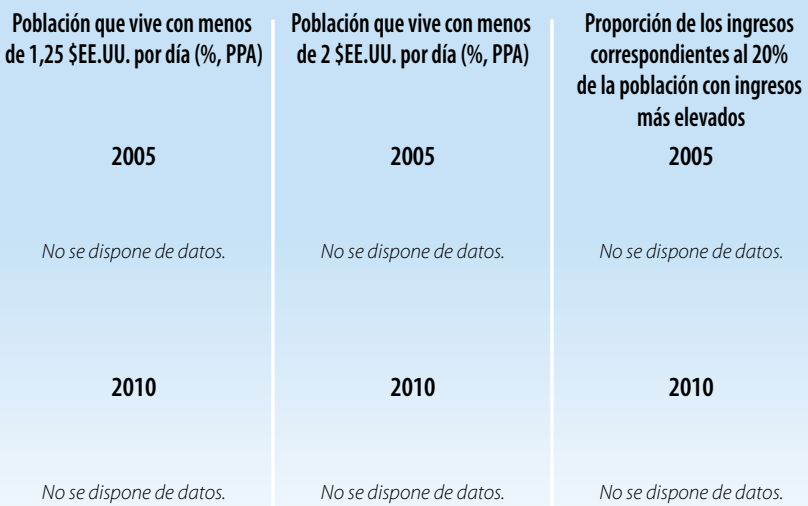

Fuentes: Banco Mundial, Indicadores del Desarrollo Mundial.

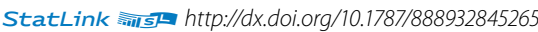


Indicadores de la ayuda, el comercio y el desarrollo relativos a Guatemala

\section{INVERSIÓN Y FINANCIACIÓN (APORTES)}

\begin{tabular}{|c|c|c|c|c|}
\hline Indicador (millones de \$EE.UU. corrientes) & 2005 & 2008 & 2010 & $\Delta: 05-10(\%)$ \\
\hline Formación bruta de capital fijo & $4.979,0$ & $7.018,0$ & $6.121,4$ & $23 \%$ \\
\hline del cual: público & 750,3 & n.d. & n.d. & n.d. \\
\hline del cual: privado & $4.228,7$ & n.d. & n.d. & n.d. \\
\hline \multicolumn{5}{|l|}{ Entrada de financiación externa } \\
\hline Entradas de IED & 508,6 & 753,8 & 881,1 & $73 \%$ \\
\hline $\begin{array}{l}\text { Deuda externa a largo plazo y fondos } \\
\text { desembolsados por el FMI }\end{array}$ & $2.184,3$ & $1.037,2$ & $1.442,0$ & $-34 \%$ \\
\hline $\begin{array}{l}\text { Corrientes comerciales en condiciones no } \\
\text { concesionarias }\end{array}$ & 6,7 & 49,4 & 124,7 & $1767 \%$ \\
\hline Corrientes de Ayuda para el Comercio & 21,9 & 34,2 & 85,7 & $291 \%$ \\
\hline $\begin{array}{l}\text { Remesas de trabajadores y remuneración } \\
\text { de empleados }\end{array}$ & $3.066,6$ & $4.459,7$ & $4.229,2$ & $38 \%$ \\
\hline
\end{tabular}

Fuentes: OCDE, base de datos del SNPA del CAD sobre las actividades de ayuda; Banco Mundial, Indicadores del Desarrollo Mundial; Banco Mundial, estadísticas de la deuda internacional.

Desembolsos de la ayuda para el comercio, por sector (millones de \$EE.UU. corrientes)

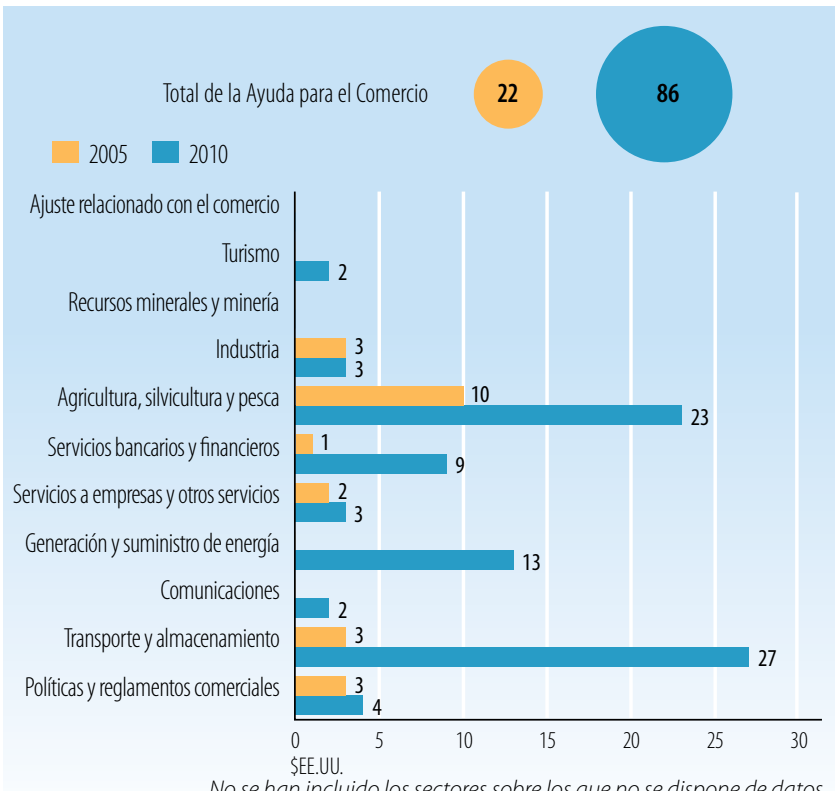

No se han incluido los sectores sobre los que no se dispone de datos.

Fuentes: OCDE, base de datos del SNPA del CAD sobre las actividades de ayuda

Desembolsos de la ayuda para el comercio: principales donantes (millones de \$EE.UU. corrientes)

\begin{tabular}{|l|c|c|}
\hline $\mathbf{2 0 0 5}$ & Valor & $\%$ \\
\hline España & 6,8 & 31 \\
\hline Alemania & 3,1 & 14 \\
\hline Japón & 2,7 & 13 \\
\hline Instituciones de la UE & 2,4 & 11 \\
\hline Estados Unidos & 2,2 & 10 \\
\hline $\mathbf{2 0 1 0}$ & Valor & $\%$ \\
\hline Japón & 42,6 & 50 \\
\hline España & 13,4 & 16 \\
\hline Estados Unidos & 8,5 & 10 \\
\hline Instituciones de la UE & 4,1 & 5 \\
\hline Canadá & 2,8 & 3 \\
\hline
\end{tabular}

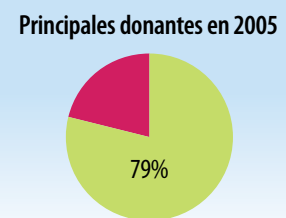

Principales donantes en 2010

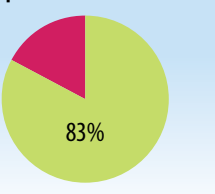

Fuentes: OCDE, base de datos del SNPA del CAD sobre las actividades de ayuda.

\section{INDICADORES COMERCIALES (PRODUCTOS)}

\section{Indicador}

$2005 \quad 2008 \quad 2011 \quad \Delta: 05-11(\%)$

Relación comercio/PIB (\%)

Exportaciones de servicios comerciales como

$\%$ de las exportaciones totales

Importaciones de servicios comerciales como

$\%$ de las importaciones totales

Productos intermedios distintos de los combustibles

(\% de las exportaciones de mercancías)

Productos intermedios distintos de los combustibles

(\% de las importaciones de mercancías)

\begin{tabular}{l|l|r|r|}
65 & 64 & 66 & 0
\end{tabular}

Fuentes: Secretaría de la OMC.

Corrientes comerciales (millones de \$̦EE.UU. corrientes)
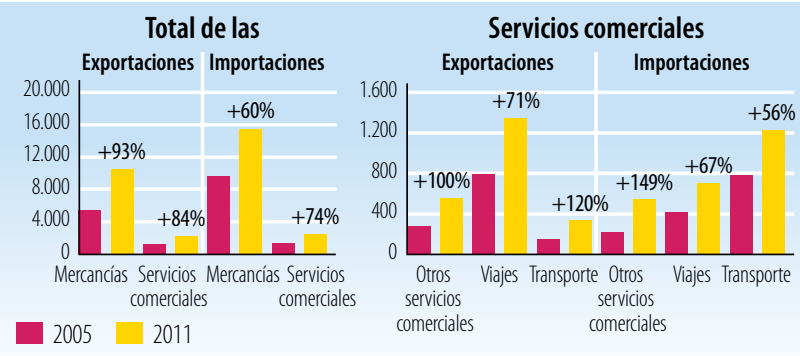

Fuentes: Secretaría de la OMC

Cinco principales mercados de exportación de mercancías (\%)

\begin{tabular}{|l|r|l|c|}
\hline 2005 & $\%$ & 2010 & $\%$ \\
\hline Estados Unidos & 50 & Estados Unidos & 39 \\
\hline El Salvador & 12 & El Salvador & 12 \\
\hline Honduras & 7 & Honduras & 8 \\
\hline UE $(27)$ & 5 & UE $(27)$ & 6 \\
\hline México & 4 & México & 5 \\
\hline
\end{tabular}

Fuentes: Secretaría de la OMC

Cinco principales productos de exportación (\% de las exportaciones de mercancías)

\begin{tabular}{|c|c|c|c|}
\hline 2005 & $\%$ & 2011 & $\%$ \\
\hline $\begin{array}{l}\text { Prendas de vestir para mujeres y niñas, } \\
\text { de punto }\end{array}$ & 13 & Café y sucedáneos del café & 11 \\
\hline Café y sucedáneos del café & 9 & $\begin{array}{l}\text { Minerales de metales preciosos y sus } \\
\text { concentrados }\end{array}$ & 9 \\
\hline $\begin{array}{l}\text { Frutas y nueces, excepto nueces } \\
\text { oleaginosas }\end{array}$ & 7 & Azúcares, melaza y miel & \\
\hline $\begin{array}{l}\text { Prendas de vestir para mujeres y niñas, } \\
\text { excepto las de punto }\end{array}$ & 6 & $\begin{array}{l}\text { Frutas y nueces, excepto nueces } \\
\text { oleaginosas }\end{array}$ & \\
\hline Azúcares, melaza y miel & 5 & $\begin{array}{l}\text { Prendas de vestir para mujeres y niñas, } \\
\text { de punto }\end{array}$ & \\
\hline
\end{tabular}

Fuentes: Secretaría de la OMC

Cinco principales mercados de importación de mercancías (\%)

\begin{tabular}{|l|r|l|c|}
\hline 2005 & $\%$ & 2010 & $\%$ \\
\hline Estados Unidos & 34 & Estados Unidos & 37 \\
\hline México & 9 & México & 11 \\
\hline UE (27) & 8 & China & 7 \\
\hline China & 7 & UE (27) & 7 \\
\hline Corea, Rep. de & 6 & El Salvador & 5 \\
\hline
\end{tabular}

Fuentes: Secretaría de la OMC

Cinco principales productos de importación (\% de las importaciones de mercancías)

\section{5}

Productos derivados del petróleo

Vehículos automotores para pasajeros,

excepto autobuses

Tejidos de punto o ganchillo, n.e.p.

Equipos de telecomunicaciones y sus

partes, n.e.p.

Medicamentos

Fuentes: Secretaría de la OMC 


\section{LA AYUDA PARA EL COMERCIO EN SINNTESIS 2013}

\section{INDICADORES COMERCIALES (RESULTADOS)}

\section{Indicador}

Crecimiento del PIB (\%)

Número de exportadores

Índice de concentración de las exportaciones (productos) ( 0 a 1)

ACR sobre mercancías notificados a la OMC

AIE (servicios) notificados a la OMC

Sectores de servicios con compromisos en el marco del AGCS

\section{Aranceles (\%)}

Importaciones: promedio aritmético de los aranceles NMF aplicados $\quad 5,6 \quad 5,5$

\begin{tabular}{l|l|l|} 
Importaciones: promedio ponderado de los aranceles NMF aplicados & 5,9
\end{tabular}

\begin{tabular}{|l|l|l|}
\hline Exportaciones: promedio ponderado de los aranceles impuestos & 8,6 & 2,7 \\
\hline
\end{tabular}

por los importadores

$54,3 \quad 93,9$

Exportaciones: libres de derechos (en \%)
Fuentes: Naciones Unidas, base de datos Comtrade; Banco Mundial, base de datos. sobre dinámica de las empresas de exportación; Banco Mundial, Indicadores del

Desarrollo Mundial; OMC, perfiles comerciales y arancelarios.

Participación en las exportaciones por región (\%)

\begin{tabular}{|l|r|r|}
\hline & 2005 & 2011 \\
\hline África & 0,3 & 0,7 \\
\hline Asia & 2,9 & 4,8 \\
\hline Comunidad de Estados Independientes & 0,0 & 0,4 \\
\hline Europa & 6,3 & 6,8 \\
\hline Oriente Medio & 1,1 & 2,0 \\
\hline América del Norte & 55,4 & 48,1 \\
\hline América del Sury América Central & 33,0 & 36,8 \\
\hline
\end{tabular}

Fuentes: OMC, perfiles comerciales y arancelarios

Indicadores de facilitación del comercio
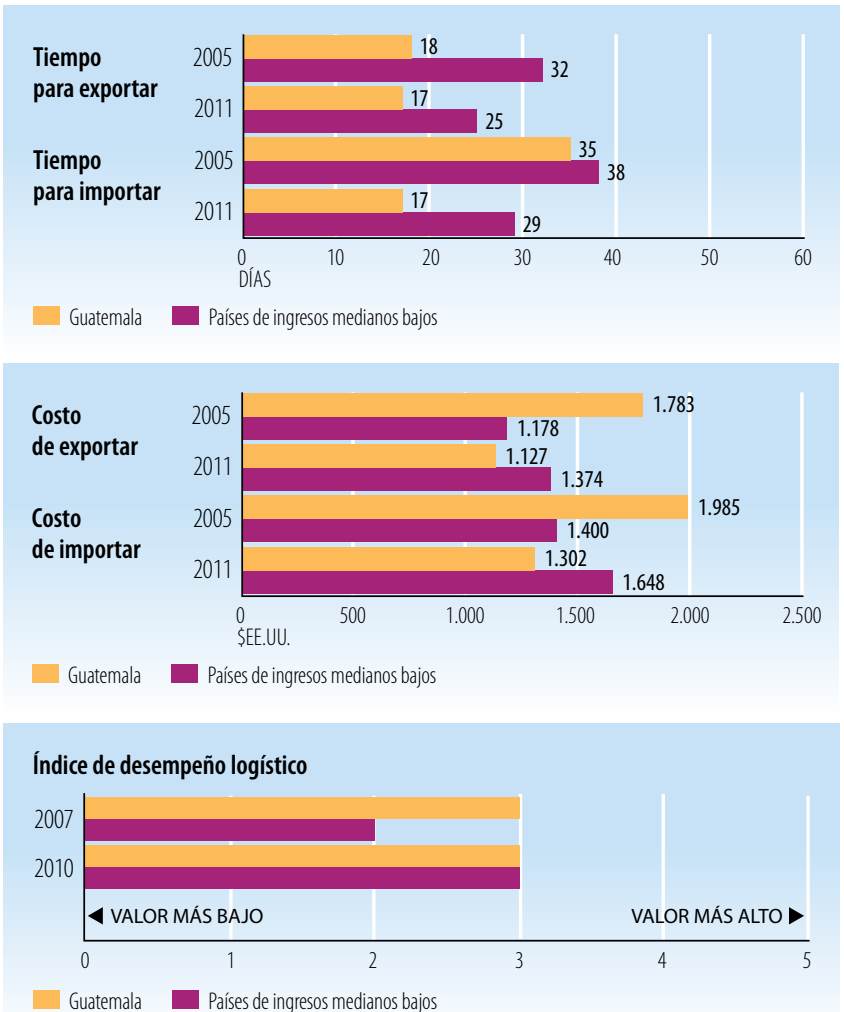

Fuentes: Banco Mundial, Indicadores del Desarrollo Mundial.

\begin{tabular}{l|r|c|}
\hline INDICADORES DE DESARROLLO (EFECTOS) & \\
\hline Indicador & $\mathbf{2 0 0 5}$ & $\mathbf{2 0 1 0}$ \\
\hline Desempleo (\% de la fuerza de trabajo total) & 1,8 & n.d. \\
\hline Población activa, mujeres (\% de la fuerza de trabajo total) & 36,3 & 38,1 \\
\hline AOD neta recibida (\% del INB) & 1,0 & 1,0 \\
\hline Derechos de importación percibidos (\% de los ingresos fiscales) & 16,0 & 6,8 \\
\hline Total del servicio de la deuda (\% de las exportaciones totales) & 17,8 & 14,3 \\
\hline Índice de desarrollo humano (0 a 1) & 0,55 & 0,57 \\
\hline
\end{tabular}

Fuentes: PNUD, indicadores internacionales sobre desarrollo humano; Banco Mundial, Indicadores del Desarrollo Mundial.

Producto interno bruto

PIB per cápita (PPA, dólares internacionales corrientes)
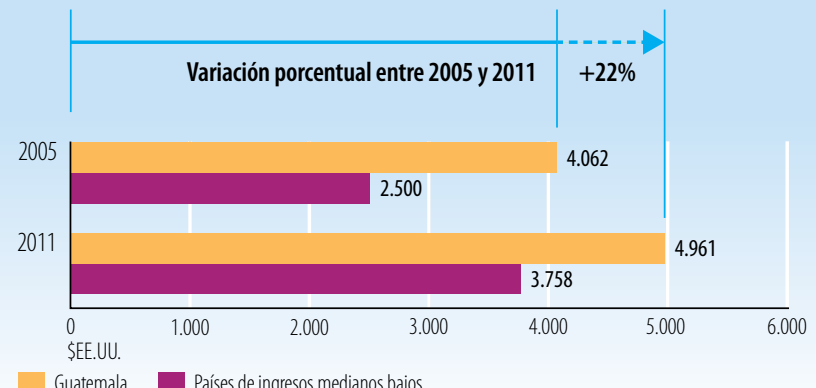

Guatemala $\square$ Páses de ingresos medianos bajos

PIB per cápita (\$EE.UU. constantes de 2000)
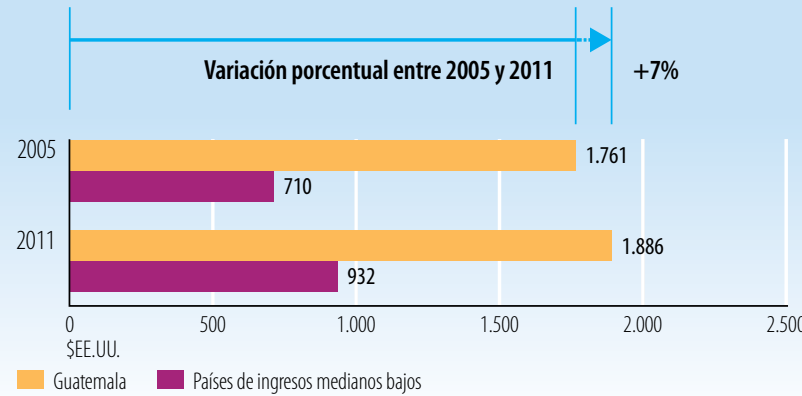

Fuentes: Banco Mundial, Indicadores del Desarrollo Mundial.

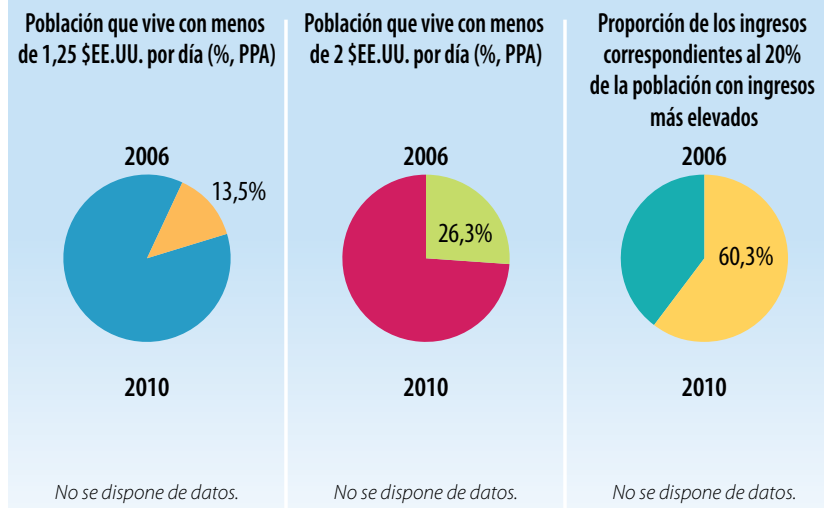

Fuentes: Banco Mundial, Indicadores del Desarrollo Mundial. StatLink aㅔ sम $h$ ttp://dx.doi.org/10.1787/888932845284 


\section{Indicadores de la ayuda, el comercio y el desarrollo relativos a Guinea}

\begin{tabular}{|c|c|c|c|c|}
\hline Indicador (millones de \$EE.UU. corrientes) & 2005 & 2008 & 2010 & $\Delta: 05-10(\%$ \\
\hline Formación bruta de capital fijo & 545,0 & 588,5 & 947,7 & $74 \%$ \\
\hline del cual: público & 82,2 & 131,7 & 205,6 & $150 \%$ \\
\hline del cual: privado & 462,7 & 456,8 & 742,1 & $60 \%$ \\
\hline \multicolumn{5}{|l|}{ Entrada de financiación externa } \\
\hline Entradas de IED & 105,0 & 381,9 & 101,4 & $-3 \%$ \\
\hline $\begin{array}{l}\text { Deuda externa a largo plazo y fondos } \\
\text { desembolsados por el FMl }\end{array}$ & 91,5 & 94,5 & 36,3 & $-60 \%$ \\
\hline $\begin{array}{l}\text { Corrientes comerciales en condiciones no } \\
\text { concesionarias }\end{array}$ & 0,0 & 0,0 & 0,0 & $0 \%$ \\
\hline Corrientes de Ayuda para el Comercio & 20,9 & 62,0 & 62,2 & $198 \%$ \\
\hline $\begin{array}{l}\text { Remesas de trabajadores y remuneración } \\
\text { de empleados }\end{array}$ & 41,6 & 71,8 & 60,4 & $45 \%$ \\
\hline
\end{tabular}

Fuentes: OCDE, base de datos del SNPA del CAD sobre las actividades de ayuda; Banco Mundial, Indicadores del Desarrollo Mundial; Banco Mundial, estadísticas de la deuda internacional.

Desembolsos de la ayuda para el comercio, por sector (millones de \$EE.UU. corrientes)

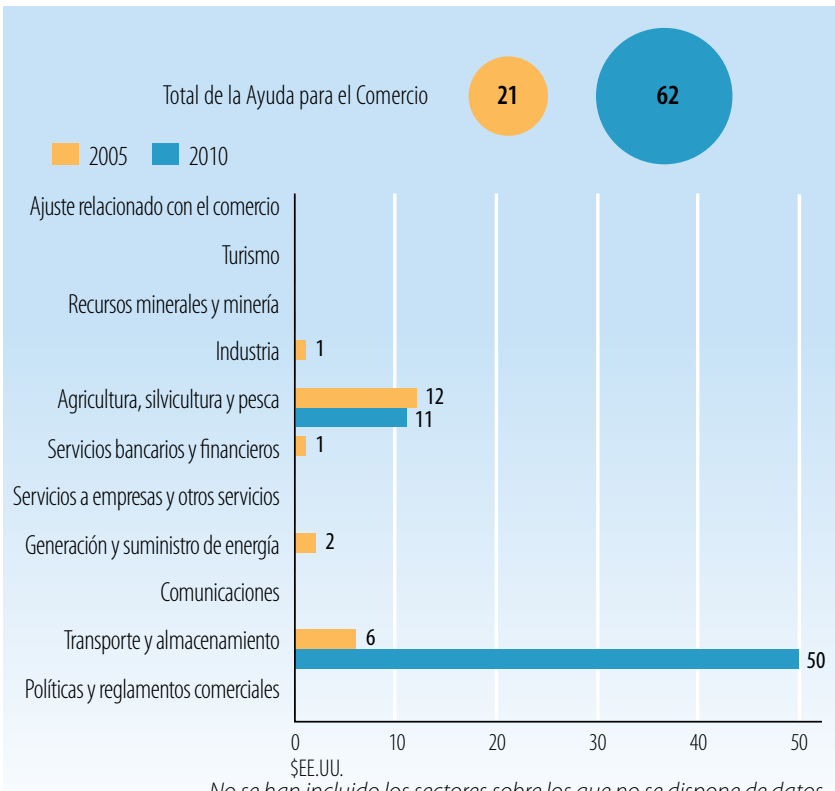

No se han incluido los sectores sobre los que no se dispone de datos.

Fuentes: OCDE, base de datos del SNPA del CAD sobre las actividades de ayuda

Desembolsos de la ayuda para el comercio: principales donantes (millones de \$EE.UU. corrientes)

\begin{tabular}{|l|r|r|r|}
\hline $\mathbf{2 0 0 5}$ & Valor & $\%$ & Principales donantes en 2005 \\
\hline Instituciones de la UE & 5,6 & 27 & \\
\hline Japón & 3,6 & 17 & \\
\hline Banco Africano de Desarrollo & 3,0 & 14 & $86 \%$ \\
\hline Francia & 2,9 & 14 & \\
\hline Banco Mundial & 2,9 & 14 & \\
\hline $\mathbf{2 0 1 0}$ & Valor & $\%$ & Principales donantes en $\mathbf{2 0 1 0}$ \\
\hline Instituciones de la UE & 41,1 & 66 & \\
\hline Francia & 6,5 & 11 & \\
\hline Banco Africano de Desarrollo & 6,0 & 10 & \\
\hline Kuwait & 2,2 & 4 & $\mathbf{9 3 \%}$ \\
\hline Alemania & 2,0 & 3 & \\
\hline
\end{tabular}

Fuentes: OCDE, base de datos del SNPA del CAD sobre las actividades de ayuda.

\section{INDICADORES COMERCIALES (PRODUCTOS)}

\section{Indicador}

$20052008 \quad 2011 \quad \Delta: 05-11(\%)$

Relación comercio/PIB (\%)

Exportaciones de servicios comerciales como

$\%$ de las exportaciones totales

Importaciones de servicios comerciales como

$\%$ de las importaciones totales

Productos intermedios distintos de los combustibles

(\% de las exportaciones de mercancías)

Productos intermedios distintos de los combustibles

(\% de las importaciones de mercancías)

\begin{tabular}{l|l|l|l|}
63 & 85 & 81 & 18 \\
\hline
\end{tabular}

Fuentes: Secretaría de la OMC.

Corrientes comerciales (millones de \$EE.UU. corrientes)

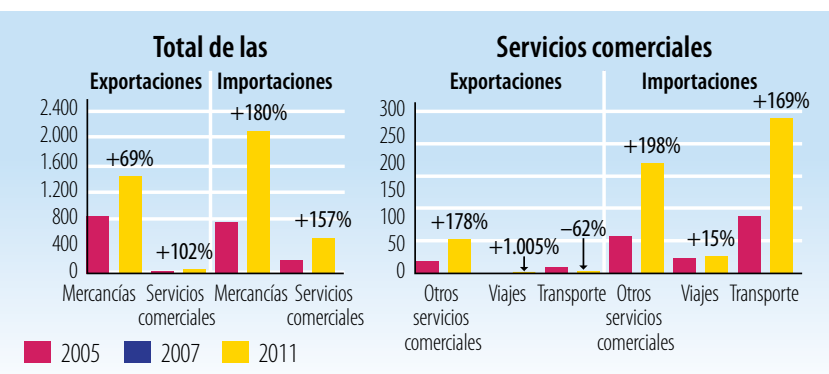

Fuentes: Secretaría de la OMC

Cinco principales mercados de exportación de mercancías (\%)

\begin{tabular}{|l|r|l|c|}
\hline 2005 & $\%$ & 2008 & $\%$ \\
\hline UE (27) & 64 & UE (27) & 50 \\
\hline Estados Unidos & 10 & Suiza & 19 \\
\hline Senegal & 3 & Federación de Rusia & 11 \\
\hline Canadá & 3 & Estados Unidos & 7 \\
\hline Malí & 3 & Canadá & 4 \\
\hline
\end{tabular}

Fuentes: Secretaría de la OMC

Cinco principales productos de exportación (\% de las exportaciones de mercancías)

\begin{tabular}{|c|c|c|c|}
\hline 2005 & $\%$ & 2008 & $\%$ \\
\hline $\begin{array}{l}\text { Minerales de aluminio y sus concentrados, } \\
\text { etc. }\end{array}$ & 65 & $\begin{array}{l}\text { Minerales de aluminio y sus concentrados, } \\
\text { etc. }\end{array}$ & 51 \\
\hline Oro no monetario, excepto minerales & 13 & Oro no monetario, excepto minerales & 32 \\
\hline Perlas y piedras preciosas & 7 & Impresos & 8 \\
\hline Pescado, fresco, refrigerado o congelado & 6 & Madera trabajada simplemente & 2 \\
\hline Caucho natural, etc. & 2 & Caucho natural, etc. & 2 \\
\hline
\end{tabular}

Fuentes: Secretaría de la OMC

Cinco principales mercados de importación de mercancías (\%)

\begin{tabular}{|l|r|l|c|}
\hline 2005 & $\%$ & 2008 & $\%$ \\
\hline UE (27) & 20 & UE (27) & 54 \\
\hline Côte d'Ivoire & 14 & China & 7 \\
\hline Estados Unidos & 7 & Estados Unidos & 5 \\
\hline China & 4 & Australia & 4 \\
\hline Tailandia & 3 & Brasil & 3 \\
\hline Fuentes: Secretaría de la OMC & & & \\
\hline
\end{tabular}

Cinco principales productos de importación (\% de las importaciones de mercancías)

\begin{tabular}{|l|r|l|c|}
\hline 2005 & $\%$ & 2008 & $\%$ \\
\hline Operaciones especiales no clasificadas & 52 & Productos derivados del petróleo & 33 \\
\hline Arroz & 6 & Equipo de ingeniería civil & 8 \\
\hline Cal, cemento y materiales de construcción & 3 & Cal, cemento y materiales de construcción & 4 \\
\hline Tabaco manufacturado & 3 & Arroz & 4 \\
\hline Estructuras metálicas, n.e.p. & 2 & $\begin{array}{l}\text { Equipos de telecomunicaciones y sus } \\
\text { partes, n.e.p. }\end{array}$ & 4 \\
\hline Fuentes:Secretaría de la OMC & & &
\end{tabular}




\section{LA AYUDA PARA EL COMERCIO EN SINNTESIS 2013}

\section{INDICADORES COMERCIALES (RESULTADOS)}

\section{Indicador}

Crecimiento del PIB (\%)

Número de exportadores

Índice de concentración de las exportaciones (productos) ( 0 a 1)

ACR sobre mercancías notificados a la OMC

AIE (servicios) notificados a la OMC

Sectores de servicios con compromisos en el marco del AGCS

\section{Aranceles (\%, 2005 et 2010)}

\begin{tabular}{l|l|l|l|l|} 
Importaciones: promedio aritmético de los aranceles NMF aplicados & 11,9 & 11,8
\end{tabular}

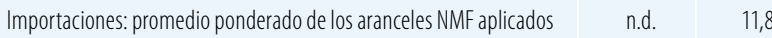

\begin{tabular}{|l|l|l|l|}
\hline Exportaciones: promedio ponderado de los aranceles impuestos & 1,6 & 2,4 \\
\hline
\end{tabular}

por los importadores

Exportaciones: libres de derechos (en \%)

$60,8 \quad 63,3$

Fuentes: Naciones Unidas, base de datos Comtrade; Banco Mundial, base de datos sobre dinámica de las empresas de exportación; Banco Mundial, Indicadores del Desarrollo Mundial; OMC, perfiles comerciales y arancelarios.

Participación en las exportaciones por región (\%)

\begin{tabular}{|l|r|r|}
\hline & $\mathbf{2 0 0 5}$ & $\mathbf{2 0 0 8}$ \\
\hline África & 7,3 & 2,7 \\
\hline Asia & 0,9 & 2,2 \\
\hline Comunidad de Estados Independientes & 1,2 & 14,1 \\
\hline Europa & 77,1 & 69,6 \\
\hline Oriente Medio & 0,1 & 0,6 \\
\hline América del Norte & 13,1 & 10,8 \\
\hline América del Sury América Central & 0,1 & 0,0 \\
\hline
\end{tabular}

Fuentes: OMC, perfiles comerciales y arancelarios

Indicadores de facilitación del comercio
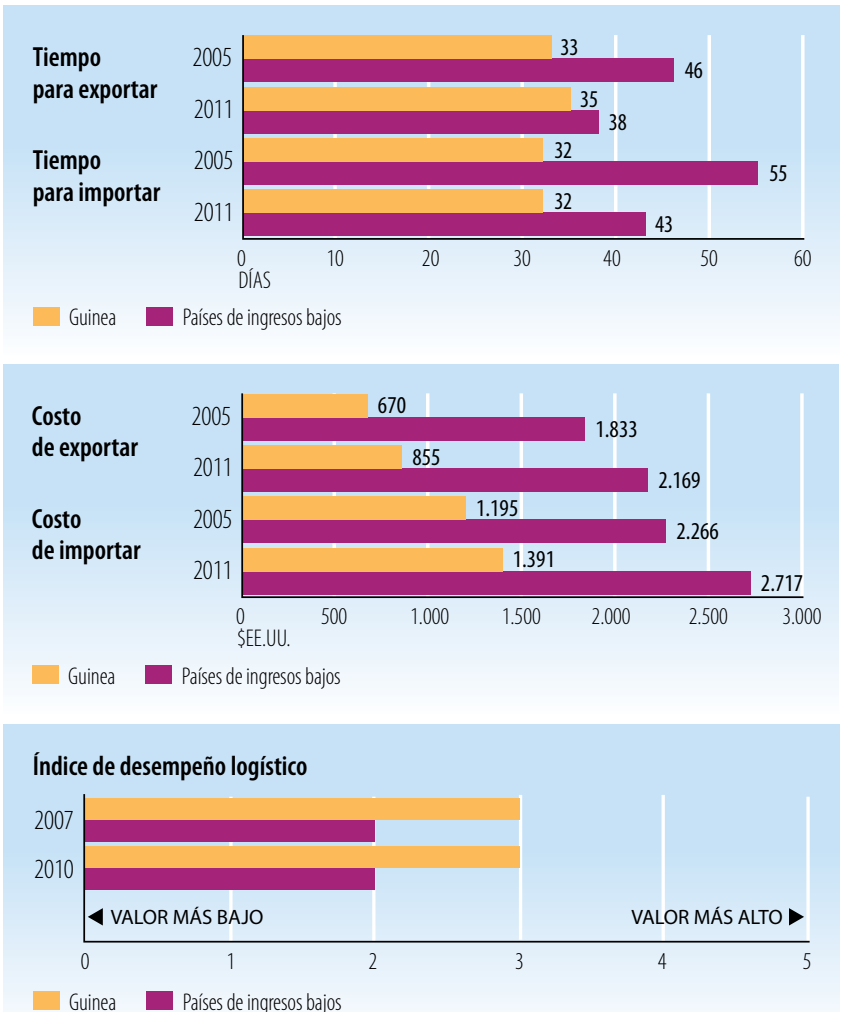

Fuentes: Banco Mundial, Indicadores del Desarrollo Mundial.

\begin{tabular}{|l|c|c|}
\hline INDICADORES DE DESARROLLO (EFECTOS) & \\
\hline Indicador & $\mathbf{2 0 0 5}$ & $\mathbf{2 0 1 0}$ \\
\hline Desempleo (\% de la fuerza de trabajo total) & n.d. & n.d. \\
\hline Población activa, mujeres (\% de la fuerza de trabajo total) & 44,7 & 45,2 \\
\hline A0D neta recibida (\% del InB) & 7,5 & 5,1 \\
\hline Derechos de importación percibidos (\% de los ingresos fiscales) & n.d. & n.d. \\
\hline Total del servicio de la deuda (\% de las exportaciones totales) & 17,5 & 5,6 \\
\hline Índice de desarrollo humano (0 a 1) & 0,33 & 0,34 \\
\hline
\end{tabular}

Fuentes: PNUD, indicadores internacionales sobre desarrollo humano; Banco Mundial, Indicadores del Desarrollo Mundial.

Producto interno bruto

PIB per cápita (PPA, dólares internacionales corrientes)

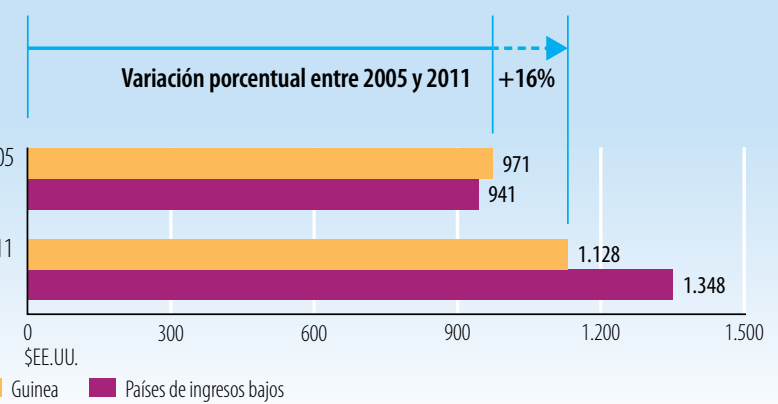

PIB per cápita (\$EE.UU. constantes de 2000)
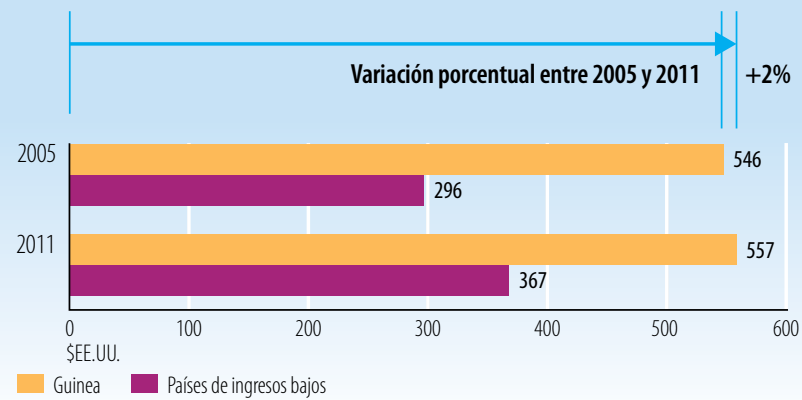

Fuentes: Banco Mundial, Indicadores del Desarrollo Mundial.

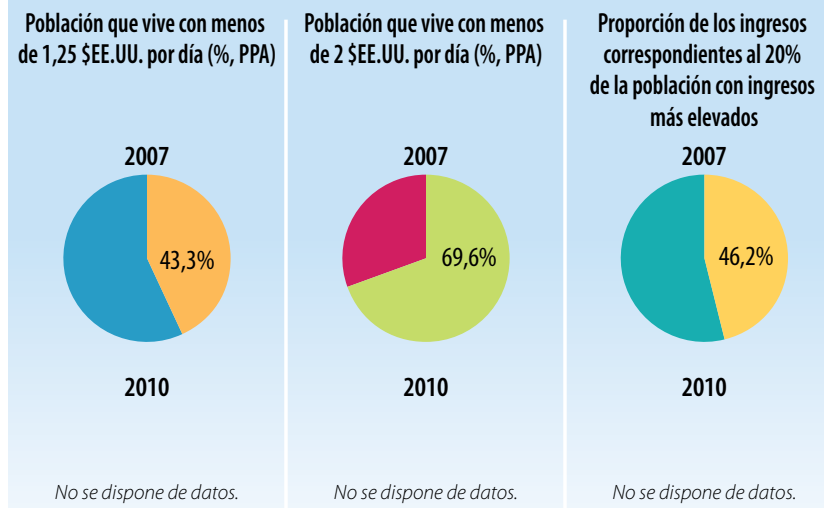

Fuentes: Banco Mundial, Indicadores del Desarrollo Mundial.

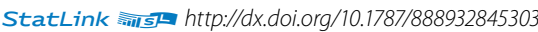




\section{Indicadores de la ayuda, el comercio y el desarrollo relativos a Haití}

\begin{tabular}{|c|c|c|c|c|}
\hline Indicador (millones de \$̦EE.UU. corrientes) & 2005 & 2008 & 2010 & $\Delta: 05-10(\%$ \\
\hline Formación bruta de capital fijo & n.d. & n.d. & n.d. & n.d. \\
\hline del cual: público & n.d. & n.d. & n.d. & n.d. \\
\hline del cual: privado & n.d. & n.d. & n.d. & n.d. \\
\hline \multicolumn{5}{|l|}{ Entrada de financiación externa } \\
\hline Entradas de IED & 26,0 & 29,8 & 150,0 & $477 \%$ \\
\hline $\begin{array}{l}\text { Deuda externa a largo plazo y fondos } \\
\text { desembolsados por el FMl }\end{array}$ & 92,8 & 406,2 & 410,9 & $343 \%$ \\
\hline $\begin{array}{l}\text { Corrientes comerciales en condiciones no } \\
\text { concesionarias }\end{array}$ & 0,0 & 0,0 & 3,3 & d.p.c. \\
\hline Corrientes de Ayuda para el Comercio & 25,4 & 83,0 & 312,7 & $1131 \%$ \\
\hline $\begin{array}{l}\text { Remesas de trabajadores y remuneración } \\
\text { de empleados }\end{array}$ & 986,2 & 1. 369,8 & $1.498,7$ & $52 \%$ \\
\hline
\end{tabular}

Fuentes: OCDE, base de datos del SNPA del CAD sobre las actividades de ayuda; Banco Mundial, Indicadores del Desarrollo Mundial; Banco Mundial, estadísticas de la deuda internacional.

Desembolsos de la ayuda para el comercio, por sector (millones de \$EE.UU. corrientes)

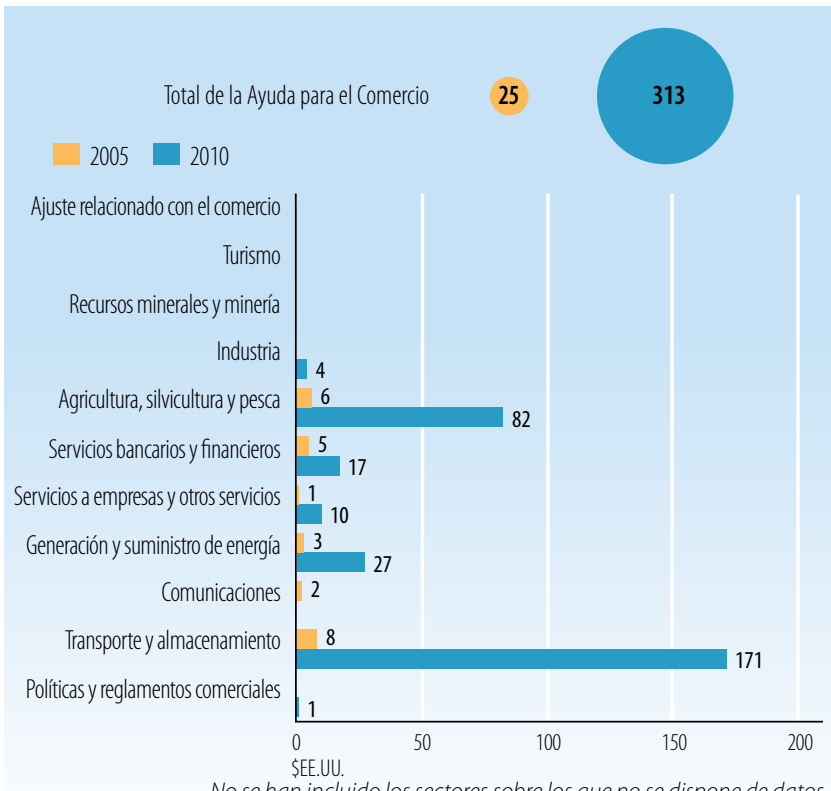

Fuentes: OCDE, base de datos del SNPA del CAD sobre las actividades de ayuda

Desembolsos de la ayuda para el comercio: principales donantes (millones de \$EE.UU. corrientes)

\begin{tabular}{|l|c|c|c|}
\hline $\mathbf{2 0 0 5}$ & Valor & $\%$ & Principales donantes en 2005 \\
\hline Banco Mundial & 11,3 & 45 & \\
\hline Canadá & 8,3 & 33 & \\
\hline Instituciones de la UE & 2,1 & 8 & $94 \%$ \\
\hline España & 1,0 & 4 & \\
\hline Alemania & 1,0 & 4 & \\
\hline $\mathbf{2 0 1 0}$ & Valor & $\%$ & Principales donantes en $\mathbf{2 0 1 0}$ \\
\hline BID & 76,9 & 25 & \\
\hline Canadá & 71,5 & 23 & \\
\hline Francia & 54,8 & 18 & \\
\hline Estados Unidos & 35,3 & 11 & $87 \%$ \\
\hline Banco Mundial & 32,4 & 10 \\
\hline
\end{tabular}

Fuentes: OCDE, base de datos del SNPA del CAD sobre las actividades de ayuda.

\section{INDICADORES COMERCIALES (PRODUCTOS)}

\section{Indicador}

$2005 \quad 2008 \quad 2011 \quad \Delta: 05-11(\%)$

Relación comercio/PIB (\%)

Exportaciones de servicios comerciales como

$\%$ de las exportaciones totales

Importaciones de servicios comerciales como

$\%$ de las importaciones totales

Productos intermedios distintos de los combustibles

(\% de las exportaciones de mercancías)

Productos intermedios distintos de los combustibles

(\% de las importaciones de mercancías)

\begin{tabular}{|l|l|l|l|l|}
\hline 57 & 56 & 67 & 10 \\
\hline
\end{tabular}

\begin{tabular}{|l|l|l|r|}
16 & 37 & 21 & 5
\end{tabular}

\begin{tabular}{l|l|l|l|}
28 & 25 & 27 & -2
\end{tabular}

n.d. n.d. n.d. n.d.

n.d. n.d. n.d. n.d.

Fuentes: Secretaría de la OMC.

Corrientes comerciales (millones de \$EE.UU. corrientes)

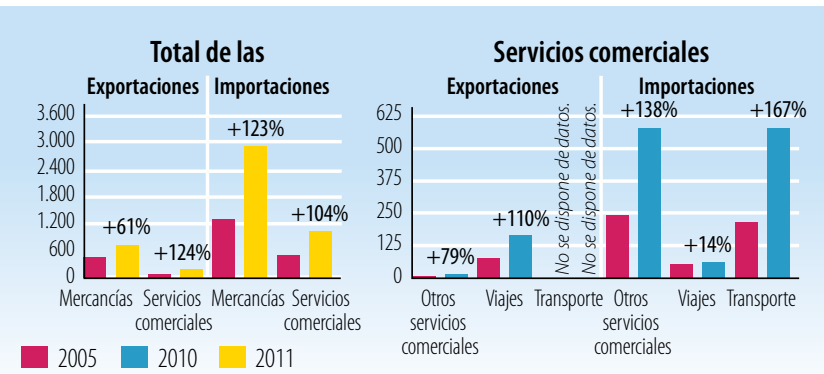

Fuentes: Secretaría de la OMC

Cinco principales mercados de exportación de mercancías (\%)

\begin{tabular}{|c|c|c|c|}
\hline & $\%$ & & $\%$ \\
\hline Nosedispone de datos. & & Nosedispone de datos. \\
\hline
\end{tabular}

Fuentes: Secretaría de la OMC

Cinco principales productos de exportación (\% de las exportaciones de mercancías)

No se dispone de datos.

No se dispone de datos.

Fuentes: Secretaría de la OMC

Cinco principales mercados de importación de mercancías (\%)

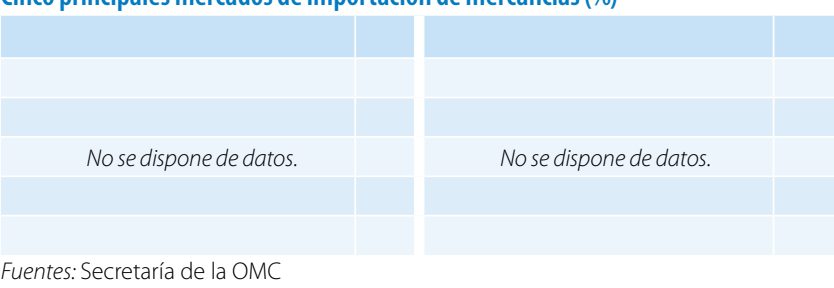

Cinco principales productos de importación (\% de las importaciones de mercancías)

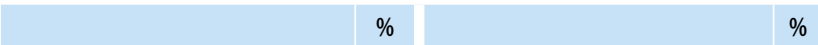

No se dispone de datos.

No se dispone de datos. 


\section{LA AYUDA PARA EL COMERCIO EN SIINTESIS 2013}

\section{INDICADORES COMERCIALES (RESULTADOS)}

Indicador

Crecimiento del PIB (\%)

Número de exportadores

Índice de concentración de las exportaciones (productos) (0 a 1)

ACR sobre mercancías notificados a la OMC

AIE (servicios) notificados a la OMC

Sectores de servicios con compromisos en el marco del AGCS

\section{Aranceles (\%, 2006 et 2011)}

\begin{tabular}{|l|l|l|l|}
\hline Importaciones: promedio aritmético de los aranceles NMF aplicados & 2,8 & 4,7
\end{tabular}

Importaciones: promedio ponderado de los aranceles NMF aplicados n.d. n.d.

\begin{tabular}{|l|l|l|l|}
\hline Exportaciones: promedio ponderado de los aranceles impuestos & 16,2 & 0,7
\end{tabular}

por los importadores

Exportaciones: libres de derechos (en \%)

$16,5 \quad 97,5$

Fuentes: Naciones Unidas, base de datos Comtrade; Banco Mundial, base de datos sobre dinámica de las empresas de exportación; Banco Mundial, Indicadores del

Desarrollo Mundial; OMC, perfiles comerciales y arancelarios.

Participación en las exportaciones por región (\%)

\begin{tabular}{|l|c|c|}
\hline África & 2005 & 2011 \\
\hline Asia & n.d. & n.d. \\
\hline Comunidad de Estados Independientes & n.d. & n.d. \\
\hline Europa & n.d. & n.d. \\
\hline Oriente Medio & n.d. & n.d. \\
\hline América del Norte & n.d. & n.d. \\
\hline América del Sury América Central & n.d. & n.d. \\
\hline
\end{tabular}

Fuentes: OMC, perfiles comerciales y arancelarios

Indicadores de facilitación del comercio

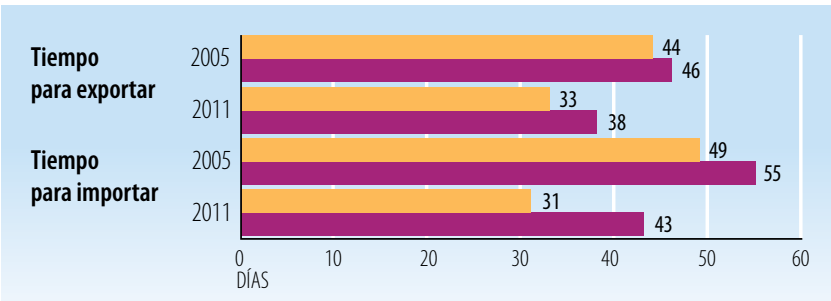

Haiti Páises de ingresos bajos
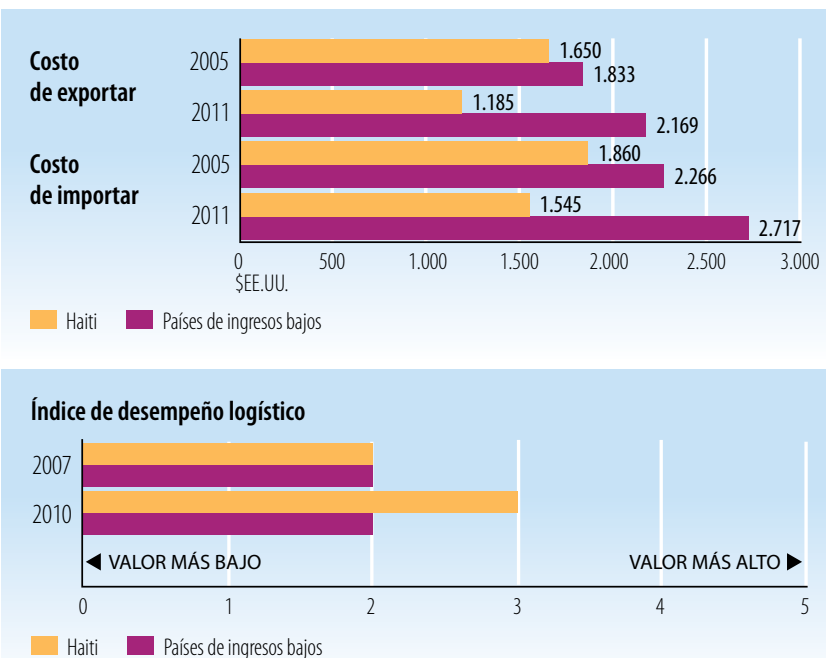

Fuentes: Banco Mundial, Indicadores del Desarrollo Mundial.

\begin{tabular}{|l|c|c|}
\hline INDICADORES DE DESARROLLO (EFECTOS) & \\
\hline Indicador & $\mathbf{2 0 0 5}$ & $\mathbf{2 0 1 0}$ \\
\hline Desempleo (\% de la fuerza de trabajo total) & n.d. & n.d. \\
\hline Población activa, mujeres (\% de la fuerza de trabajo total) & 46,8 & 47,0 \\
\hline AOD neta recibida (\% del INB) & 10,1 & 45,5 \\
\hline Derechos de importación percibidos (\% de los ingresos fiscales) & n.d. & n.d. \\
\hline Total del servicio de la deuda (\% de las exportaciones totales) & 9,4 & 15,7 \\
\hline Índice de desarrollo humano (0 a 1) & 0,43 & 0,45 \\
\hline
\end{tabular}

Fuentes: PNUD, indicadores internacionales sobre desarrollo humano; Banco Mundial, Indicadores del Desarrollo Mundial.

Producto interno bruto

PIB per cápita (PPA, dólares internacionales corrientes)

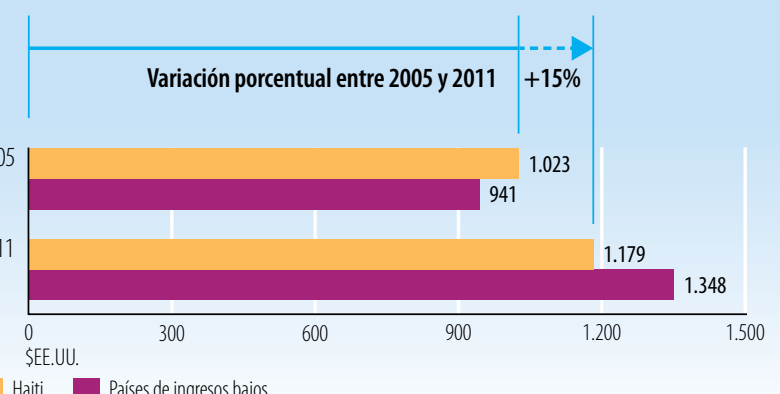

Haiti $\square$ Países de ingresos bajos

PIB per cápita (\$EE.UU. constantes de 2000)

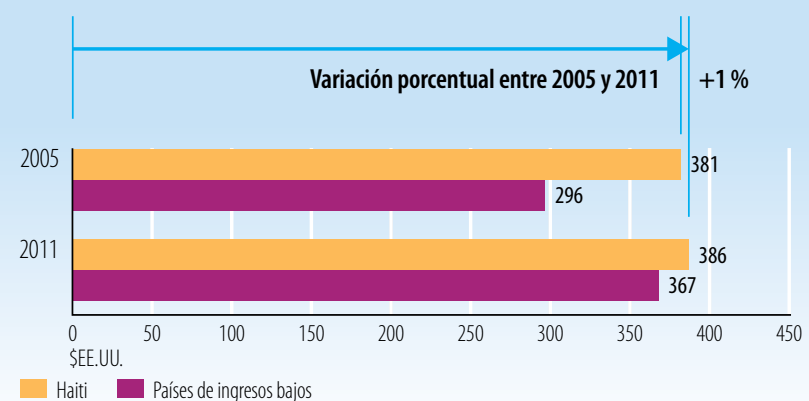

Fuentes: Banco Mundial, Indicadores del Desarrollo Mundial.

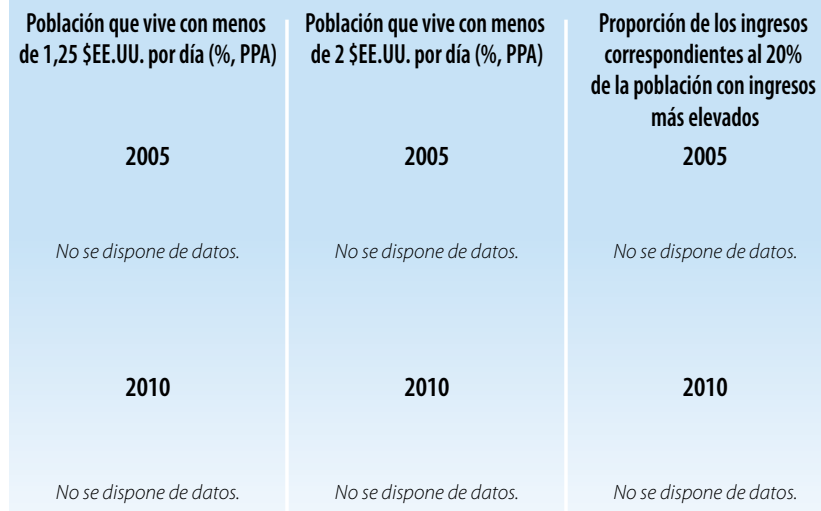

Fuentes: Banco Mundial, Indicadores del Desarrollo Mundial.

StatLink ㅊiाs] $h$ ttp://dx.doi.org/10.1787/888932845322 
Indicadores de la ayuda, el comercio y el desarrollo relativos a Honduras

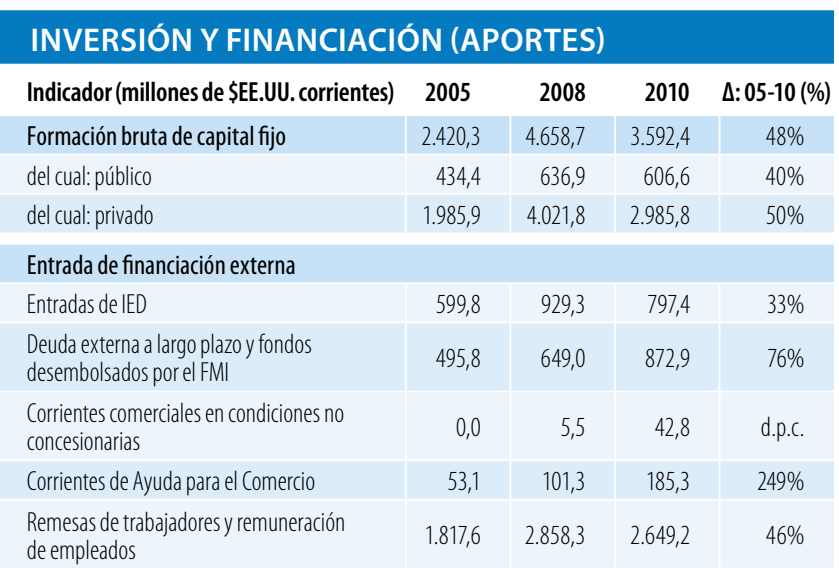

Fuentes: OCDE, base de datos del SNPA del CAD sobre las actividades de ayuda; Banco Mundial, Indicadores del Desarrollo Mundial; Banco Mundial, estadísticas de la deuda internacional.

Desembolsos de la ayuda para el comercio, por sector (millones de \$EE.UU. corrientes)

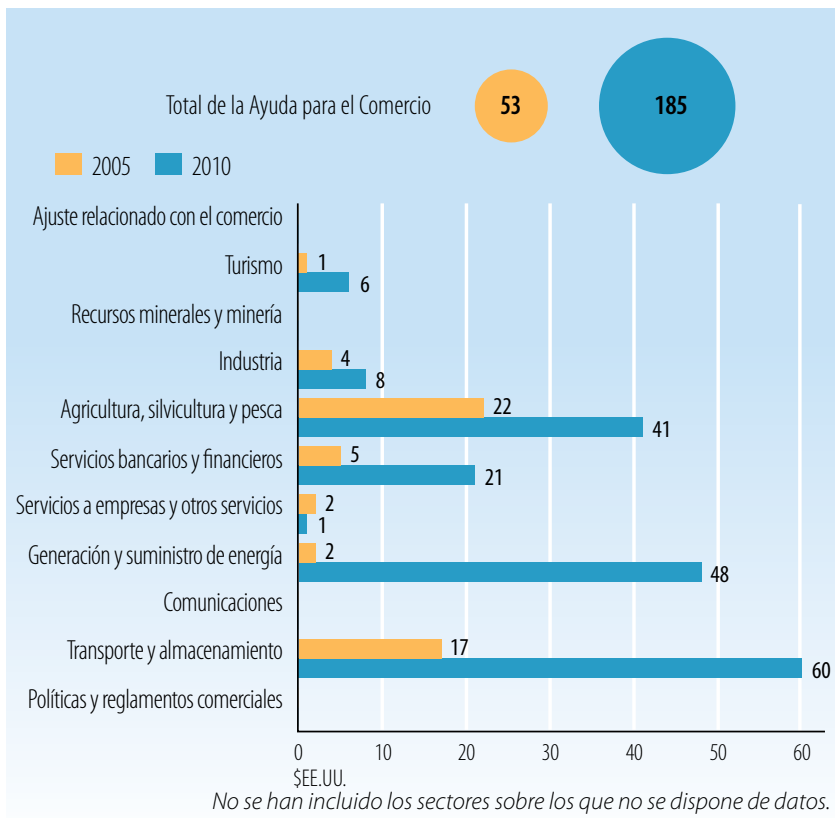

Fuentes: OCDE, base de datos del SNPA del CAD sobre las actividades de ayuda

Desembolsos de la ayuda para el comercio: principales donantes (millones de \$EE.UU. corrientes)

\begin{tabular}{|l|r|r|r|}
\hline $\mathbf{2 0 0 5}$ & Valor & $\%$ & Principales donantes en 2005 \\
\hline Banco Mundial & 34,6 & 65 & \\
\hline España & 4,9 & 9 & \\
\hline Alemania & 4,2 & 8 & \\
\hline Japón & 2,9 & 5 & \\
\hline Estados Unidos & 1,5 & 3 & \\
\hline 2010 & Valor & $\%$ & Principales donantes en 2010 \\
\hline Estados Unidos & 72,5 & 39 & \\
\hline BID & 37,7 & 20 & \\
\hline Reino Unido & 25,2 & 14 & \\
\hline Banco Mundial & 18,5 & 10 & $86 \%$ \\
\hline Alemania & 5,2 & 3 & \\
\hline
\end{tabular}

Fuentes: OCDE, base de datos del SNPA del CAD sobre las actividades de ayuda.

\section{INDICADORES COMERCIALES (PRODUCTOS)}

Indicador

$20052008 \quad 2011 \quad \Delta: 05-11(\%)$

Relación comercio/PIB (\%)

\begin{tabular}{|l|l|l|l|}
136 & 135 & 117 & -19 \\
\hline
\end{tabular}

Exportaciones de servicios comerciales como

$\%$ de las exportaciones totales

Importaciones de servicios comerciales como

$\%$ de las importaciones totales

Productos intermedios distintos de los combustibles

(\% de las exportaciones de mercancías)

Productos intermedios distintos de los combustibles

(\% de las importaciones de mercancías)

\begin{tabular}{|c|c|c|c|}
\hline 12 & 12 & 13 & 1 \\
\hline 12 & 10 & 13 & 1 \\
\hline 58 & n.d. & n.d. & n.d. \\
\hline 39 & n.d. & n.d. & n.d. \\
\hline
\end{tabular}

Fuentes: Secretaría de la OMC.

Corrientes comerciales (millones de \$EE.UU. corrientes)

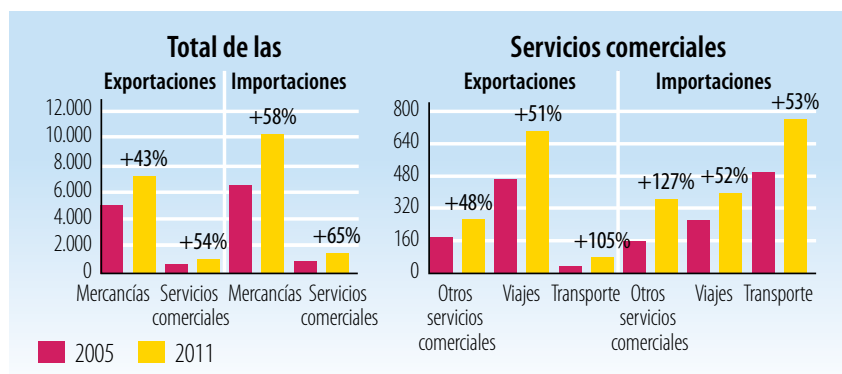

Fuentes-Secretaría de la OMC

Cinco principales mercados de exportación de mercancías (\%)

\begin{tabular}{|l|r|l|c|}
\hline $\mathbf{2 0 0 5}$ & $\%$ & $\mathbf{2 0 0 9}$ & $\%$ \\
\hline Estados Unidos & 42 & Estados Unidos & 48 \\
\hline UE (27) & 22 & UE (27) & 19 \\
\hline El Salvador & 10 & El Salvador & 7 \\
\hline Guatemala & 7 & Guatemala & 6 \\
\hline Nicaragua & 4 & Nicaragua & 4 \\
\hline
\end{tabular}

Fuentes: Secretaría de la OMC

Cinco principales productos de exportación (\% de las exportaciones de mercancías)

\begin{tabular}{|c|c|c|c|}
\hline 2005 & $\%$ & 2009 & $\%$ \\
\hline Caféy sucedáneos del café & 25 & Café y sucedáneos del café & 20 \\
\hline $\begin{array}{l}\text { Frutas y nueces, excepto nueces } \\
\text { oleaginosas }\end{array}$ & 15 & Impresos & 14 \\
\hline $\begin{array}{l}\text { Otros aceites y grasas fijos de origen } \\
\text { vegetal }\end{array}$ & 5 & $\begin{array}{l}\text { Frutas y nueces, excepto nueces } \\
\text { oleaginosas }\end{array}$ & 10 \\
\hline Jabón, preparados para limpiar y pulir, etc. & 3 & Oro no monetario, excepto minerales & 6 \\
\hline $\begin{array}{l}\text { Minerales de metales preciosos y sus } \\
\text { concentrados }\end{array}$ & 3 & $\begin{array}{l}\text { Otros aceites y grasas fijos de origen } \\
\text { vegetal }\end{array}$ & 5 \\
\hline
\end{tabular}

Fuentes: Secretaría de la OMC

Cinco principales mercados de importación de mercancías (\%)

\begin{tabular}{|l|r|l|c|}
\hline 2005 & $\%$ & 2009 & $\%$ \\
\hline Estados Unidos & 37 & Estados Unidos & 36 \\
\hline Guatemala & 8 & Guatemala & 11 \\
\hline UE (27) & 7 & México & 7 \\
\hline México & 6 & El Salvador & 6 \\
\hline Costa Rica & 5 & UE (27) & 6 \\
\hline
\end{tabular}

Fuentes: Secretaría de la OMC

Cinco principales productos de importación (\% de las importaciones de mercancías)

\begin{tabular}{|c|c|c|c|}
\hline 2005 & $\%$ & 2009 & $\%$ \\
\hline Productos derivados del petróleo & 21 & Productos derivados del petróleo & 18 \\
\hline Medicamentos & 5 & Medicamentos & 6 \\
\hline Productos y preparados comestibles, n.e.p. & 3 & $\begin{array}{l}\text { Equipos de telecomunicaciones y sus } \\
\text { partes, n.e.p. }\end{array}$ & 3 \\
\hline $\begin{array}{l}\text { Vehículos automotores para el transporte } \\
\text { de mercancías y vehículos automotores } \\
\text { para usos especiales }\end{array}$ & 3 & Productos y preparados comestibles, n.e.p. & 3 \\
\hline $\begin{array}{l}\text { Equipos de telecomunicaciones y sus } \\
\text { partes, n.e.p. }\end{array}$ & 3 & $\begin{array}{l}\text { Vehículos automotores para el transporte } \\
\text { de mercancías y vehículos automotores } \\
\text { para usos especiales }\end{array}$ & 2 \\
\hline
\end{tabular}




\section{INDICADORES COMERCIALES (RESULTADOS)}

\section{Indicador}

Crecimiento del PIB (\%)

Número de exportadores

Índice de concentración de las exportaciones (productos) (0 a 1)

ACR sobre mercancías notificados a la OMC

AIE (servicios) notificados a la OMC

Sectores de servicios con compromisos en el marco del AGCS

\section{Aranceles (\%)}

Importaciones: promedio aritmético de los aranceles NMF aplicado

Importaciones: promedio ponderado de los aranceles NMF aplicados

Exportaciones: promedio ponderado de los aranceles impuestos

por los importadores

Exportaciones: libres de derechos (en \%)

Uase de datos Comtrade; Banco Mundial, base de datos sobre dinámica de las empresas de exportación; Banco Mundial, Indicadores del

Desarrollo Mundial; OMC, perfiles comerciales y arancelarios.

Participación en las exportaciones por región (\%)

\begin{tabular}{|l|r|r|}
\hline África & $\mathbf{2 0 0 5}$ & $\mathbf{2 0 0 9}$ \\
\hline Asia & 0,0 & 0,4 \\
\hline Comunidad de Estados Independientes & 5,1 & 5,6 \\
\hline Europa & 0,5 & 0,1 \\
\hline Oriente Medio & 22,8 & 19,9 \\
\hline América del Norte & 0,1 & 0,3 \\
\hline América del Sury América Central & 44,5 & 50,2 \\
\hline
\end{tabular}

Fuentes: OMC, perfiles comerciales y arancelarios

Indicadores de facilitación del comercio
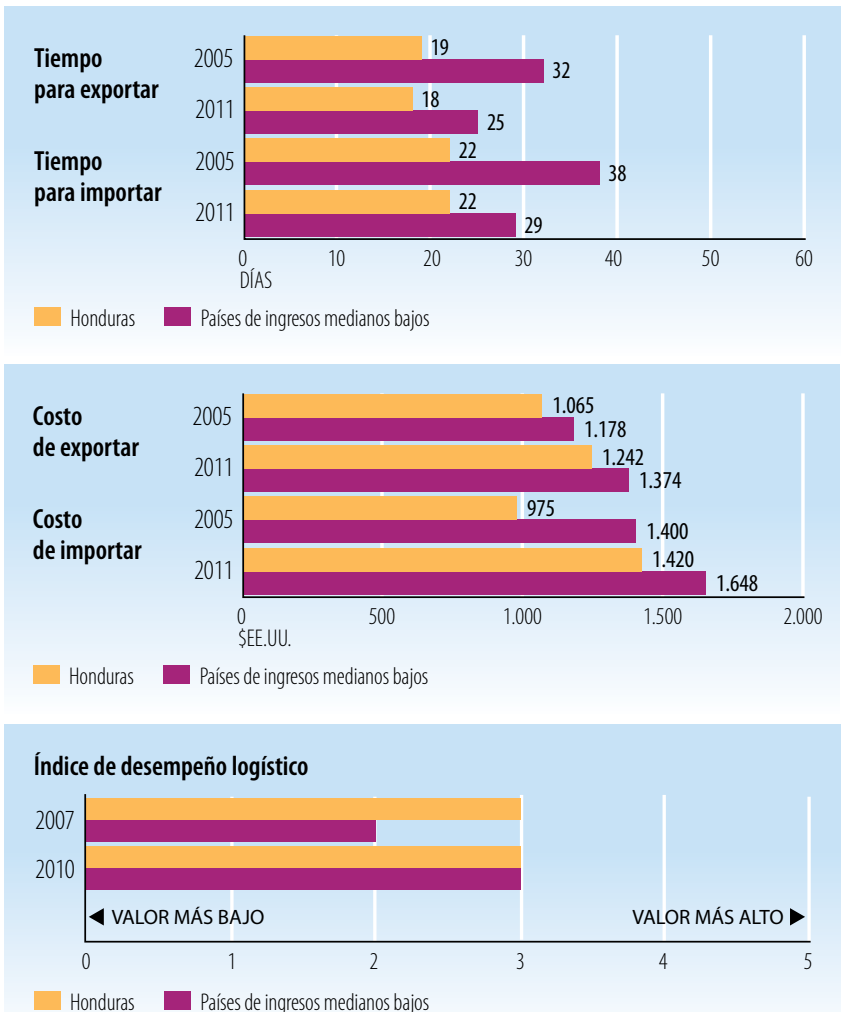

Fuentes: Banco Mundial, Indicadores del Desarrollo Mundial.

\begin{tabular}{l|c|c|}
\hline \multicolumn{2}{|l}{ INDICADORES DE DESARROLLO (EFECTOS) } \\
\hline Indicador & $\mathbf{2 0 0 5}$ & $\mathbf{2 0 1 0}$ \\
\hline Desempleo (\% de la fuerza de trabajo total) & 4,2 & n.d. \\
\hline Población activa, mujeres (\% de la fuerza de trabajo total) & 32,8 & 34,1 \\
\hline AOD neta recibida (\% del INB) & 7,5 & 3,9 \\
\hline Derechos de importación percibidos (\% de los ingresos fiscales) & 7,7 & 5,5 \\
\hline Total del servicio de la deuda (\% de las exportaciones totales) & 6,5 & 7,6 \\
\hline Índice de desarrollo humano (0 a 1) & 0,60 & 0,62 \\
\hline
\end{tabular}

Fuentes: PNUD, indicadores internacionales sobre desarrollo humano; Banco Mundial, Indicadores del Desarrollo Mundial.

Producto interno bruto

PIB per cápita (PPA, dólares internacionales corrientes)

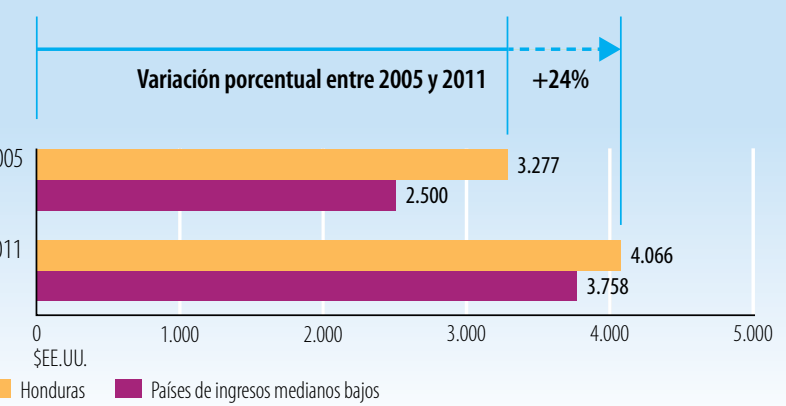

PIB per cápita (\$EE.UU. constantes de 2000)
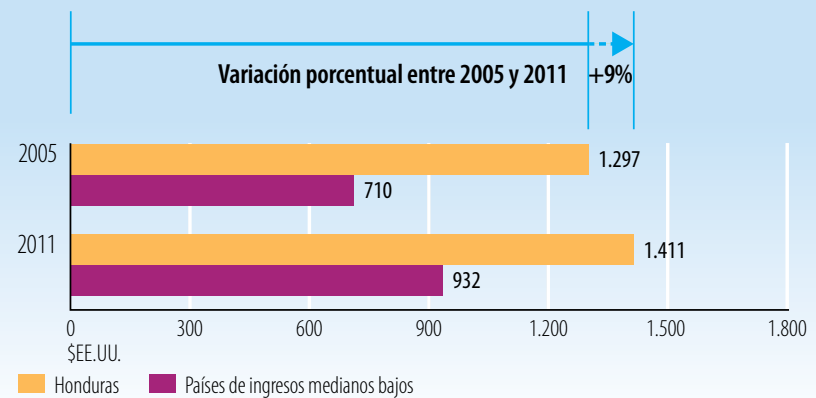

Fuentes: Banco Mundial, Indicadores del Desarrollo Mundial.

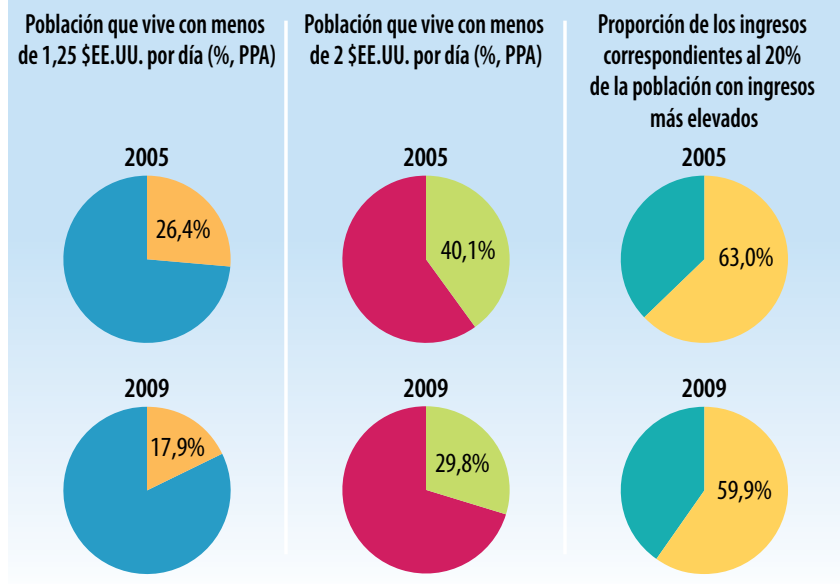

Fuentes: Banco Mundial, Indicadores del Desarrollo Mundial.

StatLink inा St http://dx.doi.org/10.1787/888932845341 
Indicadores de la ayuda, el comercio y el desarrollo relativos a la India

\begin{tabular}{|c|c|c|c|c|}
\hline Indicador (millones de \$̦EE.UU. corrientes) & 2005 & 2008 & 2010 & $\Delta: 05-10(\%)$ \\
\hline Formación bruta de capital fijo & $253.039,0$ & $395.946,0$ & $511.692,2$ & $102 \%$ \\
\hline del cual: público & $61.287,5$ & $104.514,1$ & $136.060,8$ & $122 \%$ \\
\hline del cual: privado & $191.751,6$ & $291.432,0$ & $375.631,4$ & $96 \%$ \\
\hline \multicolumn{5}{|l|}{ Entrada de financiación externa } \\
\hline Entradas de IED & $7.606,4$ & $43.406,3$ & $24.159,2$ & $218 \%$ \\
\hline $\begin{array}{l}\text { Deuda externa a largo plazo y fondos } \\
\text { desembolsados por el FMl }\end{array}$ & $19.380,3$ & $38.689,9$ & $43.419,8$ & $124 \%$ \\
\hline $\begin{array}{l}\text { Corrientes comerciales en condiciones no } \\
\text { concesionarias }\end{array}$ & 826,8 & $1.128,0$ & $4.540,1$ & $449 \%$ \\
\hline Corrientes de Ayuda para el Comercio & 894,2 & $1.661,3$ & $2.298,5$ & $157 \%$ \\
\hline $\begin{array}{l}\text { Remesas de trabajadores y remuneración } \\
\text { de empleados }\end{array}$ & $22.125,1$ & $49.977,3$ & $54.034,7$ & $144 \%$ \\
\hline
\end{tabular}

Fuentes: OCDE, base de datos del SNPA del CAD sobre las actividades de ayuda; Banco Mundial, Indicadores del Desarrollo Mundial; Banco Mundial, estadísticas de la deuda internacional.

Desembolsos de la ayuda para el comercio, por sector (millones de \$EE.UU. corrientes)

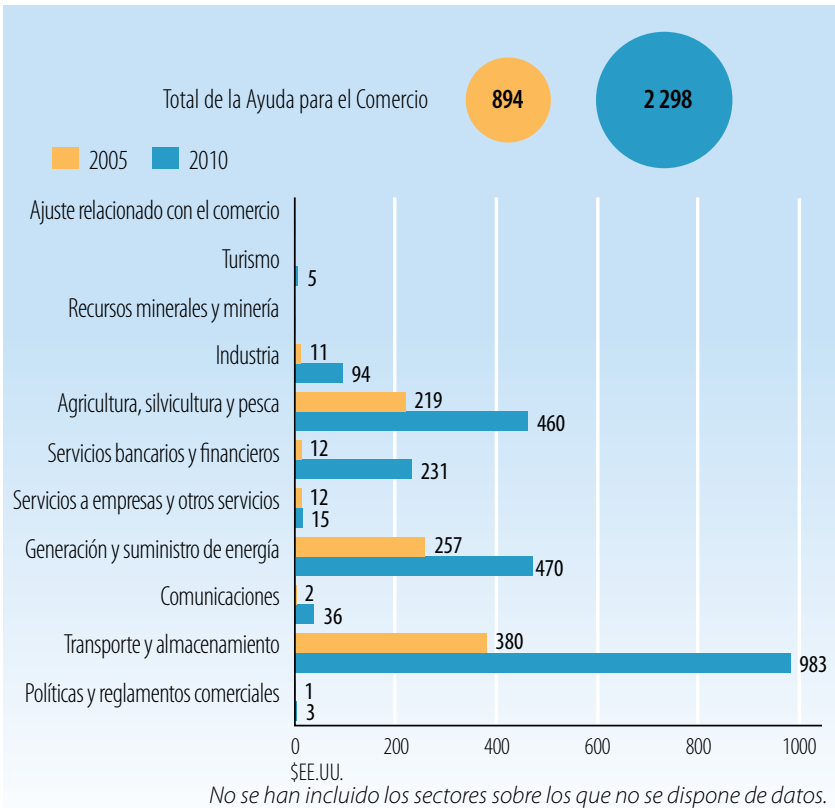

Fuentes: OCDE, base de datos del SNPA del CAD sobre las actividades de ayuda

Desembolsos de la ayuda para el comercio: principales donantes (millones de \$EE.UU. corrientes)

\begin{tabular}{|l|r|r|}
\hline $\mathbf{2 0 0 5}$ & Valor & $\%$ \\
\hline Japón & 492,6 & 55 \\
\hline Banco Mundial & 290,8 & 33 \\
\hline Reino Unido & 32,6 & 4 \\
\hline Noruega & 17,9 & 2 \\
\hline Alemania & 16,1 & 2 \\
\hline $\mathbf{2 0 1 0}$ & Valor & $\%$ \\
\hline Japón & 1372,0 & 60 \\
\hline Alemania & 400,8 & 17 \\
\hline Banco Mundial & 285,4 & 12 \\
\hline Reino Unido & 186,4 & 8 \\
\hline Estados Unidos & 22,5 & 1 \\
\hline
\end{tabular}

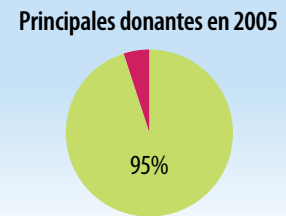

Principales donantes en 2010

Fuentes: OCDE, base de datos del SNPA del CAD sobre las actividades de ayuda.

\section{INDICADORES COMERCIALES (PRODUCTOS)}

\section{Indicador}

$2005 \quad 2008 \quad 2011 \quad \Delta: 05-11(\%)$

Relación comercio/PIB (\%)

Exportaciones de servicios comerciales como

$\%$ de las exportaciones totales

Importaciones de servicios comerciales como

$\%$ de las importaciones totales

Productos intermedios distintos de los combustibles

(\% de las exportaciones de mercancías)

Productos intermedios distintos de los combustibles

(\% de las importaciones de mercancías)

\begin{tabular}{|l|l|l|l|}
\hline 40 & 56 & 53 & 13 \\
\hline
\end{tabular}

Fuentes: Secretaría de la OMC.

Corrientes comerciales (millones de \$EE.UU. corrientes)

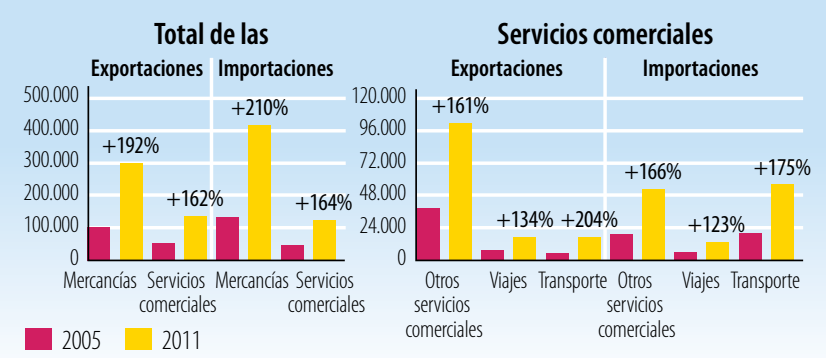

Fuentes: Secretaría de la OMC

Cinco principales mercados de exportación de mercancías (\%)

\begin{tabular}{|l|r|l|c|}
\hline 2005 & $\%$ & 2010 & $\%$ \\
\hline UE (27) & 23 & UE (27) & 19 \\
\hline Estados Unidos & 16 & Emiratos Árabes Unidos & 12 \\
\hline Emiratos Árabes Unidos & 8 & Estados Unidos & 11 \\
\hline China & 7 & China & 8 \\
\hline Singapur & 5 & Hong Kong, China & 4 \\
\hline
\end{tabular}

Fuentes: Secretaría de la OMC

Cinco principales productos de exportación (\% de las exportaciones de mercancías) 2005

Perlas y piedras preciosas

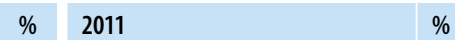

Productos derivados del petróleo

12 Productos derivados del petróleo 18

Mineral de hierro y sus concentrados

10 Perlas y piedras preciosas

Joyas y objetos de oro o plata, n.e.p.

Prendas de vestir para mujeres y niñas,

excepto las de punto

4 Joyas y objetos de oro o plata, n.e.p. 5

4 Operaciones especiales no clasificadas 5

Fuentes: Secretaría de la OMC

Cinco principales mercados de importación de mercancías (\%)

\begin{tabular}{|l|r|l|c|}
\hline 2005 & $\%$ & 2010 & $\%$ \\
\hline UE (27) & 17 & UE (27) & 12 \\
\hline China & 7 & China & 12 \\
\hline Estados Unidos & 6 & Emiratos Árabes Unidos & 9 \\
\hline Suiza & 5 & Suiza & 6 \\
\hline Emiratos Árabes Unidos & 4 & Arabia Saudita, Reino de la & 6 \\
\hline
\end{tabular}

Fuentes: Secretaría de la OMC

Cinco principales productos de importación (\% de las importaciones de mercancías)

\begin{tabular}{|c|c|c|}
\hline 2005 & $\%$ & 2011 \\
\hline Aceites de petróleo, crudos & 25 & Aceites de petróleo, crudos \\
\hline Oro no monetario, excepto minerales & 8 & Oro no monetario, excepto minerales \\
\hline Perlas y piedras preciosas & 8 & Perlas y piedras preciosas \\
\hline $\begin{array}{l}\text { Equipos de telecomunicaciones y sus } \\
\text { partes, n.e.p. }\end{array}$ & 4 & Hulla sin aglomerar \\
\hline Productos derivados del petróleo & 4 & $\begin{array}{l}\text { Equipos de telecomunicaciones y sus } \\
\text { partes, n.e.p. }\end{array}$ \\
\hline
\end{tabular}

Fuentes: Secretaría de la OMC 


\section{LA AYUDA PARA EL COMERCIO EN SÍNTESIS 2013}

\begin{tabular}{|l|c|r|}
\hline \multicolumn{3}{|l}{ INDICADORES COMERCIALES (RESULTADOS) } \\
\hline Indicador & 2005 & 2011 \\
\hline Crecimiento del PIB (\%) & 9,3 & 6,9 \\
\hline Número de exportadores & n.d. & n.d. \\
\hline Índice de concentración de las exportaciones (productos) (0 a 1) & 0,02 & 0,03 \\
\hline ACR sobre mercancías notificados a la OMC & n.d. & 15 \\
\hline AIE (servicios) notificados a la OMC & n.d. & 4 \\
\hline Sectores de servicios con compromisos en el marco del AGCS & 37 & 37 \\
\hline Aranceles (\%, 2005-2010) & & \\
\hline Importaciones: promedio aritmético de los aranceles NMF aplicados & 19,2 & 12,6 \\
\hline Importaciones: promedio ponderado de los aranceles NMF aplicados & 14,7 & 7,2 \\
\hline Exportaciones: promedio ponderado de los aranceles impuestos & 2,9 & 2,0 \\
\hline por los importadores & 66,2 & 70,7 \\
\hline Exportaciones: libres de derechos (en \%) & & \\
\hline
\end{tabular}

Fuentes: Naciones Unidas, base de datos Comtrade; Banco Mundial, base de datos sobre dinámica de las empresas de exportación; Banco Mundial, Indicadores del Desarrollo Mundial; OMC, perfiles comerciales y arancelarios.

Participación en las exportaciones por región (\%)

\begin{tabular}{|l|r|r|}
\hline & 2005 & 2011 \\
\hline África & 6,7 & 7,7 \\
\hline Asia & 32,8 & 30,8 \\
\hline Comunidad de Estados Independientes & 1,2 & 1,0 \\
\hline Europa & 24,1 & 19,9 \\
\hline Oriente Medio & 14,6 & 18,3 \\
\hline América del Norte & 17,9 & 12,0 \\
\hline América del Sury América Central & 2,4 & 3,9 \\
\hline
\end{tabular}

Fuentes: OMC, perfiles comerciales y arancelarios

Indicadores de facilitación del comercio
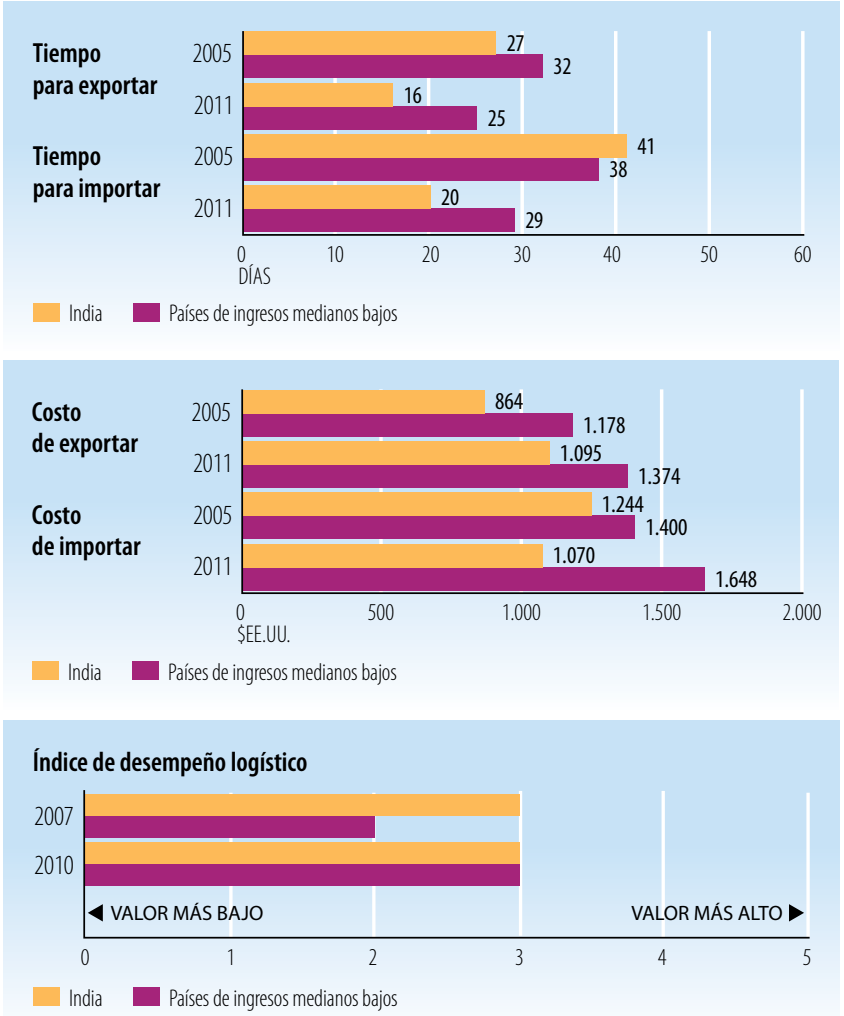

Fuentes: Banco Mundial, Indicadores del Desarrollo Mundial.

\begin{tabular}{l|c|c|}
\hline INDICADORES DE DESARROLLO (EFECTOS) \\
\hline Indicador & 2005 & $\mathbf{2 0 1 0}$ \\
\hline Desempleo (\% de la fuerza de trabajo total) & 4,4 & n.d. \\
\hline Población activa, mujeres (\% de la fuerza de trabajo total) & 29,5 & 25,3 \\
\hline AOD neta recibida (\% del INB) & 0,2 & 0,2 \\
\hline Derechos de importación percibidos (\% de los ingresos fiscales) & n.d. & n.d. \\
\hline Total del servicio de la deuda (\% de las exportaciones totales) & 14,9 & 5,6 \\
\hline Índice de desarrollo humano (0 a 1) & 0,50 & 0,54 \\
\hline
\end{tabular}

Fuentes: PNUD, indicadores internacionales sobre desarrollo humano; Banco Mundial, Indicadores del Desarrollo Mundial.

Producto interno bruto

PIB per cápita (PPA, dólares internacionales corrientes)

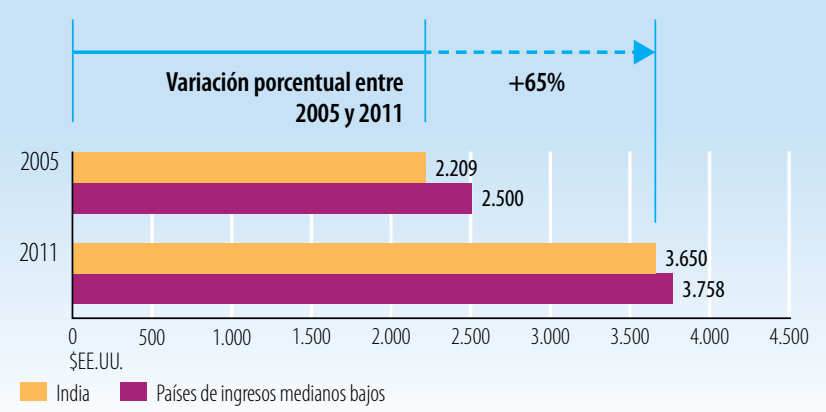

PIB per cápita (\$EE.UU. constantes de 2000)

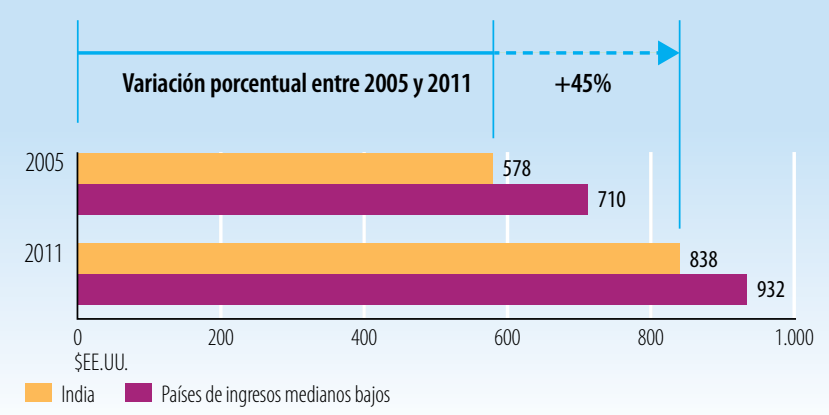

Fuentes: Banco Mundial, Indicadores del Desarrollo Mundial.

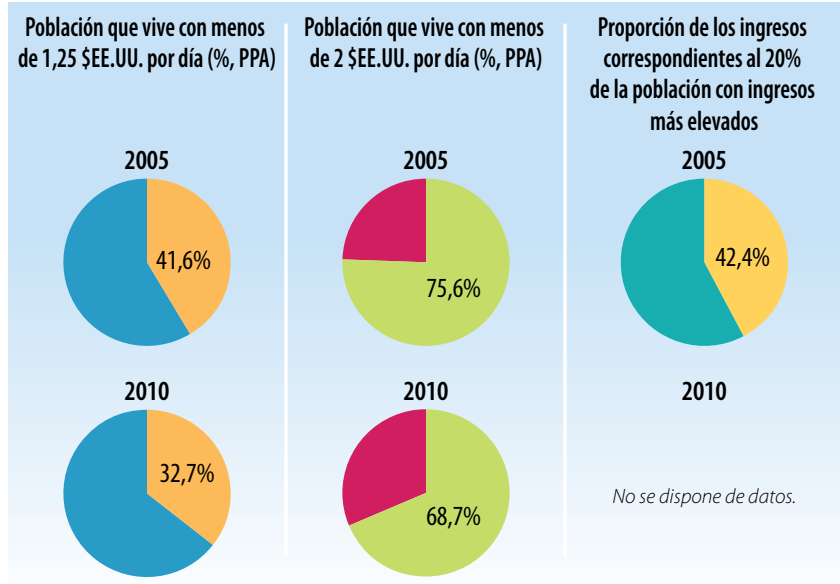

Fuentes: Banco Mundial, Indicadores del Desarrollo Mundial.

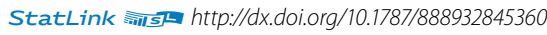




\section{Indicadores de la ayuda, el comercio y el desarrollo relativos a Indonesia}

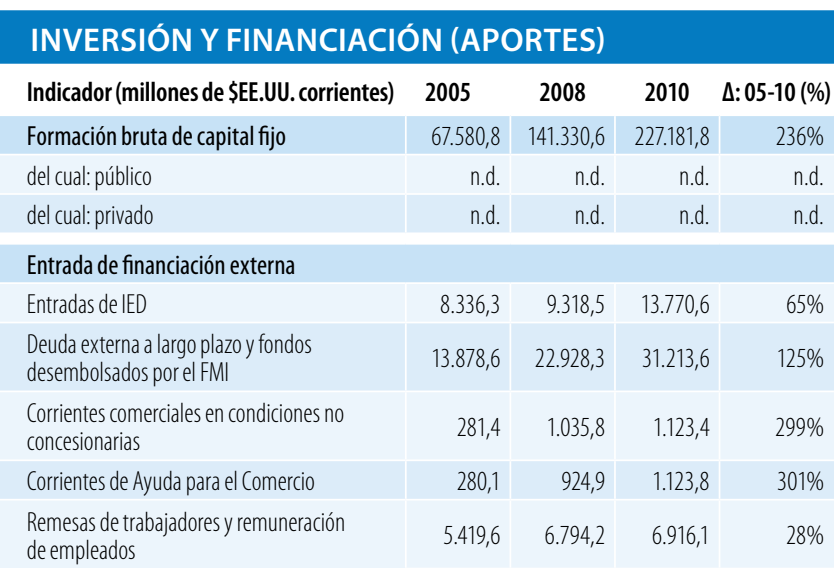

Fuentes: OCDE, base de datos del SNPA del CAD sobre las actividades de ayuda; Banco Mundial, Indicadores del Desarrollo Mundial; Banco Mundial, estadísticas de la deuda internacional.

Desembolsos de la ayuda para el comercio, por sector (millones de \$EE.UU. corrientes)

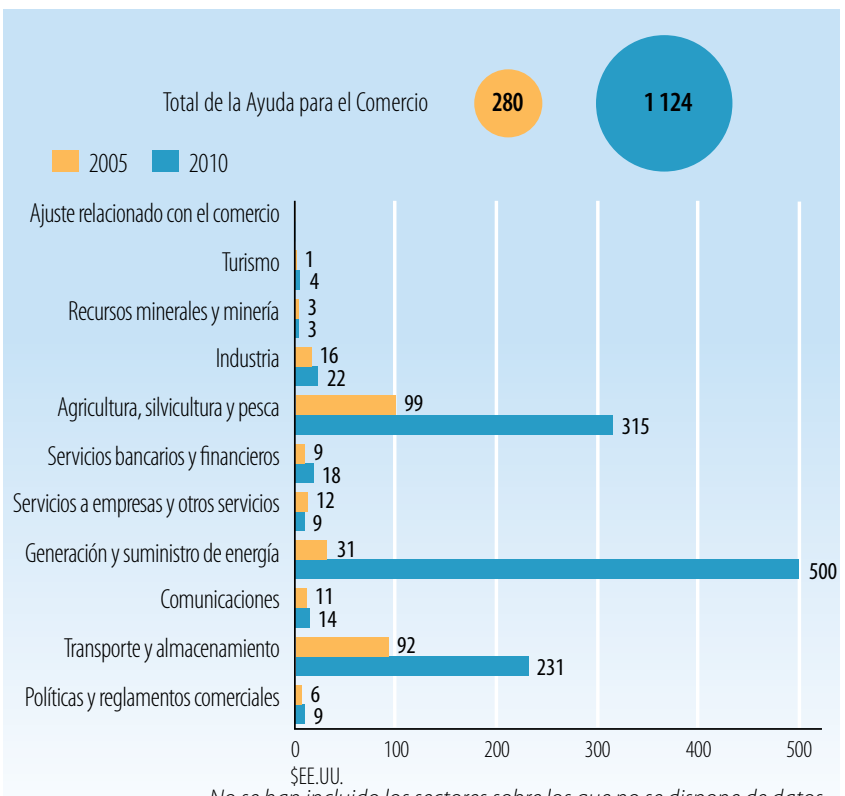

Fuentes: OCDE, base de datos del SNPA del CAD sobre las actividades de ayuda

Desembolsos de la ayuda para el comercio: principales donantes (millones de \$EE.UU. corrientes)

\begin{tabular}{|l|c|c|c|}
\hline $\mathbf{2 0 0 5}$ & Valor & $\%$ & Principales donantes en $\mathbf{2 0 0 5}$ \\
\hline Japón & 182,1 & 65 & \\
\hline Alemania & 34,9 & 12 & \\
\hline Países Bajos & 10,8 & 4 & $87 \%$ \\
\hline Banco Mundial & 8,1 & 3 & \\
\hline Reino Unido & 7,9 & 3 & \\
\hline $\mathbf{2 0 1 0}$ & Valor & $\%$ & Principales donantes en $\mathbf{2 0 1 0}$ \\
\hline Japón & 779,7 & 69 & \\
\hline Estados Unidos & 75,7 & 7 & \\
\hline Australia & 72,4 & 6 & \\
\hline Alemania & 39,8 & 4 & $89 \%$ \\
\hline Noruega & 31,8 & 3 & \\
\hline
\end{tabular}

Fuentes: OCDE, base de datos del SNPA del CAD sobre las actividades de ayuda.

\section{INDICADORES COMERCIALES (PRODUCTOS)}

Indicador $2005 \quad 2008 \quad 2011 \quad \Delta: 05-11(\%)$

Relación comercio/PIB (\%)

\begin{tabular}{l|l|l|l|}
67 & 59 & 50 & -17
\end{tabular}

Exportaciones de servicios comerciales como

$\%$ de las exportaciones totales

Importaciones de servicios comerciales como

$\%$ de las importaciones totales

Productos intermedios distintos de los combustibles

(\% de las exportaciones de mercancías)

Productos intermedios distintos de los combustibles

(\% de las importaciones de mercancías)

\begin{tabular}{l|l|l|l|}
13 & 10 & 9 & -4
\end{tabular}

Fuentes: Secretaría de la OMC.

Corrientes comerciales (millones de \$EE.UU. corrientes)

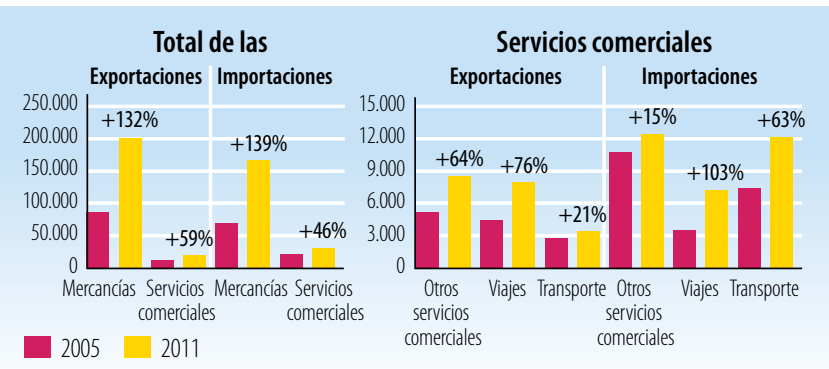

Fuentes: Secretaría de la OMC

Cinco principales mercados de exportación de mercancías (\%)

\begin{tabular}{|l|r|l|c|}
\hline 2005 & $\%$ & 2010 & $\%$ \\
\hline Japón & 21 & Japón & 16 \\
\hline UE (27) & 12 & UE (27) & 11 \\
\hline Estados Unidos & 12 & China & 10 \\
\hline Singapur & 9 & Estados Unidos & 9 \\
\hline Corea, Rep. de & 8 & Singapur & 9 \\
\hline
\end{tabular}

Fuentes: Secretaría de la OMC

Cinco principales productos de exportación (\% de las exportaciones de mercancías)

\begin{tabular}{|l|c|l|l|}
\hline $\mathbf{2 0 0 5}$ & $\%$ & $\mathbf{2 0 1 1}$ & $\%$ \\
\hline $\begin{array}{l}\text { Gas natural } \\
\text { Aceites de petróleo, crudos }\end{array}$ & 10 & Hulla sin aglomerar & 13 \\
\hline $\begin{array}{l}\text { Otros aceites y grasas fijos de origen } \\
\text { vegetal }\end{array}$ & 6 & $\begin{array}{l}\text { Otros aceites y grasas fijos de origen } \\
\text { vegetal }\end{array}$ & 11 \\
\hline $\begin{array}{l}\text { Hulla sin aglomerar } \\
\text { Minerales de cobrey sus concentrados }\end{array}$ & 5 & Aceites de petróleo, crudos & 7 \\
\hline \begin{tabular}{l} 
Fuentes: Secretaría de la OMC \\
\hline
\end{tabular} & & Caucho natural, etc. & 6 \\
\hline
\end{tabular}

Cinco principales mercados de importación de mercancías (\%)

\begin{tabular}{|l|c|l|c|}
\hline $\mathbf{2 0 0 5}$ & $\%$ & $\mathbf{2 0 1 0}$ & $\%$ \\
\hline Singapur & 16 & China & 15 \\
\hline Japón & 12 & Singapur & 15 \\
\hline UE $(27)$ & 10 & Japón & 13 \\
\hline China & 10 & UE (27) & 7 \\
\hline Estados Unidos & 7 & Estados Unidos & 7 \\
\hline
\end{tabular}

Fuentes: Secretaría de la OMC

Cinco principales productos de importación (\% de las importaciones de mercancías)

\begin{tabular}{|c|c|c|c|}
\hline 2005 & $\%$ & 2011 & $\%$ \\
\hline Productos derivados del petróleo & 18 & Productos derivados del petróleo & 16 \\
\hline Aceites de petróleo, crudos & 12 & Aceites de petróleo, crudos & 6 \\
\hline Hidrocarburos, n.e.p., y sus derivados & 3 & $\begin{array}{l}\text { Equipos de telecomunicaciones y sus } \\
\text { partes, n.e.p. }\end{array}$ & 4 \\
\hline $\begin{array}{l}\text { Equipos de telecomunicaciones y sus } \\
\text { partes, n.e.p. }\end{array}$ & 2 & Equipo de ingeniería civil & 2 \\
\hline $\begin{array}{l}\text { Partes y piezas de tractores y vehículos } \\
\text { automotores }\end{array}$ & 2 & Aeronaves y equipo conexo & 2 \\
\hline
\end{tabular}




\section{LA AYUDA PARA EL COMERCIO EN SÍNTESIS 2013}

\section{INDICADORES COMERCIALES (RESULTADOS)}

\section{Indicador}

Crecimiento del PIB (\%)

Número de exportadores

Índice de concentración de las exportaciones (productos) (0 a 1)

ACR sobre mercancías notificados a la OMC

AIE (servicios) notificados a la OMC

Sectores de servicios con compromisos en el marco del AGCS

\section{Aranceles (\%, 2006 et 2011)}

\begin{tabular}{|l|l|l|l|}
\hline Importaciones: promedio aritmético de los aranceles NMF aplicados & 6,9 & 7,0
\end{tabular}

\begin{tabular}{l|l|l|} 
Importaciones: promedio ponderado de los aranceles NMF aplicados & 4,8 & 4,1
\end{tabular}

\begin{tabular}{|l|l|l|}
\hline Exportaciones: promedio ponderado de los aranceles impuestos & 2,5 & 5,1
\end{tabular}

por los importadores

Exportaciones: libres de derechos (en \%)

$71,3 \quad 71,1$

Fuentes: Naciones Unidas, base de datos Comtrade; Banco Mundial, base de datos sobre dinámica de las empresas de exportación; Banco Mundial, Indicadores del

Desarrollo Mundial; OMC, perfiles comerciales y arancelarios.

Participación en las exportaciones por región (\%)

\begin{tabular}{|l|r|r|}
\hline & 2005 & 2011 \\
\hline África & 1,9 & 2,8 \\
\hline Asia & 68,3 & 72,6 \\
\hline Comunidad de Estados Independientes & 0,5 & 0,7 \\
\hline Europa & 13,0 & 10,9 \\
\hline Oriente Medio & 2,7 & 2,5 \\
\hline América del Norte & 12,4 & 8,9 \\
\hline América del Sury América Central & 1,2 & 1,6 \\
\hline
\end{tabular}

Fuentes: OMC, perfiles comerciales y arancelarios

Indicadores de facilitación del comercio
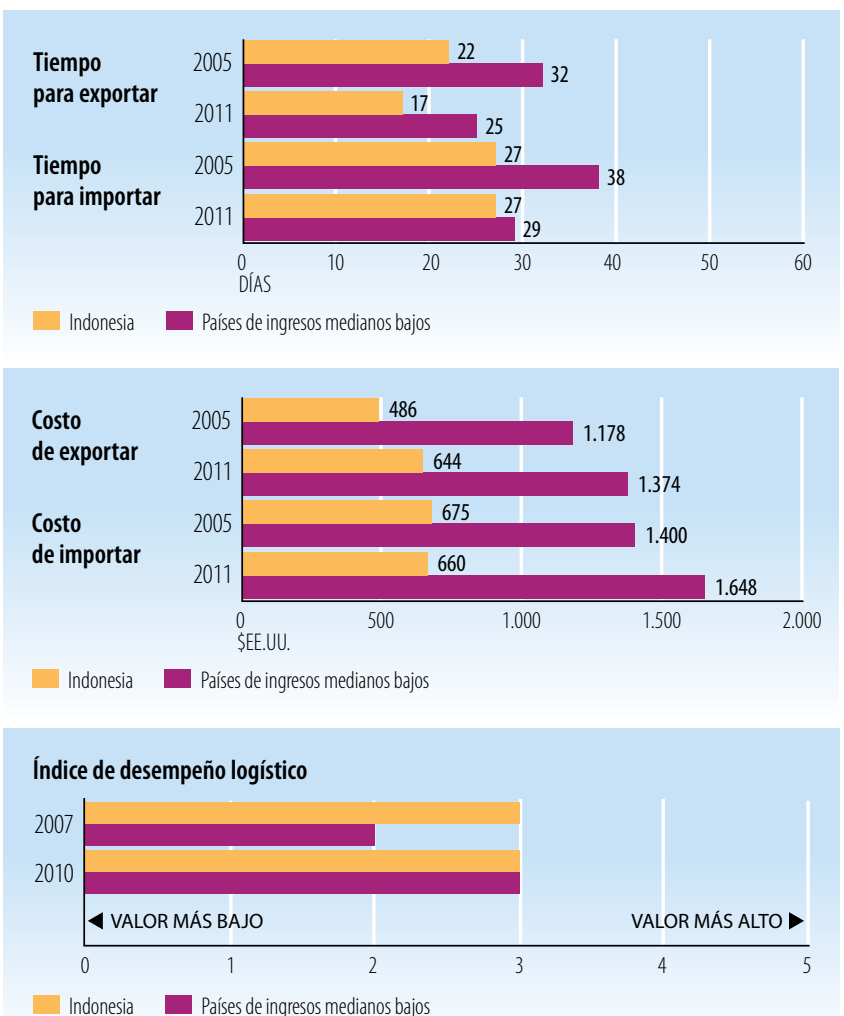

Fuentes: Banco Mundial, Indicadores del Desarrollo Mundial.

\begin{tabular}{|l|c|c|}
\hline INDICADORES DE DESARROLLO (EFECTOS) & \\
\hline Indicador & $\mathbf{2 0 0 5}$ & $\mathbf{2 0 1 0}$ \\
\hline Desempleo (\% de la fuerza de trabajo total) & 11,2 & 7,1 \\
\hline Población activa, mujeres (\% de la fuerza de trabajo total) & 37,4 & 38,2 \\
\hline A0D neta recibida (\% del INB) & 0,9 & 0,2 \\
\hline Derechos de importación percibidos (\% de los ingresos fiscales) & n.d. & n.d. \\
\hline Total del servicio de la deuda (\% de las exportaciones totales) & 19,8 & 16,6 \\
\hline Índice de desarrollo humano (0 a 1) & 0,57 & 0,61 \\
\hline
\end{tabular}

Fuentes: PNUD, indicadores internacionales sobre desarrollo humano; Banco Mundial, Indicadores del Desarrollo Mundial.

Producto interno bruto

PIB per cápita (PPA, dólares internacionales corrientes)

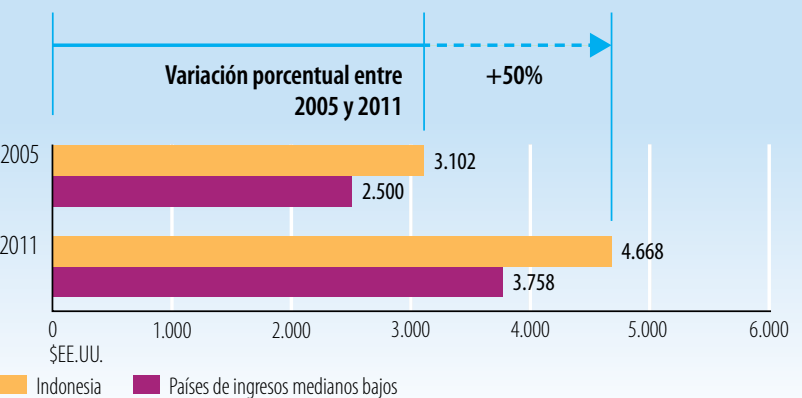

- Indonesia Países de ingresos medianos bajos

PIB per cápita (\$EE.UU. constantes de 2000)

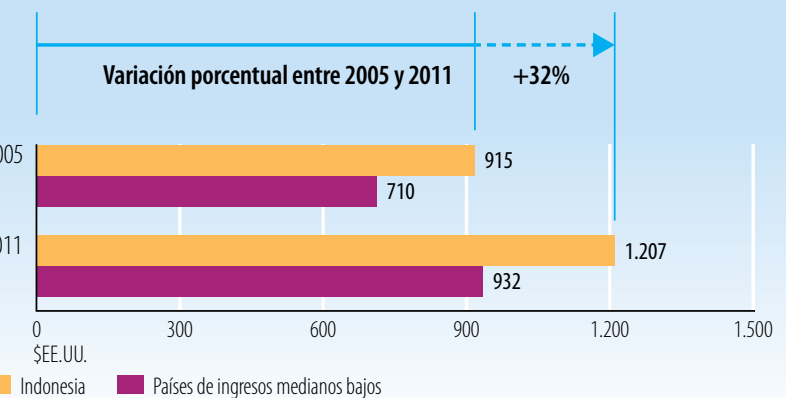

Fuentes: Banco Mundial, Indicadores del Desarrollo Mundial.

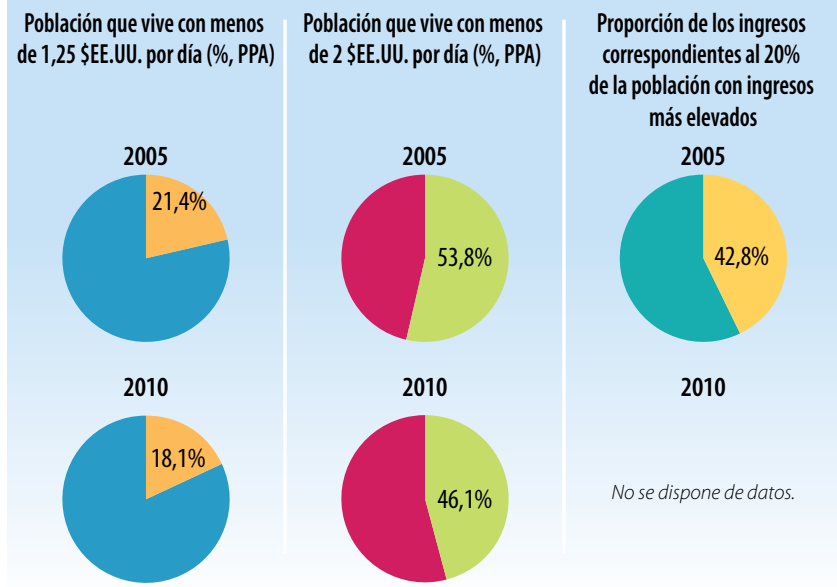

Fuentes: Banco Mundial, Indicadores del Desarrollo Mundial.

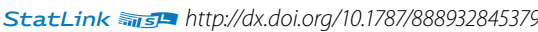


Indicadores de la ayuda, el comercio y el desarrollo relativos a Jamaica

\begin{tabular}{|c|c|c|c|c|}
\hline \multicolumn{5}{|c|}{ INVERSIÓN Y FINANCIACIÓN (APORTES) } \\
\hline Indicador (millones de \$EE.UU. corrientes) & 2005 & 2008 & 2010 & $\Delta: 05-10(\%)$ \\
\hline Formación bruta de capital fijo & $2.946,4$ & $3.214,5$ & $2.912,0$ & $-1 \%$ \\
\hline del cual: público & n.d. & n.d. & 638,2 & n.d. \\
\hline del cual: privado & n.d. & n.d. & $2.273,8$ & n.d. \\
\hline \multicolumn{5}{|l|}{ Entrada de financiación externa } \\
\hline Entradas de IED & 682,5 & $1.436,6$ & 227,7 & $-67 \%$ \\
\hline $\begin{array}{l}\text { Deuda externa a largo plazo y fondos } \\
\text { desembolsados por el FMl }\end{array}$ & $1.346,4$ & 691,9 & $3.137,8$ & $133 \%$ \\
\hline $\begin{array}{l}\text { Corrientes comerciales en condiciones no } \\
\text { concesionarias }\end{array}$ & 0,5 & 1,5 & 69,2 & $13171 \%$ \\
\hline Corrientes de Ayuda para el Comercio & 29,8 & 76,9 & 52,8 & $77 \%$ \\
\hline $\begin{array}{l}\text { Remesas de trabajadores y remuneración } \\
\text { de empleados }\end{array}$ & $1.783,8$ & $2.180,6$ & $2.011,0$ & $13 \%$ \\
\hline
\end{tabular}

Fuentes: OCDE, base de datos del SNPA del CAD sobre las actividades de ayuda; Banco Mundial, Indicadores del Desarrollo Mundial; Banco Mundial, estadísticas de la deuda internacional.

Desembolsos de la ayuda para el comercio, por sector

(millones de \$EE.UU. corrientes)

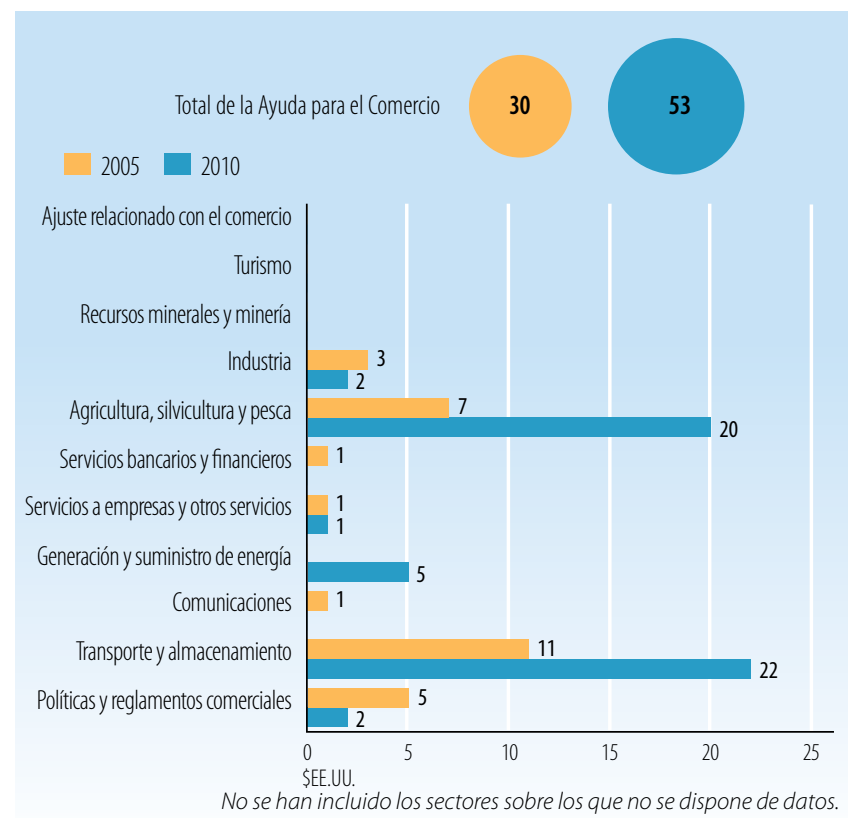

Fuentes: OCDE, base de datos del SNPA del CAD sobre las actividades de ayuda

Desembolsos de la ayuda para el comercio: principales donantes (millones de \$EE.UU. corrientes)

\begin{tabular}{|l|r|r|r|}
\hline $\mathbf{2 0 0 5}$ & Valor & $\%$ & Principales donantes en 2005 \\
\hline Instituciones de la UE & 17,7 & 60 & \\
\hline Estados Unidos & 6,7 & 22 & \\
\hline Bélgica & 2,0 & 7 & $98 \%$ \\
\hline Japón & 1,7 & 6 & \\
\hline Canadá & 1,1 & 4 & \\
\hline 2010 & Valor & $\%$ & Principales donantes en 2010 \\
\hline Instituciones de la UE & 25,1 & 48 & \\
\hline OFID & 12,1 & 23 & \\
\hline Estados Unidos & 6,4 & 12 & \\
\hline Bélgica & 4,6 & 9 & \\
\hline Canadá & 1,9 & 4 & \\
\hline
\end{tabular}

Fuentes: OCDE, base de datos del SNPA del CAD sobre las actividades de ayuda.

\begin{tabular}{|c|c|c|c|c|}
\hline Indicador & 2005 & 2008 & 2011 & $\Delta: 05-11(\%)$ \\
\hline Relación comercio/PIB (\%) & 87 & 114 & 79 & -8 \\
\hline $\begin{array}{l}\text { Exportaciones de servicios comerciales como } \\
\% \text { de las exportaciones totales }\end{array}$ & 58 & 50 & 62 & 4 \\
\hline $\begin{array}{l}\text { Importaciones de servicios comerciales como } \\
\% \text { de las importaciones totales }\end{array}$ & 28 & 23 & 25 & -4 \\
\hline $\begin{array}{l}\text { Productos intermedios distintos de los combustibles } \\
\text { (\% de las exportaciones de mercancías) }\end{array}$ & 80 & 71 & n.d. & n.d. \\
\hline $\begin{array}{l}\text { Productos intermedios distintos de los combustibles } \\
\text { (\% de las importaciones de mercancías) }\end{array}$ & 34 & 29 & n.d. & n.d. \\
\hline
\end{tabular}
Fuentes: Secretaría de la OMC.

Corrientes comerciales (millones de \$EE.UU. corrientes)

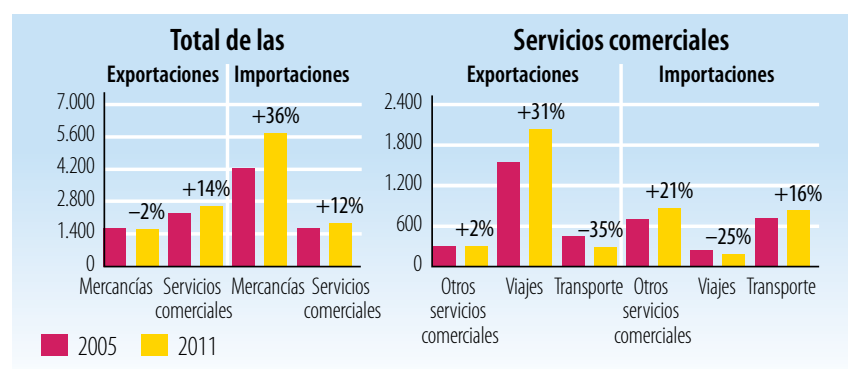

Fuentes: Secretaría de la OMC

Cinco principales mercados de exportación de mercancías (\%)

\begin{tabular}{|l|c|l|c|}
\hline $\mathbf{2 0 0 5}$ & $\%$ & 2010 & $\%$ \\
\hline Estados Unidos & 26 & Estados Unidos & 50 \\
\hline UE (27) & 24 & UE (27) & 13 \\
\hline Canadá & 19 & Canadá & 12 \\
\hline China & 7 & Noruega & 5 \\
\hline Antillas Neerlandesas & 6 & Federación de Rusia & 3 \\
\hline Fuentes: Secretaría de la OMC & & & \\
\hline
\end{tabular}

Cinco principales productos de exportación (\% de las exportaciones de mercancías)

\begin{tabular}{|c|c|c|c|}
\hline 2005 & $\%$ & 2010 & $\%$ \\
\hline $\begin{array}{l}\text { Minerales de aluminio y sus concentrados, } \\
\text { etc. }\end{array}$ & 67 & $\begin{array}{l}\text { Minerales de aluminio y sus concentrados, } \\
\text { etc. }\end{array}$ & 40 \\
\hline Productos derivados del petróleo & 7 & Productos derivados del petróleo & 21 \\
\hline Azúcares, melaza y miel & 5 & Bebidas alcohólicas & 7 \\
\hline Bebidas alcohólicas & 4 & Alcoholes, fenoles, etc., y sus derivados & 4 \\
\hline Alcoholes, fenoles, etc., y sus derivados & 2 & Azúcares, melaza y miel & 3 \\
\hline
\end{tabular}

Cinco principales mercados de importación de mercancías (\%)

\begin{tabular}{|l|c|l|c|}
\hline $\mathbf{2 0 0 5}$ & $\%$ & 2010 & $\%$ \\
\hline Estados Unidos & 42 & Estados Unidos & 36 \\
\hline Trinidady Tabago & 15 & Venezuela, Rep. Bolivariana de & 14 \\
\hline UE (27) & 7 & Trinidady Tabago & 14 \\
\hline Venezuela, Rep. Bolivariana de & 5 & UE (27) & 7 \\
\hline $\begin{array}{l}\text { Japón } \\
\text { Fuentes: Secretaría de la OMC }\end{array}$ & 4 & China & 5 \\
\hline
\end{tabular}

Fuentes: Secretaría de la OMC

Cinco principales productos de importación (\% de las importaciones de mercancías)

\begin{tabular}{|c|c|c|c|}
\hline 2005 & $\%$ & 2010 & $\%$ \\
\hline Productos derivados del petróleo & 24 & Productos derivados del petróleo & 17 \\
\hline Aceites de petróleo, crudos & 4 & Aceites de petróleo, crudos & 12 \\
\hline $\begin{array}{l}\text { Vehículos automotores para pasajeros, } \\
\text { excepto autobuses }\end{array}$ & 4 & Alcoholes, fenoles, etc., y sus derivados & 4 \\
\hline $\begin{array}{l}\text { Equipos de telecomunicaciones y sus } \\
\text { partes, n.e.p. }\end{array}$ & 3 & Medicamentos & 3 \\
\hline Elementos químicos inorgánicos & 2 & $\begin{array}{l}\text { Equipos de telecomunicaciones y sus } \\
\text { partes, n.e.p. }\end{array}$ & 2 \\
\hline
\end{tabular}




\section{LA AYUDA PARA EL COMERCIO EN SÍNTESIS 2013}

\section{INDICADORES COMERCIALES (RESULTADOS)}

\section{Indicador}

Crecimiento del PIB (\%)

Número de exportadores

Índice de concentración de las exportaciones (productos) (0 a 1)

ACR sobre mercancías notificados a la OMC

AIE (servicios) notificados a la OMC

Sectores de servicios con compromisos en el marco del AGCS

\section{Aranceles (\%, 2006 et 2011)}

\begin{tabular}{|l|l|l|l|}
\hline Importaciones: promedio aritmético de los aranceles NMF aplicados & 7,3 & 7,6
\end{tabular}

Importaciones: promedio ponderado de los aranceles NMF aplicados n.d. 10,1

Exportaciones: promedio ponderado de los aranceles impuestos
por los importadores

Exportaciones: libres de derechos (en \%)

$85,1 \quad 98,4$

Fuentes: Naciones Unidas, base de datos Comtrade; Banco Mundial, base de datos sobre dinámica de las empresas de exportación; Banco Mundial, Indicadores del

Desarrollo Mundial; OMC, perfiles comerciales y arancelarios.

Participación en las exportaciones por región (\%)

\begin{tabular}{|l|r|r|}
\hline & 2005 & 2010 \\
\hline África & 0,0 & 0,1 \\
\hline Asia & 9,2 & 4,5 \\
\hline Comunidad de Estados Independientes & 1,4 & 4,4 \\
\hline Europa & 30,9 & 20,0 \\
\hline Oriente Medio & 1,8 & 1,1 \\
\hline América del Norte & 45,3 & 62,3 \\
\hline América del Sury América Central & 11,4 & 7,7 \\
\hline
\end{tabular}

Fuentes: OMC, perfiles comerciales y arancelarios

Indicadores de facilitación del comercio
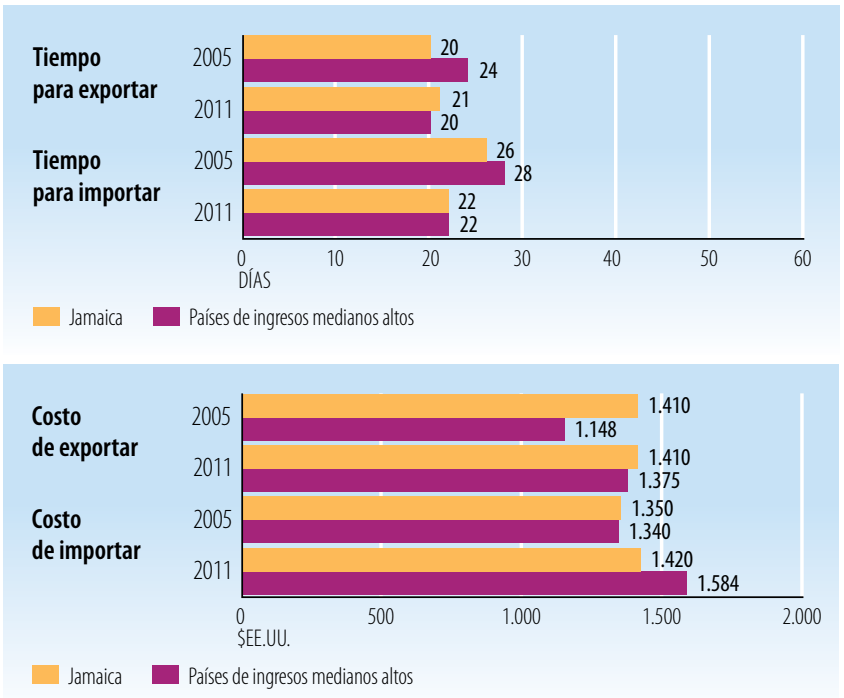

Índice de desempeño logístico

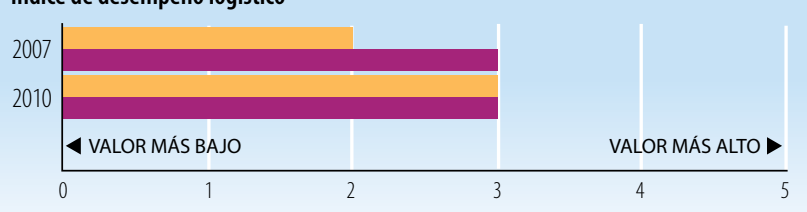

- Jamaica Países de ingresos medianos altos

Fuentes: Banco Mundial, Indicadores del Desarrollo Mundial.

\begin{tabular}{l|c|c|}
\hline \multicolumn{2}{|l}{ INDICADORES DE DESARROLLO (EFECTOS) } \\
\hline Indicador & 2005 & $\mathbf{2 0 1 0}$ \\
\hline Desempleo (\% de la fuerza de trabajo total) & 10,9 & 11,4 \\
\hline Población activa, mujeres (\% de la fuerza de trabajo total) & 44,3 & 45,1 \\
\hline AOD neta recibida (\% del INB) & 0,4 & 1,1 \\
\hline Derechos de importación percibidos (\% de los ingresos fiscales) & 8,6 & n.d. \\
\hline Total del servicio de la deuda (\% de las exportaciones totales) & 22,4 & 27,9 \\
\hline Índice de desarrollo humano (0 a 1) & 0,70 & 0,73 \\
\hline
\end{tabular}

Fuentes: PNUD, indicadores internacionales sobre desarrollo humano; Banco Mundial, Indicadores del Desarrollo Mundial.

Producto interno bruto

PIB per cápita (PPA, dólares internacionales corrientes)

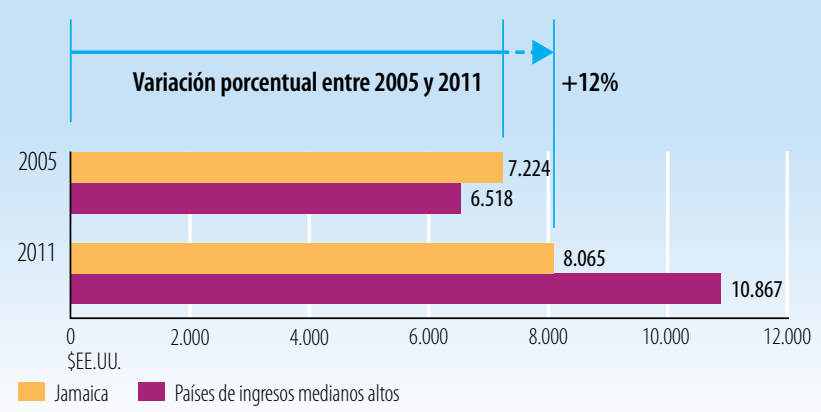

PIB per cápita (\$ॄE.UU. constantes de 2000)
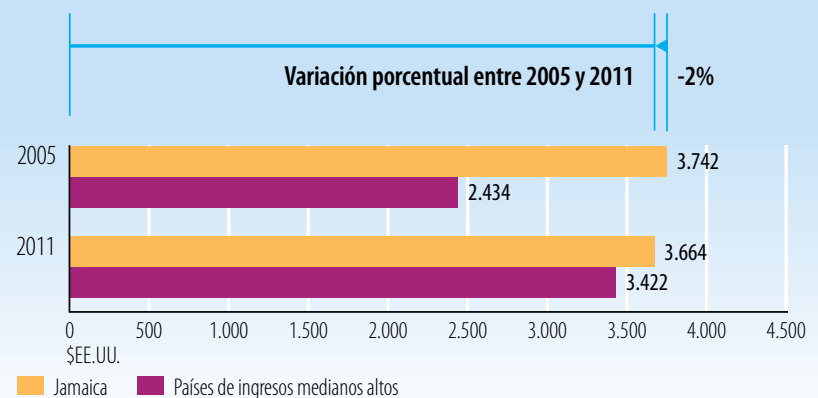

- Jamaica Países de ingresos medianos altos

Fuentes: Banco Mundial, Indicadores del Desarrollo Mundial.

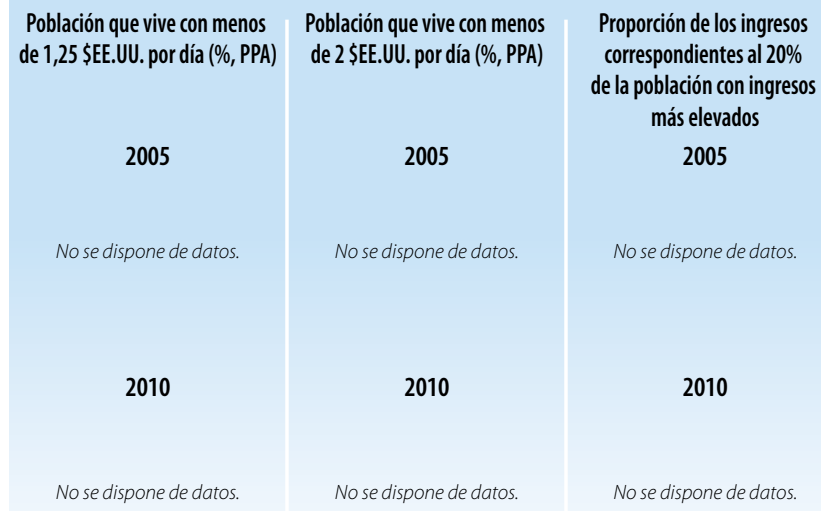

Fuentes: Banco Mundial, Indicadores del Desarrollo Mundial.

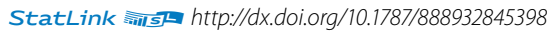




\section{Indicadores de la ayuda, el comercio y el desarrollo relativos a Jordania}

\begin{tabular}{|c|c|c|c|c|}
\hline \multicolumn{5}{|c|}{ INVERSIÓN Y FINANCIACIÓN (APORTES) } \\
\hline Indicador (millones de \$ॄE.UU. corrientes) & 2005 & 2008 & 2010 & $\Delta: 05-10(\%)$ \\
\hline Formación bruta de capital fijo & $3.855,7$ & $6.119,3$ & $6.074,8$ & $58 \%$ \\
\hline del cual: público & 921,5 & $1.164,9$ & $1.168,0$ & $27 \%$ \\
\hline del cual: privado & $2.934,2$ & $4.954,4$ & $4.906,9$ & $67 \%$ \\
\hline \multicolumn{5}{|l|}{ Entrada de financiación externa } \\
\hline Entradas de IED & $1.984,5$ & $2.826,7$ & $1.701,4$ & $-14 \%$ \\
\hline $\begin{array}{l}\text { Deuda externa a largo plazo y fondos } \\
\text { desembolsados por el FMl }\end{array}$ & 434,2 & 230,0 & $1.389,3$ & $220 \%$ \\
\hline $\begin{array}{l}\text { Corrientes comerciales en condiciones no } \\
\text { concesionarias }\end{array}$ & 5,4 & 11,4 & 256,6 & $4634 \%$ \\
\hline Corrientes de Ayuda para el Comercio & 35,9 & 126,2 & 366,1 & $919 \%$ \\
\hline $\begin{array}{l}\text { Remesas de trabajadores y remuneración } \\
\text { de empleados }\end{array}$ & $2.499,7$ & $3.794,0$ & $3.640,6$ & $46 \%$ \\
\hline
\end{tabular}

Fuentes: OCDE, base de datos del SNPA del CAD sobre las actividades de ayuda; Banco Mundial, Indicadores del Desarrollo Mundial; Banco Mundial, estadísticas de la deuda internacional.

Desembolsos de la ayuda para el comercio, por sector (millones de \$EE.UU. corrientes)

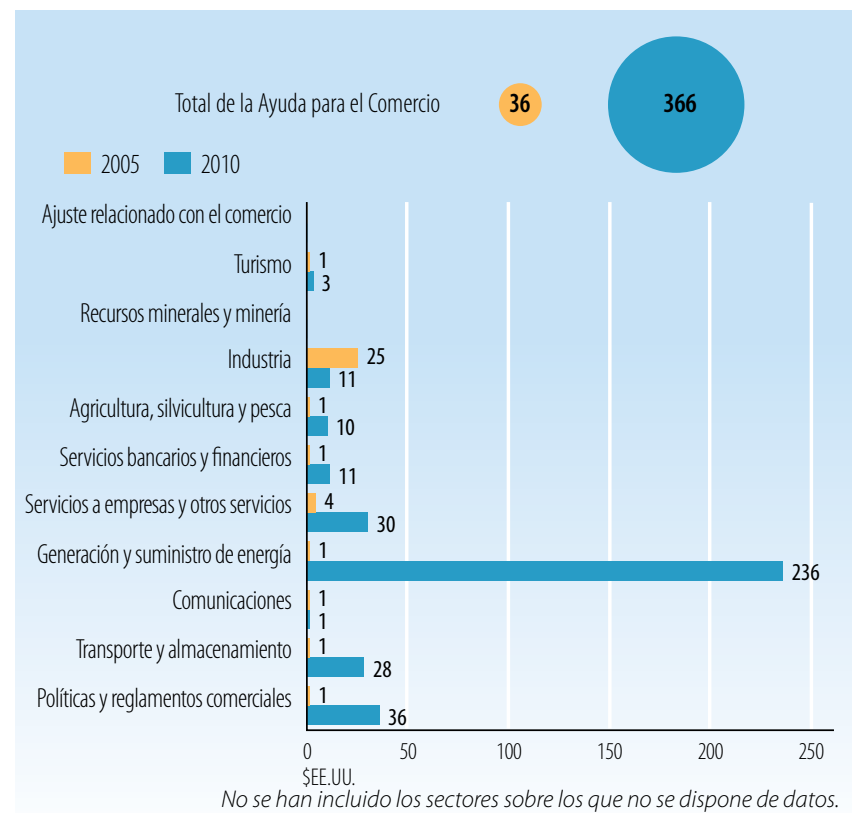

Fuentes: OCDE, base de datos del SNPA del CAD sobre las actividades de ayuda

Desembolsos de la ayuda para el comercio: principales donantes (millones de \$EE.UU. corrientes)

\begin{tabular}{|l|c|c|c|}
\hline $\mathbf{2 0 0 5}$ & Valor & $\%$ & Principales donantes en 2005 \\
\hline Instituciones de la UE & 19,8 & 55 & \\
\hline Japón & 9,5 & 26 & \\
\hline Italia & 1,4 & 4 & \\
\hline Estados Unidos & 1,1 & 3 & \\
\hline Alemania & 1,0 & 3 & \\
\hline 2010 & Valor & $\%$ & Principales donantes en 2010 \\
\hline Fondo Árabe & 186,9 & 51 & \\
\hline Kuwait & 68,3 & 19 & \\
\hline Estados Unidos & 44,8 & 12 & \\
\hline Instituciones de la UE & 35,5 & 10 & \\
\hline Japón & 12,6 & 3 & \\
\hline
\end{tabular}

Fuentes: OCDE, base de datos del SNPA del CAD sobre las actividades de ayuda.

\begin{tabular}{|c|c|c|c|c|}
\hline Indicador & 2005 & 2008 & 2011 & $\Delta: 05-11(\%)$ \\
\hline Relación comercio/PIB (\%) & 146 & 143 & 115 & -30 \\
\hline $\begin{array}{l}\text { Exportaciones de servicios comerciales como } \\
\% \text { de las exportaciones totales }\end{array}$ & 34 & 35 & 37 & 3 \\
\hline $\begin{array}{l}\text { Importaciones de servicios comerciales como } \\
\% \text { de las importaciones totales }\end{array}$ & 21 & 21 & 21 & 0 \\
\hline $\begin{array}{l}\text { Productos intermedios distintos de los combustibles } \\
\text { (\% de las exportaciones de mercancías) }\end{array}$ & 41 & 53 & 55 & 15 \\
\hline $\begin{array}{l}\text { Productos intermedios distintos de los combustibles } \\
\text { \% de las importaciones de mercancías) }\end{array}$ & 40 & 41 & 38 & -2 \\
\hline
\end{tabular}

Fuentes: Secretaría de la OMC.

Corrientes comerciales (millones de \$̦E.UU. corrientes)

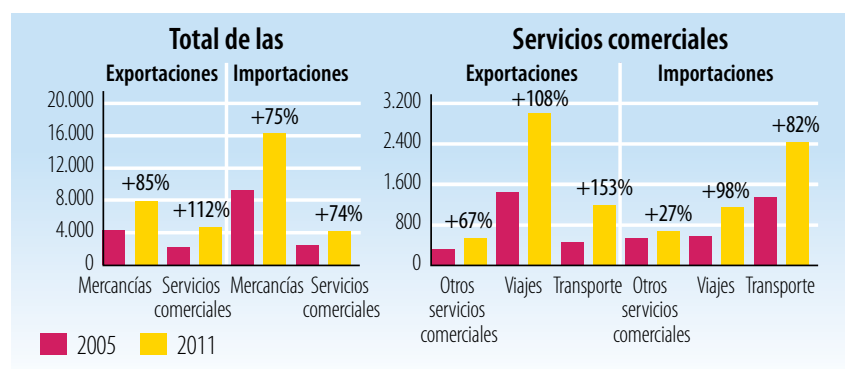

Filentes-Secretaría de la OMC

Cinco principales mercados de exportación de mercancías (\%)

\begin{tabular}{|l|r|l|r|}
\hline 2005 & $\%$ & 2011 & $\%$ \\
\hline Estados Unidos & 26 & Iraq & 15 \\
\hline Iraq & 17 & Estados Unidos & 13 \\
\hline India & 8 & India & 11 \\
\hline Arabia Saudita, Reino de la & 6 & Arabia Saudita, Reino de la & 9 \\
\hline República Árabe Siria & 5 & UE (27) & 4 \\
\hline
\end{tabular}

Fuentes: Secretaría de la OMC

Cinco principales productos de exportación (\% de las exportaciones de mercancías)

\begin{tabular}{|c|c|c|c|}
\hline 2005 & $\%$ & 2011 & $\%$ \\
\hline Abonos en bruto & 10 & Abonos, excepto los del grupo 272 & 15 \\
\hline $\begin{array}{l}\text { Prendas de vestir para mujeres y niñas, } \\
\text { excepto las de punto }\end{array}$ & 8 & $\begin{array}{l}\text { Otros artículos textiles y prendas de } \\
\text { vestir, n.e.p. }\end{array}$ & 12 \\
\hline $\begin{array}{l}\text { Otros artículos textiles y prendas de } \\
\text { vestir, n.e.p. }\end{array}$ & 7 & Abonos en bruto & 8 \\
\hline $\begin{array}{l}\text { Prendas de vestir para mujeres y niñas, } \\
\text { de punto }\end{array}$ & 7 & Medicamentos & 7 \\
\hline Medicamentos & 7 & Legumbres & 6 \\
\hline
\end{tabular}

Cinco principales mercados de importación de mercancías (\%)

\begin{tabular}{|l|r|l|c|}
\hline 2005 & $\%$ & 2011 & $\%$ \\
\hline UE (27) & 25 & Arabia Saudita, Reino de la & 23 \\
\hline Arabia Saudita, Reino de la & 24 & UE (27) & 21 \\
\hline China & 9 & China & 10 \\
\hline Estados Unidos & 6 & Estados Unidos & 6 \\
\hline Corea, Rep. de & 4 & Egipto & 4 \\
\hline
\end{tabular}

Fuentes: Secretaría de la OMC

Cinco principales productos de importación (\% de las importaciones de mercancías)

\begin{tabular}{|c|c|c|c|}
\hline 2005 & $\%$ & 2011 & $\%$ \\
\hline Aceites de petróleo, crudos & 16 & Aceites de petróleo, crudos & 14 \\
\hline $\begin{array}{l}\text { Equipos de telecomunicaciones y sus } \\
\text { partes, n.e.p. }\end{array}$ & 5 & Productos derivados del petróleo & 12 \\
\hline Productos derivados del petróleo & 4 & $\begin{array}{l}\text { Vehículos automotores para pasajeros, } \\
\text { excepto autobuses }\end{array}$ & 3 \\
\hline Tejidos de punto o ganchillo, n.e.p. & 4 & $\begin{array}{l}\text { Equipos de telecomunicaciones y sus } \\
\text { partes, n.e.p. }\end{array}$ & 2 \\
\hline $\begin{array}{l}\text { Vehículos automotores para pasajeros, } \\
\text { excepto autobuses }\end{array}$ & 4 & Medicamentos & 2 \\
\hline
\end{tabular}




\section{LA AYUDA PARA EL COMERCIO EN SIINTESIS 2013}

\section{INDICADORES COMERCIALES (RESULTADOS)}

\section{Indicador}

Crecimiento del PIB (\%)

Número de exportadores

Índice de concentración de las exportaciones (productos) ( 0 a 1)

ACR sobre mercancías notificados a la OMC

AIE (servicios) notificados a la OMC

Sectores de servicios con compromisos en el marco del AGCS

\section{Aranceles (\%, 2006 et 2011)}

\begin{tabular}{|l|l|l|l|}
\hline Importaciones: promedio aritmético de los aranceles NMF aplicados & 11,5 & 10,0
\end{tabular}

\begin{tabular}{|l|l|l|l|}
\hline Importaciones: promedio ponderado de los aranceles NMF aplicados & 8,7 & 8,6
\end{tabular}

\begin{tabular}{|l|l|l|l|}
\hline Exportaciones: promedio ponderado de los aranceles impuestos & 7,7 & 1,6
\end{tabular}

por los importadores

Exportaciones: libres de derechos (en \%)

$47,2 \quad 72,1$

Fuentes: Naciones Unidas, base de datos Comtrade; Banco Mundial, base de datos sobre dinámica de las empresas de exportación; Banco Mundial, Indicadores del

Desarrollo Mundial; OMC, perfiles comerciales y arancelarios.

Participación en las exportaciones por región (\%)

\begin{tabular}{|l|r|r|}
\hline África & $\mathbf{2 0 0 5}$ & $\mathbf{2 0 1 1}$ \\
\hline Asia & 6,4 & 7,1 \\
\hline Comunidad de Estados Independientes & 12,3 & 20,9 \\
\hline Europa & 0,4 & 0,6 \\
\hline Oriente Medio & 4,4 & 6,6 \\
\hline América del Norte & 41,1 & 41,4 \\
\hline América del Sury América Central & 26,5 & 13,6 \\
\hline
\end{tabular}

Fuentes: OMC, perfiles comerciales y arancelarios

Indicadores de facilitación del comercio
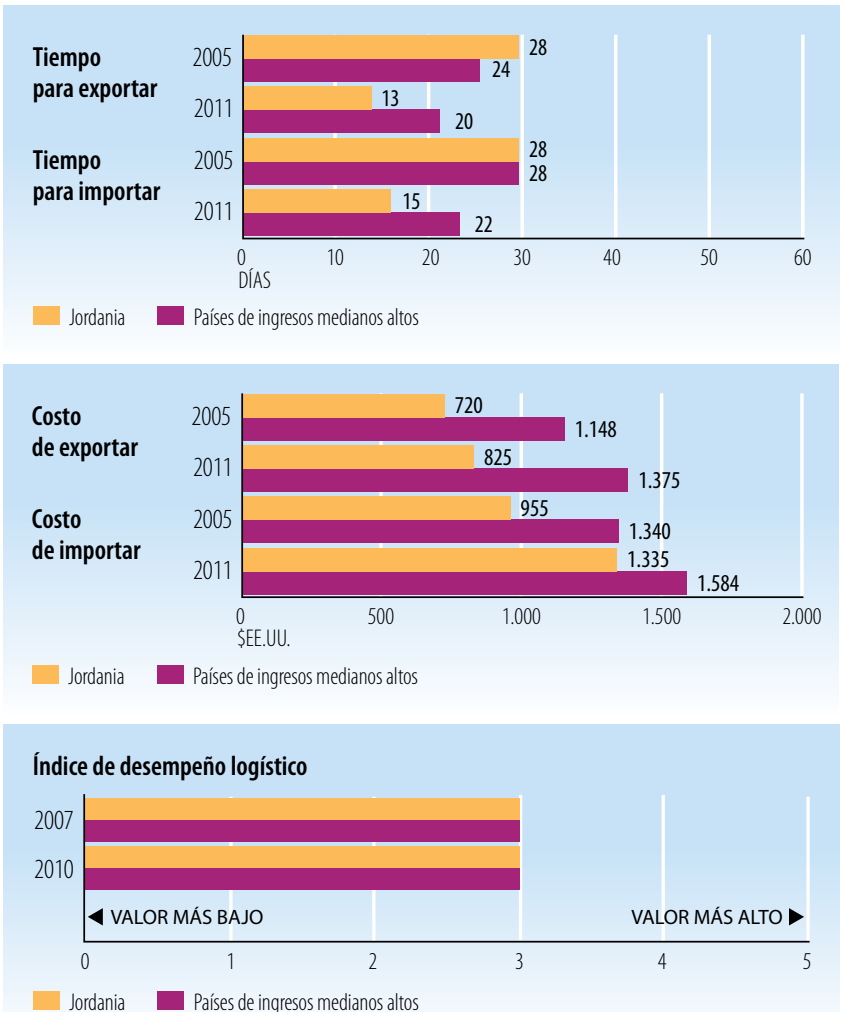

Fuentes: Banco Mundial, Indicadores del Desarrollo Mundial.

\begin{tabular}{|l|c|c|}
\hline INDICADORES DE DESARROLLO (EFECTOS) & \\
\hline Indicador & $\mathbf{2 0 0 5}$ & $\mathbf{2 0 1 0}$ \\
\hline Desempleo (\% de la fuerza de trabajo total) & n.d. & 12,9 \\
\hline Población activa, mujeres (\% de la fuerza de trabajo total) & 14,3 & 18,0 \\
\hline A0D neta recibida (\% del InB) & 5,5 & 3,6 \\
\hline Derechos de importación percibidos (\% de los ingresos fiscales) & n.d. & n.d. \\
\hline Total del servicio de la deuda (\% de las exportaciones totales) & 8,3 & 4,9 \\
\hline Índice de desarrollo humano (0 a 1) & 0,67 & 0,70 \\
\hline
\end{tabular}

Fuentes: PNUD, indicadores internacionales sobre desarrollo humano; Banco Mundial, Indicadores del Desarrollo Mundial.

Producto interno bruto

PIB per cápita (PPA, dólares internacionales corrientes)

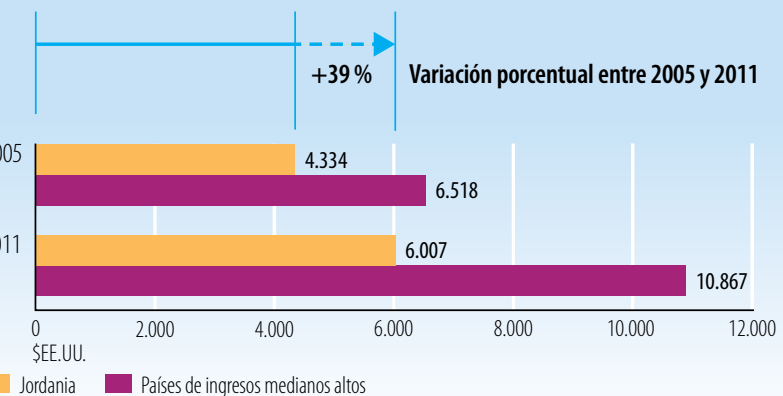

Jordania $\square$ Páses de ingresos medianos altos

PIB per cápita (\$EE.UU. constantes de 2000)

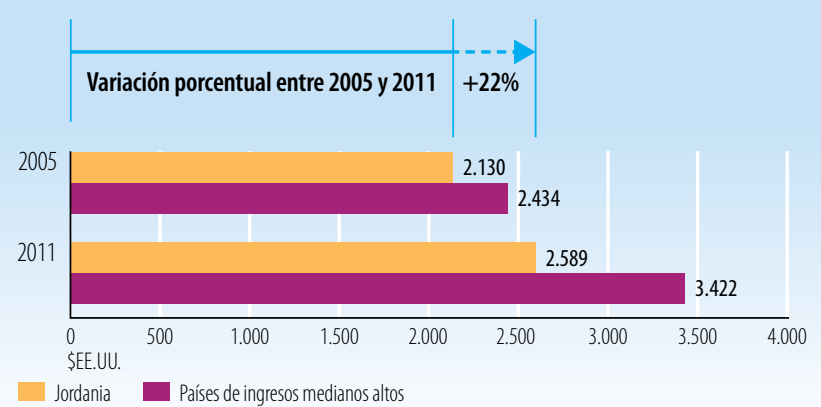

Fuentes: Banco Mundial, Indicadores del Desarrollo Mundial.

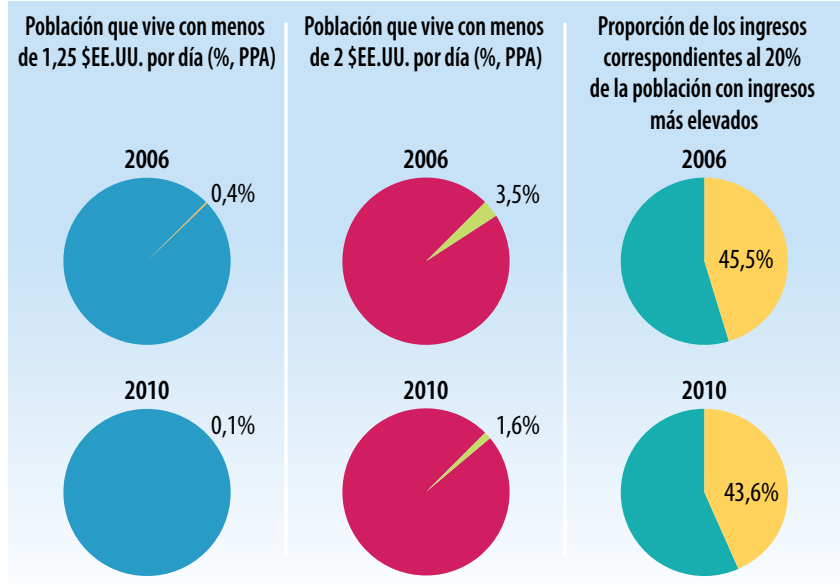

Fuentes: Banco Mundial, Indicadores del Desarrollo Mundial.

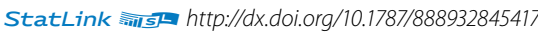


Indicadores de la ayuda, el comercio y el desarrollo relativos a Kenya

\begin{tabular}{|c|c|c|c|c|}
\hline Indicador (millones de \$EE.UU. corrientes) & 2005 & 2008 & 2010 & $\Delta: 05-10(\%$ \\
\hline Formación bruta de capital fijo & $3.503,8$ & $5.921,1$ & $6.417,2$ & $83 \%$ \\
\hline del cual: público & 467,1 & $1.333,1$ & 0,0 & $-100 \%$ \\
\hline del cual: privado & $3.036,7$ & $4.588,0$ & $6.417,2$ & $111 \%$ \\
\hline \multicolumn{5}{|l|}{ Entrada de financiación externa } \\
\hline Entradas de IED & 21,2 & 95,6 & 185,8 & $776 \%$ \\
\hline $\begin{array}{l}\text { Deuda externa a largo plazo y fondos } \\
\text { desembolsados por el FMl }\end{array}$ & 242,1 & 350,0 & 529,8 & $119 \%$ \\
\hline $\begin{array}{l}\text { Corrientes comerciales en condiciones no } \\
\text { concesionarias }\end{array}$ & 15,6 & 58,4 & 36,0 & $130 \%$ \\
\hline Corrientes de Ayuda para el Comercio & 128,4 & 322,9 & 390,5 & $204 \%$ \\
\hline $\begin{array}{l}\text { Remesas de trabajadores y remuneración } \\
\text { de empleados }\end{array}$ & 805,0 & $1.692,0$ & $1.777,0$ & $121 \%$ \\
\hline
\end{tabular}

Fuentes: OCDE, base de datos del SNPA del CAD sobre las actividades de ayuda; Banco Mundial, Indicadores del Desarrollo Mundial; Banco Mundial, estadísticas de la deuda internacional.

Desembolsos de la ayuda para el comercio, por sector (millones de \$EE.UU. corrientes)

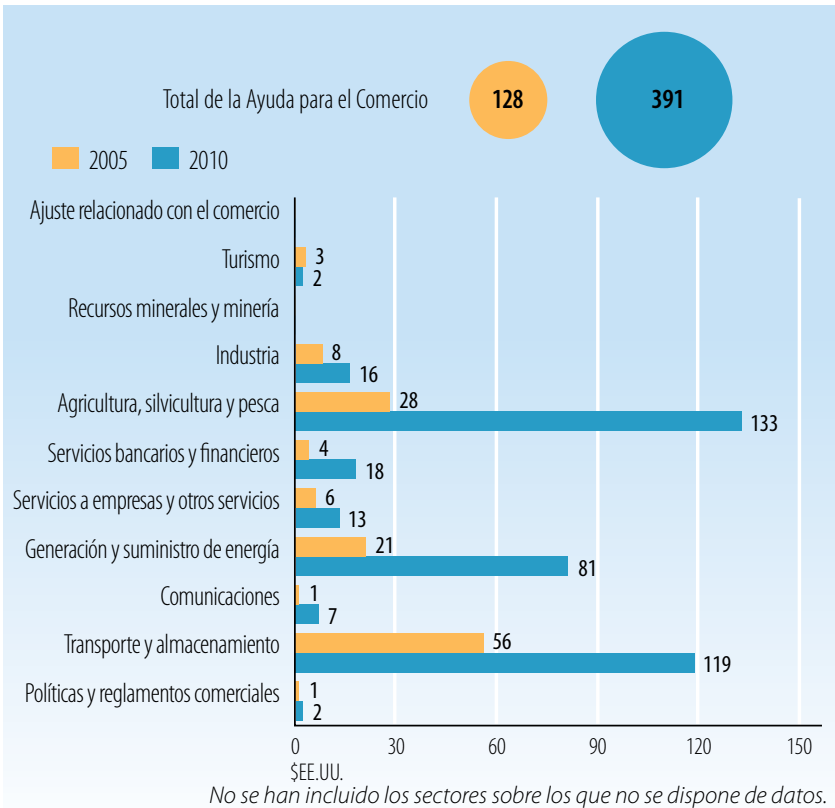

Fuentes: OCDE, base de datos del SNPA del CAD sobre las actividades de ayuda

Desembolsos de la ayuda para el comercio: principales donantes (millones de \$EE.UU. corrientes)

\begin{tabular}{|l|c|c|c|}
\hline $\mathbf{2 0 0 5}$ & Valor & $\%$ & Principales donantes en 2005 \\
\hline Instituciones de la UE & 42,9 & 33 & \\
\hline Japón & 25,6 & 20 & \\
\hline Banco Mundial & 13,6 & 11 & $80 \%$ \\
\hline Estados Unidos & 10,7 & 8 & \\
\hline Alemania & 9,6 & 8 & \\
\hline $\mathbf{2 0 1 0}$ & Valor & $\%$ & Principales donantes en $\mathbf{2 0 1 0}$ \\
\hline Banco Mundial & 104,0 & 27 & \\
\hline Banco Africano de Desarrollo & 79,9 & 20 & \\
\hline Francia & 39,0 & 10 & \\
\hline Japón & 37,6 & 10 & $73 \%$ \\
\hline Alemania & 23,1 & 6 & \\
\hline
\end{tabular}

Fuentes: OCDE, base de datos del SNPA del CAD sobre las actividades de ayuda.

\section{INDICADORES COMERCIALES (PRODUCTOS)}

\section{Indicador}

$2005 \quad 2008 \quad 2011 \quad \Delta: 05-11(\%)$

Relación comercio/PIB (\%)

\begin{tabular}{|l|l|l|l|}
62 & 65 & 74 & 12 \\
\hline
\end{tabular}

Exportaciones de servicios comerciales como

$\%$ de las exportaciones totales

Importaciones de servicios comerciales como

$\%$ de las importaciones totales

Productos intermedios distintos de los combustibles

(\% de las exportaciones de mercancías)

Productos intermedios distintos de los combustibles

(\% de las importaciones de mercancías)

\begin{tabular}{|l|l|l|l|}
31 & 33 & 33 & 2
\end{tabular}

\begin{tabular}{|l|l|l|l|}
\hline 15 & 13 & 15 & 0
\end{tabular}

\begin{tabular}{l|l|l|l|}
28 & 36 & n.d.
\end{tabular}

\begin{tabular}{ll|l|l|}
41 & 42 & n.d. & n.d.
\end{tabular}

Fuentes: Secretaría de la OMC

Corrientes comerciales (millones de \$EE.UU. corrientes)

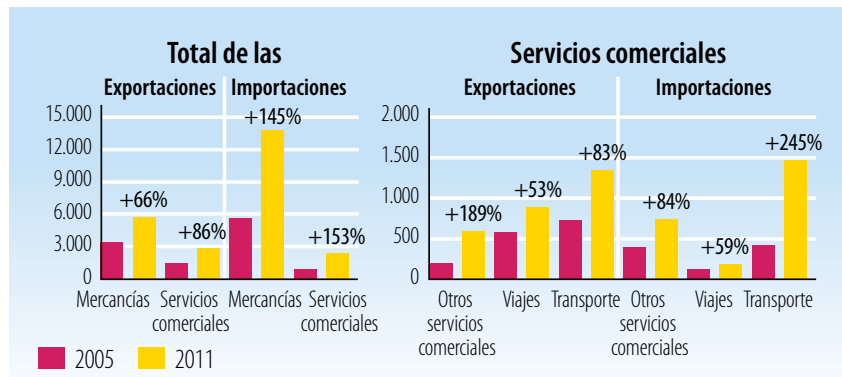

Fuentes: Secretaría de la OMC

Cinco principales mercados de exportación de mercancías (\%)

\begin{tabular}{|l|r|l|c|}
\hline 2005 & $\%$ & 2010 & $\%$ \\
\hline UE $(27)$ & 25 & UE $(27)$ & 24 \\
\hline Uganda & 17 & Uganda & 13 \\
\hline Tanzanía & 8 & Tanzanía & 8 \\
\hline Estados Unidos & 7 & Estados Unidos & 6 \\
\hline Pakistán & 5 & Emiratos Árabes Unidos & 5 \\
\hline
\end{tabular}

Fuentes: Secretaría de la OMC

Cinco principales productos de exportación (\% de las exportaciones de mercancías)

\begin{tabular}{|l|r|l|c|}
\hline 2005 & $\%$ & 2010 & $\%$ \\
\hline Productos derivados del petróleo & 18 & Téy mate & 23 \\
\hline Téy mate & 17 & Productos vegetales en bruto, n.e.p. & 10 \\
\hline Productos vegetales en bruto, n.e.p. & 9 & Legumbres & 5 \\
\hline Legumbres & 6 & Café sucedáneos del café & 4 \\
\hline Caféy sucedáneos del café & 4 & Productos derivados del petróleo & 4 \\
\hline
\end{tabular}

Fuentes: Secretaría de la OMC

Cinco principales mercados de importación de mercancías (\%)

\begin{tabular}{|l|c|l|c|}
\hline 2005 & $\%$ & 2010 & $\%$ \\
\hline UE (27) & 21 & UE (27) & 19 \\
\hline Emiratos Árabes Unidos & 14 & China & 13 \\
\hline Sudáfrica & 10 & Emiratos Árabes Unidos & 12 \\
\hline Estados Unidos & 10 & India & 11 \\
\hline Arabia Saudita, Reino de la & 6 & Sudáfrica & 6 \\
\hline
\end{tabular}

Fuentes: Secretaría de la OMC

Cinco principales productos de importación (\% de las importaciones de mercancías)

\begin{tabular}{|c|c|c|c|}
\hline 2005 & $\%$ & 2010 & $\%$ \\
\hline Aceites de petróleo, crudos & 12 & Productos derivados del petróleo & 14 \\
\hline Productos derivados del petróleo & 11 & Aceites de petróleo, crudos & 8 \\
\hline Aeronaves y equipo conexo & 10 & $\begin{array}{l}\text { Equipos de telecomunicaciones y sus } \\
\text { partes, n.e.p. }\end{array}$ & 5 \\
\hline $\begin{array}{l}\text { Otros aceites y grasas fijos de origen } \\
\text { vegetal }\end{array}$ & 3 & Aeronaves y equipo conexo & 4 \\
\hline $\begin{array}{l}\text { Productos laminados planos de hierro, } \\
\text { etc. }\end{array}$ & 3 & $\begin{array}{l}\text { Otros aceites y grasas fijos de origen } \\
\text { vegetal }\end{array}$ & 4 \\
\hline
\end{tabular}




\section{LA AYUDA PARA EL COMERCIO EN SÍNTESIS 2013}

\section{INDICADORES COMERCIALES (RESULTADOS)}

\section{Indicador}

Crecimiento del PIB (\%)

Número de exportadores

Índice de concentración de las exportaciones (productos) (0 a 1)

ACR sobre mercancías notificados a la OMC

AIE (servicios) notificados a la OMC

Sectores de servicios con compromisos en el marco del AGCS

\section{Aranceles (\%, 2006 et 2011)}

\begin{tabular}{l|l|l|l|} 
Importaciones: promedio aritmético de los aranceles NMF aplicados & 12,7 & 12,5
\end{tabular}

Importaciones: promedio ponderado de los aranceles NMF aplicados $\quad 6,2 \quad 10,1$

\begin{tabular}{|l|l|l|} 
Exportaciones: promedio ponderado de los aranceles impuestos & 1,5 & 0,8
\end{tabular}

por los importadores

Exportaciones: libres de derechos (en \%)

$86,3 \quad 92,2$

Fuentes: Naciones Unidas, base de datos Comtrade; Banco Mundial, base de datos sobre dinámica de las empresas de exportación; Banco Mundial, Indicadores del

Desarrollo Mundial; OMC, perfiles comerciales y arancelarios.

Participación en las exportaciones por región (\%)

\begin{tabular}{|l|r|r|}
\hline & $\mathbf{2 0 0 5}$ & $\mathbf{2 0 1 0}$ \\
\hline África & 46.7 & 46.1 \\
\hline Asia & 11.4 & 12.6 \\
\hline Comunidad de Estados Independientes & 1.1 & 1.9 \\
\hline Europa & 25.4 & 24.8 \\
\hline Oriente Medio & 3.5 & 7.4 \\
\hline América del Norte & 6.9 & 5.8 \\
\hline América del Sury América Central & 0.3 & 0.1 \\
\hline
\end{tabular}

Fuentes: OMC, perfiles comerciales y arancelarios

Indicadores de facilitación del comercio
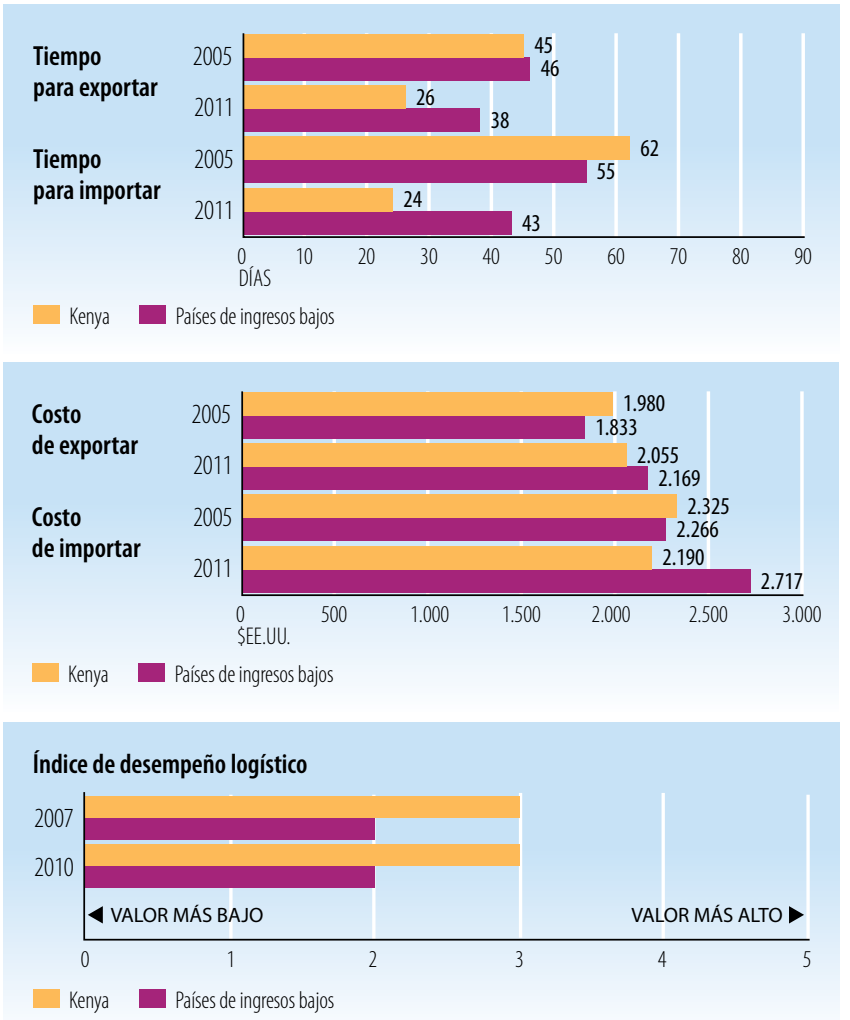

Fuentes: Banco Mundial, Indicadores del Desarrollo Mundial.

\begin{tabular}{l|c|c|}
\hline INDICADORES DE DESARROLLO (EFECTOS) \\
\hline Indicador & $\mathbf{2 0 0 5}$ & $\mathbf{2 0 1 0}$ \\
\hline Desempleo (\% de la fuerza de trabajo total) & n.d. & n.d. \\
\hline Población activa, mujeres (\% de la fuerza de trabajo total) & 46,5 & 46,5 \\
\hline AOD neta recibida (\% del INB) & 4,1 & 5,1 \\
\hline Derechos de importación percibidos (\% de los ingresos fiscales) & 8,9 & 8,3 \\
\hline Total del servicio de la deuda (\% de las exportaciones totales) & 9,9 & 4,4 \\
\hline Índice de desarrollo humano (0 a 1) & 0,47 & 0,51 \\
\hline
\end{tabular}

Fuentes: PNUD, indicadores internacionales sobre desarrollo humano; Banco Mundial, Indicadores del Desarrollo Mundial.

Producto interno bruto

PIB per cápita (PPA, dólares internacionales corrientes)

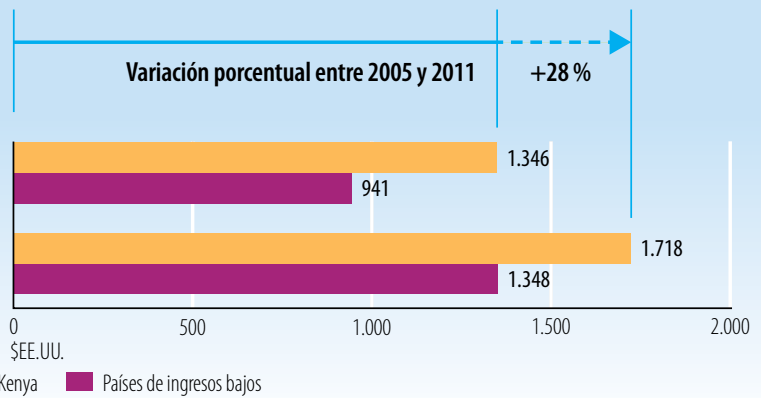

PIB per cápita (\$EE.UU. constantes de 2000)

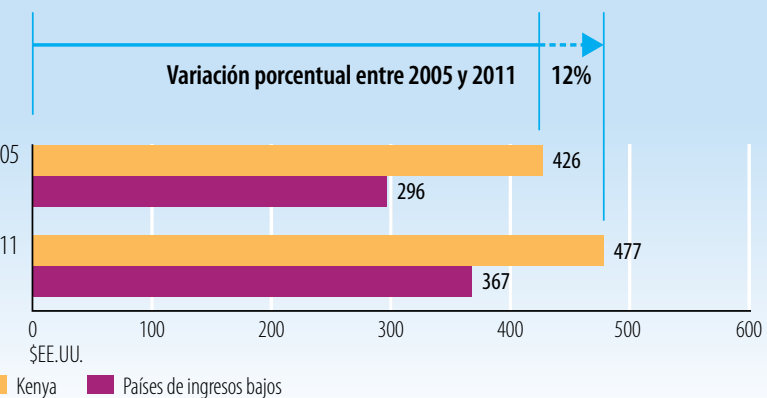

Fuentes: Banco Mundial, Indicadores del Desarrollo Mundial.

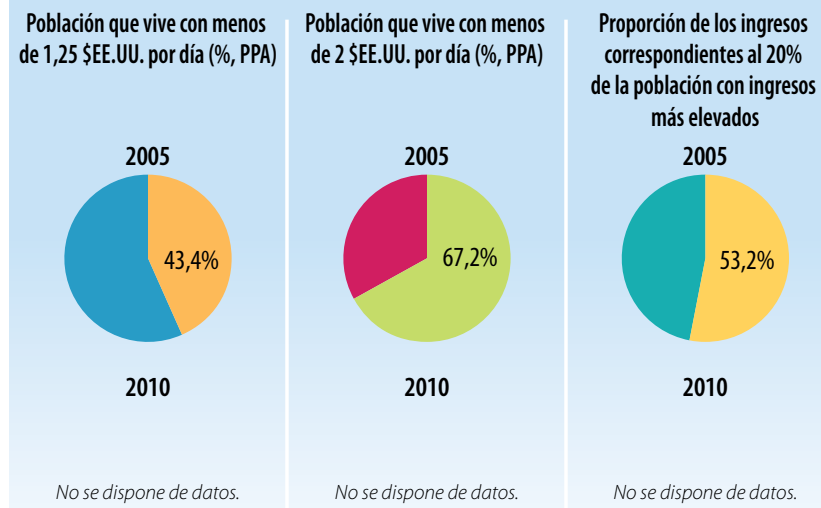

Fuentes: Banco Mundial, Indicadores del Desarrollo Mundial.

StatLink aㅔsम http://dx.doi.org/10.1787/888932845436 
Indicadores de la ayuda, el comercio y el desarrollo relativos a Lesotho

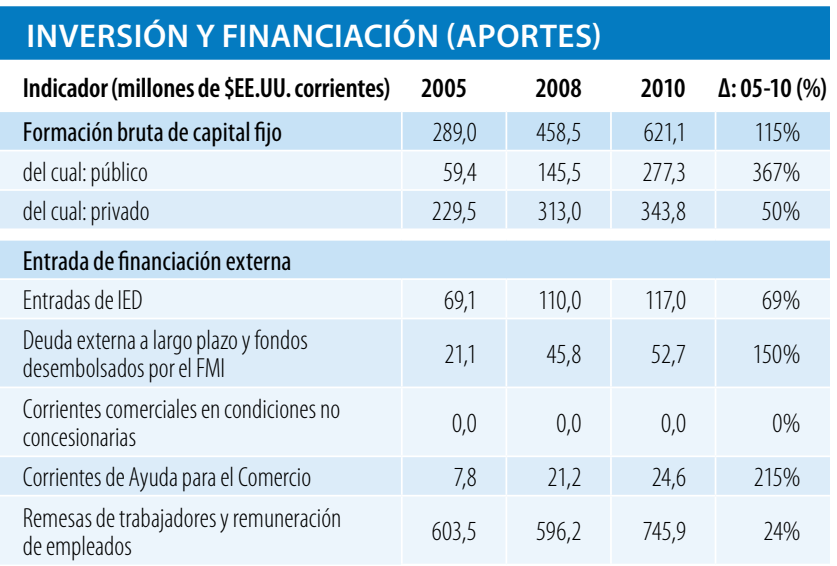

Fuentes: OCDE, base de datos del SNPA del CAD sobre las actividades de ayuda; Banco Mundial, Indicadores del Desarrollo Mundial; Banco Mundial, estadísticas de la deuda internacional.

Desembolsos de la ayuda para el comercio, por sector (millones de \$EE.UU. corrientes)

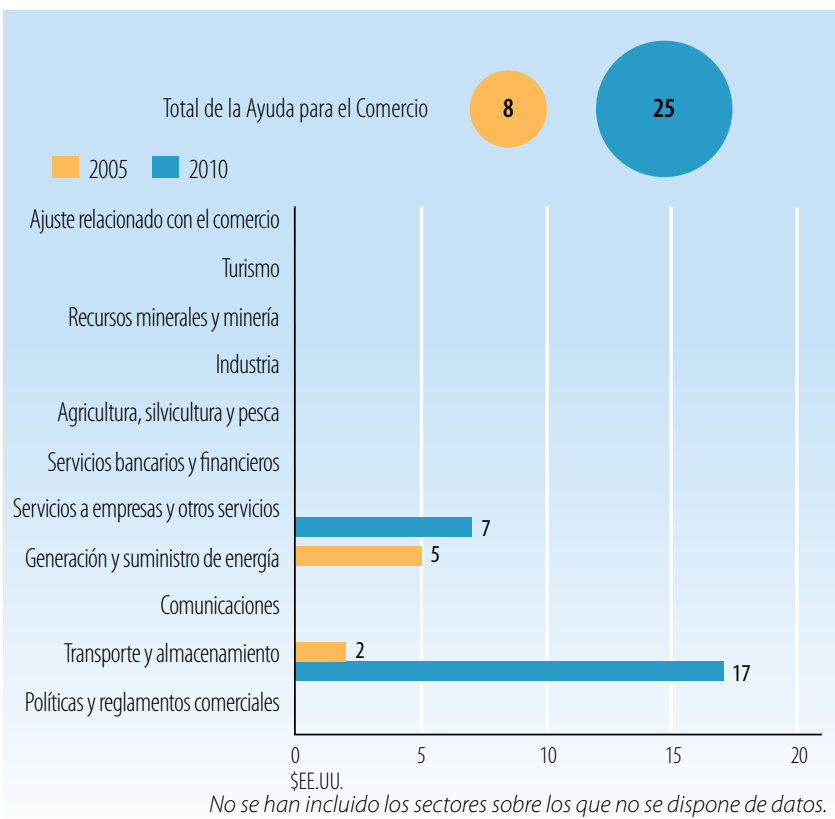

Fuentes: OCDE, base de datos del SNPA del CAD sobre las actividades de ayuda

Desembolsos de la ayuda para el comercio: principales donantes (millones de \$EE.UU. corrientes)

\begin{tabular}{|l|r|r|r|}
\hline $\mathbf{2 0 0 5}$ & Valor & $\%$ & Principales donantes en $\mathbf{2 0 0 5}$ \\
\hline Banco Mundial & 4,6 & 59 & \\
\hline Instituciones de la UE & 1,2 & 16 & $100 \%$ \\
\hline Irlanda & 1,1 & 15 & \\
\hline Alemania & 0,6 & 8 & \\
\hline Reino Unido & 0,3 & 3 & \\
\hline $\mathbf{2 0 1 0}$ & Valor & $\%$ & Principales donantes en 2010 \\
\hline Banco Mundial & 16,1 & 66 & \\
\hline Instituciones de la UE & 5,1 & 21 & \\
\hline Kuwait & 2,1 & 9 & $97 \%$ \\
\hline Banco Africano de Desarrollo & 0,3 & 1 & \\
\hline Alemania & 0,3 & 1 & \\
\hline
\end{tabular}

Fuentes: OCDE, base de datos del SNPA del CAD sobre las actividades de ayuda.

\section{INDICADORES COMERCIALES (PRODUCTOS)}

Indicador

$2005 \quad 2008 \quad 2011 \quad \Delta: 05-11(\%)$

Relación comercio/PIB (\%)

\begin{tabular}{|l|l|l|l|}
169 & 172 & 137 & -32 \\
\hline
\end{tabular}

Exportaciones de servicios comerciales como

$\%$ de las exportaciones totales

Importaciones de servicios comerciales como

$\%$ de las importaciones totales

\begin{tabular}{l|l|l|l}
5 & 4 & n.d. & n.d.
\end{tabular}

Productos intermedios distintos de los combustibles

(\% de las exportaciones de mercancías)

Productos intermedios distintos de los combustibles

(\% de las importaciones de mercancías)

\begin{tabular}{l|l|l|l|}
\hline 22 & 18 & n.d.
\end{tabular}

n.d. $51 \quad$ n.d. $\quad$ n.d.

n.d. $35 \quad$ n.d. $\quad$ n.d.

Fuentes: Secretaría de la OMC.

Corrientes comerciales (millones de \$EE.UU. corrientes)

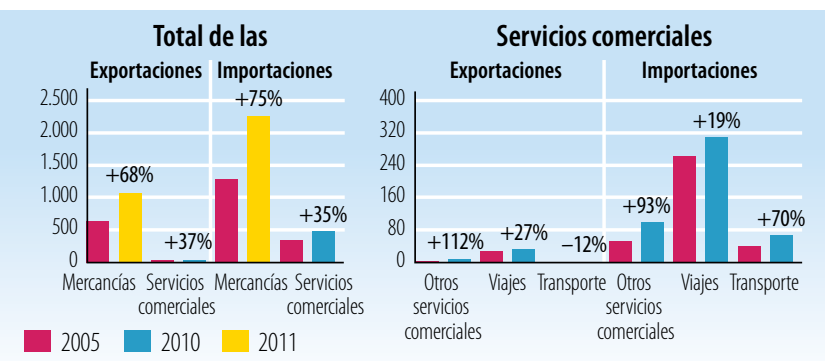

Fuentes: Secretaría de la OMC

Cinco principales mercados de exportación de mercancías (\%)

\begin{tabular}{|l|l|l|c|}
\hline & $\%$ & 2008 & $\%$ \\
\hline & & Sudáfrica & 83 \\
\hline No se dispone de datos. & & Estados Unidos & 15 \\
\hline & Madagascar & 1 \\
\hline & Kenya & 1 \\
\hline & Canadá & 0 \\
\hline
\end{tabular}

Fuentes: Secretaría de la OMC

Cinco principales productos de exportación (\% de las exportaciones de mercancías)

\begin{tabular}{|c|c|c|c|}
\hline 2008 & $\%$ & 2009 & $\%$ \\
\hline Receptores de televisión, etc. & 21 & $\begin{array}{l}\text { Otros artículos textiles y prendas de vestir, } \\
\text { n.e.p. }\end{array}$ & 17 \\
\hline $\begin{array}{l}\text { Circuitos eléctricos de conmutación } \\
\text { y relé }\end{array}$ & 18 & $\begin{array}{l}\text { Prendas de vestir para hombres y niños, } \\
\text { excepto las de punto }\end{array}$ & 14 \\
\hline Calzado & 7 & $\begin{array}{l}\text { Prendas de vestir para hombres y niños, } \\
\text { de punto }\end{array}$ & 11 \\
\hline Lana y otros pelos de animales & 6 & $\begin{array}{l}\text { Prendas de vestir para mujeres y niñas, } \\
\text { excepto las de punto }\end{array}$ & 10 \\
\hline $\begin{array}{l}\text { Prendas de vestir para hombres y niños, } \\
\text { excepto las de punto }\end{array}$ & 6 & Circuitos eléctricos de conmutación y relé & 7 \\
\hline
\end{tabular}

Fuentes: Secretaría de la OMC

Cinco principales mercados de importación de mercancías (\%)

\begin{tabular}{|c|c|c|c|}
\hline & $\%$ & 2008 & $\%$ \\
\hline & & Sudáfrica & 95 \\
\hline & & Japón & 2 \\
\hline \multirow[t]{3}{*}{ No se dispone de datos. } & & UE (27) & 2 \\
\hline & & Estados Unidos & 1 \\
\hline & & Swazilandia & 0 \\
\hline
\end{tabular}

Fuentes: Secretaría de la OMC

Cinco principales productos de importación (\% de las importaciones de mercancías)

\begin{tabular}{|c|c|c|c|}
\hline 2008 & $\%$ & 2009 & $\%$ \\
\hline Operaciones especiales no clasificadas & 13 & Productos derivados del petróleo & 6 \\
\hline Productos derivados del petróleo & 7 & Vehículos automotores de carretera, n.e.p. & 6 \\
\hline Productos de perfumería, cosméticos, etc. & 4 & Otras sémolas y harinas de cereales & 3 \\
\hline $\begin{array}{l}\text { Artículos manufacturados diversos, } \\
\text { n.e.p. }\end{array}$ & 4 & Otras carnes y despojos de carnes & 3 \\
\hline $\begin{array}{l}\text { Vehículos automotores de carretera, } \\
\text { n.e.p. }\end{array}$ & 4 & Muebles, cojines, etc. & 3 \\
\hline
\end{tabular}




\section{LA AYUDA PARA EL COMERCIO EN SÍNTESIS 2013}

\section{INDICADORES COMERCIALES (RESULTADOS)}

\section{Indicador}

Crecimiento del PIB (\%)

Número de exportadores

Índice de concentración de las exportaciones (productos) ( 0 a 1)

ACR sobre mercancías notificados a la OMC

AIE (servicios) notificados a la OMC

Sectores de servicios con compromisos en el marco del AGCS

\section{Aranceles $(\%, 2006$ et 2011)}

\begin{tabular}{ll|} 
Importaciones: promedio aritmético de los aranceles NMF aplicados $\quad 7,9$ & 7,6
\end{tabular}

Importaciones: promedio ponderado de los aranceles NMF aplicados n.d. n.d.

Exportaciones: promedio ponderado de los aranceles impuestos

por los importadores

Exportaciones: libres de derechos (en \%)

$0,0 \quad 0,1$

$99,9 \quad 99,1$

Fuentes: Naciones Unidas, base de datos Comtrade; Banco Mundial, base de datos sobre dinámica de las empresas de exportación; Banco Mundial, Indicadores del

Desarrollo Mundial; OMC, perfiles comerciales y arancelarios.

Participación en las exportaciones por región (\%)

\begin{tabular}{|l|r|r|}
\hline & 2005 & 2009 \\
\hline África & n.d. & 50,1 \\
\hline Asia & n.d. & 0,7 \\
\hline Comunidad de Estados Independientes & n.d. & 0,0 \\
\hline Europa & n.d. & 2,0 \\
\hline Oriente Medio & n.d. & 0,0 \\
\hline América del Norte & n.d. & 47,0 \\
\hline América del Sury América Central & n.d. & 0,0 \\
\hline
\end{tabular}

Fuentes: OMC, perfiles comerciales y arancelarios

Indicadores de facilitación del comercio
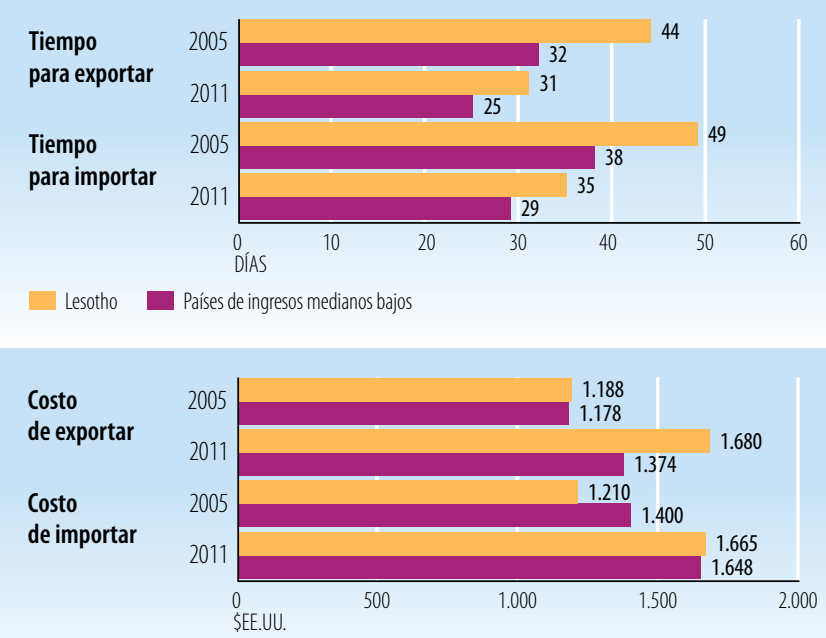

Lesotho Países de ingresos medianos bajos

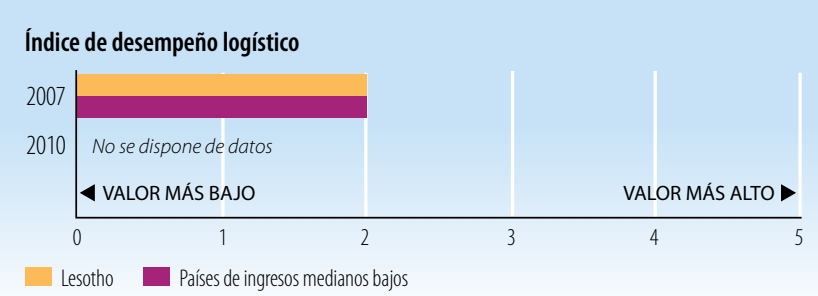

Fuentes: Banco Mundial, Indicadores del Desarrollo Mundial.

\begin{tabular}{|l|r|r|}
\hline INDICADORES DE DESARROLLO (EFECTOS) & \\
\hline Indicador & $\mathbf{2 0 0 5}$ & $\mathbf{2 0 1 0}$ \\
\hline Desempleo (\% de la fuerza de trabajo total) & n.d. & 25,3 \\
\hline Población activa, mujeres (\% de la fuerza de trabajo total) & 47,5 & 46,0 \\
\hline AOD neta recibida (\% del INB) & 3,6 & 9,5 \\
\hline Derechos de importación percibidos (\% de los ingresos fiscales) & 57,2 & n.d. \\
\hline Total del servicio de la deuda (\% de las exportaciones totales) & 5,7 & 1,9 \\
\hline Índice de desarrollo humano (0 a 1) & 0,42 & 0,45 \\
\hline
\end{tabular}

Fuentes: PNUD, indicadores internacionales sobre desarrollo humano; Banco Mundial, Indicadores del Desarrollo Mundial.

Producto interno bruto

PIB per cápita (PPA, dólares internacionales corrientes)

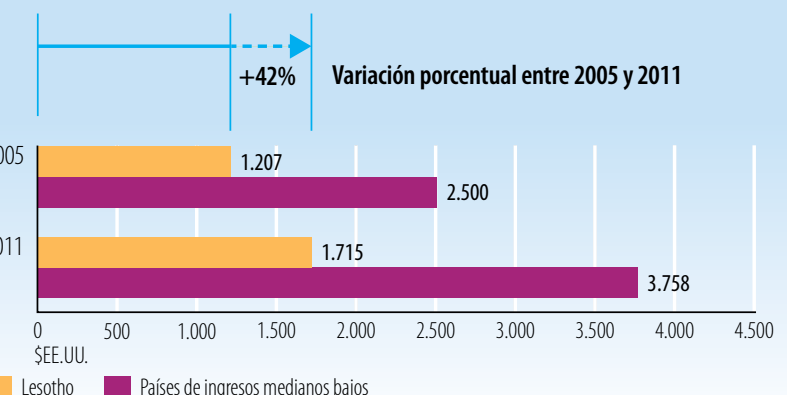

Lesotho Países de ingresos medianos bajos

PIB per cápita (\$EE.UU. constantes de 2000)

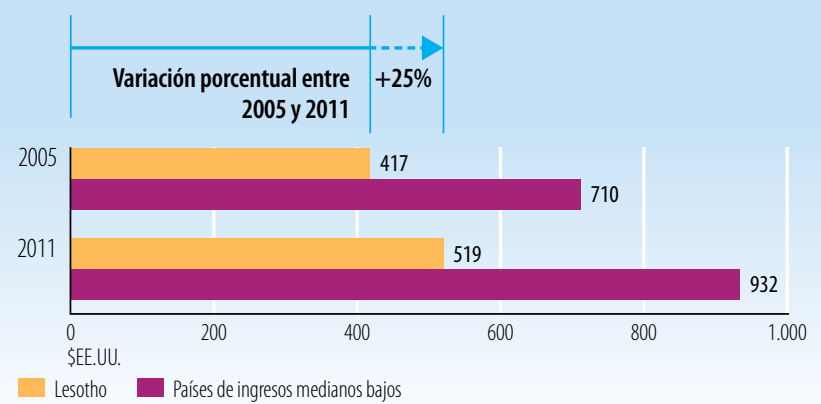

Fuentes: Banco Mundial, Indicadores del Desarrollo Mundial.

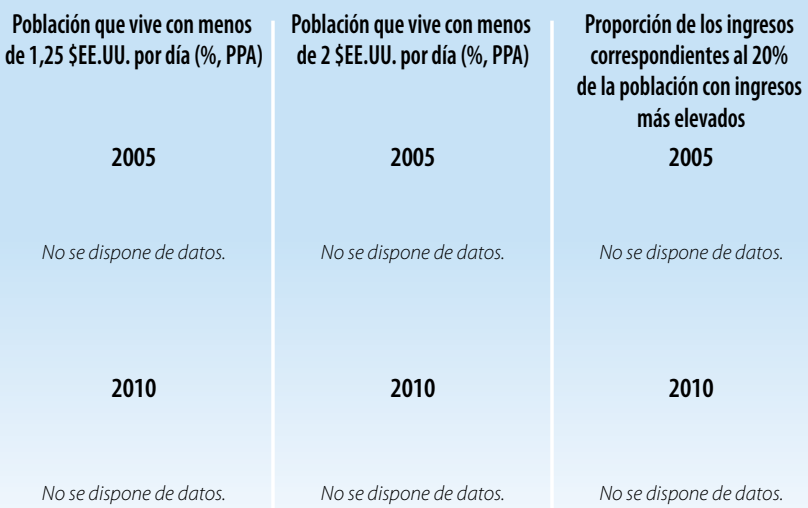

Fuentes: Banco Mundial, Indicadores del Desarrollo Mundial.

StatLink ㅊiाs] $h t$ tp://dx.doi.org/10.1787/888932845455 
Indicadores de la ayuda, el comercio y el desarrollo relativos a Liberia

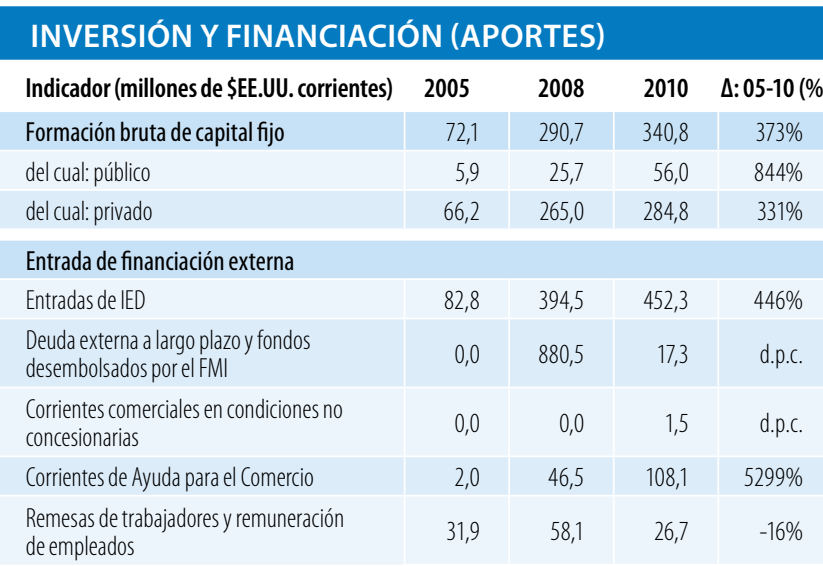

Fuentes: OCDE, base de datos del SNPA del CAD sobre las actividades de ayuda; Banco Mundial, Indicadores del Desarrollo Mundial; Banco Mundial, estadísticas de la deuda internacional.

Desembolsos de la ayuda para el comercio, por sector (millones de \$EE.UU. corrientes)

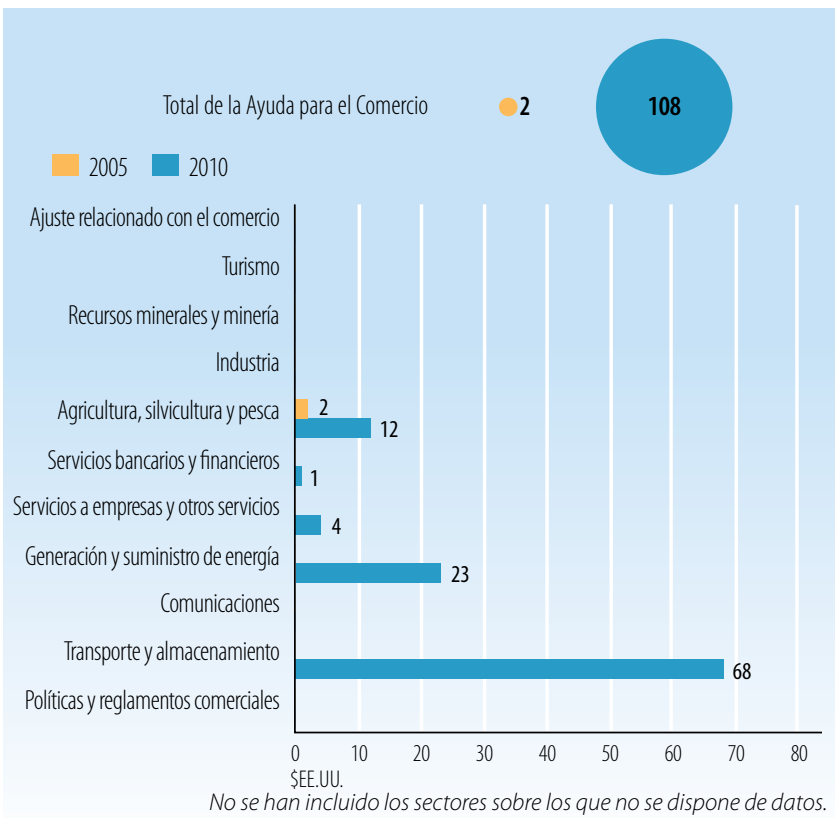

Fuentes: OCDE, base de datos del SNPA del CAD sobre las actividades de ayuda

Desembolsos de la ayuda para el comercio: principales donantes (millones de \$EE.UU. corrientes)

\begin{tabular}{|l|c|c|c|}
\hline $\mathbf{2 0 0 5}$ & Valor & $\%$ & Principales donantes en 2005 \\
\hline Estados Unidos & 1,1 & 56 & \\
\hline Irlanda & 0,7 & 33 & $100 \%$ \\
\hline Alemania & 0,1 & 6 & \\
\hline Instituciones de la UE & 0,1 & 5 & \\
\hline & & & \\
\hline $\mathbf{2 0 1 0}$ & Valor & $\%$ & Principales donantes en 2010 \\
\hline Instituciones de la UE & 49,0 & 45 & \\
\hline Estados Unidos & 13,8 & 13 & \\
\hline Noruega & 11,8 & 11 & $\mathbf{8 7 \%}$ \\
\hline Banco Mundial & 10,1 & 9 & \\
\hline Reino Unido & 9,4 & 9 &
\end{tabular}

Fuentes: OCDE, base de datos del SNPA del CAD sobre las actividades de ayuda.

\section{INDICADORES COMERCIALES (PRODUCTOS)}

\section{Indicador}

$20052008 \quad 2011 \quad \Delta: 05-11(\%)$

Relación comercio/PIB (\%)

\begin{tabular}{|l|l|l|l|}
114 & 177 & 125 & 10 \\
\hline
\end{tabular}

Exportaciones de servicios comerciales como

$\%$ de las exportaciones totales

$\begin{array}{llll}38 & 42 & \text { n.d. } & \text { n.d. }\end{array}$

Importaciones de servicios comerciales como

$\%$ de las importaciones totales

\begin{tabular}{ll|l|l}
25 & 32 & n.d. & n.d.
\end{tabular}

Productos intermedios distintos de los combustibles

(\% de las exportaciones de mercancías)

Productos intermedios distintos de los combustibles

(\% de las importaciones de mercancías)

n.d. n.d. n.d. n.d.

Fuentes: Secretaría de la OMC

Corrientes comerciales (millones de \$EE.UU. corrientes)

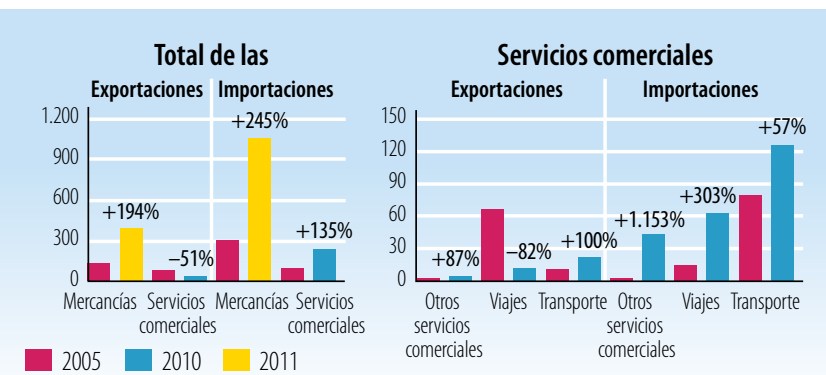

Fuentes: Secretaría de la OMC

Cinco principales mercados de exportación de mercancías (\%)

$\%$

No se dispone de datos.

No se dispone de datos.

Fuentes: Secretaría de la OMC

Cinco principales productos de exportación (\% de las exportaciones de mercancías) $\%$ $\%$

No se dispone de datos.

No se dispone de datos.

Fuentes: Secretaría de la OMC

Cinco principales mercados de importación de mercancías (\%)

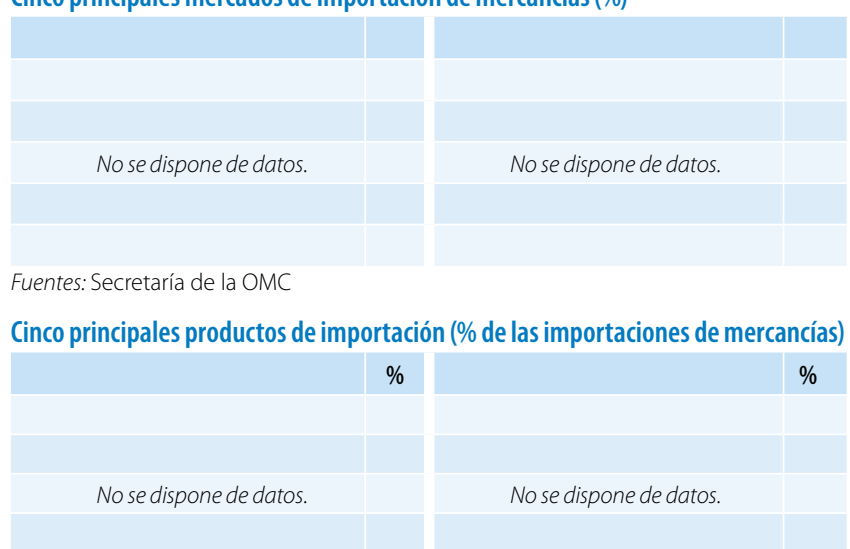

Fuentes: Secretaría de la OMC 


\section{LA AYUDA PARA EL COMERCIO EN SÍNTESIS 2013}

\section{INDICADORES COMERCIALES (RESULTADOS)}

\section{Indicador}

Crecimiento del PIB (\%)

Número de exportadores

Índice de concentración de las exportaciones (productos) ( 0 a 1)

ACR sobre mercancías notificados a la OMC

AIE (servicios) notificados a la OMC

Sectores de servicios con compromisos en el marco del AGCS

\section{Aranceles (\%)}

Importaciones: promedio aritmético de los aranceles NMF aplicados n.d. n.d.

Importaciones: promedio ponderado de los aranceles NMF aplicados n.d. n.d.

Exportaciones: promedio ponderado de los aranceles impuestos n.d. n.d.

por los importadores

n.d. n.d.

Exportaciones: libres de derechos (en \%)

Fuentes: Naciones Unidas, base de datos Comtrade; Banco Mundial, base de datos sobre dinámica de las empresas de exportación; Banco Mundial, Indicadores del

Desarrollo Mundial; OMC, perfiles comerciales y arancelarios.

Participación en las exportaciones por región (\%)

\begin{tabular}{|l|c|c|}
\hline & 2005 & 2011 \\
\hline África & n.d. & n.d. \\
\hline Asia & n.d. & n.d. \\
\hline Comunidad de Estados Independientes & n.d. & n.d. \\
\hline Europa & n.d. & n.d. \\
\hline Oriente Medio & n.d. & n.d. \\
\hline América del Norte & n.d. & n.d. \\
\hline América del Sury América Central & n.d. & n.d. \\
\hline
\end{tabular}

Fuentes: OMC, perfiles comerciales y arancelarios

Indicadores de facilitación del comercio
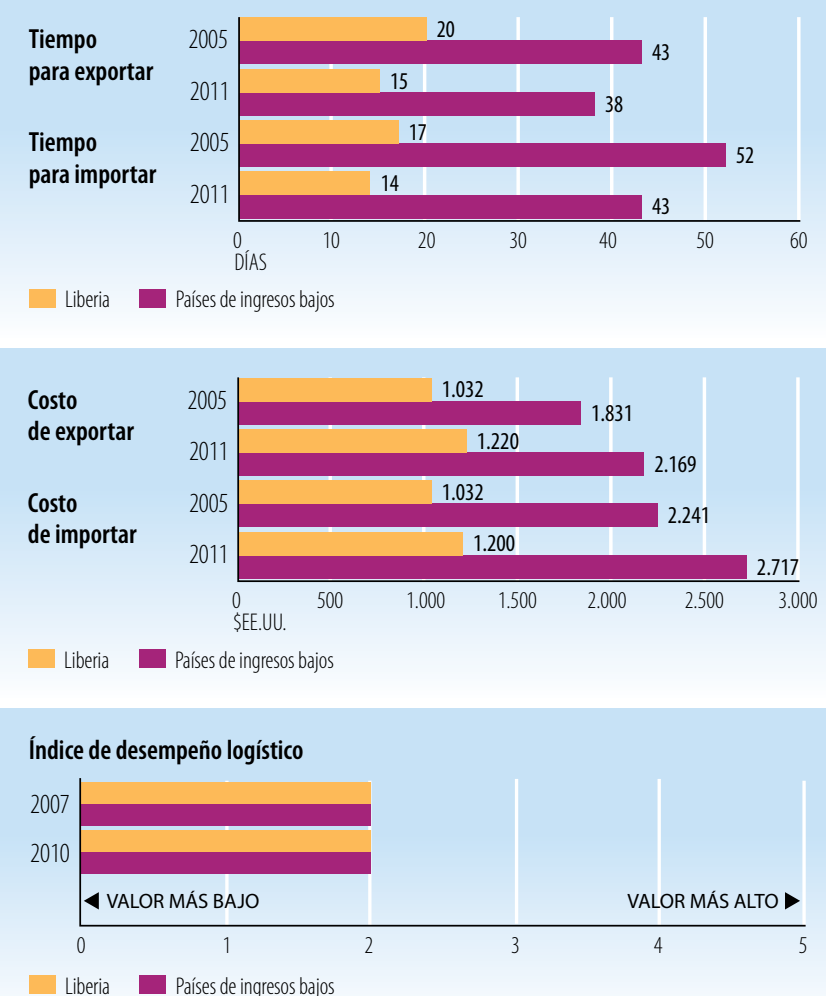

Fuentes: Banco Mundial, Indicadores del Desarrollo Mundial.

\begin{tabular}{|l|c|c|}
\hline INDICADORES DE DESARROLLO (EFECTOS) & \\
\hline Indicador & 2005 & 2010 \\
\hline Desempleo (\% de la fuerza de trabajo total) & n.d. & 3,7 \\
\hline Población activa, mujeres (\% de la fuerza de trabajo total) & 48,7 & 47,7 \\
\hline AOD neta recibida (\% del INB) & 56,4 & 175,5 \\
\hline Derechos de importación percibidos (\% de los ingresos fiscales) & 41,5 & n.d. \\
\hline Total del servicio de la deuda (\% de las exportaciones totales) & 0,3 & 1,3 \\
\hline Índice de desarrollo humano (0 a 1) & 0,30 & 0,33 \\
\hline
\end{tabular}

Fuentes: PNUD, indicadores internacionales sobre desarrollo humano; Banco Mundial, Indicadores del Desarrollo Mundial.

Producto interno bruto

PIB per cápita (PPA, dólares internacionales corrientes)
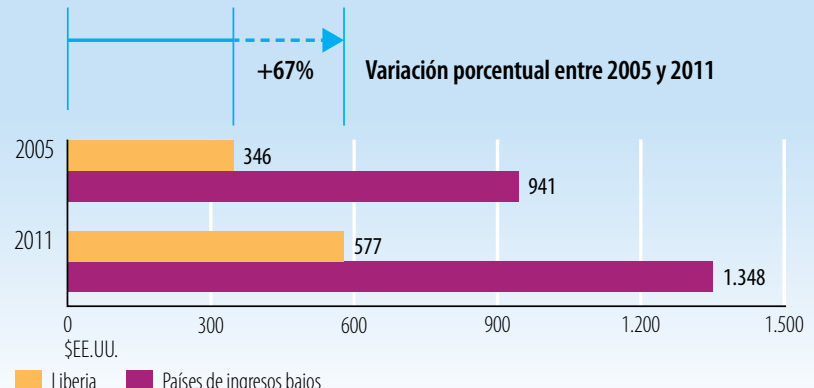

PIB per cápita (\$EE.UU. constantes de 2000)
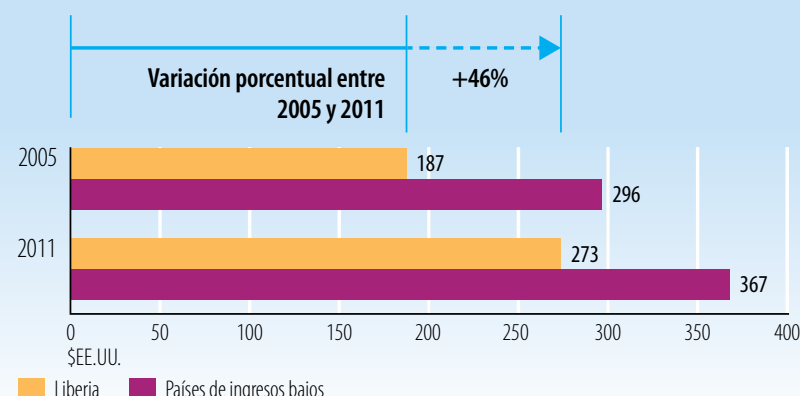

Fuentes: Banco Mundial, Indicadores del Desarrollo Mundial.

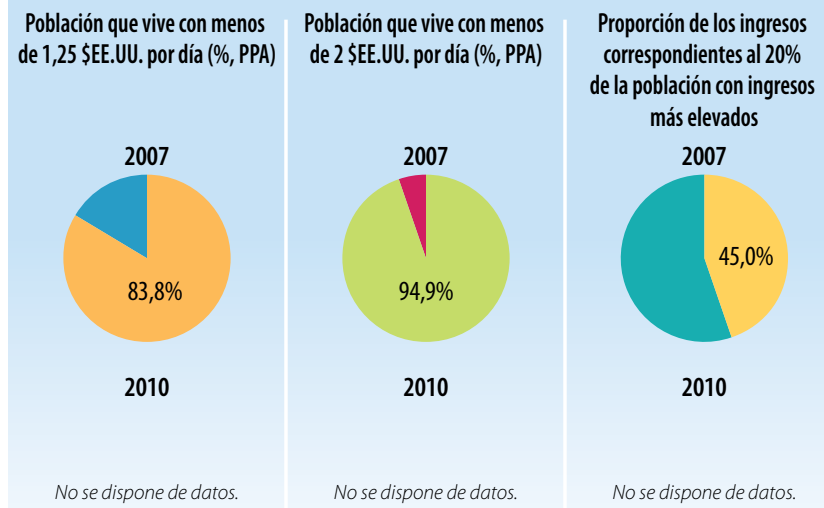

Fuentes: Banco Mundial, Indicadores del Desarrollo Mundial.

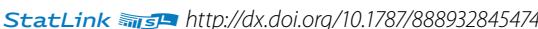




\section{Indicadores de la ayuda, el comercio y el desarrollo relativos a Madagascar}

\begin{tabular}{|c|c|c|c|c|}
\hline Indicador (millones de \$EE.UU. corrientes) & 2005 & 2008 & 2010 & $\Delta: 05-10(\%)$ \\
\hline Formación bruta de capital fijo & $1.118,5$ & $3.795,1$ & n.d. & n.d. \\
\hline del cual: público & 438,9 & 668,2 & n.d. & n.d. \\
\hline del cual: privado & 679,6 & $3.126,9$ & n.d. & n.d. \\
\hline \multicolumn{5}{|l|}{ Entrada de financiación externa } \\
\hline Entradas de IED & 85,4 & $1.169,4$ & 860,4 & $907 \%$ \\
\hline $\begin{array}{l}\text { Deuda externa a largo plazo y fondos } \\
\text { desembolsados por el FMl }\end{array}$ & 265,4 & 404,1 & 211,3 & $-20 \%$ \\
\hline $\begin{array}{l}\text { Corrientes comerciales en condiciones no } \\
\text { concesionarias }\end{array}$ & 0,0 & 343,3 & 207,5 & d.p.c. \\
\hline Corrientes de Ayuda para el Comercio & 218,4 & 269,2 & 126,7 & $-42 \%$ \\
\hline $\begin{array}{l}\text { Remesas de trabajadores y remuneración } \\
\text { de empleados }\end{array}$ & 11,0 & n.d. & n.d. & n.d. \\
\hline
\end{tabular}

Fuentes: OCDE, base de datos del SNPA del CAD sobre las actividades de ayuda; Banco Mundial, Indicadores del Desarrollo Mundial; Banco Mundial, estadísticas de la deuda internacional.

Desembolsos de la ayuda para el comercio, por sector (millones de \$EE.UU. corrientes)

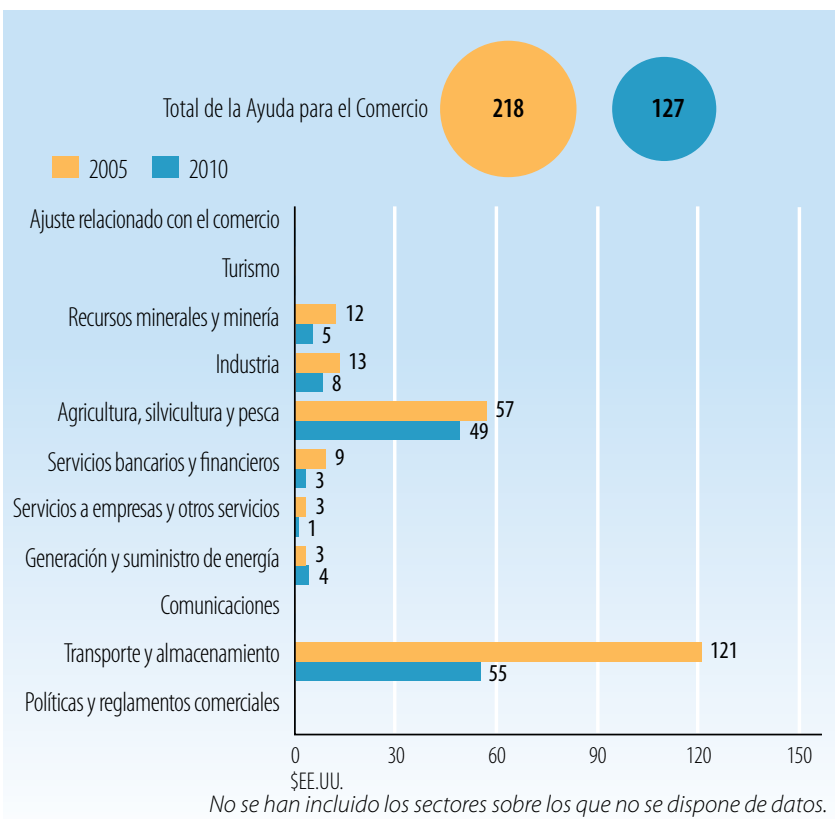

Fuentes: OCDE, base de datos del SNPA del CAD sobre las actividades de ayuda

Desembolsos de la ayuda para el comercio: principales donantes (millones de \$EE.UU. corrientes)

\begin{tabular}{|l|r|r|}
\hline $\mathbf{2 0 0 5}$ & Valor & $\%$ \\
\hline Banco Mundial & 93,5 & 43 \\
\hline Instituciones de la UE & 80,0 & 37 \\
\hline Japón & 14,4 & 7 \\
\hline Francia & 10,2 & 5 \\
\hline Banco Africano de Desarrollo & 8,7 & 4 \\
\hline $\mathbf{2 0 1 0}$ & Valor & $\%$ \\
\hline Banco Mundial & 52,3 & 41 \\
\hline Francia & 19,8 & 16 \\
\hline Instituciones de la UE & 10,2 & 8 \\
\hline OFID & 9,8 & 8 \\
\hline Banco Africano de Desarrollo & 9,1 & 7 \\
\hline
\end{tabular}
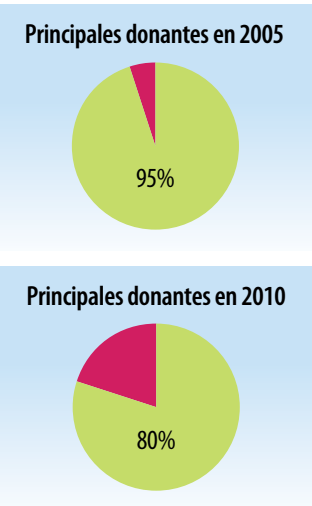

Fuentes: OCDE, base de datos del SNPA del CAD sobre las actividades de ayuda.

\section{INDICADORES COMERCIALES (PRODUCTOS)}

Indicador $2005 \quad 2008 \quad 2011 \quad \Delta: 05-11(\%)$

Relación comercio/PIB (\%)

Exportaciones de servicios comerciales como

$\%$ de las exportaciones totales

Importaciones de servicios comerciales como

$\%$ de las importaciones totales

Productos intermedios distintos de los combustibles

(\% de las exportaciones de mercancías)

Productos intermedios distintos de los combustibles

(\% de las importaciones de mercancías)

\begin{tabular}{|l|l|l|r|}
62 & 74 & 61 & -1 \\
\hline
\end{tabular}

Fuentes: Secretaría de la OMC.

Corrientes comerciales (millones de \$EE.UU. corrientes)

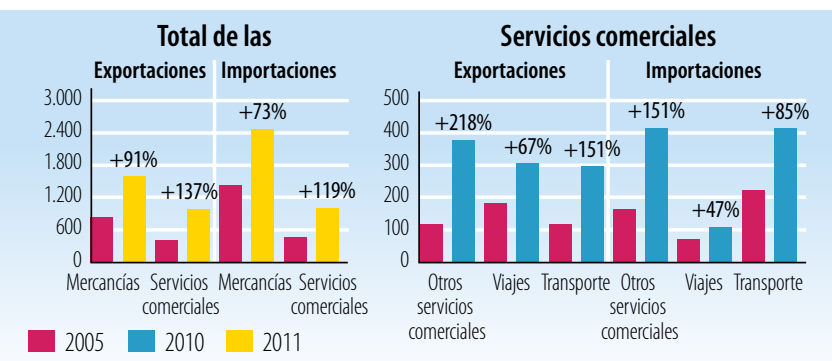

Fuentes: Secretaría de la OMC

Cinco principales mercados de exportación de mercancías (\%)

\begin{tabular}{|l|r|l|r|}
\hline 2005 & $\%$ & 2010 & $\%$ \\
\hline UE (27) & 51 & UE (27) & 54 \\
\hline Estados Unidos & 22 & China & 5 \\
\hline China & 4 & Côte d'Ivoire & 5 \\
\hline Bahrein & 3 & India & 4 \\
\hline Japón & 2 & Estados Unidos & 4 \\
\hline
\end{tabular}

Cinco principales productos de exportación (\% de las exportaciones de mercancías)

\begin{tabular}{|c|c|c|c|}
\hline 2005 & $\%$ & 2010 & $\%$ \\
\hline Crustáceos, moluscos, etc. & 13 & $\begin{array}{l}\text { Otros artículos textiles y prendas de } \\
\text { vestir, n.e.p. }\end{array}$ & 14 \\
\hline $\begin{array}{l}\text { Otros artículos textiles y prendas de } \\
\text { vestir, n.e.p. }\end{array}$ & 10 & Crustáceos, moluscos, etc. & 7 \\
\hline $\begin{array}{l}\text { Prendas de vestir para mujeres y niñas, } \\
\text { excepto las de punto }\end{array}$ & 9 & $\begin{array}{l}\text { Minerales de metales comunes y sus } \\
\text { concentrados }\end{array}$ & 6 \\
\hline Operaciones especiales no clasificadas & 8 & Productos derivados del petróleo & 6 \\
\hline Especias & 8 & Operaciones especiales no clasificadas & 5 \\
\hline
\end{tabular}

Cinco principales mercados de importación de mercancías (\%)

\begin{tabular}{|l|r|l|c|}
\hline 2005 & $\%$ & 2010 & $\%$ \\
\hline UE (27) & 26 & UE (27) & 25 \\
\hline China & 14 & China & 12 \\
\hline Bahrein & 13 & Sudáfrica & 8 \\
\hline Mauricio & 7 & Estados Unidos & 6 \\
\hline India & 6 & Bahrein & 5 \\
\hline
\end{tabular}

Fuentes: Secretaría de la OMC

Cinco principales productos de importación (\% de las importaciones de mercancías)

\begin{tabular}{|c|c|c|c|}
\hline 2005 & $\%$ & 2010 & $\%$ \\
\hline Productos derivados del petróleo & 15 & Productos derivados del petróleo & 14 \\
\hline Arroz & 6 & Grifos, llaves, válvulas, etc. & 4 \\
\hline Hilados de fibra textil & 4 & Hilados de fibra textil & 4 \\
\hline $\begin{array}{l}\text { Vehículos automotores para el transporte } \\
\text { de mercancías y vehículos automotores } \\
\text { para usos especiales }\end{array}$ & 4 & Arroz & 2 \\
\hline Tejidos de algodón & 4 & Azúcares, melaza y miel & 2 \\
\hline
\end{tabular}




\section{LA AYUDA PARA EL COMERCIO EN SÍNTESIS 2013}

\section{INDICADORES COMERCIALES (RESULTADOS)}

Indicador

Crecimiento del PIB (\%)

Número de exportadores

Índice de concentración de las exportaciones (productos) ( 0 a 1)

ACR sobre mercancías notificados a la OMC

AIE (servicios) notificados a la OMC

Sectores de servicios con compromisos en el marco del AGCS

\section{Aranceles (\%, 2006 et 2011)}

\begin{tabular}{|l|l|l|} 
Importaciones: promedio aritmético de los aranceles NMF aplicados & 13,3 & 11,6
\end{tabular}

\begin{tabular}{l|l|l|l|} 
Importaciones: promedio ponderado de los aranceles NMF aplicados & 9,3 & 8,7
\end{tabular}

Exportaciones: promedio ponderado de los aranceles impuestos

por los importadores

$0,3 \quad 0,3$

Exportaciones: libres de derechos (en \%)

$99,3 \quad 98,2$

Fuentes: Naciones Unidas, base de datos Comtrade; Banco Mundial, base de datos sobre dinámica de las empresas de exportación; Banco Mundial, Indicadores del

Desarrollo Mundial; OMC, perfiles comerciales y arancelarios.

Participación en las exportaciones por región (\%)

\begin{tabular}{|l|r|r|}
\hline & 2005 & 2011 \\
\hline África & 4,3 & 7,0 \\
\hline Asia & 13,1 & 23,2 \\
\hline Comunidad de Estados Independientes & 0,0 & 0,1 \\
\hline Europa & 51,6 & 55,0 \\
\hline Oriente Medio & 3,6 & 1,6 \\
\hline América del Norte & 22,7 & 8,2 \\
\hline América del Sury América Central & 0,1 & 0,2 \\
\hline
\end{tabular}

Fuentes: OMC, perfiles comerciales y arancelarios

Indicadores de facilitación del comercio
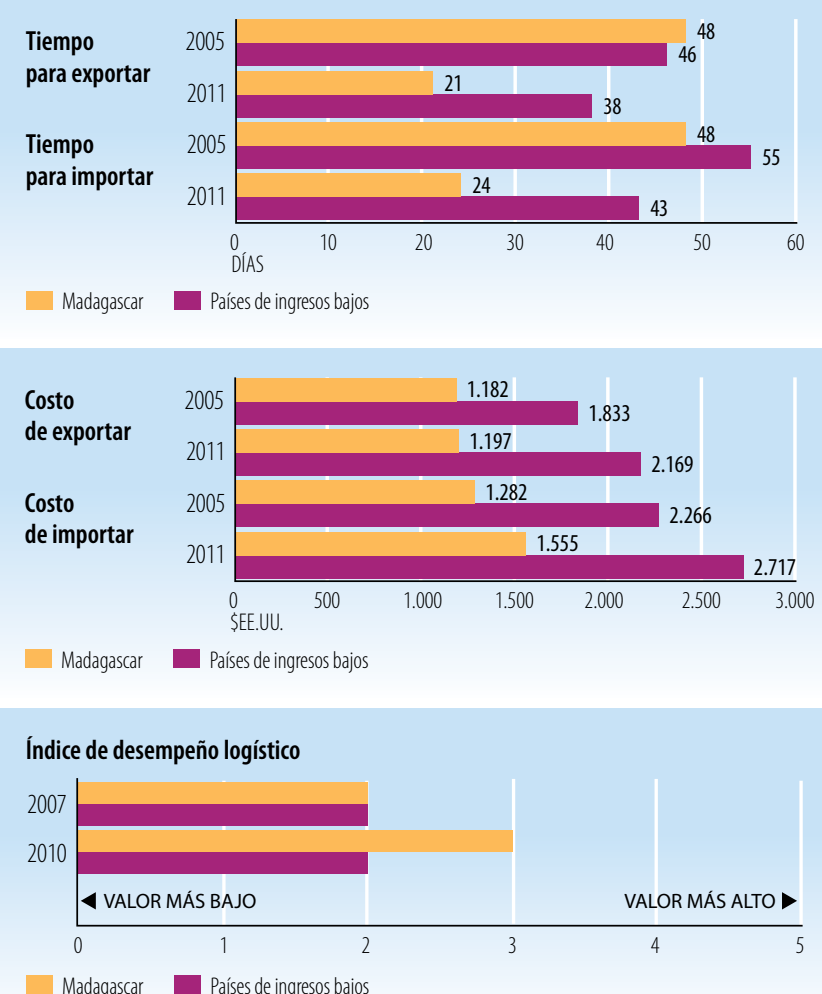

Madagascar Países de ingresos bajos

Fuentes: Banco Mundial, Indicadores del Desarrollo Mundial.

\begin{tabular}{|l|r|r|}
\hline INDICADORES DE DESARROLLO (EFECTOS) & \\
\hline Indicador & $\mathbf{2 0 0 5}$ & $\mathbf{2 0 1 0}$ \\
\hline Desempleo (\% de la fuerza de trabajo total) & 2,6 & n.d. \\
\hline Población activa, mujeres (\% de la fuerza de trabajo total) & 48,9 & 48,9 \\
\hline AOD neta recibida (\% del INB) & 18,4 & 5,4 \\
\hline Derechos de importación percibidos (\% de los ingresos fiscales) & 48,1 & n.d. \\
\hline Total del servicio de la deuda (\% de las exportaciones totales) & 5,8 & 2,6 \\
\hline Índice de desarrollo humano ( 0 a 1) & 0,47 & 0,48 \\
\hline
\end{tabular}

Fuentes: PNUD, indicadores internacionales sobre desarrollo humano; Banco Mundial, Indicadores del Desarrollo Mundial.

Producto interno bruto

PIB per cápita (PPA, dólares internacionales corrientes)
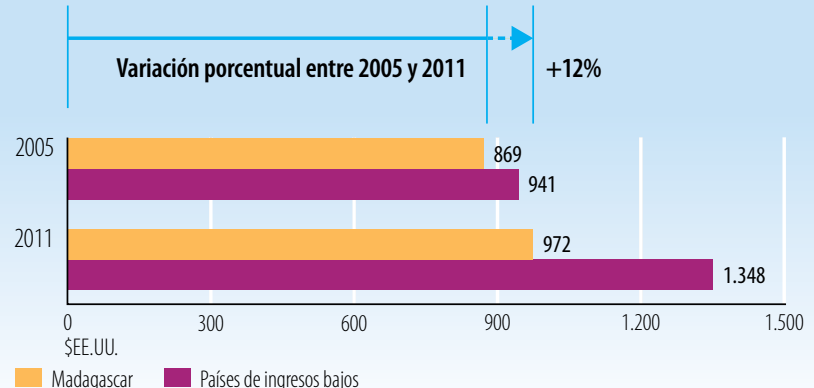

PIB per cápita (\$EE.UU. constantes de 2000)
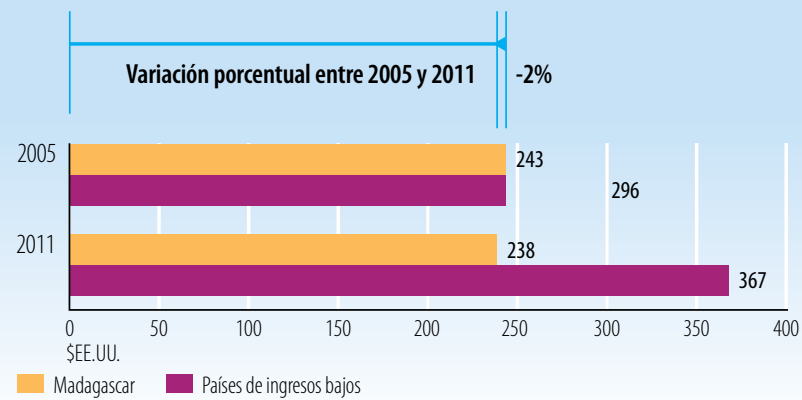

Fuentes: Banco Mundial, Indicadores del Desarrollo Mundial.

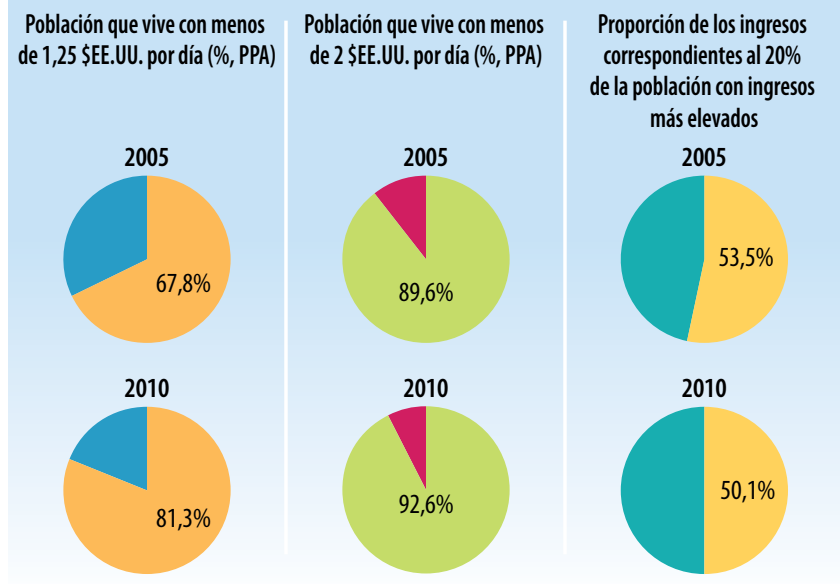

Fuentes: Banco Mundial, Indicadores del Desarrollo Mundial.

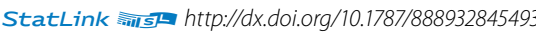


Indicadores de la ayuda, el comercio y el desarrollo relativos a Malawi

\begin{tabular}{|c|c|c|c|c|}
\hline Indicador (millones de \$EE.UU. corrientes) & 2005 & 2008 & 2010 & $\Delta: 05-10(\%$ \\
\hline Formación bruta de capital fijo & 556,1 & 947,6 & $1.095,3$ & $97 \%$ \\
\hline del cual: público & 198,9 & 383,3 & 239,0 & $20 \%$ \\
\hline del cual: privado & 357,2 & 564,3 & 856,3 & $140 \%$ \\
\hline \multicolumn{5}{|l|}{ Entrada de financiación externa } \\
\hline Entradas de IED & 38,1 & 175,8 & 140,0 & $267 \%$ \\
\hline $\begin{array}{l}\text { Deuda externa a largo plazo y fondos } \\
\text { desembolsados por el FMl }\end{array}$ & 96,5 & 162,5 & 99,9 & $4 \%$ \\
\hline $\begin{array}{l}\text { Corrientes comerciales en condiciones no } \\
\text { concesionarias }\end{array}$ & 0,0 & 3,4 & 0,0 & $0 \%$ \\
\hline Corrientes de Ayuda para el Comercio & 116,1 & 113,4 & 184,4 & $59 \%$ \\
\hline $\begin{array}{l}\text { Remesas de trabajadores y remuneración } \\
\text { de empleados }\end{array}$ & n.d. & n.d. & n.d. & n.d. \\
\hline
\end{tabular}

Fuentes: OCDE, base de datos del SNPA del CAD sobre las actividades de ayuda; Banco Mundial, Indicadores del Desarrollo Mundial; Banco Mundial, estadísticas de la deuda internacional.

Desembolsos de la ayuda para el comercio, por sector (millones de \$EE.UU. corrientes)

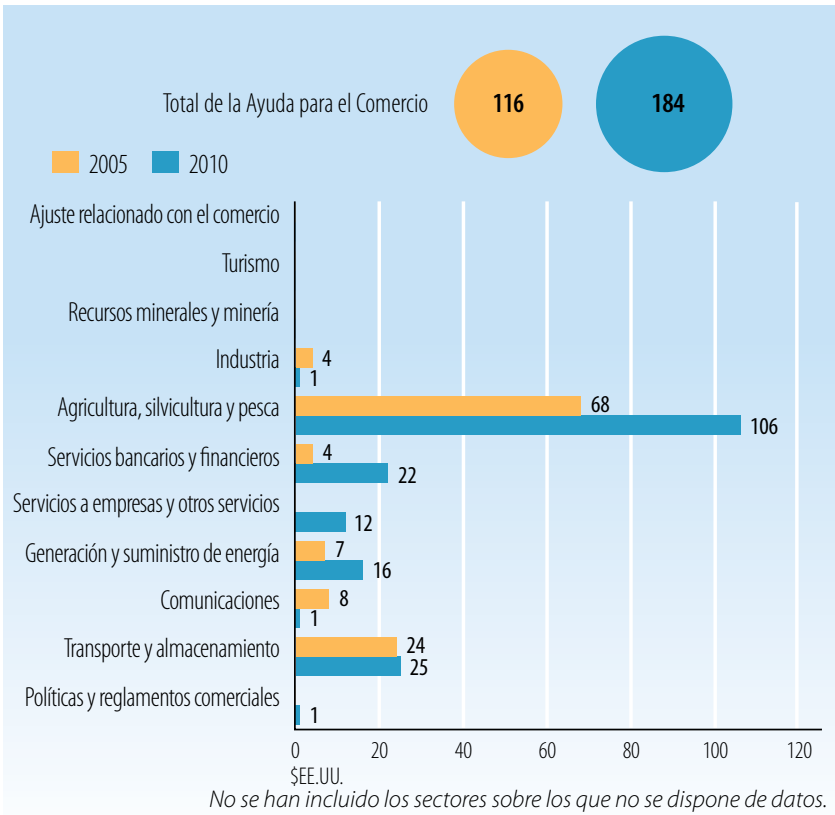

Fuentes: OCDE, base de datos del SNPA del CAD sobre las actividades de ayuda

Desembolsos de la ayuda para el comercio: principales donantes (millones de \$EE.UU. corrientes)

\begin{tabular}{|l|c|c|}
\hline $\mathbf{2 0 0 5}$ & Valor & $\%$ \\
\hline Banco Mundial & 56,2 & 48 \\
\hline Estados Unidos & 13,7 & 12 \\
\hline Instituciones de la UE & 13,5 & 12 \\
\hline Reino Unido & 9,6 & 8 \\
\hline Japón & 7,0 & 6 \\
\hline $\mathbf{2 0 1 0}$ & Valor & $\%$ \\
\hline Banco Mundial & 66,2 & 36 \\
\hline Japón & 36,7 & 20 \\
\hline Instituciones de la UE & 21,6 & 12 \\
\hline Noruega & 15,1 & 8 \\
\hline Estados Unidos & 10,5 & 6 \\
\hline
\end{tabular}

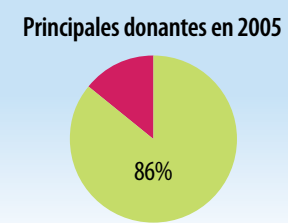

Principales donantes en 2010

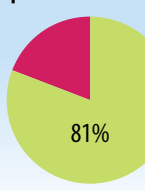

Fuentes: OCDE, base de datos del SNPA del CAD sobre las actividades de ayuda.

\section{INDICADORES COMERCIALES (PRODUCTOS)}

\section{Indicador}

$20052008 \quad 2011 \quad \Delta: 05-11(\%)$

Relación comercio/PIB (\%)

Exportaciones de servicios comerciales como

$\%$ de las exportaciones totales

Importaciones de servicios comerciales como

$\%$ de las importaciones totales

Productos intermedios distintos de los combustibles

(\% de las exportaciones de mercancías)

Productos intermedios distintos de los combustibles

(\% de las importaciones de mercancías)

\begin{tabular}{|l|l|l|l|}
75 & 75 & 76 & 1 \\
\hline
\end{tabular}

$\begin{array}{llll}16 & 11 & \text { n.d. }\end{array}$

\begin{tabular}{l|l|l|l}
9 & 4 & n.d. & n.d.
\end{tabular}

\begin{tabular}{|l|l|l|l|}
\hline 74 & 86 & 82 & 8
\end{tabular}

\begin{tabular}{|l|l|l|r|}
\hline 57 & 53 & 55 & -2 \\
\hline
\end{tabular}

Fuentes: Secretaría de la OMC.

Corrientes comerciales (millones de \$EE.UU. corrientes)

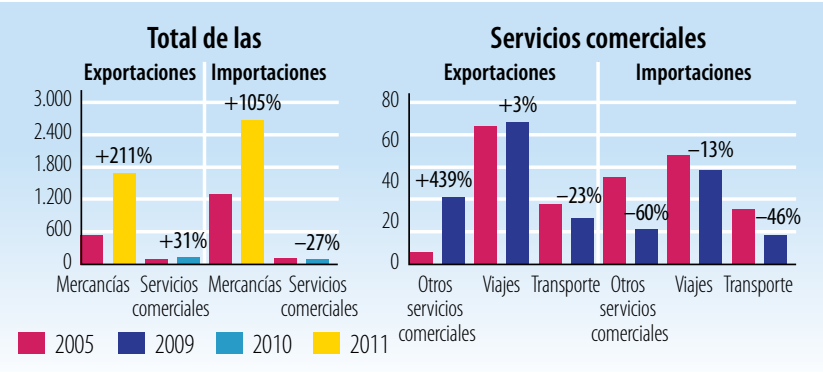

Fuentes: Secretaría de la OMC

Cinco principales mercados de exportación de mercancías (\%)

\begin{tabular}{|l|r|l|c|}
\hline 2005 & $\%$ & 2010 & $\%$ \\
\hline UE (27) & 36 & UE $(27)$ & 37 \\
\hline Sudáfrica & 19 & Canadá & 11 \\
\hline Estados Unidos & 11 & Egipto & 9 \\
\hline Suiza & 7 & Estados Unidos & 6 \\
\hline Federación de Rusia & 4 & Sudáfrica & 6 \\
\hline
\end{tabular}

Fuentes: Secretaría de la OMC

Cinco principales productos de exportación (\% de las exportaciones de mercancías)

\begin{tabular}{|c|c|c|c|}
\hline 2005 & $\%$ & 2011 & $\%$ \\
\hline Tabaco sin elaborar & 53 & Tabaco sin elaborar & 40 \\
\hline Téy mate & 10 & Azúcares, melaza y miel & 15 \\
\hline Azúcares, melaza y miel & 9 & Minerales, etc., de uranio o torio & 8 \\
\hline Algodón & 3 & Téy mate & 6 \\
\hline $\begin{array}{l}\text { Prendas de vestir para hombres y niños, } \\
\text { excepto las de punto }\end{array}$ & 3 & Maíz sin moler & 6 \\
\hline
\end{tabular}

Cinco principales mercados de importación de mercancías (\%)

\begin{tabular}{|l|r|l|c|}
\hline 2005 & $\%$ & 2010 & $\%$ \\
\hline Sudáfrica & 33 & Sudáfrica & 30 \\
\hline UE (27) & 15 & UE (27) & 14 \\
\hline Mozambique & 13 & China & 9 \\
\hline Zimbabwe & 8 & India & 8 \\
\hline Zambia & 5 & Zambia & 6 \\
\hline
\end{tabular}

Cinco principales productos de importación (\% de las importaciones de mercancías)

\begin{tabular}{|l|r|l|c|}
\hline 2005 & $\%$ & 2011 & $\%$ \\
\hline Abonos, excepto los del grupo 272 & 10 & Productos derivados del petróleo & 8 \\
\hline Productos derivados del petróleo & 10 & Abonos, excepto los del grupo 272 & 8 \\
\hline Tabaco sin elaborar & 8 & Medicamentos & 6 \\
\hline Impresos & 3 & Equipo electromédico y de rayos X & 4 \\
\hline Medicamentos & 3 & Tabaco sin elaborar & 3 \\
\hline
\end{tabular}

Fuentes: Secretaría de la OMC 


\section{LA AYUDA PARA EL COMERCIO EN SIINTESIS 2013}

\section{INDICADORES COMERCIALES (RESULTADOS)}

\section{Indicador}

Crecimiento del PIB (\%)

Número de exportadores

Índice de concentración de las exportaciones (productos) ( 0 a 1)

ACR sobre mercancías notificados a la OMC

AIE (servicios) notificados a la OMC

Sectores de servicios con compromisos en el marco del AGCS

\section{Aranceles $(\%, 2006$ et 2011)}

\begin{tabular}{l|l|l|l|} 
Importaciones: promedio aritmético de los aranceles NMF aplicados & 13,5 & 12,7
\end{tabular}

Importaciones: promedio ponderado de los aranceles NMF aplicados n.d. $\quad 9,5$

\begin{tabular}{|l|l|l|l|} 
Exportaciones: promedio ponderado de los aranceles impuestos & 14,7 & 9,8
\end{tabular}

por los importadores

Exportaciones: libres de derechos (en \%)

$85,7 \quad 96,6$

Fuentes: Naciones Unidas, base de datos Comtrade; Banco Mundial, base de datos sobre dinámica de las empresas de exportación; Banco Mundial, Indicadores del

Desarrollo Mundial; OMC, perfiles comerciales y arancelarios.

Participación en las exportaciones por región (\%)

\begin{tabular}{|l|r|r|}
\hline & $\mathbf{2 0 0 5}$ & $\mathbf{2 0 1 1}$ \\
\hline África & 33,0 & 38,1 \\
\hline Asia & 6,4 & 11,3 \\
\hline Comunidad de Estados Independientes & 4,2 & 3,0 \\
\hline Europa & 43,9 & 32,1 \\
\hline Oriente Medio & 0,3 & 0,6 \\
\hline América del Norte & 11,7 & 14,2 \\
\hline América del Sury América Central & 0,5 & 0,6 \\
\hline
\end{tabular}

Fuentes: OMC, perfiles comerciales y arancelarios

Indicadores de facilitación del comercio
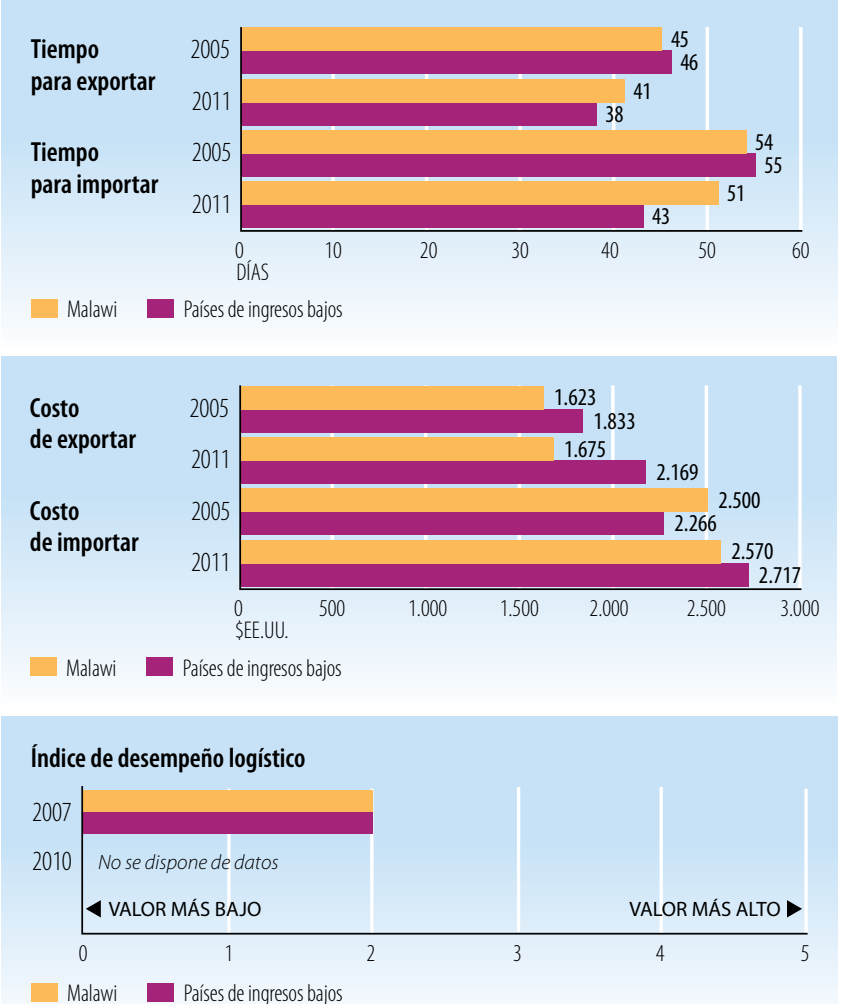

Fuentes: Banco Mundial, Indicadores del Desarrollo Mundial.

\begin{tabular}{l|c|c|}
\hline INDICADORES DE DESARROLLO (EFECTOS) & \\
\hline Indicador & $\mathbf{2 0 0 5}$ & $\mathbf{2 0 1 0}$ \\
\hline Desempleo (\% de la fuerza de trabajo total) & n.d. & n.d. \\
\hline Población activa, mujeres (\% de la fuerza de trabajo total) & 48,5 & 51,5 \\
\hline AOD neta recibida (\% del INB) & 21,1 & 20,8 \\
\hline Derechos de importación percibidos (\% de los ingresos fiscales) & n.d. & n.d. \\
\hline Total del servicio de la deuda (\% de las exportaciones totales) & n.d. & n.d. \\
\hline Índice de desarrollo humano (0 a 1) & 0,35 & 0,40 \\
\hline
\end{tabular}

Fuentes: PNUD, indicadores internacionales sobre desarrollo humano; Banco Mundial, Indicadores del Desarrollo Mundial.

Producto interno bruto

PIB per cápita (PPA, dólares internacionales corrientes)

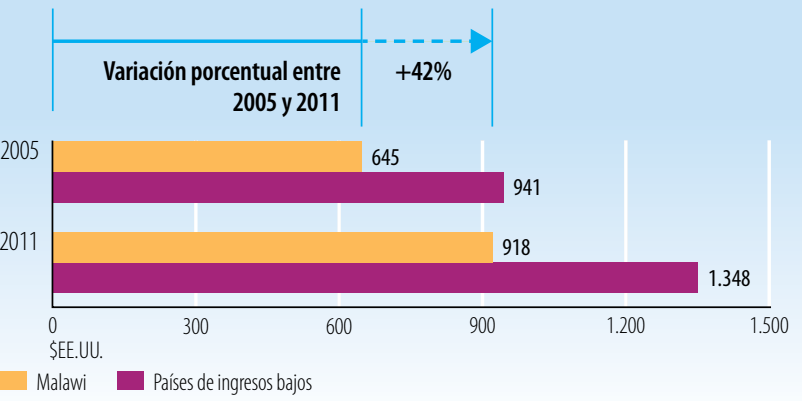

PIB per cápita (\$EE.UU. constantes de 2000)

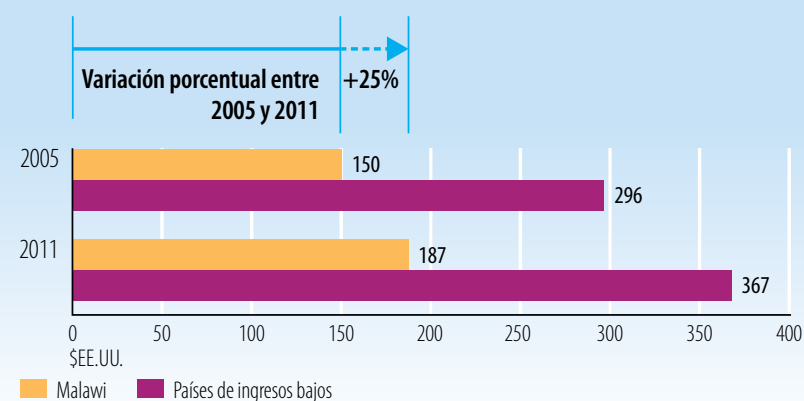

Fuentes: Banco Mundial, Indicadores del Desarrollo Mundial.

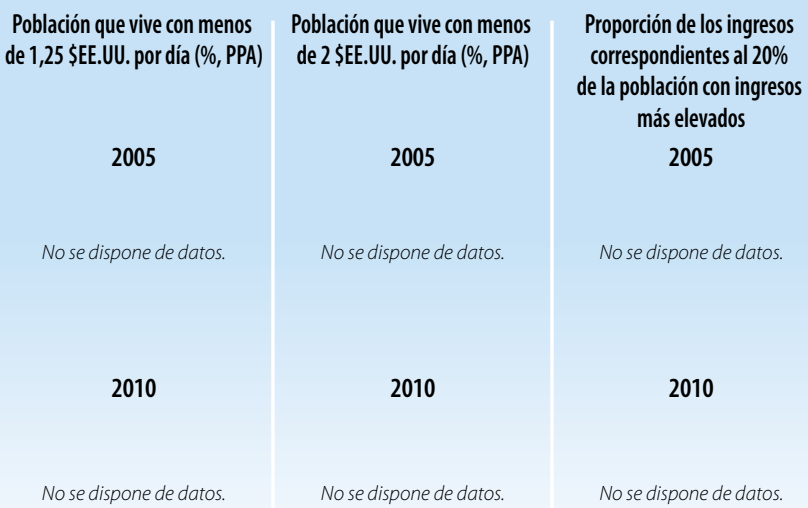

Fuentes: Banco Mundial, Indicadores del Desarrollo Mundial.

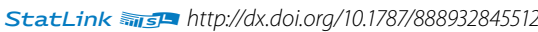




\section{Indicadores de la ayuda, el comercio y el desarrollo relativos a Malí}

\begin{tabular}{|c|c|c|c|c|}
\hline \multicolumn{5}{|c|}{ INVERSIÓN Y FINANCIACIÓN (APORTES) } \\
\hline Indicador (millones de \$EE.UU. corrientes) & 2005 & 2008 & 2010 & $\Delta: 05-10(\%)$ \\
\hline Formación bruta de capital fijo & $1.201,4$ & n.d. & n.d. & n.d. \\
\hline del cual: público & 407,6 & n.d. & n.d. & n.d. \\
\hline del cual: privado & 793,8 & n.d. & n.d. & n.d. \\
\hline \multicolumn{5}{|l|}{ Entrada de financiación externa } \\
\hline Entradas de IED & 188,1 & 131,7 & 147,6 & $-22 \%$ \\
\hline $\begin{array}{l}\text { Deuda externa a largo plazo y fondos } \\
\text { desembolsados por el FMl }\end{array}$ & 282,4 & 262,7 & 317,7 & $13 \%$ \\
\hline $\begin{array}{l}\text { Corrientes comerciales en condiciones no } \\
\text { concesionarias }\end{array}$ & 0,0 & 0,0 & 0,0 & $0 \%$ \\
\hline Corrientes de Ayuda para el Comercio & 183,6 & 240,2 & 336,6 & $83 \%$ \\
\hline $\begin{array}{l}\text { Remesas de trabajadores y remuneración } \\
\text { de empleados }\end{array}$ & 177,2 & 431,0 & 436,2 & $146 \%$ \\
\hline
\end{tabular}

Fuentes: OCDE, base de datos del SNPA del CAD sobre las actividades de ayuda: Banco Mundial, Indicadores del Desarrollo Mundial; Banco Mundial, estadísticas de la deuda internacional.

Desembolsos de la ayuda para el comercio, por sector (millones de \$EE.UU. corrientes)

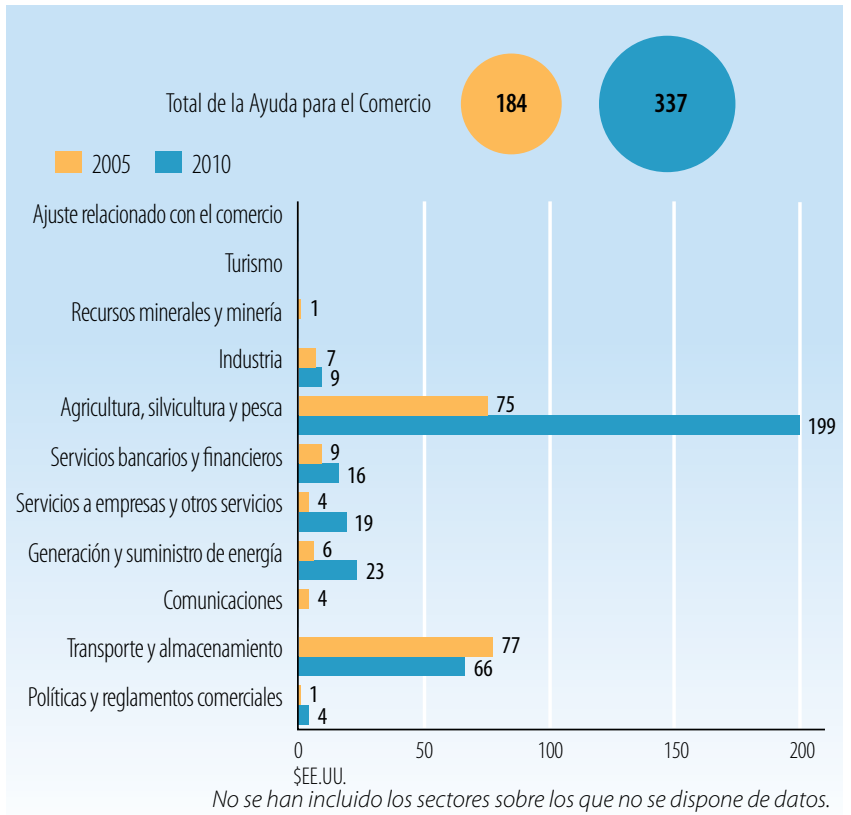

Fuentes: OCDE, base de datos del SNPA del CAD sobre las actividades de ayuda

Desembolsos de la ayuda para el comercio: principales donantes (millones de \$EE.UU. corrientes)

\begin{tabular}{|l|c|c|c|}
\hline $\mathbf{2 0 0 5}$ & Valor & $\%$ & Principales donantes en 2005 \\
\hline Banco Mundial & 65,7 & 36 & \\
\hline Instituciones de la UE & 59,1 & 32 & \\
\hline Banco Africano de Desarrollo & 16,9 & 9 & $87 \%$ \\
\hline Francia & 13,0 & 7 & \\
\hline Suiza & 4,8 & 3 & \\
\hline $\mathbf{2 0 1 0}$ & Valor & $\%$ & Principales donantes en $\mathbf{2 0 1 0}$ \\
\hline Estados Unidos & 110,8 & 33 & \\
\hline Banco Mundial & 59,3 & 18 & \\
\hline Banco Africano de Desarrollo & 40,2 & 12 & \\
\hline Instituciones de la UE & 23,6 & 7 & $75 \%$ \\
\hline Alemania & 18,5 & 5 & \\
\hline
\end{tabular}

Fuentes: OCDE, base de datos del SNPA del CAD sobre las actividades de ayuda.

\section{INDICADORES COMERCIALES (PRODUCTOS)}

\section{Indicador}

$2005 \quad 2008 \quad 2011 \quad \Delta: 05-11(\%)$

Relación comercio/PIB (\%)

\begin{tabular}{|l|l|l|l|}
60 & 72 & 53 & -7 \\
\hline
\end{tabular}

Exportaciones de servicios comerciales como

$\%$ de las exportaciones totales

\begin{tabular}{l|l|l|l}
19 & 17 & n.d. & n.d.
\end{tabular}

mportaciones de servicios comerciales como

$\%$ de las importaciones totales

\begin{tabular}{l|l|l|l}
32 & 27 & n.d. & n.d.
\end{tabular}

Productos intermedios distintos de los combustibles

(\% de las exportaciones de mercancías)

Productos intermedios distintos de los combustibles

(\% de las importaciones de mercancías)

\begin{tabular}{l|l|l|l}
97 & 95 & n.d. & n.d.
\end{tabular}

\begin{tabular}{|l|l|l|l|}
43 & 45 & n.d. & n.d.
\end{tabular}

Fuentes: Secretaría de la OMC.

Corrientes comerciales (millones de \$EE.UU. corrientes)

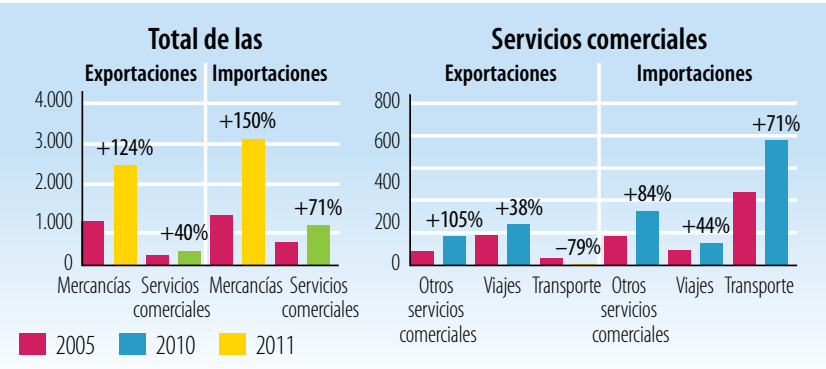

Fuentes: Secretaría de la OMC

Cinco principales mercados de exportación de mercancías (\%)

\begin{tabular}{|l|r|l|c|}
\hline 2005 & $\%$ & 2010 & $\%$ \\
\hline Sudáfrica & 35 & Sudáfrica & 57 \\
\hline Suiza & 30 & Suiza & 12 \\
\hline Senegal & 7 & UE (27) & 9 \\
\hline China & 6 & Senegal & 4 \\
\hline UE (27) & 6 & Estados Unidos & 3 \\
\hline
\end{tabular}

Fuentes: Secretaría de la OMC

Cinco principales productos de exportación (\% de las exportaciones de mercancías)

\begin{tabular}{|l|r|l|c|}
\hline 2005 & $\%$ & 2010 & $\%$ \\
\hline Oro no monetario, excepto minerales & 64 & Oro no monetario, excepto minerales & 79 \\
\hline Algodón & 24 & Algodón & 8 \\
\hline Animales vivos & 5 & Animales vivos & 3 \\
\hline Equipo de ingeniería civil & 1 & Abonos, excepto los del grupo 272 & 2 \\
\hline Productos derivados del petróleo & 1 & Productos derivados del petróleo & 1 \\
\hline
\end{tabular}

Cinco principales mercados de importación de mercancías (\%)

\begin{tabular}{|l|c|l|c|}
\hline 2005 & $\%$ & 2010 & $\%$ \\
\hline UE (27) & 21 & UE $(27)$ & 24 \\
\hline Senegal & 11 & Senegal & 14 \\
\hline Côte d'Ivoire & 10 & Benin & 10 \\
\hline Benin & 9 & China & 10 \\
\hline Togo & 7 & Estados Unidos & 9 \\
\hline
\end{tabular}

Fuentes: Secretaría de la OMC

Cinco principales productos de importación (\% de las importaciones de mercancías)

\begin{tabular}{|c|c|c|c|}
\hline 2005 & $\%$ & 2010 & $\%$ \\
\hline Productos derivados del petróleo & 24 & Productos derivados del petróleo & 26 \\
\hline Abonos, excepto los del grupo 272 & 6 & Medicamentos & 7 \\
\hline Cal, cemento y materiales de construcción & 6 & $\begin{array}{l}\text { Cal, cemento y materiales de } \\
\text { construcción }\end{array}$ & 4 \\
\hline Arroz & 4 & Equipo de ingeniería civil & 3 \\
\hline Equipo de ingeniería civil & 4 & Abonos, excepto los del grupo 272 & 2 \\
\hline
\end{tabular}




\section{LA AYUDA PARA EL COMERCIO EN SINNTESIS 2013}

\section{INDICADORES COMERCIALES (RESULTADOS)}

Indicador

Crecimiento del PIB (\%)

Número de exportadores

Índice de concentración de las exportaciones (productos) ( 0 a 1)

ACR sobre mercancías notificados a la OMC

AIE (servicios) notificados a la OMC

Sectores de servicios con compromisos en el marco del AGCS

\section{Aranceles (\%, 2006 et 2011)}

Importaciones: promedio aritmético de los aranceles NMF aplicados $\quad 12,0 \quad 11,9$

Importaciones: promedio ponderado de los aranceles NMF aplicados n.d. 10,2

\begin{tabular}{|l|l|l|l|}
\hline Exportaciones: promedio ponderado de los aranceles impuestos & 17,1 & 2,0 \\
\hline
\end{tabular}

por los importadores

Exportaciones: libres de derechos (en \%)

$51,3 \quad 49,0$

Fuentes: Naciones Unidas, base de datos Comtrade; Banco Mundial, base de datos sobre dinámica de las empresas de exportación; Banco Mundial, Indicadores del

Desarrollo Mundial; OMC, perfiles comerciales y arancelarios.

Participación en las exportaciones por región (\%)

\begin{tabular}{|l|r|r|}
\hline & $\mathbf{2 0 0 5}$ & $\mathbf{2 0 1 0}$ \\
\hline África & 46,0 & 67,5 \\
\hline Asia & 16,5 & 7,0 \\
\hline Comunidad de Estados Independientes & 0,0 & 0,0 \\
\hline Europa & 36,3 & 21,1 \\
\hline Oriente Medio & 0,8 & 1,1 \\
\hline América del Norte & 0,2 & 3,2 \\
\hline América del Sury América Central & 0,2 & 0,0 \\
\hline
\end{tabular}

Fuentes: OMC, perfiles comerciales y arancelarios

Indicadores de facilitación del comercio

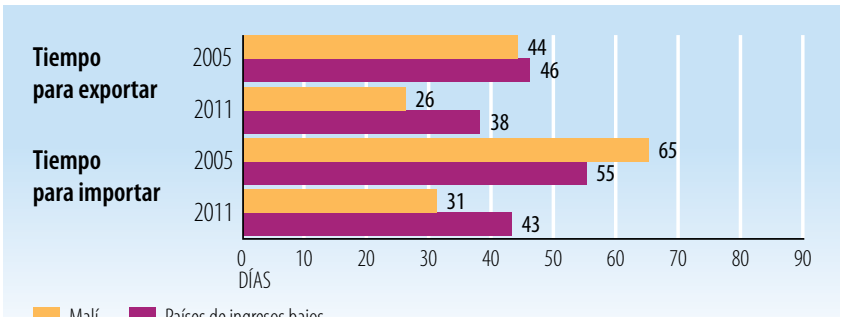

Países de ingresos bajos

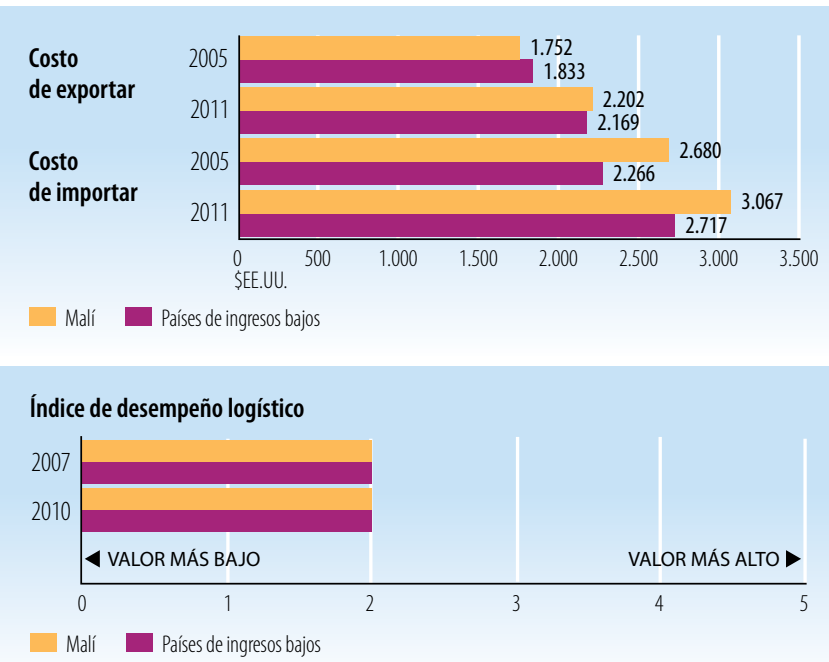

Fuentes: Banco Mundial, Indicadores del Desarrollo Mundial.

\begin{tabular}{|l|c|c|}
\hline INDICADORES DE DESARROLLO (EFECTOS) & \\
\hline Indicador & $\mathbf{2 0 0 5}$ & $\mathbf{2 0 1 0}$ \\
\hline Desempleo (\% de la fuerza de trabajo total) & n.d. & n.d. \\
\hline Población activa, mujeres (\% de la fuerza de trabajo total) & 36,1 & 35,5 \\
\hline AOD neta recibida (\% del INB) & 14,1 & 12,1 \\
\hline Derechos de importación percibidos (\% de los ingresos fiscales) & 17,4 & 13,9 \\
\hline Total del servicio de la deuda (\% de las exportaciones totales) & 7,1 & 2,5 \\
\hline Índice de desarrollo humano (0 a 1) & 0,32 & 0,36 \\
\hline
\end{tabular}

Fuentes: PNUD, indicadores internacionales sobre desarrollo humano; Banco Mundial, Indicadores del Desarrollo Mundial.

Producto interno bruto

PIB per cápita (PPA, dólares internacionales corrientes)

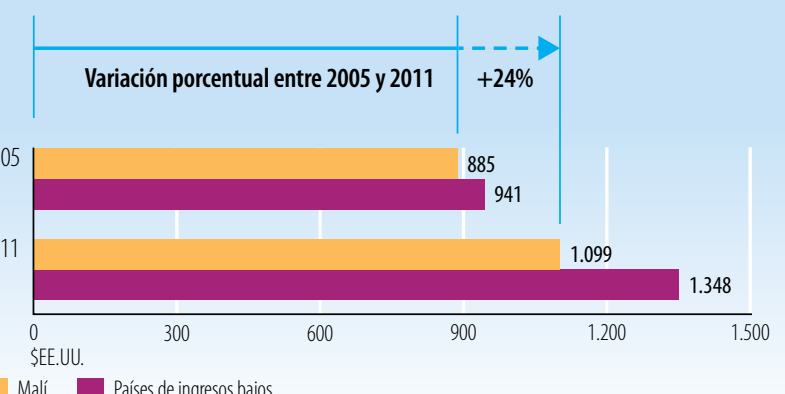

Malí Países de ingresos bajos

PIB per cápita (\$EE.UU. constantes de 2000)
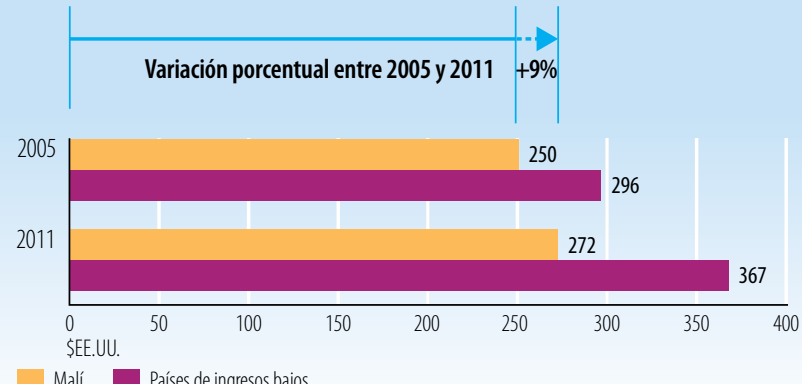

Fuentes: Banco Mundial, Indicadores del Desarrollo Mundial.

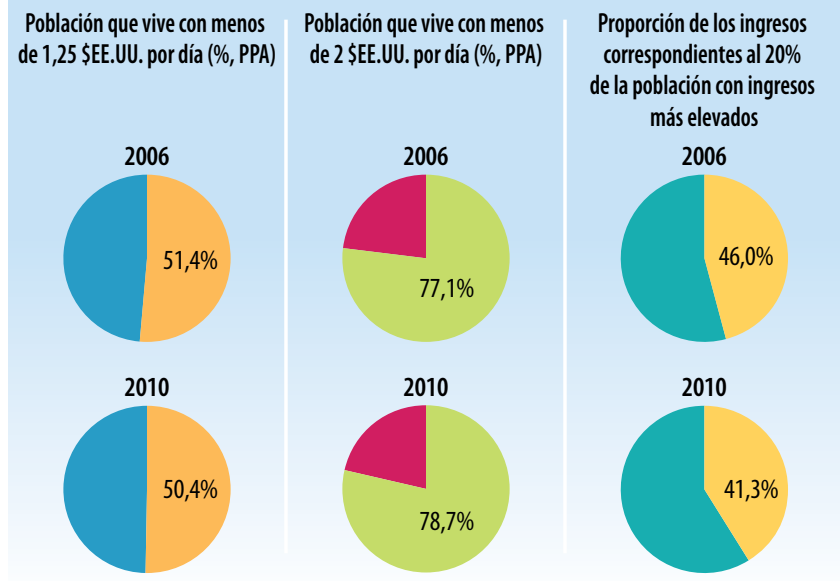

Fuentes: Banco Mundial, Indicadores del Desarrollo Mundial.

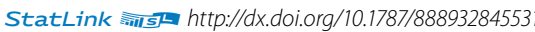




\section{Indicadores de la ayuda, el comercio y el desarrollo relativos a Marruecos}

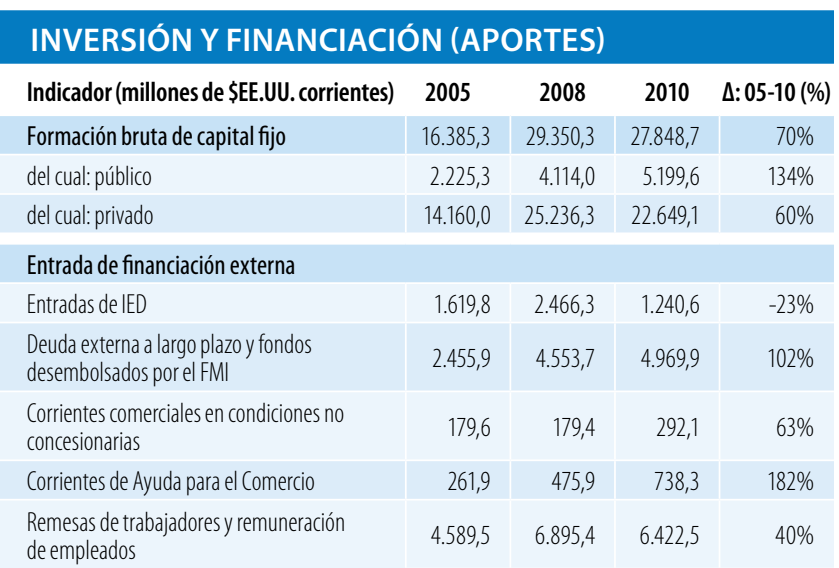

Fuentes: OCDE, base de datos del SNPA del CAD sobre las actividades de ayuda; Banco Mundial, Indicadores del Desarrollo Mundial; Banco Mundial, estadísticas de la deuda internacional.

Desembolsos de la ayuda para el comercio, por sector (millones de \$EE.UU. corrientes)

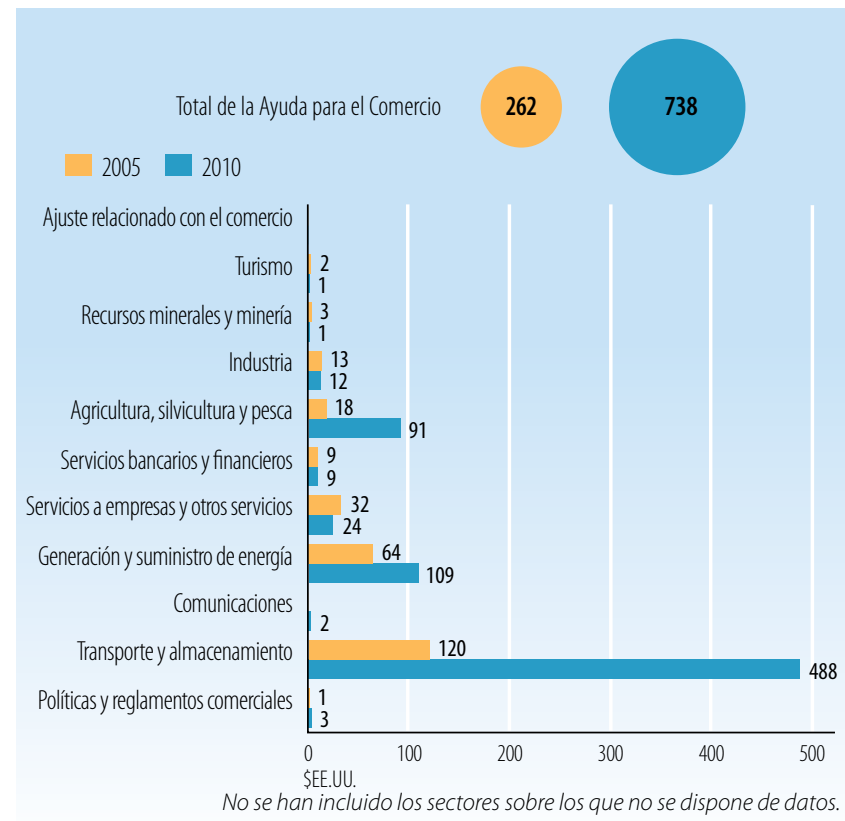

Fuentes: OCDE, base de datos del SNPA del CAD sobre las actividades de ayuda

Desembolsos de la ayuda para el comercio: principales donantes (millones de \$EE.UU. corrientes)

\begin{tabular}{|l|c|c|c|}
\hline $\mathbf{2 0 0 5}$ & Valor & $\%$ & Principales donantes en 2005 \\
\hline Instituciones de la UE & 118,5 & 45 & \\
\hline Francia & 57,2 & 22 & \\
\hline Italia & 35,8 & 14 & \\
\hline Japón & 27,0 & 10 & \\
\hline Alemania & 8,7 & 3 & \\
\hline 2010 & Valor & $\%$ & Principales donantes en 2010 \\
\hline Fondo Árabe & 187,6 & 25 & \\
\hline Japón & 131,4 & 18 & \\
\hline Francia & 127,1 & 17 & \\
\hline Instituciones de la UE & 74,1 & 10 & $80 \%$ \\
\hline España & 66,9 & 9 & \\
\hline
\end{tabular}

Fuentes: OCDE, base de datos del SNPA del CAD sobre las actividades de ayuda.

\section{INDICADORES COMERCIALES (PRODUCTOS)}

Indicador $2005 \quad 2008 \quad 2011 \quad \Delta: 05-11(\%)$

Relación comercio/PIB (\%)

\begin{tabular}{l|l|l|l|}
68 & 88 & 83 & 15 \\
\hline
\end{tabular}

Exportaciones de servicios comerciales como

$\%$ de las exportaciones totales

Importaciones de servicios comerciales como

$\%$ de las importaciones totales

Productos intermedios distintos de los combustibles

(\% de las exportaciones de mercancías)

Productos intermedios distintos de los combustibles

(\% de las importaciones de mercancías)

\begin{tabular}{l|l|l|l|}
41 & 39 & 39 & -3
\end{tabular}

Fuentes: Secretaría de la OMC.

Corrientes comerciales (millones de \$EE.UU. corrientes)

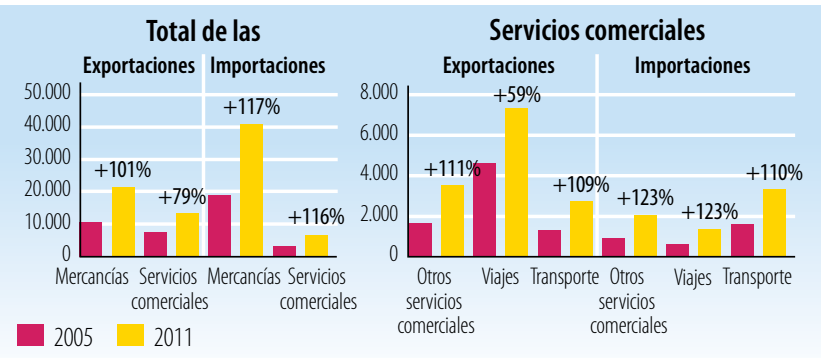

Fuentes: Secretaría de la OMC

Cinco principales mercados de exportación de mercancías (\%)

\begin{tabular}{|l|r|l|r|}
\hline 2005 & $\%$ & 2010 & $\%$ \\
\hline UE (27) & 74 & UE $(27)$ & 60 \\
\hline India & 4 & India & 6 \\
\hline Estados Unidos & 3 & Brasil & 4 \\
\hline Brasil & 2 & Estados Unidos & 4 \\
\hline Federación de Rusia & 1 & Singapur & 2 \\
\hline
\end{tabular}

Fuentes: Secretaría de la OMC

Cinco principales productos de exportación (\% de las exportaciones de mercancías)

\begin{tabular}{|c|c|c|c|}
\hline 2005 & $\%$ & 2010 & $\%$ \\
\hline $\begin{array}{l}\text { Prendas de vestir para mujeres y niñas, } \\
\text { excepto las de punto }\end{array}$ & 9 & Elementos químicos inorgánicos & 9 \\
\hline Elementos químicos inorgánicos & 8 & $\begin{array}{l}\text { Equipo para distribución de electricidad, } \\
\text { n.e.p. }\end{array}$ & 9 \\
\hline $\begin{array}{l}\text { Otros artículos textiles y prendas de vestir, } \\
\text { n.e.p. }\end{array}$ & 8 & Abonos, excepto los del grupo 272 & 9 \\
\hline $\begin{array}{l}\text { Equipo para distribución de electricidad, } \\
\text { n.e.p. }\end{array}$ & 6 & $\begin{array}{l}\text { Prendas de vestir para mujeres y niñas, } \\
\text { excepto las de punto }\end{array}$ & 7 \\
\hline $\begin{array}{l}\text { Prendas de vestir para hombres y niños, } \\
\text { excepto las de punto }\end{array}$ & 6 & Abonos en bruto & 6 \\
\hline
\end{tabular}

Cinco principales mercados de importación de mercancías (\%)

\begin{tabular}{|l|r|l|r|}
\hline 2005 & $\%$ & 2010 & $\%$ \\
\hline UE (27) & 53 & UE (27) & 49 \\
\hline Federación de Rusia & 7 & China & 8 \\
\hline Arabia Saudita, Reino de la & 7 & Estados Unidos & 7 \\
\hline China & 5 & Arabia Saudita, Reino de la & 6 \\
\hline Estados Unidos & 3 & Federación de Rusia & 4 \\
\hline
\end{tabular}

Fuentes: Secretaría de la OMC

Cinco principales productos de importación (\% de las importaciones de mercancías)

\begin{tabular}{|l|r|l|c|}
\hline 2005 & $\%$ & $\mathbf{2 0 1 0}$ & $\%$ \\
\hline Aceites de petróleo, crudos & 13 & Aceites de petróleo, crudos & 8 \\
\hline Productos derivados del petróleo & 3 & Productos derivados del petróleo & 7 \\
\hline $\begin{array}{l}\text { Vehículos automotores para pasajeros, } \\
\text { excepto autobuses }\end{array}$ & 3 & Propano y butano licuados & 4 \\
\hline Tejidos de algodón & 3 & $\begin{array}{l}\text { Vehículos automotores para pasajeros, } \\
\text { excepto autobuses }\end{array}$ & 4 \\
\hline Propano y butano licuados & 3 & Trigo y morcajo o tranquillón, sin moler & 2 \\
\hline
\end{tabular}

Fuentes: Secretaría de la OMC 


\section{LA AYUDA PARA EL COMERCIO EN SÍNTESIS 2013}

\section{INDICADORES COMERCIALES (RESULTADOS)}

Indicador

Crecimiento del PIB (\%)

Número de exportadores

Índice de concentración de las exportaciones (productos) ( 0 a 1$)$

ACR sobre mercancías notificados a la OMC

AIE (servicios) notificados a la OMC

Sectores de servicios con compromisos en el marco del AGCS

\section{Aranceles (\%, 2006 et 2011)}

\begin{tabular}{l|l|l|l|l|} 
Importaciones: promedio aritmético de los aranceles NMF aplicados & 24,5 & 14,3
\end{tabular}

\begin{tabular}{ll|l|l|} 
Importaciones: promedio ponderado de los aranceles NMF aplicados & 18,9 & 13,1
\end{tabular}

\begin{tabular}{|l|l|l|} 
Exportaciones: promedio ponderado de los aranceles impuestos & 1,3 & 1,3
\end{tabular}

por los importadores

Exportaciones: libres de derechos (en \%)

$89,3 \quad 82,8$

Fuentes: Naciones Unidas, base de datos Comtrade; Banco Mundial, base de datos sobre dinámica de las empresas de exportación; Banco Mundial, Indicadores del

Desarrollo Mundial; OMC, perfiles comerciales y arancelarios.

Participación en las exportaciones por región (\%)

\begin{tabular}{|l|r|r|}
\hline África & $\mathbf{2 0 0 5}$ & $\mathbf{2 0 1 0}$ \\
\hline Asia & 4,3 & 7,2 \\
\hline Comunidad de Estados Independientes & 8,5 & 14,4 \\
\hline Europa & 1,3 & 1,2 \\
\hline Oriente Medio & 76,2 & 63,8 \\
\hline América del Norte & 2,3 & 2,6 \\
\hline América del Sury América Central & 3,8 & 4,7 \\
\hline
\end{tabular}

Fuentes: OMC, perfiles comerciales y arancelarios

Indicadores de facilitación del comercio
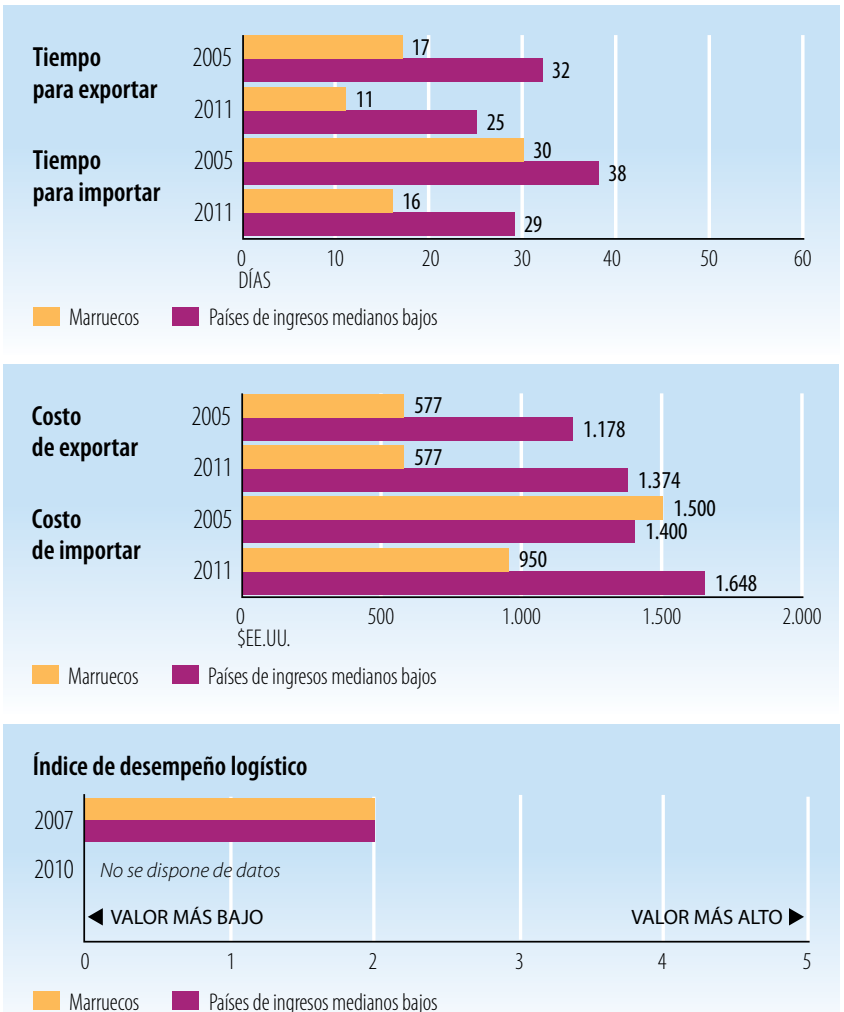

Fuentes: Banco Mundial, Indicadores del Desarrollo Mundial.

\begin{tabular}{|l|c|c|}
\hline INDICADORES DE DESARROLLO (EFECTOS) & \\
\hline Indicador & $\mathbf{2 0 0 5}$ & $\mathbf{2 0 1 0}$ \\
\hline Desempleo (\% de la fuerza de trabajo total) & 11,0 & 10,0 \\
\hline Población activa, mujeres (\% de la fuerza de trabajo total) & 27,7 & 27,1 \\
\hline AOD neta recibida (\% del INB) & 1,2 & 1,1 \\
\hline Derechos de importación percibidos (\% de los ingresos fiscales) & 10,2 & 6,6 \\
\hline Total del servicio de la deuda (\% de las exportaciones totales) & 14,0 & 10,7 \\
\hline Índice de desarrollo humano (0 a 1) & 0,55 & 0,58 \\
\hline
\end{tabular}

Fuentes: PNUD, indicadores internacionales sobre desarrollo humano; Banco Mundial, Indicadores del Desarrollo Mundial.

Producto interno bruto

PIB per cápita (PPA, dólares internacionales corrientes)

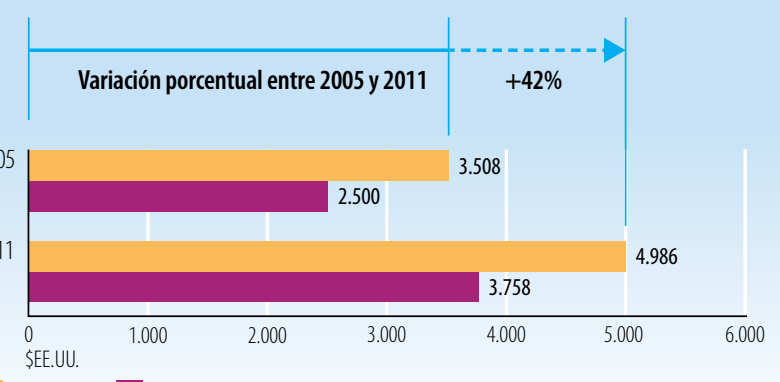

Marruecos Países de ingresos medianos bajos

PIB per cápita (\$EE.UU. constantes de 2000)
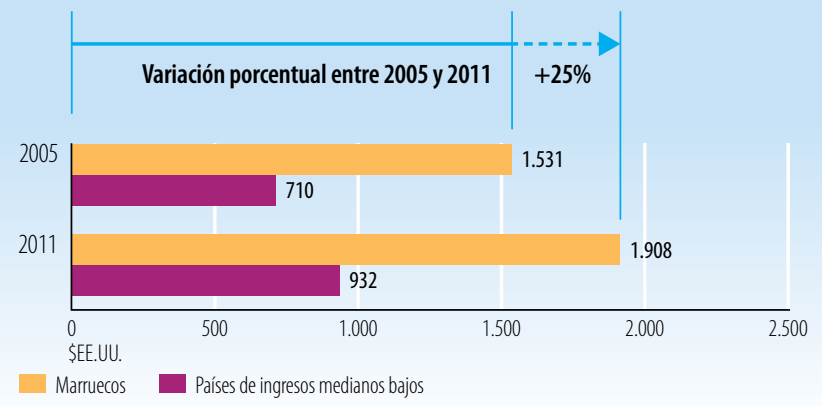

Fuentes: Banco Mundial, Indicadores del Desarrollo Mundial.

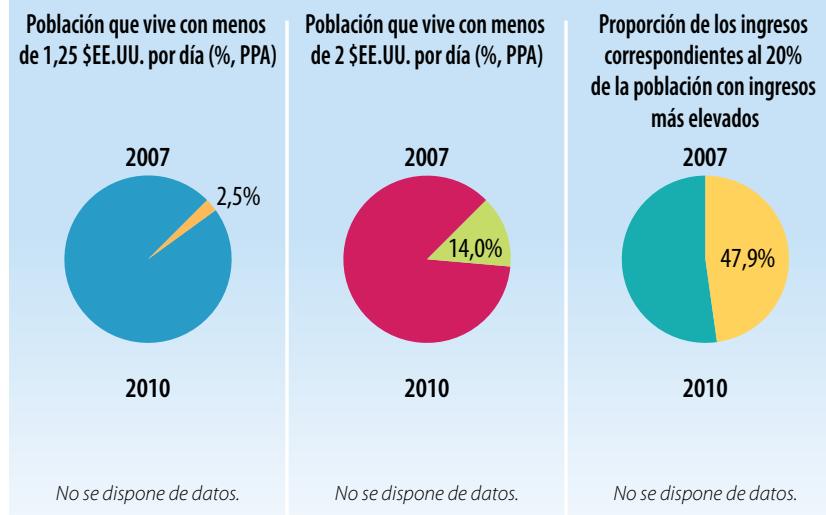

Fuentes: Banco Mundial, Indicadores del Desarrollo Mundial.

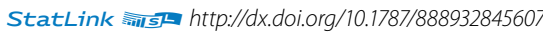




\section{Indicadores de la ayuda, el comercio y el desarrollo relativos a Mauricio}

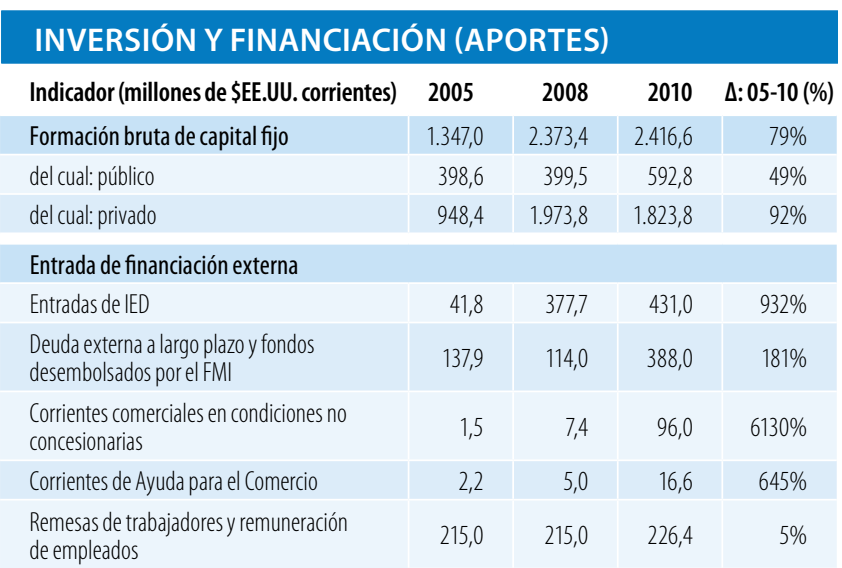

Fuentes: OCDE, base de datos del SNPA del CAD sobre las actividades de ayuda; Banco Mundial, Indicadores del Desarrollo Mundial; Banco Mundial, estadísticas de la deuda internacional.

Desembolsos de la ayuda para el comercio, por sector

(millones de \$EE.UU. corrientes)

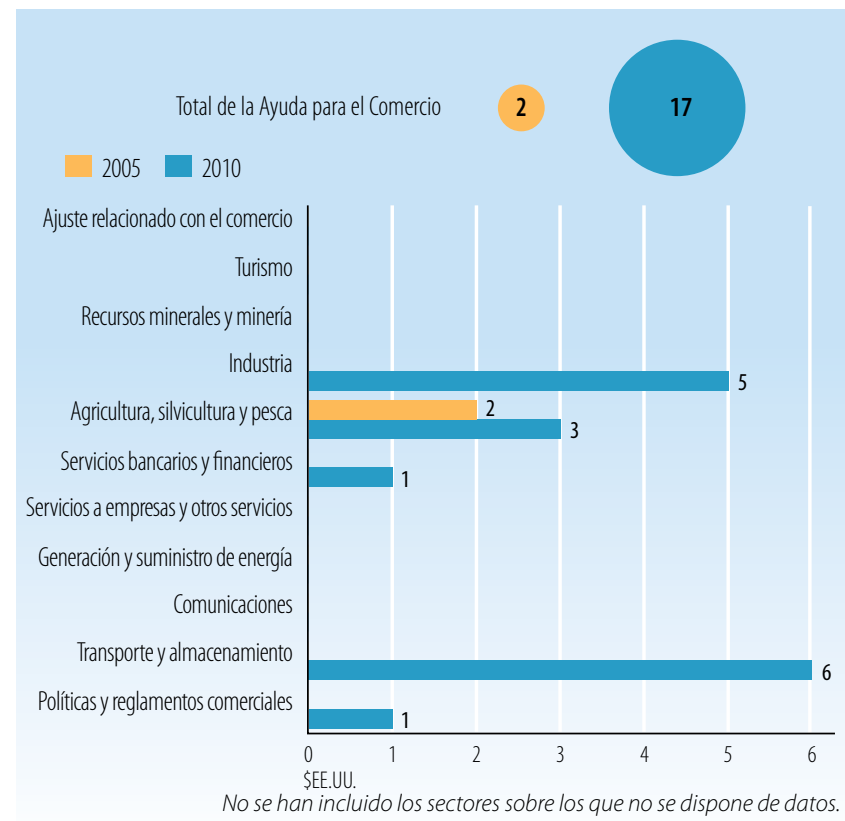

Fuentes: OCDE, base de datos del SNPA del CAD sobre las actividades de ayuda

Desembolsos de la ayuda para el comercio: principales donantes (millones de \$EE.UU. corrientes)

\begin{tabular}{|l|r|r|r|}
\hline $\mathbf{2 0 0 5}$ & Valor & $\%$ & Principales donantes en 2005 \\
\hline Instituciones de la UE & 1,2 & 54 & \\
\hline Japón & 0,9 & 39 & \\
\hline Alemania & 0,1 & 3 & $98 \%$ \\
\hline Australia & 0,0 & 1 & \\
\hline PNUD & 0,0 & 1 & \\
\hline $\mathbf{2 0 1 0}$ & Valor & $\%$ & Principales donantes en 2010 \\
\hline Francia & 12,1 & 73 & \\
\hline Instituciones de la UE & 2,4 & 15 & \\
\hline Reino Unido & 0,9 & 6 & \\
\hline Estados Unidos & 0,4 & 3 & $97 \%$ \\
\hline Noruega & 0,3 & 2 & \\
\hline
\end{tabular}

Fuentes: OCDE, base de datos del SNPA del CAD sobre las actividades de ayuda.

\begin{tabular}{|c|c|c|c|c|}
\hline Indicador & 2005 & 2008 & 2011 & $\Delta: 05-11(\%)$ \\
\hline Relación comercio/PIB (\%) & 125 & 116 & 117 & -8 \\
\hline $\begin{array}{l}\text { Exportaciones de servicios comerciales como } \\
\% \text { de las exportaciones totales }\end{array}$ & 43 & 51 & 55 & 12 \\
\hline $\begin{array}{l}\text { Importaciones de servicios comerciales como } \\
\text { \% de las importaciones totales }\end{array}$ & 29 & 30 & 33 & 4 \\
\hline $\begin{array}{l}\text { Productos intermedios distintos de los combustibles } \\
\text { (\% de las exportaciones de mercancías) }\end{array}$ & 30 & 27 & 22 & -7 \\
\hline $\begin{array}{l}\text { Productos intermedios distintos de los combustibles } \\
\text { (\% de las importaciones de mercancías) }\end{array}$ & 38 & 38 & 38 & 0 \\
\hline
\end{tabular}

Fuentes: Secretaría de la OMC.

Corrientes comerciales (millones de \$̦E.UU. corrientes)

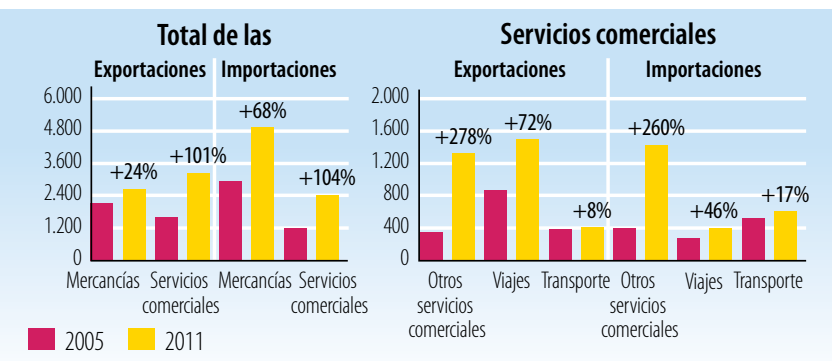

Fuentes: Secretaría de la OMC

Cinco principales mercados de exportación de mercancías (\%)

\begin{tabular}{|l|r|l|r|}
\hline 2005 & $\%$ & 2010 & $\%$ \\
\hline UE (27) & 61 & UE (27) & 64 \\
\hline Estados Unidos & 9 & Estados Unidos & 11 \\
\hline Emiratos Árabes Unidos & 8 & Madagascar & 5 \\
\hline Madagascar & 5 & Sudáfrica & 5 \\
\hline Sudáfrica & 1 & Suiza & 2 \\
\hline Fuentes: Secretaría de la OMC & & & \\
\hline
\end{tabular}

Cinco principales productos de exportación (\% de las exportaciones de mercancías)

\begin{tabular}{|c|c|c|c|}
\hline 2005 & $\%$ & 2011 & $\%$ \\
\hline $\begin{array}{l}\text { Otros artículos textiles y prendas de } \\
\text { vestir, n.e.p. }\end{array}$ & 22 & $\begin{array}{l}\text { Otros artículos textiles y prendas de } \\
\text { vestir, n.e.p. }\end{array}$ & 20 \\
\hline Azúcares, melaza y miel & 16 & Azúcares, melaza y miel & 14 \\
\hline $\begin{array}{l}\text { Equipos de telecomunicaciones y sus } \\
\text { partes, n.e.p. }\end{array}$ & 12 & $\begin{array}{l}\text { Pescados, etc., preparados o en conserva, } \\
\text { n.e.p. }\end{array}$ & 12 \\
\hline $\begin{array}{l}\text { Prendas de vestir para hombres y niños, } \\
\text { excepto las de punto }\end{array}$ & 8 & $\begin{array}{l}\text { Prendas de vestir para hombres y niños, } \\
\text { excepto las de punto }\end{array}$ & 11 \\
\hline Operaciones especiales no clasificadas & 7 & $\begin{array}{l}\text { Prendas de vestir para mujeres y niñas, } \\
\text { de punto }\end{array}$ & 4 \\
\hline
\end{tabular}

\section{Cinco principales mercados de importación de mercancías (\%)}

\begin{tabular}{|l|c|l|c|}
\hline 2005 & $\%$ & 2010 & $\%$ \\
\hline UE (27) & 31 & UE (27) & 23 \\
\hline China & 10 & India & 22 \\
\hline Sudáfrica & 9 & China & 13 \\
\hline India & 7 & Sudáfrica & 8 \\
\hline Bahrein & 5 & Japón & 3 \\
\hline
\end{tabular}

Cinco principales productos de importación (\% de las importaciones de mercancías)

\begin{tabular}{|c|c|c|c|}
\hline 2005 & $\%$ & 2011 & $\%$ \\
\hline Productos derivados del petróleo & 14 & Productos derivados del petróleo & 18 \\
\hline $\begin{array}{l}\text { Equipos de telecomunicaciones y sus } \\
\text { partes, n.e.p. }\end{array}$ & 10 & Pescado, fresco, refrigerado o congelado & 6 \\
\hline Pescado, fresco, refrigerado o congelado & 4 & $\begin{array}{l}\text { Vehículos automotores para pasajeros, } \\
\text { excepto autobuses }\end{array}$ & 3 \\
\hline Hilados de fibra textil & 3 & Hilados de fibra textil & 2 \\
\hline $\begin{array}{l}\text { Vehículos automotores para pasajeros, } \\
\text { excepto autobuses }\end{array}$ & 2 & Medicamentos & 2 \\
\hline
\end{tabular}

Fuentes: Secretaría de la OMC 


\section{LA AYUDA PARA EL COMERCIO EN SIINTESIS 2013}

\section{INDICADORES COMERCIALES (RESULTADOS)}

\section{Indicador}

Crecimiento del PIB (\%)

Número de exportadores

Índice de concentración de las exportaciones (productos) ( 0 a 1)

ACR sobre mercancías notificados a la OMC

AIE (servicios) notificados a la OMC

Sectores de servicios con compromisos en el marco del AGCS

\section{Aranceles $(\%, 2006$ et 2011)}

\begin{tabular}{ll|l|l|l|} 
Importaciones: promedio aritmético de los aranceles NMF aplicados & 3,5 & 1,4
\end{tabular}

\begin{tabular}{|l|l|l|l|}
\hline Importaciones: promedio ponderado de los aranceles NMF aplicados & 2,0 & 1,4
\end{tabular}

Exportaciones: promedio ponderado de los aranceles impuestos $\quad 1,6 \quad 0,3$

por los importadores

Exportaciones: libres de derechos (en \%)

$95,3 \quad 98,9$

Fuentes: Naciones Unidas, base de datos Comtrade; Banco Mundial, base de datos sobre dinámica de las empresas de exportación; Banco Mundial, Indicadores del

Desarrollo Mundial; OMC, perfiles comerciales y arancelarios.

Participación en las exportaciones por región (\%)

\begin{tabular}{|l|r|r|}
\hline & 2005 & 2011 \\
\hline África & 8,9 & 17,0 \\
\hline Asia & 4,1 & 5,3 \\
\hline Comunidad de Estados Independientes & 0,1 & 0,3 \\
\hline Europa & 62,8 & 65,1 \\
\hline Oriente Medio & 8,2 & 0,7 \\
\hline América del Norte & 9,2 & 10,8 \\
\hline América del Sury América Central & 0,2 & 0,3 \\
\hline
\end{tabular}

Fuentes: OMC, perfiles comerciales y arancelarios

Indicadores de facilitación del comercio
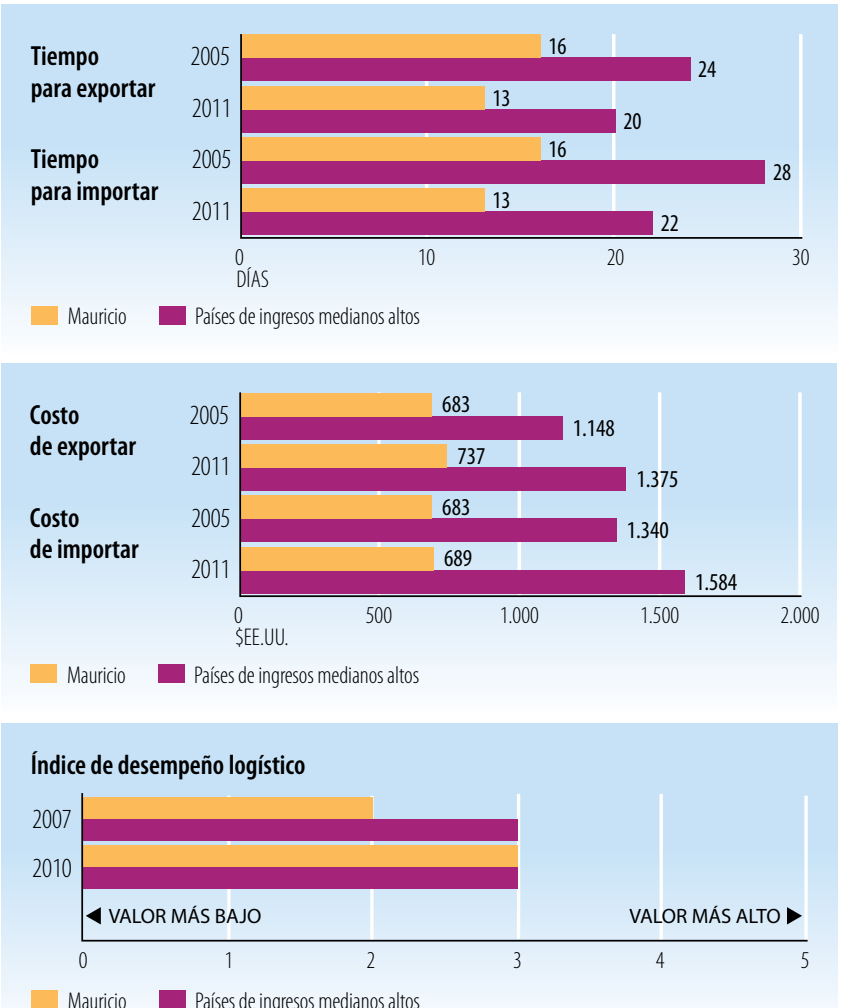

Mauricio Países de ingresos medianos altos

Fuentes: Banco Mundial, Indicadores del Desarrollo Mundial.

\begin{tabular}{|l|c|c|}
\hline INDICADORES DE DESARROLLO (EFECTOS) & \\
\hline Indicador & $\mathbf{2 0 0 5}$ & $\mathbf{2 0 1 0}$ \\
\hline Desempleo (\% de la fuerza de trabajo total) & 9,6 & 7,7 \\
\hline Población activa, mujeres (\% de la fuerza de trabajo total) & 35,8 & 37,7 \\
\hline AOD neta recibida (\% del INB) & 0,6 & 1,3 \\
\hline Derechos de importación percibidos (\% de los ingresos fiscales) & n.d. & 2,7 \\
\hline Total del servicio de la deuda (\% de las exportaciones totales) & 5,8 & 2,4 \\
\hline Índice de desarrollo humano ( 0 a 1) & 0,70 & 0,73 \\
\hline
\end{tabular}

Fuentes: PNUD, indicadores internacionales sobre desarrollo humano; Banco Mundial, Indicadores del Desarrollo Mundial.

Producto interno bruto

PIB per cápita (PPA, dólares internacionales corrientes)

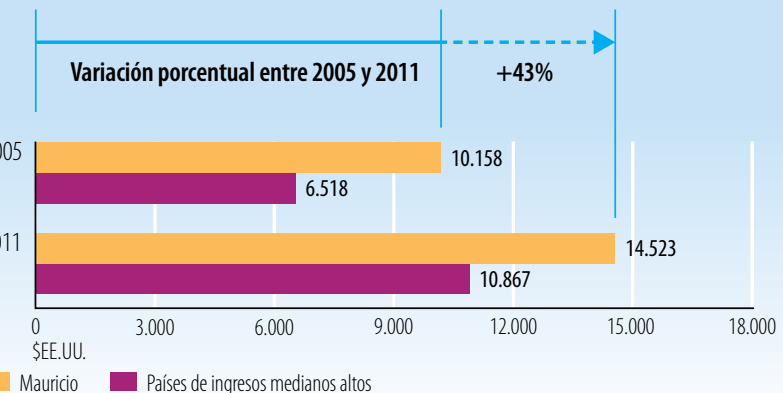

Mauricio Países de ingresos medianos altos

PIB per cápita (\$EE.UU. constantes de 2000)

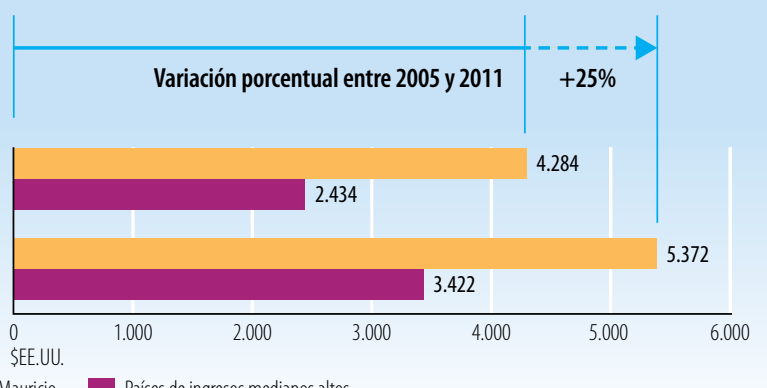

Mauricio Países de ingresos medianos altos

Fuentes: Banco Mundial, Indicadores del Desarrollo Mundial.

\begin{tabular}{|c|c|c|}
\hline $\begin{array}{l}\text { Población que vive con menos } \\
\text { de } 1,25 \$ \text { EE.UU. por día }(\%, P P A)\end{array}$ & $\begin{array}{l}\text { Población que vive con menos } \\
\text { de } 2 \text { \$EE.UU. por día }(\%, \text { PPA) }\end{array}$ & $\begin{array}{c}\text { Proporción de los ingresos } \\
\text { correspondientes al } 20 \% \\
\text { de la población con ingresos } \\
\text { más elevados }\end{array}$ \\
\hline 2005 & 2005 & 2005 \\
\hline No se dispone de datos. & No se dispone de datos. & No se dispone de datos. \\
\hline 2010 & 2010 & 2010 \\
\hline No se dispone de datos. & No se dispone de datos. & No se dispone de datos. \\
\hline
\end{tabular}




\section{$\star \quad$ MAURITANIA}

\section{LA AYUDA PARA EL COMERCIO EN SÍNTESIS 2013}

\section{Indicadores de la ayuda, el comercio y el desarrollo relativos a Mauritania}

\begin{tabular}{|c|c|c|c|c|}
\hline Indicador (millones de \$̦EE.UU. corrientes) & 2005 & 2008 & 2010 & $\Delta: 05-10(\%$ \\
\hline Formación bruta de capital fijo & $1.287,9$ & 978,4 & 884,2 & $-31 \%$ \\
\hline del cual: público & 148,9 & 233,4 & 284,5 & $91 \%$ \\
\hline del cual: privado & $1.139,0$ & 745,0 & 599,7 & $-47 \%$ \\
\hline \multicolumn{5}{|l|}{ Entrada de financiación externa } \\
\hline Entradas de IED & 814,1 & 338,4 & 13,6 & $-98 \%$ \\
\hline $\begin{array}{l}\text { Deuda externa a largo plazo y fondos } \\
\text { desembolsados por el FMl }\end{array}$ & 143,2 & 297,3 & 445,8 & $211 \%$ \\
\hline $\begin{array}{l}\text { Corrientes comerciales en condiciones no } \\
\text { concesionarias }\end{array}$ & 0,5 & 19,0 & 23,3 & $4561 \%$ \\
\hline Corrientes de Ayuda para el Comercio & 62,7 & 96,2 & 117,0 & $87 \%$ \\
\hline $\begin{array}{l}\text { Remesas de trabajadores y remuneración } \\
\text { de empleados }\end{array}$ & n.d. & n.d. & n.d. & n.d. \\
\hline
\end{tabular}

Fuentes: OCDE, base de datos del SNPA del CAD sobre las actividades de ayuda; Banco Mundial, Indicadores del Desarrollo Mundial; Banco Mundial, estadísticas de la deuda internacional.

Desembolsos de la ayuda para el comercio, por sector (millones de \$EE.UU. corrientes)

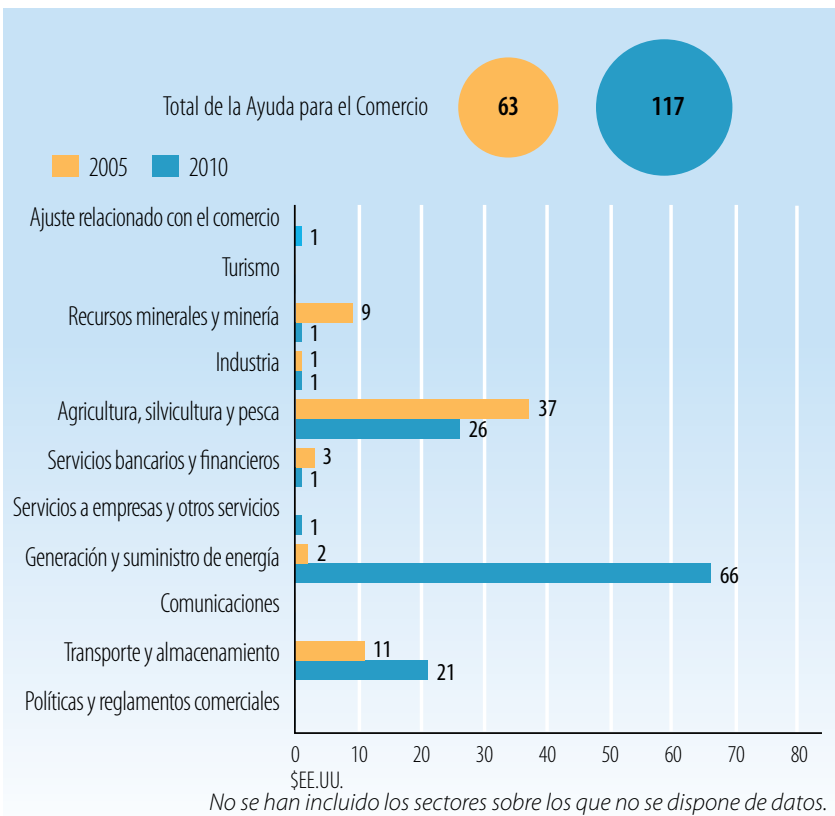

Fuentes: OCDE, base de datos del SNPA del CAD sobre las actividades de ayuda

Desembolsos de la ayuda para el comercio: principales donantes (millones de \$EE.UU. corrientes)

\begin{tabular}{|l|c|c|}
\hline $\mathbf{2 0 0 5}$ & Valor & $\%$ \\
\hline Instituciones de la UE & 15,6 & 25 \\
\hline Banco Mundial & 13,4 & 21 \\
\hline Japón & 10,5 & 17 \\
\hline España & 8,9 & 14 \\
\hline Banco Africano de Desarrollo & 5,2 & 8 \\
\hline $\mathbf{2 0 1 0}$ & Valor & $\%$ \\
\hline Fondo Árabe & 65,4 & 56 \\
\hline Banco Mundial & 18,9 & 16 \\
\hline Instituciones de la UE & 15,6 & 13 \\
\hline España & 7,9 & 7 \\
\hline Banco Africano de Desarrollo & 3,2 & 3 \\
\hline
\end{tabular}

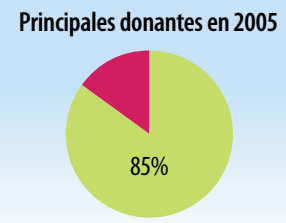

Principales donantes en 2010

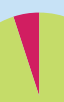

$95 \%$

Fuentes: OCDE, base de datos del SNPA del CAD sobre las actividades de ayuda.

\section{INDICADORES COMERCIALES (PRODUCTOS)}

\section{Indicador}

$2005 \quad 2008 \quad 2011 \quad \Delta: 05-11(\%)$

Relación comercio/PIB (\%)

\begin{tabular}{|l|l|l|l|}
111 & 125 & 146 & 35 \\
\hline
\end{tabular}

Exportaciones de servicios comerciales como

$\%$ de las exportaciones totales

Importaciones de servicios comerciales como

$\%$ de las importaciones totales

Productos intermedios distintos de los combustibles

(\% de las exportaciones de mercancías)

Productos intermedios distintos de los combustibles

(\% de las importaciones de mercancías)

\begin{tabular}{l|l|l|l|}
8 & 5 & 5 & -3
\end{tabular}

\begin{tabular}{l|l|l|l|}
18 & 25 & 21 & 2
\end{tabular}

\begin{tabular}{|l|l|l|l|}
\hline 69 & 63 & 23 & -46 \\
\hline
\end{tabular}

Fuentes: Secretaría de la OMC

Corrientes comerciales (millones de \$EE.UU. corrientes)

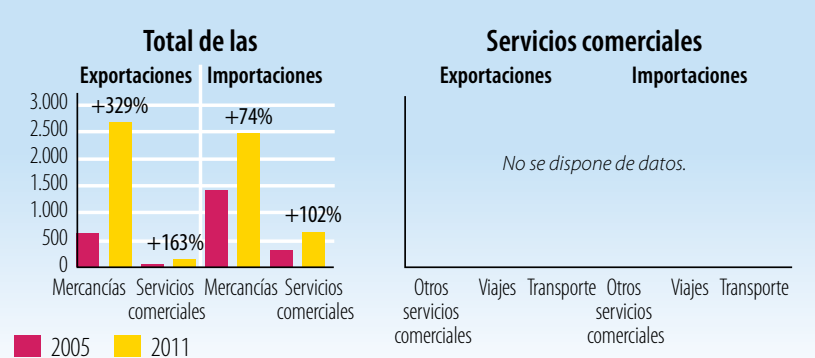

Fuentes: Secretaría de la OMC

Cinco principales mercados de exportación de mercancías (\%)

\begin{tabular}{|l|r|l|l|}
\hline $\mathbf{2 0 0 5}$ & $\%$ & $\mathbf{2 0 1 0}$ & $\%$ \\
\hline UE (27) & 76 & UE (27) & 21 \\
\hline Japón & 14 & China & 19 \\
\hline Argelia & 3 & Suiza & 19 \\
\hline Nigeria & 2 & Japón & 16 \\
\hline China & 1 & Swazilandia & 14 \\
\hline Fuentes:Secretaría de la OMC & & & \\
\hline
\end{tabular}

Cinco principales productos de exportación (\% de las exportaciones de mercancías)

\begin{tabular}{|c|c|c|c|}
\hline 2005 & $\%$ & 2011 & $\%$ \\
\hline Mineral de hierro y sus concentrados & 69 & Operaciones especiales no clasificadas & 57 \\
\hline Pescado, fresco, refrigerado o congelado & 24 & Oro no monetario, excepto minerales & 13 \\
\hline Operaciones especiales no clasificadas & 7 & Crustáceos, moluscos, etc. & 11 \\
\hline $\begin{array}{l}\text { Pescados, etc., preparados } 0 \text { en conserva, } \\
\text { n.e.p. }\end{array}$ & 1 & Minerales de cobre y sus concentrados & 7 \\
\hline $\begin{array}{l}\text { Cueros y pieles (excepto pieles finas), } \\
\text { sin curtir }\end{array}$ & 0 & Pescado, fresco, refrigerado o congelado & 5 \\
\hline
\end{tabular}

Cinco principales mercados de importación de mercancías (\%)

\begin{tabular}{|l|r|l|c|}
\hline 2005 & $\%$ & 2010 & $\%$ \\
\hline UE (27) & 43 & UE (27) & 47 \\
\hline Estados Unidos & 8 & Emiratos Árabes Unidos & 12 \\
\hline Brasil & 2 & China & 7 \\
\hline China & 2 & Singapur & 5 \\
\hline Japón & 2 & Estados Unidos & 4 \\
\hline Fuentes: Secretaría de la OMC & & & \\
\hline
\end{tabular}

Cinco principales productos de importación (\% de las importaciones de mercancías)

\begin{tabular}{|c|c|c|}
\hline 2005 & $\%$ & 2011 \\
\hline $\begin{array}{l}\text { Buques, embarcaciones y estructuras } \\
\text { flotantes }\end{array}$ & 46 & Productos derivados del petróleo \\
\hline Productos derivados del petróleo & 9 & Equipo de ingeniería civil \\
\hline Equipo de ingeniería civil & 7 & Equipos mecánicos de manipulación \\
\hline Aeronaves y equipo conexo & 5 & Trigo y morcajo o tranquillón, sin moler \\
\hline Margarina y mantecas de pastelería & 2 & $\begin{array}{l}\text { Buques, embarcaciones y estructuras } \\
\text { flotantes }\end{array}$ \\
\hline
\end{tabular}

Fuentes: Secretaría de la OMC 


\section{LA AYUDA PARA EL COMERCIO EN SÍNTESIS 2013}

\section{INDICADORES COMERCIALES (RESULTADOS)}

Indicador

Crecimiento del PIB (\%)

Número de exportadores

Índice de concentración de las exportaciones (productos) ( 0 a 1 )

ACR sobre mercancías notificados a la OMC

AIE (servicios) notificados a la OMC

Sectores de servicios con compromisos en el marco del AGCS

\section{Aranceles (\%, 2006-2010)}

\begin{tabular}{l|l|l|l|} 
Importaciones: promedio aritmético de los aranceles NMF aplicados & 10,7 & 9,6
\end{tabular}

Importaciones: promedio ponderado de los aranceles NMF aplicados n.d. $\quad 8,0$

Exportaciones: promedio ponderado de los aranceles impuestos $\quad 1,3 \quad 0,6$

por los importadores

Exportaciones: libres de derechos (en \%)

$89,4 \quad 94,0$

Fuentes: Naciones Unidas, base de datos Comtrade; Banco Mundial, base de datos sobre dinámica de las empresas de exportación; Banco Mundial, Indicadores del

Desarrollo Mundial; OMC, perfiles comerciales y arancelarios.

Participación en las exportaciones por región (\%)

\begin{tabular}{|l|r|r|}
\hline & $\mathbf{2 0 0 5}$ & $\mathbf{2 0 1 1}$ \\
\hline África & 5,3 & 3,6 \\
\hline Asia & 15,8 & 42,8 \\
\hline Comunidad de Estados Independientes & 1,3 & 1,6 \\
\hline Europa & 76,8 & 51,9 \\
\hline Oriente Medio & 0,1 & 0,0 \\
\hline América del Norte & 0,0 & 0,0 \\
\hline América del Sury América Central & 0,0 & 0,0 \\
\hline
\end{tabular}

Fuentes: OMC, perfiles comerciales y arancelarios

Indicadores de facilitación del comercio
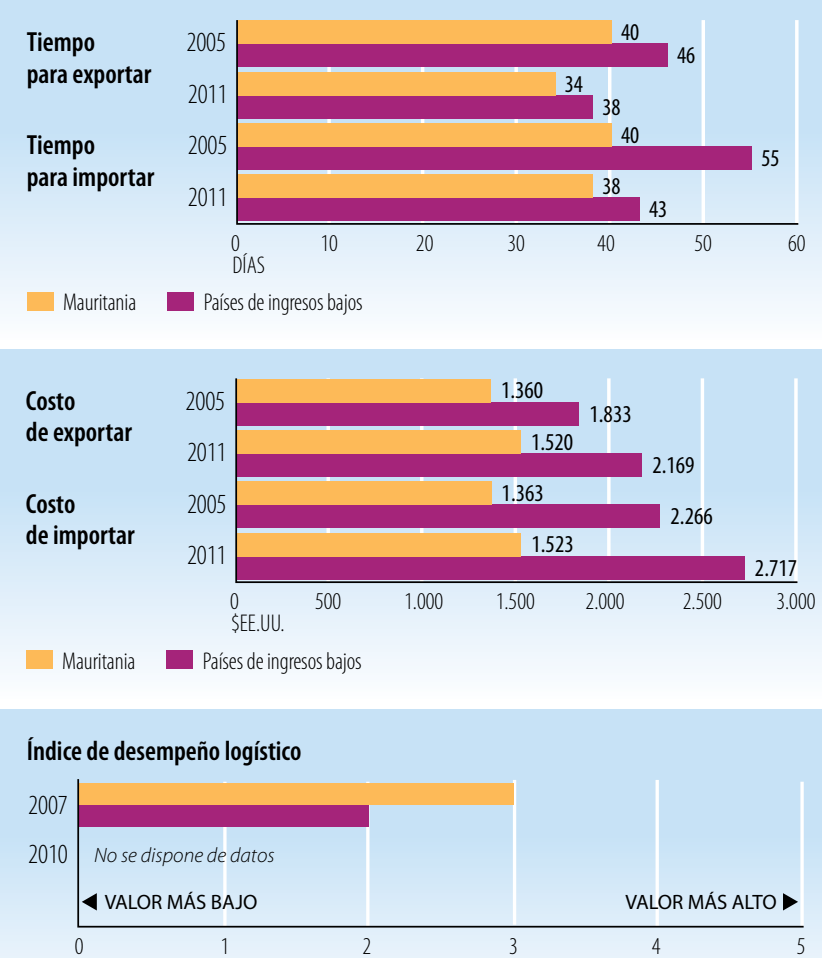

Mauritania Países de ingresos bajos

Fuentes: Banco Mundial, Indicadores del Desarrollo Mundial.

\begin{tabular}{l|c|c|}
\hline INDICADORES DE DESARROLLO (EFECTOS) & \\
\hline Indicador & $\mathbf{2 0 0 5}$ & $\mathbf{2 0 1 0}$ \\
\hline Desempleo (\% de la fuerza de trabajo total) & n.d. & n.d. \\
\hline Población activa, mujeres (\% de la fuerza de trabajo total) & 25,1 & 26,5 \\
\hline AOD neta recibida (\% del INB) & 8,4 & 10,6 \\
\hline Derechos de importación percibidos (\% de los ingresos fiscales) & n.d. & n.d. \\
\hline Total del servicio de la deuda (\% de las exportaciones totales) & 5,8 & 4,8 \\
\hline Índice de desarrollo humano ( 0 a 1) & 0,43 & 0,45 \\
\hline
\end{tabular}

Fuentes: PNUD, indicadores internacionales sobre desarrollo humano; Banco Mundial, Indicadores del Desarrollo Mundial.

Producto interno bruto

PIB per cápita (PPA, dólares internacionales corrientes)

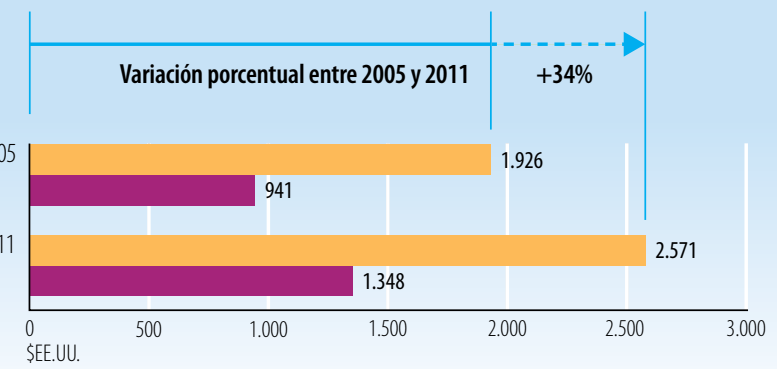

Mauritania Países de ingresos bajos

PIB per cápita (\$EE.UU. constantes de 2000)

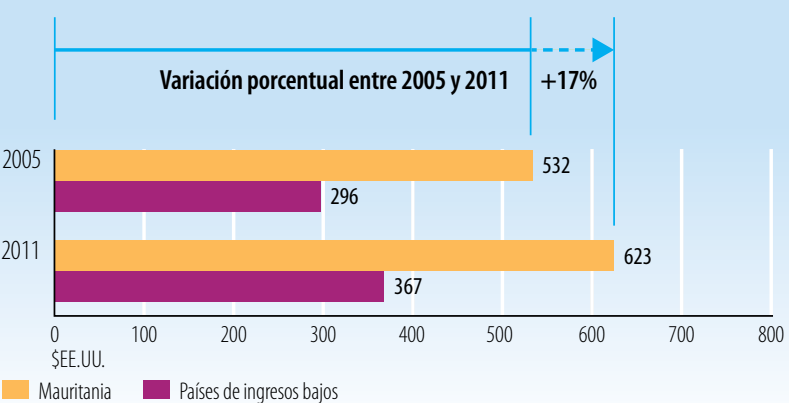

Fuentes: Banco Mundial, Indicadores del Desarrollo Mundial.

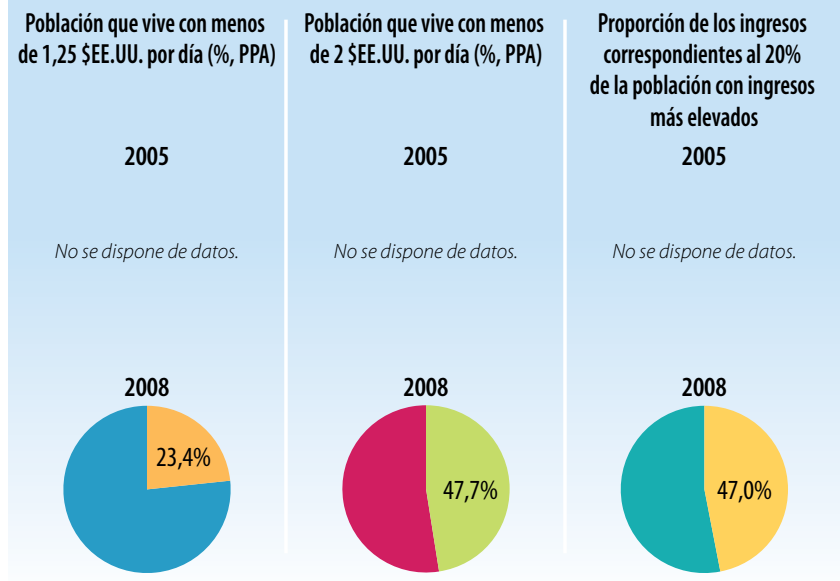

Fuentes: Banco Mundial, Indicadores del Desarrollo Mundial.

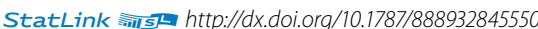


Indicadores de la ayuda, el comercio y el desarrollo relativos a México

\section{INVERSIÓN Y FINANCIACIÓN (APORTES)}

\begin{tabular}{|c|c|c|c|c|}
\hline Indicador (millones de \$EE.UU. corrientes) & 2005 & 2008 & 2010 & $\Delta: 05-10(\%)$ \\
\hline Formación bruta de capital fijo & $169.742,8$ & $242.275,2$ & $208.517,4$ & $23 \%$ \\
\hline del cual: público & $38.088,9$ & $61.490,8$ & $61.008,4$ & $60 \%$ \\
\hline del cual: privado & $131.653,9$ & $180.784,4$ & $147.509,0$ & $12 \%$ \\
\hline \multicolumn{5}{|l|}{ Entrada de financiación externa } \\
\hline Entradas de IED & $24.373,4$ & $26.888,5$ & $20.207,6$ & $-17 \%$ \\
\hline $\begin{array}{l}\text { Deuda externa a largo plazo y fondos } \\
\text { desembolsados por el FMl }\end{array}$ & $25.948,0$ & $33.703,6$ & $39.706,0$ & $53 \%$ \\
\hline $\begin{array}{l}\text { Corrientes comerciales en condiciones no } \\
\text { concesionarias }\end{array}$ & 466,7 & 615,0 & $1.355,0$ & 190 \\
\hline Corrientes de Ayuda para el Comercio & 15,2 & 32,7 & 40,1 & $164 \%$ \\
\hline $\begin{array}{l}\text { Remesas de trabajadores y remuneración } \\
\text { de empleados }\end{array}$ & $22.741,8$ & $26.035,1$ & $22.047,6$ & $-3 \%$ \\
\hline
\end{tabular}

Fuentes: OCDE, base de datos del SNPA del CAD sobre las actividades de ayuda; Banco Mundial, Indicadores del Desarrollo Mundial; Banco Mundial, estadísticas de la deuda internacional.

Desembolsos de la ayuda para el comercio, por sector (millones de \$EE.UU. corrientes)

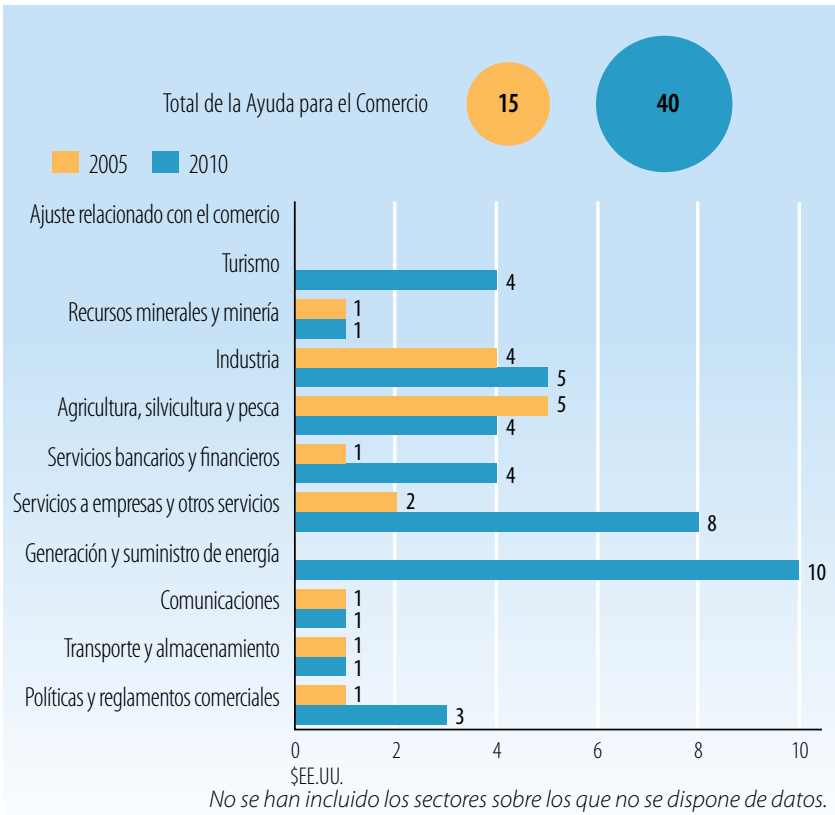

Fuentes: OCDE, base de datos del SNPA del CAD sobre las actividades de ayuda

Desembolsos de la ayuda para el comercio: principales donantes (millones de \$EE.UU. corrientes)

\begin{tabular}{|l|r|r|}
\hline $\mathbf{2 0 0 5}$ & Valor & $\%$ \\
\hline Japón & 5,8 & 38 \\
\hline Estados Unidos & 2,9 & 19 \\
\hline Instituciones de la UE & 1,8 & 12 \\
\hline Francia & 1,7 & 11 \\
\hline Alemania & 1,1 & 7 \\
\hline $\mathbf{2 0 1 0}$ & Valor & $\%$ \\
\hline Estados Unidos & 13,2 & 33 \\
\hline Alemania & 6,4 & 16 \\
\hline Japón & 5,4 & 14 \\
\hline BID & 5,3 & 13 \\
\hline Reino Unido & 4,2 & 10 \\
\hline
\end{tabular}

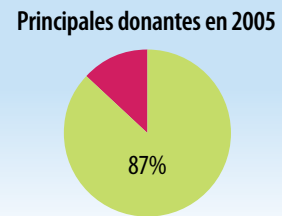

Principales donantes en 2010

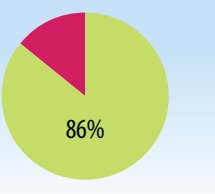

Fuentes: OCDE, base de datos del SNPA del CAD sobre las actividades de ayuda.

\section{INDICADORES COMERCIALES (PRODUCTOS)}

\section{Indicador}

$2005 \quad 2008 \quad 2011 \quad \Delta: 05-11(\%)$

Relación comercio/PIB (\%)

Exportaciones de servicios comerciales como

\% de las exportaciones totales

Importaciones de servicios comerciales como

$\%$ de las importaciones totales

Productos intermedios distintos de los combustibles

(\% de las exportaciones de mercancías)

Productos intermedios distintos de los combustibles

(\% de las importaciones de mercancías)

\begin{tabular}{|l|l|l|r|}
56 & 59 & 64 & 8 \\
\hline
\end{tabular}

Fuentes: Secretaría de la OMC

Corrientes comerciales (millones de \$̦E.UU. corrientes)

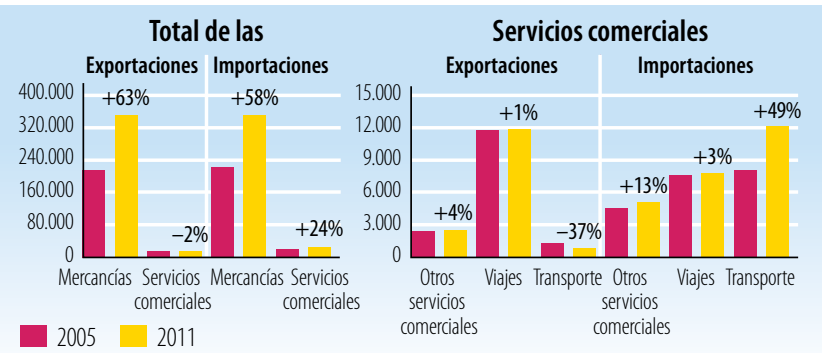

Fuentes: Secretaría de la OMC

Cinco principales mercados de exportación de mercancías (\%)

\begin{tabular}{|l|r|l|r|}
\hline 2005 & $\%$ & 2010 & $\%$ \\
\hline Estados Unidos & 86 & Estados Unidos & 80 \\
\hline UE (27) & 4 & UE (27) & 5 \\
\hline Canadá & 2 & Canadá & 4 \\
\hline Colombia & 1 & China & 1 \\
\hline Japón & 1 & Brasil & 1
\end{tabular}

Fuentes: Secretaría de la OMC

Cinco principales productos de exportación (\% de las exportaciones de mercancías)

\begin{tabular}{l|l|l|l}
2005 & $\%$ & 2011 & $\%$
\end{tabular}

\begin{tabular}{l|l|l|l} 
Aceites de petróleo, crudos & 13 & Aceites de petróleo, crudos & 14
\end{tabular} \begin{tabular}{ll|l|l|l|} 
Vehículos automotores para pasajeros, & 6 & Vehículos automotores para pasajeros, & 8
\end{tabular}

Equipos de telecomunicaciones y sus 6 Equipos de telecomunicaciones y sus partes, n.e.p.

Receptores de televisión, etc. automotores

Fuentes: Secretaría de la OMC

Cinco principales mercados de importación de mercancías (\%)

\begin{tabular}{|l|c|l|r|}
\hline 2005 & $\%$ & 2010 & $\%$ \\
\hline Estados Unidos & 54 & Estados Unidos & 48 \\
\hline UE (27) & 12 & China & 15 \\
\hline China & 8 & UE (27) & 11 \\
\hline Japón & 6 & Japón & 5 \\
\hline Corea, Rep. de & 3 & Corea, Rep. de & 4 \\
\hline
\end{tabular}

Fuentes: Secretaría de la OMC

Cinco principales productos de importación (\% de las importaciones de mercancías)

\begin{tabular}{|c|c|c|c|}
\hline 2005 & $\%$ & 2011 & $\%$ \\
\hline Transistores, válvulas, etc. & 5 & Productos derivados del petróleo & 8 \\
\hline $\begin{array}{l}\text { Equipos de telecomunicaciones y sus } \\
\text { partes, n.e.p. }\end{array}$ & 5 & $\begin{array}{l}\text { Equipos de telecomunicaciones y sus } \\
\text { partes, n.e.p. }\end{array}$ & 7 \\
\hline $\begin{array}{l}\text { Partes y piezas de tractores y vehículos } \\
\text { automotores }\end{array}$ & 5 & $\begin{array}{l}\text { Partes y piezas de tractores y vehículos } \\
\text { automotores }\end{array}$ & 5 \\
\hline Circuitos eléctricos de conmutación y relé & 4 & Transistores, válvulas, etc. & 4 \\
\hline $\begin{array}{l}\text { Vehículos automotores para pasajeros, } \\
\text { excepto autobuses }\end{array}$ & 4 & Circuitos eléctricos de conmutación y relé & 3 \\
\hline
\end{tabular}




\section{LA AYUDA PARA EL COMERCIO EN SÍNTESIS 2013}

\section{INDICADORES COMERCIALES (RESULTADOS)}

\section{Indicador}

Crecimiento del PIB (\%)

Número de exportadores

Índice de concentración de las exportaciones (productos) ( 0 a 1)

ACR sobre mercancías notificados a la OMC

AIE (servicios) notificados a la OMC

Sectores de servicios con compromisos en el marco del AGCS

\section{Aranceles (\%, 2006 et 2011)}

\begin{tabular}{ll|l|l|} 
Importaciones: promedio aritmético de los aranceles NMF aplicados & 14,0 & 8,3
\end{tabular}

\begin{tabular}{ll|l|l|l|} 
Importaciones: promedio ponderado de los aranceles NMF aplicados & 11,9 & 5,8
\end{tabular}

Exportaciones: promedio ponderado de los aranceles impuestos

por los importadores

Exportaciones: libres de derechos (en \%)

$0,2 \quad 0,2$

$98,6 \quad 98,4$

Fuentes: Naciones Unidas, base de datos Comtrade; Banco Mundial, base de datos sobre dinámica de las empresas de exportación; Banco Mundial, Indicadores del

Desarrollo Mundial; OMC, perfiles comerciales y arancelarios.

Participación en las exportaciones por región (\%)

\begin{tabular}{|l|r|r|}
\hline & $\mathbf{2 0 0 5}$ & $\mathbf{2 0 1 1}$ \\
\hline África & 0,2 & 0,2 \\
\hline Asia & 2,2 & 4,2 \\
\hline Comunidad de Estados Independientes & 0,0 & 0,2 \\
\hline Europa & 4,4 & 5,9 \\
\hline Oriente Medio & 0,1 & 0,2 \\
\hline América del Norte & 87,8 & 81,7 \\
\hline América del Sury América Central & 5,2 & 7,5 \\
\hline
\end{tabular}

Fuentes: OMC, perfiles comerciales y arancelarios

Indicadores de facilitación del comercio
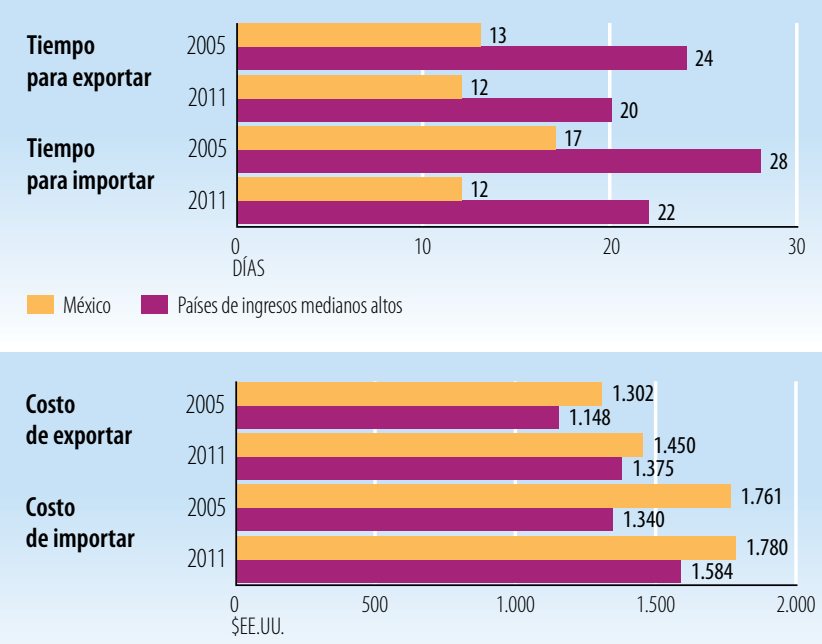

México Países de ingresos medianos altos

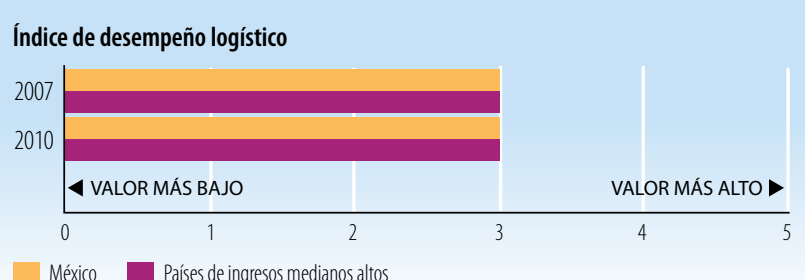

Fuentes: Banco Mundial, Indicadores del Desarrollo Mundial.

\section{INDICADORES DE DESARROLLO (EFECTOS)}

Indicador

2005

2010

Desempleo (\% de la fuerza de trabajo total)

$3,5 \quad 5,3$

Población activa, mujeres (\% de la fuerza de trabajo total)

$34,8 \quad 36,5$

AOD neta recibida (\% del INB)

$0,0 \quad 0,0$

Derechos de importación percibidos (\% de los ingresos fiscales) n.d. n.d.

Total del servicio de la deuda (\% de las exportaciones totales) $\quad 15,2 \quad 9,8$

Índice de desarrollo humano ( 0 a 1)

Fuentes: PNUD, indicadores internacionales sobre desarrollo humano; Banco Mundial, Indicadores del Desarrollo Mundial.

Producto interno bruto

PIB per cápita (PPA, dólares internacionales corrientes)
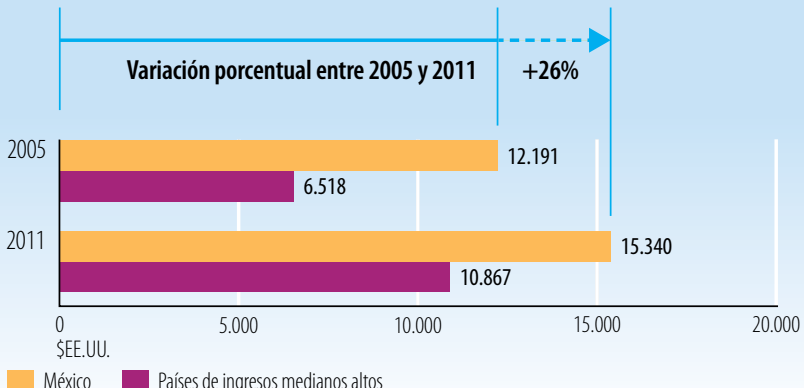

México Países de ingresos medianos altos

PIB per cápita (\$EE.UU. constantes de 2000)
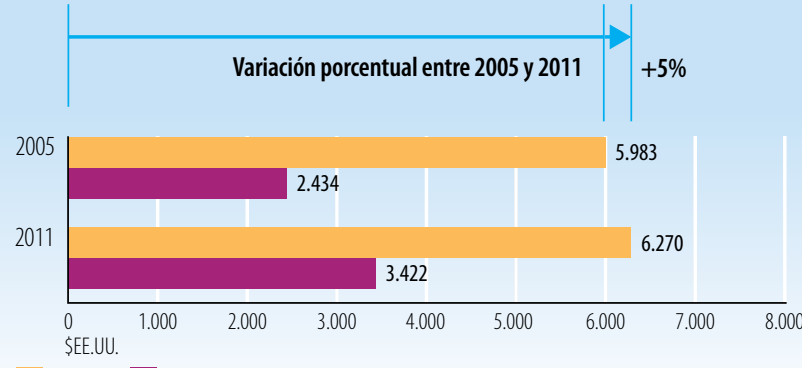

México Páses de ingresos medianos altos

Fuentes: Banco Mundial, Indicadores del Desarrollo Mundial.

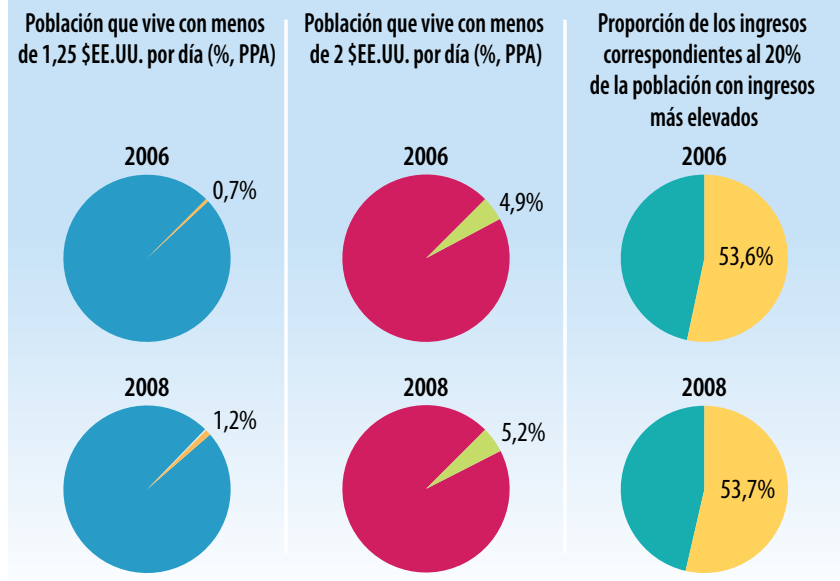

Fuentes: Banco Mundial, Indicadores del Desarrollo Mundial.

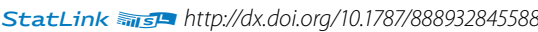




\section{LA AYUDA PARA EL COMERCIO EN SÍNTESIS 2013}

\section{Indicadores de la ayuda, el comercio y el desarrollo relativos a Mozambique}

\begin{tabular}{|c|c|c|c|c|}
\hline Indicador (millones de \$EE.UU. corrientes) & 2005 & 2008 & 2010 & $\Delta: 05-10(\%)$ \\
\hline Formación bruta de capital fijo & $1.229,8$ & $1.548,7$ & $2.272,0$ & $85 \%$ \\
\hline del cual: público & 562,5 & $1.141,7$ & $1.255,7$ & $123 \%$ \\
\hline del cual: privado & 667,3 & 407,0 & $1.016,3$ & $52 \%$ \\
\hline \multicolumn{5}{|l|}{ Entrada de financiación externa } \\
\hline Entradas de IED & 107,9 & 591,6 & 789,0 & $632 \%$ \\
\hline $\begin{array}{l}\text { Deuda externa a largo plazo y fondos } \\
\text { desembolsados por el FMl }\end{array}$ & 333,8 & 414,3 & 377,8 & $13 \%$ \\
\hline $\begin{array}{l}\text { Corrientes comerciales en condiciones no } \\
\text { concesionarias }\end{array}$ & 12,7 & 4,6 & 35,3 & $177 \%$ \\
\hline Corrientes de Ayuda para el Comercio & 337,0 & 333,1 & 342,6 & $2 \%$ \\
\hline $\begin{array}{l}\text { Remesas de trabajadores y remuneración } \\
\text { de empleados }\end{array}$ & 56,6 & 115,7 & 131,9 & $133 \%$ \\
\hline
\end{tabular}

Fuentes: OCDE, base de datos del SNPA del CAD sobre las actividades de ayuda; Banco Mundial, Indicadores del Desarrollo Mundial; Banco Mundial, estadísticas de la deuda internacional.

Desembolsos de la ayuda para el comercio, por sector (millones de \$EE.UU. corrientes)

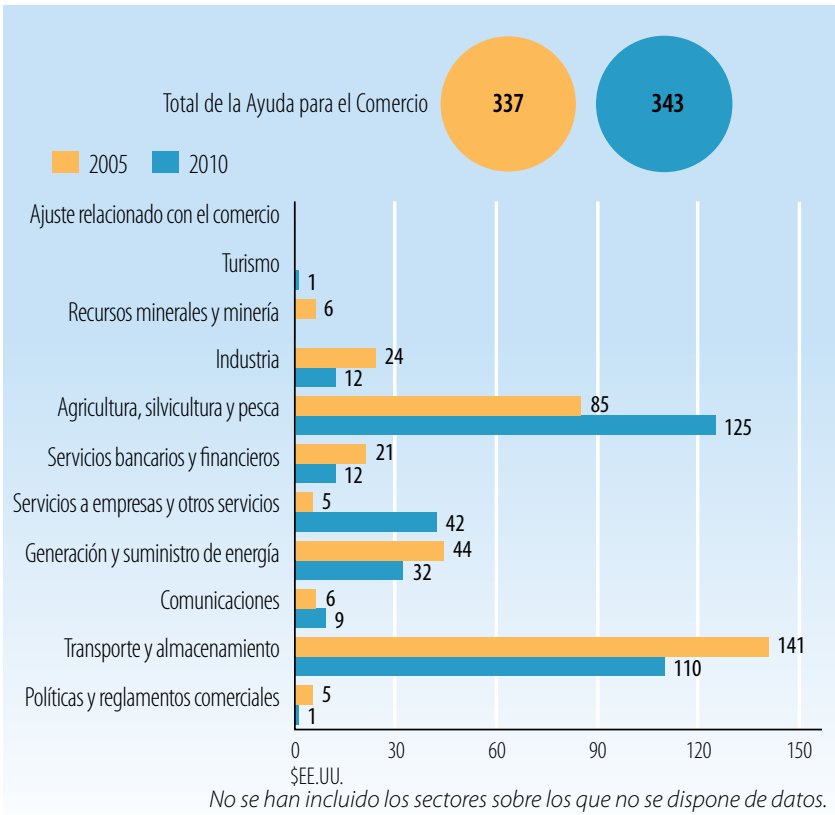

Fuentes: OCDE, base de datos del SNPA del CAD sobre las actividades de ayuda

Desembolsos de la ayuda para el comercio: principales donantes (millones de \$EE.UU. corrientes)

\begin{tabular}{|l|c|c|}
\hline $\mathbf{2 0 0 5}$ & Valor & $\%$ \\
\hline Banco Mundial & 113,1 & 34 \\
\hline Banco Africano de Desarrollo & 55,7 & 17 \\
\hline Instituciones de la UE & 37,2 & 11 \\
\hline Suecia & 34,1 & 10 \\
\hline Noruega & 20,3 & 6 \\
\hline $\mathbf{2 0 1 0}$ & Valor & $\%$ \\
\hline Banco Mundial & 90,1 & 26 \\
\hline Instituciones de la UE & 49,2 & 14 \\
\hline Banco Africano de Desarrollo & 31,0 & 9 \\
\hline Noruega & 28,6 & 8 \\
\hline Japón & 23,7 & 7 \\
\hline
\end{tabular}

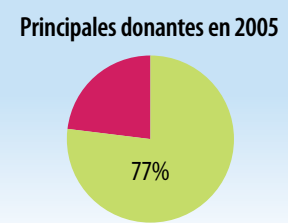

Principales donantes en 2010

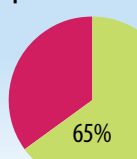

Fuentes: OCDE, base de datos del SNPA del CAD sobre las actividades de ayuda.

\section{INDICADORES COMERCIALES (PRODUCTOS)}

Indicador

$20052008 \quad 2011 \quad \Delta: 05-11(\%)$

Relación comercio/PIB (\%)

Exportaciones de servicios comerciales como

$\%$ de las exportaciones totales

Importaciones de servicios comerciales como

$\%$ de las importaciones totales

Productos intermedios distintos de los combustibles

(\% de las exportaciones de mercancías)

Productos intermedios distintos de los combustibles

(\% de las importaciones de mercancías)

\begin{tabular}{l|l|l|l|}
75 & 78 & 70 & -5 \\
\hline
\end{tabular}

\begin{tabular}{l|l|l|l|}
15 & 16 & 18 & 2
\end{tabular}

\begin{tabular}{l|l|l|l|}
22 & 20 & 25 & 4
\end{tabular}

\begin{tabular}{l|l|l|l|}
74 & 73 & n.d. & n.d.
\end{tabular}

\begin{tabular}{l|l|l|l|}
31 & 31 & n.d.
\end{tabular}

Fuentes: Secretaría de la OMC

Corrientes comerciales (millones de \$EE.UU. corrientes)

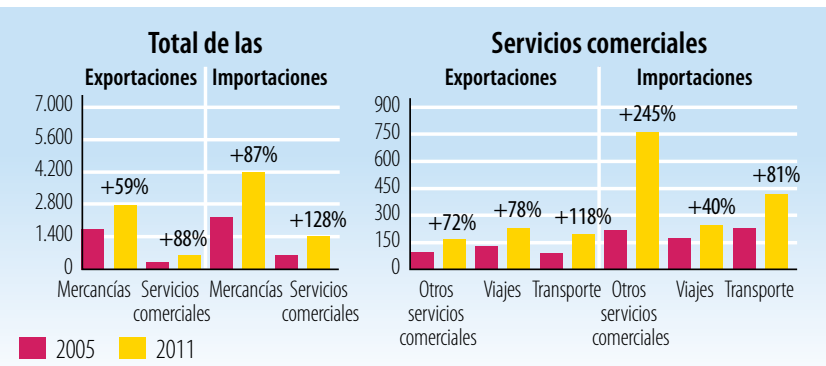

Fuentes: Secretaría de la OMC

Cinco principales mercados de exportación de mercancías (\%)

\begin{tabular}{|l|r|l|r|}
\hline 2005 & $\%$ & 2010 & $\%$ \\
\hline UE (27) & 64 & UE (27) & 61 \\
\hline Sudáfrica & 16 & Sudáfrica & 21 \\
\hline Malawi & 3 & China & 4 \\
\hline Zimbabwe & 3 & Zimbabwe & 3 \\
\hline China & 2 & India & 1 \\
\hline
\end{tabular}

Fuentes: Secretaría de la OMC

Cinco principales productos de exportación (\% de las exportaciones de mercancías)

\begin{tabular}{|l|r|l|c|}
\hline 2005 & $\%$ & 2010 & $\%$ \\
\hline Aluminio & 58 & Aluminio & 52 \\
\hline Corriente eléctrica & 8 & Corriente eléctrica & 12 \\
\hline Gas natural & 6 & Tabaco sin elaborar & 6 \\
\hline Crustáceos, moluscos, etc. & 5 & Gas natural & 6 \\
\hline Algodón & 3 & Operaciones especiales no clasificadas & 4 \\
\hline
\end{tabular}

Fuentes: Secretaría de la OMC

Cinco principales mercados de importación de mercancías (\%)

\begin{tabular}{|l|r|l|c|}
\hline 2005 & $\%$ & 2010 & $\%$ \\
\hline Sudáfrica & 41 & Sudáfrica & 34 \\
\hline UE (27) & 24 & UE (27) & 31 \\
\hline India & 4 & India & 6 \\
\hline Estados Unidos & 3 & China & 4 \\
\hline China & 3 & Japón & 4 \\
\hline Fuentes: Secretaría de la OMC & & & \\
\hline
\end{tabular}

Cinco principales productos de importación (\% de las importaciones de mercancías)

\begin{tabular}{|c|c|c|c|}
\hline 2005 & $\%$ & 2010 & $\%$ \\
\hline Operaciones especiales no clasificadas & 26 & Operaciones especiales no clasificadas & 17 \\
\hline Arroz & 5 & Productos derivados del petróleo & 15 \\
\hline $\begin{array}{l}\text { Vehículos automotores para el transporte } \\
\text { de mercancías y vehículos automotores } \\
\text { para usos especiales }\end{array}$ & 4 & $\begin{array}{l}\text { Vehículos automotores para el transporte } \\
\text { de mercancías y vehículos automotores } \\
\text { para usos especiales }\end{array}$ & 5 \\
\hline Corriente eléctrica & 3 & Corriente eléctrica & 4 \\
\hline $\begin{array}{l}\text { Equipos de telecomunicaciones y sus } \\
\text { partes, n.e.p. }\end{array}$ & 3 & Equipo de ingeniería civil & 2 \\
\hline
\end{tabular}




\section{INDICADORES COMERCIALES (RESULTADOS)}

\section{Indicador}

Crecimiento del PIB (\%)

Número de exportadores

Índice de concentración de las exportaciones (productos) (0 a 1)

ACR sobre mercancías notificados a la OMC

AIE (servicios) notificados a la OMC

Sectores de servicios con compromisos en el marco del AGCS

\section{Aranceles (\%, 2006 et 2011)}

\begin{tabular}{|l|l|l|} 
Importaciones: promedio aritmético de los aranceles NMF aplicados & 12,1 & 10,1
\end{tabular}

\begin{tabular}{|l|l|l|} 
Importaciones: promedio ponderado de los aranceles NMF aplicados & 9,1 & 7,2 \\
\hline
\end{tabular}

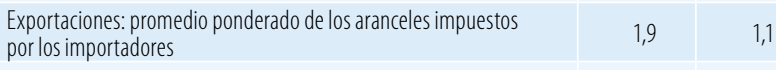

Exportaciones: libres de derechos (en \%)

$95,1 \quad 95,0$

Fuentes: Naciones Unidas, base de datos Comtrade; Banco Mundial, base de datos sobre dinámica de las empresas de exportación; Banco Mundial, Indicadores del

Desarrollo Mundial; OMC, perfiles comerciales y arancelarios.

Participación en las exportaciones por región (\%)

\begin{tabular}{|l|r|r|}
\hline & 2005 & 2011 \\
\hline África & 22,2 & 23,0 \\
\hline Asia & 5,3 & 12,2 \\
\hline Comunidad de Estados Independientes & 0,0 & 0,7 \\
\hline Europa & 65,0 & 55,8 \\
\hline Oriente Medio & 0,1 & 4,6 \\
\hline América del Norte & 1,0 & 1,6 \\
\hline América del Sury América Central & 0,0 & 2,0 \\
\hline
\end{tabular}

Fuentes: OMC, perfiles comerciales y arancelarios

Indicadores de facilitación del comercio
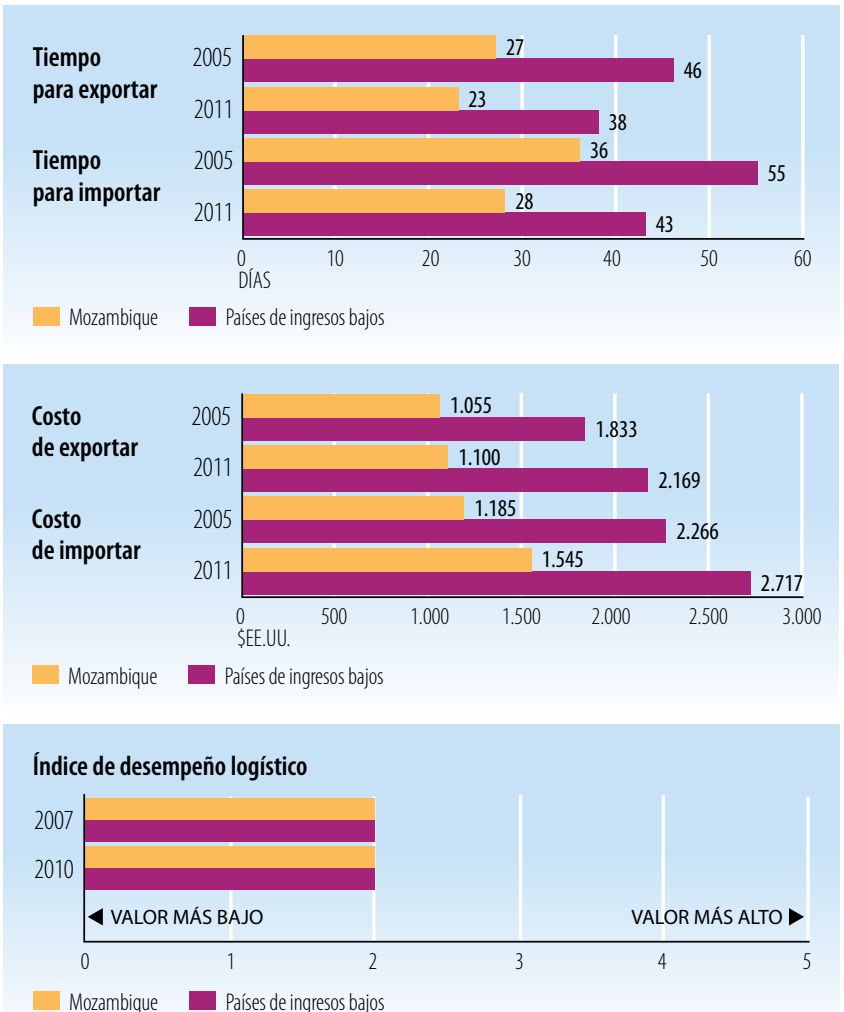

Fuentes: Banco Mundial, Indicadores del Desarrollo Mundial.

\begin{tabular}{l|c|c|}
\hline INDICADORES DE DESARROLLO (EFECTOS) \\
\hline Indicador & $\mathbf{2 0 0 5}$ & $\mathbf{2 0 1 0}$ \\
\hline Desempleo (\% de la fuerza de trabajo total) & n.d. & n.d. \\
\hline Población activa, mujeres (\% de la fuerza de trabajo total) & 54,3 & 53,6 \\
\hline AOD neta recibida (\% del INB) & 20,9 & 21,4 \\
\hline Derechos de importación percibidos (\% de los ingresos fiscales) & n.d. & n.d. \\
\hline Total del servicio de la deuda (\% de las exportaciones totales) & 3,6 & 2,9 \\
\hline Índice de desarrollo humano (0 a 1) & 0,29 & 0,32 \\
\hline
\end{tabular}

Fuentes: PNUD, indicadores internacionales sobre desarrollo humano; Banco Mundial, Indicadores del Desarrollo Mundial.

Producto interno bruto

PIB per cápita (PPA, dólares internacionales corrientes)

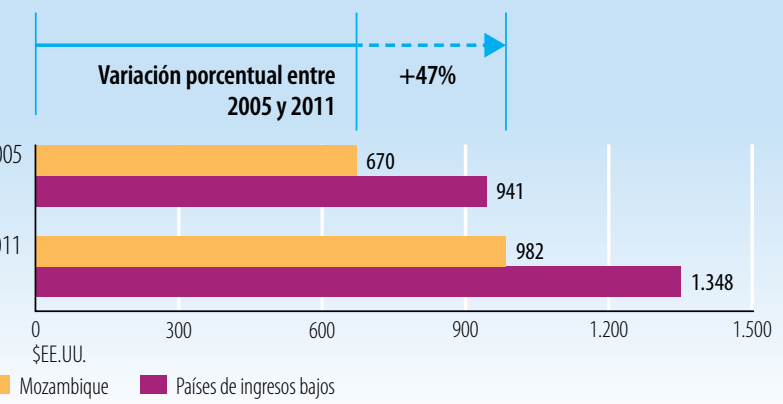

PIB per cápita (\$EE.UU. constantes de 2000)

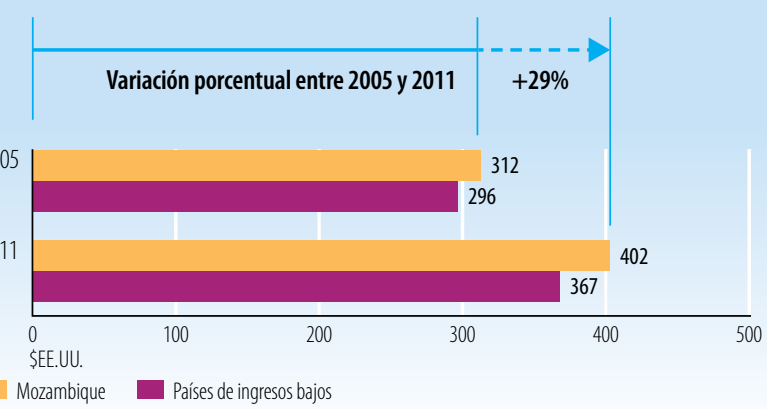

Fuentes: Banco Mundial, Indicadores del Desarrollo Mundial.

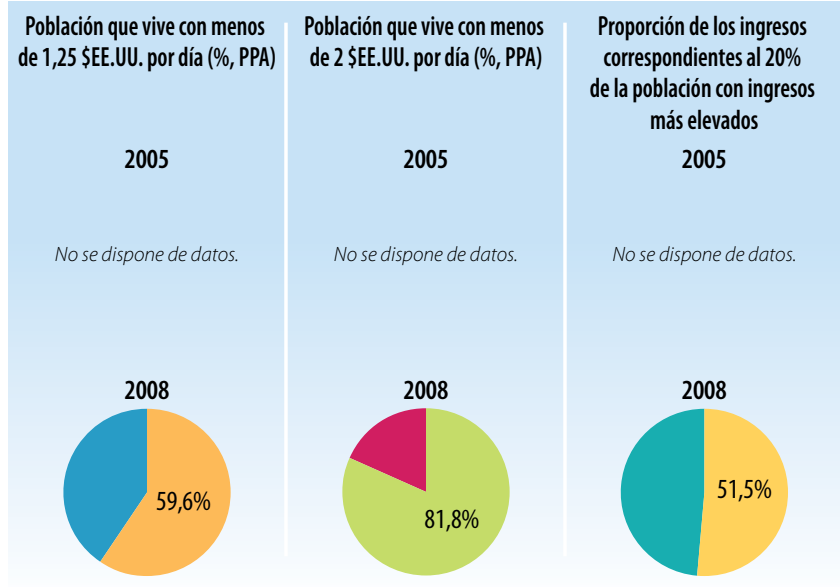

Fuentes: Banco Mundial, Indicadores del Desarrollo Mundial.

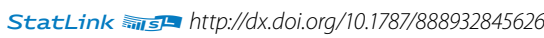


Indicadores de la ayuda, el comercio y el desarrollo relativos a Nepal

\begin{tabular}{|c|c|c|c|c|}
\hline Indicador (millones de \$EE.UU. corrientes) & 2005 & 2008 & 2010 & $\Delta: 05-10(\%$ \\
\hline Formación bruta de capital fijo & $1.621,3$ & $2.750,6$ & $3.553,6$ & $119 \%$ \\
\hline del cual: público & 237,4 & 508,6 & 719,9 & $203 \%$ \\
\hline del cual: privado & $1.383,9$ & $2.242,0$ & $2.833,7$ & $105 \%$ \\
\hline \multicolumn{5}{|l|}{ Entrada de financiación externa } \\
\hline Entradas de IED & 2,5 & 1,0 & 87,8 & $3482 \%$ \\
\hline $\begin{array}{l}\text { Deuda externa a largo plazo y fondos } \\
\text { desembolsados por el FMl }\end{array}$ & 192,4 & 103,4 & 177,3 & $-8 \%$ \\
\hline $\begin{array}{l}\text { Corrientes comerciales en condiciones no } \\
\text { concesionarias }\end{array}$ & 0,0 & 0,0 & 0,0 & $0 \%$ \\
\hline Corrientes de Ayuda para el Comercio & 127,6 & 156,6 & 251,4 & $97 \%$ \\
\hline $\begin{array}{l}\text { Remesas de trabajadores y remuneración } \\
\text { de empleados }\end{array}$ & $1.211,8$ & $2.727,1$ & $3.468,5$ & $186 \%$ \\
\hline
\end{tabular}

Fuentes: OCDE, base de datos del SNPA del CAD sobre las actividades de ayuda; Banco Mundial, Indicadores del Desarrollo Mundial; Banco Mundial, estadísticas de la deuda internacional.

Desembolsos de la ayuda para el comercio, por sector (millones de \$EE.UU. corrientes)

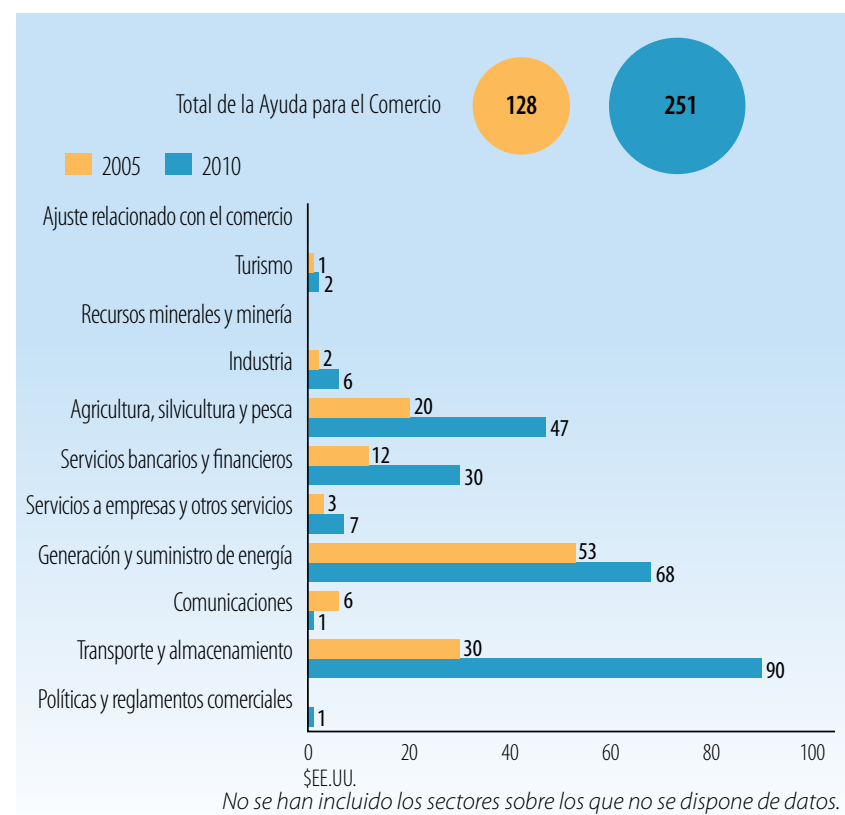

Fuentes: OCDE, base de datos del SNPA del CAD sobre las actividades de ayuda

Desembolsos de la ayuda para el comercio: principales donantes (millones de \$EE.UU. corrientes)

\begin{tabular}{|l|c|c|c|}
\hline $\mathbf{2 0 0 5}$ & Valor & $\%$ & Principales donantes en $\mathbf{2 0 0 5}$ \\
\hline Alemania & 42,6 & 33 & \\
\hline Japón & 25,9 & 20 & \\
\hline Banco Mundial & 25,1 & 20 & \\
\hline Reino Unido & 14,5 & 11 & \\
\hline Suiza & 8,3 & 6 & \\
\hline $\mathbf{2 0 1 0}$ & Valor & $\%$ & Principales donantes en 2010 \\
\hline Banco Asiático de Desarrollo & 56,4 & 22 & \\
\hline Japón & 50,4 & 20 & \\
\hline Banco Mundial & 40,2 & 16 & \\
\hline Reino Unido & 19,5 & 8 & $72 \%$ \\
\hline Corea, Rep. de & 14,2 & 6 & \\
\hline
\end{tabular}

Fuentes: OCDE, base de datos del SNPA del CAD sobre las actividades de ayuda.

\section{INDICADORES COMERCIALES (PRODUCTOS)}

\section{Indicador}

$2005 \quad 2008 \quad 2011 \quad \Delta: 05-11(\%)$

Relación comercio/PIB (\%)

Exportaciones de servicios comerciales como

$\%$ de las exportaciones totales

Importaciones de servicios comerciales como

$\%$ de las importaciones totales

Productos intermedios distintos de los combustibles

(\% de las exportaciones de mercancías)

Productos intermedios distintos de los combustibles

(\% de las importaciones de mercancías)

\begin{tabular}{|r|r|r|r|}
\hline 48 & 46 & 43 & -4 \\
\hline 23 & 33 & 44 & 21 \\
\hline 16 & 19 & 12 & -4 \\
\hline n.d. & n.d. & n.d. & n.d. \\
\hline n.d. & n.d. & n.d. & n.d. \\
\hline
\end{tabular}

Fuentes: Secretaría de la OMC.

Corrientes comerciales (millones de \$EE.UU. corrientes)

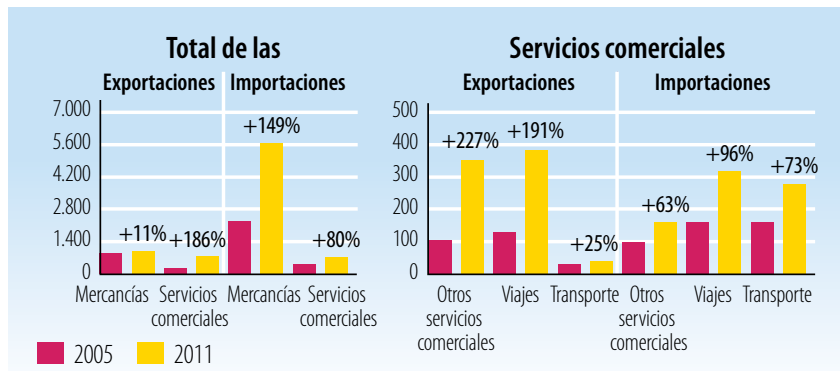

Fuentes: Secretaría de la OMC

Cinco principales mercados de exportación de mercancías (\%)

\begin{tabular}{|l|l|ll}
\hline 2009 & $\%$ & 2010 & $\%$ \\
\hline India & 64 & India & 65 \\
\hline UE (27) & 11 & UE (27) & 11 \\
\hline Estados Unidos & 7 & Estados Unidos & 6 \\
\hline Bangladesh & 7 & Bangladesh & 6 \\
\hline China & 3 & Bhután & 3
\end{tabular}

Fuentes: Secretaría de la OMC

Cinco principales productos de exportación (\% de las exportaciones de mercancías)

\begin{tabular}{|c|c|c|c|}
\hline 2009 & $\%$ & 2010 & $\%$ \\
\hline Legumbres & 9 & $\begin{array}{l}\text { Productos laminados planos, de hierro, } \\
\text { revestidos }\end{array}$ & 10 \\
\hline $\begin{array}{l}\text { Productos laminados planos, de hierro, } \\
\text { revestidos }\end{array}$ & 8 & Hilados de fibra textil & 8 \\
\hline Recubrimientos para pisos, etc. & 8 & Recubrimientos para pisos, etc. & 7 \\
\hline Hilados de fibra textil & 7 & Tejidos de fibras manufacturadas & 7 \\
\hline Tejidos de fibras manufacturadas & 6 & Legumbres & 6 \\
\hline
\end{tabular}

Fuentes: Secretaría de la OMC

Cinco principales mercados de importación de mercancías (\%)

\begin{tabular}{|c|c|l|c|}
\hline 2009 & $\%$ & $\mathbf{2 0 1 0}$ & $\%$ \\
\hline India & 57 & India & 57 \\
\hline China & 11 & China & 10 \\
\hline UE (27) & 5 & Emiratos Árabes Unidos & 9 \\
\hline Arabia Saudita, Reino de la & 3 & UE (27) & 4 \\
\hline Indonesia & 3 & Indonesia & 2 \\
\hline Fuentes: Secretaría de la OMC & & & \\
\hline
\end{tabular}

Cinco principales productos de importación (\% de las importaciones de mercancías)

\begin{tabular}{|c|c|c|c|}
\hline 2009 & $\%$ & 2010 & $\%$ \\
\hline Productos derivados del petróleo & 13 & Productos derivados del petróleo & 12 \\
\hline Oro no monetario, excepto minerales & 4 & Oro no monetario, excepto minerales & 11 \\
\hline Productos laminados planos de hierro, etc. & 3 & $\begin{array}{l}\text { Equipos de telecomunicaciones y sus } \\
\text { partes, n.e.p. }\end{array}$ & 4 \\
\hline Lingotes, etc., de hierro 0 acero & 3 & Lingotes, etc., de hierro 0 acero & 4 \\
\hline Cal, cemento y materiales de construcción & 3 & $\begin{array}{l}\text { Cal, cemento y materiales de } \\
\text { construcción }\end{array}$ & 3 \\
\hline
\end{tabular}

Fuentes: Secretaría de la OMC 


\section{LA AYUDA PARA EL COMERCIO EN SÍNTESIS 2013}

\section{INDICADORES COMERCIALES (RESULTADOS)}

\section{Indicador}

Crecimiento del PIB (\%)

Número de exportadores

Índice de concentración de las exportaciones (productos) (0 a 1)

ACR sobre mercancías notificados a la OMC

AIE (servicios) notificados a la OMC

Sectores de servicios con compromisos en el marco del AGCS

\section{Aranceles (\%)}

Importaciones: promedio aritmético de los aranceles NMF aplicados $\quad 13,9 \quad 12,3$

Importaciones: promedio ponderado de los aranceles NMF aplicados $\quad$ n.d. $\quad 13,1$

\begin{tabular}{|l|l|l|l|} 
Exportaciones: promedio ponderado de los aranceles impuestos & 11,8 & 6,8
\end{tabular}

por los importadores

$37,8 \quad 71,8$

Exportaciones: libres de derechos (en \%) sobre dinámica de las empresas de exportación; Banco Mundial, Indicadores del

Desarrollo Mundial; OMC, perfiles comerciales y arancelarios.

Participación en las exportaciones por región (\%)

\begin{tabular}{|l|r|r|}
\hline & 2005 & 2010 \\
\hline África & n.d. & 0,2 \\
\hline Asia & n.d. & 78,8 \\
\hline Comunidad de Estados Independientes & n.d. & 0,1 \\
\hline Europa & n.d. & 12,3 \\
\hline Oriente Medio & n.d. & 0,7 \\
\hline América del Norte & n.d. & 7,7 \\
\hline América del Sury América Central & n.d. & 0,3 \\
\hline
\end{tabular}

Fuentes: OMC, perfiles comerciales y arancelarios

Indicadores de facilitación del comercio
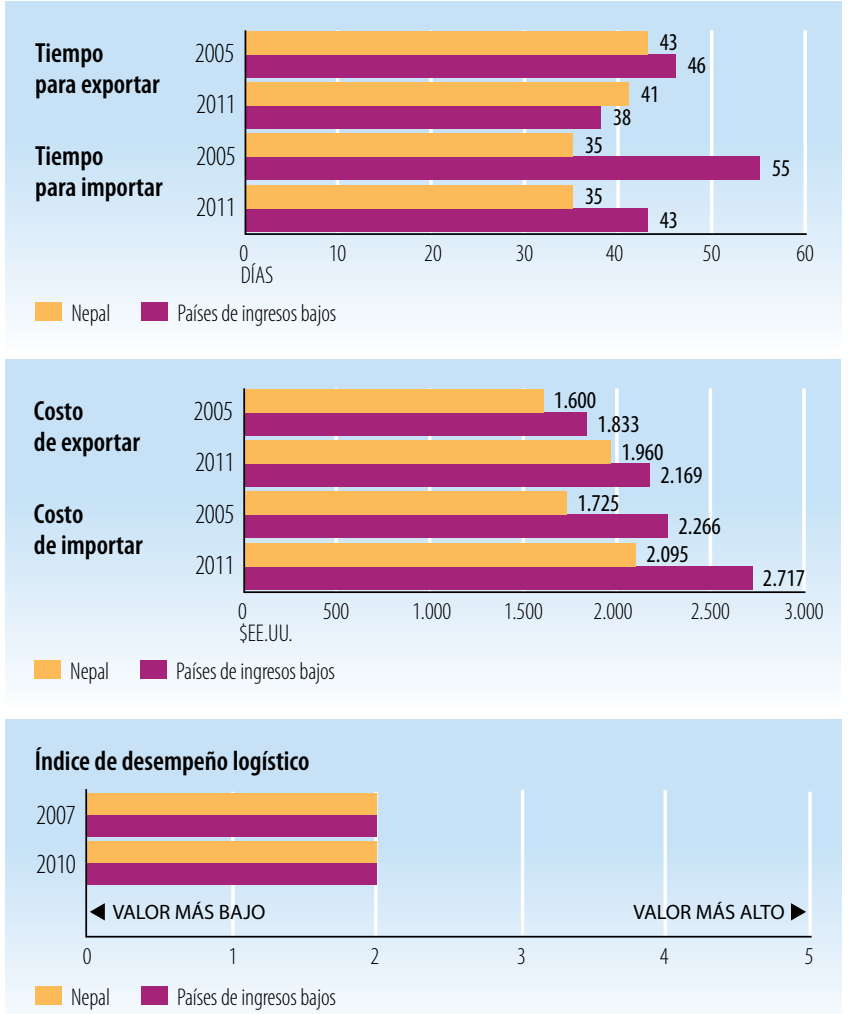

Fuentes: Banco Mundial, Indicadores del Desarrollo Mundial.

\begin{tabular}{|l|c|c|}
\hline INDICADORES DE DESARROLLO (EFECTOS) & \\
\hline Indicador & $\mathbf{2 0 0 5}$ & $\mathbf{2 0 1 0}$ \\
\hline Desempleo (\% de la fuerza de trabajo total) & $n \cdot d$. & 2,7 \\
\hline Población activa, mujeres (\% de la fuerza de trabajo total) & 49,2 & 49,2 \\
\hline AOD neta recibida (\% del INB) & 5,2 & 5,1 \\
\hline Derechos de importación percibidos (\% de los ingresos fiscales) & 27,5 & 21,0 \\
\hline Total del servicio de la deuda (\% de las exportaciones totales) & 8,2 & 10,5 \\
\hline Índice de desarrollo humano (0 a 1) & 0,42 & 0,46 \\
\hline
\end{tabular}

Fuentes: PNUD, indicadores internacionales sobre desarrollo humano; Banco Mundial, Indicadores del Desarrollo Mundial.

Producto interno bruto

PIB per cápita (PPA, dólares internacionales corrientes)

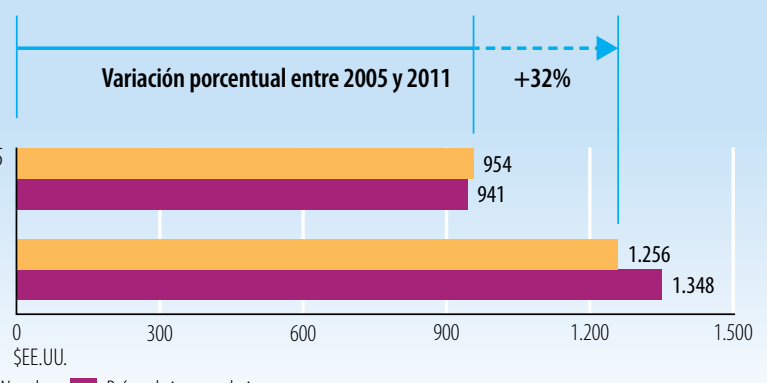

Nepal Países de ingresos bajos

PIB per cápita (\$EE.UU. constantes de 2000)

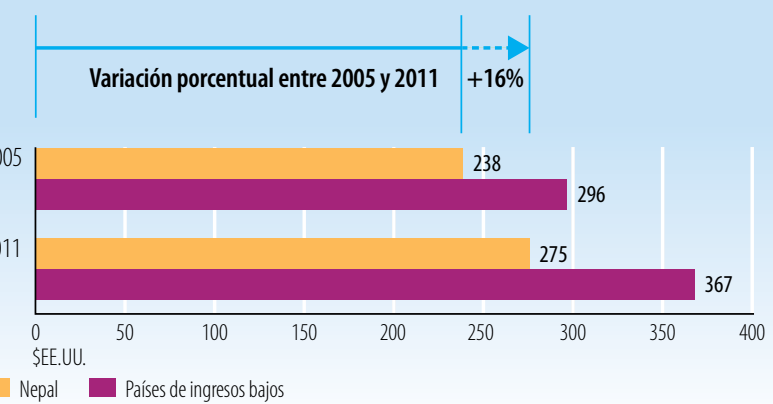

Fuentes: Banco Mundial, Indicadores del Desarrollo Mundial.

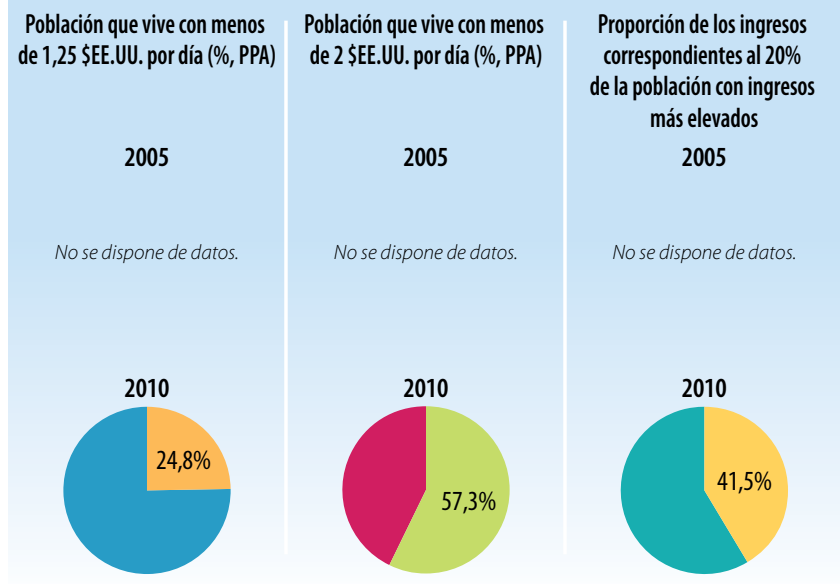

Fuentes: Banco Mundial, Indicadores del Desarrollo Mundial. StatLink inाs] $h$ ttp://dx.doi.org/10.1787/888932845645 


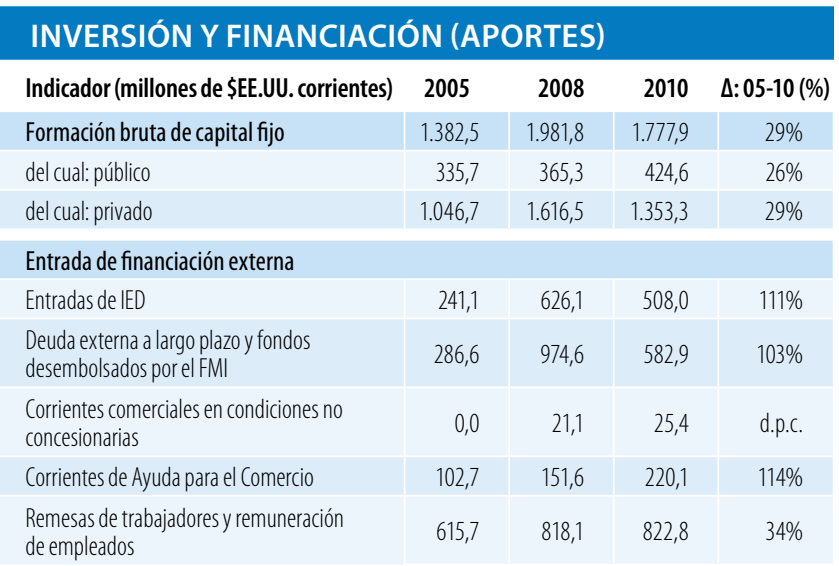

Fuentes: OCDE, base de datos del SNPA del CAD sobre las actividades de ayuda; Banco Mundial, Indicadores del Desarrollo Mundial; Banco Mundial, estadísticas de la deuda internacional.

Desembolsos de la ayuda para el comercio, por sector (millones de \$EE.UU. corrientes)

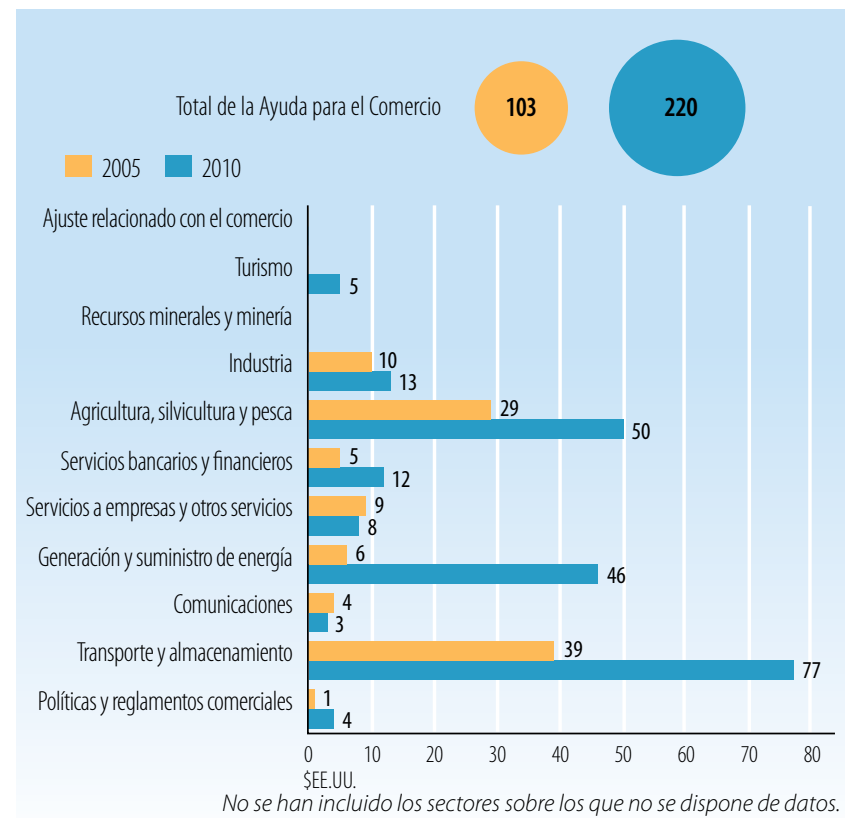

Fuentes: OCDE, base de datos del SNPA del CAD sobre las actividades de ayuda

Desembolsos de la ayuda para el comercio: principales donantes (millones de \$EE.UU. corrientes)

\begin{tabular}{|l|c|c|c|}
\hline $\mathbf{2 0 0 5}$ & Valor & $\%$ & Principales donantes en $\mathbf{2 0 0 5}$ \\
\hline Banco Mundial & 27,0 & 26 & \\
\hline Dinamarca & 17,9 & 17 & \\
\hline Japón & 9,4 & 9 & $69 \%$ \\
\hline España & 9,3 & 9 & \\
\hline Estados Unidos & 6,9 & 7 & \\
\hline $\mathbf{2 0 1 0}$ & Valor & $\%$ & Principales donantes en 2010 \\
\hline BID & 43,6 & 20 & \\
\hline Banco Mundial & 31,1 & 14 & \\
\hline Estados Unidos & 26,0 & 12 & \\
\hline Japón & 24,6 & 11 & $66 \%$ \\
\hline España & 20,0 & 9 \\
\hline
\end{tabular}

Fuentes: OCDE, base de datos del SNPA del CAD sobre las actividades de ayuda.

\section{INDICADORES COMERCIALES (PRODUCTOS)}

Indicador

$2005 \quad 2008 \quad 2011 \quad \Delta: 05-11(\%)$

Relación comercio/PIB (\%)

\begin{tabular}{l|l|l|r|}
109 & 132 & 158 & 49 \\
\hline
\end{tabular}

Exportaciones de servicios comerciales como

$\%$ de las exportaciones totales

Importaciones de servicios comerciales como

$\%$ de las importaciones totales

Productos intermedios distintos de los combustibles

(\% de las exportaciones de mercancías)

Productos intermedios distintos de los combustibles

(\% de las importaciones de mercancías)

\begin{tabular}{l|l|l|l|}
14 & 15 & 12 & -2
\end{tabular}

Fuentes: Secretaría de la OMC

Corrientes comerciales (millones de \$EE.UU. corrientes)

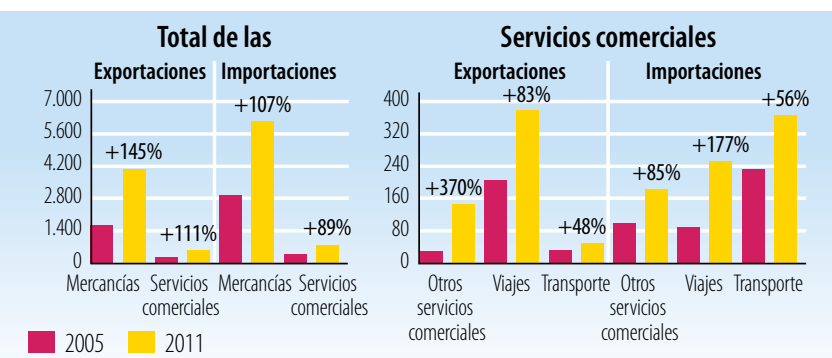

Fuentes: Secretaría de la OMC

Cinco principales mercados de exportación de mercancías (\%)

\begin{tabular}{|l|r|l|c|}
\hline $\mathbf{2 0 0 5}$ & $\%$ & $\mathbf{2 0 1 0}$ & $\%$ \\
\hline Estados Unidos & 35 & Estados Unidos & 33 \\
\hline El Salvador & 14 & Venezuela, Rep. Bolivariana de & 13 \\
\hline UE (27) & 13 & El Salvador & 11 \\
\hline Honduras & 8 & UE (27) & 10 \\
\hline Costa Rica & 6 & Canadá & 9 \\
\hline
\end{tabular}

Fuentes: Secretaría de la OMC

Cinco principales productos de exportación (\% de las exportaciones de mercancías)

\begin{tabular}{|c|c|c|c|}
\hline 2005 & $\%$ & 2011 & $\%$ \\
\hline Café y sucedáneos del café & 16 & Café y sucedáneos del café & 20 \\
\hline Carne de ganado bovino & 14 & Carne de ganado bovino & 19 \\
\hline Crustáceos, moluscos, etc. & 10 & Oro no monetario, excepto minerales & 16 \\
\hline Azúcares, melaza y miel & 7 & Azúcares, melaza y miel & 8 \\
\hline $\begin{array}{l}\text { Semillas oleaginosas (aceites vegetales } \\
\text { fijos blandos) }\end{array}$ & 6 & Crustáceos, moluscos, etc. & 5 \\
\hline
\end{tabular}

Cinco principales mercados de importación de mercancías (\%)

\begin{tabular}{|l|r|l|c|}
\hline 2005 & $\%$ & 2010 & $\%$ \\
\hline Estados Unidos & 21 & Estados Unidos & 21 \\
\hline Costa Rica & 9 & Venezuela, Rep. Bolivariana de & 18 \\
\hline México & 9 & China & 9 \\
\hline Venezuela, Rep. Bolivariana de & 7 & Costa Rica & 8 \\
\hline Guatemala & 7 & México & 8 \\
\hline
\end{tabular}

Fuentes: Secretaría de la OMC

Cinco principales productos de importación (\% de las importaciones de mercancías)

\begin{tabular}{|c|c|c|c|}
\hline 2005 & $\%$ & 2011 & $\%$ \\
\hline Aceites de petróleo, crudos & 9 & Aceites de petróleo, crudos & 12 \\
\hline Productos derivados del petróleo & 8 & Productos derivados del petróleo & 8 \\
\hline Medicamentos & 5 & Medicamentos & 6 \\
\hline $\begin{array}{l}\text { Equipos de telecomunicaciones y sus } \\
\text { partes, n.e.p. }\end{array}$ & 3 & Productos y preparados comestibles, n.e.p. & 2 \\
\hline $\begin{array}{l}\text { Vehículos automotores para el transporte } \\
\text { de mercancías y vehículos automotores } \\
\text { para usos especiales }\end{array}$ & 3 & $\begin{array}{l}\text { Vehículos automotores para el transporte } \\
\text { de mercancías y vehículos automotores } \\
\text { para usos especiales }\end{array}$ & 2 \\
\hline
\end{tabular}

Fuentes: Secretaría de la OMC 


\section{LA AYUDA PARA EL COMERCIO EN SIINTESIS $\mathbf{2 0 1 3}$}

\section{INDICADORES COMERCIALES (RESULTADOS)}

\section{Indicador}

Crecimiento del PIB (\%)

Número de exportadores

Índice de concentración de las exportaciones (productos) (0 a 1$)$

ACR sobre mercancías notificados a la OMC

AIE (servicios) notificados a la OMC

Sectores de servicios con compromisos en el marco del AGCS

\section{Aranceles (\%)}

Importaciones: promedio aritmético de los aranceles NMF aplicado Importaciones: promedio ponderado de los aranceles NMF aplicados Exportaciones: promedio ponderado de los aranceles impuestos por los importadores

Exportaciones: libres de derechos (en \%)

\begin{tabular}{|r|r|}
\hline 2005 & 2011 \\
\hline 4,3 & 4,7 \\
\hline 1.162 & 1.153 \\
\hline 0,05 & 0,09 \\
\hline n.d. & 6 \\
\hline n.d. & 4 \\
\hline 49 & 49 \\
\hline
\end{tabular}

Fuentes: Naciones Unidas, base de datos Comtrade; Banco Mundial, base de datos sobre dinámica de las empresas de exportación; Banco Mundial, Indicadores del Desarrollo Mundial; OMC, perfiles comerciales y arancelarios.

Participación en las exportaciones por región (\%)

\begin{tabular}{|l|r|r|}
\hline & $\mathbf{2 0 0 5}$ & $\mathbf{2 0 1 1}$ \\
\hline África & 0,1 & 0,3 \\
\hline Asia & 3,9 & 5,4 \\
\hline Comunidad de Estados Independientes & 1,6 & 0,9 \\
\hline Europa & 13,1 & 11,2 \\
\hline Oriente Medio & 0,2 & 0,2 \\
\hline América del Norte & 44,3 & 46,3 \\
\hline América del Sury América Central & 36,9 & 35,8 \\
\hline
\end{tabular}

Fuentes: OMC, perfiles comerciales y arancelarios

Indicadores de facilitación del comercio
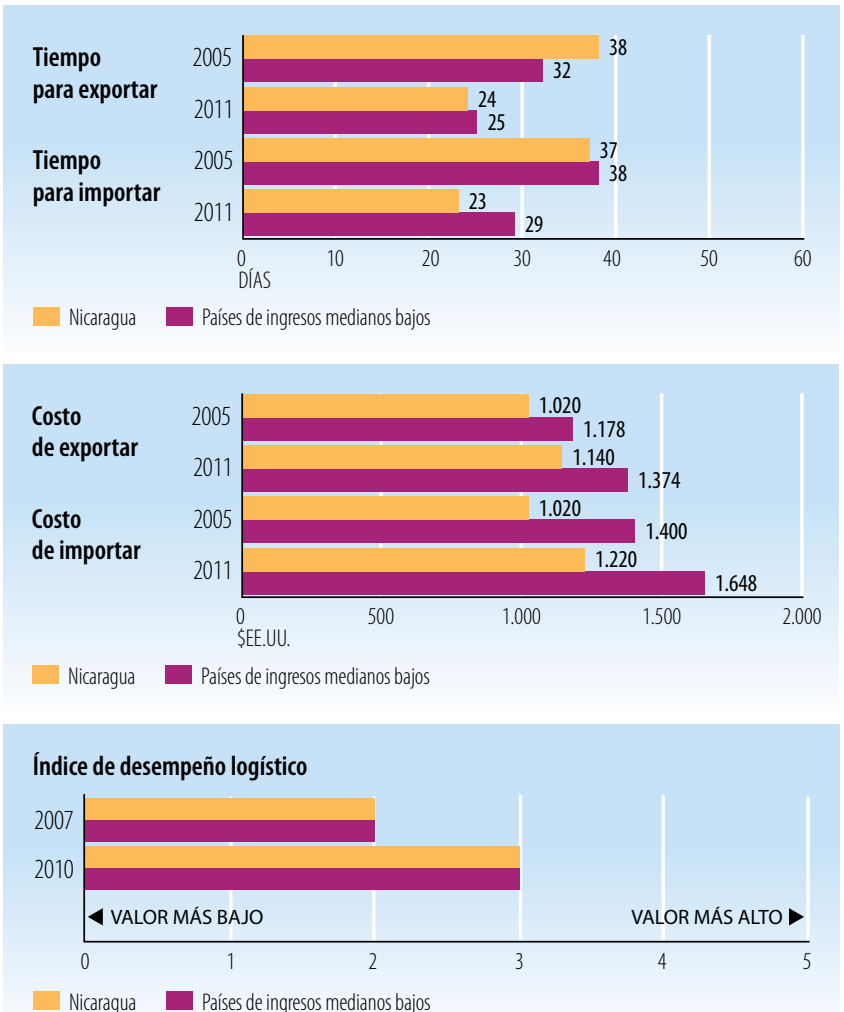

Fuentes: Banco Mundial, Indicadores del Desarrollo Mundial.

\begin{tabular}{l|c|c|}
\hline \multicolumn{2}{l}{ INDICADORES DE DESARROLLO (EFECTOS) } \\
\hline Indicador & $\mathbf{2 0 0 5}$ & $\mathbf{2 0 1 0}$ \\
\hline Desempleo (\% de la fuerza de trabajo total) & 5,6 & n.d. \\
\hline Población activa, mujeres (\% de la fuerza de trabajo total) & 36,2 & 37,9 \\
\hline AOD neta recibida (\% del INB) & 16,2 & 9,8 \\
\hline Derechos de importación percibidos (\% de los ingresos fiscales) & n.d. & n.d. \\
\hline Total del servicio de la deuda (\% de las exportaciones totales) & 8,6 & 14,3 \\
\hline Índice de desarrollo humano (0 a 1) & 0,57 & 0,59 \\
\hline
\end{tabular}

Fuentes: PNUD, indicadores internacionales sobre desarrollo humano; Banco Mundial, Indicadores del Desarrollo Mundial.

Producto interno bruto

PIB per cápita (PPA, dólares internacionales corrientes)

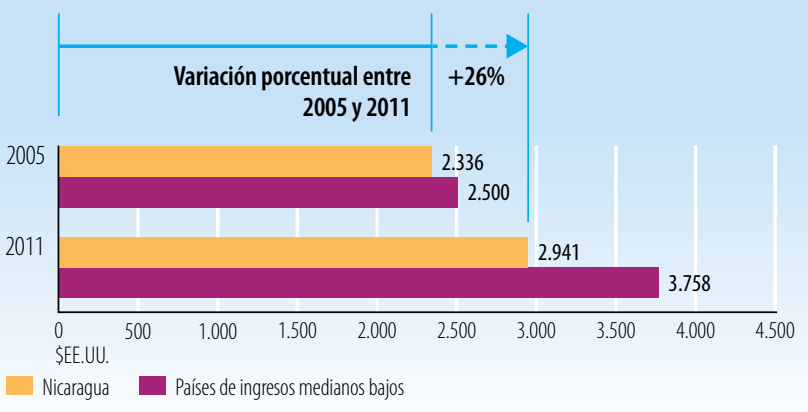

PIB per cápita (\$EE.UU. constantes de 2000)
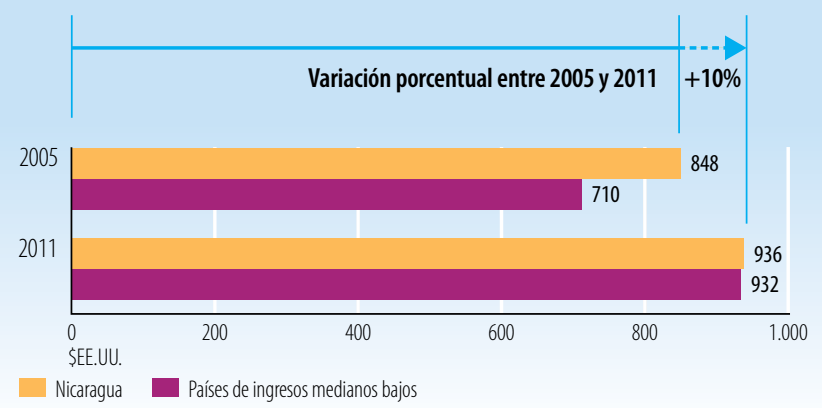

Fuentes: Banco Mundial, Indicadores del Desarrollo Mundial.

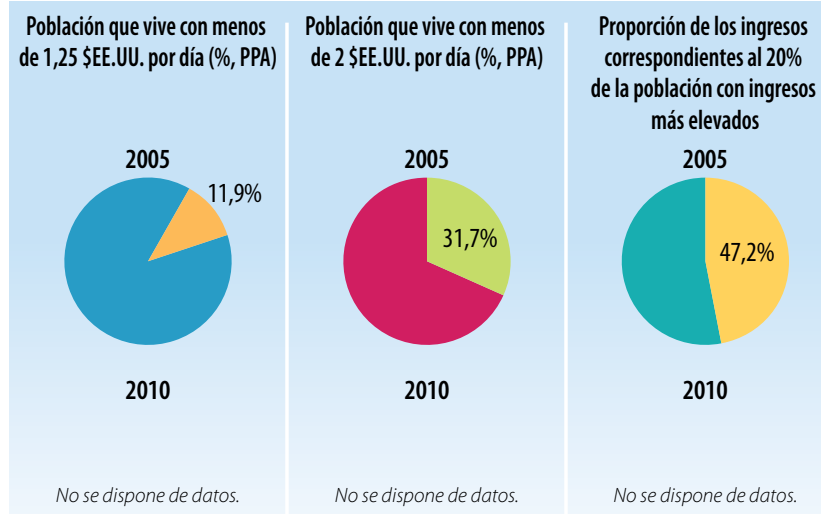

Fuentes: Banco Mundial, Indicadores del Desarrollo Mundial.

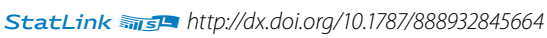




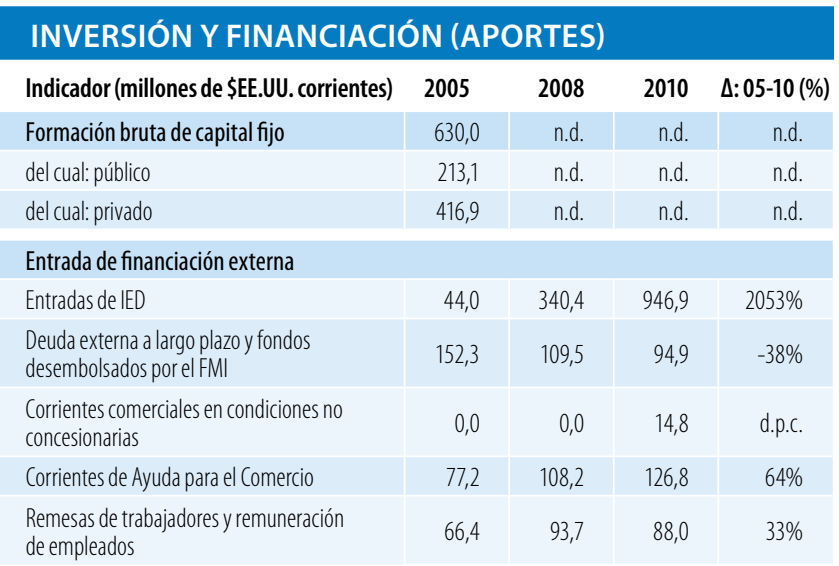

Fuentes: OCDE, base de datos del SNPA del CAD sobre las actividades de ayuda; Banco Mundial, Indicadores del Desarrollo Mundial; Banco Mundial, estadísticas de la deuda internacional.

Desembolsos de la ayuda para el comercio, por sector (millones de \$EE.UU. corrientes)

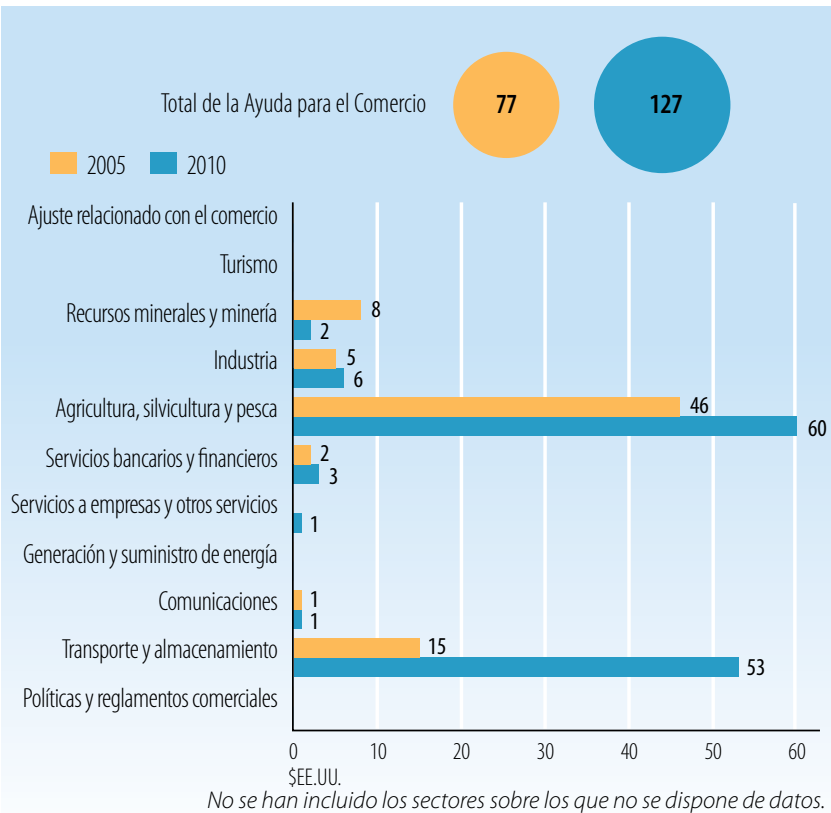

Fuentes: OCDE, base de datos del SNPA del CAD sobre las actividades de ayuda

Desembolsos de la ayuda para el comercio: principales donantes (millones de \$EE.UU. corrientes)

\begin{tabular}{|l|c|c|}
\hline $\mathbf{2 0 0 5}$ & Valor & $\%$ \\
\hline Banco Mundial & 22,4 & 29 \\
\hline Instituciones de la UE & 17,5 & 23 \\
\hline Francia & 11,4 & 15 \\
\hline Banco Africano de Desarrollo & 7,5 & 10 \\
\hline Suiza & 6,5 & 8 \\
\hline $\mathbf{2 0 1 0}$ & Valor & $\%$ \\
\hline Instituciones de la UE & 30,8 & 24 \\
\hline Banco Mundial & 28,5 & 22 \\
\hline Canadá & 19,3 & 15 \\
\hline Banco Africano de Desarrollo & 18,1 & 14 \\
\hline OFID & 7,8 & 6 \\
\hline
\end{tabular}

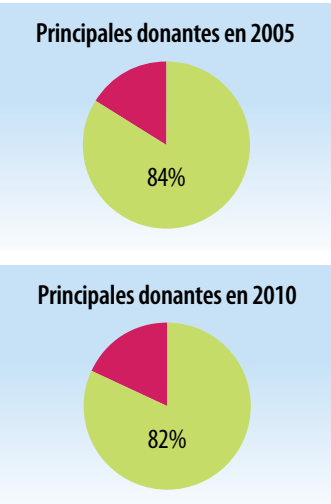

Fuentes: OCDE, base de datos del SNPA del CAD sobre las actividades de ayuda.

\section{INDICADORES COMERCIALES (PRODUCTOS)}

Indicador

$2005 \quad 2008 \quad 2011 \quad \Delta: 05-11(\%)$

Relación comercio/PIB (\%)

\begin{tabular}{|l|l|l|l|}
47 & 56 & 53 & 5 \\
\hline
\end{tabular}

Exportaciones de servicios comerciales como

$\%$ de las exportaciones totales

\begin{tabular}{l|l|l|l|}
15 & 12 & n.d.
\end{tabular}

Importaciones de servicios comerciales como

$\%$ de las importaciones totales

Productos intermedios distintos de los combustibles

(\% de las exportaciones de mercancías)

Productos intermedios distintos de los combustibles

(\% de las importaciones de mercancías)

\begin{tabular}{l|l|l|l|}
26 & 31 & n.d. & n.d.
\end{tabular}

\begin{tabular}{|l|l|l|l|}
\hline 75 & 85 & 88 & 13 \\
\hline
\end{tabular}

Fuentes: Secretaría de la OMC.

Corrientes comerciales (millones de \$EE.UU. corrientes)

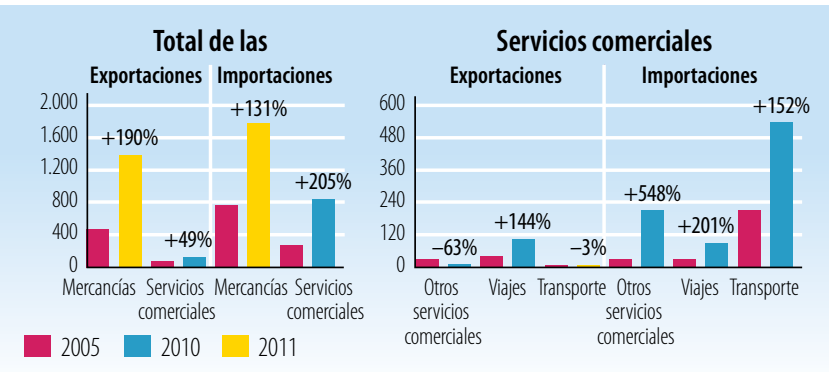

Fuentes: Secretaría de la OMC

Cinco principales mercados de exportación de mercancías (\%)

\begin{tabular}{|l|r|l|l|}
\hline $\mathbf{2 0 0 5}$ & $\%$ & $\mathbf{2 0 1 0}$ & $\%$ \\
\hline UE (27) & 33 & Estados Unidos & 17 \\
\hline Suiza & 15 & Japón & 17 \\
\hline Nigeria & 13 & UE (27) & 16 \\
\hline Japón & 10 & Suiza & 16 \\
\hline Estados Unidos & 5 & Nigeria & 11 \\
\hline
\end{tabular}

Fuentes: Secretaría de la OMC

Cinco principales productos de exportación (\% de las exportaciones de mercancías)

\begin{tabular}{|l|r|l|c|}
\hline 2005 & $\%$ & 2011 & $\%$ \\
\hline Minerales, etc., de uranio o torio & 37 & Minerales, etc., de uranio o torio & 69 \\
\hline Oro no monetario, excepto minerales & 16 & Oro no monetario, excepto minerales & 9 \\
\hline Animales vivos & 8 & Legumbres & 5 \\
\hline Legumbres & 7 & Animales vivos & 4 \\
\hline Equipo de ingeniería civil & 5 & Ropa vieja y otros artículos textiles viejos & 2 \\
\hline
\end{tabular}

Fuentes: Secretaría de la OMC

Cinco principales mercados de importación de mercancías (\%)

\begin{tabular}{|l|r|l|c|}
\hline 2005 & $\%$ & 2010 & $\%$ \\
\hline UE (27) & 24 & China & 44 \\
\hline Côte d'Ivoire & 9 & UE (27) & 25 \\
\hline China & 5 & Estados Unidos & 6 \\
\hline Nigeria & 5 & Nigeria & 4 \\
\hline Estados Unidos & 5 & Japón & 3 \\
\hline Fuentes:Secretaría de la OMC & & & \\
\hline
\end{tabular}

Cinco principales productos de importación (\% de las importaciones de mercancías)

\begin{tabular}{|c|c|c|c|}
\hline 2005 & $\%$ & 2011 & $\%$ \\
\hline Productos derivados del petróleo & 13 & Productos derivados del petróleo & 16 \\
\hline Arroz & 13 & Medicamentos & 6 \\
\hline Cal, cemento y materiales de construcción & 4 & Equipo de ingeniería civil & 5 \\
\hline $\begin{array}{l}\text { Ropa vieja y otros artículos textiles } \\
\text { viejos }\end{array}$ & 4 & $\begin{array}{l}\text { Vehículos automotores para el transporte } \\
\text { de mercancías y vehículos automotores } \\
\text { para usos especiales }\end{array}$ & 4 \\
\hline $\begin{array}{l}\text { Otros aceites y grasas fijos de origen } \\
\text { vegetal }\end{array}$ & 4 & Tubos, caños, etc., de hierro o acero & 3 \\
\hline
\end{tabular}




\section{LA AYUDA PARA EL COMERCIO EN SÍNTESIS 2013}

\section{INDICADORES COMERCIALES (RESULTADOS)}

\section{Indicador}

Crecimiento del PIB (\%)

Número de exportadores

Índice de concentración de las exportaciones (productos) ( 0 a 1$)$

ACR sobre mercancías notificados a la OMC

AIE (servicios) notificados a la OMC

Sectores de servicios con compromisos en el marco del AGCS

\section{Aranceles $(\%, 2006$ et 2011)}

Importaciones: promedio aritmético de los aranceles NMF aplicados $\quad 12,0 \quad 11,9$

Importaciones: promedio ponderado de los aranceles NMF aplicados $\quad$ n.d. $\quad 11,1$

\begin{tabular}{|ll|l|l|} 
Exportaciones: promedio ponderado de los aranceles impuestos & 0,0 & 0,6
\end{tabular}

por los importadores

Exportaciones: libres de derechos (en \%)

$99,6 \quad 91,9$

Fuentes: Naciones Unidas, base de datos Comtrade; Banco Mundial, base de datos sobre dinámica de las empresas de exportación; Banco Mundial, Indicadores del

Desarrollo Mundial; OMC, perfiles comerciales y arancelarios.

Participación en las exportaciones por región (\%)

\begin{tabular}{|l|r|r|}
\hline & 2005 & 2011 \\
\hline África & 33,7 & 11,7 \\
\hline Asia & 11,0 & 5,4 \\
\hline Comunidad de Estados Independientes & 0,0 & 0,0 \\
\hline Europa & 48,1 & 76,8 \\
\hline Oriente Medio & 0,0 & 0,2 \\
\hline América del Norte & 5,2 & 4,8 \\
\hline América del Sury América Central & 0,0 & 0,7 \\
\hline
\end{tabular}

Fuentes: OMC, perfiles comerciales y arancelarios

Indicadores de facilitación del comercio
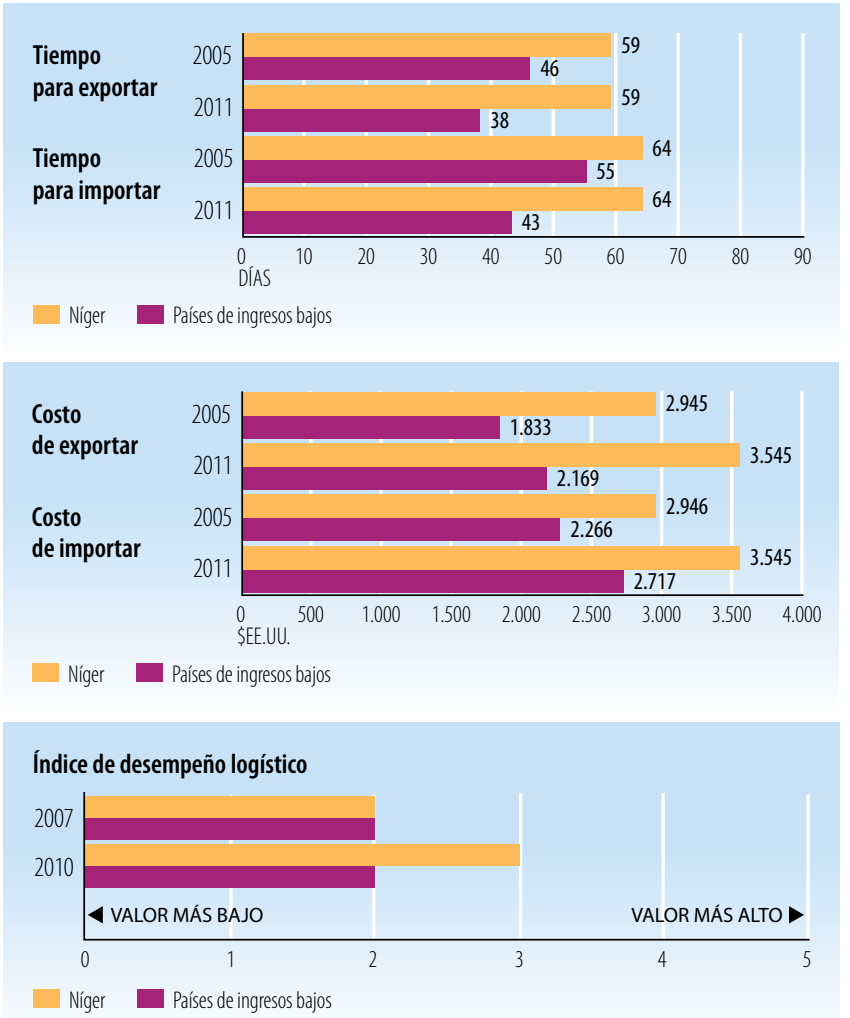

Fuentes: Banco Mundial, Indicadores del Desarrollo Mundial.

\begin{tabular}{l|c|c|}
\hline INDICADORES DE DESARROLLO (EFECTOS) & \\
\hline Indicador & $\mathbf{2 0 0 5}$ & $\mathbf{2 0 1 0}$ \\
\hline Desempleo (\% de la fuerza de trabajo total) & n.d. & n.d. \\
\hline Población activa, mujeres (\% de la fuerza de trabajo total) & 30,9 & 31,2 \\
\hline AOD neta recibida (\% del INB) & 15,4 & 13,8 \\
\hline Derechos de importación percibidos (\% de los ingresos fiscales) & 46,7 & n.d. \\
\hline Total del servicio de la deuda (\% de las exportaciones totales) & 6,7 & 2,6 \\
\hline Índice de desarrollo humano ( 0 a 1) & 0,27 & 0,29 \\
\hline
\end{tabular}

Fuentes: PNUD, indicadores internacionales sobre desarrollo humano; Banco Mundial, Indicadores del Desarrollo Mundial.

Producto interno bruto

PIB per cápita (PPA, dólares internacionales corrientes)

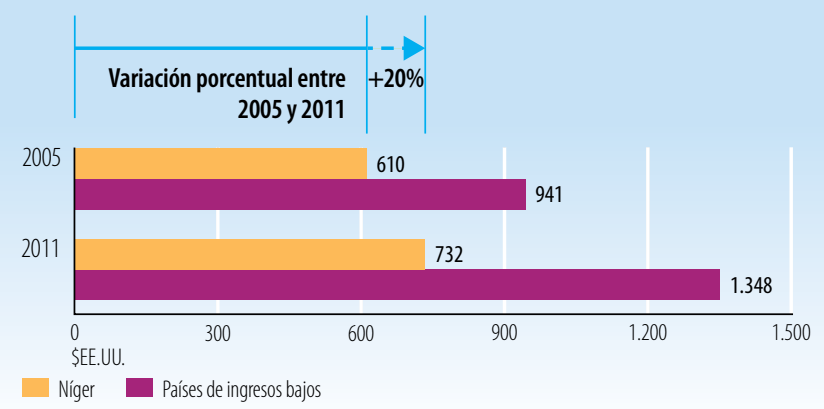

PIB per cápita (\$EE.UU. constantes de 2000)

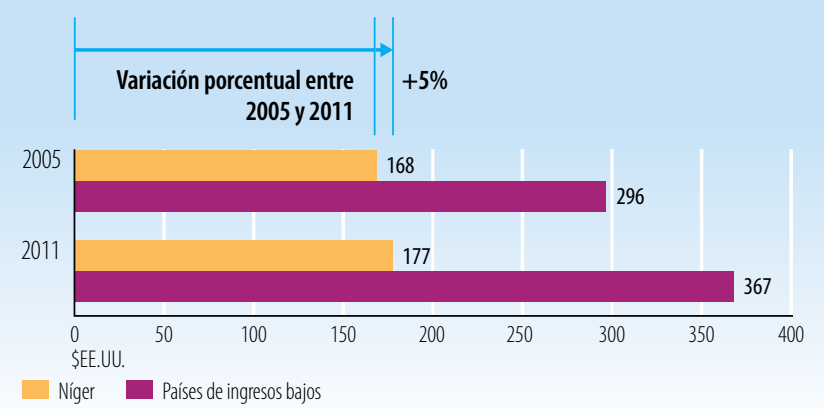

Fuentes: Banco Mundial, Indicadores del Desarrollo Mundial.

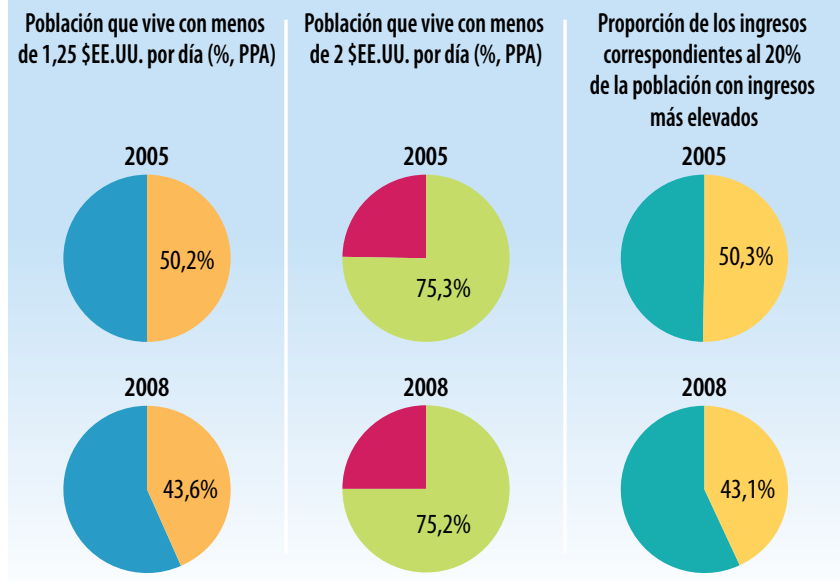

Fuentes: Banco Mundial, Indicadores del Desarrollo Mundial.

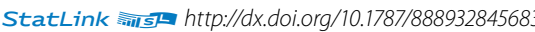


Indicadores de la ayuda, el comercio y el desarrollo relativos a Nigeria

\begin{tabular}{|c|c|c|c|c|}
\hline Indicador (millones de \$̦EE.UU. corrientes) & 2005 & 2008 & 2010 & $\Delta: 05-10(\%)$ \\
\hline Formación bruta de capital fijo & n.d. & n.d. & n.d. & n.d. \\
\hline del cual: público & n.d. & n.d. & n.d. & n.d. \\
\hline del cual: privado & n.d. & n.d. & n.d. & n.d. \\
\hline \multicolumn{5}{|l|}{ Entrada de financiación externa } \\
\hline Entradas de IED & $4.982,5$ & $8.196,6$ & $6.048,6$ & $21 \%$ \\
\hline $\begin{array}{l}\text { Deuda externa a largo plazo y fondos } \\
\text { desembolsados por el FMI }\end{array}$ & 379,0 & 408,7 & $1.050,9$ & $177 \%$ \\
\hline $\begin{array}{l}\text { Corrientes comerciales en condiciones no } \\
\text { concesionarias }\end{array}$ & 0,0 & 22,2 & 126,7 & d.p.c. \\
\hline Corrientes de Ayuda para el Comercio & 116,0 & 226,1 & 428,2 & $269 \%$ \\
\hline $\begin{array}{l}\text { Remesas de trabajadores y remuneración } \\
\text { de empleados }\end{array}$ & $3.328,7$ & $9.980,0$ & $10.045,0$ & $202 \%$ \\
\hline
\end{tabular}

Fuentes: OCDE, base de datos del SNPA del CAD sobre las actividades de ayuda; Banco Mundial, Indicadores del Desarrollo Mundial; Banco Mundial, estadísticas de la deuda internacional.

Desembolsos de la ayuda para el comercio, por sector (millones de \$EE.UU. corrientes)

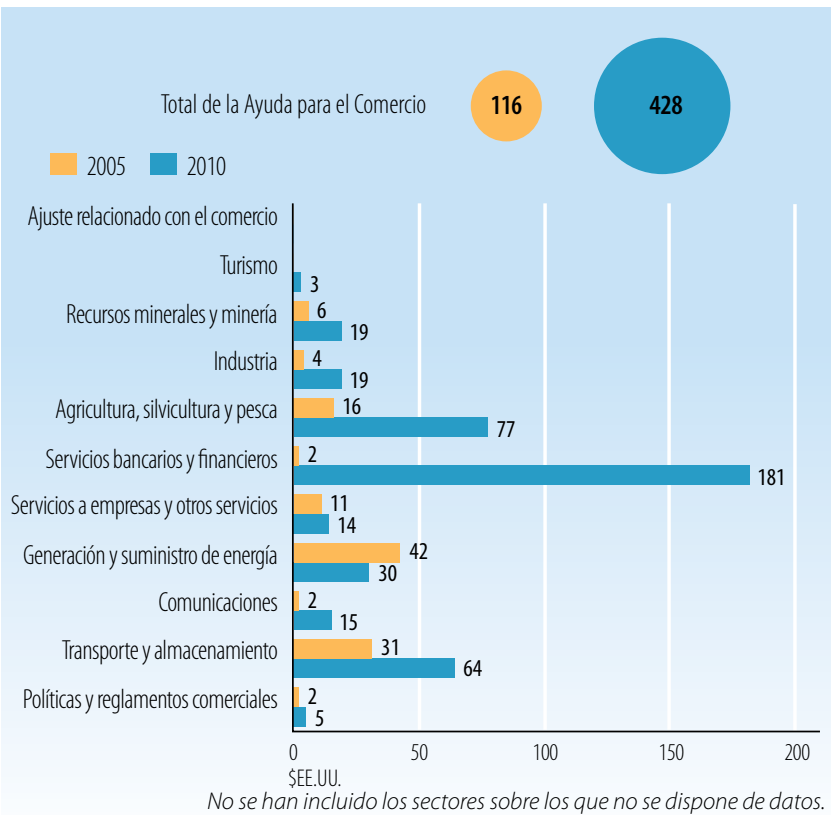

Fuentes: OCDE, base de datos del SNPA del CAD sobre las actividades de ayuda

Desembolsos de la ayuda para el comercio: principales donantes (millones de \$EE.UU. corrientes)

\begin{tabular}{|l|r|r|r|}
\hline $\mathbf{2 0 0 5}$ & Valor & $\%$ & Principales donantes en 2005 \\
\hline Banco Mundial & 86,9 & 75 & \\
\hline Estados Unidos & 9,9 & 9 & \\
\hline Reino Unido & 4,9 & 4 & $94 \%$ \\
\hline Alemania & 4,4 & 4 & \\
\hline Banco Africano de Desarrollo & 2,8 & 2 & \\
\hline $\mathbf{2 0 1 0}$ & Valor & $\%$ & Principales donantes en 2010 \\
\hline Banco Mundial & 315,7 & 74 & \\
\hline Reino Unido & 55,1 & 13 & \\
\hline Estados Unidos & 24,7 & 6 & $97 \%$ \\
\hline Banco Africano de Desarrollo & 13,0 & 3 & \\
\hline Alemania & 7,7 & 2 & \\
\hline
\end{tabular}

Fuentes: OCDE, base de datos del SNPA del CAD sobre las actividades de ayuda.

\section{INDICADORES COMERCIALES (PRODUCTOS)}

\section{Indicador}

$20052008 \quad 2011 \quad \Delta: 05-11(\%)$

Relación comercio/PIB (\%)

\begin{tabular}{|l|l|l|l|}
79 & 72 & 76 & -3 \\
\hline
\end{tabular}

Exportaciones de servicios comerciales como

$\%$ de las exportaciones totales

Importaciones de servicios comerciales como

$\%$ de las importaciones totales

$\begin{array}{llll}3 & 2 & 2 & 0\end{array}$

Productos intermedios distintos de los combustibles

(\% de las exportaciones de mercancías)

Productos intermedios distintos de los combustibles

(\% de las importaciones de mercancías)

\begin{tabular}{|l|l|l|l|}
\hline 20 & 36 & 27 & 7 \\
\hline
\end{tabular}

\begin{tabular}{l|l|l|} 
n.d. & 4 & n.d.
\end{tabular}

n.d. $53 \quad$ n.d. $\quad$ n.d.

Fuentes: Secretaría de la OMC.

Corrientes comerciales (millones de \$EE.UU. corrientes)

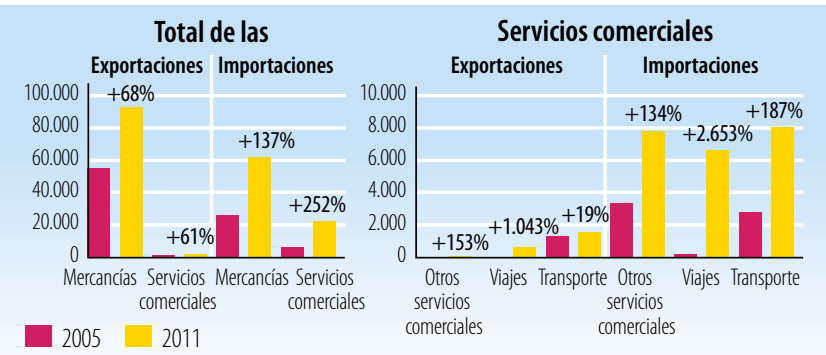

Fuentes: Secretaría de la OMC

Cinco principales mercados de exportación de mercancías (\%)

\begin{tabular}{|l|r|l|c|}
\hline 2006 & $\%$ & 2010 & $\%$ \\
\hline Estados Unidos & 45 & Estados Unidos & 34 \\
\hline UE (27) & 21 & UE (27) & 22 \\
\hline India & 9 & India & 10 \\
\hline Brasil & 4 & Brasil & 7 \\
\hline Canadá & 4 & Guinea Ecuatorial & 3 \\
\hline
\end{tabular}

Fuentes: Secretaría de la OMC

Cinco principales productos de exportación (\% de las exportaciones de mercancías)

\begin{tabular}{|l|r|l|c|}
\hline 2006 & $\%$ & 2010 & $\%$ \\
\hline Aceites de petróleo, crudos & 93 & Aceites de petróleo, crudos & 70 \\
\hline Productos derivados del petróleo & 5 & Productos derivados del petróleo & 11 \\
\hline $\begin{array}{l}\text { Buques, embarcaciones y estructuras } \\
\text { flotantes }\end{array}$ & 1 & Cuero & 4 \\
\hline $\begin{array}{l}\text { Productos vegetales en bruto, n.e.p. } \\
\text { Cuero }\end{array}$ & 0 & Gas natural & 3 \\
\hline
\end{tabular}

Fuentes: Secretaría de la OMC

Cinco principales mercados de importación de mercancías (\%)

\begin{tabular}{|l|r|l|c|}
\hline 2006 & $\%$ & 2010 & $\%$ \\
\hline UE (27) & 37 & UE (27) & 22 \\
\hline Estados Unidos & 16 & Estados Unidos & 18 \\
\hline China & 14 & China & 17 \\
\hline India & 5 & Antigua y Barbuda & 6 \\
\hline Japón & 3 & India & 5 \\
\hline
\end{tabular}

Fuentes: Secretaría de la OMC

Cinco principales productos de importación (\% de las importaciones de mercancías)

\begin{tabular}{|c|c|c|c|}
\hline 2006 & $\%$ & 2010 & $\%$ \\
\hline Trigo y morcajo o tranquillón, sin moler & 6 & $\begin{array}{l}\text { Vehículos automotores para pasajeros, } \\
\text { excepto autobuses }\end{array}$ & 9 \\
\hline $\begin{array}{l}\text { Equipos de telecomunicaciones y sus } \\
\text { partes, n.e.p. }\end{array}$ & 5 & $\begin{array}{l}\text { Vehículos automotores para el transporte } \\
\text { de mercancías y vehículos automotores } \\
\text { para usos especiales }\end{array}$ & 5 \\
\hline Armas y municiones & 4 & $\begin{array}{l}\text { Aparatos de electricidad y sus partes } \\
\text { y piezas }\end{array}$ & 3 \\
\hline $\begin{array}{l}\text { Vehículos automotores para pasajeros, } \\
\text { excepto autobuses }\end{array}$ & 4 & Vehículos automotores de carretera, n.e.p. & 3 \\
\hline Pescado, fresco, refrigerado o congelado & 3 & $\begin{array}{l}\text { Hilados especiales y tejidos especiales de } \\
\text { fibras textiles }\end{array}$ & 2 \\
\hline
\end{tabular}

Fuentes: Secretaría de la OMC 


\section{LA AYUDA PARA EL COMERCIO EN SÍNTESIS 2013}

\section{INDICADORES COMERCIALES (RESULTADOS)}

\section{Indicador}

Crecimiento del PIB (\%)

Número de exportadores

Índice de concentración de las exportaciones (productos) ( 0 a 1)

ACR sobre mercancías notificados a la OMC

AIE (servicios) notificados a la OMC

Sectores de servicios con compromisos en el marco del AGCS

\section{Aranceles $(\%, 2006$ et 2011)}

\begin{tabular}{ll|l|l|} 
Importaciones: promedio aritmético de los aranceles NMF aplicados & 12,0 & 11,7
\end{tabular}

Importaciones: promedio ponderado de los aranceles NMF aplicados n.d. $\quad 10,8$

Exportaciones: promedio ponderado de los aranceles impuestos $\quad 0,0 \quad 0,8$

por los importadores

Exportaciones: libres de derechos (en \%)

$97,5 \quad 83,6$

Fuentes: Naciones Unidas, base de datos Comtrade; Banco Mundial, base de datos sobre dinámica de las empresas de exportación; Banco Mundial, Indicadores del

Desarrollo Mundial; OMC, perfiles comerciales y arancelarios.

Participación en las exportaciones por región (\%)

\begin{tabular}{|l|r|r|}
\hline & $\mathbf{2 0 0 6}$ & $\mathbf{2 0 1 0}$ \\
\hline África & 10,0 & 11,9 \\
\hline Asia & 14,8 & 17,1 \\
\hline Comunidad de Estados Independientes & 0,0 & 0,0 \\
\hline Europa & 21,2 & 23,5 \\
\hline Oriente Medio & 0,0 & 0,3 \\
\hline América del Norte & 48,9 & 37,3 \\
\hline América del Sury América Central & 5,2 & 9,6 \\
\hline
\end{tabular}

Fuentes: OMC, perfiles comerciales y arancelarios

Indicadores de facilitación del comercio
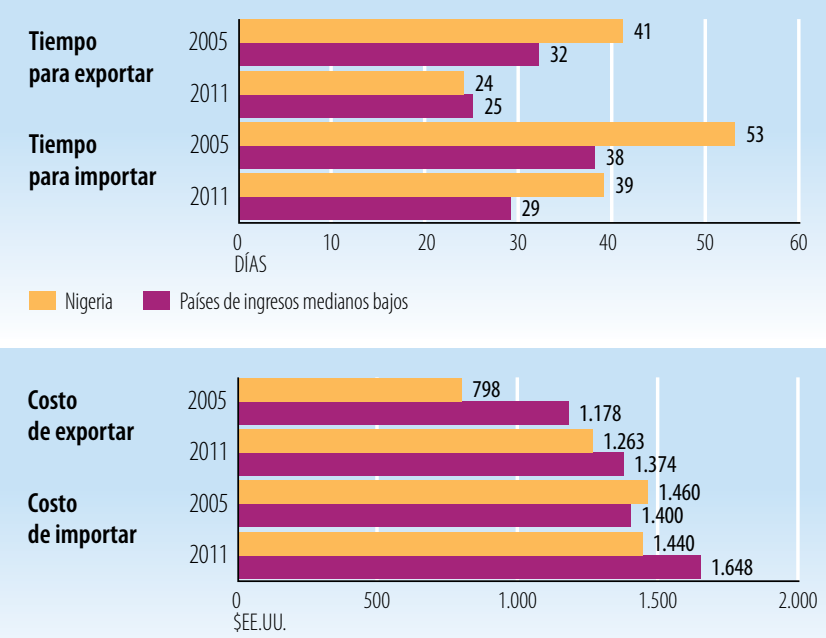

Nigeria $\square$ Países de ingresos medianos bajos

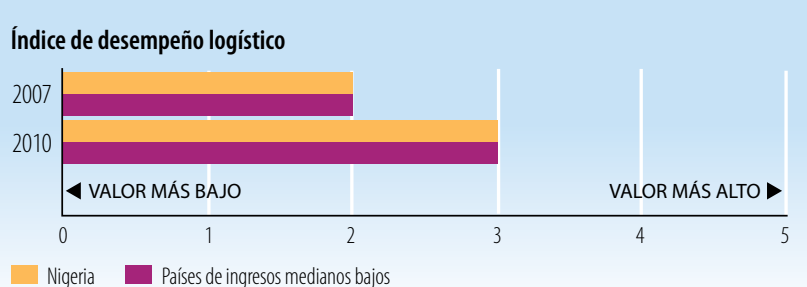

Fuentes: Banco Mundial, Indicadores del Desarrollo Mundial.

\begin{tabular}{|l|c|c|}
\hline INDICADORES DE DESARROLLO (EFECTOS) & \\
\hline Indicador & $\mathbf{2 0 0 5}$ & $\mathbf{2 0 1 0}$ \\
\hline Desempleo (\% de la fuerza de trabajo total) & n.d. & n.d. \\
\hline Población activa, mujeres (\% de la fuerza de trabajo total) & 43,3 & 42,8 \\
\hline AOD neta recibida (\% del INB) & 6,5 & 1,2 \\
\hline Derechos de importación percibidos (\% de los ingresos fiscales) & $n . d$. & n.d. \\
\hline Total del servicio de la deuda (\% de las exportaciones totales) & 15,5 & 0,4 \\
\hline Índice de desarrollo humano (0 a 1) & 0,43 & 0,45 \\
\hline
\end{tabular}

Fuentes: PNUD, indicadores internacionales sobre desarrollo humano; Banco Mundial, Indicadores del Desarrollo Mundial.

Producto interno bruto

PIB per cápita (PPA, dólares internacionales corrientes)

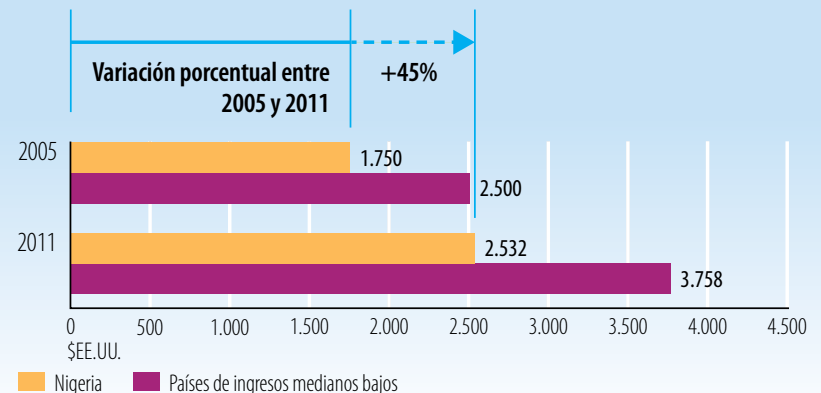

PIB per cápita (\$EE.UU. constantes de 2000)

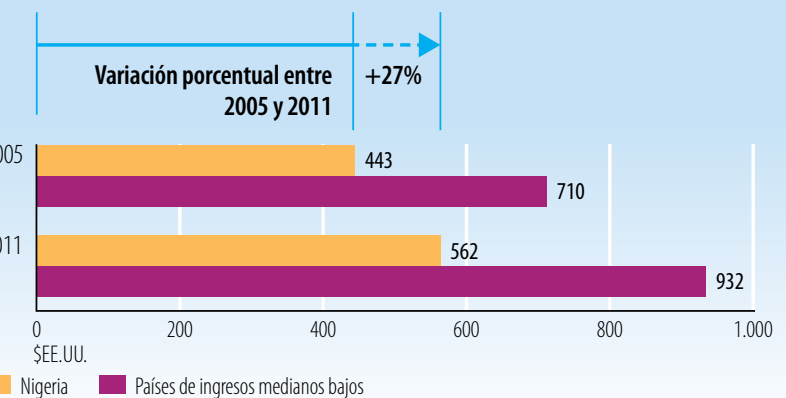

Fuentes: Banco Mundial, Indicadores del Desarrollo Mundial.

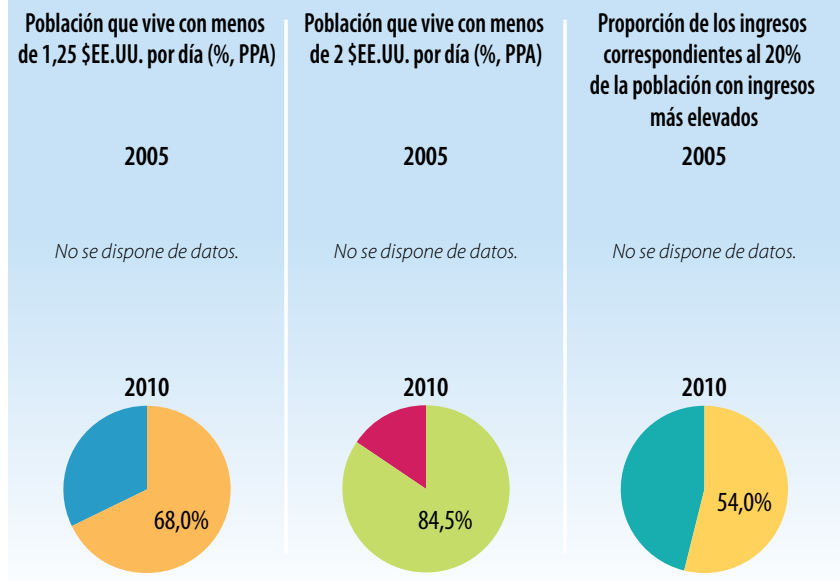

Fuentes: Banco Mundial, Indicadores del Desarrollo Mundial.

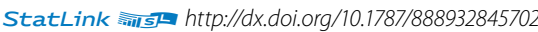


Indicadores de la ayuda, el comercio y el desarrollo relativos a Omán

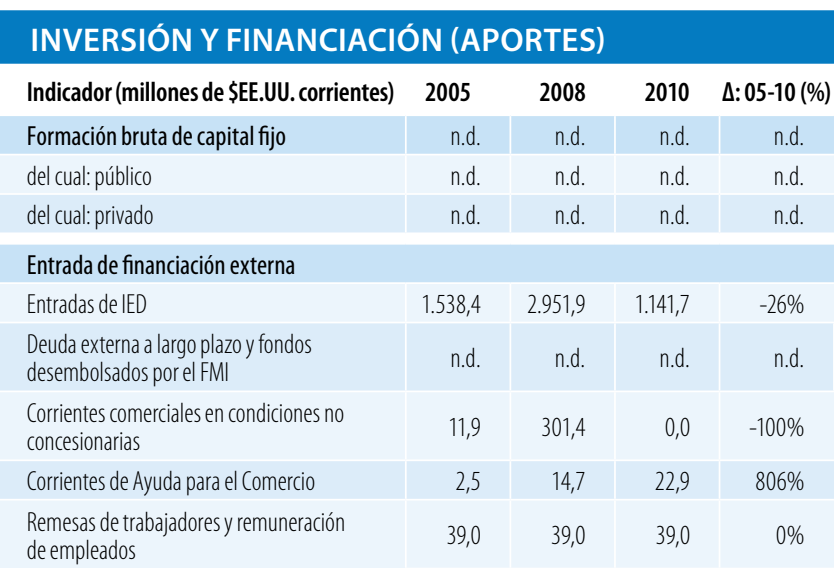

Fuentes: OCDE, base de datos del SNPA del CAD sobre las actividades de ayuda; Banco Mundial, Indicadores del Desarrollo Mundial; Banco Mundial, estadísticas de la deuda internacional.

Desembolsos de la ayuda para el comercio, por sector

(millones de \$EE.UU. corrientes)

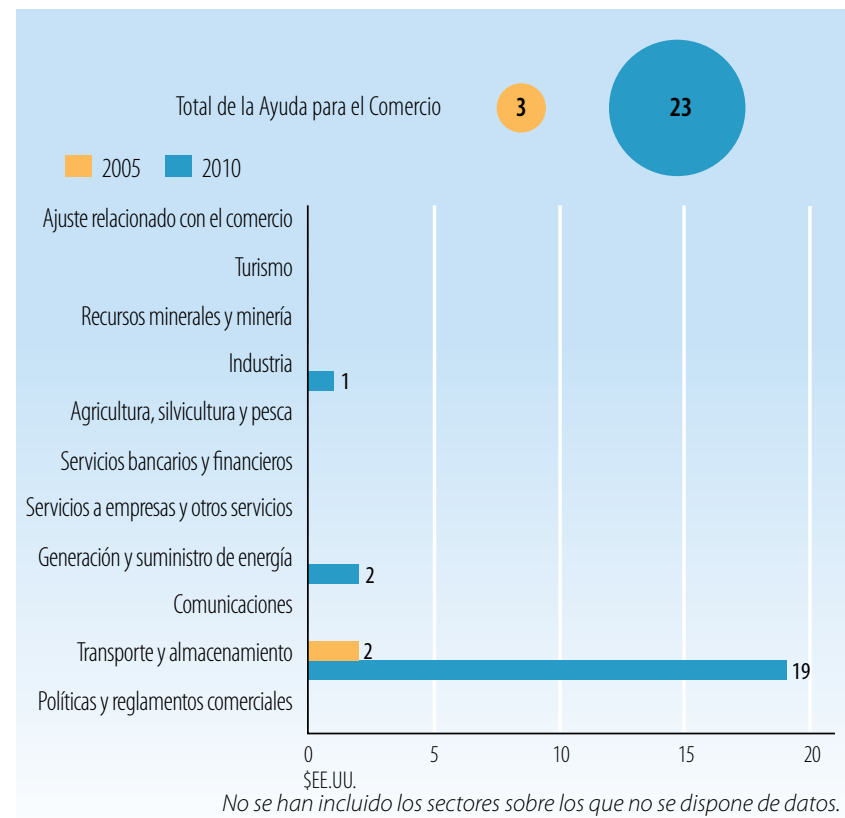

Fuentes: OCDE, base de datos del SNPA del CAD sobre las actividades de ayuda

Desembolsos de la ayuda para el comercio: principales donantes (millones de \$EE.UU. corrientes)

\begin{tabular}{|l|r|r|r|}
\hline $\mathbf{2 0 0 5}$ & Valor & $\%$ & Principales donantes en 2005 \\
\hline Japón & 2,5 & 100 & \\
\hline Francia & 0,0 & 0 & $100 \%$ \\
\hline & & & \\
\hline & & & \\
\hline $\mathbf{2 0 1 0}$ & & & \\
\hline Emiratos Árabes Unidos & 11,7 & 51 & Principales donantes en 2010 \\
\hline Kuwait & 7,5 & 33 & \\
\hline Estados Unidos & 2,4 & 10 & $100 \%$ \\
\hline Japón & 1,2 & 5 & \\
\hline Corea, Rep. de & 0,0 & 0 & \\
\hline
\end{tabular}

Fuentes: OCDE, base de datos del SNPA del CAD sobre las actividades de ayuda.

\section{INDICADORES COMERCIALES (PRODUCTOS)}

Indicador

$20052008 \quad 2011 \quad \Delta: 05-11(\%)$

Relación comercio/PIB (\%)

\begin{tabular}{l|l|l|l|}
100 & 109 & 108 & 9 \\
\hline
\end{tabular}

Exportaciones de servicios comerciales como

$\%$ de las exportaciones totales

Importaciones de servicios comerciales como

$\%$ de las importaciones totales

Productos intermedios distintos de los combustibles

(\% de las exportaciones de mercancías)

Productos intermedios distintos de los combustibles

(\% de las importaciones de mercancías)

\begin{tabular}{|r|r|r|r|}
\hline 5 & 5 & 4 & 0 \\
\hline 28 & 22 & 25 & -3 \\
\hline 6 & 9 & n.d. & n.d. \\
\hline 45 & 45 & n.d. & n.d. \\
\hline
\end{tabular}

Fuentes: Secretaría de la OMC.

Corrientes comerciales (millones de \$EE.UU. corrientes)

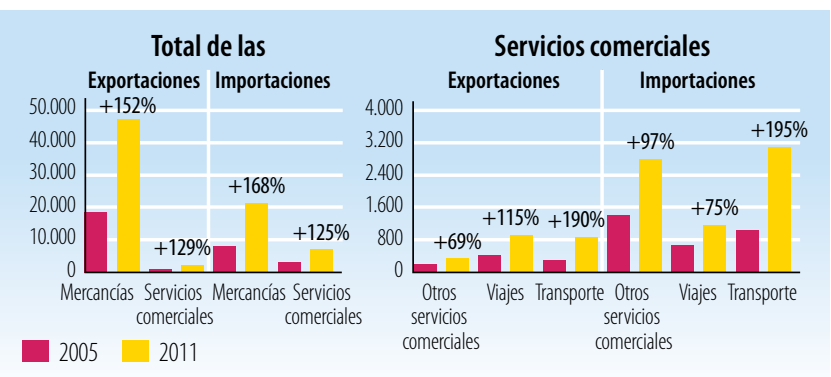

Fuentes: Secretaría de la OMC

Cinco principales mercados de exportación de mercancías (\%)

\begin{tabular}{|l|c|l|c|}
\hline $\mathbf{2 0 0 5}$ & $\%$ & $\mathbf{2 0 1 0}$ & $\%$ \\
\hline China & 27 & Emiratos Árabes Unidos & 5 \\
\hline Japón & 15 & India & 2 \\
\hline Tailandia & 14 & China & 1 \\
\hline Emiratos Árabes Unidos & 7 & UE (27) & 1 \\
\hline Corea, Rep. de & 6 & Arabia Saudita, Reino de la & 1 \\
\hline Fuentes:Secretaría de la OMC & & & \\
\hline
\end{tabular}

Cinco principales productos de exportación (\% de las exportaciones de mercancías)

\begin{tabular}{|l|r|l|c|}
\hline 2005 & $\%$ & 2010 & $\%$ \\
\hline Aceites de petróleo, crudos & 71 & Aceites de petróleo, crudos & 57 \\
\hline Gas natural & 12 & Operaciones especiales no clasificadas & 15 \\
\hline Operaciones especiales no clasificadas & 6 & Gas natural & 8 \\
\hline Productos derivados del petróleo & 1 & Productos derivados del petróleo & 4 \\
\hline Abonos, excepto los del grupo 272 & 1 & Abonos, excepto los del grupo 272 & 2 \\
\hline
\end{tabular}

Fuentes: Secretaría de la OMC

Cinco principales mercados de importación de mercancías (\%)

\begin{tabular}{|l|r|l|c|}
\hline $\mathbf{2 0 0 5}$ & $\%$ & $\mathbf{2 0 1 0}$ & $\%$ \\
\hline Emiratos Árabes Unidos & 26 & Emiratos Árabes Unidos & 24 \\
\hline UE (27) & 22 & UE (27) & 12 \\
\hline Japón & 15 & China & 4 \\
\hline Estados Unidos & 6 & India & 4 \\
\hline India & 4 & Estados Unidos & 3 \\
\hline
\end{tabular}

Fuentes: Secretaría de la OMC

Cinco principales productos de importación (\% de las importaciones de mercancías)

\begin{tabular}{|c|c|c|}
\hline 2005 & $\%$ & 2010 \\
\hline $\begin{array}{l}\text { Vehículos automotores para pasajeros, } \\
\text { excepto autobuses }\end{array}$ & 15 & Operaciones especiales no clasificadas \\
\hline Equipo de ingeniería civil & 4 & Productos derivados del petróleo \\
\hline Productos derivados del petróleo & 4 & Tubos, caños, etc., de hierro o acero \\
\hline $\begin{array}{l}\text { Partes y piezas de tractores y vehículos } \\
\text { automotores }\end{array}$ & 3 & Equipo de ingeniería civil \\
\hline Operaciones especiales no clasificadas & 3 & Cobre \\
\hline
\end{tabular}

Fuentes: Secretaría de la OMC 


\section{LA AYUDA PARA EL COMERCIO EN SÍNTESIS 2013}

\section{INDICADORES COMERCIALES (RESULTADOS)}

\section{Indicador}

Crecimiento del PIB (\%)

Número de exportadores

Índice de concentración de las exportaciones (productos) (0 a 1)

ACR sobre mercancías notificados a la OMC

AIE (servicios) notificados a la OMC

Sectores de servicios con compromisos en el marco del AGCS

\section{Aranceles (\%)}

Importaciones: promedio aritmético de los aranceles NMF aplicados

Importaciones: promedio ponderado de los aranceles NMF aplicados

Exportaciones: promedio ponderado de los aranceles impuestos

por los importadores

Exportaciones: libres de derechos (en \%)

\begin{tabular}{|r|r|}
\hline 2005 & 2011 \\
\hline 4,0 & 5,5 \\
\hline n.d. & n.d. \\
\hline 0,51 & 0,35 \\
\hline n.d. & 3 \\
\hline n.d. & 1 \\
\hline 97 & 97 \\
\hline
\end{tabular}

Fuentes: Naciones Unidas, base de datos Comtrade; Banco Mundial, base de datos sobre dinámica de las empresas de exportación; Banco Mundial, Indicadores del

Desarrollo Mundial; OMC, perfiles comerciales y arancelarios.

Participación en las exportaciones por región (\%)

\begin{tabular}{|l|r|r|}
\hline & 2005 & 2011 \\
\hline África & 1,0 & 2,4 \\
\hline Asia & 71,3 & 69,9 \\
\hline Comunidad de Estados Independientes & 0,2 & 0,1 \\
\hline Europa & 2,7 & 2,0 \\
\hline Oriente Medio & 11,5 & 12,2 \\
\hline América del Norte & 2,4 & 0,8 \\
\hline América del Sury América Central & 0,0 & 0,2 \\
\hline
\end{tabular}

Fuentes: OMC, perfiles comerciales y arancelarios

Indicadores de facilitación del comercio
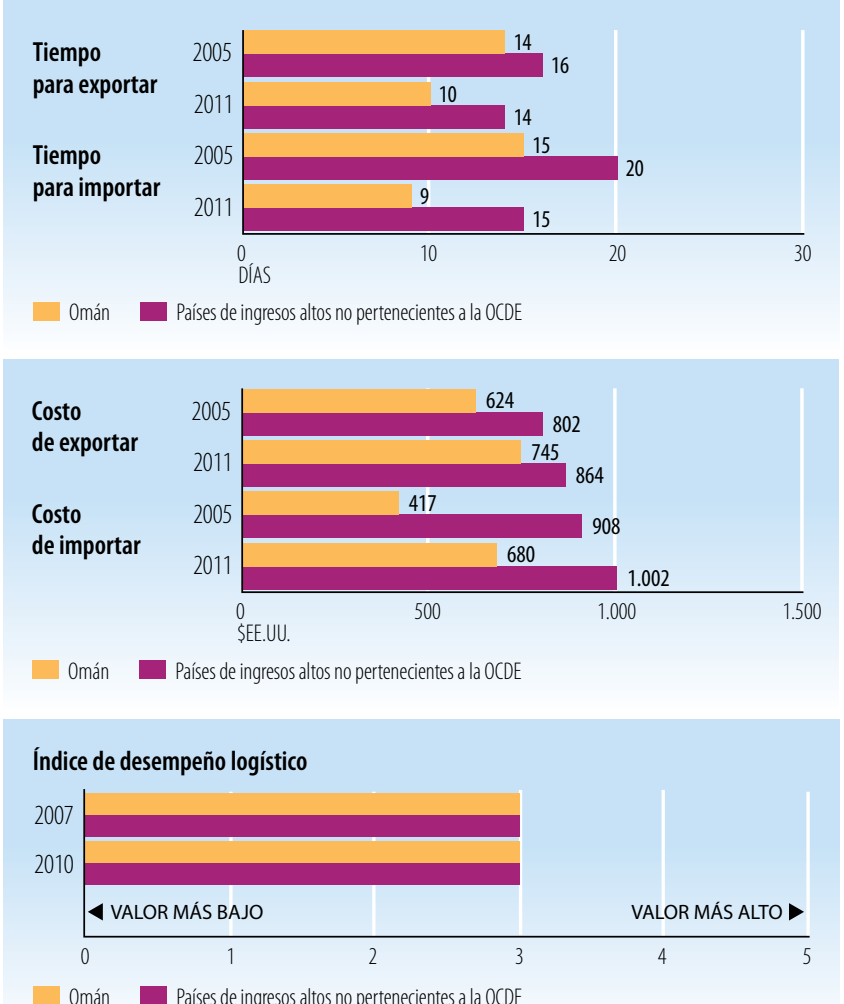

Omán Países de ingresos altos no pertenecientes a la OCDE

Fuentes: Banco Mundial, Indicadores del Desarrollo Mundial.

\begin{tabular}{l|c|c|}
\hline INDICADORES DE DESARROLLO (EFECTOS) & \\
\hline Indicador & 2005 & $\mathbf{2 0 1 0}$ \\
\hline Desempleo (\% de la fuerza de trabajo total) & n.d. & n.d. \\
\hline Población activa, mujeres (\% de la fuerza de trabajo total) & 19,9 & 17,9 \\
\hline AOD neta recibida (\% del INB) & 0,1 & $-0,1$ \\
\hline Derechos de importación percibidos (\% de los ingresos fiscales) & n.d. & n.d. \\
\hline Total del servicio de la deuda (\% de las exportaciones totales) & n.d. & n.d. \\
\hline Índice de desarrollo humano (0 a 1) & 0,69 & 0,70 \\
\hline
\end{tabular}

Fuentes: PNUD, indicadores internacionales sobre desarrollo humano; Banco Mundial, Indicadores del Desarrollo Mundial.

Producto interno bruto

\section{PIB per cápita (PPA, dólares internacionales corrientes)}
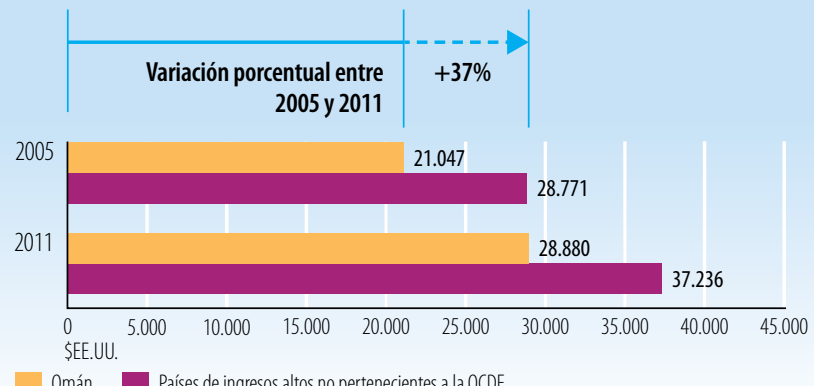

Omán Páses de ingresos altos no pertenecientes a la OCDE

PIB per cápita (\$EE.UU. constantes de 2000)

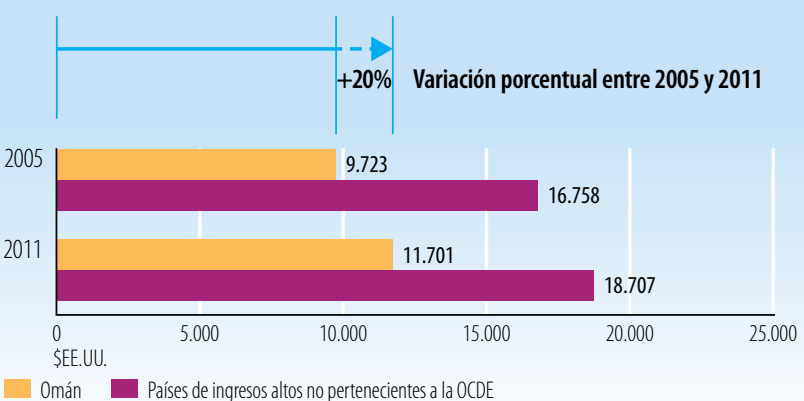

Fuentes: Banco Mundial, Indicadores del Desarrollo Mundial.

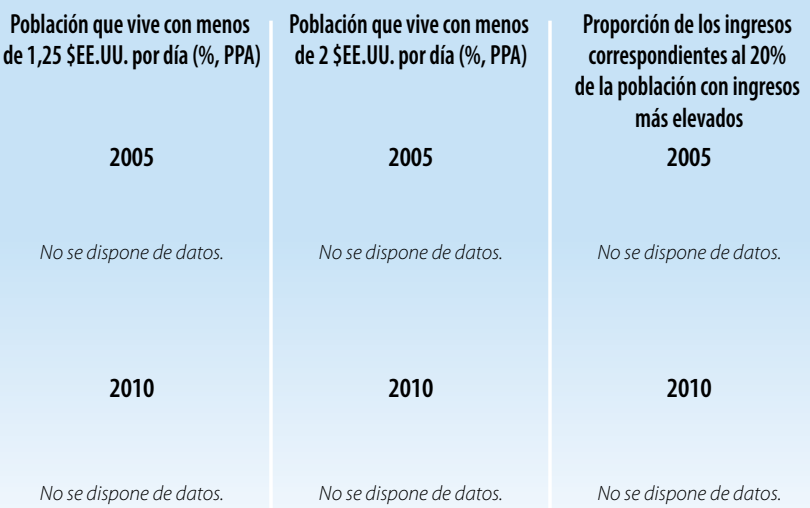

Fuentes: Banco Mundial, Indicadores del Desarrollo Mundial.

StatLink inा St http://dx.doi.org/10.1787/888932845721 
Indicadores de la ayuda, el comercio y el desarrollo relativos al Pakistán

\begin{tabular}{|c|c|c|c|c|}
\hline Indicador (millones de \$̦EE.UU. corrientes) & 2005 & 2008 & 2010 & $\Delta: 05-10(\%)$ \\
\hline Formación bruta de capital fijo & $19.137,5$ & $33.517,3$ & $24.346,5$ & $27 \%$ \\
\hline del cual: público & $4.763,8$ & $8.881,9$ & $6.332,1$ & $33 \%$ \\
\hline del cual: privado & $14.373,7$ & $24.635,4$ & $18.014,3$ & $25 \%$ \\
\hline \multicolumn{5}{|l|}{ Entrada de financiación externa } \\
\hline Entradas de IED & $2.201,0$ & $5.438,0$ & $2.018,0$ & $-8 \%$ \\
\hline $\begin{array}{l}\text { Deuda externa a largo plazo y fondos } \\
\text { desembolsados por el FMl }\end{array}$ & $2.826,7$ & $6.796,2$ & $3.646,3$ & $29 \%$ \\
\hline $\begin{array}{l}\text { Corrientes comerciales en condiciones no } \\
\text { concesionarias }\end{array}$ & 217,3 & 56,0 & 306,2 & $41 \%$ \\
\hline Corrientes de Ayuda para el Comercio & 318,2 & 349,5 & 327,0 & $3 \%$ \\
\hline $\begin{array}{l}\text { Remesas de trabajadores y remuneración } \\
\text { de empleados }\end{array}$ & $4.280,0$ & $7.039,0$ & $9.690,0$ & $126 \%$ \\
\hline
\end{tabular}

Fuentes: OCDE, base de datos del SNPA del CAD sobre las actividades de ayuda; Banco Mundial, Indicadores del Desarrollo Mundial; Banco Mundial, estadísticas de la deuda internacional.

Desembolsos de la ayuda para el comercio, por sector (millones de \$EE.UU. corrientes)

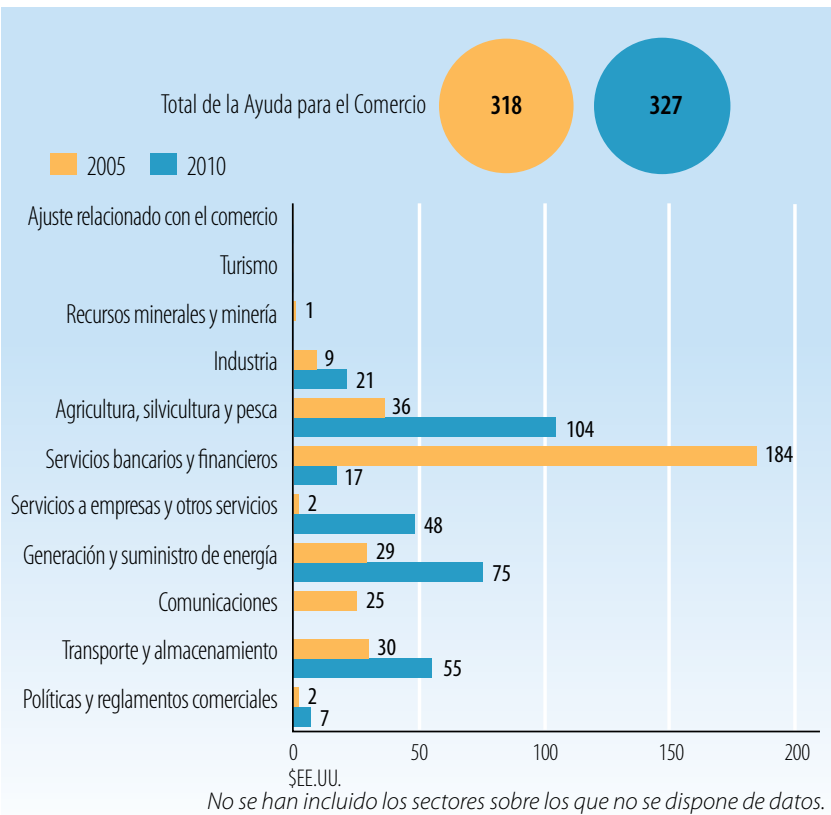

Fuentes: OCDE, base de datos del SNPA del CAD sobre las actividades de ayuda

Desembolsos de la ayuda para el comercio: principales donantes (millones de \$EE.UU. corrientes)

\begin{tabular}{|l|r|r|r|}
\hline $\mathbf{2 0 0 5}$ & Valor & $\%$ & Principales donantes en 2005 \\
\hline Banco Mundial & 287,7 & 90 & \\
\hline Japón & 6,8 & 2 & \\
\hline Estados Unidos & 5,7 & 2 & $98 \%$ \\
\hline Instituciones de la UE & 5,7 & 2 & \\
\hline Alemania & 5,6 & 2 & \\
\hline $\mathbf{2 0 1 0}$ & Valor & $\%$ & Principales donantes en $\mathbf{2 0 1 0}$ \\
\hline Estados Unidos & 157,5 & 48 & \\
\hline Japón & 67,4 & 21 & \\
\hline Banco Mundial & 53,4 & 16 & \\
\hline Corea, Rep. de & 13,4 & 4 & $92 \%$ \\
\hline Australia & 7,9 & 2 & \\
\hline
\end{tabular}

Fuentes: OCDE, base de datos del SNPA del CAD sobre las actividades de ayuda.

\section{INDICADORES COMERCIALES (PRODUCTOS)}

\section{Indicador}

$2005 \quad 2008 \quad 2011 \quad \Delta: 05-11(\%)$

Relación comercio/PIB (\%)

Exportaciones de servicios comerciales como

$\%$ de las exportaciones totales

Importaciones de servicios comerciales como

$\%$ de las importaciones totales

Productos intermedios distintos de los combustibles

(\% de las exportaciones de mercancías)

Productos intermedios distintos de los combustibles

(\% de las importaciones de mercancías)

\begin{tabular}{|l|l|l|l|}
\hline 42 & 43 & 36 & -6 \\
\hline
\end{tabular}

Fuentes: Secretaría de la OMC.

Corrientes comerciales (millones de \$EE.UU. corrientes)

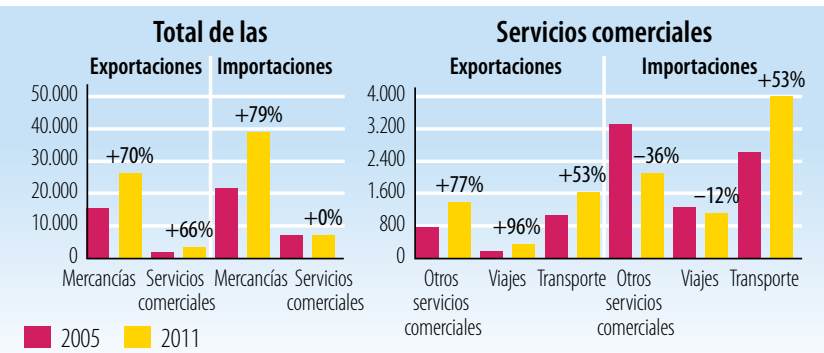

Fuentes. Secretaría de la OMr

Cinco principales mercados de exportación de mercancías (\%)

\begin{tabular}{|l|r|l|r|}
\hline 2005 & $\%$ & 2010 & $\%$ \\
\hline UE (27) & 27 & UE (27) & 24 \\
\hline Estados Unidos & 25 & Estados Unidos & 17 \\
\hline Emiratos Árabes Unidos & 8 & Emiratos Árabes Unidos & 9 \\
\hline Afganistán & 7 & Afganistán & 8 \\
\hline Hong Kong, China & 4 & China & 7
\end{tabular}

Fuentes: Secretaría de la OMC

Cinco principales productos de exportación (\% de las exportaciones de mercancías)

\begin{tabular}{|l|r|l|c|}
\hline 2005 & $\%$ & 2011 & $\%$ \\
\hline Artículos textiles, n.e.p. & 19 & Artículos textiles, n.e.p. & 14 \\
\hline Tejidos de algodón & 13 & Tejidos de algodón & 10 \\
\hline Hilados de fibra textil & 8 & Arroz & 8 \\
\hline $\begin{array}{l}\text { Arroz } \\
\begin{array}{l}\text { Prendas de vestir para hombres y niños, } \\
\text { de punto }\end{array}\end{array}$ & 7 & Hilados de fibra textil & 8 \\
\hline $\begin{array}{l}\text { Fuentes:Secretaría de la OMC } \\
\text { OMoductos derivados del petróleo }\end{array}$ & 5 \\
\hline
\end{tabular}

Cinco principales mercados de importación de mercancías (\%)

\begin{tabular}{|l|c|l|c|}
\hline $\mathbf{2 0 0 5}$ & $\%$ & $\mathbf{2 0 1 0}$ & $\%$ \\
\hline UE (27) & 18 & Emiratos Árabes Unidos & 14 \\
\hline Arabia Saudita, Reino de la & 11 & China & 14 \\
\hline Emiratos Árabes Unidos & 10 & UE (27) & 11 \\
\hline China & 9 & Arabia Saudita, Reino de la & 10 \\
\hline Japón & 7 & Kuwait & 7 \\
\hline
\end{tabular}

Fuentes: Secretaría de la OMC

Cinco principales productos de importación (\% de las importaciones de mercancías)

\begin{tabular}{|c|c|c|}
\hline 2005 & $\%$ & 2011 \\
\hline Aceites de petróleo, crudos & 11 & Productos derivados del petróleo \\
\hline Productos derivados del petróleo & 9 & Aceites de petróleo, crudos \\
\hline $\begin{array}{l}\text { Equipos de telecomunicaciones y sus } \\
\text { partes, n.e.p. }\end{array}$ & 7 & $\begin{array}{l}\text { Otros aceites y grasas fijos de origen } \\
\text { vegetal }\end{array}$ \\
\hline Maquinaria textil y para trabajar cueros & 4 & $\begin{array}{l}\text { Equipos de telecomunicaciones y sus } \\
\text { partes, n.e.p. }\end{array}$ \\
\hline $\begin{array}{l}\text { Vehículos automotores para pasajeros, } \\
\text { excepto autobuses }\end{array}$ & 3 & Abonos, excepto los del grupo 272 \\
\hline
\end{tabular}




\section{PAKISTÁN C.}

\section{LA AYUDA PARA EL COMERCIO EN SÍNTESIS 2013}

\section{INDICADORES COMERCIALES (RESULTADOS)}

\section{Indicador}

Crecimiento del PIB (\%)

Número de exportadores

Índice de concentración de las exportaciones (productos) ( 0 a 1)

ACR sobre mercancías notificados a la OMC

AIE (servicios) notificados a la OMC

Sectores de servicios con compromisos en el marco del AGCS

\section{Aranceles $(\%, 2006$ et 2011)}

\begin{tabular}{l|l|l|l|} 
Importaciones: promedio aritmético de los aranceles NMF aplicados & 14,3
\end{tabular}

\begin{tabular}{l|l|l|} 
Importaciones: promedio ponderado de los aranceles NMF aplicados & 13,1
\end{tabular}

$\begin{array}{ll}\text { Exportaciones: promedio ponderado de los aranceles impuestos } & 7,6\end{array}$

por los importadores

$19,0 \quad 25,2$

Fuentes: Naciones Unidas, base de datos Comtrade; Banco Mundial, base de dato sobre dinámica de las empresas de exportación; Banco Mundial, Indicadores del

Desarrollo Mundial; OMC, perfiles comerciales y arancelarios.

Participación en las exportaciones por región (\%)

\begin{tabular}{|l|r|r|}
\hline & $\mathbf{2 0 0 5}$ & $\mathbf{2 0 1 1}$ \\
\hline África & 5,7 & 6,7 \\
\hline Asia & 23,4 & 32,7 \\
\hline Comunidad de Estados Independientes & 0,6 & 1,2 \\
\hline Europa & 29,1 & 28,3 \\
\hline Oriente Medio & 13,3 & 12,8 \\
\hline América del Norte & 26,5 & 16,4 \\
\hline América del Sury América Central & 1,4 & 1,7 \\
\hline
\end{tabular}

Fuentes: OMC, perfiles comerciales y arancelarios

Indicadores de facilitación del comercio
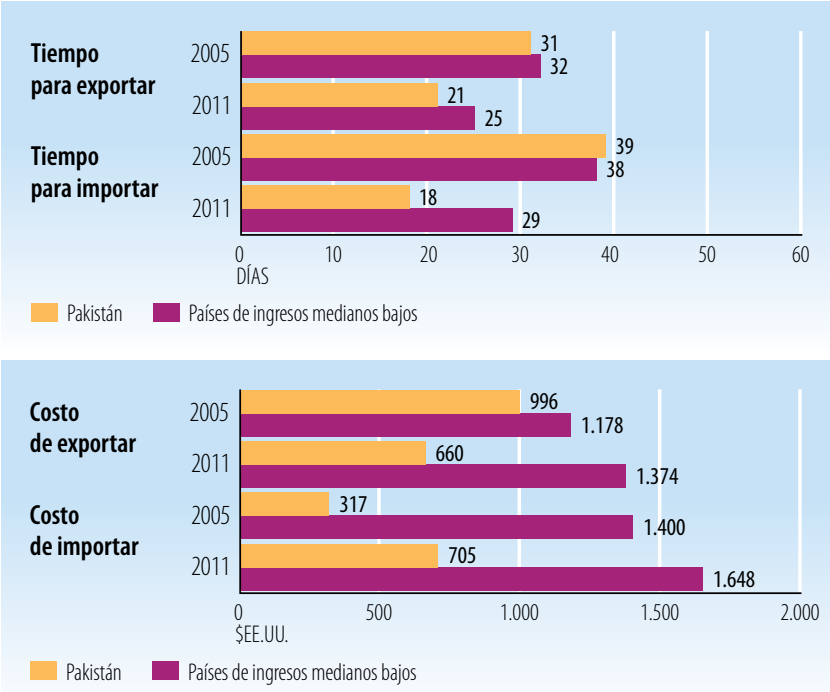

Índice de desempeño logístico

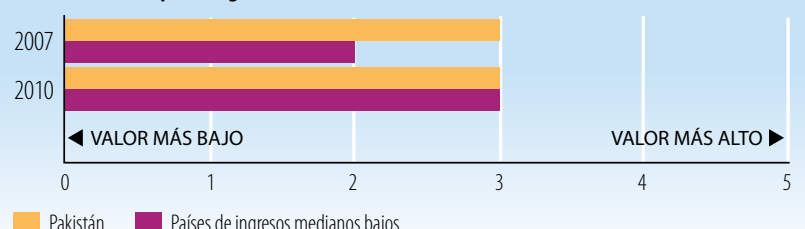

Pakistán Países de ingresos medianos bajos

Fuentes: Banco Mundial, Indicadores del Desarrollo Mundial.

\begin{tabular}{l|c|c|}
\hline INDICADORES DE DESARROLLO (EFECTOS) & \\
\hline Indicador & $\mathbf{2 0 0 5}$ & $\mathbf{2 0 1 0}$ \\
\hline Desempleo (\% de la fuerza de trabajo total) & 6,1 & 5,0 \\
\hline Población activa, mujeres (\% de la fuerza de trabajo total) & 18,0 & 20,7 \\
\hline AOD neta recibida (\% del INB) & 1,4 & 1,6 \\
\hline Derechos de importación percibidos (\% de los ingresos fiscales) & 18,8 & n.d. \\
\hline Total del servicio de la deuda (\% de las exportaciones totales) & 12,3 & 15,2 \\
\hline Índice de desarrollo humano ( 0 a 1) & 0,48 & 0,50 \\
\hline
\end{tabular}

Fuentes: PNUD, indicadores internacionales sobre desarrollo humano; Banco Mundial, Indicadores del Desarrollo Mundial.

Producto interno bruto

PIB per cápita (PPA, dólares internacionales corrientes)

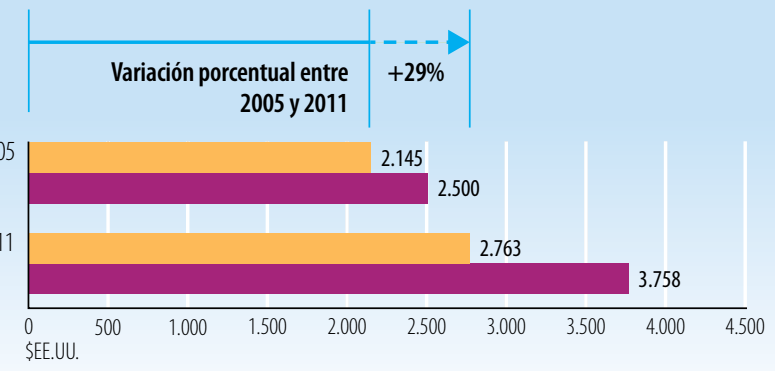

Pakistán Países de ingresos medianos bajos

PIB per cápita (\$EE.UU. constantes de 2000)
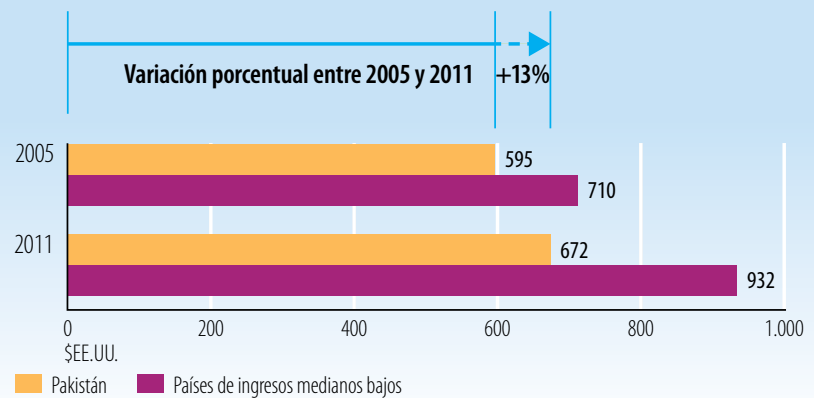

Fuentes: Banco Mundial, Indicadores del Desarrollo Mundial.

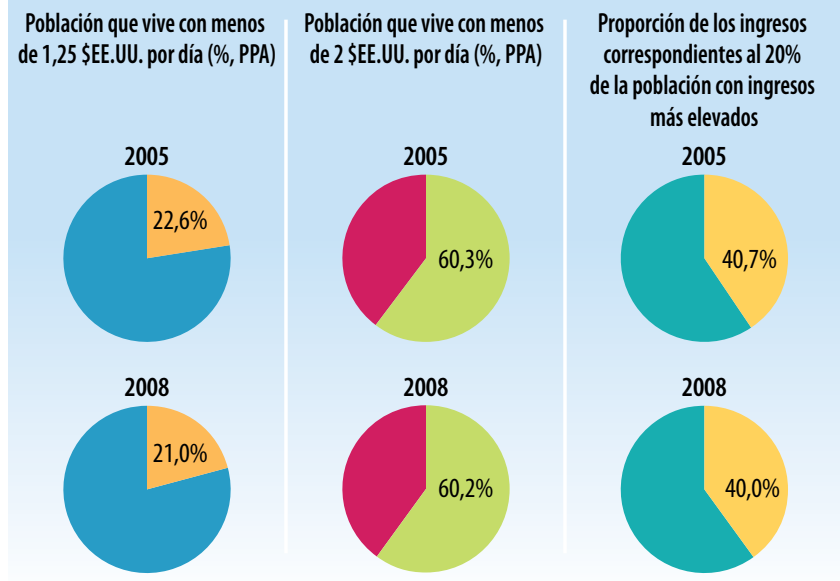

Fuentes: Banco Mundial, Indicadores del Desarrollo Mundial.

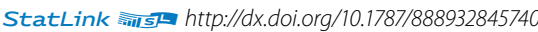


Indicadores de la ayuda, el comercio y el desarrollo relativos a Panamá

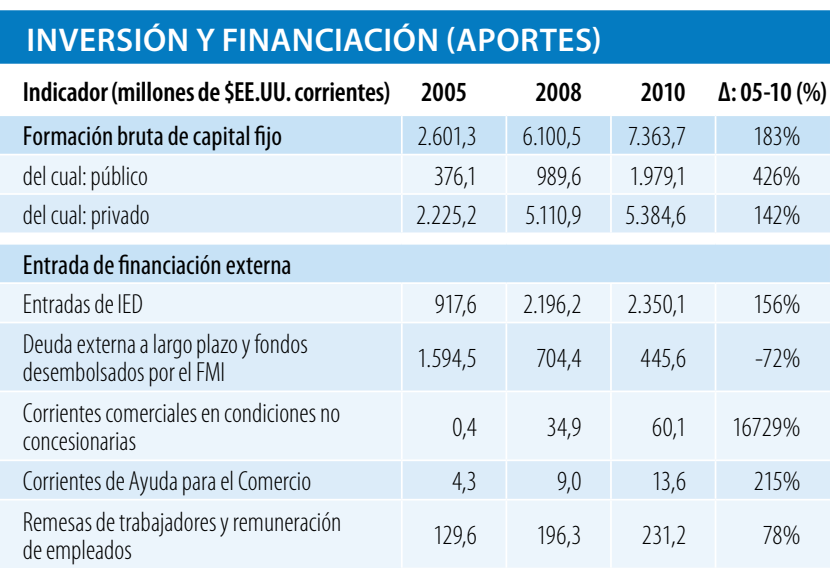

Fuentes: OCDE, base de datos del SNPA del CAD sobre las actividades de ayuda; Banco Mundial, Indicadores del Desarrollo Mundial; Banco Mundial, estadísticas de la deuda internacional.

Desembolsos de la ayuda para el comercio, por sector (millones de \$EE.UU. corrientes)

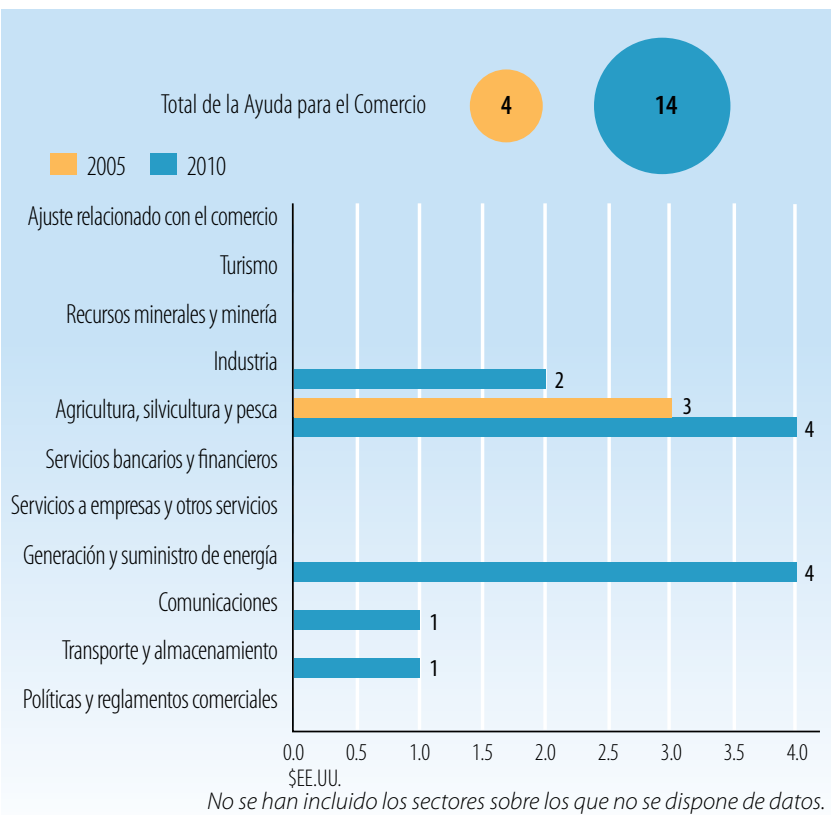

Fuentes: OCDE, base de datos del SNPA del CAD sobre las actividades de ayuda

Desembolsos de la ayuda para el comercio: principales donantes (millones de \$EE.UU. corrientes)

\begin{tabular}{|l|r|r|r|}
\hline $\mathbf{2 0 0 5}$ & Valor & $\%$ & Principales donantes en 2005 \\
\hline Japón & 3,5 & 81 & \\
\hline España & 0,3 & 6 & \\
\hline Estados Unidos & 0,2 & 4 & $97 \%$ \\
\hline Instituciones de la UE & 0,1 & 3 & \\
\hline Canadá & 0,1 & 2 & \\
\hline $\mathbf{2 0 1 0}$ & Valor & $\%$ & Principales donantes en 2010 \\
\hline Japón & 3,1 & 23 & \\
\hline España & 2,5 & 18 & \\
\hline Noruega & 2,4 & 17 & \\
\hline Estados Unidos & 2,3 & 17 & $93 \%$ \\
\hline BID & 2,3 & 17 & \\
\hline
\end{tabular}

Fuentes: OCDE, base de datos del SNPA del CAD sobre las actividades de ayuda.

\section{INDICADORES COMERCIALES (PRODUCTOS)}

Indicador

$2005 \quad 2008 \quad 2011 \quad \Delta: 05-11(\%)$

Relación comercio/PIB (\%)

\begin{tabular}{|l|l|l|l|}
137 & 146 & 164 & 26 \\
\hline
\end{tabular}

Exportaciones de servicios comerciales como

$\%$ de las exportaciones totales

Importaciones de servicios comerciales como

$\%$ de las importaciones totales

Productos intermedios distintos de los combustibles

(\% de las exportaciones de mercancías)

Productos intermedios distintos de los combustibles

(\% de las importaciones de mercancías)

\begin{tabular}{l|l|l|l|}
30 & 36 & 29 & -1
\end{tabular}

Fuentes: Secretaría de la OMC.

Corrientes comerciales (millones de \$EE.UU. corrientes)

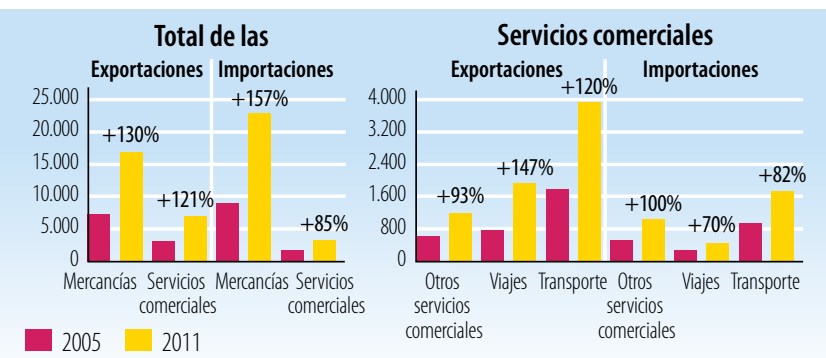

Fuentes: Secretaría de la OMC

Cinco principales mercados de exportación de mercancías (\%)

\begin{tabular}{|l|r|l|c|}
\hline 2005 & $\%$ & 2010 & $\%$ \\
\hline Estados Unidos & 45 & Estados Unidos & 20 \\
\hline UE (27) & 28 & Venezuela, Rep. Bolivariana de & 16 \\
\hline Costa Rica & 4 & Colombia & 16 \\
\hline Guatemala & 2 & Costa Rica & 5 \\
\hline Nicaragua & 2 & República Dominicana & 5 \\
\hline
\end{tabular}

Fuentes: Secretaría de la OMC

Cinco principales productos de exportación (\% de las exportaciones de mercancías)

\begin{tabular}{|c|c|c|c|}
\hline 2005 & $\%$ & 2011 & $\%$ \\
\hline Pescado, fresco, refrigerado o congelado & 32 & $\begin{array}{l}\text { Productos medicinales, etc., excepto los } \\
\text { del grupo } 542\end{array}$ & 25 \\
\hline $\begin{array}{l}\text { Frutas y nueces, excepto nueces } \\
\text { oleaginosas }\end{array}$ & 25 & Medicamentos & 9 \\
\hline Crustáceos, moluscos, etc. & 9 & Calzado & 8 \\
\hline Legumbres & 3 & Productos de perfumería, cosméticos, etc. & 4 \\
\hline Azúcares, melaza y miel & 2 & $\begin{array}{l}\text { Prendas de vestir para mujeres y niñas, } \\
\text { excepto las de punto }\end{array}$ & 4 \\
\hline
\end{tabular}

Fuentes: Secretaría de la OMC

Cinco principales mercados de importación de mercancías (\%)

\begin{tabular}{|l|r|l|r|}
\hline 2005 & $\%$ & 2010 & $\%$ \\
\hline Estados Unidos & 27 & China & 25 \\
\hline Antillas Neerlandesas & 11 & Estados Unidos & 20 \\
\hline UE (27) & 7 & Singapur & 10 \\
\hline Costa Rica & 5 & UE (27) & 9 \\
\hline Japón & 5 & Hong Kong, China & 5 \\
\hline
\end{tabular}

Fuentes: Secretaría de la OMC

Cinco principales productos de importación (\% de las importaciones de mercancías)

\begin{tabular}{|c|c|c|c|}
\hline 2005 & $\%$ & 2011 & $\%$ \\
\hline Productos derivados del petróleo & 16 & $\begin{array}{l}\text { Productos medicinales, etc., excepto los } \\
\text { del grupo } 542\end{array}$ & 17 \\
\hline $\begin{array}{l}\text { Vehículos automotores para pasajeros, } \\
\text { excepto autobuses }\end{array}$ & 7 & Calzado & 5 \\
\hline Medicamentos & 4 & Medicamentos & 5 \\
\hline $\begin{array}{l}\text { Equipos de telecomunicaciones y sus } \\
\text { partes, n.e.p. }\end{array}$ & 4 & $\begin{array}{l}\text { Prendas de vestir para mujeres y niñas, } \\
\text { excepto las de punto }\end{array}$ & 3 \\
\hline $\begin{array}{l}\text { Equipo de procesamiento automático } \\
\text { de datos }\end{array}$ & 2 & $\begin{array}{l}\text { Vehículos automotores para pasajeros, } \\
\text { excepto autobuses }\end{array}$ & 3 \\
\hline
\end{tabular}




\section{LA AYUDA PARA EL COMERCIO EN SÍNTESIS 2013}

\section{INDICADORES COMERCIALES (RESULTADOS)}

Indicador

Crecimiento del PIB (\%)

Número de exportadores

Índice de concentración de las exportaciones (productos) ( 0 a 1$)$

ACR sobre mercancías notificados a la OMC

AIE (servicios) notificados a la OMC

Sectores de servicios con compromisos en el marco del AGCS

\section{Aranceles (\%, 2006 et 2011)}

\begin{tabular}{ll|l|l|} 
Importaciones: promedio aritmético de los aranceles NMF aplicados & 7,3 & 6,9
\end{tabular}

Importaciones: promedio ponderado de los aranceles NMF aplicados n.d. $\quad 7,9$

\begin{tabular}{|l|l|l|l|}
\hline Exportaciones: promedio ponderado de los aranceles impuestos & 16,7 & 5,8 \\
\hline
\end{tabular}

por los importadores

Exportaciones: libres de derechos (en \%)

$64,1 \quad 61,9$

Fuentes: Naciones Unidas, base de datos Comtrade; Banco Mundial, base de datos sobre dinámica de las empresas de exportación; Banco Mundial, Indicadores del

Desarrollo Mundial; OMC, perfiles comerciales y arancelarios.

Participación en las exportaciones por región (\%)

\begin{tabular}{|l|r|r|}
\hline & 2005 & 2011 \\
\hline África & 0,0 & 0,1 \\
\hline Asia & 5,9 & 3,4 \\
\hline Comunidad de Estados Independientes & 0,0 & 0,0 \\
\hline Europa & 28,2 & 1,7 \\
\hline Oriente Medio & 0,2 & 0,0 \\
\hline América del Norte & 46,9 & 28,7 \\
\hline América del Sury América Central & 17,5 & 65,8 \\
\hline
\end{tabular}

Fuentes: OMC, perfiles comerciales y arancelarios

Indicadores de facilitación del comercio
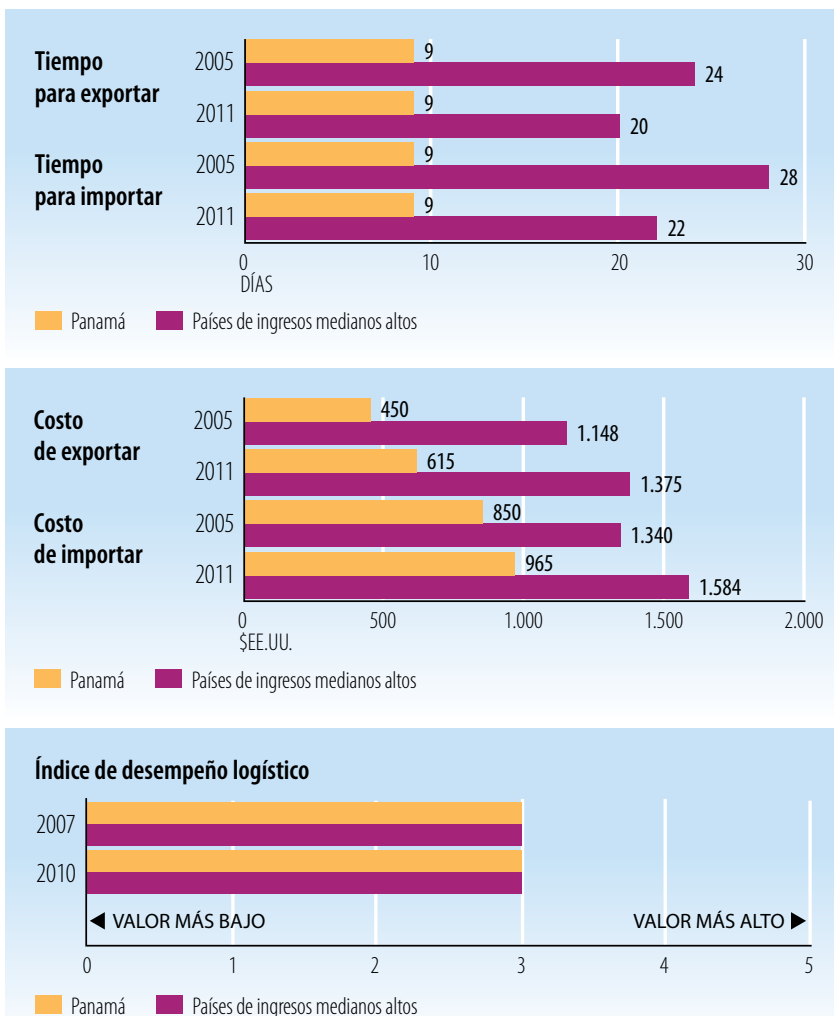

Fuentes: Banco Mundial, Indicadores del Desarrollo Mundial.

\begin{tabular}{|l|c|c|}
\hline INDICADORES DE DESARROLLO (EFECTOS) & \\
\hline Indicador & $\mathbf{2 0 0 5}$ & $\mathbf{2 0 1 0}$ \\
\hline Desempleo (\% de la fuerza de trabajo total) & 9,8 & 6,5 \\
\hline Población activa, mujeres (\% de la fuerza de trabajo total) & 37,1 & 37,3 \\
\hline A0D neta recibida (\% del InB) & 0,2 & 0,5 \\
\hline Derechos de importación percibidos (\% de los ingresos fiscales) & n.d. & n.d. \\
\hline Total del servicio de la deuda (\% de las exportaciones totales) & 17,4 & 5,7 \\
\hline Índice de desarrollo humano (0 a 1) & 0,74 & 0,77 \\
\hline
\end{tabular}

Fuentes: PNUD, indicadores internacionales sobre desarrollo humano; Banco Mundial, Indicadores del Desarrollo Mundial.

Producto interno bruto

PIB per cápita (PPA, dólares internacionales corrientes)

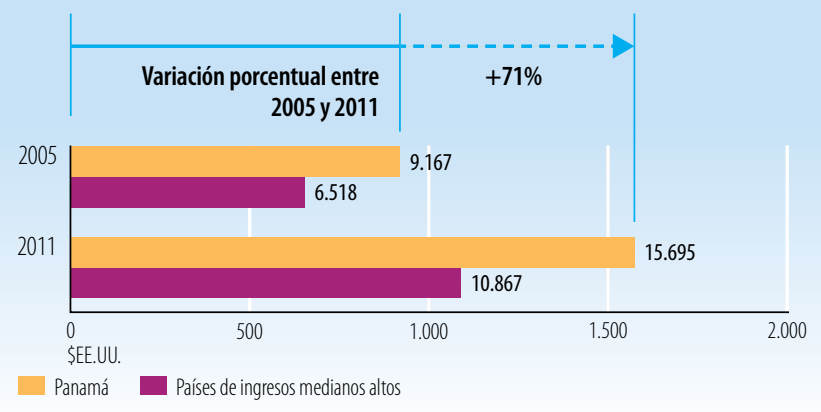

PIB per cápita (\$EE.UU. constantes de 2000)

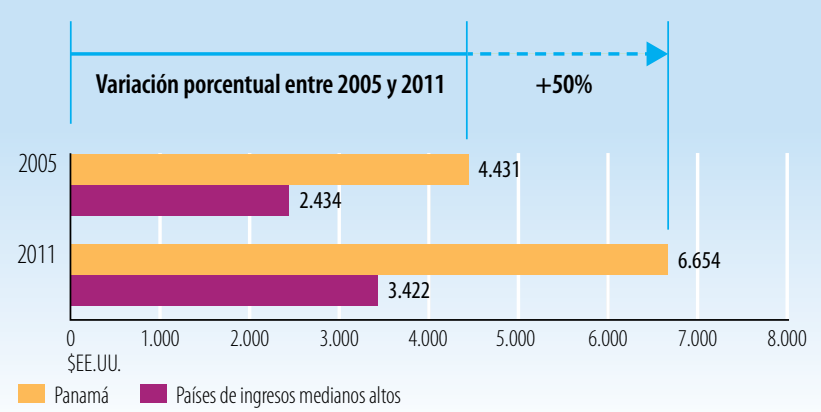

Fuentes: Banco Mundial, Indicadores del Desarrollo Mundial.

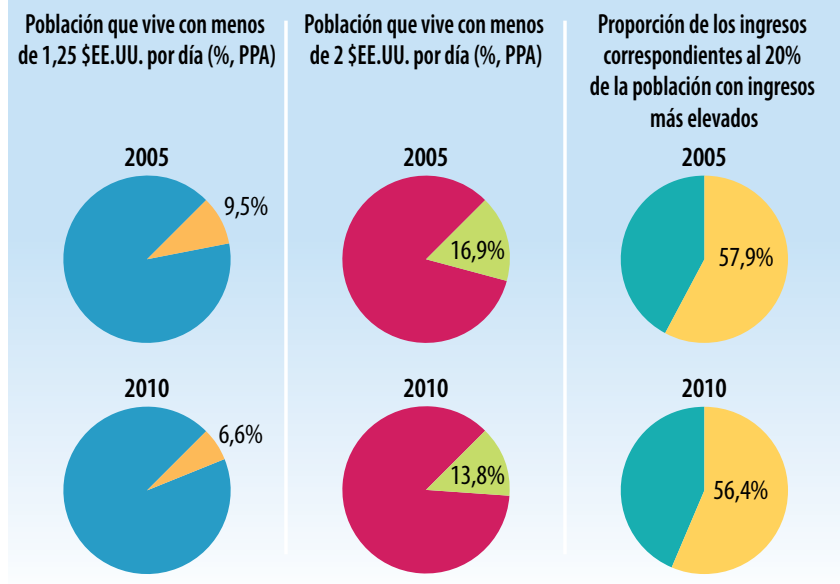

Fuentes: Banco Mundial, Indicadores del Desarrollo Mundial.

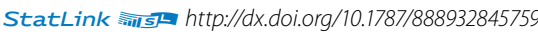




\section{Indicadores de la ayuda, el comercio y el desarrollo relativos a Papua Nueva Guinea}

\begin{tabular}{|c|c|c|c|c|}
\hline \multicolumn{5}{|c|}{ INVERSIÓN Y FINANCIACIÓN (APORTES) } \\
\hline Indicador (millones de \$EE.UU. corrientes) & 2005 & 2008 & 2010 & $\Delta: 05-10(\%)$ \\
\hline Formación bruta de capital fijo & $8.87,0$ & $1.488,2$ & $1.579,1$ & $78 \%$ \\
\hline del cual: público & n.d. & n.d. & n.d. & n.d. \\
\hline del cual: privado & n.d. & n.d. & n.d. & n.d. \\
\hline \multicolumn{5}{|l|}{ Entrada de financiación externa } \\
\hline Entradas de IED & 38,4 & $-30,5$ & 28,9 & $-25 \%$ \\
\hline $\begin{array}{l}\text { Deuda externa a largo plazo y fondos } \\
\text { desembolsados por el FMl }\end{array}$ & 334,7 & 950,5 & $3.153,1$ & $842 \%$ \\
\hline $\begin{array}{l}\text { Corrientes comerciales en condiciones no } \\
\text { concesionarias }\end{array}$ & 14,9 & 3,9 & 18,3 & $23 \%$ \\
\hline Corrientes de Ayuda para el Comercio & 69,0 & 112,0 & 124,8 & $81 \%$ \\
\hline $\begin{array}{l}\text { Remesas de trabajadores y remuneración } \\
\text { de empleados }\end{array}$ & 6,9 & 14,8 & 15,0 & $118 \%$ \\
\hline
\end{tabular}

Fuentes: OCDE, base de datos del SNPA del CAD sobre las actividades de ayuda; Banco Mundial, Indicadores del Desarrollo Mundial; Banco Mundial, estadísticas de la deuda internacional.

Desembolsos de la ayuda para el comercio, por sector (millones de \$EE.UU. corrientes)

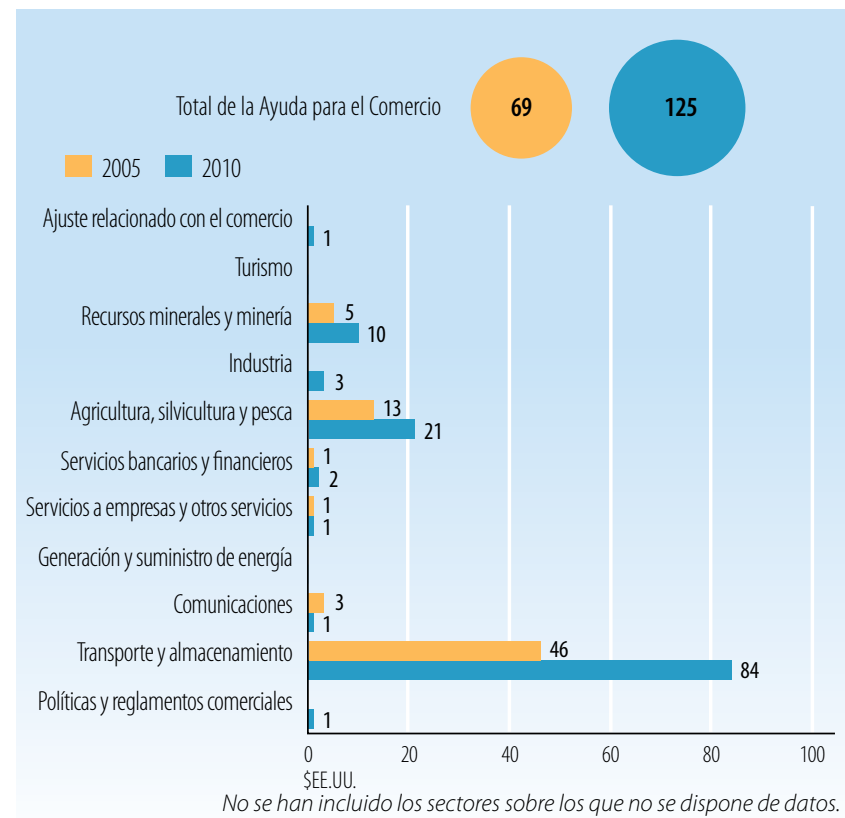

Fuentes: OCDE, base de datos del SNPA del CAD sobre las actividades de ayuda

Desembolsos de la ayuda para el comercio: principales donantes (millones de \$EE.UU. corrientes)

\begin{tabular}{|l|r|r|r|}
\hline $\mathbf{2 0 0 5}$ & Valor & $\%$ & Principales donantes en 2005 \\
\hline Australia & 49,6 & 72 & \\
\hline Instituciones de la UE & 8,5 & 12 & $100 \%$ \\
\hline Japón & 7,8 & 11 & \\
\hline Alemania & 2,5 & 4 & \\
\hline Nueva Zelandia & 0,5 & 1 & \\
\hline $\mathbf{2 0 1 0}$ & Valor & $\%$ & Principales donantes en $\mathbf{2 0 1 0}$ \\
\hline Australia & 70,9 & 57 & \\
\hline Japón & 18,8 & 15 & \\
\hline Instituciones de la UE & 12,6 & 10 & \\
\hline Banco Asiático de Desarrollo & 10,3 & 8 & \\
\hline Banco Mundial & 8,3 & 7 & \\
\hline
\end{tabular}

Fuentes: OCDE, base de datos del SNPA del CAD sobre las actividades de ayuda.

\section{INDICADORES COMERCIALES (PRODUCTOS)}

Indicador

Relación comercio/PIB (\%)

Exportaciones de servicios comerciales como

$\%$ de las exportaciones totales

Importaciones de servicios comerciales como

$\%$ de las importaciones totales

Productos intermedios distintos de los combustibles

(\% de las exportaciones de mercancías)

Productos intermedios distintos de los combustibles

(\% de las importaciones de mercancías)

Fuentes: Secretaría de la OMC

Corrientes comerciales (millones de \$EE.UU. corrientes)

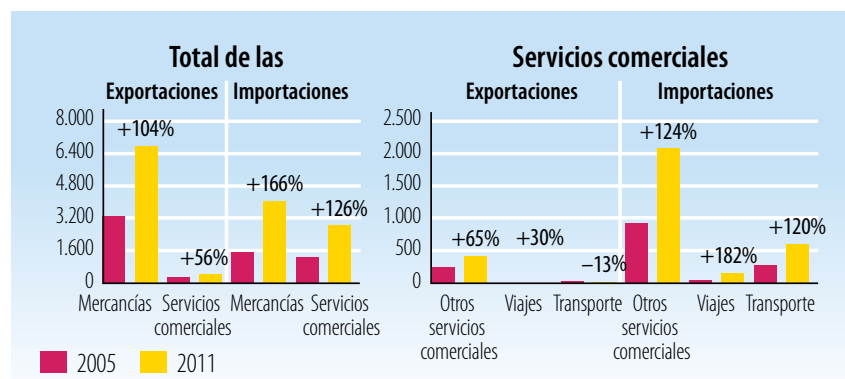

Fuentes: Secretaría de la OMC

Cinco principales mercados de exportación de mercancías (\%)

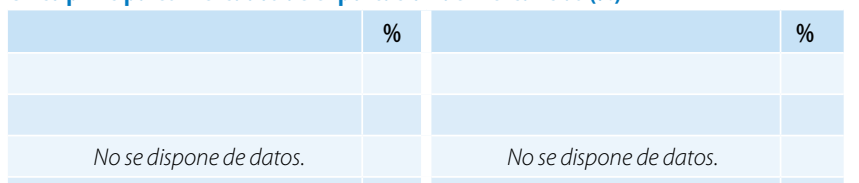

Fuentes: Secretaría de la OMC

Cinco principales productos de exportación (\% de las exportaciones de mercancías)

$\%$ $\%$

No se dispone de datos.

No se dispone de datos.

Fuentes: Secretaría de la OMC

Cinco principales mercados de importación de mercancías (\%)

No se dispone de datos

No se dispone de datos.

Fuentes: Secretaría de la OMC

Cinco principales productos de importación (\% de las importaciones de mercancías)

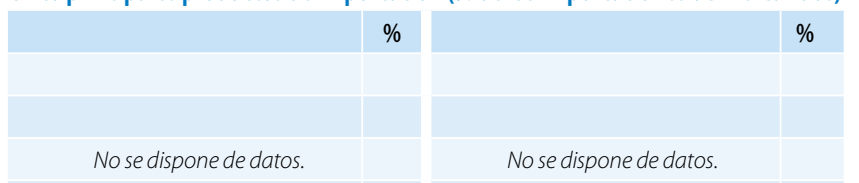




\section{LA AYUDA PARA EL COMERCIO EN SÍNTESIS 2013}

\section{INDICADORES COMERCIALES (RESULTADOS)}

\section{Indicador}

Crecimiento del PIB (\%)

Número de exportadores

Índice de concentración de las exportaciones (productos) (0 a 1)

ACR sobre mercancías notificados a la OMC

AIE (servicios) notificados a la OMC

Sectores de servicios con compromisos en el marco del AGCS

\section{Aranceles (\%, 2006-2010)}

\begin{tabular}{l|l|l|l|} 
Importaciones: promedio aritmético de los aranceles NMF aplicados & 5,5 & 5,1
\end{tabular}

Importaciones: promedio ponderado de los aranceles NMF aplicados $1,9 \quad$ n.d.

Exportaciones: promedio ponderado de los aranceles impuestos

por los importadores

Exportaciones: libres de derechos (en \%)

$0,2 \quad 0,2$

$92,5 \quad 91,5$

Fuentes: Naciones Unidas, base de datos Comtrade; Banco Mundial, base de datos sobre dinámica de las empresas de exportación; Banco Mundial, Indicadores del

Desarrollo Mundial; OMC, perfiles comerciales y arancelarios.

Participación en las exportaciones por región (\%)

\begin{tabular}{|l|c|c|}
\hline África & 2005 & 2011 \\
\hline Asia & n.d. & n.d. \\
\hline Comunidad de Estados Independientes & n.d. & n.d. \\
\hline Europa & n.d. & n.d. \\
\hline Oriente Medio & n.d. & n.d. \\
\hline América del Norte & n.d. & n.d. \\
\hline América del Sury América Central & n.d. & n.d. \\
\hline
\end{tabular}

Fuentes: OMC, perfiles comerciales y arancelarios

Indicadores de facilitación del comercio
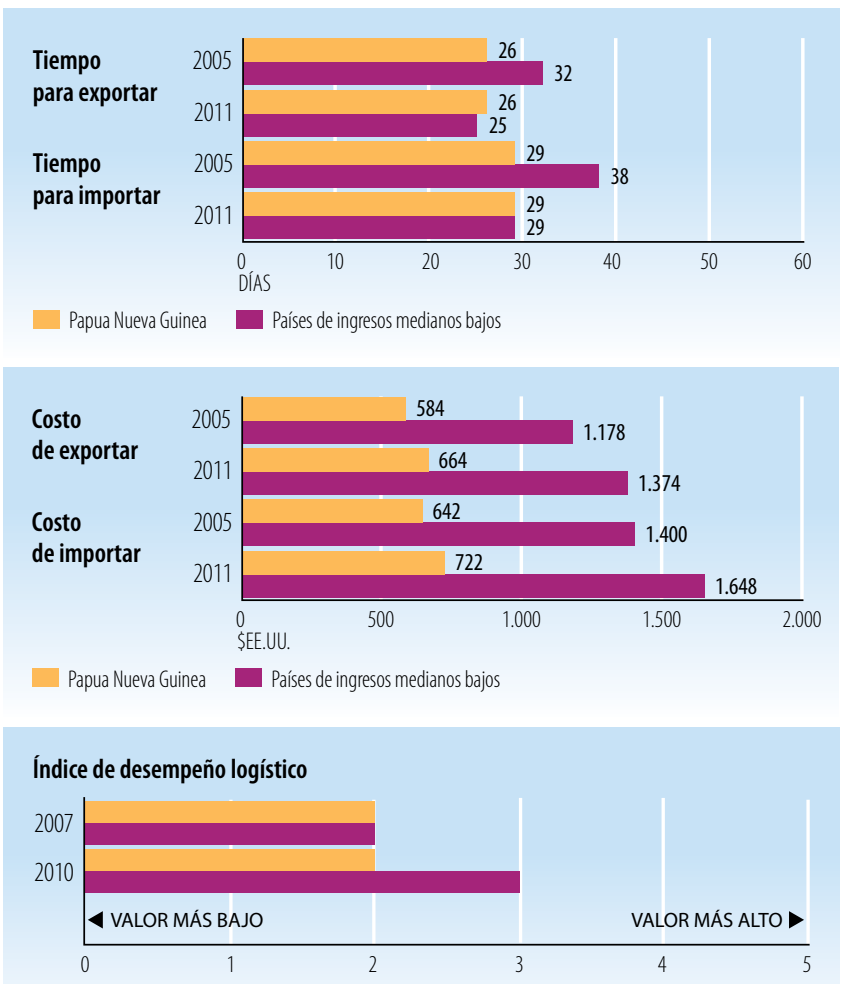

- Papua Nueva Guinea Países de ingresos medianos bajos

Fuentes: Banco Mundial, Indicadores del Desarrollo Mundial.

\begin{tabular}{l|c|c|}
\hline \multicolumn{1}{l}{ INDICADORES DE DESARROLLO (EFECTOS) } \\
\hline Indicador & $\mathbf{2 0 0 5}$ & $\mathbf{2 0 1 0}$ \\
\hline Desempleo (\% de la fuerza de trabajo total) & n.d. & n.d. \\
\hline Población activa, mujeres (\% de la fuerza de trabajo total) & 48,4 & 48,3 \\
\hline AOD neta recibida (\% del INB) & 5,9 & 5,5 \\
\hline Derechos de importación percibidos (\% de los ingresos fiscales) & n.d. & n.d. \\
\hline Total del servicio de la deuda (\% de las exportaciones totales) & 8,4 & 12,9 \\
\hline Índice de desarrollo humano (0 a 1) & 0,44 & 0,46 \\
\hline
\end{tabular}

Fuentes: PNUD, indicadores internacionales sobre desarrollo humano; Banco Mundial, Indicadores del Desarrollo Mundial.

Producto interno bruto

PIB per cápita (PPA, dólares internacionales corrientes)

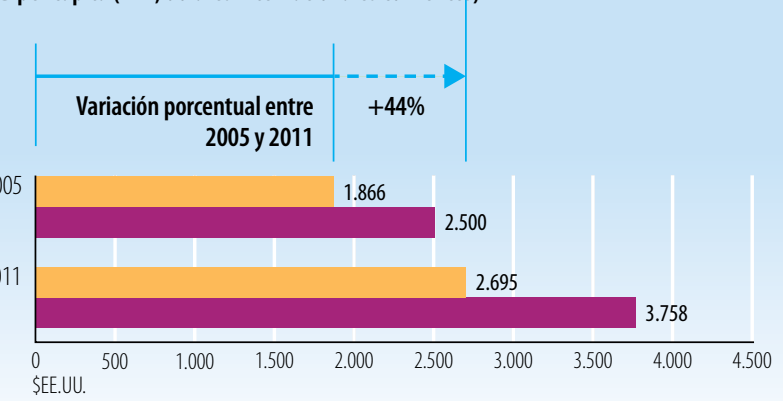

Papua Nueva Guinea Países de ingresos medianos bajos

PIB per cápita (\$EE.UU. constantes de 2000)

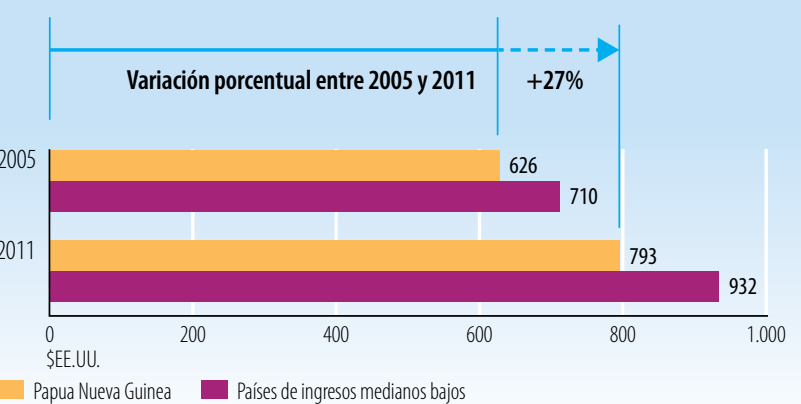

Papua Nueva Guinea Países de ingresos medianos bajos

Fuentes: Banco Mundial, Indicadores del Desarrollo Mundial.

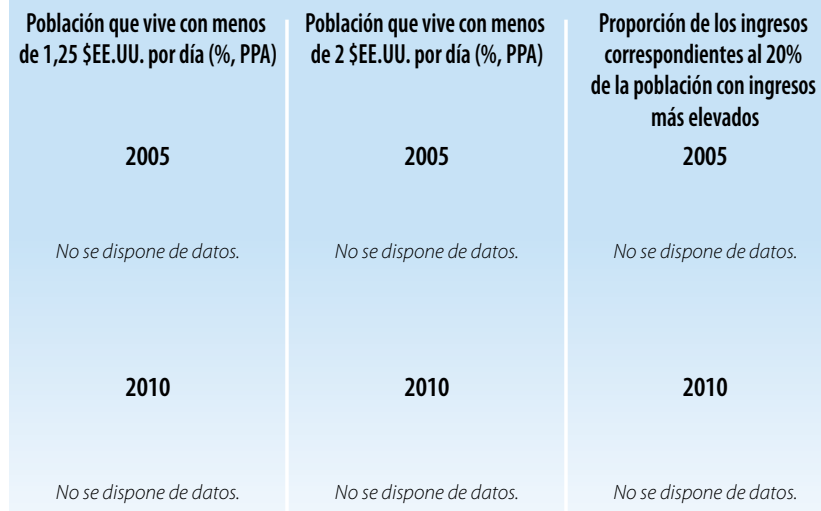

Fuentes: Banco Mundial, Indicadores del Desarrollo Mundial.

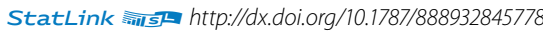


Indicadores de la ayuda, el comercio y el desarrollo relativos al Paraguay

\begin{tabular}{|c|c|c|c|c|}
\hline Indicador (millones de \$EE.UU. corrientes) & 2005 & 2008 & 2010 & $\Delta: 05-10(\%)$ \\
\hline Formación bruta de capital fijo & $1.442,8$ & $2.974,3$ & $3.336,4$ & $131 \%$ \\
\hline del cual: público & n.d. & n.d. & 923,7 & n.d. \\
\hline del cual: privado & n.d. & n.d. & $2.412,7$ & n.d. \\
\hline \multicolumn{5}{|l|}{ Entrada de financiación externa } \\
\hline Entradas de IED & 53,5 & 278,7 & 346,9 & $548 \%$ \\
\hline $\begin{array}{l}\text { Deuda externa a largo plazo y fondos } \\
\text { desembolsados por el FMI }\end{array}$ & 210,1 & 376,1 & 825,9 & $293 \%$ \\
\hline $\begin{array}{l}\text { Corrientes comerciales en condiciones no } \\
\text { concesionarias }\end{array}$ & 4,4 & 2,6 & 114,5 & $2528 \%$ \\
\hline Corrientes de Ayuda para el Comercio & 12,6 & 67,3 & 40,0 & $218 \%$ \\
\hline $\begin{array}{l}\text { Remesas de trabajadores y remuneración } \\
\text { de empleados }\end{array}$ & 269,3 & 587,8 & 673,0 & $150 \%$ \\
\hline
\end{tabular}

Fuentes: OCDE, base de datos del SNPA del CAD sobre las actividades de ayuda; Banco Mundial, Indicadores del Desarrollo Mundial; Banco Mundial, estadísticas de la deuda internacional.

Desembolsos de la ayuda para el comercio, por sector (millones de \$EE.UU. corrientes)

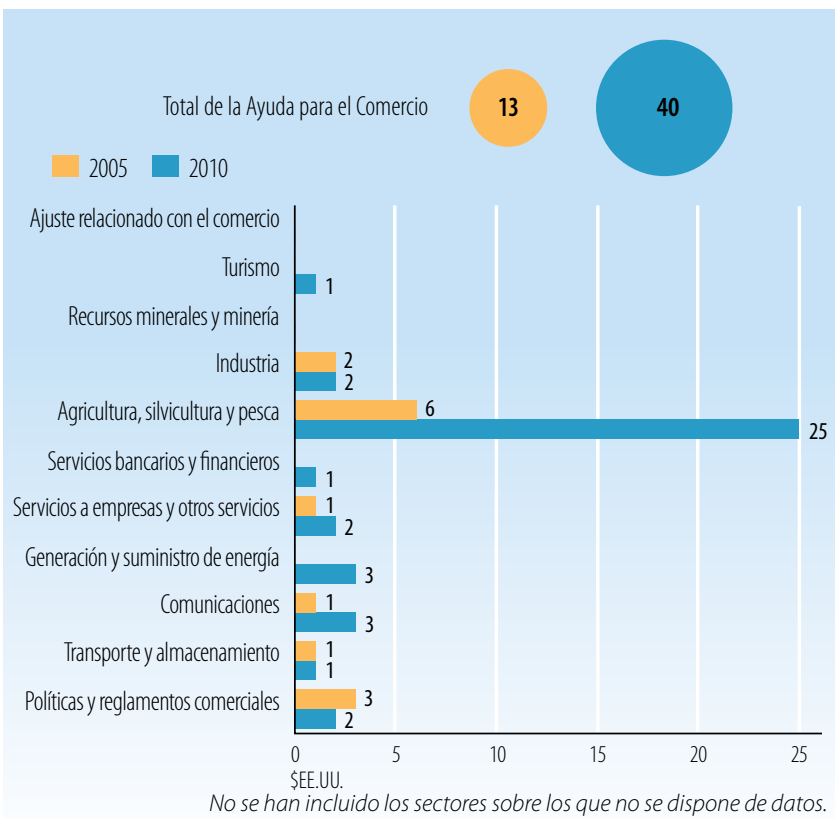

Fuentes: OCDE, base de datos del SNPA del CAD sobre las actividades de ayuda

Desembolsos de la ayuda para el comercio: principales donantes (millones de \$EE.UU. corrientes)

\begin{tabular}{|l|r|r|}
\hline $\mathbf{2 0 0 5}$ & Valor & $\%$ \\
\hline Japón & 7,0 & 56 \\
\hline Instituciones de la UE & 2,3 & 18 \\
\hline España & 1,2 & 10 \\
\hline Alemania & 1,1 & 8 \\
\hline Canadá & 1,0 & 8 \\
\hline 2010 & Valor & $\%$ \\
\hline Japón & 26,4 & 66 \\
\hline Estados Unidos & 3,2 & 8 \\
\hline España & 3,1 & 8 \\
\hline Corea, Rep. de & 2,8 & 7 \\
\hline BID & 2,6 & 7 \\
\hline
\end{tabular}

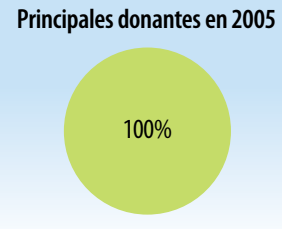

Principales donantes en 2010

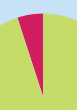

$95 \%$

Fuentes: OCDE, base de datos del SNPA del CAD sobre las actividades de ayuda.

\section{INDICADORES COMERCIALES (PRODUCTOS)}

\section{Indicador}

$2005 \quad 2008 \quad 2011 \quad \Delta: 05-11(\%)$

Relación comercio/PIB (\%)

\begin{tabular}{l|l|l|l|}
108 & 108 & 105 & -3 \\
\hline
\end{tabular}

Exportaciones de servicios comerciales como

$\%$ de las exportaciones totales

Importaciones de servicios comerciales como

$\%$ de las importaciones totales

Productos intermedios distintos de los combustibles

(\% de las exportaciones de mercancías)

Productos intermedios distintos de los combustibles

(\% de las importaciones de mercancías)

\begin{tabular}{l|l|l|l|}
15 & 12 & 15 & -1
\end{tabular}

Fuentes: Secretaría de la OMC.

Corrientes comerciales (millones de \$EE.UU. corrientes)
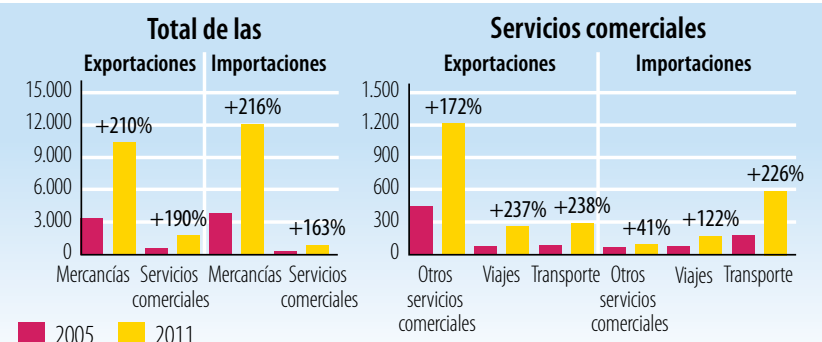

Fuentes: Secretaría de la OMC

Cinco principales mercados de exportación de mercancías (\%)

\begin{tabular}{|l|r|l|c|}
\hline $\mathbf{2 0 0 5}$ & $\%$ & $\mathbf{2 0 1 1}$ & $\%$ \\
\hline Uruguay & 29 & Uruguay & 19 \\
\hline Brasil & 19 & Argentina & 18 \\
\hline Islas Caimán & 10 & Brasil & 14 \\
\hline UE (27) & 6 & UE (27) & 9 \\
\hline Argentina & 6 & Chile & 9 \\
\hline Fuentes: Secretaría de la OMC & & &
\end{tabular}

Cinco principales productos de exportación (\% de las exportaciones de mercancías)

\begin{tabular}{|c|c|c|c|}
\hline 2005 & $\%$ & 2011 & $\%$ \\
\hline $\begin{array}{l}\text { Semillas oleaginosas (aceites vegetales } \\
\text { fijos blandos) }\end{array}$ & 36 & $\begin{array}{l}\text { Semillas oleaginosas (aceites vegetales } \\
\text { fijos blandos) }\end{array}$ & 43 \\
\hline Carne de ganado bovino & 15 & Carne de ganado bovino & 13 \\
\hline Pienso para animales & 9 & Pienso para animales & 7 \\
\hline $\begin{array}{l}\text { Aceites y grasas fijos de origen vegetal, } \\
\text { blandos }\end{array}$ & 6 & Maíz sin moler & 6 \\
\hline Algodón & 5 & $\begin{array}{l}\text { Aceites y grasas fijos de origen vegetal, } \\
\text { blandos }\end{array}$ & 6 \\
\hline
\end{tabular}

Fuentes: Secretaría de la OMC

Cinco principales mercados de importación de mercancías (\%)

\begin{tabular}{|l|r|l|c|}
\hline $\mathbf{2 0 0 5}$ & $\%$ & 2011 & $\%$ \\
\hline Brasil & 27 & China & 30 \\
\hline Argentina & 20 & Brasil & 26 \\
\hline China & 20 & Argentina & 14 \\
\hline UE (27) & 7 & UE (27) & 6 \\
\hline Estados Unidos & 6 & Estados Unidos & 5 \\
\hline
\end{tabular}

Cinco principales productos de importación (\% de las importaciones de mercancías)

\begin{tabular}{|c|c|c|c|}
\hline 2005 & $\%$ & 2011 & $\%$ \\
\hline Productos derivados del petróleo & 15 & Productos derivados del petróleo & 12 \\
\hline $\begin{array}{l}\text { Equipo de procesamiento automático } \\
\text { de datos }\end{array}$ & 4 & $\begin{array}{l}\text { Equipos de telecomunicaciones y sus } \\
\text { partes, n.e.p. }\end{array}$ & 7 \\
\hline Abonos, excepto los del grupo 272 & 4 & Cochecitos para niños, juguetes y juegos & 4 \\
\hline $\begin{array}{l}\text { Partes y piezas para máquinas de } \\
\text { oficina }\end{array}$ & 4 & Abonos, excepto los del grupo 272 & 4 \\
\hline $\begin{array}{l}\text { Vehículos automotores para pasajeros, } \\
\text { excepto autobuses }\end{array}$ & 3 & $\begin{array}{l}\text { Equipo de procesamiento automático } \\
\text { de datos }\end{array}$ & 4 \\
\hline
\end{tabular}




\section{LA AYUDA PARA EL COMERCIO EN SIINTESIS 2013}

\section{INDICADORES COMERCIALES (RESULTADOS)}

Indicador

Crecimiento del PIB (\%)

Número de exportadores

Índice de concentración de las exportaciones (productos) ( 0 a 1)

ACR sobre mercancías notificados a la OMC

AIE (servicios) notificados a la OMC

Sectores de servicios con compromisos en el marco del AGCS

\section{Aranceles (\%, 2006 et 2011)}

\begin{tabular}{ll|l|l|l|} 
Importaciones: promedio aritmético de los aranceles NMF aplicados $\quad 9,9$ & 10,2
\end{tabular}

\begin{tabular}{l|l|l|l|} 
Importaciones: promedio ponderado de los aranceles NMF aplicados & 6,5 & 6,5
\end{tabular}

Exportaciones: promedio ponderado de los aranceles impuestos $\quad 0,4 \quad 2,8$

por los importadores

\begin{tabular}{l|c|c|} 
Exportaciones: libres de derechos (en \%) & 93,2 & 74,6
\end{tabular}

Fuentes: Naciones Unidas, base de datos Comtrade; Banco Mundial, base de datos

Desarrollo Mundial; OMC, perfiles comerciales y arancelarios.

Participación en las exportaciones por región (\%)

\begin{tabular}{|l|r|r|}
\hline & $\mathbf{2 0 0 5}$ & $\mathbf{2 0 1 1}$ \\
\hline África & 1,1 & 2,5 \\
\hline Asia & 7,1 & 5,1 \\
\hline Comunidad de Estados Independientes & 6,2 & 4,2 \\
\hline Europa & 7,5 & 14,8 \\
\hline Oriente Medio & 2,2 & 3,7 \\
\hline América del Norte & 3,6 & 2,9 \\
\hline América del Sury América Central & 72,0 & 66,8 \\
\hline
\end{tabular}

Fuentes: OMC, perfiles comerciales y arancelarios

Indicadores de facilitación del comercio
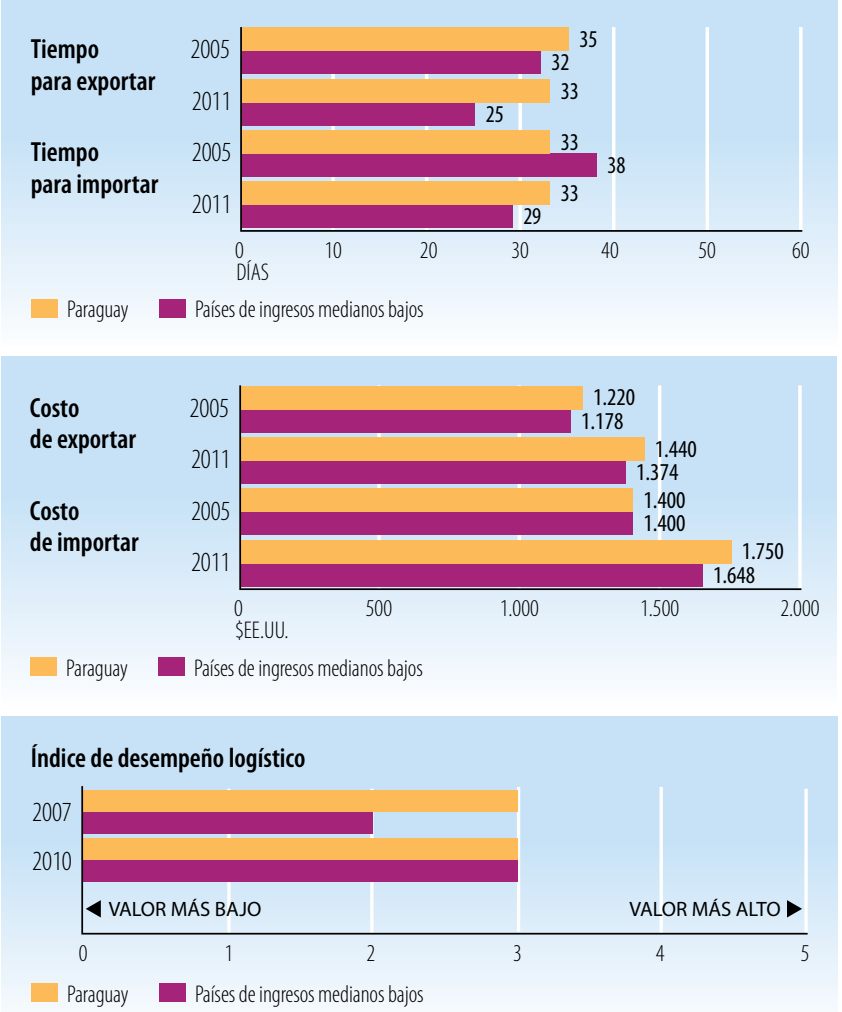

Fuentes: Banco Mundial, Indicadores del Desarrollo Mundial.

\begin{tabular}{|l|r|r|}
\hline INDICADORES DE DESARROLLO (EFECTOS) & \\
\hline Indicador & $\mathbf{2 0 0 5}$ & $\mathbf{2 0 1 0}$ \\
\hline Desempleo (\% de la fuerza de trabajo total) & 5,8 & 5,6 \\
\hline Población activa, mujeres (\% de la fuerza de trabajo total) & 38,6 & 39,7 \\
\hline AOD neta recibida (\% del INB) & 0,7 & 0,6 \\
\hline Derechos de importación percibidos (\% de los ingresos fiscales) & 14,1 & 12,8 \\
\hline Total del servicio de la deuda (\% de las exportaciones totales) & 11,3 & 4,6 \\
\hline Índice de desarrollo humano ( 0 a 1) & 0,64 & 0,66 \\
\hline
\end{tabular}

Fuentes: PNUD, indicadores internacionales sobre desarrollo humano; Banco Mundial, Indicadores del Desarrollo Mundial.

Producto interno bruto

PIB per cápita (PPA, dólares internacionales corrientes)
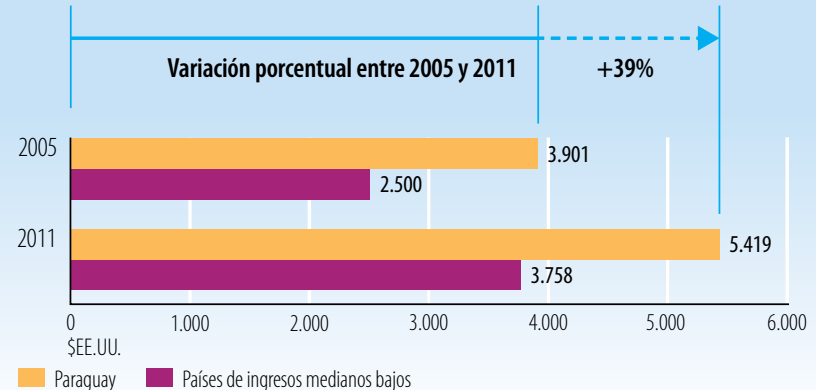

Paraquay Países de ingresos medianos bajos

PIB per cápita (\$EE.UU. constantes de 2000)
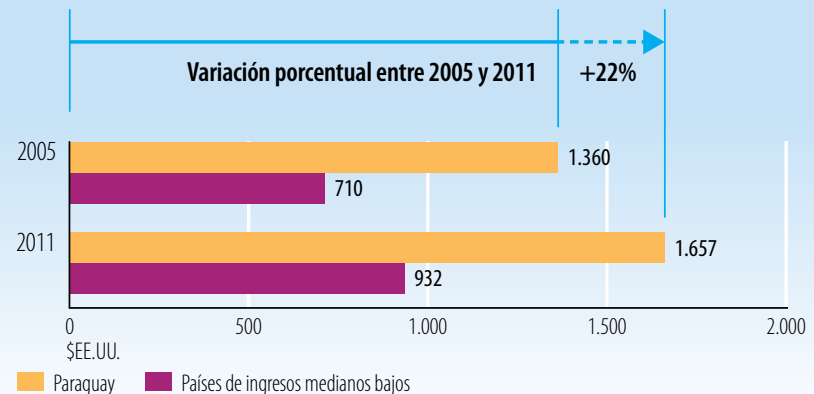

Fuentes: Banco Mundial, Indicadores del Desarrollo Mundial.

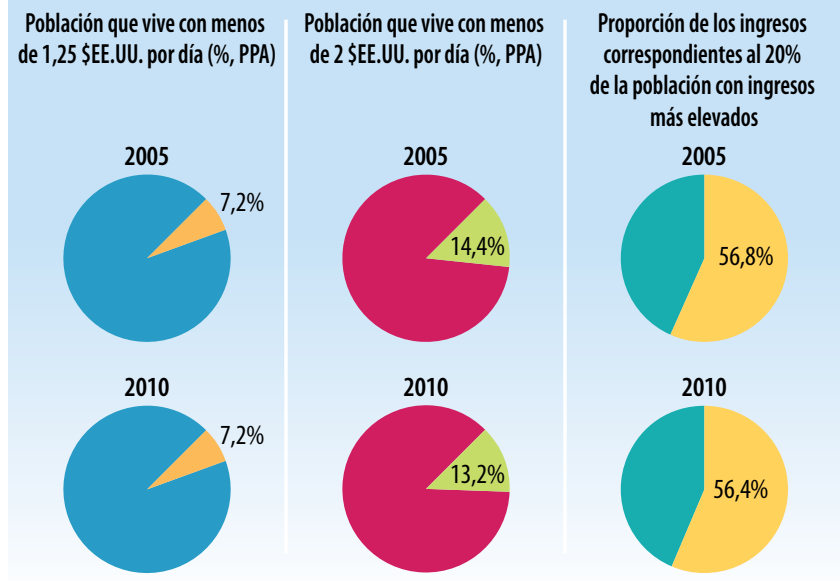

Fuentes: Banco Mundial, Indicadores del Desarrollo Mundial.

StatLink 젝ㄴ $h$ ttp://dx.doi.org/10.1787/888932845797 


\section{Indicadores de la ayuda, el comercio y el desarrollo relativos al Perú}

\section{INVERSIÓN Y FINANCIACIÓN (APORTES)}

\begin{tabular}{|c|c|c|c|c|}
\hline Indicador (millones de \$EE.UU. corrientes) & 2005 & 2008 & 2010 & $\Delta: 05-10(\%)$ \\
\hline Formación bruta de capital fijo & $14.552,9$ & $32.799,6$ & $38.608,1$ & $165 \%$ \\
\hline del cual: público & $2.274,0$ & $5.482,3$ & $9.108,2$ & $301 \%$ \\
\hline del cual: privado & $12.279,0$ & $27.317,3$ & $29.499,9$ & $140 \%$ \\
\hline \multicolumn{5}{|l|}{ Entrada de financiación externa } \\
\hline Entradas de IED & $2.578,7$ & $6.923,7$ & $7.328,2$ & $184 \%$ \\
\hline $\begin{array}{l}\text { Deuda externa a largo plazo y fondos } \\
\text { desembolsados por el FMI }\end{array}$ & $3.721,3$ & $4.630,4$ & $8.295,7$ & $123 \%$ \\
\hline $\begin{array}{l}\text { Corrientes comerciales en condiciones no } \\
\text { concesionarias }\end{array}$ & 73,8 & 171,4 & 884,7 & $1099 \%$ \\
\hline Corrientes de Ayuda para el Comercio & 100,1 & 160,6 & 163,9 & $64 \%$ \\
\hline $\begin{array}{l}\text { Remesas de trabajadores y remuneración } \\
\text { de empleados }\end{array}$ & $1.440,1$ & $2.443,6$ & $2.533,9$ & $76 \%$ \\
\hline
\end{tabular}

Fuentes: OCDE, base de datos del SNPA del CAD sobre las actividades de ayuda; Banco Mundial, Indicadores del Desarrollo Mundial; Banco Mundial, estadísticas de la deuda internacional.

Desembolsos de la ayuda para el comercio, por sector (millones de \$̦EE.UU. corrientes)

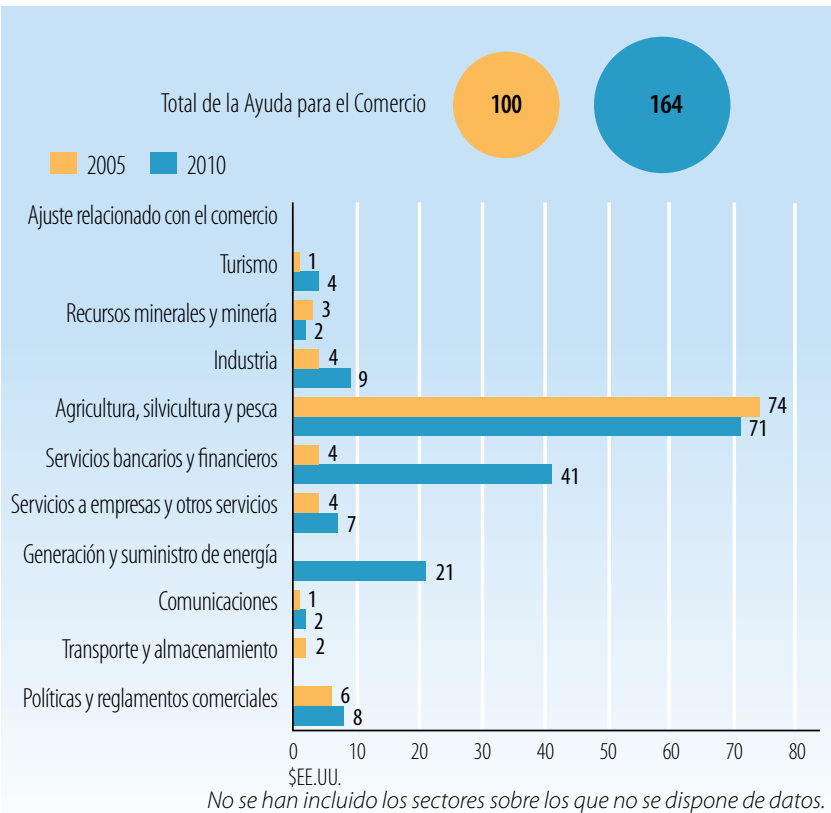

Fuentes: OCDE, base de datos del SNPA del CAD sobre las actividades de ayuda

Desembolsos de la ayuda para el comercio: principales donantes (millones de \$EE.UU. corrientes)

\begin{tabular}{|l|c|c|}
\hline $\mathbf{2 0 0 5}$ & Valor & $\%$ \\
\hline Estados Unidos & 49,6 & 50 \\
\hline Instituciones de la UE & 12,1 & 12 \\
\hline Alemania & 11,3 & 11 \\
\hline España & 8,9 & 9 \\
\hline Bélgica & 5,0 & 5 \\
\hline $\mathbf{2 0 1 0}$ & Valor & $\%$ \\
\hline España & 47,5 & 29 \\
\hline Japón & 35,4 & 22 \\
\hline Estados Unidos & 32,7 & 20 \\
\hline Bélgica & 16,3 & 10 \\
\hline BID & 6,6 & 4 \\
\hline
\end{tabular}

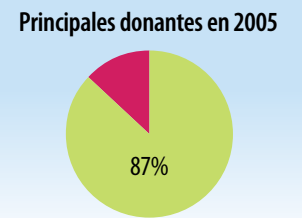

Principales donantes en 2010

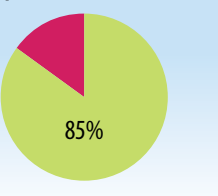

Fuentes: OCDE, base de datos del SNPA del CAD sobre las actividades de ayuda.

\section{INDICADORES COMERCIALES (PRODUCTOS)}

\section{Indicador}

$2005 \quad 2008 \quad 2011 \quad \Delta: 05-11(\%)$

Relación comercio/PIB (\%)

\begin{tabular}{l|l|l|l|l}
44 & 54 & 55 & 12
\end{tabular}

Exportaciones de servicios comerciales como

$\%$ de las exportaciones totales

Importaciones de servicios comerciales como

$\%$ de las importaciones totales

Productos intermedios distintos de los combustibles

(\% de las exportaciones de mercancías)

Productos intermedios distintos de los combustibles

(\% de las importaciones de mercancías)

\begin{tabular}{l|l|l|l|}
11 & 10 & 9 & -2
\end{tabular}

\begin{tabular}{|l|l|r|r|}
\hline 20 & 16 & 15 & -5
\end{tabular}

\begin{tabular}{|l|l|r|r|}
75 & 76 & 76 & 2 \\
\hline
\end{tabular}

\begin{tabular}{l|l|l|l|}
\hline 46 & 45 & 46 & 0
\end{tabular}

Fuentes: Secretaría de la OMC

Corrientes comerciales (millones de \$EE.UU. corrientes)

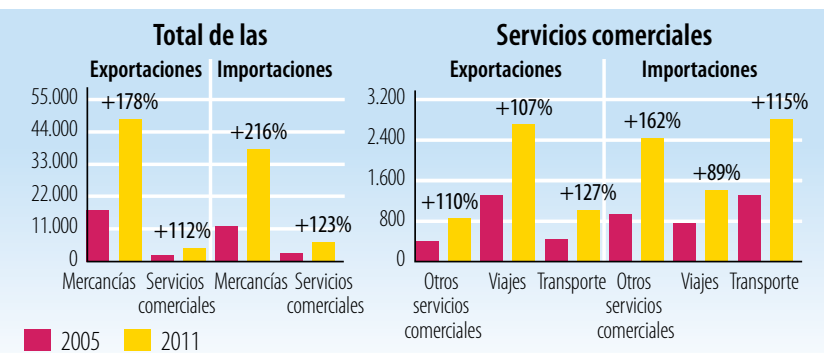

Fuentes: Secretaría de la OMC

Cinco principales mercados de exportación de mercancías (\%)

\begin{tabular}{|l|r|l|l|}
\hline 2005 & $\%$ & 2011 & $\%$ \\
\hline Estados Unidos & 31 & UE (27) & 18 \\
\hline UE (27) & 17 & China & 15 \\
\hline China & 11 & Estados Unidos & 13 \\
\hline Chile & 7 & Suiza & 13 \\
\hline Canadá & 6 & Canadá & 9 \\
\hline
\end{tabular}

Fuentes: Secretaría de la OMC

Cinco principales productos de exportación (\% de las exportaciones de mercancías)

\begin{tabular}{|c|c|c|c|}
\hline 2005 & $\%$ & 2011 & $\%$ \\
\hline Oro no monetario, excepto minerales & 18 & Oro no monetario, excepto minerales & 22 \\
\hline $\begin{array}{l}\text { Minerales de metales comunes y sus } \\
\text { concentrados }\end{array}$ & 13 & Minerales de cobre y sus concentrados & 17 \\
\hline Cobre & 12 & $\begin{array}{l}\text { Minerales de metales comunes y sus } \\
\text { concentrados }\end{array}$ & 8 \\
\hline Minerales de cobre y sus concentrados & 8 & Cobre & 7 \\
\hline Productos derivados del petróleo & 8 & Productos derivados del petróleo & 6 \\
\hline
\end{tabular}

Cinco principales mercados de importación de mercancías (\%)

\begin{tabular}{|l|r|l|r|}
\hline 2005 & $\%$ & 2011 & $\%$ \\
\hline Estados Unidos & 18 & Estados Unidos & 20 \\
\hline UE (27) & 12 & China & 17 \\
\hline China & 8 & UE (27) & 11 \\
\hline Brasil & 8 & Brasil & 6 \\
\hline Ecuador & 7 & Ecuador & 5
\end{tabular}

Fuentes: Secretaría de la OMC

Cinco principales productos de importación (\% de las importaciones de mercancías)

\begin{tabular}{|c|c|c|c|}
\hline 2005 & $\%$ & 2011 & $\%$ \\
\hline Aceites de petróleo, crudos & 14 & Aceites de petróleo, crudos & 10 \\
\hline Productos derivados del petróleo & 4 & Productos derivados del petróleo & 6 \\
\hline $\begin{array}{l}\text { Equipos de telecomunicaciones y sus } \\
\text { partes, n.e.p. }\end{array}$ & 3 & $\begin{array}{l}\text { Vehículos automotores para pasajeros, } \\
\text { excepto autobuses }\end{array}$ & 3 \\
\hline Papel y cartón & 2 & $\begin{array}{l}\text { Vehículos automotores para el transporte } \\
\text { de mercancías y vehículos automotores } \\
\text { para usos especiales }\end{array}$ & 3 \\
\hline $\begin{array}{l}\text { Vehículos automotores para pasajeros, } \\
\text { excepto autobuses }\end{array}$ & 2 & Equipo de ingeniería civil & 3 \\
\hline
\end{tabular}




\section{LA AYUDA PARA EL COMERCIO EN SÍNTESIS 2013}

\section{INDICADORES COMERCIALES (RESULTADOS)}

\section{Indicador}

Crecimiento del PIB (\%)

Número de exportadores

Índice de concentración de las exportaciones (productos) ( 0 a 1)

ACR sobre mercancías notificados a la OMC

AIE (servicios) notificados a la OMC

Sectores de servicios con compromisos en el marco del AGCS

\section{Aranceles (\%, 2006 et 2011)}

\begin{tabular}{l|l|l|l|} 
Importaciones: promedio aritmético de los aranceles NMF aplicados & 10,2 & 3,7
\end{tabular}

\begin{tabular}{ll|l|l|} 
Importaciones: promedio ponderado de los aranceles NMF aplicados $\quad 7,1$ & 2,8
\end{tabular}

Exportaciones: promedio ponderado de los aranceles impuestos $\quad 1,6 \quad 0,2$

por los importadores

Exportaciones: libres de derechos (en \%)

$84,0 \quad 94,2$

Fuentes: Naciones Unidas, base de datos Comtrade; Banco Mundial, base de datos sobre dinámica de las empresas de exportación; Banco Mundial, Indicadores del

Desarrollo Mundial; OMC, perfiles comerciales y arancelarios.

Participación en las exportaciones por región (\%)

\begin{tabular}{|l|r|r|}
\hline & $\mathbf{2 0 0 5}$ & $\mathbf{2 0 1 1}$ \\
\hline África & 0,4 & 1,0 \\
\hline Asia & 19,2 & 26,8 \\
\hline Comunidad de Estados Independientes & 0,2 & 0,2 \\
\hline Europa & 22,2 & 31,3 \\
\hline Oriente Medio & 0,1 & 0,1 \\
\hline América del Norte & 38,6 & 23,5 \\
\hline América del Sury América Central & 18,8 & 16,5 \\
\hline
\end{tabular}

Fuentes: OMC, perfiles comerciales y arancelarios

Indicadores de facilitación del comercio

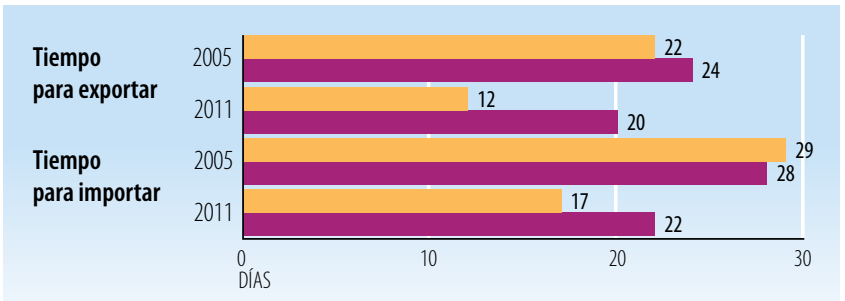

Perú Países de ingresos medianos altos
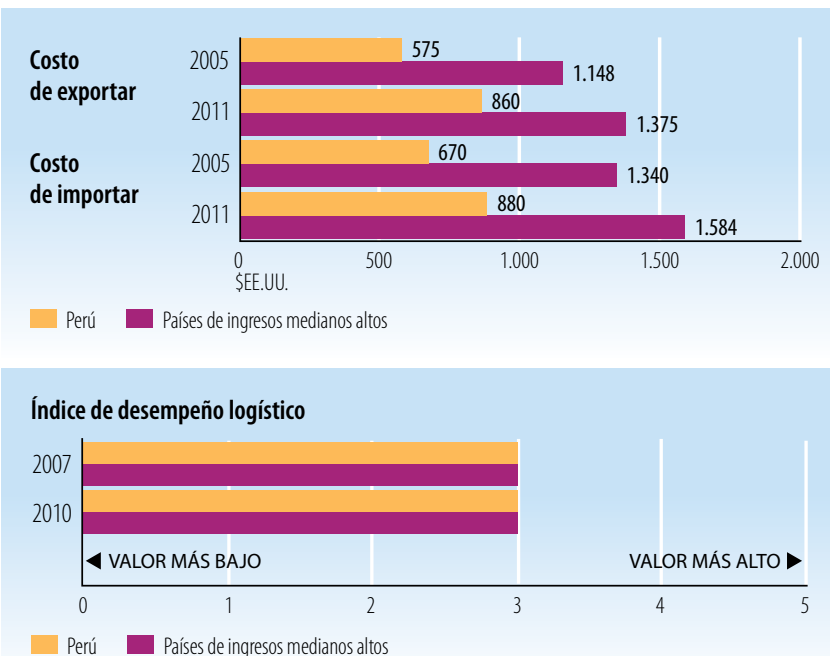

Fuentes: Banco Mundial, Indicadores del Desarrollo Mundial.

\begin{tabular}{l|c|c|}
\hline \multicolumn{2}{|l}{ INDICADORES DE DESARROLLO (EFECTOS) } \\
\hline Indicador & 2005 & 2010 \\
\hline Desempleo (\% de la fuerza de trabajo total) & 11,4 & 6,3 \\
\hline Población activa, mujeres (\% de la fuerza de trabajo total) & 42,3 & 44,6 \\
\hline AOD neta recibida (\% del INB) & 0,6 & $-0,2$ \\
\hline Derechos de importación percibidos (\% de los ingresos fiscales) & 7,3 & 2,7 \\
\hline Total del servicio de la deuda (\% de las exportaciones totales) & 29,9 & 16,7 \\
\hline Índice de desarrollo humano (0 a 1) & 0,69 & 0,72 \\
\hline
\end{tabular}

Fuentes: PNUD, indicadores internacionales sobre desarrollo humano; Banco Mundial, Indicadores del Desarrollo Mundial.

Producto interno bruto

PIB per cápita (PPA, dólares internacionales corrientes)

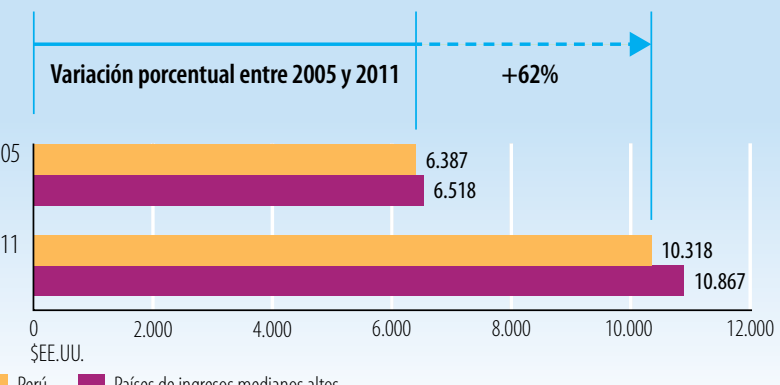

Perú — Páses de ingresos medianos altos

PIB per cápita (\$EE.UU. constantes de 2000)

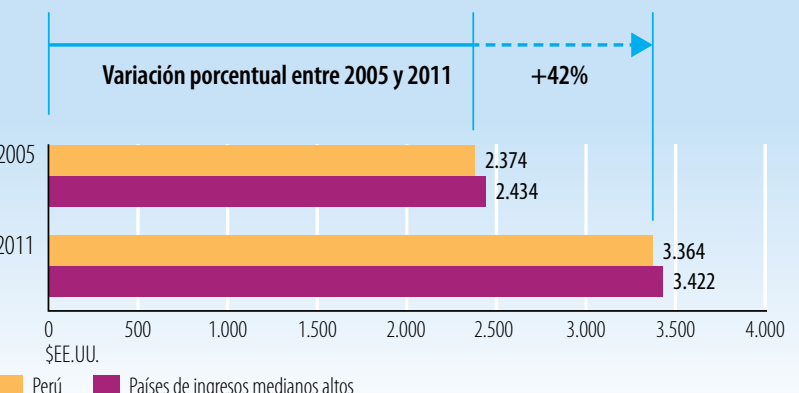

Fuentes: Banco Mundial, Indicadores del Desarrollo Mundial.

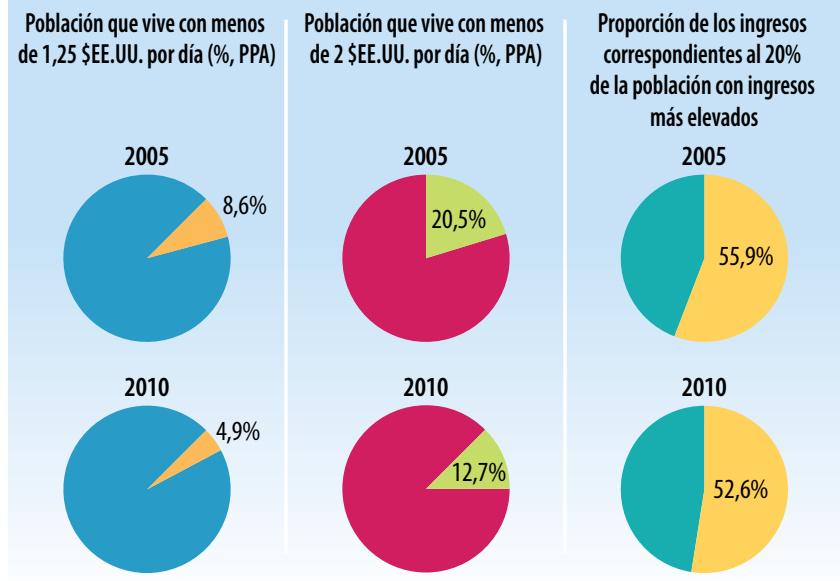

Fuentes: Banco Mundial, Indicadores del Desarrollo Mundial.

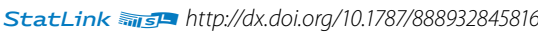


Indicadores de la ayuda, el comercio y el desarrollo relativos a la República Centroafricana

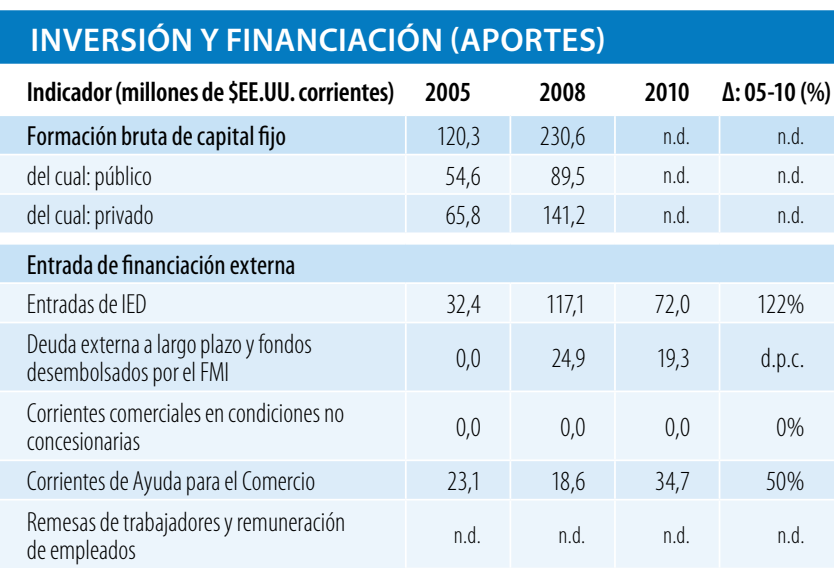

Fuentes: OCDE, base de datos del SNPA del CAD sobre las actividades de ayuda; Banco Mundial, Indicadores del Desarrollo Mundial; Banco Mundial, estadísticas de la deuda internacional.

Desembolsos de la ayuda para el comercio, por sector (millones de \$EE.UU. corrientes)

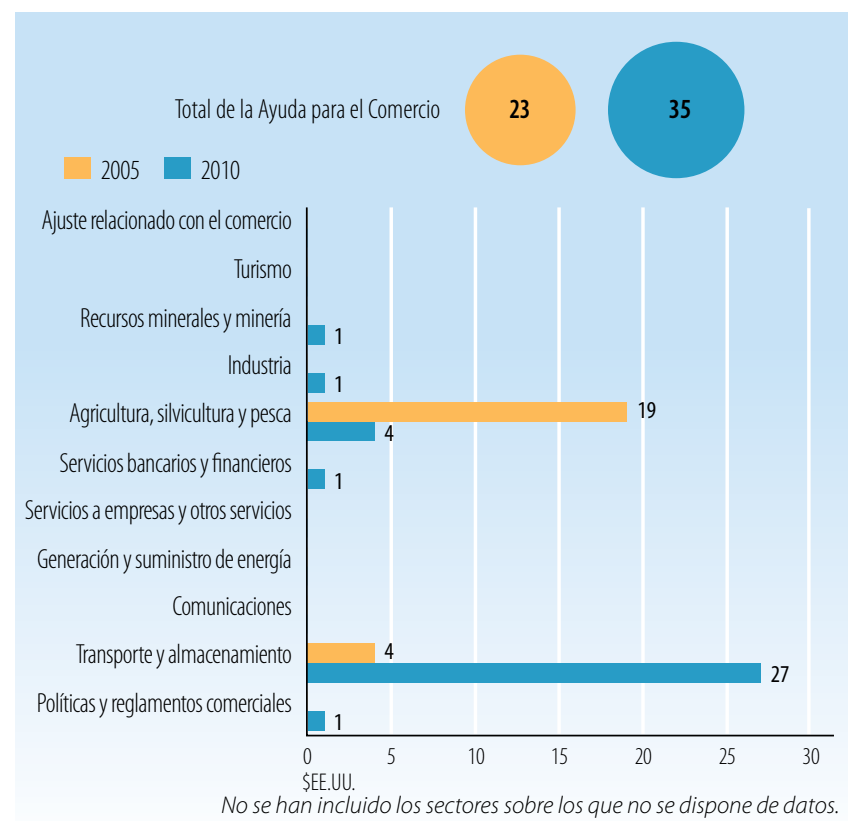

Fuentes: OCDE, base de datos del SNPA del CAD sobre las actividades de ayuda

Desembolsos de la ayuda para el comercio: principales donantes (millones de \$EE.UU. corrientes)

\begin{tabular}{|l|r|r|r|}
\hline $\mathbf{2 0 0 5}$ & Valor & $\%$ & Principales donantes en 2005 \\
\hline Estados Unidos & 16,8 & 73 & \\
\hline Francia & 3,3 & 14 & $100 \%$ \\
\hline Alemania & 2,0 & 9 & \\
\hline Instituciones de la UE & 0,7 & 3 & \\
\hline PNUD & 0,2 & 1 & \\
\hline $\mathbf{2 0 1 0}$ & Valor & $\%$ & Principales donantes en 2010 \\
\hline Instituciones de la UE & 23,0 & 66 & \\
\hline Banco Mundial & 8,2 & 24 & \\
\hline Estados Unidos & 1,7 & 5 & \\
\hline Francia & 0,7 & 2 & $98 \%$ \\
\hline PNUD & 0,4 & 1 & \\
\hline
\end{tabular}

Fuentes: OCDE, base de datos del SNPA del CAD sobre las actividades de ayuda.

\section{INDICADORES COMERCIALES (PRODUCTOS)}

Indicador $2005 \quad 2008 \quad 2011 \quad \Delta: 05-11(\%)$

Relación comercio/PIB (\%)

Exportaciones de servicios comerciales como

$\%$ de las exportaciones totales

Importaciones de servicios comerciales como

$\%$ de las importaciones totales

Productos intermedios distintos de los combustibles

(\% de las exportaciones de mercancías)

Productos intermedios distintos de los combustibles

(\% de las importaciones de mercancías)

\begin{tabular}{l|l|l|r|}
32 & 33 & 25 & -6
\end{tabular}

Fuentes: Secretaría de la OMC.

Corrientes comerciales (millones de \$EE.UU. corrientes)

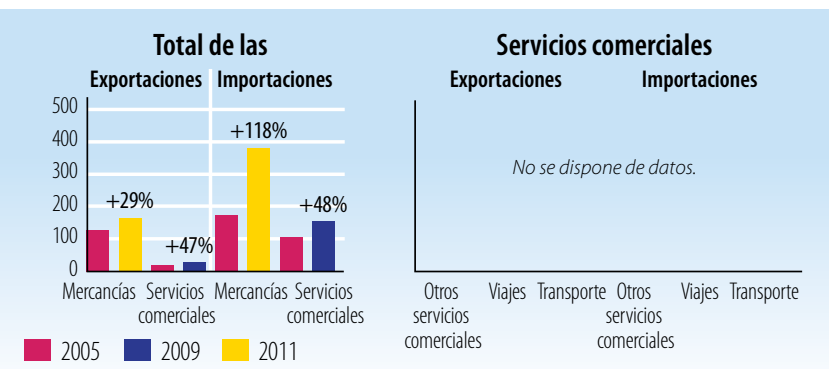

Fuentes: Secretaría de la OMC

Cinco principales mercados de exportación de mercancías (\%)

\begin{tabular}{|l|r|l|r|}
\hline 2005 & $\%$ & 2009 & $\%$ \\
\hline UE (27) & 59 & UE (27) & 80 \\
\hline Suiza & 14 & China & 9 \\
\hline Camerún & 12 & Arabia Saudita, Reino de la & 3 \\
\hline Israel & 5 & Turquía & 2 \\
\hline Hong Kong, China & 3 & Camerún & 1 \\
\hline Fuentes:Secretaría de la OMC & & & \\
\hline
\end{tabular}

Cinco principales productos de exportación (\% de las exportaciones de mercancías)

\begin{tabular}{|l|r|l|l|}
\hline $\mathbf{2 0 0 6}$ & $\%$ & $\mathbf{2 0 0 9}$ & $\%$ \\
\hline Perlas y piedras preciosas & 48 & Abrasivos naturales, n.e.p. & 62 \\
\hline Abrasivos naturales, n.e.p. & 16 & $\begin{array}{l}\text { Madera en bruto o simplemente } \\
\text { escuadrada }\end{array}$ & 20 \\
\hline $\begin{array}{l}\text { Madera trabajada simplemente } \\
\text { Madera en bruto o simplemente }\end{array}$ & 15 & Madera trabajada simplemente & 11 \\
\hline $\begin{array}{l}\text { escuadrada } \\
\text { Operaciones especiales no clasificadas }\end{array}$ & 9 & Caféy sucedáneos del café & 2 \\
\hline \begin{tabular}{l} 
Fuentes: Secretaría de la OMC \\
\hline
\end{tabular} & & Aparatos fotográficos, etc., n.e.p. & 1 \\
\hline
\end{tabular}

Cinco principales mercados de importación de mercancías (\%)

\begin{tabular}{|l|r|l|c|}
\hline 2005 & $\%$ & 2009 & $\%$ \\
\hline UE (27) & 21 & UE (27) & 40 \\
\hline Camerún & 16 & Estados Unidos & 16 \\
\hline Congo, Rep. Democrática del & 6 & Camerún & 9 \\
\hline Japón & 4 & China & 8 \\
\hline Congo, Rep. del & 4 & Japón & 4 \\
\hline Fuentes: Secretaría de la OMC & & & \\
\hline
\end{tabular}

Cinco principales productos de importación (\% de las importaciones de mercancías)

\begin{tabular}{|c|c|c|c|}
\hline 2006 & $\%$ & 2009 & $\%$ \\
\hline Perlas y piedras preciosas & 38 & Legumbres & 11 \\
\hline $\begin{array}{l}\text { Madera en bruto o simplemente } \\
\text { escuadrada }\end{array}$ & 23 & Medicamentos & 10 \\
\hline Madera trabajada simplemente & 19 & $\begin{array}{l}\text { Sémola y harina de trigo y harina de } \\
\text { morcajo o tranquillón }\end{array}$ & 6 \\
\hline Abrasivos naturales, n.e.p. & 12 & $\begin{array}{l}\text { Equipos de telecomunicaciones y sus } \\
\text { partes, n.e.p. }\end{array}$ & 5 \\
\hline Operaciones especiales no clasificadas & 7 & Otras sémolas y harinas de cereales & 4 \\
\hline
\end{tabular}




\section{LA AYUDA PARA EL COMERCIO EN SIINTESIS 2013}

\section{INDICADORES COMERCIALES (RESULTADOS)}

Indicador

Crecimiento del PIB (\%)

Número de exportadores

Índice de concentración de las exportaciones (productos) (0 a 1)

ACR sobre mercancías notificados a la OMC

AIE (servicios) notificados a la OMC

Sectores de servicios con compromisos en el marco del AGCS

\section{Aranceles (\%)}

\begin{tabular}{|l|l|l|} 
Importaciones: promedio aritmético de los aranceles NMF aplicados & 18,0 & 17,8
\end{tabular}

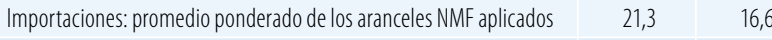

\begin{tabular}{|l|l|l|l|} 
Exportaciones: promedio ponderado de los aranceles impuestos & 0,6 & 2,0
\end{tabular}

por los importadores

Exportaciones: libres de derechos (en \%)

$98,2 \quad 90,1$

Fuentes: Naciones Unidas, base de datos Comtrade; Banco Mundial, base de datos sobre dinámica de las empresas de exportación; Banco Mundial, Indicadores del

Desarrollo Mundial; OMC, perfiles comerciales y arancelarios.

Participación en las exportaciones por región (\%)

\begin{tabular}{|l|r|r|}
\hline & $\mathbf{2 0 0 5}$ & 2009 \\
\hline África & 15,4 & 3,2 \\
\hline Asia & 3,3 & 10,1 \\
\hline Comunidad de Estados Independientes & 0,0 & 0,0 \\
\hline Europa & 74,3 & 82,5 \\
\hline Oriente Medio & 5,2 & 3,1 \\
\hline América del Norte & 0,3 & 1,1 \\
\hline América del Sury América Central & 0,0 & 0,0 \\
\hline
\end{tabular}

Fuentes: OMC, perfiles comerciales y arancelarios

Indicadores de facilitación del comercio
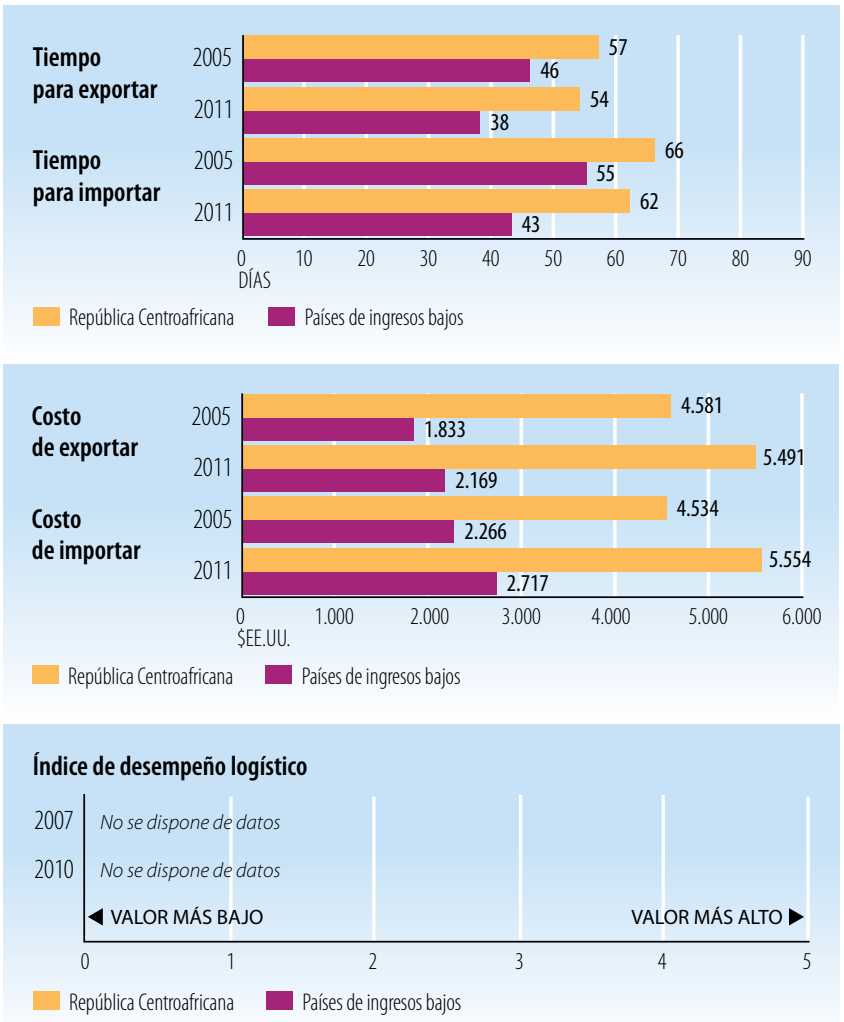

Fuentes: Banco Mundial, Indicadores del Desarrollo Mundial.

\begin{tabular}{l|c|c|}
\hline INDICADORES DE DESARROLLO (EFECTOS) & \\
\hline Indicador & $\mathbf{2 0 0 5}$ & $\mathbf{2 0 1 0}$ \\
\hline Desempleo (\% de la fuerza de trabajo total) & n.d. & n.d. \\
\hline Población activa, mujeres (\% de la fuerza de trabajo total) & 46,8 & 47,1 \\
\hline A0D neta recibida (\% del INB) & 6,6 & 13,2 \\
\hline Derechos de importación percibidos (\% de los ingresos fiscales) & n.d. & 19,4 \\
\hline Total del servicio de la deuda (\% de las exportaciones totales) & n.d. & n.d. \\
\hline Índice de desarrollo humano (0 a 1) & 0,31 & 0,34 \\
\hline
\end{tabular}

Fuentes: PNUD, indicadores internacionales sobre desarrollo humano; Banco Mundial, Indicadores del Desarrollo Mundial.

Producto interno bruto

PIB per cápita (PPA, dólares internacionales corrientes)

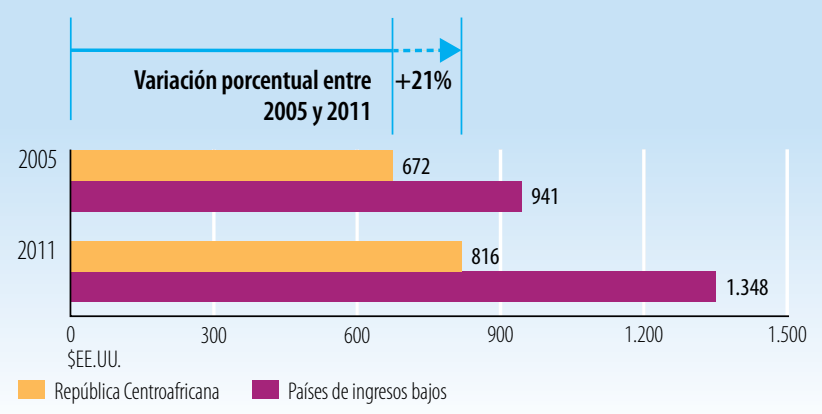

PIB per cápita (\$EE.UU. constantes de 2000)

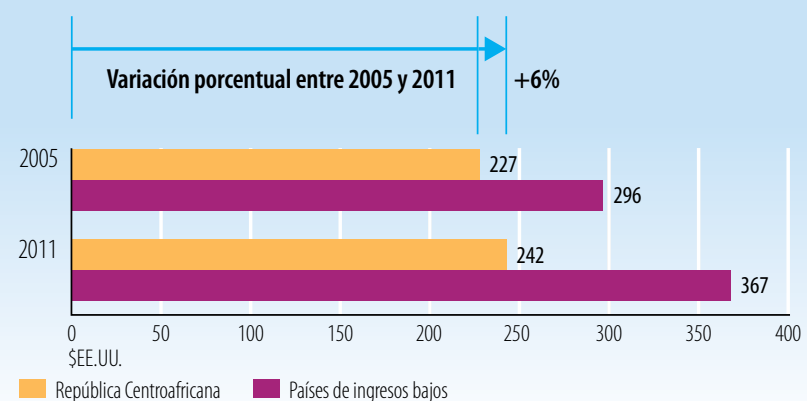

Fuentes: Banco Mundial, Indicadores del Desarrollo Mundial.

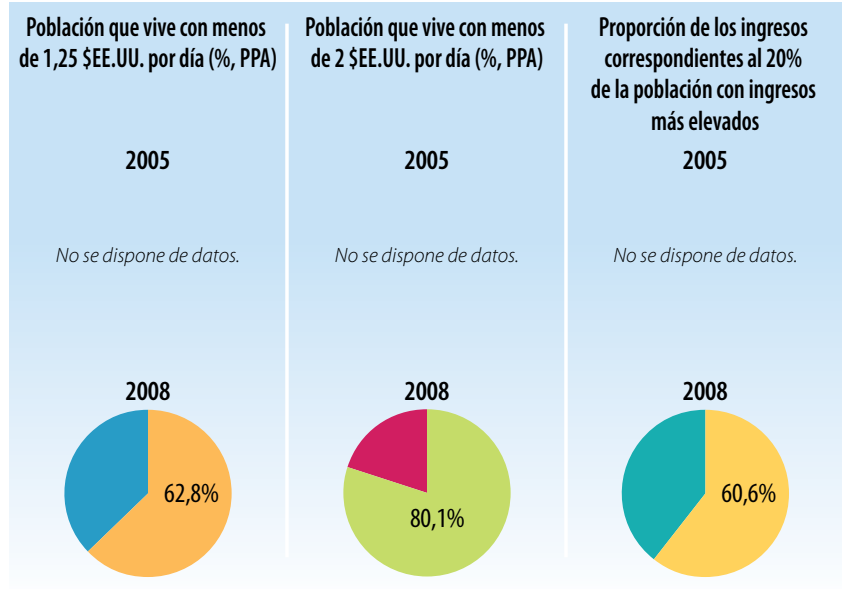

Fuentes: Banco Mundial, Indicadores del Desarrollo Mundial.

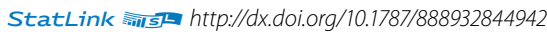




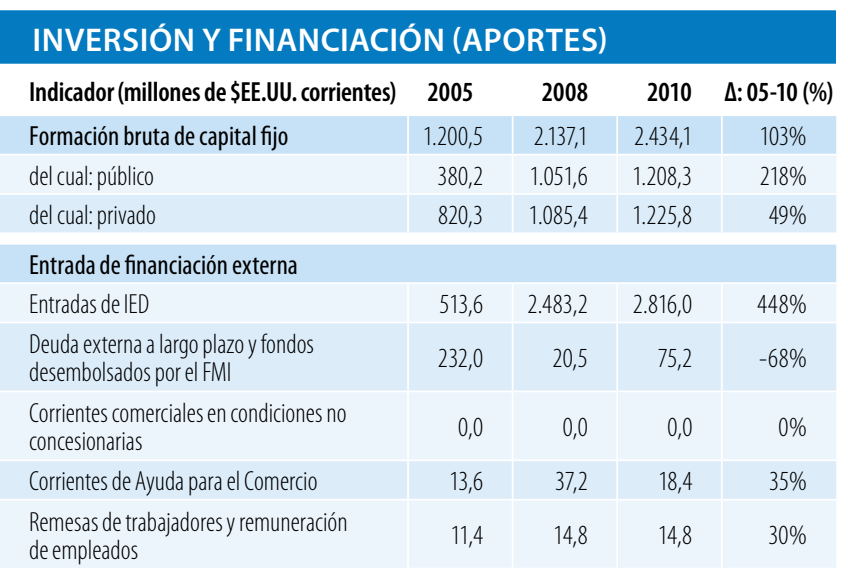

Fuentes: OCDE, base de datos del SNPA del CAD sobre las actividades de ayuda; Banco Mundial, Indicadores del Desarrollo Mundial; Banco Mundial, estadísticas de la deuda internacional.

Desembolsos de la ayuda para el comercio, por sector (millones de \$EE.UU. corrientes)

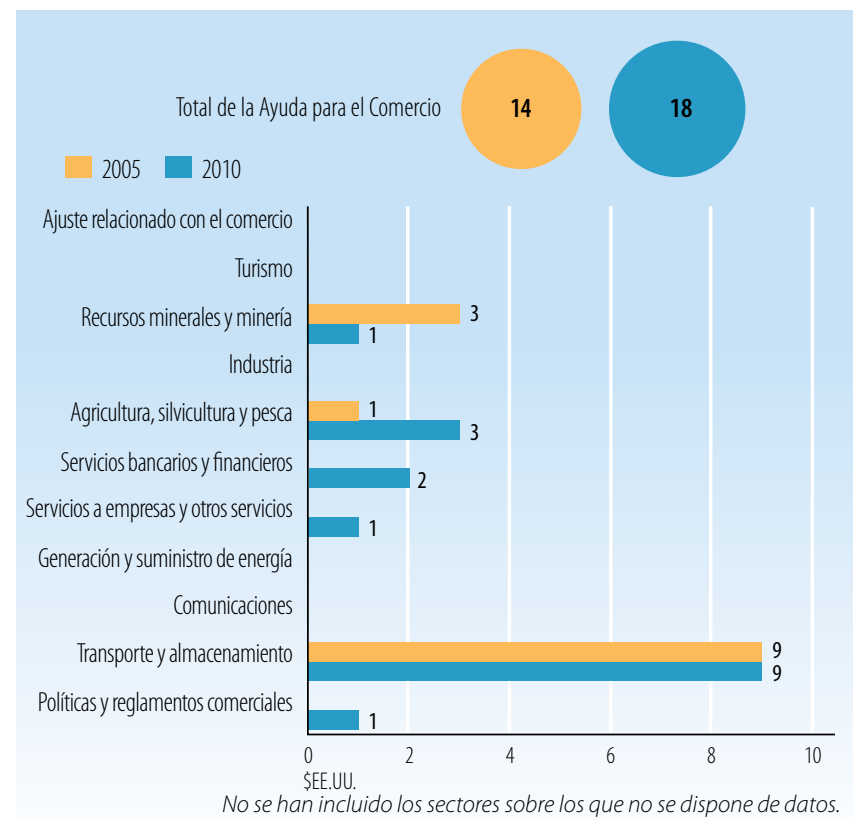

Fuentes: OCDE, base de datos del SNPA del CAD sobre las actividades de ayuda

Desembolsos de la ayuda para el comercio: principales donantes (millones de \$EE.UU. corrientes)

\begin{tabular}{|l|c|c|c|}
\hline $\mathbf{2 0 0 5}$ & Valor & $\%$ & Principales donantes en 2005 \\
\hline Banco Mundial & 12,5 & 91 & \\
\hline Francia & 0,8 & 6 & \multirow{2}{*}{ (100\% } \\
\hline Instituciones de la UE & 0,3 & 2 & \\
\hline PNUD & 0,0 & 0 & \\
\hline Bélgica & 0,0 & 0 & \\
\hline $\mathbf{2 0 1 0}$ & Valor & $\%$ & Principales donantes en 2010 \\
\hline Instituciones de la UE & 9,1 & 49 & \\
\hline Banco Mundial & 4,7 & 26 & \\
\hline Banco Africano de Desarrollo & 1,9 & 10 & \\
\hline Francia & 1,8 & 10 & \\
\hline Japón & 0,4 & 2 & \\
\hline
\end{tabular}

Fuentes: OCDE, base de datos del SNPA del CAD sobre las actividades de ayuda.

\section{INDICADORES COMERCIALES (PRODUCTOS)}

Indicador $20052008 \quad 2011 \quad \Delta: 05-11(\%)$

Relación comercio/PIB (\%)

\begin{tabular}{l|l|l|r|}
126 & 129 & 107 & -19 \\
\hline
\end{tabular}

Exportaciones de servicios comerciales como

$\%$ de las exportaciones totales

Importaciones de servicios comerciales como

$\%$ de las importaciones totales

Productos intermedios distintos de los combustibles

(\% de las exportaciones de mercancías)

Productos intermedios distintos de los combustibles

(\% de las importaciones de mercancías)

\begin{tabular}{l|l|l|l}
4 & 4 & n.d. & n.d.
\end{tabular}

\begin{tabular}{l|l|l|l|}
\hline 52 & 54 & n.d. & n.d.
\end{tabular}

n.d. 3 n.d. $\quad$ n.d.

\begin{tabular}{l|l|r|} 
n.d. & 23 & n.d.
\end{tabular}

Fuentes: Secretaría de la OMC.

Corrientes comerciales (millones de \$EE.UU. corrientes)

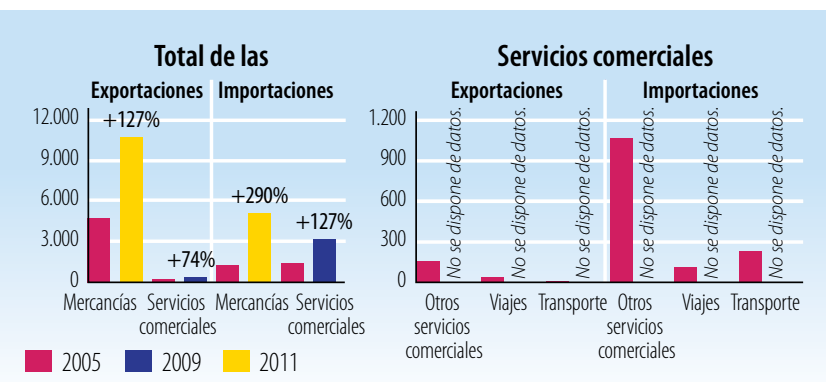

Fuentes: Secretaría de la OMC

Cinco principales mercados de exportación de mercancías (\%)

No se dispone de datos.

No se dispone de datos.

Fuentes: Secretaría de la OMC

Cinco principales productos de exportación (\% de las exportaciones de mercancías)

\begin{tabular}{|c|c|c|c|}
\hline 2007 & $\%$ & 2010 & $\%$ \\
\hline Aceites de petróleo, crudos & 84 & Aceites de petróleo, crudos & 65 \\
\hline $\begin{array}{l}\text { Buques, embarcaciones y estructuras } \\
\text { flotantes }\end{array}$ & 8 & $\begin{array}{l}\text { Buques, embarcaciones y estructuras } \\
\text { flotantes }\end{array}$ & 27 \\
\hline Productos derivados del petróleo & 2 & Propano y butano licuados & 2 \\
\hline $\begin{array}{l}\text { Madera en bruto o simplemente } \\
\text { escuadrada }\end{array}$ & 2 & $\begin{array}{l}\text { Madera en bruto o simplemente } \\
\text { escuadrada }\end{array}$ & 1 \\
\hline Madera trabajada simplemente & 1 & Instrumentos de medición y control & 1 \\
\hline
\end{tabular}

Cinco principales mercados de importación de mercancías (\%)

$\%$

No se dispone de datos.
Fuentes: Secretaría de la OMC

Cinco principales productos de importación (\% de las importaciones de mercancías)

\begin{tabular}{|c|c|c|c|}
\hline 2007 & $\%$ & 2010 & $\%$ \\
\hline $\begin{array}{l}\text { Buques, embarcaciones y estructuras } \\
\text { flotantes }\end{array}$ & 65 & $\begin{array}{l}\text { Buques, embarcaciones y estructuras } \\
\text { flotantes }\end{array}$ & 61 \\
\hline Productos derivados del petróleo & 4 & Productos derivados del petróleo & 5 \\
\hline Instrumentos de medición y control & 2 & Equipo de ingeniería civil & 3 \\
\hline Equipo de ingeniería civil & 2 & $\begin{array}{l}\text { Manufacturas de metales comunes, } \\
\text { n.e.p. }\end{array}$ & 2 \\
\hline Medicamentos & 1 & $\begin{array}{l}\text { Cal, cemento y materiales de } \\
\text { construcción }\end{array}$ & 2 \\
\hline
\end{tabular}




\section{LA AYUDA PARA EL COMERCIO EN SIINTESIS 2013}

\section{INDICADORES COMERCIALES (RESULTADOS)}

\section{Indicador}

Crecimiento del PIB (\%)

Número de exportadores

Índice de concentración de las exportaciones (productos) ( 0 a 1)

ACR sobre mercancías notificados a la OMC

AlE (servicios) notificados a la OMC

Sectores de servicios con compromisos en el marco del AGCS

\section{Aranceles $(\%, 2006$ et 2011)}

\begin{tabular}{l|l|l|l|} 
Importaciones: promedio aritmético de los aranceles NMF aplicados & 18,4
\end{tabular}

Importaciones: promedio ponderado de los aranceles NMF aplicados n.d. n.d.

$\begin{array}{ccc}\text { Exportaciones: promedio ponderado de los aranceles impuestos } & 0,6 & 0,4\end{array}$

por los importadores

$85,3 \quad 93,8$

Exportaciones: libres de derechos (en \%)
Fuentes: Naciones Unidas, base de datos Comtrade; Banco Mundial, base de dato sobre dinámica de las empresas de exportación; Banco Mundial, Indicadores del

Desarrollo Mundial; OMC, perfiles comerciales y arancelarios.

Participación en las exportaciones por región (\%)

\begin{tabular}{|l|r|r|}
\hline & $\mathbf{2 0 0 7}$ & $\mathbf{2 0 1 0}$ \\
\hline África & 10,0 & 21,7 \\
\hline Asia & 61,0 & 34,1 \\
\hline Comunidad de Estados Independientes & 0,0 & 0,0 \\
\hline Europa & 10,0 & 24,1 \\
\hline Oriente Medio & 0,0 & 0,1 \\
\hline América del Norte & 12,1 & 11,7 \\
\hline América del Sury América Central & 6,0 & 2,8 \\
\hline
\end{tabular}

Fuentes: OMC, perfiles comerciales y arancelarios

Indicadores de facilitación del comercio
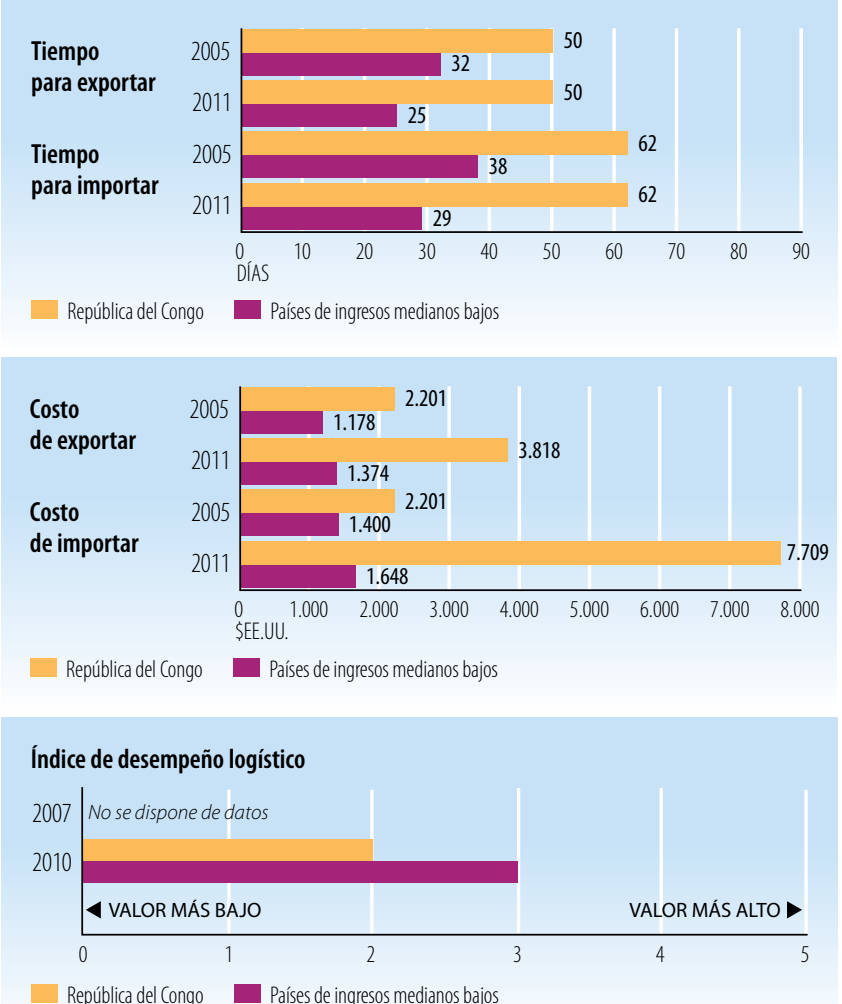

Fuentes: Banco Mundial, Indicadores del Desarrollo Mundial.

\begin{tabular}{l|c|c|}
\hline INDICADORES DE DESARROLLO (EFECTOS) & \\
\hline Indicador & $\mathbf{2 0 0 5}$ & $\mathbf{2 0 1 0}$ \\
\hline Desempleo (\% de la fuerza de trabajo total) & n.d. & n.d. \\
\hline Población activa, mujeres (\% de la fuerza de trabajo total) & 48,8 & 48,6 \\
\hline AOD neta recibida (\% del INB) & 35,4 & 14,5 \\
\hline Derechos de importación percibidos (\% de los ingresos fiscales) & 17,0 & n.d. \\
\hline Total del servicio de la deuda (\% de las exportaciones totales) & 2,2 & n.d. \\
\hline Índice de desarrollo humano ( 0 a 1) & 0,51 & 0,53 \\
\hline
\end{tabular}

Fuentes: PNUD, indicadores internacionales sobre desarrollo humano; Banco Mundial, Indicadores del Desarrollo Mundial.

Producto interno bruto

PIB per cápita (PPA, dólares internacionales corrientes)

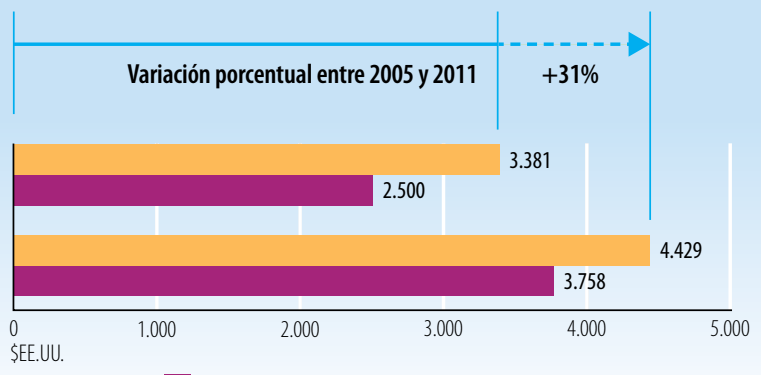

República del Congo Países de ingresos medianos bajos

PIB per cápita (\$EE.UU. constantes de 2000)
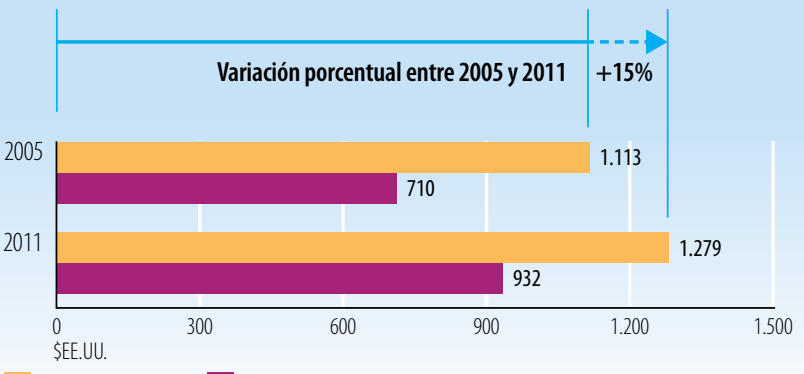

República del Congo Países de ingresos medianos bajos

Fuentes: Banco Mundial, Indicadores del Desarrollo Mundial.

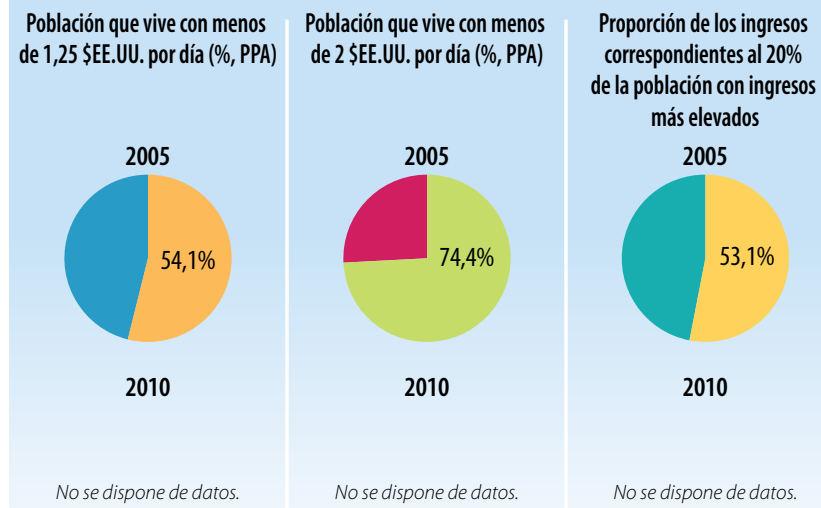

Fuentes: Banco Mundial, Indicadores del Desarrollo Mundial.

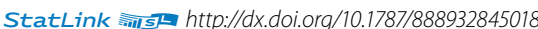


Indicadores de la ayuda, el comercio y el desarrollo relativos a la República Democrática del Congo

\begin{tabular}{|c|c|c|c|c|}
\hline Indicador (millones de \$̦EE.UU. corrientes) & 2005 & 2008 & 2010 & $\Delta: 05-10(\%$ \\
\hline Formación bruta de capital fijo & $1.008,3$ & $2.783,9$ & n.d. & n.d. \\
\hline del cual: público & 262,6 & $1.466,8$ & n.d. & n.d. \\
\hline del cual: privado & 745,7 & $1.317,0$ & n.d. & n.d. \\
\hline \multicolumn{5}{|l|}{ Entrada de financiación externa } \\
\hline Entradas de IED & n.d. & $1.726,8$ & $2.939,3$ & n.d. \\
\hline $\begin{array}{l}\text { Deuda externa a largo plazo y fondos } \\
\text { desembolsados por el FMl }\end{array}$ & 288,1 & 99,9 & 116,0 & $-60 \%$ \\
\hline $\begin{array}{l}\text { Corrientes comerciales en condiciones no } \\
\text { concesionarias }\end{array}$ & 0,0 & 0,0 & 0,0 & $0 \%$ \\
\hline Corrientes de Ayuda para el Comercio & 204,7 & 261,8 & 287,5 & $40 \%$ \\
\hline $\begin{array}{l}\text { Remesas de trabajadores y remuneración } \\
\text { de empleados }\end{array}$ & n.d. & n.d. & n.d. & n.d. \\
\hline
\end{tabular}

Fuentes: OCDE, base de datos del SNPA del CAD sobre las actividades de ayuda; Banco Mundial, Indicadores del Desarrollo Mundial; Banco Mundial, estadísticas de la deuda internacional.

Desembolsos de la ayuda para el comercio, por sector (millones de \$EE.UU. corrientes)

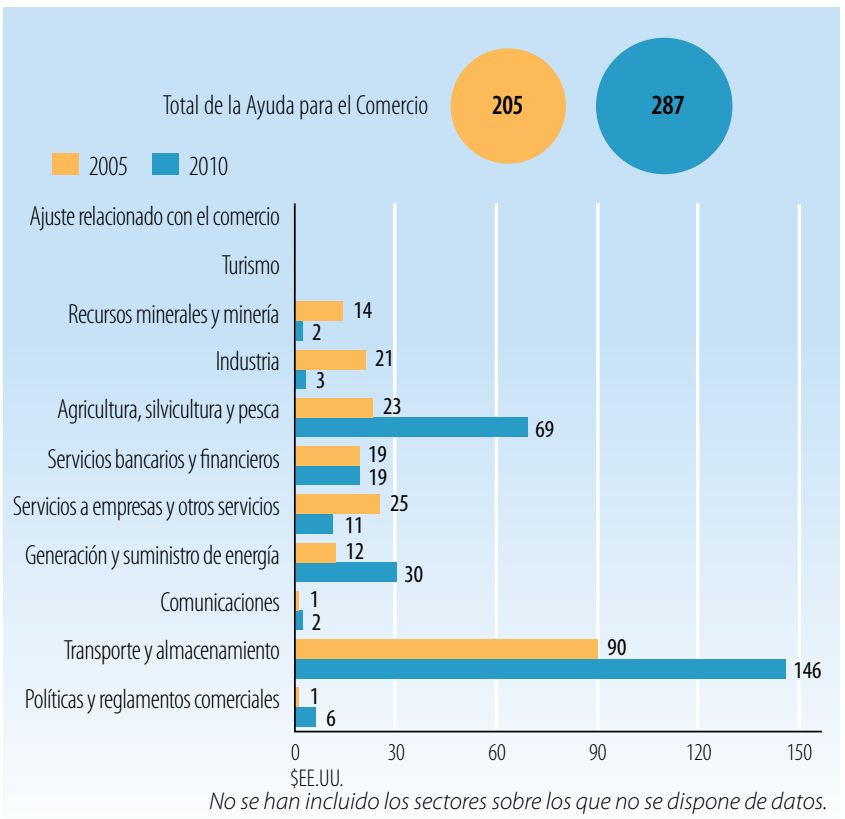

Fuentes: OCDE, base de datos del SNPA del CAD sobre las actividades de ayuda

Desembolsos de la ayuda para el comercio: principales donantes (millones de \$EE.UU. corrientes)

\begin{tabular}{|l|r|r|r|}
\hline $\mathbf{2 0 0 5}$ & Valor & $\%$ & Principales donantes en 2005 \\
\hline Banco Mundial & 172,9 & 84 & \\
\hline Instituciones de la UE & 18,2 & 9 & \\
\hline Bélgica & 6,1 & 3 & $99 \%$ \\
\hline Reino Unido & 3,2 & 2 & \\
\hline Alemania & 2,8 & 1 & \\
\hline $\mathbf{2 0 1 0}$ & Valor & $\%$ & Principales donantes en $\mathbf{2 0 1 0}$ \\
\hline Banco Mundial & 88,3 & 31 & \\
\hline Instituciones de la UE & 52,6 & 18 & \\
\hline Banco Africano de Desarrollo & 40,8 & 14 & \\
\hline Bélgica & 35,4 & 12 & $84 \%$ \\
\hline Reino Unido & 23,1 & 8 & \\
\hline
\end{tabular}

Fuentes: OCDE, base de datos del SNPA del CAD sobre las actividades de ayuda.

\section{INDICADORES COMERCIALES (PRODUCTOS)}

\section{Indicador}

Relación comercio/PIB (\%)

Exportaciones de servicios comerciales como

$\%$ de las exportaciones totales

Importaciones de servicios comerciales como

$\%$ de las importaciones totales

Productos intermedios distintos de los combustibles

(\% de las exportaciones de mercancías)

Productos intermedios distintos de los combustibles

(\% de las importaciones de mercancías)
$2005 \quad 2008 \quad 2011 \quad \Delta: 05-11(\%)$

\begin{tabular}{l|l|l|l|l|}
86 & 135 & 130 & 44 \\
\hline
\end{tabular}

$4 \quad 5 \quad$ n.d. $\quad$ n.d.

\begin{tabular}{l|l|l|l|}
27 & 22 & n.d. & n.d.
\end{tabular}

n.d. n.d. n.d. n.d.

n.d. n.d. n.d. n.d.

Fuentes: Secretaría de la OMC.

Corrientes comerciales (millones de \$EE.UU. corrientes)

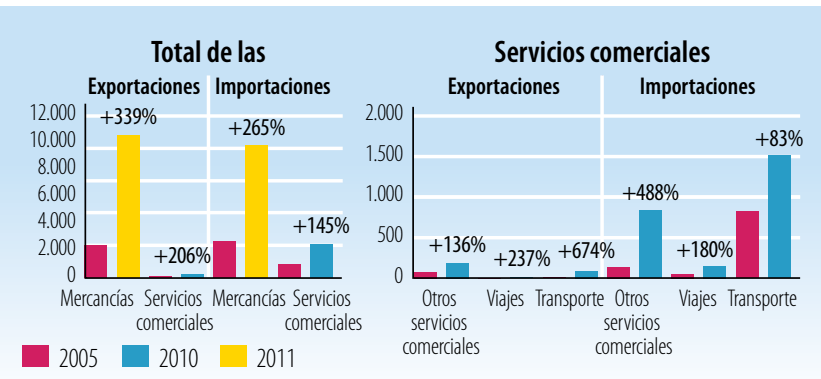

Fuentes: Secretaría de la OMC

Cinco principales mercados de exportación de mercancías (\%)

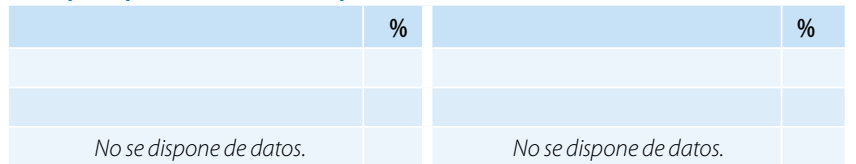

Fuentes: Secretaría de la OMC

Cinco principales productos de exportación (\% de las exportaciones de mercancías)

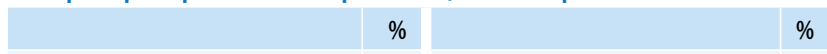

No se dispone de datos.

No se dispone de datos.

Fuentes: Secretaría de la OMC

Cinco principales mercados de importación de mercancías (\%)

$\%$

No se dispone de datos.

No se dispone de datos.

Fuentes: Secretaría de la OMC

Cinco principales productos de importación (\% de las importaciones de mercancías) $\%$ $\%$ 


\section{LA AYUDA PARA EL COMERCIO EN SÍNTESIS 2013}

\section{INDICADORES COMERCIALES (RESULTADOS)}

Indicador

Crecimiento del PIB (\%)

Número de exportadores

Índice de concentración de las exportaciones (productos) (0 a 1)

ACR sobre mercancías notificados a la OMC

AIE (servicios) notificados a la OMC

Sectores de servicios con compromisos en el marco del AGCS

\section{Aranceles (\%)}

Importaciones: promedio aritmético de los aranceles NMF aplicados Importaciones: promedio ponderado de los aranceles NMF aplicados Exportaciones: promedio ponderado de los aranceles impuestos por los importadores

Exportaciones: libres de derechos (en \%)

Fuentes: Naciones Unidas, base de datos Comtrade; Banco Mundial, base de datos sobre dinámica de las empresas de exportación; Banco Mundial, Indicadores del Desarrollo Mundial; OMC, perfiles comerciales y arancelarios.

Participación en las exportaciones por región (\%)

\begin{tabular}{|l|r|r|}
\hline África & 2005 & 2011 \\
\hline Asia & n.d. & n.d. \\
\hline Comunidad de Estados Independientes & n.d. & n.d. \\
\hline Europa & n.d. & n.d. \\
\hline Oriente Medio & n.d. & n.d. \\
\hline América del Norte & n.d. & n.d. \\
\hline América del Sury América Central & n.d. & n.d. \\
\hline
\end{tabular}

Fuentes: OMC, perfiles comerciales y arancelarios

Indicadores de facilitación del comercio
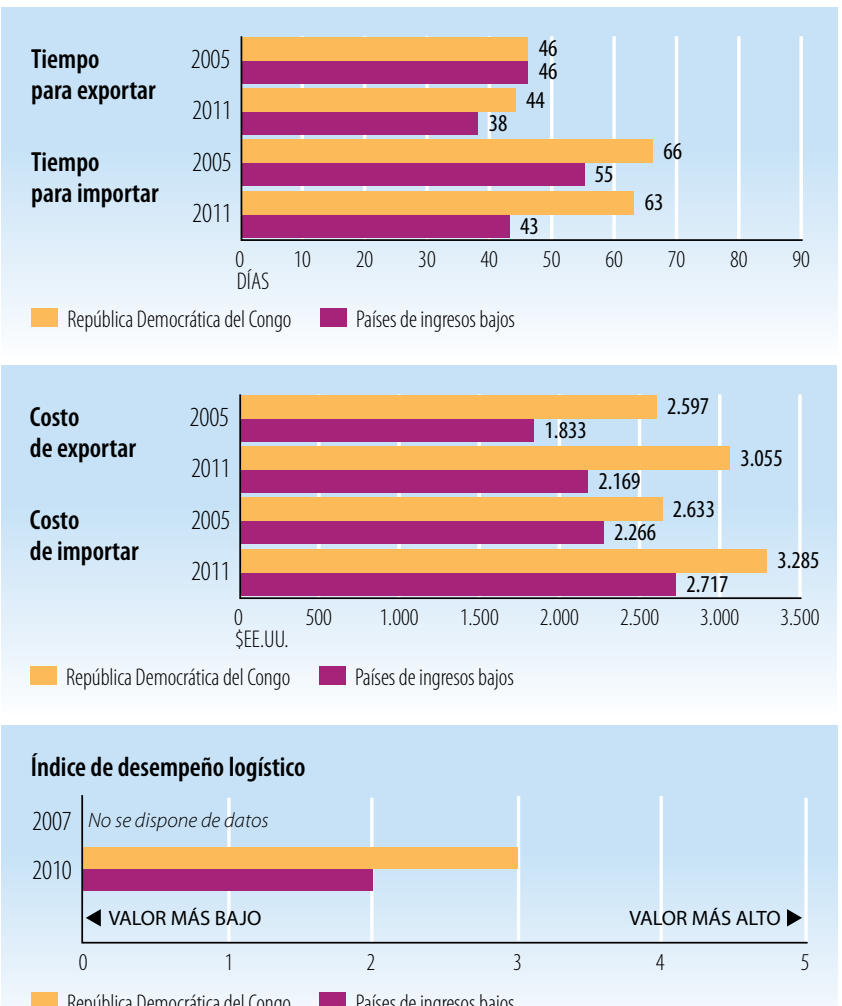

- República Democrática del Congo Países de ingresos bajos

Fuentes: Banco Mundial, Indicadores del Desarrollo Mundial.

\begin{tabular}{|l|c|c|}
\hline INDICADORES DE DESARROLLO (EFECTOS) & \\
\hline Indicador & $\mathbf{2 0 0 5}$ & $\mathbf{2 0 1 0}$ \\
\hline Desempleo (\% de la fuerza de trabajo total) & n.d. & n.d. \\
\hline Población activa, mujeres (\% de la fuerza de trabajo total) & 50,2 & 49,9 \\
\hline AOD neta recibida (\% del INB) & 28,2 & 29,0 \\
\hline Derechos de importación percibidos (\% de los ingresos fiscales) & 32,9 & 34,5 \\
\hline Total del servicio de la deuda (\% de las exportaciones totales) & 7,8 & 3,8 \\
\hline Índice de desarrollo humano (0 a 1) & 0,26 & 0,28 \\
\hline
\end{tabular}

Fuentes: PNUD, indicadores internacionales sobre desarrollo humano; Banco Mundial, Indicadores del Desarrollo Mundial.

Producto interno bruto

PIB per cápita (PPA, dólares internacionales corrientes)
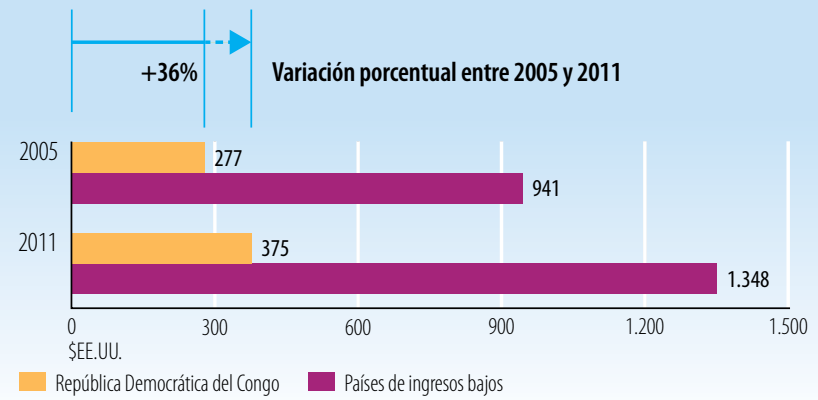

PIB per cápita (\$EE.UU. constantes de 2000)
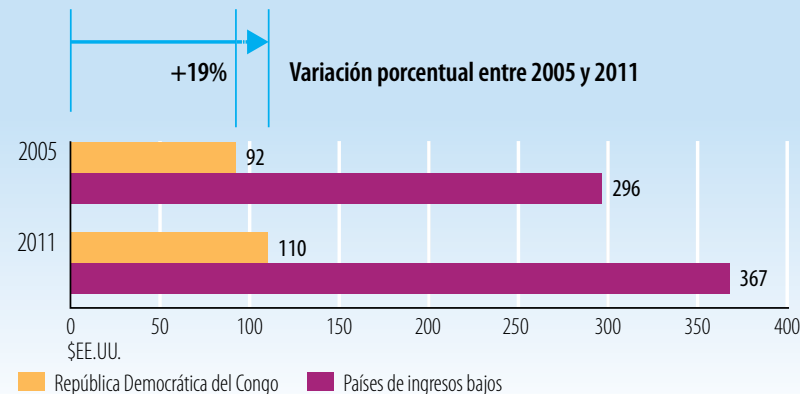

Fuentes: Banco Mundial, Indicadores del Desarrollo Mundial.

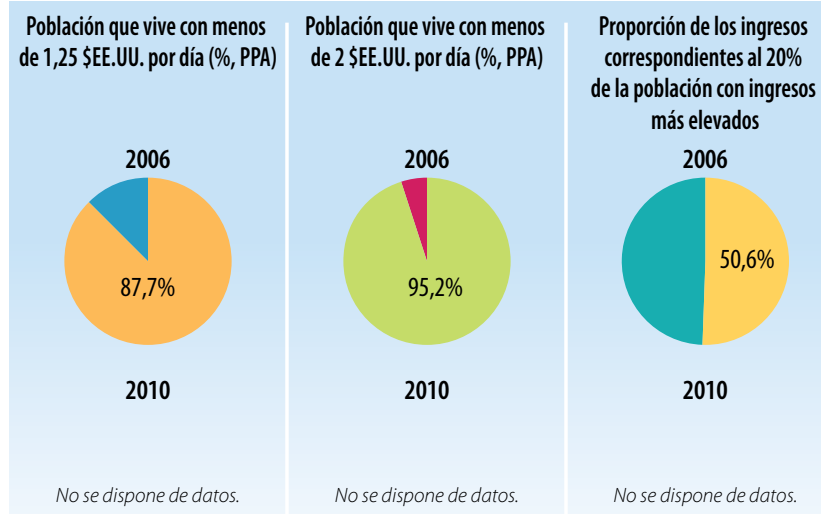

Fuentes: Banco Mundial, Indicadores del Desarrollo Mundial.

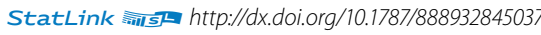


Indicadores de la ayuda, el comercio y el desarrollo relativos a la República Dominicana

\begin{tabular}{|c|c|c|c|c|}
\hline Indicador (millones de \$EE.UU. corrientes) & 2005 & 2008 & 2010 & $\Delta: 05-10(\%$ \\
\hline Formación bruta de capital fijo & $5.565,1$ & $8.324,8$ & $8.427,4$ & $51 \%$ \\
\hline del cual: público & n.d. & n.d. & n.d. & n.d. \\
\hline del cual: privado & n.d. & n.d. & n.d. & n.d. \\
\hline \multicolumn{5}{|l|}{ Entrada de financiación externa } \\
\hline Entradas de IED & $1.122,7$ & $2.870,0$ & $1.625,8$ & $45 \%$ \\
\hline $\begin{array}{l}\text { Deuda externa a largo plazo y fondos } \\
\text { desembolsados por el FMl }\end{array}$ & 894,3 & $1.420,2$ & $2.591,2$ & $190 \%$ \\
\hline $\begin{array}{l}\text { Corrientes comerciales en condiciones no } \\
\text { concesionarias }\end{array}$ & 2,7 & 1,9 & 158,8 & $5747 \%$ \\
\hline Corrientes de Ayuda para el Comercio & 20,8 & 84,5 & 45,2 & $118 \%$ \\
\hline $\begin{array}{l}\text { Remesas de trabajadores y remuneración } \\
\text { de empleados }\end{array}$ & $2.719,2$ & $3.667,0$ & $3.368,6$ & $24 \%$ \\
\hline
\end{tabular}

Fuentes: OCDE, base de datos del SNPA del CAD sobre las actividades de ayuda; Banco Mundial, Indicadores del Desarrollo Mundial; Banco Mundial, estadísticas de la deuda internacional.

Desembolsos de la ayuda para el comercio, por sector (millones de \$EE.UU. corrientes)

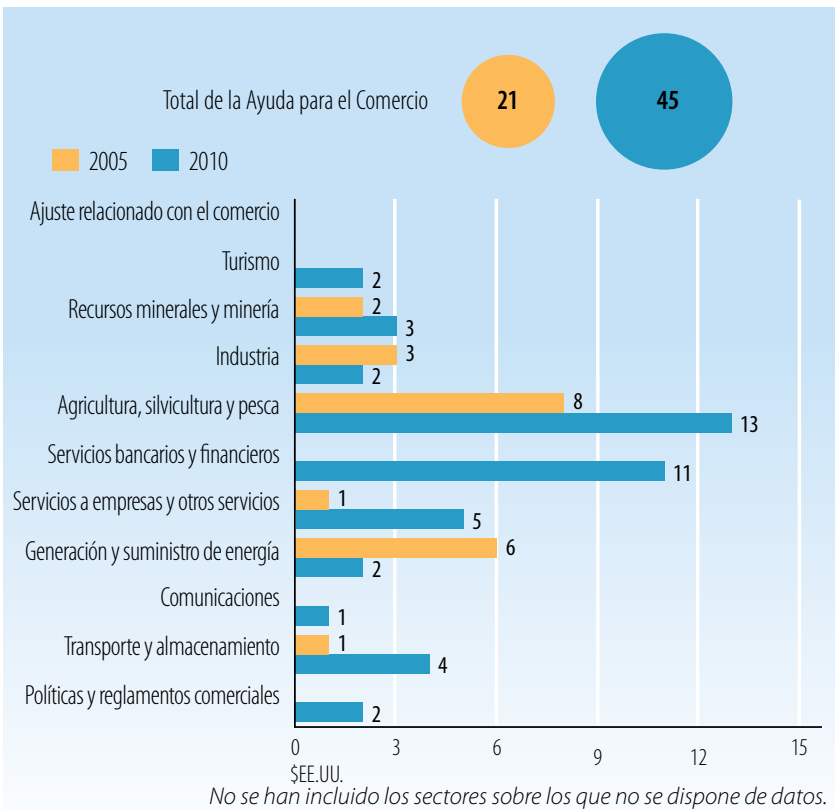

Fuentes: OCDE, base de datos del SNPA del CAD sobre las actividades de ayuda

Desembolsos de la ayuda para el comercio: principales donantes (millones de \$EE.UU. corrientes)

\begin{tabular}{|l|r|r|r|}
\hline $\mathbf{2 0 0 5}$ & Valor & $\%$ & Principales donantes en 2005 \\
\hline Instituciones de la UE & 4,4 & 21 & \\
\hline Alemania & 4,2 & 20 & \\
\hline Japón & 4,2 & 20 & $90 \%$ \\
\hline España & 3,7 & 18 & \\
\hline Dinamarca & 2,3 & 11 & \\
\hline $\mathbf{2 0 1 0}$ & Valor & $\%$ & Principales donantes en $\mathbf{2 0 1 0}$ \\
\hline España & 16,1 & 36 & \\
\hline Estados Unidos & 11,5 & 25 & \\
\hline Instituciones de la UE & 7,5 & 16 & \\
\hline Japón & 3,7 & 8 & $92 \%$ \\
\hline BID & 2,9 & 6 & \\
\hline
\end{tabular}

Fuentes: OCDE, base de datos del SNPA del CAD sobre las actividades de ayuda.

\section{INDICADORES COMERCIALES (PRODUCTOS)}

Indicador

$2005 \quad 2008 \quad 2011 \quad \Delta: 05-11(\%)$

Relación comercio/PIB (\%)

Exportaciones de servicios comerciales como

$\%$ de las exportaciones totales

Importaciones de servicios comerciales como

$\%$ de las importaciones totales

Productos intermedios distintos de los combustibles

(\% de las exportaciones de mercancías)

Productos intermedios distintos de los combustibles

(\% de las importaciones de mercancías)

\begin{tabular}{|l|l|l|r|}
63 & 64 & 59 & -4 \\
\hline
\end{tabular}

Fuentes: Secretaría de la OMC.

Corrientes comerciales (millones de \$EE.UU. corrientes)

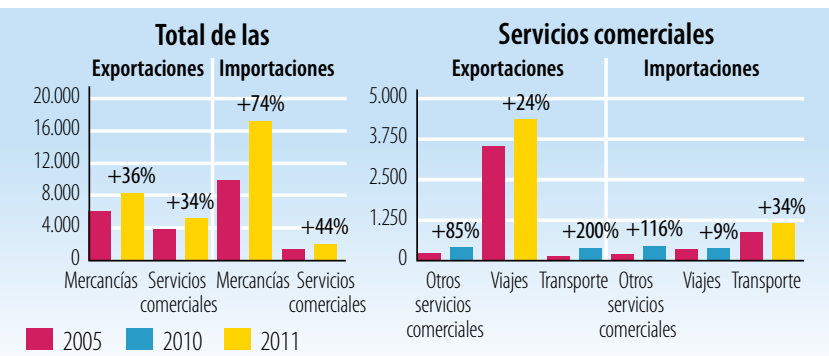

Fuentes: Secretaría de la OMC

Cinco principales mercados de exportación de mercancías (\%)

\begin{tabular}{|l|r|l|r|}
\hline 2005 & $\%$ & 2010 & $\%$ \\
\hline Estados Unidos & 70 & Estados Unidos & 57 \\
\hline UE (27) & 6 & Haití & 16 \\
\hline Haití & 3 & UE (27) & 11 \\
\hline Corea, Rep. Dem. de & 1 & China & 1 \\
\hline Canadá & 1 & Jamaica & 1 \\
\hline
\end{tabular}

Fuentes: Secretaría de la OMC

Cinco principales productos de exportación (\% de las exportaciones de mercancías)

\begin{tabular}{|c|c|c|c|}
\hline 2005 & $\%$ & 2011 & $\%$ \\
\hline $\begin{array}{l}\text { Prendas de vestir para hombres y niños, } \\
\text { excepto las de punto }\end{array}$ & 18 & Instrumentos, n.e.p., de medicina & 11 \\
\hline Instrumentos, n.e.p., de medicina & 8 & Tabaco manufacturado & 6 \\
\hline Joyas y objetos de oro o plata, n.e.p. & 8 & Arrabio, fundición especular, etc. & 5 \\
\hline Arrabio, fundición especular, etc. & 6 & Tejidos de algodón & 5 \\
\hline $\begin{array}{l}\text { Otros artículos textiles y prendas de } \\
\text { vestir, n.e.p. }\end{array}$ & 6 & Circuitos eléctricos de conmutación y relé & 4 \\
\hline
\end{tabular}

Cinco principales mercados de importación de mercancías (\%)

\begin{tabular}{|l|r|l|r|}
\hline 2005 & $\%$ & 2010 & $\%$ \\
\hline Estados Unidos & 55 & Estados Unidos & 39 \\
\hline UE (27) & 11 & China & 11 \\
\hline China & 5 & UE (27) & 9 \\
\hline Japón & 5 & Venezuela, Rep. Bolivariana de & 7 \\
\hline Brasil & 4 & México & 6 \\
\hline
\end{tabular}

Fuentes: Secretaría de la OMC

Cinco principales productos de importación (\% de las importaciones de mercancías)

\begin{tabular}{|c|c|c|c|}
\hline 2005 & $\%$ & 2011 & $\%$ \\
\hline $\begin{array}{l}\text { Vehículos automotores para pasajeros, } \\
\text { excepto autobuses }\end{array}$ & 9 & Productos derivados del petróleo & 14 \\
\hline Tejidos de algodón & 5 & Aceites de petróleo, crudos & 5 \\
\hline $\begin{array}{l}\text { Vehículos automotores para el transporte } \\
\text { de mercancías y vehículos automotores } \\
\text { para usos especiales }\end{array}$ & 3 & Propano y butano licuados & 3 \\
\hline $\begin{array}{l}\text { Otros artículos textiles y prendas de } \\
\text { vestir, n.e.p. }\end{array}$ & 3 & Artículos, n.e.p., de materiales plásticos & 3 \\
\hline Artículos, n.e.p., de materiales plásticos & 2 & Hilados de fibra textil & 2 \\
\hline
\end{tabular}




\section{LA AYUDA PARA EL COMERCIO EN SINNTESIS 2013}

\section{INDICADORES COMERCIALES (RESULTADOS)}

\section{Indicador}

Crecimiento del PIB (\%)

Número de exportadores

Índice de concentración de las exportaciones (productos) ( 0 a 1)

ACR sobre mercancías notificados a la OMC

AIE (servicios) notificados a la OMC

Sectores de servicios con compromisos en el marco del AGCS

\begin{tabular}{|r|r|}
\hline 2005 & 2011 \\
\hline 9,3 & 4,5 \\
\hline 2.588 & 3.009 \\
\hline 0,04 & 0,03 \\
\hline n.d. & 3 \\
\hline n.d. & 3 \\
\hline 60 & 60 \\
\hline
\end{tabular}

\section{Aranceles (\%)}

Importaciones: promedio aritmético de los aranceles NMF aplicados

Importaciones: promedio ponderado de los aranceles NMF aplicados

Exportaciones: promedio ponderado de los aranceles impuestos

por los importadores

Exportaciones: libres de derechos (en \%)

\begin{tabular}{|r|r|}
\hline 8,5 & n.d. \\
\hline n.d. & n.d. \\
\hline 9,0 & n.d. \\
\hline 54,1 & n.d. \\
\hline
\end{tabular}

Fuentes: Naciones Unidas, base de datos Comtrade; Banco Mundial, base de datos sobre dinámica de las empresas de exportación; Banco Mundial, Indicadores del

Desarrollo Mundial; OMC, perfiles comerciales y arancelarios.

Participación en las exportaciones por región (\%)

\begin{tabular}{|l|r|r|}
\hline & $\mathbf{2 0 0 5}$ & $\mathbf{2 0 1 1}$ \\
\hline África & 0,0 & 1,6 \\
\hline Asia & 2,9 & 8,6 \\
\hline Comunidad de Estados Independientes & 0,0 & 0,1 \\
\hline Europa & 6,7 & 8,3 \\
\hline Oriente Medio & 0,0 & 0,1 \\
\hline América del Norte & 71,0 & 55,8 \\
\hline América del Sury América Central & 4,7 & 25,4 \\
\hline
\end{tabular}

Fuentes: OMC, perfiles comerciales y arancelarios

Indicadores de facilitación del comercio
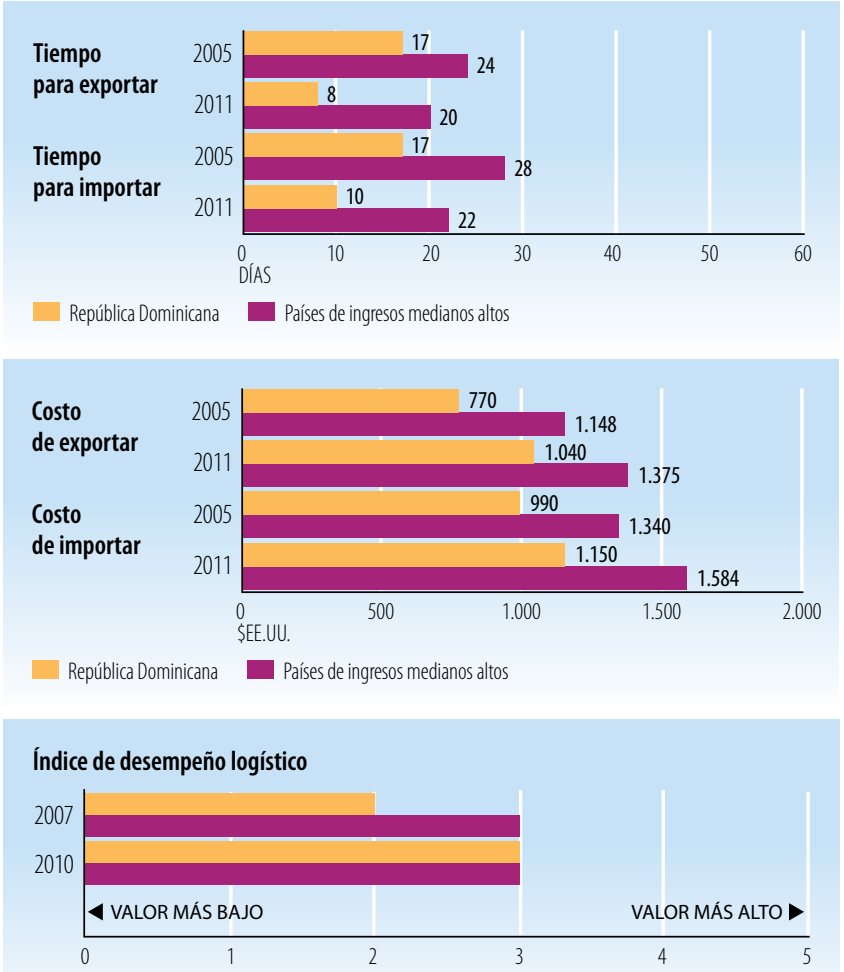

República Dominicana Países de ingresos medianos altos

Fuentes: Banco Mundial, Indicadores del Desarrollo Mundial.

\begin{tabular}{l|c|c|}
\hline INDICADORES DE DESARROLLO (EFECTOS) \\
\hline Indicador & $\mathbf{2 0 0 5}$ & $\mathbf{2 0 1 0}$ \\
\hline Desempleo (\% de la fuerza de trabajo total) & 18,0 & 14,3 \\
\hline Población activa, mujeres (\% de la fuerza de trabajo total) & 37,9 & 39,4 \\
\hline AOD neta recibida (\% del INB) & 0,3 & 0,4 \\
\hline Derechos de importación percibidos (\% de los ingresos fiscales) & 9,7 & n.d. \\
\hline Total del servicio de la deuda (\% de las exportaciones totales) & 9,6 & 11,0 \\
\hline Índice de desarrollo humano ( 0 a 1) & 0,66 & 0,69 \\
\hline
\end{tabular}

Fuentes: PNUD, indicadores internacionales sobre desarrollo humano; Banco Mundial, Indicadores del Desarrollo Mundial.

Producto interno bruto

PIB per cápita (PPA, dólares internacionales corrientes)

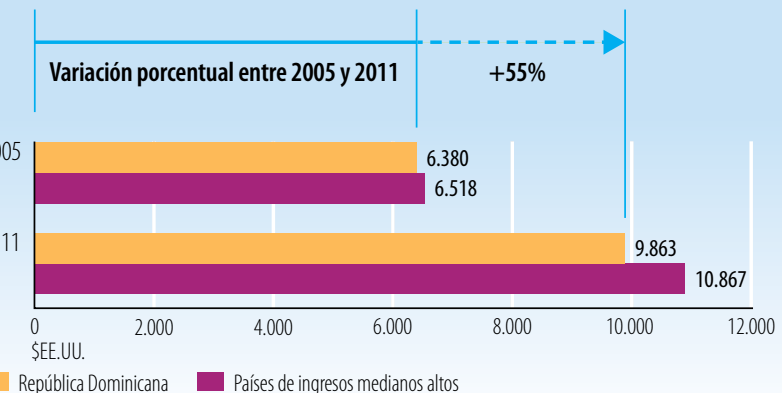

República Dominicana $\square$ Países de ingresos medianos altos

PIB per cápita (\$\$EE.UU. constantes de 2000)

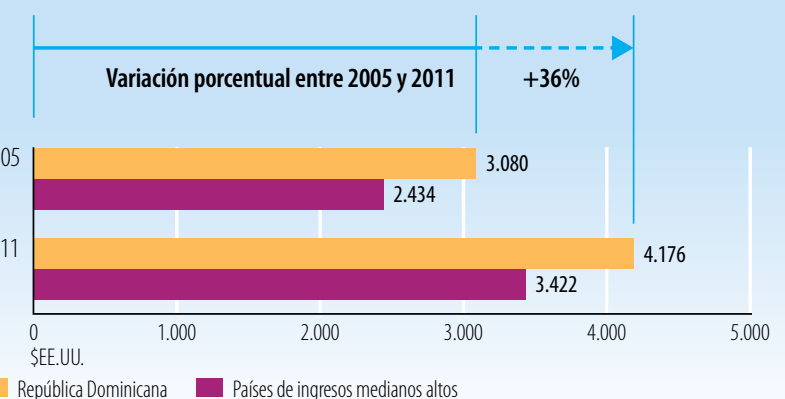

República Dominicana $\square$ Países de ingresos medianos altos

Fuentes: Banco Mundial, Indicadores del Desarrollo Mundial.

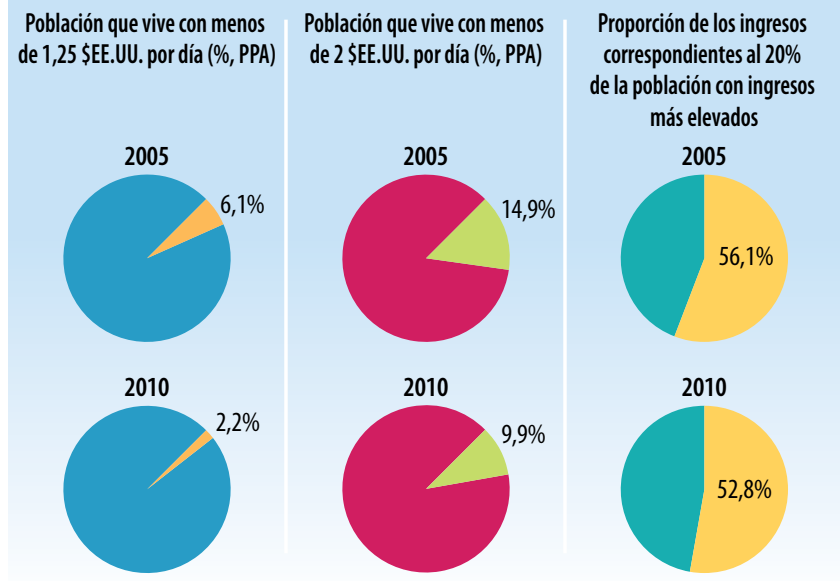

Fuentes: Banco Mundial, Indicadores del Desarrollo Mundial.

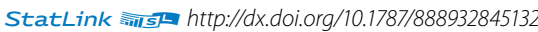




\section{Indicadores de la ayuda, el comercio y el desarrollo relativos a Rwanda}

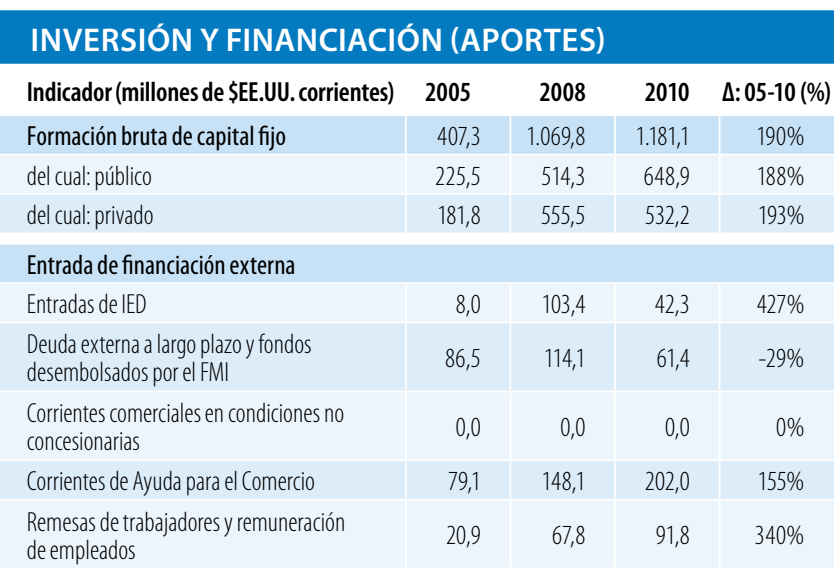

Fuentes: OCDE, base de datos del SNPA del CAD sobre las actividades de ayuda; Banco Mundial, Indicadores del Desarrollo Mundial; Banco Mundial, estadísticas de la deuda internacional.

Desembolsos de la ayuda para el comercio, por sector

(millones de \$EE.UU. corrientes)

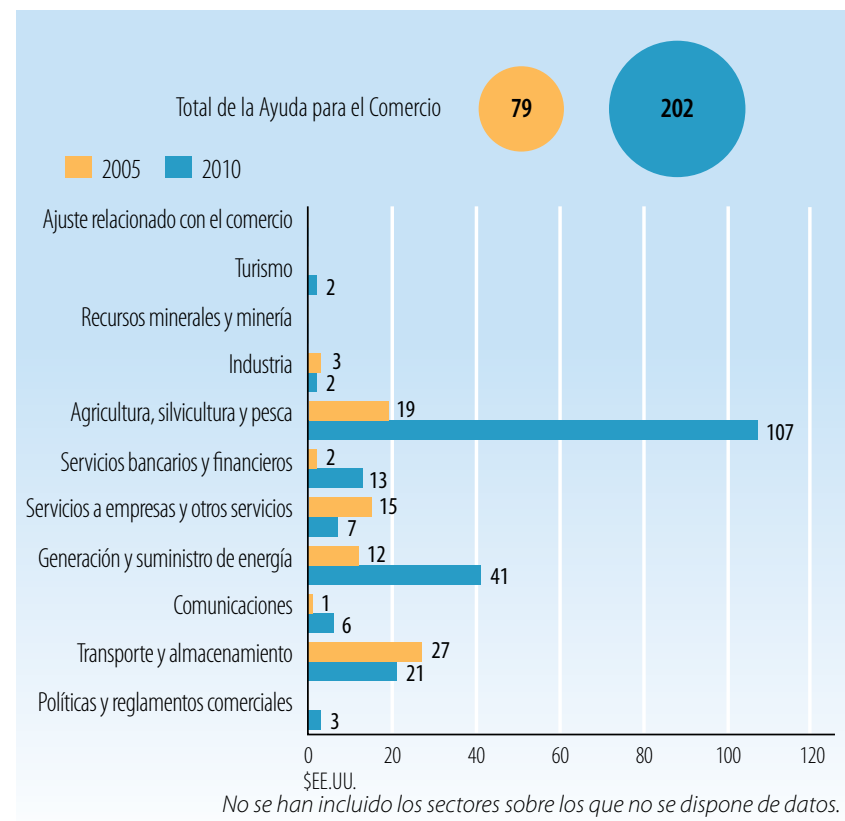

Fuentes: OCDE, base de datos del SNPA del CAD sobre las actividades de ayuda

Desembolsos de la ayuda para el comercio: principales donantes (millones de \$EE.UU. corrientes)

\begin{tabular}{|l|r|r|}
\hline $\mathbf{2 0 0 5}$ & Valor & $\%$ \\
\hline Banco Mundial & 30,8 & 39 \\
\hline Instituciones de la UE & 21,5 & 27 \\
\hline Banco Africano de Desarrollo & 8,4 & 11 \\
\hline Países Bajos & 5,2 & 7 \\
\hline Suecia & 3,4 & 4 \\
\hline $\mathbf{2 0 1 0}$ & Valor & $\%$ \\
\hline Banco Mundial & 55,6 & 27 \\
\hline Canadá & 31,1 & 15 \\
\hline Instituciones de la UE & 30,3 & 15 \\
\hline Bélgica & 24,4 & 12 \\
\hline Banco Africano de Desarrollo & 22,2 & 11 \\
\hline
\end{tabular}

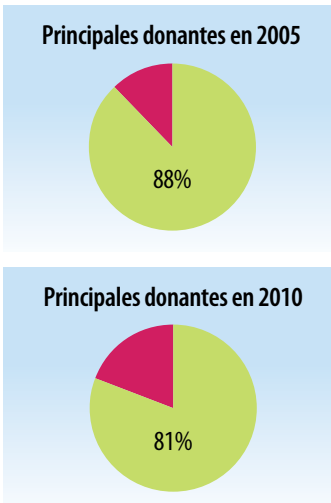

Fuentes: OCDE, base de datos del SNPA del CAD sobre las actividades de ayuda.

\section{INDICADORES COMERCIALES (PRODUCTOS)}

Indicador $2005 \quad 2008 \quad 2011 \quad \Delta: 05-11(\%)$

Relación comercio/PIB (\%)

Exportaciones de servicios comerciales como

$\%$ de las exportaciones totales

Importaciones de servicios comerciales como

$\%$ de las importaciones totales

Productos intermedios distintos de los combustibles

(\% de las exportaciones de mercancías)

Productos intermedios distintos de los combustibles

(\% de las importaciones de mercancías)

\begin{tabular}{|l|l|r|r|}
\hline 29 & 42 & 45 & 16 \\
\hline
\end{tabular}

Fuentes: Secretaría de la OMC.

Corrientes comerciales (millones de \$EE.UU. corrientes)

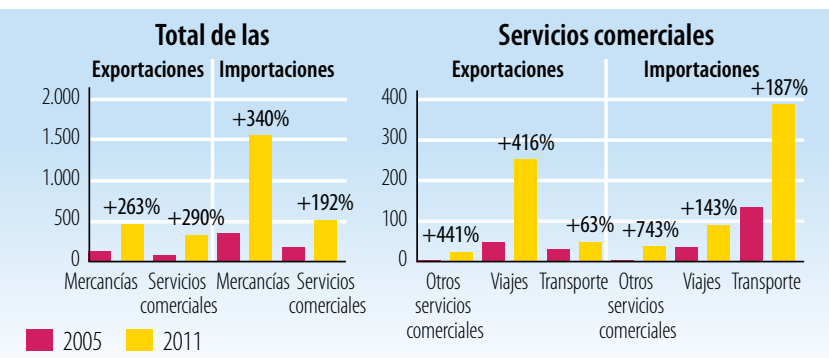

Fuentes: Secretaría de la OMC

Cinco principales mercados de exportación de mercancías (\%)

\begin{tabular}{|l|r|l|c|}
\hline 2005 & $\%$ & 2011 & $\%$ \\
\hline UE $(27)$ & 48 & UE $(27)$ & 27 \\
\hline Kenya & 22 & Suiza & 17 \\
\hline Hong Kong, China & 9 & Congo, Rep. Dem. del & 14 \\
\hline Suiza & 7 & Kenya & 14 \\
\hline Congo, Rep. Dem. del & 3 & China & 3 \\
\hline
\end{tabular}

Fuentes: Secretaría de la OMC

Cinco principales productos de exportación (\% de las exportaciones de mercancías)

\begin{tabular}{|l|r|l|c|}
\hline 2005 & $\%$ & 2011 & $\%$ \\
\hline $\begin{array}{l}\text { Minerales de metales comunes y sus } \\
\text { concentrados }\end{array}$ & 39 & $\begin{array}{l}\text { Minerales de metales comunes y sus } \\
\text { concentrados }\end{array}$ & 39 \\
\hline $\begin{array}{l}\text { Caféy sucedáneos del café } \\
\text { Téy mate }\end{array}$ & 25 & Caféy sucedáneos del café & 18 \\
\hline Productos derivados del petróleo & 16 & Téy mate & 13 \\
\hline Equipo de ingeniería civil & 3 & Productos derivados del petróleo & 5 \\
\hline
\end{tabular}

Fuentes: Secretaría de la OMC

Cinco principales mercados de importación de mercancías (\%)

\begin{tabular}{|l|c|l|c|}
\hline 2005 & $\%$ & 2011 & $\%$ \\
\hline UE (27) & 27 & UE (27) & 17 \\
\hline Kenya & 12 & Uganda & 14 \\
\hline Arabia Saudita, Reino de la & 10 & China & 12 \\
\hline Uganda & 10 & Kenya & 9 \\
\hline Emiratos Árabes Unidos & 7 & India & 7 \\
\hline Fuentes:Secretaría de la OMC & & & \\
\hline
\end{tabular}

Cinco principales productos de importación (\% de las importaciones de mercancías)

\begin{tabular}{|c|c|c|c|}
\hline 2005 & $\%$ & 2011 & $\%$ \\
\hline Productos derivados del petróleo & 11 & Productos derivados del petróleo & 8 \\
\hline Medicamentos & 5 & $\begin{array}{l}\text { Cal, cemento y materiales de } \\
\text { construcción }\end{array}$ & 4 \\
\hline $\begin{array}{l}\text { Equipos de telecomunicaciones y sus } \\
\text { partes, n.e.p. }\end{array}$ & 4 & $\begin{array}{l}\text { Vehículos automotores para pasajeros, } \\
\text { excepto autobuses }\end{array}$ & 4 \\
\hline $\begin{array}{l}\text { Vehículos automotores para pasajeros, } \\
\text { excepto autobuses }\end{array}$ & 4 & Medicamentos & 3 \\
\hline Impresos & 3 & $\begin{array}{l}\text { Equipos de telecomunicaciones y sus } \\
\text { partes, n.e.p. }\end{array}$ & 3 \\
\hline
\end{tabular}

Fuentes: Secretaría de la OMC 


\section{LA AYUDA PARA EL COMERCIO EN SÍNTESIS 2013}

\section{INDICADORES COMERCIALES (RESULTADOS)}

\section{Indicador}

Crecimiento del PIB (\%)

Número de exportadores

Índice de concentración de las exportaciones (productos) ( 0 a 1)

ACR sobre mercancías notificados a la OMC

AIE (servicios) notificados a la OMC

Sectores de servicios con compromisos en el marco del AGCS

\section{Aranceles $(\%, 2006$ et 2011)}

\begin{tabular}{ll|l|l|} 
Importaciones: promedio aritmético de los aranceles NMF aplicados & 18,7 & 12,5
\end{tabular}

\begin{tabular}{l|l|l|l|} 
Importaciones: promedio ponderado de los aranceles NMF aplicados & n.d.
\end{tabular}

\begin{tabular}{|l|l|l|l|} 
Exportaciones: promedio ponderado de los aranceles impuestos & 0,9 & 0,9
\end{tabular}

por los importadores

$90,5 \quad 91,0$

Exportaciones: libres de derechos (en \%) sobre dinámica de las empresas de exportación; Banco Mundial, Indicadores del

Desarrollo Mundial; OMC, perfiles comerciales y arancelarios.

Participación en las exportaciones por región (\%)

\begin{tabular}{|l|r|r|}
\hline & $\mathbf{2 0 0 5}$ & $\mathbf{2 0 1 1}$ \\
\hline África & 29,1 & 35,2 \\
\hline Asia & 12,1 & 9,3 \\
\hline Comunidad de Estados Independientes & 0,0 & 0,0 \\
\hline Europa & 55,2 & 43,7 \\
\hline Oriente Medio & 0,7 & 1,0 \\
\hline América del Norte & 2,2 & 2,4 \\
\hline América del Sury América Central & 0,1 & 0,9 \\
\hline
\end{tabular}

Fuentes: OMC, perfiles comerciales y arancelarios

Indicadores de facilitación del comercio
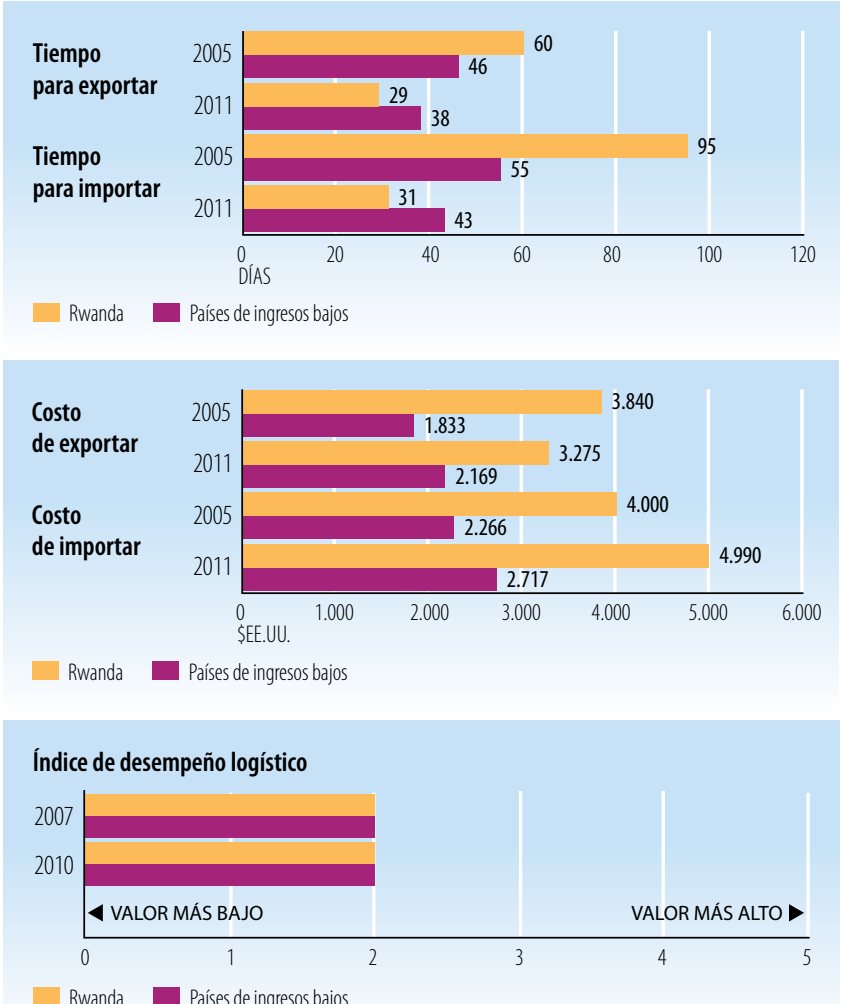

Fuentes: Banco Mundial, Indicadores del Desarrollo Mundial.

\begin{tabular}{l|c|c|}
\hline INDICADORES DE DESARROLLO (EFECTOS) & \\
\hline Indicador & $\mathbf{2 0 0 5}$ & $\mathbf{2 0 1 0}$ \\
\hline Desempleo (\% de la fuerza de trabajo total) & n.d. & n.d. \\
\hline Población activa, mujeres (\% de la fuerza de trabajo total) & 52,2 & 51,8 \\
\hline AOD neta recibida (\% del INB) & 22,6 & 18,5 \\
\hline Derechos de importación percibidos (\% de los ingresos fiscales) & n.d. & n.d. \\
\hline Total del servicio de la deuda (\% de las exportaciones totales) & 9,7 & 2,3 \\
\hline Índice de desarrollo humano ( 0 a 1) & 0,38 & 0,43 \\
\hline
\end{tabular}

Fuentes: PNUD, indicadores internacionales sobre desarrollo humano; Banco Mundial, Indicadores del Desarrollo Mundial.

Producto interno bruto

PIB per cápita (PPA, dólares internacionales corrientes)
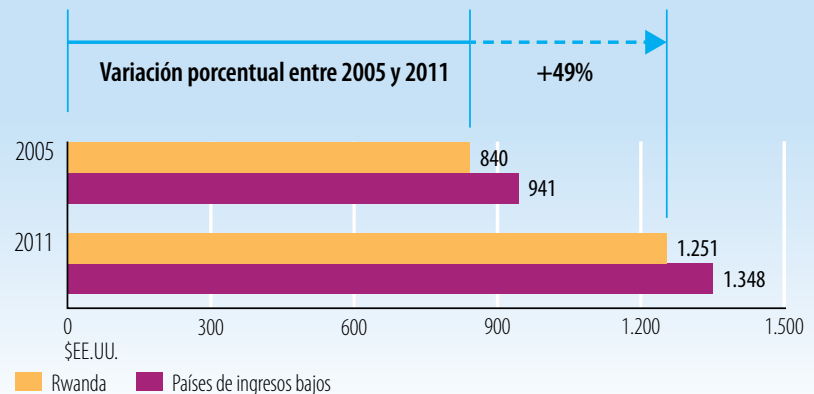

Rwanda Países de ingresos bajos

PIB per cápita (\$EE.UU. constantes de 2000)
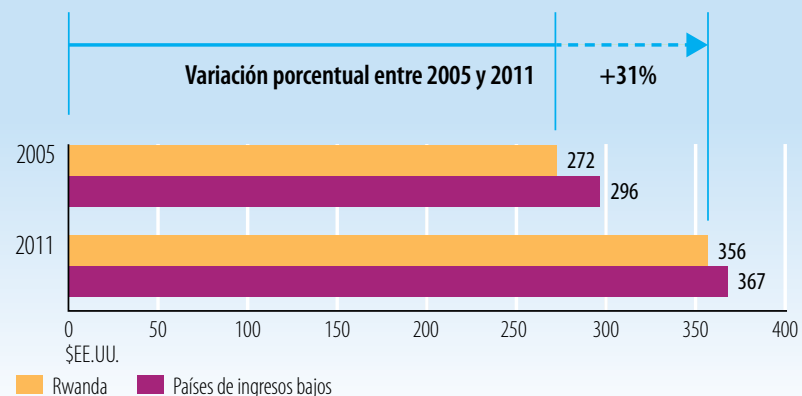

Fuentes: Banco Mundial, Indicadores del Desarrollo Mundial.

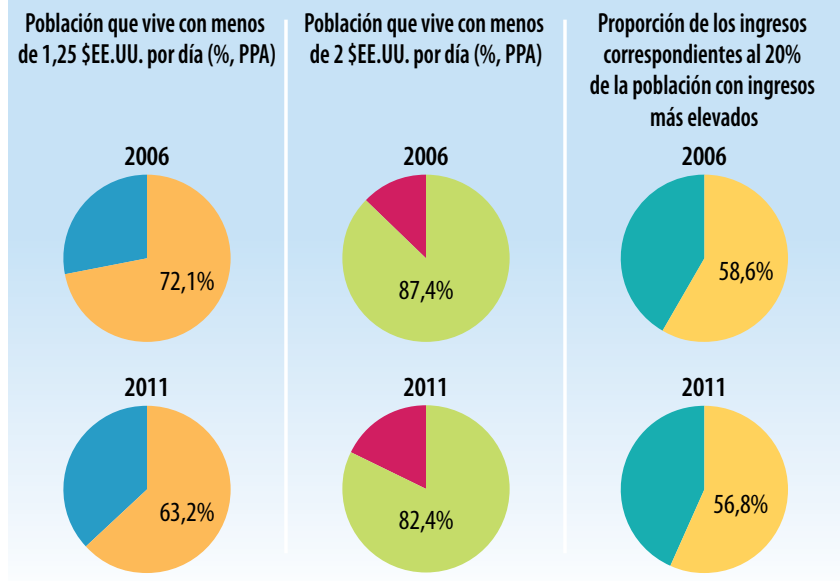

Fuentes: Banco Mundial, Indicadores del Desarrollo Mundial.

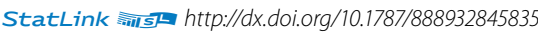




\section{LA AYUDA PARA EL COMERCIO EN SÍNTESIS 2013}

\section{Indicadores de la ayuda, el comercio y el desarrollo relativos a Saint Kitts y Nevis}

\begin{tabular}{|c|c|c|c|c|}
\hline Indicador (millones de \$EE.UU. corrientes) & 2005 & 2008 & 2010 & $\Delta: 05-10(\%)$ \\
\hline Formación bruta de capital fijo & 185,2 & 247,5 & n.d. & n.d. \\
\hline del cual: público & n.d. & n.d. & n.d. & n.d. \\
\hline del cual: privado & n.d. & n.d. & n.d. & n.d. \\
\hline \multicolumn{5}{|l|}{ Entrada de financiación externa } \\
\hline Entradas de IED & 93,0 & 177,9 & 120,4 & $29 \%$ \\
\hline $\begin{array}{l}\text { Deuda externa a largo plazo y fondos } \\
\text { desembolsados por el FMl }\end{array}$ & 6,9 & 5,0 & 7,1 & $2 \%$ \\
\hline $\begin{array}{l}\text { Corrientes comerciales en condiciones no } \\
\text { concesionarias }\end{array}$ & 0,4 & 0,1 & 0,0 & $-92 \%$ \\
\hline Corrientes de Ayuda para el Comercio & 0,7 & 0,7 & 2,7 & $290 \%$ \\
\hline $\begin{array}{l}\text { Remesas de trabajadores y remuneración } \\
\text { de empleados }\end{array}$ & 33,5 & 44,5 & 43,9 & $31 \%$ \\
\hline
\end{tabular}

Fuentes: OCDE, base de datos del SNPA del CAD sobre las actividades de ayuda; Banco Mundial, Indicadores del Desarrollo Mundial; Banco Mundial, estadísticas de la deuda internacional.

Desembolsos de la ayuda para el comercio, por sector (millones de \$EE.UU. corrientes)

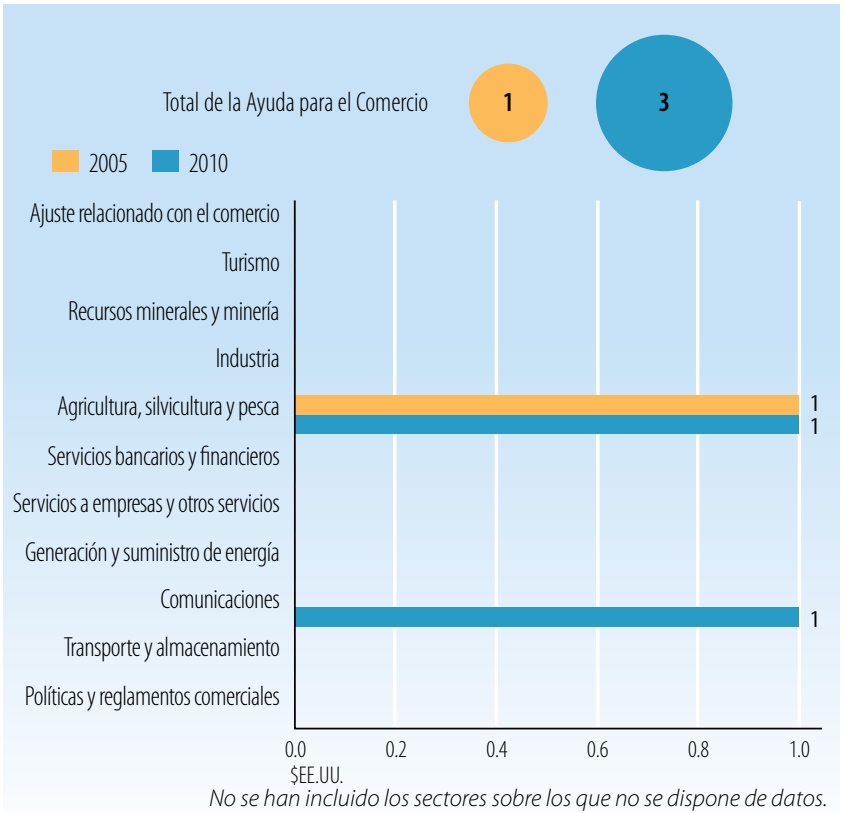

Fuentes: OCDE, base de datos del SNPA del CAD sobre las actividades de ayuda

Desembolsos de la ayuda para el comercio: principales donantes (millones de \$EE.UU. corrientes)

\begin{tabular}{|l|r|r|r|}
\hline $\mathbf{2 0 0 5}$ & Valor & $\%$ & Principales donantes en 2005 \\
\hline Japón & 0,7 & 100 & $100 \%$ \\
\hline & & & \\
\hline & & & \\
\hline & & & \\
\hline $\mathbf{2 0 1 0}$ & Valor & $\%$ & Principales donantes en 2010 \\
\hline Instituciones de la UE & 1,9 & 73 & \\
\hline Japón & 0,6 & 22 & $100 \%$ \\
\hline Australia & 0,1 & 3 & \\
\hline Alemania & 0,0 & 1 & \\
\hline Austria & 0,0 & 1 & \\
\hline
\end{tabular}

Fuentes: OCDE, base de datos del SNPA del CAD sobre las actividades de ayuda.

\section{INDICADORES COMERCIALES (PRODUCTOS)}

\section{Indicador}

$20052008 \quad 2011 \quad \Delta: 05-11(\%)$

Relación comercio/PIB (\%)

\begin{tabular}{|l|l|l|l|}
97 & 85 & 71 & -27 \\
\hline
\end{tabular}

Exportaciones de servicios comerciales como

$\%$ de las exportaciones totales

Importaciones de servicios comerciales como

$\%$ de las importaciones totales

Productos intermedios distintos de los combustibles

(\% de las exportaciones de mercancías)

Productos intermedios distintos de los combustibles

(\% de las importaciones de mercancías)

\begin{tabular}{|l|l|l|l|}
71 & 69 & 71 & 0
\end{tabular}

\begin{tabular}{|l|l|l|l}
33 & 29 & 30 & -3
\end{tabular}

\begin{tabular}{l}
$87 \quad 80 \quad$ n.d. \\
\hline
\end{tabular}

\begin{tabular}{ll|l|l}
38 & 38 & n.d. & n.d.
\end{tabular}

Fuentes: Secretaría de la OMC.

Corrientes comerciales (millones de \$EE.UU. corrientes)

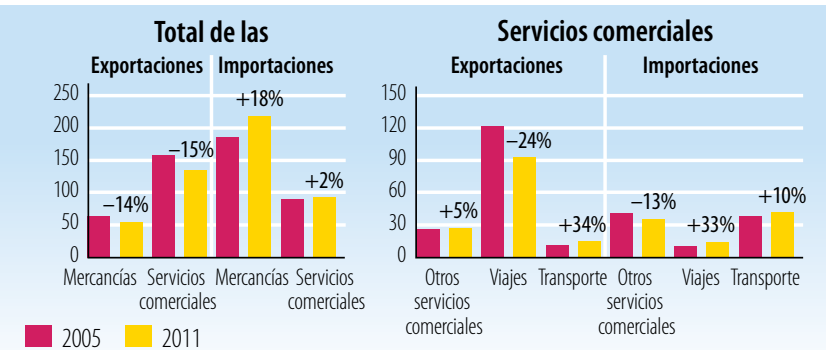

Fuentes: Secretaría de la OMC

Cinco principales mercados de exportación de mercancías (\%)

\begin{tabular}{|l|r|l|r|}
\hline 2005 & $\%$ & $\mathbf{2 0 0 8}$ & $\%$ \\
\hline Estados Unidos & 92 & Estados Unidos & 85 \\
\hline UE (27) & 3 & UE (27) & 5 \\
\hline Trinidad y Tabago & 2 & Antillas Neerlandesas & 2 \\
\hline Antillas Neerlandesas & 1 & Antigua y Barbuda & 2 \\
\hline San Vicentey las Granadinas & 0 & Granada & 1
\end{tabular}

Cinco principales productos de exportación (\% de las exportaciones de mercancías)

\begin{tabular}{|c|c|c|c|}
\hline 2005 & $\%$ & 2008 & $\%$ \\
\hline Circuitos eléctricos de conmutación y relé & 53 & Circuitos eléctricos de conmutación y relé & 42 \\
\hline Maquinaria y aparatos eléctricos, n.e.p & 27 & $\begin{array}{l}\text { Equipos de telecomunicaciones y sus } \\
\text { partes, n.e.p. }\end{array}$ & 26 \\
\hline Aparatos eléctricos rotativos & 4 & Bebidas alcohólicas & 5 \\
\hline Impresos & 2 & Impresos & 4 \\
\hline Equipo de ingeniería civil & 2 & $\begin{array}{l}\text { Partes y piezas de tractores y vehículos } \\
\text { automotores }\end{array}$ & 4 \\
\hline
\end{tabular}

Fuentes: Secretaría de la OMC

Cinco principales mercados de importación de mercancías (\%)

\begin{tabular}{|l|r|l|c|}
\hline $\mathbf{2 0 0 5}$ & $\%$ & $\mathbf{2 0 0 8}$ & $\%$ \\
\hline Estados Unidos & 58 & Estados Unidos & 61 \\
\hline Trinidady Tabago & 14 & Trinidad y Tabago & 12 \\
\hline UE (27) & 9 & UE (27) & 7 \\
\hline Japón & 4 & Japón & 3 \\
\hline Barbados & 3 & Canadá & 2 \\
\hline
\end{tabular}

Fuentes: Secretaría de la OMC

Cinco principales productos de importación (\% de las importaciones de mercancías)

\section{5}

Productos derivados del petróleo

Vehículos automotores para pasajeros, excepto autobuses

Equipos de telecomunicaciones y sus partes, n.e.p.

Artículos, n.e.p., de materiales plásticos

Circuitos eléctricos de conmutación y relé

Fuentes: Secretaría de la OMC 


\section{INDICADORES COMERCIALES (RESULTADOS)}

\section{Indicador}

Crecimiento del PIB (\%)

Número de exportadores

Índice de concentración de las exportaciones (productos) (0 a 1)

ACR sobre mercancías notificados a la OMC

AIE (servicios) notificados a la OMC

Sectores de servicios con compromisos en el marco del AGCS

\section{Aranceles (\%, 2006 et 2011)}

Importaciones: promedio aritmético de los aranceles NMF aplicados

Importaciones: promedio ponderado de los aranceles NMF aplicados

Exportaciones: promedio ponderado de los aranceles impuestos

por los importadores

Exportaciones: libres de derechos (en \%)

\begin{tabular}{|c|c|}
\hline 2005 & 2011 \\
\hline 5,6 & $-0,1$ \\
\hline n.d. & n.d. \\
\hline n.d. & 0,15 \\
\hline n.d. & 2 \\
\hline n.d. & 2 \\
\hline 8 & 8 \\
\hline
\end{tabular}

Fuentes: Naciones Unidas, base de datos Comtrade; Banco Mundial, base de datos sobre dinámica de las empresas de exportación; Banco Mundial, Indicadores del

Desarrollo Mundial; OMC, perfiles comerciales y arancelarios.

Participación en las exportaciones por región (\%)

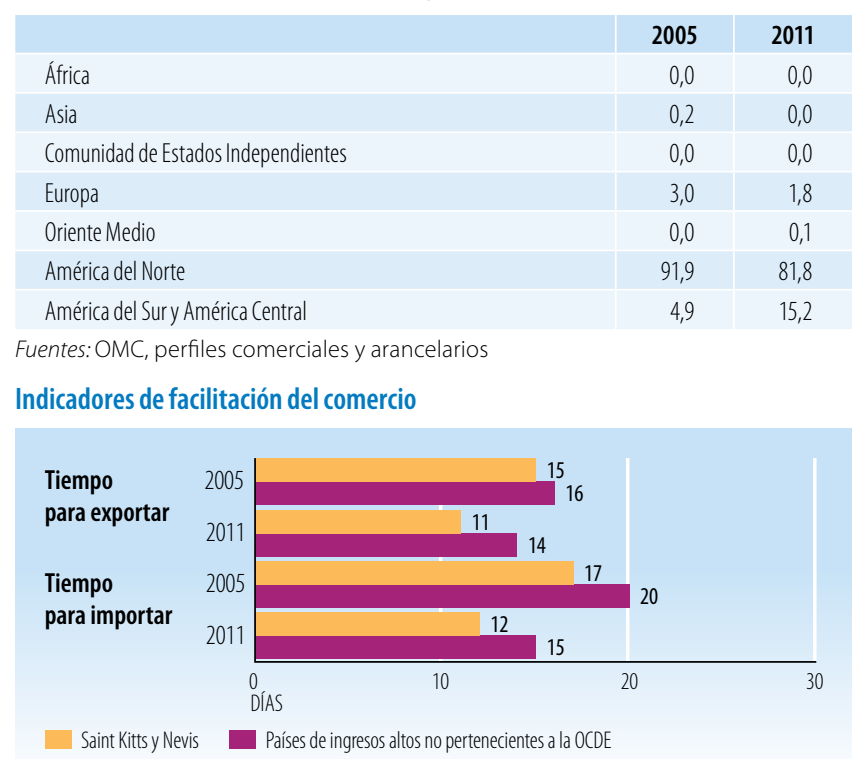
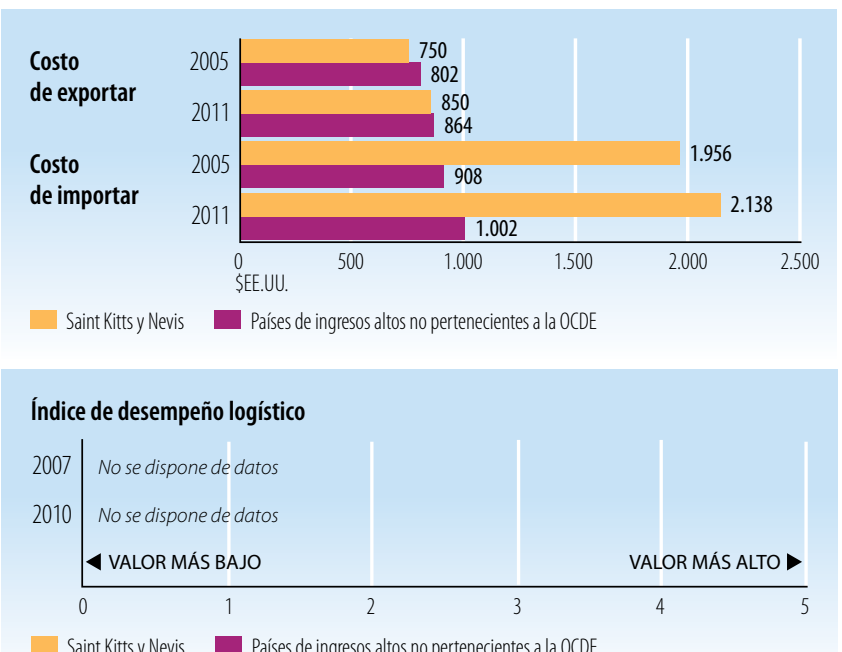

Saint Kitts y Nevis Países de ingresos altos no pertenecientes a la OCDE

Fuentes: Banco Mundial, Indicadores del Desarrollo Mundial.

\begin{tabular}{l|c|c|}
\hline \multicolumn{2}{l}{ INDICADORES DE DESARROLLO (EFECTOS) } \\
\hline Indicador & 2005 & $\mathbf{2 0 1 0}$ \\
\hline Desempleo (\% de la fuerza de trabajo total) & n.d. & n.d. \\
\hline Población activa, mujeres (\% de la fuerza de trabajo total) & n.d. & n.d. \\
\hline AOD neta recibida (\% del INB) & 0,5 & 1,8 \\
\hline Derechos de importación percibidos (\% de los ingresos fiscales) & 15,7 & 15,7 \\
\hline Total del servicio de la deuda (\% de las exportaciones totales) & 20,5 & 23,2 \\
\hline Índice de desarrollo humano (0 a 1) & n.d. & 0,74 \\
\hline
\end{tabular}

Fuentes: PNUD, indicadores internacionales sobre desarrollo humano; Banco Mundial, Indicadores del Desarrollo Mundial.

Producto interno bruto

PIB per cápita (PPA, dólares internacionales corrientes)
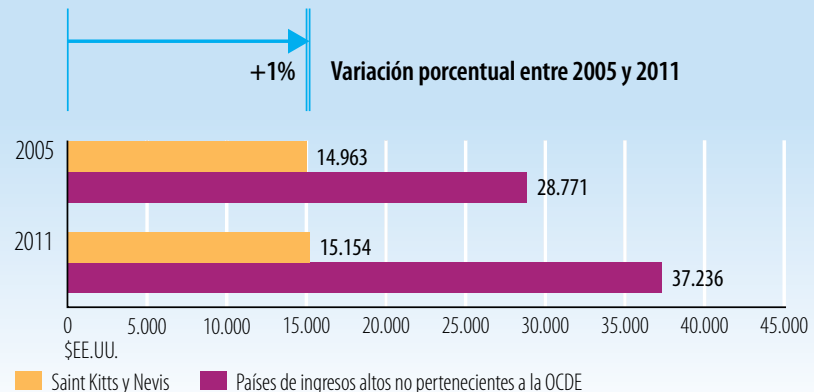

Saint Kitts y Nevis Países de ingresos altos no pertenecientes a la OCDE

\section{PIB per cápita (\$̦EE.UU. constantes de 2000)}
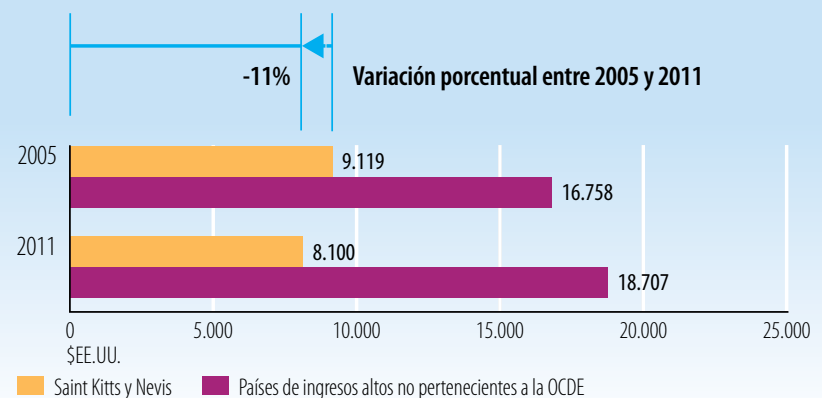

Fuentes: Banco Mundial, Indicadores del Desarrollo Mundial.

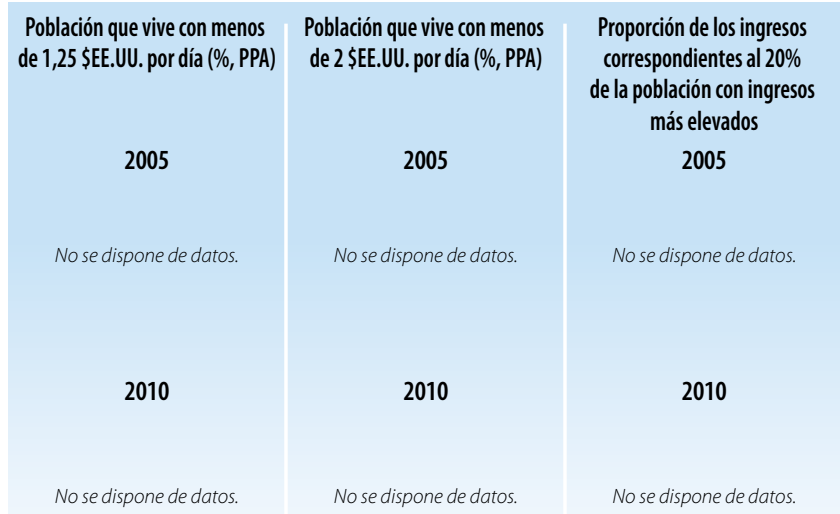

Fuentes: Banco Mundial, Indicadores del Desarrollo Mundial.

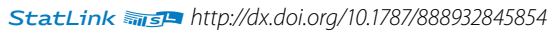


Indicadores de la ayuda, el comercio y el desarrollo relativos a San Vicente y las Granadinas

\begin{tabular}{|c|c|c|c|c|}
\hline Indicador (millones de \$̦EE.UU. corrientes) & 2005 & 2008 & 2010 & $\Delta: 05-10(\%)$ \\
\hline Formación bruta de capital fijo & 146,7 & 198,2 & n.d. & n.d. \\
\hline del cual: público & n.d. & n.d. & n.d. & n.d. \\
\hline del cual: privado & n.d. & n.d. & n.d. & n.d. \\
\hline \multicolumn{5}{|l|}{ Entrada de financiación externa } \\
\hline Entradas de IED & 40,1 & 159,2 & 102,9 & $157 \%$ \\
\hline $\begin{array}{l}\text { Deuda externa a largo plazo y fondos } \\
\text { desembolsados por el FMI }\end{array}$ & 42,4 & 23,4 & 76,2 & $80 \%$ \\
\hline $\begin{array}{l}\text { Corrientes comerciales en condiciones no } \\
\text { concesionarias }\end{array}$ & 0,0 & 0,1 & 0,0 & $2456 \%$ \\
\hline Corrientes de Ayuda para el Comercio & 5,9 & 16,9 & 4,1 & $-29 \%$ \\
\hline $\begin{array}{l}\text { Remesas de trabajadores y remuneración } \\
\text { de empleados }\end{array}$ & 26,5 & 31,1 & 30,6 & $16 \%$ \\
\hline
\end{tabular}

Fuentes: OCDE, base de datos del SNPA del CAD sobre las actividades de ayuda; Banco Mundial, Indicadores del Desarrollo Mundial; Banco Mundial, estadísticas de la deuda internacional.

Desembolsos de la ayuda para el comercio, por sector (millones de \$EE.UU. corrientes)

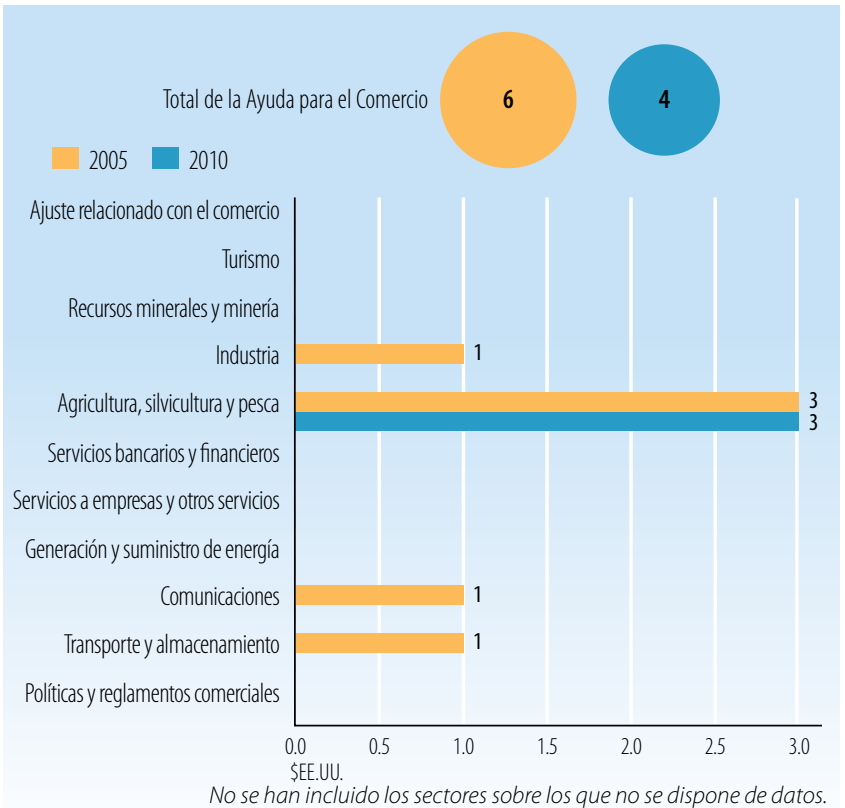

Fuentes: OCDE, base de datos del SNPA del CAD sobre las actividades de ayuda

Desembolsos de la ayuda para el comercio: principales donantes (millones de \$̦E.UU. corrientes)

\begin{tabular}{|l|r|r|r|}
\hline $\mathbf{2 0 0 5}$ & Valor & $\%$ & Principales donantes en 2005 \\
\hline Banco Mundial & 2,9 & 49 & \\
\hline Japón & 2,6 & 45 & $100 \%$ \\
\hline Instituciones de la UE & 0,3 & 5 & \\
\hline Canadá & 0,0 & 0 & \\
\hline Estados Unidos & 0,0 & 0 & \\
\hline $\mathbf{2 0 1 0}$ & Valor & $\%$ & Principales donantes en $\mathbf{2 0 1 0}$ \\
\hline Instituciones de la UE & 3,5 & 86 & \\
\hline Japón & 0,3 & 8 & \\
\hline Banco Mundial & 0,2 & 4 & $\mathbf{9 9 \%}$ \\
\hline Australia & 0,1 & 2 & \\
\hline Alemania & 0,0 & 1 & \\
\hline
\end{tabular}

Fuentes: OCDE, base de datos del SNPA del CAD sobre las actividades de ayuda.

\section{INDICADORES COMERCIALES (PRODUCTOS)}

\section{Indicador}

$2005 \quad 2008 \quad 2011 \quad \Delta: 05-11(\%)$

Relación comercio/PIB (\%)

Exportaciones de servicios comerciales como

$\%$ de las exportaciones totales

Importaciones de servicios comerciales como

$\%$ de las importaciones totales

Productos intermedios distintos de los combustibles

(\% de las exportaciones de mercancías)

Productos intermedios distintos de los combustibles

(\% de las importaciones de mercancías)

\begin{tabular}{|r|r|r|r|}
\hline 88 & 91 & 82 & -6 \\
\hline 79 & 73 & 77 & -2 \\
\hline 25 & 23 & 23 & -3 \\
\hline 32 & 37 & n.d. & n.d. \\
\hline 37 & 36 & n.d. & n.d. \\
\hline
\end{tabular}

Fuentes: Secretaría de la OMC.

Corrientes comerciales (millones de \$EE.UU. corrientes)

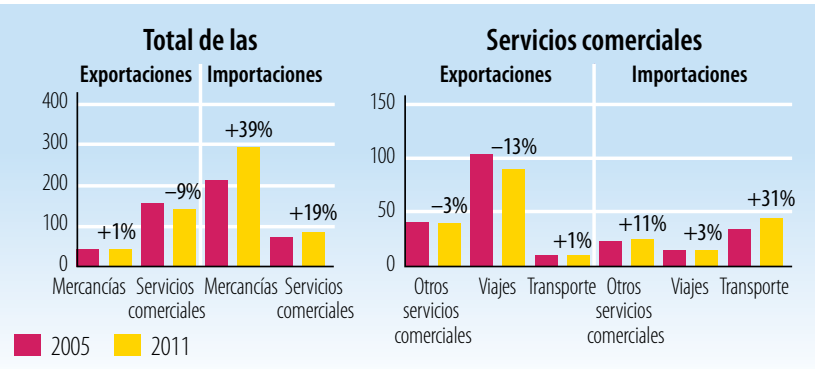

Fuentes: Secretaría de la OMC

Cinco principales mercados de exportación de mercancías (\%)

\begin{tabular}{|l|c|l|c|}
\hline 2005 & $\%$ & $\mathbf{2 0 1 0}$ & $\%$ \\
\hline UE (27) & 27 & Santa Lucía & 21 \\
\hline Barbados & 13 & Trinidad y Tabago & 16 \\
\hline Trinidady Tabago & 12 & UE (27) & 12 \\
\hline Santa Lucía & 11 & Barbados & 11 \\
\hline Estados Unidos & 9 & Antigua y Barbuda & 7 \\
\hline
\end{tabular}

Fuentes: Secretaría de la OMC

Cinco principales productos de exportación (\% de las exportaciones de mercancías)

\begin{tabular}{|l|r|l|c|}
\hline 2005 & $\%$ & $\mathbf{2 0 1 0}$ & $\%$ \\
\hline $\begin{array}{l}\text { Frutas y nueces, excepto nueces } \\
\text { oleaginosas }\end{array}$ & 34 & $\begin{array}{l}\text { Sémola y harina de trigo y harina de } \\
\text { morcajo o tranquillón }\end{array}$ & 21 \\
\hline $\begin{array}{l}\text { Sémolay harina de trigo y harina de } \\
\text { morcajo o tranquillón }\end{array}$ & 13 & $\begin{array}{l}\text { Frutas y nueces, excepto nueces } \\
\text { oleaginosas }\end{array}$ & 16 \\
\hline $\begin{array}{l}\text { Legumbres } \\
\text { Arroz }\end{array}$ & 10 & Legumbres & 10 \\
\hline $\begin{array}{l}\text { Pienso para animales } \\
\text { Fuentes:Secretaría de la OMC }\end{array}$ & 5 & Arroz & 9 \\
\hline
\end{tabular}

Cinco principales mercados de importación de mercancías (\%)

\begin{tabular}{|l|r|l|c|}
\hline 2005 & $\%$ & $\mathbf{2 0 1 0}$ & $\%$ \\
\hline Estados Unidos & 33 & Estados Unidos & 33 \\
\hline Trinidady Tabago & 24 & Trinidad y Tabago & 27 \\
\hline UE (27) & 15 & UE (27) & 10 \\
\hline Japón & 4 & China & 5 \\
\hline Barbados & 4 & Canadá & 5 \\
\hline
\end{tabular}

Fuentes: Secretaría de la OMC

Cinco principales productos de importación (\% de las importaciones de mercancías)

\begin{tabular}{|c|c|c|c|}
\hline 2005 & $\%$ & 2010 & $\%$ \\
\hline Productos derivados del petróleo & 12 & Productos derivados del petróleo & 21 \\
\hline Otras carnes y despojos de carnes & 4 & Muebles, cojines, etc. & 3 \\
\hline $\begin{array}{l}\text { Vehículos automotores para pasajeros, } \\
\text { excepto autobuses }\end{array}$ & 2 & Otras carnes y despojos de carnes & 3 \\
\hline $\begin{array}{l}\text { Equipos de telecomunicaciones y sus } \\
\text { partes, n.e.p. }\end{array}$ & 2 & Productos y preparados comestibles, n.e.p. & 2 \\
\hline Cal, cemento y materiales de construcción & 2 & Trigo y morcajo o tranquillón, sin moler & 2 \\
\hline
\end{tabular}




\section{LA AYUDA PARA EL COMERCIO EN SINNTESIS 2013}

\section{INDICADORES COMERCIALES (RESULTADOS)}

\section{Indicador}

Crecimiento del PIB (\%)

Número de exportadores

Índice de concentración de las exportaciones (productos) ( 0 a 1)

ACR sobre mercancías notificados a la OMC

AIE (servicios) notificados a la OMC

Sectores de servicios con compromisos en el marco del AGCS

\section{Aranceles (\%, 2006 et 2011)}

\begin{tabular}{ll|l|l|l|} 
Importaciones: promedio aritmético de los aranceles NMF aplicados & 9,8 & 10,1
\end{tabular}

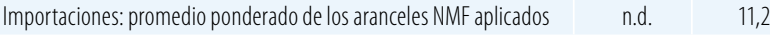

\begin{tabular}{|l|l|l|}
\hline Exportaciones: promedio ponderado de los aranceles impuestos & 2,4 & 7,2 \\
\hline
\end{tabular}

por los importadores

Exportaciones: libres de derechos (en \%)

Fuentes: Naciones Unidas, base de datos Comtrade; Banco Mundial, base de datos sobre dinámica de las empresas de exportación; Banco Mundial, Indicadores del

Desarrollo Mundial; OMC, perfiles comerciales y arancelarios.

Participación en las exportaciones por región (\%)

\begin{tabular}{|l|r|r|}
\hline & 2005 & 2011 \\
\hline África & 0,0 & 0,2 \\
\hline Asia & 0,2 & 1,0 \\
\hline Comunidad de Estados Independientes & 0,0 & 0,0 \\
\hline Europa & 27,2 & 2,9 \\
\hline Oriente Medio & 0,0 & 0,0 \\
\hline América del Norte & 9,5 & 5,3 \\
\hline América del Sury América Central & 63,1 & 90,2 \\
\hline
\end{tabular}

Fuentes: OMC, perfiles comerciales y arancelarios

Indicadores de facilitación del comercio
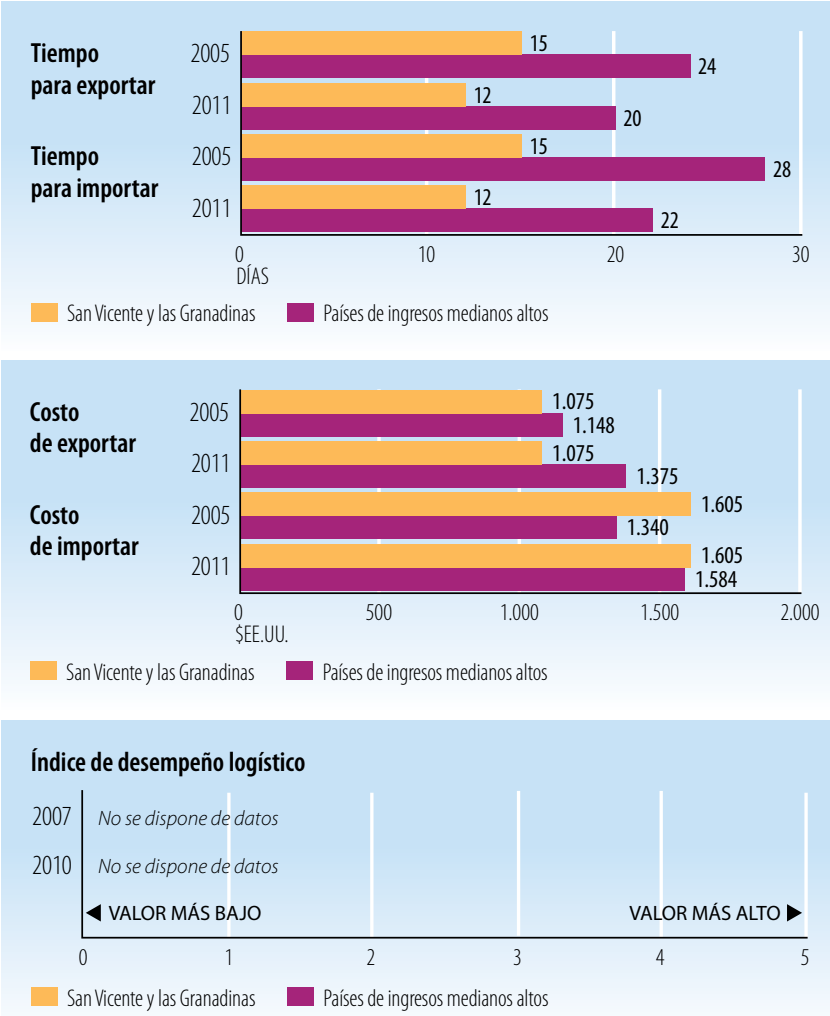

Fuentes: Banco Mundial, Indicadores del Desarrollo Mundial.

\begin{tabular}{|l|c|c|}
\hline INDICADORES DE DESARROLLO (EFECTOS) & \\
\hline Indicador & 2005 & $\mathbf{2 0 1 0}$ \\
\hline Desempleo (\% de la fuerza de trabajo total) & n.d. & n.d. \\
\hline Población activa, mujeres (\% de la fuerza de trabajo total) & 39,8 & 41,0 \\
\hline AOD neta recibida (\% del INB) & 1,5 & 2,6 \\
\hline Derechos de importación percibidos (\% de los ingresos fiscales) & 36,9 & 11,4 \\
\hline Total del servicio de la deuda (\% de las exportaciones totales) & 11,3 & 16,4 \\
\hline Índice de desarrollo humano (0 a 1) & n.d. & 0,72 \\
\hline
\end{tabular}

Fuentes: PNUD, indicadores internacionales sobre desarrollo humano; Banco Mundial, Indicadores del Desarrollo Mundial.

Producto interno bruto

PIB per cápita (PPA, dólares internacionales corrientes)

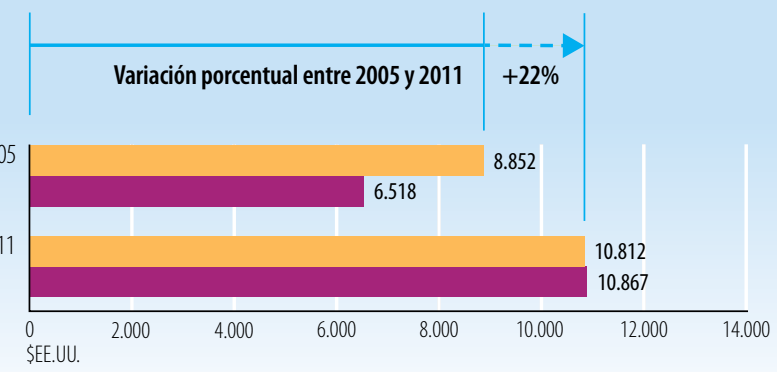

San Vicente y las Granadinas Países de ingresos medianos altos

PIB per cápita (\$EE.UU. constantes de 2000)
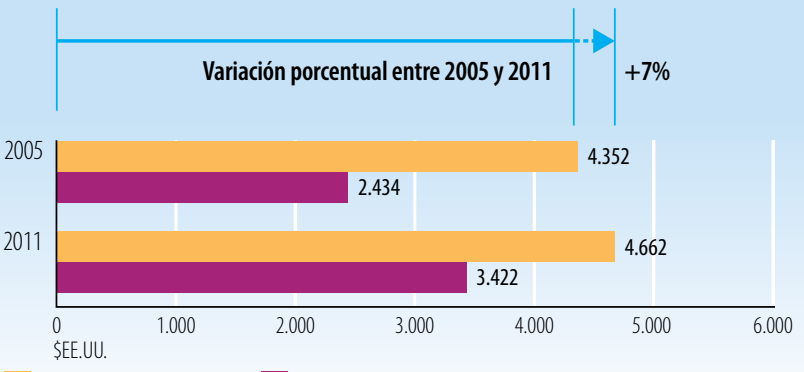

San Vicente y las Granadinas Páses de ingresos medianos altos

Fuentes: Banco Mundial, Indicadores del Desarrollo Mundial.

\begin{tabular}{|c|c|c|}
\hline $\begin{array}{l}\text { Población que vive con menos } \\
\text { de } 1,25 \$ \text { EE.UU. por día }(\%, P P A)\end{array}$ & $\begin{array}{l}\text { Población que vive con menos } \\
\text { de } 2 \text { \$EE.UU. por día }(\%, \text { PPA) }\end{array}$ & $\begin{array}{l}\text { Proporción de los ingresos } \\
\text { correspondientes al } 20 \% \\
\text { de la población con ingresos } \\
\text { más elevados }\end{array}$ \\
\hline 2005 & 2005 & 2005 \\
\hline No se dispone de datos. & No se dispone de datos. & No se dispone de datos. \\
\hline 2010 & 2010 & 2010 \\
\hline No se dispone de datos. & No se dispone de datos. & No se dispone de datos. \\
\hline
\end{tabular}

Fuentes: Banco Mundial, Indicadores del Desarrollo Mundial.

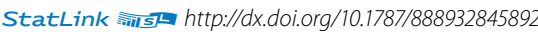


A SANTA LUCIAA

\section{LA AYUDA PARA EL COMERCIO EN SÍNTESIS 2013}

\section{Indicadores de la ayuda, el comercio y el desarrollo relativos a Santa Lucía}

\section{INVERSIÓN Y FINANCIACIÓN (APORTES)}

\begin{tabular}{|c|c|c|c|c|}
\hline Indicador (millones de \$̦EE.UU. corrientes) & 2005 & 2008 & 2010 & $\Delta: 05-10(\%)$ \\
\hline Formación bruta de capital fijo & 269,8 & 364,6 & 401,2 & $49 \%$ \\
\hline del cual: público & n.d. & n.d. & n.d. & n.d. \\
\hline del cual: privado & n.d. & n.d. & n.d. & n.d. \\
\hline \multicolumn{5}{|l|}{ Entrada de financiación externa } \\
\hline Entradas de IED & 78,2 & 161,2 & 110,0 & $41 \%$ \\
\hline $\begin{array}{l}\text { Deuda externa a largo plazo y fondos } \\
\text { desembolsados por el FMl }\end{array}$ & 11,7 & 11,5 & 21,3 & $82 \%$ \\
\hline $\begin{array}{l}\text { Corrientes comerciales en condiciones no } \\
\text { concesionarias }\end{array}$ & 1,7 & 0,1 & 1,6 & $-9 \%$ \\
\hline Corrientes de Ayuda para el Comercio & 7,8 & 12,9 & 22,3 & $188 \%$ \\
\hline $\begin{array}{l}\text { Remesas de trabajadores y remuneración } \\
\text { de empleados }\end{array}$ & 29,5 & 31,5 & 31,4 & $7 \%$ \\
\hline
\end{tabular}

Fuentes: OCDE, base de datos del SNPA del CAD sobre las actividades de ayuda; Banco Mundial, Indicadores del Desarrollo Mundial; Banco Mundial, estadísticas de la deuda internacional.

Desembolsos de la ayuda para el comercio, por sector (millones de \$̦EE.UU. corrientes)

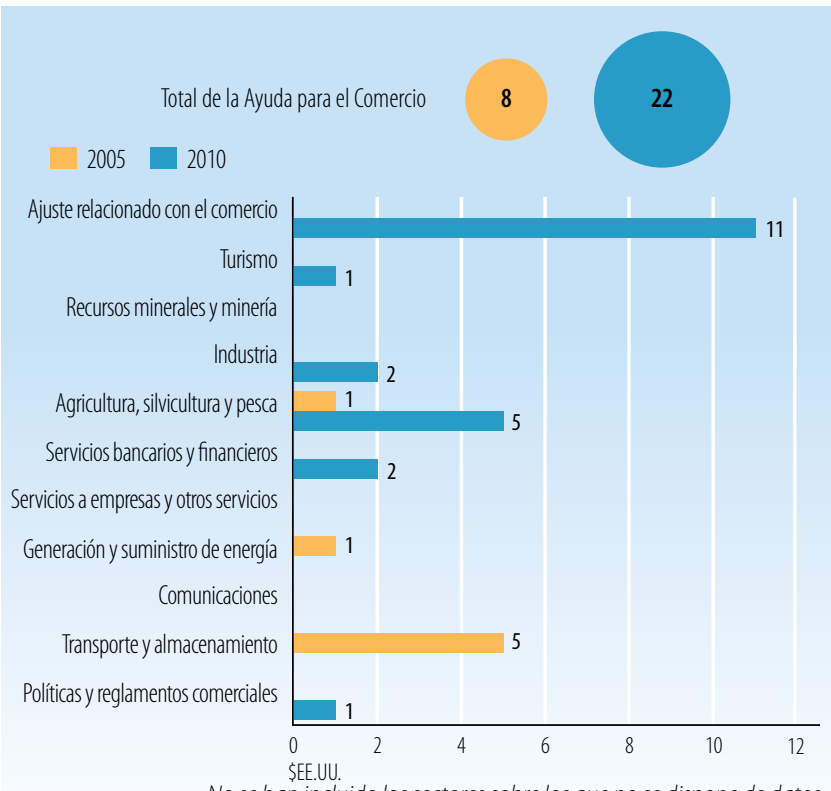

No se han incluido los sectores sobre los que no se dispone de datos.

Fuentes: OCDE, base de datos del SNPA del CAD sobre las actividades de ayuda

Desembolsos de la ayuda para el comercio: principales donantes (millones de \$EE.UU. corrientes)

\begin{tabular}{|l|c|c|c|}
\hline $\mathbf{2 0 0 5}$ & Valor & $\%$ & Principales donantes en 2005 \\
\hline Francia & 4,4 & 57 & \\
\hline Banco Mundial & 1,7 & 22 & $100 \%$ \\
\hline Instituciones de la UE & 1,2 & 16 & \\
\hline Japón & 0,4 & 5 & \\
\hline Canadá & 0,0 & 0 & Principales donantes en 2010 \\
\hline $\mathbf{2 0 1 0}$ & Valor & $\%$ & \\
\hline Instituciones de la UE & 17,8 & 80 & $100 \%$ \\
\hline Banco Mundial & 3,1 & 14 & \\
\hline Japón & 1,3 & 6 & \\
\hline Australia & 0,1 & 0 & \\
\hline PNUD & 0,0 & 0 & \\
\hline
\end{tabular}

Fuentes: OCDE, base de datos del SNPA del CAD sobre las actividades de ayuda.

\section{INDICADORES COMERCIALES (PRODUCTOS)}

\section{Indicador}

$2005 \quad 2008 \quad 2011 \quad \Delta: 05-11(\%)$

Relación comercio/PIB (\%)

\begin{tabular}{|l|l|l|l|}
127 & 119 & 112 & -15 \\
\hline
\end{tabular}

Exportaciones de servicios comerciales como

$\%$ de las exportaciones totales

\begin{tabular}{l|l|l|l|}
83 & 68 & 68 & -15
\end{tabular}

mportaciones de servicios comerciales como

$\%$ de las importaciones totales

$29 \quad 26 \quad 25 \quad-5$

Productos intermedios distintos de los combustibles

(\% de las exportaciones de mercancías)

Productos intermedios distintos de los combustibles

(\% de las importaciones de mercancías)

$16 \quad 16 \quad$ n.d. $\quad$ n.d.

$30 \quad 24 \quad$ n.d. $\quad$ n.d.

Fuentes: Secretaría de la OMC

Corrientes comerciales (millones de \$EE.UU. corrientes)

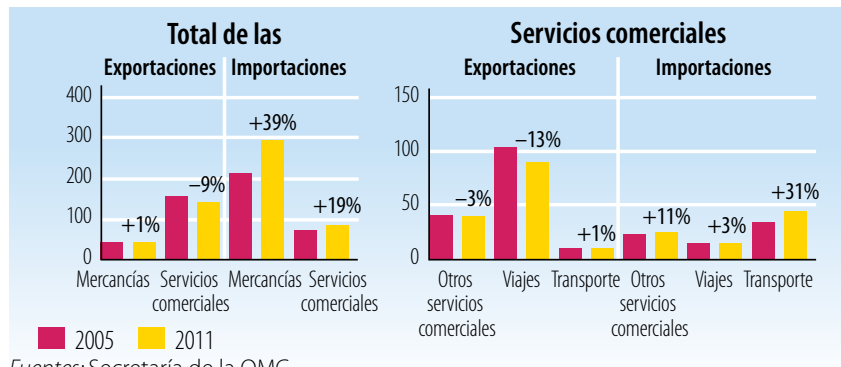

Fuentes. Secretaría de la OMC

Cinco principales mercados de exportación de mercancías (\%)

\begin{tabular}{|l|r|l|r|}
\hline $\mathbf{2 0 0 5}$ & $\%$ & $\mathbf{2 0 0 8}$ & $\%$ \\
\hline UE (27) & 28 & Estados Unidos & 34 \\
\hline Trinidady Tabago & 22 & Trinidad y Tabago & 23 \\
\hline Estados Unidos & 14 & UE (27) & 17 \\
\hline Barbados & 10 & Barbados & 8 \\
\hline Granada & 5 & San Vicente y las Granadinas & 3 \\
\hline
\end{tabular}

Fuentes: Secretaría de la OMC

Cinco principales productos de exportación (\% de las exportaciones de mercancías)

\begin{tabular}{|c|c|c|c|}
\hline 2005 & $\%$ & 2008 & $\%$ \\
\hline $\begin{array}{l}\text { Frutas y nueces, excepto nueces } \\
\text { oleaginosas }\end{array}$ & 25 & Productos derivados del petróleo & 19 \\
\hline Bebidas alcohólicas & 17 & $\begin{array}{l}\text { Frutas y nueces, excepto nueces } \\
\text { oleaginosas }\end{array}$ & 14 \\
\hline Productos derivados del petróleo & 15 & Bebidas alcohólicas & 11 \\
\hline Papeles y cartones recortados, etc. & 5 & Joyas y objetos de oro o plata, n.e.p. & 7 \\
\hline $\begin{array}{l}\text { Equipos de telecomunicaciones y sus } \\
\text { partes, n.e.p. }\end{array}$ & 3 & Relojes & 4 \\
\hline
\end{tabular}

Cinco principales mercados de importación de mercancías (\%)

\begin{tabular}{|l|r|l|r|}
\hline 2005 & $\%$ & 2008 & $\%$ \\
\hline Estados Unidos & 44 & Estados Unidos & 43 \\
\hline UE (27) & 14 & Trinidad y Tabago & 24 \\
\hline Trinidady Tabago & 14 & UE (27) & 8 \\
\hline Japón & 5 & Japón & 4 \\
\hline Barbados & 3 & Barbados & 4 \\
\hline
\end{tabular}

Fuentes: Secretaría de la OMC

Cinco principales productos de importación (\% de las importaciones de mercancías) \begin{tabular}{l|l|l|l}
2005 & $\%$ & 2008 & $\%$
\end{tabular}

\begin{tabular}{|l|l|l|l|l|}
\hline Productos derivados del petróleo & 13 & Productos derivados del petróleo & 24
\end{tabular}

$\begin{array}{llll}\text { Vehículos automotores para pasajeros, } & 3 & \text { Vehículos automotores para pasajeros, } & 4\end{array}$ excepto autobuses

Vehículos automotores para el transporte para usos especiales

\begin{tabular}{l|l|l|l|}
\hline Otras carnes y despojos de carnes & 3 & Otras carnes y despojos de carnes
\end{tabular}

Equipos de telecomunicaciones y sus

partes, n.e.p.

3 Bebidas alcohólicas

Fuentes: Secretaría de la OMC 


\section{LA AYUDA PARA EL COMERCIO EN SÍNTESIS 2013}

\section{INDICADORES COMERCIALES (RESULTADOS)}

\section{Indicador}

Crecimiento del PIB (\%)

Número de exportadores

Índice de concentración de las exportaciones (productos) (0 a 1)

ACR sobre mercancías notificados a la OMC

AIE (servicios) notificados a la OMC

Sectores de servicios con compromisos en el marco del AGCS

\section{Aranceles (\%)}

Importaciones: promedio aritmético de los aranceles NMF aplicados $\quad 8,9 \quad 10,2$

Importaciones: promedio ponderado de los aranceles NMF aplicados n.d. n.d.

Exportaciones: promedio ponderado de los aranceles impuestos $12,3 \quad$ n.d.

por los importadores

Exportaciones: libres de derechos (en \%)

$56,7 \quad 100,0$

Fuentes: Naciones Unidas, base de datos Comtrade; Banco Mundial, base de datos sobre dinámica de las empresas de exportación; Banco Mundial, Indicadores del Desarrollo Mundial; OMC, perfiles comerciales y arancelarios.

Participación en las exportaciones por región (\%)

\begin{tabular}{|l|r|r|}
\hline & $\mathbf{2 0 0 5}$ & $\mathbf{2 0 0 8}$ \\
\hline África & 0,0 & 1,3 \\
\hline Asia & 0,8 & 1,7 \\
\hline Comunidad de Estados Independientes & 0,0 & 0,1 \\
\hline Europa & 28,2 & 17,1 \\
\hline Oriente Medio & 0,0 & 0,1 \\
\hline América del Norte & 14,4 & 34,4 \\
\hline América del Sury América Central & 54,4 & 45,3 \\
\hline
\end{tabular}

Fuentes: OMC, perfiles comerciales y arancelarios

Indicadores de facilitación del comercio
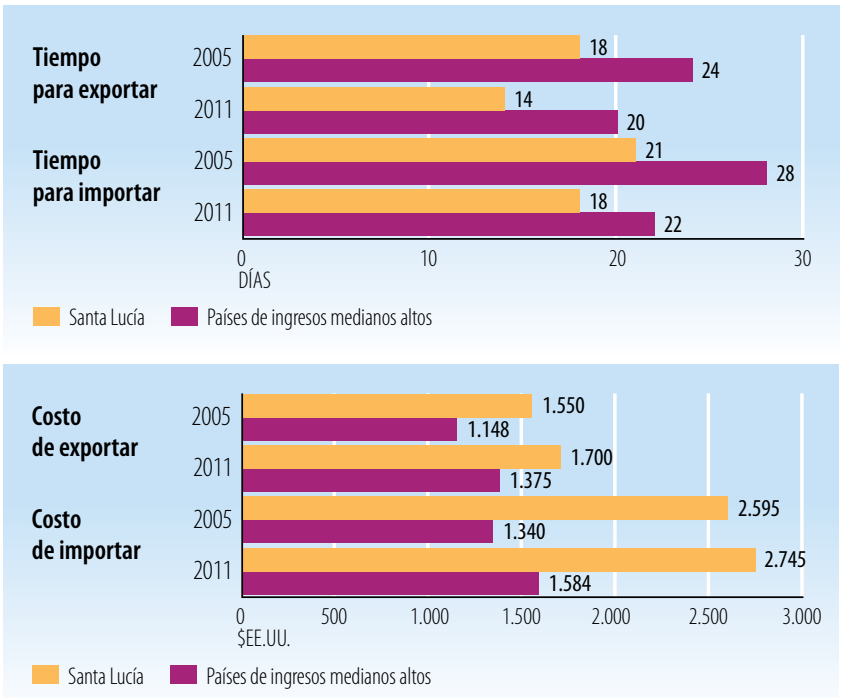

\section{Índice de desempeño logístico}

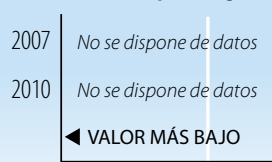

- Santa Lucía Países de ingresos medianos altos

Fuentes: Banco Mundial, Indicadores del Desarrollo Mundial.

\begin{tabular}{|l|c|c|}
\hline INDICADORES DE DESARROLLO (EFECTOS) & \\
\hline Indicador & 2005 & 2010 \\
\hline Desempleo (\% de la fuerza de trabajo total) & 16,6 & n.d. \\
\hline Población activa, mujeres (\% de la fuerza de trabajo total) & 46,7 & 47,2 \\
\hline A0D neta recibida (\% del INB) & 1,3 & 3,6 \\
\hline Derechos de importación percibidos (\% de los ingresos fiscales) & n.d. & n.d. \\
\hline Total del servicio de la deuda (\% de las exportaciones totales) & 6,0 & 7,1 \\
\hline Índice de desarrollo humano (0 a 1) & n.d. & 0,72 \\
\hline
\end{tabular}

Fuentes: PNUD, indicadores internacionales sobre desarrollo humano; Banco Mundial, Indicadores del Desarrollo Mundial.

Producto interno bruto

PIB per cápita (PPA, dólares internacionales corrientes)
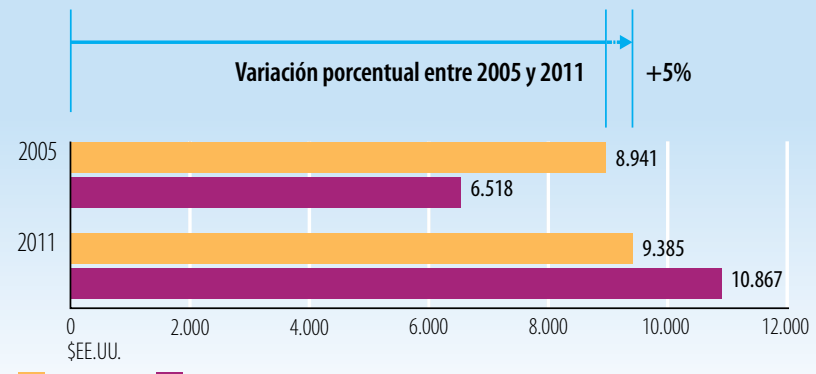

Santa Lucía Países de ingresos medianos altos

PIB per cápita (\$EE.UU. constantes de 2000)
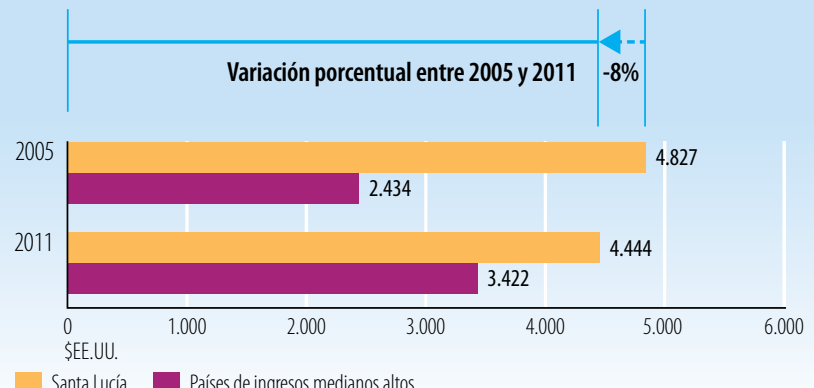

- Santa Lucía Países de ingresos medianos altos

Fuentes: Banco Mundial, Indicadores del Desarrollo Mundial.

\begin{tabular}{|c|c|c|}
\hline $\begin{array}{l}\text { Población que vive con menos } \\
\text { de } 1,25 \text { \$EE.UU. por día }(\%, \mathrm{PPA})\end{array}$ & $\begin{array}{l}\text { Población que vive con menos } \\
\text { de } 2 \text { \$EE.UU. por día (\%, PPA) }\end{array}$ & $\begin{array}{c}\text { Proporción de los ingresos } \\
\text { correspondientes al } 20 \% \\
\text { de la población con ingresos } \\
\text { más elevados }\end{array}$ \\
\hline 2005 & 2005 & 2005 \\
\hline No se dispone de datos. & No se dispone de datos. & No se dispone de datos. \\
\hline 2010 & 2010 & 2010 \\
\hline No se dispone de datos. & No se dispone de datos. & No se dispone de datos. \\
\hline
\end{tabular}




\section{Indicadores de la ayuda, el comercio y el desarrollo relativos a Samoa}

\begin{tabular}{|c|c|c|c|c|}
\hline Indicador (millones de \$EE.UU. corrientes) & 2005 & 2008 & 2010 & $\Delta: 05-10(\%$ \\
\hline Formación bruta de capital fijo & n.d. & n.d. & n.d. & n.d. \\
\hline del cual: público & n.d. & n.d. & n.d. & n.d. \\
\hline del cual: privado & n.d. & n.d. & n.d. & n.d. \\
\hline \multicolumn{5}{|l|}{ Entrada de financiación externa } \\
\hline Entradas de IED & $-3,0$ & 45,9 & 0,7 & $125 \%$ \\
\hline $\begin{array}{l}\text { Deuda externa a largo plazo y fondos } \\
\text { desembolsados por el FMl }\end{array}$ & 10,4 & 25,5 & 78,9 & $660 \%$ \\
\hline $\begin{array}{l}\text { Corrientes comerciales en condiciones no } \\
\text { concesionarias }\end{array}$ & 0,0 & 0,0 & 0,0 & $0 \%$ \\
\hline Corrientes de Ayuda para el Comercio & 10,1 & 8,8 & 32,5 & $222 \%$ \\
\hline $\begin{array}{l}\text { Remesas de trabajadores y remuneración } \\
\text { de empleados }\end{array}$ & 109,9 & 135,0 & 143,4 & $30 \%$ \\
\hline
\end{tabular}

Fuentes: OCDE, base de datos del SNPA del CAD sobre las actividades de ayuda; Banco Mundial, Indicadores del Desarrollo Mundial; Banco Mundial, estadísticas de la deuda internacional.

Desembolsos de la ayuda para el comercio, por sector (millones de \$EE.UU. corrientes)

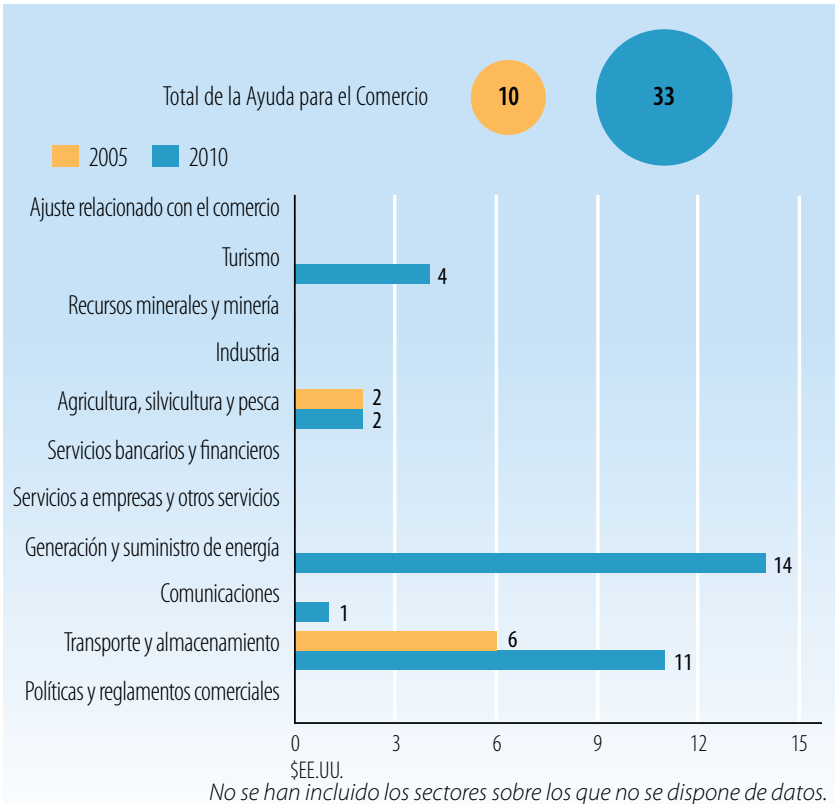

Fuentes: OCDE, base de datos del SNPA del CAD sobre las actividades de ayuda

Desembolsos de la ayuda para el comercio: principales donantes (millones de \$EE.UU. corrientes)

\begin{tabular}{|l|r|r|}
\hline $\mathbf{2 0 0 5}$ & Valor & $\%$ \\
\hline Banco Mundial & 6,2 & 61 \\
\hline Japón & 1,9 & 18 \\
\hline Australia & 1,6 & 16 \\
\hline Nueva Zelandia & 0,4 & 4 \\
\hline PNUD & 0,1 & 1 \\
\hline $\mathbf{2 0 1 0}$ & Valor & $\%$ \\
\hline Japón & 11,5 & 35 \\
\hline Banco Mundial & 9,8 & 30 \\
\hline Banco Asiático de Desarrollo & 5,3 & 16 \\
\hline Australia & 3,2 & 10 \\
\hline Nueva Zelandia & 2,3 & 7 \\
\hline
\end{tabular}

Principales donantes en 2005 $100 \%$

Principales donantes en 2010

$99 \%$
Fuentes: OCDE, base de datos del SNPA del CAD sobre las actividades de ayuda.

\section{INDICADORES COMERCIALES (PRODUCTOS)}

\section{Indicador}

$2005 \quad 2008 \quad 2011 \quad \Delta: 05-11(\%)$

Relación comercio/PIB (\%)

Exportaciones de servicios comerciales como

$\%$ de las exportaciones totales

Importaciones de servicios comerciales como

$\%$ de las importaciones totales

Productos intermedios distintos de los combustibles

(\% de las exportaciones de mercancías)

Productos intermedios distintos de los combustibles

(\% de las importaciones de mercancías)

\begin{tabular}{|l|l|l|l|}
\hline 89 & 86 & 91 & 2 \\
\hline 90 & 74 & 86 & -4 \\
\hline 23 & 20 & 19 & -4 \\
\hline 77 & 84 & 70 & -7 \\
\hline 29 & 24 & 31 & 2 \\
\hline
\end{tabular}

Fuentes: Secretaría de la OMC.

Corrientes comerciales (millones de \$EE.UU. corrientes)

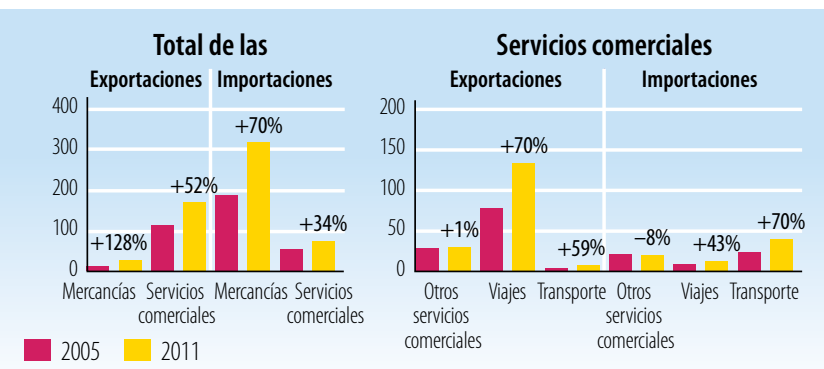

Fuentes: Secretaría de la OMC

Cinco principales mercados de exportación de mercancías (\%)

\begin{tabular}{|l|c|l|c|}
\hline 2005 & $\%$ & 2010 & $\%$ \\
\hline Australia & 75 & Australia & 77 \\
\hline Samoa Americana & 13 & Nueva Zelandia & 11 \\
\hline Estados Unidos & 6 & Samoa Americana & 5 \\
\hline Nueva Zelandia & 2 & Estados Unidos & 3 \\
\hline Tokelau & 1 & Singapur & 2 \\
\hline
\end{tabular}

Fuentes: Secretaría de la OMC

Cinco principales productos de exportación (\% de las exportaciones de mercancías)

\begin{tabular}{|c|c|c|c|}
\hline 2005 & $\%$ & 2011 & $\%$ \\
\hline $\begin{array}{l}\text { Equipo para distribución de electricidad, } \\
\text { n.e.p. }\end{array}$ & 73 & $\begin{array}{l}\text { Equipo para distribución de electricidad, } \\
\text { n.e.p. }\end{array}$ & 59 \\
\hline Pescado, fresco, refrigerado o congelado & 11 & Pescado, fresco, refrigerado o congelado & 14 \\
\hline Jugos de frutas o legumbres & 4 & $\begin{array}{l}\text { Otros aceites y grasas fijos de origen } \\
\text { vegetal }\end{array}$ & 7 \\
\hline Bebidas alcohólicas & 3 & Bebidas alcohólicas & 4 \\
\hline $\begin{array}{l}\text { Otros aceites y grasas fijos de origen } \\
\text { vegetal }\end{array}$ & 2 & Jugos de frutas o legumbres & 3 \\
\hline
\end{tabular}

Fuentes: Secretaría de la OMC

Cinco principales mercados de importación de mercancías (\%)

\begin{tabular}{|l|r|l|c|}
\hline 2005 & $\%$ & 2010 & $\%$ \\
\hline Nueva Zelandia & 33 & Nueva Zelandia & 31 \\
\hline Australia & 20 & Australia & 23 \\
\hline Estados Unidos & 14 & Estados Unidos & 11 \\
\hline Fiji & 7 & Japón & 8 \\
\hline Japón & 7 & China & 6 \\
\hline
\end{tabular}

Fuentes: Secretaría de la OMC

Cinco principales productos de importación (\% de las importaciones de mercancías)

\begin{tabular}{|c|c|c|c|}
\hline 2005 & $\%$ & 2011 & $\%$ \\
\hline Operaciones especiales no clasificadas & 22 & Productos derivados del petróleo & 21 \\
\hline Productos derivados del petróleo & 15 & Otras carnes y despojos de carnes & 6 \\
\hline $\begin{array}{l}\text { Artículos de alambre, excepto cables para } \\
\text { electricidad }\end{array}$ & 6 & Aparatos eléctricos rotativos & \\
\hline Otras carnes y despojos de carnes & 6 & Preparados de cereales & 3 \\
\hline Artículos, n.e.p., de materiales plásticos & 4 & Azúcares, melaza y miel & 2 \\
\hline
\end{tabular}




\section{LA AYUDA PARA EL COMERCIO EN SÍNTESIS 2013}

\section{INDICADORES COMERCIALES (RESULTADOS)}

Indicador

Crecimiento del PIB (\%)

Número de exportadores

Índice de concentración de las exportaciones (productos) (0a 1)

ACR sobre mercancías notificados a la OMC

AIE (servicios) notificados a la OMC

Sectores de servicios con compromisos en el marco del AGCS

\section{Aranceles (\%)}

Importaciones: promedio aritmético de los aranceles NMF aplicados n.d. n.d.

Importaciones: promedio ponderado de los aranceles NMF aplicados n.d. n.d.

Exportaciones: promedio ponderado de los aranceles impuestos $\quad$ n.d. n.d.

por los importadores

Exportaciones: libres de derechos (en \%)

n.d. n.d.

Fuentes: Naciones Unidas, base de datos Comtrade; Banco Mundial, base de datos sobre dinámica de las empresas de exportación; Banco Mundial, Indicadores del

Desarrollo Mundial; OMC, perfiles comerciales y arancelarios.

Participación en las exportaciones por región (\%)

\begin{tabular}{|l|r|r|}
\hline & 2005 & 2011 \\
\hline África & 0,0 & 0,0 \\
\hline Asia & 93,4 & 96,2 \\
\hline Comunidad de Estados Independientes & 0,0 & 0,0 \\
\hline Europa & 0,2 & 0,6 \\
\hline Oriente Medio & 0,0 & 0,0 \\
\hline América del Norte & 6,4 & 3,2 \\
\hline América del Sury América Central & 0,0 & 0,0 \\
\hline
\end{tabular}

Fuentes: OMC, perfiles comerciales y arancelarios

Indicadores de facilitación del comercio
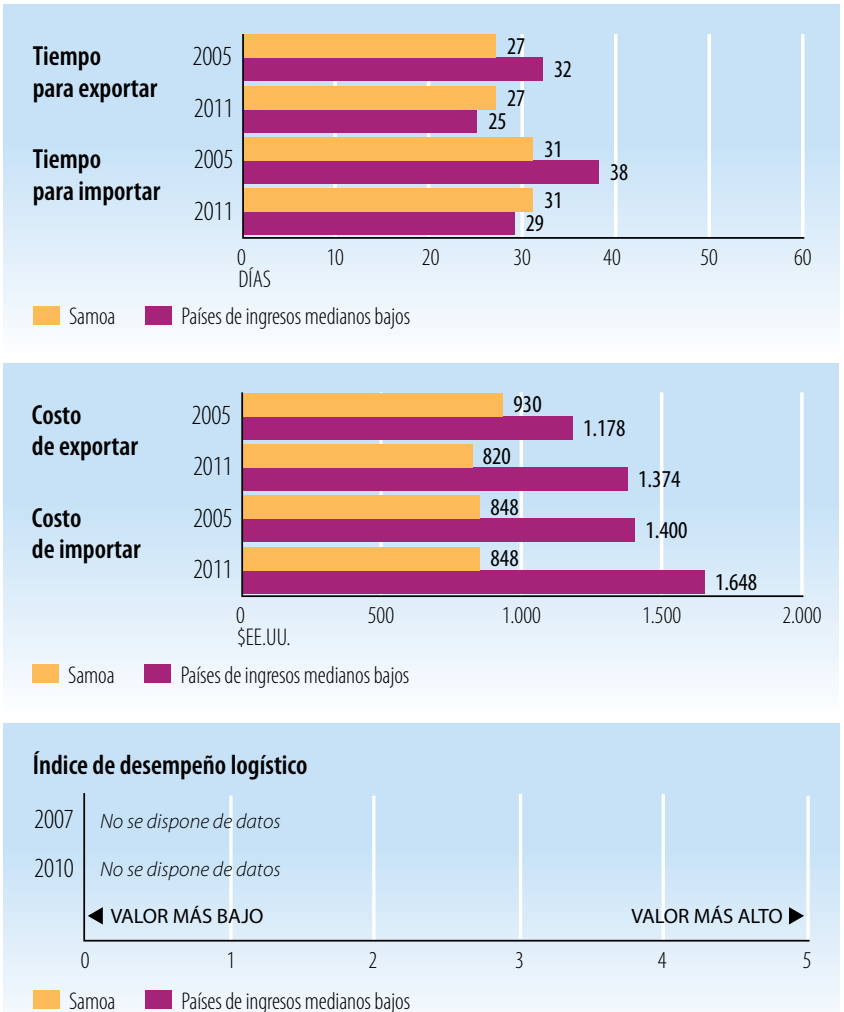

Fuentes: Banco Mundial, Indicadores del Desarrollo Mundial.

\begin{tabular}{l|c|c|}
\hline INDICADORES DE DESARROLLO (EFECTOS) \\
\hline Indicador & $\mathbf{2 0 0 5}$ & $\mathbf{2 0 1 0}$ \\
\hline Desempleo (\% de la fuerza de trabajo total) & n.d. & n.d. \\
\hline Población activa, mujeres (\% de la fuerza de trabajo total) & 33,7 & 34,3 \\
\hline AOD neta recibida (\% del INB) & 11,2 & 25,5 \\
\hline Derechos de importación percibidos (\% de los ingresos fiscales) & n.d. & n.d. \\
\hline Total del servicio de la deuda (\% de las exportaciones totales) & 4,4 & 5,2 \\
\hline Índice de desarrollo humano (0 a 1) & 0,68 & 0,69 \\
\hline
\end{tabular}

Fuentes: PNUD, indicadores internacionales sobre desarrollo humano; Banco Mundial, Indicadores del Desarrollo Mundial.

Producto interno bruto

PIB per cápita (PPA, dólares internacionales corrientes)
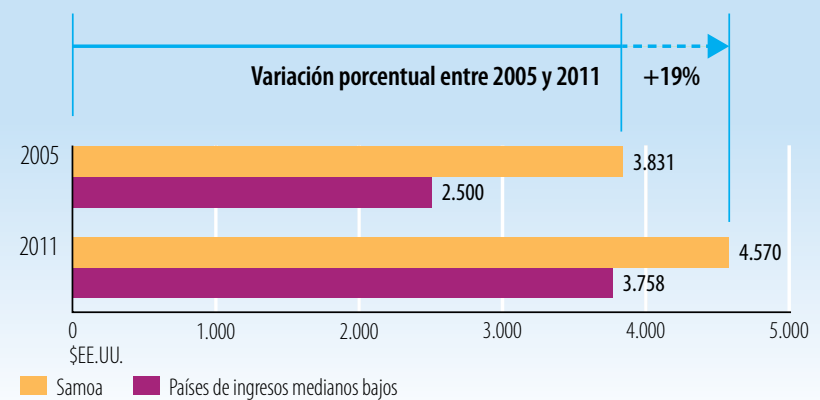

Samoa Países de ingresos medianos bajos

PIB per cápita (\$EE.UU. constantes de 2000)
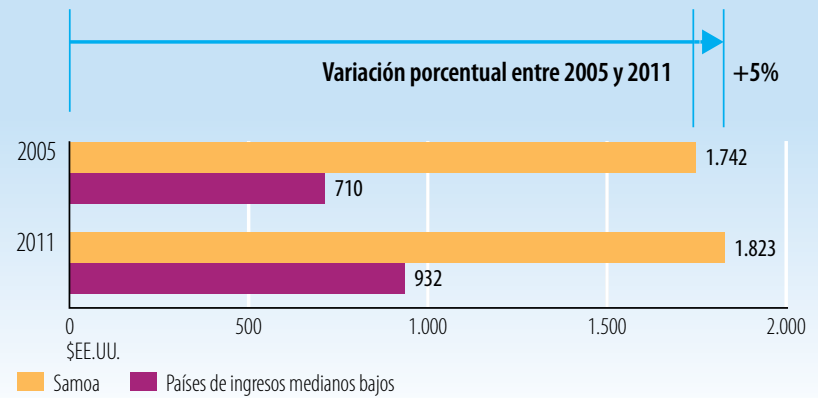

Fuentes: Banco Mundial, Indicadores del Desarrollo Mundial.

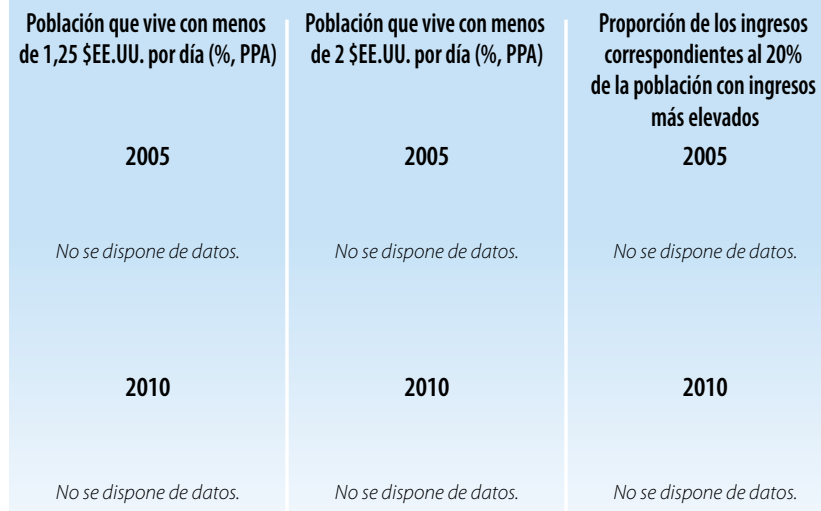

Fuentes: Banco Mundial, Indicadores del Desarrollo Mundial.

StatLink 체곤 http://dx.doi.org/10.1787/888932845911 
Indicadores de la ayuda, el comercio y el desarrollo relativos al Senegal

\begin{tabular}{|c|c|c|c|c|}
\hline Indicador (millones de \$EE.UU. corrientes) & 2005 & 2008 & 2010 & $\Delta: 05-10(\%)$ \\
\hline Formación bruta de capital fijo & $2.582,6$ & $4.042,7$ & $3.728,0$ & $44 \%$ \\
\hline del cual: público & 866,7 & $1.338,6$ & $1.388,4$ & $60 \%$ \\
\hline del cual: privado & $1.716,0$ & $2.704,0$ & $2.339,7$ & $36 \%$ \\
\hline \multicolumn{5}{|l|}{ Entrada de financiación externa } \\
\hline Entradas de IED & 44,6 & 397,6 & 237,2 & $432 \%$ \\
\hline $\begin{array}{l}\text { Deuda externa a largo plazo y fondos } \\
\text { desembolsados por el FMI }\end{array}$ & 387,1 & 560,5 & 485,4 & $25 \%$ \\
\hline $\begin{array}{l}\text { Corrientes comerciales en condiciones no } \\
\text { concesionarias }\end{array}$ & 0,0 & 4,1 & 5,5 & d.p.c. \\
\hline Corrientes de Ayuda para el Comercio & 150,9 & 292,1 & 245,0 & $62 \%$ \\
\hline $\begin{array}{l}\text { Remesas de trabajadores y remuneración } \\
\text { de empleados }\end{array}$ & 788,8 & $1.476,1$ & $1.346,0$ & $71 \%$ \\
\hline
\end{tabular}

Fuentes: OCDE, base de datos del SNPA del CAD sobre las actividades de ayuda; Banco Mundial, Indicadores del Desarrollo Mundial; Banco Mundial, estadísticas de la deuda internacional.

Desembolsos de la ayuda para el comercio, por sector (millones de \$EE.UU. corrientes)

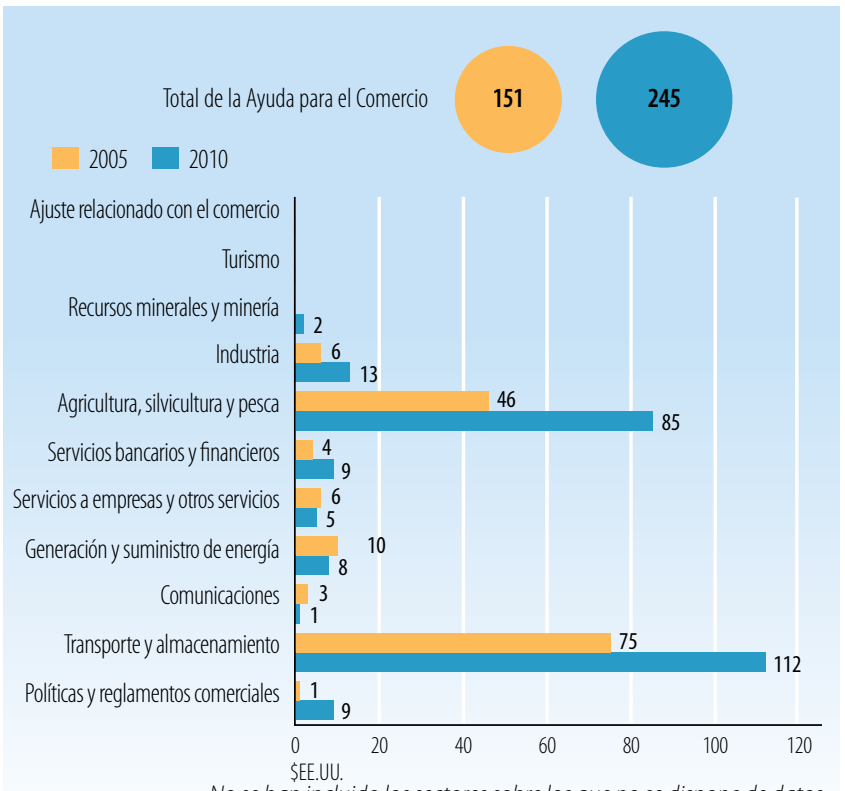

Fuentes: OCDE, base de datos del SNPA del CAD sobre las actividades de ayuda

Desembolsos de la ayuda para el comercio: principales donantes (millones de \$̦E.UU. corrientes)

\begin{tabular}{|l|c|c|c|}
\hline $\mathbf{2 0 0 5}$ & Valor & $\%$ & Principales donantes en 2005 \\
\hline Banco Mundial & 59,2 & 39 & \\
\hline Francia & 22,1 & 15 & \\
\hline Instituciones de la UE & 20,5 & 14 & $80 \%$ \\
\hline España & 10,2 & 7 & \\
\hline Japón & 8,7 & 6 & \\
\hline $\mathbf{2 0 1 0}$ & Valor & $\%$ & Principales donantes en $\mathbf{2 0 1 0}$ \\
\hline Instituciones de la UE & 50,3 & 21 & \\
\hline Banco Mundial & 50,2 & 20 & \\
\hline Banco Africano de Desarrollo & 38,1 & 16 & \\
\hline Kuwait & 20,3 & 8 & $73 \%$ \\
\hline Japón & 19,8 & 8 & \\
\hline
\end{tabular}

Fuentes: OCDE, base de datos del SNPA del CAD sobre las actividades de ayuda.

\section{INDICADORES COMERCIALES (PRODUCTOS)}

\section{Indicador}

$200520082011 \quad \Delta: 05-11(\%)$

Relación comercio/PIB (\%)

\begin{tabular}{l|l|l|l|}
68 & 77 & 53 & -16 \\
\hline
\end{tabular}

Exportaciones de servicios comerciales como

$\%$ de las exportaciones totales

\begin{tabular}{l|l|l}
30 & 35 & n.d.
\end{tabular}

mportaciones de servicios comerciales como

$\%$ de las importaciones totales

\begin{tabular}{l|l|l|l|}
21 & 20 & n.d. & n.d.
\end{tabular}

Productos intermedios distintos de los combustibles

(\% de las exportaciones de mercancías)

Productos intermedios distintos de los combustibles

(\% de las importaciones de mercancías)

\begin{tabular}{l|l|l|}
40 & 38 & 55
\end{tabular}

Fuentes: Secretaría de la OMC.

Corrientes comerciales (millones de \$EE.UU. corrientes)

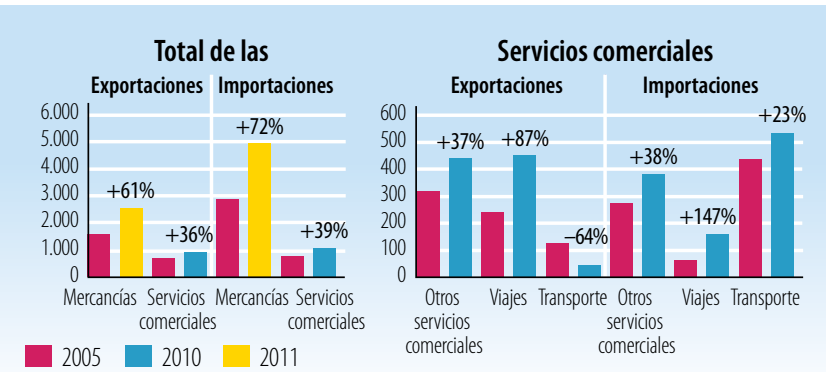

Fuentes: Secretaría de la OMC

Cinco principales mercados de exportación de mercancías (\%)

\begin{tabular}{|l|r|l|c|}
\hline 2005 & $\%$ & 2011 & $\%$ \\
\hline UE $(27)$ & 24 & Malí & 17 \\
\hline Malí & 19 & UE $(27)$ & 15 \\
\hline India & 13 & India & 14 \\
\hline Gambia & 5 & Suiza & 9 \\
\hline Guinea-Bissau & 3 & Guinea & 5 \\
\hline
\end{tabular}

Fuentes: Secretaría de la OMC

Cinco principales productos de exportación (\% de las exportaciones de mercancías)

\begin{tabular}{|l|r|l|c|}
\hline $\mathbf{2 0 0 5}$ & $\%$ & $\mathbf{2 0 1 1}$ & $\%$ \\
\hline Productos derivados del petróleo & 16 & Productos derivados del petróleo & 14 \\
\hline Elementos químicos inorgánicos & 13 & Elementos químicos inorgánicos & 13 \\
\hline Pescado, fresco, refrigerado o congelado & 9 & Oro no monetario, excepto minerales & 10 \\
\hline Crustáceos, moluscos, etc. & 7 & $\begin{array}{l}\text { Cal, cemento y materiales de } \\
\text { construcción }\end{array}$ & 9 \\
\hline Aceites de petróleo, crudos & 5 & Pescado, fresco, refrigerado o congelado & 7 \\
\hline
\end{tabular}

Fuentes: Secretaría de la OMC

Cinco principales mercados de importación de mercancías (\%)

\begin{tabular}{|l|r|l|r|}
\hline 2005 & $\%$ & 2011 & $\%$ \\
\hline UE (27) & 44 & UE (27) & 41 \\
\hline Nigeria & 10 & Nigeria & 9 \\
\hline Tailandia & 5 & China & 7 \\
\hline Brasil & 4 & Estados Unidos & 5 \\
\hline Estados Unidos & 4 & Turquía & 4 \\
\hline
\end{tabular}

Fuentes: Secretaría de la OMC

Cinco principales productos de importación (\% de las importaciones de mercancías)

\begin{tabular}{|l|r|l|c|}
\hline $\mathbf{2 0 0 5}$ & $\%$ & $\mathbf{2 0 1 1}$ & $\%$ \\
\hline Aceites de petróleo, crudos & 11 & Productos derivados del petróleo & 19 \\
\hline Arroz & 11 & Aceites de petróleo, crudos & 9 \\
\hline $\begin{array}{l}\text { Productos derivados del petróleo } \\
\begin{array}{l}\text { Vehículos automotores para pasajeros, } \\
\text { excepto autobuses }\end{array}\end{array}$ & 9 & Arroz & 6 \\
\hline Medicamentos & 3 & Barras, perfiles, etc., de hierroy acero & 3 \\
\hline
\end{tabular}

Fuentes: Secretaría de la OMC 


\section{LA AYUDA PARA EL COMERCIO EN SÍNTESIS 2013}

\section{INDICADORES COMERCIALES (RESULTADOS)}

\section{Indicador}

Crecimiento del PIB (\%)

Número de exportadores

Índice de concentración de las exportaciones (productos) ( 0 a 1)

ACR sobre mercancías notificados a la OMC

AIE (servicios) notificados a la OMC

Sectores de servicios con compromisos en el marco del AGCS

\section{Aranceles $(\%, 2006$ et 2011$)$}

Importaciones: promedio aritmético de los aranceles NMF aplicados $\quad 12,0 \quad 11,9$

\begin{tabular}{l|l|l|l|} 
Importaciones: promedio ponderado de los aranceles NMF aplicados & 9,1 & 9,2
\end{tabular}

\begin{tabular}{|l|l|l|} 
Exportaciones: promedio ponderado de los aranceles impuestos & 3,4
\end{tabular}

por los importadores

$75,7 \quad 55,9$

Exportaciones: libres de derechos (en \%)
Fuentes: Naciones Unidas, base de datos Comtrade; Banco Mundial, base de dato sobre dinámica de las empresas de exportación; Banco Mundial, Indicadores del

Desarrollo Mundial; OMC, perfiles comerciales y arancelarios.

Participación en las exportaciones por región (\%)

\begin{tabular}{|l|r|r|}
\hline & $\mathbf{2 0 0 5}$ & $\mathbf{2 0 1 1}$ \\
\hline África & 46,9 & 45,5 \\
\hline Asia & 15,7 & 17,0 \\
\hline Comunidad de Estados Independientes & 0,0 & 0,0 \\
\hline Europa & 23,9 & 24,3 \\
\hline Oriente Medio & 0,4 & 3,9 \\
\hline América del Norte & 1,2 & 0,3 \\
\hline América del Sury América Central & 0,2 & 0,1 \\
\hline
\end{tabular}

Fuentes: OMC, perfiles comerciales y arancelarios

Indicadores de facilitación del comercio
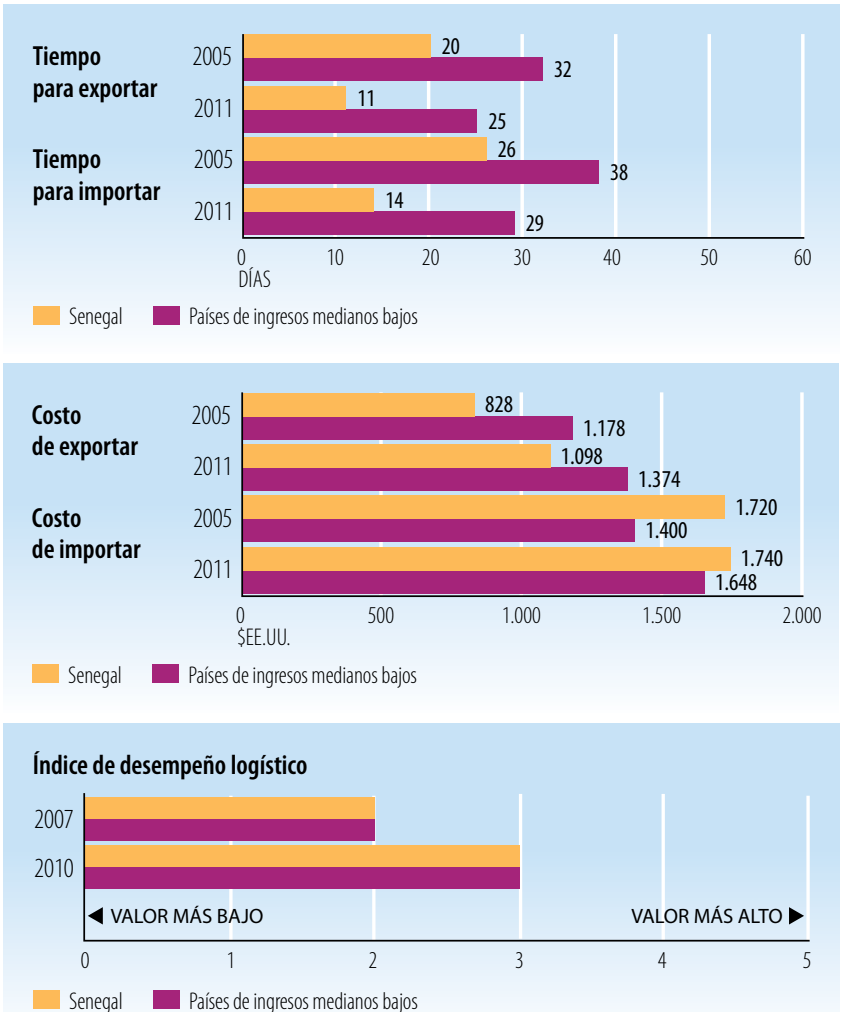

- Senegal Países de ingresos medianos bajos

Fuentes: Banco Mundial, Indicadores del Desarrollo Mundial.

\begin{tabular}{l|c|c|}
\hline INDICADORES DE DESARROLLO (EFECTOS) & \\
\hline Indicador & $\mathbf{2 0 0 5}$ & $\mathbf{2 0 1 0}$ \\
\hline Desempleo (\% de la fuerza de trabajo total) & 10,0 & n.d. \\
\hline Población activa, mujeres (\% de la fuerza de trabajo total) & 43,4 & 43,9 \\
\hline AOD neta recibida (\% del INB) & 8,2 & 7,3 \\
\hline Derechos de importación percibidos (\% de los ingresos fiscales) & n.d. & n.d. \\
\hline Total del servicio de la deuda (\% de las exportaciones totales) & 8,3 & 4,8 \\
\hline Índice de desarrollo humano ( 0 a 1) & 0,43 & 0,46 \\
\hline
\end{tabular}

Fuentes: PNUD, indicadores internacionales sobre desarrollo humano; Banco Mundial, Indicadores del Desarrollo Mundial.

Producto interno bruto

PIB per cápita (PPA, dólares internacionales corrientes)
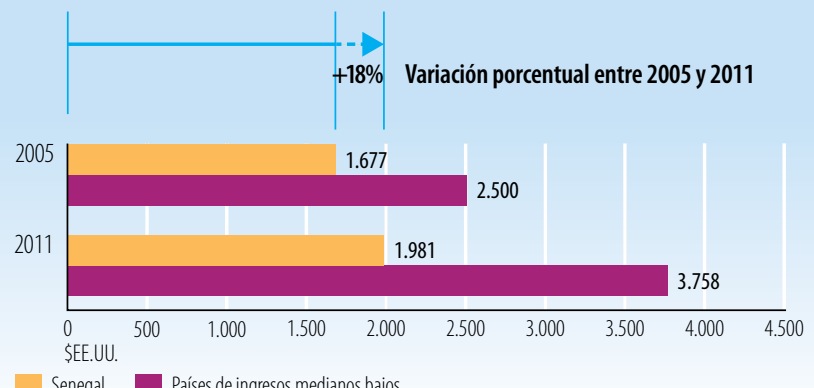

Senegal $\square$ Países de ingresos medianos bajos

PIB per cápita (\$EE.UU. constantes de 2000)
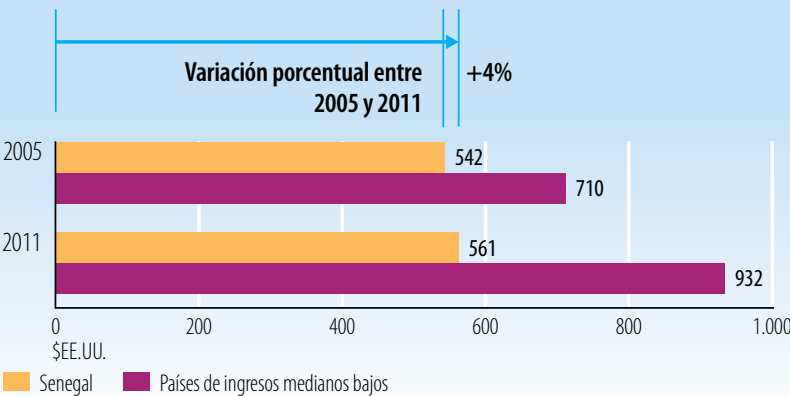

Fuentes: Banco Mundial, Indicadores del Desarrollo Mundial.

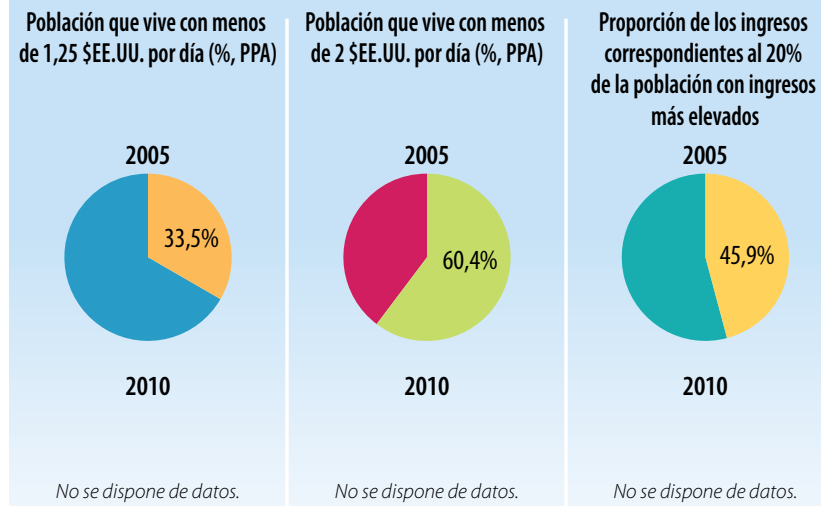

Fuentes: Banco Mundial, Indicadores del Desarrollo Mundial.

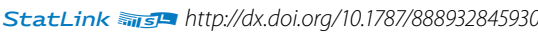


Indicadores de la ayuda, el comercio y el desarrollo relativos al Sudán

\begin{tabular}{|c|c|c|c|c|}
\hline Indicador (millones de \$̦EE.UU. corrientes) & 2005 & 2008 & 2010 & $\Delta: 05-10(\%)$ \\
\hline Formación bruta de capital fijo & $6.585,9$ & $13.195,5$ & $13.692,5$ & $108 \%$ \\
\hline del cual: público & $1.601,5$ & $3.794,2$ & $4.903,8$ & $206 \%$ \\
\hline del cual: privado & $4.984,4$ & $9.401,2$ & $8.788,7$ & $76 \%$ \\
\hline \multicolumn{5}{|l|}{ Entrada de financiación externa } \\
\hline Entradas de IED & $2.304,6$ & $2.600,5$ & $2.063,7$ & $-10 \%$ \\
\hline $\begin{array}{l}\text { Deuda externa a largo plazo y fondos } \\
\text { desembolsados por el FMl }\end{array}$ & 387,1 & 673,0 & 935,2 & $142 \%$ \\
\hline $\begin{array}{l}\text { Corrientes comerciales en condiciones no } \\
\text { concesionarias }\end{array}$ & 0,0 & 0,0 & 5,5 & d.p.c. \\
\hline Corrientes de Ayuda para el Comercio & 4,6 & 216,5 & 277,7 & $5981 \%$ \\
\hline $\begin{array}{l}\text { Remesas de trabajadores y remuneración } \\
\text { de empleados }\end{array}$ & $1.016,0$ & $3.100,4$ & $1.973,8$ & $94 \%$ \\
\hline
\end{tabular}

Fuentes: OCDE, base de datos del SNPA del CAD sobre las actividades de ayuda; Banco Mundial, Indicadores del Desarrollo Mundial; Banco Mundial, estadísticas de la deuda internacional.

Desembolsos de la ayuda para el comercio, por sector (millones de \$EE.UU. corrientes)

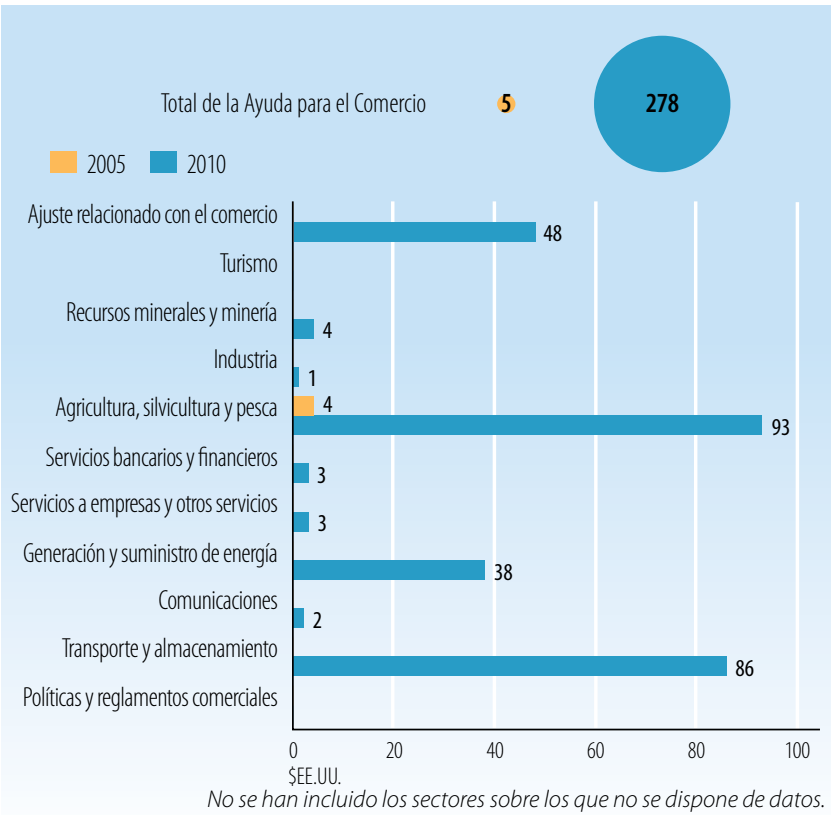

Fuentes: OCDE, base de datos del SNPA del CAD sobre las actividades de ayuda

Desembolsos de la ayuda para el comercio: principales donantes (millones de \$EE.UU. corrientes)

\begin{tabular}{|l|c|c|}
\hline $\mathbf{2 0 0 5}$ & Valor & $\%$ \\
\hline Noruega & 2,8 & 61 \\
\hline Estados Unidos & 0,8 & 16 \\
\hline Italia & 0,3 & 6 \\
\hline Francia & 0,2 & 4 \\
\hline Japón & 0,2 & 4 \\
\hline $\mathbf{2 0 1 0}$ & Valor & $\%$ \\
\hline Estados Unidos & 79,1 & 28 \\
\hline Fondo Árabe & 61,5 & 22 \\
\hline Instituciones de la UE & 48,3 & 17 \\
\hline Japón & 26,3 & 9 \\
\hline Emiratos Árabes Unidos & 16,8 & 6 \\
\hline
\end{tabular}

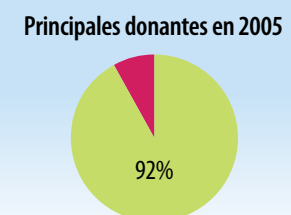

Principales donantes en 2010

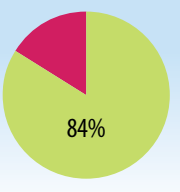

Fuentes: OCDE, base de datos del SNPA del CAD sobre las actividades de ayuda.

\section{INDICADORES COMERCIALES (PRODUCTOS)}

\section{Indicador}

$2005 \quad 2008 \quad 2011 \quad \Delta: 05-11(\%)$

Relación comercio/PIB (\%)

Exportaciones de servicios comerciales como

$\%$ de las exportaciones totales

Importaciones de servicios comerciales como

$\%$ de las importaciones totales

Productos intermedios distintos de los combustibles

(\% de las exportaciones de mercancías)

Productos intermedios distintos de los combustibles

(\% de las importaciones de mercancías)

\begin{tabular}{l|l|l|r|}
46 & 39 & 41 & -6 \\
\hline
\end{tabular}

Fuentes: Secretaría de la OMC.

Corrientes comerciales (millones de \$EE.UU. corrientes)

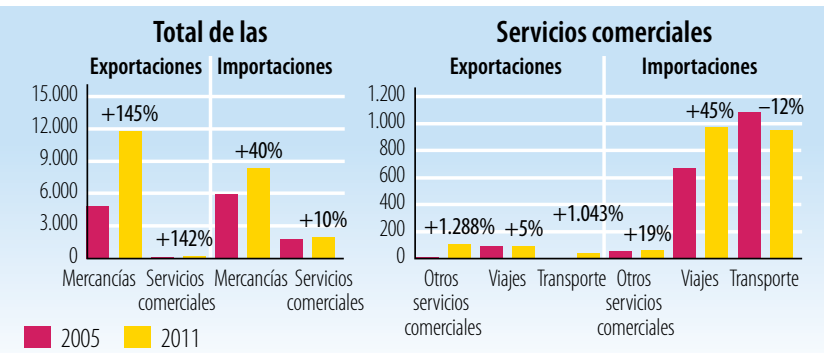

Fuentes: Secretaría de la OMC

Cinco principales mercados de exportación de mercancías (\%)

\begin{tabular}{|l|r|l|c|}
\hline 2005 & $\%$ & 2009 & $\%$ \\
\hline China & 74 & China & 65 \\
\hline Japón & 8 & Emiratos Árabes Unidos & 10 \\
\hline UE (27) & 4 & Canadá & 9 \\
\hline Arabia Saudita, Reino de la & 4 & Arabia Saudita, Reino de la & 3 \\
\hline Emiratos Árabes Unidos & 3 & Japón & 2 \\
\hline
\end{tabular}

Fuentes: Secretaría de la OMC

Cinco principales productos de exportación (\% de las exportaciones de mercancías)

\begin{tabular}{|l|r|l|c|}
\hline 2005 & $\%$ & $\mathbf{2 0 0 9}$ & $\%$ \\
\hline Productos derivados del petróleo & 83 & Aceites de petróleo, crudos & 77 \\
\hline Oro no monetario, excepto minerales & 2 & Oro no monetario, excepto minerales & 14 \\
\hline Animales vivos & 2 & Animales vivos & 3 \\
\hline Algodón & 2 & Productos derivados del petróleo & 2 \\
\hline Productos vegetales en bruto, n.e.p. & 2 & $\begin{array}{l}\text { Semillas oleaginosas (aceites vegetales } \\
\text { fijos blandos) }\end{array}$ & 2 \\
\hline
\end{tabular}

Fuentes: Secretaría de la OMC

Cinco principales mercados de importación de mercancías (\%)

\begin{tabular}{|l|r|l|c|}
\hline 2005 & $\%$ & 2009 & $\%$ \\
\hline UE (27) & 22 & China & 17 \\
\hline China & 18 & UE (27) & 14 \\
\hline Arabia Saudita, Reino de la & 8 & Japón & 10 \\
\hline Japón & 7 & Arabia Saudita, Reino de la & 8 \\
\hline Emiratos Árabes Unidos & 6 & Emiratos Árabes Unidos & 7 \\
\hline
\end{tabular}

Fuentes: Secretaría de la OMC

Cinco principales productos de importación (\% de las importaciones de mercancías)

\begin{tabular}{l|l|l|l|}
2005 & $\%$ & 2009 & $\%$
\end{tabular}

Vehículos automotores para el transporte Vehículos automotores para el transporte de mercancías y vehículos automotores 5 de mercancías y vehículos automotores 7 para usos especiales para usos especiales

Trigo y morcajo o tranquillón, sin moler 5 Vehículos automotores para pasajeros, 5

\begin{tabular}{l|l|l|l|l|l} 
Productos derivados del petróleo & 5 & Trigo y morcajo o tranquillón, sin moler 5
\end{tabular}

\begin{tabular}{l|l|l|l|}
\hline Equipo de ingeniería civil & 4 & Productos derivados del petróleo & 4
\end{tabular}

Vehículos automotores para pasajeros, $\quad 4$ Medicamentos 3

excepto autobuses

Fuentes: Secretaría de la OMC 


\section{LA AYUDA PARA EL COMERCIO EN SÍNTESIS 2013}

\section{INDICADORES COMERCIALES (RESULTADOS)}

\section{Indicador}

Crecimiento del PIB (\%)

Número de exportadores

Índice de concentración de las exportaciones (productos) ( 0 a 1)

ACR sobre mercancías notificados a la OMC

AIE (servicios) notificados a la OMC

Sectores de servicios con compromisos en el marco del AGCS

\section{Aranceles $(\%, 2006$ et 2011)}

Importaciones: promedio aritmético de los aranceles NMF aplicados $\quad 20,1 \quad 19,9$

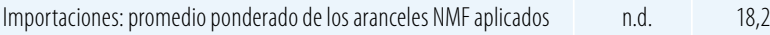

Exportaciones: promedio ponderado de los aranceles impuestos $\quad 1,3 \quad 0,1$

por los importadores

Exportaciones: libres de derechos (en \%)

$59,2 \quad 93,3$

Fuentes: Naciones Unidas, base de datos Comtrade; Banco Mundial, base de datos sobre dinámica de las empresas de exportación; Banco Mundial, Indicadores del

Desarrollo Mundial; OMC, perfiles comerciales y arancelarios.

Participación en las exportaciones por región (\%)

\begin{tabular}{|l|r|r|}
\hline & 2005 & 2009 \\
\hline África & 1,5 & 2,2 \\
\hline Asia & 84,2 & 73,0 \\
\hline Comunidad de Estados Independientes & 0,2 & 0,0 \\
\hline Europa & 4,6 & 0,9 \\
\hline Oriente Medio & 7,8 & 14,6 \\
\hline América del Norte & 1,7 & 9,0 \\
\hline América del Sury América Central & 0,0 & 0,3 \\
\hline
\end{tabular}

Fuentes: OMC, perfiles comerciales y arancelarios

Indicadores de facilitación del comercio
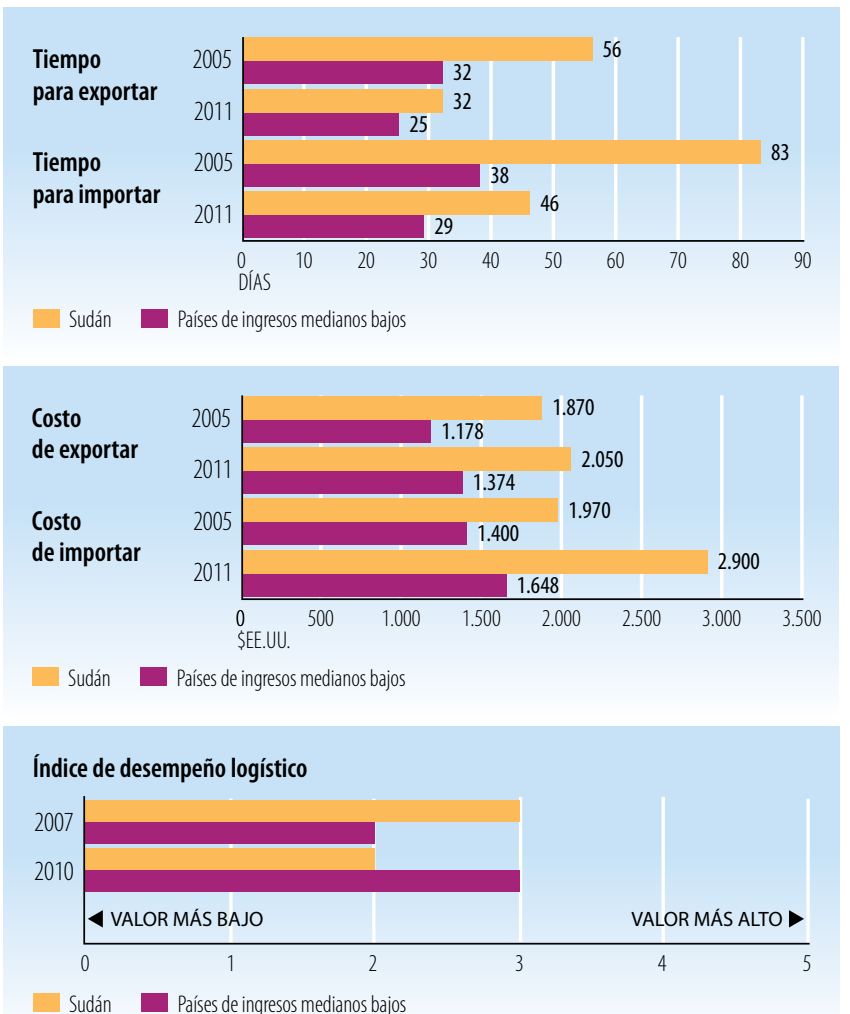

Fuentes: Banco Mundial, Indicadores del Desarrollo Mundial.

\begin{tabular}{l|c|c|}
\hline INDICADORES DE DESARROLLO (EFECTOS) & \\
\hline Indicador & 2005 & 2010 \\
\hline Desempleo (\% de la fuerza de trabajo total) & n.d. & n.d. \\
\hline Población activa, mujeres (\% de la fuerza de trabajo total) & 28,2 & 28,7 \\
\hline AOD neta recibida (\% del INB) & 7,0 & 3,4 \\
\hline Derechos de importación percibidos (\% de los ingresos fiscales) & $n . d$. & n.d. \\
\hline Total del servicio de la deuda (\% de las exportaciones totales) & 8,0 & 4,2 \\
\hline Índice de desarrollo humano (0 a 1) & 0,38 & 0,41 \\
\hline
\end{tabular}

Fuentes: PNUD, indicadores internacionales sobre desarrollo humano; Banco Mundial, Indicadores del Desarrollo Mundial.

Producto interno bruto

PIB per cápita (PPA, dólares internacionales corrientes)
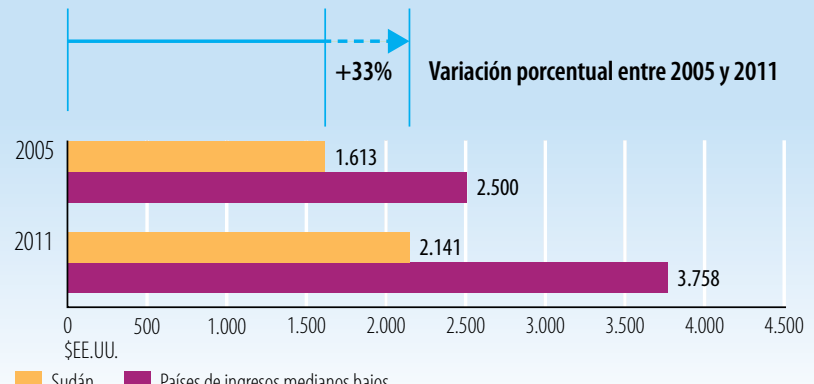

Sudán Países de ingresos medianos bajos

PIB per cápita (\$EE.UU. constantes de 2000)

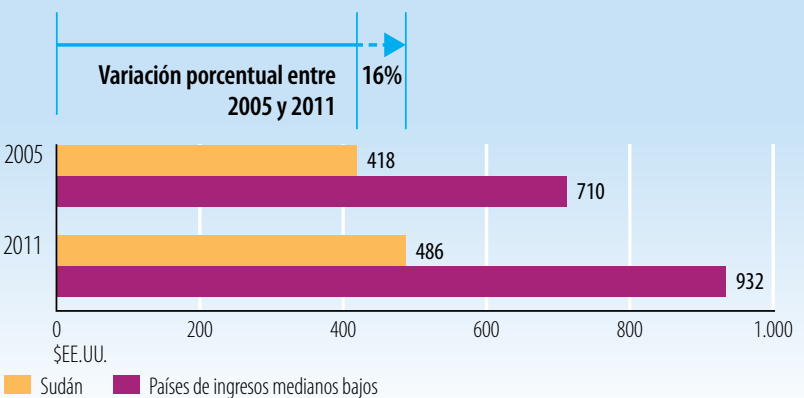

Fuentes: Banco Mundial, Indicadores del Desarrollo Mundial.

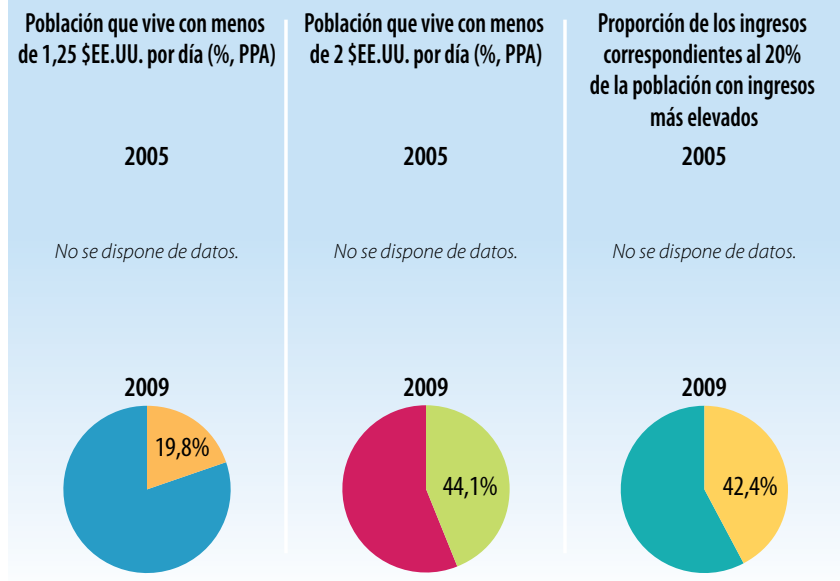

Fuentes: Banco Mundial, Indicadores del Desarrollo Mundial.

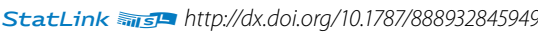


Indicadores de la ayuda, el comercio y el desarrollo relativos a Suriname

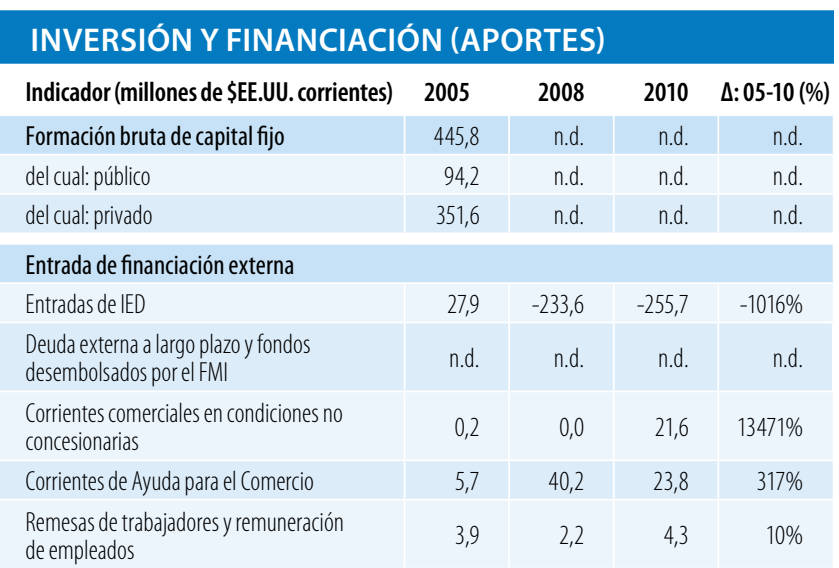

Fuentes: OCDE, base de datos del SNPA del CAD sobre las actividades de ayuda; Banco Mundial, Indicadores del Desarrollo Mundial; Banco Mundial, estadísticas de la deuda internacional.

Desembolsos de la ayuda para el comercio, por sector

(millones de \$EE.UU. corrientes)

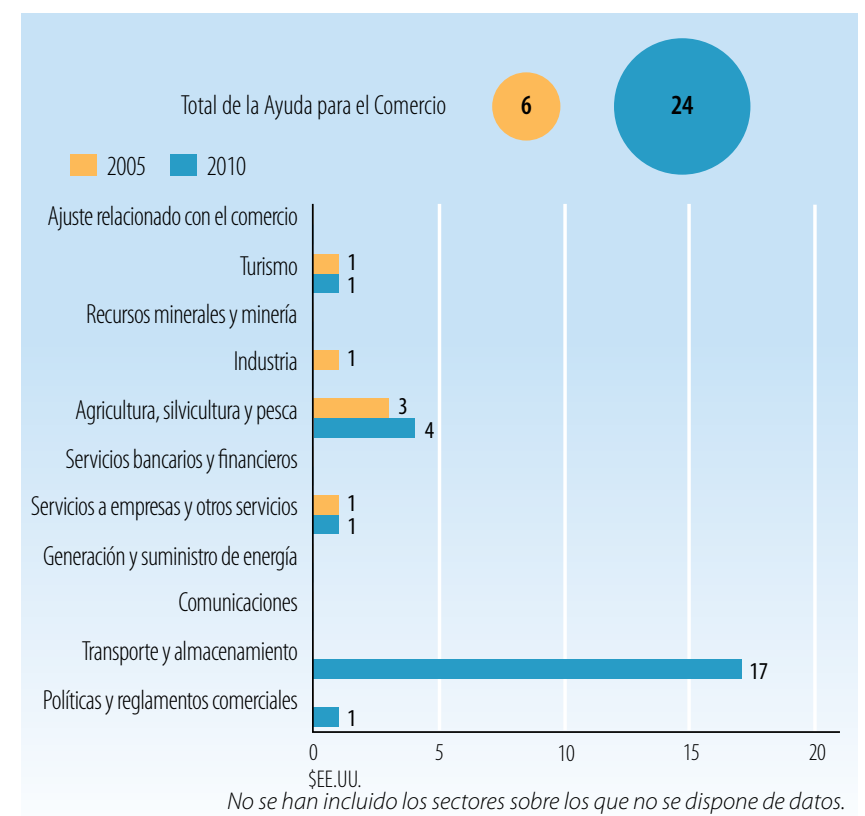

Fuentes: OCDE, base de datos del SNPA del CAD sobre las actividades de ayuda

Desembolsos de la ayuda para el comercio: principales donantes (millones de \$̦E.UU. corrientes)

\begin{tabular}{|l|r|r|r|}
\hline $\mathbf{2 0 0 5}$ & Valor & $\%$ & Principales donantes en 2005 \\
\hline Instituciones de la UE & 3,7 & 66 & \\
\hline Países Bajos & 1,8 & 32 & $100 \%$ \\
\hline Japón & 0,1 & 2 & \\
\hline & & & \\
\hline $\mathbf{2 0 1 0}$ & Valor & $\%$ & Principales donantes en 2010 \\
\hline Instituciones de la UE & 16,0 & 67 & \\
\hline Países Bajos & 6,7 & 28 & $100 \%$ \\
\hline BID & 0,9 & 4 & \\
\hline OMC & 0,1 & 0 & \\
\hline Australia & 0,1 & 0 & \\
\hline
\end{tabular}

Fuentes: OCDE, base de datos del SNPA del CAD sobre las actividades de ayuda.

\section{INDICADORES COMERCIALES (PRODUCTOS)}

Indicador

$200520082011 \quad \Delta: 05-11(\%)$

Relación comercio/PIB (\%)

Exportaciones de servicios comerciales como

$\%$ de las exportaciones totales

Importaciones de servicios comerciales como

$\%$ de las importaciones totales

Productos intermedios distintos de los combustibles

(\% de las exportaciones de mercancías)

Productos intermedios distintos de los combustibles

(\% de las importaciones de mercancías)

\begin{tabular}{l|l|l|l|}
163 & 104 & n.d.
\end{tabular}

\begin{tabular}{|l|l|l|l|}
\hline 13 & 12 & 7 & -6 \\
\hline
\end{tabular}

\begin{tabular}{|l|l|l|l|}
\hline 22 & 21 & 25 & 3 \\
\hline
\end{tabular}

n.d. n.d. n.d. n.d.

n.d. n.d. n.d. n.d.

Fuentes: Secretaría de la OMC.

Corrientes comerciales (millones de \$EE.UU. corrientes)

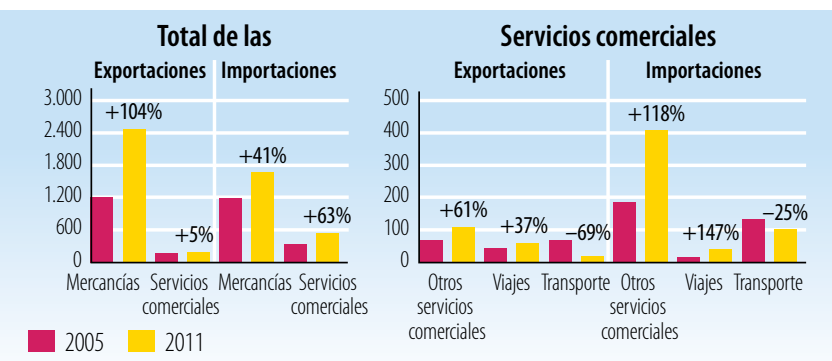

Fuentes: Secretaría de la OMC

Cinco principales mercados de exportación de mercancías (\%)

\begin{tabular}{|l|r|l|c|}
\hline 2005 & $\%$ & 2010 & $\%$ \\
\hline UE (27) & 16 & Canadá & 29 \\
\hline Canadá & 14 & UE (27) & 19 \\
\hline Emiratos Árabes Unidos & 5 & Emiratos Árabes Unidos & 14 \\
\hline Guyana & 3 & Suiza & 9 \\
\hline Brasil & 3 & Estados Unidos & 8 \\
\hline
\end{tabular}

Fuentes: Secretaría de la OMC

Cinco principales productos de exportación (\% de las exportaciones de mercancías)

\begin{tabular}{|l|r|l|l|}
\hline $\mathbf{2 0 0 9}$ & $\%$ & $\mathbf{2 0 1 0}$ & $\%$ \\
\hline Operaciones especiales no clasificadas & 87 & Operaciones especiales no clasificadas & 82 \\
\hline Productos derivados del petróleo & 5 & Productos derivados del petróleo & 13 \\
\hline Arroz & 2 & Arroz & 2 \\
\hline Bebidas alcohólicas & 1 & Equipo de ingeniería civil & 0 \\
\hline Bebidas no alcohólicas, n.e.p. & 0 & Madera trabajada simplemente & 0 \\
\hline
\end{tabular}

Fuentes: Secretaría de la OMC

Cinco principales mercados de importación de mercancías (\%)

\begin{tabular}{|l|r|l|c|}
\hline 2005 & $\%$ & 2010 & $\%$ \\
\hline UE $(27)$ & 22 & Estados Unidos & 25 \\
\hline Trinidady Tabago & 19 & Trinidady Tabago & 24 \\
\hline Estados Unidos & 19 & UE (27) & 23 \\
\hline China & 5 & China & 7 \\
\hline Brasil & 5 & Brasil & 4 \\
\hline
\end{tabular}

Cinco principales productos de importación (\% de las importaciones de mercancías)

\begin{tabular}{|c|c|c|c|}
\hline 2009 & $\%$ & 2010 & $\%$ \\
\hline Productos derivados del petróleo & 15 & Productos derivados del petróleo & 18 \\
\hline Equipo de ingeniería civil & 6 & Equipo de ingeniería civil & 4 \\
\hline Elementos químicos inorgánicos & 5 & $\begin{array}{l}\text { Vehículos automotores para pasajeros, } \\
\text { excepto autobuses }\end{array}$ & 3 \\
\hline $\begin{array}{l}\text { Vehículos automotores para el transporte } \\
\text { de mercancías y vehículos automotores } \\
\text { para usos especiales }\end{array}$ & 4 & $\begin{array}{l}\text { Vehículos automotores para el transporte } \\
\text { de mercancías y vehículos automotores } \\
\text { para usos especiales }\end{array}$ & 2 \\
\hline $\begin{array}{l}\text { Vehículos automotores para pasajeros, } \\
\text { excepto autobuses }\end{array}$ & 3 & Elementos químicos inorgánicos & 2 \\
\hline
\end{tabular}




\section{LA AYUDA PARA EL COMERCIO EN SIINTESIS 2013}

\section{INDICADORES COMERCIALES (RESULTADOS)}

\section{Indicador}

Crecimiento del PIB (\%)

Número de exportadores

Índice de concentración de las exportaciones (productos) ( 0 a 1)

ACR sobre mercancías notificados a la OMC

AIE (servicios) notificados a la OMC

Sectores de servicios con compromisos en el marco del AGCS

\section{Aranceles (\%)}

Importaciones: promedio aritmético de los aranceles NMF aplicados n.d. 10,3

\begin{tabular}{l|l|l|} 
Importaciones: promedio ponderado de los aranceles NMF aplicados & n.d.
\end{tabular}

Exportaciones: promedio ponderado de los aranceles impuestos $\quad$ n.d.

por los importadores

n.d. $\quad 99,8$

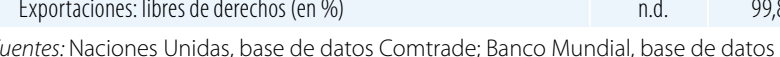
sobre dinámica de las empresas de exportación; Banco Mundial, Indicadores del

Desarrollo Mundial; OMC, perfiles comerciales y arancelarios.

Participación en las exportaciones por región (\%)

\begin{tabular}{|l|r|r|}
\hline & $\mathbf{2 0 0 5}$ & $\mathbf{2 0 1 1}$ \\
\hline África & 0,3 & 0,7 \\
\hline Asia & 0,4 & 1,0 \\
\hline Comunidad de Estados Independientes & 0,0 & 0,0 \\
\hline Europa & 16,7 & 27,2 \\
\hline Oriente Medio & 5,4 & 26,1 \\
\hline América del Norte & 14,5 & 29,8 \\
\hline América del Sury América Central & 8,9 & 15,3 \\
\hline
\end{tabular}

Fuentes: OMC, perfiles comerciales y arancelarios

Indicadores de facilitación del comercio
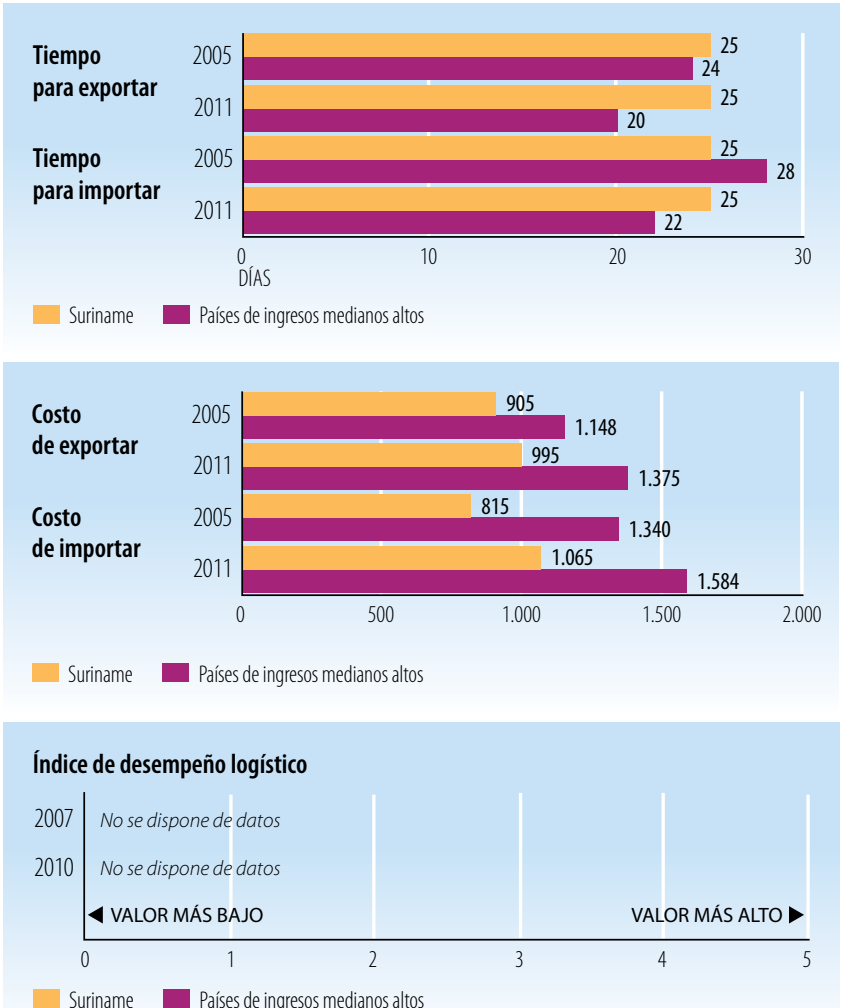

Países de ingresos medianos altos

Fuentes: Banco Mundial, Indicadores del Desarrollo Mundial.

\begin{tabular}{l|c|c|}
\hline INDICADORES DE DESARROLLO (EFECTOS) \\
\hline Indicador & $\mathbf{2 0 0 5}$ & $\mathbf{2 0 1 0}$ \\
\hline Desempleo (\% de la fuerza de trabajo total) & n.d. & n.d. \\
\hline Población activa, mujeres (\% de la fuerza de trabajo total) & 35,9 & 37,1 \\
\hline A0D neta recibida (\% del INB) & 2,5 & 2,4 \\
\hline Derechos de importación percibidos (\% de los ingresos fiscales) & n.d. & n.d. \\
\hline Total del servicio de la deuda (\% de las exportaciones totales) & n.d. & n.d. \\
\hline Índice de desarrollo humano (0 a 1) & 0,66 & 0,68 \\
\hline
\end{tabular}

Fuentes: PNUD, indicadores internacionales sobre desarrollo humano; Banco Mundial, Indicadores del Desarrollo Mundial.

Producto interno bruto

PIB per cápita (PPA, dólares internacionales corrientes)

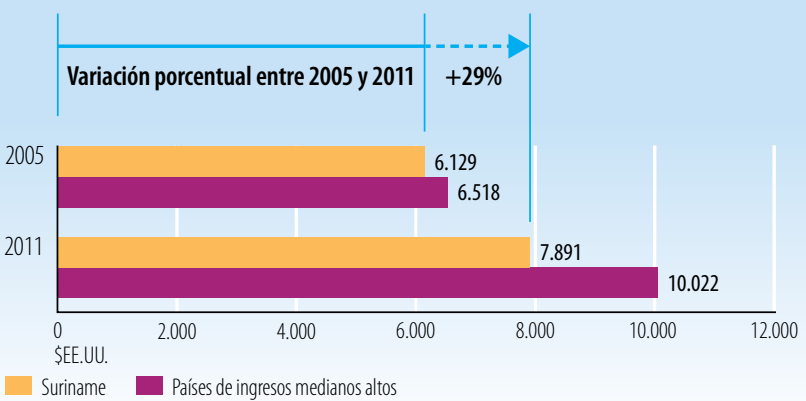

PIB per cápita (\$EE.UU. constantes de 2000)

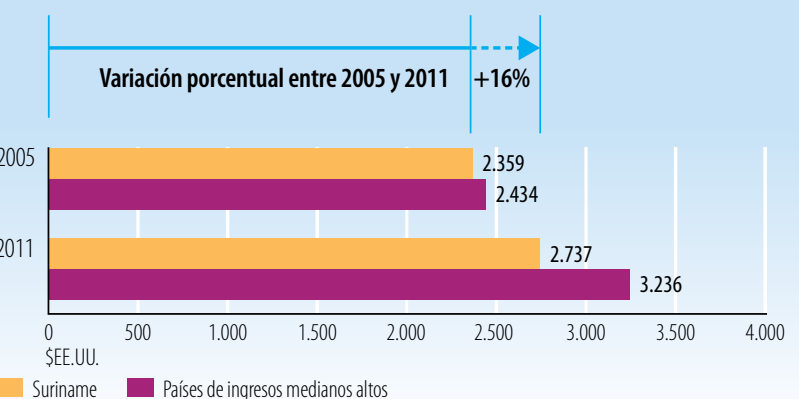

Fuentes: Banco Mundial, Indicadores del Desarrollo Mundial.

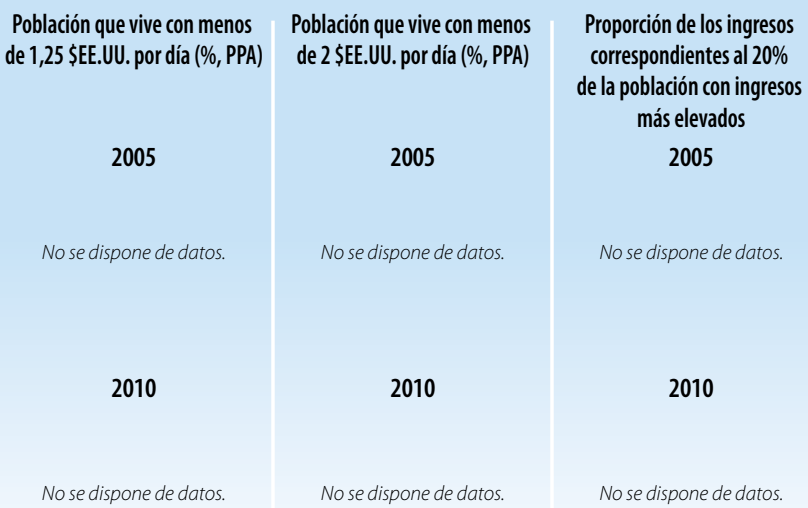

Fuentes: Banco Mundial, Indicadores del Desarrollo Mundial. StatLink ㄱiाs] $h t$ tp://dx.doi.org/10.1787/888932845968 
Indicadores de la ayuda, el comercio y el desarrollo relativos a Tanzanía

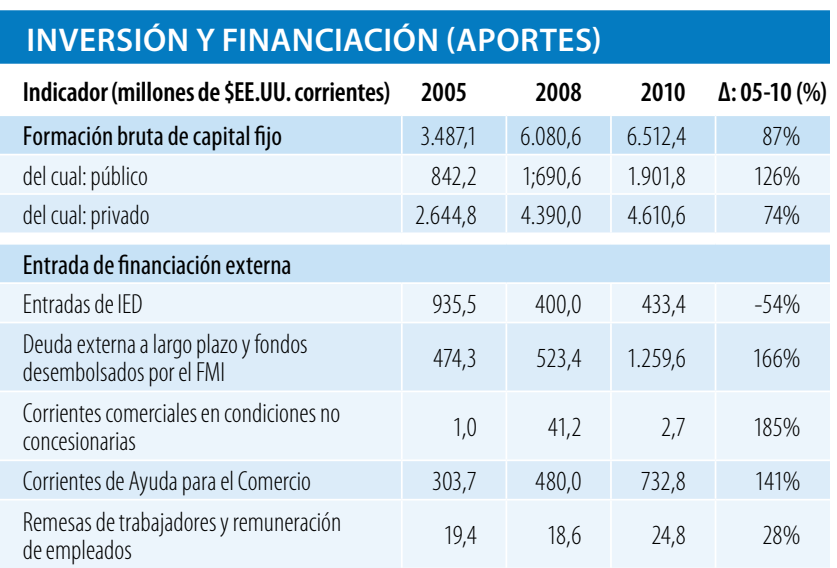

Fuentes: OCDE, base de datos del SNPA del CAD sobre las actividades de ayuda; Banco Mundial, Indicadores del Desarrollo Mundial; Banco Mundial, estadísticas de la deuda internacional.

Desembolsos de la ayuda para el comercio, por sector (millones de \$EE.UU. corrientes)

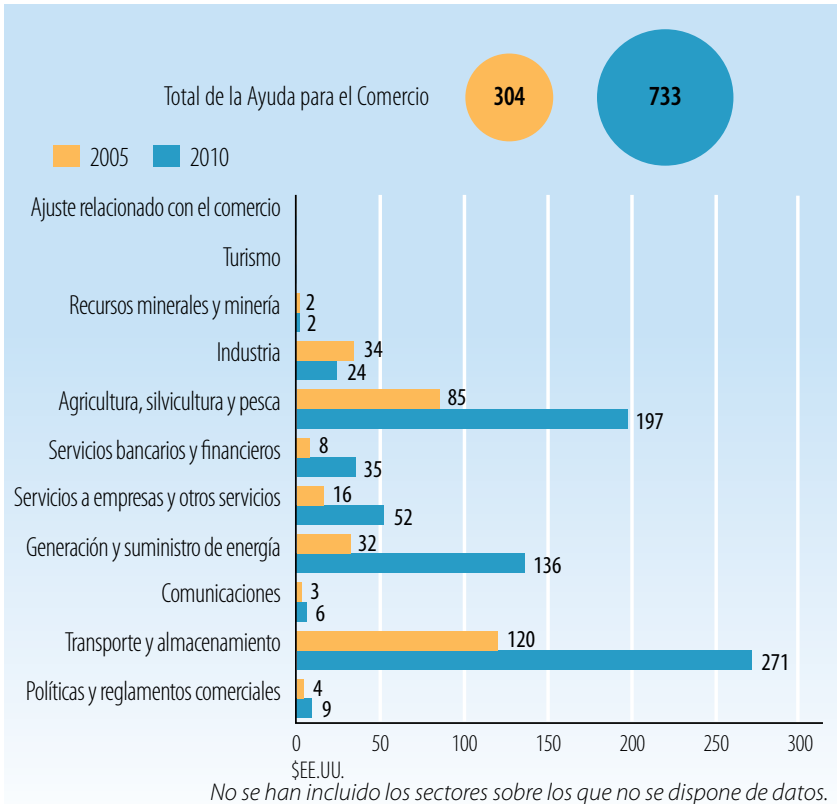

Fuentes: OCDE, base de datos del SNPA del CAD sobre las actividades de ayuda

Desembolsos de la ayuda para el comercio: principales donantes (millones de \$EE.UU. corrientes)

\begin{tabular}{|l|c|c|c|}
\hline $\mathbf{2 0 0 5}$ & Valor & $\%$ & Principales donantes en 2005 \\
\hline Banco Mundial & 119,1 & 39 & \\
\hline Instituciones de la UE & 79,3 & 26 & \\
\hline Banco Africano de Desarrollo & 27,7 & 9 & $84 \%$ \\
\hline Dinamarca & 15,5 & 5 & \\
\hline Suecia & 15,0 & 5 & \\
\hline $\mathbf{2 0 1 0}$ & Valor & $\%$ & Principales donantes en $\mathbf{2 0 1 0}$ \\
\hline Banco Mundial & 270,5 & 37 & \\
\hline Estados Unidos & 108,3 & 15 & \\
\hline Banco Africano de Desarrollo & 69,0 & 9 & \\
\hline Dinamarca & 62,1 & 8 & $77 \%$ \\
\hline Japón & 54,7 & 7 \\
\hline
\end{tabular}

Fuentes: OCDE, base de datos del SNPA del CAD sobre las actividades de ayuda.

\section{INDICADORES COMERCIALES (PRODUCTOS)}

\section{Indicador}

$2005 \quad 2008 \quad 2011 \quad \Delta: 05-11(\%)$

Relación comercio/PIB (\%)

\begin{tabular}{|l|l|l|l|}
50 & 68 & 82 & 32 \\
\hline
\end{tabular}

Exportaciones de servicios comerciales como

$\%$ de las exportaciones totales

Importaciones de servicios comerciales como

$\%$ de las importaciones totales

Productos intermedios distintos de los combustibles

(\% de las exportaciones de mercancías)

Productos intermedios distintos de los combustibles

(\% de las importaciones de mercancías)

\begin{tabular}{l|l|l|l|}
42 & 35 & 32 & -10
\end{tabular}

Fuentes: Secretaría de la OMC.

Corrientes comerciales (millones de \$EE.UU. corrientes)

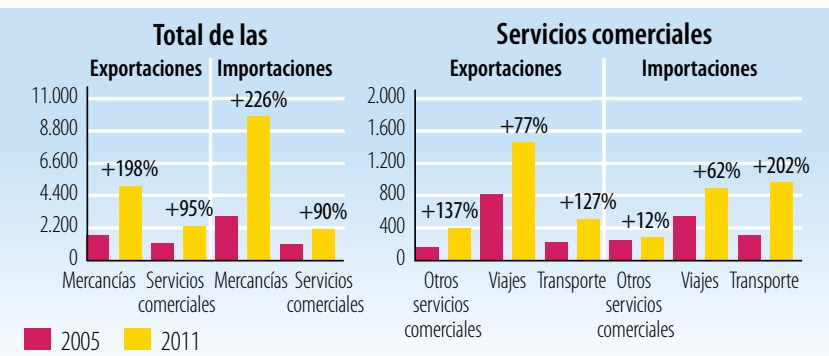

Fuentes: Secretaría de la OMC

Cinco principales mercados de exportación de mercancías (\%)

\begin{tabular}{|l|r|l|l|}
\hline 2005 & $\%$ & 2011 & $\%$ \\
\hline UE $(27)$ & 25 & Suiza & 19 \\
\hline Sudáfrica & 18 & Sudáfrica & 18 \\
\hline Suiza & 9 & China & 14 \\
\hline China & 6 & UE (27) & 12 \\
\hline Kenya & 6 & Japón & 8 \\
\hline
\end{tabular}

Fuentes:Secretaría de la OMC

Cinco principales productos de exportación (\% de las exportaciones de mercancías)

\begin{tabular}{|l|r|l|c|}
\hline 2005 & $\%$ & 2011 & $\%$ \\
\hline Oro no monetario, excepto minerales & 33 & $\begin{array}{l}\text { Oro no monetario, excepto minerales } \\
\text { Tabaco sin elaborar }\end{array}$ & 36 \\
\hline $\begin{array}{l}\text { Pescado, fresco, refrigerado o congelado } \\
\text { concentrados }\end{array}$ & 8 & $\begin{array}{l}\text { Minerales de metales comunes y sus } \\
\text { concentrados }\end{array}$ & 11 \\
\hline $\begin{array}{l}\text { Algodón } \\
\text { Minerales de metales preciososysus } \\
\text { concentrados }\end{array}$ & 7 & $\begin{array}{l}\text { Caféy sucedáneos del café } \\
\text { Frutas y nueces, excepto nueces } \\
\text { oleaginosas }\end{array}$ & 3 \\
\hline
\end{tabular}

Fuentes: Secretaría de la OMC

Cinco principales mercados de importación de mercancías (\%)

\begin{tabular}{|l|c|l|c|}
\hline 2005 & $\%$ & 2011 & $\%$ \\
\hline UE (27) & 19 & UE (27) & 14 \\
\hline Bahrein & 16 & India & 14 \\
\hline Sudáfrica & 12 & Emiratos Árabes Unidos & 11 \\
\hline China & 7 & Suiza & 10 \\
\hline Japón & 6 & China & 9 \\
\hline
\end{tabular}

Cinco principales productos de importación (\% de las importaciones de mercancías)

\begin{tabular}{|c|c|c|c|}
\hline 2005 & $\%$ & 2011 & $\%$ \\
\hline Productos derivados del petróleo & 22 & Productos derivados del petróleo & 31 \\
\hline $\begin{array}{l}\text { Vehículos automotores para pasajeros, } \\
\text { excepto autobuses }\end{array}$ & 4 & Trigo y morcajo o tranquillón, sin moler & 4 \\
\hline $\begin{array}{l}\text { Equipos de telecomunicaciones y sus } \\
\text { partes, n.e.p. }\end{array}$ & 3 & Equipo de ingeniería civil & 3 \\
\hline $\begin{array}{l}\text { Vehículos automotores para el transporte } \\
\text { de mercancías y vehículos automotores } \\
\text { para usos especiales }\end{array}$ & 3 & $\begin{array}{l}\text { Vehículos automotores para el transporte } \\
\text { de mercancías y vehículos automotores } \\
\text { para usos especiales }\end{array}$ & 3 \\
\hline Medicamentos & 3 & $\begin{array}{l}\text { Otros aceites y grasas fijos de origen } \\
\text { vegetal }\end{array}$ & 3 \\
\hline
\end{tabular}

Fuentes: Secretaría de la OMC 


\section{LA AYUDA PARA EL COMERCIO EN SIINTESIS 2013}

\section{INDICADORES COMERCIALES (RESULTADOS)}

Indicador

Crecimiento del PIB (\%)

Número de exportadores

Índice de concentración de las exportaciones (productos) ( 0 a 1)

ACR sobre mercancías notificados a la OMC

AIE (servicios) notificados a la OMC

Sectores de servicios con compromisos en el marco del AGCS

\section{Aranceles (\%, 2006 et 2011)}

\begin{tabular}{l|l|l|l|} 
Importaciones: promedio aritmético de los aranceles NMF aplicados & 12,7 & 12,5
\end{tabular}

\begin{tabular}{l|l|l|l|} 
Importaciones: promedio ponderado de los aranceles NMF aplicados & 9,7 & 8,6
\end{tabular}

\begin{tabular}{|l|l|l|} 
Exportaciones: promedio ponderado de los aranceles impuestos & 5,0 & 2,3
\end{tabular}

por los importadores

$81,6 \quad 90,7$

Exportaciones: libres de derechos (en \%) sobre dinámica de las empresas de exportación; Banco Mundial, Indicadores del

Desarrollo Mundial; OMC, perfiles comerciales y arancelarios.

Participación en las exportaciones por región (\%)

\begin{tabular}{|l|r|r|}
\hline & $\mathbf{2 0 0 5}$ & $\mathbf{2 0 1 1}$ \\
\hline África & 36,1 & 36,1 \\
\hline Asia & 20,2 & 28,6 \\
\hline Comunidad de Estados Independientes & 0,3 & 0,2 \\
\hline Europa & 35,4 & 31,6 \\
\hline Oriente Medio & 4,5 & 2,2 \\
\hline América del Norte & 3,5 & 1,2 \\
\hline América del Sury América Central & 0,1 & 0,1 \\
\hline
\end{tabular}

Fuentes: OMC, perfiles comerciales y arancelarios

Indicadores de facilitación del comercio
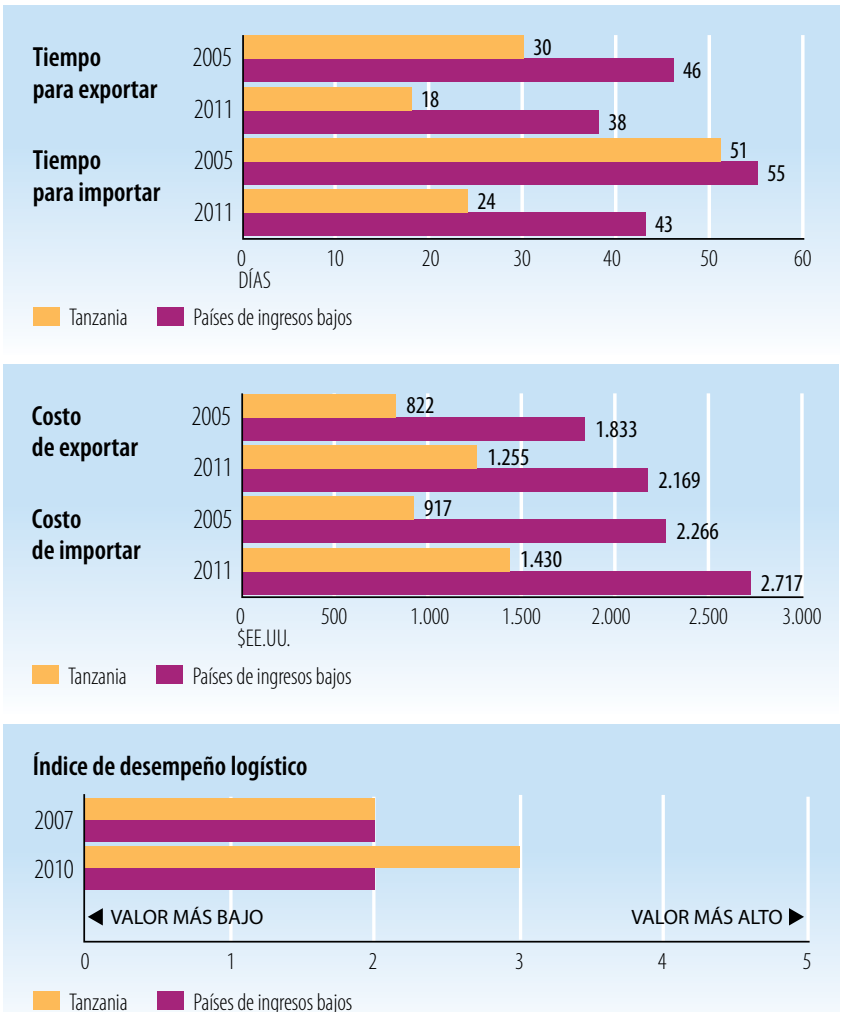

Fuentes: Banco Mundial, Indicadores del Desarrollo Mundial.

\begin{tabular}{l|c|c|}
\hline INDICADORES DE DESARROLLO (EFECTOS) & \\
\hline Indicador & $\mathbf{2 0 0 5}$ & $\mathbf{2 0 1 0}$ \\
\hline Desempleo (\% de la fuerza de trabajo total) & 4,3 & n.d. \\
\hline Población activa, mujeres (\% de la fuerza de trabajo total) & 50,1 & 49,8 \\
\hline AOD neta recibida (\% del INB) & 10,8 & 13,0 \\
\hline Derechos de importación percibidos (\% de los ingresos fiscales) & n.d. & n.d. \\
\hline Total del servicio de la deuda (\% de las exportaciones totales) & 4,3 & 3,0 \\
\hline Índice de desarrollo humano ( 0 a 1) & 0,42 & 0,46 \\
\hline
\end{tabular}

Fuentes: PNUD, indicadores internacionales sobre desarrollo humano; Banco Mundial, Indicadores del Desarrollo Mundial.

Producto interno bruto

PIB per cápita (PPA, dólares internacionales corrientes)

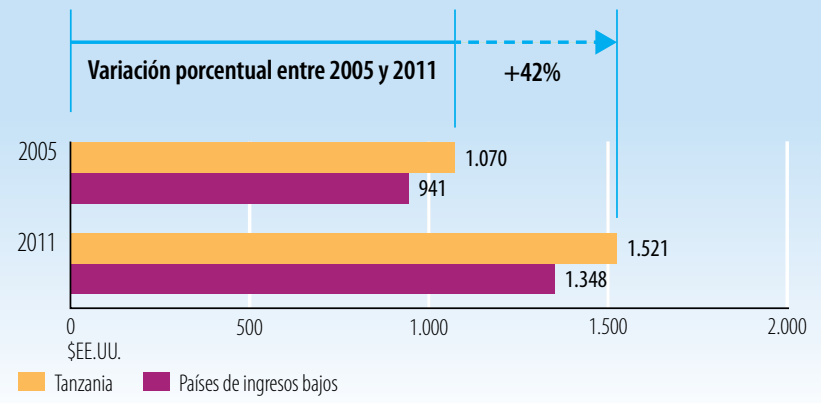

PIB per cápita (\$\$EE.UU. constantes de 2000)
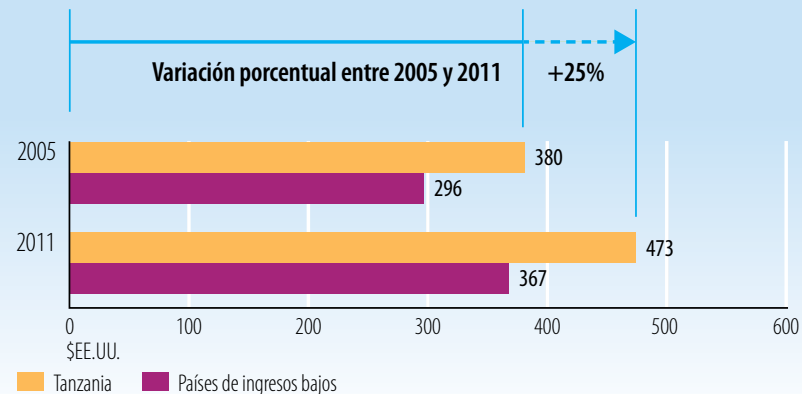

Fuentes: Banco Mundial, Indicadores del Desarrollo Mundial.

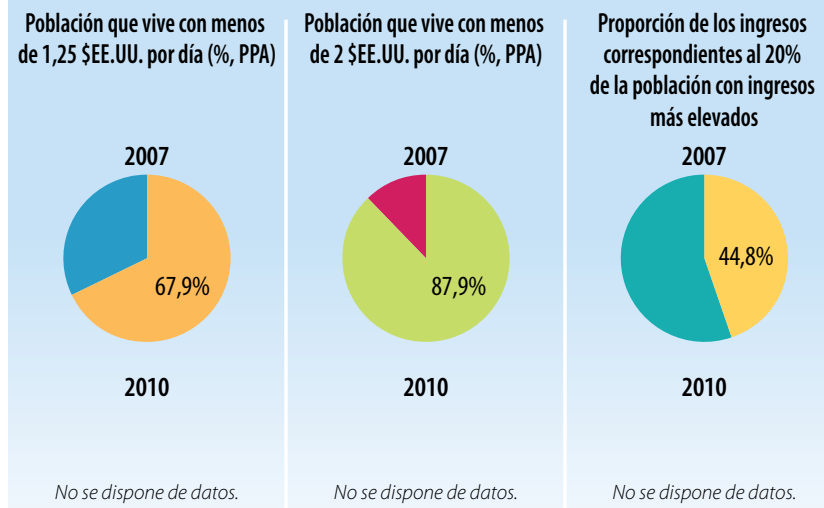

Fuentes: Banco Mundial, Indicadores del Desarrollo Mundial.

StatLink ㅊiाs] $h t$ ttp://dx.doi.org/10.1787/888932845987 


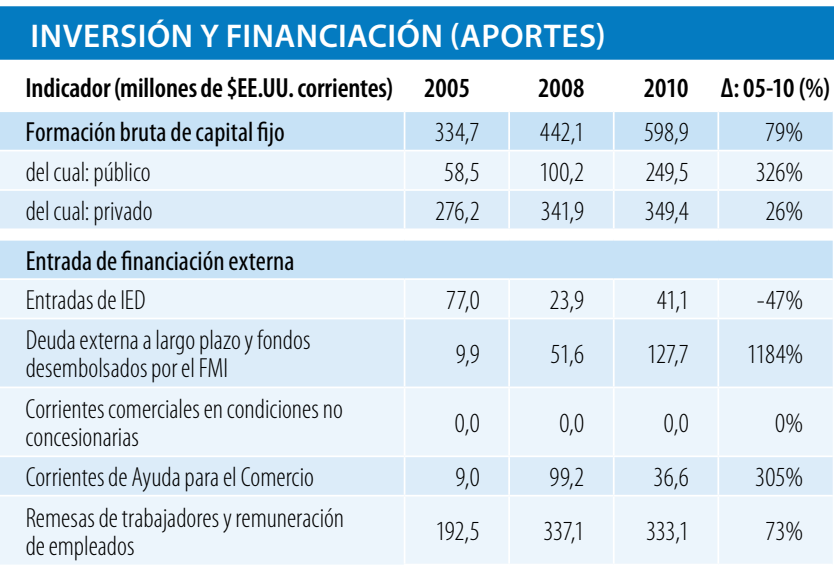

Fuentes: OCDE, base de datos del SNPA del CAD sobre las actividades de ayuda; Banco Mundial, Indicadores del Desarrollo Mundial; Banco Mundial, estadísticas de la deuda internacional.

Desembolsos de la ayuda para el comercio, por sector (millones de \$EE.UU. corrientes)

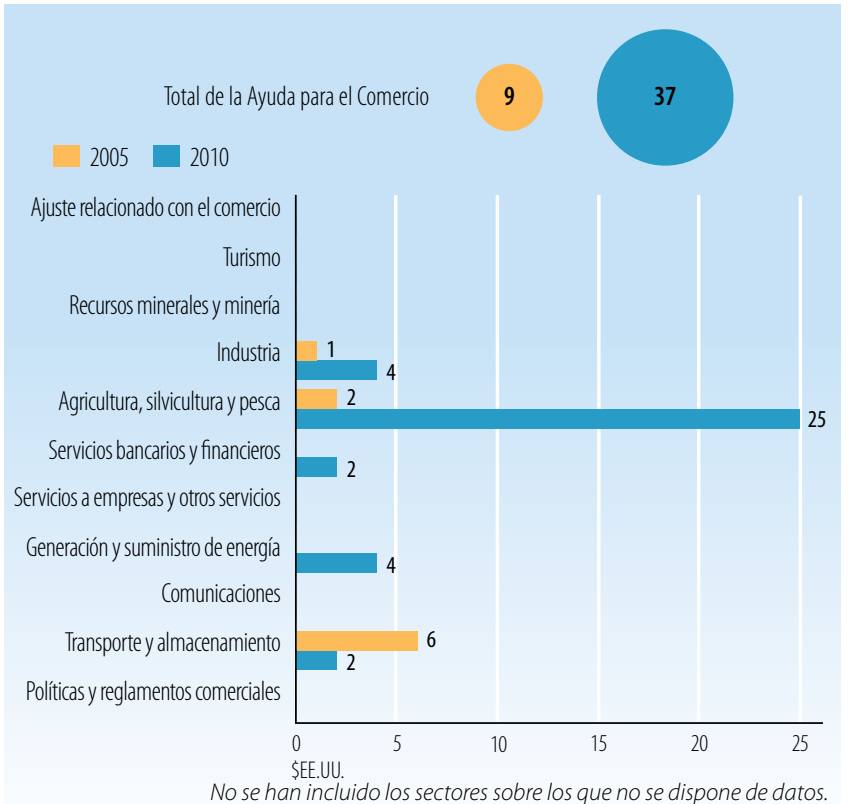

Fuentes: OCDE, base de datos del SNPA del CAD sobre las actividades de ayuda

Desembolsos de la ayuda para el comercio: principales donantes (millones de \$̦E.UU. corrientes)

\begin{tabular}{|l|c|c|c|}
\hline $\mathbf{2 0 0 5}$ & Valor & $\%$ & Principales donantes en 2005 \\
\hline Francia & 6,3 & 70 & \\
\hline Alemania & 1,1 & 12 & \\
\hline Bélgica & 0,5 & 6 & $98 \%$ \\
\hline Luxemburgo & 0,5 & 6 & \\
\hline Instituciones de la UE & 0,4 & 5 & \\
\hline $\mathbf{2 0 1 0}$ & Valor & $\%$ & Principales donantes en $\mathbf{2 0 1 0}$ \\
\hline Canadá & 22,1 & 60 & \\
\hline Banco Mundial & 10,4 & 28 & \\
\hline Instituciones de la UE & 1,2 & 3 & \\
\hline Bélgica & 0,8 & 2 & \\
\hline Italia & 0,7 & 2 & \\
\hline
\end{tabular}

Fuentes: OCDE, base de datos del SNPA del CAD sobre las actividades de ayuda.

\section{INDICADORES COMERCIALES (PRODUCTOS)}

\section{Indicador}

$2005 \quad 2008 \quad 2011 \quad \Delta: 05-11(\%)$

Relación comercio/PIB (\%)

\begin{tabular}{l|l|l|l|}
92 & 88 & 80 & -12 \\
\hline
\end{tabular}

Exportaciones de servicios comerciales como

$\%$ de las exportaciones totales

\begin{tabular}{l|l|l|l}
19 & 23 & n.d. & n.d.
\end{tabular}

mportaciones de servicios comerciales como

$\%$ de las importaciones totales

\begin{tabular}{l|l|l|l|}
21 & 21 & n.d. & n.d.
\end{tabular}

Productos intermedios distintos de los combustibles

(\% de las exportaciones de mercancías)

Productos intermedios distintos de los combustibles

(\% de las importaciones de mercancías)

\begin{tabular}{|l|l|l|l|}
\hline 80 & 62 & 81 & 1
\end{tabular}

Fuentes: Secretaría de la OMC.

Corrientes comerciales (millones de \$EE.UU. corrientes)

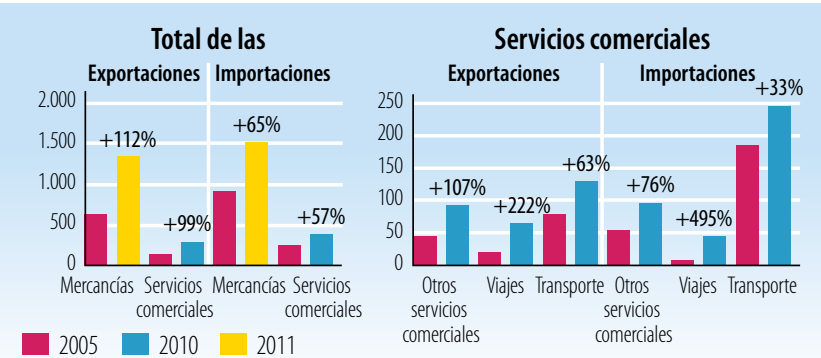

Fuentes: Secretaría de la OMC

Cinco principales mercados de exportación de mercancías (\%)

\begin{tabular}{|l|r|l|r|}
\hline $\mathbf{2 0 0 5}$ & $\%$ & $\mathbf{2 0 1 1}$ & $\%$ \\
\hline Ghana & 20 & China & 13 \\
\hline Burkina Faso & 18 & Burkina Faso & 11 \\
\hline Benin & 12 & Benin & 11 \\
\hline UE (27) & 10 & Níger & 9 \\
\hline Malí & 7 & Ghana & 6 \\
\hline
\end{tabular}

Fuentes: Secretaría de la OMC

Cinco principales productos de exportación (\% de las exportaciones de mercancías)

\begin{tabular}{|l|r|l|l|}
\hline 2005 & $\%$ & 2011 & $\%$ \\
\hline Cal, cemento y materiales de construcción & 27 & Algodón & 31 \\
\hline Abonos en bruto & 10 & $\begin{array}{l}\text { Cal, cemento y materiales de } \\
\text { construcción }\end{array}$ & 14 \\
\hline Artículos, n.e.p., de materiales plásticos & 9 & Artículos, n.e.p., de materiales plásticos & 6 \\
\hline Algodón & 8 & Abonos, excepto los del grupo 272 & 5 \\
\hline Cacao & 6 & Abonos en bruto & 5
\end{tabular}

Fuentes: Secretaría de la OMC

Cinco principales mercados de importación de mercancías (\%)

\begin{tabular}{|l|r|l|r|}
\hline 2005 & $\%$ & 2011 & $\%$ \\
\hline UE $(27)$ & 42 & UE $(27)$ & 37 \\
\hline China & 13 & China & 18 \\
\hline Côte d'Ivoire & 6 & Tailandia & 4 \\
\hline Brasil & 3 & Ghana & 3 \\
\hline India & 2 & India & 3
\end{tabular}

Fuentes: Secretaría de la OMC

Cinco principales productos de importación (\% de las importaciones de mercancías)

\begin{tabular}{|c|c|c|c|}
\hline 2005 & $\%$ & 2011 & $\%$ \\
\hline Productos derivados del petróleo & 29 & Productos derivados del petróleo & 14 \\
\hline Cal, cemento y materiales de construcción & 7 & $\begin{array}{l}\text { Cal, cemento y materiales de } \\
\text { construcción }\end{array}$ & 8 \\
\hline Medicamentos & 5 & Medicamentos & 4 \\
\hline Barras, perfiles, etc., de hierro y acero & 4 & $\begin{array}{l}\text { Vehículos automotores para pasajeros, } \\
\text { excepto autobuses }\end{array}$ & 4 \\
\hline Trigo y morcajo o tranquillón, sin moler & 4 & Barras, perfiles, etc., de hierro y acero & 3 \\
\hline
\end{tabular}




\section{LA AYUDA PARA EL COMERCIO EN SINNTESIS 2013}

\section{INDICADORES COMERCIALES (RESULTADOS)}

Indicador

Crecimiento del PIB (\%)

Número de exportadores

Índice de concentración de las exportaciones (productos) ( 0 a 1 )

ACR sobre mercancías notificados a la OMC

AIE (servicios) notificados a la OMC

Sectores de servicios con compromisos en el marco del AGCS

\section{Aranceles (\%, 2006 et 2011)}

Importaciones: promedio aritmético de los aranceles NMF aplicados $\quad 12,0 \quad 11,9$

Importaciones: promedio ponderado de los aranceles NMF aplicados $\quad 10,4 \quad 11,1$

\begin{tabular}{|l|l|l|} 
Exportaciones: promedio ponderado de los aranceles impuestos & 6,9 & 3,3
\end{tabular}

por los importadores

$66,5 \quad 61,3$

Exportaciones: libres de derechos (en \%)

dial, base de datos

sobre dinámica de las empresas de exportación; Banco Mundial, Indicadores del

Desarrollo Mundial; OMC, perfiles comerciales y arancelarios.

Participación en las exportaciones por región (\%)

\begin{tabular}{|l|r|r|}
\hline & $\mathbf{2 0 0 5}$ & $\mathbf{2 0 1 1}$ \\
\hline África & 71,6 & 54,9 \\
\hline Asia & 13,5 & 32,8 \\
\hline Comunidad de Estados Independientes & 0,0 & 0,0 \\
\hline Europa & 10,0 & 9,1 \\
\hline Oriente Medio & 0,2 & 1,0 \\
\hline América del Norte & 1,1 & 0,2 \\
\hline América del Sury América Central & 1,9 & 0,5 \\
\hline
\end{tabular}

Fuentes: OMC, perfiles comerciales y arancelarios

Indicadores de facilitación del comercio
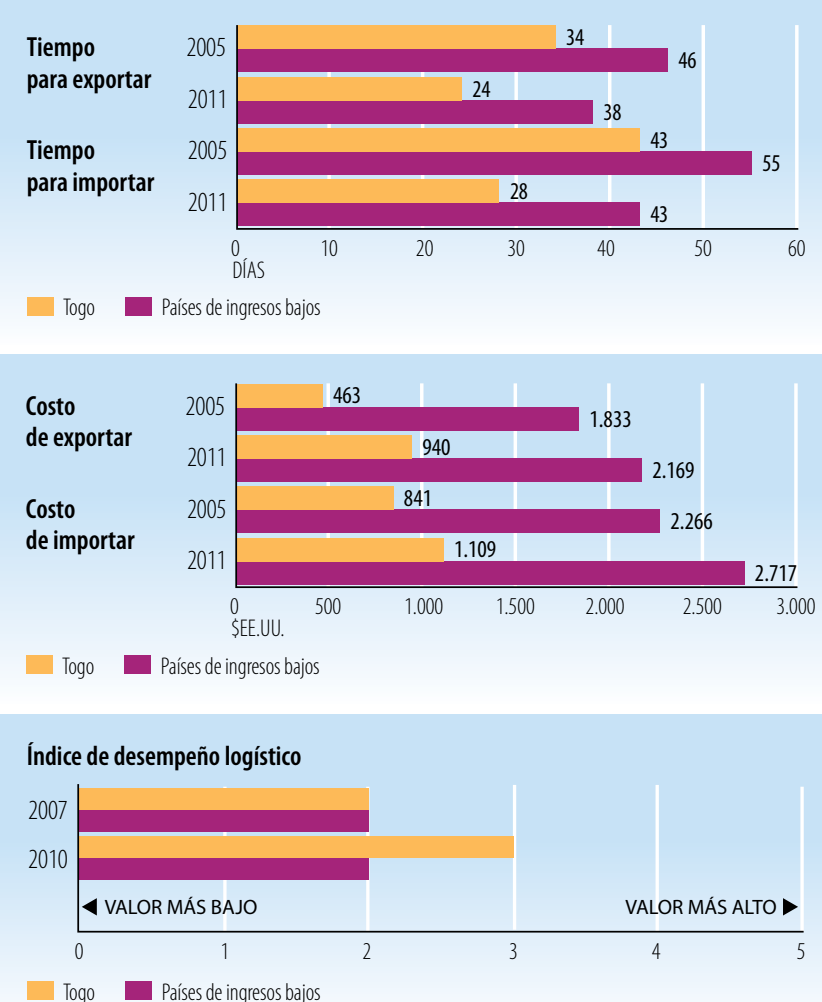

Fuentes: Banco Mundial, Indicadores del Desarrollo Mundial.

\begin{tabular}{|l|c|c|}
\hline INDICADORES DE DESARROLLO (EFECTOS) \\
\hline Indicador & $\mathbf{2 0 0 5}$ & $\mathbf{2 0 1 0}$ \\
\hline Desempleo (\% de la fuerza de trabajo total) & n.d. & n.d. \\
\hline Población activa, mujeres (\% de la fuerza de trabajo total) & 50,5 & 50,5 \\
\hline AOD neta recibida (\% del INB) & 4,0 & 13,3 \\
\hline Derechos de importación percibidos (\% de los ingresos fiscales) & 21,9 & 24,9 \\
\hline Total del servicio de la deuda (\% de las exportaciones totales) & 2,4 & 4,4 \\
\hline Índice de desarrollo humano (0 a 1) & 0,42 & 0,43 \\
\hline
\end{tabular}

Fuentes: PNUD, indicadores internacionales sobre desarrollo humano; Banco Mundial, Indicadores del Desarrollo Mundial.

Producto interno bruto

PIB per cápita (PPA, dólares internacionales corrientes)

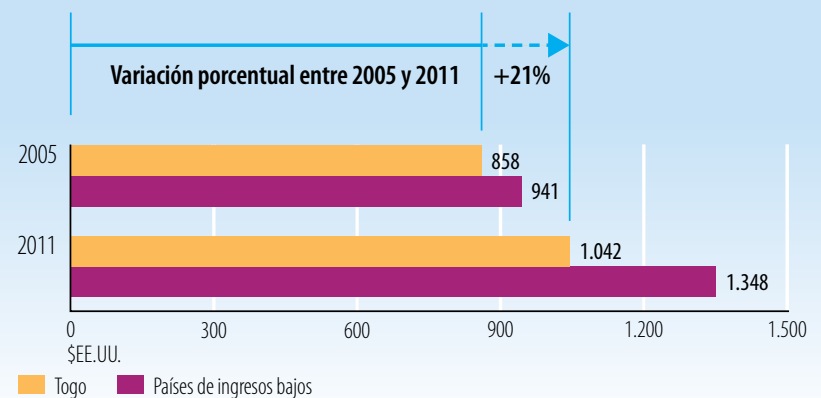

PIB per cápita (\$EE.UU. constantes de 2000)
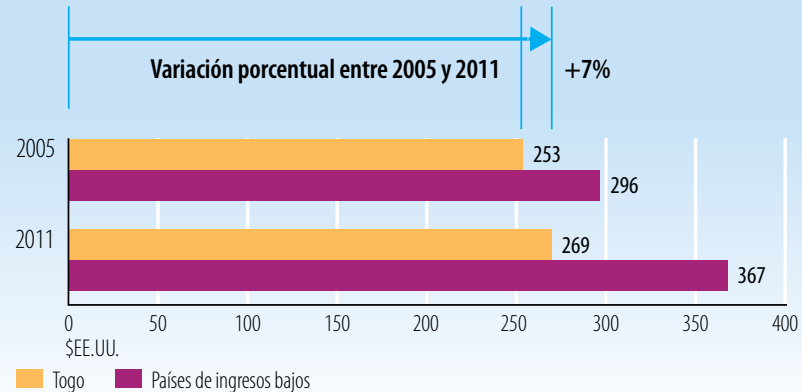

Fuentes: Banco Mundial, Indicadores del Desarrollo Mundial.

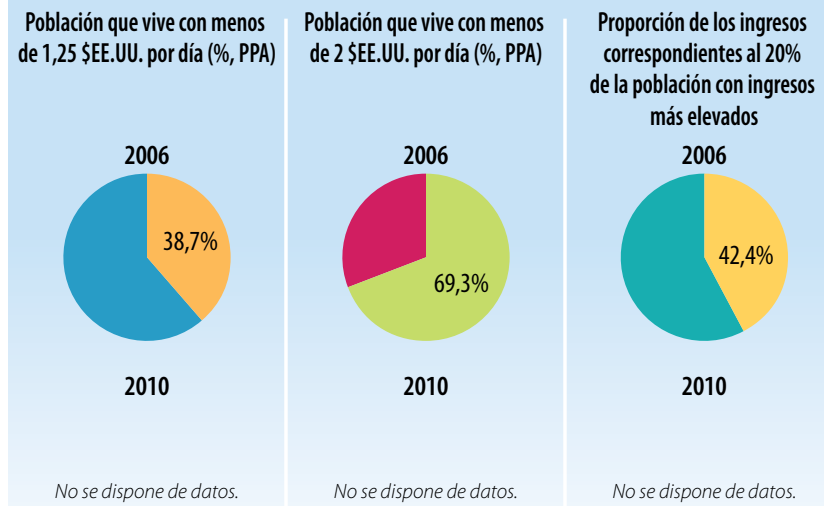

Fuentes: Banco Mundial, Indicadores del Desarrollo Mundial.

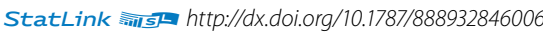




\section{Indicadores de la ayuda, el comercio y el desarrollo relativos a Trinidad y Tabago}

\begin{tabular}{|c|c|c|c|c|}
\hline Indicador (millones de \$̦EE.UU. corrientes) & 2005 & 2008 & 2010 & $\Delta: 05-10(\%)$ \\
\hline Formación bruta de capital fijo & n.d. & n.d. & n.d. & n.d. \\
\hline del cual: público & n.d. & n.d. & n.d. & n.d. \\
\hline del cual: privado & n.d. & n.d. & n.d. & n.d. \\
\hline \multicolumn{5}{|l|}{ Entrada de financiación externa } \\
\hline Entradas de IED & 939,7 & $2.800,8$ & 549,4 & $-42 \%$ \\
\hline $\begin{array}{l}\text { Deuda externa a largo plazo y fondos } \\
\text { desembolsados por el FMI }\end{array}$ & n.d. & n.d. & n.d. & n.d. \\
\hline $\begin{array}{l}\text { Corrientes comerciales en condiciones no } \\
\text { concesionarias }\end{array}$ & 1,5 & 0,0 & 0,2 & $-90 \%$ \\
\hline Corrientes de Ayuda para el Comercio & 2,4 & 0,5 & 1,3 & $-45 \%$ \\
\hline $\begin{array}{l}\text { Remesas de trabajadores y remuneración } \\
\text { de empleados }\end{array}$ & 92,4 & 94,5 & 119,9 & $30 \%$ \\
\hline
\end{tabular}

Fuentes: OCDE, base de datos del SNPA del CAD sobre las actividades de ayuda; Banco Mundial, Indicadores del Desarrollo Mundial; Banco Mundial, estadísticas de la deuda internacional.

Desembolsos de la ayuda para el comercio, por sector (millones de \$EE.UU. corrientes)

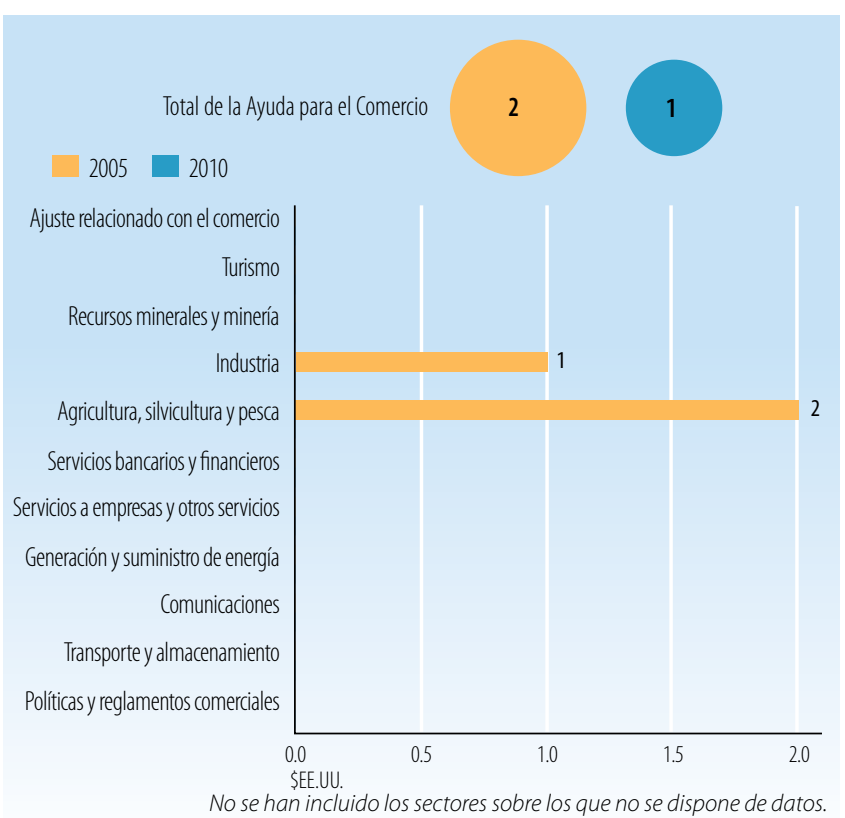

Fuentes: OCDE, base de datos del SNPA del CAD sobre las actividades de ayuda

Desembolsos de la ayuda para el comercio: principales donantes (millones de \$EE.UU. corrientes)

\begin{tabular}{|l|r|r|r|}
\hline $\mathbf{2 0 0 5}$ & Valor & $\%$ & Principales donantes en $\mathbf{2 0 0 5}$ \\
\hline Japón & 1,7 & 69 & \\
\hline Instituciones de la UE & 0,7 & 27 & $100 \%$ \\
\hline PNUD & 0,0 & 2 & \\
\hline Canadá & 0,0 & 1 & \\
\hline Francia & 0,0 & 1 & \\
\hline $\mathbf{2 0 1 0}$ & Valor & $\%$ & Principales donantes en $\mathbf{2 0 1 0}$ \\
\hline Estados Unidos & 0,6 & 47 & \\
\hline BID & 0,3 & 23 & \\
\hline Francia & 0,2 & 13 & \\
\hline Instituciones de la UE & 0,1 & 8 & \\
\hline Australia & 0,1 & 5 & \\
\hline
\end{tabular}

Fuentes: OCDE, base de datos del SNPA del CAD sobre las actividades de ayuda.

\section{INDICADORES COMERCIALES (PRODUCTOS)}

Indicador $20052008 \quad 2011 \quad \Delta: 05-11(\%)$

Relación comercio/PIB (\%)

\begin{tabular}{|l|l|l|l|}
106 & 105 & 104 & -2 \\
\hline
\end{tabular}

Exportaciones de servicios comerciales como

$\%$ de las exportaciones totales

Importaciones de servicios comerciales como

$\%$ de las importaciones totales

Productos intermedios distintos de los combustibles

(\% de las exportaciones de mercancías)

Productos intermedios distintos de los combustibles

(\% de las importaciones de mercancías)

\begin{tabular}{ll|l}
8 & 5 & n.d.
\end{tabular}

\begin{tabular}{l|l|l|l}
8 & 3 & n.d.
\end{tabular}

\begin{tabular}{l|l|l|}
25 & 26 & n.d.
\end{tabular}

\begin{tabular}{|l|l|l|l|}
\hline 36 & 36 & n.d.
\end{tabular}

Fuentes: Secretaría de la OMC

Corrientes comerciales (millones de \$EE.UU. corrientes)

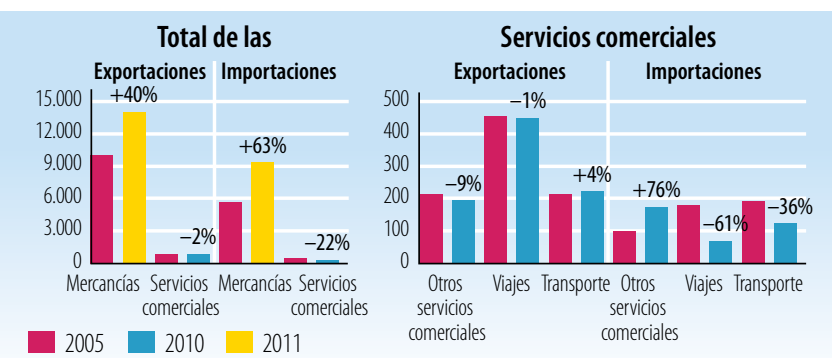

Fuentes: Secretaría de la OMC

Cinco principales mercados de exportación de mercancías (\%)

\begin{tabular}{|r|r|r|r|}
\hline 2005 & $\%$ & 2010 & $\%$ \\
\hline Estados Unidos & 59 & Estados Unidos & 48 \\
\hline Jamaica & 7 & UE (27) & 9 \\
\hline UE (27) & 7 & Jamaica & 6 \\
\hline Barbados & 4 & Barbados & 3 \\
\hline Guyana & 3 & Suriname & 3 \\
\hline Fuentes: Secretaría de la OMC & & & \\
\hline
\end{tabular}

Cinco principales productos de exportación (\% de las exportaciones de mercancías)

\begin{tabular}{|l|r|l|l|}
\hline $\mathbf{2 0 0 5}$ & $\%$ & $\mathbf{2 0 1 0}$ & $\%$ \\
\hline Productos derivados del petróleo & 31 & Productos derivados del petróleo & 31 \\
\hline Gas natural & 21 & Elementos químicos inorgánicos & 13 \\
\hline Aceites de petróleo, crudos & 15 & Aceites de petróleo, crudos & 12 \\
\hline Elementos químicos inorgánicos & 9 & Gas natural & 12 \\
\hline Alcoholes, fenoles, etc., y sus derivados & 8 & Alcoholes, fenoles, etc., y sus derivados & 6 \\
\hline
\end{tabular}

Fuentes: Secretaría de la OMC

Cinco principales mercados de importación de mercancías (\%)

\begin{tabular}{|l|r|l|c|}
\hline 2005 & $\%$ & 2010 & $\%$ \\
\hline Estados Unidos & 29 & Estados Unidos & 28 \\
\hline Brasil & 14 & Gabón & 13 \\
\hline UE $(27)$ & 12 & Colombia & 9 \\
\hline Venezuela, Rep. Bolivariana de & 6 & UE (27) & 9 \\
\hline Colombia & 6 & Brasil & 7 \\
\hline
\end{tabular}

Fuentes: Secretaría de la OMC

Cinco principales productos de importación (\% de las importaciones de mercancías)

\begin{tabular}{|c|c|c|c|}
\hline 2005 & $\%$ & 2010 & $\%$ \\
\hline Aceites de petróleo, crudos & 30 & Aceites de petróleo, crudos & 31 \\
\hline $\begin{array}{l}\text { Equipo de calefacción y refrigeración y } \\
\text { sus partes y piezas }\end{array}$ & 5 & Mineral de hierro y sus concentrados & 4 \\
\hline Productos derivados del petróleo & 4 & $\begin{array}{l}\text { Vehículos automotores para pasajeros, } \\
\text { excepto autobuses }\end{array}$ & ? \\
\hline Mineral de hierro y sus concentrados & 3 & $\begin{array}{l}\text { Buques, embarcaciones y estructuras } \\
\text { flotantes }\end{array}$ & 2 \\
\hline $\begin{array}{l}\text { Vehículos automotores para pasajeros, } \\
\text { excepto autobuses }\end{array}$ & 3 & $\begin{array}{l}\text { Otras máquinas y equipos especiales para } \\
\text { determinadas industrias }\end{array}$ & 2 \\
\hline
\end{tabular}

Fuentes: Secretaría de la OMC 


\section{LA AYUDA PARA EL COMERCIO EN SIINTESIS 2013}

\section{INDICADORES COMERCIALES (RESULTADOS)}

\section{Indicador}

Crecimiento del PIB (\%)

Número de exportadores

Índice de concentración de las exportaciones (productos) ( 0 a 1)

ACR sobre mercancías notificados a la OMC

AIE (servicios) notificados a la OMC

Sectores de servicios con compromisos en el marco del AGCS

\section{Aranceles (\%, 2006 et 2011)}

Importaciones: promedio aritmético de los aranceles NMF aplicados

Importaciones: promedio ponderado de los aranceles NMF aplicados

Exportaciones: promedio ponderado de los aranceles impuestos

por los importadores

Exportaciones: libres de derechos (en \%)

(atre de datos Comtrade; Banco Mundial, base de datos sobre dinámica de las empresas de exportación; Banco Mundial, Indicadores del

Desarrollo Mundial; OMC, perfiles comerciales y arancelarios.

Participación en las exportaciones por región (\%)

\begin{tabular}{|l|r|r|}
\hline & 2005 & 2010 \\
\hline África & 0,1 & 4,6 \\
\hline Asia & 0,1 & 1,5 \\
\hline Comunidad de Estados Independientes & 0,0 & 0,1 \\
\hline Europa & 6,9 & 9,9 \\
\hline Oriente Medio & 0,0 & 0,1 \\
\hline América del Norte & 61,7 & 50,4 \\
\hline América del Sury América Central & 30,0 & 32,2 \\
\hline
\end{tabular}

Fuentes: OMC, perfiles comerciales y arancelarios

Indicadores de facilitación del comercio
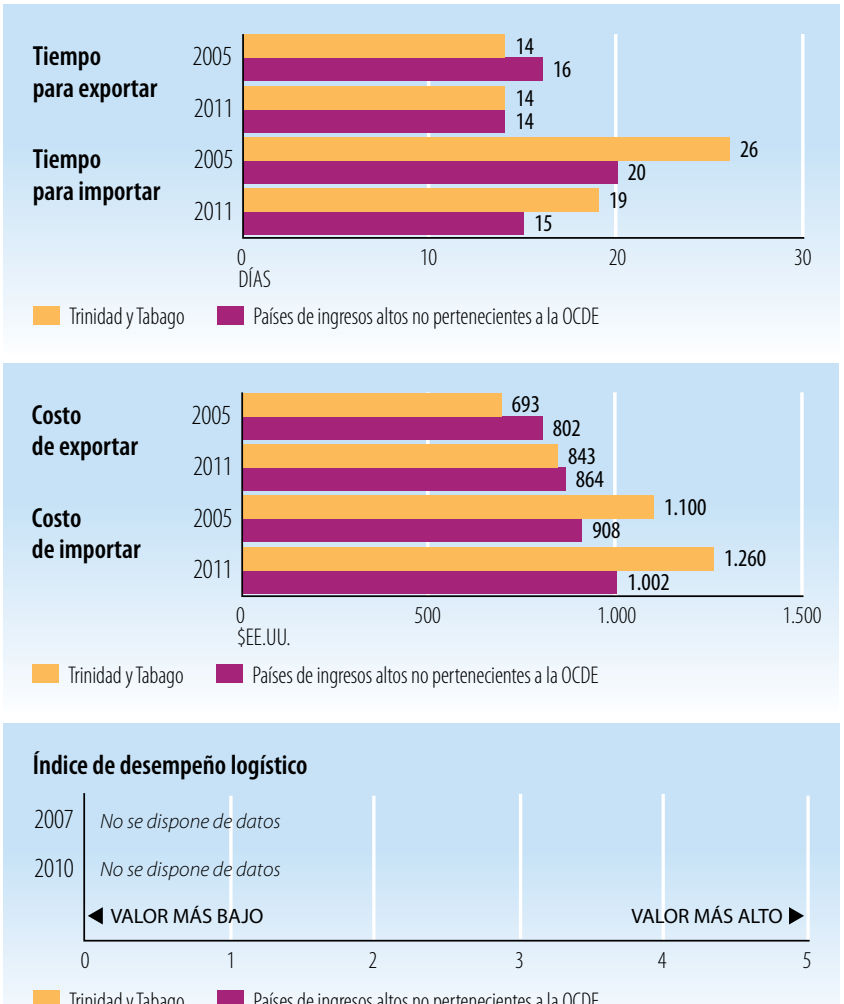

- Trinidad y Tabago Países de ingresos altos no pertenecientes a la OCDE

Fuentes: Banco Mundial, Indicadores del Desarrollo Mundial.

\begin{tabular}{l|r|r|}
\hline INDICADORES DE DESARROLLO (EFECTOS) \\
\hline Indicador & 2005 & 2010 \\
\hline Desempleo (\% de la fuerza de trabajo total) & 8,0 & 5,3 \\
\hline Población activa, mujeres (\% de la fuerza de trabajo total) & 43,2 & 43,2 \\
\hline AOD neta recibida (\% del INB) & 0,0 & 0,0 \\
\hline Derechos de importación percibidos (\% de los ingresos fiscales) & 5,5 & n.d. \\
\hline Total del servicio de la deuda (\% de las exportaciones totales) & n.d. & n.d. \\
\hline Índice de desarrollo humano (0 a 1) & 0,73 & 0,76 \\
\hline
\end{tabular}

Fuentes: PNUD, indicadores internacionales sobre desarrollo humano; Banco Mundial, Indicadores del Desarrollo Mundial.

Producto interno bruto

PIB per cápita (PPA, dólares internacionales corrientes)

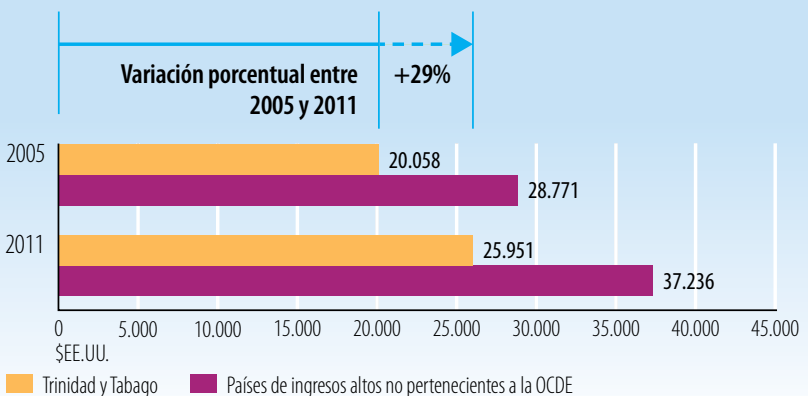

Trinidad y Tabago Países de ingresos al tos no pertenecientes a la OCDE

PIB per cápita (\$EE.UU. constantes de 2000)
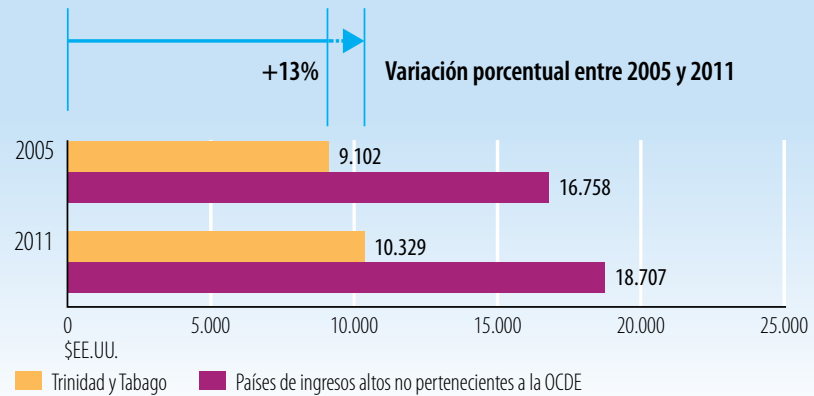

Fuentes: Banco Mundial, Indicadores del Desarrollo Mundial.

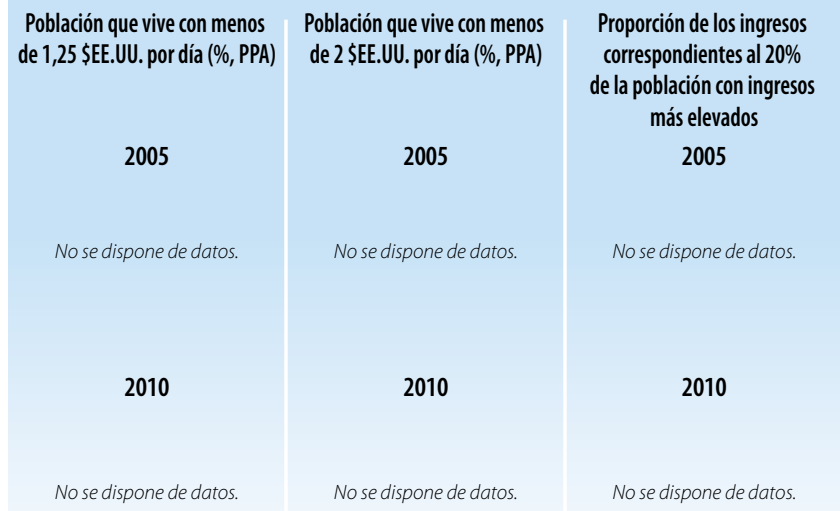

Fuentes: Banco Mundial, Indicadores del Desarrollo Mundial.

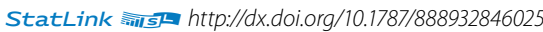




\section{Indicadores de la ayuda, el comercio y el desarrollo relativos a Túnez}

\begin{tabular}{|c|c|c|c|c|}
\hline Indicador (millones de \$̦EE.UU. corrientes) & 2005 & 2008 & 2010 & $\Delta: 05-10(\%)$ \\
\hline Formación bruta de capital fijo & $6.886,1$ & $10.551,6$ & $10.749,7$ & $56 \%$ \\
\hline del cual: público & 973,8 & $1.263,9$ & n.d. & n.d. \\
\hline del cual: privado & $5.912,3$ & $9.287,7$ & n.d. & n.d. \\
\hline \multicolumn{5}{|l|}{ Entrada de financiación externa } \\
\hline Entradas de IED & 723,0 & $2.638,5$ & $1 ; 400,9$ & $94 \%$ \\
\hline $\begin{array}{l}\text { Deuda externa a largo plazo y fondos } \\
\text { desembolsados por el FMI }\end{array}$ & $1.255,6$ & $1.078,6$ & $1 ; 714,2$ & $37 \%$ \\
\hline $\begin{array}{l}\text { Corrientes comerciales en condiciones no } \\
\text { concesionarias }\end{array}$ & 145,7 & 78,8 & 443,1 & $204 \%$ \\
\hline Corrientes de Ayuda para el Comercio & 114,5 & 304,2 & 493,0 & $331 \%$ \\
\hline $\begin{array}{l}\text { Remesas de trabajadores y remuneración } \\
\text { de empleados }\end{array}$ & $1.392,7$ & $1.977,0$ & $1 ; 970,2$ & $41 \%$ \\
\hline
\end{tabular}

Fuentes: OCDE, base de datos del SNPA del CAD sobre las actividades de ayuda; Banco Mundial, Indicadores del Desarrollo Mundial; Banco Mundial, estadísticas de la deuda internacional.

Desembolsos de la ayuda para el comercio, por sector (millones de \$EE.UU. corrientes)

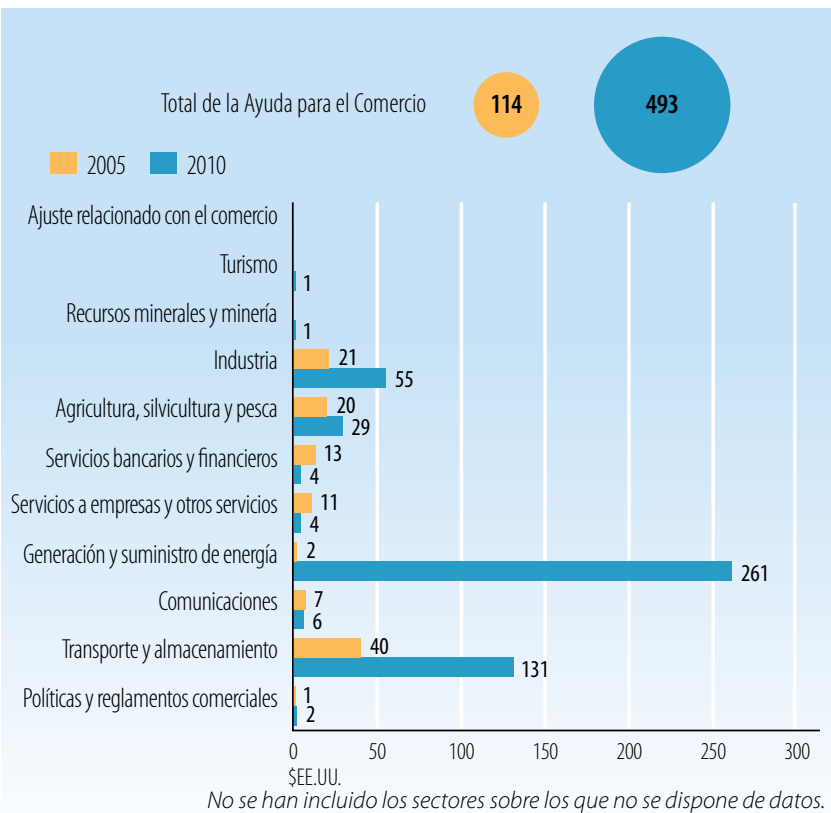

Fuentes: OCDE, base de datos del SNPA del CAD sobre las actividades de ayuda

Desembolsos de la ayuda para el comercio: principales donantes (millones de \$EE.UU. corrientes)

\begin{tabular}{|l|c|c|c|}
\hline $\mathbf{2 0 0 5}$ & Valor & $\%$ & Principales donantes en 2005 \\
\hline Japón & 41,0 & 36 & \\
\hline Francia & 29,1 & 25 & \\
\hline Instituciones de la UE & 18,1 & 16 & $97 \%$ \\
\hline Alemania & 16,9 & 15 & \\
\hline Italia & 5,4 & 5 & \\
\hline $\mathbf{2 0 1 0}$ & Valor & $\%$ & Principales donantes en $\mathbf{2 0 1 0}$ \\
\hline España & 153,0 & 31 & \\
\hline Fondo Árabe & 139,2 & 28 & \\
\hline Japón & 78,2 & 16 & \\
\hline Instituciones de la UE & 48,4 & 10 & \\
\hline Francia & 29,9 & 6 & $91 \%$ \\
\hline
\end{tabular}

Fuentes: OCDE, base de datos del SNPA del CAD sobre las actividades de ayuda.

\section{INDICADORES COMERCIALES (PRODUCTOS)}

Indicador

$2005 \quad 2008 \quad 2011 \quad \Delta: 05-11(\%)$

Relación comercio/PIB (\%)

\begin{tabular}{|l|l|l|l|}
90 & 115 & 105 & 15 \\
\hline
\end{tabular}

Exportaciones de servicios comerciales como

$\%$ de las exportaciones totales

Importaciones de servicios comerciales como

$\%$ de las importaciones totales

Productos intermedios distintos de los combustibles

(\% de las exportaciones de mercancías)

Productos intermedios distintos de los combustibles

(\% de las importaciones de mercancías)

\begin{tabular}{|l|l|l|l|}
27 & 23 & 20 & -7
\end{tabular}

Fuentes: Secretaría de la OMC.

Corrientes comerciales (millones de \$EE.UU. corrientes)

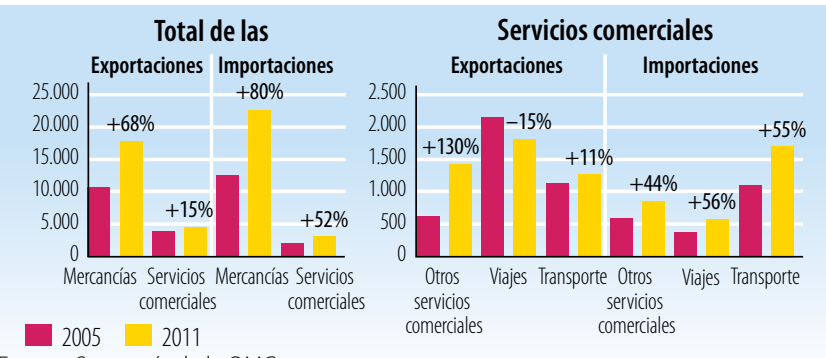

Fuentes: Secretaría de la OMC

Cinco principales mercados de exportación de mercancías (\%)

\begin{tabular}{|l|r|l|r|}
\hline 2005 & $\%$ & 2010 & $\%$ \\
\hline UE $(27)$ & 80 & UE $(27)$ & 73 \\
\hline Libia & 5 & Libia & 4 \\
\hline Argelia & 2 & Argelia & 3 \\
\hline Marruecos & 1 & Estados Unidos & 2 \\
\hline Turquía & 1 & India & 2 \\
\hline
\end{tabular}

Fuentes: Secretaría de la OMC

Cinco principales productos de exportación (\% de las exportaciones de mercancías)

\begin{tabular}{|c|c|c|c|}
\hline 2005 & $\%$ & 2010 & $\%$ \\
\hline $\begin{array}{l}\text { Otros artículos textiles y prendas de } \\
\text { vestir, n.e.p. }\end{array}$ & 13 & Aceites de petróleo, crudos & 13 \\
\hline Aceites de petróleo, crudos & 10 & $\begin{array}{l}\text { Otros artículos textiles y prendas de } \\
\text { vestir, n.e.p. }\end{array}$ & 10 \\
\hline $\begin{array}{l}\text { Prendas de vestir para hombres y niños, } \\
\text { excepto las de punto }\end{array}$ & 9 & $\begin{array}{l}\text { Equipo para distribución de electricidad, } \\
\text { n.e.p. }\end{array}$ & 8 \\
\hline $\begin{array}{l}\text { Equipo para distribución de electricidad, } \\
\text { n.e.p. }\end{array}$ & 6 & Abonos, excepto los del grupo 272 & 5 \\
\hline $\begin{array}{l}\text { Prendas de vestir para mujeres y niñas, } \\
\text { excepto las de punto }\end{array}$ & 5 & Circuitos eléctricos de conmutación y relé & 5 \\
\hline
\end{tabular}

Cinco principales mercados de importación de mercancías (\%)

\begin{tabular}{|l|r|l|r|}
\hline 2005 & $\%$ & 2010 & $\%$ \\
\hline UE (27) & 70 & UE (27) & 61 \\
\hline Libia & 4 & China & 6 \\
\hline China & 3 & Federación de Rusia & 5 \\
\hline Federación de Rusia & 3 & Estados Unidos & 4 \\
\hline Estados Unidos & 3 & Turquía & 3 \\
\hline
\end{tabular}

Fuentes: Secretaría de la OMC

Cinco principales productos de importación (\% de las importaciones de mercancías)

\begin{tabular}{|c|c|c|c|}
\hline 2005 & $\%$ & 2010 & $\%$ \\
\hline Productos derivados del petróleo & 8 & Productos derivados del petróleo & 8 \\
\hline Tejidos de algodón & 6 & Circuitos eléctricos de conmutación y relé & 4 \\
\hline Circuitos eléctricos de conmutación y relé & 4 & Tejidos de algodón & 4 \\
\hline Aceites de petróleo, crudos & 3 & $\begin{array}{l}\text { Vehículos automotores para pasajeros, } \\
\text { excepto autobuses }\end{array}$ & 4 \\
\hline $\begin{array}{l}\text { Vehículos automotores para pasajeros, } \\
\text { excepto autobuses }\end{array}$ & 3 & $\begin{array}{l}\text { Equipo para distribución de electricidad, } \\
\text { n.e.p. }\end{array}$ & 2 \\
\hline
\end{tabular}




\section{LA AYUDA PARA EL COMERCIO EN SÍNTESIS 2013}

\section{INDICADORES COMERCIALES (RESULTADOS)}

\section{Indicador}

Crecimiento del PIB (\%)

Número de exportadores

Índice de concentración de las exportaciones (productos) ( 0 a 1)

ACR sobre mercancías notificados a la OMC

AIE (servicios) notificados a la OMC

Sectores de servicios con compromisos en el marco del AGCS

\section{Aranceles $(\%, 2006$ et 2011)}

\begin{tabular}{l|l|l|l|} 
Importaciones: promedio aritmético de los aranceles NMF aplicados $\quad 26,8$ & 16,0
\end{tabular}

\begin{tabular}{l|l|l|l|} 
Importaciones: promedio ponderado de los aranceles NMF aplicados & 20,2 & 14,4
\end{tabular}

\begin{tabular}{|l|l|l|} 
Exportaciones: promedio ponderado de los aranceles impuestos & 1,7 & 0,5
\end{tabular}

por los importadores

Exportaciones: libres de derechos (en \%)

$92,5 \quad 95,2$

Fuentes: Naciones Unidas, base de datos Comtrade; Banco Mundial, base de datos sobre dinámica de las empresas de exportación; Banco Mundial, Indicadores del

Desarrollo Mundial; OMC, perfiles comerciales y arancelarios.

Participación en las exportaciones por región (\%)

\begin{tabular}{|l|r|r|}
\hline & $\mathbf{2 0 0 5}$ & $\mathbf{2 0 1 1}$ \\
\hline África & 9,0 & 11,3 \\
\hline Asia & 2,4 & 2,6 \\
\hline Comunidad de Estados Independientes & 0,1 & 0,1 \\
\hline Europa & 81,7 & 78,6 \\
\hline Oriente Medio & 1,4 & 1,2 \\
\hline América del Norte & 1,0 & 1,7 \\
\hline América del Sury América Central & 0,7 & 0,7 \\
\hline
\end{tabular}

Fuentes: OMC, perfiles comerciales y arancelarios

Indicadores de facilitación del comercio
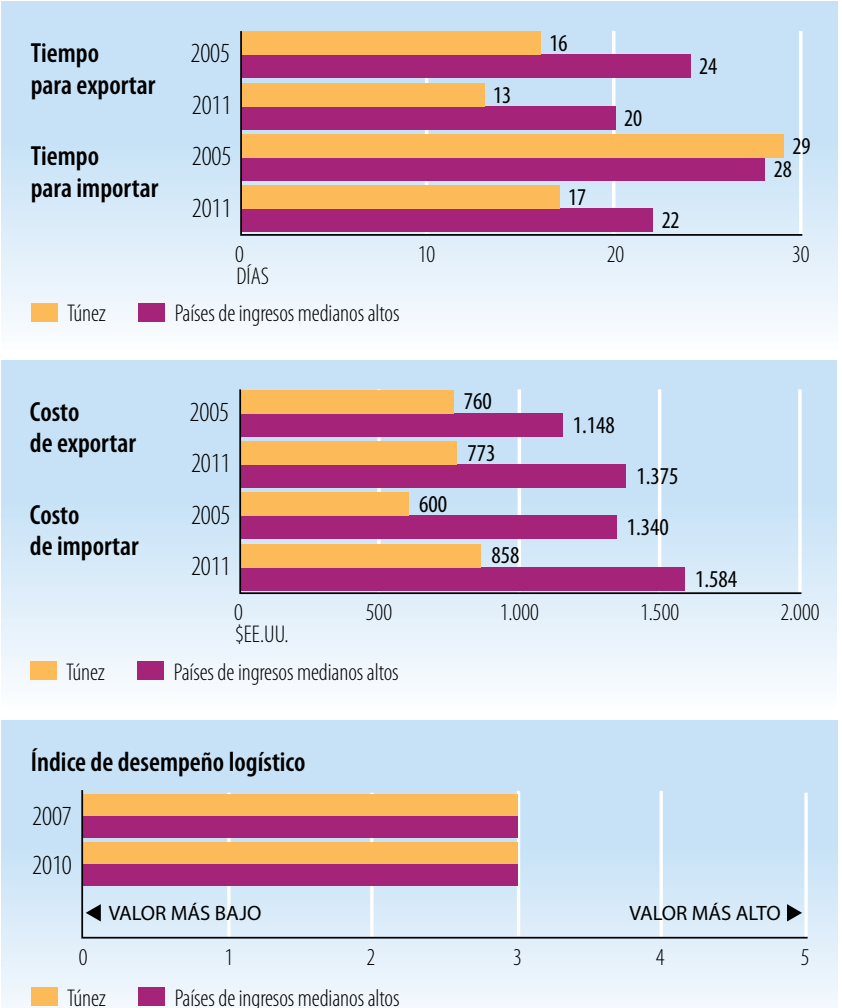

Fuentes: Banco Mundial, Indicadores del Desarrollo Mundial.

\begin{tabular}{l|c|c|}
\hline INDICADORES DE DESARROLLO (EFECTOS) \\
\hline Indicador & $\mathbf{2 0 0 5}$ & $\mathbf{2 0 1 0}$ \\
\hline Desempleo (\% de la fuerza de trabajo total) & 14,2 & 14,2 \\
\hline Población activa, mujeres (\% de la fuerza de trabajo total) & 26,4 & 26,9 \\
\hline AOD neta recibida (\% del INB) & 1,2 & 1,3 \\
\hline Derechos de importación percibidos (\% de los ingresos fiscales) & n.d. & 8,6 \\
\hline Total del servicio de la deuda (\% de las exportaciones totales) & 13,6 & 10,4 \\
\hline Índice de desarrollo humano ( 0 a 1) & 0,67 & 0,70 \\
\hline
\end{tabular}

Fuentes: PNUD, indicadores internacionales sobre desarrollo humano; Banco Mundial, Indicadores del Desarrollo Mundial.

Producto interno bruto

PIB per cápita (PPA, dólares internacionales corrientes)

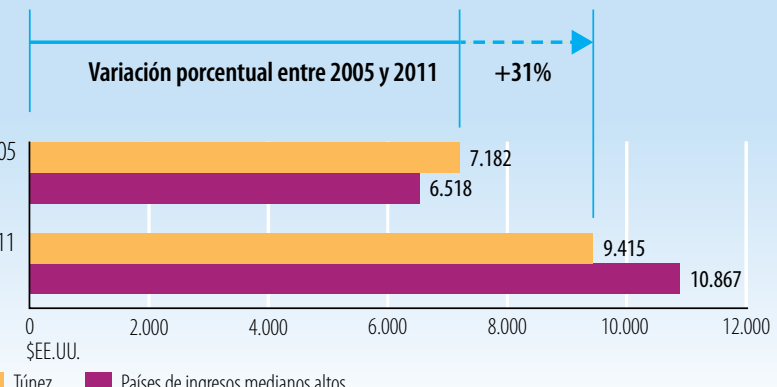

Túnez $\square$ Países de ingresos medianos altos

PIB per cápita (\$EE.UU. constantes de 2000)
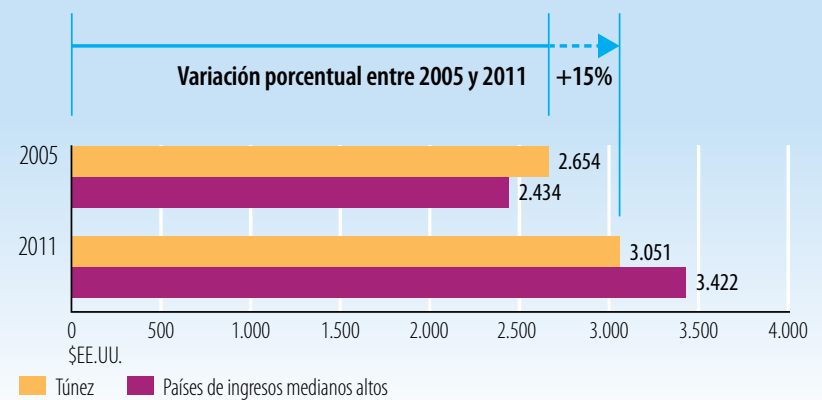

Fuentes: Banco Mundial, Indicadores del Desarrollo Mundial.

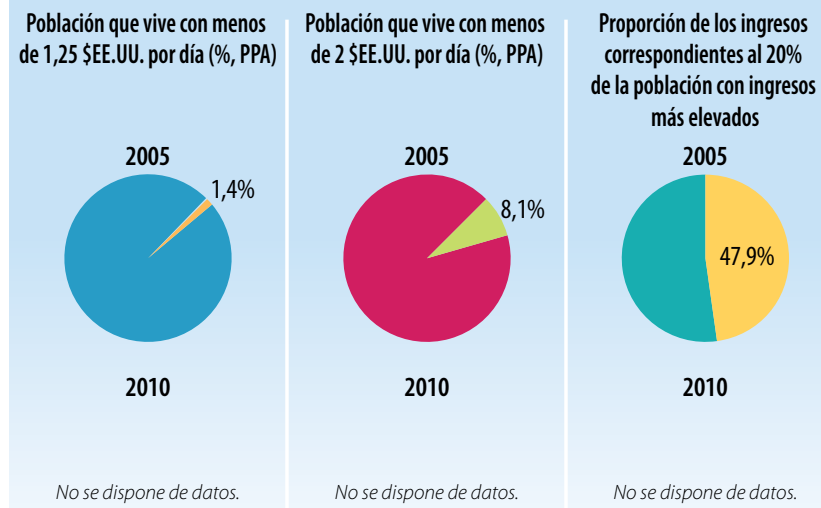

Fuentes: Banco Mundial, Indicadores del Desarrollo Mundial.

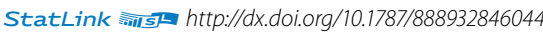


Indicadores de la ayuda, el comercio y el desarrollo relativos a Tuvalu

\begin{tabular}{|c|c|c|c|c|}
\hline Indicador (millones de \$̦E.UU. corrientes) & 2005 & 2008 & 2010 & $\Delta: 05-10(\%$ \\
\hline Formación bruta de capital fijo & n.d. & n.d. & n.d. & n.d. \\
\hline del cual: público & n.d. & n.d. & n.d. & n.d. \\
\hline del cual: privado & n.d. & n.d. & n.d. & n.d. \\
\hline \multicolumn{5}{|l|}{ Entrada de financiación externa } \\
\hline Entradas de IED & 0,0 & 1,7 & 1,5 & $7600 \%$ \\
\hline $\begin{array}{l}\text { Deuda externa a largo plazo y fondos } \\
\text { desembolsados por el FMl }\end{array}$ & n.d. & n.d. & n.d. & n.d. \\
\hline $\begin{array}{l}\text { Corrientes comerciales en condiciones no } \\
\text { concesionarias }\end{array}$ & 0,0 & 0,0 & 0,0 & $0 \%$ \\
\hline Corrientes de Ayuda para el Comercio & 0,9 & 4,4 & 1,6 & $73 \%$ \\
\hline $\begin{array}{l}\text { Remesas de trabajadores y remuneración } \\
\text { de empleados }\end{array}$ & n.d. & n.d. & n.d. & n.d. \\
\hline
\end{tabular}

Fuentes: OCDE, base de datos del SNPA del CAD sobre las actividades de ayuda; Banco Mundial, Indicadores del Desarrollo Mundial; Banco Mundial, estadísticas de la deuda internacional.

Desembolsos de la ayuda para el comercio, por sector (millones de \$EE.UU. corrientes)

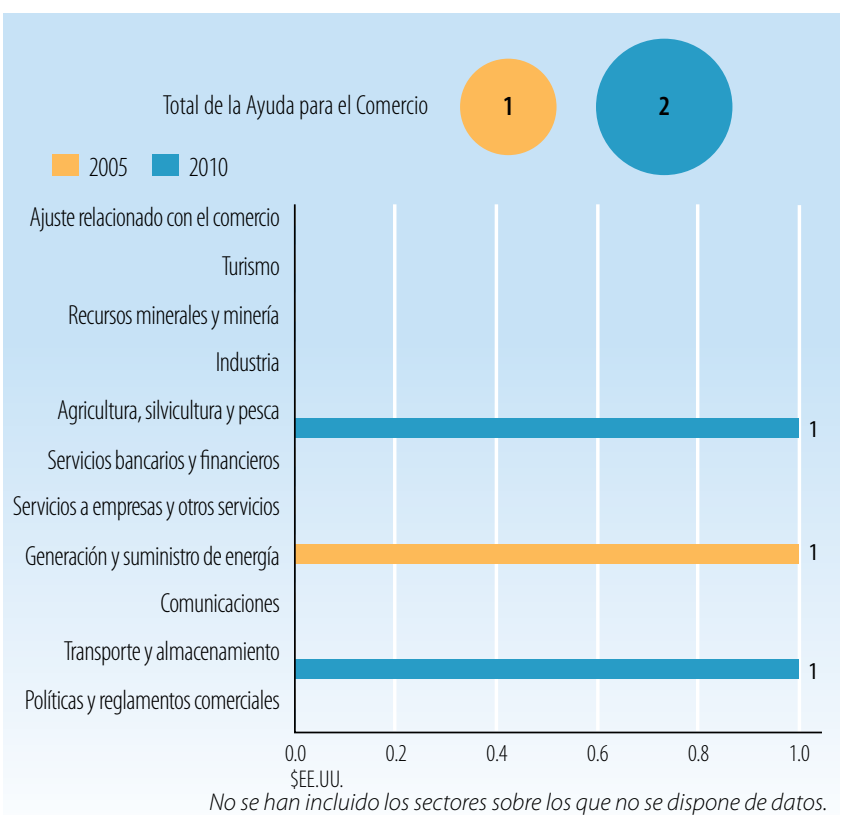

Fuentes: OCDE, base de datos del SNPA del CAD sobre las actividades de ayuda

Desembolsos de la ayuda para el comercio: principales donantes (millones de \$EE.UU. corrientes)

\begin{tabular}{|l|c|c|c|}
\hline $\mathbf{2 0 0 5}$ & Valor & $\%$ & Principales donantes en 2005 \\
\hline Japón & 0,9 & 93 & \\
\hline Australia & 0,1 & 7 & $100 \%$ \\
\hline & & & \\
\hline & & & \\
\hline $\mathbf{2 0 1 0}$ & & & Principales donantes en $\mathbf{2 0 1 0}$ \\
\hline Japón & Valor & $\%$ & $100 \%$ \\
\hline Nueva Zelandia & 0,7 & 45 & \\
\hline Australia & 0,5 & 29 & \\
\hline Corea, Rep. de & 0,3 & 20 & \\
\hline
\end{tabular}

Fuentes: OCDE, base de datos del SNPA del CAD sobre las actividades de ayuda.

\section{INDICADORES COMERCIALES (PRODUCTOS)}

\section{Indicador}

$20052008 \quad 2011 \quad \Delta: 05-11(\%)$

Relación comercio/PIB (\%)

\begin{tabular}{ll|l|l|}
61 & 71 & n.d. n.d.
\end{tabular}

Exportaciones de servicios comerciales como

$\%$ de las exportaciones totales

n.d. n.d. n.d. n.d.

mportaciones de servicios comerciales como

$\%$ de las importaciones totales

n.d. n.d. n.d. n.d.

Productos intermedios distintos de los combustibles

(\% de las exportaciones de mercancías)

Productos intermedios distintos de los combustibles

(\% de las importaciones de mercancías)

n.d. n.d. n.d. n.d.

n.d. n.d. n.d. n.d.

Fuentes: Secretaría de la OMC.

Corrientes comerciales (millones de \$EE.UU. corrientes)

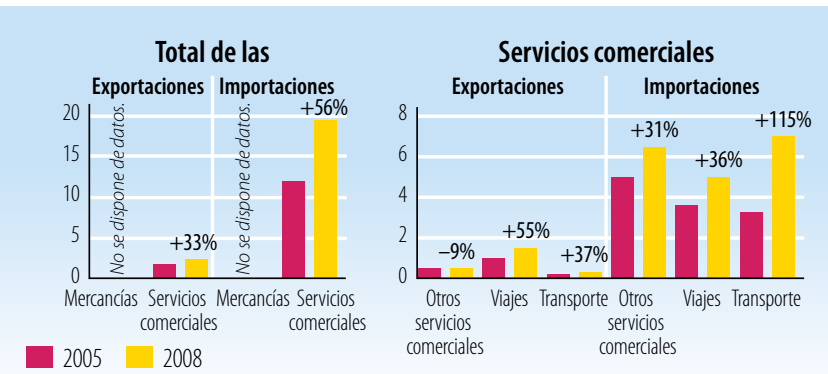

Fuentes: Secretaría de la OMC

Cinco principales mercados de exportación de mercancías (\%)

\begin{tabular}{|c|c|c|c|}
\hline 2005 & $\%$ & & $\%$ \\
\hline Fiji & 78 & & \\
\hline Nueva Zelandia & 18 & & \\
\hline Indonesia & 2 & No se dispone de datos. & \\
\hline Australia & 2 & & \\
\hline
\end{tabular}

Fuentes: Secretaría de la OMC

Cinco principales productos de exportación (\% de las exportaciones de mercancías) $\%$
No se dispone de datos.

Fuentes: Secretaría de la OMC

Cinco principales mercados de importación de mercancías (\%)

\begin{tabular}{|l|c|l|c|}
\hline 2005 & $\%$ & 2008 & $\%$ \\
\hline Australia & 34 & Fiji & 24 \\
\hline Fiji & 20 & Australia & 18 \\
\hline Singapur & 18 & Nueva Zelandia & 17 \\
\hline Nueva Zelandia & 10 & Japón & 16 \\
\hline China & 5 & Taipei Chino & 11
\end{tabular}

Fuentes: Secretaría de la OMC

Cinco principales productos de importación (\% de las importaciones de mercancías) $\%$ 


\section{LA AYUDA PARA EL COMERCIO EN SINNTESIS 2013}

\section{INDICADORES COMERCIALES (RESULTADOS)}

\section{Indicador}

Crecimiento del PIB (\%)

Número de exportadores

Índice de concentración de las exportaciones (productos) ( 0 a 1)

ACR sobre mercancías notificados a la OMC

AIE (servicios) notificados a la OMC

Sectores de servicios con compromisos en el marco del AGCS

\section{Aranceles (\%)}

$\begin{array}{lll}\text { Importaciones: promedio aritmético de los aranceles NMF aplicados } \quad \text { n.d. } & \text { 7,7 }\end{array}$

Importaciones: promedio ponderado de los aranceles NMF aplicados n.d. n.d.

Exportaciones: promedio ponderado de los aranceles impuestos $\quad$ n.d. $\quad 4,8$

por los importadores

n.d. $\quad 12,8$

Exportaciones: libres de derechos (en \%) sobre dinámica de las empresas de exportación; Banco Mundial, Indicadores del Desarrollo Mundial; OMC, perfiles comerciales y arancelarios.

Participación en las exportaciones por región (\%)

\begin{tabular}{|l|r|r|}
\hline África & 2005 & 2011 \\
\hline Asia & 0,0 & n.d. \\
\hline Comunidad de Estados Independientes & 100,0 & n.d. \\
\hline Europa & 0,0 & n.d. \\
\hline Oriente Medio & 0,0 & n.d. \\
\hline América del Norte & 0,0 & n.d. \\
\hline América del Sury América Central & 0,0 & n.d. \\
\hline
\end{tabular}

Fuentes: OMC, perfiles comerciales y arancelarios

Indicadores de facilitación del comercio

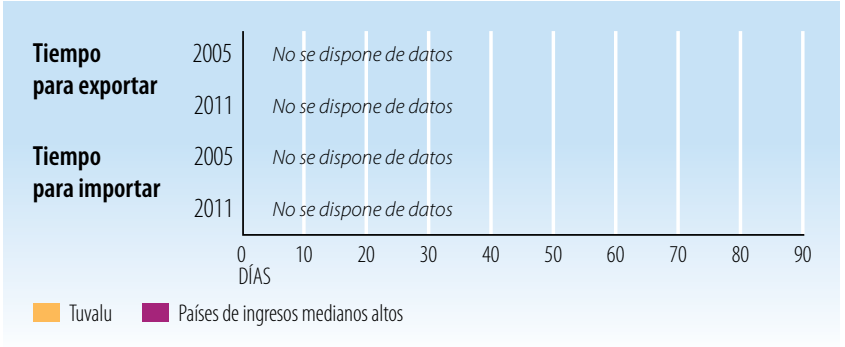

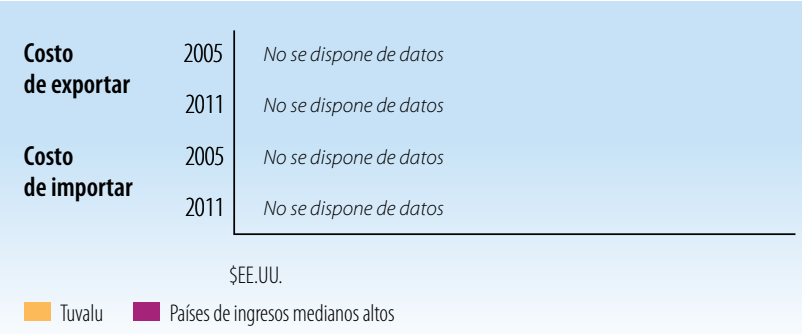

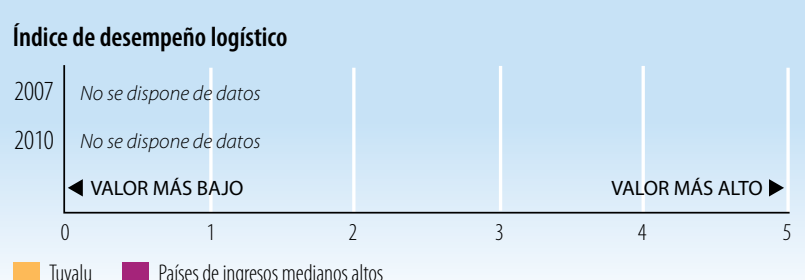

Tuvalu Países de ingresos medianos altos.

Fuentes: Banco Mundial, Indicadores del Desarrollo Mundial.

\begin{tabular}{l|c|c|}
\hline INDICADORES DE DESARROLLO (EFECTOS) & \\
\hline Indicador & $\mathbf{2 0 0 5}$ & $\mathbf{2 0 1 0}$ \\
\hline Desempleo (\% de la fuerza de trabajo total) & 6,5 & n.d. \\
\hline Población activa, mujeres (\% de la fuerza de trabajo total) & n.d. & n.d. \\
\hline AOD neta recibida (\% del INB) & 24,4 & 26,2 \\
\hline Derechos de importación percibidos (\% de los ingresos fiscales) & n.d. & n.d. \\
\hline Total del servicio de la deuda (\% de las exportaciones totales) & n.d. & n.d. \\
\hline Índice de desarrollo humano ( 0 a 1) & n.d. & n.d. \\
\hline
\end{tabular}

Fuentes: PNUD, indicadores internacionales sobre desarrollo humano; Banco Mundial, Indicadores del Desarrollo Mundial.

Producto interno bruto

PIB per cápita (PPA, dólares internacionales corrientes)

Variación porcentual entre 2005 y $2011 \quad$ No se dispone de datos

$2011 \mid \begin{aligned} & \text { No se dispone de datos } \\ & \text { No se dispone de datos } \\ & \text { No se dispone de datos } \\ & \text { No se dispone de datos }\end{aligned}$

PIB per cápita (\$EE.UU. constantes de 2000)
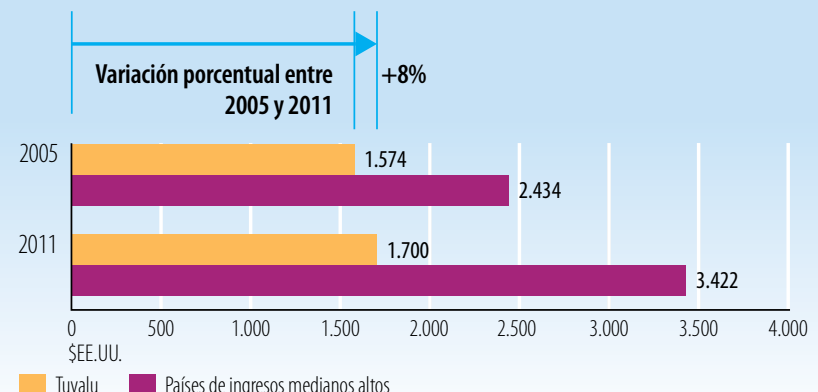

Tuvalu Países de ingresos medianos altos

Fuentes: Banco Mundial, Indicadores del Desarrollo Mundial.

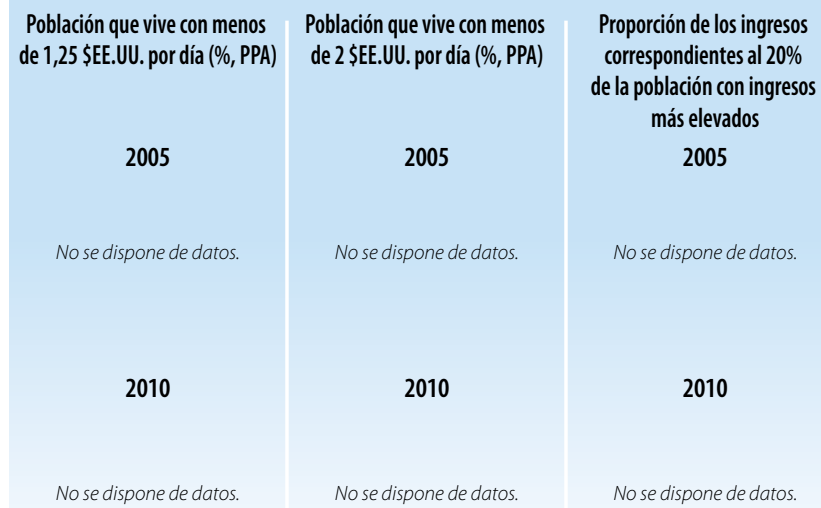

Fuentes: Banco Mundial, Indicadores del Desarrollo Mundial.

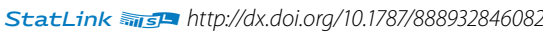




\section{Indicadores de la ayuda, el comercio y el desarrollo relativos a Turquía}

\begin{tabular}{|c|c|c|c|c|}
\hline Indicador (millones de \$EE.UU. corrientes) & 2005 & 2008 & 2010 & $\Delta: 05-10(\%)$ \\
\hline Formación bruta de capital fijo & $101.574,2$ & $145.289,5$ & $137.658,3$ & $36 \%$ \\
\hline del cual: público & $15.935,1$ & $28.217,5$ & $28.318,3$ & $78 \%$ \\
\hline del cual: privado & $85.639,2$ & $117.072,0$ & $109.340,0$ & $28 \%$ \\
\hline \multicolumn{5}{|l|}{ Entrada de financiación externa } \\
\hline Entradas de IED & $10.031,0$ & $19.504,0$ & $9.038,0$ & $-10 \%$ \\
\hline $\begin{array}{l}\text { Deuda externa a largo plazo y fondos } \\
\text { desembolsados por el FMI }\end{array}$ & $40.595,2$ & $68.553,0$ & $46.498,6$ & $15 \%$ \\
\hline $\begin{array}{l}\text { Corrientes comerciales en condiciones no } \\
\text { concesionarias }\end{array}$ & 314,6 & 782,1 & $1.983,7$ & $531 \%$ \\
\hline Corrientes de Ayuda para el Comercio & 132,4 & 611,0 & 720,6 & $444 \%$ \\
\hline $\begin{array}{l}\text { Remesas de trabajadores y remuneración } \\
\text { de empleados }\end{array}$ & 887,0 & $1.476,0$ & 874,0 & $-1 \%$ \\
\hline
\end{tabular}

Fuentes: OCDE, base de datos del SNPA del CAD sobre las actividades de ayuda; Banco Mundial, Indicadores del Desarrollo Mundial; Banco Mundial, estadísticas de la deuda internacional.

Desembolsos de la ayuda para el comercio, por sector (millones de \$EE.UU. corrientes)

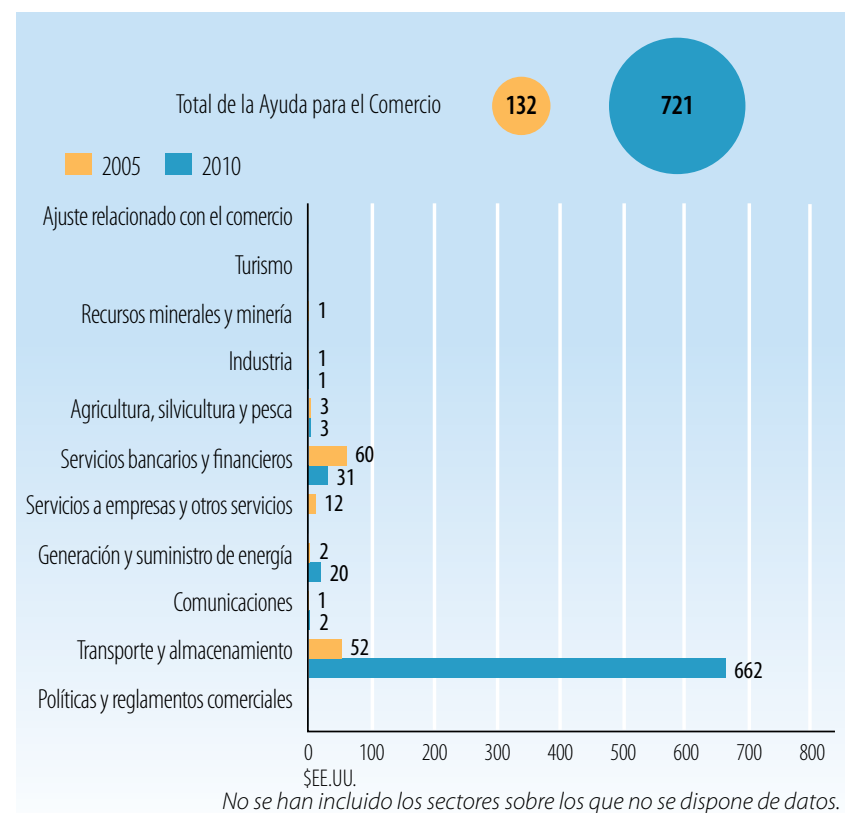

Fuentes: OCDE, base de datos del SNPA del CAD sobre las actividades de ayuda

Desembolsos de la ayuda para el comercio: principales donantes (millones de \$̦E.UU. corrientes)

\begin{tabular}{|l|c|c|c|}
\hline $\mathbf{2 0 0 5}$ & Valor & $\%$ & Principales donantes en $\mathbf{2 0 0 5}$ \\
\hline Francia & 44,2 & 33 & \\
\hline Japón & 37,8 & 29 & \\
\hline Alemania & 20,2 & 15 & $96 \%$ \\
\hline Instituciones de la UE & 12,6 & 10 & \\
\hline España & 11,8 & 9 & \\
\hline $\mathbf{2 0 1 0}$ & Valor & $\%$ & Principales donantes en $\mathbf{2 0 1 0}$ \\
\hline Japón & 588,7 & 82 & \\
\hline España & 51,5 & 7 & \\
\hline Francia & 26,5 & 4 & \\
\hline Alemania & 23,5 & 3 & \\
\hline Instituciones de la UE & 16,0 & 2 & \\
\hline Fuentes: OCDE, base de datos del SNPA del CAD sobre las actividades de ayuda. \\
\hline
\end{tabular}

\section{INDICADORES COMERCIALES (PRODUCTOS)}

\section{Indicador}

$2005 \quad 2008 \quad 2011 \quad \Delta: 05-11(\%)$

Relación comercio/PIB (\%)

Exportaciones de servicios comerciales como

$\%$ de las exportaciones totales

Importaciones de servicios comerciales como

$\%$ de las importaciones totales

Productos intermedios distintos de los combustibles

(\% de las exportaciones de mercancías)

Productos intermedios distintos de los combustibles

(\% de las importaciones de mercancías)

\begin{tabular}{l|l|r|r|}
\hline 47 & 53 & 56 & 9 \\
\hline
\end{tabular}

Fuentes: Secretaría de la OMC.

Corrientes comerciales (millones de \$EE.UU. corrientes)

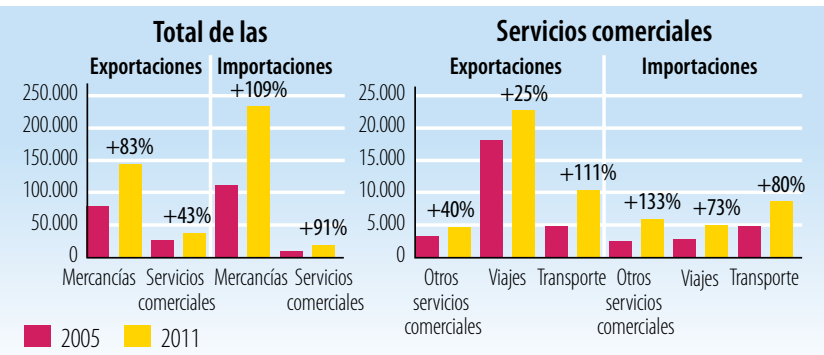

Fuentes: Secretaría de la OMC

Cinco principales mercados de exportación de mercancías (\%)

\begin{tabular}{|l|r|l|r|}
\hline 2005 & $\%$ & 2010 & $\%$ \\
\hline UE (27) & 57 & UE (27) & 47 \\
\hline Estados Unidos & 7 & Iraq & 5 \\
\hline Iraq & 4 & Federación de Rusia & 4 \\
\hline Federación de Rusia & 3 & Estados Unidos & 3 \\
\hline Emiratos Árabes Unidos & 2 & Emiratos Árabes Unidos & 3 \\
\hline
\end{tabular}

Fuentes: Secretaría de la OMC

Cinco principales productos de exportación (\% de las exportaciones de mercancías)

\begin{tabular}{|l|c|l|c|}
\hline $\mathbf{2 0 0 5}$ & $\%$ & $\mathbf{2 0 1 1}$ & $\%$ \\
\hline $\begin{array}{l}\text { Otros artículos textiles y prendas de } \\
\text { vestir, n.e.p. }\end{array}$ & 6 & Barras, perfiles, etc., de hierro y acero & 5 \\
\hline $\begin{array}{l}\text { Vehículos automotores para pasajeros, } \\
\text { excepto autobuses }\end{array}$ & 6 & $\begin{array}{l}\text { Vehículos automotores para pasajeros, } \\
\text { excepto autobuses }\end{array}$ & 5 \\
\hline $\begin{array}{l}\text { Barras, perfiles, etc., de hierro y acero } \\
\text { Receptores de televisión, etc. }\end{array}$ & 4 & $\begin{array}{l}\text { Productos derivados del petróleo } \\
\text { Otros artículos textiles y prendas de }\end{array}$ & 4 \\
\hline $\begin{array}{l}\text { Prendas de vestir para mujeresy niñas, } \\
\text { excepto las de punto }\end{array}$ & 4 & $\begin{array}{l}\text { vestir, n.e.p. } \\
\text { de mercancías y vehículos automotores } \\
\text { para usos especiales }\end{array}$ & 3 \\
\hline
\end{tabular}

Fuentes: Secretaría de la OMC

Cinco principales mercados de importación de mercancías (\%)

\begin{tabular}{|l|r|l|r|}
\hline 2005 & $\%$ & 2010 & $\%$ \\
\hline UE $(27)$ & 45 & UE (27) & 39 \\
\hline Federación de Rusia & 11 & Federación de Rusia & 12 \\
\hline China & 6 & China & 9 \\
\hline Estados Unidos & 5 & Estados Unidos & 7 \\
\hline Suiza & 3 & Irán & 4
\end{tabular}

Fuentes: Secretaría de la OMC

Cinco principales productos de importación (\% de las importaciones de mercancías)

\begin{tabular}{|c|c|c|c|}
\hline 2005 & $\%$ & 2011 & $\%$ \\
\hline Aceites de petróleo, crudos & 7 & Operaciones especiales no clasificadas & 15 \\
\hline Operaciones especiales no clasificadas & 5 & Productos derivados del petróleo & 6 \\
\hline $\begin{array}{l}\text { Vehículos automotores para pasajeros, } \\
\text { excepto autobuses }\end{array}$ & 4 & $\begin{array}{l}\text { Desperdicios y desechos ferrosos } \\
\text { (chatarra) }\end{array}$ & 4 \\
\hline Oro no monetario, excepto minerales & 3 & $\begin{array}{l}\text { Vehículos automotores para pasajeros, } \\
\text { excepto autobuses }\end{array}$ & 4 \\
\hline Productos derivados del petróleo & 3 & Oro no monetario, excepto minerales & 3 \\
\hline
\end{tabular}




\section{LA AYUDA PARA EL COMERCIO EN SÍNTESIS 2013}

\section{INDICADORES COMERCIALES (RESULTADOS)}

\section{Indicador}

Crecimiento del PIB (\%)

Número de exportadores

Índice de concentración de las exportaciones (productos) (0 a 1$)$

ACR sobre mercancías notificados a la OMC

AIE (servicios) notificados a la OMC

Sectores de servicios con compromisos en el marco del AGCS

\section{Aranceles (\%, 2006 et 2011)}

Importaciones: promedio aritmético de los aranceles NMF aplicados

Importaciones: promedio ponderado de los aranceles NMF aplicados

Exportaciones: promedio ponderado de los aranceles impuestos

por los importadores

Exportaciones: libres de derechos (en \%)

\begin{tabular}{|r|r|}
\hline 2005 & 2011 \\
\hline 8,4 & 8,5 \\
\hline 40.089 & 48.010 \\
\hline 0,01 & 0,01 \\
\hline n.d. & 19 \\
\hline n.d. & 0 \\
\hline 77 & 77 \\
\hline
\end{tabular}

Fuentes: Naciones Unidas, base de datos Comtrade; Banco Mundial, base de datos sobre dinámica de las empresas de exportación; Banco Mundial, Indicadores del

Desarrollo Mundial; OMC, perfiles comerciales y arancelarios.

Participación en las exportaciones por región (\%)

\begin{tabular}{|l|r|r|}
\hline & $\mathbf{2 0 0 5}$ & $\mathbf{2 0 1 1}$ \\
\hline África & 4,9 & 7,7 \\
\hline Asia & 3,4 & 5,7 \\
\hline Comunidad de Estados Independientes & 6,9 & 10,7 \\
\hline Europa & 59,7 & 49,8 \\
\hline Oriente Medio & 12,8 & 18,3 \\
\hline América del Norte & 7,4 & 4,2 \\
\hline América del Sury América Central & 0,7 & 1,7 \\
\hline
\end{tabular}

Fuentes: OMC, perfiles comerciales y arancelarios

Indicadores de facilitación del comercio
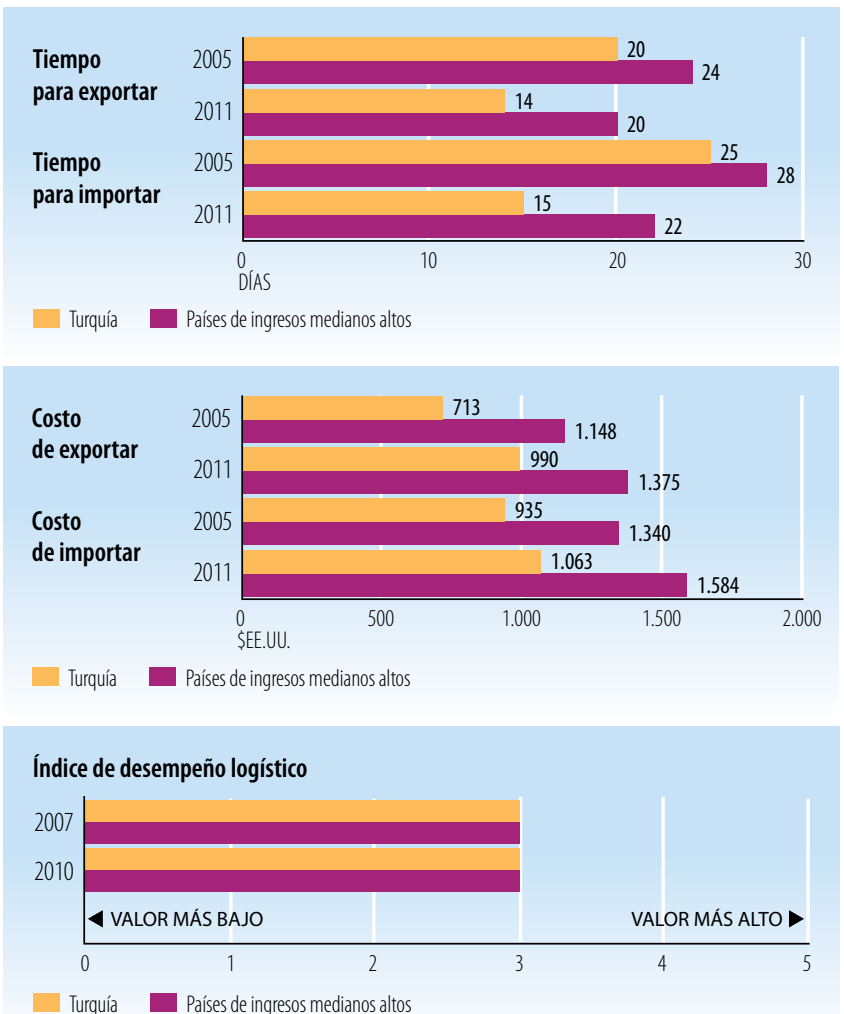

Fuentes: Banco Mundial, Indicadores del Desarrollo Mundial.

\begin{tabular}{|l|c|c|}
\hline INDICADORES DE DESARROLLO (EFECTOS) & \\
\hline Indicador & $\mathbf{2 0 0 5}$ & $\mathbf{2 0 1 0}$ \\
\hline Desempleo (\% de la fuerza de trabajo total) & 10,6 & 11,9 \\
\hline Población activa, mujeres (\% de la fuerza de trabajo total) & 25,4 & 28,7 \\
\hline AOD neta recibida (\% del INB) & 0,1 & 0,1 \\
\hline Derechos de importación percibidos (\% de los ingresos fiscales) & n.d. & 1,4 \\
\hline Total del servicio de la deuda (\% de las exportaciones totales) & 36,6 & 36,7 \\
\hline Índice de desarrollo humano (0 a 1) & 0,67 & 0,70 \\
\hline
\end{tabular}

Fuentes: PNUD, indicadores internacionales sobre desarrollo humano; Banco Mundial, Indicadores del Desarrollo Mundial.

Producto interno bruto

PIB per cápita (PPA, dólares internacionales corrientes)

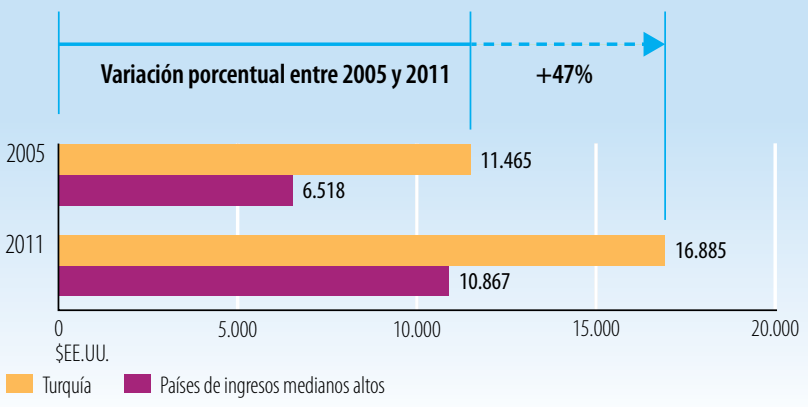

PIB per cápita (\$EE.UU. constantes de 2000)

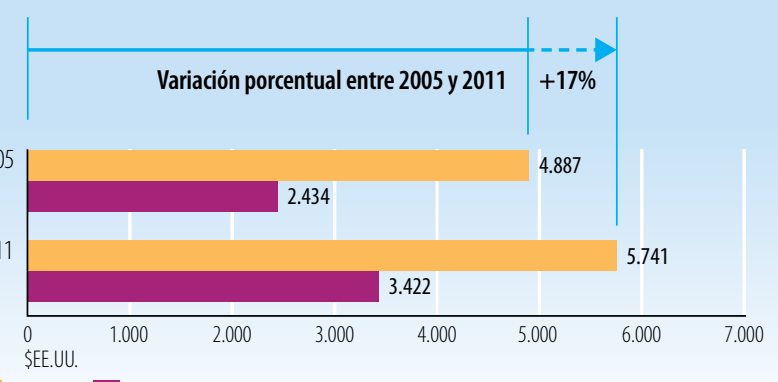

- Turquía Países de ingresos medianos altos

Fuentes: Banco Mundial, Indicadores del Desarrollo Mundial.

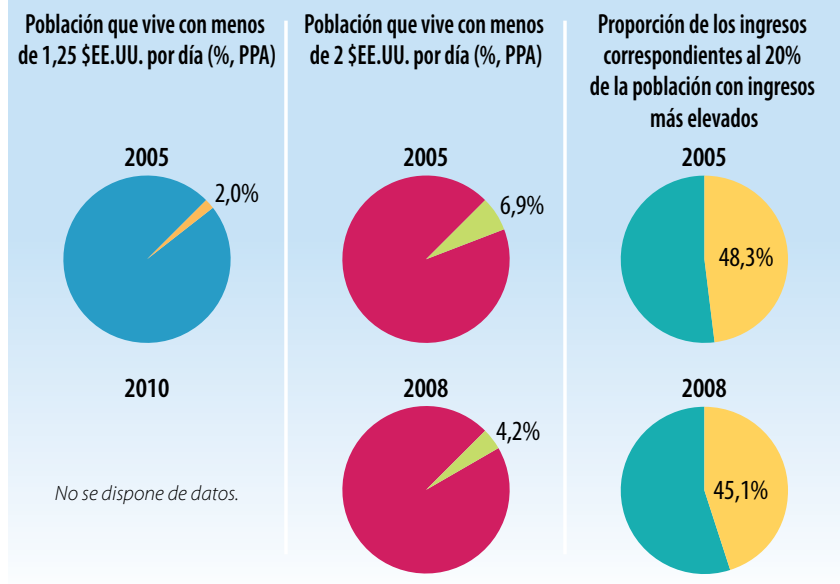

Fuentes: Banco Mundial, Indicadores del Desarrollo Mundial.

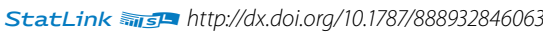


Indicadores de la ayuda, el comercio y el desarrollo relativos a Uganda

\begin{tabular}{|c|c|c|c|c|}
\hline Indicador (millones de \$EE.UU. corrientes) & 2005 & 2008 & 2010 & $\Delta: 05-10(\%)$ \\
\hline Formación bruta de capital fijo & $2.050,8$ & $3.284,9$ & $3.999,3$ & $95 \%$ \\
\hline del cual: público & 459,2 & 642,2 & 963,4 & $110 \%$ \\
\hline del cual: privado & $1.591,7$ & $2.642,7$ & $3 ; 035,9$ & $91 \%$ \\
\hline \multicolumn{5}{|l|}{ Entrada de financiación externa } \\
\hline Entradas de IED & 379,8 & 728,9 & 543,9 & $43 \%$ \\
\hline $\begin{array}{l}\text { Deuda externa a largo plazo y fondos } \\
\text { desembolsados por el FMI }\end{array}$ & 229,8 & 275,4 & 486,1 & $112 \%$ \\
\hline $\begin{array}{l}\text { Corrientes comerciales en condiciones no } \\
\text { concesionarias }\end{array}$ & 9,0 & 49,6 & 36,1 & $301 \%$ \\
\hline Corrientes de Ayuda para el Comercio & 183,9 & 440,2 & 423,0 & $130 \%$ \\
\hline $\begin{array}{l}\text { Remesas de trabajadores y remuneración } \\
\text { de empleados }\end{array}$ & 321,8 & 723,5 & 914,5 & $184 \%$ \\
\hline
\end{tabular}

Fuentes: OCDE, base de datos del SNPA del CAD sobre las actividades de ayuda; Banco Mundial, Indicadores del Desarrollo Mundial; Banco Mundial, estadísticas de la deuda internacional.

Desembolsos de la ayuda para el comercio, por sector (millones de \$EE.UU. corrientes)

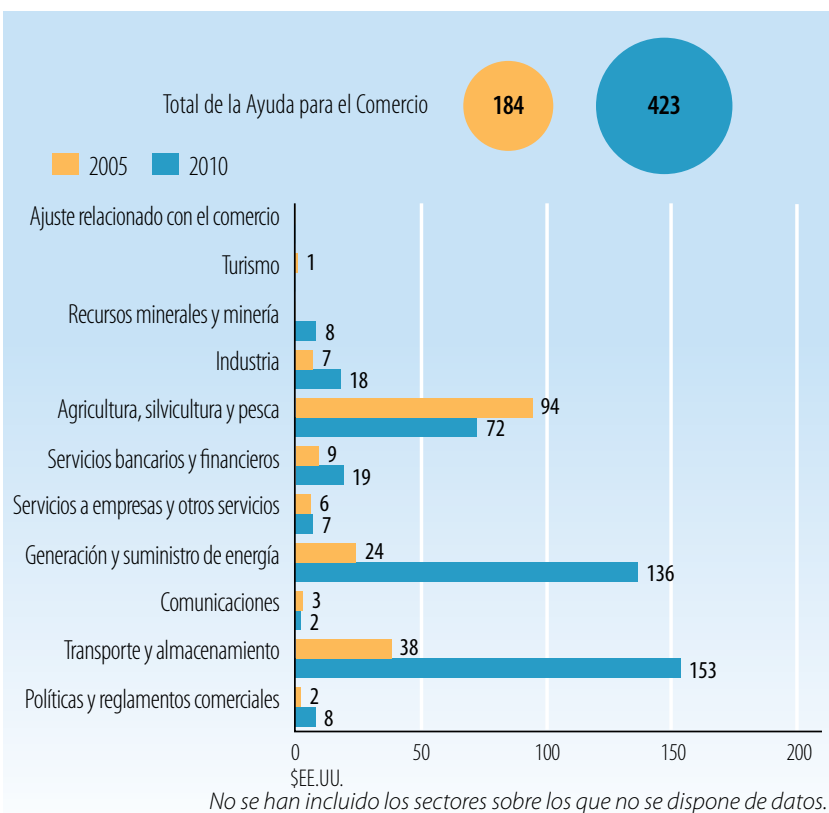

Fuentes: OCDE, base de datos del SNPA del CAD sobre las actividades de ayuda

Desembolsos de la ayuda para el comercio: principales donantes (millones de \$EE.UU. corrientes)

\begin{tabular}{|l|c|c|c|}
\hline $\mathbf{2 0 0 5}$ & Valor & $\%$ & Principales donantes en 2005 \\
\hline Banco Mundial & 98,0 & 53 & \\
\hline Estados Unidos & 18,8 & 10 & \\
\hline Instituciones de la UE & 15,1 & 8 & $83 \%$ \\
\hline Banco Africano de Desarrollo & 10,6 & 6 & \\
\hline Dinamarca & 9,4 & 5 & \\
\hline $\mathbf{2 0 1 0}$ & Valor & $\%$ & Principales donantes en 2010 \\
\hline Banco Mundial & 150,4 & 36 & \\
\hline Banco Africano de Desarrollo & 75,6 & 18 & \\
\hline Instituciones de la UE & 56,5 & 13 & $82 \%$ \\
\hline Japón & 37,4 & 9 & \\
\hline Noruega & 24,9 & 6 & \\
\hline
\end{tabular}

Fuentes: OCDE, base de datos del SNPA del CAD sobre las actividades de ayuda.

\section{INDICADORES COMERCIALES (PRODUCTOS)}

\section{Indicador}

$2005 \quad 2008 \quad 2011 \quad \Delta: 05-11(\%)$

Relación comercio/PIB (\%)

Exportaciones de servicios comerciales como

$\%$ de las exportaciones totales

Importaciones de servicios comerciales como

$\%$ de las importaciones totales

Productos intermedios distintos de los combustibles

(\% de las exportaciones de mercancías)

Productos intermedios distintos de los combustibles

(\% de las importaciones de mercancías)

\begin{tabular}{|r|r|r|r|}
\hline 42 & 57 & 68 & 26 \\
\hline 32 & 24 & 34 & 2 \\
\hline 25 & 23 & 30 & 5 \\
\hline 60 & 63 & n.d. & n.d. \\
\hline 45 & 43 & n.d. & n.d. \\
\hline
\end{tabular}

Fuentes: Secretaría de la OMC.

Corrientes comerciales (millones de \$EE.UU. corrientes)

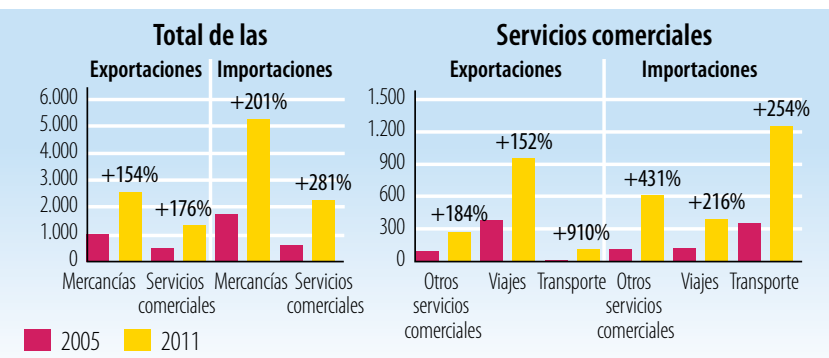

Fuentes: Secretaría de la OMC

Cinco principales mercados de exportación de mercancías (\%)

\begin{tabular}{|l|r|l|c|}
\hline 2005 & $\%$ & 2010 & $\%$ \\
\hline UE $(27)$ & 32 & UE $(27)$ & 23 \\
\hline Emiratos Árabes Unidos & 10 & Sudán & 13 \\
\hline Suiza & 9 & Kenya & 12 \\
\hline Kenya & 9 & Congo, Rep. Dem. del & 11 \\
\hline Congo, Rep. Dem. del & 7 & Rwanda & 9 \\
\hline
\end{tabular}

Fuentes: Secretaría de la OMC

Cinco principales productos de exportación (\% de las exportaciones de mercancías)

\begin{tabular}{|c|c|c|c|}
\hline 2005 & $\%$ & 2010 & $\%$ \\
\hline Café y sucedáneos del café & 21 & Café y sucedáneos del café & 18 \\
\hline Pescado, fresco, refrigerado o congelado & 17 & Pescado, fresco, refrigerado o congelado & 7 \\
\hline Oro no monetario, excepto minerales & 9 & $\begin{array}{l}\text { Equipos de telecomunicaciones y sus } \\
\text { partes, n.e.p. }\end{array}$ & 5 \\
\hline Algodón & 4 & Productos derivados del petróleo & 5 \\
\hline Productos vegetales en bruto, n.e.p. & 4 & $\begin{array}{l}\text { Cal, cemento y materiales de } \\
\text { construcción }\end{array}$ & 4 \\
\hline
\end{tabular}

Fuentes:Secretaría de la OMC

Cinco principales mercados de importación de mercancías (\%)

\begin{tabular}{|l|r|l|r|}
\hline $\mathbf{2 0 0 5}$ & $\%$ & $\mathbf{2 0 1 0}$ & $\%$ \\
\hline Kenya & 25 & UE $(27)$ & 16 \\
\hline UE (27) & 19 & India & 15 \\
\hline Japón & 7 & Kenya & 11 \\
\hline Sudáfrica & 7 & China & 9 \\
\hline Emiratos Árabes Unidos & 7 & Emiratos Árabes Unidos & 8 \\
\hline Fuentes:Secretaría de la OMC & & &
\end{tabular}

Cinco principales productos de importación (\% de las importaciones de mercancías)

\begin{tabular}{|c|c|c|c|}
\hline 2005 & $\%$ & 2010 & $\%$ \\
\hline Productos derivados del petróleo & 16 & Productos derivados del petróleo & 19 \\
\hline Trigo y morcajo o tranquillón, sin moler & 4 & $\begin{array}{l}\text { Equipos de telecomunicaciones y sus } \\
\text { partes, n.e.p. }\end{array}$ & 4 \\
\hline $\begin{array}{l}\text { Vehículos automotores para pasajeros, } \\
\text { excepto autobuses }\end{array}$ & 4 & $\begin{array}{l}\text { Vehículos automotores para pasajeros, } \\
\text { excepto autobuses }\end{array}$ & \\
\hline $\begin{array}{l}\text { Equipos de telecomunicaciones y sus } \\
\text { partes, n.e.p. }\end{array}$ & 4 & $\begin{array}{l}\text { Otros aceites y grasas fijos de origen } \\
\text { vegetal }\end{array}$ & \\
\hline Medicamentos & 3 & Medicamentos & \\
\hline
\end{tabular}

Fuentes: Secretaría de la OMC 


\section{LA AYUDA PARA EL COMERCIO EN SIINTESIS 2013}

\section{INDICADORES COMERCIALES (RESULTADOS)}

\section{Indicador}

Crecimiento del PIB (\%)

Número de exportadores

Índice de concentración de las exportaciones (productos) (0 a 1)

ACR sobre mercancías notificados a la OMC

AIE (servicios) notificados a la OMC

Sectores de servicios con compromisos en el marco del AGCS

\section{Aranceles (\%, 2006 et 2011)}

\begin{tabular}{|l|l|l|l|} 
Importaciones: promedio aritmético de los aranceles NMF aplicados & 12,7 & 12,5
\end{tabular}

\begin{tabular}{ll|l|l|} 
Importaciones: promedio ponderado de los aranceles NMF aplicados & 11,6 & 10,6
\end{tabular}

Exportaciones: promedio ponderado de los aranceles impuestos

por los importadores

Exportaciones: libres de derechos (en \%)

$1,1 \quad 0,2$

$96,8 \quad 97,0$

Fuentes: Naciones Unidas, base de datos Comtrade; Banco Mundial, base de datos sobre dinámica de las empresas de exportación; Banco Mundial, Indicadores del

Desarrollo Mundial; OMC, perfiles comerciales y arancelarios.

Participación en las exportaciones por región (\%)

\begin{tabular}{|l|r|r|}
\hline África & $\mathbf{2 0 0 5}$ & $\mathbf{2 0 1 1}$ \\
\hline Asia & 35,5 & 49,4 \\
\hline Comunidad de Estados Independientes & 7,5 & 8,2 \\
\hline Europa & 0,2 & 0,5 \\
\hline Oriente Medio & 41,2 & 27,7 \\
\hline América del Norte & 10,8 & 7,4 \\
\hline América del Sury América Central & 2,3 & 1,8 \\
\hline
\end{tabular}

Fuentes: OMC, perfiles comerciales y arancelarios

Indicadores de facilitación del comercio
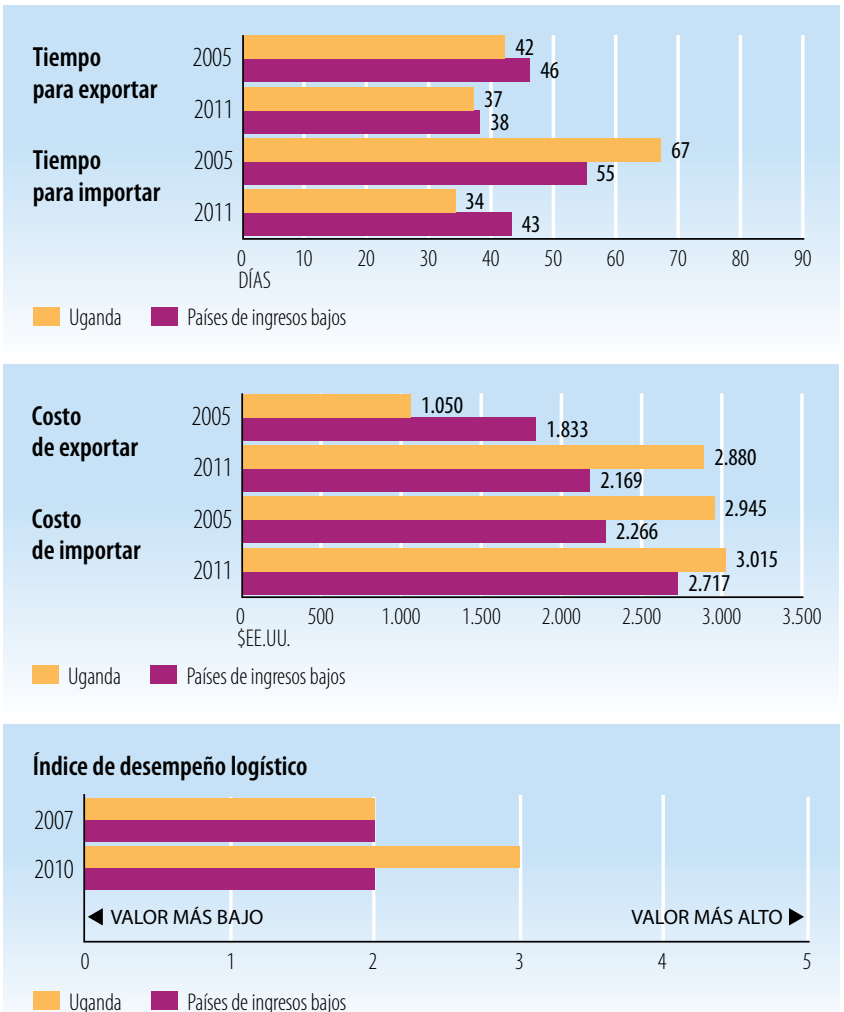

Fuentes: Banco Mundial, Indicadores del Desarrollo Mundial.

\begin{tabular}{|l|c|c|}
\hline INDICADORES DE DESARROLLO (EFECTOS) & \\
\hline Indicador & $\mathbf{2 0 0 5}$ & $\mathbf{2 0 1 0}$ \\
\hline Desempleo (\% de la fuerza de trabajo total) & 2,0 & 4,2 \\
\hline Población activa, mujeres (\% de la fuerza de trabajo total) & 49,5 & 49,3 \\
\hline AOD neta recibida (\% del INB) & 13,3 & 10,2 \\
\hline Derechos de importación percibidos (\% de los ingresos fiscales) & 11,7 & 10,0 \\
\hline Total del servicio de la deuda (\% de las exportaciones totales) & 10,7 & 1,8 \\
\hline Índice de desarrollo humano (0 a 1) & 0,40 & 0,44 \\
\hline
\end{tabular}

Fuentes: PNUD, indicadores internacionales sobre desarrollo humano; Banco Mundial, Indicadores del Desarrollo Mundial.

Producto interno bruto

PIB per cápita (PPA, dólares internacionales corrientes)
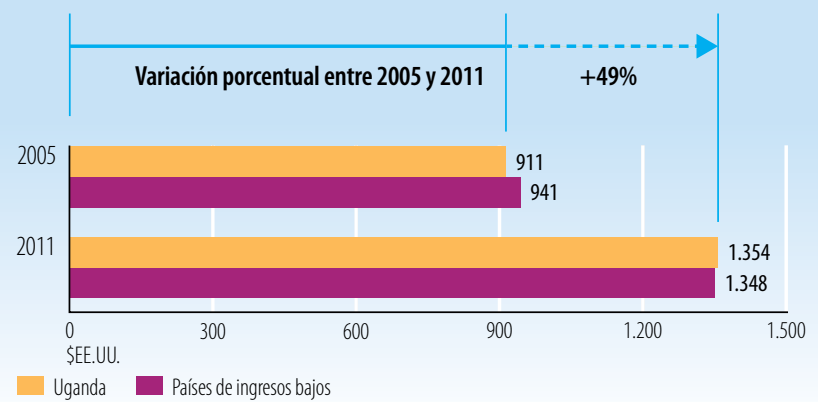

PIB per cápita (\$EE.UU. constantes de 2000)
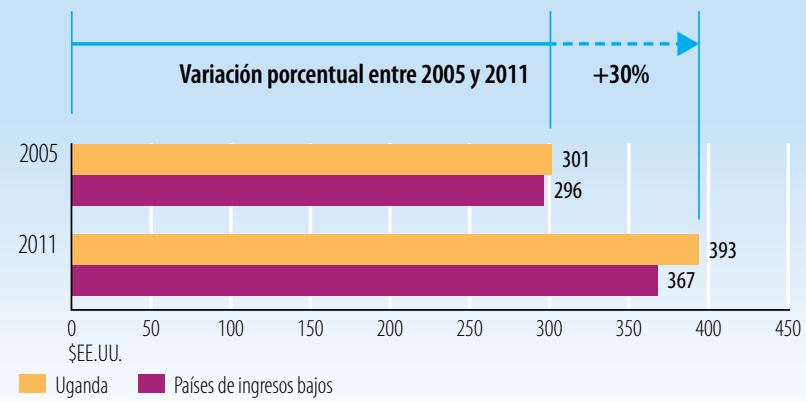

Uganda Países de ingresos bajos

Fuentes: Banco Mundial, Indicadores del Desarrollo Mundial.

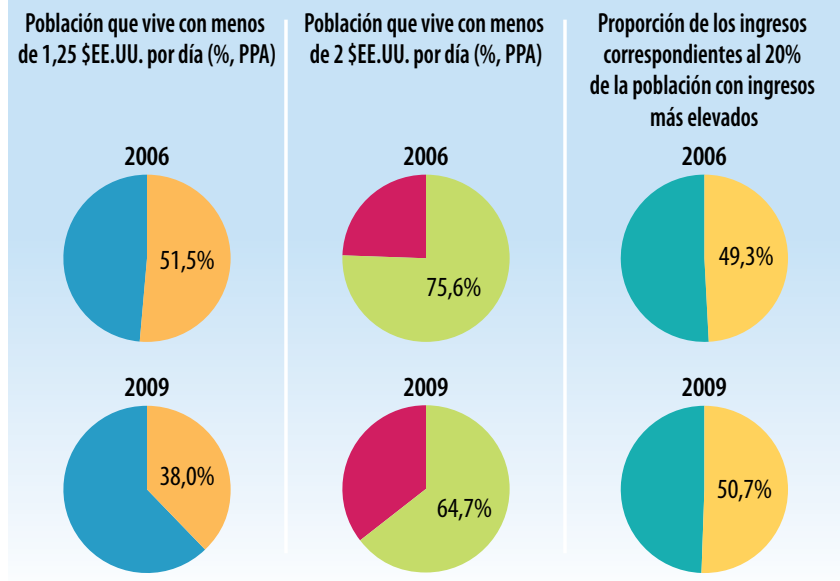

Fuentes: Banco Mundial, Indicadores del Desarrollo Mundial.

StatLink 新 1 L $h$ ttp://dx.doi.org/10.1787/88893284610 
Indicadores de la ayuda, el comercio y el desarrollo relativos al Uruguay

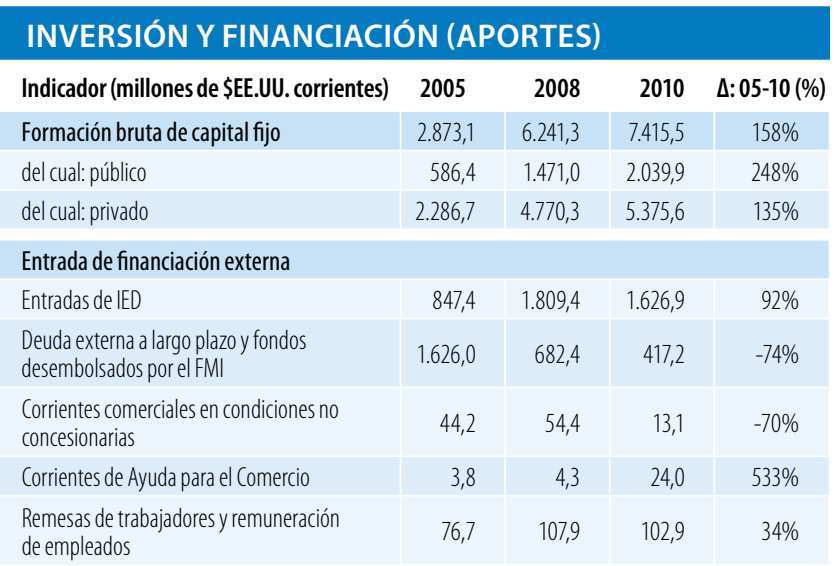

Fuentes: OCDE, base de datos del SNPA del CAD sobre las actividades de ayuda; Banco Mundial, Indicadores del Desarrollo Mundial; Banco Mundial, estadísticas de la deuda internacional.

Desembolsos de la ayuda para el comercio, por sector (millones de \$EE.UU. corrientes)

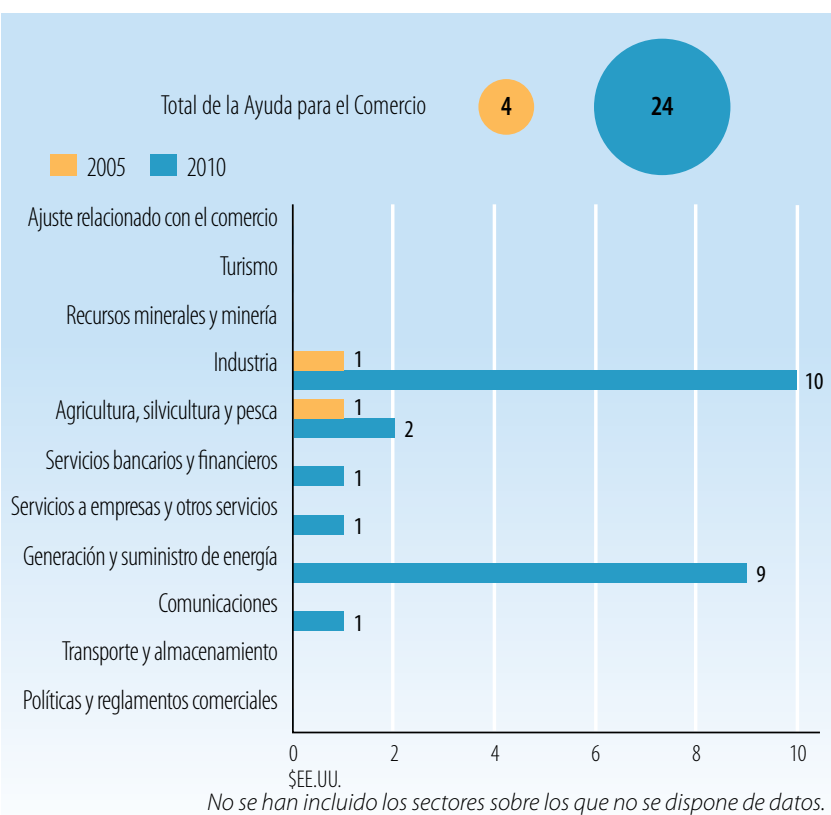

Fuentes: OCDE, base de datos del SNPA del CAD sobre las actividades de ayuda

Desembolsos de la ayuda para el comercio: principales donantes (millones de \$̦E.UU. corrientes)

\begin{tabular}{|l|c|c|c|}
\hline $\mathbf{2 0 0 5}$ & Valor & $\%$ & Principales donantes en $\mathbf{2 0 0 5}$ \\
\hline Instituciones de la UE & 1,4 & 37 & \\
\hline Japón & 1,2 & 33 & \\
\hline España & 0,5 & 12 & $96 \%$ \\
\hline Estados Unidos & 0,4 & 12 & \\
\hline Canadá & 0,1 & 3 & \\
\hline $\mathbf{2 0 1 0}$ & Valor & $\%$ & Principales donantes en $\mathbf{2 0 1 0}$ \\
\hline Japón & 10,2 & 42 & \\
\hline Italia & 7,2 & 30 & \\
\hline BID & 2,3 & 9 & \\
\hline España & 2,3 & 9 & $95 \%$ \\
\hline Instituciones de la UE & 1,0 & 4 & \\
\hline
\end{tabular}

Fuentes: OCDE, base de datos del SNPA del CAD sobre las actividades de ayuda.

\section{INDICADORES COMERCIALES (PRODUCTOS)}

\section{Indicador}

$200520082011 \quad \Delta: 05-11(\%)$

Relación comercio/PIB (\%)

Exportaciones de servicios comerciales como

$\%$ de las exportaciones totales

Importaciones de servicios comerciales como

$\%$ de las importaciones totales

Productos intermedios distintos de los combustibles

(\% de las exportaciones de mercancías)

Productos intermedios distintos de los combustibles

(\% de las importaciones de mercancías)

\begin{tabular}{|l|l|l|l|}
56 & 65 & 54 & -2 \\
\hline
\end{tabular}

\begin{tabular}{|l|l|l|l|}
\hline 25 & 24 & 27 & 1
\end{tabular}

\begin{tabular}{|l|l|l|l|}
\hline 19 & 14 & 15 & -4 \\
\hline
\end{tabular}

\begin{tabular}{|l|l|l|l|}
\hline 46 & 49 & n.d. & n.d.
\end{tabular}

\begin{tabular}{l|l|l|l|}
\hline 42 & 34 & n.d.
\end{tabular}

Fuentes: Secretaría de la OMC

Corrientes comerciales (millones de \$EE.UU. corrientes)

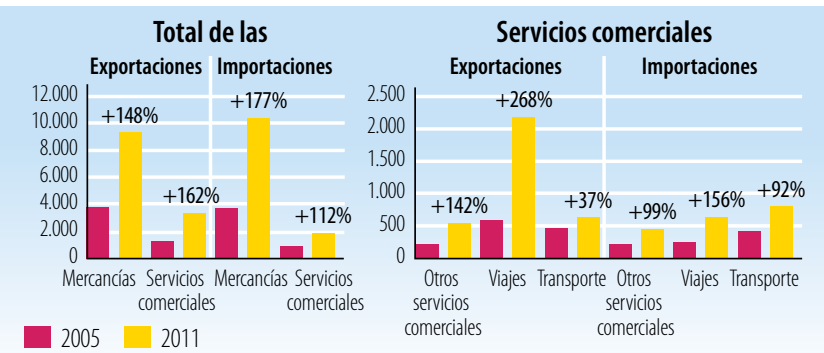

Fuentes: Secretaría de la OMC

Cinco principales mercados de exportación de mercancías (\%)

\begin{tabular}{|l|r|l|c|}
\hline 2005 & $\%$ & 2009 & $\%$ \\
\hline Estados Unidos & 23 & Brasil & 20 \\
\hline UE(27) & 18 & UE (27) & 15 \\
\hline Brasil & 13 & Argentina & 6 \\
\hline Argentina & 8 & China & 4 \\
\hline México & 4 & Federación de Rusia & 4 \\
\hline
\end{tabular}

Fuentes: Secretaría de la OMC

Cinco principales productos de exportación (\% de las exportaciones de mercancías)

\begin{tabular}{|l|r|l|c|}
\hline 2005 & $\%$ & 2009 & $\%$ \\
\hline Carne de ganado bovino & 22 & Carne de ganado bovino & 18 \\
\hline Cuero & 7 & Arroz & 9 \\
\hline Arroz & 6 & $\begin{array}{l}\text { Semillas oleaginosas (aceites vegetales } \\
\text { fijos blandos) }\end{array}$ & 9 \\
\hline Productos derivados del petróleo & 4 & Trigo y morcajo o tranquillón, sin moler & 5 \\
\hline Lana y otros pelos de animales & 4 & Lechey crema & 4 \\
\hline
\end{tabular}

Fuentes: Secretaría de la OMC

Cinco principales mercados de importación de mercancías (\%)

\begin{tabular}{|l|r|l|c|}
\hline 2005 & $\%$ & 2009 & $\%$ \\
\hline Brasil & 21 & Argentina & 24 \\
\hline Argentina & 20 & Brasil & 21 \\
\hline UE (27) & 11 & China & 12 \\
\hline Federación de Rusia & 8 & UE (27) & 11 \\
\hline Estados Unidos & 7 & Estados Unidos & 8 \\
\hline Fuentes: Secretaría de la OMC & & & \\
\hline
\end{tabular}

Cinco principales productos de importación (\% de las importaciones de mercancías)

\begin{tabular}{|c|c|c|c|}
\hline 2005 & $\%$ & 2009 & $\%$ \\
\hline Aceites de petróleo, crudos & 19 & Aceites de petróleo, crudos & 12 \\
\hline $\begin{array}{l}\text { Equipos de telecomunicaciones y sus } \\
\text { partes, n.e.p. }\end{array}$ & 3 & Productos derivados del petróleo & 8 \\
\hline Abonos, excepto los del grupo 272 & 2 & Corriente eléctrica & 4 \\
\hline Productos derivados del petróleo & 2 & $\begin{array}{l}\text { Vehículos automotores para pasajeros, } \\
\text { excepto autobuses }\end{array}$ & 3 \\
\hline $\begin{array}{l}\text { Vehículos automotores para pasajeros, } \\
\text { excepto autobuses }\end{array}$ & 2 & $\begin{array}{l}\text { Equipos de telecomunicaciones y sus } \\
\text { partes, n.e.p. }\end{array}$ & 2 \\
\hline
\end{tabular}




\section{LA AYUDA PARA EL COMERCIO EN SIINTESIS 2013}

\section{INDICADORES COMERCIALES (RESULTADOS)}

Indicador

Crecimiento del PIB (\%)

Número de exportadores

Índice de concentración de las exportaciones (productos) ( 0 a 1)

ACR sobre mercancías notificados a la OMC

AIE (servicios) notificados a la OMC

Sectores de servicios con compromisos en el marco del AGCS

\section{Aranceles (\%, 2006 et 2011)}

\begin{tabular}{l|l|l|l|} 
Importaciones: promedio aritmético de los aranceles NMF aplicados & 10,6 & 10,5
\end{tabular}

Importaciones: promedio ponderado de los aranceles NMF aplicados $\quad 7,6 \quad 8,9$

Exportaciones: promedio ponderado de los aranceles impuestos

por los importadores

Exportaciones: libres de derechos (en \%)

$8,7 \quad 9,7$

$67,8 \quad 63,1$

Fuentes: Naciones Unidas, base de datos Comtrade; Banco Mundial, base de datos sobre dinámica de las empresas de exportación; Banco Mundial, Indicadores del

Desarrollo Mundial; OMC, perfiles comerciales y arancelarios.

Participación en las exportaciones por región (\%)

\begin{tabular}{|l|r|r|}
\hline & 2005 & 2009 \\
\hline África & 3,9 & 4,6 \\
\hline Asia & 8,2 & 8,6 \\
\hline Comunidad de Estados Independientes & 1,2 & 4,1 \\
\hline Europa & 19,4 & 18,1 \\
\hline Oriente Medio & 3,9 & 5,5 \\
\hline América del Norte & 29,8 & 6,7 \\
\hline América del Sury América Central & 30,6 & 37,3 \\
\hline
\end{tabular}

Fuentes: OMC, perfiles comerciales y arancelarios

Indicadores de facilitación del comercio
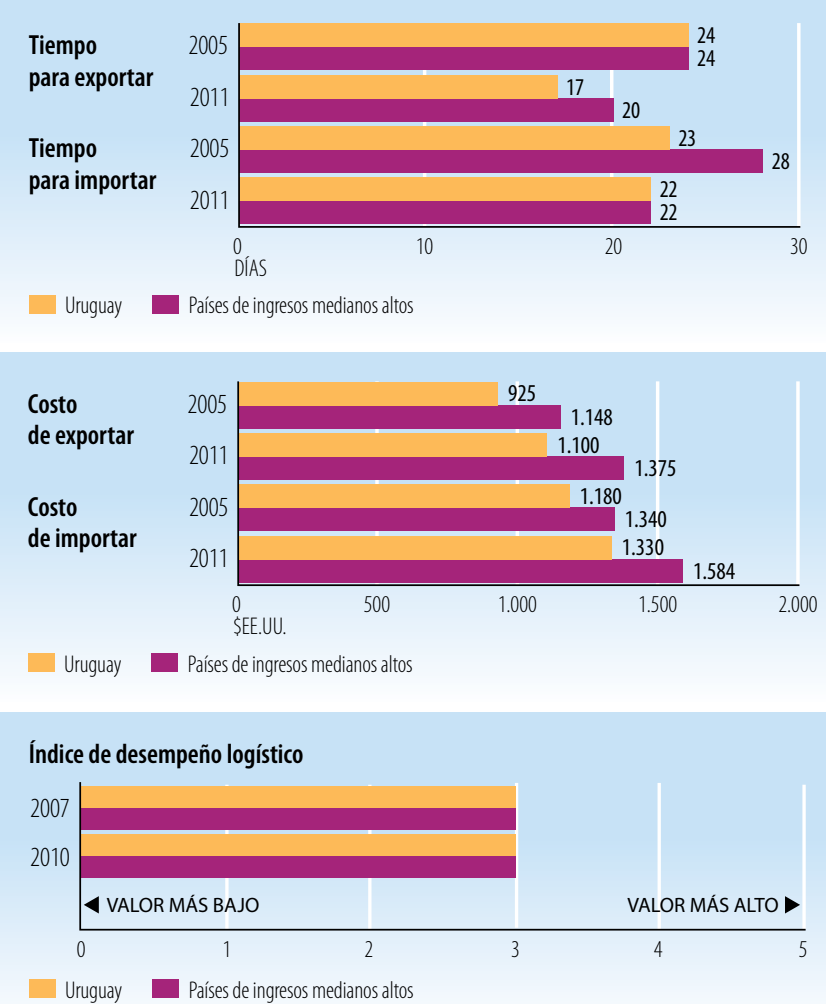

Fuentes: Banco Mundial, Indicadores del Desarrollo Mundial.

\section{INDICADORES DE DESARROLLO (EFECTOS)}

Indicador

2005

2010

Desempleo (\% de la fuerza de trabajo total)

$12,2 \quad 7,3$

Población activa, mujeres (\% de la fuerza de trabajo total)

$44,2 \quad 44,5$

AOD neta recibida (\% del INB)

$0,1 \quad 0,1$

\begin{tabular}{ll|l} 
Derechos de importación percibidos (\% de los ingresos fiscales) & 6,8 & 5,6
\end{tabular}

$\begin{array}{lll}\text { Total del servicio de la deuda (\% de las exportaciones totales) } \quad 33,7 & 12,4\end{array}$

Índice de desarrollo humano (0 a 1)

Fuentes: PNUD, indicadores internacionales sobre desarrollo humano; Banco Mundial, Indicadores del Desarrollo Mundial.

Producto interno bruto

PIB per cápita (PPA, dólares internacionales corrientes)

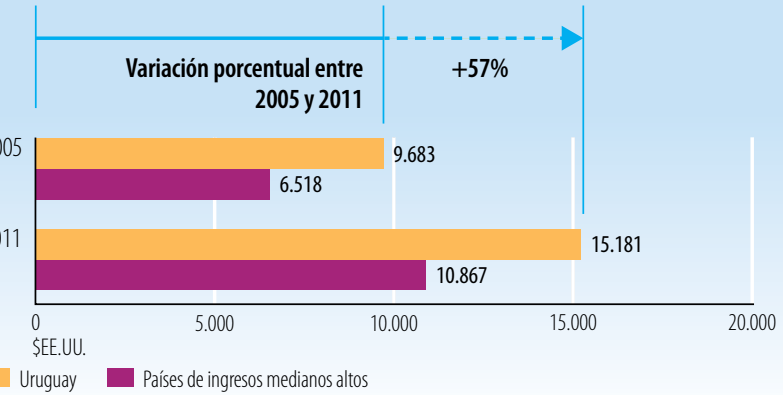

PIB per cápita (\$EE.UU. constantes de 2000)

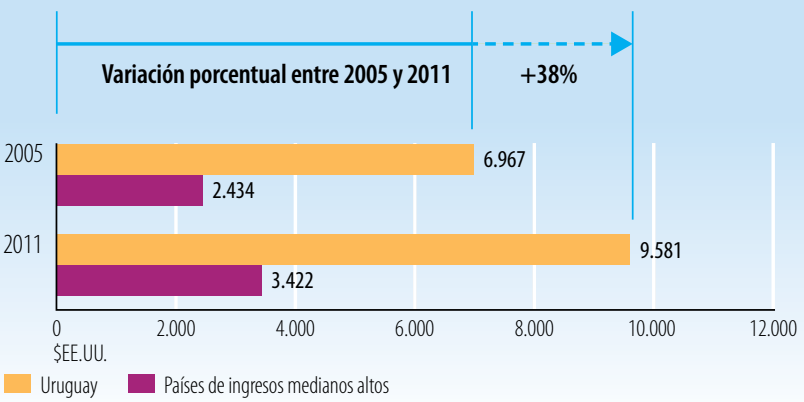

Fuentes: Banco Mundial, Indicadores del Desarrollo Mundial.

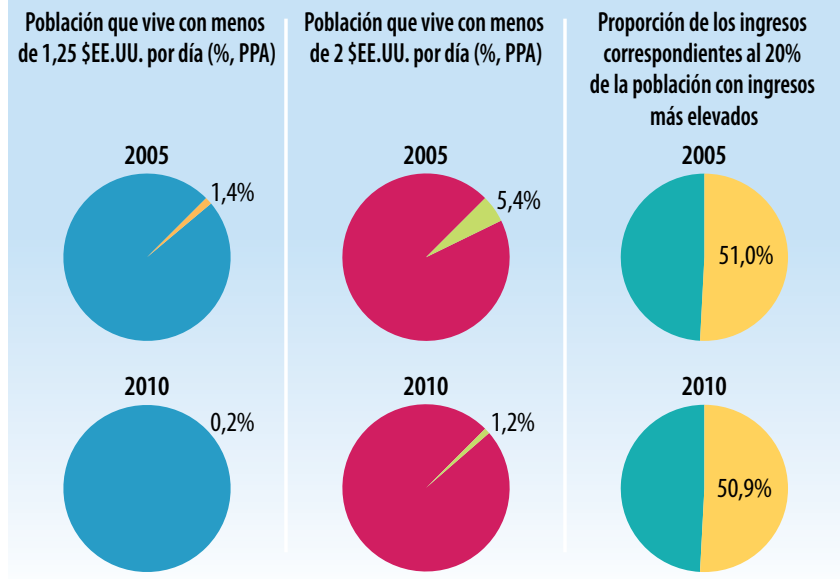

Fuentes: Banco Mundial, Indicadores del Desarrollo Mundial.

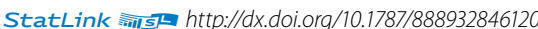


Indicadores de la ayuda, el comercio y el desarrollo relativos a Vanuatu

\begin{tabular}{|c|c|c|c|c|}
\hline Indicador (millones de \$EE.UU. corrientes) & 2005 & 2008 & 2010 & $\Delta: 05-10(\%)$ \\
\hline Formación bruta de capital fijo & 77,0 & n.d. & n.d. & n.d. \\
\hline del cual: público & n.d. & n.d. & n.d. & n.d. \\
\hline del cual: privado & n.d. & n.d. & n.d. & n.d. \\
\hline \multicolumn{5}{|l|}{ Entrada de financiación externa } \\
\hline Entradas de IED & 13,3 & 43,9 & 38,9 & $194 \%$ \\
\hline $\begin{array}{l}\text { Deuda externa a largo plazo y fondos } \\
\text { desembolsados por el FMl }\end{array}$ & 0,0 & 10,1 & 0,0 & $0 \%$ \\
\hline $\begin{array}{l}\text { Corrientes comerciales en condiciones no } \\
\text { concesionarias }\end{array}$ & 0,0 & 0,0 & 0,0 & $0 \%$ \\
\hline Corrientes de Ayuda para el Comercio & 5,6 & 45,5 & 35,8 & $541 \%$ \\
\hline $\begin{array}{l}\text { Remesas de trabajadores y remuneración } \\
\text { de empleados }\end{array}$ & 5,1 & 5,5 & 6,4 & $26 \%$ \\
\hline
\end{tabular}

Fuentes: OCDE, base de datos del SNPA del CAD sobre las actividades de ayuda; Banco Mundial, Indicadores del Desarrollo Mundial; Banco Mundial, estadísticas de la deuda internacional.

Desembolsos de la ayuda para el comercio, por sector (millones de \$̦EE.UU. corrientes)

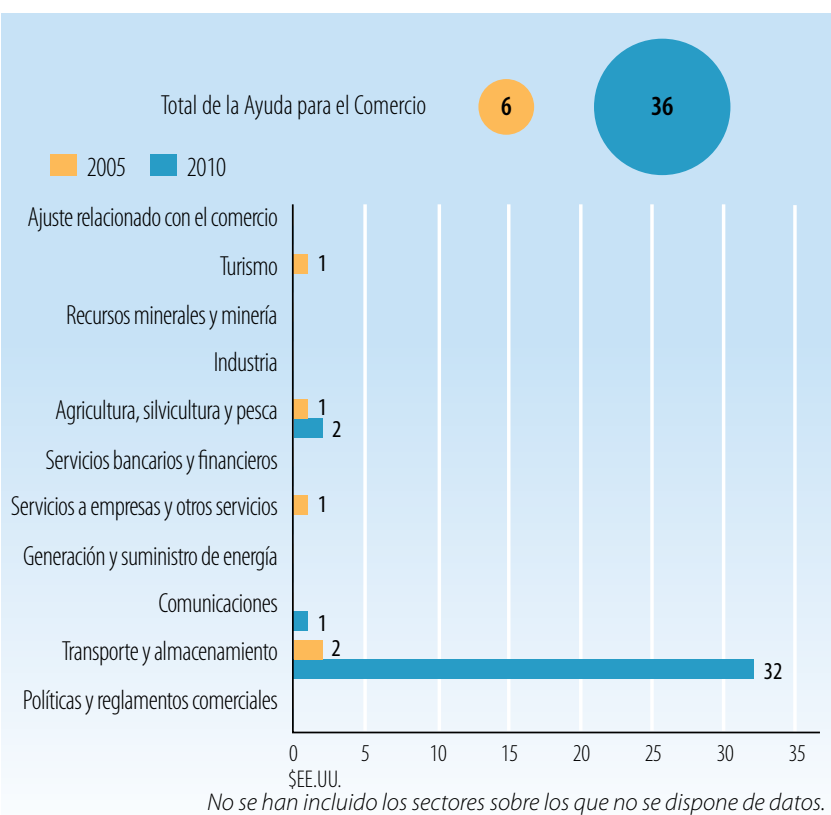

Fuentes: OCDE, base de datos del SNPA del CAD sobre las actividades de ayuda

Desembolsos de la ayuda para el comercio: principales donantes (millones de \$EE.UU. corrientes)

\begin{tabular}{|l|r|r|r|}
\hline $\mathbf{2 0 0 5}$ & Valor & $\%$ & Principales donantes en 2005 \\
\hline Instituciones de la UE & 1,8 & 33 & \\
\hline Japón & 1,2 & 21 & $100 \%$ \\
\hline Francia & 1,2 & 21 & \\
\hline Australia & 0,8 & 14 & \\
\hline Nueva Zelandia & 0,6 & 11 & \\
\hline $\mathbf{2 0 1 0}$ & Valor & $\%$ & Principales donantes en $\mathbf{2 0 1 0}$ \\
\hline Estados Unidos & 17,2 & 48 & \\
\hline Japón & 11,0 & 31 & \\
\hline Australia & 4,1 & 12 & $\mathbf{9 9 \%}$ \\
\hline Nueva Zelandia & 2,7 & 8 & \\
\hline Instituciones de la UE & 0,4 & 1 & \\
\hline
\end{tabular}

Fuentes: OCDE, base de datos del SNPA del CAD sobre las actividades de ayuda.

\section{INDICADORES COMERCIALES (PRODUCTOS)}

\section{Indicador}

$20052008 \quad 2011 \quad \Delta: 05-11(\%)$

Relación comercio/PIB (\%)

Exportaciones de servicios comerciales como

$\%$ de las exportaciones totales

Importaciones de servicios comerciales como

$\%$ de las importaciones totales

Productos intermedios distintos de los combustibles

(\% de las exportaciones de mercancías)

Productos intermedios distintos de los combustibles

(\% de las importaciones de mercancías)

\begin{tabular}{l|l|r|r|}
95 & 120 & 98 & 3 \\
\hline
\end{tabular}

Fuentes: Secretaría de la OMC.

Corrientes comerciales (millones de \$EE.UU. corrientes)

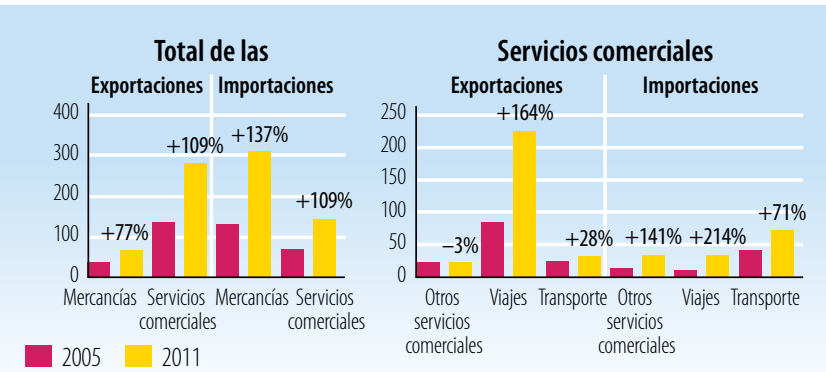

Fuentes: Secretaría de la OMC

Cinco principales mercados de exportación de mercancías (\%)

\begin{tabular}{|l|r|r|r|}
\hline 2006 & $\%$ & & $\%$ \\
\hline Fiji & 12 & \\
\hline UE (27) & 10 & \\
\hline Australia & 8 & No se dispone de datos. \\
\hline Nueva Caledonia & 7 & \\
\hline Singapur & 5 & \\
\hline Fuentes: Secretaría de la OMC & &
\end{tabular}

Cinco principales productos de exportación (\% de las exportaciones de mercancías)

\begin{tabular}{|l|c|c|c|}
\hline 2006 & $\%$ & & $\%$ \\
\hline Operaciones especiales no clasificadas & 37 & & \\
\hline Legumbres & 18 & \\
\hline Carne de ganado bovino & 8 & No se dispone de datos. \\
\hline Semillas oleaginosas (otros aceites vegetales fijos) & 8 & & \\
\hline Cacao & 7 &
\end{tabular}

Fuentes: Secretaría de la OMC

Cinco principales mercados de importación de mercancías (\%)

\begin{tabular}{|l|r|r|}
\hline 2006 & $\%$ & \\
\hline Australia & 41 & \\
\hline Nueva Zelandia & 16 & \\
\hline Fiji & 9 & No se dispone de datos. \\
\hline UE (27) & 6 & \\
\hline Singapur & 5 & \\
\hline Fuentes:Secretaría de la OMC & & \\
\hline
\end{tabular}

Cinco principales productos de importación (\% de las importaciones de mercancías)

\begin{tabular}{|l|r|r|}
\hline 2006 & $\%$ & \\
\hline Productos derivados del petróleo & 11 & \\
\hline Arroz & 5 & \\
\hline Medicamentos & 5 & No se dispone de datos. \\
\hline Muebles, cojines, etc. & 3 & \\
\hline Equipos de telecomunicaciones y sus partes, n.e.p. & 2 & \\
\hline Fuentes:Secretaría de la OMC & &
\end{tabular}




\section{LA AYUDA PARA EL COMERCIO EN SIINTESIS 2013}

\section{INDICADORES COMERCIALES (RESULTADOS)}

Indicador

Crecimiento del PIB (\%)

Número de exportadores

Índice de concentración de las exportaciones (productos) (0 a 1$)$

ACR sobre mercancías notificados a la OMC

AIE (servicios) notificados a la OMC

Sectores de servicios con compromisos en el marco del AGCS

\section{Aranceles (\%)}

Importaciones: promedio aritmético de los aranceles NMF aplicado

Importaciones: promedio ponderado de los aranceles NMF aplicados

Exportaciones: promedio ponderado de los aranceles impuestos

por los importadores

Exportaciones: libres de derechos (en \%)

\begin{tabular}{|r|r|}
\hline 2005 & 2011 \\
\hline 5,2 & 4,3 \\
\hline n.d. & n.d. \\
\hline 0,08 & n.d. \\
\hline n.d. & 3 \\
\hline n.d. & 0 \\
\hline 0 & 70 \\
\hline
\end{tabular}

Fuentes: Naciones Unidas, base de datos Comtrade; Banco Mundial, base de datos sobre dinámica de las empresas de exportación; Banco Mundial, Indicadores del

Desarrollo Mundial; OMC, perfiles comerciales y arancelarios.

Participación en las exportaciones por región (\%)

\begin{tabular}{|l|r|r|}
\hline África & 2006 & 2011 \\
\hline Asia & 0,3 & n.d. \\
\hline Comunidad de Estados Independientes & 51,2 & n.d. \\
\hline Europa & 0,0 & n.d. \\
\hline Oriente Medio & 10,2 & n.d. \\
\hline América del Norte & 0,2 & n.d. \\
\hline América del Sury América Central & 0,8 & n.d. \\
\hline
\end{tabular}

Fuentes: OMC, perfiles comerciales y arancelarios

Indicadores de facilitación del comercio
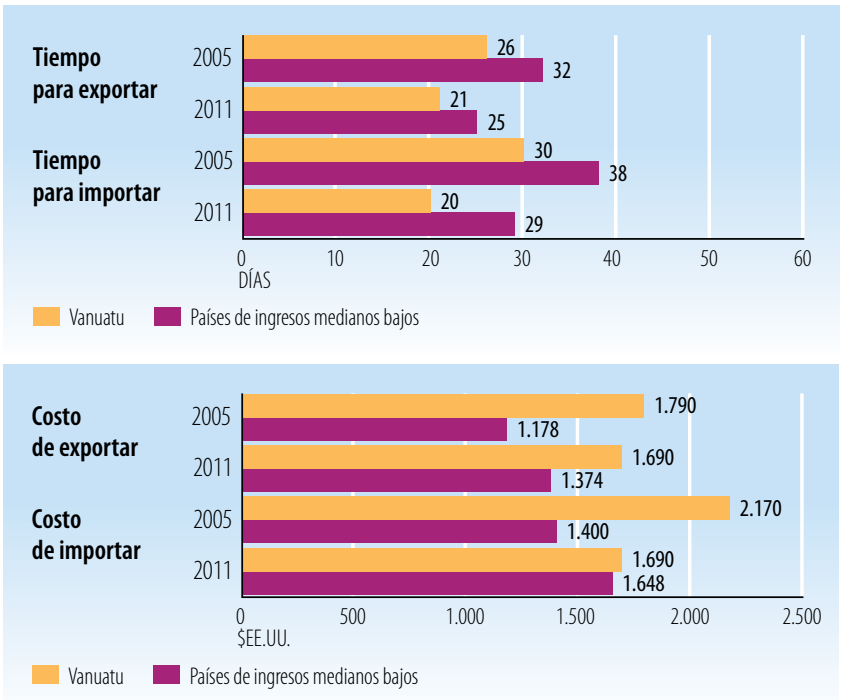

\section{Índice de desempeño logístico}

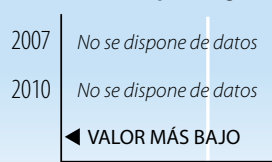

Vanuatu Países de ingresos medianos bajos

Fuentes: Banco Mundial, Indicadores del Desarrollo Mundial.

\begin{tabular}{|l|c|c|}
\hline INDICADORES DE DESARROLLO (EFECTOS) & \\
\hline Indicador & $\mathbf{2 0 0 5}$ & $\mathbf{2 0 1 0}$ \\
\hline Desempleo (\% de la fuerza de trabajo total) & n.d. & 4,6 \\
\hline Población activa, mujeres (\% de la fuerza de trabajo total) & 43,8 & 42,9 \\
\hline AOD neta recibida (\% del INB) & 10,7 & 16,2 \\
\hline Derechos de importación percibidos (\% de los ingresos fiscales) & n.d. & n.d. \\
\hline Total del servicio de la deuda (\% de las exportaciones totales) & 1,3 & 1,7 \\
\hline Índice de desarrollo humano (0 a 1) & n.d. & 0,62 \\
\hline
\end{tabular}

Fuentes: PNUD, indicadores internacionales sobre desarrollo humano; Banco Mundial, Indicadores del Desarrollo Mundial.

Producto interno bruto

PIB per cápita (PPA, dólares internacionales corrientes)

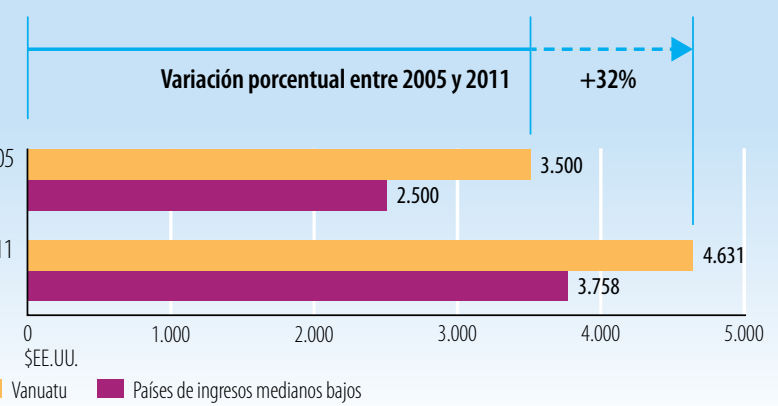

PIB per cápita (\$EE.UU. constantes de 2000)
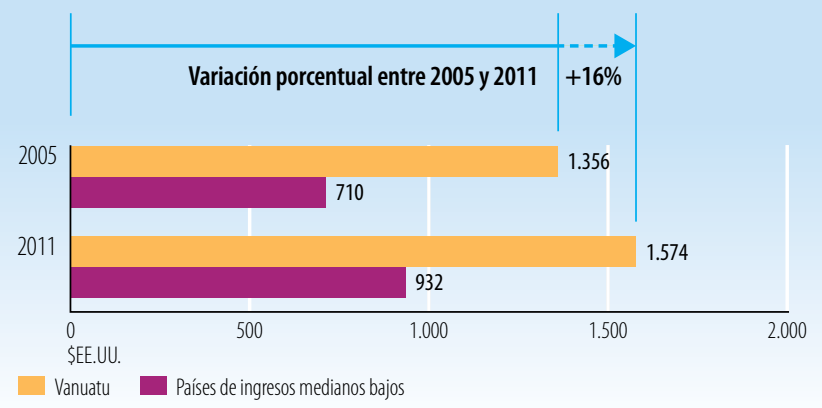

Fuentes: Banco Mundial, Indicadores del Desarrollo Mundial.

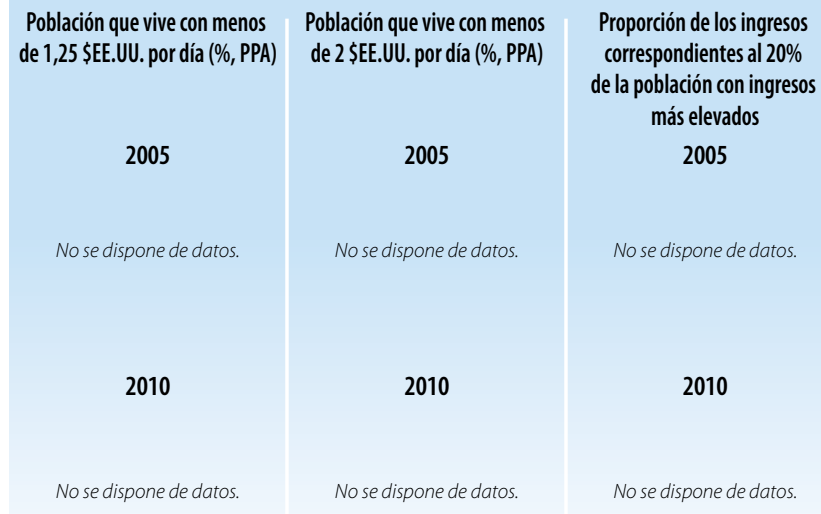

Fuentes: Banco Mundial, Indicadores del Desarrollo Mundial.

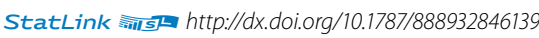


Indicadores de la ayuda, el comercio y el desarrollo relativos al Yemen

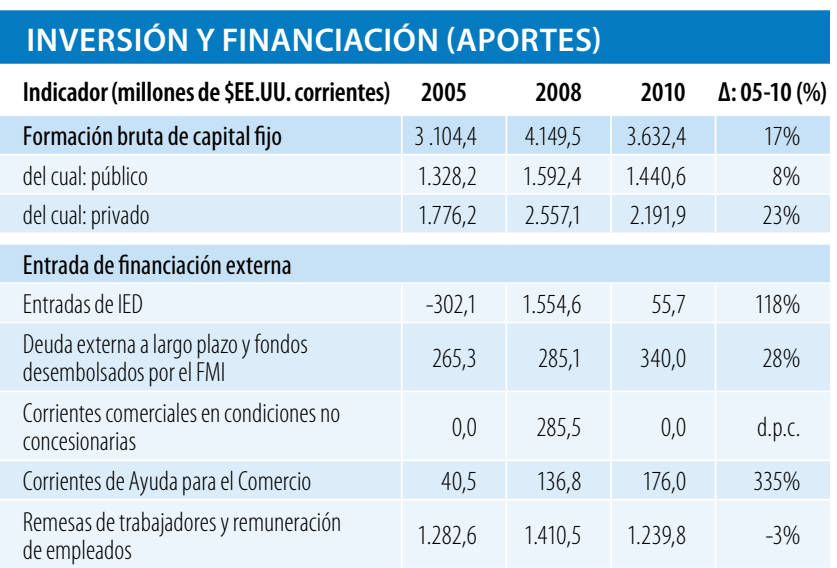

Fuentes: OCDE, base de datos del SNPA del CAD sobre las actividades de ayuda; Banco Mundial, Indicadores del Desarrollo Mundial; Banco Mundial, estadísticas de la deuda internacional.

Desembolsos de la ayuda para el comercio, por sector (millones de \$EE.UU. corrientes)

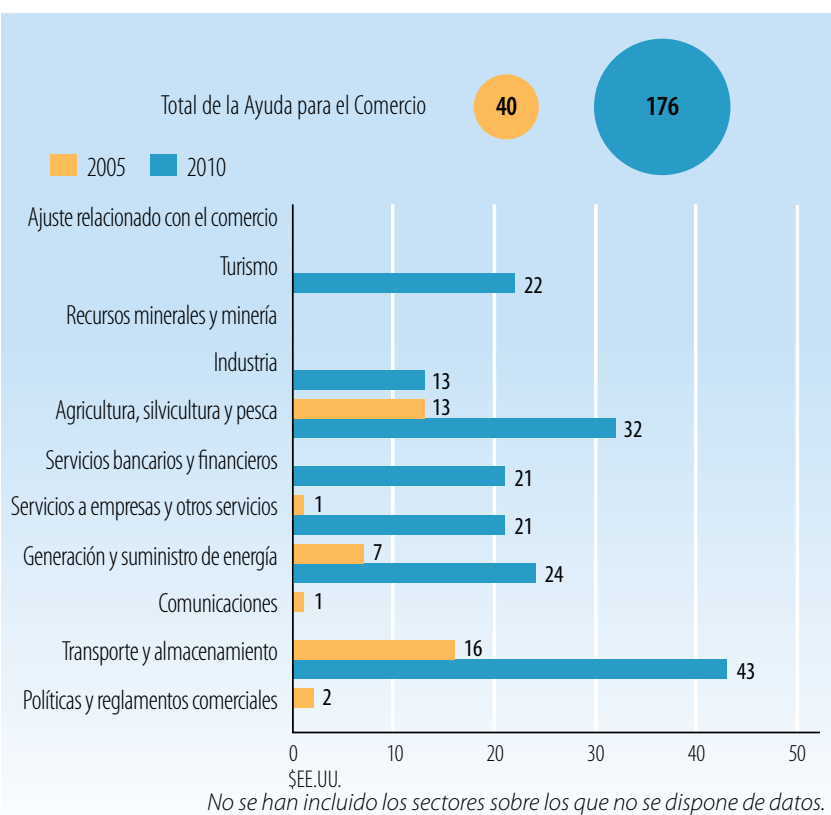

Fuentes: OCDE, base de datos del SNPA del CAD sobre las actividades de ayuda

Desembolsos de la ayuda para el comercio: principales donantes (millones de \$EE.UU. corrientes)

\begin{tabular}{|l|r|r|r|}
\hline $\mathbf{2 0 0 5}$ & Valor & $\%$ & Principales donantes en 2005 \\
\hline Banco Mundial & 31,7 & 78 & \\
\hline Instituciones de la UE & 3,7 & 9 & \\
\hline Japón & 3,4 & 8 & $99 \%$ \\
\hline Alemania & 1,0 & 2 & \\
\hline Países Bajos & 0,5 & 1 & \\
\hline $\mathbf{2 0 1 0}$ & Valor & $\%$ & Principales donantes en 2010 \\
\hline Banco Mundial & 75,2 & 43 & \\
\hline Fondo Árabe & 47,2 & 27 & \\
\hline Emiratos Árabes Unidos & 22,2 & 13 & \\
\hline Japón & 7,8 & 4 & $91 \%$ \\
\hline Reino Unido & 7,3 & 4 & \\
\hline
\end{tabular}

Fuentes: OCDE, base de datos del SNPA del CAD sobre las actividades de ayuda.

\section{INDICADORES COMERCIALES (PRODUCTOS)}

\section{Indicador}

$20052008 \quad 2011 \quad \Delta: 05-11(\%)$

Relación comercio/PIB (\%)

Exportaciones de servicios comerciales como

$\%$ de las exportaciones totales

Importaciones de servicios comerciales como

$\%$ de las importaciones totales

Productos intermedios distintos de los combustibles

(\% de las exportaciones de mercancías)

Productos intermedios distintos de los combustibles

(\% de las importaciones de mercancías)

\begin{tabular}{l|l|l|r|}
75 & 80 & 60 & -15 \\
\hline
\end{tabular}

Fuentes: Secretaría de la OMC.

Corrientes comerciales (millones de \$EE.UU. corrientes)

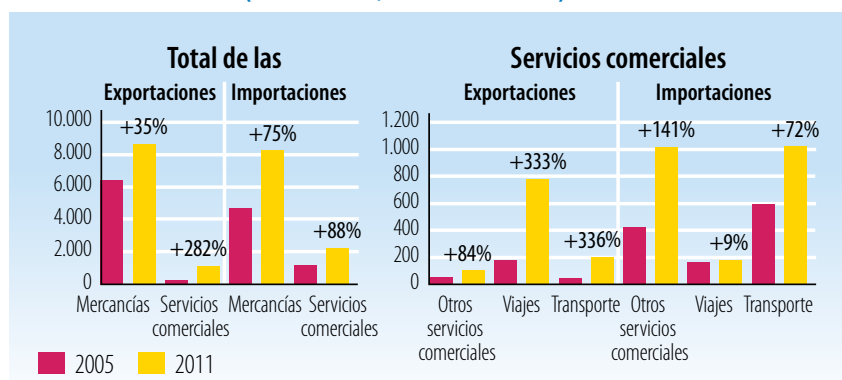

Fuentes: Secretaría de la OMC

Cinco principales mercados de exportación de mercancías (\%)

\begin{tabular}{|l|c|l|l|}
\hline 2005 & $\%$ & 2009 & $\%$ \\
\hline China & 35 & China & 25 \\
\hline India & 16 & India & 20 \\
\hline Tailandia & 12 & Tailandia & 18 \\
\hline Japón & 7 & Singapur & 7 \\
\hline Corea, Rep. de & 6 & Sudáfrica & 6 \\
\hline
\end{tabular}

Fuentes: Secretaría de la OMC

Cinco principales productos de exportación (\% de las exportaciones de mercancías)

2005

Aceites de petróleo, crudos

Productos derivados del petróleo

Pescado, fresco, refrigerado o congelado

Productos residuales derivados de

petróleo

Vehículos automotores para pasajeros,

excepto autobuses

Fuentes: Secretaría de la OMC

Cinco principales mercados de importación de mercancías (\%)

\begin{tabular}{|l|r|l|c|}
\hline 2005 & $\%$ & 2009 & $\%$ \\
\hline UE (27) & 15 & UE (27) & 15 \\
\hline Suiza & 9 & Emiratos Árabes Unidos & 10 \\
\hline Emiratos Árabes Unidos & 8 & China & 9 \\
\hline Estados Unidos & 7 & Estados Unidos & 6 \\
\hline Arabia Saudita, Reino de la & 6 & Japón & 6 \\
\hline Fuentes:Secretaría de la OMC & & &
\end{tabular}

Cinco principales productos de importación (\% de las importaciones de mercancías)

\begin{tabular}{|c|c|c|c|}
\hline 2005 & $\%$ & 2011 & $\%$ \\
\hline Productos derivados del petróleo & 19 & Productos derivados del petróleo & 29 \\
\hline Trigo y morcajo o tranquillón, sin moler & 7 & Trigo y morcajo o tranquillón, sin moler & 10 \\
\hline $\begin{array}{l}\text { Vehículos automotores para pasajeros, } \\
\text { excepto autobuses }\end{array}$ & 3 & Azúcares, melaza y miel & 5 \\
\hline Azúcares, melaza y miel & 3 & $\begin{array}{l}\text { Vehículos automotores para pasajeros, } \\
\text { excepto autobuses }\end{array}$ & 4 \\
\hline Leche y crema & 3 & Impresos & 4 \\
\hline
\end{tabular}

Fuentes: Secretaría de la OMC 


\section{LA AYUDA PARA EL COMERCIO EN SÍNTESIS 2013}

\section{INDICADORES COMERCIALES (RESULTADOS)}

\section{Indicador}

Crecimiento del PIB (\%)

Número de exportadores

Índice de concentración de las exportaciones (productos) ( 0 a 1)

ACR sobre mercancías notificados a la OMC

AIE (servicios) notificados a la OMC

Sectores de servicios con compromisos en el marco del AGCS

\section{Aranceles $(\%, 2006$ et 2011)}

$\begin{array}{ll}\text { Importaciones: promedio aritmético de los aranceles NMF aplicados } \quad 7,1 & 7,1\end{array}$

\begin{tabular}{l|l|l|} 
Importaciones: promedio ponderado de los aranceles NMF aplicados & n.d.
\end{tabular}

\begin{tabular}{|l|l|l|} 
Exportaciones: promedio ponderado de los aranceles impuestos & 0,5 & 1,7
\end{tabular}

por los importadores

$83,2 \quad 63,4$

Exportaciones: libres de derechos (en \%)
Fuentes: Naciones Unidas, base de datos Comtrade; Banco Mundial, base de datos sobre dinámica de las empresas de exportación; Banco Mundial, Indicadores del

Desarrollo Mundial; OMC, perfiles comerciales y arancelarios.

Participación en las exportaciones por región (\%)

\begin{tabular}{|l|r|r|}
\hline & $\mathbf{2 0 0 5}$ & 2011 \\
\hline África & 1,2 & 2,8 \\
\hline Asia & 79,8 & 75,7 \\
\hline Comunidad de Estados Independientes & 0,0 & 0,0 \\
\hline Europa & 6,4 & 6,2 \\
\hline Oriente Medio & 7,7 & 9,0 \\
\hline América del Norte & 3,6 & 4,6 \\
\hline América del Sury América Central & 0,1 & 0,6 \\
\hline
\end{tabular}

Fuentes: OMC, perfiles comerciales y arancelarios

Indicadores de facilitación del comercio
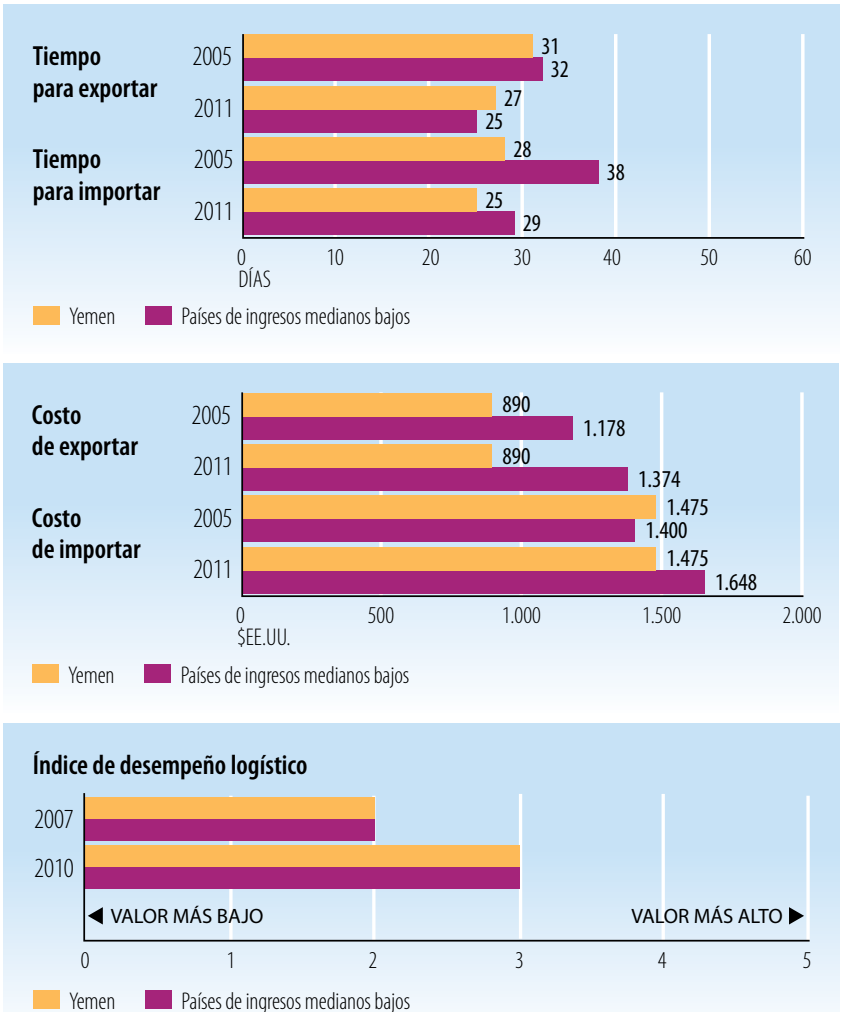

Fuentes: Banco Mundial, Indicadores del Desarrollo Mundial.

\begin{tabular}{l|c|c|}
\hline INDICADORES DE DESARROLLO (EFECTOS) \\
\hline Indicador & $\mathbf{2 0 0 5}$ & $\mathbf{2 0 1 0}$ \\
\hline Desempleo (\% de la fuerza de trabajo total) & 16,1 & 14,6 \\
\hline Población activa, mujeres (\% de la fuerza de trabajo total) & 25,0 & 25,8 \\
\hline AOD neta recibida (\% del INB) & 2,0 & 2,3 \\
\hline Derechos de importación percibidos (\% de los ingresos fiscales) & 18,3 & 14,5 \\
\hline Total del servicio de la deuda (\% de las exportaciones totales) & 3,0 & 2,8 \\
\hline Índice de desarrollo humano ( 0 a 1) & 0,42 & 0,46 \\
\hline
\end{tabular}

Fuentes: PNUD, indicadores internacionales sobre desarrollo humano; Banco Mundial, Indicadores del Desarrollo Mundial.

Producto interno bruto

PIB per cápita (PPA, dólares internacionales corrientes)

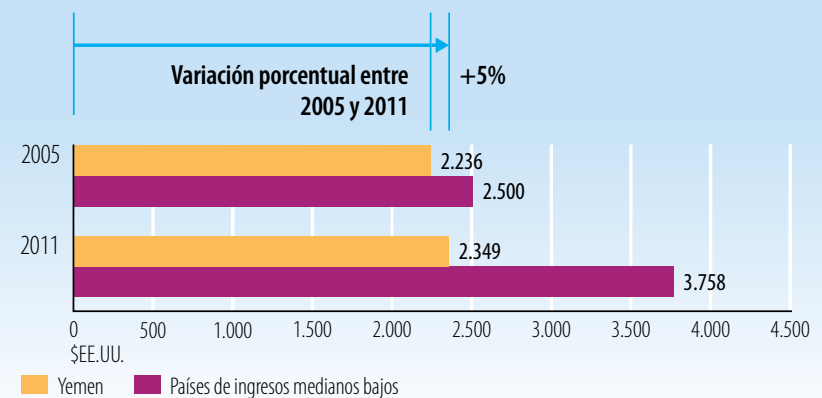

PIB per cápita (\$EE.UU. constantes de 2000)
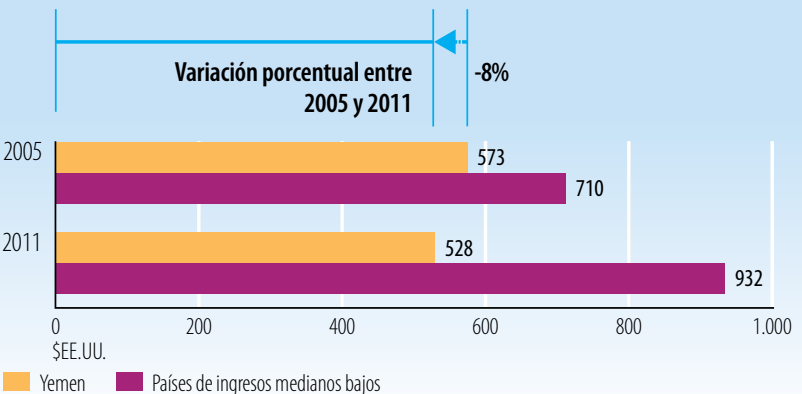

Fuentes: Banco Mundial, Indicadores del Desarrollo Mundial.

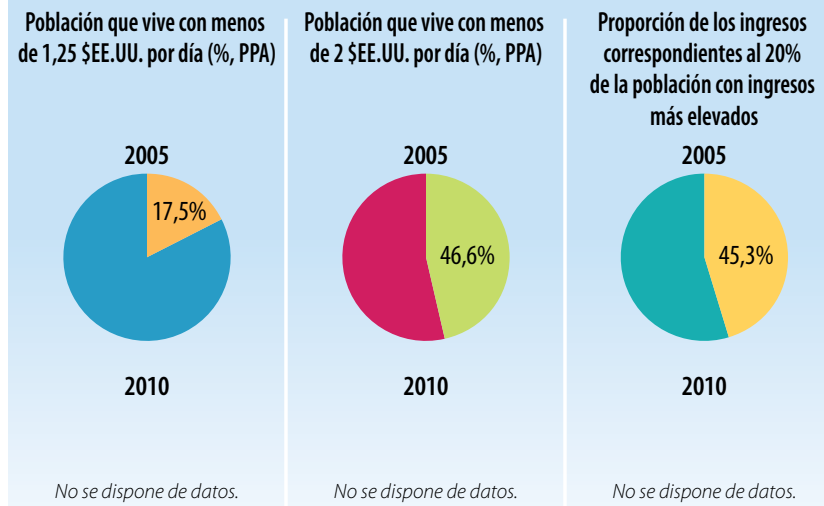

Fuentes: Banco Mundial, Indicadores del Desarrollo Mundial.

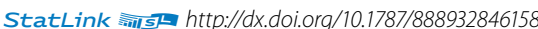




\section{Indicadores de la ayuda, el comercio y el desarrollo relativos a Zambia}

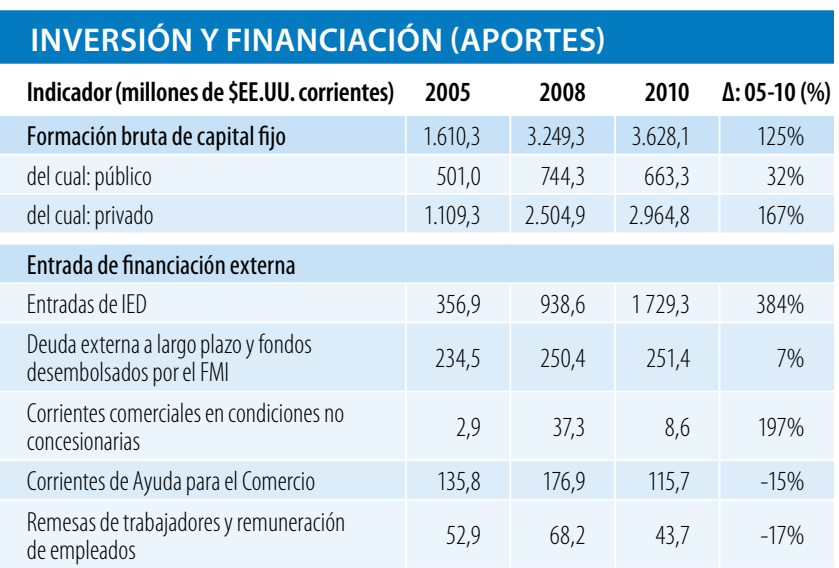

Fuentes: OCDE, base de datos del SNPA del CAD sobre las actividades de ayuda; Banco Mundial, Indicadores del Desarrollo Mundial; Banco Mundial, estadísticas de la deuda internacional.

Desembolsos de la ayuda para el comercio, por sector (millones de \$EE.UU. corrientes)

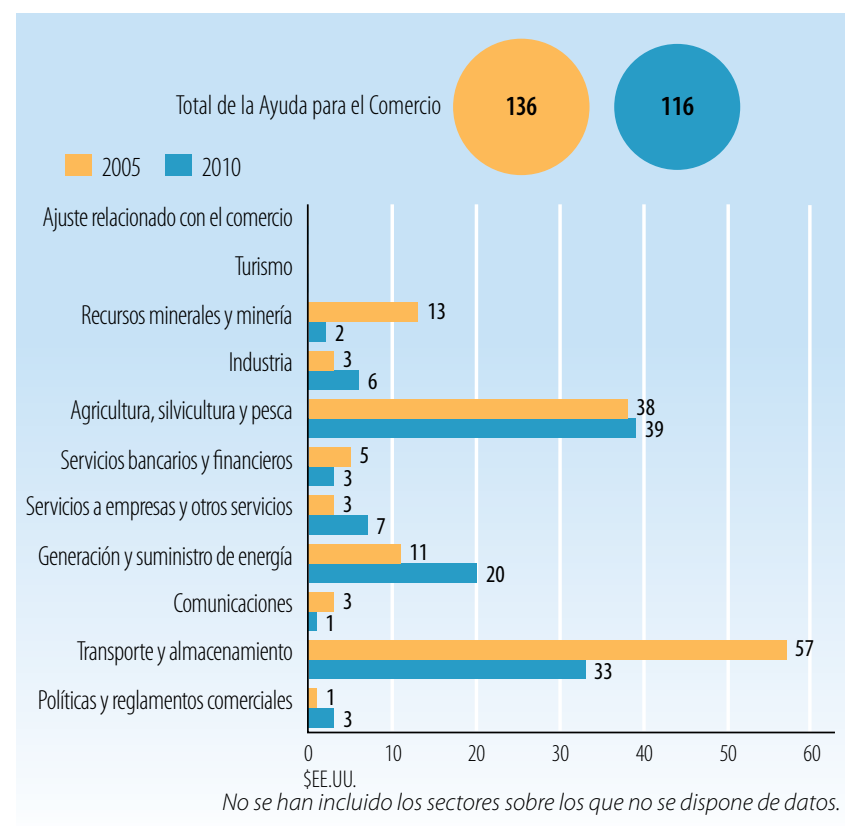

Fuentes: OCDE, base de datos del SNPA del CAD sobre las actividades de ayuda

Desembolsos de la ayuda para el comercio: principales donantes (millones de \$EE.UU. corrientes)

\begin{tabular}{|l|c|c|c|}
\hline $\mathbf{2 0 0 5}$ & Valor & $\%$ & Principales donantes en 2005 \\
\hline Instituciones de la UE & 40,6 & 30 & \\
\hline Banco Mundial & 37,8 & 28 & \\
\hline Dinamarca & 12,1 & 9 & $81 \%$ \\
\hline Suecia & 11,1 & 8 & \\
\hline Banco Africano de Desarrollo & 9,2 & 7 & \\
\hline $\mathbf{2 0 1 0}$ & Valor & $\%$ & Principales donantes en 2010 \\
\hline Japón & 27,2 & 24 & \\
\hline Banco Mundial & 18,0 & 16 & \\
\hline Instituciones de la UE & 14,2 & 12 & \\
\hline Suecia & 11,0 & 10 & $69 \%$ \\
\hline Estados Unidos & 9,5 & 8 & \\
\hline
\end{tabular}

Fuentes: OCDE, base de datos del SNPA del CAD sobre las actividades de ayuda.

\begin{tabular}{|c|c|c|c|c|}
\hline \multicolumn{5}{|c|}{ INDICADORES COMERCIALES (PRODUCTOS) } \\
\hline Indicador & 2005 & 2008 & 2011 & $\Delta: 05-11(\%)$ \\
\hline Relación comercio/PIB (\%) & 70 & 73 & 87 & 16 \\
\hline $\begin{array}{l}\text { Exportaciones de servicios comerciales como } \\
\text { \% de las exportaciones totales }\end{array}$ & 8 & 6 & 4 & -4 \\
\hline $\begin{array}{l}\text { Importaciones de servicios comerciales como } \\
\% \text { de las importaciones totales }\end{array}$ & 17 & 16 & 15 & -2 \\
\hline $\begin{array}{l}\text { Productos intermedios distintos de los combustibles } \\
\text { (\% de las exportaciones de mercancías) }\end{array}$ & 93 & 96 & n.d. & n.d. \\
\hline $\begin{array}{l}\text { Productos intermedios distintos de los combustibles } \\
\text { (\% de las importaciones de mercancías) }\end{array}$ & 59 & 51 & n.d. & n.d. \\
\hline
\end{tabular}
Fuentes: Secretaría de la OMC.

Corrientes comerciales (millones de \$EE.UU. corrientes)

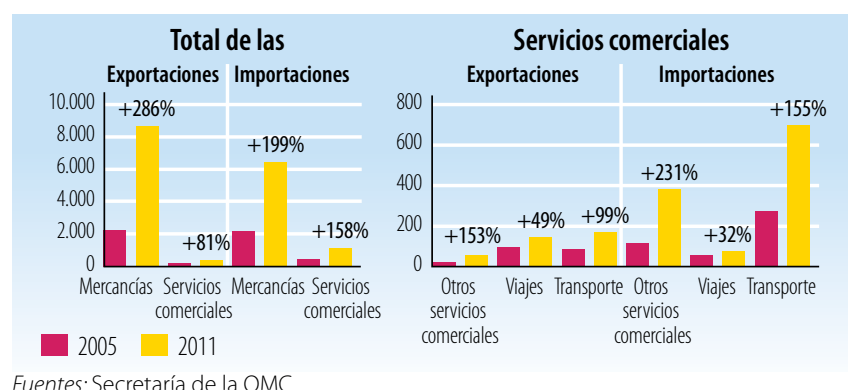

Cinco principales mercados de exportación de mercancías (\%)

\begin{tabular}{|l|r|l|r|}
\hline 2005 & $\%$ & 2010 & $\%$ \\
\hline Suiza & 29 & Suiza & 51 \\
\hline UE (27) & 24 & China & 20 \\
\hline Sudáfrica & 19 & Sudáfrica & 9 \\
\hline Congo, Rep. Dem. del & 5 & Congo, Rep. Dem. del & 5 \\
\hline Tanzanía & 5 & UE (27) & 4 \\
\hline
\end{tabular}

Fuentes: Secretaría de la OMC

Cinco principales productos de exportación (\% de las exportaciones de mercancías)

\begin{tabular}{|l|r|l|c|}
\hline 2005 & $\%$ & 2010 & $\%$ \\
\hline Cobre & 55 & Cobre & 75 \\
\hline Manufacturas de metales comunes, n.e.p. & 9 & Minerales de cobrey sus concentrados & 3 \\
\hline Minerales de cobrey sus concentrados & 4 & Manufacturas de metales comunes, n.e.p. & 3 \\
\hline Azúcares, melaza y miel & 4 & Azúcares, melaza y miel & 2 \\
\hline Tabaco sin elaborar & 3 & $\begin{array}{l}\text { Minerales de metales comunes y sus } \\
\text { concentrados }\end{array}$ & 2 \\
\hline Fuentes: Secretaría de la OMC & & & \\
\hline
\end{tabular}

Cinco principales mercados de importación de mercancías (\%)

\begin{tabular}{|l|r|l|r|}
\hline 2005 & $\%$ & 2010 & $\%$ \\
\hline Sudáfrica & 48 & Sudáfrica & 34 \\
\hline UE (27) & 22 & Congo, Rep. Dem. del & 24 \\
\hline Zimbabwe & 4 & Kuwait & 10 \\
\hline Emiratos Árabe Unidos & 4 & UE (27) & 9 \\
\hline $\begin{array}{l}\text { China } \\
\text { Fuentes: Secretaría de la OMC }\end{array}$ & 3 & China & 5 \\
\hline
\end{tabular}

Cinco principales productos de importación (\% de las importaciones de mercancías)

\begin{tabular}{|l|r|l|c|}
\hline 2005 & $\%$ & 2010 & $\%$ \\
\hline Impresos & 10 & Minerales de cobre y sus concentrados & 12 \\
\hline Abonos, excepto los del grupo 272 & 6 & Aceites de petróleo, crudos & 10 \\
\hline Productos derivados del petróleo & 5 & Equipo de ingeniería civil & 6 \\
\hline Aceites de petróleo, crudos & 4 & Cobre & 5 \\
\hline $\begin{array}{l}\text { Equipo de ingeniería civil } \\
\text { Fuentes: Secretaría de la OMC }\end{array}$ & 3 & $\begin{array}{l}\text { Minerales de metales comunes y sus } \\
\text { concentrados }\end{array}$ & 4 \\
\hline
\end{tabular}




\section{LA AYUDA PARA EL COMERCIO EN SINNTESIS 2013}

\section{INDICADORES COMERCIALES (RESULTADOS)}

Indicador

Crecimiento del PIB (\%)

Número de exportadores

Índice de concentración de las exportaciones (productos) ( 0 a 1)

ACR sobre mercancías notificados a la OMC

AIE (servicios) notificados a la OMC

Sectores de servicios con compromisos en el marco del AGCS

\section{Aranceles (\%)}

\begin{tabular}{|l|l|l|} 
Importaciones: promedio aritmético de los aranceles NMF aplicados & 13,9 & 13,4
\end{tabular}

\begin{tabular}{l|l|l|l|}
\hline Importaciones: promedio ponderado de los aranceles NMF aplicados & 10,6 & 8,7
\end{tabular}

\begin{tabular}{|l|l|l|l|} 
Exportaciones: promedio ponderado de los aranceles impuestos & 2,9 & 0,6
\end{tabular}

por los importadores

Exportaciones: libres de derechos (en \%)

$84,5 \quad 89,0$

Fuentes: Naciones Unidas, base de datos Comtrade; Banco Mundial, base de datos sobre dinámica de las empresas de exportación; Banco Mundial, Indicadores del

Desarrollo Mundial; OMC, perfiles comerciales y arancelarios.

Participación en las exportaciones por región (\%)

\begin{tabular}{|l|r|r|}
\hline África & $\mathbf{2 0 0 5}$ & $\mathbf{2 0 1 0}$ \\
\hline Asia & 40,6 & 19,9 \\
\hline Comunidad de Estados Independientes & 5,7 & 21,5 \\
\hline Europa & 0,0 & 0,1 \\
\hline Oriente Medio & 52,8 & 55,4 \\
\hline América del Norte & 0,1 & 3,0 \\
\hline América del Sury América Central & 0,8 & 0,1 \\
\hline
\end{tabular}

Fuentes: OMC, perfiles comerciales y arancelarios

Indicadores de facilitación del comercio
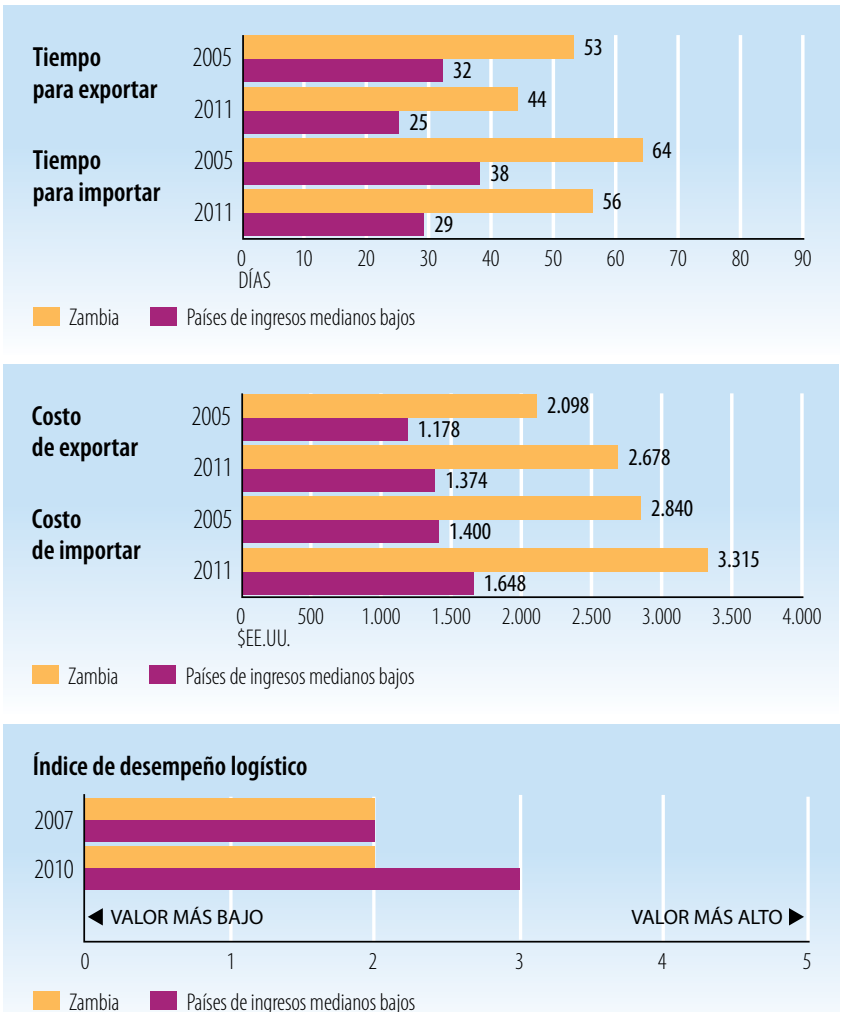

Fuentes: Banco Mundial, Indicadores del Desarrollo Mundial.

\begin{tabular}{l|c|c|}
\hline \multicolumn{2}{|l}{ INDICADORES DE DESARROLLO (EFECTOS) } \\
\hline Indicador & $\mathbf{2 0 0 5}$ & $\mathbf{2 0 1 0}$ \\
\hline Desempleo (\% de la fuerza de trabajo total) & 15,9 & n.d. \\
\hline Población activa, mujeres (\% de la fuerza de trabajo total) & 46,3 & 46,1 \\
\hline AOD neta recibida (\% del INB) & 17,8 & 6,4 \\
\hline Derechos de importación percibidos (\% de los ingresos fiscales) & n.d. & 9,8 \\
\hline Total del servicio de la deuda (\% de las exportaciones totales) & 11,1 & 1,9 \\
\hline Índice de desarrollo humano (0 a 1) & 0,39 & 0,43 \\
\hline
\end{tabular}

Fuentes: PNUD, indicadores internacionales sobre desarrollo humano; Banco Mundial, Indicadores del Desarrollo Mundial.

Producto interno bruto

PIB per cápita (PPA, dólares internacionales corrientes)
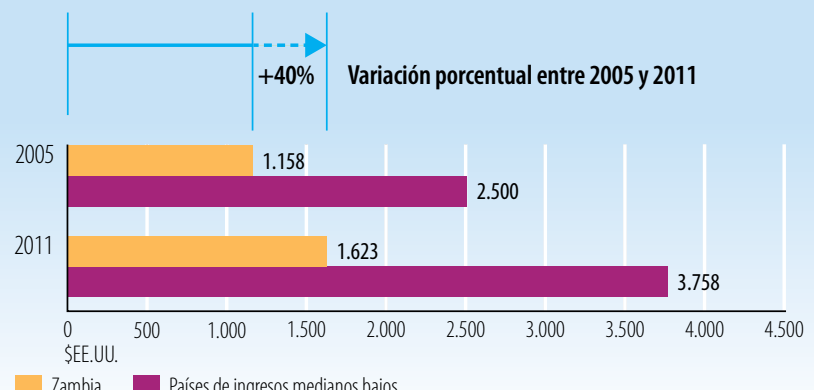

Zambia Países de ingresos medianos bajos

PIB per cápita (\$EE.UU. constantes de 2000)

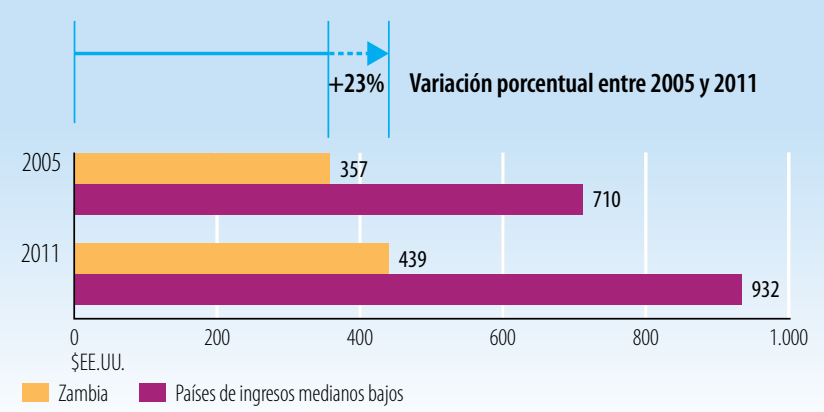

Fuentes: Banco Mundial, Indicadores del Desarrollo Mundial.

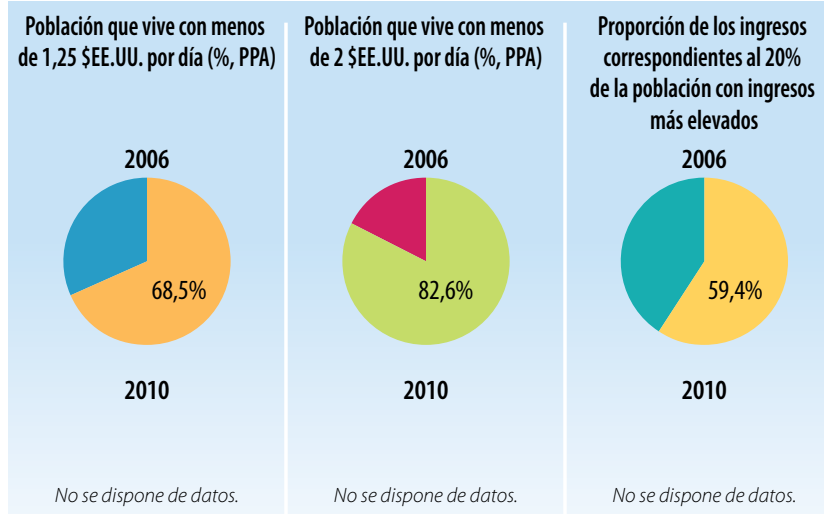

Fuentes: Banco Mundial, Indicadores del Desarrollo Mundial.

StatLink *iाls $h$ ttp://dx.doi.org/10.1787/888932846177 


\section{LA AYUDA PARA EL COMERCIO EN SÍNTESIS 2013}

\section{Indicadores de la ayuda, el comercio y el desarrollo relativos a Zimbabwe}

\section{INVERSIÓN Y FINANCIACIÓN (APORTES)}

\begin{tabular}{|c|c|c|c|c|}
\hline Indicador (millones de \$EE.UU. corrientes) & 2005 & 2008 & 2010 & $\Delta: 05-10(\%)$ \\
\hline Formación bruta de capital fijo & 115,1 & 145,1 & 422,0 & $267 \%$ \\
\hline del cual: público & n.d. & 14,3 & 415,3 & n.d. \\
\hline del cual: privado & n.d. & 130,8 & 6,8 & n.d. \\
\hline \multicolumn{5}{|l|}{ Entrada de financiación externa } \\
\hline Entradas de IED & 102,8 & 51,6 & 105,4 & $3 \%$ \\
\hline $\begin{array}{l}\text { Deuda externa a largo plazo y fondos } \\
\text { desembolsados por el FMl }\end{array}$ & 25,4 & 93,7 & 369,4 & $1353 \%$ \\
\hline $\begin{array}{l}\text { Corrientes comerciales en condiciones no } \\
\text { concesionarias }\end{array}$ & 0,0 & 0,0 & 0,0 & $0 \%$ \\
\hline Corrientes de Ayuda para el Comercio & 6,8 & 9,7 & 80,1 & $1076 \%$ \\
\hline $\begin{array}{l}\text { Remesas de trabajadores y remuneración } \\
\text { de empleados }\end{array}$ & n.d. & n.d. & n.d. & n.d. \\
\hline
\end{tabular}

Fuentes: OCDE, base de datos del SNPA del CAD sobre las actividades de ayuda; Banco Mundial, Indicadores del Desarrollo Mundial; Banco Mundial, estadísticas de la deuda internacional.

Desembolsos de la ayuda para el comercio, por sector (millones de \$̦EE.UU. corrientes)

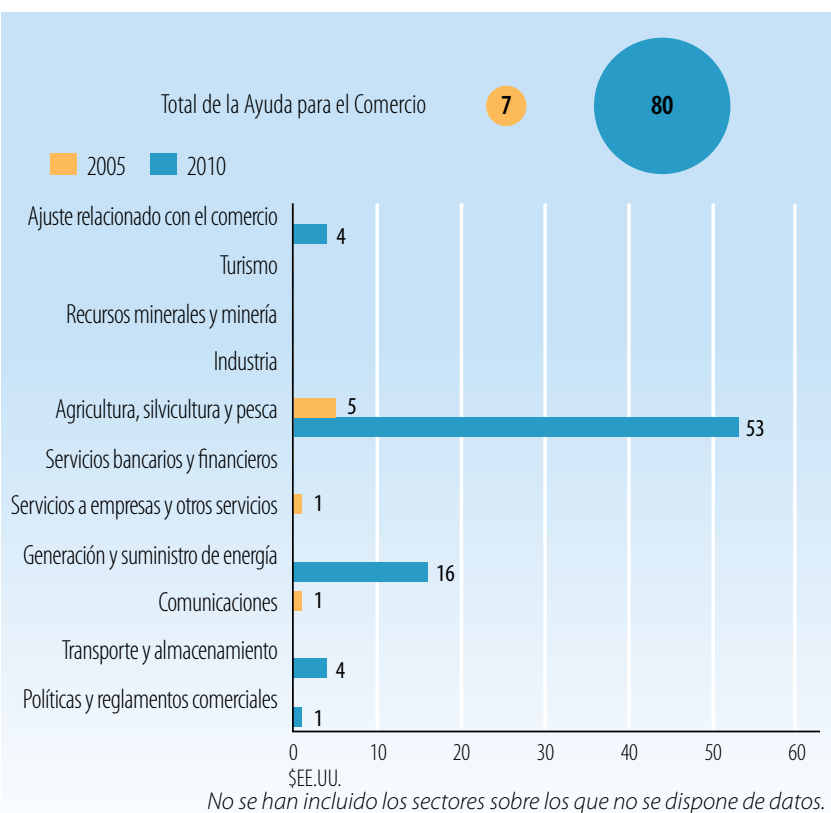

Fuentes: OCDE, base de datos del SNPA del CAD sobre las actividades de ayuda

Desembolsos de la ayuda para el comercio: principales donantes (millones de \$EE.UU. corrientes)

\begin{tabular}{|l|c|c|c|}
\hline $\mathbf{2 0 0 5}$ & Valor & $\%$ & Principales donantes en 2005 \\
\hline Alemania & 2,7 & 40 & \\
\hline Japón & 1,3 & 19 & \\
\hline Reino Unido & 0,9 & 13 & $90 \%$ \\
\hline Noruega & 0,7 & 10 & \\
\hline Bélgica & 0,5 & 8 & \\
\hline $\mathbf{2 0 1 0}$ & Valor & $\%$ & Principales donantes en $\mathbf{2 0 1 0}$ \\
\hline Instituciones de la UE & 19,9 & 25 & \\
\hline Reino Unido & 15,4 & 19 & \\
\hline Dinamarca & 15,0 & 19 & \\
\hline Australia & 11,6 & 15 & $\mathbf{8 7 \%}$ \\
\hline Alemania & 7,2 & 9 & \\
\hline
\end{tabular}

Fuentes: OCDE, base de datos del SNPA del CAD sobre las actividades de ayuda.

\section{INDICADORES COMERCIALES (PRODUCTOS)}

\section{Indicador}

$2005 \quad 2008 \quad 2011 \quad \Delta: 05-11(\%)$

Relación comercio/PIB (\%)

84113 n.d. n.d.

Exportaciones de servicios comerciales como

\% de las exportaciones totales

$\begin{array}{lll}12 & 7 & \text { n.d. }\end{array}$

mportaciones de servicios comerciales como

$\%$ de las importaciones totales

96 n.d. n.d.

Productos intermedios distintos de los combustibles

(\% de las exportaciones de mercancías)

Productos intermedios distintos de los combustibles

(\% de las importaciones de mercancías)

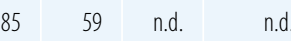

$67 \quad 48 \quad$ n.d. n.d.

Fuentes: Secretaría de la OMC

Corrientes comerciales (millones de \$EE.UU. corrientes)
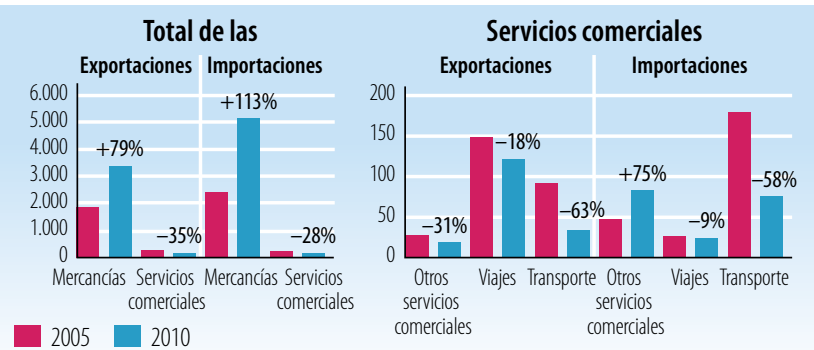

Fuentes: Secretaría de la OMC

Cinco principales mercados de exportación de mercancías (\%)

\begin{tabular}{|l|r|l|c|}
\hline 2005 & $\%$ & 2010 & $\%$ \\
\hline Sudáfrica & 41 & Sudáfrica & 54 \\
\hline UE (27) & 17 & UE (27) & 11 \\
\hline Estados Unidos & 7 & Emiratos Árabes Unidos & 10 \\
\hline Suiza & 6 & China & 7 \\
\hline Zambia & 6 & Mozambique & 3 \\
\hline
\end{tabular}

Fuentes: Secretaría de la OMC

Cinco principales productos de exportación (\% de las exportaciones de mercancías)

\begin{tabular}{l|r|l|l|}
\hline $\mathbf{2 0 0 5}$ & $\%$ & $\mathbf{2 0 1 0}$ & $\%$ \\
\hline $\begin{array}{l}\text { Oro no monetario, excepto minerales } \\
\text { Tabaco sin elaborar }\end{array}$ & 15 & $\begin{array}{l}\text { Minerales de níquel y sus concentrados, } \\
\text { y matas de níquel }\end{array}$ & 22 \\
\hline $\begin{array}{l}\text { Minerales de níquel y sus concentrados, } \\
\text { y matas de níquel }\end{array}$ & 14 & Impresos & 17 \\
\hline $\begin{array}{l}\text { Arrabio, fundición especular, etc. } \\
\text { Impresos }\end{array}$ & 9 & Oro no monetario, excepto minerales & 9 \\
\hline laborar & Abrasivos naturales, n.e.p. & 7
\end{tabular}

Fuentes: Secretaría de la OMC

Cinco principales mercados de importación de mercancías (\%)

\begin{tabular}{|l|r|l|r|}
\hline 2005 & $\%$ & 2010 & $\%$ \\
\hline Zambia & 41 & Sudáfrica & 50 \\
\hline Sudáfrica & 15 & Estados Unidos & 9 \\
\hline Mozambique & 10 & UE (27) & 8 \\
\hline UE (27) & 7 & China & 6 \\
\hline Botswana & 5 & Emiratos Árabes Unidos & 5 \\
\hline
\end{tabular}

Fuentes: Secretaría de la OMC

Cinco principales productos de importación (\% de las importaciones de mercancías)

\begin{tabular}{|l|r|l|c|}
\hline 2005 & $\%$ & 2010 & $\%$ \\
\hline Cobre & 22 & $\begin{array}{l}\text { Minerales de níquel y sus concentrados, } \\
\text { y matas de níquel }\end{array}$ & 10 \\
\hline Corriente eléctrica & 9 & Productos derivados del petróleo & 9 \\
\hline Minerales de cobre y sus concentrados & 9 & Impresos & 6 \\
\hline Diversos metales comunes no ferrosos & 6 & Tabaco sin elaborar & 6 \\
\hline Productos derivados del petróleo & 6 & $\begin{array}{l}\text { Vehículos automotores para pasajeros, } \\
\text { excepto autobuses }\end{array}$ & 5 \\
\hline
\end{tabular}

Fuentes: Secretaría de la OMC 


\section{LA AYUDA PARA EL COMERCIO EN SIINTESIS 2013}

\section{INDICADORES COMERCIALES (RESULTADOS)}

Indicador

Crecimiento del PIB (\%)

Número de exportadores

Índice de concentración de las exportaciones (productos) (0 a 1)

ACR sobre mercancías notificados a la OMC

AIE (servicios) notificados a la OMC

Sectores de servicios con compromisos en el marco del AGCS

\section{Aranceles (\%)}

Importaciones: promedio aritmético de los aranceles NMF aplicados n.d. $\quad 15,9$

Importaciones: promedio ponderado de los aranceles NMF aplicados n.d. $\quad 15,4$

\begin{tabular}{ll|l|l|} 
Exportaciones: promedio ponderado de los aranceles impuestos & n.d. & 1,4
\end{tabular}

por los importadores

Exportaciones: libres de derechos (en \%)

n.d. $\quad 76,4$

Fuentes: Naciones Unidas, base de datos Comtrade; Banco Mundial, base de datos sobre dinámica de las empresas de exportación; Banco Mundial, Indicadores del Desarrollo Mundial; OMC, perfiles comerciales y arancelarios.

Participación en las exportaciones por región (\%)

\begin{tabular}{|l|r|r|}
\hline & 2005 & 2011 \\
\hline África & 58,6 & 64,7 \\
\hline Asia & 8,1 & 11,6 \\
\hline Comunidad de Estados Independientes & 1,2 & 0,2 \\
\hline Europa & 23,6 & 11,9 \\
\hline Oriente Medio & 1,2 & 10,6 \\
\hline América del Norte & 7,0 & 1,0 \\
\hline América del Sury América Central & 0,2 & 0,1 \\
\hline
\end{tabular}

Fuentes: OMC, perfiles comerciales y arancelarios

Indicadores de facilitación del comercio
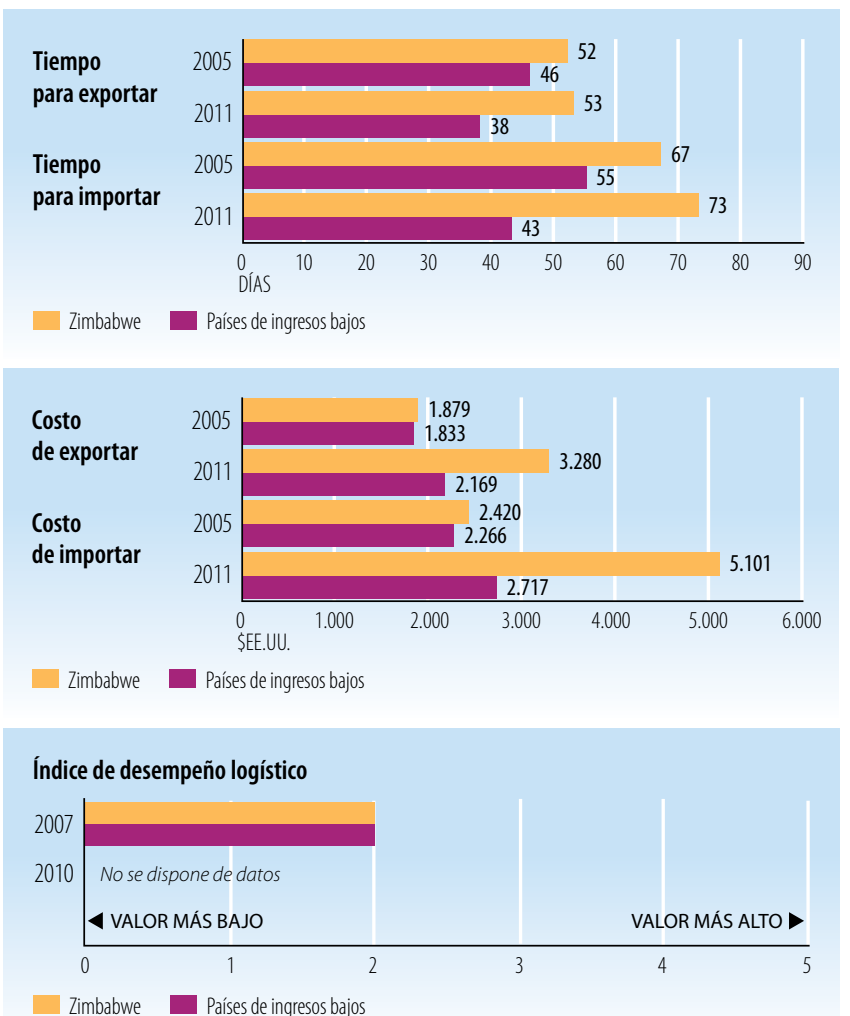

Fuentes: Banco Mundial, Indicadores del Desarrollo Mundial.

\begin{tabular}{|l|c|c|}
\hline INDICADORES DE DESARROLLO (EFECTOS) & \\
\hline Indicador & $\mathbf{2 0 0 5}$ & $\mathbf{2 0 1 0}$ \\
\hline Desempleo (\% de la fuerza de trabajo total) & n.d. & n.d. \\
\hline Población activa, mujeres (\% de la fuerza de trabajo total) & 48,8 & 49,3 \\
\hline AOD neta recibida (\% del INB) & 6,8 & 10,1 \\
\hline Derechos de importación percibidos (\% de los ingresos fiscales) & n.d. & n.d. \\
\hline Total del servicio de la deuda (\% de las exportaciones totales) & n.d. & n.d. \\
\hline Índice de desarrollo humano (0 a 1) & 0,35 & 0,36 \\
\hline
\end{tabular}

Fuentes: PNUD, indicadores internacionales sobre desarrollo humano; Banco Mundial, Indicadores del Desarrollo Mundial.

Producto interno bruto

PIB per cápita (PPA, dólares internacionales corrientes)

Variación porcentual entre 2005 y $2011 \quad$ No se dispone de datos

$$
\begin{aligned}
& 2005 \text { No se dispone de datos } \\
& \text { Nose dispone de datos } \\
& 2011 \text { No se dispone de datos } \\
& \text { No se dispone de datos } \\
& \text { \$EE.UU. } \\
& \text { Zimbabwe Países de ingresos bajos }
\end{aligned}
$$

PIB per cápita (\$EE.UU. constantes de 2000)
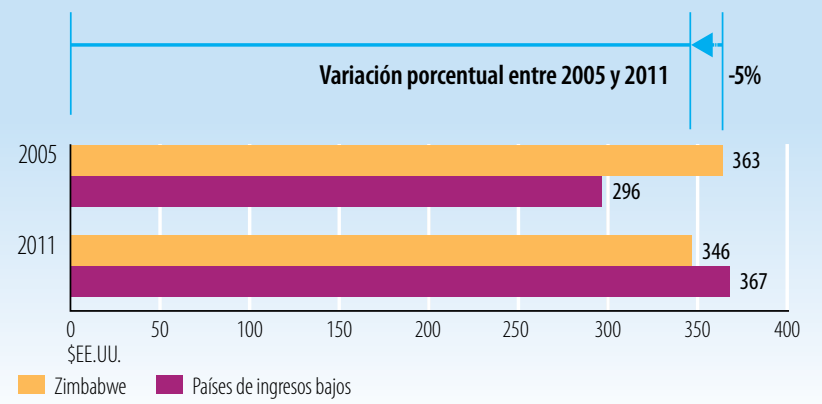

Fuentes: Banco Mundial, Indicadores del Desarrollo Mundial.

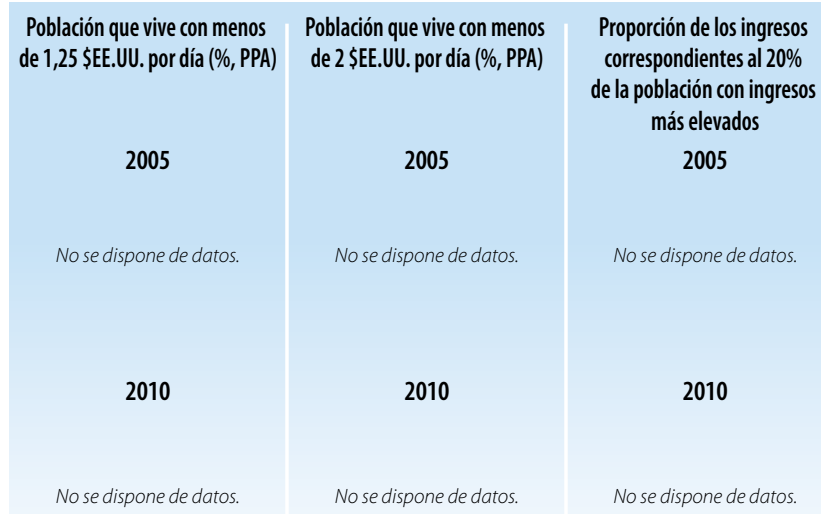

Fuentes: Banco Mundial, Indicadores del Desarrollo Mundial.

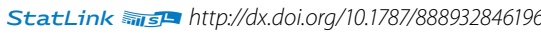





\section{NOTAS ESTADÍSTICAS RELATIVAS A LOS DATOS PRINCIPALES SOBRE LA AYUDA PARA EL COMERCIO}

Según el Equipo de Trabajo sobre la Ayuda para el Comercio de la OMC, los proyectos y programas deberán considerarse parte de la ayuda para el comercio siempre que hayan sido identificados como prioridades para el desarrollo relacionado con el comercio en las estrategias nacionales de desarrollo de los países asociados. Además, el Equipo de Trabajo de la OMC llegó a la conclusión de que, para medir las corrientes de ayuda para el comercio se debían tener en cuenta las siguientes categorías:

a) la asistencia técnica en relación con políticas y reglamentos comerciales: por ejemplo, la ayuda a los países para elaborar estrategias comerciales, negociar acuerdos comerciales y poner en práctica sus resultados;

b) la infraestructura relacionada con el comercio: por ejemplo, construcción de carreteras, puertos y redes de telecomunicaciones para conectar los mercados nacionales con la economía mundial;

c) la creación de capacidad productiva (con inclusión del fomento del comercio): por ejemplo, ayuda al sector privado para que aproveche sus ventajas comparativas y diversifique sus exportaciones;

d) el ajuste relacionado con el comercio: ayuda a los países en desarrollo en lo que respecta a los costos derivados de la liberalización del comercio, como las reducciones arancelarias, la erosión de las preferencias o el deterioro de la relación de intercambio; $y$

e) otras necesidades relacionadas con el comercio: si se identifican como prioridades para el desarrollo relacionado con el comercio en las estrategias nacionales de desarrollo de los países asociados.

Se reconoció que la base de datos sobre las actividades de ayuda del CAD de la OCDE (SNPA) -base de datos que abarca el 90\% aproximadamente de toda la AOD- era la mejor fuente de datos disponible para realizar un seguimiento de las corrientes mundiales de ayuda para el comercio. El SNPA, que fue establecido en 1967, recopila información sobre la asistencia oficial para el desarrollo (AOD) y otras corrientes oficiales dirigidas a los países en desarrollo. Constituye una fuente de datos reconocida internacionalmente sobre las actividades de ayuda (desglosadas por regiones geográficas y sectores) y es ampliamente utilizado por los gobiernos, las organizaciones y los investigadores que se ocupan del desarrollo. La OCDE utiliza el SNPA para vigilar determinadas cuestiones de política, incluida la ayuda para el comercio. El SNPA permite realizar un seguimiento de los compromisos y desembolsos de ayuda y proporciona datos comparables a lo largo del tiempo y entre países. La utilización de esta base de datos ha permitido ahorrar tiempo y recursos considerables en el seguimiento efectivo de las corrientes de ayuda para el comercio. Las políticas y directrices para la notificación al SNPA son aprobadas por los miembros del CAD representados en el Grupo de Trabajo sobre Estadísticas del Comité. La OCDE recopila y coteja los datos, verifica su compatibilidad y mantiene al día la base de datos.

Hay que tener presente que los datos que proporciona el SNPA no encuadran exactamente en las categorías de ayuda para el comercio indicadas precedentemente. De hecho, el SNPA proporciona indicadores indirectos en relación con los cuatro epígrafes siguientes:

Políticas y reglamentos comerciales. En el SNPA se utilizan cinco códigos para clasificar las actividades relacionadas con las políticas y los reglamentos comerciales según el sector al que se destinan las fuentes. Esos códigos corresponden a las cinco subcategorías siguientes: política comercial y gestión administrativa; facilitación del comercio; acuerdos comerciales regionales; negociaciones comerciales Donantes multilateraleses; y enseñanza/ formación comercial. 
Infraestructura económica. En el SNPA, los datos que figuran bajo el epígrafe "Infraestructura y servicios económicos" son datos indirectos sobre los compromisos en materia de ayuda para infraestructura relacionada con el comercio. Ese epígrafe incluye datos sobre transporte y almacenamiento; comunicaciones; y generación y suministro de energía.

- Creación de capacidad productiva (incluido el fomento del comercio). El SNPA contiene información completa sobre todas las actividades de los sectores de producción y de servicios, como la agricultura; la industria; los recursos minerales y la minería; los servicios a las empresas; y los servicios bancarios. Las actividades de fomento del comercio se identifican por medio del marcador de las políticas de fomento del comercio y se vienen identificando por separado en la serie de datos del SNPA desde 2007. Esas actividades forman una subcategoría de las actividades de creación de capacidad productiva y se clasifican según contribuyan de manera principal o de manera importante al fomento del comercio. Sin embargo, a la hora de presentar la información, algunos donantes pueden tener dificultades para identificar las actividades de ayuda que incluyen un componente de comercio definido. Esto puede menoscabar la exactitud de esos datos; de ahí que las cuantías incluidas en relación con el fomento del comercio constituyan, en el mejor de los casos, una aproximación.

- Ajuste relacionado con el comercio. Se introdujo en el SNPA en 2007 para realizar un seguimiento de las corrientes de ayuda destinadas al ajuste relacionado con el comercio. Esta categoría abarca las contribuciones a los presupuestos de los países en desarrollo destinadas a ayudarlos a aplicar reformas comerciales y hacer ajustes en relación con las medidas de política comercial adoptadas por otros países, así como a aliviar los déficits de la balanza de pagos ocasionados por cambios en el entorno comercial mundial.

El SNPA abarca toda la AOD, pero sólo identifica como ayuda para el comercio las actividades notificadas en el marco de las cuatro categorías indicadas precedentemente. No es posible distinguir actividades en el contexto de "Otras necesidades relacionadas con el comercio". Para estimar el volumen de estas "otras" actividades, los donantes tendrían que examinar proyectos de ayuda en sectores distintos de los considerados hasta ahora, por ejemplo en materia de salud y educación, e indicar, en su caso, qué proporción de esas actividades tiene un componente importante relacionado con el comercio. Un programa de salud, por ejemplo, podría dar lugar a un aumento del comercio en lugares donde la tasa de morbilidad anteriormente constituía un obstáculo para el comercio. Por consiguiente, para una vigilancia rigurosa de la ayuda para el comercio habría que comparar los datos del SNPA con las autoevaluaciones de esa ayuda por los donantes y los países asociados.

\section{Notas a los cuadros con los datos principales sobre la ayuda para el comercio}

La mayor parte de los datos que figuran en el Anexo A se han tomado del SNPA. La serie completa de datos del SNPA se puede consultar en el sitio Web siguiente:

\section{www.oecd.org/dac/stats/idsonline}

Los datos demográficos necesarios para elaborar los cuadros A6.A y A6.B se han obtenido del Banco Mundial (Indicadores del Desarrollo Mundial).

La expresión "otros tipos de ayuda" (cuadros A.11, A.12 y A.13B) incluye los préstamos de AOD y la inversión en acciones de empresas (es decir, una inversión en un país incluido en la Lista de receptores de AOD del CAD no destinada a adquirir una participación duradera en una empresa). 


\section{Proveedores de ayuda:}

La lista de proveedores de ayuda se divide en países miembros del CAD, otros donantes bilaterales y organizaciones Donantes multilateraleses. El nombre completo de las organizaciones Donantes multilateraleses figura en la sección "Siglas y abreviaturas".

Corea ingresó en el CAD en 2010. Las corrientes de ayuda comenzaron a notificar oficialmente a partir de 2009. Los datos de años anteriores pueden ser parciales.

Islandia y la República Checa ingresaron en el CAD en 2013. Las corrientes de ayuda comenzarán a notificarse oficialmente en los informes correspondientes a 2012. Los datos correspondientes a años anteriores figuran en "Otros donantes bilaterales".

Los datos obtenidos de la FAO, el FMI, el ITC, la CESPAP, la CESPAO, la OMC y Turquía abarcan información especializada sobre las corrientes de ayuda para el comercio desde 2007 y pueden, por ello, no reflejar la totalidad de la financiación destinada a la ayuda que presta cada uno de esos proveedores.

El BID modificó la metodología para la presentación de informes al SNPA, la metodología modificada comenzó a aplicarse en relación con las corrientes de ayuda correspondientes a 2009.

Los datos recopilados en relación con "Otros donantes Donantes multilateraleses" abarcan pequeñas cantidades apartadas por varios organismos Donantes multilateraleses. "Siglas y abreviaturas" figura una lista de esos organismos.

\section{Receptores de ayuda:}

Los cambios en la Lista de receptores de AOD del CAD son indicio del considerable aumento de la prosperidad mundial en los últimos decenios. Si se compara la lista actual con la Lista de 1970, se observa que sólo se han añadido 17 países, 11 de los cuales son antiguas repúblicas de la Unión Soviética. En cambio, 55 países han salido de la lista, fundamentalmente como resultado del aumento de los ingresos per cápita. La tendencia al aumento de los ingresos ha continuado a pesar de la crisis financiera. En la revisión más reciente de la lista, realizada en 2011, cinco países salieron de la lista y 25 de los que siguieron estando en ella pasaron a una categoría de ingresos más alta, mientras que sólo dos bajaron de categoría.

La Lista de receptores de AOD del CAD, figura en los Anexos B y C. Para ver los países incluidos en la Lista del CAD y sacados de ella a lo largo del tiempo, consúltese el siguiente sitio Web: $\boldsymbol{w} w \boldsymbol{w}$.oecd.org/dac/stats/daclist

\section{Canales de suministro:}

La lista que figura en el cuadro A.14 contiene los principales canales de suministro del SNPA. La lista completa correspondiente a cada categoría (actualizada en junio de 2012) se puede consultar en el siguiente sitio Web:

\section{www.oecd.org/dac/stats/methodology}

La categoría "Otros" abarca canales de suministro como las universidades, las facultades y otras instituciones docentes, institutos de investigación o grupos de análisis.

\section{Leyenda:}

El signo ".." indica que no se ha notificado ninguna actividad.

0,0 indica cantidades inferiores a 0,5 millones de dólares EE.UU. 



\section{ANEXO A}

\section{AYUDA PARA EL COMERCIO: DATOS PRINCIPALES}

\section{CUADRO A.1 Ayuda para el comercio, por categoría}

\begin{tabular}{|c|c|c|c|c|c|c|c|c|c|}
\hline & \multicolumn{5}{|c|}{ COMPROMISOS } & \multicolumn{4}{|c|}{ DESEMBOLSOS } \\
\hline & $\begin{array}{l}\text { Promedio } \\
2002-05\end{array}$ & $\begin{array}{c}\text { Promedio } \\
2006-08\end{array}$ & 2009 & 2010 & 2011 & $\begin{array}{l}\text { Promedio } \\
2006-08\end{array}$ & 2009 & 2010 & 2011 \\
\hline \multicolumn{10}{|c|}{ POLÍTICA Y REGLAMENTACIÓN COMERCIALES } \\
\hline $\begin{array}{l}\text { Política comercial y } \\
\text { gestión administrativa }\end{array}$ & 624,5 & 719,0 & 822,6 & 662,0 & 696,7 & 519,1 & 502,6 & 691,4 & 532,7 \\
\hline Facilitación del comercio & 81,8 & 202,4 & 339,1 & 421,9 & 381,1 & 129,4 & 158,7 & 347,5 & 259,3 \\
\hline Acuerdos comerciales regionales & 81,1 & 132,1 & 310,2 & 323,7 & 180,4 & 73,0 & 188,0 & 125,8 & 124,8 \\
\hline $\begin{array}{l}\text { Negociaciones comerciales Donantes } \\
\text { multilateraleses }\end{array}$ & 16,6 & 45,0 & 27,2 & 18,5 & 15,9 & 27,3 & 49,3 & 33,3 & 30,4 \\
\hline $\begin{array}{l}\text { Educación/formación en la esfera } \\
\text { del comercio }\end{array}$ & 11,0 & 35,7 & 38,5 & 37,2 & 39,3 & 24,5 & 32,9 & 39,8 & 35,4 \\
\hline TOTAL PARCIAL & 815,0 & $1.134,2$ & $1.537,6$ & $1.463,4$ & $1.313,3$ & 773,3 & 931,5 & $1.237,7$ & 982,5 \\
\hline \multicolumn{10}{|l|}{ Infraestructura económica } \\
\hline Transporte y almacenamiento & $7.472,9$ & $10.774,4$ & $14.750,5$ & $15.138,9$ & $11.590,3$ & $6.962,5$ & $8.972,4$ & $10.451,4$ & $10.164,9$ \\
\hline Comunicaciones & 688,5 & 543,4 & 709,9 & 468,7 & 617,5 & 532,0 & 600,7 & 571,0 & 505,6 \\
\hline Generación y suministro de energía & $5.956,8$ & $7.409,6$ & $7.992,1$ & $13.004,3$ & $9.750,3$ & $5.102,9$ & $5.550,5$ & $7.773,5$ & $7.070,4$ \\
\hline TOTAL PARCIAL & $14.118,3$ & $18.727,4$ & $23.452,5$ & $28.612,0$ & $21.958,1$ & $12.597,4$ & $15.123,7$ & $18.795,8$ & $17.741,0$ \\
\hline \multicolumn{10}{|l|}{ Creación de capacidad productiva } \\
\hline Servicios a empresas y otros servicios & $1.432,9$ & $2.140,3$ & $1.834,1$ & $2.168,8$ & $2.217,6$ & $1.921,8$ & $1.623,3$ & $1.669,7$ & $1.599,6$ \\
\hline Servicios bancarios y financieros & $1.838,7$ & $2.604,6$ & $3.898,6$ & $2.870,7$ & $2.650,6$ & $2.261,6$ & $4.223,8$ & $2.597,5$ & $2.699,2$ \\
\hline Agricultura & $4.398,5$ & $6.288,8$ & $8.538,8$ & $8.835,2$ & $8.927,7$ & $4.421,5$ & $6.297,5$ & $7.190,7$ & $6.552,9$ \\
\hline Silvicultura & 631,7 & 773,3 & 675,6 & $1.174,3$ & $1.267,9$ & 615,7 & 747,9 & $1.083,9$ & 931,5 \\
\hline Pesca & 308,0 & 401,0 & 659,9 & 433,9 & 424,9 & 325,6 & 477,2 & 368,6 & 351,2 \\
\hline Industria & $1.981,2$ & $1.813,9$ & $1.712,8$ & $1.891,7$ & $2.208,6$ & $1.355,2$ & $1.349,4$ & $1.498,6$ & $2.060,1$ \\
\hline Industrias extractivas & 852,8 & 449,8 & 480,1 & 510,8 & 416,2 & 439,5 & 232,5 & 186,2 & 463,7 \\
\hline Turismo & 114,6 & 256,7 & 191,3 & 179,2 & 121,7 & 80,3 & 135,0 & 166,4 & 166,8 \\
\hline TOTAL PARCIAL & $11.558,4$ & $14.728,6$ & $17.991,2$ & $18.064,7$ & $18.235,3$ & $11.421,2$ & $15.086,6$ & $14.761,6$ & $14.825,0$ \\
\hline $\begin{array}{l}\text { AJUSTE RELACIONADO } \\
\text { CON EL COMERCIO }\end{array}$ & $"$ & 2,3 & 16,2 & 30,9 & 62,8 & 9,1 & 36,8 & 72,3 & 17,4 \\
\hline TOTAL & $26.491,7$ & $34.592,5$ & $42.997,4$ & $48.171,0$ & $41.569,6$ & $24.801,0$ & $31.178,5$ & $34.867,5$ & $33.565,9$ \\
\hline \multicolumn{10}{|l|}{ Ayuda centrada en el fomento del comercio } \\
\hline Objetivo principal & & $1.342,6$ & $2.044,9$ & $2.895,8$ & $2.255,1$ & $1.169,7$ & $1.391,9$ & $2.404,7$ & $2.628,0$ \\
\hline Objetivo importante & & $2.085,0$ & $2.733,3$ & $2.293,7$ & $3.135,4$ & 926,1 & $1.834,6$ & $2.184,1$ & $2.002,1$ \\
\hline $\begin{array}{l}\text { TOTAL DE LA AYUDA } \\
\text { PARA EL FOMENTO DEL COMERCIO }\end{array}$ & 73,1 & $3.427,6$ & $4.778,2$ & $5.189,5$ & $5.390,5$ & $2.095,8$ & $3.226,5$ & $4.588,9$ & $4.630,2$ \\
\hline
\end{tabular}


CUADRO A.2A Ayuda para el comercio, por donante y por categoría (página 1 de 2)

\begin{tabular}{|c|c|c|c|c|c|c|c|c|c|c|}
\hline & \multicolumn{5}{|c|}{ POLÍTICA Y REGLAMENTACIÓN COMERCIALES } & \multicolumn{5}{|c|}{ INFRAESTRUCTURA ECONÓMICA } \\
\hline & $\begin{array}{c}\text { Promedio } \\
2002-05\end{array}$ & $\begin{array}{c}\text { Promedio } \\
2006-08\end{array}$ & 2009 & 2010 & 2011 & $\begin{array}{l}\text { Promedio } \\
2002-05\end{array}$ & $\begin{array}{l}\text { Promedio } \\
2006-08\end{array}$ & 2009 & 2010 & 2011 \\
\hline \multicolumn{11}{|l|}{ Países miembros del CAD } \\
\hline Alemania & 15,7 & 37,9 & 47,9 & 44,6 & 20,3 & 615,6 & $1.000,6$ & $1.056,4$ & $3.083,1$ & $1.656,3$ \\
\hline Australia & 12,3 & 7,7 & 20,4 & 66,3 & 22,5 & 88,9 & 184,3 & 383,7 & 271,2 & 251,3 \\
\hline Austria & 0,1 & 1,5 & 0,1 & 0,1 & 0,2 & 26,3 & 21,0 & 32,8 & 28,2 & 28,6 \\
\hline Bélgica & 4,5 & 5,6 & 20,6 & 5,4 & 9,8 & 61,0 & 84,9 & 152,4 & 85,1 & 67,0 \\
\hline Canadá & 22,9 & 24,6 & 56,9 & 19,2 & 35,6 & 53,7 & 90,5 & 23,9 & 24,1 & 300,5 \\
\hline Corea & $"$ & 6,7 & 2,5 & 2,0 & 11,7 & $"$ & 378,3 & $1.061,5$ & 642,0 & 594,7 \\
\hline Dinamarca & 0,5 & 3,4 & 2,1 & 2,6 & 34,7 & 232,7 & 126,9 & 92,2 & 36,1 & 109,5 \\
\hline España & 1,6 & 5,1 & 3,8 & 6,7 & 1,6 & 268,6 & 494,2 & 464,2 & 458,9 & 13,1 \\
\hline Estados Unidos & 249,8 & 247,3 & 159,3 & 163,1 & 137,6 & $1.825,2$ & $2.964,5$ & $2.067,1$ & $2.591,9$ & $1.419,9$ \\
\hline Finlandia & 2,6 & 7,0 & 12,2 & 12,2 & 14,4 & 32,7 & 21,9 & 177,3 & 57,6 & 63,9 \\
\hline Francia & 4,9 & 3,1 & 2,9 & 2,2 & 0,2 & 408,0 & 955,9 & 821,0 & 834,1 & 776,9 \\
\hline Grecia & 0,4 & 0,7 & 0,7 & $"$ & $"$ & 8,3 & 9,0 & 10,3 & 19,3 & 20,7 \\
\hline Irlanda & 0,1 & 1,1 & 0,4 & $"$ & 0,6 & 7,6 & 2,9 & 0,9 & 1,5 & 1,9 \\
\hline Italia & 2,0 & 0,5 & 0,1 & 0,0 & 0,8 & 169,8 & 132,8 & 48,3 & 81,0 & 40,4 \\
\hline Japón & 64,7 & 68,7 & 27,4 & 87,1 & 88,7 & $4.774,2$ & $5.428,2$ & $5.543,6$ & $8.964,5$ & $6.422,5$ \\
\hline Luxemburgo & 0,2 & 0,4 & " & 2,6 & 1,7 & 1,3 & 6,4 & 0,9 & 2,6 & 4,7 \\
\hline Noruega & 12,2 & 34,0 & 18,4 & 11,5 & 16,8 & 126,7 & 204,9 & 297,3 & 193,4 & 320,9 \\
\hline Nueva Zelandia & 1,8 & 3,2 & 4,8 & 5,2 & 5,3 & 4,5 & 16,2 & 18,6 & 28,8 & 92,6 \\
\hline Países Bajos & 20,1 & 71,7 & 57,4 & 224,3 & 204,9 & 159,0 & 199,4 & 291,0 & 131,8 & 130,0 \\
\hline Portugal & 0,1 & 0,1 & 0,1 & 0,0 & 0,0 & 41,0 & 28,4 & 87,0 & 54,2 & 22,6 \\
\hline Reino Unido & 27,4 & 63,6 & 230,7 & 185,6 & 9,1 & 304,5 & 174,7 & 523,7 & 355,3 & 353,2 \\
\hline Suecia & 19,3 & 37,9 & 60,6 & 54,2 & 64,9 & 121,9 & 106,7 & 53,6 & 138,2 & 42,6 \\
\hline Suiza & 42,4 & 19,4 & 39,6 & 27,8 & 47,1 & 45,6 & 53,4 & 19,5 & 84,9 & 44,2 \\
\hline TOTAL PARCIAL & 505,7 & 651,1 & 769,1 & 922,9 & 728,2 & $9.377,0$ & $12.685,7$ & $13.227,3$ & $18.167,8$ & $12.778,1$ \\
\hline \multicolumn{11}{|l|}{ Otros donantes bilaterales } \\
\hline Emiratos Árabes Unidos & $"$ & $"$ & $"$ & $"$ & $"$ & $"$ & $"$ & 509,2 & 211,9 & 191,6 \\
\hline Islandia & $"$ & $"$ & " & $"$ & $"$ & $"$ & $"$ & " & " & 2,8 \\
\hline Kuwait & $"$ & $"$ & $"$ & $"$ & $"$ & $"$ & $"$ & $"$ & 764,8 & 230,3 \\
\hline República Checa & $"$ & $"$ & 0,1 & 0,0 & $"$ & $"$ & $"$ & $"$ & " & 5,1 \\
\hline Turquía & $"$ & $"$ & 27,7 & 103,7 & $"$ & $"$ & $"$ & $"$ & 1,6 & " \\
\hline TOTAL PARCIAL & $"$ & $"$ & 27,8 & 103,8 & $"$ & $"$ & $"$ & 509,2 & 978,2 & 429,8 \\
\hline \multicolumn{11}{|l|}{ Donantes multilaterales } \\
\hline BADEA & " & $"$ & $"$ & " & $"$ & " & " & $"$ & $"$ & 65,9 \\
\hline BAfD & 25,5 & $"$ & " & $"$ & $"$ & 68,4 & 605,6 & $1.636,5$ & $1.703,5$ & 692,2 \\
\hline Banco Islámico de Desarrollo & " & $"$ & $"$ & 1,1 & $"$ & " & " & " & 49,3 & " \\
\hline Banco Mundial & 63,1 & 43,4 & 197,4 & 94,9 & 59,8 & $2.569,3$ & $2.665,0$ & $4.137,6$ & $3.421,6$ & $3.842,3$ \\
\hline $\mathrm{BAsD}$ & 9,5 & 2,0 & " & 26,6 & " & 404,0 & 327,0 & 706,2 & $1.170,6$ & $1.161,0$ \\
\hline BID & $"$ & 0,7 & 9,4 & 6,7 & 0,4 & 137,5 & 98,7 & 175,1 & 242,9 & 309,0 \\
\hline CEPE & $"$ & 0,3 & 0,0 & 0,1 & 0,2 & " & 1,0 & 5,3 & 3,4 & 2,6 \\
\hline CESPAP & $"$ & 0,1 & 0,4 & 0,4 & 0,4 & $"$ & $"$ & $"$ & " & " \\
\hline CESPAO & $"$ & 0,1 & 0,1 & $"$ & 0,1 & $"$ & 0,0 & 0,0 & 0,0 & 0,0 \\
\hline FADES & $"$ & " & " & $"$ & $"$ & $"$ & 323,2 & $1.013,6$ & $1.031,4$ & 994,1 \\
\hline FAO & $"$ & 21,3 & 42,9 & 47,3 & 44,4 & $"$ & " & " & " & " \\
\hline FIDA & $"$ & " & $"$ & $"$ & $"$ & 14,2 & 23,5 & 84,1 & 19,7 & 42,6 \\
\hline FMI & $"$ & 11,5 & 15,2 & 14,6 & 15,5 & " & " & " & " & " \\
\hline $\begin{array}{l}\text { Fondo para la Consolidación } \\
\text { de la Paz }\end{array}$ & $"$ & $"$ & $"$ & 0,5 & $"$ & $"$ & 3,1 & $"$ & $"$ & " \\
\hline Instituciones de la UE & 209,5 & 380,2 & 447,9 & 204,2 & 445,4 & $1.544,5$ & $1.987,1$ & $1.565,1$ & $1.337,1$ & $1.345,1$ \\
\hline ITC & " & " & " & " & " & " & " & " & " & " \\
\hline OMC & $"$ & 14,8 & 16,1 & 20,9 & 15,2 & $"$ & $"$ & $"$ & $"$ & " \\
\hline ONUDI & $"$ & 4,3 & 6,7 & 16,4 & 1,7 & $"$ & 1,4 & 18,9 & 2,1 & 6,5 \\
\hline PNUD & 1,7 & 3,5 & 4,7 & 3,1 & 2,0 & 2,4 & 5,9 & 11,8 & 9,5 & 8,4 \\
\hline PNUMA & $"$ & " & " & $"$ & $"$ & $"$ & $"$ & $"$ & " & " \\
\hline Otros donantes multilaterales & $"$ & 0,9 & $"$ & " & $"$ & 1,2 & $"$ & 361,6 & 474,9 & 280,4 \\
\hline TOTAL PARCIAL & 309,4 & 483,0 & 740,8 & 436,7 & 585,2 & $4.741,3$ & $6.041,7$ & $9.715,9$ & $9.465,9$ & $8.750,2$ \\
\hline TOTAL & 815,0 & $1.134,2$ & $1.537,6$ & $1.463,4$ & $1.313,3$ & $14.118,3$ & $18.727,4$ & $23.452,5$ & $28.612,0$ & $21.958,1$ \\
\hline
\end{tabular}


CUADRO A.2A Ayuda para el comercio, por donante y por categoría (página 2 de 2)

Compromisos, en millones de \$EE.UU. (dólares constantes de 2011)

\begin{tabular}{|c|c|c|c|c|c|c|c|c|c|c|c|c|c|c|}
\hline & \multicolumn{5}{|c|}{ CREACIÓN DE CAPACIDAD PRODUCTIVA } & \multicolumn{4}{|c|}{$\begin{array}{l}\text { AJUSTE RELACIONADO } \\
\text { CON EL COMERCIO }\end{array}$} & \multicolumn{5}{|c|}{ TOTAL } \\
\hline & $\begin{array}{c}\text { Promedio } \\
2002-05\end{array}$ & $\begin{array}{l}\text { Promedio } \\
2006-08\end{array}$ & 2009 & 2010 & 2011 & $\begin{array}{c}\text { Promedio } \\
2006-08\end{array}$ & 2009 & 2010 & 2011 & $\begin{array}{c}\text { Promedio } \\
2002-05\end{array}$ & $\begin{array}{l}\text { Promedio } \\
2006-08\end{array}$ & 2009 & 2010 & 2011 \\
\hline \multicolumn{15}{|c|}{ Países miembros del CAD } \\
\hline Alemania & 717,8 & $1.247,5$ & $1.568,2$ & $1.561,2$ & $2.052,5$ & " & " & " & " & $1.349,1$ & $2.286,0$ & $2.672,5$ & $4.688,9$ & $3.729,0$ \\
\hline Australia & 161,5 & 204,7 & 173,7 & 363,4 & 311,1 & 0,3 & $"$ & 1,1 & 0,3 & 262,7 & 397,1 & 577,8 & 701,9 & 585,1 \\
\hline Austria & 24,3 & 37,4 & 51,3 & 73,4 & 42,1 & $"$ & $"$ & " & $"$ & 50,8 & 59,8 & 84,3 & 101,7 & 70,9 \\
\hline Bélgica & 199,7 & 201,4 & 390,1 & 356,9 & 401,1 & $"$ & $"$ & " & $"$ & 265,2 & 291,9 & 563,1 & 447,4 & 477,9 \\
\hline Canadá & 327,0 & 327,3 & 486,0 & 706,0 & 401,1 & 0,1 & 0,1 & 0,1 & " & 403,5 & 442,5 & 567,0 & 749,3 & 737,2 \\
\hline Corea & $"$ & 74,6 & 69,9 & 108,6 & 152,0 & $"$ & " & " & " & 0,0 & 459,6 & $1.134,0$ & 752,6 & 758,5 \\
\hline Dinamarca & 247,8 & 183,1 & 271,2 & 342,1 & 158,3 & $"$ & $"$ & $"$ & " & 481,0 & 313,3 & 365,6 & 380,9 & 302,6 \\
\hline España & 170,9 & 300,5 & 461,6 & 941,0 & 628,9 & $"$ & $"$ & $"$ & " & 441,0 & 799,7 & 929,6 & $1.406,5$ & 643,6 \\
\hline Estados Unidos & $1.876,0$ & $2.368,5$ & $2.429,1$ & $3.182,5$ & $2.056,4$ & $"$ & $"$ & " & $"$ & $3.951,0$ & $5.580,3$ & $4.655,6$ & $5.937,5$ & $3.613,8$ \\
\hline Finlandia & 52,0 & 112,5 & 179,0 & 209,5 & 240,5 & $"$ & $"$ & $"$ & 10,7 & 87,3 & 141,4 & 368,5 & 279,4 & 329,5 \\
\hline Francia & 392,4 & 744,9 & 728,5 & 970,5 & 506,9 & $"$ & $"$ & $"$ & " & 805,2 & $1.703,9$ & $1.552,4$ & $1.806,9$ & $1.284,0$ \\
\hline Grecia & 5,9 & 12,0 & 7,5 & 1,3 & 0,4 & $"$ & $"$ & $"$ & $"$ & 14,7 & 21,7 & 18,5 & 20,5 & 21,2 \\
\hline Irlanda & 21,9 & 43,7 & 59,0 & 66,5 & 67,6 & $"$ & $"$ & $"$ & $"$ & 29,6 & 47,7 & 60,3 & 68,0 & 70,1 \\
\hline Italia & 119,5 & 132,9 & 230,5 & 103,2 & 47,6 & $"$ & $"$ & $"$ & $"$ & 291,3 & 266,2 & 278,9 & 184,2 & 88,9 \\
\hline Japón & $1.226,0$ & $2.192,9$ & $1.244,4$ & $1.084,2$ & $1.387,7$ & $"$ & $"$ & $"$ & 0,4 & $6.064,9$ & $7.689,8$ & $6.815,4$ & $10.135,8$ & $7.899,3$ \\
\hline Luxemburgo & 17,9 & 29,0 & 33,4 & 34,5 & 34,6 & $"$ & $"$ & $"$ & " & 19,4 & 35,8 & 34,3 & 39,8 & 41,0 \\
\hline Noruega & 214,7 & 344,6 & 584,2 & 847,3 & 750,4 & $"$ & $"$ & $"$ & $"$ & 353,6 & 583,5 & 899,8 & $1.052,2$ & $1.088,0$ \\
\hline Nueva Zelandia & 16,5 & 26,6 & 13,6 & 36,5 & 89,1 & $"$ & $"$ & " & $"$ & 22,8 & 46,0 & 36,9 & 70,6 & 187,1 \\
\hline Países Bajos & 445,3 & 538,5 & 337,4 & 241,4 & 847,0 & " & $"$ & " & $"$ & 624,5 & 809,6 & 685,8 & 597,5 & $1.181,9$ \\
\hline Portugal & 8,3 & 3,9 & 6,2 & 2,9 & 3,1 & $"$ & $"$ & $"$ & $"$ & 49,4 & 32,4 & 93,3 & 57,1 & 25,8 \\
\hline Reino Unido & 410,1 & 689,7 & $1.250,7$ & 470,3 & 425,4 & $"$ & $"$ & $"$ & $"$ & 742,0 & 928,0 & $2.005,1$ & $1.011,2$ & 787,6 \\
\hline Suecia & 126,8 & 243,8 & 299,4 & 229,5 & 238,1 & $"$ & $"$ & " & 2,6 & 268,1 & 388,5 & 413,6 & 421,8 & 348,1 \\
\hline Suiza & 250,5 & 229,3 & 172,1 & 228,5 & 342,8 & $"$ & $"$ & $"$ & 5,8 & 338,6 & 302,1 & 231,3 & 341,2 & 439,8 \\
\hline TOTAL PARCIAL & $7.033,0$ & $10.289,3$ & $11.047,2$ & $12.161,0$ & $11.184,8$ & 0,4 & 0,1 & 1,1 & 19,8 & $16.915,7$ & $23.626,6$ & $25.043,6$ & $31.252,9$ & $24.710,8$ \\
\hline \multicolumn{15}{|l|}{ Otros donantes bilaterales } \\
\hline Emiratos Árabes Unidos & " & $"$ & 0,6 & 0,9 & $"$ & $"$ & $"$ & $"$ & " & $"$ & $"$ & 509,9 & 212,8 & 191,6 \\
\hline Islandia & $"$ & $"$ & " & " & 5,0 & $"$ & $"$ & $"$ & $"$ & $"$ & $"$ & $"$ & " & 7,8 \\
\hline Kuwait & $"$ & $"$ & $"$ & 29,0 & 23,1 & $"$ & $"$ & $"$ & $"$ & $"$ & $"$ & $"$ & 793,8 & 253,4 \\
\hline República Checa & $"$ & $"$ & $"$ & 0,1 & 7,3 & $"$ & $"$ & " & $"$ & $"$ & $"$ & 0,1 & 0,2 & 12,5 \\
\hline Turquía & $"$ & $"$ & 3,0 & 6,1 & " & $"$ & $"$ & $"$ & $"$ & $"$ & $"$ & 30,7 & 111,4 & " \\
\hline TOTAL PARCIAL & $"$ & $"$ & 3,7 & 36,1 & 35,4 & $"$ & $"$ & $"$ & $"$ & $"$ & $"$ & 540,7 & $1.118,1$ & 465,2 \\
\hline \multicolumn{15}{|l|}{ Donantes multilaterales } \\
\hline BADEA & " & $"$ & $"$ & $"$ & 16,8 & $"$ & $"$ & " & " & $"$ & $"$ & $"$ & $"$ & 82,7 \\
\hline BAfD & 72,2 & 188,5 & 672,8 & 66,9 & 232,8 & $"$ & $"$ & $"$ & $"$ & 166,2 & 794,0 & $2.309,3$ & $1.770,4$ & 925,1 \\
\hline Banco Islámico de Desarrollo & $"$ & $"$ & $"$ & 140,0 & $"$ & $"$ & $"$ & " & " & $"$ & $"$ & " & 190,4 & " \\
\hline Banco Mundial & $2.402,3$ & $2.032,5$ & $2.794,0$ & $2.168,9$ & $3.455,5$ & " & $"$ & 6,5 & " & $5.034,7$ & $4.740,8$ & $7.129,0$ & $5.691,8$ & $7.357,6$ \\
\hline BAsD & 428,6 & 256,5 & 195,1 & 398,3 & 289,7 & $"$ & " & " & " & 842,1 & 585,4 & 901,3 & $1.595,5$ & $1.450,7$ \\
\hline BID & 135,3 & 25,2 & 71,0 & 147,7 & 175,7 & $"$ & $"$ & $"$ & " & 272,8 & 124,7 & 255,5 & 397,2 & 485,1 \\
\hline CEPE & " & 0,1 & 0,4 & 0,9 & 1,2 & $"$ & $"$ & $"$ & $"$ & $"$ & 1,5 & 5,7 & 4,3 & 4,0 \\
\hline CESPAP & " & 0,2 & 0,1 & " & 0,4 & $"$ & " & " & $"$ & $"$ & 0,4 & 0,5 & 0,4 & 0,8 \\
\hline CESPAO & " & $"$ & 0,1 & 0,3 & 0,2 & $"$ & $"$ & $"$ & $"$ & $"$ & 0,1 & 0,2 & 0,3 & 0,3 \\
\hline FADES & $"$ & 111,5 & 51,5 & 174,6 & 181,3 & $"$ & $"$ & $"$ & " & $"$ & 434,7 & $1.065,1$ & $1.206,0$ & $1.175,3$ \\
\hline FAO & $"$ & 126,4 & 267,1 & 263,9 & 247,7 & $"$ & $"$ & $"$ & $"$ & " & 147,8 & 310,0 & 311,2 & 292,2 \\
\hline FIDA & 287,3 & 398,7 & 444,0 & 602,4 & 745,3 & $"$ & $"$ & " & $"$ & 301,5 & 422,2 & 528,1 & 622,1 & 788,0 \\
\hline FMI & " & " & " & " & " & $"$ & " & " & " & " & 11,5 & 15,2 & 14,6 & 15,5 \\
\hline $\begin{array}{l}\text { Fondo para la Consolidación } \\
\text { de la Paz }\end{array}$ & $"$ & 0,6 & 0,3 & 2,8 & 0,4 & $"$ & $"$ & " & $"$ & $"$ & 3,7 & 0,3 & 3,3 & 0,4 \\
\hline Instituciones de la UE & $1.190,2$ & $1.223,1$ & $2.178,6$ & $1.559,9$ & $1.353,3$ & 1,9 & 16,1 & 23,3 & 43,0 & $2.944,2$ & $3.592,4$ & $4.207,7$ & $3.124,5$ & $3.186,8$ \\
\hline ITC & $"$ & 33,7 & 56,5 & 59,7 & 64,7 & $"$ & $"$ & " & $"$ & $"$ & 33,7 & 56,5 & 59,7 & 64,7 \\
\hline OMC & $"$ & " & " & " & " & $"$ & $"$ & $"$ & $"$ & $"$ & 14,8 & 16,1 & 20,9 & 15,2 \\
\hline ONUDI & $"$ & 24,6 & 89,0 & 25,0 & 39,7 & $"$ & $"$ & $"$ & $"$ & $"$ & 30,3 & 114,6 & 43,5 & 47,9 \\
\hline PNUD & 9,3 & 17,7 & 29,7 & 22,0 & 20,8 & $"$ & $"$ & $"$ & $"$ & 13,4 & 27,1 & 46,2 & 34,7 & 31,2 \\
\hline PNUMA & " & $"$ & $"$ & " & " & $"$ & $"$ & $"$ & $"$ & " & " & " & " & $"$ \\
\hline Otros donantes multilaterales & $"$ & $"$ & 90,2 & 234,4 & 189,6 & $"$ & $"$ & $"$ & $"$ & 1,2 & 0,9 & 451,8 & 709,3 & 470,1 \\
\hline TOTAL PARCIAL & $4.525,3$ & $4.439,3$ & $6.940,4$ & $5.867,6$ & $7.015,1$ & 1,9 & 16,1 & 29,8 & 43,0 & $9.576,0$ & $10.965,9$ & $17.413,2$ & $15.800,0$ & $16.393,6$ \\
\hline TOTAL & $11.558,4$ & $14.728,6$ & $17.991,2$ & $18.064,7$ & $18.235,3$ & 2,3 & 16,2 & 30,9 & 62,8 & $26.491,7$ & $34.592,5$ & $42.997,4$ & $48.171,0$ & $41.569,6$ \\
\hline
\end{tabular}


CUADRO A.2B Ayuda para el comercio, por donante y por categoría (página 1 de 2)

\begin{tabular}{|c|c|c|c|c|c|c|c|c|}
\hline & \multicolumn{8}{|c|}{ Desembolsos, en millones de \$EE.UU. (dólares constantes de 2011) } \\
\hline & \multicolumn{4}{|c|}{ POLÍTICA Y REGLAMENTACIÓN COMERCIALES } & \multicolumn{4}{|c|}{ INFRAESTRUCTURA ECONÓMICA } \\
\hline & $\begin{array}{c}\text { Promedio } \\
2006-08\end{array}$ & 2009 & 2010 & 2011 & $\begin{array}{c}\text { Promedio } \\
2006-08\end{array}$ & 2009 & 2010 & 2011 \\
\hline \multicolumn{9}{|l|}{ Países miembros del CAD } \\
\hline Alemania & 27,1 & 30,0 & 39,0 & 24,1 & 687,2 & 920,1 & $1.680,9$ & $1.517,4$ \\
\hline Australia & 7,2 & 9,8 & 13,6 & 22,5 & 134,1 & 203,9 & 217,0 & 251,3 \\
\hline Austria & 1,4 & 0,2 & 0,1 & 0,2 & 10,5 & 13,8 & 14,1 & 23,3 \\
\hline Bélgica & 4,3 & 10,2 & 8,2 & 12,6 & 36,9 & 103,6 & 82,0 & 97,6 \\
\hline Canadá & 18,2 & 39,8 & 35,5 & 36,7 & 57,7 & 53,5 & 64,9 & 331,1 \\
\hline Corea & 9,2 & 10,3 & 2,2 & 11,3 & 128,5 & 208,8 & 281,2 & 327,7 \\
\hline Dinamarca & 0,8 & 0,2 & 7,9 & 3,4 & 149,5 & 140,8 & 122,4 & 171,8 \\
\hline España & 4,9 & 3,9 & 5,3 & 1,7 & 303,4 & 654,7 & 426,3 & 161,8 \\
\hline Estados Unidos & 139,1 & 174,7 & 171,9 & 162,1 & $1.973,3$ & $1.752,3$ & $1.913,7$ & $1.795,5$ \\
\hline Finlandia & 5,9 & 6,4 & 7,8 & 8,8 & 14,5 & 20,9 & 45,2 & 45,2 \\
\hline Francia & 2,6 & 3,8 & 5,7 & 3,9 & 408,8 & 527,5 & 615,3 & 783,9 \\
\hline Grecia & 0,7 & 0,7 & $" \prime$ & $"$ & 9,0 & 10,3 & 19,3 & 20,7 \\
\hline Irlanda & 1,1 & 0,4 & $"$ & 0,6 & 2,9 & 0,9 & 1,5 & 1,9 \\
\hline Italia & 0,3 & 0,3 & 0,0 & 0,8 & 168,3 & 65,9 & 89,9 & 76,7 \\
\hline Japón & 65,0 & 20,0 & 92,7 & 88,7 & $3.901,2$ & $4.303,0$ & $5.598,8$ & $4.698,6$ \\
\hline Luxemburgo & 0,4 & " & 2,6 & 1,7 & 6,4 & 0,9 & 2,6 & 4,7 \\
\hline Noruega & 21,8 & 25,9 & 23,3 & 18,2 & 266,5 & 120,0 & 194,2 & 280,6 \\
\hline Nueva Zelandia & 2,6 & 4,3 & 1,9 & 3,3 & 8,4 & 22,5 & 15,2 & 31,8 \\
\hline Países Bajos & 51,2 & 58,8 & 65,5 & 70,3 & 134,5 & 170,2 & 112,3 & 173,2 \\
\hline Portugal & 0,1 & 0,1 & 0,0 & 0,0 & 37,0 & 26,4 & 88,8 & 53,2 \\
\hline Reino Unido & 49,2 & 80,1 & 222,4 & 73,8 & 147,6 & 320,9 & 453,0 & 495,0 \\
\hline Suecia & 30,5 & 58,6 & 43,4 & 48,6 & 105,0 & 104,7 & 99,3 & 99,4 \\
\hline Suiza & 27,4 & 32,7 & 20,9 & 20,2 & 45,9 & 27,6 & 35,8 & 34,2 \\
\hline TOTAL PARCIAL & 471,3 & 571,2 & 769,9 & 613,6 & $8.737,0$ & $9.773,2$ & $12.173,6$ & $11.476,7$ \\
\hline \multicolumn{9}{|l|}{ Otros donantes bilaterales } \\
\hline Emiratos Árabes Unidos & $"$ & $"$ & $"$ & $"$ & $"$ & 218,7 & 69,4 & 109,4 \\
\hline Islandia & $"$ & $"$ & $"$ & $"$ & $"$ & $"$ & $"$ & 2,8 \\
\hline Kuwait & $"$ & " & $"$ & " & $"$ & $"$ & 434,7 & 331,9 \\
\hline República Checa & " & " & 0,0 & $"$ & " & " & $"$ & 5,0 \\
\hline Turquía & $"$ & 27,7 & 103,7 & $"$ & $"$ & $"$ & 1,6 & " \\
\hline TOTAL PARCIAL & $"$ & 27,7 & 103,8 & $"$ & $"$ & 218,7 & 505,7 & 449,0 \\
\hline \multicolumn{9}{|l|}{ Donantes multilaterales } \\
\hline BADEA & " & $"$ & $"$ & $"$ & $"$ & $"$ & $"$ & 32,1 \\
\hline BAfD & 0,4 & 2,0 & $"$ & $"$ & 198,7 & 462,0 & 581,8 & 806,3 \\
\hline Banco Islámico de Desarrollo & $"$ & $"$ & $"$ & " & $"$ & $"$ & $"$ & " \\
\hline Banco Mundial & 33,1 & 57,7 & 45,5 & 80,9 & $1.962,4$ & $2.360,1$ & $2.199,1$ & $2.075,8$ \\
\hline BAsD & $"$ & $"$ & 6,8 & 4,0 & $"$ & " & 594,2 & 525,1 \\
\hline $\mathrm{BID}$ & $"$ & 5,1 & 4,9 & 6,6 & " & 177,7 & 214,6 & 284,5 \\
\hline CEPE & 0,3 & 0,0 & 0,1 & 0,2 & 1,0 & 5,3 & 3,4 & 2,6 \\
\hline CESPAP & 0,1 & 0,4 & 0,4 & 0,3 & " & $"$ & $"$ & " \\
\hline CESPAO & 0,1 & 0,1 & " & 0,1 & 0,0 & 0,0 & 0,0 & 0,0 \\
\hline FADES & $"$ & $"$ & 0,9 & $"$ & 235,8 & 654,1 & 869,3 & 524,4 \\
\hline $\mathrm{FAO}$ & 21,3 & 42,9 & 47,3 & 44,4 & " & $"$ & $" \prime$ & " \\
\hline FIDA & $"$ & $"$ & $"$ & " & " & $"$ & $"$ & " \\
\hline FMI & $"$ & $"$ & $"$ & $"$ & $"$ & $"$ & $"$ & $"$ \\
\hline $\begin{array}{l}\text { Fondo para la Consolidación } \\
\text { de la Paz }\end{array}$ & $"$ & $"$ & 0,4 & 0,1 & 1,3 & 5,0 & 0,4 & 0,1 \\
\hline Instituciones de la UE & 227,5 & 203,5 & 233,8 & 214,9 & $1.448,5$ & $1.308,7$ & $1.470,9$ & $1.434,7$ \\
\hline ITC & $"$ & $"$ & $"$ & $"$ & $"$ & $"$ & $"$ & " \\
\hline OMC & 14,8 & 16,1 & 20,9 & 15,2 & $"$ & $"$ & " & $"$ \\
\hline ONUDI & $"$ & $"$ & $"$ & $"$ & $"$ & $"$ & $"$ & $"$ \\
\hline PNUD & 3,4 & 4,7 & 3,1 & 2,0 & 11,5 & 12,6 & 13,9 & 14,6 \\
\hline PNUMA & " & " & $"$ & " & 1,2 & 3,4 & 1,7 & 1,1 \\
\hline Otros donantes multilaterales & 0,9 & " & " & " & $"$ & 143,0 & 167,2 & 114,1 \\
\hline TOTAL PARCIAL & 302,0 & 332,5 & 364,0 & 369,0 & $3.860,4$ & $5.131,8$ & $6.116,5$ & $5.815,2$ \\
\hline TOTAL & 773,3 & 931,5 & $1.237,7$ & 982,5 & $12.597,4$ & $15.123,7$ & $18.795,8$ & $17.741,0$ \\
\hline
\end{tabular}


CUADRO A.2B Ayuda para el comercio, por donante y por categoría (página 2 de 2)

Desembolsos, en millones de \$EE.UU. (dólares constantes de 2011)

\begin{tabular}{|c|c|c|c|c|c|c|c|c|c|c|c|c|}
\hline & \multicolumn{4}{|c|}{ CREACIÓN DE CAPACIDAD PRODUCTIVA } & \multicolumn{4}{|c|}{ AJUSTE RELACIONADO CON EL COMERCIO } & \multicolumn{4}{|c|}{ TOTAL } \\
\hline & $\begin{array}{l}\text { Promedio } \\
2006-08\end{array}$ & 2009 & 2010 & 2011 & $\begin{array}{c}\text { Promedio } \\
2006-08\end{array}$ & 2009 & 2010 & 2011 & $\begin{array}{c}\text { Promedio } \\
2006-08\end{array}$ & 2009 & 2010 & 2011 \\
\hline \multicolumn{13}{|c|}{ Países miembros del CAD } \\
\hline Alemania & $1.140,7$ & $1.364,1$ & $1.476,3$ & $1 ; 515,0$ & " & $"$ & $"$ & $" \prime$ & $1.855,0$ & $2.314,1$ & $3.196,3$ & $3.056,5$ \\
\hline Australia & 182,3 & 177,9 & 292,8 & 311,1 & 0,3 & 0,0 & 1,3 & 0,3 & 323,9 & 391,7 & 524,6 & 585,1 \\
\hline Austria & 32,6 & 53,0 & 60,8 & 41,8 & $"$ & $"$ & " & " & 44,6 & 67,0 & 75,0 & 65,2 \\
\hline Bélgica & 160,3 & 356,8 & 312,6 & 336,4 & $"$ & $"$ & $"$ & $"$ & 201,5 & 470,6 & 402,8 & 446,5 \\
\hline Canadá & 259,5 & 333,9 & 725,4 & 487,0 & 0,0 & 0,1 & 0,0 & " & 335,5 & 427,2 & 825,9 & 854,8 \\
\hline Corea & 50,3 & 66,3 & 70,3 & 72,6 & $"$ & " & $"$ & " & 188,0 & 285,4 & 353,6 & 411,6 \\
\hline Dinamarca & 152,4 & 178,8 & 239,5 & 277,9 & $"$ & $"$ & $"$ & $"$ & 302,7 & 319,8 & 369,8 & 453,2 \\
\hline España & 253,2 & 381,9 & 885,3 & 427,3 & $"$ & $"$ & $"$ & $"$ & 561,5 & $1.040,5$ & $1.316,9$ & 590,8 \\
\hline Estados Unidos & $1.926,5$ & $1.734,9$ & $2.131,7$ & $2.039,8$ & $"$ & " & " & " & $4.038,8$ & $3.661,9$ & $4.217,2$ & $3.997,5$ \\
\hline Finlandia & 48,3 & 91,6 & 110,3 & 119,1 & $"$ & $"$ & $"$ & 1,3 & 68,6 & 118,9 & 163,3 & 174,4 \\
\hline Francia & 612,3 & 667,4 & 457,6 & 754,2 & $"$ & " & " & $"$ & $1.023,7$ & $1.198,6$ & $1.078,6$ & $1.542,0$ \\
\hline Grecia & 12,0 & 7,5 & 1,3 & 0,4 & $"$ & $"$ & $"$ & " & 21,7 & 18,5 & 20,5 & 21,2 \\
\hline Irlanda & 43,7 & 59,0 & 66,5 & 67,6 & $"$ & $"$ & $"$ & " & 47,7 & 60,3 & 68,0 & 70,1 \\
\hline Italia & 111,8 & 68,5 & 106,8 & 102,4 & $"$ & $"$ & $"$ & $"$ & 280,5 & 134,7 & 196,6 & 180,0 \\
\hline Japón & $1.523,5$ & $1.515,9$ & $1.599,3$ & $1.563,2$ & $"$ & $"$ & $"$ & 0,4 & $5.489,8$ & $5.838,9$ & $7.290,9$ & $6.351,0$ \\
\hline Luxemburgo & 29,0 & 33,4 & 34,5 & 34,6 & $"$ & $"$ & $"$ & $"$ & 35,8 & 34,3 & 39,8 & 41,0 \\
\hline Noruega & 239,8 & 430,5 & 495,5 & 538,2 & $"$ & $"$ & $"$ & $"$ & 528,1 & 576,3 & 712,9 & 837,0 \\
\hline Nueva Zelandia & 20,2 & 18,7 & 19,4 & 44,5 & $"$ & $"$ & $"$ & $"$ & 31,2 & 45,5 & 36,6 & 79,6 \\
\hline Países Bajos & 376,5 & 403,7 & 282,9 & 340,4 & $"$ & $"$ & $"$ & " & 562,3 & 632,7 & 460,7 & 583,9 \\
\hline Portugal & 3,9 & 6,2 & 2,9 & 3,1 & " & " & " & " & 41,0 & 32,7 & 91,7 & 56,4 \\
\hline Reino Unido & 755,7 & 987,3 & 616,4 & 784,1 & $"$ & $"$ & $"$ & $"$ & 952,5 & $1.388,3$ & $1.291,9$ & $1.352,8$ \\
\hline Suecia & 255,1 & 318,1 & 210,4 & 258,0 & $"$ & $"$ & 0,0 & 0,1 & 390,6 & 481,5 & 353,1 & 406,0 \\
\hline Suiza & 205,9 & 199,4 & 191,2 & 249,6 & $"$ & $"$ & $"$ & 3,0 & 279,2 & 259,7 & 247,9 & 307,0 \\
\hline TOTAL PARCIAL & $8.395,6$ & $9.454,7$ & $10.389,8$ & $10.368,3$ & 0,3 & 0,1 & 1,3 & 5,0 & $17.604,1$ & $19.799,2$ & $23.334,6$ & $22.463,5$ \\
\hline \multicolumn{13}{|c|}{ Otros donantes bilaterales } \\
\hline Emiratos Árabes Unidos & " & 0,6 & 41,9 & 44,8 & $"$ & $"$ & $"$ & $"$ & $"$ & 219,3 & 111,4 & 154,2 \\
\hline Islandia & $"$ & $"$ & " & 5,0 & $"$ & $"$ & $"$ & $"$ & $"$ & " & & 7,8 \\
\hline Kuwait & $"$ & $"$ & 46,9 & 32,2 & $"$ & $"$ & $"$ & $"$ & $"$ & $"$ & 481,6 & 364,0 \\
\hline República Checa & $"$ & $"$ & 0,1 & 7,2 & $"$ & $"$ & $"$ & $"$ & $"$ & $"$ & 0,2 & 12,2 \\
\hline Turquía & $"$ & 3,0 & 6,1 & $"$ & $"$ & $"$ & $"$ & $"$ & $"$ & 30,7 & 111,4 & " \\
\hline TOTAL PARCIAL & $"$ & 3,7 & 95,0 & 89,2 & $"$ & $"$ & $"$ & $"$ & $"$ & 250,0 & 704,5 & 538,2 \\
\hline \multicolumn{13}{|l|}{ Donantes multilaterales } \\
\hline BADEA & $"$ & $"$ & $"$ & 17,6 & " & $"$ & " & " & " & " & $"$ & 49,6 \\
\hline BAfD & 227,2 & $1.380,0$ & 434,6 & 356,5 & $"$ & $"$ & $"$ & $"$ & 426,3 & $1.843,9$ & $1.016,4$ & $1.162,8$ \\
\hline $\begin{array}{l}\text { Banco Islámico de } \\
\text { Desarrollo }\end{array}$ & $"$ & $"$ & $"$ & $"$ & $"$ & $"$ & $"$ & $"$ & $"$ & " & $"$ & " \\
\hline Banco Mundial & $1.673,3$ & $2.344,0$ & $1.899,4$ & $1.756,5$ & " & " & " & 1,4 & $3.668,9$ & $4.761,8$ & $4.144,0$ & $3.914,7$ \\
\hline $\mathrm{BAsD}$ & " & " & 199,9 & 292,4 & $"$ & $"$ & $"$ & " & " & " & 800,9 & 821,5 \\
\hline $\mathrm{BID}$ & $"$ & 80,7 & 147,4 & 194,9 & $"$ & $"$ & " & " & " & 263,5 & 366,9 & 486,0 \\
\hline CEPE & 0,1 & 0,4 & 0,9 & 1,2 & $"$ & $"$ & $"$ & $"$ & 1,5 & 5,7 & 4,3 & 4,0 \\
\hline CESPAP & 0,1 & 0,1 & $"$ & 0,3 & $"$ & $"$ & $"$ & $"$ & 0,2 & 0,5 & 0,4 & 0,7 \\
\hline CESPAO & $"$ & 0,1 & 0,3 & 0,2 & $"$ & $"$ & $"$ & $"$ & 0,1 & 0,2 & 0,3 & 0,3 \\
\hline FADES & 30,6 & 91,5 & 86,6 & 173,8 & $"$ & $"$ & $"$ & $"$ & 266,4 & 745,6 & 956,9 & 698,1 \\
\hline FAO & 126,4 & 267,1 & 263,9 & 247,7 & $"$ & $"$ & $"$ & $"$ & 147,8 & 310,0 & 311,2 & 292,2 \\
\hline FIDA & $"$ & $"$ & " & $"$ & $"$ & $"$ & $"$ & $"$ & $"$ & $"$ & $"$ & " \\
\hline FMI & " & $"$ & " & $"$ & $"$ & $"$ & $"$ & " & " & " & " & " \\
\hline $\begin{array}{l}\text { Fondo para la } \\
\text { Consolidación de la Paz }\end{array}$ & 0,2 & 1,0 & 0,3 & 0,1 & $"$ & " & " & $"$ & 1,5 & 6,0 & 1,1 & 0,3 \\
\hline Instituciones de la UE & 910,2 & $1.291,0$ & $1.112,9$ & $1.190,1$ & 8,8 & 36,7 & 71,0 & 11,0 & $2.595,1$ & $2.840,0$ & $2.888,7$ & $2.850,8$ \\
\hline ITC & 33,2 & 56,5 & 55,4 & 61,1 & " & $"$ & $"$ & " & 33,2 & 56,5 & 55,4 & 61,1 \\
\hline OMC & $"$ & $"$ & $"$ & $"$ & $"$ & $"$ & $"$ & " & 14,8 & 16,1 & 20,9 & 15,2 \\
\hline ONUDI & $"$ & $"$ & $"$ & $"$ & $"$ & $"$ & $"$ & " & " & " & " & " \\
\hline PNUD & 18,0 & 29,5 & 22,8 & 21,2 & $"$ & $"$ & $"$ & $"$ & 32,9 & 46,7 & 39,7 & 37,8 \\
\hline PNUMA & 1,6 & 3,2 & 5,4 & 5,7 & $"$ & $"$ & $"$ & $"$ & 2,8 & 6,6 & 7,1 & 6,7 \\
\hline $\begin{array}{l}\text { Otros donantes } \\
\text { multilaterales }\end{array}$ & 4,5 & 83,2 & 46,9 & 48,2 & $"$ & $"$ & $"$ & " & 5,4 & 226,2 & 214,2 & 162,3 \\
\hline TOTAL PARCIAL & $3.025,6$ & $5.628,2$ & $4.276,7$ & $4.367,5$ & 8,8 & 36,7 & 71,0 & 12,5 & $7.196,9$ & $11.129,3$ & $10.828,4$ & $10.564,2$ \\
\hline TOTAL & $11.421,2$ & $15.086,6$ & $14.761,6$ & $14.825,0$ & 9,1 & 36,8 & 72,3 & 17,4 & $24.801,0$ & $31.178,5$ & $34.867,5$ & $33.565,9$ \\
\hline
\end{tabular}


CUADRO A.3 Ayuda para el comercio, por donante y por región (página 1 de 4)

\begin{tabular}{|c|c|c|c|c|c|c|c|c|c|c|}
\hline & \multicolumn{5}{|c|}{ ÁFRICA } & \multicolumn{5}{|c|}{ AMÉRICA } \\
\hline & $\begin{array}{l}\text { Promedio } \\
2002-05\end{array}$ & $\begin{array}{c}\text { Promedio } \\
2006-08\end{array}$ & 2009 & 2010 & 2011 & $\begin{array}{l}\text { Promedio } \\
2002-05\end{array}$ & $\begin{array}{c}\text { Promedio } \\
2006-08\end{array}$ & 2009 & 2010 & 2011 \\
\hline \multicolumn{11}{|l|}{ Países miembros del CAD } \\
\hline Alemania & 415,9 & 467,0 & 466,5 & $1.155,3$ & 857,3 & 95,2 & 285,3 & 503,5 & 392,0 & 299,6 \\
\hline Australia & 13,0 & 0,8 & 2,3 & 39,4 & 44,5 & 0,3 & 0,2 & 2,5 & 1,2 & 8,5 \\
\hline Austria & 10,1 & 16,5 & 20,9 & 29,6 & 11,3 & 5,1 & 6,0 & 9,0 & 11,6 & 2,1 \\
\hline Bélgica & 128,6 & 187,1 & 297,2 & 223,9 & 250,1 & 50,9 & 38,3 & 42,3 & 57,7 & 54,6 \\
\hline Canadá & 168,5 & 141,5 & 336,2 & 345,4 & 219,0 & 77,2 & 110,6 & 93,6 & 194,3 & 108,0 \\
\hline Corea & $"$ & 69,7 & 178,2 & 213,6 & 258,9 & $"$ & 14,5 & 77,2 & 23,7 & 148,5 \\
\hline Dinamarca & 273,1 & 192,5 & 271,2 & 265,3 & 217,1 & 44,5 & 6,3 & 8,2 & 41,7 & 5,0 \\
\hline España & 130,3 & 363,1 & 469,1 & 366,8 & 455,4 & 110,5 & 139,1 & 255,5 & 313,2 & 146,4 \\
\hline Estados Unidos & 550,8 & $1.408,5$ & $1.440,8$ & $1.685,2$ & 831,8 & 279,2 & 501,6 & 504,5 & 463,0 & 668,9 \\
\hline Finlandia & 23,3 & 53,0 & 197,5 & 150,6 & 168,5 & 12,3 & 10,2 & 39,4 & 24,2 & 32,0 \\
\hline Francia & 469,0 & 971,7 & $1.028,4$ & $1.208,4$ & 425,7 & 34,5 & 65,8 & 51,6 & 71,9 & 370,9 \\
\hline Grecia & 0,9 & 1,3 & 2,4 & 0,6 & " & $"$ & 0,0 & $"$ & " & " \\
\hline Irlanda & 24,0 & 32,7 & 50,4 & 46,7 & 50,3 & 0,7 & 3,2 & 2,6 & 4,5 & 6,3 \\
\hline Italia & 158,1 & 110,3 & 36,8 & 22,3 & 26,4 & 43,5 & 13,9 & 20,9 & 35,6 & 15,3 \\
\hline Japón & 431,7 & $1.197,6$ & 738,1 & $2.411,5$ & 719,7 & 135,3 & 287,5 & 228,1 & 343,1 & 116,3 \\
\hline Luxemburgo & 8,9 & 19,3 & 10,3 & 12,3 & 18,1 & 2,0 & 4,0 & 3,8 & 4,0 & 5,3 \\
\hline Noruega & 161,0 & 264,3 & 461,2 & 274,8 & 395,2 & 25,6 & 24,6 & 111,2 & 282,8 & 250,2 \\
\hline Nueva Zelandia & 0,2 & 0,1 & $"$ & 0,0 & 2,5 & 0,6 & 1,5 & 0,8 & 0,7 & 0,1 \\
\hline Países Bajos & 94,9 & 123,5 & 191,7 & 54,6 & 129,2 & 46,6 & 45,2 & 60,6 & 19,8 & 6,7 \\
\hline Portugal & 27,4 & 29,7 & 91,3 & 55,4 & 23,5 & 0,2 & 0,0 & 0,1 & 0,2 & 0,2 \\
\hline Reino Unido & 237,6 & 295,5 & 982,4 & 449,7 & 284,6 & 70,4 & 20,2 & 69,0 & 80,8 & 49,5 \\
\hline Suecia & 100,7 & 167,3 & 92,0 & 213,7 & 152,0 & 15,8 & 9,9 & 27,8 & 19,0 & 4,3 \\
\hline Suiza & 80,3 & 74,3 & 52,2 & 64,3 & 54,7 & 52,2 & 44,0 & 36,7 & 76,2 & 23,1 \\
\hline TOTAL PARCIAL & $3.508,3$ & $6.187,3$ & $7.417,0$ & $9.289,6$ & $5.595,7$ & $1.102,8$ & $1.631,8$ & $2.149,0$ & $2.461,2$ & $2.321,8$ \\
\hline \multicolumn{11}{|l|}{ Otros donantes bilaterales } \\
\hline Emiratos Árabes Unidos & $"$ & $"$ & 81,3 & 181,2 & 10,0 & $"$ & $"$ & $"$ & $"$ & $"$ \\
\hline Islandia & $"$ & $"$ & " & 564,3 & 119,0 & $"$ & $"$ & " & $"$ & 10,0 \\
\hline Kuwait & $"$ & $"$ & $"$ & " & 3,7 & $"$ & $"$ & $"$ & $"$ & 0,7 \\
\hline República Checa & " & $"$ & 0,0 & $"$ & 2,4 & $"$ & $"$ & $"$ & $"$ & 0,2 \\
\hline Turquía & $"$ & $"$ & 0,1 & 1,7 & $"$ & $"$ & $"$ & $"$ & $"$ & " \\
\hline TOTAL PARCIAL & $"$ & $"$ & 81,4 & 747,2 & 135,1 & $"$ & $"$ & $"$ & $"$ & 10,9 \\
\hline \multicolumn{11}{|l|}{ Donantes multilaterales } \\
\hline BADEA & $"$ & $"$ & " & $"$ & 82,7 & " & $"$ & " & $"$ & $"$ \\
\hline BAfD & 166,2 & 794,0 & $2.309,3$ & $1.770,4$ & 925,1 & $"$ & $"$ & $"$ & $"$ & $"$ \\
\hline Banco Islámico de Desarrollo & " & " & " & 136,7 & " & " & $"$ & $"$ & " & $"$ \\
\hline Banco Mundial & $2.331,8$ & $2.626,0$ & $4.799,8$ & $3.632,0$ & $3.313,5$ & 147,3 & 100,3 & 119,7 & 112,9 & 273,3 \\
\hline BAsD & " & " & " & " & " & " & " & " & " & " \\
\hline $\mathrm{BID}$ & $"$ & $"$ & $"$ & $"$ & $"$ & 272,8 & 124,7 & 255,5 & 397,2 & 485,1 \\
\hline CEPE & $"$ & $"$ & $"$ & " & $"$ & $"$ & $"$ & $"$ & $"$ & $"$ \\
\hline CESPAP & $"$ & $"$ & $"$ & $"$ & $"$ & $"$ & $"$ & $"$ & $"$ & $"$ \\
\hline CESPAO & $"$ & $"$ & " & " & $"$ & " & $"$ & " & $"$ & $"$ \\
\hline FADES & $"$ & 310,0 & 477,5 & $1.018,8$ & 818,5 & $"$ & $"$ & $"$ & $"$ & $"$ \\
\hline FAO & " & " & $"$ & " & $"$ & $"$ & $"$ & " & $"$ & $"$ \\
\hline FIDA & 157,0 & 213,3 & 294,9 & 415,6 & 466,0 & 13,5 & 20,1 & 16,1 & 7,5 & 33,7 \\
\hline FMI & $"$ & 4,4 & 7,4 & 6,5 & 7,3 & " & 2,1 & 2,1 & 1,4 & 2,9 \\
\hline $\begin{array}{l}\text { Fondo para la Consolidación } \\
\text { de la Paz }\end{array}$ & $"$ & 3,7 & 0,3 & 3,3 & $"$ & " & $"$ & $"$ & $"$ & $"$ \\
\hline Instituciones de la UE & $1.781,4$ & $2.018,1$ & $1.584,3$ & $1.241,5$ & $1.503,2$ & 289,0 & 309,2 & 502,3 & 288,1 & 346,6 \\
\hline ITC & $"$ & $"$ & " & $"$ & $"$ & $"$ & $"$ & " & $"$ & " \\
\hline $\mathrm{OMC}$ & " & 5,1 & 3,9 & 5,9 & 4,2 & $"$ & 3,2 & 1,5 & 2,6 & 1,6 \\
\hline ONUDI & $"$ & 17,4 & 43,9 & 13,7 & 21,2 & $"$ & 2,2 & 10,6 & 1,1 & 1,8 \\
\hline PNUD & 5,2 & 14,3 & 22,2 & 14,0 & 15,8 & 0,2 & 0,8 & 1,1 & 0,6 & 0,5 \\
\hline PNUMA & $"$ & " & " & " & " & " & " & " & " & " \\
\hline Otros donantes multilaterales & 0,7 & 0,2 & 181,9 & 234,1 & 233,9 & 0,2 & 0,1 & 117,8 & 289,1 & 43,6 \\
\hline TOTAL PARCIAL & $4.442,3$ & $6.006,6$ & $9.725,5$ & $8.492,6$ & $7.391,5$ & 722,8 & 562,7 & $1.026,6$ & $1.100,7$ & $1.189,1$ \\
\hline TOTAL & $7.950,6$ & $12.193,9$ & $17.223,9$ & $18.529,4$ & $13.122,3$ & $1.825,6$ & $2.194,5$ & $3.175,6$ & $3.561,9$ & $3.521,8$ \\
\hline
\end{tabular}


CUADRO A.3 Ayuda para el comercio, por donante y por región (página 2 de 4)

\begin{tabular}{|c|c|c|c|c|c|c|c|c|c|c|}
\hline & \multicolumn{5}{|c|}{ ASIA } & \multicolumn{5}{|c|}{ EUROPA } \\
\hline & $\begin{array}{l}\text { Promedio } \\
2002-05\end{array}$ & $\begin{array}{c}\text { Promedio } \\
2006-08\end{array}$ & 2009 & 2010 & 2011 & $\begin{array}{l}\text { Promedio } \\
2002-05\end{array}$ & $\begin{array}{c}\text { Promedio } \\
2006-08\end{array}$ & 2009 & 2010 & 2011 \\
\hline \multicolumn{11}{|l|}{ Países miembros del CAD } \\
\hline Alemania & 645,6 & $1.046,4$ & $1.236,1$ & $1.455,4$ & $1.273,8$ & 112,7 & 334,1 & 184,2 & 603,9 & 534,1 \\
\hline Australia & 122,7 & 198,7 & 462,1 & 377,9 & 255,6 & $"$ & 0,0 & $"$ & $"$ & " \\
\hline Austria & 30,1 & 18,1 & 10,0 & 21,4 & 23,8 & 4,1 & 14,0 & 27,7 & 20,9 & 10,0 \\
\hline Bélgica & 35,0 & 21,4 & 35,6 & 36,5 & 38,6 & 1,9 & 3,0 & 1,3 & 1,4 & 0,6 \\
\hline Canadá & 141,0 & 145,5 & 93,5 & 150,1 & 81,4 & 1,7 & 11,7 & 31,1 & 1,6 & 11,7 \\
\hline Corea & " & 367,3 & 867,3 & 512,9 & 346,7 & $"$ & 3,7 & 0,5 & 0,3 & 0,8 \\
\hline Dinamarca & 134,4 & 98,3 & 56,1 & 57,3 & 41,5 & 0,2 & 1,0 & 26,4 & 13,4 & 22,2 \\
\hline España & 115,9 & 114,4 & 132,0 & 108,0 & 33,4 & 74,5 & 167,7 & 14,3 & 190,9 & 0,2 \\
\hline Estados Unidos & $2.806,0$ & $3.343,2$ & $2.350,9$ & $3.103,5$ & $1.727,8$ & 157,9 & 140,3 & 168,8 & 476,8 & 106,0 \\
\hline Finlandia & 36,6 & 42,6 & 78,9 & 29,8 & 76,5 & 2,8 & 2,9 & 5,5 & 7,9 & 4,3 \\
\hline Francia & 196,8 & 402,5 & 217,9 & 312,4 & 118,1 & 24,1 & 147,9 & 15,6 & 3,3 & 72,3 \\
\hline Grecia & 3,7 & 5,8 & 3,4 & 0,8 & 0,5 & 10,0 & 14,1 & 12,0 & 19,2 & 20,7 \\
\hline Irlanda & 2,3 & 8,8 & 5,5 & 7,4 & 6,2 & 0,3 & 0,3 & 0,1 & " & " \\
\hline Italia & 33,8 & 75,2 & 209,3 & 75,6 & 42,0 & 52,0 & 66,2 & 11,6 & 50,5 & 4,9 \\
\hline Japón & $4.983,1$ & $5.976,7$ & $5.557,5$ & $6.721,9$ & $6.547,1$ & 401,3 & 20,0 & 164,7 & 531,9 & 373,1 \\
\hline Luxemburgo & 3,6 & 5,3 & 7,6 & 7,2 & 6,5 & 4,0 & 3,0 & 4,5 & 3,8 & 2,4 \\
\hline Noruega & 83,8 & 141,6 & 78,1 & 134,2 & 147,7 & 41,9 & 29,7 & 25,3 & 12,1 & 26,8 \\
\hline Nueva Zelandia & 7,5 & 9,6 & 5,1 & 12,9 & 45,3 & $"$ & $"$ & $"$ & $"$ & " \\
\hline Países Bajos & 119,2 & 83,4 & 87,7 & 38,5 & 46,2 & 20,4 & 16,9 & 5,2 & 0,0 & 0,0 \\
\hline Portugal & 3,1 & 1,9 & 1,0 & 0,9 & 1,2 & 17,0 & 0,0 & 0,0 & 0,0 & 0,0 \\
\hline Reino Unido & 315,0 & 384,0 & 722,4 & 393,3 & 204,7 & 6,7 & 6,2 & 4,0 & 0,7 & 0,8 \\
\hline Suecia & 67,3 & 57,6 & 17,4 & 59,8 & 40,0 & 32,1 & 29,8 & 37,2 & 41,3 & 23,1 \\
\hline Suiza & 116,5 & 94,2 & 55,3 & 93,1 & 118,8 & 33,3 & 28,2 & 16,1 & 32,8 & 43,4 \\
\hline TOTAL PARCIAL & $10.002,9$ & $12.642,1$ & $12.291,0$ & $13.711,0$ & $11.223,3$ & 999,0 & $1.040,7$ & 756,0 & $2.012,8$ & $1.257,4$ \\
\hline \multicolumn{11}{|l|}{ Otros donantes bilaterales } \\
\hline Emiratos Árabes Unidos & $"$ & " & 428,1 & 27,7 & 126,6 & $"$ & " & " & $"$ & 50,0 \\
\hline Islandia & $"$ & $"$ & $"$ & 227,9 & 124,4 & $"$ & " & $"$ & 1,5 & , \\
\hline Kuwait & $"$ & " & $"$ & $"$ & $"$ & $"$ & " & $"$ & $"$ & " \\
\hline República Checa & " & $"$ & 0,0 & 0,0 & 5,9 & $"$ & " & 0,0 & 0,1 & 3,9 \\
\hline Turquía & $"$ & $"$ & 28,7 & 107,5 & $"$ & $"$ & " & 1,9 & 1,6 & " \\
\hline TOTAL PARCIAL & $\prime$ & $"$ & 456,9 & 363,2 & 256,9 & $"$ & $"$ & 2,0 & 3,2 & 53,9 \\
\hline \multicolumn{11}{|l|}{ Donantes multilaterales } \\
\hline BADEA & $"$ & $"$ & $"$ & " & " & $"$ & " & " & $"$ & " \\
\hline BAfD & $"$ & $"$ & $"$ & $"$ & " & $"$ & " & $"$ & $"$ & " \\
\hline Banco Islámico de Desarrollo & " & " & $"$ & 41,5 & " & $"$ & $"$ & $"$ & 5,8 & " \\
\hline Banco Mundial & $2.290,2$ & $1 ; 893,8$ & $2.162,1$ & $1.851,3$ & $3.579,4$ & 259,6 & 84,4 & 47,4 & 26,0 & 24,8 \\
\hline BAsD & 815,2 & 564,6 & 780,5 & $1.480,5$ & $1.400,6$ & $"$ & " & $"$ & $"$ & " \\
\hline BID & $"$ & $"$ & $"$ & $"$ & $"$ & $"$ & $"$ & $"$ & $"$ & " \\
\hline CEPE & $"$ & 0,0 & 0,1 & 0,1 & 0,1 & $"$ & 1,5 & 5,6 & 4,2 & 4,0 \\
\hline CESPAP & $"$ & 0,1 & 0,5 & 0,4 & 0,8 & $"$ & " & $"$ & $"$ & " \\
\hline CESPAO & $"$ & 0,0 & $"$ & $"$ & $"$ & $"$ & " & $"$ & " & " \\
\hline FADES & $"$ & 124,7 & 581,1 & 184,1 & 348,0 & $"$ & " & $"$ & " & " \\
\hline FAO & " & " & $"$ & " & " & " & " & $"$ & " & " \\
\hline FIDA & 119,9 & 172,8 & 217,1 & 164,9 & 274,8 & 11,1 & 16,0 & $"$ & 18,0 & 13,5 \\
\hline FMl & " & 3,4 & 3,4 & 3,7 & 3,8 & $"$ & 1,2 & 1,6 & 2,2 & 1,0 \\
\hline $\begin{array}{l}\text { Fondo para la Consolidación } \\
\text { de la Paz }\end{array}$ & $"$ & $"$ & $"$ & " & 0,4 & $"$ & " & $"$ & 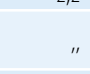 & " \\
\hline Instituciones de la UE & 292,7 & 319,1 & 310,9 & 363,0 & 239,6 & 389,0 & 666,9 & 677,5 & 888,9 & 731,2 \\
\hline ITC & $"$ & $"$ & $"$ & $"$ & $"$ & $"$ & $"$ & $"$ & " & " \\
\hline OMC & $"$ & 1,8 & 2,1 & 1,7 & 2,9 & $"$ & 0,5 & 0,0 & 0,4 & 0,0 \\
\hline ONUDI & " & 6,3 & 42,9 & 20,3 & 12,0 & $"$ & 0,6 & 1,3 & 2,0 & 1,9 \\
\hline PNUD & 7,3 & 11,0 & 16,2 & 15,6 & 11,2 & 0,5 & 0,8 & 1,1 & 0,8 & 0,3 \\
\hline PNUMA & $"$ & $"$ & $"$ & $"$ & $"$ & $"$ & $"$ & $"$ & " & " \\
\hline Otros donantes multilaterales & 0,3 & 0,1 & 144,3 & 133,5 & 107,0 & $"$ & $"$ & 6,5 & 16,6 & 32,2 \\
\hline TOTAL PARCIAL & $3.525,6$ & $3.097,6$ & $4.261,3$ & $4.260,6$ & $5.980,6$ & 660,2 & 771,8 & 741,0 & 964,8 & 808,8 \\
\hline TOTAL & $13.528,5$ & $15.739,8$ & $17.009,2$ & $18.334,8$ & $17.460,7$ & 1659,2 & $1.812,5$ & $1.499,0$ & $2.980,8$ & $2.120,2$ \\
\hline
\end{tabular}


CUADRO A.3 Ayuda para el comercio, por donante y por región (página 3 de 4)

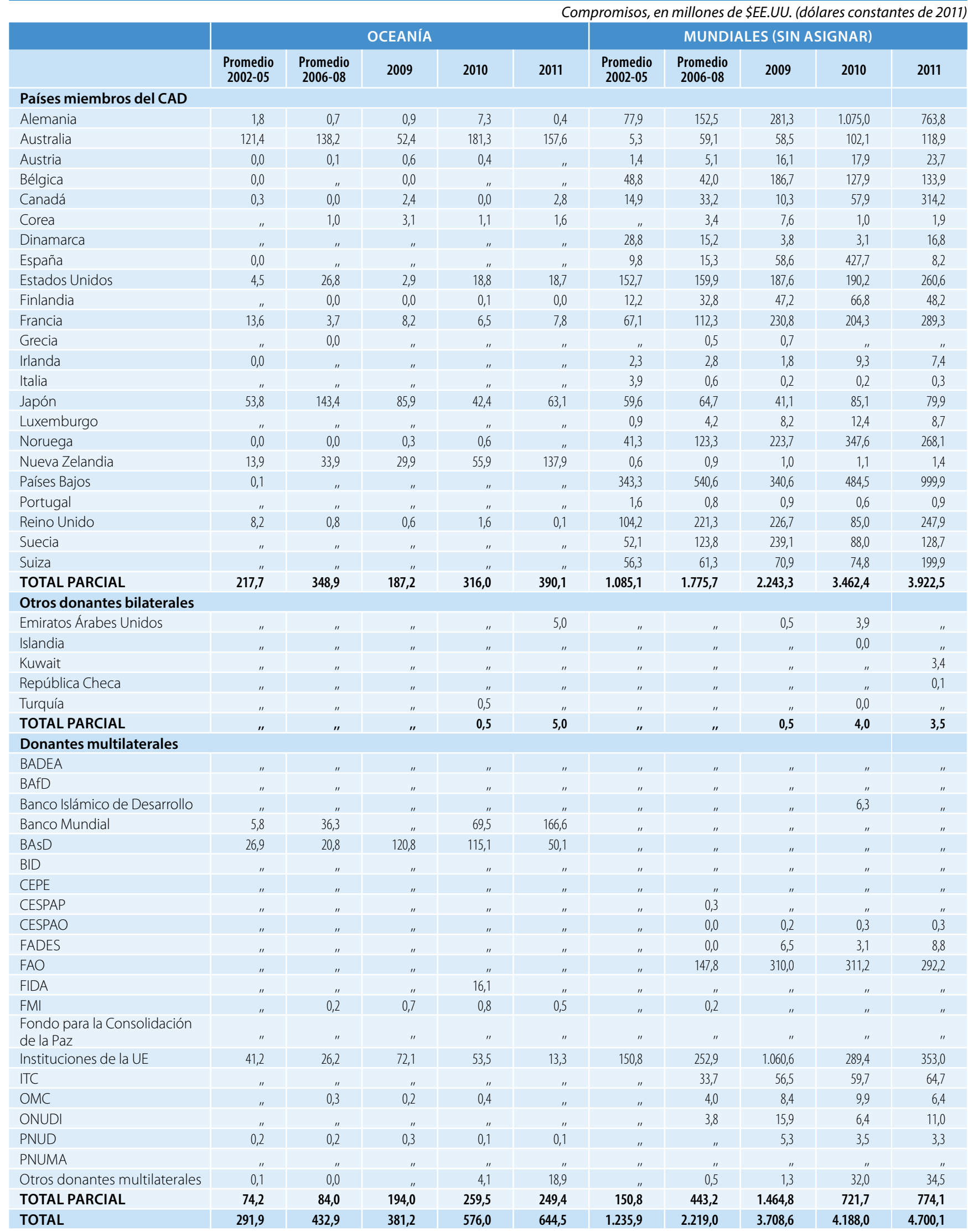


CUADRO A.3 Ayuda para el comercio, por donante y por región (página 4 de 4)

\begin{tabular}{|c|c|c|c|c|c|}
\hline & \multicolumn{5}{|c|}{ Compromisos, en millones de \$EE.UU. (dólares constantes de 2011) } \\
\hline & \multicolumn{5}{|c|}{ TOTAL } \\
\hline & Promedio 2002-05 & Promedio 2006-08 & 2009 & 2010 & 2011 \\
\hline \multicolumn{6}{|l|}{ Países miembros del CAD } \\
\hline Alemania & $1.349,1$ & $2.286,0$ & $2.672,5$ & $4.688,9$ & $3.729,0$ \\
\hline Australia & 262,7 & 397,1 & 577,8 & 701,9 & 585,1 \\
\hline Austria & 50,8 & 59,8 & 84,3 & 101,7 & 70,9 \\
\hline Bélgica & 265,2 & 291,9 & 563,1 & 447,4 & 477,9 \\
\hline Canadá & 403,5 & 442,5 & 567,0 & 749,3 & 737,2 \\
\hline Corea & 0,0 & 459,6 & $1.134,0$ & 752,6 & 758,5 \\
\hline Dinamarca & 481,0 & 313,3 & 365,6 & 380,9 & 302,6 \\
\hline España & 441,0 & 799,7 & 929,6 & $1.406,5$ & 643,6 \\
\hline Estados Unidos & $3.951,0$ & $5.580,3$ & $4.655,6$ & $5.937,5$ & $3.613,8$ \\
\hline Finlandia & 87,3 & 141,4 & 368,5 & 279,4 & 329,5 \\
\hline Francia & 805,2 & $1.703,9$ & $1.552,4$ & $1.806,9$ & $1.284,0$ \\
\hline Grecia & 14,7 & 21,7 & 18,5 & 20,5 & 21,2 \\
\hline Irlanda & 29,6 & 47,7 & 60,3 & 68,0 & 70,1 \\
\hline Italia & 291,3 & 266,2 & 278,9 & 184,2 & 88,9 \\
\hline Japón & $6.064,9$ & $7.689,8$ & $6.815,4$ & $10.135,8$ & $7.899,3$ \\
\hline Luxemburgo & 19,4 & 35,8 & 34,3 & 39,8 & 41,0 \\
\hline Noruega & 353,6 & 583,5 & 899,8 & $1.052,2$ & $1.088,0$ \\
\hline Nueva Zelandia & 22,8 & 46,0 & 36,9 & 70,6 & 187,1 \\
\hline Países Bajos & 624,5 & 809,6 & 685,8 & 597,5 & $1.181,9$ \\
\hline Portugal & 49,4 & 32,4 & 93,3 & 57,1 & 25,8 \\
\hline Reino Unido & 742,0 & 928,0 & $2.005,1$ & $1.011,2$ & 787,6 \\
\hline Suecia & 268,1 & 388,5 & 413,6 & 421,8 & 348,1 \\
\hline Suiza & 338,6 & 302,1 & 231,3 & 341,2 & 439,8 \\
\hline TOTAL PARCIAL & $16.915,7$ & $23.626,6$ & $25.043,6$ & $31.252,9$ & $24.710,8$ \\
\hline \multicolumn{6}{|l|}{ Otros donantes bilaterales } \\
\hline Emiratos Árabes Unidos & $"$ & $"$ & 509,9 & 212,8 & 191,6 \\
\hline Islandia & $"$ & $"$ & " & 793,8 & 253,4 \\
\hline Kuwait & $"$ & $"$ & " & $"$ & 7,8 \\
\hline República Checa & $"$ & $"$ & 0,1 & 0,2 & 12,5 \\
\hline Turquía & $"$ & $"$ & 30,7 & 111,4 & , \\
\hline TOTAL PARCIAL & $"$ & $"$ & 540,7 & $1.118,1$ & 465,2 \\
\hline \multicolumn{6}{|l|}{ Donantes multilaterales } \\
\hline BADEA & $"$ & $"$ & " & $"$ & 82,7 \\
\hline BAfD & 166,2 & 794,0 & $2.309,3$ & $1.770,4$ & 925,1 \\
\hline Banco Islámico de Desarrollo & " & " & " & 190,4 & 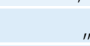 \\
\hline Banco Mundial & $5.034,7$ & $4.740,8$ & $7.129,0$ & $5.691,8$ & $7.357,6$ \\
\hline BAsD & 842,1 & 585,4 & 901,3 & $1.595,5$ & $1.450,7$ \\
\hline $\mathrm{BID}$ & 272,8 & 124,7 & 255,5 & 397,2 & 485,1 \\
\hline CEPE & " & 1,5 & 5,7 & 4,3 & 4,0 \\
\hline CESPAP & $"$ & 0,4 & 0,5 & 0,4 & 0,8 \\
\hline CESPAO & $"$ & 0,1 & 0,2 & 0,3 & 0,3 \\
\hline FADES & 0,0 & 434,7 & $1.065,1$ & $1.206,0$ & $1.175,3$ \\
\hline FAO & $"$ & 147,8 & 310,0 & 311,2 & 292,2 \\
\hline FIDA & 301,5 & 422,2 & 528,1 & 622,1 & 788,0 \\
\hline FMI & " & 11,5 & 15,2 & 14,6 & 15,5 \\
\hline $\begin{array}{l}\text { Fondo para la Consolidación } \\
\text { de la Paz }\end{array}$ & $"$ & 3,7 & 0,3 & 3,3 & 0,4 \\
\hline Instituciones de la UE & $2.944,2$ & $3.592,4$ & $4.207,7$ & $3.124,5$ & $3.186,8$ \\
\hline ITC & " & 33,7 & 56,5 & 59,7 & 64,7 \\
\hline $\mathrm{OMC}$ & $"$ & 14,8 & 16,1 & 20,9 & 15,2 \\
\hline ONUDI & $"$ & 30,3 & 114,6 & 43,5 & 47,9 \\
\hline PNUD & 13,4 & 27,1 & 46,2 & 34,7 & 31,2 \\
\hline PNUMA & $"$ & " & " & " & " \\
\hline Otros donantes multilaterales & 1,2 & 0,9 & 451,8 & 709,3 & 470,1 \\
\hline TOTAL PARCIAL & $9.576,0$ & $10.965,9$ & $17.413,2$ & $15.800,0$ & $16.393,6$ \\
\hline TOTAL & $26.491,7$ & $34.592,5$ & $42.997,4$ & $48.171,0$ & $41.569,6$ \\
\hline
\end{tabular}


CUADRO A.4 Ayuda para el comercio, por donante y por grupo de países según nivel de ingresos (página 1 de 3)

Compromisos, en millones de \$EE.UU. (dólares constantes de 2011)

\begin{tabular}{|c|c|c|c|c|c|c|c|c|c|c|}
\hline & \multicolumn{5}{|c|}{ PAÍSES MENOS ADELANTADOS } & \multicolumn{5}{|c|}{ OTROS PAÍSES DE INGRESOS BAJOS } \\
\hline & $\begin{array}{c}\text { Promedio } \\
2002-05\end{array}$ & $\begin{array}{c}\text { Promedio } \\
2006-08\end{array}$ & 2009 & 2010 & 2011 & $\begin{array}{c}\text { Promedio } \\
2002-05\end{array}$ & $\begin{array}{c}\text { Promedio } \\
2006-08\end{array}$ & 2009 & 2010 & 2011 \\
\hline \multicolumn{11}{|c|}{ Países miembros del CAD } \\
\hline Alemania & 232,6 & 229,9 & 246,7 & 308,1 & 369,6 & 33,2 & 41,6 & 41,4 & 82,8 & 178,4 \\
\hline Australia & 33,0 & 42,2 & 39,6 & 134,2 & 120,8 & 2,0 & 0,0 & 1,5 & 20,5 & 17,6 \\
\hline Austria & 17,6 & 11,1 & 8,4 & 10,1 & 6,2 & 0,3 & 0,4 & 0,7 & 0,2 & 0,1 \\
\hline Bélgica & 75,0 & 115,3 & 222,2 & 181,1 & 204,9 & 4,3 & 7,8 & 39,0 & 11,7 & 6,1 \\
\hline Canadá & 106,0 & 203,8 & 323,1 & 385,3 & 140,1 & 10,0 & 7,3 & 4,9 & 2,6 & 23,1 \\
\hline Corea & " & 179,6 & 308,4 & 353,4 & 321,4 & " & 1,7 & 0,4 & 0,9 & 2,4 \\
\hline Dinamarca & 246,3 & 197,4 & 119,7 & 133,3 & 81,3 & 10,3 & 15,6 & 7,3 & 83,4 & 36,3 \\
\hline España & 46,4 & 62,1 & 59,9 & 192,4 & 122,6 & 0,1 & 6,3 & 0,0 & 3,3 & 0,0 \\
\hline Estados Unidos & 542,1 & $1.912,9$ & $1.933,3$ & $2.626,8$ & $1.631,0$ & 60,9 & 36,5 & 95,0 & 114,6 & 180,8 \\
\hline Finlandia & 9,9 & 31,6 & 127,3 & 70,4 & 86,8 & 8,4 & 5,3 & 19,7 & 40,5 & 5,7 \\
\hline Francia & 150,4 & 219,9 & 178,4 & 294,9 & 254,1 & 21,9 & 45,0 & 103,3 & 214,8 & 79,4 \\
\hline Grecia & 0,2 & 0,2 & 0,6 & $"$ & " & 0,0 & 0,1 & $"$ & $"$ & " \\
\hline Irlanda & 24,2 & 34,9 & 48,6 & 46,0 & 49,7 & 0,8 & 2,6 & 3,0 & 4,3 & 5,7 \\
\hline Italia & 114,3 & 78,0 & 66,8 & 58,8 & 49,5 & 1,0 & 6,5 & 0,2 & 0,9 & 2,2 \\
\hline Japón & 424,0 & 698,8 & $1.188,6$ & $1.757,3$ & $1.295,3$ & 48,7 & 174,1 & 40,1 & 761,4 & 51,3 \\
\hline Luxemburgo & 5,7 & 10,5 & 11,0 & 8,9 & 14,9 & $"$ & 0,0 & " & $"$ & " \\
\hline Noruega & 153,1 & 205,1 & 269,6 & 246,4 & 332,7 & 5,1 & 5,5 & 13,9 & 7,1 & 20,0 \\
\hline Nueva Zelandia & 4,9 & 20,0 & 18,9 & 35,5 & 77,8 & 0,2 & 0,0 & $"$ & 0,1 & 0,4 \\
\hline Países Bajos & 86,4 & 79,0 & 179,0 & 25,2 & 78,7 & 1,8 & 1,7 & 1,1 & 0,5 & 4,0 \\
\hline Portugal & 9,9 & 6,0 & 5,5 & 3,1 & 8,5 & $"$ & $"$ & , & $"$ & " \\
\hline Reino Unido & 177,1 & 243,5 & 565,2 & 140,9 & 112,1 & 14,9 & 7,0 & 117,6 & 26,0 & 8,6 \\
\hline Suecia & 77,5 & 108,4 & 81,6 & 189,3 & 69,2 & 10,2 & 34,9 & 9,6 & 1,4 & 10,4 \\
\hline Suiza & 70,9 & 61,8 & 21,2 & 89,8 & 67,4 & 26,7 & 10,1 & 10,1 & 5,1 & 9,2 \\
\hline TOTAL PARCIAL & $2.607,5$ & $4.752,0$ & $6.023,8$ & $7.291,1$ & $5.494,5$ & 260,9 & 409,8 & 508,8 & $1.382,2$ & 641,7 \\
\hline
\end{tabular}

\section{Otros donantes bilaterales}

Emiratos Árabes Unidos

Islandia

Kuwait

República Checa

Turquía

TOTAL PARCIAL

\begin{tabular}{|l|l|l|l|l|l|l|l|l|}
\hline " & 369,8 & 22,4 & 41,4 \\
\hline
\end{tabular}

\section{Donantes multilaterales}

\section{BADEA}

BAfD

Banco Islámico de Desarrollo

Banco Mundial

BAsD

BID

CEPE

CESPAP

CESPAO

FADES

FAO

FIDA

FMI

Fondo para la Consolidación de la Paz

Instituciones de la UE

ITC

OMC

ONUDI

PNUD

PNUMA

Otros donantes multilaterales

TOTAL PARCIAL

TOTAL

\section{es}


CUADRO A.4 Ayuda para el comercio, por donante y por grupo de países según nivel de ingresos (página 2 de 3)

\begin{tabular}{|c|c|c|c|c|c|c|c|c|c|c|}
\hline & \multicolumn{10}{|c|}{ Compromisos, en millones de \$EE.UU. (dólares constantes de 2011} \\
\hline & \multicolumn{5}{|c|}{ PAÍSES DE INGRESOS MEDIANOS BAJOS } & \multicolumn{5}{|c|}{ PAÍSES DE INGRESOS MEDIANOS ALTOS } \\
\hline & $\begin{array}{l}\text { Promedio } \\
2002-05\end{array}$ & $\begin{array}{c}\text { Promedio } \\
2006-08\end{array}$ & 2009 & 2010 & 2011 & $\begin{array}{l}\text { Promedio } \\
\text { 2002-05. }\end{array}$ & $\begin{array}{c}\text { Promedio } \\
2006-08\end{array}$ & 2009 & 2010 & 2011 \\
\hline \multicolumn{11}{|l|}{ Países miembros del CAD } \\
\hline Alemania & 551,6 & 664,4 & 849,6 & $1.216,3$ & $1.136,8$ & 415,5 & 736,7 & 726,0 & $1.508,5$ & 683,2 \\
\hline Australia & 174,9 & 254,1 & 446,7 & 324,9 & 274,0 & 11,6 & 19,0 & 10,9 & 5,4 & 5,4 \\
\hline Austria & 19,4 & 11,9 & 17,9 & 15,3 & 20,5 & 9,7 & 12,7 & 8,9 & 24,6 & 3,6 \\
\hline Bélgica & 60,3 & 53,3 & 49,0 & 86,3 & 85,8 & 53,6 & 53,6 & 36,2 & 33,1 & 20,7 \\
\hline Canadá & 118,9 & 104,2 & 97,0 & 163,9 & 115,6 & 78,4 & 18,7 & 24,8 & 13,1 & 44,9 \\
\hline Corea & $"$ & 248,8 & 782,5 & 364,5 & 377,9 & $"$ & 23,4 & 32,3 & 30,9 & 52,2 \\
\hline Dinamarca & 159,7 & 66,3 & 137,2 & 112,8 & 56,6 & 22,8 & 15,2 & 36,1 & 13,3 & 6,6 \\
\hline España & 128,9 & 203,4 & 268,5 & 162,9 & 69,3 & 240,6 & 482,4 & 375,0 & 309,0 & 64,5 \\
\hline Estados Unidos & $2.736,6$ & $2.899,4$ & $1.657,7$ & $2.168,0$ & 979,7 & 328,8 & 442,4 & 644,9 & 652,0 & 352,7 \\
\hline Finlandia & 22,3 & 22,2 & 73,8 & 22,0 & 54,5 & 23,8 & 15,2 & 14,7 & 7,9 & 49,0 \\
\hline Francia & 262,1 & 861,7 & 706,3 & 714,3 & 265,5 & 272,0 & 461,6 & 316,1 & 374,0 & 379,8 \\
\hline Grecia & 3,7 & 5,1 & 4,9 & 1,3 & 0,5 & 10,6 & 15,4 & 12,3 & 19,1 & 20,7 \\
\hline Irlanda & 1,6 & 6,1 & 3,7 & 7,1 & 6,2 & 0,7 & 1,1 & 0,5 & 0,3 & 0,5 \\
\hline Italia & 64,5 & 62,0 & 173,4 & 42,5 & 12,5 & 98,5 & 115,3 & 34,4 & 80,0 & 18,5 \\
\hline Japón & $3.990,2$ & $5.795,0$ & $4.188,4$ & $6.207,9$ & $5.794,0$ & $1.508,2$ & 695,3 & $1.196,2$ & $1.261,9$ & 472,0 \\
\hline Luxemburgo & 6,5 & 11,1 & 7,1 & 7,9 & 9,7 & 5,5 & 5,6 & 4,6 & 3,5 & 1,9 \\
\hline Noruega & 44,2 & 80,0 & 53,1 & 105,2 & 100,2 & 46,2 & 39,8 & 128,9 & 292,6 & 256,4 \\
\hline Nueva Zelandia & 9,2 & 11,4 & 10,0 & 15,8 & 43,9 & 4,0 & 3,0 & 2,1 & 8,6 & 28,5 \\
\hline Países Bajos & 119,0 & 76,3 & 109,9 & 39,6 & 10,2 & 41,0 & 35,6 & 16,1 & 4,7 & 4,7 \\
\hline Portugal & 19,5 & 24,8 & 85,9 & 52,8 & 16,1 & 17,2 & 0,0 & 0,0 & 0,0 & 0,2 \\
\hline Reino Unido & 219,1 & 214,6 & 368,2 & 353,6 & 195,8 & 181,1 & 110,4 & 228,7 & 170,2 & 156,1 \\
\hline Suecia & 46,0 & 29,4 & 50,6 & 55,5 & 45,4 & 32,9 & 22,8 & 13,2 & 33,1 & 8,5 \\
\hline Suiza & 80,4 & 67,5 & 53,5 & 79,2 & 85,1 & 46,2 & 43,5 & 29,9 & 34,6 & 33,5 \\
\hline TOTAL PARCIAL & $8.838,9$ & $11.773,1$ & $10.194,9$ & $12.319,6$ & $9.755,8$ & $3.449,0$ & $3.368,9$ & $3.892,7$ & $4.880,5$ & $2.664,1$ \\
\hline \multicolumn{11}{|l|}{ Otros donantes bilaterales } \\
\hline Emiratos Árabes Unidos & $"$ & $"$ & 22,7 & 159,9 & 39,5 & $"$ & $"$ & 116,8 & $"$ & 110,7 \\
\hline Islandia & $"$ & $"$ & " & " & 0,7 & $"$ & " & " & $"$ & 0,1 \\
\hline Kuwait & $"$ & $"$ & $"$ & 392,5 & 139,7 & $"$ & $"$ & $"$ & 57,3 & 24,0 \\
\hline República Checa & $"$ & $"$ & 0,1 & 0,1 & 4,5 & $"$ & " & $"$ & 0,1 & 3,8 \\
\hline Turquía & $"$ & $"$ & 0,0 & 1,9 & $"$ & $"$ & " & 2,0 & 1,4 & " \\
\hline TOTAL PARCIAL & $"$ & $"$ & 22,9 & 554,4 & 184,3 & $"$ & $\prime \prime$ & 118,8 & 58,8 & 138,6 \\
\hline \multicolumn{11}{|l|}{ Donantes multilaterales } \\
\hline BADEA & $"$ & $"$ & $"$ & $"$ & 10,3 & $"$ & $"$ & $"$ & $"$ & 0,1 \\
\hline BAfD & 8,2 & 43,0 & 136,3 & 322,0 & 26,7 & $"$ & $"$ & $"$ & $"$ & 1,7 \\
\hline Banco Islámico de Desarrollo & $"$ & " & " & 27,4 & " & $"$ & " & $"$ & 18,8 & " \\
\hline Banco Mundial & $2.095,4$ & $2.049,5$ & $3.387,1$ & $1.800,7$ & $3.241,0$ & 266,2 & 83,8 & 69,8 & 84,5 & 85,6 \\
\hline BAsD & 384,1 & 355,6 & 719,8 & 624,7 & 369,7 & 7,0 & 6,8 & 15,3 & " & 1,0 \\
\hline $\mathrm{BID}$ & 231,2 & 118,0 & 152,7 & 185,8 & 165,8 & $"$ & $"$ & 48,5 & 48,1 & 62,3 \\
\hline CEPE & " & " & " & " & " & $"$ & $"$ & " & " & " \\
\hline CESPAP & $"$ & $"$ & $"$ & $"$ & 0,0 & " & $"$ & $"$ & $"$ & $"$ \\
\hline CESPAO & $"$ & 0,0 & $"$ & $"$ & " & $"$ & $"$ & $"$ & $"$ & $"$ \\
\hline FADES & $"$ & 98,0 & 648,4 & 881,3 & 125,1 & $"$ & 47,0 & 266,0 & 154,3 & 152,5 \\
\hline FAO & " & $"$ & " & $"$ & $"$ & " & " & $"$ & $"$ & $"$ \\
\hline FIDA & 101,0 & 141,7 & 180,9 & 176,0 & 347,8 & 30,7 & 59,4 & 33,2 & $"$ & 32,9 \\
\hline FMl & " & 3,2 & 4,7 & 3,8 & 5,3 & " & 3,1 & 3,9 & 3,6 & 4,2 \\
\hline $\begin{array}{l}\text { Fondo para la Consolidación } \\
\text { de la Paz }\end{array}$ & $"$ & $"$ & $"$ & $"$ & $"$ & $"$ & $"$ & $"$ & $"$ & $"$ \\
\hline Instituciones de la UE & 485,7 & 701,7 & 514,3 & 720,4 & 567,5 & 694,7 & 744,6 & 669,4 & 858,7 & 804,8 \\
\hline ITC & " & " & " & " & $"$ & $"$ & $"$ & " & $"$ & " \\
\hline OMC & $"$ & 2,5 & 0,6 & 3,4 & 0,0 & $"$ & 4,7 & 0,9 & 4,1 & 0,1 \\
\hline ONUDI & $"$ & 6,4 & 48,3 & 21,5 & 6,9 & $"$ & 5,2 & 23,3 & 4,3 & 7,5 \\
\hline PNUD & 4,0 & 4,9 & 9,1 & 8,3 & 6,1 & 2,1 & 3,5 & 3,5 & 2,3 & 1,8 \\
\hline PNUMA & $"$ & $"$ & " & " & " & $"$ & " & $"$ & $"$ & " \\
\hline Otros donantes multilaterales & 0,4 & 0,0 & 219,9 & 137,6 & 50,8 & 0,1 & 0,0 & 49,5 & 184,3 & 72,1 \\
\hline TOTAL PARCIAL & $3.309,9$ & $3.524,4$ & $6.022,0$ & $4.912,8$ & $4.923,1$ & $1.000,8$ & 958,2 & $1.183,4$ & $1.363,0$ & $1.226,5$ \\
\hline TOTAL & $12.148,8$ & $15.297,5$ & $16.239,8$ & $17.786,9$ & $14.863,2$ & $4.449,8$ & $4.327,0$ & $5.194,9$ & $6.302,3$ & $4.029,2$ \\
\hline
\end{tabular}


CUADRO A.4 Ayuda para el comercio, por donante y por grupo de países según nivel de ingresos (página 3 de 3)

\begin{tabular}{|c|c|c|c|c|c|c|c|c|c|c|}
\hline & \multicolumn{5}{|c|}{ MUNDIALES (SIN ASIGNAR) } & \multicolumn{5}{|c|}{ TOTAL } \\
\hline & $\begin{array}{l}\text { Promedio } \\
2002-05\end{array}$ & $\begin{array}{l}\text { Promedio } \\
2006-08\end{array}$ & 2009 & 2010 & 2011 & $\begin{array}{l}\text { Promedio } \\
2002-05\end{array}$ & $\begin{array}{c}\text { Promedio } \\
2006-08\end{array}$ & 2009 & 2010 & 2011 \\
\hline \multicolumn{11}{|l|}{ Países miembros del CAD } \\
\hline Alemania & 116,2 & 613,4 & 808,8 & $1.573,2$ & $1.360,9$ & $1.349,1$ & $2.286,0$ & $2.672,5$ & $4.688,9$ & $3.729,0$ \\
\hline Australia & 41,3 & 81,7 & 79,1 & 216,9 & 167,3 & 262,7 & 397,1 & 577,8 & 701,9 & 585,1 \\
\hline Austria & 3,7 & 23,7 & 48,4 & 51,6 & 40,4 & 50,8 & 59,8 & 84,3 & 101,7 & 70,9 \\
\hline Bélgica & 72,0 & 61,9 & 216,7 & 135,2 & 160,4 & 265,2 & 291,9 & 563,1 & 447,4 & 477,9 \\
\hline Canadá & 90,3 & 108,5 & 117,1 & 184,2 & 413,5 & 403,5 & 442,5 & 567,0 & 749,3 & 737,2 \\
\hline Corea & " & 6,1 & 10,4 & 2,8 & 4,6 & " & 459,6 & $1.134,0$ & 752,6 & 758,5 \\
\hline Dinamarca & 41,8 & 18,8 & 65,4 & 38,1 & 121,7 & 481,0 & 313,3 & 365,6 & 380,9 & 302,6 \\
\hline España & 25,1 & 45,4 & 226,2 & 739,0 & 387,2 & 441,0 & 799,7 & 929,6 & $1.406,5$ & 643,6 \\
\hline Estados Unidos & 282,6 & 289,2 & 324,6 & 376,2 & 469,7 & $3.951,0$ & $5.580,3$ & $4.655,6$ & $5.937,5$ & $3.613,8$ \\
\hline Finlandia & 22,8 & 67,0 & 133,0 & 138,5 & 133,5 & 87,3 & 141,4 & 368,5 & 279,4 & 329,5 \\
\hline Francia & 98,8 & 115,8 & 248,3 & 209,0 & 305,1 & 805,2 & $1.703,9$ & $1.552,4$ & $1.806,9$ & $1.284,0$ \\
\hline Grecia & 0,1 & 1,0 & 0,7 & 0,1 & " & 14,7 & 21,7 & 18,5 & 20,5 & 21,2 \\
\hline Irlanda & 2,3 & 2,9 & 4,5 & 10,3 & 7,9 & 29,6 & 47,7 & 60,3 & 68,0 & 70,1 \\
\hline Italia & 13,0 & 4,4 & 4,1 & 2,0 & 6,3 & 291,3 & 266,2 & 278,9 & 184,2 & 88,9 \\
\hline Japón & 93,8 & 326,6 & 202,2 & 147,3 & 286,6 & $6.064,9$ & $7.689,8$ & $6.815,4$ & $10.135,8$ & $7.899,3$ \\
\hline Luxemburgo & 1,6 & 8,5 & 11,6 & 19,4 & 14,5 & 19,4 & 35,8 & 34,3 & 39,8 & 41,0 \\
\hline Noruega & 104,9 & 253,2 & 434,3 & 400,9 & 378,7 & 353,6 & 583,5 & 899,8 & $1.052,2$ & $1.088,0$ \\
\hline Nueva Zelandia & 4,6 & 11,6 & 5,9 & 10,6 & 36,6 & 22,8 & 46,0 & 36,9 & 70,6 & 187,1 \\
\hline Países Bajos & 376,3 & 617,0 & 379,8 & 527,4 & $1.084,4$ & 624,5 & 809,6 & 685,8 & 597,5 & $1.181,9$ \\
\hline Portugal & 2,8 & 1,5 & 1,8 & 1,3 & 0,9 & 49,4 & 32,4 & 93,3 & 57,1 & 25,8 \\
\hline Reino Unido & 149,6 & 352,6 & 725,3 & 320,5 & 315,1 & 742,0 & 928,0 & $2.005,1$ & $1.011,2$ & 787,6 \\
\hline Suecia & 101,4 & 193,0 & 258,6 & 142,4 & 214,7 & 268,1 & 388,5 & 413,6 & 421,8 & 348,1 \\
\hline Suiza & 114,5 & 119,2 & 116,6 & 132,6 & 244,6 & 338,6 & 302,1 & 231,3 & 341,2 & 439,8 \\
\hline TOTAL PARCIAL & $1.759,5$ & $3.322,9$ & $4.423,3$ & $5.379,4$ & $6.154,8$ & $16.915,7$ & $23.626,6$ & $25.043,6$ & $31.252,9$ & $24.710,8$ \\
\hline \multicolumn{11}{|l|}{ Otros donantes bilaterales } \\
\hline Emiratos Árabes Unidos & " & $"$ & 0,5 & 3,9 & $"$ & $"$ & $"$ & 509,9 & 212,8 & 191,6 \\
\hline Islandia & $"$ & $"$ & $"$ & $" \prime$ & 4,0 & $"$ & $"$ & $"$ & $"$ & 7,8 \\
\hline Kuwait & $"$ & $"$ & " & 0,0 & " & $"$ & $"$ & $"$ & 793,8 & 253,4 \\
\hline República Checa & " & $"$ & $"$ & " & 0,1 & $"$ & $"$ & 0,1 & 0,2 & 12,5 \\
\hline Turquía & " & " & 28,7 & 105,8 & " & " & $"$ & 30,7 & 111,4 & " \\
\hline TOTAL PARCIAL & $"$ & $\prime \prime$ & 29,1 & 109,8 & 4,1 & $"$ & $"$ & 540,7 & $1.118,1$ & 465,2 \\
\hline \multicolumn{11}{|l|}{ Donantes multilaterales } \\
\hline BADEA & $"$ & $"$ & $"$ & " & 0,8 & $"$ & $"$ & $"$ & $"$ & 82,7 \\
\hline BAfD & 8,4 & 250,9 & $1.039,7$ & 415,6 & 137,4 & 166,2 & 794,0 & $2.309,3$ & $1.770,4$ & 925,1 \\
\hline Banco Islámico de Desarrollo & $"$ & $"$ & $"$ & 6,3 & $"$ & $"$ & " & $"$ & 190,4 & " \\
\hline Banco Mundial & 57,5 & 17,4 & $"$ & $"$ & 18,0 & $5.034,7$ & $4.740,8$ & $7.129,0$ & $5.691,8$ & $7.357,6$ \\
\hline $\mathrm{BAsD}$ & " & $"$ & $"$ & " & " & 842,1 & 585,4 & 901,3 & $1.595,5$ & $1.450,7$ \\
\hline BID & $"$ & $"$ & 23,8 & 58,1 & 37,4 & 272,8 & 124,7 & 255,5 & 397,2 & 485,1 \\
\hline CEPE & " & 1,5 & 5,7 & 4,3 & 4,0 & $"$ & 1,5 & 5,7 & 4,3 & 4,0 \\
\hline CESPAP & $"$ & 0,3 & 0,5 & 0,4 & 0,8 & $"$ & 0,4 & 0,5 & 0,4 & 0,8 \\
\hline CESPAO & " & 0,1 & 0,2 & 0,3 & 0,3 & " & 0,1 & 0,2 & 0,3 & 0,3 \\
\hline FADES & $"$ & 0,0 & 6,5 & 3,1 & 8,8 & $"$ & 434,7 & $1.065,1$ & $1.206,0$ & $1.175,3$ \\
\hline FAO & $"$ & 147,8 & 310,0 & 311,2 & 292,2 & $"$ & 147,8 & 310,0 & 311,2 & 292,2 \\
\hline FIDA & $"$ & $"$ & " & " & " & 301,5 & 422,2 & 528,1 & 622,1 & 788,0 \\
\hline FMI & $"$ & 1,1 & $"$ & " & $"$ & $"$ & 11,5 & 15,2 & 14,6 & 15,5 \\
\hline $\begin{array}{l}\text { Fondo para la Consolidación } \\
\text { de la Paz }\end{array}$ & $"$ & $"$ & $"$ & $"$ & " & " & 3,7 & 0,3 & 3,3 & 0,4 \\
\hline Instituciones de la UE & 588,5 & 886,6 & $1.555,9$ & 733,9 & 907,7 & $2.944,2$ & $3.592,4$ & $4.207,7$ & $3.124,5$ & $3.186,8$ \\
\hline ITC & $"$ & 33,7 & 56,5 & 59,7 & 64,7 & $"$ & 33,7 & 56,5 & 59,7 & 64,7 \\
\hline OMC & $"$ & 4,7 & 13,6 & 10,4 & 15,2 & $"$ & 14,8 & 16,1 & 20,9 & 15,2 \\
\hline ONUDI & $"$ & 6,7 & 21,8 & 12,0 & 16,2 & " & 30,3 & 114,6 & 43,5 & 47,9 \\
\hline PNUD & 0,0 & 0,0 & 5,3 & 3,5 & 4,1 & 13,4 & 27,1 & 46,2 & 34,7 & 31,2 \\
\hline PNUMA & $"$ & $"$ & $"$ & $"$ & $"$ & $"$ & $"$ & $"$ & $"$ & " \\
\hline Otros donantes multilaterales & 0,0 & 0,6 & 5,8 & 173,3 & 76,1 & 1,2 & 0,9 & 451,8 & 709,3 & 470,1 \\
\hline TOTAL PARCIAL & 654,4 & $1.351,5$ & $3.045,4$ & $1.791,9$ & $1.583,6$ & $9.576,0$ & $10.965,9$ & $17.413,2$ & $15.800,0$ & $16.393,6$ \\
\hline TOTAL & $2.413,9$ & $4.674,3$ & $7.497,9$ & $7.281,1$ & $7.742,5$ & $26.491,7$ & $34.592,5$ & $42.997,4$ & $48.171,0$ & $41.569,6$ \\
\hline
\end{tabular}


CUADRO A.5A Los 20 principales beneficiarios de ayuda para el comercio en 2011, por compromisos

En millones de \$EE.UU. (dólares constantes de 2011)

\begin{tabular}{|c|c|c|c|c|c|c|c|}
\hline & & & & & APROMI & & \\
\hline & Región & Grupo de ingresos & $\begin{array}{l}\text { Promedio } \\
2002-2005\end{array}$ & $\begin{array}{c}\text { Promedio } \\
2006-08\end{array}$ & 2009 & 2010 & 2011 \\
\hline India & Asia & Países de ingresos medianos bajos & $1.784,7$ & $2.758,8$ & $1.957,2$ & $3.504,3$ & $3.779,1$ \\
\hline Viet Nam & Asia & Países de ingresos medianos bajos & $1.747,6$ & $2.028,3$ & $2.775,8$ & $1.843,9$ & $3.443,1$ \\
\hline Afganistán & Asia & Países menos adelantados & 792,8 & $1.522,7$ & $1.538,7$ & $2.052,5$ & $1.955,9$ \\
\hline Bangladesh & Asia & Países menos adelantados & 828,0 & 858,0 & 971,2 & $1.274,7$ & $1.910,3$ \\
\hline Filipinas & Asia & Países de ingresos medianos bajos & 395,9 & 262,2 & 963,4 & 154,0 & 852,4 \\
\hline Kenya & África & Otros países de ingresos bajos & 335,7 & 543,6 & $1.033,9$ & $1.750,0$ & 825,1 \\
\hline Congo, Rep. Dem. del & África & Países menos adelantados & 531,8 & 317,2 & 746,4 & 756,1 & 808,1 \\
\hline Haití & América & Países menos adelantados & 92,4 & 105,1 & 344,2 & 401,5 & 779,3 \\
\hline Serbia & Europa & Países de ingresos medianos altos & 460,0 & 304,0 & 111,1 & 314,2 & 672,7 \\
\hline Sri Lanka & Asia & Países de ingresos medianos bajos & 545,9 & 438,8 & 390,3 & 395,3 & 659,8 \\
\hline Indonesia & Asia & Países de ingresos medianos bajos & $1.317,7$ & 980,3 & $1.417,1$ & 871,5 & 648,1 \\
\hline Sudán & África & Países menos adelantados & 25,2 & 235,9 & 247,9 & 391,4 & 627,1 \\
\hline Tanzanía & África & Países menos adelantados & 434,3 & 814,6 & 847,3 & $1.502,6$ & 607,8 \\
\hline Pakistán & Asia & Países de ingresos medianos bajos & 647,0 & 792,6 & 733,4 & $1.041,5$ & 601,9 \\
\hline Ghana & África & Países de ingresos medianos bajos & 297,6 & 634,8 & 799,5 & 884,7 & 552,5 \\
\hline Nigeria & África & Países de ingresos medianos bajos & 257,7 & 360,8 & $1.051,2$ & 348,6 & 486,0 \\
\hline Etiopía & África & Países menos adelantados & 559,9 & 799,9 & 791,8 & 975,1 & 466,8 \\
\hline Uganda & África & Países menos adelantados & 278,2 & 465,9 & $1.041,5$ & 803,4 & 458,8 \\
\hline Zambia & África & Países menos adelantados & 233,2 & 245,3 & 317,5 & 182,9 & 456,7 \\
\hline Nepal & Asia & Países menos adelantados & 183,1 & 224,5 & 315,1 & 463,0 & 453,4 \\
\hline TOTAL PARCIAL & & & $11.748,5$ & $14.693,3$ & $18.394,4$ & $19.911,2$ & $21.044,9$ \\
\hline TOTAL DE LA AYUDA & MERCIO & & $26.491,7$ & $34.592,5$ & $42.997,4$ & $48.171,0$ & $41.569,6$ \\
\hline $\begin{array}{l}\text { Proporción del total } \\
\text { a los } 20 \text { principales } b\end{array}$ & ara el com & orrespondiente & $44.3 \%$ & $42.5 \%$ & $42.8 \%$ & $41.3 \%$ & $50.6 \%$ \\
\hline
\end{tabular}

CUADRO A.5B Los 20 principales beneficiarios de ayuda para el comercio en 2011, por desembolsos

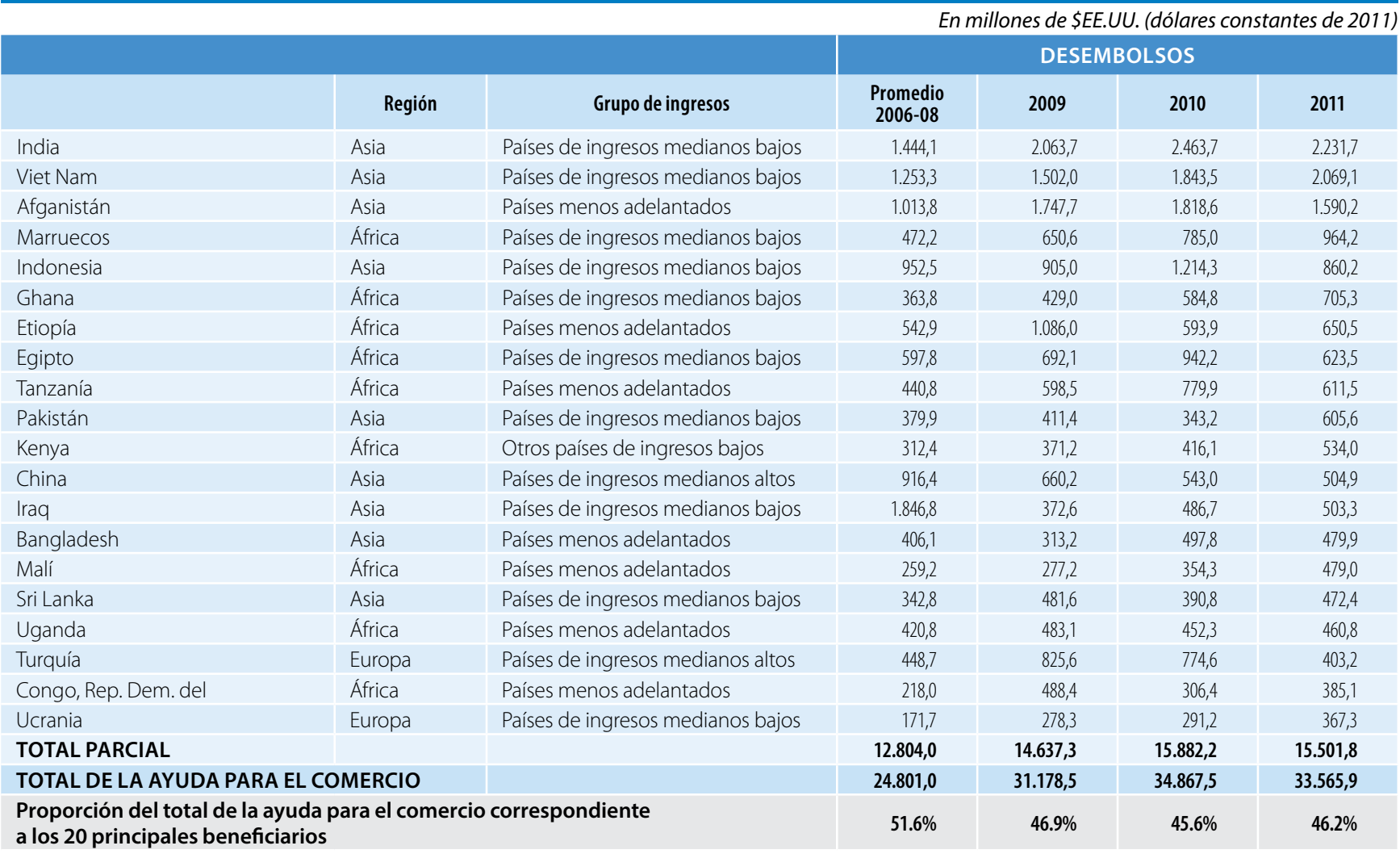




\section{CUADRO A.6A Ayuda para el comercio per cápita: los 20 principales beneficiarios de ayuda en 2011}

En millones de \$EE.UU. (dólares constantes de 2011)

\begin{tabular}{|c|c|c|c|c|c|c|c|c|}
\hline & & & & OMPRON & SOS PE & CÁPITA & & POBLACIÓN (MILES) \\
\hline & Región & Grupo de ingresos & $\begin{array}{l}\text { Promedio } \\
2002-2005\end{array}$ & $\begin{array}{l}\text { Promedio } \\
2006-2008\end{array}$ & 2009 & 2010 & 2011 & 2011 \\
\hline Nive & Oceanía & Países de ingresos medianos altos & $1.667,0$ & $1.347,9$ & $3.767,7$ & $4.109,7$ & $10.265,6$ & 1 \\
\hline Tokelau & Oceanía & Países de ingresos medianos bajos & $1.314,5$ & $1.138,1$ & $1.134,6$ & 570,0 & $9.791,5$ & 1 \\
\hline Santa Elena & África & Países de ingresos medianos altos & $5.387,4$ & $1.929,2$ & $2.969,7$ & $1.094,3$ & $8.051,7$ & 8 \\
\hline Tuvalu & Oceanía & Países menos adelantados & 479,2 & 651,7 & 166,6 & 146,1 & $1.734,5$ & 10 \\
\hline Islas Cook & Oceanía & Países de ingresos medianos altos & 74,5 & 42,8 & 728,6 & 463,9 & $1.494,5$ & 11 \\
\hline Kiribati & Oceanía & Países menos adelantados & 101,2 & 93,6 & 99,6 & 49,6 & $1.093,1$ & 101 \\
\hline Tonga & Oceanía & Países de ingresos medianos bajos & 32,2 & 159,1 & 41,5 & 315,2 & 751,4 & 105 \\
\hline Montserrat & América & Países de ingresos medianos altos & 879,0 & $1.813,3$ & 513,1 & 16,8 & 437,4 & 5 \\
\hline Wallis y Futuna & Oceanía & Países de ingresos medianos altos & 491,9 & 119,5 & 202,9 & 323,9 & 340,3 & 15 \\
\hline Samoa & Oceanía & Países menos adelantados & 95,7 & 186,0 & 28,9 & 138,7 & 164,2 & 184 \\
\hline Santo Tomé y Príncipe & África & Países menos adelantados & 55,2 & 44,7 & 153,0 & 28,9 & 150,7 & 169 \\
\hline Granada & América & Países de ingresos medianos altos & 87,5 & 16,1 & 141,7 & 16,1 & 149,5 & 105 \\
\hline Nauru & Oceanía & Países de ingresos medianos altos & 208,8 & 913,8 & 566,9 & 39,2 & 146,8 & 9 \\
\hline Islas Salomón & Oceanía & Países menos adelantados & 31,4 & 57,2 & 16,7 & 89,7 & 124,8 & 552 \\
\hline Guyana & América & Países de ingresos medianos bajos & 62,0 & 78,3 & 62,4 & 57,0 & 103,3 & 756 \\
\hline Serbia & Europa & Países de ingresos medianos altos & 61,6 & 41,2 & 15,2 & 43,1 & 92,6 & 7261 \\
\hline Cabo Verde & África & Países de ingresos medianos bajos & 180,5 & 150,0 & 258,2 & 143,4 & 91,7 & 501 \\
\hline Mauritania & África & Países menos adelantados & 42,0 & 44,7 & 17,2 & 20,0 & 88,8 & 3.542 \\
\hline Vanuatu & Oceanía & Países menos adelantados & 35,7 & 203,3 & 128,9 & 84,0 & 81,2 & 246 \\
\hline Haití & América & Países menos adelantados & 10,1 & 10,9 & 34,9 & 40,2 & 77,0 & 10.124 \\
\hline
\end{tabular}

StatLink 商ISTh htp://dx.doi.org/10.1787/888932854708

\section{CUADRO A.6B Ayuda para el comercio per cápita: los 20 principales beneficiarios de ayuda en 2011}

En millones de \$EE.UU. (dólares constantes de 2011)

\begin{tabular}{|c|c|c|c|c|c|c|c|}
\hline & & & & $\mathrm{MBOL}$ & ER CÁF & & POBLACIÓN (MILES) \\
\hline & Región & Grupo de ingresos & $\begin{array}{c}\text { Promedio } \\
2006-08\end{array}$ & 2009 & 2010 & 2011 & 2011 \\
\hline Santa Elena & África & Países de ingresos medianos altos & $1.904,3$ & $2.074,1$ & $1.198,7$ & $9.423,6$ & 8 \\
\hline Niue & Oceanía & Países de ingresos medianos altos & $2.013,2$ & 669,5 & $4.973,2$ & $9.382,4$ & 1 \\
\hline Tokelau & Oceanía & Países de ingresos medianos bajos & $2.384,3$ & 989,3 & $1.046,5$ & $5.857,6$ & 1 \\
\hline Montserrat & América & Países de ingresos medianos altos & 707,8 & $1.956,4$ & $2.202,8$ & $2.104,1$ & 5 \\
\hline Islas Cook & Oceanía & Países de ingresos medianos altos & 87,1 & 174,6 & 282,0 & 801,8 & 11 \\
\hline Wallis y Futuna & Oceanía & Países de ingresos medianos altos & 119,5 & 203,2 & 449,3 & 693,4 & 15 \\
\hline Tuvalu & Oceanía & Países menos adelantados & 642,2 & 741,8 & 176,1 & 384,8 & 10 \\
\hline $\begin{array}{l}\text { Estado Federados de } \\
\text { Micronesia }\end{array}$ & Oceanía & Países de ingresos medianos bajos & 98,1 & 79,1 & 147,0 & 246,4 & 112 \\
\hline Dominica & América & Países de ingresos medianos altos & 144,7 & 351,6 & 290,5 & 220,8 & 68 \\
\hline Samoa & Oceanía & Países menos adelantados & 60,5 & 122,8 & 192,9 & 195,5 & 184 \\
\hline Cabo Verde & África & Países de ingresos medianos bajos & 136,9 & 157,0 & 335,3 & 174,0 & 501 \\
\hline Tonga & Oceanía & Países de ingresos medianos bajos & 79,7 & 111,2 & 352,7 & 159,0 & 105 \\
\hline Nauru & Oceanía & Países de ingresos medianos altos & 881,9 & 608,6 & 116,5 & 145,8 & 9 \\
\hline Kiribati & Oceanía & Países menos adelantados & 129,9 & 72,2 & 39,7 & 129,6 & 101 \\
\hline Antigua y Barbuda & América & Países de ingresos medianos altos & 13,7 & 24,8 & 81,6 & 121,1 & 90 \\
\hline Guyana & América & Países de ingresos medianos bajos & 24,0 & 85,3 & 73,0 & 119,9 & 756 \\
\hline Santo Tomé y Príncipe & África & Países menos adelantados & 45,4 & 19,9 & 35,2 & 112,8 & 169 \\
\hline Bhután & Asia & Países menos adelantados & 44,0 & 57,0 & 128,6 & 95,5 & 738 \\
\hline Islas Salomón & Oceanía & Países menos adelantados & 41,5 & 49,5 & 54,8 & 91,5 & 552 \\
\hline Granada & América & Países de ingresos medianos altos & 10,9 & 27,8 & 100,9 & 91,2 & 105 \\
\hline
\end{tabular}


CUADRO A.7 Ayuda para el comercio, por beneficiario (página 1 de 3)

En millones de \$EE.UU. (dólares constantes de 2011)

\begin{tabular}{|c|c|c|c|c|c|c|c|c|c|}
\hline & \multicolumn{5}{|c|}{ COMPROMISOS } & \multicolumn{4}{|c|}{ DESEMBOLSOS } \\
\hline & $\begin{array}{l}\text { Promedio } \\
2002-05\end{array}$ & $\begin{array}{l}\text { Promedio } \\
2006-08\end{array}$ & 2009 & 2010 & 2011 & $\begin{array}{c}\text { Promedio } \\
2006-08\end{array}$ & 2009 & 2010 & 2011 \\
\hline Afganistán & 792,8 & $1.522,7$ & $1.538,7$ & $2.052,5$ & $1.955,9$ & $1.013,8$ & $1.747,7$ & $1.818,6$ & $1.590,2$ \\
\hline Albania & 141,4 & 127,9 & 46,5 & 220,4 & 133,6 & 96,9 & 136,4 & 159,9 & 122,9 \\
\hline Angola & 21,1 & 90,1 & 21,3 & 77,8 & 19,4 & 34,3 & 59,9 & 87,6 & 41,4 \\
\hline Anguila & 1,5 & 6,0 & 0,1 & 0,1 & " & 2,9 & 1,1 & 8,9 & " \\
\hline Antigua y Barbuda & 3,0 & 0,3 & 17,0 & 0,4 & 1,1 & 1,2 & 2,2 & 7,3 & 10,9 \\
\hline Arabia Saudita & 1,9 & 1,4 & " & " & " & 1,5 & " & " & " \\
\hline Argelia & 110,8 & 152,7 & 13,9 & 27,3 & 38,3 & 129,5 & 105,6 & 45,4 & 51,6 \\
\hline Argentina & 49,6 & 28,8 & 30,6 & 77,9 & 27,4 & 36,1 & 32,2 & 60,5 & 33,3 \\
\hline Armenia & 122,7 & 224,3 & 181,9 & 172,8 & 97,6 & 113,1 & 243,8 & 176,7 & 124,2 \\
\hline Azerbaiyán & 153,5 & 100,2 & 160,9 & 107,8 & 181,4 & 86,5 & 120,9 & 65,7 & 157,7 \\
\hline Bangladesh & 828,0 & 858,0 & 971,2 & $1.274,7$ & $1.910,3$ & 406,1 & 313,2 & 497,8 & 479,9 \\
\hline Barbados & 0,5 & 11,8 & 2,4 & 0,5 & " & 0,2 & 9,2 & 11,0 & " \\
\hline Belarús & 0,6 & 8,7 & 20,1 & 61,7 & 4,6 & 4,6 & 8,6 & 29,3 & 13,4 \\
\hline Belice & 9,5 & 10,1 & 25,0 & 27,2 & 8,9 & 6,4 & 10,1 & 13,7 & 9,2 \\
\hline Benin & 120,8 & 204,2 & 244,9 & 254,1 & 164,0 & 126,1 & 185,7 & 194,4 & 275,2 \\
\hline Bhután & 47,7 & 47,8 & 80,4 & 59,1 & 49,7 & 30,2 & 40,7 & 93,3 & 70,4 \\
\hline Bolivia & 269,7 & 170,7 & 274,4 & 275,1 & 411,1 & 153,3 & 230,4 & 259,8 & 216,9 \\
\hline Bosnia y Herzegovina & 123,2 & 179,1 & 259,9 & 249,3 & 170,4 & 101,5 & 111,5 & 130,2 & 116,0 \\
\hline Botswana & 16,7 & 6,1 & 5,3 & 22,2 & 5,6 & 12,6 & 23,6 & 26,6 & 15,8 \\
\hline Brasil & 54,9 & 73,1 & 288,7 & 493,4 & 299,4 & 81,7 & 185,7 & 280,1 & 240,2 \\
\hline Burkina Faso & 244,6 & 178,7 & 603,0 & 356,6 & 343,1 & 216,3 & 234,1 & 246,4 & 252,2 \\
\hline Burundi & 54,5 & 92,1 & 137,2 & 214,2 & 205,4 & 77,2 & 91,3 & 129,6 & 122,3 \\
\hline Cabo Verde & 83,6 & 72,7 & 127,0 & 71,1 & 46,0 & 66,2 & 77,2 & 166,3 & 87,2 \\
\hline Camboya & 208,8 & 234,2 & 275,2 & 496,7 & 257,4 & 147,3 & 146,8 & 226,2 & 256,4 \\
\hline Camerún & 120,3 & 305,7 & 365,9 & 170,9 & 356,4 & 143,6 & 146,7 & 168,9 & 148,1 \\
\hline Chad & 96,3 & 33,8 & 103,8 & 16,1 & 183,1 & 55,0 & 80,3 & 28,4 & 59,2 \\
\hline Chile & 42,1 & 35,9 & 72,7 & 31,7 & 18,9 & 59,5 & 38,0 & 105,8 & 33,4 \\
\hline China & 899,6 & 610,0 & 611,9 & 634,7 & 181,2 & 916,4 & 660,2 & 543,0 & 504,9 \\
\hline Colombia & 85,4 & 156,7 & 184,1 & 207,1 & 339,6 & 132,1 & 192,0 & 151,9 & 218,6 \\
\hline Comoras & 3,9 & 6,5 & 33,0 & 7,3 & 5,7 & 4,2 & 4,6 & 8,4 & 4,9 \\
\hline Costa Rica & 54,7 & 24,2 & 14,2 & 18,1 & 55,5 & 49,1 & 94,1 & 84,6 & 20,2 \\
\hline Côte d'Ivoire & 57,3 & 115,9 & 283,8 & 240,3 & 219,7 & 101,3 & 215,6 & 194,4 & 125,2 \\
\hline Croacia & 68,7 & 120,9 & 79,0 & 78,1 & " & 40,8 & 24,7 & 46,6 & " \\
\hline Cuba & 10,1 & 12,5 & 14,6 & 29,9 & 11,4 & 10,6 & 24,2 & 35,6 & 18,7 \\
\hline Djibouti & 23,8 & 7,1 & 26,9 & 60,5 & 56,7 & 9,6 & 45,1 & 39,5 & 15,9 \\
\hline Dominica & 15,6 & 6,9 & 9,5 & 0,2 & 0,4 & 9,9 & 23,9 & 19,8 & 15,0 \\
\hline Ecuador & 55,2 & 62,8 & 76,9 & 96,1 & 35,4 & 43,9 & 58,3 & 68,7 & 67,2 \\
\hline Egipto & 603,6 & 916,0 & 500,2 & $1.979,2$ & 351,1 & 597,8 & 692,1 & 942,2 & 623,5 \\
\hline El Salvador & 31,0 & 200,8 & 137,3 & 60,6 & 49,6 & 61,0 & 85,3 & 143,1 & 140,2 \\
\hline Eritrea & 54,0 & 37,6 & 68,0 & 16,8 & 3,3 & 20,1 & 21,1 & 26,1 & 10,7 \\
\hline Eslovenia & 6,1 & " & $"$ & $"$ & $"$ & $"$ & $"$ & $"$ & " \\
\hline Estados de la ex Yugoslavia & 58,3 & 2,3 & 2,9 & 2,8 & $"$ & 5,0 & 3,0 & 2,8 & " \\
\hline Estados Federados de Micronesia & 14,9 & 20,6 & 22,0 & 1,8 & 2,8 & 10,8 & 8,8 & 16,3 & 27,6 \\
\hline Etiopía & 559,9 & 799,9 & 791,8 & 975,1 & 466,8 & 542,9 & $1.086,0$ & 593,9 & 650,5 \\
\hline $\begin{array}{l}\text { Ex República Yugoslava } \\
\text { de Macedonia }\end{array}$ & 53,7 & 50,5 & 47,6 & 91,7 & 89,6 & 35,0 & 29,6 & 29,2 & 42,3 \\
\hline Fiji & 8,9 & 12,9 & 6,6 & 21,6 & 19,3 & 10,1 & 6,4 & 10,6 & 11,3 \\
\hline Filipinas & 395,9 & 262,2 & 963,4 & 154,0 & 852,4 & 598,3 & 628,9 & 414,5 & 356,6 \\
\hline Gabón & 43,3 & 54,3 & 23,3 & 42,6 & 4,9 & 25,8 & 18,8 & 59,2 & 27,0 \\
\hline Gambia & 29,1 & 13,2 & 35,9 & 77,6 & 59,2 & 16,5 & 35,2 & 35,8 & 59,3 \\
\hline Georgia & 104,8 & 239,3 & 551,2 & 465,9 & 85,5 & 156,6 & 237,7 & 249,9 & 178,7 \\
\hline Ghana & 297,6 & 634,8 & 799,5 & 884,7 & 552,5 & 363,8 & 429,0 & 584,8 & 705,3 \\
\hline Granada & 9,0 & 1,7 & 14,7 & 1,7 & 15,7 & 1,1 & 2,9 & 10,5 & 9,6 \\
\hline Guatemala & 31,9 & 60,9 & 98,9 & 88,2 & 54,6 & 29,6 & 66,1 & 91,5 & 53,7 \\
\hline
\end{tabular}


CUADRO A.7 Ayuda para el comercio, por beneficiario (página 2 de 3)

\begin{tabular}{|c|c|c|c|c|c|c|c|c|c|}
\hline & \multicolumn{5}{|c|}{ COMPROMISOS } & \multicolumn{4}{|c|}{ DESEMBOLSOS } \\
\hline & $\begin{array}{c}\text { Promedio } \\
2002-05\end{array}$ & $\begin{array}{c}\text { Promedio } \\
2006-08\end{array}$ & 2009 & 2010 & 2011 & $\begin{array}{c}\text { Promedio } \\
2006-08\end{array}$ & 2009 & 2010 & 2011 \\
\hline Guinea & 64,8 & 73,2 & 41,4 & 11,5 & 124,2 & 46,2 & 58,9 & 66,2 & 74,1 \\
\hline Guinea Ecuatorial & 1,0 & 0,3 & 1,3 & 0,5 & 1,6 & 0,5 & 0,6 & 0,5 & 1,6 \\
\hline Guinea-Bissau & 28,0 & 16,6 & 15,9 & 26,7 & 13,5 & 36,0 & 35,4 & 13,9 & 26,3 \\
\hline Guyana & 46,0 & 58,7 & 47,0 & 43,0 & 78,1 & 18,0 & 64,2 & 55,1 & 90,6 \\
\hline Haití & 92,4 & 105,1 & 344,2 & 401,5 & 779,3 & 62,9 & 174,0 & 332,3 & 332,6 \\
\hline Honduras & 193,3 & 75,8 & 166,9 & 219,3 & 114,2 & 81,9 & 162,3 & 194,5 & 177,6 \\
\hline India & $1.784,7$ & $2.758,8$ & $1.957,2$ & $3.504,3$ & $3.779,1$ & $1.444,1$ & $2.063,7$ & $2.463,7$ & $2.231,7$ \\
\hline Indonesia & $1.317,7$ & 980,3 & $1.417,1$ & 871,5 & 648,1 & 952,5 & 905,0 & 1214,3 & 860,2 \\
\hline Irán & 5,7 & 2,5 & 2,9 & 13,2 & 7,3 & 2,4 & 2,7 & 2,8 & 5,1 \\
\hline Iraq & $2.181,9$ & $2.291,8$ & 417,5 & 854,7 & 116,6 & $1.846,8$ & 372,6 & 486,7 & 503,3 \\
\hline Islas Cook & 1,6 & 0,5 & 8,7 & 5,1 & 16,4 & 1,4 & 2,1 & 3,1 & 8,8 \\
\hline Islas Marshall & 5,5 & 1,4 & 23,7 & 1,2 & 1,5 & 2,0 & 4,9 & 12,3 & 3,8 \\
\hline Islas Salomón & 14,2 & 28,1 & 8,7 & 48,3 & 68,9 & 20,5 & 25,9 & 29,5 & 50,5 \\
\hline Islas Turcas y Caicos & 0,1 & $"$ & $"$ & $"$ & $"$ & 0,0 & $"$ & $"$ & " \\
\hline Jamaica & 36,4 & 37,3 & 41,7 & 48,7 & 52,3 & 49,0 & 71,1 & 55,9 & 32,1 \\
\hline Jordania & 46,4 & 116,5 & 205,2 & 152,8 & 186,0 & 74,1 & 121,1 & 388,0 & 145,7 \\
\hline Kazajstán & 37,7 & 114,1 & 57,6 & 210,5 & 9,6 & 96,9 & 91,9 & 59,9 & 36,7 \\
\hline Kenya & 335,7 & 543,6 & $1.033,9$ & $1.750,0$ & 825,1 & 312,4 & 371,2 & 416,1 & 534,0 \\
\hline Kiribati & 9,1 & 8,9 & 9,8 & 5,0 & 110,4 & 12,3 & 7,1 & 4,0 & 13,1 \\
\hline Kosovo & $"$ & $"$ & 149,6 & 64,0 & 115,5 & $"$ & 75,0 & 61,2 & 89,1 \\
\hline Lesotho & 7,2 & 35,1 & 23,4 & 32,3 & 36,6 & 19,0 & 12,5 & 26,2 & 37,9 \\
\hline Líbano & 27,7 & 88,5 & 57,9 & 87,0 & 27,4 & 57,8 & 93,8 & 89,7 & 95,6 \\
\hline Liberia & 0,9 & 78,3 & 302,3 & 199,3 & 202,8 & 46,7 & 79,1 & 115,7 & 129,9 \\
\hline Libia & 2,3 & 4,7 & 8,5 & 18,1 & 3,1 & 12,3 & 15,3 & 29,7 & 1,1 \\
\hline Madagascar & 313,9 & 280,7 & 59,4 & 38,5 & 71,7 & 308,8 & 141,4 & 135,6 & 110,0 \\
\hline Malasia & 14,9 & 45,4 & 48,7 & 33,7 & 6,4 & 169,6 & 128,4 & 54,9 & 8,9 \\
\hline Malawi & 122,1 & 150,1 & 192,5 & 290,8 & 318,9 & 110,6 & 141,2 & 197,5 & 178,6 \\
\hline Maldivas & 9,4 & 16,6 & 28,2 & 17,4 & 2,1 & 4,3 & 11,2 & 34,8 & 7,3 \\
\hline Malí & 178,4 & 522,2 & 662,5 & 336,6 & 267,0 & 259,2 & 277,2 & 354,3 & 479,0 \\
\hline Marruecos & 338,2 & 924,2 & $1.047,2$ & $1.380,6$ & 312,5 & 472,2 & 650,6 & 785,0 & 964,2 \\
\hline Mauricio & 56,2 & 36,0 & 113,7 & 36,8 & 7,4 & 7,1 & 24,0 & 17,7 & 30,3 \\
\hline Mauritania & 122,7 & 143,7 & 57,9 & 69,3 & 314,6 & 85,1 & 114,3 & 124,6 & 161,8 \\
\hline Mayotte & 20,6 & 26,0 & 22,7 & 53,4 & $"$ & 21,7 & 37,1 & 53,6 & " \\
\hline México & 28,3 & 52,1 & 75,0 & 177,7 & 38,1 & 29,0 & 50,5 & 42,2 & 89,3 \\
\hline Moldova & 67,9 & 48,6 & 64,0 & 391,5 & 100,3 & 43,6 & 55,7 & 75,7 & 113,7 \\
\hline Mongolia & 63,7 & 286,7 & 134,8 & 319,5 & 116,3 & 76,9 & 135,0 & 144,5 & 154,8 \\
\hline Montenegro & 7,2 & 31,9 & 29,6 & 26,5 & 8,8 & 24,4 & 29,1 & 22,4 & 20,6 \\
\hline Montserrat & 7,9 & 12,5 & 2,6 & 0,1 & 2,2 & 4,8 & 9,8 & 11,0 & 10,5 \\
\hline Mozambique & 365,0 & 482,7 & 395,4 & 693,9 & 335,8 & 378,5 & 360,7 & 368,1 & 362,4 \\
\hline Myanmar & 13,2 & 18,9 & 23,5 & 36,3 & 58,9 & 19,8 & 30,4 & 48,2 & 85,8 \\
\hline Namibia & 34,6 & 89,1 & 135,6 & 90,8 & 57,7 & 32,2 & 64,4 & 64,9 & 113,3 \\
\hline Nauru & 2,7 & 12,8 & 7,9 & 0,4 & 1,3 & 12,3 & 8,5 & 1,0 & 1,3 \\
\hline Nepal & 183,1 & 224,5 & 315,1 & 463,0 & 453,4 & 139,5 & 171,3 & 270,9 & 278,2 \\
\hline Nicaragua & 210,4 & 213,7 & 215,1 & 295,5 & 199,3 & 151,7 & 201,6 & 235,1 & 233,1 \\
\hline Níger & 113,3 & 115,5 & 134,3 & 67,9 & 153,0 & 96,9 & 87,8 & 135,5 & 106,8 \\
\hline Nigeria & 257,7 & 360,8 & $1.051,2$ & 348,6 & 486,0 & 252,6 & 263,6 & 455,2 & 349,6 \\
\hline Niue & 2,5 & 2,0 & 3,8 & 4,1 & 10,3 & 2,3 & 0,7 & 5,0 & 9,4 \\
\hline Omán & 2,9 & 6,7 & 202,8 & 4,6 & " & 8,2 & 230,4 & 24,3 & " \\
\hline Pakistán & 647,0 & 792,6 & 733,4 & $1.041,5$ & 601,9 & 379,9 & 411,4 & 343,2 & 605,6 \\
\hline Palau & 7,9 & 7,7 & 10,4 & 1,9 & 1,4 & 10,1 & 5,1 & 8,7 & 1,4 \\
\hline Panamá & 11,2 & 13,4 & 18,7 & 18,8 & 26,6 & 9,0 & 11,4 & 14,6 & 19,5 \\
\hline Papua Nueva Guinea & 149,6 & 161,2 & 182,8 & 258,8 & 182,6 & 121,1 & 107,1 & 140,8 & 151,0 \\
\hline Paraguay & 18,6 & 109,2 & 79,9 & 130,9 & 19,4 & 41,3 & 92,4 & 42,8 & 27,3 \\
\hline Perú & 135,5 & 137,6 & 225,6 & 156,6 & 103,8 & 202,7 & 116,3 & 174,5 & 152,3 \\
\hline República Centroafricana & 36,3 & 63,8 & 92,7 & 17,9 & 92,4 & 37,5 & 28,9 & 36,8 & 93,5 \\
\hline
\end{tabular}


CUADRO A.7 Ayuda para el comercio, por beneficiario (página 3 de 3)

En millones de \$EE.UU. (dólares constantes de 2011)

\begin{tabular}{|c|c|c|c|c|c|c|c|c|c|}
\hline & \multicolumn{5}{|c|}{ COMPROMISOS } & \multicolumn{4}{|c|}{ DESEMBOLSOS } \\
\hline & $\begin{array}{l}\text { Promedio } \\
2002-05\end{array}$ & $\begin{array}{l}\text { Promedio } \\
2006-08\end{array}$ & 2009 & 2010 & 2011 & $\begin{array}{c}\text { Promedio } \\
2006-08\end{array}$ & 2009 & 2010 & 2011 \\
\hline República del Congo & 41,4 & 40,2 & 48,0 & 29,1 & 53,0 & 31,2 & 28,4 & 19,5 & 34,9 \\
\hline República Democrática del Congo & 531,8 & 317,2 & 746,4 & 756,1 & 808,1 & 218,0 & 488,4 & 306,4 & 385,1 \\
\hline República Democrática Popular Lao & 168,8 & 139,3 & 112,3 & 285,7 & 260,7 & 136,8 & 118,0 & 160,7 & 156,6 \\
\hline República Dominicana & 46,1 & 36,4 & 72,4 & 92,0 & 240,8 & 57,8 & 49,7 & 47,6 & 142,2 \\
\hline $\begin{array}{l}\text { República Popular Democrática } \\
\text { de Corea }\end{array}$ & 34,9 & 9,3 & 4,1 & 0,8 & 0,2 & 9,3 & 4,9 & 4,7 & 1,8 \\
\hline República Kirguisa & 56,6 & 87,0 & 111,5 & 175,2 & 190,3 & 59,4 & 61,7 & 86,7 & 131,1 \\
\hline Ribera Occidental y Franja de Gaza & 67,1 & 94,0 & 237,5 & 193,2 & 86,5 & 73,4 & 143,3 & 223,8 & 178,8 \\
\hline Rwanda & 81.5 & 139.4 & 440.4 & 226.3 & 315.9 & 110.2 & 175.3 & 215.8 & 304.1 \\
\hline Saint Kitts y Nevis & 2,0 & 0,3 & " & 0,7 & 1,1 & 2,5 & 3,4 & 2,9 & 2,0 \\
\hline Samoa & 17,2 & 33,7 & 5,3 & 25,4 & 30,2 & 11,0 & 22,4 & 35,3 & 36,0 \\
\hline San Vicente y las Granadinas & 7,4 & 8,7 & 1,7 & 0,4 & 0,5 & 10,9 & 12,9 & 4,4 & 8,5 \\
\hline Santa Elena & 41,8 & 15,4 & 23,8 & 8,8 & 64,4 & 15,2 & 16,6 & 9,6 & 75,4 \\
\hline Santa Lucía & 9,9 & 9,4 & 0,8 & 3,9 & 7,2 & 7,9 & 19,5 & 23,8 & 10,6 \\
\hline Santo Tomé y Príncipe & 8,2 & 7,0 & 24,9 & 4,8 & 25,5 & 7,1 & 3,2 & 5,8 & 19,1 \\
\hline Senegal & 196,3 & 256,1 & 424,4 & 836,6 & 246,2 & 238,7 & 223,3 & 260,4 & 316,0 \\
\hline Serbia & 460,0 & 304,0 & 111,1 & 314,2 & 672,7 & 257,1 & 237,2 & 277,4 & 229,1 \\
\hline Seychelles & 3,4 & 6,8 & 2,5 & 1,6 & 1,4 & 3,8 & 11,0 & 5,6 & 7,5 \\
\hline Sierra Leona & 100,8 & 87,8 & 36,5 & 178,4 & 88,5 & 57,1 & 113,5 & 122,8 & 101,9 \\
\hline Siria & 18,9 & 31,1 & 291,5 & 193,3 & 113,1 & 49,5 & 99,9 & 89,9 & 130,3 \\
\hline Somalia & 4,7 & 15,2 & 40,8 & 14,7 & 39,3 & 6,6 & 18,6 & 26,0 & 33,6 \\
\hline Sri Lanka & 545,9 & 438,8 & 390,3 & 395,3 & 659,8 & 342,8 & 481,6 & 390,8 & 472,4 \\
\hline Sudáfrica & 136,3 & 167,8 & 168,2 & 223,0 & 112,7 & 203,6 & 130,3 & 133,9 & 156,9 \\
\hline Sudán & 25,2 & 235,9 & 247,9 & 391,4 & 627,1 & 88,9 & 232,2 & 293,2 & 219,8 \\
\hline Sudán del Sur & $"$ & " & " & " & 126,0 & $"$ & " & " & 129,8 \\
\hline Suriname & 24,5 & 19,5 & 62,2 & 0,4 & 6,3 & 25,1 & 50,5 & 25,3 & 28,2 \\
\hline Swazilandia & 18,8 & 23,5 & 24,5 & 26,2 & 78,3 & 13,9 & 12,6 & 11,2 & 27,2 \\
\hline Tailandia & 430,3 & 298,9 & 808,9 & 397,2 & 26,9 & 212,7 & 126,0 & 215,6 & 263,3 \\
\hline Tanzanía & 434,3 & 814,6 & 847,3 & $1.502,6$ & 607,8 & 440,8 & 598,5 & 779,9 & 611,5 \\
\hline Tayikistán & 102,2 & 126,3 & 92,4 & 252,5 & 233,6 & 50,2 & 78,3 & 183,3 & 129,4 \\
\hline Timor-Leste & 36,8 & 37,9 & 34,1 & 98,6 & 55,0 & 27,8 & 35,1 & 47,2 & 49,1 \\
\hline Togo & 6,0 & 35,1 & 63,4 & 160,6 & 78,5 & 38,3 & 29,6 & 39,2 & 50,6 \\
\hline Tokelau & 1,6 & 1,3 & 1,1 & 0,6 & 9,8 & 2,6 & 1,0 & 1,0 & 5,9 \\
\hline Tonga & 3,2 & 16,3 & 4,3 & 32,8 & 78,9 & 8,1 & 11,6 & 36,7 & 16,7 \\
\hline Trinidad y Tabago & 16,8 & 9,8 & 16,0 & 25,1 & " & 2,3 & 2,0 & 1,4 & " \\
\hline Túnez & 231,1 & 316,7 & 315,4 & 551,9 & 276,9 & 226,8 & 376,3 & 525,1 & 275,9 \\
\hline Turkmenistán & 2,7 & 1,9 & 2,6 & 19,5 & 5,6 & 2,0 & 3,2 & 2,8 & 3,0 \\
\hline Turquía & 522,0 & 438,4 & 289,6 & 1013,8 & 422,1 & 448,7 & 825,6 & 774,6 & 403,2 \\
\hline Tuvalu & 4,8 & 6,5 & 1,7 & 1,5 & 17,3 & 6,4 & 7,4 & 1,8 & 3,8 \\
\hline Ucrania & 96,1 & 253,8 & 307,3 & 181,5 & 291,8 & 171,7 & 278,3 & 291,2 & 367,3 \\
\hline Uganda & 278,2 & 465,9 & $1.041,5$ & 803,4 & 458,8 & 420,8 & 483,1 & 452,3 & 460,8 \\
\hline Uruguay & 6,7 & 4,7 & 15,5 & 11,9 & 5,8 & 7,3 & 13,1 & 25,7 & 7,6 \\
\hline Uzbekistán & 171,6 & 57,6 & 132,4 & 533,3 & 64,5 & 56,7 & 76,4 & 93,4 & 73,2 \\
\hline Vanuatu & 7,2 & 44,9 & 30,2 & 20,2 & 20,0 & 24,7 & 55,9 & 38,1 & 17,8 \\
\hline Venezuela & 2,8 & 1,9 & 1,8 & 1,8 & 2,5 & 2,6 & 2,5 & 2,2 & 1,8 \\
\hline Viet Nam & $1.747,6$ & $2.028,3$ & $2.775,8$ & $1.843,9$ & $3.443,1$ & $1.253,3$ & $1.502,0$ & $1.843,5$ & $2.069,1$ \\
\hline Wallis y Futuna & 7,9 & 1,8 & 3,0 & 4,9 & 5,1 & 1,8 & 3,0 & 6,7 & 10,4 \\
\hline Yemen & 53,1 & 155,4 & 679,0 & 330,8 & 262,4 & 81,0 & 139,6 & 187,5 & 90,1 \\
\hline Zambia & 233,2 & 245,3 & 317,5 & 182,9 & 456,7 & 162,1 & 139,9 & 125,0 & 178,5 \\
\hline Zimbabwe & 11,0 & 16,9 & 118,1 & 124,2 & 78,5 & 12,4 & 55,3 & 86,2 & 91,5 \\
\hline TOTAL & $24.136,1$ & $29.920,5$ & $35.502,5$ & $40.892,7$ & $33.827,1$ & $21.403,1$ & $25.486,6$ & $28.529,2$ & $27.335,5$ \\
\hline $\begin{array}{l}\text { Regionales/mundiales } \\
\text { (sin asignar) }\end{array}$ & $2.355,6$ & $4.672,0$ & $7.495,0$ & $7.278,3$ & $7.742,5$ & $3.397,9$ & $5.691,9$ & $6.338,3$ & $6.230,3$ \\
\hline $\begin{array}{l}\text { TOTAL DE LA AYUDA } \\
\text { PARA EL COMERCIO }\end{array}$ & $26.491,7$ & $34.592,5$ & $42.997,4$ & $48.171,0$ & $41.569,6$ & $24.801,0$ & $31.178,5$ & $34.867,5$ & $33.565,9$ \\
\hline
\end{tabular}


CUADRO A.8A Programas multinacionales de ayuda para el comercio, por región

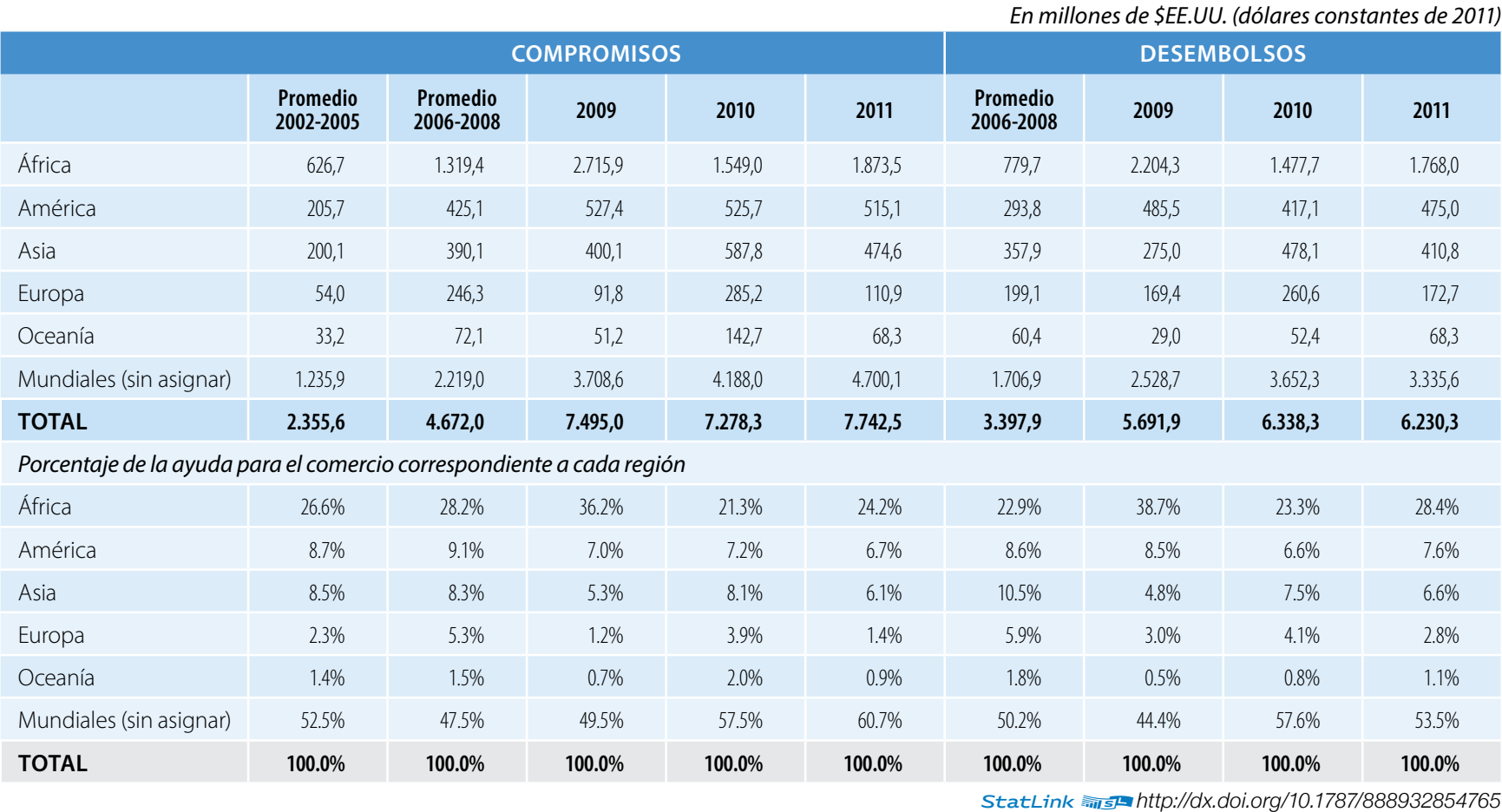

\section{CUADRO A.8B Programas multinacionales de ayuda para el comercio, por categoría}

En millones de \$SE.UU. (dólares constantes de 2011)

\begin{tabular}{|c|c|c|c|c|c|c|c|c|c|}
\hline & \multicolumn{5}{|c|}{ COMPROMISOS } & \multicolumn{4}{|c|}{ DESEMBOLSOS } \\
\hline & $\begin{array}{l}\text { Promedio } \\
2002-2005\end{array}$ & $\begin{array}{l}\text { Promedio } \\
2006-2008\end{array}$ & 2009 & 2010 & 2011 & $\begin{array}{l}\text { Promedio } \\
2006-2008\end{array}$ & 2009 & 2010 & 2011 \\
\hline Política y reglamentación comerciales & 283,6 & 541,3 & 725,0 & 938,8 & 861,4 & 380,2 & 514,0 & 763,4 & 569,3 \\
\hline Infraestructura económica & 519,3 & $1.011,3$ & $2.127,8$ & $2.142,7$ & $1.492,5$ & 526,2 & 926,1 & $1.755,9$ & $1.690,0$ \\
\hline Creación de capacidad productiva & $1.552,8$ & $3.119,4$ & $4.642,2$ & $4.195,7$ & $5.377,9$ & $2.491,4$ & $4.251,7$ & $3.818,9$ & $3.969,7$ \\
\hline Ajuste relacionado con el comercio & " & 0,1 & " & 1,1 & 10,7 & 0,0 & 0,1 & " & 1,3 \\
\hline TOTAL & $2.355,6$ & $4.672,0$ & $7.495,0$ & $7.278,3$ & $7.742,5$ & $3.397,9$ & $5.691,9$ & $6.338,3$ & $6.230,3$ \\
\hline \multicolumn{10}{|c|}{ Porcentaje de la ayuda para el comercio correspondiente a cada categoría } \\
\hline Política y reglamentación comerciales & $12.0 \%$ & $11.6 \%$ & $9.7 \%$ & $12.9 \%$ & $11.1 \%$ & $11.2 \%$ & $9.0 \%$ & $12.0 \%$ & $9.1 \%$ \\
\hline Infraestructura económica & $22.0 \%$ & $21.6 \%$ & $28.4 \%$ & $29.4 \%$ & $19.3 \%$ & $15.5 \%$ & $16.3 \%$ & $27.7 \%$ & $27.1 \%$ \\
\hline Creación de capacidad productiva & $65.9 \%$ & $66.8 \%$ & $61.9 \%$ & $57.6 \%$ & $69.5 \%$ & $73.3 \%$ & $74.7 \%$ & $60.3 \%$ & $63.7 \%$ \\
\hline Ajuste relacionado con el comercio &. & $0.0 \%$ &. & $0.0 \%$ & $0.1 \%$ & $0.0 \%$ & $0.0 \%$ &. & $0.0 \%$ \\
\hline TOTAL & $100.0 \%$ & $100.0 \%$ & $100.0 \%$ & $100.0 \%$ & $100.0 \%$ & $100.0 \%$ & $100.0 \%$ & $100.0 \%$ & $100.0 \%$ \\
\hline
\end{tabular}


CUADRO A.9 Distribución de la ayuda para el comercio, por región

En millones de \$EE.UU. (dólares constantes de 2011)

\begin{tabular}{|c|c|c|c|c|c|c|c|c|c|}
\hline & \multicolumn{5}{|c|}{ COMPROMISOS } & \multicolumn{4}{|c|}{ DESEMBOLSOS } \\
\hline & $\begin{array}{l}\text { Promedio } \\
2002-2005\end{array}$ & $\begin{array}{l}\text { Promedio } \\
2006-2008\end{array}$ & 2009 & 2010 & 2011 & $\begin{array}{l}\text { Promedio } \\
2006-2008\end{array}$ & 2009 & 2010 & 2011 \\
\hline \multicolumn{10}{|l|}{ África } \\
\hline Política y reglamentación comerciales & 378,5 & 375,0 & 649,3 & 390,6 & 355,0 & 223,4 & 314,6 & 395,5 & 327,7 \\
\hline Infraestructura económica & $3.932,4$ & $6.734,7$ & $9.413,8$ & $11.371,9$ & $6.217,2$ & $4.129,8$ & $5.347,8$ & $6.258,7$ & $6.383,7$ \\
\hline Creación de capacidad productiva & $3.639,7$ & $5.082,6$ & $7.160,1$ & $6.766,8$ & $6.534,6$ & $3.791,3$ & $5.962,3$ & $5.159,9$ & $5.563,3$ \\
\hline Ajuste relacionado con el comercio & $"$ & 2,5 & 0,7 & 0,1 & 15,5 & 13,0 & 31,8 & 55,9 & 3,1 \\
\hline TOTAL PARCIAL & $7.950,6$ & $12.193,9$ & $17.223,9$ & $18.529,4$ & $13.122,3$ & $8.153,2$ & $11.656,5$ & $11.870,0$ & $12.277,8$ \\
\hline \multicolumn{10}{|l|}{ América } \\
\hline Política y reglamentación comerciales & 69,5 & 119,0 & 229,2 & 78,7 & 237,9 & 89,3 & 106,5 & 113,4 & 76,0 \\
\hline Infraestructura económica & 512,6 & 801,7 & $1.313,6$ & $1.178,0$ & $1.523,0$ & 503,8 & 992,6 & $1.294,4$ & $1.317,0$ \\
\hline Creación de capacidad productiva & $1.243,5$ & $1.273,3$ & $1.617,3$ & $2.280,8$ & $1.717,9$ & $1.146,4$ & $1.548,5$ & $1.640,5$ & $1.528,7$ \\
\hline Ajuste relacionado con el comercio & $"$ & 0,6 & 15,5 & 24,4 & 43,0 & $"$ & 0,9 & 12,8 & 6,5 \\
\hline TOTAL PARCIAL & $1.825,6$ & $2.194,5$ & $3.175,6$ & $3.561,9$ & $3.521,8$ & $1.739,5$ & $2.648,5$ & $3.061,1$ & $2.928,2$ \\
\hline \multicolumn{10}{|l|}{ Asia } \\
\hline Política y reglamentación comerciales & 174,0 & 267,3 & 292,3 & 442,2 & 207,0 & 187,3 & 215,7 & 348,7 & 227,5 \\
\hline Infraestructura económica & $8.341,4$ & $9.705,6$ & $11.287,2$ & $12.645,8$ & $11.690,5$ & $6.783,1$ & $7.156,3$ & $8.423,0$ & $7.939,9$ \\
\hline Creación de capacidad productiva & $5.013,1$ & $5.766,6$ & $5.429,7$ & $5.240,3$ & $5.559,7$ & $4.484,4$ & $4.679,2$ & $4.946,3$ & $4.723,4$ \\
\hline Ajuste relacionado con el comercio & $"$ & $.0,5$ & $"$ & 6,5 & 3,5 & 0,7 & 2,7 & 1,5 & 6,2 \\
\hline TOTAL PARCIAL & $13.528,5$ & $15.739,8$ & $17.009,2$ & $18.334,8$ & $17.460,7$ & $11.455,2$ & $12.053,8$ & $13.719,6$ & $12.897,0$ \\
\hline \multicolumn{10}{|l|}{ Europa } \\
\hline Política y reglamentación comerciales & 30,3 & 89,7 & 75,0 & 35,4 & 75,0 & 29,9 & 36,5 & 79,5 & 39,8 \\
\hline Infraestructura económica & 949,2 & 938,5 & 722,3 & $1.963,7$ & $1.314,9$ & 816,1 & $1.155,5$ & $1.505,8$ & 953,8 \\
\hline Creación de capacidad productiva & 679,7 & 784,3 & 701,6 & 981,7 & 729,4 & 582,3 & 790,8 & 574,8 & 695,2 \\
\hline Ajuste relacionado con el comercio & $"$ & $"$ & $"$ & $"$ & $.0,8$ & $"$ & 1,3 & 1,0 & 1,5 \\
\hline TOTAL PARCIAL & $1.659,2$ & $1.812,5$ & $1.499,0$ & $2.980,8$ & $2.120,2$ & $1.428,3$ & $1.984,1$ & $2.161,1$ & $1.690,4$ \\
\hline \multicolumn{10}{|l|}{ Oceanía } \\
\hline Política y reglamentación comerciales & $.4,0$ & 5,1 & $.9,0$ & 93,1 & 11,6 & 2,7 & 8,4 & 7,2 & 19,5 \\
\hline Infraestructura económica & 161,1 & 264,5 & 252,0 & 257,3 & 440,1 & 170,4 & 198,0 & 261,0 & 266,3 \\
\hline Creación de capacidad productiva & 126,8 & 163,3 & 120,3 & 225,6 & 192,8 & 144,9 & 100,5 & 134,1 & 151,2 \\
\hline Ajuste relacionado con el comercio & $"$ & $.0,0$ & 0,0 & 0,0 & $"$ & $"$ & $"$ & 1,1 & $"$ \\
\hline TOTAL PARCIAL & 291,9 & 432,9 & 381,2 & 576,0 & 644,5 & 317,9 & 306,9 & 403,4 & 437,0 \\
\hline \multicolumn{10}{|l|}{ Mundiales (sin asignar) } \\
\hline Política y reglamentación comerciales & 158,7 & 278,1 & 282,7 & 423,3 & 426,9 & 240,7 & 249,8 & 293,4 & 292,0 \\
\hline Infraestructura económica & 221,7 & 282,4 & 463,5 & $1.195,3$ & 772,3 & 194,2 & 273,6 & $1.052,8$ & 880,3 \\
\hline Creación de capacidad productiva & 855,5 & $1.658,5$ & $2.962,3$ & $2.569,4$ & $3.500,8$ & $1.272,0$ & $2.005,4$ & $2.306,1$ & $2.163,2$ \\
\hline Ajuste relacionado con el comercio & $"$ & $"$ & $"$ & $"$ & $"$ & $"$ & $"$ & $"$ & $.0,0$ \\
\hline TOTAL PARCIAL & $1.235,9$ & $2.219,0$ & $3.708,6$ & $4.188,0$ & $4.700,1$ & $1.706,9$ & $2.528,7$ & $3.652,3$ & $3.335,6$ \\
\hline TOTAL & $26.491,7$ & $34.592,5$ & $42.997,4$ & $48.171,0$ & $41.569,6$ & $24.801,0$ & $31.178,5$ & $34.867,5$ & $33.565,9$ \\
\hline
\end{tabular}

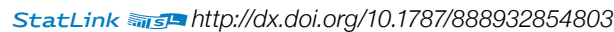


CUADRO A.10 Distribución de la ayuda para el comercio, por grupo de países según nivel de ingresos

En millones de \$EE.UU. (dólares constantes de 2011)

\begin{tabular}{|c|c|c|c|c|c|c|c|c|c|}
\hline & \multicolumn{5}{|c|}{ COMPROMISOS } & \multicolumn{4}{|c|}{ DESEMBOLSOS } \\
\hline & $\begin{array}{l}\text { Promedio } \\
2002-05 .\end{array}$ & $\begin{array}{l}\text { Promedio } \\
\text { 2006-08. }\end{array}$ & 2009 & 2010 & 2011 & $\begin{array}{l}\text { Promedio } \\
2006-08 .\end{array}$ & 2009 & 2010 & 2011 \\
\hline \multicolumn{10}{|l|}{ Países menos adelantados } \\
\hline Política y reglamentación comerciales & 94,3 & 215,9 & 335,3 & 228,9 & 124,8 & 129,8 & 132,3 & 136,6 & 183,1 \\
\hline Infraestructura económica & $3.821,2$ & $5.598,5$ & $7.110,1$ & $8.461,6$ & $8.001,8$ & $3.412,1$ & $4.361,1$ & $5.059,9$ & $5.129,5$ \\
\hline Creación de capacidad productiva & $3.023,3$ & $3.694,5$ & $5.258,8$ & $5.801,1$ & $5.353,7$ & $2.904,7$ & $4.197,1$ & $4.134,7$ & $4.130,1$ \\
\hline Ajuste relacionado con el comercio & $"$ & 2,6 & 0,6 & 6,6 & 0,6 & 13,4 & 31,8 & 51,6 & 2,2 \\
\hline TOTAL PARCIAL & $6.938,7$ & $9.510,6$ & $12.704,9$ & $14.498,1$ & $13.481,0$ & $6.455,5$ & $8.722,3$ & $9.382,8$ & $9.445,0$ \\
\hline \multicolumn{10}{|l|}{ Otros países de ingresos bajos } \\
\hline Política y reglamentación comerciales & 28,9 & 5,3 & 10,8 & 5,3 & 5,1 & 4,9 & 8,9 & 9,3 & 8,1 \\
\hline Infraestructura económica & 290,9 & 473,6 & 863,9 & $1.603,7$ & $1.035,9$ & 207,5 & 291,8 & 405,0 & 611,0 \\
\hline Creación de capacidad productiva & 220,8 & 304,1 & 485,2 & 693,5 & 412,8 & 231,2 & 270,7 & 358,0 & 398,5 \\
\hline Ajuste relacionado con el comercio & " & 0,1 & 0,0 & 0,0 & 0,0 & " & $"$ & 4,5 & 0,0 \\
\hline TOTAL PARCIAL & 540,5 & 783,0 & $1.360,0$ & $2.302,6$ & $1.453,8$ & 443,6 & 571,4 & 776,8 & $1.017,6$ \\
\hline \multicolumn{10}{|l|}{ Países de ingresos medianos bajos } \\
\hline Política y reglamentación comerciales & 298,1 & 214,1 & 308,8 & 222,0 & 190,7 & 160,8 & 153,0 & 207,4 & 142,1 \\
\hline Infraestructura económica & $7.050,8$ & $9.615,2$ & $10.359,0$ & $12.445,9$ & $9.491,8$ & $6.273,9$ & $6.817,9$ & $8.308,2$ & $7.960,7$ \\
\hline Creación de capacidad productiva & $4.800,0$ & $5.468,2$ & $5.572,0$ & $5.119,0$ & $5.173,4$ & $3.866,9$ & $4.309,5$ & $4.628,8$ & $4.633,3$ \\
\hline Ajuste relacionado con el comercio & " & 0,1 & 0,0 & 0,0 & 7,3 & 0,0 & 1,2 & 2,3 & 6,2 \\
\hline TOTAL PARCIAL & $12.148,8$ & $15.297,5$ & $16.239,8$ & $17.786,9$ & $14.863,2$ & $10.301,7$ & $11.281,6$ & $13.146,7$ & $12.742,4$ \\
\hline \multicolumn{10}{|l|}{ Países de ingresos medianos altos } \\
\hline Política y reglamentación comerciales & 110,2 & 157,6 & 157,8 & 68,4 & 131,4 & 97,6 & 123,3 & 121,0 & 79,9 \\
\hline Infraestructura económica & $2.392,0$ & $2.028,6$ & $2.991,6$ & $3.958,0$ & $1.936,1$ & $2.176,2$ & $2.726,7$ & $3.266,7$ & $2.349,6$ \\
\hline Creación de capacidad productiva & $1.947,5$ & $2.140,5$ & $2.030,1$ & $2.252,6$ & $1.917,6$ & $1.923,3$ & $2.054,7$ & $1.818,3$ & $1.693,4$ \\
\hline Ajuste relacionado con el comercio & $"$ & 0,6 & 15,5 & 23,3 & 44,1 & 0,3 & 3,7 & 14,0 & 7,6 \\
\hline TOTAL PARCIAL & $4.449,8$ & $4.327,0$ & $5.194,9$ & $6.302,3$ & $4.029,2$ & $4.197,4$ & $4.908,4$ & $5.220,0$ & $4.130,6$ \\
\hline \multicolumn{10}{|l|}{ Mundiales (sin asignar) } \\
\hline Política y reglamentación comerciales & 283,6 & 541,3 & 725,0 & 938,8 & 861,4 & 380,3 & 514,0 & 763,4 & 569,3 \\
\hline Infraestructura económica & 563,5 & $1.011,5$ & $2.127,8$ & $2.142,7$ & $1.492,5$ & 527,6 & 926,1 & $1.755,9$ & $1.690,0$ \\
\hline Creación de capacidad productiva & $1.566,8$ & $3.121,4$ & $4.645,1$ & $4.198,5$ & $5.377,9$ & $2.495,0$ & $4.254,6$ & $3.821,7$ & $3.969,7$ \\
\hline Ajuste relacionado con el comercio & " & 0,2 & $"$ & 1,1 & 10,7 & 0,0 & 0,1 & " & 1,3 \\
\hline TOTAL PARCIAL & $2.413,9$ & $4.674,3$ & $7.497,9$ & $7.281,1$ & $7.742,5$ & $3.402,8$ & $5.694,9$ & $6.341,1$ & $6.230,3$ \\
\hline TOTAL & $26.491,7$ & $34.592,5$ & $42.997,4$ & $48.171,0$ & $41.569,6$ & $24.801,0$ & $31.178,5$ & $34.867,5$ & $33.565,9$ \\
\hline
\end{tabular}

StatLink -inis $h t t p: / / d x . d o i . o r g / 10.1787 / 888932854822$ 
CUADRO A.11 Donaciones y otros tipos de ayuda para el comercio, por categoría

\begin{tabular}{|c|c|c|c|c|c|c|c|c|c|}
\hline & \multicolumn{5}{|c|}{ COMPROMISOS } & \multicolumn{4}{|c|}{ DESEMBOLSOS } \\
\hline & $\begin{array}{l}\text { Promedio } \\
2002-2005\end{array}$ & $\begin{array}{c}\text { Promedio } \\
2006-2008\end{array}$ & 2009 & 2010 & 2011 & $\begin{array}{l}\text { Promedio } \\
2006-2008\end{array}$ & 2009 & 2010 & 2011 \\
\hline \multicolumn{10}{|c|}{ Política y reglamentación comerciales } \\
\hline Donaciones & 728,0 & $1.088,4$ & $1.455,2$ & $1.379,3$ & $1.269,4$ & 737,3 & 878,0 & $1.178,8$ & 925,9 \\
\hline Otros tipos de ayuda & 87,0 & 45,7 & 82,4 & 84,1 & 43,9 & 36,0 & 53,5 & 59,0 & 56,6 \\
\hline TOTAL PARCIAL & 815,0 & $1.134,2$ & $1.537,6$ & $1.463,4$ & $1.313,3$ & 773,3 & 931,5 & $1.237,7$ & 982,5 \\
\hline \multicolumn{10}{|c|}{ Infraestructura económica } \\
\hline Donaciones & $5.333,2$ & $7.744,9$ & $8.151,2$ & $9.032,9$ & $8.025,5$ & 5536,8 & 5914,3 & $6.861,7$ & $7.219,3$ \\
\hline Otros tipos de ayuda & $8.785,1$ & $10.982,5$ & $15.301,2$ & $19.579,1$ & $13.932,6$ & $7.060,6$ & $9.209,4$ & $11.934,1$ & $10.521,7$ \\
\hline TOTAL PARCIAL & $14.118,3$ & $18.727,4$ & $23.452,5$ & $28.612,0$ & $21.958,1$ & $12.597,4$ & $15.123,7$ & $18.795,8$ & $17.741,0$ \\
\hline \multicolumn{10}{|c|}{ Creación de capacidad productiva } \\
\hline Donaciones & $6.769,4$ & $8.682,8$ & $11.901,6$ & $12.273,8$ & $10.933,5$ & $7.344,4$ & $10.062,2$ & $9.733,2$ & $9.510,9$ \\
\hline Otros tipos de ayuda & $4.788,9$ & $6.045,8$ & $6.089,6$ & $5.790,9$ & $7.301,9$ & $4.076,8$ & $5.024,4$ & $5.028,4$ & $5.314,0$ \\
\hline TOTAL PARCIAL & $11.558,4$ & $14.728,6$ & $17.991,2$ & $18.064,7$ & $18.235,3$ & $11.421,2$ & $15.086,6$ & $14.761,6$ & $14.825,0$ \\
\hline \multicolumn{10}{|c|}{ Ajuste relacionado con el comercio } \\
\hline Donaciones & " & 3,5 & 16,2 & 30,9 & 52,1 & 13,7 & 36,8 & 72,3 & 16,2 \\
\hline Otros tipos de ayuda & $"$ & $"$ & $"$ & $"$ & 10,7 & " & " & $"$ & 1,3 \\
\hline TOTAL PARCIAL & $"$ & 3,5 & 16,2 & 30,9 & 62,8 & 13,7 & 36,8 & 72,3 & 17,4 \\
\hline TOTAL & $26.491,7$ & $34.592,5$ & $42.997,4$ & $48.171,0$ & $41.569,6$ & $24.801,0$ & $31.178,5$ & $34.867,5$ & $33.565,9$ \\
\hline
\end{tabular}

\section{CUADRO A.12 Donaciones y otros tipos de ayuda para el comercio, por grupo de ingresos}

\begin{tabular}{|c|c|c|c|c|c|c|c|c|c|}
\hline & \multicolumn{9}{|c|}{ En millones de \$EE.UU. (dólares constantes de 2011) } \\
\hline & \multicolumn{5}{|c|}{ COMPROMISOS } & \multicolumn{4}{|c|}{ DESEMBOLSOS } \\
\hline & $\begin{array}{l}\text { Promedio } \\
2002-2005\end{array}$ & $\begin{array}{l}\text { Promedio } \\
2006-2008\end{array}$ & 2009 & 2010 & 2011 & $\begin{array}{l}\text { Promedio } \\
2006-2008\end{array}$ & 2009 & 2010 & 2011 \\
\hline \multicolumn{10}{|c|}{ Países menos adelantados } \\
\hline Donaciones & $3.869,9$ & $6.185,8$ & $8.301,5$ & $8.611,6$ & $7.994,8$ & $4.346,9$ & $6.039,7$ & $6.584,9$ & $6.567,8$ \\
\hline Otros tipos de ayuda & $3.068,8$ & $3.324,8$ & $4.403,3$ & $5.886,5$ & $5.486,2$ & $2.108,6$ & $2 ; 682,5$ & $2.798,0$ & $2.877,2$ \\
\hline TOTAL PARCIAL & $6.938,7$ & $9.510,6$ & $12.704,9$ & $14.498,1$ & 13481,0 & $6.455,5$ & $8.722,3$ & $9.382,8$ & $9.445,0$ \\
\hline \multicolumn{10}{|c|}{ Otros países de ingresos bajos } \\
\hline Donaciones & 222,8 & 293,8 & 551,7 & 790,9 & 677,7 & 239,0 & 269,7 & 418,6 & 606,6 \\
\hline Otros tipos de ayuda & 317,7 & 489,2 & 808,3 & $1.511,7$ & 776,1 & 204,7 & 301,6 & 358,2 & 411,0 \\
\hline TOTAL PARCIAL & 540,5 & 783,0 & $1.360,0$ & $2.302,6$ & $1.453,8$ & 443,6 & 571,4 & 776,8 & $1.017,6$ \\
\hline \multicolumn{10}{|c|}{ Países de ingresos medianos bajos } \\
\hline Donaciones & $4.800,3$ & $5.461,9$ & $4.463,9$ & $5.431,0$ & $3.539,5$ & $4.682,0$ & $3.742,8$ & $4.435,3$ & $3.960,4$ \\
\hline Otros tipos de ayuda & $7.348,5$ & $9.835,6$ & $11.775,9$ & $12.355,8$ & $11.323,8$ & $5.619,6$ & $7.538,7$ & $8.711,4$ & $8.782,0$ \\
\hline TOTAL PARCIAL & $12.148,8$ & $15.297,5$ & $16.239,8$ & $17.786,9$ & $14.863,2$ & $10.301,7$ & $11.281,6$ & $13.146,7$ & $12.742,4$ \\
\hline \multicolumn{10}{|c|}{ Países de ingresos medianos altos } \\
\hline Donaciones & $1.780,0$ & $2.107,0$ & $2.399,7$ & $2.845,3$ & $2.178,3$ & $1.812,5$ & $2.152,3$ & $2.019,2$ & $1.701,2$ \\
\hline Otros tipos de ayuda & $2.669,8$ & $2.220,0$ & $2.795,2$ & $3.457,0$ & $1.850,8$ & $2.384,9$ & $2.756,1$ & $3.200,8$ & $2.429,4$ \\
\hline TOTAL PARCIAL & $4.449,8$ & $4.327,0$ & $5.194,9$ & $6.302,3$ & $4.029,2$ & $4.197,4$ & $4.908,4$ & $5.220,0$ & $4.130,6$ \\
\hline \multicolumn{10}{|c|}{ Mundiales (sin asignar) } \\
\hline Donaciones & $2.157,6$ & $3.470,0$ & $5.807,4$ & $5.038,1$ & $5.890,3$ & $2.547,2$ & $4.686,7$ & $4.388,0$ & $4.836,4$ \\
\hline Otros tipos de ayuda & 256,3 & $1.204,4$ & $1.690,5$ & $2.243,0$ & $1.852,2$ & 855,6 & $1.008,2$ & $1.953,1$ & $1.394,0$ \\
\hline TOTAL PARCIAL & $2.413,9$ & $4.674,3$ & $7.497,9$ & $7.281,1$ & $7.742,5$ & $3.402,8$ & $5.694,9$ & $6.341,1$ & $6.230,3$ \\
\hline TOTAL & $26.491,7$ & $34.592,5$ & $42.997,4$ & $48.171,0$ & $41.569,6$ & $24.801,0$ & $31.178,5$ & $34.867,5$ & $33.565,9$ \\
\hline
\end{tabular}


CUADRO A.13A Donaciones en concepto de ayuda para el comercio, por donante

\begin{tabular}{|c|c|c|c|c|c|c|c|c|c|}
\hline & & & & & & \multicolumn{4}{|c|}{ En millones de \$EE.UU. (dólares constantes de 2011) } \\
\hline & \multicolumn{5}{|c|}{ COMPROMISOS } & \multicolumn{4}{|c|}{ DESEMBOLSOS } \\
\hline & $\begin{array}{l}\text { Promedio } \\
2002-2005\end{array}$ & $\begin{array}{l}\text { Promedio } \\
2006-2008\end{array}$ & 2009 & 2010 & 2011 & $\begin{array}{l}\text { Promedio } \\
2006-2008\end{array}$ & 2009 & 2010 & 2011 \\
\hline \multicolumn{10}{|l|}{ Países miembros del CAD } \\
\hline Alemania & 700,4 & 796,4 & $1.073,7$ & $1.197,0$ & $1.268,0$ & 748,2 & $1.062,7$ & $1.025,3$ & $1.000,9$ \\
\hline Australia & 262,7 & 397,1 & 246,6 & 701,9 & 523,1 & 320,8 & 337,6 & 486,6 & 523,1 \\
\hline Austria & 50,5 & 56,9 & 80,0 & 97,5 & 70,9 & 43,1 & 62,6 & 69,1 & 63,8 \\
\hline Bélgica & 233,2 & 275,6 & 534,2 & 416,8 & 477,9 & 193,8 & 436,3 & 400,3 & 440,7 \\
\hline Canadá & 395,7 & 442,5 & 567,0 & 749,3 & 737,2 & 335,5 & 427,2 & 825,9 & 854,8 \\
\hline Corea & " & 128,4 & 132,0 & 157,5 & 141,6 & 89,3 & 104,7 & 129,1 & 113,5 \\
\hline Dinamarca & 454,2 & 313,3 & 365,6 & 380,9 & 302,6 & 302,7 & 319,8 & 369,8 & 453,2 \\
\hline España & 146,9 & 210,3 & 413,0 & 565,2 & 190,9 & 218,2 & 367,9 & 444,6 & 205,1 \\
\hline Estados Unidos & $3.951,0$ & $5.580,3$ & $4.655,6$ & $5.937,5$ & $3.613,8$ & $4.038,8$ & $3.661,9$ & $4.217,2$ & $3.997,5$ \\
\hline Finlandia & 76,8 & 105,9 & 340,0 & 246,7 & 274,9 & 58,6 & 92,4 & 124,7 & 135,0 \\
\hline Francia & 310,4 & 532,1 & 396,2 & 451,5 & 423,3 & 485,9 & 369,8 & 467,1 & 383,6 \\
\hline Grecia & 14,7 & 21,7 & 18,5 & 20,5 & 21,2 & 21,7 & 18,5 & 20,5 & 21,2 \\
\hline Irlanda & 29,6 & 47,7 & 60,3 & 68,0 & 70,1 & 47,7 & 60,3 & 68,0 & 70,1 \\
\hline Italia & 84,9 & 106,3 & 131,0 & 106,3 & 88,9 & 103,8 & 58,3 & 82,6 & 86,9 \\
\hline Japón & $1.093,5$ & 1296,8 & $1.480,8$ & $1.885,1$ & $1.430,8$ & $1.160,7$ & $1.167,5$ & $1.822,8$ & $1.342,8$ \\
\hline Luxemburgo & 19,4 & 35,8 & 34,3 & 39,8 & 41,0 & 35,8 & 34,3 & 39,8 & 41,0 \\
\hline Noruega & 309,6 & 426,8 & 718,3 & 922,5 & 770,4 & 336,8 & 522,2 & 592,8 & 553,2 \\
\hline Nueva Zelandia & 22,8 & 46,0 & 36,9 & 70,6 & 187,1 & 31,2 & 45,5 & 36,6 & 79,6 \\
\hline Países Bajos & 624,5 & 809,6 & 685,8 & 597,5 & $1.181,9$ & 562,3 & 632,7 & 460,7 & 583,9 \\
\hline Portugal & 15,3 & 8,9 & 8,4 & 4,8 & 9,9 & 8,9 & 8,4 & 4,8 & 9,9 \\
\hline Reino Unido & 532,3 & 607,5 & $1.405,5$ & 442,1 & 476,9 & 476,1 & 788,7 & 722,7 & $1.042,2$ \\
\hline Suecia & 264,9 & 349,0 & 309,6 & 406,3 & 301,9 & 350,0 & 377,0 & 337,6 & 359,8 \\
\hline Suiza & 301,8 & 268,4 & 211,5 & 292,0 & 368,1 & 245,4 & 227,5 & 213,1 & 235,2 \\
\hline TOTAL PARCIAL & $9.895,2$ & $12.863,0$ & $13.904,9$ & $15.757,0$ & $12.972,3$ & $10.215,3$ & $11.183,8$ & $12.961,6$ & $12.596,6$ \\
\hline \multicolumn{10}{|l|}{ Otros donantes bilaterales } \\
\hline Emiratos Árabes Unidos & $"$ & $"$ & 433,3 & 15,7 & 39,5 & " & 185,1 & 46,9 & 66,3 \\
\hline Islandia & $"$ & $"$ & " & " & 7,8 & $"$ & " & " & 7,8 \\
\hline Kuwait & $"$ & $\prime \prime$ & $"$ & 14,8 & 6,8 & " & " & 3,8 & 3,2 \\
\hline República Checa & $"$ & $"$ & 0,1 & 0,2 & 12,5 & $"$ & $"$ & 0,2 & 12,2 \\
\hline Turquía & $"$ & $"$ & 30,7 & 111,4 & $"$ & " & 30,7 & 111,4 & $"$ \\
\hline TOTAL PARCIAL & $"$ & $"$ & 464,1 & 142,1 & 66,5 & $"$ & 215,8 & 162,3 & 89,4 \\
\hline \multicolumn{10}{|l|}{ Donantes multilaterales } \\
\hline BADEA & $"$ & $"$ & $"$ & $"$ & 2,7 & " & " & $"$ & 2,7 \\
\hline BAfD & 58,5 & 137,2 & 917,9 & 654,7 & 340,3 & 57,8 & $1.167,6$ & 187,4 & 299,6 \\
\hline Banco Islámico de Desarrollo & " & " & " & 10,5 & " & $"$ & $"$ & $"$ & $"$ \\
\hline Banco Mundial & 528,8 & 894,4 & $1.156,5$ & $1.470,7$ & $1.662,9$ & 525,0 & 937,4 & 771,0 & 957,6 \\
\hline BAsD & $"$ & $"$ & $"$ & 444,7 & 834,3 & " & $"$ & 263,0 & 236,3 \\
\hline BID & $"$ & $"$ & 99,9 & 207,7 & 309,1 & $"$ & 67,3 & 153,0 & 197,6 \\
\hline CEPE & $"$ & 1,5 & 5,7 & 4,3 & 4,0 & 1,5 & 5,7 & 4,3 & 4,0 \\
\hline CESPAP & $"$ & 0,4 & 0,5 & 0,4 & 0,8 & 0,2 & 0,5 & 0,4 & 0,7 \\
\hline CESPAO & $"$ & 0,1 & 0,2 & 0,3 & 0,3 & 0,1 & 0,2 & 0,3 & 0,3 \\
\hline FADES & $"$ & 2,2 & 8,4 & 3,1 & 52,1 & 1,4 & 8,2 & 7,3 & 9,2 \\
\hline FAO & $"$ & 147,8 & 310,0 & 311,2 & 292,2 & 147,8 & 310,0 & 311,2 & 292,2 \\
\hline FIDA & 1,5 & 63,5 & 174,9 & 158,1 & 170,1 & $"$ & $"$ & " & " \\
\hline FMI & " & 11,5 & 15,2 & 14,6 & 15,5 & $"$ & $"$ & $"$ & " \\
\hline $\begin{array}{l}\text { Fondo para la Consolidación } \\
\text { de la Paz }\end{array}$ & $"$ & 3,7 & 0,3 & 3,3 & 0,4 & 1,5 & 6,0 & 1,1 & 0,3 \\
\hline Instituciones de la UE & $2.332,2$ & $3.286,5$ & $4.207,7$ & $3.124,5$ & $3.186,8$ & $2.588,0$ & $2.840,0$ & $2.888,7$ & $2.850,8$ \\
\hline ITC & $"$ & 33,7 & 56,5 & 59,7 & 64,7 & 33,2 & 56,5 & 55,4 & 61,1 \\
\hline OMC & " & 14,8 & 16,1 & 20,9 & 15,2 & 14,8 & 16,1 & 20,9 & 15,2 \\
\hline ONUDI & $"$ & 30,3 & 114,6 & 43,5 & 47,9 & " & $"$ & " & $"$ \\
\hline PNUD & 13,4 & 27,1 & 46,2 & 34,7 & 31,2 & 32,9 & 46,7 & 39,7 & 37,8 \\
\hline PNUMA & $"$ & $"$ & $"$ & $"$ & $"$ & 2,8 & 6,6 & 7,1 & 6,7 \\
\hline Otros donantes multilaterales & 1,2 & 0,9 & 24,7 & 251,1 & 211,2 & 5,3 & 22,9 & 11,2 & 14,3 \\
\hline TOTAL PARCIAL & $2.935,5$ & $4.655,6$ & $7.155,2$ & $6.817,9$ & $7.241,7$ & $3.412,3$ & $5.491,7$ & $4.722,1$ & $4.986,3$ \\
\hline TOTAL & $12.830,7$ & $17.518,5$ & $21.524,2$ & $22.716,9$ & $20.280,5$ & $13.627,6$ & $16.891,3$ & $17.846,0$ & $17.672,3$ \\
\hline
\end{tabular}




\section{CUADRO A.13B Otros tipos de ayuda para el comercio, por donante}

\begin{tabular}{|c|c|c|c|c|c|c|c|c|c|}
\hline & \multicolumn{9}{|c|}{ En millones de \$EE.UU. (dólares constantes de 2011) } \\
\hline & \multicolumn{5}{|c|}{ COMPROMISOS } & \multicolumn{4}{|c|}{ DESEMBOLSOS } \\
\hline & $\begin{array}{l}\text { Promedio } \\
2002-2005\end{array}$ & $\begin{array}{l}\text { Promedio } \\
2006-2008\end{array}$ & 2009 & 2010 & 2011 & $\begin{array}{l}\text { Promedio } \\
2006-2008\end{array}$ & 2009 & 2010 & 2011 \\
\hline \multicolumn{10}{|l|}{ Países miembros del CAD } \\
\hline Alemania & 648,8 & $1.489,5$ & $1.598,8$ & $3.492,0$ & $2.461,0$ & $1.106,9$ & $1.251,4$ & $2.171,0$ & $2.055,6$ \\
\hline Australia & " & " & 331,2 & " & 62,1 & 3,1 & 54,1 & 38,1 & 62,1 \\
\hline Austria & 0,2 & 2,9 & 4,3 & 4,3 & " & 1,5 & 4,3 & 5,9 & 1,5 \\
\hline Bélgica & 32,0 & 16,3 & 28,9 & 30,7 & $"$ & 7,7 & 34,3 & 2,5 & 5,8 \\
\hline Canadá & 7,8 & " & " & $"$ & $"$ & $"$ & $"$ & $"$ & $"$ \\
\hline Corea & " & 331,2 & $1.002,0$ & 595,1 & 616,8 & 98,7 & 180,7 & 224,5 & 298,1 \\
\hline Dinamarca & 26,8 & " & $"$ & $"$ & $"$ & $"$ & $"$ & $"$ & " \\
\hline España & 294,2 & 589,4 & 516,6 & 841,4 & 452,7 & 343,3 & 672,6 & 872,2 & 385,8 \\
\hline Estados Unidos & " & " & $"$ & $"$ & $"$ & $"$ & $"$ & $"$ & " \\
\hline Finlandia & 10,5 & 35,5 & 28,5 & 32,7 & 54,6 & 10,0 & 26,5 & 38,6 & 39,5 \\
\hline Francia & 494,8 & $1.171,8$ & $1.156,2$ & $1.355,4$ & 860,6 & 537,7 & 828,9 & 611,5 & $1.158,4$ \\
\hline Italia & 206,4 & 159,8 & 147,8 & 77,9 & 0,0 & 176,7 & 76,4 & 114,0 & 93,1 \\
\hline Japón & $4.971,3$ & $6.393,1$ & $5.334,7$ & $8.250,8$ & $6.468,5$ & $4.329,0$ & $4.671,4$ & $5.468,1$ & $5.008,2$ \\
\hline Noruega & 44,0 & 156,8 & 181,5 & 129,6 & 317,7 & 191,3 & 54,1 & 120,0 & 283,8 \\
\hline Países Bajos & " & " & " & $"$ & $"$ & " & $"$ & $"$ & $"$ \\
\hline Portugal & 34,1 & 23,5 & 84,9 & 52,4 & 15,9 & 32,1 & 24,3 & 86,9 & 46,5 \\
\hline Reino Unido & 209,7 & 320,5 & 599,6 & 569,1 & 310,7 & 476,4 & 599,6 & 569,1 & 310,7 \\
\hline Suecia & 3,2 & 39,5 & 104,0 & 15,6 & 46,2 & 40,6 & 104,5 & 15,6 & 46,2 \\
\hline Suiza & 36,8 & 33,7 & 19,8 & 49,2 & 71,7 & 33,8 & 32,2 & 34,8 & 71,7 \\
\hline TOTAL PARCIAL & $7.020,5$ & $10.763,6$ & $11.138,7$ & $15.495,9$ & $11.738,5$ & $7.388,8$ & $8.615,4$ & $10.373,0$ & $9.866,9$ \\
\hline \multicolumn{10}{|l|}{ Otros donantes bilaterales } \\
\hline Emiratos Árabes Unidos & " & " & 76,6 & 197,1 & 152,1 & " & 34,2 & 64,4 & 87,9 \\
\hline Kuwait & " & " & " & 779,0 & 246,6 & " & $"$ & 477,8 & 360,9 \\
\hline TOTAL PARCIAL & " & $"$ & 76,6 & 976,1 & 398,7 & " & 34,2 & 542,2 & 448,8 \\
\hline \multicolumn{10}{|l|}{ Donantes multilaterales } \\
\hline BADEA & " & " & $"$ & $"$ & 80,0 & " & $"$ & " & 46,9 \\
\hline BAfD & 107,7 & 656,8 & $1.391,4$ & $1.115,7$ & 584,8 & 368,5 & 676,3 & 829,0 & 863,2 \\
\hline Banco Islámico de Desarrollo & " & $"$ & " & 179,9 & " & " & $"$ & " & $"$ \\
\hline Banco Mundial & $4.505,9$ & $3.846,4$ & $5.972,5$ & $4.221,0$ & $5.694,7$ & $3.143,9$ & $3.824,4$ & $3.373,0$ & $2.957,1$ \\
\hline BAsD & 842,1 & 585,4 & 901,3 & $1.150,8$ & 616,4 & " & " & 537,9 & 585,2 \\
\hline BID & 272,8 & 124,7 & 155,6 & 189,6 & 176,0 & " & 196,2 & 213,9 & 288,4 \\
\hline FADES & " & 432,6 & $1.056,8$ & $1.202,9$ & $1.123,2$ & 265,0 & 737,4 & 949,6 & 689,0 \\
\hline FIDA & 300,0 & 358,7 & 353,2 & 464,0 & 617,8 & " & " & " & $"$ \\
\hline Instituciones de la UE & 612,0 & 305,8 & " & $"$ & " & 7,1 & " & $"$ & $"$ \\
\hline Otros donantes multilaterales & $"$ & $"$ & 427,1 & 458,3 & 258,9 & 0,2 & 203,3 & 203,0 & 148,0 \\
\hline TOTAL PARCIAL & $6.640,5$ & $6.310,3$ & $10.257,9$ & $8.982,1$ & $9.151,8$ & $3.784,6$ & $5.637,6$ & $6.106,3$ & $5.577,8$ \\
\hline TOTAL & $13.661,0$ & $17.074,0$ & $21.473,2$ & $25.454,0$ & $21.289,1$ & $11.173,4$ & $14.287,2$ & $17.021,5$ & $15.893,6$ \\
\hline
\end{tabular}




\section{CUADRO A.14 Cauces para el suministro de la ayuda para el comercio}

En millones de \$EE.UU. (dólares constantes de 2011)

\begin{tabular}{|c|c|c|c|c|c|c|c|c|c|}
\hline & \multicolumn{5}{|c|}{ COMPROMISOS } & \multicolumn{4}{|c|}{ DESEMBOLSOS } \\
\hline & $\begin{array}{l}\text { Promedio } \\
\text { 2002-2005 }\end{array}$ & $\begin{array}{l}\text { Promedio } \\
2006-2008\end{array}$ & 2009 & 2010 & 2011 & $\begin{array}{l}\text { Promedio } \\
2006-2008\end{array}$ & 2009 & 2010 & 2011 \\
\hline Instituciones del sector público & $1.536,6$ & $21.060,6$ & $24.429,1$ & $29.271,9$ & $22.270,1$ & $8.934,1$ & $17.233,9$ & $18.406,2$ & $17.776,1$ \\
\hline ONG y sociedad civil & 109,9 & $1.003,9$ & $1.478,0$ & $1.486,2$ & $1.692,0$ & 925,6 & $1.786,9$ & $2.019,0$ & $1.928,1$ \\
\hline Redes y asociaciones públicas y privadas & 1,0 & 26,0 & 150,2 & 376,2 & 405,9 & 12,5 & 114,6 & 454,4 & 455,9 \\
\hline Organizaciones multilaterales & 225,3 & $1.593,5$ & $3.411,9$ & $3.981,2$ & $4.740,6$ & $1.292,6$ & $2.666,1$ & $3.649,1$ & $3.882,8$ \\
\hline Otros cauces & $1.753,6$ & $2.244,7$ & $4.064,7$ & $3.879,3$ & $2.829,6$ & $2.771,5$ & $2.984,5$ & $4.615,6$ & $4.507,8$ \\
\hline Cauces no notificados & $22.865,4$ & $8.663,8$ & $9.463,6$ & $9.176,2$ & $9.631,5$ & $10.864,7$ & $6.392,5$ & $5.723,1$ & $5.015,3$ \\
\hline TOTAL & $26.491,7$ & $34.592,5$ & $42.997,4$ & $48.171,0$ & $41.569,6$ & $24.801,0$ & $31.178,5$ & $34.867,5$ & $33.565,9$ \\
\hline
\end{tabular}

StatLink anisla http://dx.doi.org/10.1787/888932854917

\section{CUADRO A.15 Porcentaje de la ayuda para el comercio en la AOD asignada a determinados sectores y en la AOD total}

\begin{tabular}{|c|c|c|c|c|c|c|c|c|c|}
\hline & \multicolumn{9}{|c|}{ En millones de \$EE.UU. (dólares constantes de 2011} \\
\hline & \multicolumn{5}{|c|}{ COMPROMISOS } & \multicolumn{4}{|c|}{ DESEMBOLSOS } \\
\hline & $\begin{array}{l}\text { Promedio } \\
2002-2005\end{array}$ & $\begin{array}{l}\text { Promedio } \\
2006-2008\end{array}$ & 2009 & 2010 & 2011 & $\begin{array}{l}\text { Promedio } \\
2006-2008\end{array}$ & 2009 & 2010 & 2011 \\
\hline Total de la ayuda para el comercio & $26.491,7$ & $34.592,5$ & $42.997,4$ & $48.171,0$ & $41.569,6$ & $24.801,0$ & $31.178,5$ & $34.867,5$ & $33.565,9$ \\
\hline AOD asignada a determinados sectores & $79.810,8$ & $108.323,4$ & $132.962,5$ & $138.873,0$ & $124.210,3$ & $84.700,0$ & $104.180,9$ & $113.107,4$ & $108.531,4$ \\
\hline $\begin{array}{l}\text { Porcentaje de la ayuda para el comercio } \\
\text { en la AOD asignada a sectores concretos }\end{array}$ & $33.2 \%$ & $31.9 \%$ & $32.3 \%$ & $34.7 \%$ & $33.5 \%$ & $29.3 \%$ & $29.9 \%$ & $30.8 \%$ & $30.9 \%$ \\
\hline Total de la AOD & $124.569,7$ & $155.485,6$ & $174.235,8$ & $177.331,0$ & $160.410,9$ & $150.099,7$ & $147.018,0$ & $157.260,1$ & $150.862,9$ \\
\hline $\begin{array}{l}\text { Porcentaje de la ayuda para el } \\
\text { comercio en la AOD total }\end{array}$ & $21.3 \%$ & $22.2 \%$ & $24.7 \%$ & $27.2 \%$ & $25.9 \%$ & $16.5 \%$ & $21.2 \%$ & $22.2 \%$ & $22.2 \%$ \\
\hline
\end{tabular}

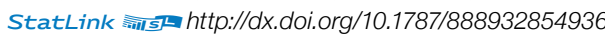

\section{CUADRO A.16 Porcentaje de las otras corrientes oficiales (OCO) relacionadas con el comercio en las OCO} asignadas a determinados sectores y en el total de las OCO

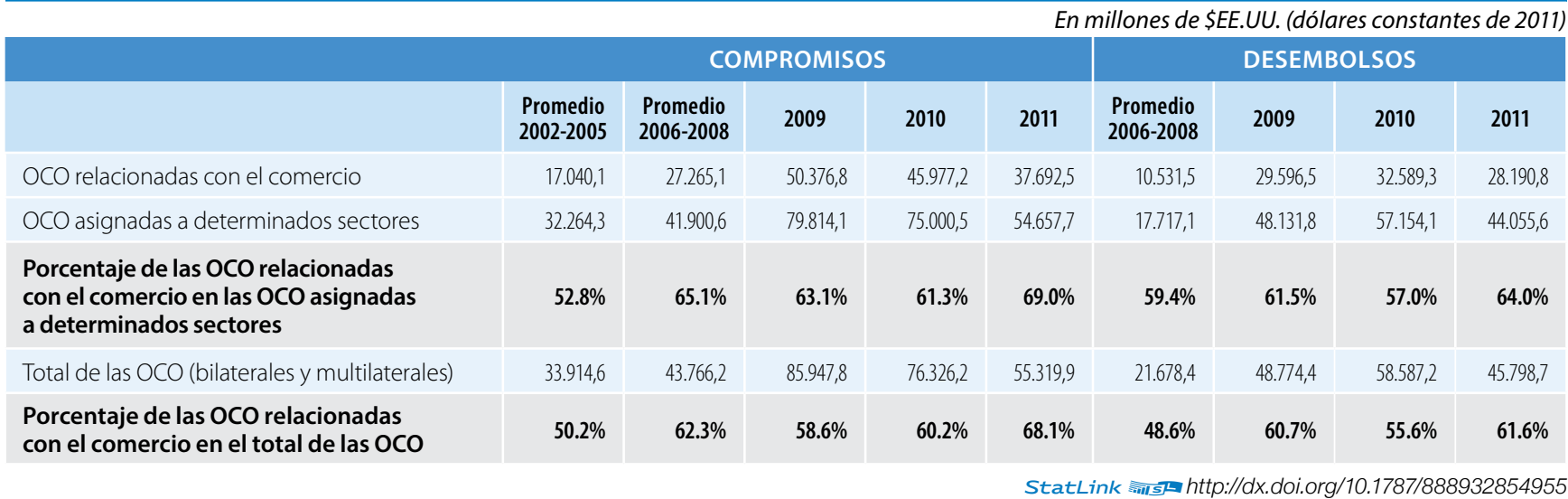


CUADRO A.17 Otras corrientes oficiales relacionadas con el comercio, por categoría

En millones de \$EE.UU. (dólares constantes de 2011)

\begin{tabular}{|c|c|c|c|c|c|c|c|c|c|}
\hline & \multicolumn{5}{|c|}{ COMPROMISOS } & \multicolumn{4}{|c|}{ DESEMBOLSOS } \\
\hline & $\begin{array}{l}\text { Promedio } \\
2002-2005\end{array}$ & $\begin{array}{l}\text { Promedio } \\
2006-2008\end{array}$ & 2009 & 2010 & 2011 & $\begin{array}{l}\text { Promedio } \\
2006-2008\end{array}$ & 2009 & 2010 & 2011 \\
\hline \multicolumn{10}{|l|}{ Política y reglamentación comerciales } \\
\hline Política comercial y gestión administrativa & 352,7 & 155,3 & 690,3 & 55,2 & 147,3 & 62,9 & 315,6 & 52,0 & 117,5 \\
\hline Facilitación del comercio & 108,7 & 32,1 & 409,0 & 254,3 & 97,6 & 18,3 & 120,6 & 345,3 & 94,0 \\
\hline Acuerdos comerciales regionales & 90,0 & 0,0 & 45,8 & $"$ & " & 0,0 & 23,9 & 6,4 & 20,1 \\
\hline Negociaciones comerciales multilaterales & " & 13,2 & 10,8 & $"$ & " & 12,5 & $"$ & $"$ & " \\
\hline TOTAL PARCIAL & 551,4 & 200,6 & $1.155,9$ & 309,5 & 244,8 & 93,8 & 460,0 & 403,7 & 231,6 \\
\hline \multicolumn{10}{|l|}{ Infraestructura económica } \\
\hline Transporte y almacenamiento & $6.420,7$ & $8.904,8$ & $12.258,6$ & $11.610,2$ & $11.726,0$ & $2.850,6$ & $4.779,8$ & $7.797,6$ & $8.217,8$ \\
\hline Comunicaciones & 760,5 & 724,0 & 659,7 & 612,0 & 553,0 & 253,4 & 648,3 & 709,5 & 685,0 \\
\hline Generación y suministro de energía & 2352,7 & $6.398,6$ & $14.977,3$ & $13.965,8$ & $9.126,8$ & $1.309,1$ & $7.384,7$ & $5.863,3$ & $5.817,3$ \\
\hline TOTAL PARCIAL & $9.533,9$ & $16.027,4$ & $27.895,6$ & $26.187,9$ & $21.405,8$ & $4.413,1$ & $12.812,8$ & $14.370,4$ & $14.720,1$ \\
\hline \multicolumn{10}{|l|}{ Creación de capacidad productiva } \\
\hline Servicios a empresas y otros servicios & 666,7 & $1.028,6$ & $2.079,0$ & $1.331,8$ & 916,7 & 492,0 & $1.775,7$ & $1.319,0$ & 894,5 \\
\hline Servicios bancarios y financieros & $2.707,4$ & $2.777,0$ & $12.361,6$ & $6.443,8$ & $6.090,4$ & $1.882,5$ & $8.268,3$ & $8.084,9$ & $5.061,1$ \\
\hline Agricultura & $1.308,6$ & $1.201,0$ & $2.049,3$ & $2.784,4$ & $1.491,1$ & 811,8 & $1.035,3$ & $1.532,7$ & $1.135,0$ \\
\hline Silvicultura & 95,9 & 76,5 & 19,7 & 523,9 & 360,6 & 58,0 & 62,9 & 263,9 & 217,4 \\
\hline Pesca & 8,7 & 1,7 & 88,1 & 46,5 & 6,8 & 1,8 & 6,6 & 55,3 & 7,0 \\
\hline Industria & $1.731,0$ & $4.846,7$ & $3.535,4$ & $5.301,2$ & $5.023,4$ & $2.090,1$ & $4.087,2$ & $4.599,7$ & $4.447,5$ \\
\hline Industrias extractivas & 306,1 & $1.015,9$ & $1.073,8$ & $2.473,8$ & $1.803,3$ & 628,9 & 992,1 & $1.835,3$ & $1.372,7$ \\
\hline Turismo & 130,5 & 89,6 & 118,4 & 574,4 & 349,6 & 59,6 & 95,6 & 124,3 & 103,9 \\
\hline TOTAL PARCIAL & $6.954,9$ & $11.037,1$ & $21.325,2$ & $19.479,8$ & $16.041,9$ & $6.024,7$ & $16.323,6$ & $17.815,2$ & $13.239,1$ \\
\hline TOTAL & $17.040,1$ & $27.265,1$ & $50.376,8$ & $45.977,2$ & $37.692,5$ & $10.531,5$ & $29.596,5$ & $32.589,3$ & $28.190,8$ \\
\hline
\end{tabular}

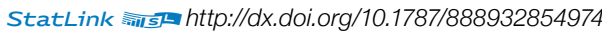


CUADRO A.18 Otras corrientes oficiales relacionadas con el comercio, por donante

En millones de \$EE.UU. (dólares constantes de 2011)

\begin{tabular}{|c|c|c|c|c|c|c|c|c|c|}
\hline & \multicolumn{5}{|c|}{ COMPROMISOS } & \multicolumn{4}{|c|}{ DESEMBOLSOS } \\
\hline & $\begin{array}{l}\text { Promedio } \\
2002-2005\end{array}$ & $\begin{array}{l}\text { Promedio } \\
2006-2008\end{array}$ & 2009 & 2010 & 2011 & $\begin{array}{l}\text { Promedio } \\
2006-2008\end{array}$ & 2009 & 2010 & 2011 \\
\hline \multicolumn{10}{|l|}{ Países miembros del CAD } \\
\hline Alemania & $"$ & $1.205,3$ & $1.341,1$ & $1.014,6$ & $1.258,1$ & 943,4 & $1.454,3$ & $1.270,0$ & $1.279,5$ \\
\hline Austria & 1,5 & $"$ & $"$ & " & " & " & " & $"$ & " \\
\hline Bélgica & " & $"$ & $"$ & 0,0 & " & " & " & $"$ & " \\
\hline Corea & " & $1.956,3$ & $2.383,1$ & $4.019,9$ & $5.887,4$ & $1.784,7$ & $2.149,1$ & $3.879,9$ & $4.702,3$ \\
\hline Dinamarca & 8,3 & " & $"$ & " & " & $"$ & " & $"$ & " \\
\hline España & " & 5,4 & " & " & " & $"$ & " & $"$ & " \\
\hline Estados Unidos & 173,6 & 364,7 & 702,5 & 741,3 & 574,5 & 115,8 & 278,2 & 396,7 & 314,5 \\
\hline Finlandia & 17,7 & 33,5 & 91,3 & 39,7 & 6,7 & 32,7 & 68,4 & 46,3 & 19,2 \\
\hline Francia & 284,2 & 320,6 & 503,8 & 678,9 & 43,5 & 303,3 & 472,2 & 491,4 & " \\
\hline Grecia & " & 1,7 & $"$ & " & $"$ & 1,7 & " & $"$ & " \\
\hline Italia & " & " & " & 0,5 & 0,9 & $"$ & " & $"$ & 1,3 \\
\hline Japón & $1.254,7$ & $2.097,3$ & " & " & " & 56,6 & " & $"$ & " \\
\hline Países Bajos & 9,2 & $"$ & $"$ & " & $"$ & $"$ & $"$ & $"$ & " \\
\hline Portugal & " & $"$ & " & 559,8 & 0,7 & $"$ & $"$ & 559,8 & 0,7 \\
\hline Reino Unido & 210,5 & 15,2 & 351,7 & 1,3 & 0,7 & $-5,7$ & 351,7 & 1,2 & 0,7 \\
\hline Suecia & 1,9 & $"$ & $"$ & " & 3,5 & $"$ & " & $"$ & $"$ \\
\hline TOTAL PARCIAL & $1.961,8$ & $5.999,9$ & $5.373,5$ & $7.056,0$ & $7.775,8$ & $3.232,5$ & $4.773,9$ & $6.645,3$ & $6.318,3$ \\
\hline \multicolumn{10}{|l|}{ Donantes multilaterales } \\
\hline BAsD & $3.768,8$ & $4.250,8$ & $4.193,0$ & $4.538,7$ & $6.036,4$ & $"$ & " & $3.474,9$ & $3.776,5$ \\
\hline BAfD & 376,9 & $1.054,4$ & $7.081,3$ & $1.299,2$ & $3.371,5$ & 547,5 & $3.699,6$ & $1.667,8$ & $1.744,5$ \\
\hline Banco Islámico de Desarrollo & " & " & $"$ & $2.891,2$ & $"$ & $"$ & " & $"$ & " \\
\hline Banco Mundial & $6.438,6$ & $8.156,1$ & $21.276,3$ & $18.360,2$ & $9.379,2$ & $6.046,6$ & $11.545,9$ & $12.011,9$ & $7.716,2$ \\
\hline BERD & $"$ & $"$ & $4.074,0$ & $6.157,0$ & $4.931,9$ & " & $3.709,2$ & $3.814,4$ & $3.978,9$ \\
\hline BID & $1.953,2$ & $3.021,8$ & $7.589,7$ & $5.150,5$ & $5.116,6$ & " & $5.516,6$ & $4.610,0$ & $3.507,2$ \\
\hline FIDA & 25,1 & 39,4 & 87,4 & 67,7 & 59,5 & " & $"$ & $"$ & " \\
\hline Instituciones de la UE & $2.515,8$ & $4.742,6$ & $"$ & " & 672,8 & 704,9 & " & $"$ & 635,6 \\
\hline Otros donantes multilaterales & " & $"$ & 701,5 & 456,7 & 348,8 & " & 351,2 & 365,0 & 513,4 \\
\hline TOTAL PARCIAL & $15.078,4$ & $21.265,2$ & $45.003,3$ & $38.921,2$ & $29.916,7$ & $7.299,1$ & $24.822,5$ & $25.944,0$ & $21.872,4$ \\
\hline TOTAL & $17.040,1$ & $27.265,1$ & $50.376,8$ & $45.977,2$ & $37.692,5$ & $10.531,5$ & $29.596,5$ & $32.589,3$ & $28.190,8$ \\
\hline
\end{tabular}

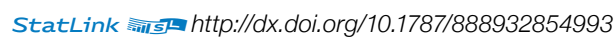


CUADRO A.19 Otras corrientes oficiales relacionadas con el comercio, por beneficiario (página 1 de 3)

En millones de \$EE.UU. (dólares constantes de 2011)

\begin{tabular}{|c|c|c|c|c|c|c|c|c|c|}
\hline & \multicolumn{5}{|c|}{ COMPROMISOS } & \multicolumn{4}{|c|}{ DESEMBOLSOS } \\
\hline & $\begin{array}{l}\text { Promedio } \\
2002-2005\end{array}$ & $\begin{array}{l}\text { Promedio } \\
2006-2008\end{array}$ & 2009 & 2010 & 2011 & $\begin{array}{l}\text { Promedio } \\
2006-2008\end{array}$ & 2009 & 2010 & 2011 \\
\hline Afganistán & 8,2 & 26,6 & 8,8 & 52,9 & $"$ & 14,9 & 17,9 & 27,1 & 7,1 \\
\hline Albania & 13,3 & 33,6 & 130,3 & 68,6 & 130,8 & 11,2 & 99,5 & 80,9 & 116,6 \\
\hline Angola & " & 7,3 & 6,1 & 66,9 & " & " & " & 71,7 & 11,8 \\
\hline Argelia & 117,1 & 0,0 & $"$ & " & $"$ & 4,0 & $"$ & " & " \\
\hline Argentina & 584,8 & $1.524,2$ & 776,9 & $1.153,1$ & 713,9 & 184,8 & 913,8 & $1.285,8$ & 943,2 \\
\hline Armenia & " & 16,0 & 204,2 & 141,4 & 328,6 & 17,0 & 127,7 & 225,6 & 157,5 \\
\hline Azerbaiyán & 14,9 & 512,4 & 263,0 & 533,2 & 329,7 & 34,0 & 255,6 & 323,9 & 351,8 \\
\hline Bangladesh & 108,1 & 284,5 & $"$ & 427,2 & 565,0 & 14,7 & 53,4 & 154,8 & 151,5 \\
\hline Barbados & " & 4,9 & 21,5 & 58,6 & " & " & 0,2 & 49,7 & " \\
\hline Belarús & " & 26,8 & 288,6 & 202,7 & 154,4 & 12,0 & 137,0 & 60,2 & 48,0 \\
\hline Belice & 2,7 & 1,0 & 14,5 & $"$ & 10,0 & 0,0 & 4,4 & 4,6 & 2,1 \\
\hline Benin & $"$ & $"$ & 14,0 & $"$ & " & $"$ & " & " & 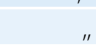 \\
\hline Bhután & $"$ & $"$ & 54,9 & $"$ & $"$ & $"$ & $"$ & 22,4 & 15,1 \\
\hline Bolivia & 15,2 & 12,1 & 121,1 & 73,6 & 7,1 & 7,0 & 7,1 & 12,2 & " \\
\hline Bosnia y Herzegovina & 57,5 & 186,8 & 204,3 & 203,7 & 133,4 & 48,0 & 211,1 & 160,7 & 176,2 \\
\hline Botswana & 14,6 & 2,4 & $2.101,6$ & 220,3 & " & " & $1.050,6$ & 2,9 & 60,5 \\
\hline Brasil & $2.000,9$ & $1.580,2$ & $1.309,1$ & $4.958,3$ & $2.250,1$ & 494,9 & $2.306,0$ & $2.476,5$ & $2.029,3$ \\
\hline Burkina Faso & " & $"$ & 15,0 & 6,7 & $"$ & " & $"$ & $"$ & " \\
\hline Cabo Verde & $"$ & $"$ & 30,5 & 32,4 & 41,7 & $"$ & 31,1 & 2,9 & 66,9 \\
\hline Camboya & 6,2 & 1,3 & 23,4 & 6,0 & 23,3 & 5,1 & 16,2 & 6,0 & 16,3 \\
\hline Camerún & 5,2 & 10,8 & $\prime$ & 24,0 & 36,6 & 18,8 & 59,9 & 24,6 & 33,8 \\
\hline Chad & 0,8 & 5,4 & $"$ & 54,5 & " & 5,4 & " & $"$ & " \\
\hline Chile & 65,7 & 292,6 & 7,0 & 197,3 & 232,3 & 71,6 & 15,1 & 177,0 & 338,4 \\
\hline China & $2.435,7$ & $3.306,0$ & $3.322,2$ & $3.816,2$ & $3.797,1$ & $1.670,9$ & $1.876,3$ & $3.225,4$ & $3.458,5$ \\
\hline Colombia & 412,5 & 517,3 & 899,1 & 308,9 & $1.070,0$ & 349,4 & 599,6 & 263,4 & 520,1 \\
\hline Comoras & " & " & " & 5,6 & " & " & " & 2,8 & " \\
\hline Costa Rica & 60,2 & 32,9 & 234,1 & 79,7 & 37,1 & 22,0 & 53,2 & 226,8 & 260,2 \\
\hline Côte d'Ivoire & $"$ & 2,2 & $"$ & 16,8 & " & 1,7 & $"$ & $"$ & " \\
\hline Croacia & 183,0 & 506,9 & 486,9 & 628,9 & $"$ & 115,1 & 468,9 & 660,8 & " \\
\hline Cuba & 1,2 & $"$ & $"$ & $"$ & $"$ & $"$ & $"$ & $"$ & " \\
\hline Djibouti & " & 3,9 & 104,8 & $"$ & $"$ & $"$ & 112,6 & 22,7 & 7,6 \\
\hline Dominica & 0,4 & $"$ & $"$ & $"$ & $"$ & $"$ & $"$ & $"$ & " \\
\hline Ecuador & 40,5 & 82,6 & 445,1 & 237,2 & 204,0 & 13,6 & 23,1 & 90,4 & 204,4 \\
\hline Egipto & 642,5 & $1.151,4$ & $1.431,9$ & $2.857,1$ & 565,8 & 490,7 & 923,1 & 949,9 & 472,1 \\
\hline El Salvador & 50,5 & 149,0 & 104,6 & 48,5 & 209,6 & 8,1 & 213,5 & 31,7 & 100,0 \\
\hline Eritrea & $"$ & $"$ & $"$ & " & $"$ & " & $"$ & $"$ & " \\
\hline Eslovenia & 73,4 & " & $"$ & " & " & $"$ & " & " & " \\
\hline Estados de la ex Yugoslavia & 66,5 & $"$ & $"$ & $"$ & $"$ & $"$ & $"$ & $"$ & " \\
\hline $\begin{array}{l}\text { Estados Federados } \\
\text { de Micronesia }\end{array}$ & $"$ & $"$ & " & $"$ & $"$ & $"$ & $"$ & $"$ & " \\
\hline Etiopía & " & 19,7 & " & 10,7 & 39,8 & $"$ & $"$ & " & 93,8 \\
\hline $\begin{array}{l}\text { Ex República Yugoslava } \\
\text { de Macedonia }\end{array}$ & 15,6 & 74,4 & 55,2 & 49,2 & 359,9 & 22,5 & 49,3 & 61,7 & 118,5 \\
\hline Fiji & 6,6 & 12,2 & 18,9 & 28,6 & " & " & " & 7,9 & 9,2 \\
\hline Filipinas & 125,7 & $1.405,7$ & 282,2 & 63,9 & 282,3 & 152,6 & 33,6 & 195,1 & 311,1 \\
\hline Gabón & 19,2 & 153,8 & $"$ & $"$ & $"$ & 10,1 & 71,2 & 38,6 & 94,7 \\
\hline Gambia & " & " & $"$ & 0,7 & $"$ & $"$ & 5,3 & $"$ & 6,8 \\
\hline Georgia & 0,3 & 40,7 & 441,0 & 446,0 & 245,0 & 20,2 & 316,5 & 199,7 & 277,0 \\
\hline Ghana & 4,3 & 104,5 & 108,1 & 102,9 & 25,0 & 35,4 & 89,3 & 52,1 & 20,4 \\
\hline Grenada & 0,5 & " & $"$ & 14,2 & $"$ & 0,0 & 3,9 & 2,2 & 0,0 \\
\hline Guatemala & 212,3 & 61,6 & 196,5 & 46,5 & 82,3 & 83,0 & 215,4 & 132,8 & 41,7 \\
\hline Guinea & $"$ & " & " & " & $"$ & " & $"$ & $"$ & " \\
\hline Guinea Ecuatorial & $"$ & $"$ & 23,8 & " & $"$ & $"$ & $"$ & $"$ & " \\
\hline Guinea-Bissau & 0,5 & $"$ & $"$ & $"$ & " & $"$ & $"$ & $"$ & " \\
\hline Guyana & " & 6,6 & 16,0 & 13,3 & $"$ & $"$ & 3,4 & 9,0 & 0,0 \\
\hline
\end{tabular}


CUADRO A.19 Otras corrientes oficiales relacionadas con el comercio, por beneficiario (página 2 de 3)

\begin{tabular}{|c|c|c|c|c|c|c|c|c|c|}
\hline & \multicolumn{5}{|c|}{ COMPROMISOS } & \multicolumn{4}{|c|}{ DESEMBOLSOS } \\
\hline & $\begin{array}{l}\text { Promedio } \\
2002-2005\end{array}$ & $\begin{array}{l}\text { Promedio } \\
2006-2008\end{array}$ & 2009 & 2010 & 2011 & $\begin{array}{l}\text { Promedio } \\
2006-2008\end{array}$ & 2009 & 2010 & 2011 \\
\hline Haití & $"$ & 0,2 & $"$ & 10,2 & $"$ & $-0,1$ & $"$ & 3,4 & 3,5 \\
\hline Honduras & 2,9 & 69,8 & 42,0 & 181,6 & 30,0 & 4,1 & 20,2 & 45,2 & 33,9 \\
\hline India & $2.599,3$ & $2.471,8$ & $7.451,2$ & $2.637,8$ & $4.033,1$ & $1.222,7$ & $1.523,5$ & $4.836,0$ & $1.974,8$ \\
\hline Indonesia & 427,1 & 849,9 & $1.116,9$ & $1.816,6$ & $2.622,6$ & 707,2 & 849,4 & $1.194,9$ & 820,8 \\
\hline Irán & 79,0 & " & " & 391,8 & 502,5 & 38,3 & 22,9 & 18,8 & 11,4 \\
\hline Iraq & 13,0 & 333,0 & 71,4 & 187,8 & 20,5 & 17,3 & 2,6 & 116,4 & 3,6 \\
\hline Islas Cook & $"$ & " & 9,3 & " & 4,7 & $"$ & $"$ & 0,0 & 5,6 \\
\hline Islas Marshall & $"$ & $"$ & 9,2 & $"$ & " & $"$ & 9,2 & " & " \\
\hline Islas Salomón & " & $"$ & " & 2,1 & 1,8 & " & " & 2,1 & 1,8 \\
\hline Jamaica & 33,8 & 35,4 & 434,5 & 131,8 & 122,7 & 1,0 & 139,0 & 73,7 & 141,8 \\
\hline Jordania & 24,2 & 60,4 & 646,7 & $"$ & $"$ & 10,8 & 256,5 & 267,1 & 31,5 \\
\hline Kazajstán & 69,3 & 71,3 & $3.257,2$ & $1.496,6$ & 859,5 & 115,9 & 413,7 & $1.325,1$ & $1.370,0$ \\
\hline Kenya & 14,6 & 46,9 & 36,9 & 114,4 & 58,4 & 33,2 & 101,8 & 38,4 & 9,4 \\
\hline Kosovo & $"$ & " & 21,2 & $"$ & $"$ & " & 9,9 & $"$ & $"$ \\
\hline Lesotho & $"$ & " & " & 21,3 & " & $"$ & " & $"$ & " \\
\hline Líbano & 77,7 & 170,0 & 79,4 & 26,2 & $"$ & 48,0 & 17,4 & 32,8 & 26,1 \\
\hline Liberia & $"$ & 19,4 & 125,2 & 1,9 & 90,0 & 0,6 & 26,2 & 1,6 & 30,2 \\
\hline Libia & $"$ & $"$ & 0,0 & $"$ & $"$ & 0,2 & 0,0 & " & $"$ \\
\hline Madagascar & 1,0 & 376,7 & 475,4 & 64,8 & 81,6 & 126,8 & 469,7 & 220,3 & 204,4 \\
\hline Malasia & 188,2 & 36,8 & 0,0 & $"$ & 30,0 & 0,3 & 0,0 & $"$ & 11,0 \\
\hline Malawi & 0,7 & 0,5 & $"$ & " & 10,0 & 1,8 & " & $"$ & " \\
\hline Maldivas & " & 24,9 & $"$ & $"$ & $"$ & " & 12,5 & $"$ & $"$ \\
\hline Malí & 0,3 & $"$ & $"$ & 31,7 & 15,7 & $"$ & " & $"$ & $"$ \\
\hline Marruecos & 378,0 & 468,3 & 780,8 & 676,2 & $1.192,9$ & 235,5 & 559,6 & 311,2 & 731,6 \\
\hline Mauricio & 8,0 & 17,2 & 125,5 & 91,8 & $"$ & 9,9 & 55,6 & 102,1 & 33,5 \\
\hline Mauritania & 8,7 & 10,0 & 136,7 & 15,9 & $"$ & 10,0 & 13,8 & 24,8 & 29,1 \\
\hline Mayotte & 3,3 & 2,0 & $"$ & $"$ & $"$ & 1,0 & " & 3,3 & " \\
\hline México & $1.437,2$ & 625,4 & $4.623,8$ & $1.695,1$ & $1.175,3$ & 611,2 & $3.752,1$ & $1.442,5$ & $1.748,4$ \\
\hline Moldova & 0,9 & 16,7 & 73,8 & 99,3 & 90,1 & 1,1 & 17,3 & 95,2 & 61,1 \\
\hline Mongolia & $"$ & " & 46,5 & 194,2 & 85,6 & " & 57,2 & 195,1 & 40,2 \\
\hline Montenegro & $"$ & 20,9 & 85,8 & 182,1 & 144,7 & 15,7 & 47,6 & 36,3 & 62,8 \\
\hline Mozambique & 50,3 & 11,3 & 0,3 & 612,6 & 4,2 & 22,0 & 6,4 & 597,4 & 0,7 \\
\hline Namibia & 22,8 & 18,4 & $"$ & " & $"$ & 23,4 & 0,8 & " & " \\
\hline Nauru & $"$ & " & $"$ & $"$ & $"$ & " & " & $"$ & $"$ \\
\hline Nicaragua & 2,8 & 36,3 & 61,8 & 94,8 & 20,9 & 14,7 & 7,3 & 26,9 & 24,4 \\
\hline Níger & " & " & " & 19,9 & " & " & " & 15,8 & " \\
\hline Nigeria & 58,8 & 139,7 & 289,1 & 107,1 & 103,5 & 26,6 & 194,5 & 135,0 & 95,3 \\
\hline Omán & 15,4 & 432,5 & 6,1 & $"$ & $"$ & 211,7 & 99,2 & $"$ & $"$ \\
\hline Pakistán & 773,9 & 838,8 & 266,6 & 699,3 & 832,0 & 155,0 & 129,9 & 326,2 & 528,4 \\
\hline Panamá & 37,8 & 315,5 & 776,4 & 77,2 & 83,2 & 20,0 & 272,4 & 64,0 & 149,3 \\
\hline Papua Nueva Guinea & 18,8 & 34,8 & $"$ & 26,6 & 80,9 & 11,5 & 1,8 & 19,5 & 10,3 \\
\hline Paraguay & 10,9 & 153,7 & 85,1 & 265,6 & 112,5 & 6,4 & 110,4 & 122,0 & 100,5 \\
\hline Perú & 289,8 & 451,2 & 648,1 & 792,7 & 336,6 & 161,4 & 648,8 & 940,3 & 217,3 \\
\hline República Centroafricana & $"$ & $"$ & $"$ & $"$ & $"$ & $"$ & $"$ & $"$ & $"$ \\
\hline República del Congo & $"$ & 0,7 & $"$ & " & " & " & $"$ & " & " \\
\hline $\begin{array}{l}\text { República Democrática } \\
\text { del Congo }\end{array}$ & $"$ & $"$ & $"$ & $"$ & $"$ & $"$ & $"$ & $"$ & " \\
\hline $\begin{array}{l}\text { República Democrática } \\
\text { Popular Lao }\end{array}$ & 29,1 & 8,9 & 18,9 & $"$ & $"$ & 11,2 & 6,1 & 15,7 & 0,1 \\
\hline República Dominicana & 143,2 & 38,5 & 551,4 & 176,5 & 373,0 & 52,5 & 125,8 & 169,1 & 318,4 \\
\hline República Kirguisa & $"$ & " & 28,3 & 10,8 & 69,1 & " & 19,8 & 23,0 & 62,2 \\
\hline $\begin{array}{l}\text { Ribera Occidental y Franja } \\
\text { de Gaza }\end{array}$ & $"$ & 113,1 & $"$ & 30,6 & " & " & $"$ & $"$ & " \\
\hline Rwanda & 3,2 & 3,4 & 26,9 & " & 47,0 & $"$ & $"$ & " & 11,6 \\
\hline
\end{tabular}


CUADRO A.19 Otras corrientes oficiales relacionadas con el comercio, por beneficiario (página 3 de 3)

\begin{tabular}{|c|c|c|c|c|c|c|c|c|c|}
\hline & & & & & & \multicolumn{4}{|c|}{ En millones de \$EE.UU. (dólares constantes de 2011} \\
\hline & \multicolumn{5}{|c|}{ COMPROMISOS } & \multicolumn{4}{|c|}{ DESEMBOLSOS } \\
\hline & $\begin{array}{l}\text { Promedio } \\
2002-2005\end{array}$ & $\begin{array}{l}\text { Promedio } \\
2006-2008\end{array}$ & 2009 & 2010 & 2011 & $\begin{array}{l}\text { Promedio } \\
2006-2008\end{array}$ & 2009 & 2010 & 2011 \\
\hline Saint Kitts y Nevis & 1,9 & $"$ & " & $"$ & 16,1 & 0,5 & 0,0 & 0,0 & 0,1 \\
\hline San Vicente y las Granadinas & 1,6 & $"$ & " & " & $"$ & 1,0 & $"$ & 0,0 & 0,0 \\
\hline Santa Lucía & 1,0 & 0,1 & $"$ & 1,6 & $"$ & 0,1 & $"$ & 1,7 & 0,1 \\
\hline Senegal & $"$ & 0,1 & 12,9 & 213,2 & 166,4 & 8,1 & 24,9 & 5,9 & 29,2 \\
\hline Serbia & 26,7 & 229,5 & 992,2 & 802,2 & 731,2 & 10,8 & 324,8 & 664,3 & 651,1 \\
\hline Seychelles & " & " & 23,9 & 4,8 & 11,3 & " & 11,5 & 5,6 & " \\
\hline Sierra Leona & $"$ & " & $"$ & 5,0 & $"$ & $"$ & $"$ & " & $"$ \\
\hline Siria & 149,5 & 41,5 & 28,4 & 7,0 & $"$ & $"$ & 41,3 & 3,5 & 3,1 \\
\hline Somalia & $"$ & " & " & " & $"$ & $"$ & " & " & " \\
\hline Sri Lanka & 141,6 & 267,4 & 145,4 & 142,7 & 246,5 & 9,6 & 16,2 & 185,3 & 199,0 \\
\hline Sudáfrica & 166,3 & 221,9 & $3.140,6$ & $4.055,6$ & $1.128,4$ & 24,8 & 885,6 & $1.039,2$ & 904,0 \\
\hline Sudán & " & 2,6 & 9,8 & 174,4 & $"$ & 2,3 & 8,4 & 5,9 & 22,6 \\
\hline Suriname & $"$ & 1,6 & $"$ & " & 40,0 & " & 12,3 & 23,0 & 44,3 \\
\hline Swazilandia & 0,1 & $"$ & $"$ & $"$ & $"$ & 10,9 & 6,8 & 4,6 & 2,3 \\
\hline Tailandia & 29,0 & 76,4 & 18,7 & 359,0 & 338,3 & 23,6 & 31,1 & 19,5 & 138,8 \\
\hline Tanzania & 7,0 & 18,3 & 10,4 & 6,0 & " & 17,3 & 20,2 & 2,9 & " \\
\hline Tayikistán & $"$ & " & 20,1 & 14,9 & 25,6 & " & 21,7 & 14,4 & 17,8 \\
\hline Togo & " & 50,9 & $"$ & $"$ & 28,0 & $"$ & 123,5 & " & 22,3 \\
\hline Trinidad y Tabago & " & 4,9 & $"$ & $"$ & $"$ & 0,8 & $"$ & 0,2 & $"$ \\
\hline Túnez & 343,9 & 429,5 & 858,6 & 852,4 & 410,4 & 223,3 & 677,9 & 472,0 & 283,8 \\
\hline Turkmenistan & " & $"$ & 3,1 & 8,6 & 398,4 & $"$ & $"$ & 9,0 & 27,9 \\
\hline Turquía & $1.316,2$ & $2.998,9$ & $1.889,2$ & $2.497,1$ & $2.669,6$ & $1.313,4$ & $2.172,2$ & $2.111,8$ & $2.425,7$ \\
\hline Ucrania & 64,6 & 474,7 & $2.292,9$ & $1.041,2$ & $1.482,9$ & 218,1 & $1.706,7$ & 667,9 & $1.142,9$ \\
\hline Uganda & 2,8 & 110,5 & 14,2 & " & 55,6 & 18,4 & 54,8 & 38,4 & 20,0 \\
\hline Uruguay & 264,7 & 153,2 & 312,8 & 44,7 & 365,9 & 66,1 & 406,0 & 13,9 & 158,8 \\
\hline Uzbekistán & 116,0 & 59,0 & 9,9 & 599,7 & 500,3 & 31,6 & 71,9 & 44,5 & 71,7 \\
\hline Vanuatu & 0,1 & $"$ & $"$ & $"$ & " & " & " & $"$ & " \\
\hline Venezuela & 14,8 & 298,7 & $1.076,8$ & 745,7 & $"$ & 0,0 & 297,4 & 565,1 & 358,5 \\
\hline Viet Nam & 33,3 & 791,6 & 952,8 & $1.777,6$ & $2.093,8$ & 202,3 & 343,2 & $1.061,7$ & 818,1 \\
\hline Wallis y Futuna & 0,0 & $"$ & $"$ & $"$ & $"$ & $"$ & $"$ & $"$ & $"$ \\
\hline Yemen & $"$ & 153,4 & 23,7 & $"$ & $"$ & 168,7 & 89,7 & 0,0 & 5,3 \\
\hline Zambia & 16,1 & 35,5 & 21,0 & 10,5 & 25,0 & 25,9 & 5,8 & 9,2 & " \\
\hline Zimbabwe & $"$ & $"$ & $"$ & $"$ & $"$ & " & 0,0 & $"$ & $"$ \\
\hline TOTAL & $16.887,8$ & $26.905,2$ & $48.030,8$ & $43.605,2$ & $35.842,8$ & $10.245,2$ & $27.719,6$ & $31.153,2$ & $26.775,1$ \\
\hline $\begin{array}{l}\text { Regionales/mundiales } \\
\text { (sin asignar) }\end{array}$ & 152,3 & 359,9 & $2.345,9$ & $2.372,0$ & $1.849,7$ & 286,3 & $1.876,8$ & $1.436,1$ & $1.415,7$ \\
\hline $\begin{array}{l}\text { TOTAL DE LA AYUDA } \\
\text { PARA EL COMERCIO }\end{array}$ & $17.040,1$ & $27.265,1$ & $50.376,8$ & $45.977,2$ & $37.692,5$ & $10.531,5$ & $29.596,5$ & $32.589,3$ & $28.190,8$ \\
\hline
\end{tabular}



ANEXO B

\section{LISTA DEL CAD DE PAÍSES Y TERRITORIOS BENEFICIARIOS DE AOD, POR GRUPO DE PAIÍSES SEGÚN EL NIVEL DE INGRESOS}

\section{PAIISES MENOS ADELANTADOS}

$\begin{array}{ll}\text { Afganistán } & \text { Gambia } \\ \text { Angola } & \text { Guinea } \\ \text { Bangladesh } & \text { Guinea Ecuatorial } \\ \text { Benin } & \text { Guinea-Bissau } \\ \text { Bhután } & \text { Haití } \\ \text { Burkina Faso } & \text { Islas Salomón } \\ \text { Burundi } & \text { Kiribati } \\ \text { Camboya } & \text { Lesotho } \\ \text { Chad } & \text { Liberia } \\ \text { Comoras } & \text { Madagascar } \\ \text { Djibouti } & \text { Malawi } \\ \text { Eritrea } & \text { Malí } \\ \text { Etiopía } & \text { Mauritania }\end{array}$

Mozambique
Myanmar
Nepal
Níger
República Centroafricana
República Democrática
del Congo
República Democrática
Popular Lao
Rwanda
Samoa
Santo Tomé y Príncipe

OTROS PAÍSES DE INGRESOS BAJOS

(INB per cápita inferior o igual a 1.005 \$EE.UU. en 2010)

$\begin{array}{lll}\text { Kenya } & \text { República Kirguisa } & \text { Tayikistán } \\ \text { República Democrática } & \text { Sudán del Sur } & \text { Zimbabwe } \\ \text { Popular de Corea } & & \end{array}$

PAÍSES Y TERRITORIOS DE INGRESOS MEDIANOS BAJOS

(INB per cápita de 1.006 \$EE.UU. a 3.975 \$EE.UU. en 2010)

$\begin{array}{lll}\text { Armenia } & \text { Filipinas } & \text { Marruecos } \\ \text { Belice } & \text { Georgia } & \text { Moldova } \\ \text { Bolivia } & \text { Ghana } & \text { Mongolia } \\ \text { Cabo Verde } & \text { Guatemala } & \text { Nicaragua } \\ \text { Camerún } & \text { Guyana } & \text { Nigeria } \\ \text { Côte d'Ivoire } & \text { Honduras } & \text { Pakistán } \\ \text { Egipto } & \text { India } & \text { Papua Nueva Guinea } \\ \text { El Salvador } & \text { Indonesia } & \text { Paraguay } \\ \text { Estados Federados } & \text { Iraq } & \text { República del Congo } \\ \text { de Micronesia } & \text { Islas Marshall } & \text { Ribera Occidental } \\ \text { Fiji } & \text { Kosovo' } & \text { y Franja de Gaza }\end{array}$

Senegal

Sierra Leona

Somalia

Sudán

Tanzanía

Timor-Leste

Togo

Tuvalu

Uganda

Vanuatu

Yemen

Zambia
Siria

Sri Lanka

Swazilandia

Tokelau*

Tonga

Turkmenistán

Ucrania

Uzbekistán

Viet Nam 
PAÍSES Y TERRITORIOS DE INGRESOS MEDIANOS ALTOS

(INB per cápita de 3.976 \$EE.UU. a 12.275 \$EE.UU. en 2010)

$\begin{array}{llll}\text { Albania } & \text { Cuba } & \text { Malasia } & \text { San Vicente y las Granadinas } \\ \text { Anguilla* } & \text { Dominica } & \text { Maldivas } & \text { Santa Elena* } \\ \text { Antigua y Barbuda } & \text { Ecuador } & \text { Mauricio } & \text { Santa Lucía } \\ \text { Argelia } & \text { ex República Yugoslava } & \text { México } & \text { Serbia } \\ \text { Argentina } & \text { de Macedonia } & \text { Montenegro } & \text { Seychelles } \\ \text { Azerbaiyán } & \text { Gabón } & \text { Montserrat* } & \text { Sudáfrica } \\ \text { Belarús } & \text { Granada } & \text { Namibia } & \text { Suriname } \\ \text { Bosnia y Herzegovina } & \text { Irán } & \text { Nauru } & \text { Tailandia } \\ \text { Botswana } & \text { Islas Cook } & \text { Niue } & \text { Túnez } \\ \text { Brasil } & \text { Jamaica } & \text { Palau } & \text { Turquía } \\ \text { Chile } & \text { Jordania } & \text { Panamá } & \text { Uruguay } \\ \text { China } & \text { Kazajstán } & \text { Perú } & \text { Venezuela } \\ \text { Colombia } & \text { Líbano } & \text { República Dominicana } & \text { Wallis y Futuna* } \\ \text { Costa Rica } & \text { Libia } & \text { Saint Kitts y Nevis } & \end{array}$

Notas:

*Territorio

1. Sin perjuicio del estatuto de Kosovo con arreglo al derecho internacional. 


\section{ANEXO C LISTA DEL CAD DE PAÍSES Y TERRITORIOS BENEFICIARIOS DE AOD, POR REGIÓN}

\section{ÁFRICA}

\section{Norte del Sáhara}

Argelia

Egipto

Libia

Marruecos

Túnez

Sur del Sáhara
Angola
Benin
Botswana
Burkina Faso
Burundi
Cabo Verde
Camerún
Chad
Comoras
Côte d'Ivoire
Djibouti
Eritrea
Gabón
Guinea
Guinea Ecuatorial
Guinea-Bissau
Kenya

Lesotho
Liberia
Madagascar
Malawi
Malí
Mauricio
Mauritania
Mozambique
Namibia
Níger
Nigeria
República Centroafricana
República del Congo
República Democrática
del Congo
Rwanda
Santa Elena

Lesotho

Madagascar

Mauricio

Mozambique
Santo Tomé y Príncipe

Senegal

Seychelles

Sierra Leona

Somalia

Sudáfrica

Sudán

Sudán del Sur

Swazilandia

Tanzanía

Togo

Uganda

Zambia

Zimbabwe

\section{AMÉRICA}

\section{América del Norte y Central}

\section{Anguila}

Antigua y Barbuda

Belice

Costa Rica

Cuba

Dominica

El Salvador

Granada

Guatemala

Haití
Jamaica

México

Montserrat

Nicaragua

Panamá

República Dominicana

Saint Kitts y Nevis

San Vicente y las Granadinas

Santa Lucía

América del Sur
Argentina
Bolivia
Brasil
Chile
Colombia
Ecuador
Guyana
Paraguay
Perú
Suriname
Uruguay
Venezuela




\section{ASIA}

\section{Lejano Oriente}

Camboya

China

Filipinas

Indonesia

Malasia

Mongolia

República Popular

Democrática de Corea

República Democrática

Popular Lao

Tailandia

Timor-Leste

Viet Nam

\section{EUROPA}

Albania

Belarús

Bosnia y Herzegovina

\section{OCEANÍA}

Estados Federados

de Micronesia

Fiji

Islas Cook

Islas Marshall

\section{Oriente Medio}

Irán

Iraq

Jordania

Líbano

Ribera Occidental y Franja

de Gaza

Siria

Yemen

Ex República Yugoslava de Macedonia

Kosovo

Islas Salomón

Kiribati

Nauru

Niue

Palau
Asia Meridional y Central

Afganistán

Myanmar

Armenia

Nepal

Azerbaiyán

Pakistán

Bangladesh

República Kirguisa

Bhután

Sri Lanka

Tayikistán

Turkmenistán

Uzbekistán

Kazajstán

Maldivas

Moldova

Montenegro

Serbia

Papua Nueva Guinea

Samoa

Tokelau

Tonga

Tuvalu
Turquía

Ucrania

Vanuatu

Wallis y Futuna 


\section{ANEXO D}

\section{CÓDIGOS-OBJETO DEL SNPA RELACIONADOS CON LA AYUDA PARA EL COMERCIO, POR CATEGORÍA}

\section{Código objeto Descripción del SNPA}

\section{POLÍTICA Y REGLAMENTACIÓN COMERCIALES Y AJUSTE RELACIONADO CON EL COMERCIO}

33110

Política comercial y gestión administrativa

$33120 \quad$ Facilitación del comercio Negociaciones comerciales multilaterales Educación/formación en la esfera del comercio con el comercio

\section{Aclaraciones/Notas complementarias sobre el objeto de la ayuda}

Política comercial y planificación; apoyo a ministerios y departamentos encargados de la política comercial; reforma de la legislación y la reglamentación comerciales; análisis de políticas y aplicación de acuerdos comerciales multilaterales, por ejemplo sobre obstáculos técnicos al comercio y medidas sanitarias y fitosanitarias, excepto a nivel regional (véase el código 33130); integración del comercio en las estrategias nacionales de desarrollo (por ejemplo, documentos de estrategia de lucha contra la pobreza); comercio al por mayor y al por menor; actividades no especificadas relacionadas con el comercio y la promoción del comercio.

Simplificación y armonización de los procedimientos internacionales de importación y exportación (por ejemplo, valoración en aduana, trámites de licencias, trámites para el transporte, pagos, seguros); apoyo a los departamentos de aduanas; reformas arancelarias.

Apoyo a los acuerdos comerciales regionales [por ejemplo, Comunidad del África Meridional para el Desarrollo (SADC), Asociación de Naciones del Asia Sudoriental (ASEAN), Área de Libre Comercio de las Américas (ALCA), Países de África, el Caribe y el Pacífico y la Unión Europea (ACP/UE)]; incluidas la labor sobre obstáculos técnicos al comercio y las medidas sanitarias y fitosanitarias a nivel regional; la elaboración de normas de origen y la introducción del trato especial y diferenciado en los acuerdos comerciales regionales.

Apoyo a la participación efectiva de los países en desarrollo en las negociaciones comerciales multilaterales, incluidas la formación de los negociadores, la evaluación de la repercusión de las negociaciones; la adhesión a la Organización Mundial del Comercio (OMC) y a otras organizaciones multilaterales relacionadas con el comercio.

Actividades de capacitación de recursos humanos en la esfera del comercio no incluidas en ninguno de los códigos mencionados supra. Abarca programas universitarios sobre comercio.

Contribuciones al presupuesto del Estado para ayudar a los beneficiarios a llevar a cabo sus propias reformas comerciales y a ajustarse a las políticas comerciales de otros países; asistencia para gestionar los déficits de balanza de pagos resultantes de la evolución del entorno comercial mundial.

INFRAESTRUCTURA ECONÓMICA

\section{TRANSPORTE Y ALMACENAMIENTO}

$21010 \quad$ Política de transporte y gestión administrativa
Política, planificación y programas del sector del transporte; ayuda a ministerios de transporte; creación de capacidad institucional y asesoramiento; medios de transporte no especificados; actividades que abarcan el transporte por carretera, por ferrocarril, por agua y/o por aire. 


\begin{tabular}{|c|c|c|}
\hline 21020 & Transporte por carretera & $\begin{array}{l}\text { Infraestructura ferroviaria, vehículos; transporte de pasajeros por carretera, } \\
\text { vehículos particulares. }\end{array}$ \\
\hline 21030 & Transporte ferroviario & $\begin{array}{l}\text { Infraestructura ferroviaria, material ferroviario, locomotoras, otro material } \\
\text { rodante, incluidos tranvías y sistemas de transporte subterráneo. }\end{array}$ \\
\hline 21040 & Transporte por agua & $\begin{array}{l}\text { Puertos y muelles, sistemas de señalización de puertos, buques y } \\
\text { embarcaciones; transporte fluvial y por otras vías de navegación interiores, } \\
\text { barcazas y embarcaciones de vías de navegación interiores. }\end{array}$ \\
\hline 21050 & Transporte aéreo & $\begin{array}{l}\text { Aeropuertos, sistemas de señalización de aeropuertos, aeronaves, equipo de } \\
\text { mantenimiento de aviones y aeronaves. }\end{array}$ \\
\hline 21061 & Almacenamiento & Relacionado o no con el transporte. \\
\hline \multirow[t]{2}{*}{21081} & $\begin{array}{l}\text { Educación y formación en materia } \\
\text { de transporte y almacenamiento }\end{array}$ & \\
\hline & \multicolumn{2}{|l|}{ COMUNICACIONES } \\
\hline 22010 & $\begin{array}{l}\text { Política de comunicaciones } \\
\text { y gestión administrativa }\end{array}$ & $\begin{array}{l}\text { Política, planificación y programas del sector de las comunicaciones; creación } \\
\text { de capacidad institucional y asesoramiento; abarca el desarrollo de los servicios } \\
\text { postales y actividades no especificadas relacionadas con las comunicaciones. }\end{array}$ \\
\hline 22020 & Telecomunicaciones & Redes de teléfonos, satélites de telecomunicaciones, estaciones terrestres. \\
\hline 22030 & Radio, televisión, prensa escrita & Enlaces y equipo de radio y televisión; periódicos; imprenta y publicación. \\
\hline \multirow[t]{2}{*}{22040} & $\begin{array}{l}\text { Tecnología de la información } \\
\text { y las comunicaciones (TIC) }\end{array}$ & $\begin{array}{l}\text { Equipo y programas de informática; acceso a Internet; capacitación en } \\
\text { tecnología de la información. Cuando no puede especificarse el sector. }\end{array}$ \\
\hline & \multicolumn{2}{|c|}{ GENERACIÓN Y SUMINISTRO DE ENERGÍA } \\
\hline 23010 & $\begin{array}{l}\text { Política de energía y gestión } \\
\text { administrativa }\end{array}$ & $\begin{array}{l}\text { Política, planificación y programas del sector de la energía; ayuda a los } \\
\text { ministerios de energía; creación de capacidad institucional y asesoramiento; } \\
\text { actividades no especificadas relacionadas con la energía, incluido el ahorro de } \\
\text { energía. }\end{array}$ \\
\hline 23020 & $\begin{array}{l}\text { Generación de energía } \\
\text { (fuentes no renovables) }\end{array}$ & $\begin{array}{l}\text { Centrales térmicas, incluidas aquéllas cuya fuente de calor no puede ser } \\
\text { determinada; centrales eléctricas combinadas de gas y carbón. }\end{array}$ \\
\hline 23030 & $\begin{array}{l}\text { Generación de energía } \\
\text { (fuentes renovables) }\end{array}$ & $\begin{array}{l}\text { Abarca políticas, planificación, programas de desarrollo, estudios e incentivos. } \\
\text { La producción de leña y carbón vegetal debe incluirse en silvicultura (31261). }\end{array}$ \\
\hline 23040 & $\begin{array}{l}\text { Transmisión y distribución } \\
\text { de electricidad }\end{array}$ & $\begin{array}{l}\text { Distribución de la energía desde la fuente hasta el consumidor final; líneas de } \\
\text { transmisión. }\end{array}$ \\
\hline 23050 & Distribución de gas & Distribución para uso por el consumidor final. \\
\hline 23061 & $\begin{array}{l}\text { Centrales eléctricas alimentadas } \\
\text { con petróleo }\end{array}$ & Abarca las centrales alimentadas con gasóleo. \\
\hline 23062 & $\begin{array}{l}\text { Centrales eléctricas alimentadas } \\
\text { con gas }\end{array}$ & \\
\hline 23063 & $\begin{array}{l}\text { Centrales eléctricas alimentadas } \\
\text { con carbón }\end{array}$ & \\
\hline 23064 & Centrales nucleares & Incluida la seguridad nuclear. \\
\hline 23065 & Centrales hidroeléctricas & Incluidas las barcazas de generación de electricidad. \\
\hline
\end{tabular}




\begin{tabular}{|c|c|c|}
\hline 23066 & Energía geotérmica & \\
\hline 23067 & Energía solar & $\begin{array}{l}\text { Abarca las células fotovoltaicas, las aplicaciones de la energía solar térmica y la } \\
\text { calefacción por energía solar. }\end{array}$ \\
\hline 23068 & Energía eólica & Energía eólica para elevar agua y generar electricidad. \\
\hline 23069 & Energía oceánica & $\begin{array}{l}\text { Abarca la conversión de la energía térmica oceánica y la energía de las mareas y } \\
\text { las olas. }\end{array}$ \\
\hline 23070 & Biomasa & $\begin{array}{l}\text { Tecnologías de densificación y utilización de la biomasa para la generación } \\
\text { directa de energía, incluido el biogás obtenido a partir de la caña de azúcar y } \\
\text { otros residuos vegetales o por digestores anaerobios. }\end{array}$ \\
\hline 23081 & $\begin{array}{l}\text { Educación y formación } \\
\text { en el ámbito de la energía }\end{array}$ & $\begin{array}{l}\text { Se aplica a todos los subsectores de la energía; todos los niveles de } \\
\text { capacitación. }\end{array}$ \\
\hline 23082 & $\begin{array}{l}\text { Investigación en el ámbito } \\
\text { de la energía }\end{array}$ & Abarca estudios e inventarios generales \\
\hline \multicolumn{3}{|c|}{ CREACIÓN DE CAPACIDAD PRODUCTIVA (abarca el FOMENTO DEL COMERCIO) } \\
\hline & \multicolumn{2}{|c|}{ SERVICIOS BANCARIOS Y FINANCIEROS } \\
\hline 24010 & $\begin{array}{l}\text { Política financiera y gestión } \\
\text { administrativa }\end{array}$ & $\begin{array}{l}\text { Política, planificación y programas del sector financiero; creación de capacidad } \\
\text { institucional y asesoramiento; mercados y sistemas financieros. }\end{array}$ \\
\hline 24020 & Instituciones monetarias & Bancos centrales. \\
\hline 24030 & $\begin{array}{l}\text { Intermediarios financieros } \\
\text { del sector formal }\end{array}$ & $\begin{array}{l}\text { Todos los intermediarios financieros del sector formal; líneas de crédito; seguros, } \\
\text { arrendamiento financiero, capital de riesgo, etc. (salvo los especializados en un } \\
\text { único sector). }\end{array}$ \\
\hline 24040 & $\begin{array}{l}\text { Intermediarios financieros } \\
\text { informales y semiformales }\end{array}$ & Microcrédito, cooperativas de ahorro y crédito, etc. \\
\hline \multirow[t]{2}{*}{24081} & $\begin{array}{l}\text { Educación y formación en } \\
\text { servicios bancarios y financieros }\end{array}$ & \\
\hline & \multicolumn{2}{|c|}{ SERVICIOS A EMPRESAS Y OTROS SERVICIOS } \\
\hline 25010 & $\begin{array}{l}\text { Servicios e instituciones de apoyo } \\
\text { a empresas }\end{array}$ & $\begin{array}{l}\text { Apoyo a asociaciones comerciales y empresariales, cámaras de comercio; } \\
\text { reformas jurídicas y reglamentarias a fin de mejorar el entorno para la inversión } \\
\text { y los negocios; asesoramiento y creación de capacidad institucional en el sector } \\
\text { privado; información comercial; establecimiento de vínculos entre el sector } \\
\text { público y el privado, incluidas las ferias comerciales; comercio electrónico. } \\
\text { Cuando no puede especificarse el sector: apoyo general a empresas del sector } \\
\text { privado (en particular, utilícese el código } 32130 \text { para las empresas del sector } \\
\text { industrial). }\end{array}$ \\
\hline \multirow[t]{2}{*}{25020} & Privatización & $\begin{array}{l}\text { Cuando no puede especificarse el sector. Abarca los programas de } \\
\text { reestructuración o desmonopolización de empresas públicas; planificación, } \\
\text { programación, asesoramiento. }\end{array}$ \\
\hline & \multicolumn{2}{|l|}{ AGRICULTURA } \\
\hline 31110 & $\begin{array}{l}\text { Política agropecuaria y gestión } \\
\text { administrativa }\end{array}$ & $\begin{array}{l}\text { Política, planificación y programas del sector agropecuario; ayuda a los } \\
\text { ministerios de agricultura; creación de capacidad institucional y asesoramiento; } \\
\text { actividades no especificadas relacionadas con la agricultura. }\end{array}$ \\
\hline 31120 & Desarrollo agrícola & Proyectos integrados; desarrollo de explotaciones agropecuarias. \\
\hline
\end{tabular}


$31130 \quad$ Recursos de tierras cultivables

$31140 \quad$ Recursos hídricos para

la agricultura

$31150 \quad$ Insumos agrícolas

$31161 \quad$ Producción de cultivos

alimentarios

31162

Cultivos industriales y cultivos de exportación

\begin{tabular}{|l|l|}
\hline 31163 & Ganadería \\
\hline 31164 & Reforma agraria \\
\hline 31165 & Desarrollo agrícola alternativo \\
\hline 31166 & Divulgación agrícola \\
\hline 31181 & Educación y formación agrícolas \\
\hline 31182 & Investigación agropecuaria \\
\hline
\end{tabular}

$31191 \quad$ Servicios agrícolas

31192 Protección de plantas y protección de cultivos después de la cosecha; lucha contra las plagas

31193 Servicios financieros agrícolas

$31194 \quad$ Cooperativas agrícolas

31195 Servicios veterinarios
Abarca la lucha contra la degradación de los suelos; la mejora de los suelos; el drenaje de zonas inundadas; la desalinización de los suelos; los estudios de tierras de cultivo; la recuperación de tierras; la lucha contra la erosión, la lucha contra la desertificación.

Riego, embalses, estructuras hidráulicas, explotación de napas freáticas para uso agrícola.

Suministro de semillas, abonos, equipo y maquinaria agrícola.

Abarca los cereales (trigo, arroz, cebada, maíz, centeno, avena, mijo, sorgo); la horticultura; las legumbres y hortalizas; las frutas y bayas; otros cultivos de especies anuales y perennes. [Utilícese el código 32161 para las agroindustrias.]

Abarcan el azúcar; el café, el cacao, el té; las semillas oleaginosas, los frutos secos; los cultivos de fibras; el tabaco; el caucho. [Utilícese el código 32161 para las agroindustrias.]

Cría de animales; ayudas para piensos.

Abarca el ajuste en el sector agrícola.

Proyectos para reducir los cultivos ilícitos (drogas) mediante otras oportunidades de comercialización y producción agrícolas (véase el código 43050, relativo al desarrollo alternativo no agrícola).

Formación agrícola no académica.

Estudios de especies vegetales, fisiología vegetal, recursos genéticos, ecología, taxonomía, lucha contra las plagas, biotecnología agrícola; incluida la investigación pecuaria (sanidad, cría y genética, nutrición y fisiología animal).

Organización y políticas de comercialización; almacenamiento y transporte; establecimiento de reservas estratégicas.

Abarca la protección integrada de las plantas, las actividades de protección biológica de las plantas, el suministro y la gestión de agroquímicos, el suministro de plaguicidas y la política y la legislación sobre la protección de las plantas.

Intermediarios financieros para el sector agropecuario, incluidos los planes de crédito; seguro de cosechas.

Abarca las organizaciones de agricultores.

Sanidad animal, gestión veterinaria, recursos genéticos y alimento para el ganado.

\section{SILVICULTURA}

$31210 \quad$ Política de silvicultura y gestión administrativa
Desarrollo de la silvicultura

Leña y carbón vegetal
Política, planificación y programas del sector de la silvicultura; creación de capacidad institucional y asesoramiento; estudios forestales; actividades forestales y agroforestales no especificadas.

Reforestación para el consumo rural e industrial; explotación y utilización; lucha contra la erosión, lucha contra la desertificación; proyectos silvícolas integrados.

Desarrollo silvícola con el objeto principal de producir leña y carbón. 


\begin{tabular}{|c|c|c|}
\hline 31281 & $\begin{array}{l}\text { Educación y formación en } \\
\text { silvicultura }\end{array}$ & \\
\hline 31282 & Investigación en silvicultura & $\begin{array}{l}\text { Abarca la regeneración artificial, la mejora genética, los métodos de producción, } \\
\text { los abonos y la recolección. }\end{array}$ \\
\hline \multirow[t]{2}{*}{31291} & Servicios forestales & \\
\hline & PESCA & \\
\hline 31310 & $\begin{array}{l}\text { Política de pesca y gestión } \\
\text { administrativa }\end{array}$ & $\begin{array}{l}\text { Política de pesca, planificación de la pesca y programas de pesca; creación de } \\
\text { capacidad institucional y asesoramiento; pesca de altura y de bajura; estudios y } \\
\text { prospección de peces de agua dulce y de agua salada; embarcaciones y equipo } \\
\text { de pesca; actividades pesqueras no especificadas. }\end{array}$ \\
\hline 31320 & Desarrollo de la pesca & $\begin{array}{l}\text { Utilización y explotación de pesquerías; protección de bancos de peces; } \\
\text { acuicultura; proyectos integrados de pesca. }\end{array}$ \\
\hline 31381 & $\begin{array}{l}\text { Educación y formación en } \\
\text { pesquerías }\end{array}$ & \\
\hline 31382 & $\begin{array}{l}\text { Investigación en el sector de la } \\
\text { pesca }\end{array}$ & $\begin{array}{l}\text { Proyectos piloto de piscicultura; investigación biológica de ecosistemas de agua } \\
\text { dulce y agua salada. }\end{array}$ \\
\hline \multirow[t]{2}{*}{31391} & Servicios pesqueros & $\begin{array}{l}\text { Puertos de pesca; mercados de pescado; transporte y almacenamiento } \\
\text { refrigerado del pescado. }\end{array}$ \\
\hline & INDUSTRIA & \\
\hline 32110 & $\begin{array}{l}\text { Política industrial y gestión } \\
\text { administrativa }\end{array}$ & $\begin{array}{l}\text { Política, planificación y programas del sector de la industria; creación } \\
\text { de capacidad institucional y asesoramiento; actividades industriales no } \\
\text { especificadas; industrias manufactureras no especificadas infra. }\end{array}$ \\
\hline 32120 & Desarrollo industrial & \\
\hline 32130 & $\begin{array}{l}\text { Desarrollo de pequeñas y } \\
\text { medianas empresas (PYME) }\end{array}$ & $\begin{array}{l}\text { Apoyo directo al desarrollo de las pequeñas y medianas empresas en el sector } \\
\text { de la industria, incluidos los servicios de contabilidad, auditoría y asesoramiento. }\end{array}$ \\
\hline 32140 & Industrias artesanales y artesanías & \\
\hline 32161 & Agroindustrias & $\begin{array}{l}\text { Elaboración de alimentos básicos, productos lácteos, mataderos y equipo } \\
\text { necesario, elaboración y conservación de productos cárnicos y pescado, aceites } \\
\text { y grasas, refinerías de azúcar, bebidas y tabaco, producción de piensos. }\end{array}$ \\
\hline 32162 & Industrias forestales & Producción de madera, producción de papel y pasta de papel. \\
\hline 32163 & Textiles, cueros y sucedáneos & Incluidas las fábricas de tejidos de punto. \\
\hline 32164 & Productos químicos & $\begin{array}{l}\text { Instalaciones de producción industrial y no industrial; incluida la fabricación de } \\
\text { pesticidas. }\end{array}$ \\
\hline 32165 & Producción de abonos & \\
\hline 32166 & Cemento, cal y yeso & \\
\hline 32167 & Generación de energía & Abarca la licuefacción de gas y las refinerías de petróleo. \\
\hline 32168 & Productos farmacéuticos & $\begin{array}{l}\text { Material y suministros médicos; medicamentos y vacunas; productos de higiene } \\
\text { corporal. }\end{array}$ \\
\hline 32169 & Industrias metalúrgicas básicas & Producción de hierro, acero y productos metálicos estructurales. \\
\hline
\end{tabular}




\begin{tabular}{|c|c|c|}
\hline 32170 & Industrias de metales no ferrosos & \\
\hline 32171 & Ingeniería & Fabricación de maquinaria eléctrica y no eléctrica, motores y turbinas. \\
\hline 32172 & Industria del equipo de transporte & $\begin{array}{l}\text { Construcción de buques, construcción de embarcaciones de pesca; material } \\
\text { ferroviario; vehículos automotores y automóviles; aeronaves; sistemas de } \\
\text { orientación y de navegación. }\end{array}$ \\
\hline \multirow[t]{2}{*}{32182} & $\begin{array}{l}\text { Investigación y desarrollo } \\
\text { tecnológicos }\end{array}$ & $\begin{array}{l}\text { Abarca normas industriales; gestión de la calidad; metrología; ensayos; } \\
\text { acreditación; certificación. }\end{array}$ \\
\hline & \multicolumn{2}{|l|}{ INDUSTRIAS EXTRACTIVAS } \\
\hline 32210 & $\begin{array}{l}\text { Política de las industrias } \\
\text { extractivas y gestión } \\
\text { administrativa }\end{array}$ & $\begin{array}{l}\text { Política, planificación y programas del sector de las industrias extractivas; } \\
\text { legislación minera, catastro minero, inventario de recursos mineros, sistemas de } \\
\text { información; creación de capacidad institucional y asesoramiento; explotación } \\
\text { de recursos mineros no especificados. }\end{array}$ \\
\hline 32220 & $\begin{array}{l}\text { Prospección y exploración } \\
\text { mineras }\end{array}$ & $\begin{array}{l}\text { Geología, geofísica y geoquímica; con exclusión de la hidrogeología (41010) y la } \\
\text { geología del medio ambiente (41010), extracción y procesamiento de minerales, } \\
\text { infraestructura, tecnología, economía, seguridad y ordenación del medio } \\
\text { ambiente. }\end{array}$ \\
\hline 32261 & Carbón & Incluidos el lignito y la turba. \\
\hline 32262 & Petróleo y gas & $\begin{array}{l}\text { Petróleo, gas natural, condensados, gas licuado de petróleo (GLP), gas natural } \\
\text { licuado (GNL); abarca las actividades de perforación y producción. }\end{array}$ \\
\hline 32263 & Metales ferrosos & Hierro y aleaciones de hierro. \\
\hline 32264 & Metales no ferrosos & Aluminio, cobre, plomo, níquel, estaño y cinc. \\
\hline 32265 & Materiales/metales preciosos & Oro, plata, platino, diamantes y piedras preciosas. \\
\hline 32266 & Minerales industriales & Barita, caliza, feldespato, caolín, arena, yeso, grava, piedras ornamentales. \\
\hline 32267 & Abonos de origen mineral & Fosfatos, potasa. \\
\hline \multirow[t]{2}{*}{32268} & Minerales marinos & Nódulos polimetálicos, fosforitos, sedimentos marinos (placeres). \\
\hline & \multicolumn{2}{|l|}{ TURISMO } \\
\hline 33210 & $\begin{array}{l}\text { Política de turismo y gestión } \\
\text { administrativa }\end{array}$ & \\
\hline
\end{tabular}




\section{ANEXO E \\ ESTIMACIONES MEDIANTE REGRESIÓN}

CUADRO E.1 Efecto de la ayuda para el comercio en las exportaciones de los países en desarrollo (con excepción de las exportaciones de minerales y petróleo) (página 1 de 2)

\begin{tabular}{|c|c|c|c|c|}
\hline $\begin{array}{l}\text { Variable dependiente } \\
\text { Exportaciones del país i } \\
\text { (EN DESARROLLO, 1995) al país j } \\
\text { (TODOS) en el año t }\end{array}$ & $\begin{array}{c}\text { (1) } \\
\text { Modelo de } \\
\text { gravedad }\end{array}$ & $\begin{array}{c}\text { (2) } \\
\text { Modelo de } \\
\text { gravedad } \\
\text { ampliado }\end{array}$ & $\begin{array}{c}\text { (3) } \\
\text { Ayuda para el } \\
\text { comercio }\end{array}$ & $\begin{array}{l}\text { (4) } \\
\text { Ayuda para el comercio } \\
\text { + variables sustitutivas } \\
\text { para países que no } \\
\text { reciben ayuda }\end{array}$ \\
\hline LnPIB_i & $\begin{array}{c}0.353^{* * *} \\
(0.017)\end{array}$ & $\begin{array}{c}0.376^{* * *} \\
(0.017)\end{array}$ & $\begin{array}{c}0.368^{* * *} \\
(0.017)\end{array}$ & $\begin{array}{c}0.364^{* * *} \\
(0.017)\end{array}$ \\
\hline Ln PIB_j & $\begin{array}{c}0.296^{* * *} \\
(0.014)\end{array}$ & $\begin{array}{c}0.337^{* * *} \\
(0.014)\end{array}$ & $\begin{array}{c}0.329 * * * \\
(0.014)\end{array}$ & $\begin{array}{c}0.329^{* * *} \\
(0.014)\end{array}$ \\
\hline LnPOB_i & $\begin{array}{c}-0.762^{* * *} \\
(0.067)\end{array}$ & $\begin{array}{c}-0.467^{* * *} \\
(0.064)\end{array}$ & $\begin{array}{c}-0.555^{* * *} \\
(0.065)\end{array}$ & $\begin{array}{c}-0.535^{* * *} \\
(0.067)\end{array}$ \\
\hline LnPOB_j & $\begin{array}{c}0.169 * * * \\
(0.049)\end{array}$ & $\begin{array}{c}0.396^{* * *} \\
(0.047)\end{array}$ & $\begin{array}{c}0.340^{* * *} \\
(0.048)\end{array}$ & $\begin{array}{c}0.339^{* * *} \\
(0.048)\end{array}$ \\
\hline Ln distancia_ij & $\begin{array}{c}-1.146^{* * *} \\
(0.004)\end{array}$ & $\begin{array}{c}-0.819^{* * *} \\
(0.005)\end{array}$ & $\begin{array}{c}-0.819 * * * \\
(0.005)\end{array}$ & $\begin{array}{c}-0.819^{* * *} \\
(0.005)\end{array}$ \\
\hline Ambos países carecen de litoral & & $\begin{array}{c}-0.623^{* * *} \\
(0.025)\end{array}$ & $\begin{array}{c}-0.622^{* * *} \\
(0.025)\end{array}$ & $\begin{array}{c}-0.622^{* * *} \\
(0.025)\end{array}$ \\
\hline Ln lejanía ij & & $\begin{array}{c}0.597^{* * *} \\
(0.057)\end{array}$ & $\begin{array}{c}0.603^{* * *} \\
(0.058)\end{array}$ & $\begin{array}{c}0.604^{* * *} \\
(0.058)\end{array}$ \\
\hline Frontera común & & $\begin{array}{c}0.889^{* * *} \\
(0.019)\end{array}$ & $\begin{array}{c}0.889^{* * *} \\
(0.019)\end{array}$ & $\begin{array}{c}0.889 * * * \\
(0.019)\end{array}$ \\
\hline Colonizador común & & $\begin{array}{c}0.393^{* * *} \\
(0.012)\end{array}$ & $\begin{array}{c}0.393^{* * *} \\
(0.012)\end{array}$ & $\begin{array}{c}0.393^{* * *} \\
(0.012)\end{array}$ \\
\hline Relación colonial & & $\begin{array}{c}0.783^{* * *} \\
(0.028)\end{array}$ & $\begin{array}{c}0.783^{* * *} \\
(0.028)\end{array}$ & $\begin{array}{c}0.783^{* * *} \\
(0.028)\end{array}$ \\
\hline Idioma común & & $\begin{array}{c}0.402^{* * *} \\
(0.010)\end{array}$ & $\begin{array}{c}0.402^{* * * *} \\
(0.010)\end{array}$ & $\begin{array}{c}0.402^{* * *} \\
(0.010)\end{array}$ \\
\hline Conflicto en i & & $\begin{array}{c}-0.098^{* * *} \\
(0.016)\end{array}$ & $\begin{array}{c}-0.092^{* * * *} \\
(0.016)\end{array}$ & $\begin{array}{c}-0.092^{* * *} \\
(0.016)\end{array}$ \\
\hline Conflicto en j & & $\begin{array}{l}-0.005 \\
(0.018)\end{array}$ & $\begin{array}{c}0.001 \\
(0.018)\end{array}$ & $\begin{array}{l}0.000 \\
(0.018)\end{array}$ \\
\hline Variable sustitutiva para ACR & & $\begin{array}{c}0.611^{* * *} \\
(0.011)\end{array}$ & $\begin{array}{c}0.613^{* * *} \\
(0.011)\end{array}$ & $\begin{array}{c}0.613^{* * *} \\
(0.011)\end{array}$ \\
\hline
\end{tabular}


CUADRO E.1 Efecto de la ayuda para el comercio en las exportaciones de los países en desarrollo (con excepción de las exportaciones de minerales y petróleo) (página 2 de 2)

(Clasificación de 1995)

\begin{tabular}{l|l|}
\hline Variable dependiente & \multicolumn{1}{|c|}{$(1)$} \\
Exportaciones del país i & Modelo de \\
(EN DESARROLLO, 1995) al país j & gravedad \\
(TODOS) en el año t &
\end{tabular}

\begin{tabular}{|c|}
\hline$(2)$ \\
Modelo de \\
gravedad \\
ampliado
\end{tabular}

(3)

Ayuda para el comercio

El país i recibió ayuda para el comercio en $\mathrm{t}-3$

El país i no recibió ayuda para el comercio en $t-3$

\section{El país j recibió ayuda para} el comercio en $\mathrm{t}-3$

El país j no recibió ayuda para

el comercio j en t-3

\section{El país i recibió otra $A O D$}

El país i no recibió otra $A O D$

\section{El país j recibió otra AOD}

El país j no recibió otra $A O D$

Efectos fijos por importador y exportador

Efectos fijos por año

Observaciones

R cuadrado (R2) 
CUADRO E.2 Efecto de la ayuda para el comercio en las exportaciones, por grupos de países clasificados según el nivel de ingresos

(Clasificación de 1995)

\begin{tabular}{|c|c|c|c|c|c|}
\hline $\begin{array}{l}\text { Variable dependiente } \\
\text { Exportaciones del país i (EN } \\
\text { DESARROLLO, 1995) al país j } \\
\text { (TODOS) en el año t }\end{array}$ & $\begin{array}{c}\text { (1) } \\
\text { Países de } \\
\text { ingresos bajos } \\
(1995\end{array}$ & $\begin{array}{c}\text { (2) } \\
\text { Países de } \\
\text { ingresos } \\
\text { medianos } \\
\text { bajos (1995) }\end{array}$ & $\begin{array}{l}\text { (3) } \\
\text { Países que } \\
\text { reciben fondos } \\
\text { de la AIF (1995) }\end{array}$ & $\begin{array}{c}\text { (4) } \\
\text { Países de ingresos } \\
\text { bajos (1995) + países } \\
\text { de ingresos medianos } \\
\text { bajos (1995) }\end{array}$ & $\begin{array}{c}((5) \\
\text { Países en } \\
\text { desarrollo } \\
(1995)\end{array}$ \\
\hline $\begin{array}{l}\text { El país i recibió ayuda para } \\
\text { el comercio en } \mathrm{t}-3\end{array}$ & $\begin{array}{c}\mathbf{0 . 0 5 5 ^ { * * * }} \\
(0.007)\end{array}$ & $\begin{array}{c}\mathbf{0 . 0 2 2} * * * \\
(0.005)\end{array}$ & 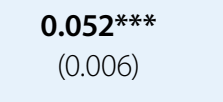 & $\begin{array}{c}\mathbf{0 . 0 3 5 * * *} \\
(0.004)\end{array}$ & $\begin{array}{c}\mathbf{0 . 0 3 0 * * *} \\
(0.003)\end{array}$ \\
\hline $\begin{array}{l}\text { El país i no recibió ayuda para } \\
\text { el comercio en t-3 }\end{array}$ & $\begin{array}{c}0.078 \\
(0.062)\end{array}$ & $\begin{array}{c}0.207^{* * *} \\
(0.034)\end{array}$ & $\begin{array}{l}0.172^{* * *} \\
(0.039)\end{array}$ & $\begin{array}{l}0.196^{* * *} \\
(0.029)\end{array}$ & $\begin{array}{c}0.021 \\
(0.019)\end{array}$ \\
\hline $\begin{array}{l}\text { El país j recibió ayuda para } \\
\text { el comercio en } \mathrm{t}-3\end{array}$ & $\begin{array}{l}\mathbf{0 . 0 0 9} \\
(0.007)\end{array}$ & $\begin{array}{c}\mathbf{0 . 0 1 3 * *} \\
(0.006)\end{array}$ & $\begin{array}{l}\mathbf{0 . 0 0 2} \\
(0.006)\end{array}$ & $\begin{array}{c}\mathbf{0 . 0 0 9 * *} \\
(0.005)\end{array}$ & $\begin{array}{c}\mathbf{0 . 0 0 8 * *} \\
(0.004)\end{array}$ \\
\hline $\begin{array}{l}\text { El país j no recibió ayuda para } \\
\text { el comercio en t-3 }\end{array}$ & $\begin{array}{l}0.038 \\
(0.032)\end{array}$ & $\begin{array}{c}-0.085^{* * *} \\
(0.026)\end{array}$ & $\begin{array}{l}-0.056^{*} \\
(0.029)\end{array}$ & $\begin{array}{c}-0.040^{*} \\
(0.021)\end{array}$ & $\begin{array}{c}-0.029^{*} \\
(0.017)\end{array}$ \\
\hline El país i recibió otra AOD & $\begin{array}{c}-0.025^{*} \\
(0.014)\end{array}$ & $\begin{array}{c}-\mathbf{0 . 0 3 6 * * *} \\
(0.009)\end{array}$ & $\begin{array}{c}-\mathbf{0 . 0 7 4 * * *} \\
(0.010)\end{array}$ & $\begin{array}{c}-0.042^{* * *} \\
(0.008)\end{array}$ & $\begin{array}{c}-\mathbf{0 . 0 1 8 * * *} \\
(0.005)\end{array}$ \\
\hline El país i no recibió otra AOD & (descartado) & $\begin{array}{c}-0.167^{* * *} \\
(0.056)\end{array}$ & $\begin{array}{l}0.094 \\
(0.145)\end{array}$ & $\begin{array}{c}-0.132^{* * *} \\
(0.049)\end{array}$ & $\begin{array}{l}-0.033 \\
(0.036)\end{array}$ \\
\hline El país j recibió otra AOD & $\begin{array}{l}\mathbf{0 . 0 0 5} \\
(0.010)\end{array}$ & $\begin{array}{c}\mathbf{0 . 0 2 4 * * *} \\
(0.008)\end{array}$ & $\begin{array}{c}\mathbf{0 . 0 2 4 * * *} \\
(0.009)\end{array}$ & $\begin{array}{l}\mathbf{0 . 0 1 6 * *} \\
(0.007)\end{array}$ & $\begin{array}{c}\mathbf{0 . 0 1 4} * * * \\
(0.005)\end{array}$ \\
\hline El país j no recibió otra AOD & $\begin{array}{l}0.038 \\
(0.050)\end{array}$ & $\begin{array}{l}-0.050 \\
(0.038)\end{array}$ & $\begin{array}{l}-0.007 \\
(0.043)\end{array}$ & $\begin{array}{l}-0.022 \\
(0.031)\end{array}$ & $\begin{array}{l}-0.033 \\
(0.024)\end{array}$ \\
\hline $\begin{array}{l}\text { Todas las variables de control } \\
\text { del cuadro E.1 }\end{array}$ & Sí & Sí & Sí & Sí & Sí \\
\hline $\begin{array}{l}\text { Efectos fijos por importador } \\
\text { y exportador }\end{array}$ & Sí & Sí & Sí & Sí & Sí \\
\hline Efectos fijos por año & Sí & Sí & Sí & Sí & Sí \\
\hline Observaciones & 37131 & 57452 & 48799 & 94583 & 142448 \\
\hline R cuadrado (R2) & 0.668 & 0.758 & 0.687 & 0.722 & 0.734 \\
\hline
\end{tabular}


CUADRO E.3 Efecto de cada categoría de ayuda para el comercio en las exportaciones, por grupos de países clasificados según el nivel de ingresos

\begin{tabular}{|c|c|c|c|c|c|}
\hline $\begin{array}{l}\text { Variable dependiente } \\
\text { Exportaciones del país i } \\
\text { (EN DESARROLLO, 1995) al país j } \\
\text { (TODOS) en el año t }\end{array}$ & $\begin{array}{c}\text { (1) } \\
\text { Países de } \\
\text { ingresos bajos } \\
\text { (1995) }\end{array}$ & $\begin{array}{c}\text { (2) } \\
\text { Países de } \\
\text { ingresos } \\
\text { medianos } \\
\text { bajos (1995) }\end{array}$ & $\begin{array}{c}\text { (3) } \\
\text { Países que } \\
\text { reciben fondos } \\
\text { de la AIF (1995) }\end{array}$ & $\begin{array}{c}(4) \\
\text { Países de ingresos } \\
\text { bajos (1995) } \\
\text { + países de ingresos } \\
\text { medianos bajos } \\
\text { (1995) }\end{array}$ & $\begin{array}{l}(5) \\
\text { Países en } \\
\text { desarrollo } \\
\text { (1995) }\end{array}$ \\
\hline $\begin{array}{l}\text { El país i recibió ayuda } \\
\text { para el comercio destinada a la } \\
\text { infraestructura económica en t-3 }\end{array}$ & $\begin{array}{c}\mathbf{0 . 0 2 3 * * *} \\
(0.006)\end{array}$ & $\begin{array}{c}\mathbf{0 . 0 1 7 * * *} \\
(0.004)\end{array}$ & $\begin{array}{c}\mathbf{0 . 0 1 6 * * *} \\
(0.005)\end{array}$ & $\begin{array}{c}\mathbf{0 . 0 2 1} \mathbf{1}^{* * *} \\
(0.003)\end{array}$ & $\begin{array}{c}\mathbf{0 . 0 1 6 * * *} \\
(0.003)\end{array}$ \\
\hline $\begin{array}{l}\text { El país i recibió ayuda para } \\
\text { el comercio destinada } \\
\text { a la capacidad productiva en } \mathrm{t}-3\end{array}$ & $\begin{array}{c}\mathbf{0 . 0 3 9 * * *} \\
(0.009)\end{array}$ & $\begin{array}{l}0.005 \\
(0.006)\end{array}$ & $\begin{array}{c}\mathbf{0 . 0 3 3 * * *} \\
(0.007)\end{array}$ & $\begin{array}{c}\mathbf{0 . 0 1 6 * * *} \\
(0.005)\end{array}$ & $\begin{array}{c}\mathbf{0 . 0 2 1} \mathbf{1}^{* * *} \\
(0.004)\end{array}$ \\
\hline $\begin{array}{l}\text { El país i recibió otra ayuda para } \\
\text { el comercio en t-3 }\end{array}$ & $\begin{array}{c}\mathbf{0 . 0 4 6 * * *} \\
(0.011)\end{array}$ & $\begin{array}{c}\mathbf{0 . 0 2 8}^{* * *} \\
(0.007)\end{array}$ & $\begin{array}{c}\mathbf{0 . 0 7 8}^{* * *} \\
(0.008)\end{array}$ & $\begin{array}{c}\mathbf{0 . 0 2 8 * * *} \\
(0.006)\end{array}$ & $\begin{array}{c}\mathbf{0 . 0 2 3 * * *} \\
(0.006)\end{array}$ \\
\hline $\begin{array}{l}\text { El país i no recibió ayuda para } \\
\text { el comercio en t-3 }\end{array}$ & $\begin{array}{c}0.049 \\
(0.062)\end{array}$ & $\begin{array}{c}0.189^{* * *} \\
(0.033)\end{array}$ & $\begin{array}{c}0.123^{* * *} \\
(0.038)\end{array}$ & $\begin{array}{c}0.173^{* * *} \\
(0.029)\end{array}$ & $\begin{array}{l}0.014 \\
(0.018)\end{array}$ \\
\hline $\begin{array}{l}\text { El país j recibió ayuda para } \\
\text { el comercio en } \mathrm{t}-3\end{array}$ & $\begin{array}{l}\mathbf{0 . 0 0 9} \\
(0.007)\end{array}$ & $\begin{array}{c}\mathbf{0 . 0 1 3 * *} \\
(0.006)\end{array}$ & $\begin{array}{l}\mathbf{0 . 0 0 2} \\
(0.006)\end{array}$ & $\begin{array}{c}\mathbf{0 . 0 0 9 * *} \\
(0.005)\end{array}$ & $\begin{array}{c}\mathbf{0 . 0 0 8 * *} \\
(0.004)\end{array}$ \\
\hline $\begin{array}{l}\text { El país j no recibió ayuda para } \\
\text { el comercio en t-3 }\end{array}$ & $\begin{array}{c}0.039 \\
(0.032)\end{array}$ & $\begin{array}{c}-0.083^{* * *} \\
(0.026)\end{array}$ & $\begin{array}{l}-0.054^{*} \\
(0.028)\end{array}$ & $\begin{array}{c}-0.039^{*} \\
(0.021)\end{array}$ & $\begin{array}{l}-0.028^{*} \\
(0.017)\end{array}$ \\
\hline El país i recibió otra AOD & $\begin{array}{c}-0.025^{*} \\
(0.014)\end{array}$ & $\begin{array}{c}-0.033^{* * *} \\
(0.009)\end{array}$ & $\begin{array}{c}-0.059 * * * \\
(0.010)\end{array}$ & $\begin{array}{c}-0.040 * * * \\
(0.008)\end{array}$ & $\begin{array}{c}-\mathbf{0 . 0 1 8 * * *} \\
(0.005)\end{array}$ \\
\hline El país i no recibió otra AOD & (descartado) & $\begin{array}{c}-0.161^{* * *} \\
(0.056)\end{array}$ & $\begin{array}{c}0.107 \\
(0.145)\end{array}$ & $\begin{array}{c}-0.133^{* * *} \\
(0.049)\end{array}$ & $\begin{array}{l}-0.033 \\
(0.036)\end{array}$ \\
\hline El país j recibió otra AOD & $\begin{array}{l}\mathbf{0 . 0 0 5} \\
(0.010)\end{array}$ & $\begin{array}{c}\mathbf{0 . 0 2 3} * * * \\
(0.008)\end{array}$ & $\begin{array}{c}\mathbf{0 . 0 2 3 * *} \\
(0.009)\end{array}$ & $\begin{array}{c}\mathbf{0 . 0 1 6 * *} \\
(0.007)\end{array}$ & $\begin{array}{c}\mathbf{0 . 0 1 4} 4^{* *} \\
(0.005)\end{array}$ \\
\hline El país j no recibió otra AOD & $\begin{array}{l}0.038 \\
(0.050)\end{array}$ & $\begin{array}{l}-0.050 \\
(0.038)\end{array}$ & $\begin{array}{l}-0.008 \\
(0.043)\end{array}$ & $\begin{array}{l}-0.022 \\
(0.031)\end{array}$ & $\begin{array}{l}-0.033 \\
(0.024)\end{array}$ \\
\hline $\begin{array}{l}\text { Todas las variables de control } \\
\text { del cuadro E.1 }\end{array}$ & Sí & Sí & Sí & Sí & Sí \\
\hline $\begin{array}{l}\text { Efectos fijos por importador y } \\
\text { exportador }\end{array}$ & Sí & Sí & Sí & Sí & Sí \\
\hline Efectos fijos por año & Sí & Sí & Sí & Sí & Sí \\
\hline Observaciones & 37131 & 57452 & 48799 & 94583 & 142448 \\
\hline R cuadrado (R2) & 0.668 & 0.758 & 0.688 & 0.722 & 0.734 \\
\hline
\end{tabular}


CUADRO E.4 Efecto de la ayuda para el comercio en las exportaciones de piezas y componentes de los países en desarrollo (página 1 of 2)

(Clasificación de 1995)

\section{Variable dependiente \\ Exportaciones intermedias del país i \\ (EN DESARROLLO, 1995) al país j (TODOS) en el año $t$}

LnPIB_i

$\operatorname{Ln} P I B_{-} j$

Ln POB_i

Ln POB_j

Ln distancia_ij

Ambos países carecen de litoral

Ln lejanía ij

Frontera común

Colonizador común

Relación colonial

Idioma común

(1)

Conflicto en i

Conflicto en j

Variable sustitutiva para ACR

El país i recibió ayuda para el comercio en $t-3$

El país i no recibió ayuda para el comercio en t-3

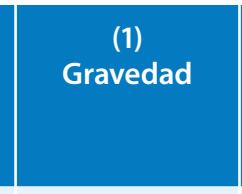

$0.552^{* * *}$

(0.017)

$0.208^{* * *}$

(0.015)

$-0.771^{* * *}$

(0.072)

$-0.060$

(0.048)

$-0.750^{* * *}$

(0.004)

(2)
Modelo
de gravedad
ampliado

$0.571^{* * *}$

(0.017)

$0.270 * * *$

(0.015)

$-0.565^{* * *}$

(0.071)

$0.133^{* * *}$

(0.047)

$-0.590^{* * *}$

(0.006)

$-0.156^{* * *}$

(0.037)

$1.311^{* * *}$

(0.059)

$0.336^{* * *}$

(0.017)

$0.365^{* * *}$

(0.014)

$0.307^{* * *}$

(0.025)

$0.203^{* * *}$

(0.011)

$-0.070^{* * *}$

(0.016)

$-0.008$

(0.020)
$0.279 * * *$
(0.012)

(3)

Ayuda para

el comercio

$0.552^{* * *}$

(0.017)

(4)

Ayuda para

el comercio +

variables sustitutivas

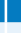

$0.547^{* * *}$

(0.017)

$0.262^{* * *}$

(0.015)

(0.015)

$-0.796^{* * *}$

(0.074)

$(0.072)$

$0.099 * *$

(0.049)

(0.049)

$-0.590^{* * *}$

(0.006)

(0.006)

$-0.155^{* * *}$

(0.037)

(0.037)

$1.230^{* * *}$

$1.297^{* * *}$

(0.060)

(0.059)

$0.335^{* * *}$

(0.017)

$0.335^{* * *}$

$0.366^{* * *}$

$0.365^{* * *}$

(0.014)

(0.014)

$0.307^{* * *}$

(0.025)

(0.025)

$0.202^{* * *}$

$0.202^{* * *}$

(0.011)

(0.011)

$-0.053^{* * *}$

(0.016)

(0.016)

$-0.001$

(0.021)

(0.021)

$0.281^{* * *}$

(0.012)

(0.012)

$0.036^{* * *}$

$0.035^{* * *}$

(0.003)

(0.004)

0.002

(0.025) 
CUADRO E.4 Efecto de la ayuda para el comercio en las exportaciones de piezas y componentes de los países en desarrollo (página 2 of 2)

(Clasificación de 1995)

Variable dependiente

Exportaciones intermedias del país $\mathrm{i}$

(EN DESARROLLO, 1995) al país j (TODOS) en

el año $t$

\section{El país j recibió ayuda para el comercio}

en $t-3$

El país j no recibió ayuda para el comercio en t-3

\section{El país i recibió otra AOD}

El país i no recibió otra AOD

\section{El país j recibió otra AOD}

El país j no recibió otra AOD

Efectos fijos por país

Efectos fijos por año

Observaciones

R cuadrado (R2)

$(1)$
Gravedad

\begin{tabular}{|c|}
\hline (2) \\
Modelo \\
de gravedad \\
ampliado
\end{tabular}

(ay

(3)

Ayuda para

el comercio

(4)

Ayuda para

el comercio +

variables sustitutivas

$0.007^{*}$

(0.004)

$\mathbf{0 . 0 1 6 * * *}$

(0.004)

$0.071^{* * *}$

(0.021)

$-0.006$

$(0.004)$

$0.025^{* * *}$

(0.005)

$0.304^{* * *}$

(0.038)

$\mathbf{0 . 0 0 1}$

$0.012^{* *}$

(0.004)

$(0.006)$

0.050

(0.031)

Sí $\quad-190$

Sí Si

Sí Sí

Sí

Sí

Sí

82322

82322

82322

82322

0.580

0.596

0.597

0.597 
CUADRO E.5 Efectos de la ayuda para el comercio en las exportaciones de los países en desarrollo en situaciones de buena gestión, por grupos de países clasificados según el nivel de ingresos

(utilización de variable sustitutiva "eficiencia gubernamental")

\begin{tabular}{|c|c|c|c|c|c|}
\hline $\begin{array}{l}\text { Variable dependiente } \\
\text { Exportaciones del país i } \\
\text { (EN DESARROLLO, 1995) al país j } \\
\text { (TODOS) en el año t }\end{array}$ & $\begin{array}{c}\text { (1) } \\
\text { Países de } \\
\text { ingresos } \\
\text { bajos (1995) }\end{array}$ & $\begin{array}{c}(2) \\
\text { Países de } \\
\text { ingresos } \\
\text { medianos } \\
\text { bajos (1995) }\end{array}$ & $\begin{array}{l}\text { (3) } \\
\text { Países que } \\
\text { reciben } \\
\text { fondos de la } \\
\text { AIF (1995) }\end{array}$ & $\begin{array}{c}\text { (4) } \\
\text { Países de ingresos } \\
\text { bajos (1995) + países } \\
\text { de ingresos medianos } \\
\text { bajos (1995) }\end{array}$ & $\begin{array}{l}(5) \\
\text { Países en } \\
\text { desarrollo } \\
\text { (1995) }\end{array}$ \\
\hline $\begin{array}{l}\text { El país i recibió ayuda para } \\
\text { el comercio en t-3 }\end{array}$ & $\begin{array}{c}-\mathbf{0 . 0 5 4 * *} \\
(0.023)\end{array}$ & $\begin{array}{l}-0.017 \\
(0.020)\end{array}$ & $\begin{array}{c}-0.082^{* * *} \\
(0.021)\end{array}$ & $\begin{array}{r}-0.020 \\
(0.015)\end{array}$ & $\begin{array}{l}\mathbf{0 . 0 1 6} \\
(0.011)\end{array}$ \\
\hline $\begin{array}{l}\text { Ayuda para el comercio } \\
\text { recibida por i en } \mathrm{t}-3^{*} \text { eficiencia_ } \\
\text { gubernamental_i }\end{array}$ & $\begin{array}{c}\mathbf{0 . 2 4 5 * * *} \\
(0.053)\end{array}$ & $\begin{array}{l}\mathbf{0 . 0 7 7 *} \\
(0.042)\end{array}$ & $\begin{array}{c}\mathbf{0 . 3 0 0 * * *} \\
(0.047)\end{array}$ & $\begin{array}{c}\mathbf{0 . 1 1 3 * * *} \\
(0.032)\end{array}$ & $\begin{array}{l}\mathbf{0 . 0 2 3} \\
(0.021)\end{array}$ \\
\hline $\begin{array}{l}\text { El país i no recibió ayuda para el } \\
\text { comercio en } t-3\end{array}$ & $\begin{array}{l}0.043 \\
(0.062)\end{array}$ & $\begin{array}{l}0.178^{* * *} \\
(0.034)\end{array}$ & $\begin{array}{c}0.153^{* * *} \\
(0.039)\end{array}$ & $\begin{array}{l}0.161^{* * *} \\
(0.029)\end{array}$ & $\begin{array}{l}0.006 \\
(0.019)\end{array}$ \\
\hline $\begin{array}{l}\text { El país j recibió ayuda para el } \\
\text { comercio en } t-3\end{array}$ & $\begin{array}{l}\mathbf{0 . 0 1 0} \\
(0.007)\end{array}$ & $\begin{array}{l}\mathbf{0 . 0 1 3 * *} \\
(0.006)\end{array}$ & $\begin{array}{l}\mathbf{0 . 0 0 2} \\
(0.006)\end{array}$ & $\begin{array}{c}\mathbf{0 . 0 1 0 * *} \\
(0.005)\end{array}$ & $\begin{array}{l}\mathbf{0 . 0 0 9 * *} \\
(0.004)\end{array}$ \\
\hline $\begin{array}{l}\text { El país j no recibió ayuda para el } \\
\text { comercio en } \mathrm{t}-3\end{array}$ & $\begin{array}{l}0.044 \\
(0.032)\end{array}$ & $\begin{array}{c}-0.083^{* * *} \\
(0.026)\end{array}$ & $\begin{array}{l}-0.051^{*} \\
(0.028)\end{array}$ & $\begin{array}{c}-0.037^{*} \\
(0.021)\end{array}$ & $\begin{array}{l}-0.027 \\
(0.017)\end{array}$ \\
\hline El país i recibió otra AOD & $\begin{array}{c}-\mathbf{0 . 1 1 8 * * *} \\
(0.021)\end{array}$ & $\begin{array}{c}-0.059 * * * \\
(0.020)\end{array}$ & $\begin{array}{c}-\mathbf{0 . 1 1 3 * * *} \\
(0.017)\end{array}$ & $\begin{array}{c}-0.093^{* * *} \\
(0.013)\end{array}$ & $\begin{array}{c}-\mathbf{0 . 0 7 5 * * *} \\
(0.010)\end{array}$ \\
\hline $\begin{array}{l}\text { Otra AOD recibida por } \mathbf{i}^{*} \\
\text { eficiencia_gubernamental_i }\end{array}$ & $\begin{array}{c}\mathbf{0 . 2 4 9 * * *} \\
(0.038)\end{array}$ & $\begin{array}{l}\mathbf{0 . 0 4 5} \\
(0.036)\end{array}$ & $\begin{array}{c}\mathbf{0 . 0 8 3} * * * \\
(0.032)\end{array}$ & $\begin{array}{c}\mathbf{0 . 1 1 8 * * *} \\
(0.024)\end{array}$ & $\begin{array}{c}\mathbf{0 . 1 2 1 * * *} \\
(0.016)\end{array}$ \\
\hline El país i no recibió otra AOD & (descartado) & $\begin{array}{c}-0.230^{* * *} \\
(0.061)\end{array}$ & $\begin{array}{l}-0.011 \\
(0.145)\end{array}$ & $\begin{array}{c}-0.233^{* * *} \\
(0.051)\end{array}$ & $\begin{array}{l}-0.090^{* *} \\
(0.036)\end{array}$ \\
\hline El país j recibió otra AOD & $\begin{array}{l}\mathbf{0 . 0 0 5} \\
(0.010)\end{array}$ & $\begin{array}{c}\mathbf{0 . 0 2 4} \mathbf{4}^{* * *} \\
(0.008)\end{array}$ & $\begin{array}{c}\mathbf{0 . 0 2 4} * * * \\
(0.009)\end{array}$ & $\begin{array}{c}\mathbf{0 . 0 1 6 * *} \\
(0.007)\end{array}$ & $\begin{array}{c}\mathbf{0 . 0 1 4} * * * \\
(0.005)\end{array}$ \\
\hline El país j no recibió otra AOD & $\begin{array}{l}0.045 \\
(0.050)\end{array}$ & $\begin{array}{l}-0.049 \\
(0.038)\end{array}$ & $\begin{array}{l}-0.006 \\
(0.043)\end{array}$ & $\begin{array}{l}-0.019 \\
(0.031)\end{array}$ & $\begin{array}{l}-0.030 \\
(0.024)\end{array}$ \\
\hline $\begin{array}{l}\text { Todas las variables de control } \\
\text { del cuadro E.1 }\end{array}$ & Yes & Yes & Yes & Yes & Yes \\
\hline $\begin{array}{l}\text { Efectos fijos por importador y } \\
\text { exportador }\end{array}$ & Yes & Yes & Yes & Yes & Yes \\
\hline Efectos fijos por año & Yes & Yes & Yes & Yes & Yes \\
\hline Observaciones & 37131 & 57452 & 48799 & 94583 & 142448 \\
\hline R cuadrado (R2) & 0.670 & 0.758 & 0.688 & 0.722 & 0.735 \\
\hline
\end{tabular}





\section{ANEXO F}

\section{METODOLOGÍA PARA EL ANÁLISIS ECONOMÉTRICO}

En el presente anexo se detallan los datos y procedimientos utilizados para el análisis econométrico del capítulo. En el cuadro F.1 se compara el presente estudio con otros tres estudios similares de reciente publicación sobre la repercusión de la ayuda para el comercio en los resultados de exportación de los países con el objeto de mostrar las similitudes y diferencias. En comparación con los estudios anteriores, el presente análisis abarca la ayuda para el comercio prestada a países en desarrollo en años más recientes. El análisis abarca 16 años de asistencia, empezando en 1995, año al que se refiere el primer conjunto de datos sobre ayuda para el comercio del Sistema de Notificación por parte de los Países Acreedores (SNPA). Como en otros estudios, la definición de ayuda para el comercio engloba toda la asistencia bilateral proporcionada por los donantes en el marco del SNPA a los países en desarrollo incluidos en dicho sistema. Obsérvese que los datos se refieren únicamente a la asistencia prestada por los países notificantes de la OCDE que son miembros del Comité de Asistencia para el Desarrollo (CAD), por lo que no incluye los datos de otros donantes que no son miembros de la OCDE, como China, la India, el Brasil y Kuwait, así como tampoco los datos de algunos organismos multilaterales. Además, los datos correspondientes a la asistencia multilateral prestada en los primeros años no están completos y la asistencia multilateral prestada más recientemente consiste en apoyo presupuestario y/o préstamos sectoriales, cuyo vínculo con la ayuda para el comercio es difícil de establecer.

Helble et al. (2012) crearon su propia serie de datos sobre desembolsos; los datos, que se remontan a 1990, fueron tomados de la base de datos del SNPA de la OCDE, si bien los datos anteriores a 2002 sobre los proyectos de ayuda para el comercio están sistemáticamente incompletos, ya que antes de ese año no se notificaban los proyectos multilaterales. Cali y te Velde (2010) emplearon los datos sobre desembolsos correspondientes al período 2002-2007, con un efecto diferido de un año en las exportaciones. Al igual que nosotros, Vijil, en su análisis (2012), utiliza la información sobre los compromisos para poder abarcar un período de tiempo más largo. Otra importante diferencia con el análisis de Calì y te Velde es que ellos utilizan como variable dependiente los volúmenes globales de las exportaciones correspondientes a cada país de la muestra, mientras que nosotros empleamos información sobre el comercio bilateral de exportación, por pares de países en desarrollo y del resto del mundo, lo que nos permite examinar los efectos de la ayuda para el comercio recibida por los países importadores incluidos en el análisis. Además, al igual que Helble et al. (2012) y Viji (2012), hemos incluido otras corrientes de asistencia oficial para el desarrollo (AOD) aparte de las clasificadas como ayuda para el comercio.

En el cuadro F.2 se indican las fuentes de los datos empleados en el presente análisis. Las cuatro fuentes principales son la base de datos Comtrade de las Naciones Unidas, para las corrientes bilaterales de exportación de los países en desarrollo; los Indicadores del Desarrollo Mundial, para datos como el PIB y la población de los pares de asociados comerciales; los conjuntos de datos del CEPII, para las variables de gravedad y las medidas de la distancia bilateral; y el SNPA de la OCDE, para la ayuda para el comercio y otras formas de AOD prestada por los miembros de la OCDE a los países en desarrollo. Se han utilizado los bancos de datos sobre los Indicadores mundiales de gobernabilidad y las Evaluaciones Institucionales y de Políticas por País para medir la gestión y el desempeño gubernamentales. La base de datos del proyecto Correlates of War se ha usado para crear una variable ficticia para países en situación de conflicto (externo o interno) en un período determinado. Sobre la base de las corrientes de ayuda recibidas por los países en desarrollo según la base de datos del SNPA de la OCDE, se ha creado una variable ficticia para los países que no reciben corrientes de ayuda para el comercio ni AOD en un período determinado, y estos controles se han incluido en el análisis de regresión, como proponen Cali y te Velde, y Vijil, entre otros autores. Se han excluido del análisis las exportaciones de los minerales comprendidos en las partidas 26 y 27 del SA, así como los países cuyas exportaciones de petróleo constituyen más del 75\% de sus exportaciones totales. La variable ficticia para los acuerdos regionales de libre comercio se basa en información publicada por la Organización Mundial del Comercio, y su valor es igual a 1 cuando en un par de asociados comerciales los dos países son miembros del mismo acuerdo. 
En la parte inferior del cuadro F.3 figura la lista completa de países clasificados por grupos según su nivel de ingresos (Banco Mundial, 1995), conforme a los umbrales históricos publicados por esa institución. En la parte superior del cuadro se proporciona un resumen estadístico de las variables más pertinentes: exportaciones (excepto las de minerales y petróleo), en miles de millones de dólares EE.UU. corrientes; distancia media que recorren las corrientes de exportación, en miles de kilómetros; PIB, en miles de millones de dólares EE.UU. corrientes; población total, en millones de habitantes; y corrientes de ayuda para el comercio y otras corrientes de AOD, en millones de dólares EE.UU. corrientes.

Del examen de esos promedios se desprenden claramente algunas tendencias, que son válidas cuando se comparan los grupos de países clasificados por nivel de ingresos del Banco Mundial o incluso al observar los resultados de los países menos adelantados. La primera de ellas es que los países con niveles más altos de desarrollo tienen un mayor volumen de exportaciones y que los resultados per cápita son superiores a los resultados agregados a medida que disminuye la población total de un país y aumenta el nivel de desarrollo. La distancia media recorrida por las exportaciones aumenta ligeramente con el nivel de desarrollo. Por último, existe una tendencia clara a prestar apoyo a los países menos adelantados, que suelen recibir vastas corrientes de asistencia en concepto de ayuda para el comercio y otras formas de AOD.

En el cuadro F.4 pueden verse correlaciones parciales entre las exportaciones totales de los países en desarrollo y algunas variables explicativas utilizadas al aplicar el modelo de gravedad para explicar las corrientes comerciales. El PIB y la población del país exportador son las variables en que la correlación con el valor total de las exportaciones es más alta. Las corrientes de ayuda para el comercio y otras formas de AOD también presentan una correlación positiva -aunque en menor grado- con los niveles de las exportaciones. Se han observado otras correlaciones importantes entre los dos tipos de corrientes de asistencia para el desarrollo, y también entre las corrientes de ayuda y la población total del país, lo cual era de prever habida cuenta de que la cuantía de los compromisos en materia de ayuda varía en función del tamaño del país.

En el cuadro E.1 figura el marco de base para nuestro análisis empírico. En la columna 1 del cuadro pueden verse los resultados de la aplicación del modelo de gravedad, en que las exportaciones bilaterales de los países en desarrollo son una función del tamaño de la economía exportadora, el tamaño de la economía importadora y la distancia entre los dos países según la siguiente ecuación:

$$
X_{i j}=G \frac{Y_{i}^{\alpha} Y_{j}^{\beta}}{T_{i j}^{\theta}}
$$

donde $X_{i j}$ representa las exportaciones (excepto las de minerales y petróleo) del país i al país j; $G$ es la constante gravitacional entre los dos países; Yi e Yj expresan el tamaño de la economía exportadora y la economía importadora, respectivamente; y $T_{\text {ij }}$ corresponde a la magnitud de los obstáculos al comercio entre los dos países. Inicialmente utilizamos la distancia de la base de datos del CEPII como indicador de los obstáculos al comercio para estimar la versión log-lineal del modelo de gravedad. Todas las regresiones incluyen efectos fijos por exportador, importador y año. En la columna 2 se agregan a la especificación de la línea de base algunas variables de control usadas habitualmente: una frontera común, un idioma común, relaciones coloniales y condición de país sin litoral. También se añaden otras variables de control, como la lejanía de los países, calculada como el producto de las distancias medias ponderadas por el PIB entre cada uno de los países y los demás asociados comerciales; una variable ficticia por situación de conflicto (variante temporal); y una variable ficticia para los acuerdos comerciales regionales incluidos en la lista de la Organización Mundial del Comercio. En la columna 3 se incluyen las corrientes de ayuda recibidas por los países exportadores y los países importadores -expresadas como logaritmos de las corrientes de ayuda para el comercio y demás corrientes de asistencia oficial comprometidas por los donantes bilaterales. En la columna 4 se incluyen variables ficticias para los países que no reciben corrientes de ayuda; esto afecta mayormente a los países importadores, ya que la mayoría de los exportadores recibe corrientes de ayuda. A fin de evitar posibles problemas de endogeneidad relacionados con las corrientes de ayuda para el comercio, hemos utilizado compromisos de ayuda para el comercio con un retraso de tres años. En el cuadro F.5 se proporciona un análisis de sensibilidad de las exportaciones a los compromisos diferidos en materia de ayuda para el comercio. Ese análisis demuestra que las condiciones óptimas para que se registre un incremento de las exportaciones se dan después de transcurrido cierto lapso (tres años), y que la repercusión de los compromisos aumenta con el tiempo. 
CUADRO F.1 Comparación del análisis de la OCDE con otros estudios recientes

\begin{tabular}{|c|c|c|c|c|}
\hline & Helble et al. (2012) & Cali y te Velde (2010) & Vijil (2012) & $\begin{array}{l}\text { OCDE (2013) - } \\
\text { Newfarmer y Ugarte }\end{array}$ \\
\hline Período abarcado & $1990-2005$ & $2002-2007$ & 1995-2005 & 1995-2011 \\
\hline Países abarcados & $\begin{array}{l}170 \text { países } \\
\text { comerciantes }\end{array}$ & 120 países en desarrollo & $\begin{array}{l}\text { Todas las corrientes } \\
\text { comerciales positivas }\end{array}$ & $\begin{array}{l}109 \text { países en desarrollo } \\
\text { que exportan a todos } \\
\text { los países }\end{array}$ \\
\hline Observaciones & 108304 & 508 & 95280 & 142448 \\
\hline Variable explicada & $\begin{array}{l}\text { Importaciones anuales } \\
\text { en el país j procedentes } \\
\text { del país i }\end{array}$ & $\begin{array}{l}\text { Exportaciones totales } \\
\text { de un país en un año } \\
\text { determinado }\end{array}$ & $\begin{array}{l}\text { Exportaciones del país i } \\
\text { al país j en el año t }\end{array}$ & $\begin{array}{l}\text { Exportaciones del país i } \\
\text { al país j en el año t }\end{array}$ \\
\hline $\begin{array}{l}\text { Corrientes comerciales } \\
\text { nulas }\end{array}$ & No & (No se menciona) & No & No \\
\hline Ayuda para el comercio & $\begin{array}{l}\text { Corrientes recibidas } \\
\text { por el importador } \\
\text { y el exportador }\end{array}$ & $\begin{array}{l}\text { Corrientes recibidas por } \\
\text { el exportador }\end{array}$ & $\begin{array}{l}\text { Corrientes recibidas } \\
\text { por el importador y el } \\
\text { exportador }\end{array}$ & $\begin{array}{l}\text { Corrientes recibidas por } \\
\text { el importador } \\
\text { y el exportador }\end{array}$ \\
\hline $\begin{array}{l}\text { Definición de ayuda } \\
\text { para el comercio }\end{array}$ & $\begin{array}{l}\text { Desembolsos } \\
\text { (calculados a partir de } \\
\text { los datos del SNPA para } \\
\text { 1990-2005); política } \\
\text { y reglamentación } \\
\text { comerciales, } \\
\text { desarrollo comercial } \\
\text { e infraestructura } \\
\text { económica }\end{array}$ & $\begin{array}{l}\text { Desembolsos (2002- } \\
\text { 2007); facilitación del } \\
\text { comercio, política } \\
\text { y reglamentación } \\
\text { comerciales, } \\
\text { capacidad productiva } \\
\text { e infraestructura } \\
\text { económica }\end{array}$ & $\begin{array}{l}\text { Compromisos } \\
\text { (1995-2005); política } \\
\text { y reglamentación } \\
\text { comerciales, } \\
\text { capacidad productiva } \\
\text { e infraestructura } \\
\text { económica }\end{array}$ & $\begin{array}{l}\text { Compromisos } \\
\text { (1995-2010) diferidos } \\
\text { tres años; capacidad } \\
\text { productiva, desarrollo } \\
\text { comercial y otras } \\
\text { formas de ayuda para } \\
\text { el comercio }\end{array}$ \\
\hline $\begin{array}{l}\text { Desagregación de } \\
\text { la ayuda para el comercio } \\
\text { en las exportaciones }\end{array}$ & $\begin{array}{l}\text { No, pero se ensayan } \\
\text { varias agregaciones de } \\
\text { categorías anteriores }\end{array}$ & $\begin{array}{l}\text { Sí. Capacidad } \\
\text { productiva e } \\
\text { infraestructura }\end{array}$ & $\begin{array}{l}\text { Sí. Instituciones, } \\
\text { capacidad productiva e } \\
\text { infraestructura }\end{array}$ & $\begin{array}{l}\text { Sí. } \\
\text { Capacidad productiva, } \\
\text { infraestructura y otras } \\
\text { formas de ayuda para } \\
\text { el comercio }\end{array}$ \\
\hline AOD & $\begin{array}{l}\text { Todas las demás } \\
\text { corrientes de asistencia } \\
\text { no incluidas en la } \\
\text { ayuda para el comercio } \\
\text { para ambos países }\end{array}$ & No & $\begin{array}{l}\text { Todas las demás } \\
\text { corrientes de asistencia } \\
\text { no incluidas en la } \\
\text { ayuda para el comercio } \\
\text { para ambos países }\end{array}$ & $\begin{array}{l}\text { Todas las demás } \\
\text { corrientes de asistencia } \\
\text { no incluidas en la } \\
\text { ayuda para el comercio } \\
\text { para ambos países }\end{array}$ \\
\hline $\begin{array}{l}\text { Variables ficticias para } \\
\text { países que no reciben } \\
\text { ayuda para el comercio } \\
\text { ni AOD }\end{array}$ & No & Sí & Sí & Sí \\
\hline Efectos fijos & $\begin{array}{l}\text { Efecto fijo por año y } \\
\text { efecto fijo bilateral } \\
\text { ( } 5 \text { años) }\end{array}$ & Año y exportador & Año & $\begin{array}{l}\text { Año, exportador } \\
\text { e importador }\end{array}$ \\
\hline
\end{tabular}


CUADRO F.2 Definición de las variables

\section{Variable}

Ln

Exportaciones_ijt

Ln PIB_it

LnPOB_it

Ln Distance_ij

País sin litoral (i y j)

Frontera común

Colonizador común

Relación colonial

Idioma común

Ayuda para el comercio

recibida por i (en el año t)

Otra AOD recibida por i

(en el año t)

El país i no recibió ayuda para el comercio (otra AOD) (en el año t)

Eficacia gubernamental (en el año t)

Variable ficticia para ACR

Conflicto en el país i

(en el año t)

Exportadores de petróleo excluidos

\section{Descripción}

Exportaciones totales del país i al país j en el año t, en millones de dólares EE.UU. corrientes (expresadas como logaritmo). No se incluyen las exportaciones de petróleo ni de minerales. Sólo se tienen en cuenta los valores positivos

PIB del país i en el año t, en millones de dólares EE.UU. corrientes (expresado como logaritmo)

Población total del país i en el año t (expresada como logaritmo)

Distancia entre el país i y el país j (expresada como logaritmo)

Variable ficticia cuyo valor es igual a 1 si al menos uno de los países carece de litoral

Variable ficticia para la contigüidad

Variable ficticia para la existencia de un colonizador común

Variable ficticia para la existencia de una antigua relación colonial

Variable ficticia para la existencia de un idioma oficial común

Cuantía total de la ayuda para el comercio recibida por el país i de todos los donantes bilaterales en el año t, en millones de dólares EE.UU. corrientes (expresada como logaritmo)

Cuantía total de la asistencia oficial para el desarrollo, excepto la ayuda para el comercio, recibida por el país i de todos los donantes bilaterales en el año t, en millones de dólares EE.UU. corrientes (expresada como logaritmo)

Variables ficticias cuyo valor es igual a 1 si el país i no recibió corrientes de ayuda para el comercio (otra AOD) en el año $t$

Eficacia gubernamental (calidad de los servicios públicos, calidad de la administración pública y su grado de independencia respecto de las presiones políticas, calidad de la formulación y aplicación de políticas, y confianza en que el Gobierno cumplirá el compromiso de aplicar esas políticas). Su valor va de $-2,5$ a 2,5, pero aquí se ha normalizado a valores entre 0 y 1

Variable ficticia cuyo valor es igual a 1 para los ACR en vigor

Variable ficticia para países en situación de conflicto en el año t. Se tienen en cuenta las guerras entre Estados y las guerras civiles. Se considera que un país está en guerra cuando, como resultado del conflicto, hay por lo menos 1.000 muertos en un período de 12 meses www.correlatesofwar.org/COW2\%20Data/WarData_NEW/COW\%20 Website\%20-\%20Typology\%20of\%20war.pdf (http://Www.correlatesofwar.org/ COW2 Data/WarData_NEW/COWW Website - Typology of war.pdf)

Argelia; Angola; Azerbaiyán; Bahrein; Congo, Rep. del; Gabón; Irán; Iraq; Kazajstán; Kuwait; Libia; Nigeria; Noruega; Omán; Qatar; Federación de Rusia; Arabia Saudita; Emiratos Árabes Unidos; Yemen; y Venezuela. Estos países son los principales exportadores de petróleo o bien sus exportaciones de petróleo constituyen el $75 \%$ o más de sus exportaciones totales

\section{Fuente}

Naciones Unidas, base de datos Comtrade

Banco Mundial, Indicadores del Desarrollo Mundial

Banco Mundial, Indicadores del Desarrollo Mundial

CEPII

CEPII

CEPII

CEPII

CEPII

CEPII

OCDE, base de datos del SNPA

OCDE, base de datos del SNPA

OCDE, base de datos del SNPA

Banco Mundial, Indicadores mundiales de gobernabilidad

OMC

Correlates of War 4.0

Cálculos propios a partir de datos comerciales 
CUADRO F.3 Resumen estadístico de las principales variables, por grupos de países clasificados según su nivel de ingresos (1995)

\begin{tabular}{|c|c|c|c|c|c|c|c|}
\hline Grupo de ingresos & & $\begin{array}{l}\text { Exportaciones } \\
\text { totales (miles } \\
\text { de millones } \\
\text { \$EE.UU. } \\
\text { corrientes) }\end{array}$ & $\begin{array}{c}\text { Distancia } \\
\text { (miles de km) }\end{array}$ & $\begin{array}{l}\text { PIB (miles de } \\
\text { millones \$EE. } \\
\text { UU. corrientes) }\end{array}$ & $\begin{array}{l}\text { Población } \\
\text { (millones de } \\
\text { habitantes) }\end{array}$ & $\begin{array}{c}\text { Ayuda para } \\
\text { el comercio } \\
\text { recibida } \\
\text { (millones \$EE. } \\
\text { UU. corrientes) }\end{array}$ & $\begin{array}{c}\text { Otra AOD } \\
\text { recibida } \\
\text { (millones } \\
\text { \$EE.UU. } \\
\text { corrientes) }\end{array}$ \\
\hline \multirow{2}{*}{$\begin{array}{l}\text { Países de ingresos } \\
\text { bajos }\end{array}$} & Media & 5.2 & 6.2 & 43.9 & 65.1 & 160.4 & 443.6 \\
\hline & $\begin{array}{r}\text { Desviación } \\
\text { típica }\end{array}$ & 19.7 & 1.4 & 185.4 & 210.5 & 358.7 & 559.5 \\
\hline \multirow{2}{*}{$\begin{array}{l}\text { Países de ingresos } \\
\text { medianos bajos }\end{array}$} & Media & 29.1 & 7.1 & 119.1 & 58.8 & 153.4 & 323.5 \\
\hline & $\begin{array}{r}\text { Desviación } \\
\text { típica }\end{array}$ & 148.8 & 2.2 & 558.9 & 217.2 & 279.3 & 415.3 \\
\hline \multirow{2}{*}{$\begin{array}{l}\text { Países de ingresos } \\
\text { medianos altos }\end{array}$} & Media & 26.0 & 7.6 & 147.5 & 24.0 & 44.3 & 123.1 \\
\hline & $\begin{array}{r}\text { Desviación } \\
\text { típica }\end{array}$ & 48.7 & 2.4 & 311.7 & 43.8 & 103.0 & 192.6 \\
\hline \multirow{2}{*}{$\begin{array}{l}\text { Países menos } \\
\text { adelantados }\end{array}$} & Media & 0.7 & 6.2 & 6.1 & 15.5 & 64.4 & 303.0 \\
\hline & $\begin{array}{r}\text { Desviación } \\
\text { típica }\end{array}$ & 1.5 & 1.4 & 9.8 & 24.2 & 100.5 & 387.5 \\
\hline \multirow{2}{*}{$\begin{array}{l}\text { Países que reciben } \\
\text { fondos de la AIF }\end{array}$} & Media & 18.7 & 6.2 & 77.2 & 47.9 & 98.5 & 338.5 \\
\hline & $\begin{array}{r}\text { Desviación } \\
\text { típica }\end{array}$ & 138.4 & 1.6 & 520.9 & 201.6 & 204.5 & 412.5 \\
\hline \multirow{2}{*}{$\begin{array}{l}\text { Todos los países en } \\
\text { desarrollo }\end{array}$} & Media & 20.5 & 6.9 & 102.2 & 51.8 & 127.3 & 310.3 \\
\hline & $\begin{array}{r}\text { Desviación } \\
\text { típica }\end{array}$ & 100.4 & 2.1 & 410 & 186.3 & 281.4 & 444.4 \\
\hline
\end{tabular}

Países de ingresos bajos

Países de ingresos medianos bajos

Países de ingresos medianos altos

Países menos adelantados

Países que reciben fondos de la AIF
Bangladesh, Benin, Burkina Faso, Burundi, Camboya, República Centroafricana, Comoras, Eritrea, Etiopía, Gambia, Ghana, Guinea, Guinea-Bissau, Haití, India, Kenya, República Kirguisa, Madagascar, Malawi, Malí, Mauritania, Mozambique, Nepal, Níger, Pakistán, Papua Nueva Guinea, Rwanda, Santo Tomé y Príncipe, Sierra Leona, Sudán, Tayikistán, Tanzanía, Togo, Uganda, Viet Nam, Zambia y Zimbabwe.

Albania, Armenia, Belarús, Bhután, Bolivia, Bosnia y Herzegovina, Camerún, Cabo Verde, China, Côte d'Ivoire, Colombia, Djibouti, República Dominicana, Ecuador, República Árabe de Egipto, El Salvador, Georgia, Guatemala, Guyana, Honduras, Indonesia, Jordania, Kiribati, Lesotho, ex República Yugoslava de Macedonia, Moldova, Marruecos, Mongolia, Nicaragua, Paraguay, Perú, Filipinas, Samoa, Senegal, Islas Salomón, Sri Lanka, Swazilandia, República Árabe Siria, Tailandia, Tonga, Turkmenistán, Ucrania y Vanuatu.

Argentina, Belice, Brasil, Botswana, Bulgaria, Chile, Costa Rica, Cuba, Dominica, Fiji, Granada, Líbano, Letonia, Lituania, Malasia, Maldivas, Mauricio, México, Namibia, Panamá, Polonia, Suriname, Túnez, Turquía, Tuvalu, Uruguay, Santa Lucía, San Vicente y las Granadinas y Sudáfrica.

Bangladesh, Benin, Bhután, Burkina Faso, Burundi, Camboya, Cabo Verde, República Centroafricana, Comoras, Djibouti, Eritrea, Etiopía, Gambia, Guinea, Guinea-Bissau, Haití, Kiribati, Lesotho, Madagascar, Malawi, Maldivas, Malí, Mauritania, Mozambique, Nepal, Níger, Rwanda, Samoa, Santo Tomé y Príncipe, Senegal, Sierra Leona, Islas Salomón, Sudán, Togo, Tanzanía, Tuvalu, Uganda, Vanuatu y Zambia.

Albania, Benin, Bangladesh, Bhután, Burkina Faso, Burundi, Camboya, Camerún, República Centroafricana, China, Comoras, Côte d'Ivoire, Djibouti, República Árabe de Egipto, Eritrea, Etiopía, Gambia, Ghana, Guinea, Guinea-Bissau, Guyana, Haití, Honduras, Kenya, República Kirguisa, Kiribati, Lesotho, ex República Yugoslava de Macedonia, Madagascar, Malawi, Maldivas, Malí, Mauritania, Moldova, Mozambique, Nicaragua, Níger, Nepal, Papua Nueva Guinea, Rwanda, Samoa, Senegal, Sierra Leona, Islas Salomón, Sudán, Santo Tomé y Príncipe, Tayikistán, Tanzanía, Togo, Tonga, Tuvalu, Uganda, Vanuatu y Zambia. 


\begin{tabular}{|l|c|c|c|c|c|c|}
\hline CUADRO F.4 & Matriz de correlación de las variables de interés & & \\
\hline & $\begin{array}{c}\text { Exportaciones } \\
\text { totales }\end{array}$ & $\begin{array}{c}\text { Distancia } \\
\text { media }\end{array}$ & PIB & Población & $\begin{array}{c}\text { Ayuda para el } \\
\text { comercio recibida }\end{array}$ \\
\hline Exportaciones totales & 1.00 & & & \\
\hline Distancia media & 0.20 & 1.00 & & \\
\hline PIB & 0.94 & 0.22 & 1.00 & & \\
\hline Población & 0.64 & 0.18 & 0.71 & 1.00 & 1.00 \\
\hline $\begin{array}{l}\text { Ayuda para el comercio } \\
\text { recibida }\end{array}$ & 0.23 & 0.18 & 0.32 & 0.60 & \\
\hline AOD recibida & 0.27 & 0.15 & 0.30 & 0.40 & 0.48 \\
\hline
\end{tabular}

Notas: La matriz de correlación se calcula a partir de valores agregados o valores medios de las variables para todos los países exportadores. En ese sentido, las exportaciones totales corresponden a las exportaciones agregadas de un país en desarrollo en un año determinado. La distancia media es el promedio de la distancia recorrida por todas las corrientes bilaterales de exportación de un país en desarrollo en un año determinado. El PIB y la población corresponden al producto interno bruto y la población total anuales de cada país. La ayuda para el comercio y la AOD recibidas se refieren a la cuantía total de las corrientes de ayuda para el comercio y de las demás formas de $A O D$ recibidas por el país exportador en cada uno de los períodos aqui considerados. 
CUADRO F.5 Efecto diferido de la ayuda para el comercio en las exportaciones de los países en desarrollo (1995) (página 1 de 2)

\begin{tabular}{|c|c|c|c|c|c|c|}
\hline $\begin{array}{l}\text { Variable dependiente } \\
\text { Exportaciones del país i } \\
\text { (EN DESARROLLO, 1995) al país j } \\
\text { (TODOS) en el año t }\end{array}$ & $\begin{array}{l}\text { (1) } \\
\text { Ayuda para } \\
\text { el comercio } \\
t-1\end{array}$ & $\begin{array}{l}\text { (2) } \\
\text { Ayuda para } \\
\text { el comercio } \\
\mathrm{t}-2\end{array}$ & $\begin{array}{l}\text { (3) } \\
\text { Ayuda para } \\
\text { el comercio } \\
\text { t-3 }\end{array}$ & $\begin{array}{l}\text { (4) } \\
\text { Ayuda para } \\
\text { el comercio } \\
\text { t-4 }\end{array}$ & $\begin{array}{l}\text { (5) } \\
\text { Ayuda para } \\
\text { el comercio } \\
\text { t-5 }\end{array}$ & $\begin{array}{c}(6) \\
\text { TOTAL } \\
\text { EFECTO } \\
\text { DIFERIDO }\end{array}$ \\
\hline País i recibió otra AOD & $\begin{array}{c}-0.015^{* * *} \\
(0.006)\end{array}$ & $\begin{array}{c}-0.018^{* * *} \\
(0.005)\end{array}$ & $\begin{array}{c}-0.018^{* * *} \\
(0.005)\end{array}$ & $\begin{array}{c}-0.018^{* * *} \\
(0.005)\end{array}$ & $\begin{array}{c}-0.015^{* * *} \\
(0.005)\end{array}$ & $\begin{array}{c}-0.018^{* * *} \\
(0.006)\end{array}$ \\
\hline País i no recibió otra AOD & $\begin{array}{l}-0.039 \\
(0.037)\end{array}$ & $\begin{array}{l}-0.039 \\
(0.036)\end{array}$ & $\begin{array}{l}-0.033 \\
(0.036)\end{array}$ & $\begin{array}{l}-0.041 \\
(0.035)\end{array}$ & $\begin{array}{l}-0.043 \\
(0.035)\end{array}$ & $\begin{array}{l}-0.037 \\
(0.037)\end{array}$ \\
\hline País j recibió otra AOD & $\begin{array}{l}0.015^{* * *} \\
(0.006)\end{array}$ & $\begin{array}{c}0.016^{* * *} \\
(0.005)\end{array}$ & $\begin{array}{l}0.014^{* * *} \\
(0.005)\end{array}$ & $\begin{array}{l}0.013^{* *} \\
(0.005)\end{array}$ & $\begin{array}{l}0.012^{* *} \\
(0.005)\end{array}$ & $\begin{array}{c}0.005 \\
(0.006)\end{array}$ \\
\hline País j no recibió otra AOD & $\begin{array}{l}-0.029 \\
(0.024)\end{array}$ & $\begin{array}{l}-0.027 \\
(0.024)\end{array}$ & $\begin{array}{l}-0.033 \\
(0.024)\end{array}$ & $\begin{array}{l}-0.031 \\
(0.024)\end{array}$ & $\begin{array}{l}-0.038 \\
(0.024)\end{array}$ & $\begin{array}{l}-0.036 \\
(0.024)\end{array}$ \\
\hline $\begin{array}{l}\text { País i recibió ayuda para el comercio } \\
\text { en t-1 }\end{array}$ & $\begin{array}{c}0.005 \\
(0.003)\end{array}$ & & & & & $\begin{array}{l}-0.004 \\
(0.004)\end{array}$ \\
\hline $\begin{array}{l}\text { País i no recibió ayuda para } \\
\text { el comercio en t-1 }\end{array}$ & $\begin{array}{l}-0.007 \\
(0.020)\end{array}$ & & & & & $\begin{array}{l}-0.014 \\
(0.021)\end{array}$ \\
\hline $\begin{array}{l}\text { País i recibió ayuda para el comercio } \\
\text { en t-2 }\end{array}$ & & $\begin{array}{c}0.018^{* * *} \\
(0.003)\end{array}$ & & & & $\begin{array}{c}0.004 \\
(0.004)\end{array}$ \\
\hline $\begin{array}{l}\text { País i no recibió ayuda para el } \\
\text { comercio en t-2 }\end{array}$ & & $\begin{array}{c}0.015 \\
(0.020)\end{array}$ & & & & $\begin{array}{c}0.011 \\
(0.021)\end{array}$ \\
\hline $\begin{array}{l}\text { País i recibió ayuda para el comercio } \\
\text { en t-3 }\end{array}$ & & & $\begin{array}{c}0.030^{* * *} \\
(0.003)\end{array}$ & & & $\begin{array}{l}0.015^{* * *} \\
(0.004)\end{array}$ \\
\hline $\begin{array}{l}\text { País i no recibió ayuda para } \\
\text { el comercio en } t-3\end{array}$ & & & $\begin{array}{c}0.021 \\
(0.019)\end{array}$ & & & $\begin{array}{c}0.012 \\
(0.021)\end{array}$ \\
\hline $\begin{array}{l}\text { País i recibió ayuda para el comercio } \\
\text { en t-4 }\end{array}$ & & & & $\begin{array}{c}0.033^{* * *} \\
(0.003)\end{array}$ & & $\begin{array}{c}0.013^{* * *} \\
(0.004)\end{array}$ \\
\hline $\begin{array}{l}\text { País i no recibió ayuda para } \\
\text { el comercio en } \mathrm{t}-4\end{array}$ & & & & $\begin{array}{c}0.026 \\
(0.019)\end{array}$ & & $\begin{array}{c}0.021 \\
(0.021)\end{array}$ \\
\hline $\begin{array}{l}\text { País i recibió ayuda para el comercio } \\
\text { en t-5 }\end{array}$ & & & & & $\begin{array}{c}0.043^{* * *} \\
(0.003)\end{array}$ & $\begin{array}{c}0.034^{* * *} \\
(0.003)\end{array}$ \\
\hline $\begin{array}{l}\text { País i no recibió ayuda para el } \\
\text { comercio en t-5 }\end{array}$ & & & & & $\begin{array}{c}0.044^{* *} \\
(0.019)\end{array}$ & $\begin{array}{l}0.045^{* *} \\
(0.021)\end{array}$ \\
\hline $\begin{array}{l}\text { País j recibió ayuda para el comercio } \\
\text { en t-1 }\end{array}$ & $\begin{array}{l}0.007^{*} \\
(0.004)\end{array}$ & & & & & $\begin{array}{c}0.006 \\
(0.004)\end{array}$ \\
\hline $\begin{array}{l}\text { País j no recibió ayuda para el } \\
\text { comercio en t-1 }\end{array}$ & $\begin{array}{l}-0.028 \\
(0.018)\end{array}$ & & & & & $\begin{array}{l}-0.010 \\
(0.018)\end{array}$ \\
\hline
\end{tabular}


CUADRO F.5 Efecto diferido de la ayuda para el comercio en las exportaciones de los países en desarrollo (1995) (página 2 de 2)

\section{Variable dependiente Exportaciones del país $\mathrm{i}$ (EN DESARROLLO, 1995) al país j (TODOS) en el año $t$}

País j recibió ayuda para el comercio en $t-2$

País j no recibió ayuda para

el comercio en $\mathrm{t}-2$

País j recibió ayuda para el comercio en $\mathrm{t}-3$

\section{País j no recibió ayuda para}

el comercio en $t-3$

País j recibió ayuda para el comercio en $\mathrm{t}-4$

País j no recibió ayuda para

el comercio en t-4

País j recibió ayuda para el comercio en $\mathrm{t}-5$

País j no recibió ayuda para

el comercio en t-5

Todas las variables de control del cuadro E.1

Efectos fijos por importadory exportador

Efectos fijos por año

Observaciones

R cuadrado (R2)
(1)

\section{Ayuda para}

el comercio

$t-1$

(2) Ayuda para el comercio $\mathrm{t}-2$

t-2

0.003

(0.004)

(3)

Ayuda para

el comercio

t-3

(4)

(5)

Ayuda para

el comercio

$\mathrm{t}-4$

Ayuda para
el comercio
t-5

(6)

TOTAL

EFECTO

DIFERIDO

$-0.003$

(0.004)

$-0.041^{* *}$

$(0.017)$

$-0.017$

(0.019)

0.003

(0.004)

(0.004)

0.002

$-0.029^{*}$

(0.017)

(0.019)

$-0.001$

(0.004)

(0.004)

$-0.048^{* * *}$

$-0.029$

(0.017)

$0.012^{* * *}$

$0.010^{* *}$

(0.004)

(0.004)

$-0.032^{*}$

$-0.018$

(0.016)

(0.018)

Sí Sí

$$
\text { Sí }
$$

Sí

Sí

Sí

Sí

Sí Si

Sí

Sí

142448

142448

0.734

0.734

Sí
448
34

\begin{tabular}{|c|}
\hline Sí \\
\hline Sí \\
\hline 142448 \\
\hline 0.734 \\
\hline
\end{tabular}

\begin{tabular}{|r|}
\hline \\
\hline
\end{tabular}

S

Sí

142448

0.734

Sí

Sí

Sí

Sí Sí

\begin{tabular}{|c|c|}
\hline 142448 & 142448 \\
\hline 0.735 & 0.735 \\
\hline
\end{tabular}




\section{REFERENCIAS}

Calì, M. y D.W. te Velde (2010), "Does Aid for Trade Really Improve Trade Performance?", World Development, Vol. 39(5), páginas 725-740.

Helble, M., C. Mann y J. Wilson (2012), "Aid for Trade Facilitation", Review of World Economics, Vol. 148, № 2, páginas 357-376.

Vijil, M. (2012), "Aid for Trade Effectiveness: Complementarities with Economic Integration", documento preparado para el taller "Aid for Trade: What have we Learnt? Which Way Ahead?", 6 de diciembre de 2012, Ginebra. Revisado en enero de 2013.

Fondation pour les études et recherches sur le développement international (FERDI) y Centro de Comercio Internacional (ITC), Ginebra. 


\section{ORGANIZACIÓN DE COOPERACIÓN Y DESARROLLO ECONÓMICOS}

La OCDE constituye un foro único en su género, donde los gobiernos trabajan conjuntamente para afrontar los retos económicos, sociales y medioambientales que plantea la globalización. La OCDE está a la vanguardia de los esfuerzos emprendidos para ayudar a los gobiernos a entender y responder a los cambios preocupaciones del mundo actual, como el gobierno corporativo, la economía de la información y los retos que genera el envejecimiento de la población. La Organización ofrece a los gobiernos un marco en el que pueden comparar sus experiencias políticas, buscar respuestas a problemas comunes, identificar buenas prácticas y trabajar en la coordinación de políticas nacionales e internacionales.

Los países miembros de la OCDE son: Alemania, Australia, Austria, Bélgica, Canadá, Chile, Corea, Dinamarca, Eslovenia, España, Estados Unidos de América, Estonia, Finlandia, Francia, Grecia, Hungría, Irlanda, Islandia, Israel, Italia, Japón, Luxemburgo, México, Noruega, Nueva Zelanda, Países Bajos, Polonia, Portugal, Reino Unido, República Checa, República Eslovaca, Suecia, Suiza y Turquía. La Comisión Europea participa en el trabajo de la OCDE.

Las publicaciones de la OCDE aseguran una amplia difusión de los trabajos de la Organización. Éstos incluyen los resultados de la compilación de estadísticas, los trabajos de investigación sobre temas económicos, sociales y medioambientales, así como las convenciones, directrices y los modelos desarrollados por los países miembros.

\section{ORGANIZACIÓN MUNDIAL DEL COMERCIO}

La Organización Mundial del Comercio (OMC) es la única organización mundial que se ocupa de las normas que rigen el comercio entre los países. El núcleo central del sistema son los acuerdos de la OMC, negociados y firmados por la mayoría de las naciones del mundo que practican el comercio, y ratificados por sus parlamentos. El objetivo es ayudar a los productores, exportadores e importadores de bienes y servicios a realizar sus actividades

Las principales funciones de la Organización son:

- administrar los acuerdos comerciales de la OMC;

- servir de foro para las negociaciones comerciales;

- solucionar las diferencias comerciales;

- supervisar las políticas comerciales nacionales;

- proporcionar asistencia técnica y formación a los países en desarrollo, y

- cooperar con otras organizaciones internacionales.

La OMC cuenta actualmente con 159 Miembros que representan casi el 90 por ciento del comercio mundial. La mayoría de los Miembros son gobiernos, pero también pueden ser territorios aduaneros.

Publicaciones de la OCDE

2, rue André-Pascal, 75775 Paris CEDEX 16

ISBN OMC - 978-92-870-3870-8 ISBN OCDE - 978-92-64-20361-7 (impreso); 978-92-64-20362-4 (PDF); ISSN 24102024 


\section{LA AYUDA PARA EL COMERCIO EN SINTTESIS 2013 CONECTARSE A LAS CADENAS DE VALOR}

En la presente publicación conjunta de la OCDE y la OMC se centra la atención en la ayuda para el comercio con el objeto de evaluar lo que funciona, lo que no funciona y los aspectos que es preciso mejorar. En particular, se analizan las tendencias de las políticas, los programas y las prácticas en materia de ayuda para el comercio, y se muestra que la Iniciativa de Ayuda para el Comercio produce resultados tangibles en cuanto a mejorar los resultados comerciales y las condiciones de vida en los países en desarrollo, sobre todo los de la mujer.

En el informe se hace hincapié en que la ayuda para el comercio desempeña un papel importante en la tarea de allanar el camino para que las empresas de los países en desarrollo puedan conectarse a las cadenas de valor 0 avanzar en ellas. De hecho, la aparición de cadenas de valor confirma la razón de ser de la ayuda para el comercio.

Los grupos interesados siguen participando activamente en la Iniciativa de Ayuda para el Comercio. La labor de vigilancia de 2013 se basó en las autoevaluaciones de 80 países en desarrollo, 28 donantes bilaterales, 15 donantes multilaterales y 9 proveedores de cooperación Sur-Sur. También se recibieron opiniones de 524 proveedores de países en desarrollo y 173 empresas principales, en su mayoría de países de la OCDE.

\section{Índice}

Capítulo 1. ¿Se está adaptando la ayuda para el comercio a las nuevas realidades?

Capítulo 2. Corrientes de ayuda para el comercio y financiación

Capítulo 3. Las cadenas de valor y el camino del desarrollo

Capítulo 4. Fomento de las cadenas de valor por medio de la ayuda para el comercio a nivel regional

Capítulo 5. Evaluación de la eficacia de la ayuda para el comercio

Capítulo 6. El camino a seguir

Fichas informativas por países sobre la ayuda para el comercio

Anexo A. Ayuda para el comercio: datos principales

Anexo $B$. Lista de receptores de $A O D$ del CAD, por grupos de ingresos

Anexo C. Lista de receptores de AOD del CAD, por regiones

Anexo D. Códigos del SNPA relacionados con la ayuda para el comercio, por categorías

Anexo E. Estimaciones del análisis de regresión

Anexo F. Metodología para el análisis econométrico

Sírvanse citar esta publicación como:

OCDE/OMC (2015), La ayuda para el comercio en síntesis 2013: Conectarse a las cadenas de valor,

Publicaciones de la OCDE

DOI: http://dx.doi.org/10.1787/ayuda_sintesis-2013-es

www.aid4trade.org 